

\section{DISCLAIMER}

This report was prepared as an account of work sponsored by an agency of the United States Government. Neither the United States Government nor any agency Thereof, nor any of their employees, makes any warranty, express or implied, or assumes any legal liability or responsibility for the accuracy, completeness, or usefulness of any information, apparatus, product, or process disclosed, or represents that its use would not infringe privately owned rights. Reference herein to any specific commercial product, process, or service by trade name, trademark, manufacturer, or otherwise does not necessarily constitute or imply its endorsement, recommendation, or favoring by the United States Government or any agency thereof. The views and opinions of authors expressed herein do not necessarily state or reflect those of the United States Government or any agency thereof. 


\section{DISCLAIMER}

Portions of this document may be illegible in electronic image products. Images are produced from the best available original document. 


\section{Nuclear Safety}

Nuclear Safety is a quarterly Technical Progress Review prepared by the Nuclear Safety Information Center and sponsored by the U.S. Atomic Energy Commission's Division of Technical Information. The Review is intended to assist interested persons in keeping abreast of significant developments in the field of nuclear safety. It is not a comprehensive abstract of all literature published in this field during a given quarter, but rather it is a mechanism for presenting concise reviews of selected subjects as prevailing interest and available information warrant.

Coverage of the Review is limited to topics relevant to the analysis and control of hazards associated with nuclear reactors, operations involving fissionable materials, and the products of nuclear fission. Primary emphasis is on safety in reactor design, construction, and operation; however, safety considerations in reactor fuel fabrication, spent-fuel processing, nuclear waste disposal, and related operations are also treated. Safety in the use of radioisotopes in industry, medicine, and research is excluded, as are most topics considered to be the province of health physics. Even with these exclusions, the nuclear safety field overlaps such diverse fields as nuclear physics, solid-state physics, mechanics, chemistry, meteorology, geology, seismology, metallurgy, law, and nearly all branches of engineering. The authors will therefore review material from these fields that, in their opinion, has a direct bearing on nuclear safety.

Three types of articles appear in Nuclear Safety. First, there are frequent feature articles, which are solicited monographs written by nationally recognized specialists on particular topics of interest selected by the editors. Second, there are special review articles, usually written by invited authors, that are concerned with special topics and permit discussion of pertinent subjects that cannot be adequately considered by reference to only the current literature. Current review articles, which constitute the major portion of the journal, make up the third type; these articles are generally written by permanent reviewers who are senior staff specialists at Oak Ridge National Laboratory and summarize the literature and occurrences in the specialists' fields on roughly a yearly rotating basis.

Nuclear Safety may be purchased from the Superintendent of Documents, U.S. Government Printing Office, Washington, D.C. Total cost is $\$ 2.50$ per year or $\$ 0.70$ per issue.

Wm. B. COTTRELL, Editor; W. H. JORDAN, Advisory Editor J. P. BLAKELY, Managing Editor

J. R. BUCHANAN, K. E. COWSER, T. D. ANDERSON, C. E. GUTHRIE, H. C. MCCURDY, A. W. SAVOLAINEN, and C. S. WALKER, Assistant Editors

Oak Ridge National Laboratory 
ORNL-NSIC-32

CONTRACT NO. W-7405-ENG-26

CESTI RRICES

н. с.3.00; 12.65

NUCLEAR SAFETYY INFORMATION CENTER

RELEASED FOR ANNOLNCENENT

IN WUELEAF SCIRNCE ABETRACIS

INDEXED BIBLIOGRAPHY OF CURRENT

NUCLEAR SAFETY LITERATURE - 8

\title{
NSIC STAFF
}

\section{LEGAL NOTICE}

Thin roport was prepared as an account of Government sponsored work. Netther the Untted states, nur the Cummioolon, ner any person acting on benalf of Ute Cummiootons

A. Makes any warranty or representation, expres ged or implied, with respect to the atur-

racy, completeness, or usefulness of the information contained in this report, or that the use

of any information, apparatus, method, or process disclosed in this report may not infringe privately owned rights; or

B. Assumes any liabilities with respect to the use of, or for damages resulting from the - use uf auy information, apparatis, method, or process disclosed in thls report.

As used in the above, "person acting on behalf of the Commission" includes any em.

it pluyee or contractor of the finmmission, or employee of such contractor, to the extent that auoh omployee or contractor of the commlsgion, or employee of auch contraclui' preparen disseminates, or provides access to, any information pursuant $w$ bls employment or contrart with the Commission, or his employment with such contractor

$$
\rightarrow-
$$

\section{MARCH 1967}

\author{
OAK RIDGE NATIONAL LABORATORY \\ OAK RIOGE, TENNESSEE \\ OPERATED BY \\ UNION CARBIDE CORPORATION \\ FOR THE \\ U.S. ATOMIC ENERGY COMMISSION
}


Printed in the United States of America. Avoilable from Cleoringhouse for Federal Scientific and Technical Information, National Bureou of Standards,

U.S. Department of Commerce, Springfield, Virginio 22151

Price: Printed Copy $\$ 3.00$; Microfiche $\$ 0.65$

\section{LEGAL NOTICE}

This report wos prepared as an account of Government sponsored work. Neither the United States, nor the Commission, nor any person octing on behalf of the Commission:

A. Mokes ony warranty or representation, expressed or implied, with respect to the accuracy, completeness, or usefulness of the information contained in this report, or that the use of ony information, apparatus, method, or process disclosed in this report may not infringe privately owned rights; or

B. Assumes any liabilities with respect to the use of, or for domages resulting from the use of ony information, apparatus, method, or process disclosed in this report.

As used in the above, "person acting on behalf of the Commission" includes ony employee or contractor of the Commission, or employee of such contractor, to the extent that such employee or contractor of the Commission, or employee of such contractor prepores, disseminotes, or provides access to, any information pursuant to his employment or contract with the Commission, or his employment with such controctor. 
THE INDEXED BIBLIOGRAPHY OF CURRENT NUCLEAR SAFETY LITERATURE IS PUBLISHED FOUR TIMES ANNUALLY UNDER THE AUSPICES OF THE NUCLEAR SAFETY INFORMATION CENTER. THE CENTER WAS ESTABLISHED IN MARCH 1963 AT THE OAK RIDGE NATIONAL LABORATORY UNDER THE SPONSORSHIP OF THE U. S. ATOMIC ENERGY COMMISSION AND SERVES AS A FOCAL POINT FOR THE COLLECTION, STORAGE, EVALUATION, AND DISSEMINATION OF NUCLEAR SAFETY INFORMATION. IT CONTAINS AN EXTENSIVE COLLECTION OF MATERIAL FILED IN A MANUAL RAPID-ACCESS SYSTEM TO PROVIDE REACY ANSWERS TO QUESTIONS ARISING IN THE FIELD OF NUCLEAR SAFETY.

BIBLIOGRAPHIC DATA AND ABSTRACTS HAVE BEEN STORED IN BOTH A COMPUTER AND A MANUAL FILE SINCE SEPTEMBER 1964. THE PRODUCTION OF THIS BIBLIOGRAPHY WAS MAOE POSSIBLE THROUGH IBM-7090 COMPUTER PROGRAMS DEVELOPED BY THE INFORMATION SYSTEMS DEPARTMENT OF THE COMPUTER SCIENCES CENTER AT OAK RIDGE.

BIBLIOGRAPHIC ITEMS HAVE BEEN SORTED INTO 19 CATEGORIES OF NUCLEAR SAFETY INFORMATION. ITEMS MAY APPEAR. IN AS MANY $\triangle S$ THREE CATEGORIES. A SELECTOR INDEX AND AN AUTHOR INDEX ARE PROVIDED FOR THE CONVENIENCE OF THE USER.

EACH BIBLIOGRAPHIC ITEM CONSISTS OF AUTHOR(S), TITLE, CORPORATE AUTHOR(S), NUMBER OF PAGES, TABLES, FIGURES, REFERENCES, DATE, DOCUMENT NUMBER(S), AVAILABILITY (IF NOT OBVIOUS), AN INFORMATIVE ABSTRACT OF LESS THAN IOO WORDS, AND SEVERAL SELECTOR TERMS. THE SELECTOR TERMS OR KEYWORDS ARE ASSIGNED BY NSIC PERSONNEL TO SERVE AS COORDINATE INDEXING TERMS FOR STORAGE AND FUTURE RETRIEVAL OF INFORMATION. THE MOST SIGNIFICANT SELECTOR TERMS FOR EACH BIBLIOGRAPHIC ENTRY ARE ASTERISKED AS WEIGHTING FACTORS. SELECTOR TERMS ARE INCLUDED WITH THIS BIBLIOGRAPHY SINCE THEY CAN, THROUGH THE SELECTOR INDEX, BE OF AID TO THE READER IN LOCATING ITEMS OF INTEREST. MANY READERS, HOWEVER,' WILL PREFER TO SCAN THE CATEGORIES MOST RELATED TO THEIR FIELD OF INTEREST.

NSIC STAFF MEMBERS SELECTED, EXTRACTED, AND KEYWORDED THE VARIOUS ENTRIES IN THE BIBLIOGRAPHY. THE ASSIGNMENTS OF THE STAFF MEMBERS, MOST OF WHOM WORK HALF TIME FOR THE CENTER, ARE AS FOLLOWS

WM. B. COTTRELL - DIRECTOR

J. R. BUCHANAN - ASST. DIRECTOR AND CONTAINMENT OF NUCLEAR FACILITIES

J. P. BLAKELY - GENERAL SAFETY CRITERIA AND SOURCES OF ENERGY RELEASE UNDER ACCIDENT CONDITIONS

E. N. CRAMER - OPERATIONAL SAFETY AND EXPERIENCE

W. K. ERGEN - REACTOR TRANSIENTS, KINETICS, AND STABILITY

M. H. FONTANA - HEAT TRANSFER AND FLUID DYNAMICS

D. G. JACOBS - RADIONUCLIDE RELEASE AND MOVEMENT IN THE ENVIRONMENT

G. W. KEILHOLTZ - FISSION-PRODUCT RELEASE, TRANSPORT, AND REMOVAL

T. F. LOMENICK - ENVIRONMENTAL SURVEYS, MONITORING AND RADIATION EXPOSURE OF MAN

T. L. MCLEAN - NUCLEAR INSTRUMENTATION, CONTROL AND SAFETY SYSTEMS

J. G. MERKLE - STRUCTURAL INTEGRITY

C. M. MURPHY - INFORMATION SPECIALIST

H. G. OBRIEN - NUCLEAR INSTRUMENTATION, CONTROL AND SAFETY SYSTEMS

J. B. RUCH - RADIOCHEMICAL PLANT SAFETY AND PLANT SAFETY FEATURES

R. L. SCOTT - OPERATIONAL SAFETY AND EXPERIENCE

L. B. SHAPPERT - TRANSPORTATION AND HANDLING OF RADIOACTIVE MATERIALS

C. S. WALKER - NUCLEAR INSTRUMENTATION, CONTROL, AND SAFETY SYSTEMS

H. B. WHETSEL - TECHNICAL EOITING

M. L. WINTON - SOI PROGRAM

S. P. HENDRIX - INFORMATION SPECIALIST

R. G. WALLACE - INFORMATION SPECIALIST 
THE SERVICES OF THE CENTER INCLUDE PRINCIPALLY 11 PREPARATION OF STATE-OF-THE-ART REPORTS (ISSUED WITH ORNL-NSIC REPORT NUMBERS) IN THE SUBJECT AREAS LISTED ABOVE WITH STAFF ASSIGNMENTS, $(2)$ PREPARATION OF THE QUARTERLY TECHNICAL PROGRESS REVIEW, NUCLEAR SAFETY, (3) ANSWERING TECHNICAL INQUIRIES AS TIME IS AVAILABLE, AND (4) COUNSEL AND GUIDANCE ON NUCLEAR SAFETY PROBLEMS IN THE ABOVE SUBJECT AREAS. THE COMPUTER CODE USED IN THE PREPARATION OF THIS BIBLIOGRAPHY IS ALSO USED FOR SELECTIVE DISSEMINATION OF INFORMATION AND SPECIAL LITERATURE SEARCHES.

SERVICES OF THE NSIC ARE AVAILABLE WITHOUT CHARGE TO GOVERNMENT AGENCIES, RESEARCH AND EDUCATIONAL INSTITUTIONS, AND THE NUCLEAR INDUSTRY. THE NSIC SERVICES ARE AS LISTED ABOVE BUT UNDER NO CIRCUMSTANCES DO THEY INCLUDE FURNISHING COPIES OF ANY DOCUMENTS (EXCEPT NSIC REPORTS) ALTHOUGH ALL DOCUMENTS MAY BE EXAMINED AT THE CENTER BY QUALIFIED PERSONNEL. INQUIRIES CONCERNING THE CAPABILITIES AND OPERATION OF THE CENTER MAY BE AODRESSED TO

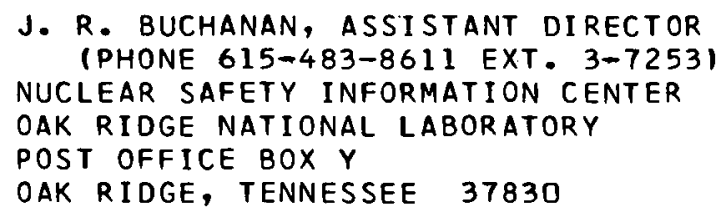

THE PUBL ICATIONS CONTAINED IN THIS REPORT WERE PROCESSED BY THE NSIC STAFF DURING THE PERIOD ENDING IN OCTOBER 1966.

PREVIOUS NUCLEAR SAFETY INFORMATION CENTER BIBLIOGRAPHIC REPORTS ARE AS FOLLOWS

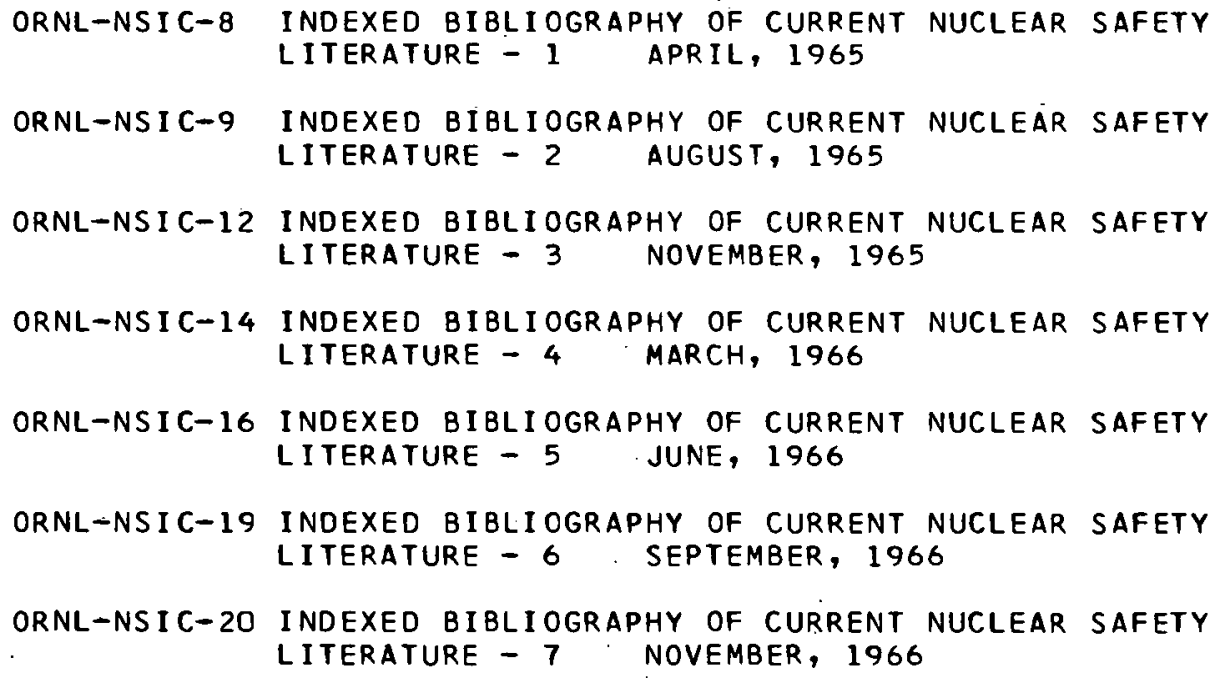




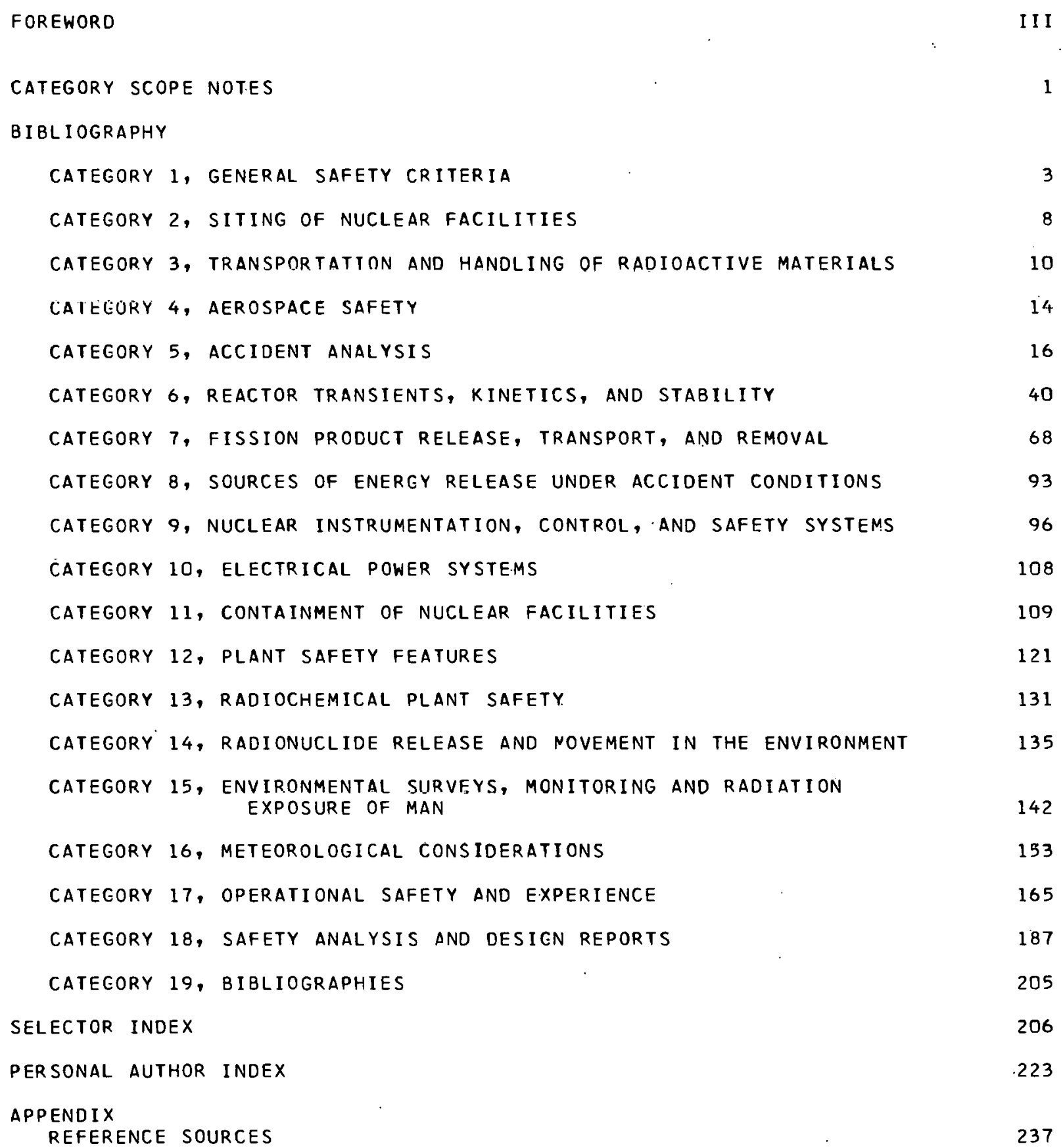




\section{CATEGORY SCOPE NOTES}

A BRIEF EXPLANATION OF THE COMPOSITION OF EACH CATEGORY WITHIN THE SCOPE OF THE NUCLEAR SAFETY. INFORMATION CENTER FOLLOWS

\section{GENERAL SAFETY CRITERIA}

THIS CATEGORY ENCOMPASSES. ALL SAFETY ASPECTS OF RADIATION PHILOSOPHY, STANDARDS, CODES, COST, FINANCIAL LIABILITY AND INSURANCE. OTHER ITEMS OF INTEREST ARE CRITICALITY SAFETY AND THE COMPARATIVE RISK TO THE PUBLIC HEALTH AND SAFETY FROM NUCLEAR AND NONNUCLEAR HAZARDS.

\section{SITING OF NUCLEAR FACILITIES}

THIS CATEGORY DEALS WITH DOCUMENTS RELATEO TO THE FACTORS USED IN EVALUATING SITES SUCH AS CHARACTERISTICS OF THE FACILITY DESIGN, PROPOSED OPERATION, POPULATION DENSITY, USE CHARACTERISTICS OF THE SITE ENVIRONS, PHYSICAL CHARACTFRISTIC.S OF THE SITE, AND THE RELATIONSHIP OF ENGINEERED SAFEGUARDS TO NUCLEAR FACILITY SITING.

\section{TRANSPORTATION AND HANDLING OF RADIOACTIVE MATERIALS}

THIS CATEGORY CONTAINS ARTICLES DEALING WITH SHIPPING CONTAINERS, SHIPPING REGULATIONS, CRITICALITY SAFETY AS RELATED TO SHIPPING AND HANDLING, TRANSPORTATION ACCIDENTS, AND ALL OTHER ITEMS DEALING WITH SAFETY DURING THE TRANSPORTATION AND/OR HANCLING OF RADIOACTIVE MATERIALS.

\section{AEROSPACE SAFETY}

THIS CATEGORY COVERS SAFETY CONSIDERATIONS SUCH AS LAUNCH AND REENTRY PROBLEMS THAT ARE UNIQUE TO NUCLEAR SYSTEMS USED IN AEROSPACE VEHICLES.

\section{ACCIDENT ANALYSIS}

ALL FACETS OF THE ANALYSIS OF POSTULATED ACCIDENTS ARE CONSIDERED IN THIS CATEGORY. INCLUDED ARE BURNOUT HEAT FLUX, CRITICAL HEAT TRANSFER, RELIABILITY ANALYSIS, IN PILE EXPERIMENTS, COOLANT ACTIVITY BUILDUP, PIPE RUPTURE, AND EXPERIMENTS, I.E. LOFT. EXPERIMENTS RELATED TO REACTOR KINETICS ARE CATALOGED IN CATEGORY 6 .

6. REACTOR TRANSIENTS, KINETICS, AND STABILITY

THIS CATEGORY INCLUDES THE VARIOUS STUDIES, BOTH ANALYTICAL AND EXPERIMENTAL, SUCH AS TREAT AND SPERT IN WHICH THE TRANSIENT BEHAVIOR OF REACTORS AND CRITICALITY ACCIDENTS ARE EXAMINED.

7. FISSION PRODUCT RELEASE, TRANSPORT, AND REMOVAL

THE RELEASE OF FISSION PRODUCTS FROM VARIOUS MATERIALS AND THEIR MOVEMENT HITHIN A NUCLEAR FAC.IIITY C.ONTATNMENT SYSTEM ARE INCLUDED IN THIS CATEGORY. TRANSPORT OF THE FISSION PRODUCT INVOLVES THE PHYSICAL AND CHEMICAL CHARACTERIZATION OF THE RELEASED RAOIOACTIVE MATERIALS, AS WELL AS THE VARIOUS MECHANISMS SUCH AS DEPOSITION, ADSORPTION, FILTRATION, FALLOUT, ETC., THAT WOULD ATTENUATE THEIR CONCENTRATION WITHIN THE CONTAINMENT SYSTEM.

\section{SOURCES OF ENERGY RELEASE UNDER ACCIDENT CONDITIONS}

SOURCES OF ENERGY CONSIOERED IN THIS CATEGORY INCLUDE NUCLEAR, WIGNER, AND GAMMA ENERGIES, AS WELL AS CHEMICAL REACTIONS, METAL-WATER REACTIONS, AND ANY OTHER TYPES OF ENERGY THAT MIGHT BE RELEASED AS THE RESULT OF A NUCLEAR ACCIDENT.

9. NUCLEAR INSTRUMENTATION, CCNTROL, AND SAFETY SYSTEMS

THE DESIGN OF CONTROL AND SAFETY SIYSTEMS FOR VARIOUS NUCLEAR PROCESSES, AS WELL AS THE REQUIRED INSTRUMENTATION AND HARDWARE, ARE INCLUDED IN THIS CATEGORY. THE PROBLEMS INVOLVED ARE THE PERFORMANCE REQUIRED OF SAFETY SYSTEMS THE SPECIFICATION OF INSTRUMENTATION THE CONCEPTS OF COINCIDENCE, REDUNDANCE, FAILURE MODES, AND RELIABILITY THE ADEQUACY OF SHUTDOWN MARGINS THE DESIGN FEATURES OF DIFFERENT MECHANICAL DEVICES AND RELATED SUBJECTS. 
10. ELECTRICAL POWER SYSTEMS

INFORMATION RELATED TO ROUTINE AND EMERGENCY MEANS OF SUPPLYING ELECTRICAL POWER TO NUCLEAR FACILITIES IS COVERED IN THIS CATEGORY.

11. CONTAINMENT OF NUCLEAR FACILITIES

THIS CATEGORY ENCOMPASSES ALL ASPECTS OF PRESSURE CONTAINMENT, PRESSURE RELEASE CONTAINMENT, AND MULTIPLE BARRIER CONTAINMENT FOR REACTORS, RADIOCHEMICAL PLANTS, HOT CELLS, SOURCES, ETC., AND WILL INCLUDE SUCH ASPECTS AS DESIGN CONSIDERATIONS, LEAKAGE, PENETRATIONS, STRUCTURAL INTEGRITY, AND TEST TESTING.

\section{PLANT SAFETY FEATURES}

THE SAFETY ASPECTS OF MAINTENANCE, DECONTAMINATION, REACTOR SYSTEMS, URANIUM MINING AND MILLING, AND FUEL FABRICATION AND STORAGE ARE COVERED IN THIS CATEGORY. ENGINEERING DEVICES SUCH AS PRESSURE AND TEMPERATURE REDUCING SYSTEMS, AIR CLEANING SYSTEMS, AND CORE SPRAY AND SAFETY INJECTION SYSTEMS THAT ARE DESIGNED TO MINIMIZE THE CONSEQUENCES OF NUCLEAR ACCIDENTS ARE INCLUDED.

\section{RADIOCHEMICAL PLANT SAFETY}

NUCLEAR SAFETY INFORMATION RELATED SPECIFICALLY TO RADIOCHEMICAL PLANTS IS COVERED IN THIS CATEGORY.

\section{RADIONUCLIDE RELEASE AND MOVEMENT IN THE ENVIRONMENT}

ALL ASPECTS OF THE INTENTIONAL OR ACCIDENTAL RELEASE OF RADIOACTIVITY TO THE ENVIRONMENT ARE INCLUDED IN. THIS CATEGORY. RADIOACTIVE WASTE MANAGEMENT, INCLUDING WASTE TRANSPORTATION, TREATMENT, DISPOSAL AND EFFLUENT CONTROL IS OF PRIMARY IMPORTANCE AS IS RADIONUCLIDE OCCURRENCE AND MOVEMENT. THE LATTER INCLUDES FALLOUT, GEOLOGICAL CONSIDERATIONS, COUNTERMEASURES, ANALYTICAL TECHNIQUES, HYDROLOGIC CONSIDERATIONS, AND RADIONUCLIDE MOVEMENT IN SOIL AND WATER.

15. ENVIRONMENTAL SURVEYS, MONITORING, AND RADIATION EXPOSURE OF MAN

THIS CATEGORY INCLUDES ITEMS RELATED TO 11 ENVIRONMENTAL AND PERSONNEL MONITORING DURING ROUTINE AND ACCIDENTAL RADIONUCLIDE RELEASE, (2) MONITORING METHODS AND TECHNIQUES, (3) DOSE MEASUREMENT AND CALCULATION, (4) DETERMINATION OF MAXIMUM PERMISSIBLE DOSE AND CONCENTRATION, AND (5) INTERNAL AND EXTERNAL EXPOSURE TO RADIONUCLIDES.

\section{METEOROLOGICAL CONSIDERATIONS}

THIS CATEGORY CONSIDERS NOT ONLY DIFFUSION AND DEPOSITION OF RADIOACTIVE MATERIAL NEAR THE EARTHS SURFACE IN CONNECTION WITH REACTOR OPERATIONS BUT ALSO THE ATMOSPHERIC TRANSPORT AND FALLOUT IN THE TROPOSPHERE AND STRATOSPHERE AS A RESULT OF NUCLEAR WEAPONS TESTS.

\section{OPERATIONAL. SAFETY AND EXPERIENCE}

THIS CATEGORY INCLUDES COVERAGE OF THE SAFETY ASPECTS OF ROUTINE REACTOR OPERATION AND OF INCIDENTS OR UNUSUAL OPERATING OCCURRENCES, LARGE OR SMALL. POWER, RESEARCH, AND TEST REACTORS AND FUEL REPROCESSING PLANTS WILL BE COVERED. ALL AVAILABLE OPERATING, INCIDENTS, SAFEGUARDS, AND INSPECTION REPORTS WILL BE COLLECTED AND INDEXED.

\section{SAFETY ANALYSIS AND DESIGN REPORTS}

ROUTINE LISTINGS OF THE LATEST NUCLEAR FACILITY SAFETY ANALYSIS AND DESIGN REPORTS ARE TO BE FOUND IN THIS CATEGORY. INCLUDED ARE BOTH ANALYSES AND REPORTS BY FACILITY. DESIGNERS AND BY THE AEC REGULATORY STAFF.

\section{BIBLIOGRAPHIES}

THIS CATEGORY CATALOGUES DOCUMENTS ON NUCLEAR. SAFETY TOPICS THAT ARE EXCLUSIVELY BIBL IOGRAPHIES AS WELL AS THOSE THAT INCLUDE EXTENSIVE BIBLIOGRAPHIÉS WITH OTHER MATERIAL. 
CATEGORY

GENERAL SAFETY CRITERIA

1-08441 FOX TA + MUELLER RA + FORD CH + ALGEP DL

CRITICAL MASS STUDIES WITH NASA ZERO POWER REACTOR II. I - CLEAN HOMOGENEOUS CONFIGURATIONS

LEWIS RESEARCH CENTER, NATIONAL AERONAUTICS AND SPACE ADMINISTRATION, CLEVELAND, OHIO

NASA-TN-D-3097 +. 19 PAGES, 6 FIGURES, 2 TABLES, 6 REFERENCES- NOVEMBER 1965, CFSTI \$1.00 CY, \$0.50 MN

THE NASA ZERO POWER REACTOR I I (ZPR-II) HAS BEEN USED TO DETERMINE EXPERIMENTALLY THE CRITICAL MASSES FOR MORE THAN A TENFOLD RANGE OF HIGHLY ENRICHED $(93.2$ PERCENT U-235) AQUEOUS URANYL FLUORIDE FUEL CONCENTRATIONS IN CLEAN CYLINDRICAL GEOMETRIES. IN ADDITION TO THE CRITICAL MASSES, DATA ARE PRESENTED ON THE TEMPERATURE COEFFICIENT OF REACTIVITY WORTH AT CRITICALITY FOR A SIMILAR RANGE OF CONCENTRATIONS. A BRIEF DESCRIPTION OF THE ZPR-II AND THE

EXPERIMENTAL PROCEDURES USED ARE ALSO INCLUDED.

CRITICALITY EXPERIMENT + CRITICALITY SAFETY + REACTIVITY COEFFICIENT + TEMPERATURE COEFFICIENT + URANIUM

1-08716 CORNELL DC

SAFE-PCRS. A COMPUTER PROGRAM FOR THE STRESS ANALYSIS OF COMPOSITE BODIES OF REVOLUTION. INPUT INSTRUCTIONS

GENERAL ATOMIC

GA-6588 + 4 40 PAGES, FIGURES, TABLES, 2 REFERENCES- AUGUST 1, 1965- CFSTI, \$2.00 CY, \$0.75 MN.

A COMPUTER PROGRAM FOR THE STRESS ANALYSIS OF COMPOSITE BODIES OF REVOLUTION. INPUT INSTRUCTIONS.

*COMPUTER PROGRAM + \#STRESS ANALYSIS + DESIGN STUDY + PROPERTY, PHYSICAL

1-08719 MORGAN KZ

PRESENT STATUS OF RECOMMENDATIONS OF THE INTERNATIONAL COMMISSION ON RADIOLOGICAL PROTECTION, NATIONAL COUNCIL ON RADIATION PROTECTION AND FEDERAL RADIATION COUNCIL

OAK RIDGE NATIONAL LABORATORY

32 PAGES, TABLES, 35 REFERENCES, JUNE 14, 1965, PUBLISHEO IN PROGRESS IN NUCLEAR ENERGY SERIES XII, VOL. 2. TERCAMON PRESS, LONDON

THE HISTORICAL BACKGROUNDS OF THE INTERNATIONAL COMMISSION ON RADIOLOGICAL PROTECTION (ICRP), THE NATIONAL COUNCIL ON RADIATION PROTECTION (NCRP) AND THE FEDERAL RADIATION COUNCIL (FRC) ARE DISCUSSED AS WELL AS MANY CURRENT RECOMMENDATIONS MADE BY THESE ORGANIZATIONS AS THEY APPLY TO RADIATION PROTECTION IN MAN. THIS INCLUDES WORKERS IN THE RADIATION INDUSTRY, BUT ALSO THE POPULATION AT LARCE.

* RADIATION PROTECTION, ORGANIZATION + PERSONNEL EXPOSURE, RADIATION + RADIATION IN PERSPECTIVE + RADIATION SAFEYY AND CONTROL

1-09662 BRINKMANN G + SCHENK W + SCHULZ W + STOCKSCHLADER F

IMPROVING ECONOMY WITH THE USE OF STANDARDIZED, MOVABLE, IN-CELL BOXES, AND THE DECONTAMINATION OF THEIR EQUIPMENT AT THE CENTRAL DECONTAMINATION FACILITY KERFORSCHUNCSANLACE JULICH, CERMANY

13 PAGES, 7 FIGURES, 5 REFERENCES- 1965 - PP. $654-667$ OF THE PROCEEDINGS DF AN INTERNATIONAL SYMPOSIUM ON WORKING METHOOS IN HIGH ACTIVITY HOT LABORATORIES, GRENOBLE, JUNE 15-18, 1965, VOL. 2- ENEA, OCED, PUBL ISHERS

WHEN A NUCLEAR RESEARCH CENTER HAS SEVERAL HOT LABORATORIES, ALL OF WHICH USE IN-CELL BOXES, IT IS DESIRABLE TO STANDARDIZE THE CELLS AND BOXES AS FAR AS DOSSIBLE TO ACHIEVE MAXIMUM ECONOMY, EFFICIENCY, AND CONVENIENCE. THE FOLLOWING REPORT SHOWS THE PRINCIPLES OF PLANNING WHICH ARE LAID DOWN AT KFA-JULICH, IN CONNECTION WITH THE CONSTRUCTION OF SEVERAL PLANTS. IT ENUMERATES THE ADVANTAGES AND DESCRIBES THE CONDITIONS WHICH MUST BE OBSERVED DURING

PLANNING. THE SECTION ON THE DECONTAMINATION FACILITY IS INCLUDED AS AN IMPORTANT PART OF THE ENTIRE BOX-EXCHANGE SYSTEM. IN ADOITION, SOME OF THE MORE INTERESTING PDINTS CONCERNING EQUIPMENT ANO TECHNIQUES, ESPECIALLY A NEW MANIPULATOR EXCHANGE TECHNIQUE, ARE DESCRIBED.

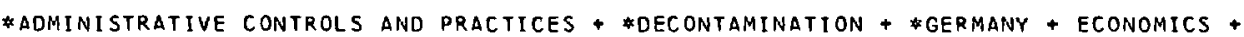
ENEA (EUROPLAN NUCLEAR ENERGY AGENCY) + HOT CELL

1-09664 WATSON CD + BERRETH EA + DUMMER JE + FULLER RK + STEARNS RF POLICY AND PROCEDURES USED IN THE UNITED STATES FOR DECONTAMINATING HOT CELLS OAK RIDGE NATIONAL LABORATORY + BATTELLE NORTHWEST + LOS ALAMOS SCIENTIFIC LABORATORY

36 PAGES, 7 FIGURES, 5 REFERENCES- 1965- PP. 678-705 OF THE PROCEEDINGS OF AN INTERNATIONAL SYMPOSIUM ON WORKING METHODS IN HIGH ACTIVITY HOT LABORATORIES, GRENOBLE, JUNE 15-18, 1965, VOL. 2- FNEA, OECD, PUBL I SHERS

IN THE UNITED STATES, hOT CELLS AND EQUIPMENT FOR HANDLING RADIOACTIVE SOL IDS OR LIQUIDS ARE SUCCESSFULLY DECONTAMINATED AS REQUIRED. THE FREQUENCY VARIES FROM ABOUT THREE TIMES A YEAR TO ONLY ONCE IN THREE YEARS FOR THE LARGER PILOT-PLANT UNITS. THE NORMAL TIME REQUIRED TO DECONTAMINATE A FACILITY IS ABOUT TWO TO SIX WEEKS. DECONTAMINATION IS USUALLY DONE REMOTELY, THROUGH APPROPRIATE DESIGN, PRECONTAMINATION APPLICATION OF PROTECTIVE COATINGS, EXPENDABLE EQUIPMENT, THE PROPER CHOICE OF CLEANING REAGENTS IOETERGENTS, ORGANIC SOLVENTS, ACIDS, ALKALIES, CHELATING AGENTS) AND PHYSICAL METHODS (GRINDING, ULTRASONIC CLEANING, BLASTING, AND ABRADINGI. METHODS HAVE BEEN DEVELOPED AND ARE PRESENTED IN THIS PAPER FOR OECONTAMINATING HOT CELLS AND ADJACENT AREAS SUBJECTED TO THE UNCONTROLLED RELEASE OF RADIOACTIVITY.

*adMinistrative Controls and practices + \#Decontamination + \#hot Cell + ENEA (EUROPEAN NUCLEAR ENERGY AGENCY) + UNITED STATES 
CATEGORY 1

GENERAL SAFETY CRITERIA

$1-09852$ RENGEL JC

SAFETY RELATED ASPECTS OF LOCATING NUCLEAR POWER PLANTS IN CITIES

WESTINGHOUSE ELECTRIC CORPORATION, PITTSBURGH, ATOMIC POWER DIV.

5 PAGES, PRESENTEO AT THE ANS SYMPOSIUM ON LOCATING NUCLEAR POWER PLANTS IN CITIES, MARCH 22 , 1966 , NEW YORK CITY

PUTS RELIABILITY AND ACCIDENT-PREVENTION SAFEGUARDS AHEAD OF CONSEQUENCE-LIMITING SAFEGUAPDS. RELIABILITY ENSURED BY DESIGN, INTEGRITY OF MANUFACTURER, INSPECTION, TEST, AND OPERATION CRITERIA FOR URBAN SITING.

* SITING, REACTOR + CODES AND STANDARDS + DESIGN CRITERIA + ENGINEERED SAFEGUARD

1-09854 SZAWLEWICZ SA

THE AEC REACTOR SAFETY PROGRAM

U. S. ATOMIC ENERGY COMMISSION

7 PAGES, PRESENTED AT THE ANS SYMPOSIUM ON LOCATING. NUCLEAR POWER PLANTS IN CITIES, MARCH 22,1966, NEW YORK CITY

STEER ING COMMITTEE ON SAFETY RESEARCH. ACCIDENT-PREVENTING AND CONSEQUENCE-LIMITING SAFEGUARDS. ENGINEERED SAFEGUARDS. LOSS-OF-COOLANT ACCIDENT AND MECHANICAL LOAD IT CREATES, IN-CORE SPRAY AND EMERGENCY COOLING SYSTEM, METAL-WATER REACTION, FUEL MELTDOWN, FISSION-PRODUCT RELEASE, RELIABILITY OF PIPING. LIST OF PLANNED ORNL SUMMARY REPORT BUDGET. IN-PLANT TEST PROGRAM. NUCLEAR SAFETY PILOT PLANT, CONTAINMENT SYSTEMS EXPERIMENT, LOFT, POMER BURST FACILITY.

CSE (CONTAINMENT SYSTEMS EXPERIMENT) + EMERGENCY COOLING + ENGINEERED SAFEGUARD +

FISSION PRODUCT RELEASE, GENERAL + FUEL MELTDOWN + LOFT (LOSS OF FLUID TEST) + METAL WATER REACTION + NSPP (NUCLEAR SAFETY PILOT PLANT) + PBF (POWER BURST FACILITY) + REACTOR, PRESSURIZED WATER

$1-09855 \quad B E C K$ CK

CURRENT TRENDS AND PERSPECTIVES IN REACTOR LOCATION AND SAFETY REQUIREMENTS

U. S. ATOMIC ENERGY COMMISSION, WASHINGTON

14 PAGES, PRESENTED AT THE ANS SYMPOSIUM ON LOCATING NUCLEAR POWER PLANTS IN CITIES, MARCH 22 , 1966 , NEW YORK CITY

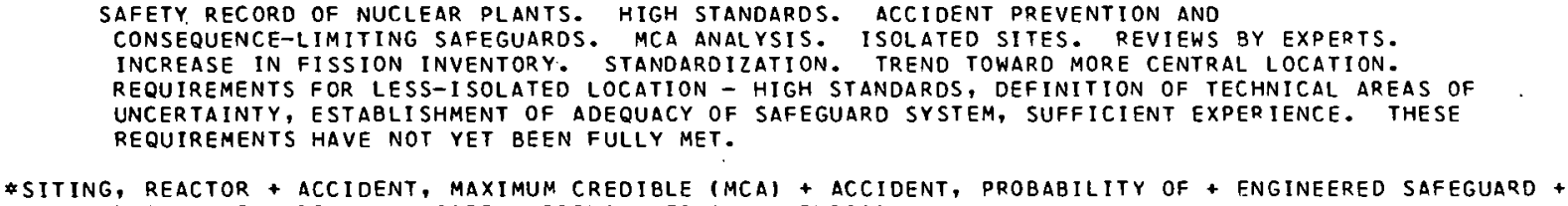

* SITING, REACTOR + ACCIDENT, MAXIMUM CREDIBLE (MCA) + ACCIDENT, PROBABILITY OF + ENGINEERED SAFEgUARD + REGULATION, AEC + REVIEW + SAFETY PRINCIPLES AND PHILOSOPHY

$1-09856$ CAHILL WJ

REMARKS BY WILLIAM J. CAHILL, JR. MECHANICAL PLANT ENGINEER CONSOLIOATED EOISON COMPANY OF NEW YORK, INC. AT THE SYMPOSIUM ON LOCATING NUCLEAR POWER PLANTS IN CITIES, AMERICAN NUCLEAR SOCIETY, MARCH 22 , I966 CONSOLICATEO EDISON COMPANY, NEW YORK

2 PAGES, PRESENTED AT THE ANS SYMPOSIUM ON LOCATING NUCLEAR POWER PLANTS IN CITIES, MARCH 22 , 1966

BRIEF DESCRIPTION OF ENGINEERED SAFEGUAROS, SITES, LICENSING EXPERIENCE, ANO PUBLIC ACCEPTANCE OF INDIAN POINT 1 AND 2 , AND RAVENSWOOD.

*INDIAN POINT I + \#INDIAN POINT II + \#RAVENSWOOD + *SITING, REACTOR + ENGINEERED SAFEGUARD + REACTOR, PRESSURIZED WATER + REGULATION, AEC

1-09971 SAUER MC

A METHOD FOR AUTOMATIC ANALYSIS OF DATA ON THE KINETICS OF FAST CHEMICAL REACTIONS IN THE FORM OF PICTURES OF OSCILLOSCOPE TRACES

ARGONNE NATIONAL LABORATORY

ANL-7113 +. 15 PAGES, 10 FIGURES- OCTOBER 1965- CFSTI, \$1.DO CY, \$0.50 MN

THE CHLOE SYSTEM FOR DIRECT DIGITIZATION OF PHOTOGRAPHIC DATA WAS USED IN CONJUNCTION WITH THE CONTROL DATA CORPORATION 3600 COMPUTER SYSTEM TO ANALYZE DATA, IN THE FORM OF PICTURES OF OSCILLOSCOPE TRACES, ON THE KINETICS OF FAST CHEMICAL REACTIONS. ALL MEASUREMENTS AND ANALYTICAL PROCESSES WERE DONE BY MACHINE IN A COMPLETELY AUTOMATIC METHOD.

* ANALYTICAL MODEL + *CHEMICAL KINETICS + \#CHEMICAL REACTION + *COMPUTER PROGRAM + \#COMPUTER, DIGITAL

1-10310 SHAW AE

THE SAFE TRANSPORT OF RADIOACTIVE MATERIALS. A KEY TO THE 1964 REVISION OF THE INTERNATIONAL ATOMIC ENERGY AGENCYS REGULATIONS

UNITED. KINGDOM ATOMIC ENERGY AUTHORITY, RISLEY

TRG-1073 (D)+. 21 PAGES, 1 FIGURE, 4 TABLES, JULY 1965, BIS, \$0.70 CY

A KEYED INDEX TO HELP THE DAY-TO-DAY USER OF THE INTERNATIONAL ATOMIC ENERGY AGENCY DOCUMENT REGULATIONS FOR THE SAFE TRANSPORT OF RADIOACTIVE MATERIALS 11964 REVISION OF MAY 1961 REGULATIONS). IF IT IS KNOWN WHAT RADIOACTIVE MATERIAL HAS TO BE TRANSPORTED (IN TERMS OF ELEMENT, ISOTOPE, ITS TOTAL AND SPECIFIC ACTIVITIES ITS CHEMICAL AND PHYSICAL FORM, AND 
CATEGORY

GENERAL SAFETY CRITERIA

\section{1-10310 *CONTINUED*}

DETAILS OF THE PACKAGE TYPE ALONG WITH SURFACE CONTAMINATION AND EXTERNAL RADIATION DOSF-RATE MEASUREMENTSI, STEP-BY-STEP USE OF THE KEY WILL INOICATE THE CORRECT PROCEDURE. THIS KEY DOES NOT AVOID THE NEED TO UNDERSTAND THE DETAIL OF THE IAEA DOCUMENT BUT IS INTENDED AS A SUMMARY FOR DAY-TO-DAY USAGE BY THE CONSIGNOR. ANY REFERENCE IN THE KEY TO THE REGULATIONS IMPLIES THE REVISED IAEA REgULATIONS.

\#RFGULATION, IAEA + *SHIPPING CONTAINER + \#TRANSPORTATION AND HANOLING

1-10335 BARON S

ENGINEERING FOR COMMUNITY ACCEPTANCE - THE ARCHITECT-ENGINFER ROLE BURNS AND ROE, INC.

13 PAGES, 1 FIGURE, PRESENTEO AT THE AMERICAN POWER CONFERENCE $28 T H$ ANNUAL MEETING, APRIL $26-28$, 1966 , CHICAGO, APC

COMMENTS ON AEC DESIGN CRITERIA AND TURNKEY CONTRACTS. SUGGESTS TIGHT CONTRACT PRICE LEAVES LITTLE LEEWAY FOR AEC - REQUIRED MODIFICATIONS, TURNKEY CONTRACT A-E CANNOT SERVE AS SUBCONTRACTOR AND STILL ENGINEER PLANT FOR COMMUNITY ACCEPTANCE. LITTLE OR NO STANDBY CAPACITY AVAILABLE FOR MAJOR COMPONENT FAILURE, CHEAPER BUT LESS RELIABLE EOUIPMENT INEVITABLE. CONCENTRATION ON ACCIDENT ANALYSES, CONTAINMENT, AND SAFETY SYSTEMS REDUCE EFFORT ON MAINTAINABILITY AND LOCAL RADIATION CONTROL. SUGGESTS ELIMINATION OF FIXED-PRICE CONTRACTS TO ALLOW CONTINUED ENGINEERING RATHER THAN TOO $\cdots$ EARLY STANDARDIZATION, TO MEET ECONOMIC CHALLENGE.

* DESIGN CRITERIA + *SAFETY PRINCIPLES AND PHILOSOPHY + RADIATION, PUBLIC EDUCATION/ACCEPTANCE

1-10337 LONGSON B

THE HYDROGEN EMBRITTLEMENT OF NIOBIUM

UNITED KINGDOM ATOMIC ENERGY AUTHORITY, CULCHETH

TRG-REPORT-1035 +. 40 PAGES, 37 FIGURES, 2 TABLES, RFFERENCES, JULY 27,1965, UKAEA

HYDROGEN IN SOLIO SOLUTION EMBRITTLEC NIOBIUM IN THE TEMPERATURE RANGE - 196 TO $400 C$ SUSCEPTIBILITY TO EMBRITTLEMENT WAS NOT STRAIN-RATE DEPENDENT AT ROOM TEMPERATURE, BUT, AT THE TEMPERATURES INVESTIGATED, SUSCEPTIBILITY WAS INCREASED BY INCREASED OXYGEN CONTENT IROOM TEMPERATURE TO 400C), INCREASED GRAIN SIZE (ROOM TEMPERATURE TO 2ODC), AND BY COLO WORKINC (ROOM TEMPERATURE TO $100 \mathrm{C}$ ). A HYDRIDE PHASE, FORMED BY A SHEAR PQOCESS ACCOMPANIED BY HYDROGEN DIFFUSION, WAS FOUND FROM - 74C TO ABOUT 2OOC. THE ACTIVATION ENERSY OF BOTH EMBRITTLEMENT AND HYDRIDE FORMATION WAS 3 KCAL PER GRAM-ATOM FOR A GRAIN SIZE OF O.OOZ2 CM AND WAS GRAIN-SIZE DEPENDENT.

*EMBRITTLEMENT + *HYDROGEN + \#NIOBIUM + CHEMICAL REACTION + HYDRIDE

1-10409 PETRENKO LI + SAVITSKII PS + SINITSIN VI + KOLOTYRKIN YM + SYRKUS NP + ROMM RF THE USES OF RADIOACTIVE ISOTOPES AND NUCLEAR RADIATION IN THE U.S.S.R. PROCFEDINGS DF THE ALL-UNION CONFERENCE HELD IN RIGA, 12-16 APRIL 1960. VOLUME ONE. GENERAL PROBLEMS CONNECTEO WITH THE UISE OF 1SUTOPES. DEVICES INCORPORATING RAOIOACTIVE OIL INDUSIRIES

AEC-TR-6466-1 + CONF-600 402 (VOL I) +. 339 PAGES, FIGURES, TABLES, 1961, CFSTI, \$7.00 CY

AN ALL-UNION CONFERENCE WAS HELD IN RIGA IN 1960 DN THE USES OF RADIOACTIVE ISOTOPES AND NUCLEAR RADIATION IN THE U.S.S.R. PROCEEDINGS WERE REPORTED IN FOUR VOLUMES. THIS ONE IVOL. 1) INCLUDES GENERAL PROBLEMS CONNECTED HITH THE USE OF ISOTOPES $(6$ PAPERS), DEVICES INCORPORATING RADIOACTIVE SOURCES (17 PAPERS), RADIATION CHEMISTRY (13 PAPEPS), AND CHEMICAL AND OII. INDUSTRIFS 114 PAPFRSI. NO BIRL IOGRAPHY OR REFERFNC.FS ARE GIVEN.

\#RADIOISOTOPE + ECONOMIC STUDY + INSTRUMENTATION, GENERAL + RADIOCHEMICAL PROCESSING + SOURCF, RADIATION + UNION OF SOVIET SOCIALIST REPUBLICS

1-10525 BUCHANAN JR A HUTTON TC

ANALYSIS AND AUTOMATED HANDL ING OF TECHNICAL INFORMATION AT THE NUCLEAR SAFETY INFORMATION CENTER OAK RIDGE NATIONAL LABORATORY + OAK RIDGE GASEOUS DIFFUSION PLANT, UNION CARBIDE

TID-22972 +. 14 PAGES, I FIGURE, 3 TABLES, 15 REFERENCES, JUNE 1966, PP. $29-43$ OF INFORMATION FOR NUCLFAR

TECHNOLOGY, PANEL DISCUSSION, PRESENTED AT ANS ANNUAL MEETING, JUNE 20-23, 1966, DENVER, COLORADO

THE NUCLEAR SAFETY INFORMATION CENTER SERVES THE NUCLEAR COMMUNITY BY COLLECTING, STORING, EVALUATING AND DISSEMINATING SAFETY INFORMATION RELEVANT TO THE DESIGN AND OPERATION OF NUCLEAR FACILITIES. IN 1964 AFTER ABOUT A YEAR OF OPERATION, THE INFORMATION HANOLING SYSTEM WAS COMPUTERIZED IN ORDER TO BROADLY INCREASE THE SCOPE OF THE CENTERS SERVICES AND ENABLE IT TO EFFICIENTLY FUNCTION IN THE FUTURE. COMPUTER PROGRAMS HAVE BEEN DEVELOPED FOR THE

PREPARATION OF A BIBLIOGRAPHY, COMPLETE WITH KEYWOROS AND PERSONAL AUTHOR INOEXES, THAT IS ISSUED QUARTERLY AND FOR A PROGRAM OF SELECTIVE DISSEMINATION OF INFORMATION (SDI) THAT IS PRODUCED ON 5- BY B-IN CARDS. THESE PROGRAMS AND OTHER SERVICES DF THE CENTER ARE DISCUSSED.

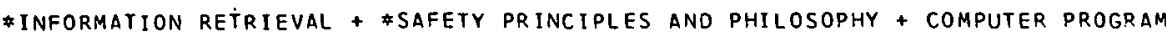

1-10565 SMITH CB

UCLA REQUESTS RE-EVALUATION OF REQUEST TO ALLOW VISITORS OPERATE REACTOR DURING OPEN HOUSE

UNIVERSITY OF CALIFORNIA, LOS ANGELES, CALIFORNIA

2 PAGES, JUNE 13,1966 , DOCKET 50-142, ATOMIC ENERGY CLEARING HOUSE, 12(27), PAGES 23-24, (JULY 4, 1966)

UCLA REQUESTS THAT AEC ALLOW VISITORS TO PUSH REACTOR CONTROL BUTTONS UNOER CLOSE SUPERVISION

ACCESSION NUMBER 1-10310 TO 1-10565 
CATEGORY

GENERAL SAFETY CRITERIA

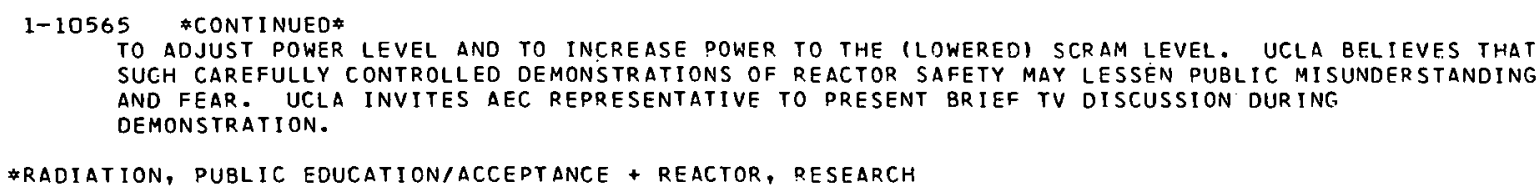

1-10619 BRUNA JG + BRUNET JP + CAIZERGUES R + CLOUET D ORVAL C + KREMSER J + TELLIER H + VERRIERE P ALECTO - RESULTS OBTAINED WITH HOMOGENEOUS CRITICAL EXPERIMENTS ON PLUTONIUM 239 , URANIUM 235 ANO URANIUM 233

COMMISSARIAT A L ENERGIE ATOMIGUE, FRANCE, CENTRE D ETUDES NUCLEAIRES, SACLAY

CEA-R-2814 †. 130 PAGES, 37 FIGURES, 24 TABLES, OCTOBER 1965, DEP. MN

IN THIS REPORT ARE GIVEN THE RESULTS OF THF HOMOGENEOUS CRITICALITY EXPERIMENTS ALECTO, MADE ON PLUTONIUM-239, URANIUM-235 AND URANIUM-233. AFTER A BRIEF DESCRIPTION OF THE EQUIPMENT, THE CRITICAL MASSES FOR CYLINDERS OF DIAMETERS VARYING FROM 25 TO 42 CM ARE GIVEN AND COMPARED WITH OTHER VALUES (FOREIGN RESULTS, CRITICALITY GUIDEI. EXPERIMENTS. RELATING TO CROSS SECTIONS AND CONSTANTS TO PE USED ON THESE MATERIALS ARE PRESENTED. LASTLY, KINETIC EXPERIMENTS ALLOW ONE TO COMPARE PULSED-NEUTRON METHODS WITH FLUCTUATION METHODS.

* CRITICALITY EXPERIMENT + CRITICALITY SAFETY + NOISE ANALYSIS + PLUTONIUM + PULSED NEUTRON TECHNIQUE + URANIUM

1-10656 MALAKHOF $V+$ SIMON W

CRITICALITY OF FUEL REPROCESSING EQUIPMENT

GENERAL ATOMIC

GAMD-6623 +. 20 PAGES, AUGUST 17,1965 , CFSTI, $\$ 1.00 \mathrm{CY}, \$ 0.50 \mathrm{MN}$

A STUDY OF THE CRITICALITY OF FUEL-PARTICLE STORAGE CONTAINERS AND OF ARRAYS OF SUCH

CONTAINERS WAS CARRIED OUT THE OBJECTIVE WAS TO COMPUTE THE MULTIPLICATION FACTOR AS A

FUNCTION OF LENGTH AND DI.AMETER FOR CYLINDRICAL CONTAINERS AND TO COMPUTE MASS LIMITS FOR

VARIOUS KINDS DF FUEL PARTICLES THAT HAVE BEEN COATED WITH PYROLYTIC CARBON.

\#CARBON + \#CRITICALITY SAFETY + \#PYROLYTIC + \#URANIUM + COMPUTER, DIGITAL + THORIUM

1-10687 PAXTON HC

THE CRISIS IN CRITICALITY

2 PAGES, NUCLEAR NEWS $9(8)-27-28$ (AUGUST 1966)

REAASON FOR NATIONAL TOPICAL ANS MEFTING ON CRITICALITY SAFETY, LAS VEGAS, DETEMBER 13-15,

1966: MAINLY TO BRING INDUSTRY INTO DISCUSSION WITH AEC AND ITS CONTRACTORS AND TO RESOLVE

THE DOUBLE STANDARD OF REGULATION WHICH REGULATES LICENSEES AND AEC PRODUCTION PLANTS

DIFFERENTLY.

\#CRITICALITY SAFETY + \#REGULATION, AEC

1-10695 LONG JK + MCVEAM RL + REYNOLOS AB + STEWART SL + WEITZBERG A + LERIDONA

CRITICAL MASS OF SEFOR MOCKUP IN ZPR-III

ARGONNE NATIONAL LABORATORY, IDAHO FALLS, IDAHO + GENERAL ELECTRIC COMPANY, SAN JOSE, CALIFORNIA + CENTRE D ETUDES NUCLEAIRES DE CADARACHE, FRANCE

2 PAGES, 1 Figure, I TABLE, 12 ReferenCES, NUCLEAR SCIENCE AND ENGINEERING 25 (4)- $442-443$ (1966)

CRITICALITY OF THE MOCKUP OF THE SOUTHWEST EXPERIMENTAL FAST OXIDE REACTOR (SEFOR) IN THE ZPR-III FACILITY WAS ACHIEVED NOVEMBER 17, 1965. THE NEUTRON SPECTRUM AND

URANIUM-TO-PLUTONIUM RATIO OF THIS ALL-PLUTONIUM CRITICAL. IS CHARACTERISTIC OF LARGE, FAST, CERAMIC POWER REACTORS. THE CRITICAL LOADING WAS THE FIRST IN A SERIES OF EXPERIMENTS.

* SEFOR (SOUTHWEST EXP. FAST OXIDE REACTOR) + CRITICAL ASSEMBLY FACILIT.Y + CRITICALITY EXPERIMENT + REACTOR, BREEOER + REACTOR, FAST + ZPR III (ANL ZERO POWER REACTOR)

1-10703 CLARK HK

CRITICAL AND SAFE MASSES AND OIMENSIONS OF LATTICES OF U AND UO2 RODS IN WATER

SAVANNAH RIVER LABORATORY, AIKEN, SOUTH CAROLINA

DP-1014 + CONF-651103-29 +. 60 PAGES, 1 FIGURE, 8 TABLES, 11 REFERENCES, FEBRUARY 1966, CFSTI, \$3.OO CY, $\$ 0.75 \mathrm{MN}$

A SURVEY IS GIVEN OF CRITICAL AND EXPONENTIAL DATA OBTAINED WITH WATER-REFLECTED LATTICES OF 
2-09680 KOUTS HJ

SITE SELECTION IN RELATION TO ENGINEERED SAFEgUARDS. AN AMERICAN VIEW

BROOKHAVEN NATIONAL. LABORATORY

BNL-10137 + CONF-660312-3+. 15 PAGES, APRIL, 1966, ATOOMFORUN CONFERENTIE, UTRFCHT, MARCH 2-28, 1966, CFSTI, \$1.00 FS, $\$ 0.50 \mathrm{MN}$

THE AUTHOR DESCRIBES THE EVOLUTION OF THE EVALUATION OF REACTOR SITES IN THE UNITED STATES AND GIVES A PERSONAL VIEW OF SOME OF THE TRENDS.

\#SITING, GENERAL + UNITED STATES

2-09851 COUSINS $N$

REMARKS BY NORMAN COUSINS EOITOR, SATURDAY REVIEW AT THE SYMPOSIUM ON LOCATING NUCLEAR POWER PLANTS IN CITIES.

5 PAGES, PRESENTED AT THE ANS SYMPOSIUM ON LOCATING NUCLEAR POWER PLANTS IN CITIES, MARCH 22 , 1966 , NEW YORK CITY

LAYMANS VIEW AT THE SAFETy OF NUCLEAR PLANTS (AUTHOR IS EDITOR OF SATURDAY REVIEW). THE PAPER IS VERY GENERAL.

*SITING, REACTOR

2-09852 RENGEL JC

SAFETY RELATED ASPECTS OF LOCATING NUCLEAR POWER PLANTS IN CITIES

WESTINGHOUSE ELECTRIC CORPORATION, PITTSBURGH, ATOMIC POWER DIV.

5 PAGES, PRESENTED AT THE ANS SYMPOSIUM ON LOCATING NUCLEAR POWER PLANTS IN CITIES, MAPCH 22, 1966 , NEW YORK CITY

PUTS RELIABILITY AND ACCIDENT-PREVENTION SAFEGUARDS AHEAD OF CONSEOUENCE-LIMITING SAFEGUARDS. RELIABILITY ENSURED BY DESIGN, INTEGRITY OF MANUFACTURER, INSPECTION, TEST, AND OPERATION CRITER IA FOR URBAN SITING.

* SITING, REACTOR + CODES AND STANDARDS + DESIGN CRITERIA + ENGINEERED SAFEGUARD

2-09853 PIERATTI A

AIR POLLUTION FROM CENTRAL POWER PLANTS

NEW YORK OPERATIONS OFFICE

7 PAGES, PRESENTED AT THE ANS SYMPOSIUM ON LOCATING NUCLEAR POWER PLANTS IN CITIES, MARCH 22 , 1966 , NEH YORK CITY

AIR POLLUTANTS AND THEIR SOURCES. SULFUR DIOXIDE MOST GASEOUS AND DESTRUCTIVE. BITUMINOUS

COAL AND NUMBER-6 FUEL OIL MOST IMPORTANT SOURCES OF SULFUR DIOXIDE, MOSTLY IN UTILITY

PLANTS. ALTERNATIVES - USE NATURAL GAS, MINE-MOUTH PLANTS, OR HYDROELECTRICITY.

*atmospreric pOLLUTiOn + sulfur

2-09855 BECK CK

CURRENT TRENDS AND PERSPECTIVES IN REACTOR LOCATION AND SAFETY REQUIREMENTS

U. S. ATOMIC ENERGY COMMISSION, WASHINGTON

14 PAGES, PRESENTED AT THE ANS SYMPOSIUM ON LOCATING NUCLEAR POWER PLANTS IN CITIES, MARCH 22 , 1966 , NEW YORK CITY

SAFETY RECORD OF NUCLEAR PLANTS. HIGH STANDARDS. ACCIDENT PREVENTION AND

CONSEQUENCE-LIMITING SAFEGUARDS. MCA ANALYSIS. ISOLATED SITES. RFVIEWS BY EXPERTS.

INCREASE IN FISSION INVENTORY. STANDAROIZATION. TREND TOWARD MORE CENTRAL LOCATION.

REQUIREMENTS FOR LESS-ISOLATED LOCATION - HIGH STANDARDS, DEFINITION OF TECHNICAL AREAS OF

UNCERTAINTY, ESTABLISHMENT OF ADEQUACY OF SAFEGUARD SYSTEM, SUFFICIENT EXPERIENCE. THESE

REQUIREMENTS HAVE NOT YET BEEN FULLY MET.

* SITING, REACTOR + ACCIDENT, MAXIMUM CREDIBLE (MCA) + ACCIDENT, PROBABILITY OF + ENGINEERED SAFEGUARD + REgULATION, AEC + REVIEW + SAFETY PRINCIPLES AND PHILOSOPHY

2-09856 CAHILL WJ

REMARKS BY WILLIAM J. CAHILL, JR. MECHANICAL PLANT ENGINEER CONSOLIDATED EDISON COMPANY OF NEW YORK, INC. AT THE SYMPOSIUM ON LOCATING NUCLEAP. POWER PLANTS IN CITIES, AMERICAN NUCLEAR SOCIETY, MARCH 22 , I966 CONSOLICATED EDISON COMPANY, NEW YORK

2 PAGES, PRESENTED AT THE ANS SYMPOSIUM ON LOCATING NUCLEAR POWER PLANTS IN CITIES, MARCH 22 , I966

BRIEF DESCRIPTION OF ENGINEERED SAFEGUAROS, SITES, LICENSING EXPERIENCE, ANO PUBLIC ACCEPTANCS

OF INDIAN POINT 1 AND 2 , AND RAVENSWOOD.

*INDIAN POINI I + \#INDIAN POINT II + \#RAVENSWOOD + \#SITING, REACTOR + ENGINEERED SAFEGUARD + REACTOR, PRESSURIZEO WATER + REGULATION, AEC

2-09857 CRAWFORD WD

REMARKS BY W. DONHAM CRAWFORO, VICE PRESIDENT, CONSOLIDATED EDISON COMPANY, AT A SYMPOSIUM. ON LOCATING NUCLEAR POWER PLANTS IN CITIES, SPONSORED BY THE METROPOLITAN SECTION OF THE AMERICAN NUCLEAR SOCIETY, MARCH 22, 1966 
CATEGORY 2

SITING OF NUCLEAR FACILITIES

2-09857 \#CONTINUED*

CONSOL IDATED EDISON COMPANY, NEW YORK

4 PAGES, PRESENTED AT THE ANS SYMPOSIUM ON LOCATING NUCLEAP. POWER PLANTS IN CITIES, MARCH 22 , I966, NEW YORK CITY

ACVANTAGES OF SITING OF NUCLEAR PLANTS IN POPULATED CENTERS - LOW AIR POLLUTION, RELIABLE FUEL SUPPLY, SHORT TRANSMISSION, STEAM FROM PLANTS MAY SE USED, ECONOMIC ADVANTAGES. LICENSING EXPERIENCE HITH RAVENSWOOD AND INDIAN POINT NO. 2

* INDIAN POINT I + *INDIAN POINT II + *SITING, REACTOR + ECONOMICS + RAVENSWOOD + REACTOR, PRESSURIZED HATER

2-09858 STOLLER SM

ECONOMIC CONSIDERATIONS OF URRAN SITING

S. M. STOLLER ASSOCIATES

3 PAGES, PRESENTED AT THE ANS SYMPOSIUM ON LOCATING NUCLEAR POMER PLANTS IN CITIES, MARCH 22 , 1966 , NeW YORK CITY

HISTORY OF POMER COHPANIES MOST CONVENTIONAL PLANTS CLOSER TO LOADS THAN SITING GUIDF HOIJLD PERMIT FOR NUCLEAR PLANTS. TREND TOYARO MANY CONVENTIONAL PLANTS BETHEEN LOAD CENTERS OR TO MINE MOUTH. COST OF LOCATING NUCLEAR. OLANT WITHIN SITING GUIDES RATHER THAN MOST ECONOMICALLY, S10-15 PER KILOWATT. TAX REVENUE TO CITIES. AIP POLLUTION VERSUS COST OF SAFEGUARDS. RELIABILITY MUST BE GREATER IN URSAN LOCATION.

- ECONOMICS + "SITING, REACTOR + ATMOSPHERIC POLLUTION + POHER DISTRIBUTION

2-11014 BRITTAN RO

REACTOR CONTAINMENT AND ENVIRONMENTAL CONDITIONS

ARGONNE NATIONAL LABORATORY, ILL.

2 PAGES, PROCEEDINGS OF THE AMERICAN SOCIETY OF CIVIL ENGINEERS, 92(UP1), PAGES 81-82 (MAY, 1966)

THE CONCLUDING DISCUSSION FOR DAPER ON REACTOR CONTAINMENT BY R. O. BRITTAN THAT ARPEARED IN SEPTEMBER 1964 IS PRESENTED. THE INFLUENCE OF SAFEGUARDS ON POPULATION DISTANCE IS BPIEFLY TREATED. ELEVEN ITEMS OF ERRATA FOR THE ORIGINAL PAPER ARE ALSO GIVEN.

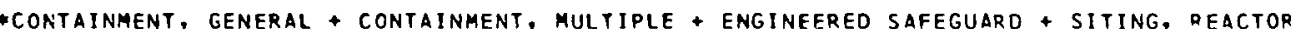

2-11091 ELLMER M

SITE SELECTION

2 PAGES, ATOMHIRTSCMAFT, 10(11), PAGES 567-568 (NOVEMBER 1965), IN GERMAN

FOR THE POWER PLANT RWE-BAYERNWERK (KRB), THE MOST FAVORABLE SITE ORIGINALLY SEEMED TO BE ONE NEAR BERTOLDSHEIM. HOWEVER, THE WATER AUTHORITIES REJECTED IT FOR TECHNICAL AND EMOTIONAL-POLITICAL REASONS, ALTHOUGH ATTEMPTS WERE MADE TO DEMONSTRATE THAT DRINKING HATER AND NUCLEAR POHER ARE NOT MUTUALLY EXCLUSIVE. THE ATOMIC PLANT WILL BE BUILT IN

GUNDREMMINGFN. A METEOROLOGICAL IUWER $118 \mathrm{M}$ HIGH WILL BE ERECTED. A SMALLER DESICN OF THE PLANT WAS REQUIRED. WE STUDIED THE COOLING-WATER REMOVAL AND RECYCLE TO FIND THE OPIIMUM COMPROMISE BETWEEN WATER ECONOMY ANO ENERGY ECONOMY.

"EERMANY + METEOROLOGY + WATER POLLUTION I HATER, DRINKIHG

2-11154 BLAINE RA

REACTOR KINETICS AND REACTOR SAFETY STUDIES

ATOMICS INTERNATIONAL, CANOGA PARY

NAA-SR-MEMO-9837 +. 32 PAGES, REFERENCES, APRIL 24, 1964, CFSTI 52.00 CY

THE GOALS AND ACCOMPLISHMENTS IN REACTOR KINETICS AND REACTOR SAFETY STUDIES OF THE ATOMICS INTERNATIONAL REACTOR SAFETY PROGRAM DRF RFVIEWED. PHESENT UIRFCTIONS AND FUTURE REQUIREMENTS ARE PRESENTED. SUBJECTS RELEVANT TO NUCLEAR SAFETY INCLUDE - AIPEK. EDUATIONS, NOISE ANALYSIS, POISON MIXTURES TO ENHANCE REACTOR SAFETY, BUBBLE GRONTH, MULTICHANNEL FLOH STABILITY, REACTOR SITING, SPACE-DEPENDENT KINETICS, AND MULTIREGION-MULTIGROUD KINETICS.

* REACTOR DYNAMICS + * SITING, REACTOR + HYDRAULIC ANALYSIS + KEHB IKINETIC EXPERIMENT ON WATER BOILERSI + NOISE ANALYSIS + POISON, SOLUBLE + REACTOR, HOMOGENEOUS + REACTOR, RESEARCH + SPACE DEPENDENT DYNAMICS + THERMAL ANALYSIS * VOID COEFFICIENT

2-11152 BLAINE RA + JARRETT AA

AN EXAMPLE OF THE APPLICATION OF A DIGITAL COMPUTER PROGRAM FOR REACTOR SITING HAZARD EVALUATION ATOMICS INTERNATIONAL, CANOGA PARK

NAA-SR-MFMO-10290 +. 68 PAGES, AUGUST 17,1964 , CFST1 $\$ 5.00 \mathrm{CY}$

A DIGITAL COMPUTER PROGRAM FOR REACTOR SITING HAZARO EVALUATION - DARAMETRIC STUDIES OF EFFECT OF DESIGN VARIABLES IOR ENGINEERED SAFEGUARD MALFUNCTIONSI ON RADIOLOGICAL PERIL TO THE ENVIRONMENT. C.OMPUTER PROGRAM AISITE II (WITH SUPERSCRIPI ASTERISK) WAS USED TO CALCULATF ENYIRONMENTAL RADIATION DOSES AND USAEC REACTOR SITING CRITERIA, IO CFR 1ON, RESULIING FROM ASSUMED ACCIDENT IN SODJUM-COOLED REACTOR. GRAPHICAL OUTPUTS OF TYPICAL PAPAMETRIC SURVEYS HERE MADE TO DISPLAY DOSE VERSUS DISTANCE BY SPECIFIC ORGAN OR SPECIFIED CRITICAL DISTANCES VERSUS VARIABLE PARAMETER.

*COMPUTER, DIGITAL + *SITING, REACTOR + DOSE CALCULATION, EXTERNAL + DOSE CALCULATION, INTEPNAL + ENGINEERED SAFEGUARD + SODIUM 
CATEGORY

3

TRANSPORTATION AND HANDL ING OF RAOIOACTIVE MATERIALS

3-G8719 MORGAN K2

PRESENT STATUS OF RECOMMENDATIONS OF THE INTERNATIONAL COMMISSION ON RADIOLOGICAL PROTECTION, NATIONAL COUNCIL ON RADIATION PROTECTION ANO FEDERAL RADIATION COUNCIL

DAK RIDGE NATIONAL LABORATORY

32 PAGES, TABLES, 35 REFERENCES, JUNE 14, 1965, PUBLISHED IN PROGRESS IN NUCLEAR FNERGY SERIES XII, VOL. 2. PERGAMON PRESS, LONDON

THE HISTORICAL BACKGPOUNDS OF THE INTERNATIONAL COMMISSION ON RADIOLOGICAL PROTECTION (ICRPI, THE NATIONAL COUNCIL ON RADIATION PROTECTION (NCRP) AND THE FEDERAL RADIATION COUNCIL IFRCI ARE DISCUSSED AS WELL AS MANY CURRENT RECDMMENDATIONS MADE BY THESE ORGANIZATIONS AS IHEY APPLY TO RADIATION PROTECTION IN MAN. THIS INCLUDES WORKERS IN THE RADIATION INDUSTRY, BUT ALSO THE POPULATION AT LARGE.

\#RADIATION PROTECTION, ORGANIZATION + PERSONNEL EXPOSURE, RAOIATION + RADIATION IN PERSPECTIVE + RADIATION SAFETY AND CONTROL

3-1005E MALLETT AJ + WHEATLEY SJ

FISSILE-MATERIAL CONTAINER AND PACKAGING DEVELOPMENT AND TESTING PROGRAM UNION CARBIDE CORPORATION, OAK RIDGE, ORGDP

K-1661 +. 41 PAGES, 10 FIGURES, APRIL 1966, CFSTI, $\$ 2.00 \mathrm{CY}, \$ 0.50 \mathrm{MN}$

PRESSURE TESTS (400 PSIG) WERE MADE ON THE 5-, 8-, 12-, AND 30-IN.-DIAM URANIUM HEXAFLUORIDE CYLINDERS. IN ADOITION, SIMILAR CONTAINERS HERE SUBJECTEO TO DROP TESTS FROM HEIGHTS OF 4 AND $30 \mathrm{FT}$. TO OBTAIN AODITIONAL STRUCTURAL DATA, A 30-IN.-DIAM CYLINOER WAS MOUNTED ON A QUARTER-SCALE-MODEL TRUCK BED AND DROPPED FROM VARIOUS HEIGHTS TO SIMULATE COLLISIONS. VARIOUS TIEDOWN COMPONENTS WERE ASSESSED. IN RELATED COMPONENT ASSESSMENT, A FOAM PLASTIC THAT HAS EXCELLENT SHOCK ABSORPTION, INSULATING, AND NEUTRON ATTENUATING PROPERTIES WAS DEVELOPED AT ORGDP AND TESTED. IT APPEARS SUPERIOR TO MANY OTHERS USED IN THESE APPLICATIONS.

* ACCIDENT ANALYSIS + *SHIPPING CONTAINER + \#TRANSPORTATION AND HANDLING + *URANIUM HEXAFLUORIDE

3-10308 SPALLER AE + SHOBE LR

STRUCTURAL ANALYSIS OF SHIPPING CASKS VOL. I. ANALYSIS OF A SHIPPING CASK SUBJECTED TO INTERNAL PRESSURE OAK RIDGE NATIONAL LABORATORY, OAK RIDGE

ORNL-TM-1312 +. 58 PAGES, 19 FIGURES, 9 TABLES, MARCH 1966, CFSTI, \$3.CO CY, \$0.75 MN

FORMULAS TO BE USED BY THE DESIGN ENGINEER TO CALCULATE THE MAXIMUM STRESS PRODUCED IN A CASK USED TO SHIP RADIOACTIVE MATERIALS WHEN IT IS SUBJECTED TO INTERNAL PRESSURE ARE PRESENTED. THE FORMULAS WERE DEVELOPED FOR USE AS A GUIDE TO INDICATE COMPLIANCE WITH THE PROPOSED AEC REGULATION PERTAINING TO THE DESIGN REQUIREMENT FOR RESISTANCE TO INTERNAL PRESSURE. HOWEVER, USE OF THESE FORMULAS, WHICH TAKE INTO ACCOUNT THE ELASTIC NATURE OF THE LEAD SHIELDING, ARE DERIVED TO DETERMINE THE THICKNESS OF THE CAVITY WALL FOR CASKS OF BOTH PRISMATIC AND CYLINDRICAL CONFIGURATION, THE FORMULAS ARE TABULATED, AND EXAMPLE PROBLEMS ARE GIVEN. CREEP OF THE LEAD SHIELD IS EVALUATED, AND IT IS CONCLUDED THAT THE CREEP PROBLEM TENDS TO BE SELF-ALLEVIATING.

*PRESSURE, INTERNAL + \#SHIPPING CONTAINER + \#STRESS ANALYSIS + \#IRANSPORTATION AND HANDLING

3-10309 SALMON R

ESTIMATION OF FUEL-SHIPPING COSTS FOR NUCLEAR POWER COST-EVALUATION PURPOSES OAK RIDGE NAIIONAL LABORATORY, OAK RIDGE

ORNL-3943 +. 67 PAGES, 23 FIGURES, 9 TABLES, 23 REFERENCES, MARCH 1966, CFSTI \$3.00 CY, \$O.75 MN

THE AEC GUIDE TO NUCLEAR POWER COST EVALUATION, TID-7O25 (MARCH 1962), SUGGESTED THAT COSTS OF $\$ 3$ PER KG U FOR FRESH FUELS AND \$16 PER KG U FOR SPENT FUELS BE USED FOR EVALUATION PURPOSES. THE WORK REPORTED HERE IS AN ATTEMPT TO PROVIDE A MORE DETAILED BASIS FOR SHIPPING-COST ESTIMATION, SO THAT DIFFERENCES INHERENT IN THE REACTOR AND FUEL ASSEMBLY DESIGN MAY RE ACCOUNTED FOR. THE METHODS PRESENTED FOLLOW GENERALLY THE APPROACH USED BY THE AUTHOR IN COMPUTER CODES MYRA AND NORA. THE MAJOR NEW FEATURES ARE THAT II) OESIGN CHARTS BASED ON. DATA CORRELATIONS ARE USED AS A MEANS OF ARRIVING AT AN APPROXIMATE CASK DESIGN, WHEREAS THE PREVIOUS WORK DEPENDED ON THE USE OF COMPUTER CODES, (2) THE SCOPE OF THE WORK HAS BEEN ENLARGED TO COVER THE SHIPMENT OF FRESH FUELS, INCLUDING THOSE CONTAINING GAMMA-ACTIVE RECYCLED MATERIALS, AND (3) A SECTION ON THE SHIPMENT OF CERTAIN FUEL C.HEMICALS HAS BEEN ADDED. RECENT CHANGES IN SHIPPING REGULATIONS (DECEMBER 1965) GOVERNING CASK DESIGN HAVE ALSO BEEN TAKEN INTO ACCOUNT. THIS REPORT WILL PROVIDE A RAPID MEANS OF ESTIMATING FUEL SHIPPING COSTS.FOR THOSE HHO DO NOT HAVE ACCESS TO THE COMPUTER CODES MENTIONED.

*ECONOMIC STUDY + \#TRANSPORTATION AND HANDLING + DESIGN STUOY + HEAT TRANSFER + SHIPPING CONTAINER

3-10310 SHAW AE

THE SAFE TRANSPORT OF RADIOACTIVE MATERIALS. A KEY TO THE 1964 REVISION OF THE INTERNATIONAL ATOMIC ENERGY AGENCYS REGULATIONS

UNITED KINGDOM ATOMIC ENERGY AUTHORITY, RISLEY

TRG-1073 (D) +. 21 PAGES, 1 FIGURE, 4 TABLES, JULY 1965, BIS, \$0.70 CY

A KEYED INOEX TO HELP THE DAY-TO-DAY USER OF THE INTERNATIONAL ATOMIC ENERGY AGENCY DOCUMENT REGULATIONS FOR THE SAFE TRANSPORT OF RADIOACTIVE MATERIALS 11964 REVISION OF MAY 1961 REGULATIONS). IF IT IS KNOWN WHAT RADIOACTIVE MATERIAL HAS TO BE TRANSPORTED (IN TERMS OF ELEMENT, I SOTOPE, ITS TOTAL AND SPECIFIC ACTIVITIES ITS CHEMICAL AND PHYSICAL FORM, AND DETAILS OF THE PACKAGE TYPE ALONG WITH SURFACE CONTAMINATION AND EXTERNAL RADIATION DOSE-RATE MEASUREMENTSI, STEP-BY-STEP USE OF THE KEY WILL INDICATE THE CORRECT PROCEDURE. THIS KEY DOES NOT AVOID THE NEED YO UNDERSTANO THE DETAIL OF THE IAEA DOCUMENT BUT IS INTENOED AS A 
CATEGORY

3

TRANSPORTATION AND HANDLING OF RADIOACTIVE MATERIALS

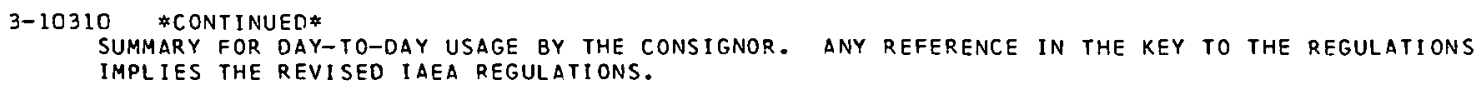

*REGULATION, IAEA + *SHIPPING CONTAINER + \#TRANSPORTATION AND HANDL ING

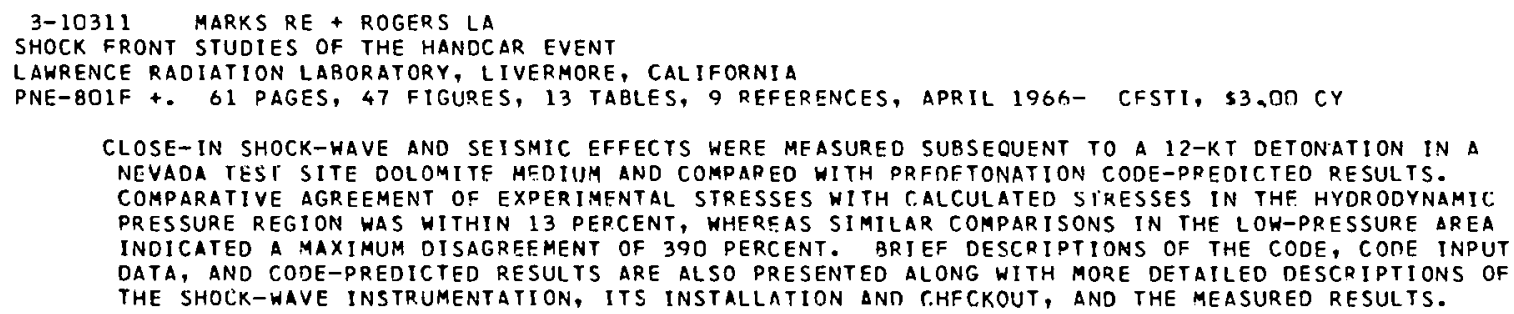

3-10807 AEC REVISES REGULATIONS ON TRANSPORT OF RADIOACTIVE MATERIAL

U. S. ATOMIC ENERGY COMMISSION

PRESS REL. NO, J-178 +2 PAGES, JULY 21,1066, DPI

THE AEC APPROVED A REVISION OF ITS REGULATTONS ON THE SAFE TRANSPORTATION OF LICENSED RADIOACTIVE MATERIAL. IT IS REPORTED IN THE CODE OF FEDERAL REGULATIONS, TITLE ID PART 71. THE STANDAROS INCLUDE A MINIMUM OF DETAIL ON REOUIRED PACKAGING SPECIFICATTONS. EMPHASIS HAS PLACED ON PERFormanCE STANDARDS TO PROVIDE THE NEEDED FLEXIBILITY TO DEVELOP IMPROVED SHIPPING METHOOS. THE PERFORMANCE STANDARDS ARE COMPATIBLE WITH THOSE DEVELOPED BY THE INTERNATIONAL ATOMIC. ENERGY AGENCY DURING THE PAST FEW YEARS, BUT THIS NFW VERSION MUST BE USED IN CONJUNCTION WITH ORDER NO. TO OF THE ICC.

*REgULATION, AEC + *SHIPPING CONTAINER + *TRANSPORTATION AND HANDLING + FUEL HANOLING

3-10808 DUGAN FA

BROOKHAVEN EXPER IENCE HITH HANDLING AND SHIPPING OF, AND CASK DESIGN FOP, REACTOR SPENT-FUEL ELEMENTS BROOKHAVEN NATIONAL LABORATORY

CONF-651-110-22 + 65-HA/NE-7 +. 7 PAGES, 7 FIGURES, 3 REFERENCES, PRESENTED AT AMERICAN SOCIEIY CF MECHANICAL ENGINEERS WINTER MEETING, CHICAGO, ILL., NOVEMBFR 7-11, 1965, SOURCE, \$1.50 CY

THE GFNERAL PROBLEMS OF HANDLING, SHIPPING, AND DESIGNING SPENT-FUEL SHIPPING CASKS .ARE PRESENTED. SOLUTIONS TO SPECIFIC PROBLEMS A'T BROOKHAVEN ARE DISCUSSED IN RELATION TO THF GENERAL PROBLEM. PRESENTATION COVERS (A) CANAL STORAGE FACILITIES, (BI METHODS OF SHIPMENT, (C) BRIEF REVIEW OF THE AEC AND ICC REGULATORY REQUIREMENTS, (D) OPTIMIZED DESIGN OF THE SHIPPING CONTAINER. SPECIFIC SOLUTIONS USED BY BNL OVER A SIX-YEAR PERIOD ARE DESCRIBED. THE NEED FOR COMPLETE AND EARLY ANALYSIS OF THE SPECIFIC PROBLEM IS INDICATEO.

DESIGN STUDY + FUEL STORAGE + REGULATION, AEC + SHIPPING CONTAINER + TRANSPORTATION AND HANOLING

3-10839 A SUMMARY OF INCIDENTS INVOLVING USAEC SHIPMENTS OF RADIOACTIVE MATERIAL, 1963-1964 DIVISION OF OPERATIONAL SAFETY, USAEC

TID-16764 (SUPPL. 2) +. 23 PAGES, 8 TARLES, APRIL, 1966, GP0, $\$ 0.20$

THIS SUMMARY WAS PREPARED TO PRESENT INFORMATION PERTAINING TO INCIDENTS SUSTAINED BY THE AEC IN THE TRANSPORTATION OF RADIOACTIVE MATERIALS, COVERING THE PERIOD FROM JANUARY I, 1963, THROUGH DECEMBER 31, 1964. IN THE PEPIOD COVERED BY THIS REPORT, THERE WERE TWFNTY-FOUR INCIDENTS REPORTED. THIRTSEN OF THE TWENTY FOUR INCIDENTS DID NOT RESULT IN RELEASE OF RADIOACTIVE MATERIALS. OF THE REMAINING ELEVEN, WHICH DID INVOLVE RADIATION RELFASES, SIX WERE LIMITED TO THE CARRIER VEHICLE AND ONLY ONE INVOLVED COSTLY CLEANUP. OF THE THENTY-FOUR INCIDENTS REPORTED, ONLY ONE INVOLVED IMPACT DAMAGE TO THE SHIPPING CONTAINER, WHILE THE VEHICLES INVOLVED SUFFERED DAMAGF RANGING. FROM NONE TO TOTAL DESTRUCTION.

* ACCIUENT, CUNSEQUENCES + tTRANSPORTATION AND HANRLING + RADIOACTIVITY, RELEASE + SHIPPING CONTAINER 
CATEGORY

3

TRANSPORTATION AND HANDLING OF RADIOACTIVE MATERIALS

3-10840 CLARKE HG + DOSHI KD

STRUCTURAL INTEGRITY OF SHIPPING CONTAINERS FOR RADIOACTIVE MATERIALS. PART III. ANALYSIS OF CONTAINER TIEOOHN DURING COLLISION OF HIGHWAY VEHICLES

FRANKLIN INSTITUTE RESEARCH LABORATORIES

NYO-2539-2+I-A2412-3+.70 PAGES, FEBRUARY, 1966, CFSTI, \$3.00 CY, \$0.75 MN

ANALYTICAL AND GRAPHICAL PROCEDURES $\triangle R E$ PRESENTED FOR DETERMINING APPROXIMATELY THE DYNAMIC RESPONSE OF CONTAINER TIEDOWNS DURING LONGITUDINAL COLLISIONS OF HIGHWAY VEHICLES. THE METHOD IS BASED ON A SIMPLIFIED MODEL OF THE VEHICLE-CONTAINER-TIEDOWN SYSTEM AND ON AN ASSUMED FORCE PULSE. ILLUSTRATIVE EXAMPLES ARE GIVEN OF THE CALCULATED RESPONSE OF A FOUR-POINT TIEDOWN MADE FROM SEVERAL DIFFERENT MATERIALS. THE ANALYTICAL METHOD IS APPLICABLE TO OTHER TIEDOWN GEOMETRIES AND MATERIALS WITHIN THE LIMITS IMPOSED BY THE CONDITIONS OF THE DERIVATION. THE METHOD SHOULD BE USEFUL TO DESIGNERS AND SHIPPERS FOR COMPARATIVE EVALUATION OF VARIOUS TIEDOWNS.

\# ACCIDENT ANALYSIS + \#TRANSPORTATION ANO HANDLING + ANALYTICAL MODEL + DYNAMICS, NONLINEAR + IMPACT SHOCK

3-10842 NEWLON CE + MALLETT AJ

HYOROGEN MODERATION - A PRIMARY NUCLEAR SAFETY CONTROL FOR HANDLING AND TRANSPORTING LOW-ENRICHMENT UFG OAK RIDGE GASEOUS DIFFUSION PLANT

K-1663+. 20 PAGES, MAY 31, 1966, CFSTI, \$1.00 CY, \$0.5C MN

THE USE OF HYDROGEN MODERATION AS A PRIMARY NUCLEAR SAFETY CONTROL HAS BEEN IN EFFECT FOP. MANY Y.EARS FOR LARGE-SCALE UFG SHIPMENTS AMONG AEC-OWNED CONTRACTOR OPERATED FACILITIES. THE EXTENSION OF THE USE CF MODERATION-CONTROLLED SHIPMENTS TO LICENSEES AS WELL AS CONTRACTOR ORGANIZATIONS IS DESIRABLE, AND THIS REPORT SUMMARIZES, IN SUPPORT OF THIS METHOD, THF WORK DONE IN DEVELOPING BASIC CRITICALITY DATA AND THE NECESSARY EQUIPMENT AND OPERATIONAL TECHNIQUES.

* TRANSPORTATION AND haNDLING + *URANIUM HEXAFLUORIDE + CONTROL, generAL + HYDROGEN +

SAFETY REVIEW (OPERATIONS, EXPERIMENTS)

3-11221 JAPAN RETURNING IRRADIATED FUEL ELEMENTS TO U.S. FOR REPROCESSING - FIRST TO BE SHIPPED FROM ASIA

ATOMIC ENERGY COMMISSION, WASHINGTON, D.C.

PRESS REL. J-194+. 1 PAGE, AUGUST 15,1966 , DPI

THE FIRST CONSIGNMENT OF IRRADIATED NUCLEAR FUEL FROM ASIA TO BE REPROCESSED IN THE UNITED STATES WILL ARRIVE FROM JAPAN AT SEATTLE, WASHINGTON, ON AUGUST 16, 1966 . TWENTY-FOUR IRRADIATED FUEL ELEMENTS, CONTAINED IN TWO 11-TON CASKS, WILL BE REMOVED FROM THE NIKKEI-MARU OF THE JAPANESE SHOWA LINE AND SHIPPED DIRECTLY BY TRUCK TO THE $\triangle E C$ IDAHO CHEMICAL PROCESSING PLANT AT THE NATIONAL REACTOR TESTING STATION IN IDAHO. SEATTLE IS $\triangle M O N G$ THE 44 U. S. PORTS THAT HAVE NOTIFIED. THE U.S. COAST GUARD THAT THEIR PORT AND COMMUNITY FACILITIES ARE

AVAILABLE FOR. THE ACCEPTANCE AND TRANSIT OF SHIPMENTS OF RADIOACTIVE MATERIALS, PROVIDEO THAT THERE IS COMPLIANCE WITH THE REGULATIONS OF THE U.S. AGENCIES EXERCISING JURISOICTION OVER THE ENTRY AND MOVEMENT OF SUCH MATERIALS INTO AND WITHIN THE COUNTRY.

\#FUEL HANDLING + JAPAN + SHIPPING CONTAINER + TPANSPORTATION AND HANOLING

3-11222 GASKILL JR + TAYLOR RD

IMPROVED SHIPPING CONTAINER FOR FISSILE MATERIAL

LAWRENCE RADIATION LAB., UNIV. OF CALIF., LIVERMORE

UCRL-14903+. 26 PAGES, 14 FIGURES, 3 TABLES, JUNE 3, 1966, CFSTI $\$ 2.00 \mathrm{CY}, \$ 0.50 \mathrm{MN}$

BASED ON AN ORNL DESIGN, WHICH CALLED FOR A FOAM-GLASS SPACER IN A 55-GAL DRUM, AN IMPROVED SHIPPING CONTAINER FOR UNIRRADIATED FISSILE MATERIALS WAS DEVELOPED. IT PASSED THE NORMAL AND ACC IDENT TESTS PROPOSED IN THE CURRENT REVISION OF AEC SAFETY STANDARDS. FURTHER, A CRITICALITY ANALYSIS BY THE LRL CRITICALITY SAFETY ADVISORY GROUP ESTABLISHED QUANTITATIVE LIMITS FOR SHIPPING SOLID FORMS OF ENRICHED URANIUM AND PLUTONIUM ACCORDING TO AEC CRITEPIA FOR BOTH CLASS I AND CLASS II CATEGORIES.

\#SHIPPING CONTAINER + \#TEST, DROP + CRITICALITY SAFETY + FIRE + TEST, DESTRUCTIVE

3-11223 STETSON FT

AN ANALYSIS OF STEADY-STATE HEAT TRANSFER IN A SPRING-LOADED DRY SHIPPING CASK

KNOLLS ATOMIC POWER LABORATORY, SCHENECTADY, NEW YORK

KAPL-M-6106 +. 18 PAGES, 6 FIGURES, FEBRUARY 11,1964 , CFSTI, \$1.60 FS, \$0.80 MN

THIS REPORT PRESENTS THE RESULTS OF AN ANALYSIS OF HEAT REMOVAL FROM A KAPL SPRING-LOADED DRY SHIPPING CASK. THE INTERNAL HEAT GENERATION IS PROVIDED BY DECAY HEAT FROM TEST SPECIMENS IRRADIATED IN THE MTR AND ETR. THE RESULTS REPRESENT MAXIMUM TEMPERATURES OF THE SPECIMENS, TEMPERATURE DISTRIBUTIONS, AND THE TEMPERATURE DISTRIBUTION OF THE HOLDERS. THE VARIABLES WERE THE INTERNAL HEAT GENERATION RATES, THE METAL-TO-METAL CONTACT RESISTANCES, AND THE SPECIMEN LOADING IN THE HOLDER.

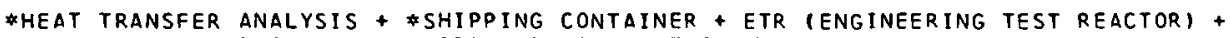

MTR (MATERIAL TESTING REACTOR) + REACTOR, TEST,

3-11505 MINOR JE + RASTRELLI LU

INVESTIGATION OF LOW-LEVEL RADIOACTIVE WASTE CONTAINERS IN AN ACCIDENT ENVIRONMENT. PART I - SURVEY OF 
CATEGORY

TRANSPORTATION AND HANDLING OF RADIOACTIVE MATERIALS

\begin{abstract}
3-11505 \#CONTINUED*
TRANSPORT AND DISPOSAL PROCEDURES. PART II - STRUCTURAL INTEGRITY OF TYPICAL LOH-LEVEL RADIOACTIVE WASTE CONTAINERS

SOUTHWEST RESEARCH INSTITUTE, SAN ANTONIO, HOUSTON, TEXAS

SHRI-1262-4 +. 155 PAGES, 25 FIGURES, 13 TABLES, 23 REFERENCES, OCTOBER 1965, SOURCE

THE DISCUSSIONS IN PART I CONSTITUTE A TIMELY, COMPREHENSIVE SURVFY OF CURRENT DISPOSAL PRACTICES AND PROVIDE A BASIS FOR CONTAINEP STRUCTURAL INTEGRITY EVALUATIONS PRESENTED IN PART II. IN PART II, AN ANALYSIS OF THE ACCIOENT ENVIRONMFNT, BASED ON PREVIOUSLY

ACCOMPL ISHED STATISTICAL AND EXPERIMENTAL INVESTIGATIONS, IS PRESFNTED. IDENTIFICATION OF THE DYNAMIC FORCES THAT MAY BE EXPERIENCED BY A LOW-LEVEL RADIOACTIVE MATERIAL CONTAINER IN A HIGHWAY ACCIDENT LEAD TO THE DEVELOPMENT OF ANALYTICAL PROCEDURES FOR PREDICTING THE DYNAMIC. RESPONSE OF TYPICAL CONTAINERS. A COMPAPISON OF STRUCTURAL-INTEGRITY PROPERTIES OF TYPICAL C.Y1. INDER AND BOX CONTAINERS IS PRESENTED, AND CONCLUSIONS PELATING THE EFFECTIVENESS WITH WHICH THE TWO CONTAINER TYPES CAN WITHSTAND AN ACCIDENT ARE ADVANCEO.

ACCIDENT ANALYSIS + FIRE + IMPACT SHOCK + REGULATION, GENERAL + STRESS ANALYSIS + STRUCTIJRAL INTEGRITY + WASTE TRANSPORTATION
\end{abstract}


CATEGORY 4

AEROSPACE SAFETY

4-09601 ELLIOTT RD

METHODS FOR PREDICTING AEROOYNAMIC HEATING RATES TO HIGH-VELOCITY BOOIES IN THE UPPER ATMOSPHERE ATOMICS INTERNATIONAL

NAA-SR-11704 +. 39 PAGES, 22 FIGURES, 1 TABLE, REFERENCES, JANUAPY 15, 1966, CFSTI \$2.00 CY, \$0.50 MN

THE BASIC PHYSICAL PHENOMENA ASSOCIATED WITH AERODYNAMIC heATING ARE DESCRIBED. THE METHODS NOW USED AT ATOMICS INTERNATIONAL FOR DREDICTING HEATING RATES OF BODIES MOVING AT HIGH VELOCITIES THROUGH THE ATMOSPHERE ARE SUMMARIZED. THE METHODS DESCRIBED DROVIDE THE PRINCIPAL INPUT DATA FOR THE ANALYTICAL STUDIES OF SNAP REENTRY DISINTEGRATION IN THE AEROSPACE NUCLEAR SAFETY PROGRAM.

\# AEROSPACE SAFETY + \#HEAT GENERATION, NONUNIFORM + *HIGH TEMPERATURE +

* SNAP, GENERAL (SYSTEMS FOR NUCLEAR AUX. POWER) + *THERMAL ANALYSIS + ATMOSPHERIC CHEMISTRY + TEST, PHYSICS

4-09603 THOMPSON RC

SNPO AND SNAP BIOLOGICAL STUDIES. SUMMARY TECHNICAL REPORT

BATTELLE NORTHWEST, PACIFIC NORTHWEST LABORATORY, RICHLANO

BNWL-182 +. 19 PAGES, 3 TABLES, JANUARY 3, 1966, CFSTI \$1.00, \$0.50 MN

A SHARP DISTINCTION CANNOT BE MADE BETWEEN THOSE PHASES OF OUR INVESTIGATIONS WHICH WERE PRIMARILY CONCERNED WITH SNPO (SPACE NUCLEAR PROPULSION OFFICE) PROBLEMS AND THOSE PHASES CONCERNED WITH SNAP (SYSTEMS FOR NUCLEAR AUXILIARY POWER) PROBLEMS BECAUSE THE OBJECTIVES WERE VERY SIMILAR. THEREFORE, WE ARE NOT SEPARATING THIS REPORT INTO SNPO AND SNAP SECTIONS. HOWEVER, IF SUCH DISTINCTION IS NECESSARY, THE PU-23P FEEDING STUDY IS PRIMARILY RELATED TO SNAP, AND THE STUDIES WITH THE OAK RIDGE-PREPARED SIMULATED FUEL PARTICLES ARE PRIMARILY RELATED TO SNPO. THE LARGE-PARTICLE INHALATION STUDIES AND THE SOLUBILITY STUDIES CLEARLY HAVE APPLICATION TO BOTH SNPO ANO SNAP PROBLEMS. EXPERIMENTAL WORK CONSISTED OF SEVERAL SEPARATE INVESTIGATIONS. IN MANY INSTANCES, THESE INVESTIGATIONS ARE STILL CONTINUING, AND FINAL CONCLUSIONS CANNOT BE DRAWN.

* $\triangle E R O S P A C E$ SAFETY + \#BIOMEDICAL + \#PARTICLE, RADIOACTIVE +

* SNAP, GENERAL (SYSTEMS FOR NUCLFAR AUX. POWER) + EXPER IMENT, GENERAL + INGESTION + INHALATION + PLUTONIUM

4-10037 BARSELL AW + MCNTGOMERY LD + ARNOLD JE

THERMAL BEHAVIOR OF SNAP REACTOR FUEL ELEMENTS DURING ATMOSPHERIC REFNTRY

ATOMICS INTERNATIONAL, CANOGA PARK

NAA-SR-11502 +. 123 PAGES, 57 FIGURES, 20 TABLES, 67 REFERENCES, MARCH 1966, CFSTI, \$4. CO CY, \$1. QI MN

AN ANALYTICAL MODEL IS DEVELOPED TO DESCRIBE THE THERMO-CHEMICAL BEHAVIOR OF SNAP FUEL ELEMENTS DURING ATMOSPHERIC REENTRY. THE AERODYNAMIC HEATING, TRANSPIRATION COOLING, AND THE CHEMICAL REACTIONS OF THE FUEL WITH AIR ARE INVESTIGATED. A DETAILED EVALUATION OF ZLRCONIUM-URANIUM HYDRIDE FUEL MATERIAL PROPERTIES IS PRESENTED. RESULTS OF THE USE OF THE ANALYTICAL MODEL ARE PRESENTED AND COMPARED WITH EXPERIMENTAL DATA. A STATISTICAL PROBABILITY ANALYSIS OF INITIAL FUEL ABLATION IS CONOUCTED FOR SNAP IOA ELEMENTS. THE STATISTICAL PROCEDURE IS CONCLUDED TO BE A VALID, OPTIMUM APPROACH. PARAMETER INFLUENCE IS PRECISELY FIXED ANO RANKED, PROVIDING DIRECTION FOR EXPERIMENTAL SUPPORT INVESTIGATIONS. THE PROCEDURE ALSO ENABLES AN ORGANIZED, REITERATIVE NARROWING OF THE ACCURACY ATTRIBUTED TO THE STUDY RESULTS.

* AEROSPACE SAFETY + \#CHEMICAL REACTION + *COMDARISON, THEORY AND EXPERIENCE + *FUEL ELEMENT + \#FUEL INTEGRITY + *SNAP IOA (SYSTEMS FOR NUCLEAR AUXILIARY POWERI + \#URANIUM HYDRIDE + \#ZIRCONIUM

4-1C52C AHLQUIST AJ + SANDERS Fh

GAMMA DOSE RATE MEASUREMENTS ON THE PHOEBUS 1A-321 REACTOR

LOS ALAMOS SCIENTIFIC LABORATORY

LA-3448-MS +. 22 PAGES, 14 FIGURES, I TABLE, REFERENCES, MAY 10, 1966, CFSTI \$2.00 CY, \$O.50 MN

GAMMA-RAY DOSE-RATE MEASUREMENTS WERE MADE ON EXPERIMENTAL PLANS 2 , 3 , AND 4 OF THE PHOERUS 1A-321 REACTOR-TESTING SERIES. EXTRAPOLATION OF DATA FROM 180 FEET GAVE A DOSE RATE OF 36.0 R/MIN-MW AT THE 6O-FOOT STATION DURING THE FULL-POWER. RUN IEXPERIMENTAL PLAN 4 I. THE AVERAGE GAMMA-RAY DOSE RATE OF THE EIGHT KIWI REACTORS AT THE 6O-FOOT STATION WAS 35.1 R/MIN-MW. INSTRUMENT DIFFICULTIES NECESSITATED USING XYLENE (GAMMA-NEUTRON SENSITIVE) DETECTORS AS GAMMA DETECTORS. INTEGRAL DOSES SHOW THAT THEY GIVE A REASONABLE APPROXIMATION OF GAMMA DOSE RATES.

\#AEROSPACE SAFETY + \#DOSE MEASUREMENT, EXTERNAL + *KIWI TNT (TRANSIENT NUCLEAR TESTI + DOSE + DOSE CALCULATION, EXTERNAL

4-10521 CULOTTA AJ + FERNANDEZ I + ANOERSON DC RFD-2 FLIGHT TEST PROGRAM, SUPPLEMENTARY ANALYSIS REPORT MARTIN MARIETTA CORPORATION, BALTIMORE

MND-3283-3 +. 30 PAGES, 35 FIGURES, 3 TABLES, 22 REFERENCES, JANUARY 1966

THIS REPORT PRESENTS THE RESULTS OF A STUDY WHOSE OBJFCTIVE WAS TO CALCULATE IN A DETAILED MANNER THE REENTRY BEHAVIOR OF SIMULATED RADIOISOTOPIC FUEL ELEMENTS RELEASED DURING REENTRY FLIGHT DEMONSTRATI ON NUMBER TWO, CONDUCTED IN THE FALL OF 1964, AND, THEREUPON, TO COMPARE CALCULATED BURNUP TIMES AND ALTITUDES WITH THOSE OBSERVED IN THE REENTRY EXPER IMENT.

* aerospace safeTy + *Fuel element + *TesiIng + heat transfer 
CATEGORY 4

AEROSPACE SAFETY

4-11053 CONARD RA

HERMATOLOGICAL EFFECTS OF SPACE RADIATION

BROOKHAVEN NATIONAL LABORATORY

BNL-10221 +. 31 PAGES, 1965, CFSTI, \$2.00 CY, \$0.50 MN

THE HEMATOI OGICAL RESPONSES OF MAN TO SHORT-TERM EXPOSURE OF CONVENTIONAL RADIATION ARE REASONABLY WELL KNOWN. LESS IS KNOWN ABOUT EFFFCTS OF PROTRACIION, FRACTIONATION, AND OUALITY OF RADIATIONS TO WHICH MAN MAY BE SUBJECTED IN SPACE. USEFUL DATA ON THE HUMAN BEING IS EXTREMELY LIMITED, AND MUCH OF IT THAT IS AT ALL HELPFUL IS DERIVED FROM ANIMAL STUDIES, MOST OF WHICH ARE NOT DESIGNED WITH SPACE PROBLEMS IN MIND. ONE IS FORCEO, THEREFORE, TO ATTEMPT SOME DEGREE OF EXTRAPOLATION OF ANIMAL DATA TO MAN, WHICH IS, NEEDLESS TO SAY, FRAUGHT WITH UNCERTAINTY. THEREFORE, MANY QUESTIONS CAN BE ONLY PARTLY ANSWERED AT THIS TIME.

*aERosPaCe safeTy + *BIOMEDICAL

4-11054 CURET HD

STEP PROJECT. QUARTERLY TECHNICAL REPORT, JANUARY 1965 - MARCH 1965

PHILLIPS PETROLEUM COMPANY, IIJAHO FALLS, IOAHO

IDO-17126 +. 59 PAGES, 29 FIGURES, REFERENCES, MARCH 1966, CFSTI, $\$ 3.00 \mathrm{CY}, \$ 0.75 \mathrm{MN}$

THE NUTI.FAR SAFETY TECHNOLOGY ENGINEERING AND TEST BRANCH CONDUCTED SNAPTRAN-1 TRANSIENT TESTS, PERFORMED ANALYTICAL STUDIES FOR SNAPTRAN-1, -2, ANU LUFT, AND DETERMINED THE DLSIGN CHARACTERISTICS FOR A ZIRCALOY-CLAD CORE.

* AEROSPACE SAFETY + \#OFT (LOSS OF FLUID TEST) + \#SNAPTRAN (SNAP TRANSIENT REACTOR TEST SERIES) + * STEP (SAFETY TEST ENGINEERING PROGRAM) + TESTING + RELIABILITY, COMPONENT

4-11055 WOOD GM

STATUS OF SNAP-SO/SPUR PUMP DEVELOPMENT PROGRAM

PRATT AND WHITNEY AIRCRAFT, MIDDLETOWN, CONN.

CNLM-6358 4. 60 PAGES, FIGURES, MAY 27, 1965, CFSTI, \$3.00 CY, \$0.75 MN

WORK ON THE SNAP-50 PROGRAM HAS STARTED AT CANEL DURING MAY 1962. FOR THE CURRENT SNAP-50/SPUR POWERPLANT, CANEL HAS THE RESPONSIBILITY FOR THE DESIGN AND DEVELOPMENT OF ALL PUMPS IN BOTH THE REACTCR COOLANT AND THE POWER-CONVERSION SYSTEMS. AS PRESENTLY CONCEIVED FOR THE 300-KWE POWERPLANT, THIS WOPK ENTAILS THE DEVELOPMENT OF A REACTOR COOLANT PUMP CIRCULATING LITHIUM, A CONDENSATE PUMP CIRCULATING POTASSIUM, AND A CONDENSER COOLANT PUMP CIRCULATING NAK. THFSF PIIMPS MUST OPERATE WITH A HIGH DEGREE OF RELIABILITY FOR PERIODS IN EXCESS OF 10,000 HR WITHOUT MAINTENANCE. HERMETICALLY SEALED CENTRIFUGAL PUMPS POWERED BY CANNED ELECTRIC MOTOR DRIVES HAVE REEN SELECTED FOR ALL THREE PUMPING APPLICATIONS. A OISCUSSION OF THE SNAP-5O/SPUR PUMP DEVELOPMENT PROGRAM IS PRECEDED BY A SHORT DESCRIPTION OF THE DESIGN CONCEPTS OF THE HERMETICALLY SEALED CENTRIFUGAL PUMPS.

\# AEROSPACE SAFETY + \#PUMP

4-11163 CAMPANA RJ

DESIGN OF THE SNAP-15A GENERATOR

GENERAL ATOMIC

GA-5296 +. 34 PAGES, 9 FIGURES, 12 TABLES, JUNE 1964 , CFSTI $\$ 2.00 \mathrm{CY}, \$ 0.50 \mathrm{MN}$

THIS REPORT SUMMARIZED THE CONSIDERATIONS AND ANALYSIS LEADING TO THE DESIGN OF A PU-238 FUELED, METAL-THERMOCOUPLE GENERATOR PROVIDING AROUT 1 MW AT GREATER THAN $4.5 \mathrm{~V}$ FOR 5 YEARS WITH VERY HIGH RELIABILITY EVEN UNDER EXTREME ENVIRONMENTAL CONDITIONS. BEFORE THE DESIGN WAS COMPLETED, A FEW EXPERIMENTAL GENERATORS WERE BUILT AND TESTED. THEY INFI,UFNCED THE FINAL DESIGN, ESPECIALLY WITH RESPECT TO THE TRANSIENT RESPONSE OF THE GENERATOR LOAD VOLTAGE TO STEP CHANGES IN THE AMBIENT TEMPERATURE. THE PRESENTATION OF THE WORK IS MADE IN THE CHRONOLOGICAL. SEQUENCE IN WHICH THE DESIGN EVOLVED.

\#LESIGN STIIDY + APLUTONIUM + *THERMOELECTRIC CONVERSION + SNAP I.5 ISYSTEMS FOR NUCLEAR AUXILIARY POWER

4-11252 HENDERSON RW + LARSON OW + FULTYN RV

RADIATION MEASUREMENTS OF THE EFFLUENT FROM THE PHOEBUS 1A-32I REACTOR

LOS ALAMOS SCIENTIFIC LABORATORY, LOS ALAMOS

LA-3396-MS +. 62 PAGES, 22 FIGURES, 9 TABLES, 2 REFERENCES, FEBRUARY 1966, CFSTI \$3.00 CY, \$O.75 MN

PRESENTED ARE THE RESULTS OF DOCUMENTATION STUDIES ON THE EFFLUENT FROM THF FULL-POHER TEST OF THE PHOEBUS IA-321 REACTOR. A DESCRIPTION OF PROCEDURES AND EQUIPMENT IS GIVEN. AN ANALYSIS OF THE ENVIRONMENTAL EFFECTS DUE TO THE PASSAGE AND DEPOSITION OF THE RELEASED MATERIAL IS GIVEN, AS WELL AS DEPOSITION VELOCITIFS MEASURED AT VARIOUS LOCATIONS. APPENDIX A GIVES THE RESULTS OF THE STUDY OF SELECTED RESIN-COATED TRAYS BY THE LASL INDUSTRIAL HYGIENE GROUP $(H-5)$.

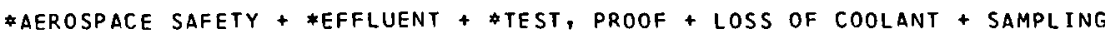


CATEGORY 5

ACCIDENT ANALYSIS

5-08969 HELM JW

EFFECT OF NEUTRON IRRADIATION ON UHTREX GRAPHITE AND CARBON

BATTELLE-NORTHWEST, RICHLAND

ENHL-191 +. 17 PAGES, 3 FIGURES, 5 TABLES, 7 REFERENCES, FEBRUARY 1966, CFSTI, \$1.00 CY, \$0.50 MN

THE DIMENSIONAL STABILITY OF THE GRAPHITE AND CARBON MATERIALS USED IN UHTREX WAS DETERMINED TO NEUTRON EXPOSURES EQUAL TO EXPECTEO LIFETIME EXPOSURES, AND THE BEHAVIOR OF THESE MATERIALS WAS COMPARED WITH A CONVENTIONAL NUCLEAR GRAPHITE. IRRADIATIONS WERE CONDUCTED IN THE ETR TO MAXIMUM NEUTRON EXPOSURES OF $7 \times 10$ TO THE 20 NVT, E GREATER THAN $\Pi .18$ MEV AT SAMPLE TEMPERATURES BETWEEN 900 AND 1800 DEGREES C. AT IRPADIATION TEMPERATURES OF IOOO AND 1800 DEGREES C, CGL GRAPHITE BEHAVES ABOUT THE SAME AS CSF, AND THE LENGTH CHANGES ARE LESS THAN - 0.06 PERCENT IN BOTH ORIENTATIONS AT THE MAXIMUM EXPOSURES.

* GRAPHITE + \#RADIATION DAMAGE + \#RADIATION EFFECT + CARBON + IN PILE LOOP + PROPERTY, PHYSICAL

5-09385 KOEISCIN JJ

PRESSURE DROP, HEAT TRANSFER, AND MAXIMUM DISCHARGE IN FORCED-CONVECTION, HORIZONTAL BOILING LEHIGH UNIVERSITY

2 PAGES, DISSERTATION ABSTRACTS, 26(5), PAGES 2627-2628 (1965), ORDER NO. 65-11,304

a ForCed-CONVECTION BOILING STUDY WAS CONDUCTED in a hORIZONTAL CHANNEL WITH SCALEO AND POLISHED SURFACES AT ATMOSPHERIC PRESSURE. THE OBJECTIVES WERE TO OBTAIN FORCEO-CONVECTION-BOILING CURVES OESCRIBING PRESSURE-DROP--MASS-VELOCITY CHARACTERISTICS, TO STUOY THE RANGE OF VARIABLES WHERE FLOW, PRESSURE, AND TEMPERATURE INSTABILITIES APPEAR, TO DETERMINE WHETHER CRITICAL DISCHARGE PHENOMENA APE IN ANY WAY ASSOCIATED WITH SUCH

INSTABILITIES. PRESSURE-DROP--HEAT-TRANSFER CORRELATIONS ARE PRESENTED.

* CONVECTIVE BOILING + \#FLOW, TWO PHASE + \#HEAT TRANSFER + \#HEAT TRANSFER CORRELATION +

\#HEAT TRANSFER, BOILING + HEAT TRANSFER EXPERIMENT + HEAT TRANSFER, CONVECTION + HYDRAULIC EXPERIMENT

5-09558 PRESLER AF

AN EXPERIMENTAL INVESTIGATION OF HEAT TRANSFER TO TURBULENT FLOW IN SMOOTH TUBES FOR THE REACTING NZO4-NOZ SYSTEM

LEWIS RESEARCH CENTER, CLEVELAND, OHIO

NASA-TN-D-3230 +. 49 PAGES, 24 FIGURES, 4 TABLES, JANUARY 1966, CFSTI, $\$ 2.00$

LOCAL TURBULENT-HEAT-TRANSFER COEFFICIENTS WERE OBTAINED EXPERIMENTALLY FOR THE DISSOCIATING SYSTEM NITROGEN TETROXIOE-CNITROGEN DIOXIDE FLOWING THPOUGH AN ELECTRICALLY HEATED TUBE. MODIFIEO LOCAL HEAT-TRANSFER COEFFICIENTS, BASED ON WALL- TO BULK-ENTHALPY DIFFERENCES, WERE CORRELATED VERY WELL AS A SIMPLE POWER OF THE MASS AVERAGE VELOCITY. THE LOCAL MODIFIED HEAT-TRANSFER COEFFICIENTS WERE CORRELATED WITH A DITTUS-BOELTER-COLBURN-TYPE RELATION WITH ALL EQUILIBRIUM TRANSPORT AND THERMAL PROPERTIES EVALUATED ON A MEANGTEMPERATURE INTFGRAL BASIS. THE BEST CURVE THROUGH THE DATA WAS $\triangle B O U T$ TEN PERCENT BELOW THE CURVE FROM CONSTANT-PROPERTY ANALYSES.

* CHEMICAL REACTION + \#HEAT TRANSFER + \#HEAT TRANSFER ANALYSIS + *HEAT TRANSFER EXPERIMENT + FLOW, TUBE + FLOW, TURBULENT

5-09605 LAWRENCE RA

AN INVESTIGATION OF THE THERMAL RESPONSE OF THE AEROSPACE SHIELO TEST PEACTOR TO LOSS OF COOLANT GENERAL DYNAMICS, FORT WORTH

WL-TR-64-137+FZK-209+. 106 PAGES, APRIL 1965, CFSTI

THE PRIMARY PURPOSE OF THIS EXPERIMENT HAS TO DETFRMINE THE POSSIPLE CONSEQUENCE OF A COMPLETE LOSS OF COOLANT FROM THE INTERIOR OF A REACTOR, SPECIFICALLY THE ASTR IAEROSPACE SYSTEMS TEST REACTORI. A HEAT-TRANSFER MODEL WAS DEVELOPED AND COMPARED WITH EXPERIMENTAL DATA. THIS COMPARISON REVEALED THAT THE MODEL WAS CONSERVATIVE AND THAT THE HEATING RATE AND HEAT-LOSS

RATE WERE EXCESSIVE. THE DATA WERE ACQUIRED FROM THE ASTR IN SERIES OF TESTS THAT INVOLVED REMOVAL OF THE COOLANT FROM THE REACTOR FOLLOWING OPERATION AT VARIOUS POWER LEVELS AND OPERATING TIMES. IT IS CONCLUDED THAT OVER-HEATED FUFL ELEMENTS CAN BE COOLED BY ADDING WATER, WITH RELATIVELY LITTLE HAZARD OF RUPTURING A FUEL PLATE.

*LOSS OF COOLANT + *REACTOR COOLANT + HEAT TRANSFER + HEAT TRANSFER ANALYSIS + HEAT TRANSFEP. EXPERIMENT + REACTOR TEST FACILITY

5- 9622 LARKIN BK

SOME FINITE DIFFERENCE METHODS FOR PROBLEMS IN TRANSIENT HEAT FLOW

MARTIN COMPANY, DENVER

11 PAGES, 6 FIGURES, 10 REFERENCES, PP 1-11 OF HEAT TRANSFER - CLEVELAND, ICHEMICAL ENGINEERING PROGRESS

SYMPOSIUM SERIES 59(61) 1965), AMERICAN INSTITUTE OF CHEMICAL ENGINEERS, \$15.OO CY, SOURCE

FOUR METHODS FOR DIGITAL SOLUTION OF TRANSIENT HEAT FLOW PROBLEMS ARE COMPARED. THE FIRST STEP IN DEVELOPING THESE METHODS IS TO REPLACE SPATIAL DERIVATIVES BY FINITE-DIFFFRENCE QUOTIENTS. THE RESULT IS A SYSTEM. OF FIRST-ORDER DIFFERENTIAL EQUATIONS. BY USING FOUR METHODS FOR NUMERICAL INTEGRATION, ONE OBTAINS FOUR COMPUTING PROCEDURES. PROBLEMS IN TRANSIENT CONDUCTION, CONVECTION, AND RADIATION IN ANY NUMBER OF SPACE DIMENSIONS WITH ARBITRARY BOUNDARY ANO INITIAL CONDITIONS ARE CONSIDERED. EULFRS METHOD IS THF SIMPLEST ONE FOR NUMER ICAL INTEGRATION OF A SYSTEM OF DIFFERENTIAL EQUATIONS, AND IT LEADS TO THE WELL-KNOWN METHOD OF DUSINBERRE. HOWFVER, THIS METHOO OFTEN EXHIBITS DOOR STABILITY PROPERTIES. TWO, AND PERHAPS ALL THREE, OF THE OTHED METHODS HAVE UNCONDITIONAL STABILITY. ESTIMATES ARE MADE OF CUMULATIVE TRUNCATION ERROP IN TIME. THE WELL KNOWN METHOD AND ONE OF THE NEWER ONES YIELD ERRORS PROPORTIONAL TO THE TIME INCREMENT. THE OTHER METHODS YIELD 
CATEGORY 5

ACCIDENT ANALYSIS

\begin{abstract}
$5-09622$ *CONTINUED*
ERRORS PROPORTIONAL TO THE INCREMENT SQUAPED. APPLICATION DF THE METHOOS IS ILLUSTRATED RY USE OF AN EXAMPLE PROBLEM WHERE THE SUPERIOR STABILITY PROPERTIES OF THF NEWER METHODS ARE NOTEO.
\end{abstract}

*COMPUTER, DIGITAL + \#HEAT CONDUCTION + \#HFAT TRANSFER + \#HEAT TRANSFER anALYSIS + \#TEMPERATURE TRANSIENT

5-09623 OLCER NY + MILLER D + SUNDERLAND JE

UNSTEAOY TEMPERATURE DISTRIRUTIONS IN FINITE REGIONS

ARGONNE NATIONAL LABORATORY + ORDNANCE ENGINEERING ASSOCIATES, INC., DFS PLAINES, ILLINOIS + GEORGIA

INSTITUTE OF TECHNOLOGY

7 PAGES, 2 REFERENCES, PP 12-18 OF HEAT TRANSFER - CLEVELAND, ICHFMICAL ENGINEERING, PROTRESS SYMPOSIUM

SERIES $59(61) 1965)$, AMERICAN INSTITUTE OF CHEMICAL ENGINEERS, SOURCE, \$15.OO CY

THE PROBLEM OF UNSTEADY HEAT CONDUCTION IN A FINITE HOMOGENEOUS REGION OEF ARBITRARY CONFIGURATION AND INITIAL CONDITIONS WITH INHOMOGENEOUS BOUNOARY CONDITIONS IS SOLVFD ANALYTICALLY. SOLUTIONS ARE GIVEN IN A CONVENIENT FORM THAT ELIMINATES CONVOLUTION INTEGRALS WHEN INTERNAL AND SURFACE HEAT SOURCES CAN BE EXPRESSED BY SERIES EXPANSIONS IN TIME. THE METHOD IS ILLUSTRATED BY SOLUTION OF THE PROBLEM OF AN INFINITE SLAG WITHA HEAT FLUX GIVEN AS A POLYNOMIAL IN TIME.

* COMPUTER, DIGITAL + \#HEAT CONOUCTION + \#HEAT TRANSFER + \#hCAT TRANSFER ANALYSIS + *TEMPERATURE TRANSIENT

$5-09624$ ZEH OW + GILL WN

BINARY DIFFUSION AND HEAT TRANSFER IN LAMINAR BOUNOARY LAYERS ON VSRTICAL SURFACES

SYRACUSE UNIVERSITY + CLARKSON COLLEGE OF TECHNOLOGY

17 PAGES, 10 FIGURES, 30 REFERENCES, PP $19-35$ OF HEAT' TRANSFER - CLEVELAND, (CHEMICAL ENTINEERING PROGRESS

SYMPOSIUM SERIES 59(61) 1965), AMERICAN, INSTITUTE OF CHEMICAL ENGINEERS, SOURCE \$IS.OOO CY

COMBINED FREE AND FORCED CONVECTION IN LAMINAR BOUNOARY LAYERS WITH COUPLED MOMENTUM, HEAT, AND RINARY MASS TRANSFEP, IS INVESTICATED. MASS-TRANSFCR RATE, BUOYANCY, DISSIPATION, AND SPECIES ENTHALPY DIFFERENCES ARE CONSIDEREO IN DETAIL. THE IMPORTANT EFFECTS OF ENTHALPY DIFFERENCES AND MASS-TRANSFER RATES ARE OESCRIBED BY EXACT SOLUTIONS AND AN APPROXIMATE CLOSED FORM.

*BOUNDARY LAYER + \#DIFFUSION + \#FLOW, LAMINAR + *HEAT TRANSFFR + *HEAT TRANSFER ANALYSIS + \#MASS TRANSFFR

5-C9625 SINGER RM

UNSTEADY CONVECTIVE MAGNETOHYDROOYNAMIC CHANNEL FLOH

ARGONNE NATIONAL LABORATORY

14 PAGES, 13 FIGURES, 13 REFERENCES, PP $36-49$ OF HEAT TRANSFER - CLEVELAND, ICHEMICAL ENGINEERING PROSRESS SYMPOSIUM SERIES 59161) 19651, AMERICAN INSTITUTE OF CHEMICAL ENGINEERS, SOURCE BI5.DO CY

THE UNSTEAOY, COMBINED FREE AND FORCED CONVECTIVE FLOW OF AN ELECTRICALLY CONDUCTING FLUID THROYISH A TRANSVED.SE MAGNETIC FIELD IS ANALYZED. ALLOWING TIIC CIIANHEL-HALL TEMPERATURE TO VARY LINEARLY WITH THE AXIAL CUUNUINAIL UF IHE DUCT ALLOWS A FULLY DEVELOPEN FLOW SITIJATION THAT LINEARIZES THE GOVERNING EQUATIONS AND PERMITS AN ANALYTICAL SOLUTION. THE UNSTEADINESS MAY OCCUR BECAUSE OF VARIATIONS IN THE AXIAL PRFSSURE GRADIENT, WALL TEMPERATURE, OR INTERNAL ENERGY-GENERATION RATE. THE EFFECTS OF THF THFRMAL AND MAFNETIC PQANDTL NUMBFRS, THE HARTMANN NUMBER, THE RAYLEIGH NUMBER, AND INTERNAL ENERGY GENERATION UPON THE FLOW AND HEAT HARTMANN NUMBER, THE RAYLEIGH NUMBER, AND INYERNAL ENERGY GENERATION UPON THE FLOW AND HEAT
TRANSFER ARE STUDIEO. OSCILLATORY BEHAVIOR IS OBSERVED FOP. LARGE VALUES OF RA AND M AND FOR PR NEAR UNITY, AND THE LENGTH OF THE TRANSIENT PERIOD IS FOUND TO OEPEND STRONGLY ON THESE FACTORS.

*HEAT TRANSFER ANALYSIS + FLOW, PULSATING + FluCTUATION + HFAT TRANSFER + HEAT TRANSFEP, CONVECTION + HEAT TRANSFER, NATURAL CONVECTION

5-09628 STEIN R.P

THE GRAETZ PROBLEM IN CONCURRENT FLOW DOUBLE PIPE HEAT EXCHANGERS

ARGONNE NATIONAL LABORATORY

12 PAGES, 6 FIGURES, 7 REFERENCES, PP $76-87$ OF HEAT• TRANSFER - CLEVELAND, ICHEMICAL ENGINEERING PROGRESS SYMPOSIUM SERIES $59(61)$ 1965), AMERICAN INSTITUTE OF CHEMICAL SNGINEERS, SOURCE 15.00 C.Y

THE GRAETZ PROBLEM PERTAINING TO THE CONCURPENT-FLOW DOUBLE-PIPE HEAT EXCHANGER CAN BE STUDIED ANALYTICALLY BY EXTENSIONS OF FAMILIAR MATHEMATICAL TCCHNIOUFS. NUMERTCAL RESULTS ARE OBTAINED ILLUSTRATING THE FOLLOWING - 1 . THE VALUES OF FIJLLY DEVELOPFO LAMINAR FLOW HEAT-TRANSFER (FILM) COEFFICIENTS IN CONCURRENT-FLOW DOUBLE-PIPE HEAT EXCHANGERS CAN BE SIGNIFICANTLY LESS THAN THE VALUE CORRESPONDING TO THE BOUNOARY CONDITION OF UNIFORM WALL TEMPERATURE. 2. USE OF THE CUSTOMARY DESIGN EOUATION APPLIED TO LAMINAR FLOW HEAT EXCHANGERS CAN RESULT IN LARGE ERRORS EVEN WHEN THE HEAT TRANSFER IS FULLY DEVELOPEO. A NEW HEAT-EXCHANGER DESIGN OUANTITY, CALLEO THE EFFECTIVENESS COEFFICIFNT, IS INTRODUCED, AND ITS SIGNIFICANCE IS ILLUSTRATED.

*Flow, laminar + *heat transfer analysis + *heat transfer, convection + anNulus + heat exchangep + HEAT TRANSFER

5- 09629 BURGE HL

HIGH HEAT FLUX REMOVAL BY LIQUID METAL SPRAY COOLING OF SURFACES

ROCKE TDYNE, CANOGA PARK, CAL IFORNIA

12 PAGES, 13 FIGURES, 9 REFERENCES, PP $115-126$ OF HEAT TRANSFER - CLEVELAND, ICHEMICAL ENGINEERING 
CATEGORY 5

ACCIDENT ANALYSIS

$5-09629$ \#CONTINUED*

PROGRESS SYMPOSIUM SERIES $59(61) 1965)$, AMERICAN INSTITUTE OF CHEMICAL ENGINEERS, SOURCE \$15. OO CY

RESULTS OF LIQUID-METAL-SPRAY COOLING STUDIES ARE REPORTED FOR LITHIUM, SODIUM, AND MERCURY. THE RESULTS SHOW THAT SUCH TECHNIQUES OF COOLING CAN ACCOMODATE HEAT FLUXFS FAR IN EXCESS OF CALCULATEO POOL-BOILING LIMITS. IMPORTANT FACTORS, SUCH AS DROPLET SIZE, IMPINGEMENT VELOCITY, AND ANGLE ARE DISCUSSED, ALONG WITH A HYPOTHESIZED EXPLANATION FOR THE INCREASED HEAT-TRANSFER CAPABILITY. THEORETICAL CONSIDERATIONS SHOW THAT A SATURATED-TEMPERATURE OROPLET ACTUALLY RESIDES ON A HOT SURFACE $\triangle S$ A SUBCOOLED DROPLET FOR A TIME, DUP. ING WHICH THE DROPLET ABSORBS ENERGY AS SENSIBLE HEAT. IIPON RELIEF OF HIGH LOCAL SURFACE DPESSURES, THE DROPLET FLASHES TO VAPOR, THUS PROVIDING THE MECHANISM FOR HIGH-HEAT-FLUX CAPABILITY:

*HEAT TRANSFER ANALYSIS + \#HEAT TRANSFER EXPERIMENT + \#METAL, LIOUID + \#SPRAY, GENERAL + HEAT TRANSFFR + LITHIUM + MERCURY + SODIUM + SURFACE, GENERAL

5- 99630 NURICK WH + SEADER JD + COULTAS TA TRANSIENT HEAT TRANSFER FROM A LIQUIO METAL SPRAY IMPINGING ON A VERTICAL SURFACE ROCKETDYNE, CANOGA PARK

11 PAGES, 22 FIGURES, 6 TABLES, 6 REFERENCES, PP 127-137 OF HEAT TRANSFER - CLEVELAND, ICHEMICAL ENGINEER ING PROGRESS SYMPOSIUM SERIES $59(61) 1965)$, AMERICAN INSTITUTE OF CHEMICAL ENGINEERS, SOURCE

THE OBJECTIVE WAS TO OBTAIN DATA TO DEVELOP AN EMPIRICAL CORRELATION FOR DETERMINING HEAT TRANSFER FROM A HOT SODIUM SPRAY IMPINGING ON A VERTICAL PLATE. SODIUM WAS USED BECAUSE IT IS EASILY HANOLED. IN THE LIQUID STATE OVER A WIDE TEMPERATURE RANGE. THE MAJOR VARIABLES WERE DROPLET SIZE, ANGLE OF IMPINGEMENT, FLOW RATE PER UNIT AREA, SODTUM TEMPERAIURE, ANU IMPINGEMENT VELOCITY RFSULTS FROM EXPERIMENTS HITH SODIUM AT TEMPERATURES FROM 645 DEGREES TO 1,130 DEGREES F, SPRAYED ONTO A VERTICAL PLATE, INDICATE THAT AFTER A FILM WAS DEVELOPED ON THE SURFACE THE HEAT-TRANSFER COEFFICIENT VARIED FROM ABOUT 275 TO 725 BTU/(HR) (SO. FT) (OEGREE F) WHEN THE. IMPINGING VELOCITY WAS VARIED FROM ABOUT 150 TO 250 FT/SEC. A CORRELATION OF THE HEAT-TRANSFER DATA WAS DEVELOPED WITH CONVENTIONAL DIMENSIONLESS

PARAMETERS. THE RESULTING EQUATION FOR SODIUM VS NU EOUALS 0.0034 RE TO THE 0.407 POWER.

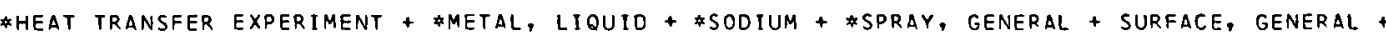
TEMPERATURE TRANSIENT

5-09631 DESOTOS

THE RAOIATION FROM AN AXISYMMETRIC, REAL GAS SYSTEM WITH A NONISOTHERMAL. TEMPERATURE DISTRIBUTION ROCKETDYNE, CANOGA PARK

17 PAGES, 13 FIGURES, 3 REFERENCES, PP 138-154 OF HEAT TRANSFER - CLEVELAND, (CHEMICAL ENGINEERING PROGRESS SYMPOSIUM SERIES 59(61) 19651, AMERICAN INSTITUTE OF CHEMICAL ENGINEERS, SOURCE

A METHOD WAS DEVELOPED TO DETERMINE THE RADIANT FLUX TO THE BASE REGION OF A GAS SYSTEM WITH AN AXISYMMETRIC GEOMETRY AND ANY AXISYMMETRIC PROPERTY OISTRIBUTION. THE GRAYGGAS SIMPLIFICATION IS NOT MADE, AND INTERLAYER ABSORPTION IS ACCOUNTED FOP. THAT IS, NO SIMPLIFYING ASSUMPTION IS MADE AS TO THE MAGNITUDE OF THE OPTICAL THICKNESS. THE EFFECT OF THE SHADOW OR SILHOUETTE OF ANY AXISYMMETRIC OCCLUSION IS ALSO ACCOUNTED FOR. AN EXAMPLE OF THE ANALYSIS IS GIVEN USING SMOOTHED VALUES OF THE SPECTRAL ABSORPTION COEFFICIENT OF CARBON DIOXIDE FOR THE 2.7-, 4.3-, AND 15-MICRON BANDS. OWING TO THE COMPLEXITY OF THE FUNCTIONAL RELATIONSHIPS OF THE PERTINENT PARAMETERS, A NUMERICAL INTEGRATION TECHNIQUE IS NECESSARY IN GENERAL.

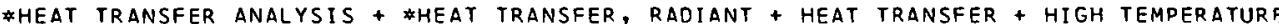

5-09632 TIEN LC + CHURCHILL. SW

AN EVALUATION OF ADPROXIMATIONS FOR RADIANT TRANSPORT WITH ISOTROPIC SCATTERING

THE UNIVERSITY OF MICHIGAN, ANN ARBOR

7 PAGES, 7 FIGURES, 2 TABLES, 15 REFERENCES, PP 155-161 OF HEAT TRANSFER - CLEVELAND, ICHEMICAL

ENGINEER ING PROGRESS SYMPOSIUM SERIES 59161119651 , AMERICAN INSTITUTE OF CHEMICAL ENGINEERS, SOURCE

THE INTEGRO-DIFFERENTIAL EQUATION THAT DESCRIBES THE TRANSPORT OF RADIATION THROUGH DISPERSEO MATERIAL HAS BEEN SOLVED EXACTLY ONLY FOR A FEW LIMITING AND IDEALIZED CONDITIONS. BECAUSE OF THE GREAT IMPORTANCE OF THIS PROBLEM IN A WIDE VARIETY OF APPLICATIONS, MANY APPROXIMATE SOLUTIONS HAVE BEEN PROPOSED. THE APPROXIMATE MODELS ARE USEFUL FOR UNDERSTANDING AS WELL AS FOR CAL CULATIONS, SINCE THE COMPLEX NUMERICAL INTEGRATION USED FOR THF EXACT CALCULATIONS PROVIDES ONLY SPECIFIC TABULATED VALUES. THE APPROXIMATIONS ARE COMPARED WITH THE EXACT SOLUTION FOR THE REFLECTION AND TRANSMISSION OF PARALLEL-PLANE RADIATION OBLIOUELY INCIDENT ON AN ABSORBING AND ISOTROPICALLY SCATTERING MEOIUM. THE MODIFIED DIFFUSIONAL MODELS OF CHU, CHURCHILL, ANO PANG AND OF GROSJEAN WERE QUITE AT,CURATE FOR ALL CONDITIONS. THE APPROXIMATION OF RICHARDS IS GENERALLY QUITE POOR, AND THE CLASSICAL DIFFUSION MODEL IS GENERALLY OF FAIR ACCURACY. THE P-SUB-3 APPROXIMATION IS QUITE ACCURATE FOR WEAKLY ABSORBING DISPERSIONS.

* COMPAR ISON, THEORY AND EXPERIENCE + \#HEAT TRANSFER, RADIANT + *TRANSPORT THEORY + HEAT TRANSFCR + HEAT TRANSFER ANALYSIS + HIGH TEMPERATURE

5-09633 HOWELL JR

DETERMINATION OF COMBINED CONDUCTION AND RADIATION OF HEAT THROUGH ABSORBING MEDIA BY THE EXCHANGE FACTOR APPROXIMATION

LEWIS RESEARCH CENTER, CLEVELAND

10 PAGES, 4 FIGURES, 1 TABLE, 11 REFERENCES, PP $162-171$ OF HEAT TRANSFER - CLEVELAND, ICHEMICAL

ENGINEERING PROGRESS SYMPOSIUM SERIES 59161) 19651 , AMERICAN INSTITUTE OF CHEMICAL ENGINEERS, SOURCE 
CATEGORY 5

ACCIOENT ANALYSIS

5-09633 *CONTINUED*

A SIMPLE SOLUTION FOR A GROUP OF PROBLEMS INVOLVING THE COMBINED MODES OF RADIATION AND CONOUCTION HEAT EXCHANGE THROUGH RADIANT MEDIA IS PROPOSED. CONSIDERING THE RADIANT EXCHANGE FACTORS INVOLVED IN THE EQUATIONS OF TRANSFER TO BF INDEPENDENT OF THE CONDUCTION PP.OCESS REPLACES THE INTEGRALS IN THESE EQUATIONS BY CONSTANTS THAT CAN RE DETERMINED EITHER. FROM PURE RADIATION SOLUTIONS AVAILABLE IN THE LITERATURE OR BY AN INDEPENDENT SOLUTION. COMPARISON OF APPROXIMATE RADIATION-CONDUCTION SOLUTIONS IS MADE WITH EXACT SOLUTIONS OF THE INTEGRO-DIFFERENTIAL EQUATIONS PRESENT IN THE LITERATURE, AND AGREEMENT IS FOUND OVER A LARGE RANGE OF PARAMETERS.

* COMPARISON, THEORY AND EXPERIENCE + *HEAT TRANSFER ANALYSIS + \#HEAT TRANSFER, RADIANT + HEAT TRANSFER + RADIATION MODEL

5-09634 HRYCAK P + HELGANS RE

EOUIL IBRIUM TEMPERATURE OF LONG THIN-WALLED CYLINDERS IN SPACE

BELL TELEPHONE LABORATORIES, INC., MURRAY HILL + NEWARK COLLEGE OF ENGINEERING, NEWARK

7 PAGES, 4 FIGURES, 12 REFERENCES, PP 172-178 OF HEAT TRANSFER - CLEVELAND, ICHEMICAL ENGINEERING PROGRESS

SYMPOSIUM SERIES 59161) 1965), AMERICAN INSTITUTE OF CHEMICAL ENGINEERS, SOURCE.

A FORMULA FOR STEAOY-STATE TEMPERATURE DISTRIBUTION IS DERIVED FOR CYLINDRICAL SHELLS UNDER SPACE CONOITIONS, AND THE EFFECT OF INTERNAL RADIATIDN AND OF SURFACE COATINGS IS CALCULATED. EXPERIMENTS INDICATE THAT THIS TEMPERATURE DISTRIBUTION LEADS TO CONSERVATIVE RESULTS IN CALCULATIONS OF MAXIMUM DEFLECTIONS OF LONG TUBES MADE FRDM TWISTED TAPE IN SPACE.

*COMPAR ISON, THEORY AND EXPFRIENCE + *HEAT TRANSFER, RADIANT + \#SPACECPAFT + HEAT TRANSFER + HEAT TPANSFER ANALYSIS + HEAT TRANSFER, EXPERIMENT

5-09635 SEIDER WD + CHURCHILL SW

THE EFFECT OF INSULATION ON FREEZING FRONT MOTION

THE UNIVERSITY OF MICHIGAN, $\triangle N N$ ARBOR

6 PAGES, 7 FIGURES, 4 REFERENCES, PP $179-184$ OF HEAT TRANSFER - CLEVELAND, (CHEMICAL ENGINEERING PR OGRESS SYMPOSIUM SERIES 59(61) 1965), AMERICAN INSTITUTE OF CHEMICAL ENGINEERING, SDURCE

A NUMERICAL METHOD OF SOLUTION IS PRESFNTED FOR THE MOTION OF A FREEZING FRONT THROUGH A SEMI-INFINITE REGION, INITIALIY AT UNIFORM TEMPERATURE, ADJACENT TO AN INSULATED ISOTHERMAL SURFACE. AN ANALYTICAL SOLUTION DOES NOT APPEAR TO BE FEASIBLE FOR THIS PROBLEM.

ILLUSTRATIVE CALCULATIONS WERE CARRIED OUT WITH A DIGITAL COMPUTER. THE RESULTS ARE COMPARED WITH THE ANALYTICAL SOLUTIONS FOR THE LIMITING CASES OF NO INSULATION AND NO LATENT HEAT AND

WITH A HKEVIUUSLY PROPOSED APPROXTMATE SOLUTION.

*PHASE CHANGE + *THERMAL INSULATION + COMPARISON, THEORY AND EXPERIENCE + COMPUTER, DIGITAL + HEAT TRANSFER + HEAT TRANSFER ANALYSIS + THERMODYNAMICS

5-09636 TELLER AS + CHURCHILL SW

FREEZING OUTSIDE A SPHERE

THE UNIVERSITY OF MICHIGAN, ANN ARBOR

5 PAGES, 5 FIGURES, 1 TABLE, PP $185-189$ OF HEAT TRANSFER - CLEVELAND, (CHEMICAL ENGINEERING DROGRESS

SYMPOSIUM SERIES 59161) 1965), AMERICAN INSTITUTE OF CHEMICAL ENGINEERING, SOURCE

A NUMERICAL METHOD OF SOLUTION IS PRESENTED FOR THE MOTION DF A FREEZING FRONT IHROUGH A REGION, INITIALLY AT UNIFORM TEMPERATURE, SURROUNDING AN ISOTHERMAL SPHERE. A GENERAL ANALYTICAL EQUATION DOES NOT APPEAR TO BE FEASIBLE FOR THIS PROBLEM. NUMERICAL CALCULATIONS WERE CARRIED OUT WITH A DIGITAL COMPUTER FOR A WIDE RANGE OF THE IMPORTANT DIMENSIONLESS PARAMETERS. STABILITY AND CONVERGENCE WERE TESTED EXPERIMENTALLY. ILLUSTRATIVE VALUES OF THE HEAT FLUX DENSITY AND THE FREEZING FRONT LOCATION ARE PRESENTED GRAPHICALLY IN FORMS CHOSEN TO ASSIST INTERPOLATION. THE RESULTS ARE COMPARED WITH THE ANALYTICAL SOLUTIONS FOR THE LIMITING CASES OF NO LATENT HEAT, NO HEAT CAPACITY, STEADY STATE, AND THE FLAT PLATE.

* Phase Change + SPhere + Computer, digital + heat tranjfer + heat transter analysis

5- 09637 ROSSON HF + MYERS JA

POINT VALUES OF CONDENSING FILM COEFFICIENTS INSIDE A HORIZONTAL PIPE

UNIVERSITY OF KANSAS + VILLANOVA UNIVERSITY

10 PAGES, 9 FIGURES, PP $190-199$ OF HEAT TRANSFER - CLEVELAND, ICHEMICAL ENGINEERING PROGRESS SYMPOSIUM SERIES 59(61) 1965), AMERICAN INSTITUTE OF CHEMICAL ENGINEERING, SOURCE

POINT VALUES OF THE CONDENSING-FILM COEFFICIENTS FOR METHANOL AND ACETONE WERE MEASURED FOR CONDENSATION INSIDE A HORIZONTAL PIPE. THE HEAT FLUX AT A POINT HAS MEASURED WITH A HEAT METER, AN ELECTRICAL ANALOG DEVICE COUPLED DIRECTLY TO THE HEAT TRANSFER MEDIUM.

COEFFICIENTS VARIED GREATLY FROM THE TOP OF THE PIPE TO THE BOTTOM. NEAR THE TOP, THE COEFFICIENT IS PREDICTED BY INCLUDING THE EFFECT OF VAPOR SHEAR IN NUSSELTS EOUATION. NEAR THE BOTTOM, AN ANALOGY BETUEEN HEAT AND MOMENTUM TRANSFER IS USED TO PREDICT THE COEFFICIENT INTERVENING COEFFICIENTS ARE CORRELATED WITH REYNOLDS NUMBERS OF VAPOR AND LIQUID, TEMPERATURE DROP, AND GRAVITY.

\#CONDENSATION + \#FILM, GENERAL + \#HEAT TRANSFER CORPELATION + FLOW, TUBE + HEAT TRANSFER + HEAT TRANSFER EXPERIMENT + PHASE CHANGE

$5-C 9638$ LEE J

REMARKS ON THE LIQUTO METAL CONDENSATION 
CATEGORY 5

ACCIDENT ANALYSIS

5-09638 \#CONTINUED \#

AEROSPACE RESEARCH LABORATORIES, OHIO

10 PAGES, 6 FIGURES, PP 200-209 OF HEAT TRANSFER - CLEVELAND, ICHEMICAL ENGINEERING PROGRESS SYMPOSIUM SERIES 59161) 19651, AMERICAN INSTITUTE OF CHEMICAL ENGINEER ING, SOURCE

a two-phase tURBULENT CONDENSATION has formulated with THE EDOY VISCOSITIES OF DEISSLER AND VON KARMAN. THE PREDICTED CONDENSATION HEAT-TRANSFER COEFFICIENTS ARE STILL HIGHER THAN THE LIQUID-METAL DATA OF MISRA AND BONILLA. HOWEVER, IT WAS SHOWN THAT THE UPWARD VAPOR FLOW CAN DECREASE THE HEAT-TRANSFER COEFFICIENT GREATLY, AND THE SCATTER OF DATA MAY BE ATTRIBUTED TO THE VARIATION OF VAPIR VELDCITY.

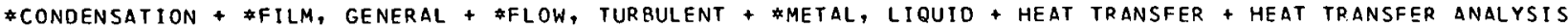

5-09639 FAUSKE HK

THE DISCHARGE OF. SATURATED HATER THROUGH TUBES

ARGONNE NATIONAL LABORATORY, ARGONNE

7 PAGES, 2 FIGURES, 2 TABLES, PP 210-216 OF HEAT TRANSFFR - CLEVELAND (CHEMICAL ENGINEFRING PROGRESS SYMPOSIUM SERIES $59(61) 1965)$, AMERICAN INSTITUTE OF CHEMICAL ENGINEERING, SOURCE

A NEW HIGH-PRESSURE FACILITY DESIGNED FOR MEASURING OISCHARGE RATES OF WATER. FROM VARIDUS TUBE CONFIGURATIONS UP TO 2000 LB/SQ. IN. IS BRIEFLY DESCRIBED. DATA ARE REPORTED ON DISCHARGE RATES OF SATURATEO WATER FROM TUBES OF LENGTH-TO-DIAMETER IL/DI RATIO FROM O TO 40 , WITH INITIAL PRESSURE UP TO 200O LB/SO: IN. PRESSURE PROFILES IN THE TUBES WEPE MEASURED FOR VARIOUS UPSTREAM CONDITIONS, AND THE CRITICAL PRESSURE RATIO WAS DETEPMINED AS A FUNCTION OF L/D RATIO ANO FOUNO INDEPENDENT OF INITIAL CONDITIONS.

\#FLOW, TUBE + \#FLOW, TWO PHASE + HEAT TRANSFER + HEAT TRANSFER EXPERIMENT + LOSS OF FLOW

5-C9640 JACKSON BW + TROUPE RA

LAMINAR FLOW IN A.PLATE HEAT EXCHANGER

NORTHEASTERN UNIVERSITY, BOSTON

5 PAGES, 5 FIGURES, I TABLE, 16 REFERENCES, PP $220-224$ OF HEAT TRANSFER - CLEVELAND ICHEMICAL ENGINEERING

PROGRESS SYMPOSIUM SERIES 59161) 1965), AMERICAN INSTITUTE OF CHEMICAL ENGINEERING, SOURCE

A CORRELATION IS PRESENTED FOR THE LAMINAR-FILM HEAT-TRANSFER COEFFICIENT OF STRFAMS WITH VISCOSITIES UP TO 1400 CENTIPOISES UNDERGOING HEATING OR COOLING IN A PLATE HEAT EXCHANGER. DATA IN THE TRANSITION AND TURBULENT REGIONS ARE GIVEN. LOG-MEAN TEMPERATURE CORPECTION FACTORS ARE NEEDED FOR DESIGNING COMPLICATED FLOW PATTERNS.

*FLOW, LAMINAR + \#HEAT EXCHANGER + \#HEAT TRANSFER CORRELATION + FILM, GENERAL + HEAT TRANSFER + HEAT TRANSFER EXPERIMENT

5- 09641 CUMO M + LOPEZ S + PINCHERA GC NUMER ICAL CALCULATION OF EXTENDED SURFACE EFFICIENCY COMITATO NAZIONALE ENERGIA NUCLEARE (CNEN) ITALY

9 PAGES, 9 FIGURES, 14 REFERENCES, PP 225-233 OF HEAT TRANSFER - CLEVELAND ICHEMICAL ENGINEERING PR DGRESS SYMPOSIUM SERIES $59(61) 1965)$, AMERICAN INSTITUTE OF CHEMICAL ENGINEERING, SOURCE

THE PAPER PRESENTS THE NUMERICAL CALCULATION OF EXTENDED-SURFACE TWO-DIMENSIONAL TEMPERATURE DISTRIBUTION AND EFFICIENCY WITH AND WITHOUT INTERNAL HEAT GENERATION AND WITH UNIFORM AND NONUNIFORM HEAT-TRANSFER COEFFICIENT. FORCED CONVECTION AND NUCLEATE BOILING COOLING ARE TREATED. THE INTEGRATION SYSTEM IS THE ENTIRE EXTENDEO SURFACE OF ANY FORM, INCLUDING THE BASE OF SOLID-FLUID CONDITIONS ANO FIN DIMENSIONS.

\#COMPARISON, THEORY AND EXPERIENCE + \#FIN + *HEAT TRANSFER AUGMENTATION + *HFAT TRANSFER, CONVECTION + COMPUTER, DIGITAL + HEAT CONDUCTION + HEAT TRANSFER + HFAT TRANSFER ANALYSIS + HFAT TRANSFER, BOILING

5-09642 COLVER CP + BALZHISER RE

A STUDY OF SATURATED POOL BOILING POTASSIUM UP TO BURNOUT HEAT FLUXES

THE UNIVERSITY OF MICHIGAN + THE UNIVERSITY OF OKLAHOMA

11 PAGES, 13 FIGURES, 30 REFERENCES, PP 253-263 OF HEAT TRANSFER - CLEVELANO ICHEMICAL ENGINEER ING

PROGRESS SYMPOSIUM SERIES 59(61) 1965), AMERICAN INSTITUTE OF CHEMICAL ENGINEERING, SOURCE

POTASSIUM POOL BOILING FROM THE OUTER SURFACE OF A HORIZONTAL 3/8-IN-DIAM BY $1.25-I N$. LONG HAYNES- 25 TUBE WAS STUDIED AT HEAT FLUXES UP TO AND INCLUDING BURNOUT. THE SCOPE OF THE INVESTIGATION INCLUDED OPERATING OVER A PRESSURE RANGE OF 0.23 TO 45 LB/SO. IN. ABS. BURNDUT MEASUREMENTS WERE MADE AT PRESSURES UP TO 22 LB/SO. IN ABS. AN EMPIRICAL FIT OF THE BURNOUT RESULTS CAN BE REPRESENTEO BY AN EQUATION. PRONOUNCED TEMPERATURE FLUCTUATIONS BETWEEN IO ANO 150 DEGREES F EXISTED IN THE HEAT-TRANSFER SURFACE OURING THE BOILING OF POTASSIUM. BELOW 250, OOO BTU/(HR)(SQ. FT,), TEMPERATURE FLUCTUATIONS WERE COMMON IN THF BULK LIQUID AND WERE ACCOMPANIED WITH NOTICEABLE PRESSURE FLUCTUATIONS.

* BURNOUT HEAT FLUX + *HEAT TRANSFER EXPERIMENT + \#METAL, LIQUID + \#POOL BOILING + \#POTASSIUM + HEAT TRANSFER

5-09643 YOUNG RK + HUMMEL RL

IMPROVED NUCLEATE BOILING HEAT TRANSFER

UNIVERSITY OF TORONTO, TORONTO, ONTARIO, CANADA

7 PAGES, 7 FIGURES, 19 REFERENCES, PP $264-270$, OF HEAT TRANSFER - CLEVELAND ICHEMICAL ENGINEERING PROGRESS

SYMPOSIUM SERIES 59(61) 1965), AMERICAN INSTITUTE OF CHEMICAL ENGINEERING, REPRINTED FROM CHEMICAL 
CATEGORY 5

ACCIDENT ANALYSIS

5-09643 \#CONTINUED*

ENGINEERING PROGRESS SYMPOSIUM SERIES 6017) 19641, PP 53-58, SOURCE

HEAT TRANSFER SURFACES THAT GIVE RISE TO HIGH COEFFICIENTS THROUGHDUT THE LOWER REgION OF THF NUCLEATE BOILING REGIME HAVE BEEN DEVELOPED. THE SURFACES ARE CHARACTERIZED BY A LARSE DENSITY OF SPOTS OF POORLY WETTED MATERIAL ON A SURFACE THAT IS WETTED BY THE BOILING LIOUID. EUBBLING AT SUCH SITES DURING POOL BOILING OF WATER AT THE SATURATION TEMPERATURE UNDER ATMOSPHER IC PRESSURE HAS BEEN OBSERVED AT AVERAGE SURFACE SUPERHEATS OF ONLY 2 TO 4 DEGREES F. HEAT-TRANSFER COEFFICIENTS OF UP TO 6500 BTU/(HR.)(SQ. FT.) (DEGREE F) AT A SURFACE HEAT FLUX OF 70,000 BTU/(HR.)(SQ. FT.) ARE REPORTED. AT A HEAT FLUX OF 1D,ODN BTU/(HR.)(SQ. FT.), THE COMMON FLUX FOR EVAPORATOR USAGE, THE HEAT-TRANSFER COEFFICIENT WAS 26DO BTU/(HR.) $(S Q$ FT. I (DEGREE FI, AND THE TEMPERATURE DIFFERENCE WAS ONLY 3.8 DEGREES F.

* COATING, SURFACE + \#UCleATE bOILING + *STEAM + \#WATER, gENERAL + hEAT TRANSFER + HEAT TRANSFER EXPERIMENT

5-09644 COSTELLOCP + BOCK CO+ NICHOLS CC

A STUOY OF INDUCEO CONVECTIVE EFFECTS ON SATURATED POOL $80 I L I N G$ BURNOUT UNIVERSITY OF WASHINGTON, SEATTLE

10 PAGES, 5 FIGURES, 1 TABLE, 13 REFERENCES, PP $271-280$ OF HFAT TRANSFER - CLEVELAND ICHEMICAL ENGINEERING PROGRESS SYMPOSIUM SERIES 59(61) 19651, AMERICAN INSTITUTE OF CHEMICAL ENGINEERING, SOURCE

EARLIER EXPERIMENTAL STUDIES SHOWING APPRECIABLE SIZE AND SURFACE EFFECTS ON POOL-ROILING DURNOUT ARE EXTENDED TO CASES OF VERY LARGE FLAT -PLATE HEAIERS. IT IS SHOWN THAT IT MAY RE POSSIBLE TO ASCRIBE THE SIZE EFFECT TO CONVECTIVE ENERGY TRANSFER TO LIQUID WHICH FLOWS IN FROM THE SIDES OF THE HEATERS TOWARD THE CENTER. LINE. THE FLOW IS NATURALLY INDUTED BY THF BOILING PROCESS. IT IS POSTULATED THAT THE IMMEOIATE CAUSE OF BURNOUT IS DRYOUT UNDER VAPOR PATCHES WHICH OCCUR UPON THE HEATER SURFACES. BURNOUT IS BELIEVED TO OCCUR WHEN AN AMOUNT OF ENERGY LIMITED BY SURFACE WETTABILITY MUST BE REMOVED FROM THE HEATFR BY LATENT-HFAT TRANSPORT. SUPERIMPOSED UPON THE AMOUNT OF ENERGY REMOVABLE BY LATENT-HEAT TRANSPORT IS COMPONENT OF ENERGY REMOVED BY THE INDUCED CONVECTIVE EFFECTS. THE CONVECTIVE COMPONFNT VARIES WITH THE HEATER SIZE. DATA FROM THE PRESENT TESTS SEEM TO BE EXPLAINABLE DN THF. BASIS OF THE PROPOSED MODEL OF BURNOUT, WHICH IS SUBJECT TO CONSIDERABLE REFINEMENT.

\#BURNOUT HEAT FLUX I *CONVECTIVE BOILING + \#HEAT TRANSFER EXPERIMENT + FHEAT IKANSFER, BOILING + * POOL BOILING + COMPARISON, THEORY AND EXPERIENCE + HEAT TRANSFER + HEAT TRANSFER, CONVECTION

5-09645 CARNE M

SOME EFFECTS OF TEST SECTION GEOMETRY IN SATURATED POOL BOILING ON THE CRITICAL HEAT FLUX COR SOME ORGANIC LIQUIOS AND LIQUID MIXTURES

CHALK RIVER, AECL + M. W. KELL GGG COMPANY, NEW YORK

9 PAGES, 14 FIGURES, 1 TABLE, 14 REFERENCES, PP 281-289 OF HEAT TRANSFER - CLEVELAND ICHFMICAL ENGINEERING PROGRESS SYMPOSIUM SERIES 59(61) 1965), AMERICAN INSTITUTE OF CHEMICAL ENGINEERING, SOURCE

CRITICAL HEAT FLUX DATA ARE PRESENTED FOR SIX ORGANIC LIOUIDS AND FIVE WATER-OPGANIC PAIRS BOILING AT ATMOSPHERIC SATURATED POOL CONOITIONS ON HORIZONTAL STEEL ELEMENTS. THE DIAMETERS OF THE ELEMENTS RANGED FROM 0.8 TO 6.4 MM, AND THE WALL THICKNESSFS FROM D.15 TO 3.2 MM. THE CRITICAL HEAT FLUXES OF THE PURE ORGANICS WERE INOEPENDENT OF THE ELEMENT DIAMETER, D, FOP SOL TO ELEMENTS WITII D EQUAL TO OR GREATER THAN 2.4 MM. , BUT 15 TO 40 PERCENT HIGHER FUR D SOLIO ELEMENTS WITII O EQUAL TO OR GREATER THAN 2.4 MM.
EQUAL TO OR LESS THAN $1.6 \mathrm{MM}$. THIS BEHAVIOR OF THE SMALL-DIAMETER ELEMENTS IS IN CONTRAST WITH THE DATA REPORTED BY BERNATH AND IVEY AND MORRIS FOR WATER. THE DIFFERENCES IN RESULTS ARE EXPLAINED ON THE BASIS OF A GEOMETRY EFFECT ON CRITICAL HEAT FLUX AT HIGH WATER CONCENTRATIONS. THE DATA FOP. THE MIXTURES ARE USED TO DEMONSTRATE TIIAT THE FORM OF THE CORRELATION EQUATION ORIGINALLY PROPOSED BY KUTATELADZE IS NOT ADEQUATE FOR PREDICTING THE CRITICAL HEAT FLUXES FOR MIXTURES.

\#HEAT TRANSFER, BOILING + \#POOL BOILING + HEAT TRANSFER + HEAT TRANGTER EXPERIMENT

$5-09646$ HSU HY

GRADUAL TRANSITION OF NUCLEATE BOILING FROM DISCRETE BUBBLE REGIME TO MULTIBUBBLE REGIME LEHIS RESEARCH CENTER, NATIONAL AERONAUTICS ANU SHACE AUMINISTRATION, R.IFVFI.

9 PAGES, 7 FIGURES, 1 TABLE, 22 REFERENCES, PP 290-298 OF HFAT TRANSFER - CLEVELAND ICHEMICAL ENGINEERING PROCRESS SYMROSIUM SLRICS 59(61) 1965), AMERICAN INSTITUTE OF CHEMICAL ENGINEER INE, SOURCE

A PHOTOGRAPHIC STUDY WAS MADE OF OVER 5 DOOO BUBELES IN THE NUCLEATE BOILING OF METHANOL AND WATER ON A NARROW HEATING STRIP AT VARIOUS HEAT FLUXES AND DEGREES OF SUBCOOLING. THE RESULTS SHOWED THAT TRANSITIONS FROM THE DISCRETF-BUBBLE REGIME TO THE MULTIBUBRLE REGIME WAS GRADUAL. THE FRACTION OF HEATING AREA COVERED BY MULTIBURBLES INCREASES WITH THE INCRFASING HEAT FLUX AND IS PREDICTAELE. THE AREA FRACTION IS A POISSON FUNCTION OF THE PRODUCT OF THE MEAN AREA OF INFLUENCE OF SINGLE BUBBLES AND THE INSTANTANEOUS POPULATION DENSITY.

\#HEAT TPANSHEK, BÚILING + "NUCLEATE BOILING I HEAT TRANGFER + HEAT TRANSFER. aNALYSIS + HEAT TRANSFER CORRELATION + HEAT TRANSFER EXPERIMENT

5-09647 HOFFMAN HW + KEYES JJ STUDIES IN HEAT TRANSFER AND FLUID MECHANICS, PROGRESS REPORT FOR PERIOD OCTOBER 1 , 1963 - JUNE 30 , 1964 OAK RIDGE NATIONAL LABORATORY

ORNL-TM-1148 +. 129 PAGES, 60 FIGURES, 5 TABLES, REFERENCES, $\triangle$ UGUST, 1965, CFSTI

THIS REPORT IS A SUMMARY OF WORK IN THE FOLLOWING AREAS - BOILING-POTASSIUM HEAT TRANSFER, FORCED-CONVECTION SYSTEMS AND SUPERHEAT PHENOMENA, BOILING IN MULTIROD GEOMETRIES, CRITICAL HEAT FLUX FOR NATURAL CONVECTION OF WATER IN BLOCKED VERTICAL CHANNELS, SWIRL-FLOW HEAT TRANSFER, EXPERIMENTAL AND THEORETICAL STUDIES OF HYOROMAGNETIC STABILIZATION IN VORTEX FLUID 
5-09647 \#CONT INUED* MECHANICS, POTENTIAL VORTEX FLOW NEAR A STATIONARY DISK, BOUNDARY-LAYER TRANSIENT PHENOMENA, TURBULENT TRANSPORT STUDIES, AND THERMOPHYSICAL PROPERTIES OF LIOUID LITHIUM AND POTASSIUM.

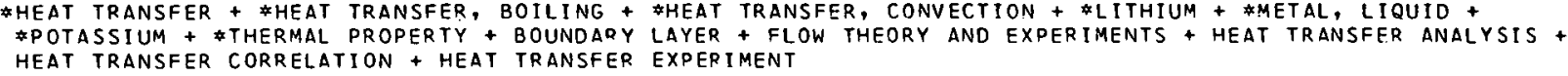

\#RADIATION EFFECT + \#STEEL + \#TENSILE PROPERTY + ALLOY + CREEP PROPERTY + RADIATION DAMAGE + X-RAY

5-09918 SMITH BE

AN X-RAY STUDY OF FISSION FRAGMENT DAMAGE IN STEELS

UNITED KINGDOM ATOMIC ENERGY AUTHORITY, HARWELL

5 PAGES, 4 TABLES, I FIGURE, 11 REFERENCES, JOURNAL OF NUCLEAR MATER IALS, 17(1), PAGES 167-171 (1965)

LATTICE-PARAMETER MEASUREMENTS WERE MADE ON STEELS BOMBARDED WITH FISSION FRAGMENTS AT ABOUT $60 \mathrm{C}$. THE RESULTS FOR ONE AUSTENITIC STEEL ICR, 20 WT PERCENT, NI, 20 WT PERCENT, NB, O.44 WT PERCENT, ARE DISCUSSED IN CONJUNCTION WITH PUBLISHED RESULTS OBTAINEO BY ELECTRON MICROSCOPY AND ARE CONSIDERED CONSISTENT WITH THE HYPOTHESIS THAT THE PROPORTION OF SMALL DEFECTS IN THIS STEEL IS GREATEST WHEN IRRADIATION DOSE RATES ARE HIGH. IN TWO OTHER AUSTENITIC STEELS (CR, 18 WT PERCENT, NI, 37 WT PERCENT) AND (CR, 18 WT PERCENT, NI, 12 WT PERCENT) ANO A FERRITIC STEEL (CR, 15 WT PERCENT, NI, 5 WT PERCENTI, A MEASURABLE PROPORTION OF SMALL DEFECTS WAS PRESENT AFTER IRRAOIATION AT A DOSE RATE INTERMEOIATE BETWEEN THE TWO USED FOR THE 20/20 AUSTENITE.

* ALLOY + *RADIATION DAMAGE + *STEEL + ELECTRON MICROSCOPY + RADIATION EFFECT + X-RAY

5-C9920 COWAN A

METALLURGICAL TESTING AT CULCHETH

UNITED KINGDOM ATOMIC ENERGY AUTHORITY, REACTOR MATERIALS LABORATORY, CULCHETH

4 PAGES, 3 FIGURES, ATOM(112), PAGES 33-36 (FEBRUARY, 1966)

A LARGE PROPORTION OF THE WORK AT THE REACTOR MATERIALS LABORATORY IS METALLURGICAL, AND EXTENSIVE FACILITIES HAVE BEEN DEVELOPEO TO ALLOW FULL-SCALE INVESTIGATIONS OF THE BEHAVIOUR OF METALS RANGING IN SECTION FROM THIN FOIL TO THICK STEEL PLATES. IN ADOITION TO CONVENTIONAL TESTS, EQUIPMENT HAS BFEN DEVISED TO GIVE BETTER SIMULATION OF ACTUAL SERVICE CONDITIONS, ESPECIALLY WHERE APPLICATION OF NORMAL TEST DATA IS INADEQUATE OR FVEN UNREALISTIC. IN SEVERAL CASES THIS INCLUDEO TESTS ON EITHER THE FULL-SIZE COMPONENT OR LARGE SAMPLES, NECESSARY TO BE REASONABLY REPRESENTATIVE OF THE FINAL PRODUCT. CREEP TESTING. BRITTLE FRACTURE TESTS. TESTS ON MODEL VESSELS. POSTIRRADIATION TESTING FACILITIES. OTHER FACILITIES.

\#EQUIPMENT DESIGN + \#METAL + \#TESTING + ERITTLF FRACTURF + CORROSION + CREEP PROPERTY + IMPACT PRUPERIY + RAOIATION EFFECT + TENSILE PROPERTY + TEST, PRESSURE VESSEL

5-09921 JABLONOWSKI EJ + RITZMAN RL + DEMASTRY JA FISSION-FRAGMENT EFFECTS IN STRUCTURAL MATERIALS. QUARTERLY PROGRESS REPORT, JULY-SEPTEMBER I965 BATTELLE MEMORIAL INSTITUTE

BMI-X-10146+EURAEC-1527+. 7 PAGES, OCTOBER 1, 1965, CFSTI, \$1.00 CY,\$0.50 MN

THE OBJECTIVE OF THIS PROGRAM IS TO DETERMINE THE TYPE AND MAGNITUDE OF MECHANICAL-PROPERTY CHANGES PRODUCED ANNEALED AISI TYPE 304 STAINLESS STEEL AND ANNEALED ZIRCALOY-2 BY FISSION-FRAGMENT IRRADIATIONS. TESTING OF TUBE-BURST AND BEND SPECIMENS OF RECOIL-IMPREGNATED ZIRCALOY-2 AND TYPE 304 . STAINLESS STEEL WAS COMPLETED. NOMINAL INCRFASES OF 8 TO 10 PERCENT IN AVERAGE PROPORTIONAL LIMIT AND YIELD-STRENGTH VALUES OF FISSION-FRAGMENT-DAMAGED OVER NEUTRON-DAMAGED MATERIALS WERE NOTED FROM BOTH THE BEND AND TUBE-BURST DATA. LIGHT AND ELECTRON METALLOGRAPHIC ANALYSES OF THE RECOIL-IMPREGNATED MATERIALS WERE COMPLETED. NO STRUCTURAL CHANGES WERE NOTED AS THE RESULT OF FISSION-FRAGMENT OR NEUTRON DAMAGE FRACTURE ANALYSIS OF RUPTURES PRODUCED IN THE TUBE-BURST EXPERIMENTS INDICATED NO CHANGE IN FRACTURE MODE (DUCTILE) AS A RESULT OF FISSION-FRAGMENT IRRADIATION. THE MAXIMUM RADIATION-INDUCED TENSILE AND COMPRESSIVE STRESSES IN 2 IRCALOY- 2 AND TYPE 304 STAINLESS STEEL WERE CALCULATED ON THE BASIS OF EXPER IMENTALLY DETERMINED VALUES OF RADIATION EXPANSION COEFFICIENTS AND FISSION-FRAGMENT CONCENTRATIONS. ALTHOUGH CALCULATED TENSILE STRESSES WERE NOMINAL, CONPRESSIVE STRESSES OF 14,300 PSI (STAINLESS STEEL) AND 42,400 PSI (ZIRCALOY-2) WERE OBTAINED.

*RADIATION DAMAGE + *STEEL, STAINLESS + *TENSILE PROPERTY + ALLOY + ELECTRON MICROSCOPY + FAILURE, PIPE + TESTING + ZIRCONIUM 
CATEGORY 5

ACCIDENT ANALYSIS

5-09926 \#CONTINUED*

RADIATION EMBRITTLEMENT OF REACTOR PRESSURE VESSEL STEELS

U.S. NAVAL RESEARCH LABORATORY, WASHINGTON, D.C.

12 PAGES, 6 TABLES, 7 FIGURES, 8 REFERENCES, NUCLEAR ENGINEERING AND DESIGN, $3(2)$, PAGFS $287-298$ (1966)

THE PROBLEM OF RADIATION EMBRITTLEMENT OF REACTOR PRESSURE VESSEL STFELS IS CONSIDERED HITHIN THE FRAMEWORK OF NEW NAVAL RESEARCH LABORATORY CONCEPTS OF FRACTURE ANALYSIS AND IN REFERENCE TO THE PRIMARY VARIABLES, CONPOSITION OF THE STEEL, NEUTRON EXPOSURE, AND EXPOSURE TEMPERATURE. THIS PAPER SUMMARI ZES THE STATUS OF THE NRL EMBRITTLEMENT STUDY, WITH EMPHASIS ON MAJOR FACTORS SUCH AS THE EFFECTS ON DIFFERENT STEELS AND THE EFFECTS OF NUCLEAR AND THERMAL ENVIRONMENT DURING IRRADIATION. IN ADDITION, POSTIRRADIATION HEAT TREATMENT TO RESTORE NOTCH DUCTILITY WAS INVESTIGATED OVER A RANGE OF IRRADIATION AND ANNEALING

CONDITIONS. CURRENT AND PLANNED PROGRAMS ARE REVIEWED WITH REFERENCE TO SUMMARY OBSERVATIONS.

*BRITTLE FRACTURE + \#EMBRITTLEMENT + \#FAILURE, PRFSSURE VESSEL + \#IMPACT PROPERTY + \#RADIATION DAMAGE + \#RADIATION EFFECT + \#STFFI. + ALLOY + ANALYTICAL TECHNIQUE, CALIBRATION + CONTAINMENT, PRESSURE VESSEL + FLAW + IMPACT SHOCK + NDT DATA (NIL DUCTILITY TRANSITIONI + REACTOR, PRESSURIZED WATER + STRESS + STRESS ANALYSIS + TENSILE PROPERTY + TEST, DESTRUCTIVE

5-09953 ERICKSON LE + FAN LT + FOX VG

HFAT AND MASS TRANSFER ON A MOVING CONTINUOUS FLAT PLATE WITH SUCTION OR INJECTION KANSAS STATE UNIVERSITY

7 PAGES, 7 FIGURES, 1 TABLE, 10 REFERENCES, IND. AND ENG. CHEM., FUNDAMENTALS, 5(1), PAGES 19-?5 (FEBRUARY, 1966 )

THE LAMINAR BOUNDARY LAYER ON A MOVING, CONTINUOUS, FLAT SURFACE WITH SUCTION AND INJECTION IS INVESTIGATED FOR CASES WHERE THE NONZERO TRANSVERSF VELOCITY PROFILE AT THE SURFACE IS SUCH THAT SIMILAR SOLUTIONS MAY BE OBTAINED. UNDER THESE CONDITIONS, THE THERMAL AND CONCENTRATION BOUNDARY LAYERS ARE INVESTIGATED FOR THE CASE OF CONSTANT TEMPERATURE AND CONCENTRATION AT THE FLAT SURFACE. NUMERICAL SOLUTIONS OF THE BOUNDARY-LAYER MOMENTUM, ENERGY, AND DIFFUSION DIFFERENTIAL EQUATIONS ARE PRESENTED FOR A WIDE RANGE OF THE INJECTION PARAMETER, F(O), AT PRANDTL AND SCHMIDT NUMBERS OF 1,10 , AND 100.

*BOUNDARY LAYER + *FLOW, LAMINAR + HEAT TPANSFER + HEAT TRANSFER ANALYSIS + MASS TRANSFER

5-09954 MILLER D

HIGHLIGHTS OF THE 8TH NATIONAL HEAT TRANSFER CONFERENCF

GENERAL NUCLEAR ENCINEERING CORPOPATION

17 PAGES, 3 FIGURES, POWER REACTOR TECHNOLOGY, 8(4), PAGES 228-244 (FALL, 1965)

MANY PAPERS OF FUNDAMENTAL AND APPL IED INTEPEST FOR REACTOR TECHNOLOGY WERE PRESENTED AND DISCUSSED AT THE 8TH NATIONAL HEAT TRANSFER CONFERENCE, LOS ANGELES, AUGUST 9-11, 1965. TOPICS DISCUSSED RANGED FROM APPLICATIONS SUCH AS HEAT EXCHANGERS, PACKED BEDS,

DESALINIZATION, AND LOSS-OF-COOLANT ACCIDENTS IN REACTORS TO MORE FUNDAMENTAL STUDIES OF BOILING ANO CONDENSATION, TWO-PHASE FLOH ANO PRESSURE DROP, AND RADIATION AND THERMOPHYSICAL PROPERTIES.

*FLOW, TWO PHASE + HEAT TRANSFER, BOILING + \#POOL BOILING + CONDFNSATIDN + FIN + FLOW, TUBE + FOG + HEAT EXCHANGER + HEAT TRANSFER + HEST TRANSFFR ANALYSIS + HEAT TRANSFEP EXPERIMENT + LOSS OF COOLANT + METAL, LIQUID + THERMAL PROPERTY

5-09956 ROGERS JT

HEAT TRANSFER FAILURE MECHANISMS IN SIMULATED ORGANIC-COOLED FUEL BUNDLES

CANADIAN GENERAL ELECTRIC COMPANY, LTD.

RG4CAPID +. BQ PAGES, FIGURES, TABLES, REFERENCES, MAY, 1965, DEP/MN

EXPERIMENTS IN THO-ELEMENT TEST SECTIONS WITH HB-4O AND WITH SANTOWAX OM PLUS 30 PERCENT HIGH BOILERS SHOW THAT THE HEAT TRANSFER MECHANISM MAY BE EITHER TRUE, LOCALIZED, DNB OR COKE-OUT. THE COKE-OUT PHENOMENON IS EXPLAINED AND CONDITIONS FOR ITS OCCURRENCE ARE EXAMINED. THE ADEQUACY OF THE WR-I FUEL DESIGN FAILURE CRITERION IS SHOWN.

*ORGANIC COOLANT + DNB IDEPARTURE FROM NUCLEATE BOILINGI + FILM, GENERAL + HEAT TRANSFER + HEAT TRANSFER EXPERIMENT

5-09957 BERGLES AE + SUO M

INVESTIGATION OF BOILING WATER FLOW REGIMES AT HIGH PRESSURE . REPORT NO. 621

DYNATECH CORPOPATION, CAMBRIDGE, MASS.

NYO-3304-8+. 61 PAGES, REFERENCES, FEBRUARY 1, 1966, CFSTI, \$3.0 CY, \$0.75 MN

AN EXPERIMENTAL SYSTEM HAS BEEN DEVELOPED FOR THE STUDY OF BOILING FLOW REGIMES AT HIGH PRESSURE FLOW REGIME INFORMATION WAS OBTAINED FOR BOILING WATER FLOWING VERTICALLY UPHARD IN CIRCULAR TUBES OF 0.4 IN. DIAMETER AND LENGTHS OF TWO TO EIGHT FEET. INLET CONDITIONS WERE SUBCOOLED, PRESSURES WERE 500 AND 1000 PSIA, ANO MASS VELOCITIES RANGED FROM O.4 $X$ IO TO THE 6 TO $4.0 \times 10$ TO THE 6 LBM/HR-FT SQUARED. UNIFORM HEAT FLUXFS WERE OBTAINED RY DIRECT-CURRENT RESISTANCE HEATING. THE TRENDS IN THE DATA CAN BE QUALITATIVELY RELATED TO AGGLOMERATION LENGTH, NUCLEATE BOILING AGITATION, AND NONEOUILIBRIUM VOIDS.

*FLOW, TUBE + \#HEAT TRANSFER, BOILING + FLOW THEORY ANO EXPERIMENTS + FLOW, TWO PHASE + HEAT TRANSFER + HEAT TRANSFER CORRELATION + HEAT TRANSFER EXPERIMENT + PRESSURE, INTERNAL 
CATEGORY 5

ACCIDENT ANALYSIS

5-09958 TURNER JM + WALLIS GB

TWO-PHASE FLOW AND BOILING HEAT TRANSFER. AN ANALYSIS OF THE LIQUID FILM IN ANNULAR FLOW. INTERIM REPORT DARTMOUTH COLLEGE, THAYER SCHOOL OF ENGINEERING, HANOVER, NEH HAMPSHIRE

NYO-3114-13 + EURAEC-1572 +. 117 PAGES, FIGURES, TABLES, REFERENCES, DECEMBER, 1965, CFSTI, \$4.OO C.Y,

$\$ 0.75 \mathrm{MN}$

AN ANALYSIS OF THE LIQUID FILM IN ANNULAR FLOW HAS BEEN CARRIED OUT FROM WHICH THE PRESSURE DROP CAN BE PREDICTED EXPLICITLY IN TERMS OF THE VOID FRACTION, THE ENTRAINMENT, AND KNOWN QUANTITIES SUCH AS THE FLOW RATES, FLUIO PROPERTIES, AND PIPE DIAMETER. EOUATIONS SUMMARIZE THE FINAL RESULTS. THE ANALYSIS IS RASED ON THE PRINCIPAL HYPOTHESIS THAT THE LIOUID FILM EEHAVES AS THOUGH IT WERE PART OF A SINGLE-PHASE FLOW OF LIQUID FILLING THE HHOLE PIPE.

*FILM, EENERAL + \#FLOW THEORY ANO EXPERIMENTS + \#FLOW, TWO PHASE + ANNULUS + FLOW, TUBE

5-C9960 BROWN AR + THOMAS MA

COMEINEC FREE AND FORCED CONVECTION HEAT TRANSFER FOR LAMINAR FLOW IN HORIZONTAL TUBFS ENGL ISH ELECTRIC COMPANY, LTO, WHETSTONE

9 PAGES, 9 FIGURES, 1 TABLE, 7 REFERENCES, JOURNAL MECHANICAL ENGINEERING SCIENCE, 7 (4), PAGES $440-448$ (DECEMBER, 1965 )

THIS PAPER DESCRIBES AN INVESTIGATION INTO COMBINED FREE AND FORCED CONVECTION HEAT TRANSFER FOR LAMINAR WATER FLOW IN HORIZONTAL TUBES. THE EXPERIMENTAL DATA OBTAINFD DO NOT AGRFE WITH EXISTING CORRELATIONS, WHICH RELATE MAINLY TO OILS. A NEW CORRELATION HAS BEEN DERIVED WHICH FITS THE WATER DATA TO WITHIN PLUS OR MINUS 8 PERCENT.

\#FLOW, LAMINAR + \#FLOW, TUBE + \#HEAT TRANSFER CORRELATION + HEAT TRANSFER + HEAT TRANSFER ANALYSIS + HEAT TRANSFER EXPERIMENT + HEAT TRANSFER, CONVECTION

$5 \rightarrow 09961$ BECK JV

TRANSIENT DETERMINATION OF . THERMAL PROPERTIES

MICHIGAN STATE UNIVERSITY

9 PAGES, 5 FIGURES, 4 TABLES, 18 REFERFNCES, NUCLEAR ENGINEERING ANO DESIGN, 3 (3) PAGES $373-381$ (APRIL 19661

A POWERFUL STATISTICAL PROCEDURE CALLED NONLINEAR ESTIMATION CAN BE USED TO SIMULTANEOUSLY DETERMINE SEVERAL PPOPERTIES APPEARING IN CERTAIN PARTIAL OIFFERENTIAL EQUATIONS IF APPROPRIATE MEASUREMENTS ARE MADE. THESE PROPERTIES MIGHT INCLUDE A NUMBER OF THOSE OF PARTICULAR INTEREST IN NUCLEAR ENGINEERING. THE METHOD IS ILLUSTRATED, HOWEVER, FOR DETERMINING THERMAL CONDUCTIVITY AND SPECIFIC HEAT, GIVEN TRANSIENT TEMPERATURE MEASUREMENTS. THE PROPERTIES ARE FOUND BY MAKING THE CALCULATED TEMPERATURES MATCH THE MEASURED TEMPERATURES IN A LEAST-SQUARES SENSE. THE METHOD UTILIZES FINITE DIFFERENCES FOR THE SOLUTION OF THE HEAT-CONOUCTION EQUATION AND FOR MINIMIZING A SUM-OF-SQUARES FUNCTION. THE METHOD IS WELL-ADAPTED FOR USE WITH A DIGITAL COMPUTER. CERTAIN EXPERIMENTS ARE DISCUSSED FOR WHICH THE THERMAL PROPERTIES CAN BE ACCURATELY DETERMINED. THE USE OF THE METHOD TO CALCULATE THERMAL PROPERTIES FROM EXACT AND EXPFRIMENTAL DATA IS DESCRIBED.

* TEMPERATURE TRANSIENT + \#HHERMAL PROPERTY + HEAT TRANSFER + HEAT TPANSFER ANALYSIS + HEAT TRANSFER EXPERIMENT

5-09978 ORR WL + STERNBERG HI + DERAMAIX P + CHASTAIN RH + BINDLER L + IMPINK AJ SAXTON PLUTONIUM PROGRAM. NUCLEAR DESIGN OF THE SAXTON PARTIAL PLUTONIUM CORE WESTINGHOUSE ELECTRIC CORPORATION, PITTSBURGH, ATOMIC POWER DIV.

WCAP-3385-51 t. 350 PAGES (APPROX.), 108 FIGURES, 70 TABLES, DECEMBER 1965, CFSTI.\$7.00 CY, \$1.75 MN.

REPORTS PARAMETER STUDIES ON PERFORMANCE IN SAXTON SPFCIFIC-DESIGN CALCULATION TO SET ENRICHMENT AND PERFORMANCE, AND CRITICALITY EXPERIMENTS TO CONFIRM DESIGN. PLUTONIUM ELEMENTS ARE EXPECTED TO REACH 13,600 MWD/METRIC TON (AV), WITHIN A LINEAR POWER LIMIT OF 16 KW/FT. NINE UO2-PUO2 ELEMENTS WERE SURROUNDED BY 12 UO2 ELEMENTS. INITIAL STUDIES SHOWED A 2.6 PERCENT DELTA K/K DISCREPANCY BETWEEN CALCULATION AND HANFORD EXPERIMENTS. ANALYSIS ALSO UNDERESTIMATED ROD WORTH IN PLUTONIUM REGIONS. MORE-SEVERE LOCAL POWER PEAKING NEAR WATER SLOTS OCCURREO IN PLUTONIUM REGIONS.

* Comparison, theORY aND EXPERIENCE + \#CRITICALITY EXPERIMENT + *FuEL ELEMENT + \#HDT SPOT + \#PLUTONIUM OXIDE + \#REACTIVITY EFFECT + \#SAXTON + \#URANIUM DIOXIDE

5-09999 MACBETH RV

BURN-OUT ANALYSIS. PART 5. EXAMINATION OF PUBLISHED WORLD DATA FOR ROD BUNDLES

UNITED KINGDOM ATOMIC ENERGY AUTHORITY, WINFRITH

$\triangle E E W-R-358+99$ PAGES, JUNE, 1964 , DEP/MN

BURN-OUT DATA AND DESCRIPTIVE DETAILS OF 24 DIFFERENT ROD-BUNDLE GEOMETRIFS HAVE BFEN COMPILED AND SUBJECTED TO ANALYSIS. THE MAJORITY APE AT ABOUT 1 , OOO PSIA, AND THE CONCLUSIONS REACHED REFER MAINLY TO THIS PRESSURE WITH FORCED CONVECTION AND WITH LIOUID WATER INLET. THE MOST IMPORTANT CONCLUSION IS THAT DETAILS OF THE INTERNAL STRUCTURE OF A BUNDLE IN GENERAL HAVE NO EFFECT ON BURN-OUT, AND THIS IS SUBSTANTIATED BY A WIDE VARIETY OF ROD SUPPORTS AND SDACERS USED. THE ONLY IMPORTANT CROSS-SECTIONAL GEOMETRY PARAMETER HAS BEEN IDFNTIFIED AS THE HEATED EQUIVALENT DIAMETER $(4$ X FLOW. AREA/HEATED PERIMETER $)$.

\# BURNOUT HEAT FLUX + DNB IDEPARTURE FROM NUCLEATE BOILINGi + FUEL FLEMENT + HEAT TRANSFER + HEAT TRANSFER ANALYSIS + HEAT TRANSFER CORRELATION 
CATEGORY 5

ACCIDENT ANALYSIS

5-10120 SCHNEIDER GA + STOKER DJ

STEAM CYCLE INFLUENCE ON FAST BREEDER REACTOR DESIGN

ATOMICS INTERNATIONAL, CANOGA PARK

25 PAGES, 7 FIgURES, 7 TABLES, APRIL 1966, PRESENTED AT THE AMERICAN POWER CONFERENCE $28 T H$ ANNUAL MEETING,

APRIL 26-28, 1966, CHICAGO, ILLINOIS

PROBLEM - DETERMINE EFFECT OF STEAM CYCLE ON FAST-BREEDER-REACTOR DESIGN USING SODIUM COOLANTS. SOLUTION - SODIUM FROM THE REACTUR EXCHANGES HEAT IN AN INTERMEDIATE HEAT EXCHANGER WITH A SECONO UN-RADIOACTIVE SODIUM STREAM. PARAMETERS STUDIED ARE - REACTOR SODIUM OUTLET TEMPERATURES, SECONDARY SODIUM HOT LEG TEMPERATURE, REACTOR (PRIMARY) SOOIUM TEMPERATURE RISE, SECONDARY SODIUM TEMPERATURE RISE, MAIN/REHEAT TEMPERATURES. RESULTS INCREASING STEAM PRESSURE REDUCES COST PER KH. ALLOHABLE COSTS OF STEAM GENERATOR INCREASE WITH STEAM MEASURE. REACTOR SODIUM TEMPERATURE RISE OPTIMIZES AT APPROXIMATELY $275-300$ DEGREES F DEPENDING ON SECONDARY RADIUM TEMPERATURE RISE. CONCLUSIONS - 35 O PSIG OR 2400 PSIG STEAM PRESSURE IS NEAR OPTIMUM. WITHIN RANGE OF PRIMARY SODIUM OUTLET TEMPERATURE OF $1050 \mathrm{~F}$ TO $1200 \mathrm{~F}$, STEAM TEMPERATURE OF $850 \mathrm{~F}$ TO 950 F APPEAR OPTIMUM. FUTURE REACTORS SHOULO BE DESIGNED FOR REACTOR SODIUM OUTPUT TEMPERATURE OF $1150 \mathrm{~F}$ TO $1200 \mathrm{~F}$ FROM STANDPOINT OF SYSTEM EQUIPMENT COST. RECOMMENDED PRIMARY SODIUM TEMPERATURE RISE IS $250-325 \mathrm{~F}$. RECOMMENDED SECONDARY SODIUM TEMPERATURE RISE IS 300-375 F.

* SODIUM + THERMODYNAMICS + ECONOMIC STUOY + HEAT TRANSFER + METAL, LIQUID + REACTOR COOLANT + STEAM

5-10121 FALCON JA + JACOBSON J

STEAM CYCLE CONSIDERATIONS FOR LARGE HEAVY WATER MODERATED, ORGANIC-COOLED REACTOR PLANTS ATOMICS INTERNATIONAL

24 PAGES, 7 FIGURES, 3 TABLES, REFERENCES, APRIL 1966. PRESENTED AT THE AMERICAN POWER CONFERENCE 28TH ANNIIAI MFFTINF,, ADQII 26-39, 1חG6, GHIGACO, ILLINOIS

THIS PAPER DELVES INTO ONE ASPECT OF A 1OOO-MWE DESIGN OF A HEAVY HATER MODERATED ORGANIC COOLEO REACTOR PLANT, THE SELECTION OF STEAM CYCLE PARAMETERS. IN A SENSE, THIS MIGHT BE CONSIDERED THE FIRST IN S SERIES OF PROGRESS REPORTS ON THE DESIGN OF THE PLANT. AS SUR.H, THE FINAL OESIGN MAY DIFFER FROM THE PARAMETERS NOTED HEREIN- THE CONSIDERATIONS INVOLVED, HOMEVER, AND THE TECHNIQUES USED WILL BE AS REVIEWED IN THIS PAPER.

* STEAM + *THERMODYNAMICS + ENERgY SOURCE + heAT franSFER + REACTOR POWER

5-10272 BOLDMAN DR + SCHMIOT JF + FORTINI A

TURBULENCE, HEAT-TRANSFER, AND BOUNDAPY LAYER MEASUREMENTS IN A CONICAL NOZZLE HITH A CONTROLLED INLET VELOCITY PROF ILE

NASA, LEYIS RESEAKCH CENTER, CLEVELAND

NASA-TN-D-3221 +. 26 PAGES, 13 FIGURES, 5 TABLES, REFERENCES, MARCH 1966, CFSTI SO.40 CY

TURBULENCE, HEAT-TRANSFER, AND BOUNDARY-LAYER MEASUREMENTS WERE OBTAINEO IN A CONICAL NOZZLE OPERATING IN AIR AT A NOMINAL TOTAL TEMPERATURE AND PRESSURE OF 960R AND 300 PSIA, RESPECT IVELY. EXPERIMENTAL HEAT-TRANSFER COEFFICIENTS WERE COMPARED TO VALUES DETERMINED BY THREE PREDICTION TECHNIQUES, NAMELY, 11 ) NUSSELT NUMBER CORRELATION, (2) A

COMPRESSIBLE-B OUNDARY-LAYER THEORY, AND 131 AN INCOAPRESSIBLE-BOUNDARY-LAYER THEORY. METHODS (1) AND (2) YIELDED NOZZLE HEAT-TRANSFER COEFFICIENTS THAI WERE APPRECIABLY HTGHFR THAN EXPERIMENTAL VALUES, HOWEVER, METHOD 131 PREDICTED THE NOZZLE HEAT-TRANSFER COEFFICIENTS VERY WELL, YIELDING RESULTS THAT WERE WITHIN ABOUT 2 PERCENT OF THE EXPERIMENTAL VALUES AT THE THROAT. IN PART OF THE INVESTIGATION, A SIMULATED NUCLEAR REACTOR-CORE TURBULENCE GENEPATOR INSTALLED 3 INCHES UPSTREAM OF THE CYLINORICAL INLET FAILED TO ALTER THE NOZZLE HEAT-TRANSFER COEFFICIENTS. IN ADDITION, THE TURBULENCE GENERATOR HAD ESSENTIALLY NO EFFECT ON THE BOUNOARY-LAYER TEMPERATURE PROFILES IN THE NOZZLE.

* boundary layer + *nozzle + *turbulence, convective + heat transfer + heat transfer experiment

5-10273 GRIMES JH + MORRIS JR

URANIUM CORROSION STUDIES. PART 2. THE RATE OF REACTION OF POLISHED URANIUM AND WATER VAPOUR AT VARIOUS TEMPERATURES

UNITEO KINGDOM ATOMIC ENERGY AUTHORITY, ALOERMASTON

AMRE-0-68/65 t. 22 PAGES, 10 FIGURES, 6 TABLES, REFERENLES, SEPTEMBER 1965, BIS \$0.65 CY

THE RATE OF REACTION OF URANIUM AND WATER VAPOUR WAS DETERMINED USING AN

OPTICAL-INTERFEROMETRIC METHOD AT TEMPERATURES IN THE RANGE 30 TO $90 C$. AN ACTIVATION ENERGY OF 9 KCAL/G MOLE WAS DERIVED. COMPARISONS ARE MADE BETWEEN THE RATE OF CORROSION OF URANIUM FOUND BY THE MEASUREMENT OF OXIDE FILM GRONTH AND THAT FOUND BY OTHER METHODS.

* Chemical kinetics + *Chemical Reaction + uranium + uranium dioxide + water, general

5-1031E MULVIHILL RJ

A PROBABILISTIC METHOOOLOGY FOR THE SAFETY ANALYSIS OF NUCLEAR POWER REACTORS, VOLUME 1 AND 2 PLANNING RESEARCH CORPORATION, LUS ANGELES, CALIFORNIA

SAN-570-2 + PRC-R-657+. 430 PAGES, FEB. 1966 CFSTI \$7.30 CY, \$2.00 MN

THE PRC METHOOOLOGY SUPERIMPOSES PRCBABILITIES ON A DETERMINISTIC ANALYSIS WHICH INCIIINFS THE BEST AVAILABLE ANALYTICAL MODELS FOR THE SEVERAL STAGES INVOLVEO IN AN ACCIDENT SEOUENCF IE.G., REACTOR KINETICS, MEAT TRANSFER, FISSION PRODUCT TRANSPORT WITHIN THF CONTAINMENT, ATMOSPHERIC TRANSPORT OUTSIDE THE CONTAINMENTI. IT IS ALSO ESSENTIAL TO UNDEPSTAND THE LIMITATIONS OF THE PRC METHODOLOGY. WHEN FULLY IMPLEMENTED, THIS PROCEDURE WOULD THEORETICALLY YIELD A PROBABILITY VALUE FOR EACH CONCEIVABLE ACCIDENT INVOLVING THE RELEASE OF FISSION PRODUCTS, WITH THE SPECTRUM OF POTENTIAL DAMAGE FPOM EACH ACCIDENT DISPLAYED IN 
CATEGOPY

ACCIDENT ANALYSIS

5-1031E \#CONT INUED*

ASSOCIATION WITH THE APPROPRIATE PROBABILITY FOR EACH GIVEN LEVEL OF DAMAGE.

* ACCIDENT ANALYSIS + \#MATHEMATICAL STUDY + \#STATISTICAL CORRELATION + ANALYTICAL MODEL \&

ATMOSPHERIC POLLUTION + COMPUTER PROGRAM + FISSION PRODUCT TRANSPORT + HEAT TRANSFER + REACTOR KINETICS

5-10428 KATTCHEE N + REYNOLOS WC

ARMY GAS-COOLED REACTOR SYSTEMS PROGRAM. HECTIC-II--AN IBM TO9O FORTRAN COMPUTER PROGRAM FOR HEAT

TRANSFER ANALYSIS OF GAS OR LIQUID COOLED REACTOR PASSAGES.

AEROJET-GENERAL NUCLEONICS

IDO- 28595 (REV.) +. 79 PAGES, 7 FIGURES, 6 REFERENCES, DECEMBER 1965, CFST1, \$2.00 CY, 50.75 MN

HECTIC-II IS AN IBM 7090 FORTRAN COMPUTER PROGRAM FOR CALCULATING PRESSURE DROP, FLOW RATES, HEAT TRANSFER RATES, AND TEMPERATURE IN HEAT EXCHANGERS SUCH AS FUEL ELEMENTS OF TYPICAL GASOR LIQUID-COOLED NUCLEAR REACTORS. THE PROGRAM IS UNIQUE AND EXTREMELY VERSATILE IN THAT THE EFFECTS OF TURBULENT MOMENTUM AND HEAT INTERCHANGE BETWEEN FLOW PASSAGES ARE CONSIDERED. THE COMPUTATION AMOUNTS TO A NODAL OR. LUMPED-PARAMETER TYPE OF CALCULATION. THE AXIAL MESH SIZE IS AUTOMATICALLY SELECTED TO ENSURE THAT A PRESCRIRED ACCURACY OF RESULTS IS OBTAINED. HECTIC-II SUPERSEDES HECTIC. THE WORK ON HECTIC-II WAS CARRIEO OUT UNDER U. S. AEC CONTRACT AT $(10-1)-880$

* COMPUTER, DIGITAL + *HEAT TRANSFER ANALYSIS + \#HYDRODYNAMIC ANALYSIS + FUEL ELEMENT + HEAT EXCHANGER + HEAT TRANSFER + WATER, GENERAL

5-10430 ARGONNE NATIONAL LABORATORY PUBLICATIONS, JULY $1,1964-$ JUNE 30,1965 ARGONNE NATIONAL LABORATORY, ARGONNE, ILLINOIS

$A N L-7087+. \quad 328$ PAGES, AUGUST 1965 CFSTI, $\$ 7.00 \mathrm{CY}, \$ 1.50 \mathrm{MN}$

THIS PUBLICATION LIST IS A BIBLIOGRAPHY OF SCIENTIFIC AND. TECHNICAL ACCOUNTS ORIGINATED AT ARGONNE AND PUBLISHED DURING FISCAL YEAR 1965. IT INCLUDES ITEMS PUBLISHED AS JOURNAL ARTICLES, TECHNICAL REPORTS, BOOKS, ETC., ALL OF WHICH HAVE BEEN MADE AVAILABLE TO THE PUBLIC. THE LIST IS DIVIDED INTO THREE PARTS - THE FIRST A LIST DIVISION, THE SECOND AN ALPHABETICAL AUTHOR INDEX, AND THE THIRD PART A KWIC SUBJECT INDEX. INCLUDED ARE SECTIONS ON RADIOLOGICAL PHYSICS, REACTOR PHYSICS, REACTOR ENGINEERING, INOUSTRIAL HYGIENE AND SAFETY, FIRE PROTECTION, AND CHEMICAL ENGINEERING.

* BI IL IOGRAPHY + \# BURNOUT HEAT FLUX + \#CHEMICAL REACTION + \#DOSE MEASUREMENT, EXTERNAL + \#HEAT TRANSFER + \#REACTOR DYNAMICS + \#REACTOR STABILITY + ACCIDENT ANALYSIS +

FARET (FAST ARGONNE REACTOR EXPERIMENT TEST) + METAL WATER REACTION + NOISE + REACTIVITY COEFFICIENT + PEACTOR KINETICS + REACTOR TRANSIENT + REACTOR, BREEDER + REACTOR, FAST + REACTOR, LIOUID METAL COOLED + SPACE DEPENDENT DYNAMICS + VOIO COEFFICIENT

5-10475 COATES RL + HORTON NR

RSAC--A RADIOLOGICAL SAFETY ANALYSIS COMPUTER PROGRAM

PHILLIPS PETROLEUM COMPANY, IDAHO

I D0-17151 +. 208 PAGES, 3 TABLES, 7 REFERENCES, MAY 1966 , CFSTI, \$6.00 CY, \$1.25 MN

AN IBM 7040 PROGRAM WHICH COMPUTES THE POTENTIAL RADIOLOGICAL DOSES RESULTING FROM A CONTINUOUS OR INSTANTANEOUS RELEASE OF FISSION PRODUCTS TO THE ATMOSPHERE. DEVELOPED AS PART OF LOFT AND GENERAL NUCLEAR SAFETY PROGRAMS TO PROVIDE A GENFRALIZED COMPUTER PROGRAM FOR A COMPLETE PARAMETRIC INVESTIGATION OF RADIOLOGICAL HAZARDS. DOSES CONSIDERED ARE CLOUD GAMMA, DEPOSITION GAMMA, INGESTION, AND INHALATION, ANO ARE BASED UPON THE RELEASE OF UP TO 200 ISOTOPES, THE RELATIVE ABUNDANCE OF EACH ISOTOPE BEING DEPENDENT UPON THE OPERATING HISTORY OF THE NUCLEAR REACTOR UNDER CONSIDERATION. INCLUDED ARE THE MATHEMATICAL MODELS, CONVERSION FACTORS, ASSUMPTIONS, FLOW CHARTS, PROGRAM LISTINGS, AND OTHER DATA PERTINENT TO THE OVERALL DEVELOPMENT OF THIS PROGRAM.

* COMPUTER PROGRAM + *DOSE CALCULATION, EXTERNAL + \#DOSE CALCULATION, INTERNAL +

*FISSION PRODUCT RELEASE, GENERAL + SUTTON DIFFUSION FORMULA

5-10487 VAN DYKE M

THE BLUNT-BODY PROBLEM REVISITED

STANFORD UNIVERSITY

18 PAGES, 13 FIGURES, 25 REFERENCES, PP 52-59 OF FUNDAMENTAL PHENOMENA IN HYPERSONIC FLOW, J, GORDON HALL, EDITOR, PROCEEDINGS OF THE INTERNATIONAL SYMPOSIUM SPONSORED BY CORNELL AERONAUTICAL LABORATORY, CORNELL UNIVERSITY PRESS, 1966

WE SUGEEST THAT UNDUE RELIANCE HAS BEEN PLACED UPON MACHINE COMPUTATION IN SOLVING THE PROBLEM OF SUPERSONIC FLOH PAST A BLUNT BODY, AND THAT ANALYTIC AND SEMI-ANALYTIC METHODS SHOULD BE RE-EXAMINED IN AN EFFORT TO IMPROVE THE POOR CONVERGENCE THAT LED TO THEIR REJECTION. FOUR METHODS ARE DISCUSSEO - TAYLOR-SERIES EXPANSION FROM THE SHOCK WAVE, THE NEWTON-BUSEMANN EXPANSION, EXPANSION IN POWERS OF-TIME FOR AN IMPULSIVE START FROM REST, AND A TRUNCATED SERIES EXPANSION FROM THE AXIS. IN EACH CASE, A TRANSFORMATION IS PROPOSED THAT SIGNIFICANTLY IMPROVES THE CONVEREENCE, JUDGED BY COMPARISON WITH ACCURATE NUMERICAL SOLUTIONS FOR THE TEST PROBLEM OF A PARABOLOIDAL SHOCK WAVE AT M EQUALS INFINITY AND GAMMA EQUALS $7 / 5$. WE CONCLUDE THAT THE IMPROVEO TRUNCATION METHOD SHOWS THE GREATEST PROMISE FOR EXTENSION TO SUCH NEW PROBLEMS AS THE BLUNT BODY AT ANGLE OF ATTACK.

\#FLOW, HIGH SPEED + *HEAT TRANSFER + \#HYORODYNAMIC ANALYSIS + MATHEMATICAL STUDY + SHOCK WAVE 
CATEGORY

ACRIDENT ANALYSIS

$5-10532 \quad J U D D A M$

LOSS-OF-COOLANT ACCIDENTS IN A LARGE SODIUMTCOOLED FAST REACTOR

U.K. ATOMIC ENERGY AUTHORITY, WINFRITH

ANL-7120+. 15 PAGES, 11 FIGURES, 2 TABLES, 8 REFERENCES, PP. 67-81 OF PROCEEDINGS OF THE CONFERENCE ON

SAFETY, FUELS, AND CORE OESIGN IN LARGE FAST POWER REACTORS, OCTOBER 11-14, 1965, CFSTI \$9.25 CY

BASICALLY, THE APPROACH USED HERE IS TO CONSIDER A SERIES OF FAULT CONOITIONS WHICH MIGHT ARISE IN A TYPICAL OXIDE-FUELLED, SODIUM-COOLED FAST REACTOR. THE ACCIDENTS PESULTING FROM THESE FAULTS ARE THEN ANALYSED STEP-BY-STEP, USUALLY UNDER SOME PESSIMISTIC ASSUMPTIONS, SUCH AS THE FAILURE OF ONE OR MORE REACTOR TRIP CIRCUITS. THERE ARE, HOWEVER, SOME MECHANISMS WHICH ARE IMPORTANT FOR SEVERAL OF THE ACCIDENTS AND REOUIRE DETAILED CONSIDERATION, SUCH AS COOLANT AND FUEL REACTIVITY WORTH, THE BEHAVIOUR OF THE COOLANT AS IT BOILS, AND PARTICULARLY THE EFFECTS OF NUCLEATE BOILING, THE PELEASE OF FISSION-PRODUCT GAS FROM A BURST FUEL CAN. AS A RESULT OF THESE ANALYSES, CFRTAIN PROBLEMS STAND OUT AS BEING PARTICULARLY IMPORTANT FOR THE SAFETY OF THE REACTOR, INCLUOING THE POSSIBILITY OF A SINGLE SUBASSEMBLY ACCIDENT

SPREADING TO THE WHOLE CORE ANN THE TIME FGR AVAILABLE FOR A TRIP MECHANISM TO OPERATE.

* ACCIOENT, MAXIMUM CREDIBLE (MCA) + \#LOSS CF COOLANT + \#REACTOR, FAST + FUEL ELEMENT + HEAT TRANSFER + METAL, LIQUID + RADIUM + REACTOR KINETICS + TEMPERATURE TRANSIENT + URANIUM DIOXIDE

5-10547 SANATHANAN CK I CARTER JC + BRITTAN RO

TRANSIENT TEMPERATURE DISTRIBUTIONS IN FAST REACTOR FUELS WITH WIDELY VARYING THERMAL OIFFUSIVITY ARGONNE NATIONAL LABORATORY, ARGONNE

ANL $7120+8$ PAGES, 9 FIGURES, 29 REFERENCES, PP. 478-485 OF PROCEEDINGS OF THE CONFERENCE ON SAFETY,

FUELS, AND CORE DESIGN IN LARGE FAST POWER REACTORS, OCTOBER 11-14, 1965, CFSTI, \$9.25 CY

THE LIMITATIONS ON THE THERMAL PERFORMANCE OF REACTOR FUELS, STATICALLY AND DYNAMICALLY, ARE GOVERNED BY THE THERMAL DIFFUSIVITY OF THE FUEL MATERIAL. ESTIMATES OF THE PEAK CENTRAL IEMPERATURES ARE NECESSARY TO DE TERMINE LIMITING POWER DENSITIES FOR NORMAL OPERATION ANO OF PHYSICAL BEHAVIOR IN ABNORMAL CIRCUMSTANCES. ALSO, COMPLETE TEMPERATURE DISTRIBUTIONS ARE NECESSARY TO DETERMINE COUPLING BETWEEN HEAT GENERATION AND COOLING, STATICALLY AND DYNAMICALLY, IT HAS BEEN POSSIBLE TO MEET THIS PROBLEM IN THE PAST BECAUSE FUEL MATERIALS HAVE HAD HIGH THERMAL CCNDUCTIVITY AND BECAUSE FUELS HAVE HAD OPERATING TEMPERATURFS LIMITED BY LOH MELTING POINTS. NOW, UO2 FUELS HAVE BEEN PROPOSEO FOR LARGE FAST REACTORS. IN CALCULATING TEMPERATURE DISTRIBUTIONS FOR THESE FUELS, LARGE ERRORS WILL ENSUE IF SIMPLIFIED METHOOS ARE EMPLOYED. BECAUSE OF THESE DESIGN AND TEST REOUIREMENTS, A STUDY HAS BEEN MADE IN WHICH NEW CALCULATIONAL METHODS FOR DETERMINING TRANSIENT TEMPERATURE DISTRIBUTIONS IN UOZ FUEL ELEMENTS HAVE BEEN DEVISED, AND DETERMINATION OF TRANSIENT TEMPERATURE AND HEAT FLON BEHAVIOR UNDERTAKEN.

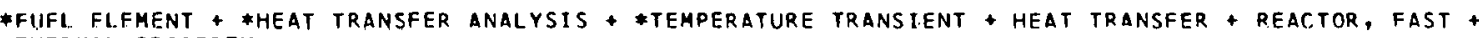
THERMAL PROPERTY

5-10548 GODTS JE + RESTELLI EF TRANSIENT TEMPERATURF DISTRIBUTION IN FUEL ELEMENTS WESTINGHOUSE ELECTRIC CORPORATION, PITTSBURGH

ANLT7120 +. 8 PAGES, 10 FIGURES, 9 REFERENCES, PP. 486-493 OF PROCEEOINGS OF THE CONFERENCE ON SAFETY, FUELS, AND CORE OESIGN TN IARGF FAST POWER REACIORS, ULIUBEK 11-14, 1965, CFSTI S9.25 CY

ALTERNATIVES TO THE NODAL APPROACH IN EVALUATING TEMPERATURE TRANSIENTS INVOLVE FINDING TRANSFORM SOLUTIONS, IN WHICH SPATIAL MODES DESCRIBE THE SPATIAL DEPENOENCY OF THE SOLUTION. AN ADVANTAGE OF THE TRANSFORM-SOLUTION METHOD IS THAT THE TEMPERATURE AND ITS DER IVATIVE MAY BE GIVEN OIRECTLY AT ANY POINT ON THE PROFILE. IN FAST REACTORS ESPECIALLY DUE TO THE HIGH POWER DENSITIES, FUEL AND CLAD MOTION (BY THERMAL EXPANSIONI EXERT A DETERMINING EFFECT ON STABILITY AND CONTROL AND THUS MAVE A STRONG BEARING ON POWER DISTRIBUTION.

\#FUEL ELEMENT + *HEAT TRANSFER + \#REACTOR, FAST + *TEMPERATURE TRANSIENT + HEAT TRANSFER ANALYSIS + MATHEMATICAL STUDY

5-10549 PETERSON RE + COLDSMITH S FAST REACTOR SAFETY CONSIDERATIONS RELATED TO FUEL MACROSTRUCIUKE BATTELLE MEMORIAL INSTITUTE, RICHLAND

ANL-7120 +. 7 PAGES, 5 FIGURES, 3 TABLES, 11 REFERENCES, PP, $497-503$ OF PROCEEDINGS OF THF CONFERENCE ON SAFETY, FUELS, ANO CORE DESIGN IN LARGE FAST POWER REACTORS, OCTOBER 11-14, 1965, CFSTI, \$9.25 CY

THE TRANSIENT RESPONSE OF THE FUEL TO A VERY FAST BURST, WHETHER IT BE ENTIRELY THERMAL OR THERMOELASTIC, DEPENOS UPON SUCH MACROSCOPIC PROPERTIES AS DENSITY, HOMOGENEITY, THERMAL CONDUCTIVITY, SPECIFIC HEAT, AND ELASTIC MODULUS. INVESTIGATIONS HERE MADE TO ASSESS THE IMPORTANCE OF HOMOGENEITY TO PROMPT DODPLER FEEDBACK IN MIXED OXIOE FUELS. HOWEVER, NO EVALUATINNS OF THIS KIND HAVE BFEN PUBLISHED FOR OTHER CERAMIC FUELS OR FOR CERMETS.

FURTHER, IT IS OF INTEREST TO INVESTIGATE THE IMPORTANCE OF OTHER MACROSCOPIC FUEL PROPERTIES TO INHERENT SAFETY AS WELL. THIS PAPER SUMMARIZES RECENT WORK RELATING THESE PROPERTIES TO FAST REACTOR SAFETY WHEN THE REACTOR UNDERGOES A PROMPT BURST ACCIDENT.

*FUEL ELEMENT + \#HEAT TRANSFER + \#REACTOR, FAST + REACTOR KINETICS + TEMPERATURE TRANSIENT + THERMAL PROPERTY

5-10550 STACHURA SJ + SILBERBERG M

THE APPLICATION OF EXPERIMENTAL DATA FROM TREAT MELTDOWN STUDIES TO REACTOR ACCIDENT ANALYSIS ATOMICS INTERNATIONAL, CANOGA PARK

ANL-7120+. 10 PAGES, 7 FIGURES, 2 TABLES, 3 REFERENCES, PP. $514-523$ OF PROCEEDINGS OF THE CONFEPENCE ON SAFETY, FUELS, AND CORE DESIGN IN LARGE FAST POWER REACTORS, OCTOBER 11-14, 1965, CFSTI, \$9.25 CY 
CATEGORY 5

ACCIDENT-ANALYSIS

5-10550 *CONTINUED*

RESULTS OF RECENT TREAT MELTDOWN STUDIES OF CERAMIC FUEL' IN SODIUM : $A R E$ PRESENTED, AND THE' SIGNIFICANCE OF THESE RESULTS WITH RESPECT TO LARGE CORE MELTDOWN IS 'TNDICATED:- THE COURSE' OF FUEL MOTION. IN A LARGE CORE WAS ESTIMATED FOR 'A SIMPLIFIED 'CASE, AND THE ASSOCIATED': REACTIVITY EFFECTS HERE DETERMINED. 'THESE'REACTIVITY 'EFFECTS 'WERE THEN INCORPORATED INTO 'THE " AIREK REACTOR KINETICS CODE TO ESTIMATE CORE BEHAVIOR AFTER GROSS FUEL MELTING IN CENTRAL REGIONS OF THE'CORE: A DISCUSSION, OF THOSE FACTORS WHICH CAN INFLUENCE MELTDOWN BEHAVIOR :WAS * PRESENTED.

* ACCIDENT, GËNERAL + \#CORE MELTOOOWN + \#FUEL MELTDOWN + \#REACTOR, FAST +

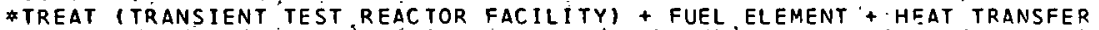
?.

$5-10551$ DICKERMAN CE —ROBINSON ARGONNE NATIONAL MELTDOWN STUD IES

ANL-7120 +: "6"PAGES" 8 FIGURES, ' 12 REFERENCES,'PP."534-539 -OF 'PROCEEDINGS OF 'THE CONFERENCE'ON'SAFETY,, , " FUELS, AND CORE DESIGN IN'LARGE FAST POWER REACTORS, OCTOBER 11-14, 1965 , CFSTI, $\$ 9.25 ! C Y, ?, \cdots,: 14$

ANALYSIS OF THE CONSEQUENCES OF A MELTDOWN-TYPE INCIDENT IN A FAST REACTOR REQUIPES KNOWLEDGE OF THE PHENOMENA GOVERNING THE MOVEMENT OF CORE MATERIALS--COOLANT, AS WELL AS FUEL AND STRUCTURE--RESULTING FROM ABNORMAL OPERATING CONDITIONS.' 'INFORMATION'NEEDED INCLUDES'MODES OF FÜEL 'FAILURE AND THE CONDITIONS 'WHICH: PRODUCE THE VVARIOUS"TYPES ' OF! FATLURE; "TYPES'AND*. VELOCITIES OF FUEL MOVEMENT, ANO COOLANT EFFECTS. PRE-FAILURE MOVEMENTS OF "COOLANT OR:FUEL MAY AL'SO BE' INVOLVED. . EVEN IN'THE CASE OF 'THE MOST WIDELY'STUDIED SYSTEM,' 'EBR'=II; ;

MELTDOWN-RELATED DATA áRE INCOMPLETE: THIS PAPER REVIËWS THE CUPRENT ISTATUS'OF MELTDOWN

STUDIES, EMPHASIZING RECENT WORK, RESTRICTED TO THE ARGONNE NATIONAL LARORATORY PROGRAM.

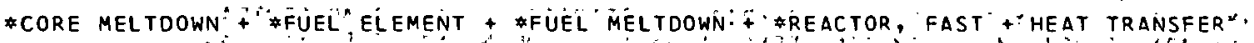

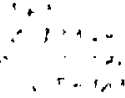


CATEGORY 5

ACCIDENT ANALYSIS

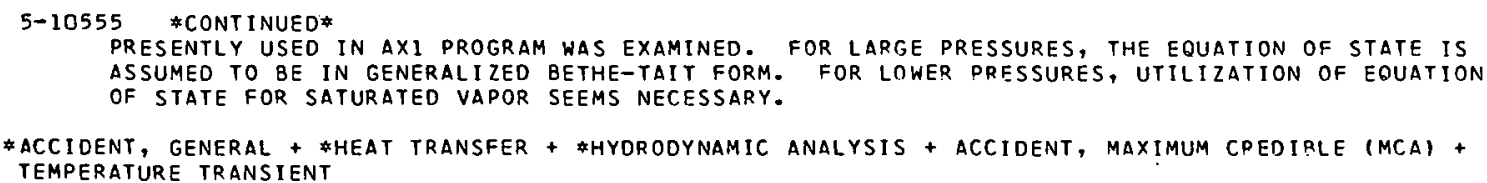

THE INVESTIGATION OF THE SAFETY OF LARGE, FAST, SODIUM-COOLED REACTORS LEADS TO THE PROBLEM OF COOLANT BEHAVIOUR IN THE COOLING CHANNELS DURING A POWFR FXCIIRSION, PRIMAPILY A HYDRODYNAMIC PROBLEM, BUT LINKEO IO THE NEUTRON BEHAVIOUR OF THE CORE VIA THE COOLANT-VOID EFFECT. THE TIME CHARACTERISTIC FOR THE EXPULSION OF COOLANT TOGETHER WITH THE REACTIVITY VALUE OF VOIDING THE COOLANT CHANNELS RESULT IN A RAMP RATE OF A POSITIVE REACTIVITY INSERTION. THE REACTIVITY VALUE OF VOIDING THE COOLANT CHANNELS WAS CALCULATED IN A RECENT STUDY. THE FIRST VALUE CALCULATED WAS $\$ 3.00$. MORE RECENT RESULTS INDICATE NEARLY \$7.OD. BUT THE DURATION OF THE EXPULSION OF THE COOLANT IS PROBABLY EVEN MORE UNCERTAIN. ITS CALCULATION IS A PROBLEM OF TWO-PHASE SODIUM HYORODYNAMICS. ATTACKING THIS PROBLEM, ONE REALIZES SOON THE CRUCIAL IMPORTANCE OF SHOCK-FRONT PHFNOMENA, ANO THE EFFECT OF THE VELOCITY OF SOUND. THEREFORE, BOTH THE INVESTIGATION OF THE SHOCK-FRONT CONOITIONS AND THE VELOCITY OF SOUND ARE NECESSARY AS FIRST STEPS FOR A MORE COMPLETE THEORETICAL ANALYSIS OF THE WHOLE PROCESS OF THE EXPULSION OF THE COOLANT.

\#FLOW, TWO PHASE + \#RADIUM + *REACTOR, FAST + \#SHOCK WAVE + HEAT TRANSFER + HYDRODYNAMIC ANALYSIS + METAL, LIQUID

5- 10573 WILLIS DR + TAUB P

AERODYNAMIC DRAG AND HEAT TRANSFER FOR FLOW PAST TWO-DIMENSIONAL BODIES AT HIGH KNUDSEN NUMRERS AEROSPACE RESEARCH LABORATORIES, PRINCETON UNIVERSITY

ARL $-6 C-0007+.37$ PAGES, 6 FIGURES, 2 TABLES, 12 REFERENCES, JANUARY 1966, DOD

USING THE INTEGRAL ITERATION METHOD, THEORETICAL RESULTS ARE OBTAINED FOR AERODYNAMIC DRAG AND HEAT TRANSFER IN THE NEARLY FREE-MOLECULAR REGIME. THE CONFIGURATIONS CONSIDERFD ARE CIRCULAR CYLINDERS, INCLINED FLAT PLATES, AND WEDGES, ALL TWO-DIMENSIONAL. PERTURBATION TO THE FREE-MOLECULAR RESULTS ARE OBTAINED CORRECT TO ORDER (1/KN) IN KN ONLY (KN IS THE KNUDSEN NUMBER). THE FREE-STREAM SPEED RATIO IS GREATER THAN TWO, AND THE BODY TFMPERATURES RANGE FROM FREE-STREAM TO RECOVERY. THE RESULTS ARE SIMILAR TO THOSE OBTAINED PREVIOUSLY FOR A NORMAL FLAT STRIP, EXCEPT THAT FOR SMALL-ANGLE WEDGES AND FLAT STRIPS AT SMALL ANGLES OF ATTACK, THE DRAG COEFFICIENT IS PREDICTED TO FXCEED THE FP.EE-MOLECULAR VALUE.

\#FLOW, KNUDSEN + \#HEAT TRANSFER ANALYSIS + \#MYORODYNAMIC ANALYSIS + FLOW THEORY AND EXPERIMFNTS + HEAT TRANSFER

5-10574 LEITZ FJ + IMHOFF CH + MCEWEN LH

TECHNOL OGICAL DEVELOPMENTS OF NUCLEAR SUPERHEAT

GENERAL ELECTRIC COMPANY, SAN JOSE, CALIFORNIA

19 PAGES, 7 FIGURES, 2 TABLES, 1966, PRESENTED AT AMERICAN POWER CONFERENCE, $28 T H$ ANNUAL MEETING, CHICAGO, ILLINOIS, APRIL 26-28, 1966, APC.

IHIS PAPER DESCRIBES BRIEFLY THE EVESR (ESADA VALLECITOS EXPERIMENTAL SIJPERHEAT REACTORI DESIGN AND OPERATING EXPERIENCE. EVESR IS A HETEROGENEOUS, LIGHT-WATER MODERATED, THERMAL-NEUTRON-SPECTRUM, SUPERHEATING REACTOR OF 17 MHITI OUTPUT, PRODUCING 9OO-PSI 9OD-F STEAM. SATURATED STEAM IS PRODUCED BY OIL FIRING AND IS NUCLEARLY SUPERHEATED. FUEL FAILURES AND FISSION-GAS RELEASE HAVE OCCURRED, BUT WITH NO MAJOR EFFECT ON PLANT OPERATION.

\#REACTOR, SUPERHEAT + \#STEAM + \#VESR (VALLECITOS EXP. SUPERHEAT REACTOR-ESADA) + HEAT TRANSFER + REACTOR, BOILING WATER + REACTOR, THERMAL + REACTOR, WATER

5-10578 OITTZ KA

QUARTERLY TECHNICAL REPORT - STEP PROJECT, APRIL 1965-JUNE 1965 
CATEGORY 5

ACCIDENT ANALYSIS

5-10578 \#CONTINUED

PHILLIPS PETROLEUM COMPANY, IDAHO FALLS, IDAHO

ID0-17145 +. 104 PAGES, 69 FIGURES, 14 TABLES, 30 REFERENCES, MAY 1966, CFSTI, \$4.00 CY, \$O.75 MN

QUARTERLY PROGRESS REPORT ON SNAPTRAN-1 TEST PROGRAM, LOFT CORE DESIGN, LOFT FACILITY AND EXPERIMENTAL DESIGN, LOFT ANALYSIS, LOFT RADIOLOGICAL STUDIES, ANO INSTRUMENTATION STUDIES.

*LOFT (LOSS OF FLUID TEST) + *SNAPTRAN (SNAP TRANSIENT REACTOR TEST SEP.IES) +

*STEP (SAFETY TEST ENGINEERING PROGRAM) + ANALYTICAL MODEL + CONTAINMENT DESIGN +

CONTAINMENT FILTERING SYSTEM + CONTAINMENT INSTRUMENTATION + FISSION PRODUCT TRANSPORT +

INSTRUMENTATION, GENERAL + IOOINE + REACTOR KINETICS + REACTOR, PRESSURIZED WATER + SAMPLING

5-10700 PERRAIS JP + SCHROCK VE

AN EXPERIMENTAL STUDY OF BOILING BUBBLE DYNAMICS

UNIVERSITY OF CALIFORNIA, RFRKELEY, CALIFORNIA

SAN $1012+20$ PAGES, 24 BIBLIOGRAPHY, 2 TABLES, 13 FIGURES- MARCH 1966, CFSTI, \$4.00 CY

AN EXPERIMENTAL INVESTIGATION OF BUBBLE-GPOWTH RATES AND SHAPES WAS CONDUCTED BY USING A SYSTEM IN WHICH THE THERMAL ENVIRONMENT IS KNOWN. THIS WAS ACCOMPLISHED BY VIEWING FROM TWO CIRECTIONS THOSE BUBBLES WHICH WERE FIRST NUCLEATED ON A TRANSIENTLY HEATED SURFACE. WITH STEP AND EXPONENTIAL TRANSIENT HEATING, THE PURE CONDUC.TION MODEL WAS SHOWN TO ACCURATELY PREOICT THE HEAT TRANSFER PRIOR TO BOILING. IN THIS WAY, TEMPERATURE DISTRIBUTION IN THE LIQUID AT THE TIME OF NUCLEATION MAY BE CALCULATED, ANO SINCE THE BUBBLE-GROWTH CYCLE IS RAPID COMPAREO WITH THE RATE OF CHANGE OF THIS OISTRIBUTION, IT MAY BE REGARDED AS THE THERMAL ENVIRONMENT FOR THE ENTIRE BUBBLE LIFETIME. CONCLUSIONS - 1. DATA HERE OBTAINED FOR BUBBLE-GROWTH AND COLLAPSE HISTORIES IN A KNOWN THERMAL ENVIRONMENT WHICH CLEARLY SHOW THAT THE THEORIES, BASED ON THE HEMISPHERICAL-ASYMPTOTIC MODEL, ARE INADEOUATE. 2 . IMPROVEMENTS IN THE THEORY WILL BE POSSIBLE EITHER BY MOOIFYING THE HEMISPHERICAL THEORY TO ACCOUNT FOR THE LIQUID FILM UNDER THE BUBBLE OR.-BYYACCOUNTING MORE PRECISELY FOR THE BUBBLE SHAPE. BECAUSE IT INVOLVES A VERY OIFFICULT HYORODYNAMIC PROBLEM, THE LATTER DOES NOT APPEAR FRUITFUL AT THIS TIME. WE ARE STUOYING SPHERICAL BUSBLES AS ANOTHER IDEALIZED PROBLEM THAT MAY INCREASE OUR KNOWLEDGE OF THIS PHENOMENON, 3 . THE TRANSIENT-HEATING EXPERIMENT PROVED VERY USEFUL IN STUDYING SUBCOOLED BOILING BUBBLE DYNAMICS. A VERY WIDE RANGE OF PARAMETERS WAS ACHIEVEO WITH WATER, AND, BY USING OTHER FLUIDS, THIS RANGE CAN BE EXTENDED WITHOUT IMPROVING PHOTOGRAPHIC TECHNIQUES. 4. INERTIA AND SURFACE TENSION PLAY AN IMPORTANT ROLE IN SUBCOOLED BOILING BUBBLE DYNAMICS FOR MUCH LARGER SIZES OF BUBBLES THAN IN THE CASE OF VOLUME BOILING. 5. THE SPREAD OF DATA IN FIGURE 9A SUSGESTS THAT THERE MAY BE AN INFLUENCE, NOT YET UNDERSTOOD, THAT DETERMINES THE MAXIMUM SIZE OF SUBCOOLED BOILING BUBBLES.

*HEAT TRANSFER + *HEAT TRANSFER, BOILING + HEAT CONDUCTION + HEAT EXCHANGER + HEAT TRANSFER ANALYSIS + HEAT TRANSFER EXPERIMENT + SURFACE, GENERAL + WATER, GENERAL

5-10701 TAGAMIT

INTERIM REPORT ON SAFETY ASSESSMENTS AND FACILITIES ESTABLISHMENT PROJECT IN JAPAN FOR PERIOD ENDING JUNE 1965 (NO. 1)

16 PAGES, 49 FIGURES, FEBRUARY 28,1966 , SOURCE

THIS REPORT IS A TRANSLATION OF A JAPANESE REPORT - REPORT ON EMERGENCY COOLING TEST IN THE LOSS OF COOLANT ACCIDENT - BY S. KAWAHARA, ET AL., DESCRIBING BLOWDOWN TESTS, PRESSURE AND TEMPERATURE TRANSIENTS, CONTAINMENT-PRESSURE, TRANSIENTS, EFFECTIVENESS OF CONTAINMENT-SPRAY SYSTEM, AND IN-CORE SPRAY TESTS IN THE SAFE PROJECT STARTED IN 1963.

\#FLOW THEORY AND EXPERIMENTS + \#HEAT TRANSFER, BOILING + \#LOSS OF COOLANT + \#LOSS OF PRESSURE + CONTAINMENT ANALYSIS + HEAT TRANSFER

5-10708 HOPPNER G

THERMAL LOAD LIMITS OF NUCLEAR FUEL ELEMENTS

KARLSRUHE NUCLEAR RESEARCH CENTER, GERMANY

ORNL-TR-928 +. 14 PAGES, 8 FIGURES, 22 REFERENCES, TRANSLATED FROM ATOMKERNENERGIE 10 (5-6)- 163-168 $(1965)$

PARAMETERS INFluencing the temperature VARIATION, SUCH AS THE COEFFiCIENT OF THERMAL CONDUCTIVITY OF THE FUEL AND THE CONTACT COEFFICIENT OF THE FUEL CAN ARE DISCUSSED. ONLY VERY LOW SURFACE LOADS AND POWER DENSITIES CAN BE OBTAINED WITH CYLINDRICAL FUEL ELEMENTS. VERY HIGH SURFACE LOADS AND POWER DENSITIES ARE ATTAINED WITH PLATE ELEMENTS, ALTHOUGH RESISTANCE ANO COOLING PROBLEMS ARE FNCOUNTERED. THE PROPOSED SPHERICAL ELEMENTS PERMIT HIGH SURFACE LOADS, HEAT SOURCE DENSITIES, POWER DENSITIES, AND EXTREMELY HIGH SURFACE TEMPERATURES AS A RESULT OF THE EXTERNALLY APPLIED FUEL LAYER.

* FUEL ELEMENT + HEAT CONDUCTION + \#HEAT TRANSFER + FUEL INTEGRITY + HEAT GENERATION, INTERNAL

5-10844 ALEKSEYEV GV + Z ZENKEVICH BA + SUBBOTIN VI

CRITICAL HEAT FLUXES IN ANNULAR CHANNELS WITH HEAT SUPPLY FROM TWO SIDES

WAPD-TRANS-17 +. 4 PAGES, TRANSLATED FROM INZH.-FIZ. ZHURNAL, 7(9), 30-33 (1964), CFSTI, \$1.00 CY, \$1.00 MN

RESULTS ARE GIVEN COVERING THE EXPERIMENTAL INVESTIGATIONS OF CRITICAL HEAT FLUXES IN AN ANNULAR CHANNEL WITH A TWO-WAY HEAT SUPPLY FOR A FORCED FLOW OF WATER UNDERHEATED TO SATURATION TEMPERATURE ANO A STEAM-WATER MIXTURE.

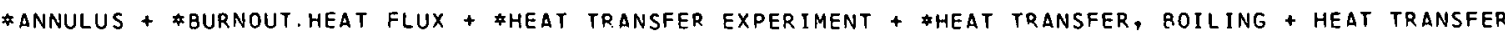


CATEGORY

ACCIDENT ANALYSIS

5-10845 EVANGEL. ISTI R

WIEDEMANN-FRANZ-L ORENZ LAW AND ITS APPLICATION IN THE HIGH-TEMPERATURE FIELD

LA-TR-66-22 +. 20 PAGES, RIV. ING. 14(8), PAGES 761-71, (1965), JCL, \$1.60 FS, \$0.80 MF

THIS REPORT DESCRIBES THE USE OF THE WFIDMANN-FRANZ-LORENZ LAW TO SSTIMATE THERMAL PROPERTIES FROM ELECTRICAL RESISTANCE MEASUREMENTS. ELECTRICAL MEASUREMENTS CAN BE MADE MORE EASILY AND WITH HIGHER PRECISION THAN THERMAL MEASUREMENTS. A 5 IMPLIFIED CORRELATION IS PRESENTED.

* THERMAL PROPERTY + \#TRANSPORT PROPERTY + HEAT TRANSFER + HEAT TRANSFER ANALYSIS + THERMOOYNAMICS

5-10846 MUELLER JJ

LA CROSSE BOILING WATER REACTOR RADIO AND WATER CHEMISTRY MANUAL

ALLIS-CHALMERS MFG. CO. , BETHESDA, MD.

ACNP-66538+. 233 PAGES, JUNE 1, 1966 , CFSTI, \$6.00 CY, \$1.25 MN

THIS MANUAL CONTAINS THE ESSENTIAL MATERIAL TO OPTIMIZE THE LACBWR POWER PLANT REQUIREMENTS BY INTERRELATING RADIOCMEMISTRY AND A WATER CHEMISTRY PROGRAM AS OUTLINED IN THIS REPORT. THE PROCEDURES ARE NUMBERED ACCORDING TO A PARTICULAR CATEGORY, SUCH AS RC SERIES IRADIOCHEMISTRY METHODS), WC SERIES (WATER CHEMISTRY METHODS), AND THE D SERIES (OISSOLUTION METHODSI. THE MANUAL HAS EIGHT SECTIONS - I - SAFETY, II - STANDARDIZATION OF CARRIER SOLUTIONS, III COUNTING TECHNIQUES AND DATA HANOLING, IV - WATER CHEMISTRY METHODS, V - RADIOCHEMISTRY METHODS, VI - DISSOLUTION METHOOS, VII - SCHEDULE FOR RADIO AND WATER CHEMISTRY ANALYSES, AND VIII - APPENDIX.

\#RADIOCHEMICAL ANALYSIS + FWATER TREATMENT + LACROSSE BOILING WATER REACTOR + REACTOR, BOILING WATER

5-10847 LOWE AL

STEAM COOLED BREEDER REACTOR. MECHANICAL AND PHYSICAL PROPERTIES OF SELECTED HIGH-TEMPERATURE MATERIALS BABCOCK AND WILCOX COMPANY

BAW-237+. 50 PAGES, 3 TABLES, JULY, 1965 , CFSTI

THIS REPORT PRESENTS A DESCRIPTION AND ENUMERATION OF MECHANICAL PROPERTIES OF SEVEN ALLOYS NOW BEING CONSIDERED FOR USE AS FUEL CLAODING IN THE STEAM COOLED BREEDER REACTOR (SCBR). THE ALLOYS ARE - TYPES 304 AND 348 STAINLESS STEELS, 19-9 DL ALLOY, HASTELLOY-X-280, INCOLOY ALLOY-800, INCONEL ALLOY-625, AND IN-102 ALLOY. THE PROPERTIES MOST IMPORTANT TO THE SELECTION OF CLADDING MATERIAL IN THE SCBR ARE ELEVATED-TEMPERATURE, ULTIMATE, YIELD, AND STRESS-RUPTURE STRENGTHS, IN COMBINATION WITH LOW NEUTRON-CAPTURE CROSS SECTION. SINCE NO SINGLE ALLOY MEETS ALL THE REQUIREMENTS FOR THE IDEAL CLADDING, THE ALLOYS ARF DESCRIBED SO THAT THEIR PROPERTIES CAN BE COMPARED. IN THIS WAY, THE ALLOY(S) HAVING THE BEST COMBINATION OF PROPERTIES FOR A PARTICULAR DESIGN APPLICATION CAN BE SELECTED.

* MATERIAL + \#PROPERTY, PHYSICAL + *STEEL, STAINLESS + CREEP PROPERTY + IMPACT PROPERTY + STEAM

5-10848 BURNOUT FOR FLOW INSIDE ROUND TUBES WITH NONUNIFORM HEAT FLUXES - TOPICAL REPORT THE BABCOCK AND WILCOX COMPANY

BAW-3238-9+EURAEC-1640 +. 114 PAGES, 5 TABLES, MAY, 1966, CFSTI, \$4.00 CY, \$D.75 MN

ON JULY 1, 1963, THE BABCOCK AND WILCOX COMPANY, AS PART OF THE JOTNT U.S.-EURATOM RESFARCH AND DEVELOPMENT PROGRAM, BEGAN AN EXPERIMENTAL AND ANALYTICAL PRDGRAM TO DETERMINE HOW IRREGULAR HEAT FLOW THRCUGH REACTOR CHANNELS AFFECTS THE OPERATING CONDITIONS THAT CAUSE BURNOUT (CRITICAL HEAT FLUX). EXPERIMENTAL WORK ON TUBULAR SPECIMENS WITH FOUR AXIAL POWER SHAPES WAS COMPLETED IN DECEMBER 1964. ANNULAR SPECIMENS WITH FIVE POWER SHAPES ARE NOW BEING TESTED, AND AN EFFORT TO CORRELATE THE EXPERIMENTAL DATA WITH EMPIRICAL AND ANALYTICAL MODELS IS BEING MADE. THE COMPLETION DATE OF THE PPOGRAM, WITH ONE EXTENSION, IS JUNE 30 , 1966. THE DATA AND RESULTS FROM THF TUBULAR TEST SECTIONS ARE PRESENTED HERE. THE FOLLOHING CRITICAL HEAT FLUX CONDITIONS WERE RUN IN ALL COMBINATIONS - AXIAL FLUX SHAPE IUNIFORM, PEAK NEAR INLET, PEAK NEAR MIDPOINT, PFAK NEAR OUTLET), PRESSURE $(2000,1500,1000$ PSIA), MASS VELOCITY (0.5, $1.5,2.5$ LB PER HP PER SQ FT TIMFS 1 MILLION), INLET SUBCOOLING (20, 50, 1OO, $150 \mathrm{~F}$ 1. TME ANALYSIS PRESENTS OBSERVATIONS REGARDING CRITICAL HEAT FLUX LOCATION AND MAGNITUDE, ALONG WITH EQUATIONS THAT EVALUATE THE EFFECT OF OPERATING CONDITIONS ON CRITICAL HEAT $\sim$ FLUX LOCATION AND MAGNITUDE.

* BURNOUT HEAT FLUX + \#FLUX DISTRIBUTION + \#HEAT TRANSFER, BOILING + \#POWER OISTRIBUTION + FLOW, TUBE + HEAT TRANSFER + HEAT TRANSFER EXPERIMENT

5-10849 TOWELL RH

EFFECT OF SPACING ON HEAT TRANSFER BURNOUT IN ROD BUNDLES

SAVANNAH RIVER LAGURATORY

CP-1013+. 21 PAGES, NOVEMBER 1965 , CFSTI $\$ 1.00 \mathrm{CY}, \$ 0.50$

THE BURNOUT HEAT FLUX FOR BOILING LIGHT-WATER IN A MOCKUP OF THE CENTRAL COOL ING CHANNEL OF A MULTIROD FUEL BUNDLE DID NOT CHANGE APPRECIABLY WHEN THE SPACE BETWEEN THE RODS WAS DECREASED TO AS LITTLE AS 0.0I9 IN. BURNOUT HEAT FLUXES MEASURED WITH FORCED BOILING FLOW HERE TWICE THE VALUES REPORTED FOR SOME MULTIROD TEST SECTIONS HITH COMPARABLE ROD SPACING IO.OIS TO 0.050 IN.), AND ABOUT 50 PERCENT HIGHER THAN VALUES REPORTED FOR LARGER ROD SPACINGS (LONGER THAN 0.070 IN.). THE HIGHER HEAT FLUXES ARE ATTRIBUTED TO THE RELATIVELY UNIFORM COOLING THAT WAS OBTAINED IN THE MOCKUP BY USE OF A SINGLE COOLANT CHANNEL OF A SYMMETRICAL SHAPE. SUCH HIGH HEAT FLUXES PROBABLY CANNOT BE DUPLICATED IN ROD BUNDLES THAT HAVE NONUNIFORM COOLANY CHANNELS.

* BURNOUT HEAT FLUX + \#HEAT TRANSFER, BOILING + FUEL ELEMENT + HEAT TRANSFER + HEAT TRANSFER EXPERIMENT 
CATEGORY 5

ACCIDENT ANALYSIS

5-10850 BIANCONE F + CAMPANILE A + GALIMI G + GOFFI M

FORCED CONVECTION BURNOUT AND HYORODYNAMIC INSTABILITY EXPERIMENTS FOR WATER AT HIGH PRESSURF. PART I.

FIAT S.P.A., SEZIONE ENERGIA NUCLEARE - TROINO

EUR-2490 +. 104 PAGES, AUGUST 1965, BEP. MN.

THE OBJECT OF THIS REPORT IS TO PRESENT THE DATA, COLLECTED DURING THE FIRST PHASE OF A COMPREHENSIVE EXPER IMENTAL INVESTIGATION OF RURNOUT BEING CONDUCTED IN THF HEAT TRANSFER LABORATORY OF THE SORIN NUCLEAR RESEARCH CENTER IN SALUGGIA. THE FIRST PHASE, DESCRIBED HERE, DEALT WITH BURNOUT EXPERIMENTS FOR WATER FLOWING UPWARD INSIDE SINGLE, ROUND, VERTICAL CHANNELS WITH BOTH UNIFORM AND NONUNIFORM AXIAL HEAT-FLUX DISTRIBUTION. AN ATTEMPT TO CORRELATE THE DATA OR TO COMPARE THEM WITH EXISTING CORRELATIONS WILL BE PRESENTED IN THE NEXT TOPICAL REPORT. TO THIS PURPOSE A COMPUTER PROGRAM HAS BEEN WRITTEN.

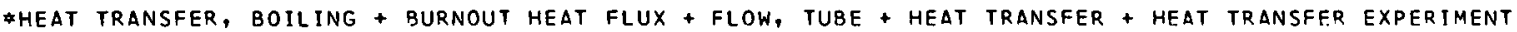

5-10867 MILLER CE + BROWNING WE

THE ADEQUACY OF SCALE-UP IN EXPERIMENTS ON FISSION PRODUCT BEHAVIOR IN REACTOR ACCIDENTS. PART I. AN ANALYSIS OF SCALE-UP IN THE U. S. NUCLEAR SAFETY PROGRAM

OAK RIDGE NATIONAL LABORATORY, OAK RIDGE, TENNESSEE

ORNL-3901 +. 48 PAGES, 2 TABLES, 17 FIGURES, 17 REFERENCES, JULY 1966, CFSTI, \$3.0D CY, \$D.50 MN

FOUR AREAS DISCUSSED - (1) RELEASE OF FISSION PRODUCTS FROM FUEL, (2) THEIR TRANSPORT TO

CONTAINMENT VESSEL, (3) THEIR REHAVIOR IN A CONTAINMENT SYSTEM, AND (4) THEIR BEHAVIOR IN GAS-CLEANING SYSTEMS. IN GENERAL, LARGE-SCALE EXPERIMENTS SUCH AS LOFT WERE THE UPPER BOUND OF THE STUDY. CONCLUSION - ITEMS (3) AND (4) ARE HELL SCALED OVER RANGE, BUT INTERMEDIATE-SCALE EXPERIMENTS (JUST BELOW LOFT) ARE NEEDED FOR ITEMS (1) ANO (2). CONTAINS GOOD GENERAL INTRODUCTION TO PROBLEM, PLUS COMPARISON OF LOFT WITH POWER REACTORS AND - BENCH-SCALE EXPERIMENTS

\# CONTAINMENT FILTERING SYSTEM + *CONTAINMENT RESEARCH AND DEVELOPMENT + *DEPOSITION + \#FISSION PRODUCT RELEASE, GENERAL + \#FISSION PRODUCT TRANSPORT + FUEL MELTDOWN + LOFT ILOSS OF FLUID TEST) + REACTOR, PRESSURIZED WATER

5-10880 FIRST SUPPLEMENT TO PRELIMINARY SAFETY ANALYSIS. INDIAN POINT NUCLEAR GENERATING UNIT NO. 2 . CONSOL IDATED EDISON COMPANY OF NEW YORK

3 PAGES OF FIRST SUPPLEMENT TO PRELIMINARY SAFETY ANALYSIS. INDIAN DOINT NUCLEAR GENERATING UNIT NO. 2 , MARCH 31, 1966, DOCKET NO. 50-247, POR

QUESTION 2, CRITERION $10--$ ADEQUATE CONDENSATE IS STORED TO RELEASE DECAY HEAT FOR 24 HR BY SECONDARY STEAM DUMP. RESIDUAL HEAT EXCHANGERS AND CONTAINMENT AIR COOLERS ALSO SUPPLIED.

* DECAY HEAT + \#DESIGN CRITERIA + \#REguLATION, AEC + * SAFEguARDS REPORT, RESPONSE TO AEC DUESTIONS + INDIAN POINT II + REACTOR, PRESSURIZED WATER

5-10881 FIRST SUPPLEMENT TC PRELIMINARY SAFETY ANALYSIS. INDIAN POINT NUCLEAR GENERATING UNIT NO. 2. CONSOLIDATED EDISON COMPANY OF NEW YORK

2 PAGES OF FIRST SUPPLEMENT TO PRELIMINARY SAFETY ANALYSIS. INDIAN POINT NUCLEAR GENERATING UNIT NO. 2 , MARCH 31, 1966, DOCKET NO. 50-247, PDR

QUESTION 2, CRITERION 11 -- REACTOR VESSEL DESIGN TRANSITION TEMPERATURE SHIFT OF 275 F WAS SELECTED, BASED ON INTEGRATED FAST NEUTRON FLUX OF $3.7 \times 10$ (19TH). CONTAINMENT LINE WILL BE MINIMUM OF $50 \mathrm{~F}$, HELL ABOVE HOTT PLUS 30.

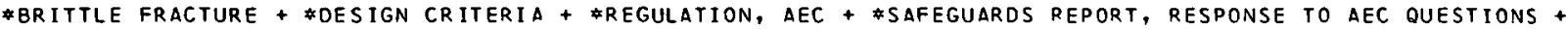
CONTAINMENT, PRESSURE VESSEL + INDIAN POINT II + REACTOR, PRESSURIZED WATER

5-10898 FIRST SUPPLEMENT TO PRELIMINARY SAFETY ANALYSIS. INDIAN POINT NUCLEAR GENERATING UNIT NO. 2 CONSOLIDATED EDISON COMPANY OF NEW YORK

25 PAGES, 1 FIGURE, 27 REFERENCES OF FIRST SUPPLEMENT TO PRELIMINARY SAFETY ANALYSIS. INDIAN POINT NUCLEAR GENERATING UNIT NO. 2, MARCH 31,1966 , DOCKET NO. 50-247, PDR

QUESTION 3 IS REALLY 12 QUESTIONS ABOUT PRESSURE-VESSEL DESIGN, NDT STRESS ANALYSIS ASSUMPIIONS, ACCEPTABLE FLAW SIZES, LEAKS, SURVEILLANCE, ETC. A FRACTURE-ANALYSIS DIAGRAM FOR VARIOUS FLAH SIZES IS INCLUDED. DIFFERENCES IN NDT THROUGH THICK PLATES ARE TAKEN INTO ACCOUNT BY CHOOSING A REFERENCE POINT $1 / 4$ THROUGH THE PLATE. ENHANCED METALLURGICAL PROPERTIES AT SURFACE COUNTERACT DECREASED NOT THERE.

* BR ITTLE FRACTURE + \#CONTAINMENT, PRESSURE VESSEL + *SAFEguARDS REPORT, RESPONSE TO aEC QUESTIONS * INOIAN POINT II + NDT DATA (NIL DUCTILITY TRANSITION) + REACTOR, PRESSURIZED WATER + STRESS ANALYSIS

5-10899 FIRST SUPPLEMENT TO PRELIMINARY SAFETY ANALYSIS. INDIAN POINT NUCLEAR GENERATING UNIT NO. 2 CONSOLIDATED EDISON COMPANY OF NEW YORK

37 PAGES, 21 FIGURES OF FIRST SUPPLEMENT TO PRELIMINARY SAFETY ANALYSIS, INDIAN POINT NUCLEAR GENERATING UNIT NO. 2, MARCH 31,1966 , DOCKET NO. 50-247, PDR

QUESTION 4 IS REALLY FIVE QUESTIONS RELATING TO CALCULATION OF DOUBLE-ENDED PIPE RUDTURE CONTAINMENT-PRESSURE TRANSIENT AND EFFECT OF VARIOUS ENGINEERED SAFEGUARDS - (A) RELATES TO METAL-WATER, HYDROGEN REACTION, AND OTHER ENERGY SOURCES, (B) SHOWS THE ENERGY DISSIPATION FOR THE FIRST 30 MIN. POST INCIDENT, (C) SHOWS PERCENTAGE OF CORE ZIRCONIUM ABOVE CERTAIN TEMPERATURES VS TIME, (D) (E) (F) PROVIDES GRAPHS OF PRESSURE TRANSIENTS WITH VARIOUS 
CATEGORY 5

ACCIDENT ANALYSIS

\section{5-10899 \#CONTINUED*}

ENGINEERED SAFEGUARDS NOT WORKING, AND WITH VARIOUS STEP INCREASES OF ENERGY.

*ENgineEred Safeguard + * oss of coolant + *Safeguards report, response to aec questions +

INDIAN POINT II + PRESSURE, INTERNAL + REACTOR, PRESSURIZED WATER

5-10927 FIRST SUPPLEMENT TO PRELIMINARY SAFETY ANALYSIS. INDIAN POINT NUCLEAR GENERATING UNIT NO. 2 CONSOLIDATED EDISON COMPANY OF NEW YORK

3 PAGES OF FIRST SUPPLEMENT TO PRELIMINARY SAFETY ANALYSIS. INDIAN POINT NUCLEAR GENERATING UNIT NO. 2,

MARCH 31,1966 , DOCKET NO. 50-247, PDR

QUESTION 19 I - DESIGN CRITERIA AND JUSTIFICATION, HOW FULFILLED, AND TEST METHODS -- WHILE

FAILURE OF CORE SUPPORT IS CONSIDERED INCREDIBLE, CORE DOWNWARD DROP WOULD BE LIMITED TO LESS

THAN 2 IN. [LESS THAN O.3 PERCENT REACTIVITYI BY THE IN-CORE INSTRUMENTATION STRUCTURE AND

ENERGY ABSORBERS. THE ENERGY ABSORBERS WOULD REST ON THE INSIDE OF THE 8OTTOM HEAD OF THE

VESSEL AND HOULD SUPPORT THE CORE THROUGH THE IN-CORE INSTRUMENTATION STRUCTURES.

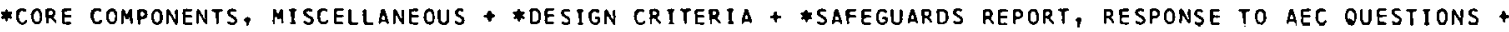
\#SUPPORT STRUCTURE + FAILURE, COMPONENT + INDIAN POINT II + INSTRUMENTATION, IN CORE +

REACTOR, PRESSURIZED WATER

5-10988 FUEL ELEMENT RUPTURE TEST FACILITY INCIDENT AT THE PLUTONIUM RECYCLE TEST REACTOR U. S. ATOMIC ENERGY COMMISSION, OIVISION OF OPERATIONAL SAFETY

ROE-66-1 +. 3 PAGES, AUGUST 5, 1966, OPERATING EXPERIENCES, REACTOR SAFETY QULLETIN, DPI

ON SEPTEMBER 29, 1965, A U02-PU02 FUEL ELEMENT HITM AN INTENTIONAL DEFECT, IRRADIATED IN A TEST LOOP, CAUSED THE FAILURE OF A PRESSURE TUBE. THE RESULTANT PRESSURE DECREASE CAUSEO TOO $G$ OF MOLTEN FUEL TO BE EJECTED FROM THE FUEL ROD THROUGH THE FAILED TUBE. ALTHOUGH THE MOLTEN FUEL WAS STOPPED BY THE SURROUNDING SHROUD TUBE, SOME FUEL ANO FISSION PRODUCT WAS SPREAD BY THE DRY GAS AND THE CONTAINMENT VENTILATION SYSTEM. THE HYPOTHESIZED COURSF OF THE INCIDENT WAS AS FOLLOWS - HATER OXIOIZED THE FUEL TO UO2.1, THERMAL CONDUCTIVITY WAS LOWERFD, INCREASING THE VOLUME OF MOLTEN FUEL ANO THE INTERNAL PRESSURE, WHICH SPLIT THE CLADDING. THE SHOLLEN FUEL INTERFERED WITH THE COOLING OF THE PRESSURE TUBE, WHICH THEN FAILED UNDER PRESSURE.

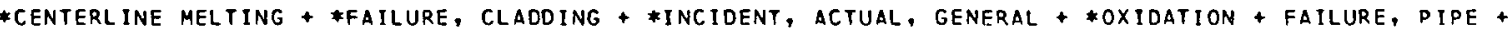
IN PILE LOOP + PRTR (PLUTONIUM RECYCLE TEST REACTOR) + REACTOR, AEC OWNED + REACTOR, HEAVY WATER + REACTOR, PRESSURE TUBE + URANIUM DIOXIDE

5-11039 TEMPORARY AUTHORIZATION TO OPERATE INDIAN POINT HITH PUMP FLOH TECHNICAL SPECIFICATIONS REQUIREMENT DELETED

U. S. ATOMIC ENERGY COMMISSION

1 PAGE, JULY 27, 1966, DOCKET 50-8, ATOMIC ENERGY CLEARING HOUSE, 12(32), DAGE 11 (AUGUST B, 1066)

TEMPORARY FULL-POWER AUTHORIZATION WITH A LOHER-THAN-TECHNICAL-SPECIFICATION VALUE ON PRIMARY COOLANT FLOW PER PUMP CRANTED TO DETLRMINE ACCURATELY FULL-FLOW VALUE.

*OPERATING LIMITS/TECHNICAL SPECIFICATIONS + FLOH, HIGH SPEED + INDIAN POINT I + PUMP + REACTOR, PRESSURIZED HATER

5-11040 FERMI POWER COEFFICIENT ANALYSIS

POWER REACTOR DEVELOPMENT COMPANY

2 PAGES, JULY 22, 1966, ATOMIC ENERGY CLEAPING HOUSE, $12(32)$, PAGES $12-13$ (AUGUST 8 , 1966 )

REVIEW OF DATA SHOWS THAT POWER COEFFICIENT IS LINEAR HITH POWER, AND TRANSFER-FUNCTION MEASUREMENTS SHOW REACTOR STRONGLY STABLE. PRINCIPLE CHANGES WERE - MORE-NEGATIVE CORE SODIUM EXPANSION EFFECT AND LESS-NEGATIVE CORE RADIAL EXPANSION EFFECT. NO CAUSE FOR CONCERN EXISTS, AS PREVIUUS SAFEIP ANALYSIS USEO POWER COEFFICIENTS AS LOH AS MINUS O. 5 CENT PER MEGAHATT, ANO PRESENT COEFFICIENT IS MINUS 0.18 .

* COMPARISON, THEORY AND EXPERIENCE + \#POMER COEFFICIENT + FERMI + REACTOR, FAST BREEDER + REACTOR, LIQUID METAL COOLED

5-11046 ANOERSON AN

CORE B LOWER FLOHS REQUIRE TECHNICAL SPECIFICATION CHANGE AT INDIAN POINT UNIT I

CONSOL IDATEO EDISON COMPANY OF NEW YORK, INC.

2 PAGES, JULY 14, 1966, DOCKET 50-3, ATOMIC ENERGY CLEAR ING HOUSE, 12(311, PAGES 14-15, (AUGUST 1, 1966)

PRELIMINARY HEAT BALANCES INDICATE THE PRIMARY-COOLANT FLOH IS ABOUT 2.5 PERCENT BFLON DESICN VALUE, ALTHOUGH THERE DOES NOT APPEAR TO BE HIGHER PRESSURE DROP ACROSS THE CORE. SINCE SPECIFICATIONS REQUIRE 18,500 GPM FLON PER PUMP, REACTOR WILL BE LIMITED TO 7 (OF 8 ) DUMPS RUNNING TO PRODUCE REQUIRED FLOW PER PUMP WITH LOWER CORE DELTA-P. THIS IS DONE FOR LITERAL COMPLIANCE WITH SPECIFICATIONS, ALTHOUGM THERE IS NO REASON TO BE SURE THAT THEY WOULD NOT BE IN COMPLIANCE WITH ALL PUMPS RUNNING.

*OPERATING LIMITS/TECHNICAL SPECIFICATIONS + FLOW, HIGH SPEED + INDIAN POINT I + PUMP + REACTOR, PRESSURIZED HATER 
CATEGORY 5

ACCIDENT ANALYSIS

5-11051 ANDERSON AN

EVALUATION OF STEAM GENERATOR TUBING FAILURES, INDIAN POINT UNIT 1

CONSOLIDATED EDISON COMPANY OF NEW YORK, INC.

2 PAGES, DOCKET 50-3, JUNE 20, 1966, ATOMIC ENERGY CLEARING HOUSE, 12(28), PAGES 16-17, (JULY 11, 1966)

EIGHT TUBE LEAKS HAVE OCCURRED SO FAR IN BOILERS 11 AND 14 , WITH NO LEAKS IN 12 OR 13 . FIVE LEAKS WERE LOCATED IN THE U-BENDS IINSPECTION SHOWED SAGGED TUBE SUPPORTS IN BOILER 14 AT THE U-BEND), AND ALL LEAKS OCCURRED DURING A PLANT HEATUP. THE LAPGEST LEAK (EQUIVALENT TO A 3/4-IN. HOLEI CAUSED PRESSURIZER LEVEL TO DROP 105 IN. IN 6 MIN WITH NORMAL MAKEUP. THE INVESTIGATION CONTINUES.

*FAILURE, PIPE + \#HEAT EXCHANGER + INDIAN POINT I + REACTOR, PRESSURIZED WATER + SUPPORT STRUCTURE + THERMAL MECHANICAL EFFECT

5-1105E NAHAVANDI AN + VON HOLLEN RF PRESSURE EFFECTS ON SPACE-DEPENDENT DYNAMICS IN BOILING SYSTEMS WESTINGHOUSE ELECTRIC CORPORATION, PITTSBURG, PA., ATOMIC POWER DIVISION CONF-650,413 +. 18 PAGES, 5 FIGURES, 5 REFERENCES, APRIL 1965, PAGES 556-583 OF NEUTRON DYNAMICS AND CONTROL, PROCEEDINGS OF THE SYMPOSIUM ON NUCLEAR ENGINEERING, UNIVERSITY OF ARIZONA, TUCSON, APRIL 5-7, 1965 , CFSTI $\$ 4.50 \mathrm{CY}, \$ 2.50 \mathrm{MN}$

EARLIER WORK WAS DONE ON CONSTANT-PRESSURE REACTOR. THIS ARTICLE REPORTS WORK DONE WHFN IT WAS REALIZED THAT LOSS OF LOAD WOULD CAUSE TURBINE-SPEED REGULATOR TO OVERCOME THE CONSTANT-DEMAND SIGNAL. EARLIER WORK AND THIS WORK WERE CHECKED AGAINST LOAD RAMP AT FULL POWER. MODEL WAS ALSO APPLIED TO DYNAMIC ANALYSIS OF A 4OD-MW (TH) VERTICAL STEAM GENERATOR.

\# HEAT TRANSFER, BOILING + HEAT EXCHANGER + LOSS OF LOAD + REACTOR, BOILING WATER

5-11083 DICKERMAN CE + ROBINSON LE

TREAT EXPERIMENTS TO PROVIDE DATA FOR FAST REACTOR SAFETY KINETICS CALCULATIONS ARGONNE NAT IONAL LABORATORY

CONF-650 413 +. 14 PAGES, 10 FIGURES, 18 REFERENCES, PP. $371-385$ OF NEUTRON DYNAMICS AND CONTROL, APRIL 7,1966, CFST I $\$ 4.50 \mathrm{CY}, \$ 2.50 \mathrm{MN}$

TREAT EXPERIMENT ON EBR-II-TYPE UO2 FUEL ENABLED THE INCLUSION OF VARIATIONS IN POWER AND COOLANT FLOW IN HYPOTHETICAL ACCIDENT MODELS. SUCH VARIATIONS MAY REDUCE REACTIVITY INSERTION RATES TENFDLD FROM SINGLE-PIN-FAILURE DATA. URANIUM SULPHIDE WAS MECHANICALLY SUPER IOR TO U02. SIGNIFICANTLY DIFFERENT FAILUPE MODES WITH DIFFERENT FAILURE THRESHOLDS WERE FOUND FOR UO2 IN FAST-REACTOR-FUEL SIZE.

\#FUEL ELEMENT + \#REACTOR TRANSIENT + EBR I AND II (EXPERIMENTAL BREEDER REACTORS) + REACTOR, GRAPHITE MODERATED + REACTOR, TEST + TREAT (TRANSIENT TEST REACTOR FACILITY) + URANIUM DIOXIDE + URANIUM SULFIDE

5-11170 CHERNOZUBOV VB + BOLOTOV AA + GOLUB SI + CHADOV VN + ZAOSTROVSKII FP + CHEMEZOV VA + MINUKHIN LA + MREZHIN LS

INTENSIFICATION OF HEAT EXCHANGE IN EVAPORATORS

AEC-TR-6737 + CONF-651005-12+. 23 PAGES, TRANSLATED FROM SWD/62 PRESENTED AT THE FIRST INTERNATIONAL

SYMPOSIUM ON WATER DESALINATION, OCTOBER $3-9,1965$, WASHINGTON, D.C., JCL $\$ 2.60$ FS, \$0.89 MF

THE DESALTING OF WATER IN MODERN INDUSTRIAL PLANTS REQUIRES EXTENSIVE USE OF METAL FOR HEAT EXCHANGER SURFACES. CONSEQUENTLY; AN INTENSIFICATION OF HEAT EXCHANGE HOULD LEAD TO A CONSIDERABLE REDUCTION IN THE COST OF FRESH WATER PRODUCTIDN. THE STUDIES OF HEAT-EXCHANGE INTENSITIFICATION WERE CARRIED OUT ALONG THE FOLLOWING APPROACHES - 111 REMOVING THE HARMFUL INFL UENCE OF NONCONDENSABLE GAS MIXTURES IN THE HEATING STEAM ON THE HEAT-TRANSFER

COEFFICIENT DURING CONDENSATION, 121 ENSURING DROPLET VAPOR CONDENSATION ON THE HEATING SURFACES, (3) DEVELOPING SUFFICIENTLY ECONOMICAL METHODS FOR INCREASING THE COEFFICIENT OF HEAT GENERATION BY THE LIQUID IN HEAT-EXCHANGERS.

* Heat exchanger + *heat transfer augmentation + *heat transfer, boIling + heAt transfer + HEAT TRANSFER EXPERIMENT + SURFACE, GENERAL

5-11173 BENNETT AW + HEWITT GF + KEARSEY HA + KEEYS RK + PULLING DJ STUDIES OF BURNOUT IN BOILING HEAT TRANSFER TO WATER IN ROUND TUQES WITH NONUNIFORM HEATING UNITED KINGOOM ATOMIC ENEREY AUTHORITY, HARWELL, BERKSHIRE

AERE-R-5076 +. 64 PAGES, 17 FIGURES, 3 TA8LES, 18 REFERENCES, MAY 1966, UKAEA

AS AN EXTENSION OF THE EARLIER WORK AT HARWELL ON THE MECHANISM OF BURNOUT, STUDIES WERE MADE OF THE EFFECT OF A COLD-PATCH OR UNHEATED LENGTH PLACED IN VARIOUS POSITIONS ALONG A TUBE IN WHICH BURNOUT HEAT FLUX IS DETERMINED. EXPERIMENTS AT LOW ANO HIGH PRESSURES CAN BE INTERPRETED TO GIVE INFORMATION ABOUT THE BEHAVIOR OF THE LIQUID PHASE IN THE CHANNEL. THIS INTERPRETATIDN HAS BEEN AIDED BY MAKING DIRFCT MEASUREMENTS OF LIQUID-FILM FLOWRATE FOR THE LOW-PRESSURE CASE. IT WAS FOUND THAT, WITH THE COLD PATCH IN CERTAIN POSITIONS, THE POWER REQUIRED FOR BURNOUT COULD ACTUALLY BE HIGHER THAN THAT FOR A UNIFORM TUBE OF THE SAME TOTAL LENGTH. THE INTERPRETATION OF THE COLD-PATCH DATA SUGGESTED THAT OTHER ARRANGEMENTS OF HEAT-FLUX DISTRIBUTION COULD GIVE SIMILARLY HIGHER POWERS. EXPERIMENTS ARE DESCRIBEO ON BURNOUT IN TUBES WITH A PEAK IN HEAT FLUX AT THE ENTRANCE AND, AS EXPECTED, THESE RESULTS SHOW AN IMPROVEMENT IN BURNOUT POWER OVER WIDE P.ANGES OF CONDITIONS. IN SOME TESTS, BURNOUT DID NOT OCCUR AT THE END OF THE HEATED TEST SECTION, AND THESE RESULTS COULD BE INTERPRETEC TO GIVE THE RATE OF DEPOSITION OF ENTRAINED DROPLETS WHICH IN TURN LEO TO A CALCULATION OF MASS-TRANSFER COEFFICIENT FOR DROPLET-TO-WALL TRANSFER. 
CATEGORY 5

ACCIDENT ANALYSIS

5-11173 \#CONTINUED*

*BURNOUT HEAT FLUX + \#FLOW, TUBE + \#HEAT TRANSFER, BOILING + \#WATER, GENERAL +

DNB (DEPARTURE FROM NUCLEATE BOILING) + HEAT TRANSFER

5-11225 DENT JC

TRANSIENT HEAT TRANSFER PRORIEMS

3 PAGES, CHEMICAL AND PROCESS ENGINEERING 47131, PAGES 134-136, MARCH 1966

THE SCHMIDT-BINDER METHOD IS APPLIED TO THE SOLUTION OF PROBLEMS INVOLVING TRANSIENT

CONOUCTION IN SLABS, WITH HEAT TRANSFER AT THE BOUNDARIES BY RADIATION AND COMBINED RADIATION

AND FREE CONVECTION. THE RESULTS OBTAINED BY THIS METHOD ARE COMPARED WITH ANALYTICAL AND

NETWORK ANALOGUE SOLUTIONS. THE METHOD IS USEFUL FOR QUICK SOLUTIONS TO SIMPLE PROBLEMS.

\#HEAT CONOUCTION + \$TEMPERATURE TRANSIENT + HEAT TRANSFER + HEAT TRANSFER ANALYSIS + TEMPERATURE GRADIENT

5-11227 ARAGONES M + GUERRERO H

THE EFFECT OF DENSITY AND GRAIN SIZE ON THE THERMAL CONDUCTIVITY OF UOZ DUR ING IRRADIATION ATOMIC ENERGY OF CANADA LIMITED, CHALK RIVER, ONTARIO

AECL-2564 +. 44 PAGES, 14 FIGURES, 10 TABLES, 19 PEFERFNCFS, APRIL; 10E6, AECL \$1.30

EIGHT HYDRAULIC-RABBIT SPECIMENS WERE IRRADIATED IN THE NRX FOR 3 MIN. FROM THE EXTENT OF MELTING IN THE U02 FUEL, VALUES OF THE CONDUCTIVITY INTEGRAL K-D-THETA WERE CALCULATED. THE DIFFERENCES DUE TO VARIATIONS IN DENSITY FROM 10.5 TO $10.8 / C U . C M$ WERE GIVEN BY AN EXPRESSION THAT RELATED INTEGRAL AS A FUNCTION OF PORE VOLUME TO THAT FOR FULLY DENSE UOZ. INCREASING THE GRAIN SIZE FROM 10 TO 100 MICRO-METERS DID NOT APPRECIABLY ALTER THE VALUE OF THE

INTEGRAL IN THE UO2 THAT HAD A DENSITY OF 10.8 .

\# HEAT CONDUCTION + \#THERMAL PROPERTY + \#URANIUM DIOXIDE + HEAT TRANSFER + POROUS MEDIA

5-11321 EDWARDS AL

TRUMP, A COMPUTER PROGRAM FOR TRANSIENT AND STEADY STATE TEMPERATURE DISTRIBUTIONS IN MULTIOIMENSIONAL

SYSTEMS

LAWRENCE RADIATION LAB, UNIVERSTTY OF CALIFORNIA

UCKL-14754 +. 149 PAGES, 16 FIGURES, FEBRUARY 24,1966 , CFSTI $\$ 5.00 \mathrm{CY}, \$ 1.00 \mathrm{MN}$

THE TRUMP COMPUTER PROGRAM WAS DEVELOPED TO SOLVE PROBLEMS INVULVING TRANSIENT AND STEADY-STATE TEMPERATURE DISTRIBUTIONS IN MULTIDIMENSIONAL SYSTEMS WITH ARBITRARY CONF IGURATIONS, INITIAL CONDITIONS, BOUNDARY CUNDITIONS, AND PHYSICAL PROPERTIES. THE MATHEMATICAL METHOO USES A UNIQUE COMBINATION OF FORWARD AND BACKWARD DIFFERENCE EQUATIONS TO ACHIEVE FAST, EFFICIENT, AND ACCURATE SOLUTIONS OF BOTH TRANSIENT AND STEADY-STATE' TEMPERATURE DISTRIBUTIONS. THE PROGRAM IS WRITTEN IN SEPARATE VERSIONS FOR THE IBM-7O94, CDC-3600, AND CDC-6600 TO MAKE FULL USE OF THE AVAILABLE MEMORY CAPACITY AND SPECIAL CHARACTERISTICS OF EACH COMPUTER. PROBLEMS MAY INCLUDE HEAT TRANSFER BY CONDUCTION, FREE AND FORCED CONVECTION, SURFACE RADIATION, AND MASS FLOW. HEAT MAY BE PRODUCED OR ABSORBED BY INTERNAL HEAT SOURCES AND SINKS, PHASE CHANGES, AND CHEMICAL REACTION. THE PROPERTIES CONTROLLING THESE EFFECTS MAY BE TABULATED AS FUNCTIONS OF TIME OR TEMPERATURE.

*HEAT CONDUCTION + \#HEAT TRANSFER ANALYSIS + \#TEMPERATURE TRANSIENT + COMPUTER, DIGITAL + HEAT TRANSFER + HEAT TRANSFER, CONVECTION + THERMAL PROPERTY

5-11322 SANDERS JP

TEMPERATURE DISTRIBUTION UNDER DIMPLES PROPOSEO AS SPACERS IN THE BONUS SUPERHEATER ASSEMBLIES OAK RIOGE NATIONAL LABORATORY, OAK RIDGE

ORNL-TM-1453 +. 17 PAGES, 2 FIGURES, 6 TABLES, 3 REFERENCES, APRIL 22, 1966, CFSTI \$1.00 CY, \$O.50 MN

IT HAS BEEN PROPOSED THAT DIMPLES IN THE COOLANT TUBE BE USED AS AN ALTERNATIVE TO THE PRESENT SPACER RING TO CENTER THE CLAD FUEL ROD IN THE COOLANT STREAM IN THE BONUS SUPERHFATER ASSEMBLIES, THF TFMPERATURE DISTRIOUTION UNDER SUCH A DIMPLE WAS INVESTIGATED USING THE HEATING CODE WRITTEN BY ASTRA, INC., OF RALEIGH, NORTH CARULINA. CALCULATIONS HERE MADE IN TWO DIMENSIONS ( $R$, THETAI USING CYL INDRICAL GEOMETRY AND A 78.5 DEGREE SEGMENT. IT WAS FOUND THAT LATERAL CONDUCTION COULD NOT OISSIPATE HEAT FROM BENEATH THE DIMPLE SUFFICIENTLY WELL TO MAINTAIN TEMPERATURES IN THE CLADOING LESS THAN $1250 \mathrm{~F}$. THE ONLY METHOD OF MAINTAINING SUFFICIENTLY LOW TEMPERATURES IN THE CLADOING WAS TO ENSURE GOOD THERMAL CONTACT BETWEEN THE CLADOING ANO THE DIMPLE. SUFFICIENT CONTACT MIGHT BE OBTAINED BY PLACING THREE DIMPLES AROUNO THE SAME PERIMETER AND CONSTRUCTING THEM TO OBTAIN AN INTERFERENCE FIT AT THE THREE POINTS OF CONTACT. THE DIMPLES MIGHT BE SLIGHTLY FLATTENED TO THE CURVATURE OF THE FUEL ROD AT THE POINT OF CONTACT, AND BOTH METAL SURFACES SHOULD BE CLEAN AND FREE OF OXIDE FILM.

*BONUS (BOILING NUCLEAR SUPERHEAT PRO.JECT) + *FUEL ELEMENT + \#HEAT EXCHANGER + HEAT TRANSFER + HEAT IRANSFER ANALYSIS + REACTOR, BOILING WATER + REACTOR, SUPERHEAT

5-11323 SANDERS JP

TEMPERATURES IN THE CLAODING UNDER THE SPACERS OF THE BONUS SUPERHEATER ASSEMBLIES OAK RIDGE NATIONAL LABORATORY, OAK RIDGE

ORNL-TM-1452 +. 16 PAGES, 4 FIGURES, 3 TABLES, 4 REFERENCES, APRIL 22,1966, CFSTI \$1.00 CY, \$O.50 MN

THE TEMPERATURE DISTRIBUTION UNDER THE SPACERS IN THE BONUS SUPERHEATER ASSEMBLIES HAS CALCULATED WITH THE HEATING PROGRAM ASSEMBLED BY ASTRA, INC, RALEIGHT, NORTH CAROLINA. A TWO-DIMENSIONAL MODEL IN CYLINDRICAL COORDINATES (R, THETA) WAS USED FOR A 60 DEGREE

SYMMETRICAL SEGMENT. THE RESULTS INDICATE THAT IF A BRAZE WIDTH AT THE POINT OF CONTACT OF 
CATEGORY 5

ACCIDENT ANALYYSIS

5-11323 \#CONT INUED*

AT LEAST 40 MILS CAN BE OBTAINED, THE MAXIMUM TEMPERATURE IN THE CLADDing WILl be LESS than $1200 \mathrm{~F}$. THE PRESENCE OF A CRACKED BRAZE. FILLET DOES NOT APPEAR TO HAVE A MAJOR ADVERSE EFFECT SO LONG AS A SUFFICIENT WIDTH OF SOUND BRAZE IS OBTAINED. IT IS RECOMMENDED THAT ADEQUATE INSPECTION PROCEDURES BE ADAPTED TO ENSURE THIS MINIMUM CONTINUOUS BRAZE WIDTH OF 40 MILS AT THE CLADDING-TO-SPACER JUNCTION. ANOTHER DESIGN THAT CONSISTS OF THREE TRI ANGULAR RIBS BRAZED LONGITUDINALLY TO THE CLADDING IS PROPOSED. HEAT DISSIPATION WOULD BE INCRFASED BY THE PRESENCE OF THESE RIBS.

* BONUS (BOILING NUCLEAR SUPERHEAT PROJECT) + FUEL ELEMENT + HEAT EXCHANGER + HEAT TRANSFER + HEAT TRANSFER ANALYSIS + REACTOR, BOILING WATER + REACTOR, SUPERHEAT

5-11324 SANDERS JP

EFFECT OF TWO-PASS FLOW IN THE BONUS SUPERHEATER ASSEMBLIES

OAK RIDGE NATIONAL LABORATORY, OAK RIDGE

ORNL-TM-1449+. 7 PAGES, 2 TABLES, 3 REFERENCES, APRIL 22, 1966, C.FSTI \$1.00 CY, \$O.50 MN

A BRIEF STUDY WAS MADE OF THE EFFECT OF REDESIGNING THE BONUS SUPERHEATER ASSEMBLIFS FOR TWO-PASS FLOW RATHER THAN FOUR-PASS. BASED ON THE DESIGN CRITERIA AND ASSUMED UNIFORM DISTRIBUTION OF FLOW, IT WAS ESTIMATED THAT THE HEAT-TRANSFER COEFFICIENT IN THE SUPERHFATER WOULD BE REDUCED FROM 598 TO 343 BTU PER HR PER SQ. FT PER DEGREE F. THIS PEDUCTION WOULD RESULT IN CLADDING TEMPERATURES APPROACHING $1500 \mathrm{~F}$ AT THE POINT OF MAXIMUM HEAT FLUX. THESE TEMPERATURES ARE ABOVE THE ALLOWABLE LIMIT FOR THE INCONEL CLADDING.

ఊBONUS 180 ILING NUCLEAR SUPERHEAT PROJECT) + *HEAT TRANSFER ANALYSIS + FUEL ELEMENT + HEAT EXCHANGER + HEAT TRANSFER + REACTOR, BOILING WATER + REACTOR, SUPERHEAT

5-11325 REILLY HJ + BAUMEISTER KJ + ALTOMARE S

HEAT-TRANSFER ANALYSIS OF THE PLUM BROOK RFACTOR

NASA, LEWIS RESEARCH CENTER, CLEVELAND

NASA-TN-D-3552 +. 31 PAGES, 12 FIGURES, I TABLE, 10 REFERENCES, AUGUST 1966, CFSTI $\$ 2.00$ CY

A HEAT-TRANSFER ANALYSIS OF THE PLUM BROOK REACTOR (PBR) CORE WAS PERFORMFD TO DETERMINE FUEL-PLATE SURFACE TEMPERATURES, HEAT FLUXES, AND THE DEPARTURE-FROM-NUCLEATE-BOILING (DNB) RATIO DURING FULL POWER OPERATION. THE HOT-SPOT--HOT-CHANNEL METHOD WAS EMPLOYED, THE HEAT-FLUX DISTRIBUTIONS IN THE COOLANT CHANNELS WERE BASED ON THE MEASURED LOW-POWER NEUTRON-FLUX DISTRIBUTIONS IN THE COLD CLEAN CORE AND IN CORES CONTAINING PARTIALLY DEPLETED ELEMENTS. THE RESULTS INDICATE THAT THE ANALYTICAL METHODS DESCRIBED GIVE MORE REALISTIC ESTIMATES OF THE HEAT-TRANSFER MARGIN DURING OPERATION AT SO MW(THI THAN WOULD BE OBTAINED WITH CONVENTIONAL METHODS. THE OBSERVED PERFORMANCE OF THE REACTDR INDICATES THAT THE METHODS USED ARE SUFFICIENTLY CONSERVATIVE TO ENSURE ITS SAFETY.

* DNB (DEPARTURE FROM NUCLEATE BOILING) + \#FUEL ELEMENT + \#HOT SPOT + \#PLUM BROOK + FUEL ELEMENT + HEAT TRANSFER + HEAT TRANSFER ANALYSIS + REACTOR, TEST

5-11326 COLLINSWT + SELBY TW

A gRAVIMETRIC GAS FLOW STANDARD - PART II. PERFoRMANCE ANO EVALUATION

UNION CARBIDE CORPORATION, OAK RIDGE, OAK RIDGE GASEOUS DIFFUSION PLANT

K-1632+CONF-660902-1+. 85 PAGES, 16 FIGURES, 15 TABLES, APRIL 15, 1966, CFSTI \$3.00 CY, \$0.75 MN

DESIGN ANO CONSTRUCTION FEATURES OF THE GRAVIMETRIC GAS FLOW STANDARD WERE REPORTED IN K-I632, PART I OF THIS SERIES. THIS REPORT, PART II, DESCRIBES THE PERFORMANCE AND EVALUATION OF THE FLOW STANDARD. PRECISION ESTIMATES BASED ON THE STANDARD DEVIATION OF LINEAR FITS TO FLOW VERSUS PRESSURE RELATIONSHIPS FOR CRITICALLY OPERATED FLOW ELEMENTS WERE PLUS-OR-MINUS O.O35 PERCENT OVER THE RANGE OF 0.05 TO 1725 OF DRY AIR PER MINUTE. THE ACCURACY WAS ESTIMATED FROM A RIGOROUS ANALYSIS OF ALL KNOWN SOURCES OF UNCERTAINTY. THE PRINCIPAL SOURCES OF UNCERTAINTY ARE DISCUSSED AND METHODS PROPOSED FOR REDUCING THEIR EFFFCT. IT WAS CONCLUDED THAT THE GRAVIMETRIC METHOD HAS A POTENTIAL IMPRECISION SIGNIFICANTLY LESS THAN PLUS OR MINUS O. 10 PERCENT STANDARO DEVIATION, AND THAT THE CONCEPT COULD BE EXTFNOEO FOR CALIBRATING GAS FLOW RATES OF SEVERAL THOUSAND STANDARD CUBIC FEET PER MINUTE.

* INSTRUMENTATION, FLOW + *INSTRUMENTATION, GENERAL + FLOW THEORY AND EXPERIMENTS + HYDRODYNAMIC ANALYSIS + INSTRUMENTATION CALIBRATION

5- $11327 \quad$ LONGWELL PA

MECHANICS OF FLUID FLOW

CALIFORNIA INST. OF TECH., PASADENA

433 PAGES, FIGURES, TABLES, 1966, MCGRAW-HILL, INC., \$14.75 CY

THIS BOOK IS INTENDED AS A TEXT IN THE AREAS OF FLUIO MECHANICS BELIEVED TO BE MOST USEFIUL TO CHEMICAL ENGINEERS. IT IS AIMED AT GIVING STUDENTS SUFFICIENT BACKGROUND AND EXPERIENCE SO THAT THEY NOT ONLY CAN READ THE CURRENT LITERATURE WITH UNDERSTANDING BUT ALSO CAN ATTACK NEW THAT THEY NOT ONLY CAN READ THE CURRENT LITERATURE WITH UNDERSTANDING BUT ALSO CAN ATTACK NEW
PROBLEMS WITH SOME COMPETENCE. THE TEXT REPRESENTS THE EXTENSION OF NOTES USED IN TEACHING A COURSE OF THE SAME TITLE FOR EIGHT YEARS TO FIRST-YEAR GRADUATE STUDENTS IN CHEMICAL

ENGINEER ING AT THE CALIFORNIA INSTITUTE OF TECHNOLOGY. THE PRIMARY EMPHASIS IS ON MOMENTUM TRANSPORT, HOWEVER, SOME ENERGY TRANSPORT IS INCLUDED TO ILLUSTRATE HOH FLUID MECHANICS ENTERS INTO THE SOLUTION OF SUCH PROSLEMS.

FLOW THEORY AND EXPERIMENIS + HEAT TRANGTLR + HYDRAULIC DNAIYYSIS + HYDPODYNAMIC ANALYSIS + MASS TRANSFER 
CATEGORY 5

ACCIDENT ANALYSIS

5- 11452 JONES LT + REBMAN HP

BLOWOUT, HEAT TRANSFER, PRESSURE OROP, AND MAXIMUM FLOW TESTS CONDUCTED ON A PROTOTYPE MARK III FUEL BUNDLE GENERAL ELECTRIC CO., SAN JOSE

GEAP-4898 +. 90 PAGES, REFERENCES, JUNE 25, 1965, CFSTI \$3.00 CY, \$0.75 MN

AN EVESR MK III MODIFIED FUEL BUNDLE WAS FULLY INSTRUMENTED AND OPERATED INTERMITTENTLY FOR THREE MONTHS AT THE MOSS LANDING POWER PLANT. THE TEST BUNDLE WAS OPERATED AT 1 DOO PSI WITH STEAM FLOWS FROM 660 TO OVER 18,100 L8/HR, AND STEAM INLET TEMPERATURES UP TO 760 F. DATA WERE RECORDEO FOR BLOWOUT, FLOW DISTRIBUTION, HEAT TRANSFER, PRESSURE DROP, AND MAXIMUM FLOW.

*FUEL ELEMENT + *LOSS OF COOLANT + \#PRESSURE DROP + HEAT TRANSFER + HEAT TRANSFER EXPERIMENT + INSTRUMENTATION, TEMPERATURE + STEAM + WATER, GENERAL

5-11453 FISHER CR

ALKOLI METALS EVALUAIION PROGRAM

AEROJET-GENERAL NUCLEONICS, SAN RAMON

AGN-8162 +. 73 PAGES, REFERENCES, JANUARY 1966, CFSTI $\$ 3.00 \mathrm{CY,} \$ 0.75 \mathrm{MN}$

INVESTIGATIONS WERE MADE OF THE HEAT-TRANSFER CHARACTERISTIC.S OF RUBIDIUM AND CESIUM UNDER CONOITIONS OF FURCED-CONVECTION CONDENSATION IN A ROIJND TUBE IN ROTH VERTICAL AND HORIZONTAL ORIENTATIONS. AN AISI TYPE 316 STAINLESS STEEL LOOP, WITH A NICKEL TFST SECTION WAS USED. DATA HERE OBTAINEO AT TEMPEKATURES UP TO $1360 \mathrm{~F}$. OPERATING PARAMETERS WERE VARIER TO OBTAIN INFORMATION USEFUL FOR. THE DFSIGN OF CONDENSERS FOR SPACE POWER SYSTEMS.

*CESIUM + \#CONDENSATION + \#METAL, LIQUID + \#RUBIDIUM + FLOW, TUBE + HEAT TRANSFER + HEAT TRANSFER EXPERIMENT

5-11457 WATERS ED

HEAT TRANSFER EXPER IMENTS FOR THE ADVANCED TEST REACTOR

BATTELLE-NORTHWEST, RICHLAND

BNWL-216 +. 106 PAGES, 28 FIGURES, TABLES, MAY 1966, CFSTI $\$ 4.00$ CY, $\$ 0.75$ MN

HEAT TRANSFER EXPERIMENTS WERE CONDUCTED WITH ELECTRICALLY HEATED TEST SECTIONS IFULL-SCALE MODELS) OF A TYPICAL COOLANT CHANNEL OF THE ADVANCED TEST REACTOR (ATR). A STEADY-STATE HEAT CONDUCTION ANALYSIS OF AN ATR FUEL CHANNEL WAS USED TO DETERMINE THE PROPER SIZE AND SHAPE OF THE RESISTANCE HEATER BARS TO PRODUCE HEAT FLUX DISTRIBUTION TYPICAL OF THE REACTOR FUEL ELEMENTS. A CHOPPED COSINE AXIAL HEAT FLUX PATTERN WAS USED IN BOTH SECTIONS, AND, IN ONE SECTION, A LATERAL FLUX PEAKING FACTOR OF 1.36 PEAK/AVERAGE WAS ALSO USED. A HYDRAULIC ANALYSIS WAS MADE FOR THE ATR CORE WITH MANY PARALLEL FLOW CHANNELS. THE ANALYSIS SHOWED THAT IF THE HYDRAULIC DEMAND (PRESSURE DROP VS FLOW) CURVES FOR ANY CUOLANT CHANNEL EXHIBITED MINIMA (NEAR BOILING) WHICH WERE GREATER THAN THE CONSTANT CORE PRESSURE DROP, THEN FLOW INSTABILITY WOULD OCCUR IN THAT CHANNFL AND LEAD TO BOILING BURN-OUT CONDITIONS. EXPERIMENTS WERE THEN PERFORMEO TO VERIFY THIS ANALYSIS. THE RESULTS SHOW THAT HYORAULIC INSTABILITY, NOT BOILING BURNOUT, WILL BE THE LIMITING FACTOR FOR THE ATR, WITH ENFOPCED STABLE FLOW, BOILING BURNOUT CONDITIONS WERE NOT ENCOUNTERED IN ANY OF THE EXPERIMENTS, EVEN THOUGH BULK BOILING WAS ALLOWED AND PEAK HEAT FLUXES UP TO 4.0 MILLION BTU/HR-SQ. FT. WERE REACHED.

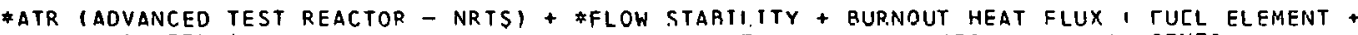
HEAT TRANSFFR ANALYSIS + HEAT TRANSFER EXFCRIMENT + REACTOR, TFSI + WATER, GENERAL

5-11460 ST.HALEK UA + GIEDT WH CONTACT CONOUCTANCE MEASUREMENTS DURING TRANSIENT HEATING LAWRENCE RADIATION LABORATORY, UNIVERSITY OF CALIFORNIA

UCRL-14227 (REV. 1) +. 11 PAGES, OCTO8ER 20, 1965, CFSTI \$1. ON C.Y, \$D.50 MN

AN EXPERIMENTAL METHOU IS DESCRIBED FOR DETERMINING THE INTERFACE CONDUCTANCE BETWEEN TWO PLATES DURING TRANSIENT HEAT TRANSFER. THE TECHNIQUE IS BASED ON HEATING ONE PLATE IN ABOUT IDO MICROSECONDS WITH A CAPACITOR-BANK DISCHARGE AND THEN RECORDING THE CONTACTING-SURFACF TEMPERATURES OF THE THO SLABS AS THEY COME TO EQUILIRRIUM. RESULTS ARE PRESENTED FOR COMBINATIONS OF $(1)$ ALIIMTNUM AND STAINLESS STEEL HITH CONTACT-SURFACE FINISH (IF 5.5 MICROINCHES, AA (ARITHMETIC AVFRAGE) OF 12-30, 15-38, ANO 50-35, AND (2) STAINLESS STEEL AND CERAMIC HITH CONTACT-SURFACE FINISHED OF 31-38 AA AND 64-38 AA. THE PRESSURE WAS VARIED FROM 100 TO 2000 PSI. FOR METALLIC CONTACTS, THE CONDUCTANCF INCREASED ABOUT 200 PERCENT WITH TIME. THE REVERSE OCCURREO WITH THE METAL-CERAMIC CONTACTS.

*HEAT CONDUCTION + *INSTRUMENTATION, TENPERATURE + HEAT TRANSFER + HEAT TRANSFER EXPERIMENT + TEMPERATURE TRANSIENT

5-11462 HAUSKNEC,HT DF COMPUTER CALCULATION OF FUEL CLADDING TEMPERATURES, HEAT FLUXES AND POWER OISTRIBUTION IN THE PNPF CORE ATOMICS INTERNATIONAL, CANOGA PARK

NAA-SR-MEMO-9492+. 69 PAGES, APRIL 4, 1964 , CFSTI $\$ 3.00 \mathrm{CY}$

A COMPUTER PROGRAM WAS WRITTEN TO MONITOR FUEL-CLADDING TEMPERATURES, HEAT FLUXES, AND OVERALL POWER DISTRIBUTION IN THE PNPF CORE ON A ROUTINE BASIS. COMPUTATION OF THE QUANTITIES OF INTEREST IS BASED ON AN EXTENSION OF FARLIER THEORETICAL ANALYSES OF THE FISSION-POWER DISTRIBUTION AND HEAT CONDUCTION IN THE CORE. AXIAL FISSION-POWER DISTRIBUTIONS WFRE FITTED WITH TRANSCENDENTAL FUNCTIONS, USING THE METHOD OF LEAST SQUARES, SO THAT THEY CAN BE EXPRESSED IN ANALYTICAL FORM, THEREBY PERMITTING THE MAXIMUM VALUES OF RELATED OUANTITIES TO BE DETERMINED BY A COMPUTER.

*CLAD + +TULL ELEMENT + *INSTRUMENTAIIUN, TEMPERATURE + HEAT CONDUCTION + HEAT TRANSFER 
CATEGORY 5

ACCIDENT ANALYSIS

5-11463 TWO-PHASE FLOW AND HEAT TRANSFER IN MULTIROD GEOMETRIES. QUARTERLY PROGRESS REPORT NO. 3 GENERAL ELECTRIC CO., SAN JOSE

GEAP-4933 +. 26 PAGES, AUGUST 1965 , CFSTI $\$ 2.00 \mathrm{CY}, \$ 0.50 \mathrm{MN}$

PRESSURE DROP AND AVERAGE IEST-SECTICN VOIO DATA FOR TWO-PHASE UPFLOW OF AIR AND WATER AT IOO PSIA IN BOTH A ROUND TUBE AND CONCENTRIC ANNULUS ARE. IN GOOD AGREEMENT WITH THE

LOCKHART-MARTINELLI CORRELATION. MEASURFMENTS MADE WITH THE ISOKINETIC SAMPLING PROBE FOR SINGLE-PHASE AIR AND SINGLE-PHASE WATER ARE WITHIN ABOUT 5 PERCENT OF A THEORETICAL CURVE BASED UPON PREDICTION OF INLET PRESSURE DROP FOR LAMINAP. FLOW IN THE SAMPLING PPOBE. FOR TWO-PHASE FLOW MEASUREMENTS, A CONTINUOUS PURGE WILL BF USED IN THE STATIC PRESSURE LINES OF THE SAMPLING PROBE SETUP. A DETAILED PROFILE INVESTIGATION OF LOW-QUALITY 16.7 PFRCENTI, TWO-PHASE FLOW IN A ROUND TUBE, BY MEANS OF THE SAMPLING PROBE SHOWS THAT THE MAXIMUM IMPACT PRESSURE DOES NOT OCCUR ON THE TUEF CENTERLINE IN SPITE OF THE EXPECTED SMOOTH DISTRIBUTIONS OF LOCAL QUALITY AND VOID FRACTION ACROSS THE TUBE.

\#FLOW, TUBE + \$FLOW, TWO PHASE + AIR + FLOW THEORY AND EXPERIMENTS + HEAT TRANSFER + WATER, GENERAL

5-11464 LEVY $S$

FORCED CONVECTION SUB-COOLEO BOILING. PREDICTION OF VADOR VOLUMETRIC FDACTION

GENERAL ELECTRIC CO., SAN JOSE

GEAP-5157 +. 33 PAGES, REFERENCES, APRIL 1966 , CFSTI $\$ 2.00 \mathrm{CY}, \$ 0.50$ MN

A MODEL IS DEVELOPEO TO PREOICT THE VAPOR VOLUMETRIC FRACTION DURING FORCED CONVECTION SUBCOOLED BOILING. THE PROPOSED METHOD OF CALCULATION CONSISTS OF THREE STEPS - (1) THE POINT OF BUBBLE DEPARTURE FROM THE HEATED SURFACE (I.E., THE LOCATION OF VAPOR VOLUMETRIC FRACTIONS SIGNIFICANTLY HIGHER. THAN ZEROI IS DETERMINED FROM A BUBBLE FORCE BALANCE AND THE SINGLE-PHASE LIQUID TURBULENT TEMPERATURE DISTRIBUTION AWAY FROM THE HEATED WALL. (2) A RELATION IS POSTULATED BETWEEN THE TRUE LOCAL VAPOR WEIGHT FRACTION AND THE CORRESPONDING THERMAL EQUILIBRIUM VALUE. (3) THE VAPOR VOLUMETRIC FPACTION IS OBTAINED FROM THE TRUE LOCAL VAPOR WEIGHT FRACTION AND AN ACCEPTED RELATIONSHIP BETWEEN VAPOR WEIGHT AND VOLUMETRIC

FRACTIONS. THE METHOD WAS APPLIED TO A VARIETY OF AVAILABLE TEST DATA, AND THE AGREEMENT WAS SATISFACTORY FOR A MULTITUDE OF FLOW, HEAT FLUX, AND FLUID PPOPERTY CONDITIONS.

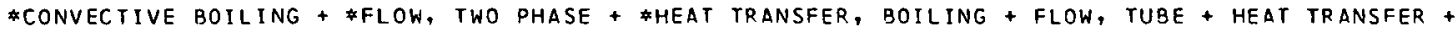
HYDRODYNAMIC ANALYSIS

5-11465 DAVIES AL

SPEED OF SOUND IN MIXTURES OF WATER AND STEAM

UNITED KINGDOM ATOMIC ENERGY ASSOCIATION, WINFRITH

$A E E W-M-452+22$ PAGES, 5 FIGURES, REFERENCFS, OCTOBER 1965, DEP. MN

THE SPEED OF SOUNO IN A HOMOGENEOUS MIXTURE OF WATER AND STEAM WAS CALCULATED FOR THO DIFFERENT SETS OF ASSUMPTIONS. IN THE FIRST CASE IT IS ASSUMEO THAT THFRE IS NO MASS TRANSFER BETHEEN THE PHASES AND THEREFORE THE WATER AND STEAM ARE INOEPENDENTLY ISENTROPIC. IN THE SECOND CASE IT IS ASSUMED THAT THE WATER AND STEAM ARE IN CONTINUOUS THEPMAL EQUILIBRIUM ON THE SATURATION LINE, WITH MASS TRANSFER BETWEEN THE PHASES. IT IS SUGGESTED THAT, IN GENERAL, COMPRESSION WAVES PROPAGATE ACCORDING TO THE FIRST SET OF ASSUMPTIONS, WHEREAS RAREFACTION WAVES PROPAGATE ACCORDING TO THE SECOND SET. THE EFFECT OF VARIOUS FLOW REGIMES AND SLIP ON THE APPLICATION OF THE RESULTS TO TWO-PHASE FLOW IS DISCUSSED, AND SOME OTHER WORK ON THE SPEED OF SOUND IS RRIEFLY OESCRIBED. RECOMMENDATIONS ARE MAOE ABOUT THE APPLICATION OF THE RESULTS TO THE PROPAGATION OF PRESSURE WAVES AND THE DETERMINATION OF CRITICAL FLOW IN WATER-REACTOR SYSTEMS.

*FLOW, TUBE + \#FLOW, TWO PHASE + \#HYDRODYNAMIC ANALYSIS + FLOW THEORY AND EXPERIMENTS + WATER, GENERAL

5-11468 KIRBY GJ

BURNOUT IN CLIMBING-FILM TWO-PHASE FLOW. A REVIEW OF THEORIES OF THE MECHANISM

UNITED KINGDOM ATOMIC ENERGY ASSOCIATION, WINERITH

AEEW-R-470 +. 63 PAGES, 9 FIGURES, REFERENCES, MARCH 1966, BIS $\$ 1.80 \mathrm{CY}$

BLRNOUT DATA FOR ANNULAR FLOW WERE. EXAMINED, AND IT WAS FOUND THAT FOR DUALITIES ABOVE ISAYI 10 PERCENT THE BURNOUT HEAT FLUX IS A FUNCTION ONLY OF PRESSURE, TUBE DIAMETER ITO THE HALF POWER, TIMES MASS FLOW RATE, AND QUALITY TO WITHIN THE ERRORS IN THE EXPERIMENTAL DATA. VARIOUS BURNOUT MODELS WERE EXAMINED AND NONE COULD DREDICT THE TRENDS GIVEN BY THE ABOVE FUNCTION. THE LITERATURE ON DROPLET DEPOSITION, ENTRAINMENT, AND ONSET OF ANNULAR FLOW WAS FUNCTION. THE LITERATURE ON DROPLET DEPOSITION, ENTRAINMENT, AND ONSET OF ANNULAR FLOW WAS
STUDIED TO SEE IF ANY NEW LIGHT COULD BE THROWN ON THE PROBLEM OF RURNOUT. ACTUAL VALUES FOR STUDIED TO SEE IF ANY NEW LIGHT COULD BE THROWN ON THE PROBLEM OF RUR NOUT. ACTUAL VALUES FOR
THE DEPOSITION RATE OF DROPLETS IN A BOILING CHANNEL WERE DERIVED, AND IT IS HOPED THAT THESE WILL PROVIDE A BASIS FOR FURTHER STUDIES OF POSSIBLE BURNOUT MODELS.

* BURNOUT HEAT FLUX + \#DNB (OEPARTURE FROM NUCLEATE BOILING) + *HEAT TRANSFFR CORRELATION + \#HEAT TRANSFER， BOILING + HEAT TRANSFER

5-11510 WILKIE D + WHITE

CALCULATION OF FLOW RESISTANCE OF PASSAGES BOUNDED BY A COMBINATION OF ROUGH AND SMOOTH SURFACE UNITED KINGDOM ATOMIC ENERGY AUTHORITY, WINDSCALE

TRG-1113 (W) +. 20 PAGES; 11 FIGURES, 11 REFERENCES, OCTOBER 22,1965 , UKAEA

A SET OF EQUATIONS IS DERIVED WHICH FORMS THE BASIS OF A METHOD OF APPLYING TRANSFORMED ROUGHENED-SURFACE FRICTION-FACTOR DATA TO THE CALCULATION OF MIXED-SURFACE PR.ESSURE DROP. DETAILED EXAMPLES OF THE METHOD APPIIED TO ANNULAR AND CLUSTER CONFIGURATIONS ARE PRESENTED, AND THE RESULTS ARE COMPAREO WITH EXPERIMENTAL VALUES. 
CATEGORY ACCIDENT ANALYSIS

5-11510 \#CONTINUED *

*FLOW, AXIAL + \#FUEL ELEMENT + \#PRESSURE DROP + FLOW THEORY AND EXPERIMENTS + FLOW, TUBE + FLOW, TURBULENT + HYDRODYNAMIC ANALYSIS 
6-08441 FOX TA + MUELLER RA + FORD CH + $\triangle L G E R$ DL

CRITICAL MASS STUDIES WITH NASA ZERO POWER REACTOR II. I - CLEAN HOMOGENEOUS CONFIGURATIONS LEHIS RESEARCH CENTER, NATIONAL AERONAUTICS ANO SPACE ADMINISTRATION, CLEVELAND, OHIO

NASA-TN-D-3097 +. 19 PAGES, 6 FIGURES, 2 TABLES, 6 REFERENCES- NOVEMBER 1965, CFSTI \$1.00 CY, \$0.50 MN

THE NASA ZERO POWER REACTOR II (ZPR-III HAS BEEN USED TO DETERMINE EXPERIMENTALLY THE CRITICAL MASSES FOR MORE THAN A TENFOLO RANGE OF HIGHLY ENRICHED 193.2 PERCENT U- 235$)$ AQUEOUS URANYL FLUORIDE FUEL CONCENTRATIONS IN CLEAN CYLINDRICAL GEOMETRIES. IN ADDITION TO THE CRITICAL MASSES, DATA ARE PRESENTED ON THE TEMPERATURE COEFFICIENT OF REACTIVITY WORTH AT CRITICALITY FOR A SIMILAR RANGE OF CONCENTRATIONS. A BRIEF DESCRIPTION OF THE ZPR-II AND THE EXPERIMENTAL PROCEDURES USED ARE ALSO INCLUDED.

CRITICALITY EXPERIMENT + CRITICALITY SAFETY + REACTIVITY COEFFICIENT + TEMPERATURE COEFFICIENT + URANIUM

6-08896 MARGOLIS SG + CURLEE NS

CONTROL-INDUCEO XENON OSCILLATIONS

WESTINGHOUSE ELECTRIC CORPORATION, BETTIS ATOMIC POWER LABORATORY

WAPD-T-1732 +. 27 PAGES, 7 SLIDES, 2 FIGURES, 2 REFERENCES, JULY, 1964, AMERICAN NUCLEAR SOCIETY WINTER MEETING, SAN FRANCISCO, CALIFORNIA, DECEMBER, 1964, SOURCE

SMALL-PERTURBATION THEORY IS SAID TO BE SATISFACTORY. THE COUPLING REQUIRED FOR STABILITY WITH AVERAGE-TEMPERATURE-CONTROL INCREASES AS FLUX IN THE CONTROLLED REGION DECREASES.

CONTROL BY ROD RATE PROPORTIONAL TO ERROR IN A LOCAL FLUX HAS ACCEPTABLE TRANSIENT RFSPONSE.

* XENON + REACTOR STABILITY

6- 69377 JONES $A B$

REACTIVITY STABILITY OF A BOILING REACTOR. PART 2

KNOLLS ATOMIC POWER LABORATORY, GENERAL ELECTRIC CO.

KAPL-3093 +. 40 PAGES, 1 FIGURE, MARCH.1, 1965, CFSTI, \$2.00 CY

EXTENSION OF KAPL-3072. LINEARIZED, DENSITY-DEPENDENT REACTIVITY STABILITY OF A ONE-FLUX-MODE BOILING REACTOR. TRANSIENT FLOW REDISTRIBUTION IS PERMITTED AT THE CHANNEL INLETS, IN ACCORDANCE WITH MOMENTUM EQUATI ON CONSIDERATIONS IN EACH CHANNEL, WITH THE IMPOSEO CONSTRAINT THAT TOTAL REACTOR INLET FLOW IS CONSTANT. DIGITAL COMPUTER PROGRAM (FABLE) IS DESCRIBED.

* REACTOR STABILITY + COMPUTER PRCGRAM + COMPUTER, DIGITAL + REACTOR, BOILING WATER

6-09404 TORL IN BZ

CALCULATION OF MODES OF LOW-LEVEL OSCILLAIION IN NUCLEAR REACTORS

ATOMNAYA ENERGIYA $18(5)-463$ (MAY 1965)

A METHOD IS PRESENTED. FOR APPROXIMATE CALCULATION OF SMALL-AMPLITUDE OSCILLATIONS. THF EQUATION GIVES THE FREQUENCIES OF THE POSSIBLE OSCILLATORY STATES, TDGETHER. WITH THE AMPLITUDES IN THE REACTIVITY AND POWER, AS WEL.L AS THE PHASE DIFFERENCES BETHEEN THESE OSCILLATIONS.

REACTOR DYNAMICS + REACTOR STABILITY + TRANSFER FUNCTION

E-09694 LAURY JH

SUMMARY OF HATER MODERATED EXDERIMENTS WITH 1.8 WT PERCENT PU-AL FUEL IN THE PRCF

BATTELLE-NORTHWEST, RICHLAND

BNWL-149 +. 13 PAGES, 1 FIGURE, 4 TABLES, 2 REFERENCES, JULY 1965, PP. 5-17 OF THE PHYSICS RESEARCH

QUARTERLY REPORT APRIL, MAY, JUNE, 1965, CFSTI, \$3. OD CY, \$0.T5 MN

THIS IS A SUMMARY OF WATER-MODERATED EXPERIMENTS WITH 1.8 PERCENT BY WEIGHT PLUTONIUM-ALUMINUM IN THE PRCF. WORTH MEASUREMENTS OF CONTROL ELEMENTS, REACTIVITY COEFFICIENTS FOR VARIOUS REACTOR MATERIALS, AND REACTOR STUDIES ARE SUMMARIZED.

* PRTR (PLUTONIUM RECYCLE TEST REACTOR) + CONTROL ROD WORTH + FUEL ELEMENT + REACTIVITY COEFFICIENT + REACTOR KINETICS + TEMPERATURE COEFFICIENT

6-09695 LIIKALARC + JENQUIN UP + REARDON WA

PUO2 - UO2 EXPERIMENT IN THE EBWR

BATTELLE-NORTHWEST, RICHLAND

BNWL-149 +. 2 PAGES, 2 REFERENCES, PP, $18-19$ OF THE PHYSICS RESEARCH QUARTERLY REPORT APRIL, MAY, JUNE,

1965 , CFSTI, \$3.00 CY, \$0.75 MN

A PLUTONIUM EXPER IMENT TO BE PERFORMED IN THE EXPERIMENTAL BOILING WATER REACTOR (EBWR) AT ARGONNE NATIONAL LABORATORY TO DEMONSTRATE THE UTILIZATION OF PLUTONIUM IN A LIGHT-WATER MODERATED POWER REACTOR. REACTIVITY WORTH OF FUEL RODS, SAFETY RODS, VOIDS, AND BORIC ACIO IN THE MOOERATOR, NEGATIVE REACTIVITY EFFECTS DUE TO VOIDS, XENON CONCENTRATIONS, INCREASED MODERATOR TEMPERATURE, AND MODERATOR VOID CHANGES ARE MEASURED. THE SUBJECT IS DISCUSSED IN MORE DETAIL IN 8 NWL-126.

*EBWR (EXPERIMENTAL BOILING WATER REACTOR) + CHEMICAL SHIM + CONTROL ROD WORTH + MODERATOR COEFFICIENT + PLUTONIUM + PLUTONIUM OXIDE + REACTIVITY COEFFICIENT + URANIUM DIOXIDE + VOID COEFFICIENT + XENON 
CATEGORY

REACTOR TRANSIENTS, KINETICS, AND STABILITY

6-09696 HOCH RJ + HUMES RM + BROWN WH

SPHER ICAL AND SLAB GEOMETRY SOLUTIONS TO A TWO-REGION BOUNDARY VALUE PROBLEM GIVING TEMPERATURE INCREASE DURING AN EXPONENTIAL POWER RISE

BATTELLE-NORTHWEST, RICHLAND

BNWL-149 +. 5 PAGES, 1 REFERENCE, JULY 1965, PP, 36-40 OF THE PHYSICS RESEARCH OUARTERLY REPORT APR IL,

MAY, JUNE, 1965, CFSTI, $\$ 3.00 \mathrm{CY}, \$ 0.75 \mathrm{MN}$

BOUNOARY VALUE PROBLEM IN HEAT CONDUICTIONS WAS DISCUSSED. HEAT IS GENFŔTIED IN SPHERICAL

PELLETS OF RADIUS (A) WHICH ARE EMBEDDED IN GRAPHITE. WITH EACH PELLET ASSOCJATE A

CONCENTRIC SPHERE OF GRAPHITE OF RADIUS (B). AN EXPONENT IAL POWER EXCURSION WITH INVERSE

PERIOD (H) OCCURS, AND THE TEMPERATURE RISE THETA $(R, T)$ IS TO BE FOUND.

*THERMAL ANALYSIS + SLAB + SPHERE + THEORETICAL INVESTIGATION

6-09697 HUMFS RM

NEUTRON PULSING POSSIBILITIES IN HTLTR

BATTELLE-NORTHWEST, RICHLAND

BNWL-149+* 4 PAGES, I TABLE, 1 REFERENCE, JULY 1965, PP. $41-44$ OF THE PHYSICS RESEARCH QUARTERLY REPORT

APRIL, MAY, JUNE, 1965 , CFSTI, $\$ 3.00 \mathrm{CY}, \$ 0.75 \mathrm{MN}$.

MEASUREMENT OF SUBCRITICALITY IN HTLTR (HIGH TEMPERATURE LATTICE TFST REACTOR.) BY MEANS OF PULSED NEUTRON SOURCE.

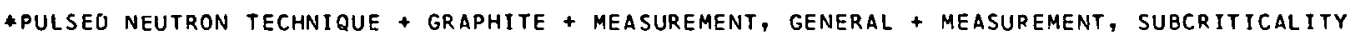

6-09724 SPERT IV -- SUBASSEMBLY TEST PROGRAM

PHILLIPS PETROLEUM COMPANY, IDAHO

IO0-17123 +. PAGES 1-17 OF QUARTERLY TECHNICAL REPORT - SPERT PROJECT, APRIL, MAY, JUNE 1965, CFSTI, $\$ 3.00 \mathrm{CY}, \$ 0.75 \mathrm{MN}$

REGARDING CDC - DESCRIPTION AND SPECIFICATIONS OF CAPSULE. TESTS WITH CHEMICAL EXPLOSIVFS. MODIFICATIONS OF EXPERIMENT TUBE. ANALYTICAL INVESTICATION OF FUEL-ROD FAILURE. SCALED-DOWN FUEL RODS.

*CORE, CAPSULE DRIVER (CDC) + BURST PRESSURE + FAILURE, FUEL ELEMENT + REACTOR, TEST + SPERT 4 ISPECIAL POWER EXCURSION REACTOR TEST)

6-09725 QUARTERLY TECHNICAL REPORT - SPERT PR.JECT, JULY, AUGUST, SEPTEMBER, 1965

PHILLIPS PETROLEUM COMPANY, IDAHO

I D0-17146 +. 29 PAGES, 9 FIGURES, 5 TARLES, 21 REFERENCES, CFSTI, $\$ 2.00$ CY, \$0.50 MN

REGARDING CDC (CAPSULE ORIVER CORE) - LOW-POWER EXPERIMENTS IN SPERT IV. DESCRIPTION OF CORE LOADING AND EXPERIMENT TUBE. SHUTDOWN MARGIN. CONTROL-ROD WORTH. FUEL-RDD WORTH. STRENGTH OF S.TEELS FOR EXPERIMENT TUBE. PRESSURE TRANSDUCER. INFLUENCE OF ENRICHMENT OF TEST SAMPLES ON FAILURE MECHANISM. SCALED-DOWN FUEL RODS. COMPUTATION OF DOPPLER FEEDBACK, INCLUDING SPACE-DEPENDENT REACTOR DYNAMICS CAI C.III ATIONS. COMPUTATION OF ENERGY OEPUSIIEO AT THF FND RQF EXLURSION WITHOIT COMPUTINC CORE TLUXES.

ANALYTICAL MODEL + COMPUTER, DIGITAL + CONTROL ROD + CRITICALITY EXPERIMENT + DESTRUCTIVE TRANSIENT + DOPPLER EFFECT + FAILURE, FUEL ELEMENT + MEASUREMENT, GENERAI + MEASUREMENT, STRAIN GAGE + PRESSURC, INTERNAL + REALTIVITY EFFECT I SHUTDOWN MARGIN + SHACE DEPENDENT DYNAMICS + STRESS ANALYSIS

6-09737 RANDLES J

FEEDBACK DUE TO ELASTIC WAVES ANU DOPPLER COEFFICIENT DURING THE EXCURSIONS OF A PULSEO FAST REACTOR EURATOM, ISPRA, ITALY

16 PAGES, 10 REFERENCES, JOURNAL OF NUCLEAR ENERGY PARTS A/B REACTOR SCIENCE AND TECHNOLOGY 2O(1)- 1-16 (JUNE 30,1965 )

FOR A PULSED REACTOR WITH POSITIVE DOPPLER EFFECT AND NEGATIVE FUEL-EXPANSION REACTIVITY COEFFICIENT, SELF-LIMITING OF EXCIJSSION DCCURS ONLY IF TIIE DOPPLER COEFFICIENT IS LFSS THAN CEK'IAIN LIMIT.

\#DOPPLER EFFECT + \#REACTOR, PULSEO + EXPANSION REACTIVITY EFFECT + REACTOR, FAST BURST

6-C.9740 HOUNGHTALING JE + NORBERG JA + HAIRE JC

ADDENDUM TO THE SPERT I I HAZARDS SUMMARY REPORT -- LOW-ENRICHMENT OXIDE CORE

PHILLIPS PETROLEUM COMPANY, IDAHO

IDO-17003 (REV. 2 ) +. 92 PAGES, 22 TABLES, 21 FIGURES, 34 REFERENCES, OCTORER 1965, CFSTI, \$3.00 CY, $\$ 0.75 \mathrm{MN}$

PERTINENT MECHANICAL CHARACTERISTICS OF THE E+CORE ARE EXPLAINED, AS WELL AS CHANGES MADE TO THE SPERT I I I CONTROL SYSTEM. INCLUDED ARE THE NUCLEAR CHARACTERISTICS OF THE CORE AS DETERMINED BY CALCULATION AND EXTRAPOLATION OF PREVIOUS EXPERIMENTAL RESULTS. ALSO, THE PREDICTED KINETIC BEHAVIOR FOR THE PLANNED TFSTS AND CERTAIN ACCIDENT CONDITIONS ARE DISCUSSED. SEVERAL ACCIDENT SITUATIONS ARE CONSIDERED AND ANALYZED TO OBTAIN NUMERICAL ESTIMATES OF RAOIOLOGICAL HAZAROS.

* SPERT 3 ISPECIAL POWER EXCURSION REACTOR TESTI + ACCIDENT ANALYSIS + CONTROL SYSTEM + DOSE + HAZARDS ANALYSIS + REACTOR KINETICS + REACTOR, PRESSURIZED WATER + REACTOR, TEST + SAFEGUAROS REPORT, GENERAL 
CATEGORY 6

REACTOR TRANSIENTS, KINETICS, AND STABILITY

6-09783 A STUDY OF A GAS-COOLED FAST BREEDER REACTOR. INIYIAL STUDY, CORE DESIGN ANALYSIS AND SYSTEM DEVELOPMENT PROGRAM. FINAL SUMMARY REPORT

GENERAL ATOMIC DIVISION, GENERAL DYNAMICS CORP.

GA-5537 +. 255 PAGES, FIGURES, TABLES, REFERENCES, AUGUST 15, 1964, CFSTI

REPORT RELATES TO DESIGN BASED ON MINIMAL EXTENSION OF PRESENT TECHNOLOGY, USING ESTABLISHED REACTOR MATERIALS, OPERATEO WELL WITHIN THEIR CAPABILITIES. CONCLUSIONS ARF. THAT GAS COOLING OFFERS ADVANTAGES BEYOND PROVISION OF AN ALTERNATIVE TECHNOLOGY, AS IT AVOIDS SOME PPACTICAL PROBLEMS ASSOCIATEO WITH SODIUM. AVOIDANCE OF THE SAFETY - AND STABILITY - DICTATED DESIGN COMPROMISES IMPOSEO BY NUCLEAR-COOLANT INTERACTION ALLOWS THE REALIZATION OF A T.OMBINATION OF HIGH INTERNAL CONVERSION RATIO AND FUEL RATING WITH VERY LOW BURNUP REACTIVITY CHANGF. AND LOW COOLANT-VOIO EFFECTS. THE RECUCED MODERATION INFLUENCE OF THE COOLANT RESULTS IN A TOLERABLF REDUCTION OF DOPPLER COEFFICIENT IN VIEW OF THE REDUCEO COOLANT-VOIO CDEFFICIENT AND LOW EXCESS REACTIVITY REQUIREMENTS. COOLANT-LOSS RATES SUFFICIENT TO HALVE PRESSURE IN $2 D$ SEC CAN BE DEALT WITH QY THE NORMAL GAS CIRCULATORS. FOR THE MORE-DETAILED STUDIES, INCLUDING ILLUSTRATION OF CONSTRUCTIONAL FEATURES ANO KINETIC-BEHAVIOR EVALUATIDN, A 500 MWIEI REFERENCE DESIGN BASED ON A 5ODO-LITER CORE WAS SELECTED.

\#DESIGN STUOY + \#REACTOR, BREEOER + \#REACTOR, GAS COOLED + DOPPLER EFFECT + FLOODING COEFFICIENT + LOSS OF COOLANT + REACTOR STABILITY + VOID COEFFICIENT

G-0S987 CARLSMITH RS + DELENE JG

RESPONSE OF A HELIUM-COOLED FAST REACTOR TO CHANGES IN COOLANT FLOH AND REACTIVITY OAK RIOGE NATIONAL LABORATORY

ORNL-P-1698 + CONF-651009-4 +. 24 PAGES, PRESENTED AT CONFERENCE ON SAFETY, FUELS AND CORE DESIGN IN LARGE FAST POWER REACTORS, ARGONNE NATIONAL LABOPATORY, OCTOBER 11-14, 1955, CFSTI, S1.OO CY, \$O.5O MN

ORNL DESIGN OF A HELIUM-COOLED FAST REACTOR STUDIFO WITH RESPECT TO STEP AND RAMP REACTIVITY INSERTIONS ANO LOSS OF COOLANT PRESSURE AND FLOW.

\#REACTOR, FAST + ACCIDENT, REACTIVITY + HELIUM + LOSS OF FLOW + LOSS OF PRESSIJRE + REACTOR, GAS COOLED

6-C.9988 MOSKALEV OB + CHUYANOV VA

CERTAIN NONL INEAR PROBLEMS IN. NUCLEAR REACTOR. THEORY

3 PAGES, I FIGURE, 3 REFERENCES, ATOMNAYA ENERGIYA, 18(3), DAGES 254-255 (MARCH, 1965)

THIS ARTICLE IS CONCERNED WITH THE EXISTENCE OF A UNIQUE, POSITIVE, NONTRIVIAL SOLUTION OF PEIERLS NONLINEAR INTEGRAL EQUATION. THE EQUATION IS SOLVED BY USING THE METHOD OF SUCCESSIVE APPROXIMATIONS UNDER NATURAL PHYSICAL ASSUMPTIONS. THE SOLUTION IS UNIQUE IF ADDITIONAL LIMITATIONS ARE IMPOSED.

DYNAMICS, NONL INEAR

6-09989 CHELINTSEV NG

PRESENTATION OF THE REACTOR DYNAMICS EQUATIONS IN TERMS OF THE RECIPROCAL PERIOD

4 PAGES, 3 REFERENCES, ATOMNAYA ENERGIYA, 1813), PAGES 292-294 (MAR.CH, 1965)

REDERIVES IN-HOUR EQUATION, TRANSFER FUNCTION, ETC.

EQUATION, IN HOUR + REACTOR DYNAMICS + TRANSFER FUNCTION

E-CI9990 SHOTKIN LM

CENTERS AND LIMIT CYCLES IN REACTOR KINETICS

EROOKHAVEN NATIONAL LABORATORY

BNL-9010+CONF-650413-14+. 33 PAGES, MARCH, 1965, SYMPOSIUM ON NEUTPON DYNAMICS AND CONTROL, TUCSON, ARIZ., CFSTI, $\$ 2.00 \mathrm{CY}$

PRACTICAL METHOD FOR COMPUTING THE AMPLITUDE AND FREQUENCY OF CENTERS AND LIMIT CYCLES, BASED ON METHOD OF KRYLOV AND BOGOLIUBOV. ANALYTIC RESULTS FOR THE TWD-TEMPERATURE PROBLEM WITH ND PROMPT POWER COEFFICIENT, ANO THE XENON PROBLEM WITH NO TEMPERATURE FEEOBACK

\#DYNAMICS, NONL INEAR

6-10039 SECTION II - PHYSICS

11 PAGES, 1 FIGURE, 1 TABLE, 56 REFERENCES, FALL 1965, POWER REACTOR TECHNOLOFY 8(4), PAGES $210-220$, SECTION II

THE SUBSECTION ON CRITICAL AND EXPONENTIAL EXPERIMENTS WITH PLUTONIUM REVIEWS WORK ON POWER AND TEMPERATURE COEFFICIENTS. INCLUDES U.S. AND FRENCH WORK WITH U-PU MIXTURES AND WITH PU THAT CONTAINS PU-240 AND -241

\#CRITICALITY EXPERIMENT + \#CRITICALITY SAFETY + \#PLUTONIUM + FRANCE + POWER COEFFICIENT +

TEMPERATURE COEFFICIENT

6-10040. HASHBURN B + HUOSON CE

PIN TECHNIQUE FOR OISPLACEMENT MEASUREMENTS IN.KIWI TNT

LOS ALAMOS SCIENTIFIC LABORATORY, LOS ALAMOS

LA-3388-MS +. 21 PAGES, 14 FIGURES, JUNE 1965, CFSTI, \$1.00 CY, \$0.05 MN 
CATEGORY $\stackrel{6}{ }$
REACTOR TRANSIENTS, KINETICS, ANO STABILITY

6-10040 *CONTINUED*

A PIN TECHNIQUE THAT WAS USED TO MEASURE RELATIVELY SMALL, EARLY, OUTWARD DISPLACEMENTS OF THE TNT REACTOR CORE AND REFLECTOR CYLINDER COMPONENTS DURING THE KIWI TRANSIENT NUCLEAR TEST IS DESCRIBED. CONSIDERATIONS NECESSARY TO ADAPT THIS METHOD TO THE ENVIRONMENT OF THE P.EACTOR TRANSIENT AND THE RESULTS ARE PRESENTED. AN EXPERIMENT TO DETERMINE THE TIMES OF CLOSING OF SELECTED PROPELLANT PASSAGES BY USING COAXIAL WIRES IS ALSO GIVEN.

\#IWI TNT (TRANSIENT NUCLEAR TEST) + INSTRUMENTATION, GENERAL

6-10346 SANDQUIST GM

XKINEQ -- A TWO-GROUP, TWO-DIMENSIONAL MULTIREGION COMPUTER CODE FOR EXAMINING FLUX STABILITY IN NUCLEAR REACTORS IN THE PRESENCE OF XENON-135

PHILLIPS PETROLEUM CO., IDAMO

IDO-17127+. 94 PAGES, 5 FIGURES, JANUARY 1966 , CFSTI $\$ 3.00 \mathrm{CY}, \$ 0.75 \mathrm{MN}$

XKINEQ IS A FORTRAN CODED DIGITAL COMPUTER PROGRAM FOR EXAMINING THE STABILITY OF THE NEUTRON FLUX DISTR IBUTION IN TIME IN A REACTOR CORE UNDER THE INFLUENCE OF XENON-135. THE PROGRAM SIMULATES KINETIC EQUATIONS WHICH EMPLOY TWO-ENERGY-GROUP DIFFUSION THEORY TO DESCRIBE THE NEUTRON FLUX AND DESCRIBES THE TWO-DIMENSIONAL RADIAL-AXIAL TIME BEHAVIOR IN MULTIREGION REACTOR CORES WITH CYLINDRICAL GEOMETRY AND ANY THO-DIMENSIONAL TIME BEHAVIOR IN MULTIREGION CORES WITH RECTANGULAR GEOMETRY.

\#COMPUTER PROgRAM + \#COMPUTER, DIGITAL + \#XNON OSCILLATION

6-10430 ARGONNE NATIONAL LABORATORY PUBLICATIONS, JULY 1,1964 - JUNE 30, 1965 ARGONNE NATIONAL LABORATORY, ARGONNE, ILLINOIS

$A N L-7087+328$ PAGES, AUGUST 1965 CFSTI, \$7.00 CY, \$1.50 MN

THIS PUBLICATION LIST IS A BIBLIOGRAPHY OF SCIENTIFIC AND TECHNICAL ACCOUNTS ORIGINATED AT ARGONNE AND PUBL ISHED DUR ING FISCAL YEAR 1965. IT INCLUDES ITEMS PUBLISHED AS JOURNAL ARTICLES, TECHNICAL REPORTS, BOOKS, ETC., ALL OF WHICH HAVE BEEN MADE AVAILABLE TO THE PUBLIC. THE LIST IS DIVIDED INTO THREE PARTS - THE FIRST A LIST DIVISION, THE SECOND AN ALPHABETICAL AUTHOR INDEX, AND THE THIRO PART A KWIC SUBJECT INDEX. INCLUDED ARE SECTIONS ON RAOIOLOGICAL PHYSICS, REACTOR PHYSICS, REACTOR ENGINEERING, INDUSTRIAL HYGIENE AND SAFETY, FIRE PROTECTION, AND CHEMICAL ENGINEERING.

*BIBLIOERAPHY + \#BURNOUT HEAT FLUX + \#CHEMICAL REACTION + \#DOSE MEASUREMENT, EXTERNAL + \#HEAT TRANSFER + *REACTOR DYNAMICS + \#REACTOR STABILITY + ACCIDENT ANALYSIS +

FARET (FAST ARGONNE REACTOR EXPERIMENT TEST) + METAL WATER REACTION + NOISE + REACTIVITY COEFFICIENT + REACTOR KINETICS + REACTOR TRANSIENT + REACTOR, BREEUER + REACTOR, FAST + REACTOR, LIOUID METAL COOLED + SPACE DEPENDENT OYNAMICS + VOID COEFFICIENT

6-10509 ANALOG MODELS FOR HNPF CONTROL AND PROTECTION STUDIES ATOMICS INTERNATIONAL, CANOGA PARK

NAA-SR-8579+. 69 PAGES, 16 FIGURES, 7 TABLES, 10 REFERENCES, JUNE 1964, CFSTI, $\$ 1.50$ CY

PROBLEM - DEVELOP A MOOEL FOR IHE UYNAMIC BEHAVIOR OF THE HNPF. APPROACH - AN ANALOG COMPUTER MODEL WAS DEVELOPED FOR USE IN STUDIES OF THE CONTROL AND SAFETY SYSTEMS. THE MODEL INCLUDES T NEUTRON KINETICS, AFTERHEAT, CORE HEAT-TRANSFER FOR AVERAGE CHANNEL AND HOT CHANNEL, PRIMARY-COOLANT HYDRAULICS FOR FORCED AND CONVECTION FLOWS, ROD DRIVES, CONTROL SYSTEM, AND PROTECTIVE SYSTEM. THE SIMULATIONS OF THE VARIOUS SECTIONS ARE DESCRIBED IN DETAIL.

* ANALYTICAL MODEL + \#COMPUTER PRCGRAM + *COMPUTER, ANALOG + *REACTOR DYNAMICS + CONTROL SYSTEM + HALLAM + MATHEMATICAL STUDY + REACTOR SAFETY SYSTEM + REACTOR, LIQUID METAL COOLED

6-10532 JUDD AM

LOSS-OF-COOLANT ACCIDENTS IN A LARGE SODIUM-COOLED FAST REACTOR

U.K. ATOMIC ENERCY AUTIIORITY, HINFRITH

ANL-1120+. 15 PAGES, 11 FIGURES, 2 TABLES, 8 REFERENCES, PP. $67-81$ OF PROCEEDINGS OF THF CONFERENCE ON

SAFETY, FUELS, AND CORE DESIGN IN LARGE FAST POWER REACTORS, OCTOBER 11-14, 1965, CFSTI \$9.25 CY

BASICALLY, THE APPROACH USEO HERE IS TO CONSIDER A SERIES OF FAULT CONDITIONS WHICH MIGHT ARISE IN A TYPICAL OXIDE-FUELLED, SODIUM-COOLED FAST REACTOR. THE ACCIDENTS RESULTING FROM THESE FAULTS ARE THEN ANALYSED STEP-BY-STEP, USUALLY UNDER SOME PESSIMISTIC ASSUMPTIONS, SUCH AS THE FAILURE OF ONE OR MORE REACTOR TRIP CIRCUITS. THERE ARE, HOWEVER, SOME MECHANISMS WHICH ARE IMPORTANT FOR SEVERAL OF THE ACCIDENTS AND REQUIRE DETAILED CONSIDERATION, SUCH AS COOLANT AND FUEL REACTIVITY WORTH, THE BEHAVIOUR OF THE COOLANT AS IT BOILS, AND PARTICULARLY THE EFFECTS OF NUCLEATE BOILING, THE RELEASE OF FISSION-PRODUCT GAS FROM A BURST FUEL CAN. AS $\triangle$ RESULT OF THESE ANALYSES, CERTAIN PROBLEMS STAND OUT AS BEING PARTICULARLY IMPORTANT FOR THE SAFETY OF THE REACTOR, INCLUDING THE POSSIBILITY OF A SINGLE SUBASSEMBLY ACCIDENT SPREADING TO THE WHOLE CORE AND THE TIME FOR AVAILABLE FOR A TRIP MECHANISM TO OPERATE.

* ACCIDENT, MAXIMUM CREDIBLE (MCA) + \#LOSS OF COOLANT + *REACTOR, FAST + FUEL ELEMENT + HEAT TRANSFER + METAL, LIQUID + RADIUM + REACTOR KINETICS + TEMPERATURE TRANSIENT + URANIUM OIOXIDE

6-10536 OKRENT D

SUMMARY OF INTERCOMPARISON CALCULATIONS PERFORMED IN CONJUNCTION WITH CONFERENCE ON SAFETY, FUELS, AND CORE DESIGN IN LARGE FAST POHER REACTORS

ARGONNE NATIONAL LABORATORY, ARGONNE

ANL-7120 +. $2 \mathrm{i}$ PAGES + 5 FIGURES, 5 TABLES, REFERENCES, PP. 3-23 OF PROCEEDINGS OF THE CONFERENCE ON

ACCESSION NUMBER 6-10040 TO 6-10536 
CATEGORY

REACTOR TRANSIENTS, KINETICS, ANO STABILITY

6-1053E *CONTINUED*

SAFETY, FUELS, AND CORE DESIGN IN LARGE FAST POWER PEACTORS, OCTOBER 11-14, 1965, CFSTI, \$9.25 CY

AMONG THE ITEMS SUBJECT TO THE INTERCOMPARISON, THE DOPPLER COEFFICIENT, THE SODIUM

COEFFICIENT, AND ITS COMPONENTS ARF OF DIRECT SAFETY INTEREST.

\#DOPPLER COEFFICIENT + \#SODIUM COEFFICIENT + COMPUTER, DIGITAL + PEACTOP, FAST

6-10537 GREEBLER P + COWAN CL + FIES CL + GYOREY GL + SUEOKA JR

CALCULATED PHYSICS PARAMETERS AND THEIR UNCERTAINTIES IN A IOOD-MW(E) FAST CERAMIC REACTOR GENERAL ELECTRIC COMPANY, SAN JOSE

ANL-7120 +. 9 PAGES, 3 FIGURES, 5 TABLFS, 25 REFERENCES, PP, $24-32$ OF PROCEEDINGS OF THE C.ONFERENCE ON

SAFETY, FUELS, ANO CORE DESIGN IN LARGE FAST POHER REACTORS, OCTOBER 11-14, 1965, CFSTI. \$9.25 CY

AMONG THE PHYSICS PARAMETERS CALCULATED, THE DOPPLER EFFECT AND THE SODIUM COEFFICIENT ARE OF DIRECT SAFETY INTEREST:- PHYSICS PERFORMANCE OF LARGE FAST REACTORS CANNOT NOW BE RELIABLY PREDICTED. FAVORABLE OR UNFAVORABLE COMBINATIONS OF THE UNCERTAINTIES STRONGLY INFLUENCE THE CORE DESIGN AND MAKE LARGE DIFFERENCES IN THE SAFETY AND ECONOMICS PARAMETERS.

*DOPPLER COEFFICIENT + \$SODIUM CCEFFICIFNT + COMPUTER, DIGITAL + REACTOR, FAST

6-10538 SHERER D8

AN ANALYSIS OF FAST REACTOR TRANSIENT RESPONSE AND SAFETY IN SELECTED ACCIDENTS

GENERAL ELECTRIC COMPANY, SAN JOSE

ANL-7120+. 8 PAGES, 5 FIGURES, 2 TABLES, 13 REFERENCES, PP. $46-53$ OF PROCEEDINGS OF THE CONFERENCE ON

SAFETY, FUELS, AND CORE DESIGN IN LARGE FAST POWFR REACTORS, OCTOBER 11-14, 1965, CFSTI, \$9.25 CY

ACCIDENTS ANALYZED WERE NONTERMINATING RAMP REACTIVITY INSERTIONS AT \$O.20/SFC AND \$2/SEC, AND LOSS OF PUMPING POWER WITH RESULTANT FLOW COASTDOWN. THE TIME AVAILABLE BEFORE $\triangle$ GIVEN TYPE OF DAMAGE OR FAILURE OCCURRED WAS CONSIDERED TO BE A MEASURE OF THE INHFRENT SAFETY OF THE REACTOR. CONSIDERATION WAS GIVEN TO A PROMPT COEFFICIENT (NORMALLY NEGATIVE) DUE TO CHANGES IN FUEL TEMPERATURE, A DELAYED NEGATIVE COEFFICIENT DUE TO EXPANSION OF THE REACTDR STRUCTURE, AND A DELAYED COEFFICIENT DUE TO COOLANT-DENSITY CHANGE, WHICH MAY BE EITHER NEGATIVE OR POSITIVE.

COMPUTER, DIGITAL + DOPPLER COEFFICIENT + EXPANSION REACTIVITY EFFECT + REACTOR TRANSIENT + REACTOR, FAST + SOOIUM COEFFICIENT

6-10539 NOVAK PE + LAURITZEN TA + PROTSIK R + DAVIES JH + ZEBROSKI EI

PLUTONIUM AND FISSION PRODUCT REDISTRIBUTION IN MIXED OXIDE FUELS

GENERAL ELECTRIC COMPANY, SAN JOSE

ANL-7120+. 8 PAGES, 7 FIGURES, 1 TABLE, PP. 392-399 OF PROCEEDINGS OF THE CONFERENCE ON SAFETY, FUELS,

AND CORE DESIGN IN LARGE FAST POWER REACTORS, OCTORER 11-14, 1965, CFSTI, \$9.25 CY

PREVIOUS OBSERVATIONS ANO RECENT MEASUREMENTS OF PLUTONIUM AND FISSION-PRODUCT CONCENTRATION GRADIENTS IN MIXED OXIDE FUEL, CONSEQUENCES OF PLUTONIUM RE-DISTRIBUTION IN THE CALCULATED DOPPLER, CONCLUSIONS.

DOPPLER EFFECT + FAILURE, FUEL ELEMENT + FUEL SEGREGATION + PLUTONIUM OXIDE + URANIUM OXIDE

6-10540 HUMMEL HH + HWANG RN + OHILLIPS K

RECENT INVESTIGATIONS OF FAST REACTOR REACTIVITY COEFFICIENTS

ARGONNE NATIONAL LABORATORY, ARGONNE

ANL-7120 +. 8 PAGES, 6 FIGURES, 5 TABLES, 23 REFERENCES, PP. $413-420$ OF PROCEEDINGS OF THE CONFERENCE ON

SAFETY, FUELS, ANO CORE DESIGN IN LARGE FAST POWER REACTORS, OCTOBER 11-14, 1965, CFSTI, \$9.25 CY

CRITICAL REVIEW OF EOUIVALENCE BETWEEN HOMOGENEOUS AND HETEROGENEOUS RESONANCE INTEGRALS IN CYLINDRICAL GEOMETRY, EFFECT OF PARAMETER VARIATIONS AND OF PU-241 ON SOOIUM - VOIDEFFECT NONL INEARITY IN SPECTRAL COMPONENT AS A FUNCTION OF SODIUM CONTENT.

\#DOPPLER EFFECT + \$SODIUM COEFFICIENT + REACTOR, FAST + VOID COEFFICIENT

6-10541 TRAVELLI A

A COMMENT ON THE COMPARISON OF SOME SOOIUM VOID COEFFICIENTS WITH EXPERIMENTAL DATA

ARGONNE NATIONAL LABORATORY, ARGONNE

ANL-7120 +. 11 PAGES, 1 TABLE, 4 REFERENCES, PP. $421-422$ OF PROCEECINGS OF THE CONFERENCE ON SAFETY,

FUELS, ANO CORE DESIGN IN LARGE FAST POWER REACTORS, OCTOBER 11-14, 1965, CFSTI, SO.25 CY

COMPARISON OF CENTRAL SODIUM WORTH, AS MEASURED ON ASSEMBLY 45A OF ZPR-3, AND IS CALCULATED BY

USING VARIOUS SETS OF CROSS SFCTIONS. SAME FOR 50 PERCENT SODIUM REMOVAL THROUGHOUT THE COPE.

\$REACTOR, FAST + \$SODIUM COEFFICIENT + ZPR III (ANL ZERO POWER REACTOR)

6-10542 KUSTERS H + METZENROTH M

THE INFLUENCE OF SOME IMPORTANT GROUP CONSTANTS ON INTEGRAL FAST REACTOR QUANTITIES KERNF OR SCHUNGSZENTRUM, KARLSRUHE, GERMANY

ANL-7120+. 11 PAGES, 9 FIGURES, 7 TABLES, 8 REFERENCES, PP $423-433$ OF PROCEEDINGS OF THE CONFERENCE ON SAFETY, FUELS, AND CORE DESIGN IN LARGE FAST POWER REACTORS, OCTOBER 11-14, 1965, CFSTI; \$9.25 CY 
CATEGORY 6

REACTOR TRANSIENTS, KINETICS, AND STABILITY

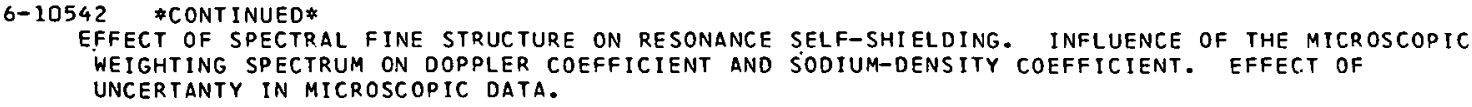

6-10543 CODO J + DURSTON C + WRIGHT WV

SOME CALCULATIONS OF FAST REACTOR DOPPLER AND SODIUM LOSS COEFFICIENTS WITH PARTICULAR REFERENCE TO THE EFFECTS OF CORE LATTICE STRUCTURE AND RADIAL FUEL TEMPERATURE DISTRIBUTION UNITED KINGDOM ATOMIC ENERGY AUTHORITY, WINFRITH

ANL-7120 +. 6 PAGES, 3 TABLES, 8 REFERENCES, PP. 434-439 OF PROCEEDINGS OF-THE CONFERENCE ON SAFETY, FUELS, AND CORE DESIGN IN LARGE FAST POWER REACTORS, OCTOBER 11-14, 1965 , CFSTI \$9.25 CY

THE REACTIVITY OF A TYPICAL DILUTE FAST POWER REACTOR CORE, AND THE DOPPLER AND SODIUM LOSS COEFFICIENTS, ARE FOUND TO BE ONLY SLIGHTLY INFLUENCED BY HETEROGENEITY EFFECTS IN THE RESONANCE ENERGY REGION BELOW 15 KEV. THE USE OF DIFFERENT DATA FOR THE 2.85-KEV SODIUM RESONANCE ALSO GIVES RISE TO ONLY SMALL CHANGES IN THE RESULTS. THE U238 RESONANCE CAPTURE IN A FUEL ROD HAVING A PARTICULAR RADIAL TEMPERATURE OISTRIBUTION AGREES CLOSELY WITH THE RESULTS FOR THE UNIFORM MEAN TEMPERATURE OVER THE ENERGY RANGE FROM 0.8 TO 2.1 KEV WHICH WAS INVEST IGATED.

*DOPPLER COEFFICIENT + \#REACTOR, FAST + *SODIUM COEFFICIENT

6-10544 FROELICH R + OTT $K$ + SHAVIV G + YIFTAH S

RESULTS OF DOPPLER COEFFICIENT CALCULATIONS FOR FAST REACTORS AND COMPARISON OF DIFFERENT METHODS KERNFORSCHUNGSZENTRUM, KARLSRUHE, GERMANY + ISRAEL INSTITUTE OF TECHNOLOGY

ANL-7120 +. 9 PAGES, 5 FIGURES, 10 TABLES, 20 REFERENCES, PP. 440-448 OF PROCEEDINGS OF THE CONFERENCE ON SAFETY, FUELS, AND CORE DESIGN IN LARGE FAST POWER REACTORS, OCTOBER 11-14, 1965, CFSTI, \$9.25 CY

RESULTS OF DOPPLER-COEFFICIENT CALCULATIONS OF THREE DIFFERENT ORIGINS ARE COMPARED ANO ANALYSED. THE AIM IS TO FIND THE SPECIAL ASSUMPTIONS RESPONSIBLE FOR OBVIOUS DISCREPANCIES. THIS PAPER GIVES PRELIMINARY RESULTS.

*DOPPLER COEFFICIENT + REACTOR, FAST

$6 \rightarrow 10545$ HWANG RN

EFFECT OF THE FLUCTUATIONS IN COLLISION DENSITY ON FAST-REACTOR DOPPLER EFFECT CALCULATIONS ARGONNE NATIONAL LABORATORY, ARGONNE

ANL-7120 +. 13 PAGES, 7 FIGURES, 8 TABLES, PP. 449-461 OF PROCEEDINGS OF THE CONFERENCE ON SAFETY, FUELS, AND CORE DESIGN IN LARGE FAST POWER REACTORS, OCTOBER 11-14, 1965, CFSTI, \$9.25 CY

PHYSICAL AND MATHEMATICAL ASPECTS OF SLOWING-DOWN PROBLEM, PLACZEK OSCILLATION DUE TO ISOLATED RESONANCES, EFFECT OF INCOMPLETE RECOVERY BETWEEN RESONANCES FOR A SINGLE RESONANCE SUBSTANCE IN THE MIXTURE, FIRST-ORDER APPROXIMATION AND GROUP REACTION RATES FOR OVERLAPPING RESONANCE

IN THE DOPPLER RECION.

\#DOPPLER EFFECT + \#REACTOR, FAST

6-10546 OLHOEFT JE + KRUG HE

COMPARISON OF MONTE CARLO AND RESONANCE INTEGRAL METHODS IN THE DETERMINATION OF DOPPLER EFFECTS IN FAST REACTORS

WESTINGHOUSE ELECTRIC CORPORATION, PITTSBURGH + ARGONNE NATIONAL LAGORATURY

ANL-7120 +. 16 PAGES, 6 FIGURES, 8 TABLES, 25 REFERENCES, PP. $462-477$ OF PROCEEDINGS OF THE CONFERENCE ON SAFETY, FUELS, AND CORE DESIGN IN LARGE FAST POWER REACTORS, OCTOBER 11-14, 1965, CFSTI, \$9.25 CY

THIS PAPER DESCRIBES A COMMPAR ISON DF THE CAI.C.ULATIONS BY THE MONTE C.ARLO METHOO AND RESONANCE-INTEGRAL TECHNI QUES, OF DOPPLER EFFECTIN FAST REACTORS. THESE COMPARISONS WERE BASED ON A COMMON SET OF GROUND RULES, SELECTED TO MINIMIZE THE EFFECT OF UNCERTAINTIES IN NONFUEL CROSS SECTIONS. IN THIS WAY, DISCREPANCIES IN RESULTS CAN BE ATTRIBUTED TO THE DIFFERENCES IN THE TREATMENTS OF THE DOPPLER-BROADENEO CROSS SECTIONS AND THE SLOWING-DOWN MODELS.

\#DOPPLER EFFECT + \#REACTOR, FAST

6-10550 STACHURA SJ + SILBERBERG·M

THE APPLICATION OF EXPERIMENTAL DATA FROM TREAT MELTDOWN STUDIES TO REACTOR ACCIDENT ANALYSIS ATOMICS INTERNATIONAL, CANOGA PARK

ANL-7120 +. 10 PAGES, 7 FIGURES, 2 TABLES, 3 REFERENCES, PP. $514-523$ OF PROCEEDINGS OF THE CONFERENCE ON SAFETY, FUELS, AND CORE DESIGN IN LARGE FAST POWER REACT.ORS, OCTOBER 11-14, 1965, CFSTI, \$9.25 CY

RESULTS OF RECENT TREAT MELTDOWN STUDIES OF CERAMIC FUEL IN SODIUM ARE PRESENTED, AND THE SIGNIFICANCE OF THESE RESULTS WITH RESPECT TO LARGE CORE MELTDOWN IS INDICATED. THE COURSE OF FUEL MOTION IN A LARGE CORE WAS ESTIMATEO FOR A SIMPLIFIED CASE, AND THE ASSOCIATED REACTIVITY EFFECTS WERE DETERMINED. THESE REACTIVITY EFFECTS WERE THEN INCORPORATED INTO THE AIREK REACTOR KINETICS CODE TO ESTIMATE CORE BEHAVIOR AFTER GROSS FUEL MELTING IN CENTRAL REGIONS OF THE CORE. A DISCUSSION OF THOSE FACTORS WHICH CAN INFLUENCE MELTDOWN BEHAVIOR WAS PRESENTED.

\#ACCIDENT, GENERAL + \#CORE MELTDOWN + \#FUEL MELTDOWN + \#REACTOR, FAST + 
CATEGORY 6

REACTOR. TRANSIENTS, KINETICS, AND STABILITY

6-10550 *CONTINUED*

*TREAT (TRANSIENT TEST REACTOR FACILITY) + FUEL ELEMENT + HEAT TRANSFER

6-10567 POWER REACTOR DEVELOPMENT COMPANY REQUESTS TECH. SPEC. CHANGE FOR DOWEP COEFFICIENT POWER REACTOR DEVELOPMENT COMPANY

1 PAGE, JUNE 24, 1966, DOCKET 50-16, ATOMIC ENERGY CLEARING HOUSE, 12(27), PAGE 21 (JULY 4, 1966)

PRESENT POWER-COEFFICIENT MEASUREMENTS HAVE A PLUS OR MINUS UNCERTAINTY DF 25 PERCENT BECAUSE OF INACCURACIFS IN HEAT BALANCE AT LOW POWER. THE LOWER LIMIT IS MINIJS D.15 CENT/MW, LFSS THAN THE SAFEGUARDS-REPORT VALVE OF 0.2 . THE SAFETY ANALYSIS WAS REDONE IN SUPDORT OF REQUESTING A CHANGE TO THE LOWER COEFFICIENT.

*OPERATING LIMITS/TECHNICAL SPECIFICATIONS + \#POWER COEFFICIENT + FERMI + REACTOR, BREEDER + TEST, PHYSICS

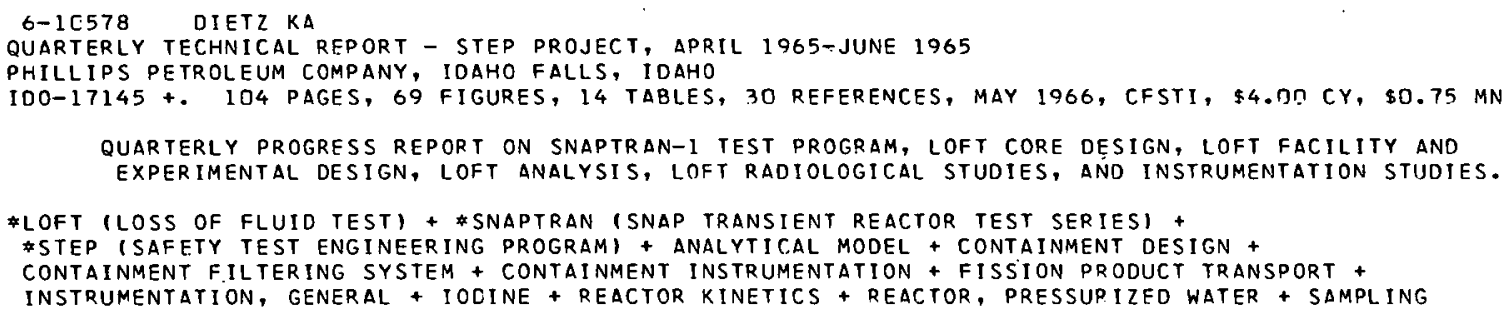

EXPERIMENTS WERE CONCUCTEO IN TREAT TO INVESTIGATE THE SAFETY PROBLEMS ASSOCIATEO WITH THE BEHAVIOR OF UO2-CORE, METAL-CLAD FUEL SPECIMENS UNOER CONDITIONS SIMULATING A POWER EXCURSION. SPECIFICALLY, THE PURPOSE DF THESE RECENT SCALE-UP TRANSIENT TESTS WAS TO OBTAIN INFORMATION ON THE CHEMICAL AND PHYSICAL CHANGES THAT TAKE PLACE UPON MELTOOWN OF A SUBASSEMBLY OR A PORTION OF A NUCLEAR REACTOR CORE. PARTICULAR FMPHASIS WAS PLACEO ON DETERMINING THE EXTENT OF METAL-WATER REACTION, THE PEAK PRESSURE PRODUCED, AND THE FINAL PART ICLE-SIZE DISTRIBUTION OF FRAGMENTEO FUEL CLUSTER. THESE PARAMETERS WERE THEN CORRELATED WITH THE ENERGY OF THE REACTOR PULSE.

* TREAT (TRANSIENT TEST REACTOR FACILITY) + \#URANIUM OXIDe + FAILURF, FUEL ELEMENT + METAL WATER REACTION + REACTOR, GRAPHITE MODERATED + REACTOR, TEST + TEST, DESTRUCTIVE

E-10611 HELLSTRAND E + ANDERSSON TL + BRUNFELTER B + KOCKUM J + LONDEN SO + TIREN LI EXPERIMENTAL STUDIES ON ASSEMBLIES 1 ANO 2 OF THE FAST REACTOR FRO

AKTIEBOLAGET ATOMENERGI, STOCKHOLM, SWEDEN

AE-207 +. 56 PAGES, FIGURES, TABLES, DECEMBER 1965, DEP/MN

CONTROL ROD CALIBRATIONS HAVE BEEN MADE BY USING THE POSITIVE PERIOD, THE INVERSE MULTIPLICATION, THE ROD DROP, AND THE PULSEO SOURCE TECHNIQUES AND SHOW SATISFACTORY AGREEMENT BETWEEN THE VARIOUS METHOOS. THE REACTIVITY WORTHS OF SAMPLES OF DIFFERENT MATERIALS AND DIFFERENT SIZES WERE MEASURED AT THE CORE CENTRE. COMPARISONS WITH PERTURBATION CALCULATIONS SHOW THAT THE REGULAR AND ADJOINT FLUXES ARE WELL-PREDICTED IN THE CENTRAL REGION OF THE CORE. THE VARIATION IN THE PROMPT NEUTRON LIFE-TIME WITH RFACTIVITY HAS BEEN STUDIES EY MEANS OF THE PULSED SOURCE AND THE ROSSI-ALPHA TECHNIOUES.

\#CONTROL ROD CALIBRATION + \#REACTOR, FAST + DANGER COEFFICIENT + PROMPT NEUTRON LIFETIME + ROSSI ALPHA + SHEDEN

E- 10612 CROCKER JG

SPERT III - EXTERNAL PRESSURE TESTS WITH SPERT III OXIDE-CORE FUEL RODS

PHILLIPS PETROLEUM COMPANY, IDAHO FALLS, IDAHO

IDO- $17179+$ PAGES $1-2$ OF QUARTERLY TECHNICAL REPORT - SPERT PROJECT, OCTOBER, NOVEMBER, DECFMBER 1965, 55 PAGES, 35 FIGURES, 2 TABLES, 28 REFERENCES, JUNE 1966, CFSTI, $\$ 3.00 \mathrm{CY}, \$ 0.75 \mathrm{MN}$ 
CATEGORY 6

REACTOR TRANSIENTS, KINETICS, AND STABILITY

6-10612 \#CONTINUED*

FOR EXPERIMENTS TO INVESTIGATE THE KINETIC BEHAVIOR OF LOW-ENRICHMENT UO2 CORES IN SPERT III, IT WAS DETERMINED THAT THE FUEL RODS SHOULD BE LIMITED TO 1750 PSIG AND 500 AND $550 \mathrm{~F}$ FOR STEADY-STATE AND TRANSIENT OPERATION RESPECTIVELY.

* SPERT 3 (SPECIAL POWER EXCURSION REACTOR TEST) + \#URANIUM OXIDE + REACTOR TRANSIENT +

REACTOR, PRESSURIZED WATER + REACTOR, TEST

6-10613 CROCKER JG

SPERT IV - CAPSULE ORIVER CORE SUBASSEMBLY TEST PROGRAM

PHILLIPS PETROLEUM COMPANY, IOAHO FALLS, IDAHO

IDO-17179+. PAGES 3-15 OF OUARTERLY TECHNICAL REPORT - SPERT PROJECT, OCTOBER, NOVEMBER, DECEMBER I965,

55 PAGES, 35 FIGURES, 2 TABLES, 28 REFERENCES, JUNE 1966, CFSTI, $\$ 3.00 \mathrm{CY,} 50.75 \mathrm{MN}$

FOR THE CAPSULE DRIVER CORE IN THE SPERT IV FACILITY INTERCALIBRATION OF TRANSIENT AND

OPERATIONAL POWER CHAMBER, FIGURES OF MERIT OF 3 AND 4 PERCENT ENRICHED URANIUM OXIDE, VOID

WORTHS AND FLUX GRADIENT WERE DETERMINED. THE LATTER IS OF IMPORTANCE FOR TRANSIENT BOWING.

FIDUCIAL TRANSIENTS TEST WITH PERIODS DOWN TO 17.5 MSEC ARE REPORTED. AN OUT-OF-PILE

EXPLOSIVE TESTING PROGRAM YIELDED CORRELATION OF PERMANENT DEFORMATION OF CAPSULE WITH

MATERIAL YIELD STRESS, INSIDE RADIUS AND WALL THICKNESS. A TRANSDUCER FOR HATER-HAMMER

VELOCITIES WAS DEVELOPED.

*SPERT 4 (SPECIAL POWER EXXURSION REACTOR TEST) + FUEL ELEMENT BOWING + REACTOR TRANSIENT + REACTOR, TEST + TEST, DESTRUCTIVE

6-10614 CROCKER JG

POWER BURST FACILITY FUEL TESTING PROGRAM

PHILLIPS PETROLEUM COMPANY, IDAHO FALLS, IOAHO

IDO-17179+. PAGES 16-30 OF QUARTERLY TECHNICAL REPORT - SPERT PROJECT, OCTOBER, NOVEMBER, DECEMBER 1965,

55 PAGES, 35 FIGURES, 2 TABLES, 28 REFERENCES, JUNE 1966 , CFSTI, \$3.00 CY, \$0.75 MN

PBF FUEL-ROD TESTS IN TREAT WERE CARRIED TO 239 CAL/G U02. A GAP OF 19 MILS BETWEEN THE INSULATOR AND THE FUEL PELLETS, AND AN INTERFERENCE FIT BETWEEN CLAD AND INSULATORS WAS CECIDED ON.

* PBF (POWER BURST FACILITY) + FUEL ELEMENT + REACTOR, GRAPHITE MODERATED + REACTOR, TEST +

TREAT (TRANSIENT TEST REACTOR FACILITYI

6-10615 CROCKER JG

TWO-DIMENSIONAL HEAT TRANSFER CALCULATIONS

PHILLIPS PETROLEUM COMPANY, IDAHO FALLS, IDAHO

IDO-17179 +. PAGES 31-55 OF QUARTERLY TECHNICAL REPORT - SPERT PROJECT, OCTOBER, NOVEMBER, DECEMBER 1965,

55 PAGES, 35 FIGURES, 2 TABLES, 28 REFERENCES, JUNE 1966 , CFSTI, $\$ 3.00 \mathrm{CY}, \$ 0.75 \mathrm{MN}$

TOODEE, A REACTOR KINETICS CODE WITH THERMAL REACTIVITY FEEOBACK INCORPORATING TWO-DIMENSIONAL ANALYSIS WAS DEVELOPED AND CHECKEO OUT. AN IMPROVED MODEL FOR CALCULATING REACTIVITY FEEDBACK DURING SHORT-PERIOD EXCURSIONS IN LOW-ENRICHMENT URANIUM OXIDE CORES WAS FORMULATED. LIST OF RECENT SPERT PUBLICATIONS.

*COMPUTER, DIGITAL + DOPPLER EFFECT + REACTOR TRANSIENT + THERMAL ANALYSIS + URANIUM OXIUE

E-10617 DURAND-SMET R

THE PROBLEM OF DETERMINATION OF NEUTRON FLUX OF SODIUM-COOLED FAST BREEDER REACTORS WITH THE SNEAK-2 COOE GESELLSCHAFT FUR KERNFORSCHUNG M.B.H., KARLSRUHE, KERNFORSCHUNGSZENTRUM

KFK-382 +. 51 PAGES, FIGURES, TABLES, 12 REFERENCES, NOVEMBER 1965, DEP. MN

SNEAK-2 ASSEMBLY. CALCULATION OF CRITICALITY FACTORS AND NEUTRON LIFETIME. FUEL-EXPANSION COEFFICIENT, DOPPLER COEFFICIENT. LOCAL DANGER COEFFICIENT OF SODIUM, CENTRAL SODIUM-VOID COEFFICIENT, HOMOGENEOUS SODIUM VOIOING COEFFICIENT.

\#REACTOR, FAST + CRITICALITY EXPERIMENT + DANGER COEFFICIENT + DOPPLER COEFFICIENT + GERMANY + PROMPT NEUTRON LIFETIME + SODIUM COEFFICIENT + VOID COEFFICIENT

6-10619 BRUNA JG + BRUNET JP + CAIZERGUES R + CL QUET D ORVAL C + KREMSER J + TELLIER H + VERRIERE P ALECTO - RESULTS OBTAINEO WITH HOMOGENEOUS CRITICAL EXPERIMENTS ON PLUTONIUM 239 , URANIUM 235 AND URANIUM 233

COMMISSARIAT a L ENFRgIE aTOMIQUE, FRANCE, CENTRE D ETUDES NUCLEAIRES, SACLAY

CEA-R-2814 +. 130 PAGES, 37 FIGURES, 24 TABLES, OCTOBER 1965, DEP. MN

IN THIS REPORT ARE GIVEN THE RESULTS OF THE HOMOGENEOUS CRITICALITY EXPERIMENTS ALECTO, MADE ON PLUTONIUM-239, URANIUM-235 AND URANIUM-233. AFTER A BRIEF DESCRIPTION OF THE EQUIPMENT, THE CRITICAL MASSES FOR CYLINDERS OF DIAMETERS VARYING FROM 25 TO 42 CM ARE GIVEN AND COMPARED. WITH OTHER VALUES (FOREIGN RESULTS, CRITICALITY GUIDE). EXPERIMENTS RELATING TO CROSS SECTIONS AND CONSTANTS TO BE USED ON THESE MATERIALS ARE PRESENTED. LASTLY, KINETIC EXPERIMENTS ALLOW ONE TO COMPARE PULSED-NEUTRON METHODS WITH FLUCTUATION METHODS.

*CRITICALITY EXPERIMENT + CRITICALITY SAFETY + NOISE ANALYSIS + PLUTONIUM + PULSED NEUTRON TECHNIQUE + URANIUM 
CATEGORY 6
REACTOR TRANSIENTS, KINETICS, AND STABILITY

6-10620 LEAMER RD + HANLEN DF + HAMILTON GN + TAYLOR EG CRITICAL EXPERIMENTS PERFORMED WITH CLUSTERED AND UNIFORM ARRAYS OF ROODED ABSORBERS HESTINGHOUSE ELECTRIC CORPORATION, PITTSBURGH

WCAP-3269-39+. 103 PAGES, 67 FIGURES, 15 TABLES, 2 REFERENCES, NOVEMBER 1965, CFSTI, \$4.0D CY, \$O.75 MN

CRITICALITY EXPERIMENTS CN REACTIVITY WORTHS DF CLUSTERS AND UNIFORM ARRAYS OF AG-IN-CD ABSORBER RODS WERE MEASURED IN WATER-MODERATED URANIUM OXIDE CORES OF LOW ENRICHMENT. EXPERIMENTAL FACTORS INCLUDED ENRICHMENT, LATTICE PITCH, DIAMETER OF POISON AND FUEL RODS, AND ABSORBER-ROD-CLADDING THICKNESS. FUEL INCLUDED STAINLESS-STEEL-CLAD FUEL RODS OF 2.7, 3.7, AND 5.7 PERCENT ENRICHMENTS, AND ZIRCALOY-4-CLAD RODS OF 2.72 PERCENT ENRICHMENT.

*CONTROL ROD WORTH + \#CRITICALITY EXPERIMENT + REACTOR, WATER + URANIUM OXIDE

6-10641 WAGNER R

IREKIN--PROGRAM FOR THE NUMERICAL SOLUIION OF THE REACTOR KINETICS EQUATIONS PHILLIPS PETROLEUM COMPANY, IDAHC

IDO- $17114+.86$ PAGES, 2 REFERENCES, JANUARY $1966^{\circ}$, CFSTI, $\$ 3.00 \mathrm{CY}, \$ 0.75 \mathrm{MN}$

IREKIN PROGRAM IS TO OBTAIN A NUMERICAL SOLUTION OF THE ORDINARY, ONE-GROUP, SPACE-INDEPENDENT, DIFFERENT IAL EQUATIONS THAT DESCRIBE THE POWER BEHAVIDR OF A NUCLEAR REACTOR IN RESPONSE TO AN ARBIIRARY FUNCTION OF REACTIVITY.

\#CYNAMICS, NONLINEAR + *REACTOR TRANSIENT + COMPUTER, DIGITAL

6-10642 HIROTA J

REACTOR PHYSICS ACTIVITIES IN JAPAN

JAPAN ATOMIC ENERGY RESEARCH INSTITUTE

EACRP-L-57 +. 7 PAGES, 25 REFERENCES, SEPTEMBER 20, 1965

SAFETY-RELATED TOPICS INCLUDE THEORY OF STATISTICAL FLUCTUATIONS OF NEUTRON AND PRECURSOR DISTRIBUTIONS IN POSITION ANO VELOCITY. SPACE, CRITICAL EXPERIMENTS ISOME INCLUDING REACTIVITY COEFFICIENTS AND FUEL-WORTH MEASUREMENTSI ON LIGHT-WATER LATTICES, REFLECTED URANYL SULFATE SOLUTION IN HEAVY WATER, GRAPHITE SYSTEMS, AND ASSEMBLIES RELATED TO LARGE FAST CORES OF CERAMIC FUEL, PULSED-NEUTRON EXPERIMENTS ON REFLECTED HIGHLY SUBCRITICAL SYSTEMS, LIGHT-WATER MODERATED AND REFLECTED NATURAL URANIUM SUBCRITICAL ASSEMBLY, AND NANOSECOND DIFFUSION IN

FAST ASSEMBLIES. LITERATURE REFERENCES, BUT NO DATA.

* JAPAN + CRITICALITY SAFETy + nOISE ANALYSIS + PUlsed NEUTRON TEChNIOUE

6-1064? INZAGHIA + MISENTAR

AIREK $\rightarrow$ PUL. A VERSION OF THE KINETIC CODE AIREK-MOO FOR PERIODICALLY PULSED FAST REACTORS

EUROPEAN ATOMIC ENERGY COMMUNITY (EURATOMI, ISPRA, ITALY.

EUR-2552.E + . T5 PAGES, NOVEMBER 1965 , SOURCE

FOR KINETIC CALCULATIONS OF A PERIODICALLY PULSED FAST REACTOR, THE CODE AIPEK-MOD WAS SUPPLEMENTED. THE NEW CODE, AIREK-PUL, INTEGRATFS THE KINETIC EQUATIONS FOR A PERIODICALLY PULSED REACTOR FOR TWO SPACE POINTS AND FEW NEUTRON GROUPS AND FOR ONE GROUP WITH AN EXTERNAL NEUTRON SOURCE. THE KINETIC EQUATIONS SOLVED BY THE CODE AIREK-PUL ARF DESCRIBED, AND THE LISTINGS OF THE THREE VERSIONS OF THE CODE ARE GIVEN.

*REACTOR, FAST + \#REACTOR, PULSED + COMPUTER, DIGITAL

6-10647 PERSSON R + WIKDAHL CE

REACTOR PHYSICS MEASUREMENTS IN RO WITH 27-ROD CLUSTERS OF NATURAL UO2, I.35 CM IN DIAMETER AKT IEBOLAGET ATOMENERGI, STOCKHOLM, SWEDEN

RFX-316 +. 28 PAGES, 10 FIGURES, REFERENCES, SEPTEMBER 30, 1964 , DEP/MN

CLUSTERS WITH THREE DIFFERENT PIN PITCHES WERE INVESTIGATEO REgARDING THE MATERIAL BUCKLING VERSUS LATTICE PITCH AND THE CHANGES OF BUCKLING AND DIFFUSION COEFFICIENTS CAUSED BY THE INTRODUCTION OF AIR AS COOLANT. THE BUCKLING CHANGE WITH VOID IS IN APPROXIMATE AGREEMENT WITH THAT PREDICTED BY A MODIFIED VERSION OF BURNUP-5 CALCULATIONS. ACTIVATION STUDIES WERE MADE IN ONE LATTICE CONFIGURATION ON VOIDED AND D2O-FILLEO CLUSTERS. THE FINF STRUCTURF WAS MEASURED BY MEANS OF COPPER FOILS AND HIRES.

SWEDEN + URANIUM, NATURAL + VOID COEFFICIENT

6-10649 LELLOUCHE GS + LEVINE MM + CHERNICK J SOME SAFETY CONSIDERATIONS BASED ON DESIGN EXPERIENCES IN THE $8 N L$ SETTLEO RED FAST REACTOR CONCEPT BROOKHAVEN NATIONAL LABORATORY

BNL-9475 + CONF-651009-1 + 8 PAGES, AUGUST, 1965 , CONFERENCE ON SAFETY, FUELS AND CORE DESIGN IN LARGE FAST POWER REACTORS, ARGONNE, ILL., CFSTI, \$1.00 CY, \$0.50 MN

THE SODIUM REGIONS ABOVE AND BELOW THE BNL SETTLED-BED FAST REACTOR EXHIRIT A STRONG, THOUGH DELAYED, NEGATIVE VOID COEFFICIENT. TYPICAL TRANSIENTS ARE DISCUSSED.

*REACTOR, FAST + BNL (BROOKHAVEN NATIONAL LABORATORY) + REACTOR TRANSIENT + SOOIUM COEFFICIENT + VOID COEFFICIENT 
CATEGORY 6

REACTOR TRANSIENTS, KINETICS, AND STABILITY

6-10654 GREEBLER P + HUTCHINS BA + KELLEY MO

FLUZ - A COMPUTER CODE FOR ANALYZING THE REACTOR RESPONSE TO SMALL REACTIVITY OSCILLATIONS GENERAL ELECTRIC COMPANY, SAN JOSE, CALIFORNIA

GEAP-4580 +. 51 PAGES, MARCH 22, 1965, CFSTI, \$3.00 CY

FLUZ COMPUTES TO THE FIRST ORDER TO AMPLITUDES AND PHASE ANGLES OF THE OSCILLATING POWER AND - FEEDBACK REACTIVITY OF A FAST REACTOR, WHICH IS OSCILLATING ABOUT CRITICALITY DUE TO AN IMPRESSED. SINUSOIDAL REACTIVITY OF GIVEN AMPL ITUDE AND FREQUENCY. BY VARYING "THIS AMPLITUDE AND FREQUENCY. AS WELL AS THE STEAOY-STATE PONER, FLUZ CAN BE USED TO SIMULATE THE POWER RESPONSE OF THE REACTOR BEING STUDIED TO THE, MAGNITUDES OF VARIOUS COEFFICIENTS OF REACTIVITY. A COMPARISON OF THE FLUZ RESULTS WITH EXPER IMENTAL RESULTS FROM OSCILLATION - TEST.S ON THE ACTUAL REACTOR CAN BE USED TO REVEAL THE MAGNITUDES OF THE VARIOUS REACTIVITY COEFFICIENTS.

COMPUTER, DIGITAL + FLUCTUATION + TRANSFER FUNCTION

6-10658 MERRILL M

BLOOST-5. A COMBINED REACTOR KINETICS-HEAT TRANSFER CODE FOR THE IBM-7044. PRELIMINARY OESCRIPTION GENERAL ATOMIC

GAMD-6644(ADD.) +. 5 PAGES, NOVEMBER 9, 1965, CFSTI, \$1.00 CY, \$0.50 MN

A MODIFICATION HAS BEEN MADE IN BLOOST-5 TO PERMIT USING THE HEAT-TRANSFER SUBROUTINES TO DESCRIBE THE ENTIRE CORE INSTEAD OF A SINGLE AVERAGE FUEL ELEMENT.

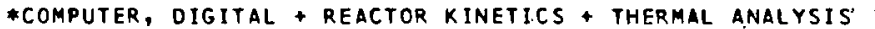

E-10667 PETERSON RE + GOLOSMITH S

FAST REACTOR SAFETY CONSIDERATIONS RELATED TO FUEL MACROSTRUCTURE

BATTELLE-NORTHWEST

BNHL-SA-346 + CONF-651009-3 +. 19 PAGES, OCTOBER 6,1965 , CONFERENCE ON SAFETY, FUELS AND CORE DESIGN IN LARGF FAST POWFR REACTORS, ARGONNE, ILL., CFSTI, \$1.00 CY, \$0.50 MN

INFLUENCE OF FUEL SEGREGATION ANO OF DELAY OF FUEL EXPANSION ON PROMPT EXCURSIONS IN FAST REACTORS.

*FUEL SEGREgATION + \#PROMPT CRITICALITY + \#REACTOR, FAST + FUEL EXPANSION COEFFICIENT

6- 10685 SMETS HB

REACTOR SAFETY RESEARCH. WATER REACTOR BEHAVIOR DURING RAPIO POWER VARIATIONS SUBJECT OF INTERNATIONAL MEETING

EUROPEAN NUCLEAR ENERGY AGENCY

2 PAGES, NUCLEAR NEWS 9(7) $32-33$ (JULY 1966)

FRENCH WORK ON ALUMINUM ANO METALLIC URANIUM PLATES, PLANS FOR OXIDE TESTS IN FLUX TRAPS. RRTTISH WORK ON FUNDAMENTAL PRINCIPLES, SPECIFICALLY, H. B. HALL, OF MANCHESTER, WOPKS ON TRANSIENTS, PRESSURES, AND MECHANISM OF TRANSIENT BOILING. GRENOBLE HORK ON OUT-OF-PILE LOOPS, TRW WORK. SAMUELS (UK) MOCKUP OF SL-1. PASCOUET (FRANCE) SIMULATION OF REACTOR EXCURSIONS BY PROGRAMMEC CHANGES. CABRI REACTOR (SIMILAR TO SPERTI). H. BLANC (FRANCE) CALCULATED REACTOR-ACCIDENT MODEL. BIRKHOFER AND KARWAT (GERMANY), SPACE-TIME CALCULATIONS ON POWER EXCURSIONS IN OXIDE-HATER REACTORS.

*FRANCE + *GERMANY + *REACTOR TRANSIENT + *UNITED KINGOOH + EXCURSION, LARGE + EXPLOSIVE, CONVENTIONAL + HEAT TRANSFER, BOILING + PRESSURE, INTERNAL + REACTOR, POOL TYPE + REACTOR, WATER + SPACE DEPENDENT DYNAMICS + THERMAL ANALYSIS

6-10686 FIRSTENBERG A + NEAL LG

KINETIC STUDIES OF HETEROCENEOUS WATCR RCACTORS, QUARTLRLY PROGRESS REPORT FOR MARCH 31 , 1966 TRH SYSTEMS, REDONDO BEACH, CALIFORNIA

STL-372-38 +. 48 PAGES, 24 FIGURES, 2 TABLES, 9 REFERENCES, APRIL 15, 1966

SIMULTANEOUS MEASUREMENT OF POWER, INLET FLOW RATE, INLET SUBCOOLING EXIT VOID FRACTION AND EXIT MOMENTUM FLUX IN THE GEOMETRY OF A SIMULATED SPERT IA MODERATOR-COOLANT CHANNEL AT ATMOSPHERIC PRESSURE. MEASUREMENT OF BOTH MASS FLUX AND MOMENTUM FLUX ALLOWS US TO DEFINE AND EVALUATE A SINGLE PARAMETER CHOSEN TO CHARACTERIZE THE DISTRIBUTIONAL EFFECTS. 1 . SOME FRACTION OF LIQUID IS ENTRAINED IN THE VAPOR PHASE TRAVELING AT THE VAPOR VELOCITY. 2 . A LIQUID FILM OF UNIFORM THICKNESS EXISTS AT THE CHANNEL WALL AND THE LIQUID VELOCITY VARIES LINEARLY WHILE THE VAPOR VELOCITY IN THE CORE OF THE CHANNEL IS UNIFORM.

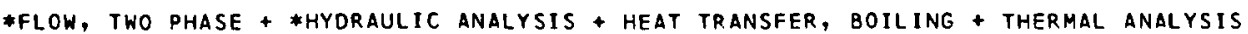

E-10688 OCCHIPINTI BB

XENON AND SAMARIUM TABLES

SAVANNAH RIVER LABORATORY, AIKEN, SOUTH CAROLINA

DP-958 +. DOCUMENT REVIEHED IN NUCLEAR NEWS $9(8)$ - 29 (AUGUST 1966). 223 DOCUMENT PAGES, CFSTI, \$6.00

CY, $\$ 1.25 \mathrm{MF}$

XENON AND SAMARIUM TABLES FOR CALCULATING THE REACTIVITY TRANSIENTS THAT RESULT FROM XE-135 OR SM-149 POISONING IN ANY THERMAL REACTOR USING U-235 AS PRINCIPAL FUEL, AND TABLES FOR THE. CHANGE IN REACTIVITY HELD IN XE AFTER STEP REDUCTIONS IN POHER. TABLES COVER A RANGE OF POWER FROM O TO 500 MW/KG. 
CATEGORY 6
REACTOR TRANSIENTS, KINETICS, AND STABILITY

6-10688 *CONTINUED*

\#REACTOR TRANSIENT + \#XENON

6-10689 TORLIN BZ

CALCULATION OF WEAK SELF-OSCILLATION REGIMES IN NUCLEAR REACTORS

9 PAGES, 3 FIGURES, 2 REFERENCES, JOURNAL OF NUCLEAR ENERGY 20(6)- 485-493 (JUNE 1966)

A PROCEDURE IS GIVEN FOR MAKING AN APPROXIMATE CALCULATION OF THE DARAMETERS ASSOCIATED WITH SELF-OSCILLATION REGIMES OF NUCLEAR REACTORS WHEN THE AMPLITUDE OF THE POWER OSCILLATIONS IS SMALL. AN EQUATION IS OBTAINED WHICH, WITHIN THE FRAMEWORK OF THE APPROXIMATIONS MADE, PERMIIS ONE TO DETERMINE THE FREQUENCIES OF THE POSSIBLE SELF-OSCILLATION STATES OF THE REACTOR, THE AMPLITUDE OF THE REACTIVITY AND DOWER OSCILLATIONS, ANO THE PHASE DIFFERENCE BETWEEN THESE OSCILLATIONS.

* REACTOR DYNAMICS + TRANSFER FUNCTION

6-10690 KRASNOYAROV NV + NIKOLSKII RV + EFIMOV IA

POWER EFFECTS IN THE BR-5 REACTOR

6 PAGES, 4 FIGURES, I TARLE, 9 REFERENCES, JOUPNAL OF NUCLEAR ENERGY 20(6)- 503-508 (JUNE 1966)

THE RESULTS OF AN EXPERIMENTAL STUDY OF THE POWER COEFFICIENT OF REACTIVITY IN THF BR-5 REACTOR AT DIFFERENT COOLANT FLOW RATES ARE DISCUSSED. A METHOD IS DESCRIBED FOR DETERMINING THE COMPONENT OF THE POWER EFFECT ASSOCIATEO WITH THE HEATING OF THF FUEL-ELEMENT CORES.

POWER COEFFICIENT + UNION OF SOVIET SOCIALIST REPUBLICS

6-10691 CHEL INTSEV NG

REPRESENTATION OF REACTOR DYNAMICS EQUATIONS IN TERMS OF A RECIPROCAL PERIOD

3 PAGES, 3 REFERENCES, JOURNAL OF NUCLEAR ENERGY 20(5)-433-435 (MAY 1966)

GENERALIZED TREATMENT OF REACTOR DYNAMICS EQUATION, WHICH YIELOS THE IN-HOUR EQUATION AS A SPECIAL CASE, AND YIELDS SOLUTION FOR ARRITRARY TIME-DEPENDENCE OF THE REACTIVITY TRANSFER FUNCTION.

* REACTOR DYNAMICS + EQUATION, IN HOUR + TRANSFER FUNCTION

6-10692 WALLACE SK + TEARE KR + GREEN JB

METHODS FOR THE COMPARISON OF PULSED-NEUTRON SHUTDOWN MEASUREMENTS WITH THEORY

ROLLS-ROYCE + ASSOCIATES LIMITED, DERBY, FNGLAND

6 PAGES, 1 FIGURE, 1 TABLE, 12 REFERENCES- NUCLEAR SCIENCE AND ENGINEERING 25(4), 407-412 (1966)

DISCUSSION OF VALIDITY OF THE PULSED-NEUTRON EXPERIMENTS FOR CHECKING CORE-SHUTOOWN

CALCULATIONS. ANALYSIS OF EXPERIMENTAL METHODS IS BASED ON ENERGY-DEPENDENT DIFFUSION THEORY, SINCE THIS, IN ITS FEW-GROUP FORM, IS THE USUAL CORE-DESISN MODEL. COMPARISON OF EXPER IMENTAL AND THEORETICAL VALUES OF THE FUNDAMENTAL-MOOE PROMPT-DECAY CONSTANT IS A VALID CHECK, BUT GARELIS AND RUSSELL METHOD BASED ON CERTAIN ASSUMPTIONS. EXPERIMENTER SHOULD CHECK EXTENT TO WHICH THESE ASSUMPTIONS ARE VIOLATED.

PULSED NEUTRON TECHNIQUE + SHUTDOWN MARGIN

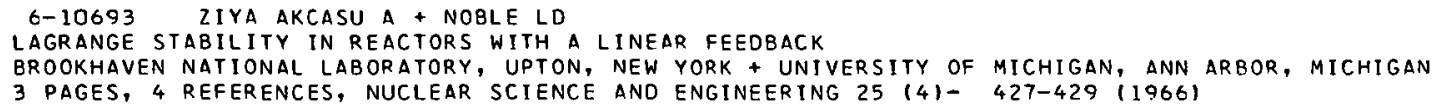

TWO CRITERIA FOR THE LAGRANGE STABILITY IN REACTORS WITH AN ARBITRARY LINEAR FEEDBACK HAVE BEEN DER I VED.

REACTOR STABILITY

6-10694 KAPLAN S + YASINSKY JB

NATURAL MODES OF THE XENON PROBLEM WITH FLOW FEEDBACK--AN EXAMPLE

BETTIS ATOMIC POWER LABORATORY + WESTINGHOUSE ELECTRIC CORPORATION, WEST MIFFLIN, PENNSYLVANIA

9 PAGES, 8 FIGURES, 1 TABLE, 9 REFERENCES, NUCLEAR SCIENCE ANO ENGINEERING 25 (4)- 43 T-438 (1966)

THE PHYSICAL QUESTICN OF THE SPATIAL STABILITY OF A REACTOR WITH RESPECT TO XENON OSCILLATIONS CORRESPONOS TO A MATHEMATICAL QUESTION REGAROING THE LOCATION IN THE COMPLEX PLANE OF THE ROOTS OF A CEPTAIN EIGENVALUE PROBLEM. THE INTRODUCTION OF FEEDRACK CONTROLLERS CORRFSPONDS TO THE IMPOSITION OF CONSTRAINTS ON THE EIGENVALUE PROBLEM. THE EFFECT OF CERTAIN SUCH CONSTRAINTS ON THE LOCATIONS OF THE EIGENVALUES IS EXAMINED IN THIS PAPER FOR THE IDEALIZED CASE OF A ONE-GROUP UNIFORM-RING REACTOR. IT IS FOUND THAT THE EIGENVALUES OBEY $\triangle$ RULE RELATED TO RAYLEIGHS SEPARATION THEOREM FOR VIBRATING MECHANICAL SYSTEMS. A NUMERICAL EXAMPLE IS GIVEN IN WHICH THE SOLUTIONS OF THE CONSTRAINED EIGENPROBLEM ARE OISPLAYED, INTERPRETED PHYSICALLY, AND COMPARED WITH THOSE OF THE UNCONSTRAINED PROBLEM.

REACTOR STABILITY + XENON OSCILLATION 
CATFGORY

REACTOR TRANSIENTS, KINETICS, AND STABILITY

6-10695 LONG JK + MCVEAM RL + REYNOLDS AB + STEWART SL + WEITZBERG A + LERIDON A

CRITICAL MASS OF SEFOR MOCKUP IN ZPR-III

ARGONNE NATIONAL LABORATORY, IOAHO FALLS, IOAHO + GENERAL ELECTRIC COMPANY, SAN JOSE, CALIFORNIA + CENTRE D ETUDES NUCLEAIRES DE CADARACHE, FRANCE

2 PAGES, 1 FIGURE, 1 TABLE, 12 REFERENCES, NUCLEAR SCIENCE ANO ENGINEERING 25 (4)- $442-443$ (1966)

CRITICALITY OF THE MOCKUP OF THE SCUTHHEST EXPERIMENTAL FAST OXIDE REACTOR (SEFOR) IN THE ZPR-III FACILITY WAS ACHIEVED NOVEMBER 17, 1965. THE NEUTRON SPECTRUM AND URANIUM-TO-PLUTONIUM RATIO OF THIS ALL-PLUTONIUM CRITICAL IS CHARACTERISTIC OF LARGE, FAST, CERAMIC POWER REACTORS. THE CRITICAL LOADING WAS THE FIRST IN A SERIES OF EXPERIMENTS.

*SEFOR (SOUTHHEST EXP. FAST OXIDE REACTOR) + CRITICAL ASSEMBLY FACILITY + CRITICALITY EXPERIMENT + REACTOR, BREEDER + REACTOR, FAST + ZPR III (ANL ZERO POWER REACTOR)

6-10696 MIHALCZO JT

URANIUM 193.2 PERCENTI METAL CYLINDERS HITH THIN STAINLESS-STEEL REFLECTORS

OAK RIDGE NATIONAL LABORATORY, OAK RIDGE, TENNESSEE

2 PAGES, 1 TABLE, 2 FIGURES, 9 REFERENCES, NUCLEAR SCIENCE AND ENGINEERING 25 (4)- 444-445 (1966)

THF POSSIAI.E USE OF STAINLESS-STEEL REFLECTORS TO FLATTEN THE FISSION-DENSITY DISTRIBUTION IN SUPERPROMPT-CRITICAL FAST-BURST REACTORS MOTIVATED A SERIES OF EXPERIMENTS IN WHICH THE PROMPT-NEUTRON DECAY CONSTANT AT DELAYED CRITICAL HERE MEASURED BY THE ROSSI-ALPHA TECHNIQUE. FOR REACTORS OF THIS TYPE. THE RESULTS INDICATE QUALITATIVELY THE EFFECT OF THE REFLECTOR ON THE BURST SHAPE AND VERIFY THE S-SUB-N METHOD OF CALCULATION USING PUBLISHED VALUES OF THE CROSS SECTIONS FOR STAINLESS STEEL.

*REACTOR, FAST BURST + \#REFLECTOR + *STEEL, STAINLESS + ROSSI aLPHA

6-10697 SMETS HB

ON THE EFFECT OF DELAYED NEUTRCNS IN REACTOR DYNAMICS

EUROPEAN NUCLEAR ENERGY AGENCY, OECD, PARIS, FRANCE

6 PAGES, 8 FIGURES, 15 REFERENCES, NUCLEAR SCIENCE AND ENGINEER ING 25(3)- 236-241 (JULY 1966)

A STUDY OF LINEARIZED REACTOR DYNAMICS EQUATIONS SHOWS THAT DELAYED NEUTRONS DO NOT ALWAYS IMPROVE THE STABILITY OF NUCLEAR REACTORS AT POWER LEVEL AND THAT A REACTOR MAY BE UNSTABLE ALTHOUGH IT IS STABLE WHEN DELAYED NEUTRONS ARE NEGLECTED. THE CRITICAL POWER FOR

INSTABILITY AND THE DAMPING OF NATURAL OSCILLATIONS ARE LARGER WHEN DELAYED NEUTRONS ARE TAKEN INTO ACCOUNT IN THE CASE OF LOH-PASS PHASE-LAGGING-REACTIVITY FEEDBACKS, BUT THIS PROPERTY IS NOT TRUE FOR ALL TYPES OF FEEDBACKS.

*DELAYED NEUTRON + *REACTOR OYNAMICS + REACTOR STABILITY

6-10698 KEANE A

AN ESTIMATE OF THE DECREASE IN THE EFFECTIVE RESONANCE INTEGRAL DUE TO RESDNANCE OVERLAP HOUSTON UNIVERSITY, HOUSTON, TEXAS

3 PACES, I TABLE, ? ReTLRENC[S, NUCLEAR SCIENCE AND ENGINEERING 25(3)- 296-298 (JULY 1966)

A SIMPLE MODEL IS INVESTIGATED ANALYTICALly WHICH SHOWS THE RANGE OF VALIDITY OF AND THE CORRECTION NECESSARY TO ROHLANOS FORMULA AND PROVIDES AN ALTERNATIVE EXPRESSION FOR THOSE CONCENTRATIONS WHERE HIS FORMULA HAS ITS GREATEST ERROR.

*Doppler EFFECT

6-10709 EICKELPASCH N

NUCLEAR SAFETY IN THE DESIGN OF POWER REACTORS

NUCLEAR ENERGY AND RADIATION PROTECTION GROUP, GERMANY, TECHNISCHER UBERHACHUNGSVEREIN BAYERN

ORNL-TK-YjU +. 14 PAGES, 2 TABLES, 2 FIGURES, TRANSLATED FROM ATOMKERNENERGIE 10 (5-6)- 187-190 (1965)

THE MOST IMPORTANT SAFETY FEATURES OF POHER REACTORS ARE LISTED, AND THEIR MECHAN.ISM OF ACTION IS EXPLAINED. THE IMPORTANCE OF THE REACTIVITY COEFFICIENTS IS ILLUSTRATED IN PARTICULAR WITH THE EXAMPLE OF SPECIAL REACTOR ACCIDENTS. A CONCEPT OF THE ORDER OF MAGNITUDE OF THE SAFETY FACTORS CITED IS TO BE ESTABLISHED.

FAILURE, FUEL ELEMENT + FUEL MELTDOWN + GERMANY + REACTIVITY COEFFICIENT + REACTIVITY, EXCESS + REACTOR, BOILING WATER + REACTOR, PRESSURIZED WATER + SAFETY PRINCIPLES ANO PHILOSOPHY

6-10714 DIETZ KA + MELLOH EW + PACE NE

QUARTERLY TECHNICAL REPORT - STEP PROJECT - JULY 1964-SEPTEMBER 1964 - OCTOBER 1964-DECEMBER 1964 PHELLIPS PETROLEUM COMPANY, IDAHO FALLS, IOAHO

IDO-17077+. 219 PAGES, 154 FIGURES, 29 TABLES, 37 REFERENCES, MARCH 1966, CFSTI, \$6.00 CY, \$1.25 MN

BRIEF DISCUSSION OF ANALYSIS OF SNAPTRAN 2/10A-3 FUEL HATER-IMMERSION TEST. SNAPTRAN 2/IOA-1 NON-DAMAGE, STEP-REACTIVITY-INSERTION, TRANSIENT TESTS. EXPERIMFNTAL MEASUREMENTS AND INSTRUMENTATION. TESTS INITIATED FROM AMBIENT TEMPERATURES OF LESS THAN IOO F. DIGITAL COMPUTER CALCULATIONS OF THE POHER AND ENERGY RESPONSE OF THE SNAPTRAN $2 / 10 A-1$ REACTOR DURING AN IMPULSE REACTIVITY INSERTION. PROPOSED SNAPTRAN $2 / 10 A-2$ DESTRUCTIVE TEST.

\# SNAPTRAN (SNAP TRANSIENT REACTOR TEST SERIES) + COMPUTER, DIGITAL + REACTOR TRANSIENT + TEST, DESTRUCTIVE 
CATEGORY $\rightarrow 6$

REACTOR TRANSIENTS, KINETICS, AND STABILITY

6-10715 FAST REACTOR SAFETY STUDIES

ARGONNE NATIONAL LABORATORY, ARGONNE, ILLINOIS

ANL-7175+.. 10 PAGES, 5 FIGURES, PP. $175-184$ OF ARGONNE NATIONAL LARORATORY CHEMICAL ENGINEFRING DIVISION RESEARCH HIGHLIGHTS, MAY 1965 - APRIL 1966 , CFSTI, \$6.00 CY, $\$ 1.25 \mathrm{MF}$.

HOT MATERIAL DROPPED INTO LIQUID SOOIUM AND CONSFQUENCES EXAMINEO AND DISCUSSED. SWINGING-ARM TECHNIQUE OF STUDYING TRANSIENT HEAT TRANSFER FROM SMALL PARTICLES. ITHE PPECEDING ITEMS HAVE BEEN PREVIOUSLY REPORTED IN MONTHLY REPORTSI. PLANS FOR STUDY OF FUEL SEGPEGATION IN MIXED URANIUM-PLUTONIUM COMPOUNDS FOR DETERMINATIONS OF HIGH-TFMPERATURE PHYSICAL PROPERTIES OF FAST-REACTOR MATERIAL. STUDIES OF SODIUM-AIR REACTION (ALSO PREVIOUSLY REPOPTED IN MONTHLY REPORTSI.

\#REACTOR, FAST + \#THERMAL ANALYSIS + FIRE + FUEL MELTDOWN + FUEL SEGREGATION + HIGH TEMDFRATURE + PROPERTY, PHYSICAL + SODIUM

6-1071E MAGNUSON DW

STATIC AND DYNAMIC TRANSPORT CALCULATIONS FOR PULSED-NEUTRON EXPERIMENTS WITH SPHERES OF URANYL NITRATE SOLUTION

OAK RIDGE NATIONAL LABORATORY, OAK RIDGE, TENNESSEE

ORNL-TM-1213 +. 15 PAGES, 1 FIGURE, 3 TABLES, APRIL 26, 1968, CFSTI, \$1.00 CY, \$0.5त MN

IN STATIC REACTOR CALCULATIONS, THE NEUTRON BALANCE is MAINTAINEO BY ACDING NEUTRONS AT FISSION ENERGIES. IN DYNAMIC REACTOR CALCULATIONS, THE BALANCE MAY BE MAINTAINED BY ADDING NEUTRONS WHICH HAVE A SPECTRUM PROPORTIONAL TO THE FLUXES AND INVERSELY PROPORTIONAL TO THE NEUTRON VELOCITY. SINCE THE NEUTRONS $\triangle D O E D$ IN THE TWO METHODS HAVE UNEQUAL IMPORTANCES, THE REACTIVITIES ARE UNEQUAL. CALCULATIONS FOR APPLICATION TO PULSED-NEUTRON EXPERIMFNTS ON SPHERES OF URANYL NITRATE SOLUTION.

\#PULSED NEUTRON TECHNIQUE

6-10717 FOULKE LR + GYFTOPOULOS EP THE.USE OF OSCILLATION TESTS TC INVESTIGATE FLUX TIL̈TING MASSACHUSETTS INSTITUTE OF TECHNOLOGY, CAMBRIDGE, MASSACHUSETTS

4 PAGES, 1 FIGURE, 6 REFERENCES, 1966 ANNUAL MEETING AMERICAN NUCLEAR SOCIETY, DENVER, COLORADO, JUNE

20-23, 1966, TRANSACTIONS OF AMERICAN NUCLEAR SOCIETY 9111- 271

SMALL-AMPLITUDE OSCILLATION TESTS CAN BE USED TO MEASURE CERTAIN MODAL EIGENVALUES, WHICH MAY BE USED TO INFER THE SUSCEPTIBILITY OF A POWER REACTOR TO FLUX TILTING. THE PROCEDURE HAS BEEN APPLIED BOTH TO COMPUTER EXPERIMENTS AND TO EXPFRIMENTAL DATA FROM THE NORA REACTOR., WITH SATISFACTORY RESULTS. IT IS SUGGESTED THAT THE OSCILLATION TECHNIQUE BE USED TO MONITOR CHANGING SPACE-TIME CHARACTERISTICS OF A REACTOR CORE DURING ITS LIFETIME.

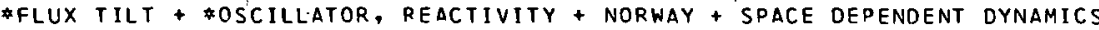

6-10718 BROWN CL

CRITICALITY SAFETY OF PUO2-SS DRIVER FUEL IN THE FFTF

BATTELLE-NORTHWEST, PACIFIC NORTHWEST LABORATORY, RICHLAND, WASHTNGTON

BNWL-222 + PAGES 10-11 OF PHYSICS RESEARCH QUARTERLY REPORT - OCTOBER, NOVFMBER, OFCEMRER I9G5. JANUARY

14,1966, CFSTI, $\$ 2.00 \mathrm{CY}, \$ 0.50 \mathrm{MN}$

UPDATES, IN THE LIGHT OF SLIGHT DESIGN CHANGES, THE REACTIVITY SAFETY CALCULATIONS OF THE PLUTONIUM OXIDE-STAINLESS STEEL DRIVER IN THE FFTF.

*FAST NEUTRON + \#HANFORD SITE + REACTIVITY, EXCESS + REACTOR, TEST

6-10719 GARLID KL + BIERMAN SR

APPLICATIONS OF PULSED NEUTRON MEASUREMENTS IN VERY LARGE SYSTEMS

BATTELLE-NORTHWEST, PACIF IC NORTHWEST LABORATORY, RICHLANO, WASHINGTON

BNWL-222 +. PAGES 12-23 OF PHYSICS RESEARCH QUARTERLY REPORT - OCTOBER, NOVEMBER, DECFMRER I965. JANUARY 14,1966 , CFSTI. \$2.00 CY, $\$ 0.50 \mathrm{MN}$

THE PURPOSE OF THIS WORK IS TO SEE IF USEFUL INFORMATION CAN BE OBTAINED FROM PULSED-NEUTRON EXPERIMENTS IN VERY LARGE MEDIA AND TO AT LEAST EXPLORE AND EXAMINE THE BEHAVIOP OIF TRANSIENT NEUTRON POPULATIONS IN SUCH MEDIA. THEORETICAL APPROACHES AND EXPERIMENTAL MEASIJREMENTS ARE DE SCR IBED.

*PUL SED NEUTRON TECHNIQUE + \#REACTOR, LARGE + CONTAINMENT, FUEL REPPOCESSING + FUEL STORAGE +

SPACE DEPENDENT DYNAMICS + WASTE STORAGE

6-10800 CHEZEM CG

ON POWER TRANSIENTS IN PROPULSION REACTORS INDUCED BY WATER INJECTION

LOS ALAMOS SCIENTIFIC LABORATORY, LOS ALAMOS, NEW MEXICO

LA-3428-MS +. 54 PAGES, 10 FIGURES, 2 TABLES, 11 REFERENCES, DECEMBER 1965, CFSTI, \$3.0N CY, SO.5O MN

MAGNITUDE OF THE NUCLEAR TRANSIENT RESULTING FROM THE INFLOW OF WATER INTO THE CORE OF A NERVA-TYPE REACTOR. CORE ASSUMED TO BE AN AKRAY UF SMALL CIRCULAR HOLES PENETRATING A THICK SOLID. INITIALLY WATER ENTERS THE ARRAY, AND THE WATER-AIR INTERFACE IS ADVANCED THROUGH THE CHANNELS IN SMALL STEPS, OURING WHICH STEAOY-STATE CONDITIONS OF FLOW, HEAT CONDUCTION, AND NUCLEAR-RADIATION HEATING ARE ASSUMED TO EXIST. REACTIVITY IS ADOED AS AN EMPIRICAL FUNCTION OF WATER PENETRATION. CORE POWER TIME PROFILE IS TRACED.

$$
\text { ACCESSION NUMBER 6-10715 TO 6-10800 }
$$


6-10801 SINGH RS + HUMMEL H.H

PARAMETRIC STUDIES OF THE REACTIVITY COFFFICIENTS FOR LARGE U-233-TH-FUELED FAST REACTORS

ARGONNE NATIONAL LABORATORY, ARGONNE, ILLINOIS

ANL-6930 +. 28 PAGES, 11 FIGURES, 12 TABLES, 22 REFERENCES, JANUARY 1966, CFSTI, \$2. DO CY, \$O.50 MN

COMPOSITION AND TEMPERATURE-DEPENDENT CROSS SECTIONS FOR THORIUM EVALUATED BY LATEST PESONANCE PARAMETERS. SODIUM-VOID COEFFICIENT STUDIED OVER A RANGE OF COMPOSITIONS AND SIZES OF CORE FOR METAL AND OXIDE FUELS. EFFECT OF U=234 AND FISSION PRODUCTS. DOPPLER EFFECT CALCULATED FOR METAL- AND OXIDE-FUELED SYSTEMS. EVEN WITH PRESENT CROSS-SECTION UNCERTAINTIES, THE REACTIVITY CHANGES DUE TO SODIUM LOSS AND THE DOPPLER EFFECT ARE ENCOURAGING FOR FAST BREEOER REACTORS WITH VERY LARGE SINGLE CORES IF U-233 AND THORIIIM ARF THF FIIFI. .

\#DOPPLER COEFFICIENT + \#REACTOR, FAST + \#SODIUM COEFFICIENT + REACTOR, LARGE + THORIUM

6-10802 THIE JA

NOISE ANALYSIS IN REACTOR SAFETY

8 PAGES, 3 TABLES, 4 FIGURES, 58 REFERENCES, NUCLEAR SAFETY, $7(3)$, PAGES 271-278 (SPRING, 1966 ), GP0, \$0.55

THE APPLICATIONS OF TECHNIQUES IN THE FIELD OF REACTOR NOISE (OR RANDOM POWER FLUCTUATIONSI TO REACTOR SAFETY ARE REVIEWEO. TABULATIONS ARE GIVEN OF NEARLY ALL THE APPLICATIONS TO DATE, BOTH IN ZERO-POWER REACTORS ANO IN POWER REACTORS. THESE CONTRIBUTE TO SAFETY BY DETERMINING THE REACTIVITY SHUTDOWN MARGIN, MONITORING FOR POSSIBLE INSTABILITIES, AND ASSISTING IN UNDERSTANDING THE DYNAMIC PROCESSES IN THE REACTOR. EXAMPLES OF RECENT WORK ARE GIVEN ALONG WITH AN EXTENSIVE BIBLIOGRAPHY, THE SIGNIFICANCE OF VARIOUS EXPERIMENTAL APPLICATIONS IS POINTED OUT, WITH COMMENTS REGARDING THEIR FUTURE PROMISE.

NOISE ANALYSIS + REACTOR STABILITY + SHUTDOWN MARGIN + SPACE DEPENDENT DYNAMICS

6-10803 8ENNETT RA + SCHMID LC

APPROACH TO CRITICAL AND CALIBRATION EXPERIMENTS IN THE PLUTONIUM RECYCLE CRITICAL FACILITY HANFORD ATOMIC PRODUCTS OPERATION

HW-80206 +. 54 PAGES, 23 FIGURES, REFERENCES, JULY, 1964 , CFSTI, $\$ 3.00$

INITIAL AFPROACH TO CRITICAL EXPERIMENT AND POWER LEVEL, CONTROL ROD, AND MODERATOR-LEVEL CALIBRAT: ON EXPERIMENTS IN THE PRCF MODERATED WITH D2O. IN A FEW CASES, THE EXPERIMENTAL RESULTS ARE COMPARED WITH ANALYTICAL RESULTS, USING THREE-GROUP DIFFUSION THEORY. RFACTOR CRITICAL AT A MODERATOR LEVEL OF 105 IN., WITH 25 URANIUM DIOXIDE FUEL CLUSTERS SURROUNDED BY 30 PU-AL FUEL CLUSTERS AT AN 8-IN. LATTICE SPACING. CONTROL RODS WORTH APPROXIMATELY 2 MK. MODERATOR-LEVEL COEFFICIENT OF REACTIVITY IS 0.16 MK/IN. AT 105 IN.

*CONTROL ROD WORTH + \$MODERATOR COEFFICIENT + HEAVY WATER + PLUTONIUM

6-10804 IOTINEN VO + SCHMID LC

THE D20 MODERATOR LEVEL COEFFICIENTS OF THE PRCF

HANFORO ATOMIC PRODUCTS OPERATION

HW-81397 +. 18 PAGES, AUGUST 27,1964, CFSTI, $\$ 1.00$

MODERATOR-LEVEL COEFFICIENTS FOR THE PLUTONIUM RECYCLE CRITICAL FACILITY (PRCF) WITH D2O MODERATOR DETERMINED FOR LEVELS BETWEEN 69 IN. AND 105 IN. EFFECT OF UNMODERATED FUEL ON THE EXTRAPOLATION DISTANCE WAS ALSO INVESTIGATEC.

* moderator coefficient + Fuel element + heavy water + measurement, reactivity + plutonium

6-10805 BIERMAN SR

PULSED NEUTRON SOURCE MEASUREMENTS OF THE Z-9 CRIB

HANFORD ATOMIC PRODUCTS OPERATION

HW-80913+. 9 PAGES, MARCH 16, 1964, CFSTI, \$1.00 CY

THE PULSED-NEUTRON TECHNIQUE IS THOUGHT OF AS A DEVICE TO MEASURE THE SUBCRITICALITY OF COMPONENTS OF PLANTS WHICH HANDLE FISSIONABLE MATERIAL. THE ACTUAL EXPERIMENTS IN THE HANFORD CRITICAL MASS LABORATORY WERE DONE IN CONJUNCTION WITH MEASUREMENTS OF CRITICAL MASS, CONTROL AND SAFETY ROD WORTH, AND NEUTRON LIFETIMES. INCLUDES ANALYSIS OF THE EXPERIMENTS.

\#FUEL HANDLING + \#PULSED NEUTRON TECHNIQUE + *SHUTDOWN MARGIN + CONTROL ROD WORTH + CRITICALITY SAFETY + PROMPT NEUTRON LIFETIME + RADIOCHEMICAL PROCESSING

6-10852 BOHLANOER H + KLODT K + RUSSE S

STABILITY INYESTIGATIONS FOR BOILING WATER REACTORS. OUARTERLY REPORT NO. 4, JANUARY 1-MARCH 31, 1965 KERNENERG IEANLAGEN, ALLGEMFINF FIFKTRICITAFTS-GESELLSCHAFT, FRANKFURT, WEST GERMANY

EURAEC-1353+EUR-2328 . 60 PAGES, CFSTI, \$3.00 CY, \$0.75 MN

MAINLY A PROGRESS REPORT ON A DEVICE IN WHICH FUEL CHANNELS ARE SIMULATED AND THE STEAM VOID FRACTION MEASURED BY GAMMA RAYS. ALSO ANALYTICAL WORK ON A TRANSFER FUNCTION INVOLVING THE VOIO FRACTION. 
6-10852 *CONTINUED*

\#HYORAULIC ANALYSIS + \#REACTOR, BOILING WATER + \#THERMAL ANALYSIS + TRANSFER FUNCTION + VOID COEFFICIENT

6-10853 IFTODE I + MIKHEILE A + PURIKA I + POSHU K + STOYAN D

METHOD FOR THE INVESTIGATION OF BOILING BY AN ANALYSIS OF FLUCTUATIONS INDUCED IN A REACTOR INSTITUTUL DE FISICA ATOMICA, ACADEMIA R.P.R., BUCHAPEST

ANL-TRANS-302 + NP-13442 +. 9 PAGES, APRIL, 1963, CFSTI, \$1.00 CY, \$0.50 MN

MEASUREMENT IN THE VVR-S REACTOR OF STEAM-BUBBLE FORMATION IN AN ELECTRICALLY HEATED ALUMINUM TUBE. FREQUENCY SPECTRUM SHOWS RESOURCES BETWEEN 0.2 CPS AND 0.25 AND AT 1.5 CPS.

HEAT TRANSFER, BOILING + REACTOR, BOILING WATER + THERMAL ANALYSIS + TRANSFER FUNCTION

6-10854 HANSON JE + FIELD JH + RABIN SA

EXPERIMENTAL STUDIES OF TRANSIENT EFFECTS IN FAST REACTOR FUELS. SERIES II. MIXED OXIDE (PUOZ-UOZ) IRRAOIATIONS

EENERAL ELECTRIC COMPANY, SAN JOSE, CALIFORNIA

GEAP-4804 +. 96 PAGES, REFFRENCES, MAY, 1965, CFSTI, \$3.00 CY, \$0.75 MN

THE RESULTS OF AN EXPERIMENTAL PROGRAM TO EVALUATE THE PERFORMANCE OF NON-PREIRRADIATED FAST-CERAMIC-REACTOR FUEL UNDER CONDITIONS SIMULATING ACCIDENTAL POWER EXCURSIONS ARE PRESENTED. RESULTS FROM THREE EXPERIMENTS IN THE TREAT FACILITY USING D.250-INCH-0.D., TYPE 347 STAINLESS STEEL CLAD, 20 WEIGHT PERCENT PUO2 - 8 D WE IGHT PERCENT UO2 FUEL SPECIMENS ARE INTERPRETED WITH REGARD TO FUEL-CLADDING TEMPERATURES, FUEL VAPOR PRESSURE, THERMAL EXPANSION OF THE FUEL, AND CLADDING INTEGRITY. INCIPIENT FAILURE LIMITS FOR AXIALLY UNRESTRAINED FUEL ARE IDENTIFIED AS FUNCTICNS OF THE MAXIMUM FUEL AND CLADDING TEMPERATURES ATTAINED DURING THE TRANSIENT.

FAILURE, FUEL ELEMENT + PLUTONIUM + STEEL, STAINLESS + TREAT (TRANSIENT TEST REACTOR FACILITY)

6-10855 HAEGGBLOM H

THEORETICAL WORK FOR FAST ZERO-POWER REACTOR FRO

AKT IEBOLAGET ATOMENERGI, STOCKHOLM, SWEDEN

AE- 194 †. 45 PAGES, TABLES, FIGURES, REFERENCES, AUGUST, 1965, DEP/MN

FOR THE FRO REACTOR, CALCULATIONS OF CONTROL ROD WORTH, PROMPT NEUTRON LIFETIME, EFFECTIVE DELAYED NEUTRON FRACTION AND OTHER ITEMS. USE OF CARLSON CODES IN SPHERICAL AND CYLINDRICAL GEOMETRY, AND OF PERTURBATION THEORY AND VARIATIONAL CALCULUS.

*REACTOR, FAST + *SWEDEN + CCNTROL ROD WORTH + DELAYED NEUTRON + PROMPT NEUTRON LIFETIME

6-10856 EUROLA $T$

NOISE EXPERIMENTS WITH THE HBWR SECOND FUEL CHARGE

INSTITUTT FOR ATOMENERGI, HALDEN, NORWAY

HPR-53 +. 82 PAGES, FIGURES, TABLES, REFERENCES, DECEMBER, $1964, \cdot$ DEP/MN

THE REPORT SUMMARIZES THE HBWR EXPERIENCE IN THE STUDY OF ROILING-WATER-REACTOR DYNAMICS BY THE NOISE TECHNIQUE. THIS EXPERIENCE IS BASED ON MEASUREMENTS OF FLUCTUATIONS OF A NUMBER OF LOCAL. IN-CORE AND INTEGRAL PARAMETERS AT VARIOUS OPERATIONAL CONDITIONS AND ON STUDIES OF A SIMPLIFIED ANALOGUE SIMULATION OF THE HRWR PLANT.

*NOISE ANALYSIS + HBWR (HALDEN BOILING WATER REACTOR) + TRANSFER FUNCTION

6-10865 ASAOKAT + MISENTAR

KINETIC THEORY AND CALCULATIONS IN A FEH-ENERGY-GROUP TWO-SPACE-POINT MODEL FOR A FAST REACTOR PERIODICALLY PULSED BY REACTIVIYY VARIATIONS

EUROPEAN ATOMIC ENERGY COMMUNITY, ISPRA, ITALY

EUR-2273.E +. 37 PAGES, REFERENCES, 1965 , DEP(MN)

FOR A FAST REACTOQ. PERIODICALLY PULSED OY REACTIVITY VARIATIONS, THERE EXISTS A CONDITION FOR THE STATIONARILY PULSED OPERATION. THIS REPORT CONSISTS OF A PERIODICALLY PULSED FASY REACTOR WHICH CONSISTS OF A CORE WITH HIGHLY ENRICHED URANIUM. THE CORF IS SURROUNDED BY A REFLECTOR CONTAINING SCATTERERS IN ORDER TO GET A HIGH THERMAL NEUTRON FLUX DURING THE POWER PULSE. THE MULTIGROUP TREATMENT HAS BEEN FXTENDED BY DIVIDING THE CORE-REFLECTOR GEOMETRY INTO TWO REGIONS, THE CORE AND THE SCATTERER REGION. THE COUPLING BETWEEN THE CORE AND SCATTERER REGION DOES NOT APPEAR EXPLICITLY. THE NUMERICAL RESULTS ARE EASILY OBTAINED, BY ASSUMING THAT THE COUPLING BETWEEN THE CORE AND SCATTERER REGION DUR ING THE PULSE IS THE SAME AS IN THE STATIC CASE.

*ITALY + \#REACTOR, PULSED + MODERATOR + REACTOR, FAST

6-10874 FIRST SUPPLEMENT TO PRELIMINARY SAFETY ANALYSIS. INDIAN POINT NUCLEAR GENERATING UNIT NO. 2. CONSOLIDATED EDISON COMPANY OF NEW YORK

2 PAGES OF FIRST SUPPLEMENT TO PRELIMINARY SAFETY ANALYSIS. INDIAN POINT NUCLEAR GENERATING UNIT NO. 2 , MARCH 31,1966 , DOCKET NO. 50-247, PDR

QUESTION 2, CRITERION 4 -- LOSS OF LOAD AND LOSS OF FLOW ARF PROTECTED AGAINST BY ROD INSERTION, STEAM DUMP, AND BY ROTATIONAL INERTIA OF CONTROLLED LEAKAGE PUMPS. 
CATEGORY 6

REACTOR TRANSIENTS, KINETICS, AND STABILITY

6-10874 \#CONTINUED*

* DESIGN CRITERIA + \#LOSS OF FLOH + \#LOSS OF LOAD + \#REGULATION, AEC +

* SAFEGUARDS REPORT, RESPONSE TO AEC QUESTIONS + INDIAN POINT II + REACTOR, PRESSURIZED WATER

6-10875 FIRST SUPPLEMENT TO PRELIMINARY SAFETY ANALYSIS. INOIAN POINT NUCLEAR GENERATING UNIT NO. 2. CONSOLIDATED EDISON COMPANY OF NEW YORK

5 PAGES, 1 FIGURE, I TABLE OF FIRST SUPPLEMENT TO PRELIMINARY SAFETY ANALYSIS. INDIAN POINT NUCLEAR GENERATING UNIT NO. 2, MARCH 31, 1966, DOCKET NO. 50-247, PDR

QUESTION 2, CRITERION 5 - SPATIAL-POWER-DISTRIBUTION INSTABILITIES (DUE TO XENON OSCILLATION OR MODERATOR TEMPERATURE VARIATIONS) WILL BE EXAMINED IN DETAIL. PRELIMINARY STUDIES

INDICATE THAT THESE CAN BE CONTROLLED IF NECESSARY. MOST OF THE EXPERIMENTAL DATA IS ON

STAINLESS-STEEL CORES, SO DAMPING DUE TO POWER COEFFICIENT CANNOT'BE ACCURATELY CHECKED IN $\angle I R C A L O Y-C L A D$ CORE.

\#DESTGN CRITERIA + \#REGULATION, AEC + \#SAFEGUARDS REPORT, RESPONSE TO AEC QUESTIONS + \#XENON OSCILLATION + INOIAN POINT II + MODERATOR COEFFICIENT + POWER DISTRIBUTION + REACTOR, PRESSURIZED WATER

E-10930 HARRIS OR + PRESCOP V

STABILITY AND STATIONARITY OF A REACTOR AS A STOCHASTIC PROCESS WITH FEEDBACK

WESTINGHOUSE ELECTRIC CORPORATION, BETTIS ATOMIC POWER LABORATORY

2 PAGES, 1 F!GURE, 5 REFERENCES, ANS TRANSACTIONS 9(1), PAGES 118-119 (JUNE, 1966), AMERICAN NUCLEAR SOCIETY ANNUAL MEETING, DENVER, COLORADO, JUNE 20-23, 1966

STABILITY IN THE DETERMINISTIC SENSE IS ANALOGOUS TO A CONDITION WHERE EACH STATE WILL

CERTAINLY RECUR. THE MEAN RECURRENCE TIME IS FINITE, AND A UNIQUE STATIONARY PROBABILITY DISTRIBUTION EXISTS. INSTABILITY CORRESPONDS TO A CONDITION WHERE NO STATIONARY DISTRIBUTION

EXISTS. THE PROBABILITY OF RECURRENCE IS INFINITE.

\#REATOR STABILITY

6-10931 CLARKE WG + HARRIS DR + NATELSON M + WALTER JF

VARI IANCES ANO COVARIANCES OF NEUTRON AND PRECURSOR POPULATIONS IN TIME-VARYING REACTORS WESTINGHOUSE ELECTRIC CORPORATION, BETTIS AYOMIC POWER LARORATORY

2 PAGES, 1 FIGURE, 2 REFERENCES. ANS TRANSACTIONS $9(1)$, PAGES 119-120, (JUNE, 1966), AMERICAN NUCLEAR SOCIETY ANNUAL MEETING, DENVER, COLORADO, JUNE 20-23, 1966

WHILE FIRST ANO SECOND MOMENTS OF REACTOR POPULATIONS HAVE BEEN DETERMINED FOR THE STATIONARY PROCESS (SUBCRITICAL CONSTANT REACTOR WITH SOURCE), STUDIES OF FIRST AND SECOND MOMENTS OF POPULATIONS IN TIME-VARYING REACTORS HAVE NOT APPEARED PREVIOUSLY AND ARE PRESENTED HERF. FEEDBACK IS IGNORED, SO THESE STUDIES APPLY TO STARTUP AND SUB-POWER-RANGE TRANSIENTS.

REACTOR DYNAMICS

6-10933 KESSLER WE + BROCKETT GF + B INGHAM GE ZIRCONIUM-HYDRIDE FUEL BEHAVIOR IN THE SNAPTRAN TRANSIENT TFSTS

PHILLIPS PETROLEUM COMPANY, IDAHO FALLS, IDAHO

1 PAGE, ANS TRANSACTIONS, $9(1)$, PAGE 155 (JUNE, 1966), AMERICAN NUCLEAR SOCIETY ANNUAL MEETING, DENVER, COLORADO, JUNE $20-23,1966$

FOR SNAP 1OA/2-TYPE REACTORS, REACTIVITY EXCURSIONS BELOW 1.7 DOLLARS ARE NONDESTRUCTIVELY SELF-LIMITED BY THE INHERENT TEMPERATURE-DEPENDENT NEGATIVE-REACTIVITY FEEDBACK MECHANISMS OF 12 CENTS/MW-SEC. FOR EXCURSIONS RESULTING FROM ESSENTIALLY ANY AMOUNT OF REACTIVITY $A B O V E$ 1.7 DOLLARS, THE INHERENT DISASSEMBLY CHARACTERISTICS OF THIS TYPE FUEL LIMITS THE ENERGY RELEASE TO HELL BELOW $100 \mathrm{MW}-S E C$. IN THE WATER IMMERSION TEST, RAPID COOLING OF THE FUEL LIMITED THE RELEASE OF NOBLE GASES AND THEIR DAUGHTERS TO THE ENVIRONMENT FROM THE FUEL TO I.FSS THAN 5 PERCENT OF THAT AVAILABLE IN THE FUEL. THE IODINE RELEASE WAS LIMITED TO LESS THAN 13 PERCENT OF THE AVAILABLE. IN THE AIR-ENVIRONMENT TEST, FUEL OISINTEGRATION WAS ACCOMPANIED BY HYDROGEN-OXYGEN COMBUSTION. ABOUT IOO PERCENT OF THE NUBLE GASES. AND 50 PERCENT OF THE AVAILABLE IODINE WERE RELEASED.

*FISSION GAS RELEASE + * SNAPTRAN (SNAP TRANSIENT REACTOR TEST SERIES) + DESTRUCTIVE TRANSIENT + FISSION PRODUCT RETENTION + FISSION PRODUCT, IODINE + HYOROGEN + REACTOR TRANSIENT

6- 10934 MOSS LI + JACKSON JF + RHDADES WA + GREEN WB + JOHNSON RP + DYE FC PRELIMINARY ANALYSES OF SNAPTR AN-? RATA ATOMICS INTERNATIONAL

3 PAGES, 2 FIgURES, 9 REFERENCES, ANS TRANSACTIONS, 9(1), PAGES 155+157, (JUNE, 1966), AMERICAN NUCLEAR SOCIETY ANNUAL MEETING, DENVER, COLORADO, JUNE 20-23, 1966

PEAK POWER, 78,000 MW. ENERGY RELEASE, 39 MW-SEC. TEMPERATURE COEFFICIENT DURING NONDESTRUCTIVE PART, 0.25 CENT PER DEGREE F. INITIAL REACTIVITY, 5 DOLLARS. INITIAL ASYMPTOTIC PFRINO, ?חM MICROSFC,ONDS. FUEL DISINTEGRATION BEGAN BEFORE POWER PEAK. PROGRESS OF IN-COR.E FUEL DISINTEGRATION MEASURED BY STRFAK-CAMERA PHOTOGRAPHS OF LIGHTS SHINING THROUGH COOLANT CHANNELS. 
6-10935 MCVEAN RL + GOIN RW + WEITZBERG A + LERIDON A

CRITICAL ASSEMBLY MOCKUP OF THE SEFOR REACTOR IN ZPR-3

ARGONNE NATIONAL LABORATORY, IDAHO + GENERAL ELECTRIC COMPANY, VALLECITOS ATOMIC POWER LABORATORY + CENTRE NUCLEAIRE DE CADARACHE, FRANCE

1 PAGE, 1 TABLE, 5 REFERENCES, ANS TRANSACTIONS, 911), PAGE 226 (JUNE, 1966), AMERICAN NUCLEAR SOCIETY

ANNUAL MEETING, DENVER, COLORADO, JUNE 20-23, 1966

AVERAGE CONTROL-ROD WORTH IS 117 CENTS. ONE HUNDRED, THIRTY-NINE CENTS REACTIVITY REDUCTION DUE TO HALF-INCH ELONGATION OF FUEL ROOS. MEASUREMENTS OF CENTRAL REACTIVITY WORTHS, DOPPLER EFFECT, AND ROSSI ALPHA.

\#SEFOR (SOUTHWEST EXP. FAST OXIDE REACTOR) + \#ZPR III (ANL ZERO POWER REACTOR) + CONTROL ROD WORTH + CRITICAL ASSEMBLY FACILITY + DOPPLER EFFECT + FUEL EXPANSION COEFFICIENT + REACTIVITY EFFECT + REACTOR, BREEDER + REACTOR, FAST + ROSSI ALPHA

E-10936 DAVEEY WG + $\triangle M U U N D S O N$ PI

ACTIVATION MEASUREMENTS OF THE DOPPLER EFFECT IN URANIUM-233 IN ZPR-3 ASSEMRLY 47 (SSEFOR.)

ARGONNE NATIONAL - LABORATORY, IDAHO

2 PAGES, 3 REFERENCES, ANS TRANSACTIONS, 9(1), PAGES 226-227 (JUNE, 1966), AMERICAN NUCLEAR SOCIETY ANNUAL MEET ING, DENVER, COLORADO, JUNE 20-23, 1966

DOPPLER MEASUREMENTS USING THE U-239 ACTIVATION IN HIGHLY DEPLETED URANIUM FOIL, COMPARING FOIL HEATED BY AN ELECTRIC FURNACE WITH A COLD FOIL OUTSIDE THE FURNACE. LOCAL ENVIRONMENT INFLUENCES. RESULTS BY A FACTOR OF 2.

\#DOPPLER EFFECT + \#SEFOR (SOUTHHEST EXP. FAST OXIDE REACTOR) + \#ZPR III (ANL ZERO POWEP. PEACTOR) + CRITICAL ASSEMBLY FACILITY + REACTOR, BREEDER + REACTOR, FAST

6-10937 REYNOLOS $\triangle B+$ STEWART SL

ANALYSIS OF SEFOR MOCKUP IN ZPR-III

GENERAL ELECTRIC COMPANY, SAN JOSE

2 PAGES, 13 REFERENCES, ANS IRANSACTIONS, 911), PAGES 227-228 (JUNE, 1966), AMERICAN NUCLEAR SOCIETY ANNUAL MEETING, DENVER, COLORADO, JUNE 20-23, 1966

COMPUTED REACTIVITY REDUCTION DUE TO HALF-INCH ELONGATION OF FUEL - 130 CENTS COMPARED WITH A MEASURED VALUE OF 140. COMPUTED AVERAGE CONTROL-ROD WORTH - 127 CENTS, COMPARED WITH 131 CENTS, MEASURED.

* SEFOR (SOUTHWEST EXP. FAST OXIDE REACTOR) + *ZPR III (ANL ZERO POWER REACTOR) + COMPUTER, DIGITAL + CONTROL ROD WORTH + CRITICAL ASSEMBLY FACILITY + FUEL EXPANSION COEFFICIENT + REACTOR, RREEDER + REACTOR, FAST

6-10938 DOERNER RC + KNAPP WG

STUDIES IN FAST CORES WITH LIGHT METAL ANO OXIDE REFLECTORS

ARGONNE NATIONAL LABORATORY

1 PAGE, ANS TRANSACTIONS, 9(1), PAGE 228, (JUNE, 1966), AMERICAN NUCLEAR SOCIETY ANNUAL MEETING, DENVER, COLORADO, JUNE 20-23, 1966

A SERIES OF FAST CRITICAL ASSEMBLIES WERE STUDIED IN THE ZPR-9 FACILITY TO EVALUATE THE IMPORTANT DIFFERENCES BETWEEN METAL- AND OXIDE-FUELED CORES AND BETWEEN AL, AL OXIDE, AND BEO REFLECTORS. MEASUREMENTS MADE IN EACH OF THE ASSEMBLIES INCLUDE A DETERMINATION OF THE CRITICAL MASS AND VOLUME, CENTRAL WORTHS OF U-235, U-238, B-10, C, AND HYOROGEN, ROSSI-ALPHA AND SPATIAL-DEPENDENT REACTIVITY WORTHS OF RE, GD, W, AND EU.

CRITICAL ASSEMBLY FACILITY + REACTIVITY EFFECT + REACTOR, FAST + ROSSI ALPHA + URANIUM. + URANIUM OXIDE + ZPR IX (ANL ZERO POWER REACTOR)

6-10939 HENRY AF

DEFINITION AND GENERAL CONSIDERATIONS CONCERNING LARGE CHANGES IN REACTIVITY

WESTINGHOUSE ELECTRIC CORPORATION, BETTIS ATOMIC POHER LABORATORY

2 PAGES, 1 TABLE, 10 REFERENCES, ANS TRANSACTIONS, $9(1)$, PAGES 235-236 (JUNE, 1966), AMERICAN NUCLEAR

SOCIETY ANNUAL MEETING, DENVER, COLORADO, JUNE 20-23, 1966

gIVES TABLE ANO DISCUSSION OF THE OIFFERENT DEFINITIONS OF REACTIVITY.

\#REACTOR DYNAMICS + \#SHUTDOWN MARGIN + PERTURBATION METHOD + PULSED NEUTRON TECHNIQUE

6-10940 GOZANI T

SUBCRITICAL REACTIVITY DETERMINATIONS-COMPARISON OF EXPERIMENTAL METHODS

RENSSELAER POLYTECHNIC INSTITUTE

2 PAGES, 22 REFERENCES, ANS TRANSACTIONS, 911), PAGES 236-237 (JUNE, 1966), AMERICAN NUCLEAR SOCIETY

ANNUAL MEET ING, DENVER, COL ORADO, JUNE 20-23, 1966

BASIC SUBCRITICAL METHODS FOR REACTIVITY MEASUREMENTS UTILIZING THE SOURCE-JFRK, THE ROD-DPOP, THE PULSED SOURCE, AND THE BORON HOMOGENEOUS POISONING METHODS ARE DISCUSSED AND COMPARED.

* SHUTDOWN MARGIN + PULSED NEUTRON TECHNIQUE 
CATEGOPY 6

REACTOR TRANSIENTS, KINETICS, AND STABILITY

$6-10941$ BECKER $M$

PRINCIPLES OF, AND PROBLEMS WITH, PULSED-NEUTRON REACTIVITY MEASUREMENTS

GENERAL ELECTRIC COMPANY, KNOLLS ATOMIC POWER LABORATORY

2 PAGES, 5 REFERENCES, ANS TRANSACTIONS, 911), PAGES 237-238 (JUNE, 1966), AMERICAN NUCLFAR SOCIETY ANNUAL

MEETING, DENVER, COLORADO, JUNE 20-23, 1966

SEVERAL METHODS haVE BEEN AIVANCED BY WHTCH PULSED-NEUTRON TECHNIQUFS CAN BE USED TO MEASURE THE REACTIVITY OF A SUBCRITICAL ASSEMBLY. IN THIS PAPER, WE DESCRIPE THE PRINCIPAL METHODS AND DISCUSS FACTORS THAT CAN INHIBIT THE APPLICATION DF SOME OF THESE PROCEDURES.

* SHUTdOWN MARgin + PUlsed NeUtron. techniQUe

6- 10942 HANSEN GE

SPECIAL PROBLEMS ASSOCIATED WITH THE DETERMINATION OF LAPGE NEGATIVE RFACTIVITY CHANGES IN FAST SYSTEMS LOS ALAMOS SCIENTIFIC LABORATORY

1 PAGE, ANS TRANSACTIONS, 911), PAGE 238 (JUNE, 1966), AMERICAN NUCLEAR SOCIETY ANNUAL MEFTING, DENVER, COLORADO, JUNE 20-23, 1966

FIRST-ORDER PERTURBATION THEORY YIELOS A HOST OF LINEARLY RELATEO REACTIVITY SCALES EDUALLY SUITABLE FOR EXPRESSING SMALL REACTIVITY CHANGES IN NEAR-CRIYICAL SYSTEMS. FOR SUFFICIENTLY LARGE CHANGES IN MATERIAL COMPOSITION OR DISPOSITION, SUCH REACTIVITY SCALES AS REPRDDUCTION NUMBER, FISSION-CHAIN LIFETIMF, FRACTTONAL CRITICAL MASS, ETC.. ARE NO LONGER SIMPLY RELATED. THIS PAPER REVIEWS SOME OF THE EXPERIMENTAL AND COMPUTAT IONAL DIFFICULTIES IN THE CORRELATION OF VARIOUS REACTIVITY CHARACTERIZATIONS OF HIGHLY SURCRITICAL FAST NEUTRON SYSTEMS.

\#REACTOR, FAST + *SHUTDOWN MARGIN + PERTURBATION METHOD

6-10943 ALBRECHT RW

APPLICATION OF CORRELATION TECHNIQUES TO DETERMINATION OF SIIBCRITICAL REACTIVITY

UNIVERSITY OF WASHINGTON

I PAGE, $\triangle N S$ TRANSACTIONS, 9111, PAGE 238 (JUNE, 1966), AMERICAN NUCLEAR SOCIETY ANNUAL MEETING, DENVER, COLORALO, JUNE 20-23, 1966

IN THIS DISCUSSION WF. RFVIFH THF BASIC PRINCIPLES OF THE VARIOUS STOCHASTIC METHODS THAT HAVE COME TO LIGHT, AND ATTEMPT TO ILLUMINATE, IN A OUALITATIVE WAY, THE ADVANTAGES AND

LIMITATIONS OF EACH AS A FUNCTION OF SYSTEM PARAMETERS AND THE USE TO $8 E$ MADE OF THE

INFORMATION. SOME OF THE ME THOOS HAVE BEEN MORE FULLY DEVELOPEO THAN OTHERS, OWING PRIMARILY

TO THEIR CLOSE RELATIONSHIP TO THE CAPABILITIES OF EXISTING ELECTRONIC ERUIPMENT AND THE

PART ICULAR NEEDS OF THE EXPERIMENTS PERFORMED. THUS, IT IS NOT ENTIRELY POSSIBLE TO GIVE AN

UNBIASED ESTIMATE OF THE POTENTIAL OF ALL THE AVAILABLe teChNigues.

\#SHUTDOWN MARGIN + NOISE ANALYSIS + PULSED NEUTRON TECHNIQUE

6-10944 SHOMO RB + HAMILTON GN + LEANER RD

ANALOG TOMPIJTER TFC.HNTQIIFS IN R.RITIC.AL EXPERIMENTS

HESTINGHOUSE ELECTRIC CORPORATION, ATOMIC POHCR DIVISION

1 PAGE, 1 FIGURE, 2 REFERENCFS, ANS TRANSACTIONS, 911 ), PAGE 261 (JUNE 1966), AMERICAN NUCLEAR SOCIETY ANNUAL MEEYING, DENVER, COLORADO, JUNE 20-23, 1966

EXPERIMENTS AT THE WESTINGHOUSE REACTOR EVALUATION CENTER (WREC) WERE PERFORMED ALMOST EXCLUSIVELY USING ON-LINE ANALOG COMPUTERS FOR THE MEASUREMENT OF BOTH POSITIVE AND NEGATIVE VALUES OF REACTIVITY. THIS METHOD OF REACTIVITY MEASUREMENT WAS USED IN BOTH HFAVY-WATFRAND LIGHT-WATER-MODERATED SYSTEMS ANO WITH CORES CONTAINING BOTH HIGHLY ENRICHED AND LOW-ENRICHED URANIUM FUEL, ANO RECENTLY WITH SYSTEMS CONTAINING URANIUM DIOXIDE AND PLUTONIUM/URANIUM DIOXIDE FUEL. A UNIQUE CIRCUIT HAS DESIGNED AND RUILT AT THE WREC TO IMPROVE THE ACCURACY, GAIN ANO READ-OUT TIME ON THE RECORDER.

6-10945 COIHN CE

FURTHER USE OF AN ON-I.TNF COMPUTTFR IN RFACTOR PHYSICS EXPERIMENTS

ARGONNE NATIONAL LABORATORY

1 PAGE, 3 REFERENCES, ANS TRANSACTIONS, 9(1), PAGE 262 (JUNF 1966), AMERICAN NUCLEAR SOCIETY ANNUAL MEETING, DENVER, COLORADO, JUNE 20-23, 1966

DIGITAL COMPUTER FOR ON-LINE DATA REDUCTION IN CRITICAL-ASSFMBLY EXPERIMENTS USED FOR REACTOR NOISE MEASUREMENTS, USING THE CROSS-CORRELATION TECHNIOUE TO REDUCE REQUIPEMENTS FOR DETECTOR EFFICIENCY. A STUDY LOOKING TOWARO THE AUTOMATIC CONTROL OF CRITICAL EXPERIMENTS WAS STARTEO WITH EXPERIMENTS ON THE STARTUP OF THE ZPR-9 FAST CRITICAL. UNDER COMPUTER CONTROL, THE LAST CONTROI DRAWER IS INSERTED TO TAKE THE REACTOR THROUGH CRITICAL TO $\triangle$ DEMAND PERIOD AND UP TO A DEMAND POWER.

*ZPR IX (ANL ZERO POWER REACTOR) + COMPUTER, OIGITAL + CRITICAL ASSEMBLY FACILITY + CRITICALITY EXPERIMENT + NOISE ANALYSIS + REACTOR, FAST + SHUTOOWN MARGIN

G-10946 STANLEY L + HOLLAND LK + HOLLADAY RL

DEVELOPMENT OF A CONTROL-ROD WORTH MINIMIZER

GENERAL ELECTRIC COMPANY, SAN JOSE, CALIFORNIA + CONTROL DATA CORPORATION

1 PAGE, ANS TRANSACTIONS 9(1), PAGE 265 (JUNE, 1966), AMERICAN NUCLEAR SOCIETY ANNUAL MEETING, DENVER, C.OLORADO, JUNE 20-23, 1966

THE ROD-WORTH MINIMIZER (RWM) WAS DEVELOPED FOR INCORPORATION INTO THE NUCLEAR POWER PLANT TO 
6-10946 \#CONTINUED*

SIGNIFICANTLY REOUCE THE PROBABILITY OF REACTOR-VESSEL DAMAGE DUF TO SUDOEN UNEXPECTED WITHDRAWAL OF ANY CONTROL ROD FROM THE CORE. THE RWM ENSURES THAT ALL CONTROL RODS IN THE CORE DO NOT EXCEED A PREDETERMINED ROD-WORTH LIMIT BY APPROPRIATE RESTRICTIONS ON CONTROL-ROD-ORIVE MOVEMENTS.

*CCNTROL ROD WORTH + ENGINEERED SAFEGUARD + REACTOR, BOILING WATER

6-10947 CANOSA J

THE EFFECT OF DELAYED NEUTRONS ON REACTOR EXCURSIONS WITH RAMP REACTIVITY INSERTION GENERAL ELECTR IC COMPANY, VALLECITOS ATOMIC LABORATORY

2 PAGES, 1 TABLE, 5 REFERENCES, ANS TRANSACTIONS, 9(1), PAGES 268-269 (JUNE, 1966), AMERICAN NUCLEAR SOCIETY ANNUAL MEETING, DENVER, COLORADO, JUNE 20-23, 1966

THE PROBLEM OF REACTOR EXCURSIONS WITH RAMP REACTIVITY INSERTION HAS BEEN SOLVED BEFORE IN THE PROMPT APPROXIMATION. THE SAME PROBLEM, BUT TAKING DELAYED NEUTRONS INTO ACCOUNT, HAS NOW BEEN SOLVED ANALYTICALLY, USING THE CONSTANT DELAYED-NEUTRON SOURCE APPROXIMATION. IT WAS FELT THAT THIS ASSUMPTION WAS ADEQUATE TO DESCRIBE ACCURATELY THE FIRST POWER BURST. THIS IS SHOWN TO BE THE CASE PYY THE GOOD AGREEMENT BETWEEN THE ANALYTICAL RESULTS AND THE EXACT ONES OBTAINED WITH THE TER CODE.

\#DELAYED NEUTRON + \#EXCURSION, LARGE + REACTOR DYNAMICS

6-10948. KAZI AH

ON THE EFFECT OF RAMP REACTIVITY INSERTIONS IN THE FUCHS-NOROHEIM REACTOR EXCURSION MODEL UNITED NUCLEAR CORPORATION

2 PAGES, 1 TABLE, 9 REFERENCES, ANS TRANSACTIONS, $9(1)$, PAGES 269-270 (JUNE, 1966), AMERICAN NUCLEAR SOCIETY ANNUAL MEETING, DENVER, COLORADO, JUNE 20-23, 1966

BY A COMPUTER PROGRAM, RPI, SIMILAR TO THE AIREK III PROGRAM, EXCURSIONS CAUSED RY RAMP REACTIVITY ADOITIONS ARE INVESTIGATED UNDER ASSUMPTIONS SIMIL.AR TO THOSE OF THE FUCHS-NORDHEIM MODEL.

EXCURSION, LARGE + FUCHS MODEL + REACTOR DYNAMIS.S

6-10949 HOUGHTALING. JE

AN IMPROVED MODEL FOR ANALYSIS OF FAST TRANSIENT REACTIVITY EFFECTS IN LOW-ENRICHED OXIOE-FUELED REACTORS PHILLIPS PETROLEUM COMPANY, IDAHO FALLS, IDAHO

1 PAGE, 8 REFERENCES, ANS TRANSACTIONS, 9(1), PAGE 270 (JUNE, 1966), AMERICAN NUCLEAR SOCIETY ANNUAL MEETING, DENVER, COLORADO, JUNE 20-23, 1966

SPANOS ORIGINAL DOPPLER REACTIVITY MODEL TO DESCRIBE FAST EXCURSION BEHAVIOR OF LOW-ENRICHMENT URANIUM OXIDE FUELED THERMAL REACTORS IS MODIFIED SO THAT THE NORMALIZATION OF THF COMPENSATED REACTIVITY BECOMES CONSISTENT WITH THE NORMALIZATION. USUALLY DEFINED FOR THE PROMPT NEUTRON GENERATION TIME ANO DELAYED NEUTRON FRACTION. THE MODIFIED MODEL WAS APPLIED TO FOUR EXCURSIONS IN THE SPERT I OXIDE CORE, USING C.URRENT CALCULATIONAL TECHNIOUES AND GAVE GOOD AGREEMENT WITH EXPER IMENT, WHEREAS SIMILAR APPLICATION OF THE ORIGINAL MODEL YIELDED POWER AND ENERGY ONLY HALF THAT OF THE EXPERIMENTAL DATA.

\#DOPPLER EFFECT + \#SPERT I (SPECIAL POWER EXCURSION REACTOR,TEST) + COMPUTER, DIGITAL + REACTOR, TEST + URANIUM OXIDE

6-10950 SANATHANAN CK + CARTER JC + BRYANT LT + AMIOT LW THE APPLICATION OF A HYBRID COMPUTER TO THE ANALYSIS OF TRANSIENT PHENOMENA IN A FAST REACTOR CORE ARGONNE NATIONAL LABORATORY, ILLINOIS

1 PAGE, 6 REFERENCES, ANS TRANSACTIONS, 911 ), PAGE 272 (JUNE, 1966), AMERICAN NUCLEAR SOCIETY ANNUAL MEETING, DENVER, COLORADO, JUNE 20-23, 1966

AN ITERATION PROCEDURE BASED ON THE PRINCIPAL OF CONTRACTION MAPPING AND THE USE OF AN ANALOG-DIGITAL HYBRID PROVIDE A COMPUTATIONAL METHOD FOR ANALYZING, THE TRANSIENT REHAVIOR OF A FAST REACTOR. CORE. THE ANALOG COMPONENT OF THE HYBRID SYSTEM IS USED FOR THE INTEGRATION OF THE EOUATIONS IN TIME, AND THE DIGITAL COMPONENT IS USED FOR MEMORY REOUIREMENTS, LOGIC, AND ARITHMETIC OPERATIONS.

*REACTOR TRANSIENT + *REACTOR, FAST + COMPUTER, ANALOG + COMPUTER, DIGITAL

6-10951 JACOBOWITZ HJ + AKCASU AZ + SHOTKIN LM

STABILITY CONSIDERATIONS WITH CONVECTION TIME DELAYS

NEW YORK UNIVERSITY + UNIVERSITY OF MICHIGAN + RROOKHAVEN NATIONAL LABORATORY

2 PAGES, 1 FIGURE, 4 REFERENCES, ANS TRANSACTIONS, 911), PAGES 272-273 (JUNE, 1966), AMERICAN NUCLEAR

SOCIETY ANNUAL MEETING, DENVER, COLORADO, JUNE 20-23, 1966

THE INFLUENCE OF THE TIME DELAY ON THE STABILITY IS INVESTIGATED BY THE PRINCIPLE OF PONTRYAGIN FOR THE LINEAR APPROXIMATION, AND BY THE CRITERIA DF WELTON AND AKCASU FOR THE NONL INEAR EQUATIONS. A STABILITY-REGION MAP IS GIVEN.

\#REACTOR DYNAMICS + \#REACTOR STABILITY 
CATEGORY 6

REACTOR TRANSIENTS, KINETICS, AND STABILITY

E-10952 ZIVI SM + JONES AB

AN ANALYSIS OF THE EBWR INSTABILITY BY THE FABLE PROGRAM

TRW SYSTEMS + GENERAL ELECTRIC COMPANY, SAN JOSE, CALIFORNIA

2 PAGES, 1 FIGURE, 5 REFERENCES, ANS TRANSACTIONS, 911 , PAGES 273-274 (JUNE, 1966 ), AMERICAN NUCLEAR

SOCIETY ANNUAL MEETING, DENVER, COLORADO, JUNE 20-23, 1966

THE CAUSES OF THE INSTABILITY OBSERVED IN THE EXPERIMENTAL BOILING HATER REACTOR ARE INVESTIGATED HERE BY COMPUTATIONS WITH THE FABLE COMPUTER PROGRAM OF JONES. THE PREDOMINANT MECHANISM OF THE INSTABILITY IS A HYORODYNAMIC INTERACTION BETWEEN DISSIMILAR REGIONS OF THE CORE. SUCH INTERACTIONS CAN OCCUR IN REACTORS WHEN VARIOUS FUEL ASSEMBLIES HAVE DISPAPATE STEAM VOID AND FLOW RESPONSES WITH RESPECT TO A POHER DISTURBANCE.

*COMPUTER, DIGITAL + \#EBWR (EXPERIMENTAL ROILING WATER REACTOR) + \#REACTOR STABILITY + HYDRAULIC ANALYSIS + REACTOR, BOILING HATER + THERMAL ANALYSIS

6-10953 G0ZANI T

THE DIRECT MEASURABILITY OF REACTIVITY (INI DOLLARSI AND IIS EXPERIMENTAL BOUNDS ITHE BRACKETING-PROCEDURE RENSSELAER POLYTECHNIC INSTITUTE

2 PACES, 10 REFERENCES, ANS TRANSACTIONS, 9(1), PAGES 274-275 (JUNE, 1966), $\triangle M E R$ ICAN NUCLEAR SOCIETY ANNUAL MEETING, DENVER, COLORADO, JUNE 20-23, 1966

IT IS SHOWN THAT THE GENERAL EVALUATION PROCEDURE FOR THE MODIFIED PULSED-SOURCE TECHNIQUE HAS A BASIC MER IT - IT LEADS TO BRACKETING THE VALUF OF REACTIVITY (IN DOLLARSI AND ROSSI ALPHA, WHICH ARE PERTINENT TO THE PERSISTING MODE, NAMELY, THE ABSOLUTELY TRUE VALUES IN BETWEEN TWO PURELY EXPERIMENTAL BOUNDS. THESE BOUNDS ARE DUE TO THE SYSTEMATIC ERRORS CAUSED BY HIGHER HARMONICS. THE HARMONICS HAVE OPPOSITE EFrECTS ON THE TWO MODIFIED PULSED-SOURCE TECHNIQUES.

* ReACTOR oynamics + pUl Seo neutron technique + Reactivity, excess

G-10954 WYKE TF + WILLOUGHBY W

CVTR MODERATOR TEMPERATURE COEFFICIENT AS A FUNCTION OF CORE DEPLETION

WESTINGHOUSE ELECTRIC CORPORATION, ATOMIC POWER DIVISION + CAROLINAS-VIRGINIA NUCLEAR POWER ASSOC IATION

1 PAGE, 2 FIGURES, 3 REFERENCES, ANS TRANSACTIONS, 911 ), PAFF 276 (JUNE 1966), AMERICAN NUCLEAR SOCIETY

ANNUAL MEETING, DENVER, COLORADC, JUNE 20-23, 1966

THE TREND IN THE MEASURED MODERATOR TEMPERATURE COEFFICIENT OVER THE CORE LIFETIME SHOWS A REDUCTION BY A FACTOR OF 2. ANALYSIS BASFD ON THE 4-FACTOR FORMULA SHOWS THAT A SUBSTANTIAL CONTRIBUTION TO THE CHANGE WOULD BE EXPECTED FROM THE PRODUCT OF ETA AND F. IN ADDITION, CONTROL-ROD REMOVAL AS A FUNCTION OF LIFE WOULD BE EXPECTED TO CONTRIBUTE A POSITIVE EFFECT.

*CVTR (CAROLINAS VIRGINIA TUEE REACTOR) + \#FUEL BURNUP + \#MODERATOR COEFFICIENT + REACTOR, HEAVY WATER + REACTOR, PRESSURE TUBE + TEMPERATURE COEFFICIENT

6-16955 WILL.OUGHAY W + NATH R.I + WYKF TF

COMPARISON OF ANALYTICAL AND EXPERIMENTAL LIFETIME AND CONTROL ROD WORTHS FOR CVTR

CAROLINAS-VIRGINIA NUCLEAR POWER ASSOCIATION + WESTINGHOUSE ELECTRIC CORPORATION, ATOMIC POWER DIVISION

2 PAGES, 1 FIGURE, I TABLE, 5 REFERENCES, ANS IRANSACTIONS, 9(1), PAGES 276-277, (JUNE 1966), AMERICAN

NUCLEAR SOCIETY ANNUAL MEETING, DENVER, COLORADO, JUNE 20-23, 1966

THE RESULTS OF ANALYTICAL AND EXPERIMENTAL DETERMINATIONS OF ROD GROUP WORTHS ARE GIVEN.

*CCNTROL ROD WORTH + \#CVTR (CAROLINAS VIRGINIA TUBE REACTOR) + COMPUTER, DIGITAL + FUEL RURNUP +

REACTOR, HEAVY WATER + REACTOR, PRESSURE TUBE

E-10956 SHEFF JR

SHORT-TERM OYNAMIC EFFECTS UPON THE UTILIZATION OF PLITONIUM AS A REACTOR FUEL

BATTELLE-NORTHWEST, RICHLAND, WASHINGTON

2 PAGES, 1 TABLE, ANS TRANSACTIONS, $9(1)$, PAGES 283-284 (JUNE 1966), AMERICAN NUCLEAP. SOCIETY ANNUAL

MEEIING, UENVER, CULURADU, JUNE 20-23, 1966

INCLUSION IN THE FUEL-CYCLE-AMALYSIS SYSTEM OF A CODE PACKAGE FOR COMPUTING AT VARIOUS TIMES

THROUGHOUT THE BURNUP SUCH KINETIC PARAMETERS AS THE TEMPERATURE COEFFICIENT.

DEL AYED-NEUTRON FRACTION FOR U-235 AND PLUTONIUM CORES IS NOT VERY DIFFERENT BECAUSE OF

PLUTONIUM BUILDUP IN U-235 CORES AND BECAUSE OF PU-241 BUILDUP IN PLUTONIUM CORES.

* DELAYED NEUTRON + *TEMPERATURE COEFFICIENT + FUEl BURNUP + PluTONIUM + URANIUM

6-10957 HARRISON LJ + IVINS RO

A PHOTOGRAPHIC STUDY OF THE TRANSIENT MELTDOWN BEHAVIOR OF ALUMINUM/URANIUM FUEL PLATES IN WATER ARGONNE NATIONAL LABORATORY, IDAHO AND ILLINOIS

1 PAGE, 5 REFERENCES, ANS TRANSACTIONS, 9(1), PAGE 305 (JUNE, 1966), AMERICAN NUCLEAR. SOCIETY ANNUAL MEETING, DENVER, COLORADO, JUNF 20-23, 1966

HIGH-SPEED COLOR MOVIES OF SPERT ID AND HFIR FUEL SAMPLES IN RELATIVELY MODERATE TREAT

TRANSIENTS SHOWED THE FUEL TO MELT, INCANDESCE, AND REACT WITH WATER. AT HIGH-ENERGY INPUTS,

IGNITION AND BURNING FOR 3.6 SEC. THRESHOLD FOR BURNING ANO FRAGMENTATION, 1400 TO 1500 C.

TEMPERATURE ABOVE 2ODC C REACHED IN SAMPLES THAT IGNITED.

ALUMINUM + CLAD + FUEL MELTOOWN , HFIR (HIGH FLUX ISOTOPE REACTOR) + METAL WATER REACTION +

REACTOR, GRAPHITE MODERATED + REACTOR, RESEARCH + REACTOR, TEST + 
CATEGORY 6

REACTOR TRANSIENTS, KINETICS, AND STABILITY

6-10957 \#CONTINUED*

SPERT 1 (SPECIAL POWER EXCURSION REACTOR TEST) + TREAT (TRANSIENT TEST REACTOR FACILITY) + URANIUM + URANIUM OXIDE

6-10958 WRIGHT RW + HUMBERSTONE GH

DISPERSAL AND PRESSURE GENERATION BY WATER IMPACT UPON MDLTEN ALUMINUM

TRH SYSTEMS, REDONDO BEACH, CALIFORNIA

2 PAGES, 1 FIGURE, 4 REFERENCES, ANS. TRANSACTIONS, 9(1), PAGES 305-306 (JUNE, 1966), AMERICAN NUCLEAR SOC.IETY ANNUAL MEETING, DENVER, COLORADO, JUNF, 20-23, 1966

A MOVING HATER COLUMN IMPACTED UPON A POOL OF MOLTEN ALUMINUM IN VACUUM. THIS EXPERIMENT DEMONSTRATED THAT WATER IMPACT UPON MOLTEN ALUMINUM PRODUCES HIGH DISPERSAL AND GENERATION RATES OF HIGH PRESSURE STEAM (OR HYDROGEN) OF THE RIGHT MAGNITUDE TO ACCDUNT FOR THE DELAYED DESTRUCTIVE PRESSURIZATION OF THE PARTIALLY VOIDED SPERT ID CORE.

* DESTRUCT IVE TRANSIENT + \#SPERT 1 (SPECIAL POWER EXCURSION REACTOR TEST) + ALUMINUM + DISPERSION + METAL WATER REACTION + PRESSURE, INTERNAL + THERMAL ANALYSIS

6-10959 CARMICHAEL BM

FAST TRANSIENTS IN LIQUID PLUTONIUM

LOS ALAMOS SCIENTIFIC LABORATORY

2 PAGES, 1 TABLE, 4 REFERENCES, ANS TRANSACTIONS, $9(1)$, PAGES 308-309 (JUNE, 19B6), AMERICAN NUCLEAR SOCIETY ANNUAL MEETING, DENVER, COLORADO, JUNE 20-23, 1966

FAST TRANSIENTS IN CLEAN FUEL WERE STUDIED BY USING A CODE, TRN, WHICH IS BEING DEVELOPED SPECIFICALLY FOR APPLICATIONS TO LIOUID-PLUTONIUM CAPSULES. THE CODE CALCULATES DISTRIBUTED VALUES FOR THE POWER, TEMPERATURE, PRESSURE, AND MOTION OF THE FUEL IN CAPSULES FOR GIVEN REACTIVITY INPUT FUNCTIONS. THE HYDRODYNAMIC-DIFFERENCE EQUATIONS ARE MODELED AFTER THOSE GIVEN BY CHEZEM AND STRATTON.

COMPUTER, DIGITAL + EXCURSION, LARGE + LAMPRE I (LASL MOLTEN PU REACTOR EXPERIMENT) + MPBE (MOLTEN PLUTONIUM. BURNUP EXPERIMENT) + REACTOR, BREEDER + REACTOR, FAST + REACTOR, LIQUID METAL GOOLED

G- 10960 LAWRENCE BR

DETERMINATION OF THE POWER VS REACTIVITY FREQUENCY RESPONSE FUNCTION OF A POWER REACTOR, WITH APPLICATION TO THE HIGH FLUX ISOTOPE PEACTOR

OAK RIDGE NATIONAL LABORATORY, OAK RIDGE, TENNESSEE

ORNL-TM-1471 +. 21 PAGES, 2 TABLES, 2 FIGURES, 5 REFERENCES- JULY 5, 1966, CFSTI, \$2.00 CY, \$O..50 MN

A NUMERICAL TECHNIQUE IS PRESENTED FOR CALCULATING THE POWER VS REACTIVITY-FREOUENCY-RESPONSF FUNCTION OF A POWER REACTOR. THE APPROACH AVOIOS THE EVALUATION OF TRANSFER FUNCTIONS IN AN ALGEBRAIC FORM. THE SPACE-INDEPENDENT REACTOR-KINETICS MODEL IS USED IN CONJUCTION WITH A GENERAL SET OF FIRST-ORDER EQUATIONS TO REPRESENT THE THERMAL PERFORMANCE OF THE REACTOP. RESULTS OBTAINED BY APPLYING THE TECHNIOUE TO THE OAK RIDGE HIGH FLUX ISUTOUE KEACTOR INDICATE THAT THE REACTOR OPERATING AT FULL POWER OF 100 MW WITH THE FLUX CONTROLLER OFF HAS A FREQUENCY RESPONSE WHICH PEAKS EROADLY AT 10 CPS WITH A PARTIAL-DERIVATIVE-OF-P OVER P-SUPERSCRIPT-ZERO VS PARTIAL-DERIVATIVE-OF-K OVER K-SUPERSCRIPT-ZERO GAIN OF 140 .

*hFir (HIGH FLUX ISOTOPE REACTOR) + REACTOR DYNAMICS + REACTOR, RESEARCH + REACTOR, TEST + TRANSFER FUNCTION

6-10970 GODT5 JE

ANALOG ANALYSIS OF TRANSIENT NEUTRON FLUX BY DISCONTINUOUS SYNTHESIS

CARNEGIE INSTITUTE OF TECHNOLOGY, PITTSBURGH, PENNSYLVANIA

HCAP-2828 +. 127 PAGES, JUNE 1965, CFSTI

ANALOG SIMULATION OF THE REACTOR-KINETICS EQUATIONS, INCLUDING SOME CRUDE THERMOHYDRAULIC FEEDBACKS.

\#COMPUTER, ANALOG + tREACTOR DYNAMICS + hYORAULIC ANALYSIS + THERMAL anALYSIS

E-10575 PETTUS WG + BALDWIN MN

DOPPLER COEFFICIENT MEASUREMENTS ON TH AND THO2 ROOS WITH NONUNIFORM TEMPERATURE DISTRIBUTIONS THE BABCOCK AND WILCOX COMPANY, LYNCHBURG, VIRGINIA

12 PAGES, 15 FIgURES, 7 TABLES, NUCLEAR SCIENCE AND ENGINEERING, 26(1), PAGES 34-46 (SEPTEMBER, 1 968)

MEASUREMENTS OF THE DOPPLER EFFECT ON THORIUM ANO THORIUM DIOXIDE RODS OF APPROXIMATELY 3/4-IN. DIAM. HAVING A NONUNIFORM TEMPERATURE DISTRIBUTION. ACTIVATION TECHNIDUE USED. DOPPLER COEFFICIENT AS A FUNCTION OF THE AVERAGE SAMPLE TEMPERATURE IS ESSENTIALLY THE SAME FOR BOTH AXIAL AND PERIPHERAL HEATING OVER THE TEMPERATURE RANGE INVESTIGATED. THE MEASURED VALUES OF THE COEFFICIENTS ARE GIVEN.

\#DOPPLER COEFFICIENT + \#TEMPERATURE GRADIENT + \#THORIUM 
6-10976 \#CONTINUED*

13 PAGes, NuClear SCIENCE AND ENGINeERING, 2611), PAGes 13-25 (SEPTEMBer 1966)

THE SPACE- AND ENERGY-DEPENDENT THEORY OF REACTOR-NOISE ANALYSIS WAS DEVEL OPED BY USING THE TECHNIQUE OF LANGEVIN, STARTING FROM THE TRANSPORT EOUATIONS. THE THEORY INCLUDES DFLAYED NEUTRONS. THE CORRELATION FUNCTION AND THE POWER SPECTRAL DENSITY FOR THE DETECTION RATE. AS WELL AS FOR THE NEUTRON DENSITY, WERE OBTAINED. THE APPLICATION OF THE GENFRAL THEORY TO SIMPLE REACTOR MOOELS IS DISCUSSED AND ILLUSTRATED BY CONSIDERING THE ONE-SPEED TRANSPORT AND ONE-SPEED DIFFUSION APPROXIMATIONS. THE CONNECTION BETWEEN THE TECHNIQUE OF LANGEVIN AND THE DOUBLET THEORY BASED ON THE LIOUVILLE EQUATION WAS ESTABLISHED. IT WAS FOUND THAT BOYH FORMULATIONS YIELD IDENTICAL RESULTS AND THAT THE POSTULATES OF LANGEVIN ARE JUSTIFIED FOR THE STUDY OF NEUTRON DISTRIBUTIONS.

*NOISE ANALYSIS + *SPACE DEPENDENT DYNAMICS

6- 10977 KAZI AH + TOMONTO JR + CHERRY EH

QUANTITATIVE EVALUATION OF THE NORDHEIM-FUCHS REACTOR. EXCURSION MODFL WITH NONLINEAR REACTIVITY FEEDBACK UNITED NUCLEAR CORPORATION

3 PAGES, 2 FIGURES, NUCLEAR SCIENCE AND ENGINEERING, 26(1), OAGES 131-133 (SEPTEMBFR, 1966)

A COMPUTER PROGRAM SHOWS FOR A THERMAL, LOW-ENRICHMENT URANIUM-OXIDE-FUELED PULSED REACTOR WITH TEMPERATURE-DEPENDENT HEAT CAPACITY OR PROMPT TEMPERATURE COEFFICIENT THAT THE POWFR TRACE OF AN EXCURSION PROCEEDS ESSENTIALLY ACCORDING TO THE PREDICTION OF WOLFE OR OF

SCALLETAR. THE RESULTS USING THE SIMPLE NORDHEIM-FUCHS MODEL WITH CONSTANT AVERAGE

PROPERTIES ARE IN REASONABLE AGREEMENT WITH THE DATA USING QUADRATIC VARIATION CF THE

REACTIVITY COEFFICIENTS AND HEAT CAPACITY WITH TEMPERATURE. USING CONSTANT COEFFICIENTS

EVALUATED AT THE INITIAL FUEL TEMPERATURE IS NONCONSERVATIVE IN PREDICTING PEAK POWER, TOTAL

ENERGY RELEASE, AND MAXIMUM CORE TEMPERATURE FOR A SAFETY ANALYSIS. FOR FXAMPLE, TOTAL

ENERGY RELEASE IS UNDERPREDICTED BY ABOUT 25 PERCENT.

EXCURSION, LARGE + FUCHS MODEL

6-10978 REACTOR PHYSICS EFFORTS REQUIRED IN SUPPORT OF THE FAST BREFDEP DEVELOPMENT PROGPAM DIVISION OF REACTOR DEVELOPMENT AND TECHNOLOGY, U.S. ATOMIC ENERGY COMMISSION, HASHINGTON, D. C. WASF-1066 +. 41 PAGES, 3 TARLES, JANUARY 1966 , CFSTI, $\$ 3.00 \mathrm{CY}, \$ 0.50 \mathrm{MN}$

SCATTERED THROUGHOUT THE REPORT ARE REFERENCES TO SODIUM COEFFICIENT, DOPPLER COEFFICIENT, CONTROL SYSTEM, AND DYNAMICS OF LARGE SYSTEMS.

* CONTROL SYSTEM + * SODIUM COEFFICIENT + CRITICAL ASSEMRLY FACILITY +

EBR I AND II (EXPERIMENTAL BREEDER REACTORS) + FERMI + REACTOR DYNAMICS + REACTOR, BREEDER +

REACTOR, FAST + REACTOR, FAST + REACTOR, LARGE + REACTOR, LIQUID METAL COOLED +

SEFOR (SOUTHWEST EXP. FAST OXIDE REACTOR) + SPACE DEPENDENT DYNAMICS +

ZPPR (ANL ZERO POWER PLUTONIUM REACTOR) + ZPR III (ANL ZERO POWER REACTOR) +

ZPR IX (ANL ZERO POWER REACTOR) + ZPR VI (ANL ZERO POWER REACTOR)

6-10979 CARTER DH + GIBSON M + KING OC + MARSHALL J + PUCKETT BJ + RICHARDS AE + WASS T + WILSON DJ BUCKLING AND REACTION RATE MEASUREMENTS IN GRAPHITE MODERATED LATTICES FUELLED WITH PLUTONIUM-IJRANIUM OXIDE CLUSTERS AT TEMPERATURES UP TO 400 DEGREES C.

UNITED KINGDOM ATOMIC ENERGY AUTHORITY, WINFRITH

AEEW-R-438 +. 147 PAGES, 30 FIGURES, 18 TABLES, 14 REFERFNCES, JULY 1965, BIS, \$4.0ก CY

THE REPORT OESCRIBES A SERIES OF EXPERIMENTS CARRIED OUT IN SCORPIO I AND II ON SUBCRITICAL GRAPHITE-MODERATED LATTICES FUELED WITH $21-R 0 D$ CLUSTERS OF PUO2/UO2. THREE FUEL BATCHES WITH NOMINAL PLUTONIUM-TG-URANIUM RATIOS OF $0.25,0.8$, ANO 1.2 PERCENT WERE INVESTIGATEO AT TEMPERATURES BETWEEN 20 AND $400 \mathrm{C}$. FROM THE RESULTS, THE TEMPERATURE COEFFICIENT MAY BE ESTIMATED.

* graphite + *temperature coefficient + *uRanium oxide + moderator + plutDNiUm oxide + united kingdom

6-1100E JAKEMAN D

PHYSICS OF NUCLEAR REACTORS. CHAPTER 9 - REACTIVITY CHANGES AND CONTROL

356 PAGES, THE ENGLISH UNIVERSITIES PRESS LTD (1966)

CHAPTER 9 CONTAINS A FEW TOPICS OF SAFFTY INTEREST. THESE INCLUDE REACTIVITY EFFECTS OF TEMPERATURE IN THERMAL REACTORS, REACTIVITY EFFECTS IN FAST REACTORS OUE TO FUEL FXPANSION, SODIUM VOIDS AND DOPPLER EFFECT, CONTROL METHODS, THEORY OF CONTROL RODS, AND RFACTOR KINETIICS.

CONTROL ROD + CONTROL, GENERAL + DOPPLER EFFECT + FUEL EXPANSION COEFFICIENT + REACTOR DYNAMICS + REACTOR, FAST + REACTOR, THERMAL + SODIUM COEFFIC,IENT + TEMDEPATURE COEFFICIENT

6-11022 FROELICH R

THEORY OF DOPPLER COEFFICIENTS OF FAST REACTORS WITH CONSIDERATION OF MUTUAL SHIELDING RFSONANCES KERNFORSCHUNGS - ZENTURUM, KARLSRUHE

KRK-367+ ANL-TRANS-320+. 81 PAGES, 7 FIGURES, NOVEMRER, 1965, DEP. MN

CHAPTER 7 IS THE IMPORTANT ȘEÇIION . DESCRIPTION DF CALCULATIONS, FROM NUCLEAR PHYSICS DATA, OF AVERAGE OF IMPORTANCE FOR THE DOPPLER EFFECT. 
6-11022 *CONTINUED* DOPPLER EFFECT

6-11059 MILEY GH + KURSTEDT HA + BECK GP

FEECBACK EFFECTS DURING SHORT-INTERVAL SERIES PULSING UNIVERSITY OF ILLINDIS

CONF-650,413 +. 17 PAGES, 7 FIGURES, 2 TABLES, 14 REFERENCES, APRIL 1965, PAGES 420-436 OF NEUTRON DYNAMICS AND CONTROL, PROCEEDINGS OF THE SYMPOSIUM ON NUCLEAR ENGINEERING AT THE UNIVERSITY OF ARIZONA, TUCSON, $\triangle P R I L 5-7,1965$, CFSTI $\$ 4.50 \mathrm{CY}, \$ 2.50 \mathrm{MN}$

THE EFFECTS OF INITIAL PULSE AMPLITUDE, TIME BETWEEN PULSES, AND TIME AFTER PEAK FOR ROD DROP WERE INVESTIGATED FOR 0.5 TO 3 PULSES PER MINUTE. A CALCULATIONAL MOOEL FOR TIME-DEPENDENT TEMPERATURE WAS FOUND. CALCULATIONS SHOW THAT THE WATER-TEMPERATURE COEFFICIENT IS POSITIVE.

\#TEMPERATURE COEFFICIENT + REACTOR TRANSIENT + REACTOR, PULSEO + REACTOR, RESEARCH +

TRIGA (TRAINING REACTOR, ISOTOPES, G.A.)

6-11060 HORNYIK K + WYMAN NE

STUDY OF THE DYNAMICS OF A TRIGA TYPE REACTOR

UNIVERSITY OF ILLINOIS

CONF-650 $413+15$ PAGES, 14 FIGURES, 10 REFERENCES, PP. $457-572$ OF NEUTRON DYNAMICS AND CONTROL, APRIL

7,1966 , CFSTI $\$ 4.50 \mathrm{CY}, \$ 2.50 \mathrm{MN}$

COOLANT FLOW AND TEMPERATURE ANALYSES MADE FROM STEADY-STATE POWER UP TO I MW AND PULSES UP TO 2 DOLLARS. A SIMPLE HEAT-TRANSFER MODEL WAS DEVELOPED THAT WAS IN GOOD AGREEMENT AFTER LESS THAN 1-DOLLAR PULSES. HEAT DENSITY AND TEMPERATURE IS CONCENTRATED IN OUTER LAYERS OF FUEL ELEMENT DURING A PULSE AND AFFECTS BOTH REACTIVITY AND HEAT TRANSFER.

\# ANALYTICAL MODEL + HEAT TRANSFER ANALYSIS + REACTOR TRANSIENT + REACTOR, PULSED + REACTOR, RESEARCH + TRIGA (TRAINING REACTOR, ISOTOPES, G.A.)

6-11081 COFFER CO + DEE JB + SHOPTAUGH JR + WEST GB CHARACTERISTICS OF LARGE REACTIVITY INSERTIONS IN A HIGH-PERFORMANCE TRIGA URANIUM-ZIRCONIUM HYORIDE CORE GENERAL ATOMIC OIVISION OF GENERAL DYNAMICS

CONF-650 413 \%. 21 PAGES, 16 FIGURES, 2 TABLES, 5 REFERENCES, PP. $398-419$ OF NEUTRON DYNAMICS ANO

CONTROL, APRIL $7, .1966$, CFSTI $\$ 4.50 \mathrm{CY}, \$ 2.50 \mathrm{MN}$

MORE THAN 400 PULSES BETWEEN 4.0 AND 4.6 DOLLARS INDICATE THAT THE STAINLFSS-STEEL-CLAD I3O4 SSI FUEL CAN WITHSTAND SUCH SERVICF. PEAK POWER, TEMPERATURE, ETC., IN A BURST COMPARE FAVORABLY WITH FUCHS-NORDHEIM-SCALLETAR MODEL USING VARIABLE HEAT CAPACITY. AT THE HIGHEST POWER $16480 \mathrm{MW}, 44.5 \mathrm{MW}$-SEC FILM BOILING OCCURED, AS INDICATED BY SMALL PATCHES OF BLUE, OXIDIZED CLAD. EXPERIMENTS SHOHEO THAT 3-4 DOLLAR PULSING RAISED FUEL TEMPERATURE IOO C WHEN REACTOR OPERATED AT SOD KW. BECAUSE GAS PRESSURES ARF LOWER THAN PREDICTED AND VARY LINEARLY WITH DOLLARS, AUTHORS BELIEVE THAT INTERNAL PRESSURE IS DUE TO AIR HEATING RATHER THAN HYDROGEN DISASSOCIATION.

\#FUCHS MODEL + \#FUEL ELEMENT + \#REACTOR TRANSIENT + COMPARISON, THEORY AND EXPERIENCE +

PRESSURE, INTERNAL + REACTOR, PULSED + REACTOR, RESEARCH + TRIGA (TRAINING REACTOR, ISOTOPES, G.A.)

6- 11084 RAJAGOPAN $V+$ SWEN GE

MEASUREMENT OF LOCAL KINETIC PARAMETERS IN THE SAXTON REACTOR

WESTINGHOUSE ELECTRIC CORPORATION, PITTSBURGH

CONF-650 $413+10$ PAGES, 6 FIGURES, 2 TABLES, 3 REFERENCES, PP, $209-311$ OF NEUTRON DYNAMICS AND CONTROL, APRIL 7, 1966 , CFSTI $\$ 4.50 \mathrm{CY}, \$ 2.50 \mathrm{MN}$

A ROTATING REACTIVITY OSCILLATOR AND MINTATURE IN-CORE ION CHAMBERS YIELDED POWFR. AND CROSS-POWER SPECTRAL ANALYSES. THE DETECTOR LOCATION WAS VARIED AXIALLY. MEASURFMENTS SHOWED THAT THE LOCAL PROMPT POWER COEFFICIENT DECREASES TOWARD THE CORE CENTER IOR AS HEAT FLUX INCREASES) AND COMPARES WELL WITH CALCULATIONS.

*OSCILLATOR, REACTIVITY + *POWER COEFFICIENT + REACTOR, PRESSURIZED WATER + SAXTON + TRANSFER FUNCTION

6-11085 PLUTA PR

COUPLED-CORE KINETHIC BEHAVIOR

GENERAL ELECTRIC COMPANY, ATOMIC POWER EQUIPMENT DEPT., SAN JOSE

CONF-650 $413+21$ PAGES, 17 FIGURES, 1 TABLE, 16 REFERENCES, PP. 544-565 OF NEUTPON DYNAMICS AND

CONTROL,. $\triangle P R I L 7,1966$, CFSTI $\$ 4.50 \mathrm{CY}, \$ 2.50 \mathrm{MN}$

POWER TRANSIENTS AND TRANSFER FUNCTIONS WITHOUT FEEDBACK ARE SHOWN. THE MODEL PROPOSED BY AVERY WAS USED. WITH CENTRAL SUPERHEAT ZONES, TWO CORES WERE USEO, ONE HAVING A FAST

SPECTRUM, AND ONE THERMAL.

\#COUPLEC CORES + REACTOR TRANSIENT + REACTOR, SUPERHEAT + TRANSFER FUNCTION

6-11088 REACTOR DEVELOPMENT PROGRAM PROGRESS REPORT, JULY 1966

ARGONNE NATIONAL LABORATORY

ANL-7245 +. 74 PAGES, 17 FIGURES, 17 TABLES, REFERENCES, AUGUST 26; 1966, CFSTI, $\$ 3.00$ CY

ACCESSION NUMBER 6-11N22 TO $6-11088$ 
CATEGORY 6
REACTOR TRANSIENTS, KINETICS, AND STABILITY

6-11088 *CONTINUED*

ARGONNE NATIONAL LABORATORY PROGRESS REPORT, JULY 1966. THIS REPORT IS ONE OF A SERIES OF

SUCH REPORTS ON THE SUBJECTS ENUMERATED BELOW. TOPICS COVEREN IN THIS REPORT ARE -

IRRAOIATION OF FUEL PINS, TREAT MELTOOWN TEST, INTEGRAL SODIUM LOOP, FAST-REACTOR SAFETY

CONTAINMENT, EQUATION OF STATE OF RFFRACTORIES SUCH AS UO2, METAL-WATER REACTIONS, AND

PLUTONIUM VOLATILITY SAFETY.

CONTAINMENT DESIGN + EQUATION OF STATE + FUEL MELTDOWN + METAL WATER REACTION + PLUTDNIUM +

REACTOR OYNAMICS + REACTOR, FAST + SODIUM + TREAT (TRANSIENT TEST PEACTOR FACILITY) + URANIUM DIOXIDE

6-11090 CAMERON IR + DRAGESET A + FREEMANTLE RG

STUDIES WITH PLUTONIUM-FUELLED CORES IN THE ZERO-ENERGY, HIGH-TEMPERATURE NUCLEAR REACTOR ZENITH UNIIED KINGOOM ATOMIC ENERGY AUTHORITY, WINFRITH + OECD HIGH TEMPERATURE REACTOR PROJECT IDRAGONI, WINFRITH + IBMIU.K.) LTD., LONDCN

26 PAGES, 11 FIGURES, 6 TABLES, 38 REFERENCES, JOURNAL OF NUCLEAR ENERGY PARTS A/B, 2014), PAGFS $285-311$ (1900)

A SERIES OF EXPERIMENTS CARRIED OUT THE AIM OF TESTING CURRENT THEORETICAL METHODS FOR CALCULATING EXCESS P.EACTIVITY, TEMPERATURE COEFFICIENTS, DIFFERENTIAL. SPECTRUM, AND REACTION-RATE DISTRIBUTIONS. TWO CORES OF WIDELY DIFFERENT FISSILE/MODERATOR ATOM RATIOS WERE LOADED TO OBTAIN SIGNIFICANTLY VARIED SDECTRUM CONDITIONS. THE GENERAL AGREEMENT IS COMPARABLE WITH THAT FOUND FOR THE U-235 CORES PREVIOUSLY INVESTICATED.

*COMPARISON, THEORY AND EXPERIENCE + \#CRITICALITY EXPERIMENT + \#PLUTONIUM + RFACTIVITY, EXCESS + REACTOR, GAS COOLED + REACTOR, GRAPHITE MODERATED + TEMPERATURE COEFFICIENT + UNITED KINGDOM

6-11107 BIRKHOFER A + KARWATH

ANALYSIS IN LARGE WATER MODERATED LOW ENRICHED UO-2 PEACTORS

TECHNISCHEN HOCHSCHULE, MUCHEN

MRR- $21+.20$ PAGES, 8 FIGURES, 2 TABLES, APRIL 1966 , SOURCE

ANALYSIS OF THE SPACE-TIME BEHAVIOUR OF PEACTOR POWER IN TWO DIMENSIONS. DIFFUSION

COEFFICIENT, ABSORPTION CROSS SECTION, FISSION CROSS SECTION, AND RESONANCE ESCAPE

PROBABILITY CAN BE SPACE AND TEMPERATURE DEPENDENT. ONE NEUTRON GROUP. SIX DELAYED-NEUTRON GROUPS. NUMEPICAL EXAMPLE. PEAK-TO-AVERAGE VALUE HIGHER THAN BY OTHER METHODS. COMPUTATION OF PRESSURE RISE BY THREE ZONES - FUEL-FAILURE ZONE, ACCELERATION ZONE, AND STFAM ZONE.

RESULTS OF COMPUTATION.

* spaCe dependent DYnamics + delayed neutron + hydraulic analysis + thermal analysis

6-11153 WEAVER LM

SRE REACTIVITY -- CALCULATION TECHNIQUF

ATOMICS INTERNATIONAL, CANOGA PARK

NAA-SR-MEMO-7936 +. 56 PACES, APRIL 10,1964 , CFSTI $\$ 3.00 \mathrm{CY}$

PROBLEM - DEVELOP A CALCULATIONAL TECHNIQUE TO PROVIDE SURVEILLANCE OF THE SRE NUCLEAP PERFORMANCE. RESULTS - A FORTRAN COMPUTER PROGRAM WAS DEVELOPED TO COMPARE THE EXCESS PEACTIVITY CALCULATED FROM REACTOR POWER AND TEMPERATURES WITH THE MFASIJRED REACTIVITY OBTAINED FROM THE POSITIONS OF THE SHIM RODS. VARIATIONS AND CHANGES IN REACTIVITY DIFFERENCES ARE INVESTIGATED ON THE BASIS OF CHANGES IN OPERATING PARAMETERS. THIS REACTIVITY-NORMALCY PROGRAM WAS SUCCESSFULLY USED FOR SRE CORE-II NUCLEAR ANALYSIS.

*COMPUTER, DIGITAL + \#SRE (SODIUM REACTOR EXPERIMENT) + REACTIVITY, EXCESS + REACTOR, GRAPHITE MODERATED + REACTOR, LIOUID METAL COOLED + TEMPERATURE COEFFICIENT

E- 11154 BLAINE RA

REACTOR KINETICS AND REACTOR SAFETY STUOITS

ATOMICS INTERNATIONAL, CANOCA TARK

NAA-SR-MEMO-9837 +32 PAGES, REFERENCES, APRIL 24,1964, CFSTI $\$ 2.00 \mathrm{CY}$

THE GOALS AND ACCOMPLISHMENTS IN REACTOR KINETICS AND REACTOR SAFETY STUNIES OF THE ATOMICS INTERNATIONAL REACTOR SAFETY PROGRAM ARE REVIEWED. PRESENT OIRECTIONS AND FUTUPE REQUIREMENTS ARE PRESENTED. SUBJECTS RELEVANT TO NUCLEAR SAFETY INCLUDE - AIREK EQUATIONS, NOISE ANALYSIS, POISON MIXTURES TO ENHANCE REACTOR SAFETY, BUBBLE GROWTH, MIJLTICHANNEL FLOW STABILITY, REACTOR SITING, SPACE-DEPENDENT KINETICS, AND MULTIREGION-MULTIGROUP KINETICS.

* REACTOR OYNAMICS + \#SITING, REACTOR + HYDRAULIC ANALYSIS + KEWB (KINETIC EXPERIMENT ON WATER ROILERSI + NOISE ANALYSIS + POISON, SOLUBLE + REACTOP, HOMOGENEOUS + REACTOR, RESEARCH + SPACE DEPENDENT DYNAMICS + THERMAL ANALYSIS + VOID COEFFICIENT

6- 11155 RFYNAI IS IM KINETICS PARAMETERS OF A HIGHLY ENRICHED HEAVY-WATER REACTOR, FINAL REPORT, FEBRUARY 26 , I965 - FEBRUARY 25,1966

GEORGIA INST. OF TECH., ATLANTA

TID-23037 +. 74 PAGES, REFERENCES, APRIL 1966 , CFSTI $\$ 3.00 \mathrm{CY}, \$ 0.75 \mathrm{MN}$

IN A HTIHI Y FNRICHED HEAVY-WATER RESEARCH REACTOR SUCH AS THE GEORGIA TECH DPSEARCH REACTOR (GTRP), WHICH HAS OPERATED AT LOW POWER, USE OF TWELVE DELAYED-NEUTRON AND PHOTONEUTRON GROUPS DESCRIBE THE KINETICS BEHAVIOR. A METHOD OF ACCOUNTING FOR THF EFFFCT OF THE PREVICUS 
CATEGORY 6

6-11155 - \#ONTINUED*

POWER HISTORY OF THE REACTOR WAS DEVELOPEO AND USED IN THE EVALUATION OF THE KINETICS PARAMETERS: A VALUE OF 9.8 RECIPROCAL SEC FOR THF RATIO OF THE EFFECTIVE DELAYED-NEUTRON FRACTION TO THE PROMPT-NEUTRON LIFETIME WAS MEASURED. SPACE DEPENDENCE OF THE OSCILLATOR-OETECTOR REACTOR TRANSFER FUNCTION WAS DEMONSTRATED BY'PILE-OSCILLATOR MEASUREMENTS. EFFECTIVE DELAYED-NEUTRON FRACTION OF THE GTRR IS BEING MEASURED.

- heavy hater + \#Reactor, research + delayeo neutron + noise analysis + Reactor kinetics + SPACE DEPENDENT OYNAMICS

6-11156 SZWARCBAUM G + YIFTAH S

CALCULATION OF THE DOPPLER EFFECT IN FAST REACTORS

ISRAEL ATOMIC ENERGY COMMISSIONS, YAVNE

I $\triangle-1039+$ + 85 PAGES, REFERENCES, MAY 1965, DEP. MN

METHODS AND PARAMETERS USEO IN THF CALCULATION OF THE DOPPLER EFFECT IN TYPICAL 8DO- TO

2500-LITER FAST REACTORS ARE DESCRIBED. THE INFLUENCE OF THE CHEMICAL COMPOSITION OF THE

FUEL AND THE ISOTOPIC COMPOSITION OF THE PLUTONIUM ON THE TOTAL DOPPLER EFFECT IS EXAMINED.

\#DOPPLER COEFFICIENT + \#REACTOR, FAST + PLUTONIUM + URANIUM + URANIUM CARBIDE + URANIUM OXIDE

6-11161 TUTTLE RJ

A SUMMARY OF THE CALCULATED CHARACTERISTICS OF THE EPITHERMAL CRITICAL ASSEMBLIES 1 THROUGH 13 ATOMICS INTERNATIONAL, CANOGA PARK

NAA-SR-MEMO-11799+. 92 PAGES, JANUARY 12,1966 , CFSTI $\$ 3.00 \mathrm{CY}, \$ 0.75$ MN

PROBLEM - SUMMARIZE THE RESULTS OF CALCULATIONS PERFORMED FOR THE CRITICAL ASSEMRLIES AT THE EPITHERMAL CRITICAL EXPERIMENT LABORATORY TO FACILITATE ANALYSIS OF THE TXPERIMENTAL RESULTS ANO AID FUTURE EXPERIMENTAL PLANNING. RESULTS - CRITICALITY CALCULATIONS AND PERTURBATION THEORY CALCULATIONS OF THE PROMPT-NEUTRON LIFETIME; EFFECTIVE DELAYED-NEUTRON FRACTION ANO AVERAGE FISSION IMPORTANCE ARE TABULATED FOR THE ECEL CORES 1-13. THE FLUX AND ADJOINT SPECTRA ARE TABULATED AND PRESENTED IN GRAPHICAL FORM. MATERIAL SPECIFICATIONS AND THE CROSS-SECTION LIBRARY USED IN THE CALCULATIONS ARE ALSO RECORDED. A $8 I B L I O G R A P H Y$ OF THE EXPERIMENTAL PROGRAM IS PROVIDED.

*CRITICALITY EXPERIMENT + DELAYED NEUTRON + PROMPT NEUTRON LIFETIME + ROSSI ALPHA

6-11174 SANDERS JP

APPROPRIATE VALUES FOR THE THERMAL CONDUCTIVITY OF UO2 FOR USE IN THE DESIGN OF THE BONUS SUPERHEATERS OAK RIDGE NATIONAL LABORATORY, OAK RIDGE, TENNESSFE

ORNL-TM-1450 +. 11 PAGES, 1 FIGURE, 6 REFERENCES, APRIL 22, 1966, CFSTI \$1.00 CY, \$0.50 MN

A LITERATURE SURVEY WAS MADE, AND A THERMAL CONDUCTIVITY OF $1.0-1.2$ BTU/HR-FT-DEG F WAS

CHOSEN. VARIOUS REPORTS INCLUDED GAS-GAP EFFECT. THERMAL CYCLING AND IRRADIATION HISTORY AFFECT CHOICE ALSO.

BONUS (BOILING NUCLEAR SUPERHEAT PROJECT) + HEAT CONDUCTION + REACTOR, ROILING WATER + REACTOR, SUPERHEAT + URANIUM DIOXIDE

6-11176 ALCORN FM + MICKLE RA + WOODHALL CB

ADVANCED TEST REACTOR TEMPERATURE AND VOID COEFFICIENTS OF REACTIVITY

BABCOCK AND WILCOX COMPANY, LYNCHBURG, VIRGINIA

IDO-24455+. 28 PAGES, MAPCH 1964 , CFSTI, $\$ 2.60 \mathrm{FS}, \$ 1.40 \mathrm{MF}$

SPATIALLY DEPENDENT TEMPERATURE AND VOID COEFFICIENTS OF REACTIVITY WFRE CALCULATED FOR THE REFERENCE CORE OF THE ADVANCED TEST REACTOR. THE FUEL-TEMPERATURE COEFFICIENT IS NEGATIVE. ALL OTHER REGIONS HAVE POSITIVE TEMPERATURE COEFFICIENTS. THE COLD-TO-HOT OPERATING TEMPERATURE DEFICIT OF REACYIVITY IS PLUS 0.0060. THE BEGINNING-OF-LIFE, HOT-OPEDATING, FUEL VOID COEFFICIENT IS NEGATIVE 0.209 WHILE ALL OTHER REGIONS ARE POSITIVF. END-OF-LIFE COEFFICIENTS ARE SIMILAR TO BEGINNING-OF-LIFE COEFFICIENTS. FUEL-TEMPERATURE COEFFICIENT HAS BECOME LESS NEGATIVE. END-OF-LIFE VOID REACTIVITY ADDITIONS HAVE ALL INCREASED.

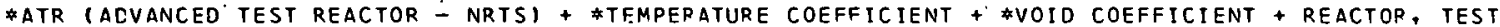

6-111.77 BOUZYK J + KUBOWAKI J + LATEK S + SUWALSKI W WATER REACTIVITY EFFECTS IN THE ANNA CRITICAL ASSEMBLY INSTITUTE OF NUCLEAR RESEARCH, WARSAW

INR-600/IX-A/PR +. 22 PAGES, FEBRUARY, 1965, DEP., IN POLISH, ENGLISH ABSTRACT

THE RESULTS OF REACTIVITY MEASUREMENTS ON LOSS OF WATER FROM THE FUEL AND GRAPHITE (EXPERIMENTAL) CHANNELS OF THE ANNA CRITICAL ASSEMBLY ARE PRESENTED. THE SHADOWING EFFECT, AS WELL AS THE OPPOSED EFFECT OF THE WATER REMOVAL FROM THE CORE AND THE SIDE REFLECTOR, RESPECTIVELY, HAS BEEN OBSERVED. THE RFSULTS ARE VERY IMPORTANT FOR THE REACTOR OPERATION.

POLAND + VOID COEFFICIENT

6-11178 GOLDMAN DT

UTILIZING MUFT RESONANCE PARAMETERS TO. INCLUDE DOPPLER BROADENING

$$
\text { . }
$$


CATEGORY 6

6-11178 \#CONTINUED*

KNOLLS ATOMIC POWER LABORATDRY, SCHENECTADY, NEH YORK

KAPL-M-6158 +. 14 PAGES, JUNE 1, 1964, CFSTI \$1.OO CY

KEEPING WITHIN THE MUFT FRAMEWORK, A METHOD IS PROPOSED FOR INCLUDING THE EFFECT OF OOPPLER (TEMPFRATURF) BROADENING OF RESONANCES ON THE CALCULATION OF RESONANCE INTEGRALS. THIS METHOD IS SEEN TO BE SINPLE IN ITS DPPLICATION. SOME ATTEMPT WAS MADE TO DETERMINE ITS RANGE OF VALIDITY, ESPECIALLY IN COMPARISON HITH THE TECHNIQUE PRESENTLY IN USE IN MUFT. FINALLY, AN ADOITIONAL PROPOSAL IS MADE TO REPLACE FOR ALL NUCLEI THE NRIA APPROXIMATION PRESFNTLY IN USE IN MUFT WITH THE NR APPROXIMATION.

* COMPUTER, DIGITAL + \#OOPPLER EFFECT

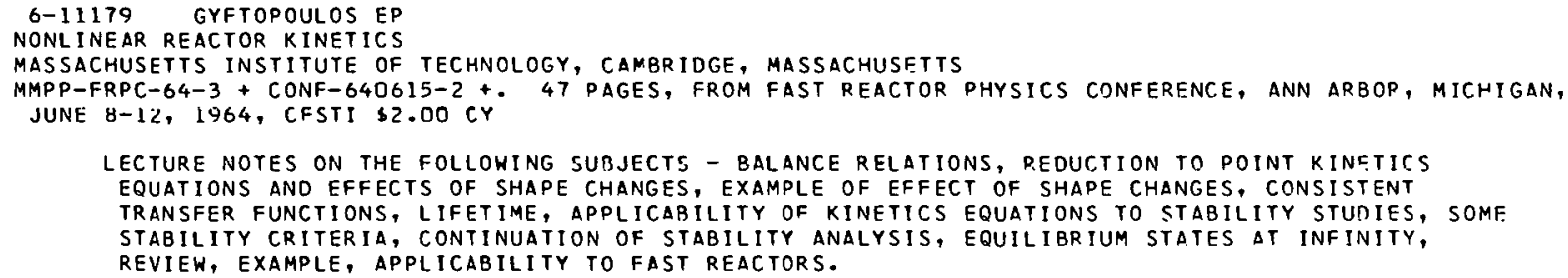

*DOPPLER EFFECT + *REACTOR, FAST + BERYLLIUM + RFACTOR, TEST

6-11303 WINSON RH

A TECHNIQUE FOR SOLVING DYNAMICS PROBLEMS BY DIGITAL COMPUTATION

ATOMICS INTERNATIONAL, CANOGA PARK, CALIFORNIA

NAA-SR-MEMO-10692 +. 8 PAGES, NOVEMBER 2, 1964, CFSTI, $\$ 1.00 \mathrm{CY}$

A SET OF FUNCTIONAL EOUATIONS IS DEVELOPED FOR GREATLY ENHANCING THE SOLUTION OF SYSTEM EQUATIONS UTILIZING DIGITAL COMPUTFRS. THE SOLUTION OF THE DIFFERENTIAL EQUATIONS, REPRESENTING THE SYSTEM, IS NOT LIMITED BY ANY APPROXIMATE NUMERICAL INTEGRATION SCHEME, HOWEVER THE COMPUTATIONAL TIME INTERVAL IS LIMITED TO THE EXTENT THAT THE SYSTEM DRIVING FUNCTION CAN BE REPRESENTED BY A SERIES OF STEPS AND RAMPS. THE METHOD CAN BE PROGRAMMED WITH THE EASE OF SIMPLE EULER INTEGRATION, WITH THE ADDED ADVANTAGE OF REQUIRING LESS COMPUTATION TIME OF EITHER EULER OR RUNGE-KUTTA NUMER ICAL INTEGRATION SCHEMES.

* COMPUTER, DIGITAL + *REACTOR OYNAMICS 
6-11315 CROCKER JG

ANALYSIS - SPACE-TIME EFFECTS AND THE POINT KINETIC EQUATIONS

PHILLIPS PETROLEUM COMPANY, IOAHO FALLS, IDAHO

ID0-17123 +. IO PAGES, PAGES 43-52 OF QUARTERLY TECHNICAL REPORT - SPERT PROJECT, APRIL, MAY, JUNE 1965, JANUARY 1966 , CFSTI, \$3.00 CY,\$0.75 MN

FOR CORES WHICH HAVE UNIFORM NEGATIVE INHERENT REACTIVITY FEEDBACK, POINT KINETICS WILL YIELO GOOD RESULTS IF THE HALF-WIDTH OF THE POWER BURST IS AT LEAST A FACTOR OF TWO GREATER THAN THE TIME REQUIPED TO PROPOGATE A PULSE ACROSS THE CORES. THE RANGE OF VALIDITY OF THE POINT-KINETIC EQUATIONS IS CONSIDERABLY GREATER THAN THAT INDICATED IN AN ANALYSIS PERFORMED BY YASINSKY AND HENRY.

SPACE DEPENDENT DYNAMICS

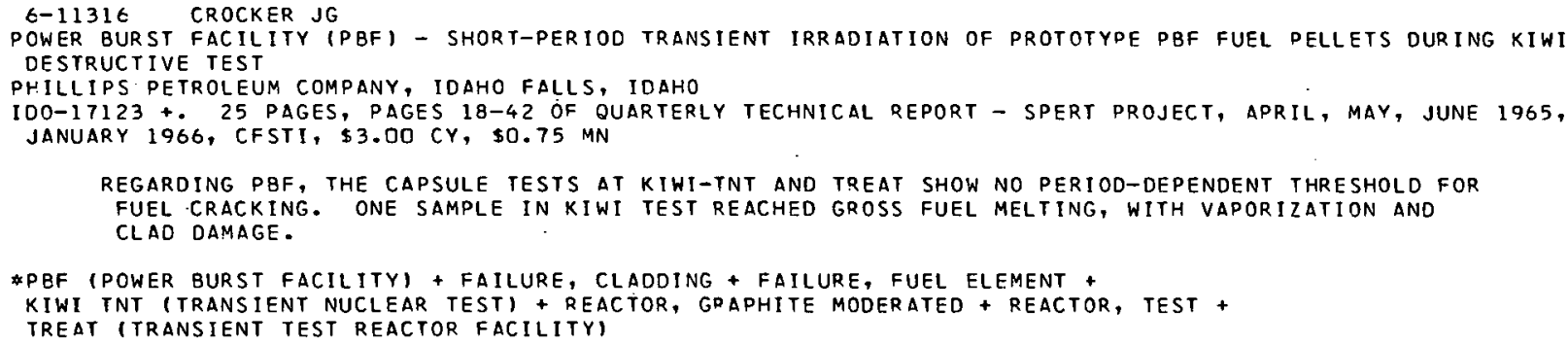

THIS REPORT IS ONE OF A SERIES OF SUCH REPORTS ON THE FOLLOWING SUBJECTS - PLANNING, EXPERIMENTAL PROGRAM IN 2PR-III, FUEL OEVELOPMENT, INSTRUMENTATION, CORE OYNAMICS, REACTIVITY CONTROL, FUEL HANOLING, AND CORE DESIGN

*RESEARCH CONTRACT + \#SEFOR (SOUTHWEST EXP. FAST OXIDE REACTOR) + \#ZPR III (ANL ZERO POHER REACTOR) + CRITICAL ASSEMBLY FACILITY + DOPPLER COEFFICIENT + FUEL ELEMENT + FUEL HANDLING + HEAT TRANSFER + INSTRUMENTATION, GENERAL + INSTRUMENTATION, TEMPERATURE + REACTOR, BREEDER + REACTOR, FAST + REACTOR, LIQUID METAL COOLED + TEST, PHYSICS

6-11432 ASH M

OPTIMAL SHUTDOWN CONTROL OF NUCLEAR REACTORS. MATHEMATICS IN SCIENCE AND ENGINEERING, VOLUME 26 E. H. PLESSET ASSOCIATES, INC., SANTA MONTCA, CALIFORNIA 169 PAGES, FIGURES, TABLES, 32 REFEPENCES, SEPTEMBER 1966, ACADEMIC PRESS, 1966, NEW YORK AND LONDON, $\$ 8.50 \mathrm{CY}$

THE PROBLEM OF CONTROLLING THE SHUTDOWN SEQUENCE OF A NUCLEAR REACTOR SO AS TO MINIMIZE THE XENON POISONING AT A LATER TIME IS SOLVED. THE GENERATION AND CHARACTERISTICS OF NUCLEAR POISONS ARE GIVEN, AS IS THE OERIVATION OF THE CONTROL THEORY. A COMPUTER CODE IS LISTED ALONG WITH COEFFICIENTS. THE PROBLEM OF XENON POISONING IS SOLVED FOR THE IRR-1 REACTOR (ISRAEL), AND THE AGREEMENT BETWFEN THEORICAL AND EXPERIMENTAL RESULTS ARE GIVEN.

*XENON + CONTROL ROD WORTH + SHUTDOWN MAREIN + XENON OSCILLATION

6-11444 ENGEL JR + HAUBENREICH PN + BALL SJ

ANALYSIS OF FILLING ACCIDENTS IN MSRE

OAK RIDGE NATIONAL LABORATCRY
ORNL-TM-497+. 41 PAGES, 14 FIGURES, 1 TABLE, AUGUST 16,1966, CFSTI $\$ 2.0 D$ CY, $\$ 0.50$ MN

POSTULATED. ACCIDENTS WERE ANALYZED TO HELP DESIGN FILLING-RATE VALVES AND GAS-CONTROL VALVES TO LIMIT SUCH EXCURSION. SEQUENTIAL FAILURE WOULD BE NEEDED TO CAUSE THE ACCIDENT, ALSO SELECTIVE SALT FREEZING TO CONCENTRATE THE FUEL.

\# ACCIDENT, REFUEL ING + MSRE. (MOLTEN SALT REACTOR EXPERIMENT) + REACTOR, CIRCULATING FUEL + 
CATEGORY 6
REACTOR TRANSIENTS, KINETICS, AND STABILITY

6-11444 \#CONTINUED* REACTOR, MOLTEN SALT 
CATEGORY 7

FISSION PRODUCT RELEASE, TRANSPORT, AND REMOVAL

7-C8682 CASTLEMAN AW + TANG IN

CHEMICAL CONSIDERATIONS IN FAST REACTOR SAFETY

BROOKHAVEN NATIONAL LABORATORY

BNL-9667 + CONF-651009-6 +. 24 PAGES, OCTOBER, 1965 , PROCEEDINGS OF THF INTERNATIONAL CONFERENCF ON

SAFETY, FUELS, AND CORE DESIGN IN LARGE FAST POWER REACTORS, ARGONNE NATIONAL LABORATCRY, OCTOBER. II-14,

1965 , CFSTI, \$2.00 FS, \$0.50 MN

THIS PAPER SUMMARIZES THE RESULTS OF STUDIES ON THE CHEMICAL STATES OF IODINF RELEASED FROM U AND UC INTO HELIUM BETWEEN 1200 AND 2500 C. THE SECOND SECTION GIVES THE CHEMICAL STATES FORMED UPON RELEASE FROM THESE FUELS INTO AIR. AND STEAM. INCLUDED ALSO ARE CALCULATIONS THAT PREDICT THE BEHAVIOR OF IODINE IN SODIUM, BASED ON THERMODYNAMIC CONSIDERATIONS.

*FISSION PRODUCT TRANSPORT + \#FISSION PRODUCT, IODINE + \#IODINE + \#THERMODYNAMICS + HELIUM + SODIUM + STEAM + URANIUM + URANIUM CARBIDE

7-08895 OAK RIDGE NATIONAL LABORATORY STATUS AND PROGRESS REPORT OAK RIOGE NATIONAL LABORATORY, OAK RIDGE

ORNL-3814 +59 PAGES, MAY 1965

RELEASE OF FISSION PRODUCTS DURING MELTING OF FUELS UNDER TRANSIENT REACTOR CONDITIONS. REMOVAL OF FISSION PRODUCTS FROM GASES UNDER REACTOR ACCIDENT CONDITIONS. RFHAVIOR OF FISSION PRODUCTS ON IN-PILE DESTRUCTION OF REACTOR FUELS. CHARACTERIZATION OF GAS-BORNE FISSION PRODUCTS PREPARATION OF HIGH-SPECIFIC-ACTIVITY METHYL IODIDE FOR USE IN TESTING CHARCOAL ABSORBER SYSTEMS. SIMULATION OF REACTOR-ACCIDENT AEROSOLS. NUCLEAR SAFETY INFORMATION CENTER. INDEXED BIBLIOGRAPHY OF CURRENT NUCLEAR SAFETY LITERATURE. NUCLEAR SAFETY PILOT PLANT.

\# $\triangle E R O S O L$ + \#FISSION PRODUCT TRANSPORT + \#FISSIDN PRODUCT, IODINE + \#IN PILE LOOP + \#ORGANIC IODIDE + FISSION PRODUCT, IODINE + FISSION PRODUCT, VOLATILE + IN PILE EXPERIMENT + IDDINE

7-09273 LIU BY + WHITBY KT

THE ELECTRICAL CHARGING OF SMALL PARTICLES A.T LOW PRESSURES

UNIVERSITY OF MINNESOTA, MINNEAPOLIS, MINNESOTA

72 PAGES, 21 FIGURES, 10 TABLES, OCTOBER 1965 , SOUR.CE

THE ELECTRIC CHARGE IMPARTED TO AEROSOL PARTICLES RANGING IN SIZE FROM O.OB TO APPROXIMATELY 3 MICRON HAS BEEN MEASURED EXPERIMENTALLY IN A COMBINED CHARGER AND MOBILITY ANALYZER OVER THF PRESSURE RANGE FROM 0.01 TO 0.001 ATM. SOLID SPHERICAL PARTICLES OF METHYLFNE BLUE WERE USED IN THESE STUDIES, AND THEY WERE CHARGED UNDER ELECTRIC FIELD INTENSITIES OF 1 TO TO 240 V/CM BY POSITIVE IONS PRODUCED IN A CORONA DISCHARGE. THE PRODUCT OF ION CONCENTRATION ANA CHARGING TIME USED IN THE EXPERIMENTS RANGED TO A MAXIMUM VALUE OF 3 MILLION (IONS/CC)(SEC). THE ELECTRIC MOBILITY OF THESE PARTICLES CHARGED UNDER THE VARIOUS CONDITIONS OF THE EXPERIMENTS WAS FOUND TO INCREASE RAPIDLY WITH DECREASING PRESSURES AND SOMEWHAT LESS RAPIDLY WITH DECREASING PARTICLE SIZE. THE MEASURED CHARGE ON PARTICLES HAS REEN COMPARED WITH VALUES PREDICTED BY VARIOUS THEORIES, AND THE RESUETS INDICATE THAT BOTH THE DIFFUSION ANO FIELD-CHARGING EQUATIONS UNDERESTIMATE THE PARTICLE CHARGE BY A FACTOR RANGING FROM APPROXIMATELY 2 TO 30 . RESULTS OF NUMERICAL SOLUTION BY A COMPUTER PROGRAM OF THE CHARGING EQUATION BASED UPON THE ASSUMPTION THAT THE CONCENTRATION OF IONS IS UNIFORM AROUND THE PARTICLE AGREE WITH THE EXPERIMENTAL RESULTS FOR PRESSURES OF $1 / 100$ AND 1/300 ATMOSPHERE, EXCEPT FOR THE HIGHEST ELECTRIC FIELD INTENSITY, TO WITHIN THE ACCURACY OF THE EXPERIMENT. FOR A PRESSURE OF 0.001 ATMOSPHERE, A SIMPLE INTERCEPTION THEORY GIVES RESULTS THAT AGREED THE BEST WITH THE EXPERIMENTAL DATA.

*AEROSOL + *ELECTROSTATIC CHARGE + \#FILTER THEORY, INTERCEPTION + COMPUTER PROGRAM + DIFFUSION + PARTICLE SIZE + PARTICULATE

7-C9350 MELEHAN JB + GATES JE

IN-PILE FISSION-GAS RELEASE FROM URANIUM CARBIDE AND URANIUM NITRIDE

BATTELLE MEMORIAL INSTITUTE, COLUMBUS

BMI-1701 +. 54 PAGES, 30 FIGURES, 13 REFERENCES, NOVEMBER 1964, CFSTI, \$1.5C CY

IN-PILE FISSION-GAS RELEASE BEHAVIOR OF CAST UCO.9, UC1.01, UC1.04, AND UCI.4, SINTERED UCI.04 (93 PERCENT DENSE), AND UN1.01 192 PERCENT DENSE) WAS STUDIED AT TEMPERATURES UP TO 1700 C. FISSION-GAS RELEASE FROM UNI.01 WAS TEMPERATURE INDEPENDENT UP TO ABOUT 8OD C. AROVE 800 C, RELEASE HAS TEMPERATURE-DEPENDENT AND COULD BE DESCRIBED IN TERMS OF DIFFUSION THEORY. BETWEEN 1000 AND 1600 C THE DIFFUSICN COEFFICIENTS FOR XE-133, XE-135, AND KR-85M COULD BE EXPRESSED BY THE RELATION- D EQUALS D SUB ZERO (EXP) E TO THE MINUS Q/RT, WHERE $D$ SUB ZERO EQUALS 3 PLUS OR MINUS $2 \times 10$ TO THE MINUS 6 CM SQUARED PER SEC, AND $Q$ EQUALS GO PLUS OR MINUS 5 KCAL PER MOLE. LIMITED DATA SUGGEST THAT BETWEEN 1000 AND $16 C O C$ THE FISSION-GAS DIFFUSION COEFFICIENTS IN SINTERED UC1.04 ARE COMPARABLE TO THOSE FOR SINTERED UNI.DI. FISSION-GAS RELEASE FROM THE CAST CARBIDES WAS TEMPERATURE DEPENDENT BETHEFN IOCO AND I6CO C BUT NEVER EXCEEDED THE THEORETICAL RECOIL RELEASE. AT 1600 C THE RATE OF FISSION-GAS RELEASF IN UC1.01 AND UC 1.4 WAS EQUAL BUT AT LOWER TEMPERATURES THE RELEASE RATE IN UCI OI WAS HIGHER THAN IN UC1.4. THIS HIGHER RELEASE RATE MIGHT BE RELATED TO THE PRESENCE OF THE INTERCONNECTED UC2 SECOND PHASE IN THE UC1.01 ALLOY. DEFINITE VALUES FOR THE FISSION-GAS DIFFUSION COEFFICIENTS IN THE CAST CARBIDES COULD NOT BE DETERMINED BECAUSE OF THE LOW RATE OF GAS RELEASE.

\#DIFFUSION + \#DIFFUSION COEFFICIENT + *FISSION GAS RELEASE + \#FISSION PRODUCT RELEASE, GENERAL + * IN PILE LOOP + FUEL BURNUP + FUEL INTEGRITY + KRYPTON + NITRIDE + URANIUM + URANIUM CARBIDF + XENON 
CATEGORY T

FISSION PRODUCT RELEASE, TRANSPORT, AND REMOVAL

7-09352 \#CONTINUED*

SOLID FISSION PRODUCTS IN IRRADIATED URANIUM DIOXIOE

UNITED KINGDOM ATOMIC ENERGY AUTHORITY, HARWELL

AERE-R-5149 +. 27 PAGES, 11 FIGURES, 4 TABLES, 19 REFERENCES, JANUARY 1966, UKAEA

BOTH SOLIO AND GASEOUS FISSION PRODUCTS ARE GENERATED DURING IRRADIATION OF UO2, AND THE DIMENSIONAL STABILITY OF THE FUEL WILL BE CONTROLLED BY THE BEHAVIOUR OF THESE FISSION PRODUCTS. FRAGMENTS OF IRRACIATED UO2 AND A COMPLETE SECTION FROM A FUEL PELLET OF 4.6 PERCENT BURN-UP AND ESTIMATED CENTRE TEMPERATURE OF APPROXIMATELY 1500 DEGREES C HAVE BEEN STUDIEO USING A C.A.M.E.C.A. ELECTRON PROBE MICROANALYZER. A MICROSTRUCTURAL FEATURE WAS THE APPEARANCE ABOVE APPROXIMATELY 3 PERCENT BURN-UP OF WHITE INCLUSIONS AT SRAIN BOUNDARIES. THE SOLID PRODUCT ELEMENTS MOLYBDENUM, TECHNETIUM, RUTHENIUM AND RHODIUM WERE IN ALL THESE INCLUSIONS. BARIUM AND STRONTIUM, ASSOCIATED WITH ZIRCONIUM AND SMALL AMOUNTS OF CERIUM WERE ADDITIONALLY PRESENT IN MANY CASES. NEODYMIUM WAS PRESENT IN THE MATRIX UO2. THF CHEMICAL STATE AND SEGREGATION OF THESE ELEMENTS IS DISCUSSED.

* ANALYTICAL TECHNIQUE, CALIBRATION + \#FISSION PRODUCT TRANSPORT + \#FISSION PROOUCT, NONVOLATILE + BARIUM + CERIUM + DIFFUSION + MOLYBOENUM + NEOOYMIUM + RHOOIUM + RUTHENIUM + STRONTIUM + TECHNETIUM + URANIUM OXIOE + ZIRCONIUM

7-09359 NELSON RC + COPLIN DH + LYONS MF + WEIDENBAUM B FISSION GAS RELEASE FROM UO2 FUEL ROUS WITH GROSS CENTRAL MELTING. 1. PELLET FUEL GENERAL ELECTRIC COMPANY, VALLEC.TTOS ATOMIC LABORATORY

GEAP-4572 + EURAEC-1435 +. 58 PAGES, REFERENCES, JULY 24, 1964, CFST1, $\$ 3.00 \mathrm{CY}, \$ 0.50 \mathrm{MN}$

THE EXTENSION OF FUEL-ROC OPERATING CONOITIONS ABOVE THE LIMIT OF CENTER MELTING AND PROCEEDING INTO GROSS AMOUNTS OF MOLTEN FUEL HAS BROUGHT WITH IT THE KNOWLEDGE OF FISSION-GAS RELEASE AT HIGH TEMPERATURE. THE FUEL WAS UO2 PELLETS WHICH WERE 1.27 CM IN DIAMFTER AND HAD A DENSITY OF $10.4 \mathrm{GM} / \mathrm{CU} . \mathrm{CM}$. THE FUEL-ROD AVERAGE OPERATING CONDITIONS RANGED FROM 69.6 TO $118.8 \mathrm{~W} / \mathrm{CM}$. THE CALCULATED VOLUME FRACTIONS OF MOLTEN UO2 EXTENDED FROM 0.002 TO D.375, AND THE CORRESPONDING FISSION GAS RELEASES RANGED FROM 10 TO 62 PERCENT. THE FISSION GAS RELEASE FROM THESE FUEL RODS WAS CORRELATED WITH THE GAS PRODUCED IN THE FUEL VOLUME WHICH EXHIBITS FISSION PRODUCT MOBILITY, AS OBSERVED BY AUTORADIOGRAPHY. THE RESULTS OF THIS ANALYSIS SHOW $\triangle$ RELEASF OF ALL THE FISSION GAS PRODUCED IN THAT VOLUME OF UO2 ABOVE 1900 C, WHERE COLUMNAR GRAIN GROWTH AND MELTING OCCURRED. IN THE REGION OF EQUIAXED GRAIN GROWTH, BETWEEN 165R AND $1900 \mathrm{C}$, ABOUT 20 PERCENT OF THE FISSION GAS PRODUCED IN THIS FUEL VOLUME WAS RELEASED. FOR UO2 FUEL RODS OPFRATING UNDFR CONDITIONS OF CENTRAL MELTING, THE FRACTION OF FISSION GAS RELEASED FROM THE FUEL VOLUME BELOW $1650 \mathrm{C}$ IS RELATIVELY SMALL AND MAY BE NEGLECTED.

\#FISSION PRODUCT TRANSPORT + \#FUEL ELEMENT + *FUEL MELTDOHN + *NOBLE GAS + *URANIUM OXIDF + ANALYTICAL MODEL + DIFFUSION + FISSION GAS RELEASE + FISSION PRODUCT RELEASE, GENERAL + FUEL BURNUD

7-C9360 PERRIGO LD

TRANSPORT AND BUILOUP OF RADIOACTIVE MATERIALS IN REACTOR SYSTEMS AS DETERMINED BY SHUTDOHN RADIATION MEASUREMENTS

BATTELLE-NORTHWEST

BNWL-SA-85 . 14 PAGES, MARCH 5, 1965, CFSTI, \$1.00 CY, \$0.50 MN

A PROGRAM OF MEASURING SHUTDOWN RAOIATION LEVELS ON THE PLUTONIUM RECYCLE TEST REACTOR BEGAN CONCURRENT WITH REACTOR STARTUP TO PROVIDE INFORMATION ON RADIOACTIVITY BUILOUP AND TRANSPORT REACTIONS. BUILDUP TRENOS WERE RELATED TO COOLANT PURITY, CORROSION, REACTOR POWER LEVEL, AND GENERAL REACTOR OPERATION, WITH THE OBJECTIVE OF FINDING METHODS FOR REDUCING RADIATION BUILDUP AND EXPOSURE AROUND REACTOR SYSTEMS. THIS PAPER PRESENTS THE SHUTDOWN-RADIATION-MEASUREMENT TECHNIQUE, COVERING ITS DEVELOPMENT AND SURSEQUENT USE, WITH EXAMPLES OF SOME OF THE RESULTS.

\#MONITOR, RADIATION, GENERAL + \#RADIATION SAFETY AND CONTROL + \#SURVEY, RAOIATION, GENERAL * FISSION PRODUCT TRANSPORT + PERSONNEL EXPOSURE, RAOIATIUN

7-09369 SMOLKINA TI + CHUBAKOV AA

INVESTIGATION OF SORPTION OF RADIOIODINE ON ACTIVATED CHARCOAL, ANO STUDY OF FORMS OF GASEOUS IODINE IN AIR 3 PAGES, 3 FIGURES, 8 REFERENCES, ATOMNAYA ENERGIYA, 18(3), PAGES 208-299 (MARCH, 1965)

\begin{abstract}
RADIOACTIVE IODINE IS CAPABLE OF EXISTING IN AIR IN TWO PHASES - AEROSOL AND VAPOR. USEFUL TOOLS FOR DETERMINING THE CONCENTPATION OF RADIOIODINE IN AIR AND FOR REMOVING IT FROM THE AIR ARE THEREFORE NOT ONLY AEROSOL PAPTICULATE FILTERS BUT ALSO FILTERS OR SORBING $\triangle G E N T S$ CAPABLE OF TRAPPING GASEOUS IODINE. THE AUTHORS MADE A STUDY OF THE SORPTION OF IODINE VAPOR EMERGING IN A STREAM OF AIR FROM A SPENT FUEL ELEMENT HFATED TO 9OD-1ODO C ON ACTIVATFD BAU GRADE CHAPCOAL AT AN AIR FLOWSPEED OF $20 \mathrm{~cm} / S E C$. THE FUEL ELEMENTS WERE MADE OF RERYLLIUM OXIDE AND ENRICHED URANIUM DIOXIDE, WIYH NO FRAGMENT-PROOF CLADDING. THE RADIOIODINE CONCENTRATION WAS 10-TO-THE-MINUS-9 TO 10-TO-THE-MINUS-10 CUR IE/LITER. THF IODINF VADOR DISTRIBUTION CURVES OVER THE LENGTH OF THE BAU CHARCOAL BED ARE PLOTTED. THE RADIOIODINE CONCENTRATION IN AIR WAS FOUND TO BE REDUCED BY A FACTOR OF ABOUT 500 BY USING A BAU CHARCOAL BED 10 CM LONG. IN STUDYING THE FILTERS THAT ARE EFFICIENT TRAPPERS OF IODIDES, WE SUCCESSFULLY ESTABLISHED THAT IODINE COMPOUNDS ARE PRESENT IN THREE FORMS IN THE VAPOR PHASE
\end{abstract} - ELEMENTAL IODINE, IODIDES, IODATES, AND POSSIBLY EVEN a MIXTURE OF SEVERAL COMPOUNDS.

* ANALYTICAL TECHNIQUE, CALIBRATION + \#FISSION PRODUCT, IODINE + ADSORPTION + CHARCOAL + FILTER + FILTER, TRAP + FISSION PRCDUCT TRANSPORT + IODINE

$7-09370$ NUTTER JI + BUPNET G

FIXED-BEO DRYING UF AIR USING MULELULAR SIEVTS 
CATEGORY 7

FISSION PRODUCT RELEASE, TRANSPORT, AND REMOVAL

7-69370 \#CONTINUED

IOWA STATE UNIVERSITY OF SCIENCE AND TECHNOLOGY, AMES, IOWA

11 PAGES, 10 FIGURES, 2 TABLES, 7 REFERENCES, I AND EC PROCESS DESIGN AND DEVELOPMENT, $5(1)$, PAGES 1-10,

(JANUARY, 1966 )

THE RATE OF DRYING OF AIR IN A FIXED BED OF MOLECULAR SIEVES WAS INVESTIGATED. EXIT AIR

MOISTURE CONTENT AS A FUNCTION OF TIME WAS MEASURED AT SEVERAL VALUES OF INLET CONCENTRATION,

FLOW RATE, FIXED-BED HEIGHT, AND BED TEMPERATURE. OVERALL, SOLID PHASE, AND GAS PHASE MASS

TRANSFER COEFFICIENTS AND PARTICLE AND PORE DIFFUSIVITIES WERE CALCULATED. THE

PORE-DIFFUSION MODEL OF VERMEULEN AND ACRIVOS BEST REPRODUCED EXPERIMENTAL DATA AND IS

RECOMMENDED AS A BASIS FOR DESIGN CALCULATIONS.

* MOLECULAR SIEVE + \#POROUS MEDIA + AIR CLEANING + ANALYTICAL MOdEL + DIFFUSION + STEAM + haTER, GENERAL

7-C9371 GIESEKE JA + MITCHELL RI

SIZE MEASUREMENT OF COLLECTED DROPS

RATTELLE MEMORIAL INSTITUTE, COLUMBUS, OHIO

4 PAGES, 2 TABLES, 2 FIGURES, 5 REFERENCES, JOURNAL OF CHEMICAL AND ENGINEERING DATA, $10(4)$, PAGES $350-353$

(OCTOBER, 1965 )

IN AN EXPER IMENTAL PROGRAM USING WATER, DIBUTYL PHTHALATE, AND NO. 2 HEATING OIL, THE MOST CONVENIENT METHOD FOR SIZING DROPS IN THE 5- TO 250-MICRON RANGE WAS TO MEASURE THE SIZE OF CRATERS FORMED BY THE DROPS ON A SLIDE COATED WITH MAGNESIUM OXIDE. SIX METHODS OF SIZING DROPS COLLECTED ON SLIDES OR IN CELLS WERE INVESTIGATED. THE CRATER COEFFICIENT FOR WATER OR DIBUTYL PHTHALATE DROPS ON THE COATED SLIDE WAS 0.82. THE OBSERVED FLATTENING COEFFICIENTS FOR DROPS ON CLEAN GLASS SLIDES WERE 0.05 FOR DIBUTYL PHTHALATF AND 0.42 FOR NO. 2 HEATING CIL.

\# AEROSOL PROPERTIES + *aNALYTICAL TECHNIQUE, CALIBPATION + \#PARTICLE SIZE + AEROSOL + MIST

7-[9373 SMITH RK + WILLS GB

APPLICATION OF PENETRATION THEORY TO GAS ABSORPIION ON A SIFVE TRAY

VIRGINIA POLYTECHNIC INSTITUTE

6 PAGES, 10 FIgURES, 10 REFERENCES, I AND EC PROCESS DESIGN AND DEVELOPMENT, 5111 , PAGES $39-44$ IJANUARY, 19661

A METHOD WAS DEVELOPED FOR EXTENDING TRANSIENT ABSORPTION MEASUREMENTS FROM SIMPLIFIED APPARATUS TO OPERATING, PILOT-SCALE ABSORPTION EQUIPMENT THROUGH MEASUREMENT OF THE EFFECTIVE TIMES OF PENETRATION AND OF THE INTERFACIAL AREAS AVAILABLE FOR MASS TRANSFER IN A 4-INCH-DIAMETER SIEVE-TRAY COLUMN. THE SYSTEM STUDIED WAS THAT OF THE ABSORPTION OF CARBON DIOXIDE INTO DILUTE AQUEOUS SOLUTIONS OF SODIUM HYDROXIDE. THE MEASURED VALUES OF THF TIMES OF PENETRATION WERE ABOUT TWICE AS LARGE AS PREVIOUS ESTIMATES. THE VALUES OF THE

INTERFACIAL AREAS DETERMINED WERE CONSISTENTT WITH PREVIOUS, INDEPENDENT ESTIMATES.

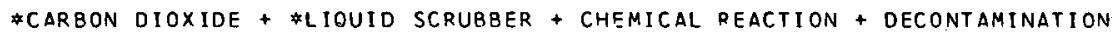

7-09374 BLUME H + STRICH ER + HATTWIG M + RISINGER HJ

ULTRAPURIFICATION OF GASES BY MEANS OF NEWLY DEVELOPED CATALYSTS

WALTER ULBRICHT PLANT, VEB LEUNA-WERKE

ORNL-TR-1081 +. 9 PAGES, 7 TABLES, 1 FIGURE, 14 REFERENCES, APRIL 1, 1966, TRANSLATED FROM CHFM. TECHN.

17. PAGES $463-466,119651$

PPOTECTIVE GASES, SUCH AS H2, N2, AND NOBLE GASES, ARE BEING EMPLOYED IN EVER-INCRFASING QUANTITIES IN THE CHEMICAL INDUSTRY, LAMP FACTORIES, SEMI-CONDUCTOR PLANTS, AS WELL AS IN METALLURGY. THESE MUST BE FPEE FROM IMPURITIES, PARTICULARLY OXYGEN. ALTHOUGH THE REMOVAL OF SMALL CONCENTRATIONS OF OXYGEN FROM H2 OR HZ-CONTAINING GASES IS CARRIED OUT MOST ADVANTAGE OUSLY WITH NOBLE METAL CATALYSTS (E.G., LEUNA-CATALYST 7748 , O.5 PERCENT PD ON GAMMA-AL 203) AT ROOM TEMPERATURE, OXYGEN REMOVAL FROM INERT GASES (N2 AND NOBLE GASESI IS PERFORMED CHIEFLY BY OXIDATION OF THE METALLIC CONSTITUENTS OF PURIFYING AGENTS. IN THE PAST YEAR, THE CATALYST GROUP OF VEB LEUNA-WERKE DISCOVERED A NICKEL CATALYST, DESIGNATED 6525, WHOSE OXYGEN-ABSORPTION POWER AT ROOM TEMPERATURE IS SEVERAL TIMES GREATER THAN THE USUAL COPPER CATALYSTS. THE PREPARATION, REDUCTION, AND STABILIZATION OF NICKEL CATALYSTS ON AN AL 203 BASE, USED FOR HYDROGENATION OF DHENOL, HAS BFFN REPORTED. ALTHOUGH THE NICKEL-CHROMIUM OXIDE COMBINATION SEEMS TO BE ESPECIALLY SUITABLE, M. GREYSON FAILED TO PLACE EMPHASIS ON IT IN THE JOURNAL, CATALYSIS. AN ACTIVE NICKEL-CHROMIUM OXIDE CATALYST WAS ALSO DEVELOPED IN THE LEUNA PLANT WHICH HAS BEEN DESIGNATED CATALYST 6540. THE PROPERTIES OF CATALYSTS 6525 AND 6540 HAVE BEEN INVESTIGATFD IN THEIR ACTION ON THE ULTRAPURIFICATION OF GASES.

*CHEMICAL KINETICS + *CHEMICAL REACTION + \#HYDROGEN + \#NOPLE GAS + \#OXYGEN + CHEMICAL EQUILIRRIUM + . DECONTAMINATION + OXIDATION

7-09678 PRADOS JW

A COMPUTER PROGRAM FOR PREDICTING COATED-PARTICLE BEHAVIOR

OAK RIDGE NATIONAL LABORATORY, OAK RIDGE

ORNL-TM-1385 +. 38 PAGES, I FIGURE, MARCH 1966, CFSTI, \$2.00 CY, \$0.50 MN

THIS REPORT DESCRIBES A COMPUTER PROGRAM FOR USE IN CALCULATING CONDITIONS UNDER WHICH THE PYROLYTIC-CARBON COATINGS OF FUEL MICROSPHERES WOULO BE EXPECTED TO FAIL. WORKINS EQUATIONS AND A LISTING OF THE FORTRAN-63 SOURCE PROGRAM ARE PRESENTED, TOGETHER WITH INSTRUCTIONS FOR FURNISHING INPUT DATA. 
CATEGORY 7

FISSION DRODUCT RELEASE, TRANSPORT, AND REMOVAL

7-09678 \#CONTINUEO*

* ANALYTICAL MODEL + \#COATED PARTICLE + \#COMPUTER PROGRAM + FUEL INTEGRITY

7-G9729 PARKER DR

EVALUATION OF MICROSCOPIC-SIZED GRAPHITE AEROSOL FROM A ROVER REACTOR DESTRUCTION TEST, JUNF I965 SANDIA CORPORATION, ALBUQUERQUE, NCW MEXICO

SC-RR-65-557+. 16 PAGES, 5 FIGURES, 4 TABLES, DECEMBER 1965, CFSTI, \$1.00 CY, \$0.50 MN

THE USE OF A ROVER/NERVA SPACE PROPULSION ENGINE FOR SPACE FLIGHT MUST BE PRECEDED BY AN ACCEPTABLE EVALUATION OF THE SAFETY CRITERIA. THESE SAFETY CRITERIA ARE DEPENDFNT ON A KNOWLEDGE OF THE DEBRIS SIZE, VELOCITY, AND DISTRIBUTION WHEN THE REACTOR IS DISPOSED OF AFTER FLIGHT OPERATION. THIS REPORT DESCRIBES ONLY THE TECHNIQUES USED TO COLLECT, SIZE, AND ANALYZE THE AIRBORNE DEBRIS RESULTING FROM THE DESTRUCTION OF A FULL-SCALE ROVER/NERVA MOCKUP ENGINE. THE AECINASA SPAC.F NIICI.EAR PROPULSION OFFICE REQUESTEO THE PARTICIPATION OF ABERDEEN PROVING GROUNO AND SANDIA CORPORATION IN A DESIRUCIION TEST OF A FULL-SCALE MOCKUP

ROVER/NERVA PROPULSION ENGINE. THIS TEST WAS SCHEDULED AND COMPLETED AT THE ABERDEEN PROVING GROUND IN JUNE 1965. THE TEST WAS PERFOPMED TO PROVIDE COMPLETE DEBRIS DATA AS WELL AS AIRBORNE DEBRIS DATA WHICH WILL ALLOW THE SAFETY ANALYSES TO BE COMPLETED ON THE SPACE ENGINE. THE ANALYSES OF THE MICROSCOPIC PARTICLES WITHIN THE AIRBORNE CLOUD SHOW THAT (1) 8D PERCENT ARE BETWEEN 0.5 AND 3.5 MICRONS IN DIAMETER, $(2)$ THE URANIUM PARTICLES CONTAINFD WTTHIN THE CORE ARE NOT CARRIED IN THE AIRRORNE CLOUD, (3) THE AIR SAMPLING OF A MULTIJET DEBRIS CLOUD DOES NOT PRODUCE RELIABLE OATA AS TO THF CONCENTRATION OF PARTICLES IN IHE CLOUD, AND (4) A MINIMAL ENVIRONMENTAL HEALTH HAZARD MAY BF EXPECTED FROM THE URANIUM IN THE CORE.

\#ACCIDENT, EXPLOSION + \#AEROSPACE SAFETY + \#ANALYTICAL TECHNIOUE, AIR + \#ROVER PROGRAM + *SAMPLING + AEROSOL + AEROSOL PRODUCTION + AEROSOL PROPERTIES + ATRBORNE RELEASE + GRAPHITE + MONITOR, RADIATION, AIR + PARTICLE SIZF

$7-C 9730$ CARFI N

PREPARATION OF ZNSIAG) PHOSPHOR SCREENS FOR DETECTION OF ALPHA PARTICLES CENTRO INFORMAZION STUDI ESPERIENZE, MILAN, ITALY

2 PAGES, 3 FIGURES, ENERGIA NUCLEARE 12(12)- 661-662 (DECEMBER 1965)

ZNS(AG) SUITABLY PREPARED IS AN EXCELLENT DETECTOR OF ALPHA PARTICLES, WITH AN EFFICIENCY ALMOST EQUAL TO 100 PERCENT AND A TOTAL DISCRIMINATION FOR BETA AND GAMMA RAYS. IN FACT, IO MG/SQ.CM THICKNESSES OF ZNSIAGI APPROXIMATELY CORRESPOND TO THE RANGE OF ALPHA PARTICLES EMITTED FROM MOST RADIOISOTOPES. OWING TO THIS FACT, THEY PRACTICALLY LOSF ALL THEIR ENERGY IN PASSING THROUGH THE PHOSPHOR AND THUS SUFFICIENTLY HIGH PULSES CAN BE OBTAINED. ON THE CONTRARY, BETA ANU GAMMA RAYS GENERALLY LOSE AN EXTREMELY SMALL AMOUNT OF THEIR. ENERGY, AND, AS A CONSEQUENCE, THEIR PULSES CAN BE EASILY DISCRIMINATED. THE PROBLEM IS ESSFNTIALLY THAT OF MAKING THE PHOSPHOR FIRMLY STICK TO THE SUPPORT.

* analytical technique, calibration + alpha emitTer + gross alpha + uranium

7-C9731 LAZZARINI E

ON TIIE DISTRIBUTION OF SOME FISSION PRODLCTS RFTWFFN C.ORE AND RECOMBINER OF L54M REACTOR-PART 4-DECAY PROBABILITY OF KR-B9 AND KR-90 IN RECOMBINER

CENTRO STUDI NUCLEARI DELLA CASACCIA, ROME, ITALY

3 PAGES, 2 TABLES, 1 FIGIJRE, FNFRGIA NUCLEARE 12(12)- 625-627 (DECEMBER 1965)

THE PROBABILITIES THAT KR-89 AND KR-OO DECAY IN THE RECOMBINER OF L54M REACTOR WERE MEASURED EY DETERMINING THE AMOUNTS OF SR-89 AND SR-90 IN THE RECOMBINER WATER. THESE PROBABILITIES, TOGETHEP. WITH THOSE PREVIOUSLY ORTAINED FOR XE-137, XE-140 AND XE-141, ARE PLOTTED AGAINST THE HALF-LIVES OF THF NUCLIDES AND INTERP.OLATED WITH CALCULATED FUNCTIONS. THE AGREEMENT RETWEEN EXPERIMENTAL AND THEORETICAL BEHAVIOURS IS DISCUSSED.

\#FISSION PRODUCT TRANSPORT + \#RECOMBINER + FISSION GAS RELEASE + KRYPTON + NOBLE GAS + STRONTIUM + WATER, GENERAL + XENON

7-09732 LAZZARINI E + SANGIUST V + TERRANI M + TERRANI $S$

ON THE DISTRIBUTION OF SOME FISSION PRODUCTS BETWEFN CORE AND RECOMBINER OF L54M REACTOR - PART 3 DETERMINATION OF THE TURNOVER TIME OF RECOMBINER WATER AND BUILDUP OF CS-13?. AND BA-I4O AND CE-14I IN IT CENTRO STUDI NUCLEARI DELLA CASACCIA, ROME, ITALY

5 PAGES, 2 FIgURES, 1 TABLe, ENERGIA NUCLEARF, 12 111)- 593-597 (NOVEM9ER 1965)

THE BUILD-UP OF FISSION PRODUCTS IN THE RECOMBINER HATER OF LS4M REACTOR HHEN IT IS OPERATING AT MAXIMUM POWER WAS STUDIED. THE TURNOVER TIME OF THE RECOMBINER WATER WAS MEASURED AND THE PROBABILITIES THAT XE-137, XE-140 AND XE-141 DFR.AY IN IT WERE ALSO OETERMINED. AN EXPRESSION FOR THESE PROBABILITIES HAS OBTAINED IN FUNCTION OF THE TRANSPORT TIME OF GASEOUS FISSION PRODUCTS FROM THE CORE TO THE RECOMBINER AND OF THEIR TRANSIT TIME THROUGH THE RECOMBINER WATER. THESE TIME INTERVALS WERE DEDUCED FROM THE PROBABILITIES, EXPERIMENTALLY DETERMINED, THAT XE-137, XE-140 AND XE-141 DECAY IN RECOMBINER WATER. VALUES OF 6.2 AND 1.9 SEC, RESPECTIVELY, WERE FDUND.

\#FISSION PRODUCT TRANSPORT + \#NOBLE GAS + \#RECOMBINER + \#XENON + BARIUM + CERIUM + CESIUM + FISSION GAS RELEASE + FISSION PRODUCT, VULLATILE + WATER, GENERAL

7-00735 PIIRT.HAS NR

WHAT IS INDUSTRIAL FILTRATION

ACCESSION NUMBER 7-09678 TO 7-09735 
CATEGORY

FISSION PRODUCT RELEASE, TRANSPORT, AND REMOVAL

7-09735 \#CONTINUED*

1 PAGE, CHEMICAL AND PROCESS ENGINEERING 46111)- 607 (NOVEMBER 1965)

AN INESCAPABLE FEATURE OF THE MODERN EXPLOSIVE GROHTH OF TECHNOLOGY IS THE PROLIFERATION OF BOTH SPECIAL TECHNIQUES AND OF NAMES FOR THESE TECHNIQUES WHICH ARE RESTRICTED TO CERTAIN AREAS OF APPLICATION. ALTHOUGH GENUINE DIFFERENCES BETWEEN THE TECHNIQUES MAY BE SLIGHT, THIS CAN BE OBSCURED EITHER BY THE SIMPLE MATTER OF TERMINOLOGY OR BY THE COMPLEXITY OF HIGHLY SPECIALIZED FEATURES OF THE DIFFERENT TECHNOLOGICAL FIELDS IN WHICH THE TECHNIQUES ARE APPLIED. TO COUNTER THIS FRAGMENTATION OF TECHNICAL KNOWLEOGE, A POSITIVE EFFORT IS NEEDED TO DEMOL ISH SOME OF THE ARTIFICIAL BOUNOARIES WHICH HAVE ARISEN. INDUSTRIAL FILTRATION IS THE MECHANICAL SEPARATION OF DISPERSFD PARTICLES OF A SOLID OR A LIQUID FROM A FLIJID.

*FILTER + \#FILTRATION + AEROSOL + AIR CLEANING + FILTER, BED + FILTER, COMMERCIAL + FILTER, CYCLONE + FILTER, ELECTROSTATIC + PARTICULATE + SCRUBBER

7-[:9736 RADIOACTIVE SAMPLE EXTRACTOR PORT

BELGIAN PAT. $652,061+$ AUGUST 20, 1964, PATENT (FOREIGN)

THE PRESENT INVENTION IS A COMMUNICATION PORT PROVIDING FOR THE FXTRACTION OF MATERIAL FROM CONTAMINATED, ENCLOSED ATMOSPHERES. THE DEVICE INCLUDES A SLEEVED PORT COMMUNICATING INTO SAID ENCLOSURE AND ADAPTED TC RECEIVE A REMOVABLE CONTAINER PROVIDED WITH A CLOSE-FITTING FLEXIBLE SHIELD RING WHICH ENGAGES THE INNER MOUTH END OF SAID SLEEVE. THE SHIELD POSITIONS AND SEALS THE CONTAINER IN THE SLEEVE DURING LOADING, REMAINS THEREIN AS THE CONTAINER IS WITHORAWN, AND IS DISPLACED INTO THE ENCLOSURE BY THE SUBSEOUENT INSERTION OF ANOTHER CONTAINER BEARING A NEW, CLEAN SHIELD.

*FILTER + \#SAMPLING + GLOVE BOX + RADIATION SAFETY AND CONTROL + RADIOCHEMICAL PROCESSING

7-C9854 SZAWLEWICZ SA

THE AEC REACTOR SAFETY PROGRAM

U. S. ATOMIC ENERGY COMMISSION

7 PAGES, PRESENTED AT THE ANS SYMPOSIUM ON LOCATING NUCLEAR POWER PLANTS IN CITIES, MARCH 22 , 1966 , NEW YORK CITY

STEER ING COMMITTEE ON SAFETY RESEARCH. ACCIDENT-PREVENTING AND CONSEQUENCE-LIMITING

SAFEGUARDS. ENGINEERED SAFEGUARDS. LOSS-OF-COOLANT ACC IDENT AND MECHANICAL LOAD IT CREATES, IN-CORE SPRAY AND EMERGENCY COOLING SYSTEM, METAL-WATER REACTION, FUEL MELTDOWN,

FISSION-PRODUCT RELEASE, RELIABILITY OF PIPING. LIST OF PLANNED ORNL SUMMARY REPORT BUDGET.

IN-PLANT TEST PROGRAM. NUCLEAR SAFETY PILOT PLANT, CONTAINMENT SYSTEMS EXPERIMENT, LOFT, POWER BURST FACILITY.

CSE (CONTAINMENT SYSTEMS EXPERIMENT) + EMERGENCY COOLING + ENGINEERED SAFEGUARD +

FISSION PRODUCT RELEASE, GENERAL + FUEL MELTDOWN + LOFT (LOSS OF FLUID TEST) + METAL WATER REACTION + NSPP (NUCLEAR SAFETY PILOT PLANT) + PBF (POWER BURST FACILITY) + REACTOR, PRESSURIZED WATER

7-09913 FRIEND JP + THOMAS DMC

THE DETERMINATION OF THE PARTICLE SIZE DISTRIBUTION OF THE PARTICULATE MATERIAL COLLECTEN DURING THE DOUBLE TRACKS AND CLEAN SLATE I EVENTS OF OPERATION ROLLER COASTER

ISOTOPES, INC., WESTWOOD, N.J.

AWRE-0-20/65 +. 34 PAGES, 11 FIGURES, 7 TABLES, FEBRUARY 1965, BIS, \$1.00 CY

MEASUREMENTS WERE MADE OF THE PARTICLE-SIZE DISTRIBUTIONS OF THE AEROSOLS PRODUCED IN THE ROLLER COASTER EXPERIMENTS FOR TWO REASONS. FIRST, SO THAT THE RESPIRABLE FRACTIONS OF THE TOTAL AIR CONCENTRATIONS AT THE LOCATIONS OF THE ANIMALS AND AT OTHER POINTS ON THE ARRAY OF SAMPLERS MIGHT BE DETERMINED AND, SECONO, TO PROVIDE SOURCE DISTRIBUTIONS FOR USE WITH THE CLOUD MODEL TO ENABLE PREDICTIONS OF THE DEPOSITION, PARTICLE-SIZE DISTRIBUTIONS, AND AIR CLOUD MODEL TO ENABLE PREDICTIONS OF THE DEPOSITION, PARTICLE-SIZE DISTRIBUTIONS, AND AIR
CONCENTRATIONS DOWNWIND TC BE MADE. THE OVERALL SIZE-PLUTONIUM DISTRIBUTIONS FOR OOURLE TRACKS AND CLEAN SLATE 1 WERE DETERMINED AND FOUND TO BE. THE SAME, WITHIN EXPERIMENTAL ERRCR. THE DISTRIBUTIONS ARE NOT LOG-NORMAL, AND THE CONTRADICTORY ESTIMATES OF THE GEOMETRIC STANDARD DEVIATION IN TG57 FROM IMPACTORS AND THE DEPOSITION MONEL ARE EXPLAINED ON A RATIONAL BASIS.

* AEROSOL + \#FILTER, CASCADE IMPACTOR + \#PARTICLE SIZE + \#PLUTONIUM + \#PLUTONIUM OXIDE + AEROSOL PROPERTIES + FILTER, CASCADE + PARTICLE SIZE OISTRIBUTION + URANIUM OXIDE

7-10270 ARNETT LM + ROSS CP + RUSCHE BC + TAYLOR CD

FINAL SAFETY ANALYSIS OF THE MAXIMUM CREOIBLE ACCIDENT IN THE HEAVY WATER COMPONENTS TEST REACTOR SAVANNAH RIVER LABORATORY, DUPONT

DP-1037+* 30 PAGES, 4 FIGURES, 7 TABLES, REFERENCES, DECEMBER 1965, CFSTI \$2.00 CY, \$O.50 MN

THE MAXIMUM CREDIBLE ACCIDENT IN THE HWCTR IS ANALYZED FOR THE CONDITIONS THAT EXIST SINCE IODINE ABSORBERS WERE INSTALLED IN THE CONTAINMENT BUILOING. THE ABSORBERS REMOVE RADIOIOOINE ISOTOPES TO THE EXTENT THAT THE THYROID AND WHOLE-BODY DOSES AT. THE SAVANNAH RIVER PLANT BOUNDARY WOULD BE LESS BY FACTORS OF SIX AND THENTY-FIVE, RESPECTIVELY, THAN THE ALLOWABLE LIMITS SET FORTH IN THE CODE OF FEDERAL REGULATIONS (1C-CFR 100$).$

* ACCIDENT, MAXIMUM CREOIBLE (MCA) + \#HWCTR (HEAVY WATER COMPONENT TEST REACTOR) + FILTER + IODINE + SAFEGUARDS REPORT, GENERAL

7-10297 SMIDT $\mathrm{C}+$ SOMMER W 
CATEGORY 7

FISSION PRODUCT RELEASE, TRANSPORT, AND REMOVAL

7-10297 \#CONTINUED*

APPLICATION OF THE VENTED FUEL CONCEPT TO A SOOIUM COOLED POWFR BRFEDER WITH 1000 MWE KERNFORSCHUNGSZENTRUM, KARLSRUHE

KFK-399 +. 15 PAGES, 2 FIGURES, 4 TABLES, OCTOBER 1965

THE PRINCIPLE OF VENTING THE FISSION GAS OF A FAST, CERAMIC-FUELET REACTOR TO ITS COOLANT HAS A NUMBER OF ADVANTAGES - (1) ND STRESS OF THE FUEL CLADDING BY FISSION-GAS PRESSURF, (2) MORF COMPACT SUBASSEMBLY, SINC,E NO FISSION-GAS PLIJENIIM IS NFT.FSSARY, (3) NO STRRAFE OF

HIGH-PRESSURE RADIOACTIVE GAS. THE VENTING OF FISSION GASES TO THE SODIUM COOLANT ALLOWS FOR SAVINGS IN THE ORDER OF 2 PERCENT OF THE TOTAL PLANT COST, IF COMPARED WITH THE REFERENCF REACTOR. IN COMPARISON WITH A MORE OPTIMIZED REACTOR, THE SAVINGS ARE MUCH SMALLER.

\#REACTOR, BREEDER + \#REACTOR, FAST + \#REACTOR, LIQUID METAL COOLED + \#SODIUM + CERAMICS + CLAD + CONTAINMENT, GENERAL + ECONOMIC STUDY + FISSION PRODUCT RETENTION + FUEL FLEMENT + REACTOR COOLANT + REACTOR OFFGAS + RELEASE RATE + SAFETY PRINCIPLES AND PHILOSOPHY

7-10299 MUHLBAIER DR

NONDESTRIJCTIVE TEST OF CARBON BEDS FOR REACTOR CONTAINMENT APPLICATIONS

SAVANNAH RIVER LABORATORY, AIKEN

OP-950 +. 15 PAGES, 4 FIGURES, 1 TABLE, 4 REFERENCES, MARCH 1965, CFSTI, \$1. DO CY

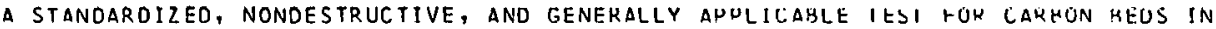
PEACTOR-CONTAINMENT FACILITIES IS PEING DEVEI OPFO RY THF SAVANNAH RIVER LABORATORY.

CONTINUING TESTS SHOW THAT THE PERMISSIBLE RANGES OF AIR VELOCITY AND WATER CONTENT OF THE

CARBON CAN BE EXTENOED TO ENCOMPASS THE DESIRFD TEST CONDITIONS FDR INSTALLED RFDS OF NFW

CARBON. THE MAJOR IMPROVEMENT REPORTED IS THAT OF SUBSTITUTING F-112 OR F-113 FOR F-12 - A

MORE VOLATILE FREON USEC IN AN EARLIER TESTING METHOD.

\#FILTER + \#TEST, NONDESTRUCTIVE + \#TESTING + CHARCOAL + FILTER, BED + FILTER, TRAP +

FISSION PRODUCT RETENTION + FISSION PRODUCT, IODINE + TEST, FILTER

7-10302 LOC.KHART IR + PATTFRSON RL + SAUNDERS AW

FILTER PACK TECHNIQUE FOR CLASSIFYING RADIOACTIVE AEPOSOLS RY PARTICLE SIZF

U. S. NAVAL RESEARCH LAB, WASHINGTON

NRL-6305 +. 18 PAGES, 6 FIGURES, 7 TABLES, O REFERENCFS, JULY 1965, CFSTI, \$1. CO CY

ABOUT 60 COLLECTIONS OF RADIOACTIVE PARTICLES DISPERSFD IN THE ATMOSPHERE HAVE BEEN MADE DURING THE PAST TWO YEARS SY USE OF FILTER PACK UTILIZING FOUR SUPERIMPOSED FILTERS. THE DISTRIBUTION OF RADIOACTIVITY AMONG THE FILTERS WAS ANALYZED MATHEMATICALLY BY MEANS OF FOUR SIMULTANEOUS LINEAR ALCEBRAIC EQUATIONS WHICH RELATE THE PAPTICLE SIZE (DIAMETER) OF THF RETAINED MATERIAL TO THE FILTER CHARACTERISTICS SO AS TO PERMIT THE ASSIGNMENT OF RADIOACTIVITY IN EACH COLLFCTICN TO FOUR. MAJOR SIZE GROUPINGS - $1.1,0.6,0.3$, AND 0.15 MICRON.

*AIRBORNE RELEASE + \# ANALYTICAL TECHNIQUE, CALIBPATIDN + \#FILTER PACK + \#PARTICLE SI7E + GROSS BETA + PARTICLE SIZE DISTRIBUTION + RADIOCHEMICAL ANALYSIS

7-1035C HIPP AL

A COMPARISON OF DIFFERENT METHODS OF PARTICLE SIZE ANALYSIS

LOS ALAMOS SCIENTIFIC LABORATORY

LA-3424-MS +. 29 PAGES, 7 FIGURES, 4 TABLES, REFERENCES, SEPTEMBEP 1965, CFSTI \$2.00 R.Y, \$D.5O MN

PARTICLE-SIZE ANALYSES WERE PERFORNED ON SEVERAL TUNGSTEN POWDFRS, USING FOUR METHODS FOR COMPARISON. TWO OF THE METHODS MEASURED ONLY SPECIFTC SURFACE AREA, AND THE DTHER THO MEASURED PARTICLE-SIZE DISTRIBUTIONS. AN APPLICATION OF LOG-NORMAL TRANSFORMATIONS WAS MACE TO CALCULATE SPECIFIC SURFACE AREA FROM THE SIZE DISTRIRUTIONS AND TO COMPARE THE DISTRIBUTIONS OBTAINEO BY DIFFERENT METHODS.

\#ANALYTICAL TECHNIQUE, SOLID + \#METAL + \#PARTICLE SIZE + \#PARTICLE SIZE DISTRIBUTION + \$SURFACE TO VOLUME PATIO + \#TUNGSTEN

7-10505 WOODS FJ + JOHNSON JE

THE IGNITION AND COMBUSTION PROPERTIES OF ACTIVATED CARRON CONTAINING AOSORBFD HYDROCAREONS

NAVAL RESEARCH LABORATORY, WASHINGTON

AD-605,193 + NRL-6090 +N64-29955+. 36 PAGES, FIGURES, TA8LES, 2C REFEPENCES, MARCH 1964, CFSTI, \$D.75 CY

ACTIVATED CARBON CONTAINED IN LARGE FILTER BEDS IS USED IN NUCLEAR SIJBMARINES FOR REMOVAL OF ODORS AND TRACF. CONTAMINANTS. BECAUSE ORGANIC VAPORS ARE CONCENTRATED IN THIS WAY IN THE CARBON, A STUOY WAS MADE TO GET INFORMATION FOR ASSESSING THE FIRE HAZARDS INVOLVED IN MAINTAINING THE CARBON FILTER IN THE VENTILATION SYSTEM OF THF SUBMARINFS. IN THIS STUDY, SPONTANEOUS IGNITION OF SUBMARINE-EXDOSED CARBONS OCCURRED AT TEMPERATURES AS LOW AS 490 DEGREES $F$ (255 DEGREES C) IN AIR AT ONE ATMOSPHERE. EXOTHERMIC OXIDATIVE REACTIONS OCCURPED IN A FLOW SYSTEM AT TEMPERATURES AS LOW AS 39 DEEREFS F 1200 DEGRFFS CI. COMBUSTION OF CARBONS CONTAINING HYDROCARBON PRODUCED CONSIDERABLE OUANTITIES OF C,ARBON DIOXIDE AND CARBON MONOXIDE, AND SIGNIFICANT AMOUNTS OF THESE GASES WERE EVOLVED EVEN UNDER PRECOMBUSTION

CONDITIONS. OF A NUMBER OF CARBONS WHICH HAD BEEN USED IN SUBMARINES, THE LOWEST FLASH DOINT FOUND WAS 160 DEGREES F. 


\author{
CATEGORY 7
FISSION PRODUCT RELEASE, TRANSPORT, AND REMOVAL
}

7-1050t KIEFER RJ + WINKLER EO

GENERAL ATOMIC IN-PILE LOOP FISSION PRODUCT TRAPPING SYSTEM. REgENERATIVE H2O-CO2 TRAD AND LIOUID NITROGEN COOLED NO. 2 CHARCOAL TRAP ASSEMBLY. INFORMATION DATA PACKAGE AND. DESIGN ANALYSIS GENERAL ATOMIC DIVISION, SAN DIEGO, CALIFORNIA

GAML-5434 +. 55 PAGES, 4 FIGURES, 5 TABLES, JULY.1964, CFSTI, $\$ 3.00 \mathrm{CY}, \$ 0.50$ MN

THE FISSION PRODUCT TRAPPING SYSTEN (FPTSI INITIALLY INSTALLED IN THE GAIL, HAS BEFN IN CONTINUOUS SERVICE FOR APPROXIMATELY THREE YEARS SINTE THE LOOP WAS FIRST OPERATED WITH NUCLEAR FUEL. THROUGHOUT THIS TIME, THE SYSTEM HAS EFFECTIVELY PERFORMED ITS INTENDED FUNCTION OF REMOVING FISSION PRODUCTS AND IMPURITIES FROM THE PURGE GAS STREAM.

\#CHARCOAL ADSORBER + \#CRYOGENICS + \#DESIGN CRITERIA + \#FILTER, BED + \#FISSION PRODUCT RETENTION + \#NITROGEN + CHARCOAL + FILTER, TRAP + FISSION PRODUCT, VOLATILE + IN PILE LOOP + OPERATING EXPERIENCE

$7-10532$ JUDO AM

LOSS-OF-COOLANT ACCIDENTS IN A LARGE SODIUM-COOLED FAST REACTOR

U.K. ATOMIC ENERGY AUTHORITY, WINFRITH.

ANL-7120 +. 15 PAGES, 11 FIGURES, 2 TABLES, 8 REFERENCES, PP. 67-81 OF DP.OCEEDINGS OF THE CONFERENCE ON

SAFETY, FUELS, ANO CORE DESIGN IN LARGE FAST POWER REACTORS, OCTOBER $11-14,1965$, CFSTI $\$ 9.25$ CY

\begin{abstract}
BASICALLY, YHE APPROACH USED HERE IS TO CONSIDER A SERIES OF FAULT CONDITIONS WHICH MIGHT ARISE IN A TYPICAL OXIDE-FUELLED, SODIUM-COOLED FAST REACTOR. THE ACCIDENTS RESULTING FROM THESE FAULTS ARE THEN ANALYSED STEP-BY-STEP, USUALLY UNDER SOME PESSIMISTIC ASSUMPTIONS, SUCH AS THE FAILURE OF ONE OR MORE REACTOR TRIP CIRCIJITS. THERE ARE, HOWEVER, SOME MECHANISMS WHICH ARE IMPORTANT FOR SEVERAL OF THE ACCIDENTS AND REQUIRE DETAILED CONSIDERATION, SUCH AS COOLANT ANO FUEL REACTIVITY WORTH, THE BEHAVI OUR OF THE COOLANT AS IT BOILS, AND PARTICULARLY THE EFFECTS OF NUCLEATE BOILING, THE RELEASE OF FISSION-PRODUCT GAS FROM A EURST FUEL CAN. AS A RESULT OF. THESE ANALYSES, CERTAIN PROBLEMS STAND OUT AS BEING PARTICULARLY IMPORTANT FOR THE SAFETY OF THE REACTOR, INCLUDING THE POSSIBILITY OF A SINGLE SUBASSEMBLY ACCIDENT SPREADING TO THE WHOLE CORE AND THE TIME FOR AVATLABLE FOR A TRIP MECHANISM TO OPFRATE.
\end{abstract}

* ACCIDENT, MAXIMUM CREDIBLE (MCA) + \#LOSS OF COOLANT + \#REACTOR, FAST + FUEL ELEMENT + HEAT TRANSFER + METAL, LIQUID + RADIUM + REACTOR KINETICS + TEMPERATURE TRANSIENT + URANIUM DIOXIDE

7-10533 SMIOT D + SOMMER H

APPLICATION OF THE VENTED FUEL CONCEPT TO A SOOIUN-COOLED POWER BREEDER HITH 1000 MHE KERNFORSCHUNGSZENTRUM, KARLSRUHF, GERMANY

ANL-7120+. 6 PAGES, 2 FIGURES, 4 TABLES, PP. 130-135 OF PROCEEDINGS OF THE CONFERENCE ON SAFETY, FUELS, AND CORE DESIGN IN LARGE FAST POWER REACTORS, OCTOBER 11-14, 1965, CFSTI, \$9.25 CY

THE PRINCIPLE OF VENTING THE FISSION GAS OF A FAST CERAMIC REACTOR TO ITS COOLANT HAS REEN WELLKNOWN FOR SOME YEARS. THERE IS AN IMPRESSIVE NUMBER OF AOVANTAGES - (1) NO STRESS OF THE FUEL CLAODING CAUSED BY FISSION GAS PRESSURE. (2) MORE COMPACT SIJBASSFMBLY, SINCE NO FISSION GAS PLENUM IS NECESSARY. (3) NO STORAGE OF HIGH-PRESSURE RADIOACTIVE GAS. THIS PAPER ANSWERS THE FOLLOWING QUESTIONS- 11 W WHA ARE THE PRINCIPAL DESIGN SPECIFICATIONS FOR THE GAS-PURIFICATION PLANT WITH RESPECT TO OPERATION AND SAFETY OF THE REACTOR, (2) WHAT ARE THE NUMERICAL RESULTS FOR A REFERENCE REACTOR, (3) WHAT IS THE ECONOMICAL BALANCE OF THE CITED ADVANTAGES AND DISADVANTAGES OF THE VENTED-TO-COOLANT CONCEPT.

*ECONOMICS + \#REACTOR, BREEDER + \#REACTOR, LIQUID METAL COOLED + CLAD + FISSION GAS RELEASE + FISSION PRODUCT TRANSPORT + REACTOR, FAST + SODIUM + THERMAL ANALYSIS

7-10534 ZEBROSKI EL + LYON WL + BAILY WE EFFECT OF STOICHIOMETRY ON THE PROPERTIES OF MIXEO OXIDE U-PU FUEL GENERAL ELECTRIC COMPANY, SAN JOSE

ANL-7120 +17 PAGES, 14 FIGURES, 4 TABLES, 31 REFERENCES, PP. $374-388$ OF PROCEEOINGS OF THF CONFERENCE

ON SAFETY, FUELS, AND CORE DESIGN IN LARGE FAST POWER REACTORS, OCTOBER 11-14, 1965 , CFSTI, S9.25 CY

CONVENTIONAL OXIDE FUELS FOR PRESENT ECONOMIC POWER REACTORS TYPICALLY EMPLOY ESSENTIALLY STOICHIOMETRIC FUEL, UO2+X, WHERE X IS POSITIVE ANO LIES IN A RANGE UP TO 0.02 . THIS HAS PROVED SATISFACTORY FOR RELATIVELY LOW-BURNUP APPLICATIONS $(10,000$ TO $25,000 \mathrm{MWO} / \mathrm{T})$ IN WHICH STOICHIOMETRY CHANGES WITH BURNUP ARE SMALL. FAST-REACTOR FUELS OF THE TYPE IU, PUIOX ARE REQUIRED TO ATTAIN AVERAGE BURNUP OF 75,000 TO 100,000 MWO/T TO BE OF ECONOMIC INTEREST, AND LOCAL PEAK BURNUPS UP TO 130,000 MWD/T. THIS PAPER IS INTENDED TO COVER THE STATUS OF SOME FUEL PREPARATION AND PROPERTIES DATA, AS WELL AS OBSERVATIONS OF FUEL PERFORMANCE, HHICH LEAD TO A TENTATIVE PREFERENCE FOR A STOICHIOMETRY OF 1.97 TO 1.98 FOR MIXED U-PU OXIDE FUEL.

\#FUEL BURNUP + \#FUEL ELEMENT + \#OXIDE + \#PLUTONIUM + \#REACTDR, FAST + \#URANIUM +

FUEL EXPANSION COEFFICIENT + FUEL HANDLING + FUEL INTEGRITY + IN PILE FXPERIMENT + RADIATION OAMAGE + RADIOCHEMICAL PROCESSING

7-10535 BAUER AA + BEISSHENGER H + GIACCHETTI G + PATRASSI E + SCHUMACHER G + THFISEN P MICROANAL YTICAL STUDIES OF MICRO- AND MACRO-SEGREGATION IN OXIDE FUELS KERNFOR SCHUNGSZENTRUM, KARLSRUME, GERMANY

ANL-7120 +. 10 PAGES, 11 FIGURES, 7 REFEPENCES, PP. 400-409 OF PROCEEDINGS OF THE CONFERENCE ON SAFETY,

FUELS, AND CORE DESIGN IN LARGE FAST POWER REACTORS, OCTOBER 11-14, 1965, CFSTI, \$9.25 CY

ELECTRON-MICROPROBE TECHNIQUES, IF AOEQUATELY ADAPTED FOR RIGH-SENSITIVITY ANALYSIS IN THE PRESENCE OF RADIOACTIVE MATERIAL, ARE UNIQUELY SUITEO TO THE STUDY OF SHORT-RANGE SEGREGATION. QUANTITATIVE ELEMENTARY MICROANALYSIS IS EFFECTIVE FOR THE ELEMENTS SORON TO PLUTONIUM (ATOMIC NUMBER Z FROM 5 TO 94), AND HIGHLY LOCALIZED POINT ANALYSIS OF MICROVOLUMES RANGING FROM 1 CU. MICRON TO INTEGRATEO SURFACE SCANNINGS OF (3O0) (300) (1) CU. MICRON WITH 
CATEGORY 7

FISSION PRODUCT RELEASE, TRANSPIRT, AND REMOVAL

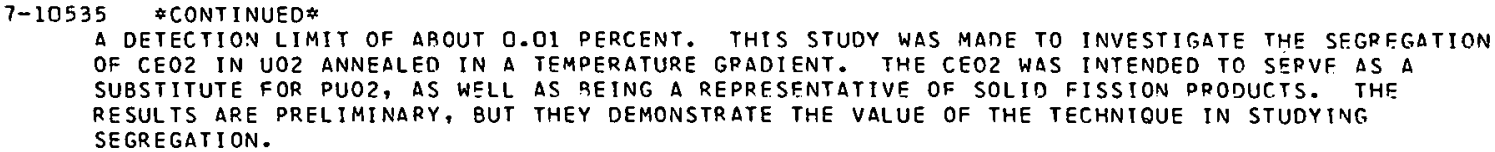

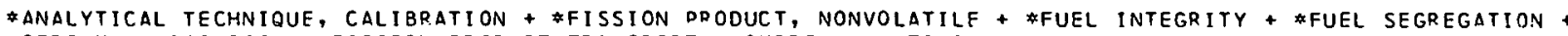
CERIUM + DIFFUSION + FISSION PRCOUCT TRANSPORT + OXIOE + PLUTONIUM + REACTOR, FAST + URANIUM

7-10550 STACHURA SJ + SILBERBERG M

THE APPLICATION OF EXPERIMENTAL DATA FROM TREAT MELTDOWN STUDIES TO REACTOR ACCIDENT ANALYSIS ATOMICS INTERNATIONAL, CANOGA PARK

ANL-7120 4. 10 PAGES, 7 FIGURES, 2 TABLES, 3 REFERFNCFS, PP, $514-523$ OF PROCEEDINGS OF THE CONFERFNCF ON SAFETY, FUELS, AND CORE DESIGN IN LARGE FAST POWER PEAC,TORS, OCTOBER 11-14, 1965, CFSTI, S9.25 CY

RESULTS OF RECENT TREAT MELTDOWN STUDIES OF CERAMIC FUEL IN SONIUM APE PRFSENTED, AND THF SIGNIFICANCE OF THESE RESULTS WITH RESPFCT TO LARGE CORE MELTDOWN IS INDICATED. THE COURSE OF FUEL MOTION IN A LARGE CORE WAS ESTIMATED FOR A SIMPLIFIED CASE, ANO THE ASSOCIATED REACTIVITY EFFECTS WERE DFTERMINED. THESE REACTIVITY EFFECTS WERE THEN INCORPORATFD INTO THE AIREK REACTOR KINETICS CODE TO ESTIMATE CORE BEHAVIOR AFTEP GROSS FUEL MELTING IN CENTRAL REGIONS OF THE CORE. A DISCUSSION OF THOSE FACTORS WHICH CAN INFLUENCE MELTDOWN RFHAVIOR WAS PRESENTED.

*aCCIDENT, GENERAL + *CORE MELTDOWN + \#FUEL MELTDOWN + \#REAC.TOR, FAST + * TREAT (TRANSIENT TEST REACTOR FACILITY) + FUFL ELEMENT + HEAT TRANSFER

7-10552 ONEILL GL + KNIGHT FW + LEITZ FJ + SHEPFP DP SAFETY AND ECONOMIC ASPECTS OF VENTED FUEL IN SODIUM-COOLEO RFACTORS GENERAL ELECTRIC COMPANY, SAN JOSE

ANL $-7120+10$ PAGES, 5 FIGURES, 3 TABLES, 3 REFEPENCES, PP, $540-549$ OF PROCEEDINGS OF THE CONFEPENCF ON SAFETY, FUELS, AND CORE DESIGN IN LARGE FAST POWER REACTORS, OCTOBER 11-14, 1965, CFSTI, SO.25 CY

THE RELEASE OF CONSIDERABLE FRACTICNS OF GENERATED FISSION GAS FROM HIGH-QURNUP, HIGH-POWER-DENSITY FCR FUEL IS WELL-KNOWN. THUS, THE ACCOMMODATION OF THESE FISSION GASES IS A MAJOR DESIGN PROBLEM FOR THE FCR FUEL ANO SYSTEM. VARIOUS WAYS FOP ACCOMMODATING FISSION GASES IN FUEL PINS ARE SHOWN. THE BROAD OBJFCTIVE OF ALL THESE DESIGNS IS TO RELIEVE THE PRESSURE BUILDUP DUE TO FISSION GAS WITHOUT PERMITTING RELEASE OF DAUGHTER ACTIVITY OR ENTRY OF SODIUM INTO THE FUEL-SLANKET REGION. IF THE GAS IS RETAINED IN THE CORE REGION, PRESSURE QUILOUP INSIDE THE FUEL ELEMENT REQUIRES RESTRAINING CLADDING THICKNESSES, WHICH ARE GENERALLY PRECLUDED GY CONSIDERATIONS OF BOTH THERMAL STRESS AND CORE COMPOSITION. ALTERNATIVELY, VERY-LOW-DENSITY FUEL, WHICH ALLOWS SPACE FOR FISSION GAS, ALSO LEAOS TO A POORER NEUTRON ECONOMY.

\#ECONOMIC STUOY + \#FISSION GAS RELEASE + \#REACTOR, BREEDER + FUEL BUPNUP + REACTOR, LIQUID METAL COOLED + SAFETY PRINCIPLES AND PHILOSOPHY + SODIUM

7-1C557 CASTLEMAN AW + TANG IN

CHEMICAL CONSIDERATIONS IN FAST REACTOR SAFETY BROOKHAVEN NATIONAL LABORATORY, UPTON

ANL-7120 +. 7 PAGES, 6 FIGURES, 2 TABLES, 11 REFERENCES, PP. $848-854$ OF PROCEEDINGS OF THE CONFERENCE DN SAFETY, FUELS, ANO CORE DESIGN IN LARGE FAST POWER REACTORS, OCTOBER 11-14, 1965, CFSTI, \$9.25 CY

THE HAZARD ASSOCIATED WITH ANY REACTOR DEPENOS, TO A laRge EXTENT, ON THE NATURE OF THE RADIOACTIVE NUCLIOES LIKELY TO BE RELEASEO IN AN ACCIOENT. A THOROUGH KNOWLEDGE OF THE CHEMICAL STATES OF THE FISSION PRODUCTS AS A FUNCTION OF TEMPERATURE, CONCFNTPATION, AND ENVIRONMENT CAN BE USED TO PREDICT BEHAVIOR UNDER A WIDE VARIETY OF CONDITIONS WHICH WOULD RE ALMOST IMPOSSIRLE TO INVESTIGATE IN LARGE-SCALE TESTS. THIS PAPER IS DIVIDED INTO TWO SECTIONS. THE FIRST SUMMARIZES THE RESULTS OF OUR STUDIES ON THF CHEMICAL STATFS OF IODINE RELEASED FROM URANIUM AND UC INTO HELIUM RETWEEN 1200 AND $2500 \mathrm{C}$. THE SECOND SECTION GIVES THE CHEMICAL STATES OF IODINE FOP.MED UPON PELEASE FP.OM THESE FUFLS INTO AIP. AND STEAM. IN ADDITION, CALCULATIONS, BASED ON THERMODYNAMIC CONSIDERATIONS, ARE INCLUDED WHICH PREDICT THE BEHAVIOR OF IODINE IN SODIUM. IN AN INERT ATMOSPHERE, TWO IODIDES AND ATDMIC IODINE ARE RELEASED FROM METALLIC URANIUM AND UC FUELS. THE RELATIVE QUANTITIES OF FACH SPECIES ARE PRIMARILY A FUNCTION OF FUEL TEMPERATURE. THE TWO IODIDES ARE TENACIOUSLY HELD ON SURFACES $\triangle T$ TEMPERATURES OF $\triangle B O U T 275$ AND 200 DEGREES C IN AN INERT ATMOSPHERE, BUT READILY EVOLVE ELEMENTAL. IODINE INTO AN OXIDIZING ENVIRONMENT. WHERE IODINE IS RELEASED DURING A METAL-WATER REACTION, CONVERSION TO HI CAN BF VALIDLY ESTIMATEO FROM THERMODYNAMIC CONSIDERATIONS. IN A SODIUM ENVIRONMENT, NEARLY ALL THE IODINE WILL AE CONVERTED TO NAI WHEN THE FISSION-PRODUCT CONCENTRATIONS ARE IN PARTS PER MILLION. EXPRESSIONS ARE GIVEN FOR CALCULATING THE VOLATILITY OF NAI IN SODIUM. SUBSEOUENT EXPOSURE TO AN OXIDIZING ENVIRONMENT SHOULD NOT RESULT IN SUBSTANTIAL NAI DXIDATION IN THE HRESENCE OF EXCESS NAZUZ.

\#FISSION PRODUCT TRANSPORT + \#FISSION PRODUCT, IODINE + \#FISSION PRODUCT, VOLATILE + \#FUEL MFLTOOWN + \# IODINE + *URANIUM + \#URANIUM CARRIDE + ANALYTICAL MODEL + CHEMICAL KINETICS + CHEMICAL REACTION + DEPOSITION + FISSION PRODUCT RELEASE, GENERAL + THFRMODYNAMICS

7-10558 KUNKEL W + BERGER S FISSION PRODUCT RETENTION IN SONIUM AND APPLICATIONS TO VENTED FUEL ELEMENT DESIGN ATOMICS INTERNATIONAL, CANOGA PARK

ANL-7120 +. 7 PAGES, 6 FIGURES, 7 TABLES, 6 REFERENCES, PP. $855-861$ OF PROCEEDINGS OF THE CONFERENCE ON SAFETY, FUELS, AND CORE DESIGN IN LARGE FAST POWER REACTORS, DCTOBER 11-14, 1965, CFSTI, \$9.25 CY 
CATEGORY 7

FISSION PRODUCT RELEASE, TRANSPORT, AND REMOVAL

\section{7-10558 \#CONTINUED*}

THE USE OF A VENTED FUEL ELEMENT REDUCES CLADDING STRAIN FPOM RELEASED FISSION-GAS PRESSURE, THEREBY INCREASING THE POTENTIAL OF THE FUEL FOR EXTENDED BURNUP ALTHOUGH THERE ARE SOME RADIOLOGICAL PROBLEMS IN MOST VENTED-FUEL-ELEMENT DESIGNS, THE SUCCESSFUL OPERATION OF THE DOUNREAY FAST REACTOR INDICATED THAT THESE PROBLEMS CAN BE SOLVED. THIS PAPER INDICATES SOME OF THE SAFETY PROBLEMS ASSOCIATED WITH THE VENTED-FUEL-ELEMENT CONCEPT AND APPLIES THE RESULTS OF RECENT EXPERIMENTAL AND ANALYTICAL STUDIES TO THOSE PROBLEMS. THE DATA INDICATE THAT THERE WAS ONLY 0.036 TIMES AS MUCH 1-131 AS KR-85. THEREFORE, THE IODINE MUST HAVE BEEN DEPLETED BY PASSAGE THROUGH THE SODIUM BOND, BY PLATING, OR BY SOME OTHER MECHANISM. THESE DATA, WHILE SPARSE, INDICATE AN APPARENT FIGURE FOR IODINE RELEASE FROM THE SODIUM OF O. 2 PERCENT. THESE RESULTS COMPARE WITH 0.02 PERCENT FOR LABORATORY CONDITIONS.

\#FISSION PRODUCT RELEASE, GENERAL + \#FISSION PRODUCT TRANSPORT + \#FISSION PRODUCT, IODINE + \#SODIUM + CERIUM + CESIUM + FUEL ELEMENT + KRYPTON + NORLE GAS + REACTOR, LIQUID METAL COOLED + RUTHENIUM + STRONTIUM + XENON + ZIRCONIUM

7-1055S PORGES KG

FUEL-FAILURE DETECTION IN SODIUM-COOLED REACTOR S

ARGONNE NATIONAL LABORATORY, ARGONNE

ANL-7120 +.. 6 PAGES, 1 FIGURE, 9 REFERENCES, PP. 862-867 OF PROCEEDINGS OF THE CONFERENCE ON SAFETY,

FUELS, AND CORE DESIGN IN LARGE FAST POHER REACTORS, OCTOBER 11-14, 1965, CFSTI, \$9.25 CY

THE ADVENT OF SODIUM COOLING PUTS AN ENTIRELY DIFFERENT EMPHASIS ON THE RATIONALE OF CLADDING-FAILURE MONITORING. SODIUM DOES NOT ATTACK THE FUEL, NOR IS THE INCREASE OF THE COOLANT ACTIVITY WHICH WOULD RESULT FROM FISSION PRODUCT CONTAMINATION IOVER ANO ABOVE THE NA-24 ACTIVITY, POSSIBLY UP TO $10 \mathrm{MCI/CM3,} \mathrm{ALREADY} \mathrm{PRESENTI} \mathrm{CAUSE} \mathrm{FOR} \mathrm{CONCERN.} \mathrm{THE} \mathrm{FBR-II}$ CLADDING-FAILURE MONITOR CONSISTS OF A FAST DELAYED-NEUTRON DETECTOR, FERDL

IFUEL-ELEMENT-RUPTURE-DETECTION LOOPI, AS WELL AS A WIRE PRECIPITATOR PRESENTLY MONITORING

THE GAS BLANKET. THE FERDL IS INSTALLED ON A LOOP THAT SAMPLES THE COOLANT AT THE HEAT

EXCHANGER, WITH A MAXIMUM LOOP FLOW OF 100 GPM OUT OF A TOTAL OF ABOUT 8000 GPM.

\#FAILURE, FUEL ELEMENT + \#INSTRUMENTATION, SURVEILLANCE + \#LEAK DETECTION + \#SODIUM +

FISSION PRODUCT RELEASE, GENERAL + FUEL INTEGRITY + INSTRUMENTATION, NUCLEAR +

MONITOR, RADIATION, GENERAL + REACTOR, LIQUID METAL COOLED

7-10575 HAUSNER H + NELSON RC

CORRELATION OF UO2 MICROSTRUCTURES FROM IN-PILE AND OUT-OF-PILE EXPERIMENTS

GENERAL ELECTRIC COMPANY, SAN JOSE, CALIFORNIA, ATOMIC POWER EOUIPMENT DEPT.

GEAP-4535 +. 42 PAGES, 25 FIGURES; 5 TABLES, 18 REFERENCES, JUNE 4, $1064, \mathrm{CFSTI,} \$ 2.00 \mathrm{CY}$

A COMPARISON WAS MADE BETWEEN MICROSTRUCTURES OBTAINED FROM OUT-OF-PILE EXPERIMENTS AND FROM IRRADIATED MATERIAL. THE MAIN DIFFERENCES ARE DISCUSSED. THE INFLUENCE OF TEMPERATURE AND DURATION OF THE HEAT TREATMENT ON THE MICROSTRUCTURAL CHANGES BELOW THE MELTING POINT WAS INVESTIGATEO, AND TEMPERATURES FOR THE ONSET OF THESE CHANGES HERE CALCULATED.

MICROSTRUCTURES OBTAINED AFTER MELTING ARE DISCUSSED, AND CHANGES OF THESE STRUCTURES. BY A SUBSEQUENT HEAT TREATMENT BELOW THE MELTING POINT ARE SHOWN IN BOTH IN-PILE AND OUT-OF-PILE EXPER IMENTS.

\#FUEL ELEMENT + \#IN PILE EXPERIMENT + \#IRRADIATION TESTING + \#URANIUM + FUEL INTEGRITY + THERMAL PROPERTY

7-10577 HAZARDS CONTROL QUARTERLY REPORT NO. 23, OCTOBER-DECEMBER 1965 AND INDEX TO HAZARDS CONTROL QUARTERLY REPORTS NOS. 20 THROUGH 23.

LAWRENCE RADIATION LAB., UNIV. OF CALIFORNIA, LIVERMORE

UCRL $-14680+.29$ PAGES, 15 FIGURES, 7 TABLES, DECEMBER 1965, CFSTI, $\$ 2.00$ CY, \$0.50 MN

GAS CHROMATOGRAPHS EQUIPPEO WITH ELECTRON-CAPTURE DETECTORS HAVE A DETECTION SENSITIVITY FOR PICOGRAM AMOUNTS OF METHYL IODIDE. AS A RESULT, IT IS POSSIBLE TO PERFORM THESE EFFICIENCY TESTS WITH STABLE METHYL IODIOE, USING CONCENTRATIONS TYPICAL OF THE RAOIOACTIVE FORM. THIS REPORT IS AN OUTLINE OF A TECHNIQUE WE FOUND USEFUL.

* ANALYTICAL TECHNIQUE, CALIBRATION + \#FISSION PRODUCT, IOOINE + \#ORGANIC IODIDE +

ANALYTICAL TECHNIQUE, AIR + CHROMATOGRAPHY + FISSION PRODUCT TRANSPORT + IODINE + MOLECULAR SIEVE

7-10578 DIETZ KA

QUARTERLY TECHNICAL REPORT - STEP PROJECT, APRIL 1965-JUNE 1965

PHILLIPS PETROLEUM COMPANY, IDAHO FALLS, IDAHO

IDO-17145 +. 104 PAGES, 69 FIGURES, 14 TAPLES, 30 REFERENCES, MAY 1966, CFSTI, \$4.00 CY, \$O.75 MN

QUARTERLY PROGRESS REPORT ON SNAPTRAN-1 TEST PROGRAM, LOFT CORE DESIGN, LOFT FACILITY AND

EXPERIMENTAL DESIGN, LOFT ANALYSIS, LOFT RADIOLOGICAL STUDIES, AND INSTRUMENTATION STUDIES.

\#LOFT (LOSS OF FLUID TEST) + "SNAPTRAN (SNAP TRANSIENT PEACTOR TEST SEP.IES) +

*STEP (SAFETY TEST ENGINEERING PROGRAM) + ANALYTICAL MODEL + CONTAINMENT DESIGN +

CONTA INMENT FILTERING SYSTEM + CONTAINMENT INSTRUMENTATION + FISSION PRODUCT TRANSOORT +

INSTRUMENTATION, GENERAL + IODINE + REACTOR KINETICS + REACTOR, PRESSURIZED WATER + SAMPLING

7-10586 NEILL FH + GRAY DL + KRESS TS

IODINE TRANSPORT AND DEPOSITION IN A HIGH TEMPERATURE HELIUM LOOP

OAK RIDGE NATIONAL LABORATORY, OAK RIDGE, TENNESSEE

ORNL-TM-1386 +. 43 PAGES, 13 FIGURES, 7 TARLES, JUNE, 1966, CFSTI, $\$ 2.00 \mathrm{CY}, 50.50 \mathrm{MN}$ 
CATEGORY 7

FISSION PRODUCT RELEASE, TRANSDORT, AND REMOVAL

7-10586 *CONTINUED*

THE MASS TRANSPORT OF TRACE AMOUNTS OF IODINE IN A TURBULENTLY FLOWING HELIUM STREAM AND ITS DEPOSITION ONTO VARIOUS SURFACE MATERIALS WERE INVESTIGATED. TESTS WERE CARRIED OUT WITH DEPOSITION SURFACES OF COPPER, SILVER, MILD STEEL, AND STAINLESS STFFL IN THE TEMPFRATURE RANCE OF 400 TO $500 \mathrm{~F}$. RESULTS INDICATE THAT IODINE SATURATES SURFACFS AT DIFFFRFNT IODINE CONCENTRATIONS, AND THAT IT DESORBS SPONTANEOUSLY AT RATES THAT DIFFFP. FOR THF VARIOLIS SURFACE MATERIALS. FLOW PERTURBATIONS AFFECTED BY A SUDDEN ENLARGEMENT OF THF FLNW DUTCT RESULTFD IN AN INCREASE IN THE PEAK MASS-TRANSFER COEFFICIFNTS, SIMILAR TO REPORTEN CHANGES IN HEAT-TRANSFER COEFFICIENTS FOR SIMILAR CHANGES IN GEOMFTRY. ALSO, STUDIES OF DEPOSITION ON THIN WIRE ARP.ANGED IN ARRAYS PERPENDICULAR TO THE COQLANT STREAM INDICATE THAT DEPOSITION PREDICTED BY THE HEAT-MASS TRANSFEP. ANALOGY WILL CORRELATE REASONARLY WITH EXPEDIMENTAL RE SULTS.

\#FISSION PRODUCT TRANSPORT + \#FISSION PRODUCT, IODINE + \#IODINE + \#OUT DF PILE LOOPS $\triangle N D$ CXPERIMENTS + ADSORPTION + ADSORPTION SURFACE + ANALYTICAL MODEL + CHEMISORPTION + COPPER + DEPDSITION + DESORPTION + MASS TRANSFER + SILVER + STEEL + STEFL, STAINZESJ + SURFACT CONTAMINATION

7-10587 HIDY GM + LILLY DK

SOLUTIONS TO THE EQUATIONS FOR THE KINETICS OF COAFULATION

NATIONAL CENTER FOR ATMOSPHERIC RESEARCH, BUULDER, COLUMAUU

8 PAGES, 2 FIGURES, 2 TABLES, 10 REFERENCES, JOURNAL OF COLLOID SCIENCE 20(8)- 867-874 (1965)

THE THFORY FOR THF KINETICS OF COAGULATION OF PADTICLFS IN BROWNIAN MOTION IS REVIEWED BRIEFLY. THE RELATIONSHIP BETWEEN THE CLASSICAL SDLITION OF SMOLUCHOWSKI AND THE SIMILARITY SOLUTION TO THE KINETIC EQUATION IS DISCUSSEN. WHEN THE CLASSICAL RESIJLT IS PLACFD IN THE FORM OF THE SIMILARITY SOLUTION, A SIMPLE EXPONENTIAL EXPRESSION RESULTS. IN SPITE OF THE THEORETICAL LIMITATIONS, THIS FXPRESSION FOR SMOLUCHOWSKIS P.ELATION CAN BE USED TO DREDICT SATISFACTORILY A SURSTANTIAL RANGE OF THE SIZE DISTRIPUTION WHICH HAS A SIMILAR OR. A SELF-PRESERVING FORM.

\#AEROSOL PROPERTIES + \#AGGLOMERATE + \#DIFFUSION + AEROSOL + ANALYTICAL MODEL + PARTICLE SIZF + PARTICLE SIZE DISTRIBUTION

7-10588 HIDY GM + BROCK JR

SOME REMARKS ABOUT THE COAGULATION OF AEROSOL OARTICLES BY BROWNIAN MOTIINN

NATIONAL CENTER FOR ATMOSPHERIC RESEARCH, BOULDER, COLORADO + DEPARTMENT OF CHEMICAL ENGINFFRING, UNIVERSITY OF TEXAS, AUSTIN, TEXAS

15 PAGES, I FIGURE, I TABLE, 21 REFERENCES, JOURNAL OF COLLOID SCIENCF 2016)-477-491 (AUSUST 1965 )

THE DEVELOPMENT OF THE THEORY FOR COLLISION $\triangle N O$ T.NARIJI $\triangle T T O N$ OF AFROSOLS IN RROWNIAN MOTION IS REVIEWED. THEORETICAL CONCLUSIONS RESULTING FROM THE APPLICATION OF CONTINUIJM THEORY AOE COMPARED WITH CALCULATIONS BASED ON THE KINETIC THEORY NF GASES. THESE TWO APPOOACHFS LEAC TO DIFFERENT RESULTS WHICH ARE APPLICABLE ONLY TO CHARGED, DILUTE AEROSOL CLOUDS, IN $\triangle$ LIMITED RANGE OF THF RATIO OF THE MEAN FRFF PATH OF THE SUSPENDING MEDIUM LAMBDA TO THE PARTICLE RAOIUS R. THE PRESENT THEORIES SUGGEST THAT (A) THE RATE OF COAGULATION OF AEROSOLS REACHES A MAXIMUM BETWEEN THE RATIO LAMBOA/R EQUALS 5 AND 10, (B) CHARSING OF PARTICLFS SHOULD HAVE AN INCRFASING EFFECT ON COAGULATION RATES AS THE RATIO OF THE AVFRAGE CHARGF PER PARTICLE TO THE PARTICLE RADIUS INCPEASES THEPE IS A SURSTANTIAL RERION OF AFROSOL BEHAVIOR FOR WHICH THE PRESENT THEORY AND EXPERIMENTAL WORK ARE INCOMPLFTE, PARTICULARLY IN ACCOUNTING FOR THE EFFECTS OF CHARGED PARTICLES. IT IS LIKELY THAT A COMPLFTION OF THE THEORY FOP. COAGULATION OF AEROSOLS MUST AWAIT NEW DEVELOPMENTS IN THE PHYSICS OF IONIZED DCNSE GASFS.

AAEROSOL PROPERTIES + *AGGLOMERATE + \#DIFFUSION + AEROSOL + ANALYTICAL MODEL + PARTICLE SI?E + PARTICLE SIZE DISTRIQUTION

7-10589 SWIFT DL + FRIEDLANDER SK

THE COAGULATION OF HYDROSOLS BY BROWNIAN MOTION AND LAMINAR SHEAR FLOW

THE JOHNS HOPKINS UNIVERSITY, MARYLAND

27 PAGES, 13 FIGURES, 2 TABLES, 35 REFERENCES, JOURNAL OF COLLOID SCIENCE 19- 621-647 (1964)

THF C.OAGHII.ATION OF HYDROSOLS hAS INVESTIGATED THERRETI CALLY AND [XFERIMENTALLY. A REOUCED FORM OF THE DARTICLE-SI ZF-DISTRIRUTION FUNCTION, DFSIGNATED SELF-PRESERVING, WAS FOUND TO SATISFY SMOLUCHOWSKIS EQUATICNS OF COAGULATION BY BROWNIAN MOTION AND SHEAR FLOW. BROWNI AN-MOTION COAGULATION EXPEPIMENTS WITH TWN HETFROGENEOUS HYDROSOLS SHOWFO THAT THE DISTRIBUTIONS WERE SELF-PRESERVING. THF RATE OF COAGULATION FOP HETEROGENERUS SYSTEMS WAS FOUND TO BE SECOND-ORDER IN TOTAL PARTICLE CONCENTRATION, CONSISTENT WITH THE SELF-PRESFRVING FORM OF THE OISTRIBUTION FUNCTION. COAGULATION EXPERIMENTS WERE CARRIED OUT IN A SIMOLE LAMINAR-SHEAR FIELO USING A HOMOGENEOUS DOW POLYSTYPENE LATEX DISPERSION. SMOLUCHOWSKIS SHEAR-FLOW THEORY WAS CONFIRMEO FOR SHEAR RATES RANGING FROM 1 TO $8 D$ SEC MINIIS 1 . THF SHEAR COAGULATION OF A HETEROGENEOUS EMULSION WAS STUDIED AT SEVERAL SHEAR RATES, AND THE SIZE DISTRIBUTIONS WEP.E SELF-PD.ESER.VING

*AEROSOL PROPERTIES + \#AGGLOMERATF + \#DIFFUSION + $\triangle E P O S O L$ + ANALYTICAL MODEL + PARTICLF SIZF + PARTICLE SIZE DISTRIBUTION + WATER, GENFRAL

7-10854 HANSON JE + +IELD JH + RABIN SA EXPERIMENTAL STUOIES OF TRANSIENT EFFECTS IN FAST REACTOR FUELS. SERIES II. MIXED OXIDF (PUO2-IJC2) IRRADIATIONS

GENERAL ELECTRIC COMPANY, SAN JOSE, CALIFCRNIA

CEAP $-4804+.96$ PAGES, REFERENCES, MAY, 1965, CFSTI, $\$ 3.00 \mathrm{CY}, \$ 0.75 \mathrm{MN}$

THE RESULTS OF AN EXPERINENTAL PROGRAM IO EVALUATE THF PERFCPMANCE OF NON-PREIRRADIATED 
7-10854 \#CONTINUEO*

FAST-CERAMIC-REACTOR FUEL UNDER CONDITIONS SIMULATING ACCIDENTAL POWER EXCURSIONS ARE PRESENTED. RESULTS FROM THREE EXPERIMENTS IN THE TREAT FACILITY USING D. 250-INC.H-O.O., TYPE 347 STAINLESS STEEL CLAD, 20 WEIGHT PERCENT PUO2 - 8ח WEIGHT DERCENT UO2 FUEL SPECIMFNS ARE INTERPRETED WITH REGARD TO FUEL-CLADOING TEMPERATURES, FUEL VAPOR PRESSURE, THERMAL EXPANSION OF THE FUEL, AND CLAODING INTEGRITY. INCIPIENT FAILURE LIMITS FOR AXIALLY UNRESTRAINED FUEL ARE IDENTIFIED AS FUNCTIONS OF THE MAXIMUM FUEL AND CLADDING TEMPERATURES ATTAINED DURING THE TRANSIENT.

FAILURE, FUEL ELEMENT + PLUTONIUM + STEEL, STAINLESS + TREAT (TRANSIENT TEST REACTOR FACILITY)

7-10867 MILLER CE + BROWNING WE

THE ADEQUACY OF SCALE-UP IN EXPERIMENTS ON FISSION PROOUCT BEHAVIOR IN REACTOR ACCIDENTS. PART I . AN ANALYSIS OF SCALE-UP IN THE U. S. NUCLEAR SAFETY PROGPAM

OAK RIDGE NATIONAL LABORATORY, OAK RIDGE, TENNESSEE

ORNL-3901 +. 48 PAGES, 2 TABLES, 17 FIGURES, 17 REFERENCES, JULY 1966, CFSTI, \$3.00 CY, \$O.5D MN

FOUR AREAS DISCUSSED - $(1)$ RELEASE OF FISSION PROOUCTS FROM FUEL, (2) THEIR TRANSPORT TO CONTAINMENT VESSEL, (3) THEIR BEHAVIOR IN A CONTAINMENT SYSTEM, AND (4) THEIR BEHAVIOR IN GAS-CLEANING SYSTEMS. IN GENERAL, LARGE-SCALE EXPERIMENTS SUCH AS LOFT WERF THE UDPER BOUND OF THE STUDY. CONCLUSION - ITEMS (3) ANO (4) ARE WELL SCALED OVER RANGE, BUT INTERMEDIATE-SCALE EXPERIMENTS (JLST BELOW LOFT) ARE NEEDED FOR ITEMS $(1)$ AND $(2)$. CONTAINS GOOD GENERAL INTRODUCTION TO PROBLEM, PLUS COMPARISON OF LOFT WITH POWER REACTORS AND BENCH-SCALE EXPERIMENTS.

*CONTAINMENT FILTERING SYSTEM + \#CONTAINMENT RESEARCH AND DEVELOPMENT + *DEPOSITION + \#FISSION PRODUCT RELEASE, GENERAL + \#FISSION PRODUCT TRANSPORT + FUEL MELTDOWN + LOFT (LOSS OF FLUIDTEST) + REACTOR, PRESSURIZED WATER

7-10876 FIRST SUPPLEMENT TO PRELIMINARY SAFETY ANALYSIS. INDIAN POINT NUCLEAR GENERATING UNIT NO. 2. CONSOLIDATED EDISON COMPANY OF NEW YORK

1 PAGE OF FIRST SUPPLEMENT TO PRELIMINARY SAFETY ANALYSIS. INDIAN POINT NUCLEAR GENERATING UNIT NO. 2, MARCH 31 , 1966 , DOCKET NO. 50-247, POR

QUESTION 2, CRITERION $6--$ EQUILI ERIUM CORE 13.92 PERCENT ENRICHMENT) HILL YIELD (AV- 27, OOO)

(MAX-45000) MWD/METRIC TON OF U BURNUP. CLADOING, n.0243 ZIRCALOY. CLADDING INTEGRITY

ENSURED BY KEEPING INTERNAL GAS PRESSURE LESS THAN REACTOR PRESSURE, DNB RATIO GREATER THAN

1.3, NO FUEL CENTERLINE MELTING, AND CLADDING STRESS BELOW YIELD POINT.

\#DESIGN CRITERIA + \#FAILURE, CLACDING + \#FUEL BURNUP + \#RFGULATION, $\triangle E C$ +

* SAFEGUARDS REPORT, RESPONSE TO AEC QUESTIONS + INDIAN POINT II + REACTOR, PRESSURIZED WATER + STRESS

7-10933 KESSLER WE + BROCKETT GF + BINGHAM GE

ZIRCONIUM-HYORIDE FUEL BEHAVIOR IN THE SNAPTRAN TRANSIENT TESTS

PHILLIPS PETROLEUM COMPANY, IDAHO FALLS, IDAHO

1 PAGE, ANS TRANSACTIONS, 9(1), PAGE 155 (JUNE, 1966), AMERICAN NUCLEAR SOCIETY ANNUAL MEETING, DENVER,

COLORADO, JUNE 20-23, 1966

FOR SNAP 1OA/2-TYPE REACTORS, REACTIVITY EXCURSIONS BELOW 1.7 DOLLARS ARE NONOESTRUCTIVELY SELF-LIMITED BY THE INHERENT TEMPFRATURE-DEPENDENT NEGATIVE-REACTIVITY FEEDRACK MECHANISMS OF 12 CENTS/MW-SEC. FOR EXCURSIONS RESULTING FROM ESSENTIALLY ANY AMOUNT OF REACTIVITY AROVE 1.7 DOLLARS, THE INHERENT DISASSEMELY CHARACTERISTICS OF THIS TYPE FUEL LIMITS THE ENERSY RELEASE TO WELL BELOW $100 \mathrm{MW}-S E C$. IN THE WATER IMMERSION TEST, RAPIO COOLING OF THE FUEL LIMITED THE RELEASE OF NOBLE GASES AND THEIR DAUGHTERS TO THE ENVIRONMENT FROM THE FUEL TO LESS THAN 5 PERCENT OF THAT AVAILABLE IN THE FUEL. THE IODINE RELEASE WAS LIMITED TO LESS LESS THAN 5 PERCENT OF THAT AVAILABLE IN THE FUEL. THE IODINE RELEASE WAS LIMITED TO LESS THE THE
THAN 13 PERCENT OF THE AVAILABLE. IN THE AIR-ENVIRONMENT TEST, FUEL DISINTEGRATION WAS ACCOMPANIED BY HYDROGEN-OXYGEN COMBUSTION. ABOUT 100 PERCENT OF THE NOBLE GASES AND SO PERCENT OF THE AVAILABLE IODINE WERE PELEASED.

\#FISSION GAS RELEASE + * SNAPTRAN (SNAP TRANSIENT REACTOR TEST SERIES) + DESTRUCTIVE TRANSIENT + FISSION PRODUCT RETENTION + FISSION PROOUCT, IODINE + HYDROGEN + REACTOR TRANSIENT

7-11270 ETTINGER HJ + MOSS WO + BUSEY H

CHARACTERISTICS OF THE AEROSOL PRODUCEO FROM BURNING SODIUM AND PLUTONIUM LOS ALAMOS SCIENTIFIC LABORATORY, LOS ALAMOS

LA-3491 +. 51 PAGES, 28 FIGURES, 7 TABLES, 12 REFERENCES, FE8RUARY, 1966, CFSTI $\$ 3.00$ CY, $\$ 0.50$ MN

SIZE CHARACTERISTICS OF THE AEROSOL PROOUCED DURING SODIUM AND PLUTONIUM FIRES HERE OFTERMINED FOR DIFFERENT ATMOSPHERES RANGING FROM AIR TO 100 PERCENT NITROGEN. GRAM QUANTITIES OF SODIUM, PLUTONIUM-COBALT-CERIUM ALLOY, AND ALPHA- AND DELTA-PHASE PLUTONIUM WERE BURNED SEPARATELY. THE AEROSOL PRODUCED BY BURNING GRAM QUANTITIES OF SODIUM WAS COMPARED WITH THAT PRODUCED BY A FIRE INVOLVING 600 POUNDS OF SODIUM. DATA WERE OBTAINED REGARDING THE FRACTION OF PLUTONIUM ALLOY AIRBORNE DURING A PLUTONIUM FIRE. FIRES SIMULATING A REACTOR ACCIOENT INVOLVING BOTH FUEL AND COOLANT DEFINED THE RELATIVE AIRBORNE CONCENTRATIONS OF PLUTONIUM AND SODIUM. SODIUM AEROSOLS PRODUCED FROM SMALL - AND LARGE-SCALE FIRES HAVE COMPARABLE SIZE CHARACTERISTICS. AEROSOL PARAMETERS CAN BE DETERMINED FOR ANY SPECIAL CONDITIONS WITHOUT BUILDING A LARGE SYSTEM FOR SUCH TESTS. OXYGEN CONCENTRATION OF THE BURNING ATMOSPHERE DOES NOT AFFECT THE PARTICLE SIZE OF THE AEROSOL PRODUCED FROM BURNING PLUTONIUM METAL OR ALLOY. FIRES INVOLVING PLUTONIUM ALLOY AND SOOIUM PRODUCE AIRRORNE PARTICLES THAT HAVE A PLUTONIUM-SODIUM RATIO RANGING FROM 0.34 TO LESS THAN 0.008 PERCENT. THE HIGH INITIAL PATIO IS RAPIDLY REDUCEO AS THE MOLTEN SODIUM BLANKETS THE RELEASE OF PLUTONIUM. 
CATEGORY 7

FISSION PRODUCT RELEASE, TRANSPORT, AND REMOVAL

7-11270 \#CONTINUED

- PAPTICLE SIZE + \#PLUTONIUM + \#SODIUM + AEROSOL PRODUCTION + AEROSOL PROPERTIFS + AEROSOL, PADIOACTIVE + AIR CLEANING + AIRBORNE RELEASE + ALLOY + FIRE + INCINERATION + OXIDATION

7-11271 KESSIE RW + RAMASWAMI D

REMOVAL OF PLUIUNIUM HEXAFLUORIDE FPOM CELL EXHAUST AIP. BY HYOROLYSIS ANM FILTPATION ARGONNE NATIONAL LABORATORY, ARGONNE

ANL-7066 +. 71 PAGES, 22 FIGURES, 15 TAELES, 42 REFERFNCFS, DECEMBER 1965, CFSTI \$3.00 CY, \$O.75 MN

THE FLUORIDE VOLATILITY PROCESS FOR RECOVERING FISSIONABLE PLUTONIUM FROM SPENT PFACTOR FUEL AS THE VOLATILE PLUTONIUM HEXAFLUORIDE (PUFG) REQUIRES A DEMONSTRATED ABILITY TO TONTAIN THE HIGHLY TOXIC PLUTONIUM. AT HIGH CONCENTRATIONS OF PUFG AND MOISTURE, THE REACTION PROCSEDS RAPIDLY IN THE GAS PHASE TO PRODUCE A FINELY DISPERSED PRODUCT PUO2F2. MOST OF THE DARTICLES ARL SMALLER THAN O.1 MICRDN. WITH AIR CONTAINING EXCFSS MOISTURF, THE FRACTION OF RFLEASED PLUTONIUM PENETRATING TWO HIGH-EFFICIENCY FILILKS IN SER IFS AMOUNTED TO BCTWEEN IU TO THF MINUS 9 AND 10 TO THE MINUS 6 AT A VELOCITY OF $1.0 \mathrm{CM} / S E C$. FILTER EFFICIFNCY IS INCREASED RY THE AGGLOMERATION OF PARTICLES BEFORE FILTRATION AND BY LOADING FFFECTS OF THF COLLECTED PARTICLES ON THE FILTERS. WHEN AN EXCESS OF MOISTURE IS AVAILARLE, AGGLOMERATION EFFFCTS TEND TO LIMIT IHE MAXIMUM OIST.HARGE RATE OF PLUTONIUM, AND LOADING EFEECTS TEND TO LIMIT THE MAXIMUM TOTAL QUANTITY OF PLUTONIUM THAT CAN BE DISCHARGED FROM $\triangle$ SINGLE FILTER. UESIGN CP.ITEP.IA OF PRAT.TIT.AI AIR-CLEANING SYSTEMS ARE PRESENTED.

\#FILTER EFFICIENCY + \#FILTER SYSTEM + \#PLUTONIUM + AIR CLEANING + $\triangle I R R M R N F$ P.ELEASE + DESIGN CRITERIA + FILTER OPERATION + FILTER SPRAY + FLUORINE + SCRUBBER + STACK + WATER VAPOR

7-11272 JOHNSON RE

FRACTURE MECHANICS- A BASIS FCR BRITTLE FRACTUPE PREVENTION HESTINGHOUSE ELECTRIC. CORP., BETTIS ATOMIC POWEP LAR

WAPD-TM-505 +. 82 PAGES, 32 FIGURES, 2 TABLES, 81 REFERENCFS, NOVEMBER 1965, CFSTI \$3.00 CY

\begin{abstract}
THE DEVELOPMENT OF FRACTURE MECHANICS IS PRESFNTED HISTORICALLY AND MATHEMATICALLY. THE CENTRAL PROBLEMS AND LIMITATIONS OF EXPEPIMENTAL FRACTURF. MFC.HANTCS ARE DETAILED, ALONG WITH THE ASSUMPTIONS AND APOROXIMATIONS USEN. THE MEANING, MEASUREMENT, AND UTILITY OF PLANE STRAIN FRACTURE TOUGHNESS (CRITICAL STRAIN ENERGY RELEASE RATF OR CDITICAL STRESS INTENSITY FACIUR) ARE OISCUSSED. THE ROLE OF DEFECTS IN COMPONENTS IS RISCUSSED, SPECIFICALLY WITH RESPECT TO THE RELATIONSHIPS BFTWEEN STRESS FIELDS, DEFECT GEOMETRY, AND MATERIAL C.ONDITION. BASIC ASPECTS OF ULTRASONIC TESTING ARE DISCUSSED WITH RESPECT TO QUANTITATIVF MEASUREMFNT OF DEFECT GEOMETRIES IN STRUCTURES. SELECTED EXPERIMENTS DEALING WITH APPLICATION OF FRACTURE MECHANICS TO PREDICT ACTUAL COMPONENT FAILURFS ARE REVIEWED. IT IS SHOWN THAT THF RELATIONSHIPS BETWEEN STRESS STATE, DEFECT GEOMETRY, CLASTIC CONSTANTS, AND FRACTIIRF TOUGHNESS EMPLOYED IN APPLIED FRACTURE MECHANICS CAN BE UTILIZED TO PREDICT BRITTLE FAILUPE CONDITIONS IN A MORE OUANTITATIVE MANNFR THAN TRANSITION TEMPERATURF CONCEPTS. BASED ON A CETAILED REVIEW OF THE METHODS AND PHYSICAL SIGNIFICANCE OF THE ENGINEERING METHOD DF FRACTURE MECHANICS, THE FOLLOWING CONCLUSIONS WERE RSACHED - (1) THE METHODS OF FRACTURE MECHANICS CAN PROVIDE MORE ACCURATE PREDICTIONS OF BRITTLE FRACTURE CONDITIONS THAN TT CONCEPTS. (2) THE FRACTURE MECHANICS PAPAMETER, PLANE STRAIN FRACTURE TOUGHNESS, APDEAPS TO PROVIDE A MEASURE OF THE FRACTURE RESISTANCF OF MFTALS. (3) PLANE STRAIN FRACTURE TOUGHNESS CAN BE MEASURED USING LABCRATORY FRACTURE TESTS AND APPI.IFO TO COMPDNENTS. (4) GEOMETRY FACTORS ENTER FRACTURE MECHANICS EOUATIONS THROUGH ELASTIC NOTCH STRESS ANALYSES. (SI THE FRACTURE MECHANICS APPROACH TO OPERATIONAL LIMITATIONS IS COMPATI PLE WITH OTHFR DFSIGN CRITERIA AND WITH OBSERVED FRACTURE BEHAVIOR. (6) A DOSSIBLE METHOD BY WHICH OPEPATIONAL STRESS LIMITS CAN BE CALCULATED ANR IISFD TO PROTFCT COMPONENTS FROM BRITTLE FRACTIJRE WAS PRESENTED.
\end{abstract}

*BRITTLE FRACTURE + *COMPARISON, THEORY AND EXPFRIENCE + \#IMPACT PROPERTY + \#TEST, PRESSURE VESSEL + CONTAINMENT, PRESSURE VESSEL + NDT DATA (NIL DIITTILITY TRANSITION) + STRESS + STRESS ANALYSIS + STRESS RUPTURE + SUPPORT STRUCTURF + TENSILF PROPERTY

7-11273 KYLE ML + ARNTZEN JD + COLEMAN LF

DESIGN AND OPERATTON OF A YILUT-PLANT GETTERING SYSTCM OF TITANIUM-METAL SPONFF FOR REMOVAL DF NITROGEN FROM ARGON

ARGONNE NAIIUNAL LABORATORY, ARGONNE, ILLINOIS

ANL-7128 +. 42 PAGES, 15 FIGURES, 3 TABLES, 24 REFERENCES, JANUARY 1966, CFSTI \$2.00 CY, \$O.50 MN

A PILOT-PLANT DESIGNED TO DEMONSTRATF THE REMOVAL OF LOW CONCENTRATIONS (LESS THAN 1T) OF NITROGEN FROM LARGE, RELATIVELY PURE VOLUMES OF INERT GASES WAS RUILT AND OPERATED. ITT UTILIZED TITANIUM-MFTAI SPONGE AT 900 C AS THE GFTTER FOR THF NITROGEN. GAS DRFHEATERS AND REGENERATIVE HEAT EXCHANGERS WERE USED TO OBTAIN BETTER UTILIZATION UH THE TITANIUM AND TO PROVIDE HEAT ECONOMY. DURING THE $18 D C$ HR OF OPEPATION, ALL EQUIPMENT ITEMS EXCEPT THE RLOWER PERFORMED WELL. THE UNIT SUCCESSFULLY DEMONSTRATED THE USEFULNESS ANO RELATIVE ECONOMY OF TITANIUM-METAL SPONGE AS A CETTEK FÜ. NITROGEN TMPIIRITY IN ARGON. THE PERFORMANC.F OF THE EQUIPMENT IS ASSESSED, AND RECOMMENDATIDNS FOR DESIGN OF LARGE PURIFICATION SYSTEMS $A R E$ PRESENTED.

*ARGON + \#DESIGN CRITERIA + \#NITRÜGEN + \#TITANIUM + NITRIDE + NOBLE GAS

7-11274 MARTIN HR + WEIR JR

IPRADIATION EMBR ITTLEMENT OF LOW- ANO HIGH-CARBON STAINLESS STEELS AT 700, 800 , AND 900 DEGPFES C. OAK RIDGE NATIONAL LABORATORY, OAK PIOGE

ORNL-TM-1516 + CONF-660613-1+. 27 PAGES, 19 FIGURES, 2 TABLES, JUNE, 1966, CFSTI \$2.00 CY, \$O.50 MN

IN GENERAL, THE DUCTILITY CF THE IRPADIATED ALLOY DECREASES WITH INCREASINE IRRADIATION 
CATEGORY 7

FISSION PROOUCT RELEASE, TRANSPORT, AND REMOVAL

7-11274 *CONTINUED*

TEMPERATURE WHEN THESE DUCTILITIES ARE DETERMINED AT TENSILE TEST TEMPERATURES WITHIN THE 650 TO 842 C TEMPERATURE RANGE. A MARKED DIFFERENCE IN THE DUCTILITY OF LOW- AND HIGH-CAR8ON IRRADIATED STAINLESS STEELS HAS OBSERVED AND APPEARS TO BE RELATED TO THE OUANTITY OF GRAIN-BOUNDARY CARBIDES. THESE DATA ARE INTERPRETED AS INDICATING THAT GRAIN-BOUNDARY CARBIDES FORMED IN IRRADIATED MATERIAL IN THIS TEMPERATURE RANGE ARE CAPABLE OF INCREASING THE STRESS AT WHICH WEDGE-TYPE GRAIN-BOUNDARY CRACKS ARE NUCLEATED AND ALSO REDUCING THE RATE OF CRACK PROPAGATION. THUS, IT APPEARS THAT AGGL OMERATED CARBIDES IN THE GRAIN BOUNOARY ARE CAPABLE OF REDUCING THE MAGNITUDE OF IRRADIATION EMBRITTLEMENT.

*EMBRITTLEMENT + *RADIATION EFFECT + *STEEL, STAINLESS + ALLOY + BRITTLE FRACTURE + CARBIDE + CLAD + RADIATION DAMAGE

7-11275 PARTRIDGE BA + ROWE PN

ANALYSIS OF GAS FLOW IN A BUBBLING FLUIDISED BED WHEN CLOUD FORMATION OCCURS

UNITED KINGDOM ATOMIC ENERGY AUTHORITY, HARWELL

AERE-R-5037 + 35 PAGES, 4 FIGURES, 15 REFERENCES, APRIL 1966, UKAEA

THIS REPORT PRESENTS AN ANALYSIS OF THE SITUATION IN WHICH GAS-CLOUD FORMATION OCCURS IN A FREELY BUBBLING GAS-FLUIDIZED BED. IN GENERAL, CLOUD FORMATION OCCURS IN THE GAS-FLUIDIZATION OF PARTICLES OF 350 MICRONS DIAMETER OR LESS. EXPRESSIONS DESCRIBING THE DISTRIBUTION OF THE FLUIDIZING GAS BETHEEN THE CLOUD AND INTERSTITIAL FLOWS ARE DERIVED. THE ANALYSIS JUSTIFIES THE COMMON ASSUMPTION THAT THE EXCESS GAS ABOVE THAT REQUIRED TO FLUIDIZE THE PARTICLES GOES THROUGH THE BED IN THE FORM OF BUBBLES, AND SHOWS IT TO BE CONSISTENT WITH PRESENT KNOWLEDGE ABOUT THE NATURE OF GAS CLOUDS.

* ANALYTICAL MODEL + \#FLOW THEORY AND EXPERIMENTS + \#FLUIDIZED BED + FLOW OISTRIBUTION +

MATHEMATICAL STUDY + POROUS MEDIA

7-11365 QUAD CITIES STATION, UNIT 1 - PLANT DESIGN ANALYSIS, VOLUME 1

COMMONWEALTH EDISON COMPANY, CHICAGO

18 PAGES, PAGES XIV-3-3 TO 6 AND 3-15 TO 30 OF QUAD CITIES STATION, PLANT DESIGN ANALYSIS, VOLUME I DOCKET

NO. 50-254, MAY 31, 1966 PDR

DRESDEN 1 - EXPERIENCE WITH FUEL FAILURES QUOTED TO BE LESS THAN 1 MILLICURE/SEC, IKR-85 TO

REPRESENT 54 CURIES - LESS THAN 1 PERCENTI IN THE GAS PLENUM. HALOGENS IN STEAM ARE ABOUT ID

TO THE MINUS 5 THAT IN WATER. A FURTHER FACTOR OF 10 TO THE MINUS 2 OCCURS IN THE CONDENSER.

THUS A REACTOR EXCURSION RUPTURING 330 FUEL RODS WOULD RELEASE ONLY 10 TO THE MINUS 4

CURIES/SEC OF HALOGENS UP THE STACK THROUGH AIR EJECTER. STEAM-LINE BREAK ESTIMATED ON

DRESDEN-1 COOLANT ACTIVITY AND WATER CARRYOVER- HOT CLOUD BREAKS BUILDING WALLS AND RISES TO

164-4100 FT (DEPENDING ON WIND), WITH DOSES IN MILLIREM RANGE. LOSS OF COOLANT WITH 100

PERCENT MELTDOWN GIVES LESS THAN D. 5 REM OFF-SITE BECAUSE OF THE HALOGEN RETENTION IN WATER,

CHARCOAL ABSORPTION, AND STACK RELEASE. EVESR CHARCOAL FILTER HAS BEEN RETAINING ORGANIC

HALOGENS WITH A FILTER EFFICIENCY OF $99.8-99.9$ PERCENT AT RELATIVE HUMIDITY OF 10 TO 15 PERCENT.

\#AIRBORNE RELEASE + \#DOSE + \#SAFEGUARDS REPORT, PRELIMINARY + ACCIDENT, CONTROL ROD DROPOUT + FAILURE, FUEL ELEMENT + LOSS OF COOLANT + OPERATING EXPERIENCE + QUAD CITIES I + REACTOR, BOILING WATER + STEAM LINE RUPTURE

7-11678 WATSON GM + PEREZ RB + FONTANA MH

EFFECTS OF CONTAINMENT SYSTEM SIZE ON FISSION PROOUCT BEHAVIDR

OAK RIDGE NATIONAL LABORATORY, OAK RIDGE

CONF-660904 +. 2 PAGES, PRESENTED AT 9TH AEC AIR CLEANING CONFERENCE, BOSTON, MASS., SEPTEMBER I3-16,

1966 , SOURCE

SIMPLE MATHEMATICAL MODELS TO AIO IN THE DETERMINATION OF EFFECT OF CONTAINMENT SIZE ON

PLATE-OUT BEHAVIOR OF IODINE HAVE BEEN POSTULATED. THO GENERAL CLASSES OF SYSTEMS HAVE BEEN

CONSIDERED, DEPENDING ON THE ABSENCE OR ON THE PRESENCE OF STEAM. IN THE ABSENCE OF STEAM

THE PRINCIPAL ASSUMPTIONS MADE WERE - (1) HOMOGENEOUS MIXING, $(2)$ BOUNDARY GAS LAYER

ENVELOPING ALL SURFACES, (3) DIFFUSION THROUGH BOUNDARY LAYER TO BE THE RATE LIMITING PROCESS, (4) MOLECULAR IODINE PRESENT, METHYL IODIDE ABSENT. MATHEMATICAL RELATIONS IN TERMS OF MASS TRANSFER COEFFICIENTS AND SURFACE-TO-VOLUME RATIOS OF CONTAINERS AND SURFACE CHARACTERIZATION PARAMETERS WERE DEVELOPED FOR CASES WITH AND WITHOUT DESORPTION FROM PARTIALLY COVERED SURFACES. IN THE PRESENCE OF CONOENSING STEAM, THERE IS BULK FLOW OF STEAM TOWARD THE WALLS. IN SUCH CASES, IT WAS ASSUMED THAT DIFFUSIVE AND BULK FLOW COMPONENTS MAY BE APPROXIMATED BY THE BULK-FLOW COMPONENT ALONE, NEGLECTING THE DIFFUSIVE COMPONENT. FURTHERMORE, IT HAS BEEN ASSUMED THAT THE SOLUBILITY OF IODINE IN STEAM-CDNDENSATE IS HIGH ENOUGH TO PERMIT THE IOOINE AND THE STEAM TO CONDENSF TOGETHER WITH THE SAME COMPOSITION AS THE GAS PHASE. AS A RESULT OF THESE ASSUMPTIONS, MATHEMATICAL RELATIONS WERE DERIVED FOR THE CONCENTRATION OF IOOINE AS A FUNCTION OF TIME IN TERMS OF THE SURFACE-TO-VOLUME RATIOS, CONOENSING STEAM FLUXES, AND STEAM CONCENTRATIONS.

* ANALYTICAL MODEL + \#CONTAINMENT FILTERING SYSTEM + \#DEPOSITION + \#FISSION PRODUCT, IOOINE + AIR CLEANING + CONTAINMENT, GENERAL + IODINE + MASS TRANSFER + ORGANIC IODIDE + STEAM + SURFACE TO.VOLUME RATIO + WATER VAPOR

7-11679 MORRISON DL + GIESEKE JA + RITZMAN RL

ANALYTICAL DESCRIPTION OF THE DISTRIBUTION OF FISSION PRDDUCTS DURING NUCLEAR REACTOR ACCIDENTS FOR WATER AND GAS COOLED REACTORS

QATTELLE MEMORIAL INSTITUTE, CCLUMBUS

CONF-660904 +. 25 PAGES, 7 FIGURES, 2 TABLES, 28 REFERENCES, PRESENTED AT 9TH AEC AIR CLEANING 
CATEGORY 7

FISSION PRODUCT RELEASE, TRANSPORT, AND REMOVAL

7-11679 \#CONTINUED*

CONFERENCE, BOSTON, MASS., SEPTEMBER 13-16, 1966, SOURCE

A MATHEMATICAL MODEL WAS DEVELOPED TO DESCRIBE FISSION-PRODUCT RELEASE DURING WATER-REACTOR ACCIDENTS. THE INPUT PARAMETERS FOP THE EQUATIONS FOR THE RELEASE FPOM THE FUFL WERF BASED UPON EXPERIMENTAL DATA, ANO THE TEMPERATURE INPUT TO THE MODEL WAS SUPPLIED FROM AN

INDEPENDENT HEAT-TRANSFER ANALYSIS. THE TRANSPORT AND DEPOSITION OF THE FISSION PRODUCTS IN THE CORE ANO PRIMARY VESSFL WERE CALCULATED TO PROVIDE THE SOURCE TERM FOR THE TRANSPORT DND DEPOSITION ANALYSIS WITHIN THE CONTAINMENT VFSSEL. TWO SIMPLE MODELS, TRANSPORT WITHIN A

WELL-MIXED GAS OR DIFFUSION IN A STAGNANT GAS, WERF CONSIDERED FOR THIS RFGION. AN ANALYTICAL DESCRIPTION OF THE TIME-SPACE DISTRTQUTION OF FISSION PRODUCTS IN AN ACCIDENT CAN BE OBTAINED BY THE PROPFR COMBINATION OF THESF MATHEMATICAL MODELS.

\# ACCIDENT MODEL + \#ANALYTICAL MOOEL + \#FISSION PRODUCT RELEASE, GENERAL + \#FISSION PPODUCT TRANSPORT + $\triangle E R O S O L$ + $\triangle E R O S O L$ DROPERTIES + $\triangle I R$ CLEANING + DEPOSITION + DIFFUSION + FISSION PRODUCT, VOLATILE + THFRMAL ANALYSIS

7-11680 LAUBEN GN + LARSON CL CHARACTERIZATION OF SOURCE TERMS FOR DEROSOI TRANSPORT DURING SODIUM FIRES ATONICS INTERNATIONAL, CANOGA PARK

CONF-660904 +. 21 PAGES, 11 FIRIIRFS, 1 TABLE, 7 REFERENCES, POESENTEO $\triangle T$ OTH $\triangle E C$ IIR CLFANING CONFERENCE, BOSTON, MASS., SEPTEMBER $13-16,1966$, SOURCE

THE PRODUCTION OF RAOIOACTIVE AEROSOLS AS A RESULT OF AN ACCIDENTAL SPILL OF SODIUM CODLANT FROM A NUCLEAR REACTOP WAS STUDIED. POSSIBLF AEROSOLS FROM MOLTEN SONIUM POOLS INCLUIDED THOSE OF CONDENSED SODIUM VAPOR, PARTICULATE SODIUM OXIDE, AND FISSION PRCDUCTS COMBINED WITH OR SEPARATE FPOM THE SODIUM. THE VAPORIZATION ANN ROMBUSTION OF SODIUM APE DISCUSSED, AND R.ESULTS OF A TEST PROGPAM DESIGNED TO MEASURE BURNING RATE AND PARTICULATE RELEASE RATE ARE PRESENTED. THE BUOYANT FORCES IN THE GAS PROVIDE A MECHANISM FOR TRANSPOPT OF PARTICULATES FROM THE SCENE OF THE SPILL, ANO AN ANALYSIS OF THESE FORCES IS GIVEN.

* $\triangle C C I D E N T$ MOOEL + *AEROSOL PRODUCTION + \#FIRE + \#FISSION PRODUCT RELEASE, GENERAL + *FISSION PRODUCT TRANSPORT + \#SODIUM + AEROSOL + AFROSOL PROPERTIES + AIR CLEANING + COOLANT CHEMISTRY

7-11681 DADILLON J

IN PILE STUDIES OF CONTAMINATION RELEASED IN C.O2 GAS COOLED REACTORS

COMMISSARIAT A L ENERGIE ATOMIOUE

CONF-660904 +. 9 PAGES, 4 FIGURES, 2 TARLES, PRESENTED AT GTH AEC AIR CLEANING CONFERENCE, aOSTON, MASS., SEPTEMBER 13-16, 1966 , SOURCE

EXPERIMENTS WERE MADE, USING AN IN-PILE LOOP IN WHICH UO2 FUEL FLEMENTS WITH CLADDING FAILURE WERE IRRADIATED. WE WERE ABLE TO SHOW THE FOLLOWING MAIN RESULTS - (I) THERE WERF AT LFAST TWO IODINE COMPOUNDS IN THE LOOP, WITH DIFFERENT BEHAVIOR IN CHARCOAL, (2) THE FFFICIENCY OF TWO IOOINE COMPOUNDS IN THE LOOP, WITH DIFFERENT BEHAVIDR IN CHARCOAL, (2) THE FFFICIENCY OF
$5 \mathrm{CM}$ OF CHARCOAL FOR THE COMPOUNDS OR THE FORMS THAT HAD NOT BEEN TRAPDED BY THE IMPREGNATER PAPER OR THE KNIT-MESH WAS ABOUT 99 PERCENT, (3) THE CHAPCOAL-IMPREGNATED PAPER TRADPED FROM 3 TO 13 PERCENT OF THE ACTIVITY, (4) ONLY ABOUT 1 PERCENT OF THF IOOINE GENFRALLY REMAINED IN THE KNIT-MESH.

*CARBON OIOXIDE + \#COOLANT CHEMISTPY + \#FAILURE, FUEL FIFMFNT + *FIS\$ION PRODUCT, IODINE + \#IN DILF LOOP + AEROSOL + AIR CLEANING + CHARCOAL + FILTER, EFFICIENCY OF + FILTER, TRAP + ORGANIC IORIOE

7-11682 BURCHSTED CA

REQUIREMENTS FOR FIRE-RESISTANT HIGH-EFFICIENCY PARTICULATE AIR FILTFRS

OAK RIOGE NATIONAL LABORATORY, OAK P.IOGE

CONF-G60004 +. 12 PAGES, 20 REFERENCES, PRFSFNTED AT 9TH AEC AIP. CLEANING CONFERENCE, ROSTON, MASS.

SEPTEMBER $13-16,1966$, SOURCF

THE ESTABLISHMENT OF CERTAIN BASIC SPECIFICATION REOUIREMENTS IS ESSFNTIAL TO THE DROCUREMENT OF SUITABLE HIGH-EFFICIENCY PARTICULATE AIR FILTERS WITH A MINIMUM OF DIFFICULTIES ANR COST. PROBLEMS HAVE BEEN EXPERIENCED IN THE MANUFACTURE AND PP.OCUREMENT OF THESE FILTERS RECAUSE OF INCONSISIENT, AMSIGUOUS, AND CONFLICTING SPICIFICATION REQUIPFMENTS, AS WFII AS PEOUIREMENTS THAI ARE NOT RESTRICTIVE ENOUGH. THE REQUIREMENTS FDR FILTERS PRESFNTFD IN THIS PAPER $\triangle R E$

INTENDED TO GUIDE THE SPECIFICATION WRITFR TOWARD STANDARDS THAT WILL PRODUCE UNIFORMITY IN

CONSTRUCTION AND TESTING PRACTICES TO BRING THE COST DOWN TO REASONABLE LEVELS WITHOUT

SACRIFICING PERFORMANCE.

*FILTLR COST + \#FILTER TEST REQUIREMENT + \#FILTER, GLASS + \#FILTER, HIGH EFFICIENCY + FILTER DFSIGN + FILTER QUALITY ASSURANCE STATION + FILTEP SYSTEM + FILTER, C.OMMERCIAL + PAP.TICULATE

7-11683 ALLAN AR

SUGGESTIONS ON SPECIFICATION WRITING FOR ARSOLUTE FILTERS

FLANDERS FILTERS, INC., RIVERHEAD, NEW YORK

CONF-660904 +. 2 PAGES, PRESENTED AT 9TH AEC AIR CLEANING CONFERENCE, BOSTON, MASS., SEPTEMBER $13-16$, 1966, SOURCE

SOME RECENT SPECIFICATIONS FOR ABSOLUTE FILTERS HAVE REFN ISSUED AND ARE UNNECESSARILY BURDENSOME TO THE FILTER MANUFACTUPERS. THEY APPEAR TO HAVE REEN WRITTFN WITHDUT A FULL KNOWLEDGE OF EITHER THE PRODUCT OR THE PROCEDURE BY WHICH THEY ARE CUSTOMARILY DURCHASED. WE RECOMMEND THAT ALL PROPOSED SPECIFICATIONS BF SUBMITTED FOR COMMENT TO THE MANUFACTURERS IN ORDER THAT THE SPECIFICATION WRITER MAY HAVE THE BENEFIT OF THF MANUFACTURERS OPINION.

*FILTER COST + \#FILTER, GLASS + \#FILTER, HIGH EFFICIENCY + AIR CLEANING + FILTER DESIGN + 
CATEGORY ?

FISSION PRODUCT RELEASE, TRANSPORT, AND REMOVAL

$7 \rightarrow 11683$ *CONTINUED*
FILTER, COMMERCIAL

7-11684 ANDERSON WL + $\triangle N D E R S O N T$

EFFECT OF SHOCX OVERPRESSURES ON HIGH EFFICIENCY FILTER UNITS

NAVAL RESEARCH LABORATORY + U. S. NAVAL ORDNANCE LABORATORY

CONF-660904 +. 11 PAGES, 9 FIGURES, 5 TABLFS, 3 REFERFNCES, PRESENTED AT OTH AEC $\triangle I R$ CLEANING CONFERENCE, BOSTON, MASS., SEPTEMBER 13-16, 1966, SOURCE

THE PRESENT NONCOMBUSTIBLE HIEH-EFFICIENCY FILTER UNITS HAVE AS GDOD A RESISTANCE TO BLAST OVERPRESSURES AS THOSE REPORTED EARLIER FOR THE COMBUSTIBLE UNITS. IT IS APPARENT THAT THE PHYSICAL DIMENSIONS OF THE FILTER UNIT ITSELF IS ONE OF THE CONTROLLING FACTORS IN RUPTURE DUE TO SHOCK WAVES. IN GENERAL, THE LONGER AND THINNER THE UNSUPPORTED SPAN OF FILTER MEDIA, THE LOWER THF SHOCK WAVE REQUIRED FOR FAILURE. THE SIMPLE ADDITION OF HARDWARE WIRE CLOTH FOR THE PREVENTION OF PHYSICAL DAMAGE SEEMS TO INCREASE MATERI ALLY THE RESISTANCE TO SHOCK. IT IS BELIEVED THAT AOOITIONAL WORK ON RESILIENT ADHFSIVES AND METHODS OF SUPPORT FOR THE CENTER AREAS OF THE LARGER FILTER UNITS WOULD RESULT IN A UNIT THAT WOULD BE MARKEDLY IMPROVED WITH RESPECT TO BLAST RESISTANCE.

\#FILTER + \#FILTER DESIGN + \#FILTER, GLASS + \#FILTER, HIGH EFFICIENCY + AIR CLEANING + EXPLOSION + FAILURE, COMPONENT + FILTER

7-11685 MURROW JL

EFFECT OF FIRE INTRUSION AND HEAT ON HEPA FILTER UNITS

LAWRENCE RADIATION LABORATORY, LIVERMORE

CONF-660904 +. 9 PAGES, 4 FIGURES, PRESENTED AT 9TH AEC AIR CLEANING CONFERENCE, BOSTON, MASS., SEPTEMBER $13-16,1966$, SOURCE

SPECIAL EQUIPMENT WAS DEVELOPED FOR THE DYNAMIC TESTING OF 1000-CFM HIGH-EFFICIENCY PARTICULATE AIR FILTERS WITH RESPECT TO FIRE INTRUSION OR HIGH TEMPERATURE. USNRL-TYPE MECHANICAL DOP GENERATOR AND PHOTOMETER SYSTEMS WERE USED TO DETERMINE BEFORE-AND-AFTER FILTER EFFICIENCIES. THE DEGREE OF PROTECTION OF THE HEPA FILTER FROM FIRE IS ALMOST DIRECTLY RELATED TO THE HEAT-ABSORBING CAPACITY OF THE PREFILTER. THREE NEW SEALING MATERIALS SUCCESSFULLY PASSED HOT GAS TESTS. PARTICLE-BOARD TREATED FOR FIRE RETARDANCE BY THE PRESSURE-SOAK METHOD WAS ACCEPTED AS FRAMING MATERIAL. PARTICLF BOARD HAVING THE FIRE-RETARDANT MATERIAL MIXED IN BEFORE PRESSING ALSO SHOWS PROMISE AS FRAMING MATERIAL AND IS LESS EXPENSIVE THAN PARTICLF ROARD OR PLYWOOD TREATED BY SOAKING.

*FILTER DESIGN + \#FILTER. SAFETY EVALUATION + *FILTER, DAMAGFo + \#FILTER, GLASS + \#FILTER, hIGH EFFICIENCY + \#FIRE + AIR CLEANING + FILTER + FILTER INSTALLATION + FILTER SYSTEM + IGNITION

7-11686 ADLEY FE

PROGRESS REPORT, FACTORS INFLUENCING HIGH-EFFIT.IFNC.Y G.SSKET LEAKAGE

HANFORO OCCUPATIONAL HEALTH FOUNDATION

CONF-660904 + HOHF- $1+$ + 40 PAGES, 25 FIGURES, 3 RFFFRFNCES, PRESENTED AT 9TH AEC AIR CLEANINC CONFERENCE, BOSTON, MASS., SEPTEMBER 13-16, 1966 , SOURCE

THIS REPORT IDENTIFIES FACTORS WHICH ADVERSELY INFLUENCE THE SEALING PROPERTY OF HIGH EFFICIENCY, PARTICULATE, AIR (HEPA) FILTER GASKETS. RECAUSE OF THE PAUCITY OF INFORMATION ON THE PERFORMANCE OF THESE GASKETS WITH RESPECT TO THE OVERALL FILTER OPERATION, THIS STUDY WAS CONDUCTEO SO THAT A MORE DETAILED STUDY COULD BE MADE OF THE SIGNIFICANT FACTORS. THE FINDINGS OF THIS STUDY HAVE IOENTIFIED CERTAIN AREAS OF GASKET SFALING THAT WARRANT MDRE EXTENSIVE FVALUATION. THE MORE IMPORTANT OF THESE ARE - $(1)$ THE EFFECT DF AGING ON GASKET LEAKAGE OF INSTALLED FILTERS OVER EXTENDED PERIONS OF OPERATION, 2 I THE EFFECT OF HIGH LEAKAGE OF INSTALLED FILTERS OVER EXTENDED PERINOS OF OPERATION, $(2)$ THE EFFECT OF HIGH
COMPRESSION ON GASKET MATERIALS AND THEIR SEALING QUALITIES, (3) THE IMPORTANCE OF GASKET SKIN IN VARIOUS CELLULAR ELASTOMERS, 141 ALTHOUGH RELATED INDIRECTLY TO GASKET SEALING, THE MAGNITUDE AND SOURCE OF FRAME LEAKAGE FOR VARIOUS TYPES OF FILTER FRAMES UNDER INSTALLATION STRESSES.

\#FAILURE, COMPONENT + \#FILTER MAINTENANCE + \#FILTER SAFETY EVALUATION + \#FILTER SYSTEM + \#FILTER, HIGH EFFICIENCY + AIR CLEANING + FILTER + FILTER, DAMAGED

7-11687 HAHS CA

DEVELOPMENTS IN CONTAMINATED FILTER REMOVAL EQUIPMENT

OAK RIOGE NATIONAL LABORATORY, OAK RIOGE

CONF-660904 +.9 PAGES, 6 FIGURES, PRESENTED AT OTH AEC AIR CLEANING CONFERENCE, ROSTON, MASS., SEPTEMPER $13-16,1966$, SOURCE

EQUIPMENT USEO TO FILTER GASES EXHAUSTED FROM A NUCLEAR FACILITY, AND THE METHODS BY WHICH THIS EQUIPMENT WILL BE REMOVED AND REPLACED, REQUIRE CAREFUL. PLANNING AT OAK RIDGE NATIONAL LABORATORY, ONE FILTER-REMOVAL CARRIER WAS DESIGNED TO REMOVE FILTERS FROM BOTH THE OLOER ANI THE NEWER FILTER-PIT INSTALLATIONS AND TO PROVIDE GAMMA AND/OR NEUTRON SHIELDING DURING THIS OPERATION. OTHER DEVELOPMENTS IN REMOVAL PROCEDURES ARE EXEMPLIFIED BY THE METHODS USED TO REMOTELY REMOVE, TRANSPORT, AND DEPOSIT IN-CELL.CANISTER FILTERS IN DISPOSABLE CASKS, AND BY THE METHODS USED TO SEAL GLOVE-BOX EXHAUST FILTERS IN THEIR OWN POLYETHYLENE TUBES BEFORE REMOVING THEM.

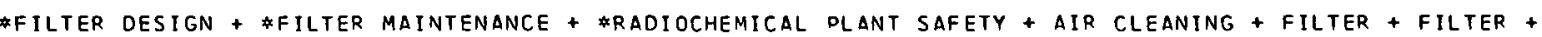
FILTER, HIGH EFFICIENCY, GLOVF, BOX 
CATEGORY 7

FISSION PRODUCT RELEASF, TRANSPRPT, AND REMOVAL

7-11688 COLLINS DA + TAYLOR LR + TAYLOP R

THE DEVELOPMENT OF IMPREGNATED C.HARCOALS FOR TRAPPING METHYL IOOIDE AT HIGH HUMINITY UNITEO KINGOOM ATOMIC ENERGY AUTHOR ITY, WINOSCALE

CONF-66C904 +. 26 PAGES, 10 FIGURES, PRESENTEN AT OTH AEC AIR CLEANING CONFERENCE, P.OSTON, MASS., SEPTEMBER $13-16,1966$, SOURCE

METHYL IODIDE CAN BE PRESENT IN RELEASES OF IODINE FROM IRRADIATED FUEL, AND AT HIGH HUMIDITY MOST ACTIVATED CIIARCOALS WILL NOT PROVIDE EFFICIENT PFRMANENT RETENTION OF METHYL IODIOE. IMPREGNATION OF ACTIVATED CHARCOAL WITH CERTAIN AMINES OR INORGANIC HALIDES HAS BEEN FOUND TD IMPROVE THE RFTENTION OF METHYL IODIDF AT HIGH HUMIOITY. THE REST RESULTS ARE GIVEN BY TRIETHYLENEDIAMINF OR POTASSIUM IODIDE SUPPORTED ON ?O7B CHARCOAL. THE BEHAVIOUR OF THESE TWO IMPREgNATED CHARCOALS HAS BEEN FXAMINED IN MORE DETAIL. THE PROPFRTIES OF THE TWO RECOMMENDED IMPREGNANTS ARE TO SOME EXTENT COMPLEMENTARY. POTASSIUM IODIDE IS NOT SFNSITIVE TO CARBON DIOXIDE OP HIGH TEMPFRATUPES, BUT WILL NOT ACCEPT AS HIGH A LOADING OF METHYL IOOIDE AS TRIETHYLENEDIAMINE AND LOWERS THE IGNITION POINT OF THE CHARCOAL. TESTS OF LARGE-SCALE RFIS FILLED WITH IMPREGNATED CHARCOAL HAVE GIVEN SATISFACTDRY RESULTS RUT RE-EMPHASIZE THE IMPDRTANCE OF ELIMINATING MECHANICAL DEFECTS WHICH CAN LEAU TO BY-PASSING OF THE CHARCOAL.

* CHARCOAL + \#FILTER, TRAP + \#FISSION PRODUCT, TODINF + \#ORGANIC IODIDE + \#WATER VAPOR + AIP CLEANINF + FILTER + FILTFR, FFFICIENCY OF + FISSION PRODUCT TRANSPORT + IODINE + UNITED KINGDOM

7-11689 ACKLEY RD + $\triangle D A M S R E+$ RPOWNING WE REMOVAL OF RADIOACTIVE METIIYL IODIDE FROM STEAM-AIP SYSTEMS OAK RIDGE NATIONAL LARORATORY, OAK RIDGF

CONF-660904 +. 15 PAGES, 3 FIGURES, 5 TABLES, 4 REFERENCES, PRESENTED $\triangle T$ 9TH $\triangle$ TEC $\triangle$ IR CLEANING CONFERFNCF, BOSTON, MASS., SEPTEMBER. 13-1F. 1966, SOURCE

CERTAIN SPECIALLY IMPREGNATED CHARCOALS HAVE BEEN ORSERVEO TO EFFECTIVELY TRAD DADIOACTIVE METHYL IODIDE, BY AN ISOTOPIC EXCHANGE MECHANISM, FROM AIR STREAMS OF FAIRLY HIGH RELATIVE MUMIDITY AT TEMPERATURES AS HIGH AS $115 \mathrm{~F}$. IN THE EVENT OF A NUCLEAR REACTOR ACCIDENT, HOWEVER, THE METHYL IDOIDE TRAPPING PRORLEM MAY BE COMPLICATED EY THF PRODUCTION OF STEAM, WITH ATTENDANT ELEVATION OF THE AIR TEMPERATURE. THE OBJECTIVE OF THIS WORK WAS TO OSTAIN APPLICABLC OATA UNDER THESE MOPE SEVERE CONDITIONS. REMOVAL OF RADIOACTIVE METHYL IODIOE FROM FLOWING STEAM-AIR BY IMPREGNATED CHARCOALS WAS INVESTIGATEO IN TWO SERIES OF TFSTS. TEMPERATURES AND PRESSURES FOR ONE SERIFS WERE AROUND 212 F AND 14.4 PSIA, AND, FOR THE OTHER SERIES, GENERALLY APOUND 280 F AND 6O PSIA. ACCORDING TO THE RESULTS, METHYL IONIDE CAN STILL BE TRAPPED EFFECTIVELY AT THFSE HIGHER TEMPERATURES AND, ALSO, AT THE HIGHER PRESSURES BY AN APPRODRIATELY SELECTED IMPREGNATED CHAPCOAL, PROVIDED THAT THE CHARCOAL HAS NOT BEFN DAMAGTD AND RROVIDED THAT THE PREVAILING RFI ATIVE HUMIDITY IN THE CHARCOAL DOES NOT EXCEED OO PERCENT.

*CHARCOAL + *FILTER, EFFICIENCY OF + *FILTER, TRAP + \#FISSION PRODUCT, IODINE + *ORGANIC IODIDE + *WATER VAPOR + AIR CLFANING + FILTER + FISSION PRODUCT TRANSPORT + IODINE

7-11690 ACKERMAN FJ + GRENS JZ MECHANISMS THAT AFFECT THE ADSORPTION OF METHYL IODIDE ON CHARCOAL UNDER HUMID CONDITIONS LAWRENCE RADIATION LABORATORY, LIVERMOP.E UCRL-14900 + CONF-660904 +. 21 PAGES, 5 FIGURES, 1 TABLE, 20 REFERENCES, DRFSFNTFD AT 9TH AEC AIR CLEANING CONFERENCE, BOSTON, MASS, SEPTEMBER 13-16, 1966 , SOURCE

BREAKTHPOUGH CUR.VES OF THF ATSORPTION OF METHYL IODIDF FROM AIR ON CHARCOAL WERE EXPERIMENTALLY MEASURED OVER THE RANGE OF 20 TO 100 DCRCENT HUMIDITY. THE CUPVES CAN BE EXPLAINED BY ASSUMING TWO RATE-CONTROLLING MECHANISMS FOR MASS TRANSFER. BULK DIFFUSION CONTROLLED THE ADSORPTION RATE DURING THE EARLY PERIOD, WHILE PORE DIFFUSION WAS CONTROLLED LATER. IN THE ADSORPTION PRDCESS. WATFR VAPOR GRFATLY LIMITS THE CAPACITY OF THF CHARCOAL FOR METHYL IONIDE. WATER VAPDR ALSO HINDERS THE RATE OF MASS TRANSFER GY PORE DIFFUSIUN.

*CHARCOAL + \#FILTER, TRAP + \#FISSION PRODUCT, IODINE + \#ORGANIC IODIDE + *WATFR VAPOR + AIR CLEANING + FILTER + FILTER, EFFICIENCY OF + FISSION PRODUCT TRANSPORT + IODINE

7-11691 MILHAM RC

HIGH TEMPERATURE CARBON FOR IODINE ADSORPTION

SAVANNAH RIVER LABORATORY, AIKEN, SOUTH CAROLINA

DP-MS-66-45 + CONF-660904 +. 12 PAGES, 4 FIGURES, 3 TABLFS, 9 REFEPENCES, PRESENTED AT OTH AEC AIR CLEANING CONFERENCE, BOSTON, MASS., SEPTEMBFR 13-16, 1966 , SOUP.CE

THE SAVANNAH RIVER LABORATORY IS STUDYING ADSORRERS FOR REDUCING THE PRORABILITY OF IGNITING EXISTING TYPES OF ACTIVATED COCONUT-SHELL CARBON IN SOME R.EACTOR CONFINFMFNT SYSTFMS. A NEW HIGH-TEMPERATURE COCONUT-SHELL CARBON (IGNITION TEMPERATURE, ABOUT 530 C) HAS BEEN DEVELOPED BY AN AMERICAN MANUFACTURER, ANO, IN PQFLIMINAPY TESTS, MEETS SPECIFICATIONS FOR THE SAVANNAH RIVER PLANT CONFINEMENT SYSTEM. A STANDARDIZFD PROCEDURE HAS REEN DEVELOPFD TO MEASURE IGNITION TEMPERATURE, TO EVALUATE PROMISING NEW TYPES OF CARRON, AND TO EVALUATE EFFECTS OF VARIABLES (SUCH AS AIR FLOW, BED DFPTH, IMPRFGNANTS, PLANT SERVICE, AND HUMIDITYI ON IGNITION TEMPERAIURE. RESULTS OF THESE EVALUATIONS ARE REPODTED.

*CHARCOAL + \#IGNITION + *IODINE + AIR CLEANING + CARBON + FILTER + FILTFR, HIGH TEMPERATURE + FILTER, TRAP + FIRE + FISSION PRODUCT TRANSPORT + OXIDATION + THERMAI PROPERTY

7-11692 BOGARDUS HF + DIETZ VR + STAMULIS A

A NDPDE STRHGTIVE METHOT! FOR TFTFRMINTNG THF RESIDUAL GAS LIFE OF CHARCOAL GEDS

U. S. NAVAL RESEARCH LABORATOPY 
CATEGORY 7

FISSION PRODUCT RELEASE, TRANSPORT, AND REMOVAL

7-11692 \#CONTINUEO*

CONF-660904 † 5 PAGES, 4 FIGURES, 3 TABLES, 2 REFERENCES, PRESENTFD AT 9TH AEC AIR CLEANING CONFERENCE, BOSTON, MASS., SEPTEMBER 13-16, 1966, SOURCE

A NONDESTRUCTIVE METHOD WAS DEVELOPED FOR DETERMINING THE RESIDUAL GAS LIFE OF CHARCOAL BEDS USED TO REMOVE GASES FROM AIR STREAMS. IT MAKES USE OF THE FACT THAT A DIRECT PELATIONSHIP EXISTS BETHEEN THE MANNER IN WHICH COZ PENETRATES A CHARCOAL BED AND THE CAPACITY OF THAT PED FOR STRONGLY ADSORBED GASES. A PULSE OF C02 IS INTRODUCED UPSTPEAM OF THE CHARCOAL BED, AND A VERY SENSITIVE INDICATOR-RECORDER SYSTEM IS USED TO SAMPLE THE DOWNSTREAM AIR AND TO TRACE THE SHAPE OF THE CO2 PULSE AS IT EMERGES FROM THE CHARCOAL BED. THE PULSE SHAPE IS DIRECTLY RELATABLE TO THE RESIDUAL GAS LIFE OF THE BED.

\#CARBON DIOXIDE + \#CHARCOAL + \#TEST, FILTER + \#TEST, FILTER SYSTEM + AIR CLEANING + FILTER +

FILTER MAINTENANCE + FILTER, BED + FILTER, TRAP

7-11693 VILES FJ + SILVERMAN L

REMOVAL OF IODINE AND METHYL IODIDE BY AEROSOL FORMATION WITH HYDRAZINES

HARVARD AIR CLEANING LABORATORY, BOSTON

CONF-660904 + 14 PAGES, 11 FIGURES, 2 TABLES, 7 REFERENCES, PRESENTED AT QTH AEC AIR CLEANING

CONFERENCE, SOSTON, MASS., SEPTEMBER 13-16, 1966 , SOURCE

STUDIES WERE MADE OF THE GAS-PHASE REACTIONS OF IODINF AND METHYL IODIDE WITH HYDRAZINF TO FORM AEROSOLS THAT COULD BE EFFECTIVELY REMOVED BY FILTRATION OR BY SETTLING, DIFFUSIONAL, OR SOLUBILITY PROCESSES. HIGH AND LOW (REALISTIC) CONCENTRATIONS OF REACTANTS WERE USED, UNDER DYNAMIC. AND STATIC CONDITIONS. REMOVAL OF METHYL IODIDE BY GAS-PHASE REACTION WITH LOW CONCENTRATIONS OF UNSYMMETRICAL DIMETHYL HYDRAZINE IS ALSO INCLUDED.

* CHARCOAL + \#COOLANT ChEMISTRY + \#IODINE + \#ORgANIC IODIDE + AIR CLEANING + DECONTAMINATION SPRAY + FILTER + FISSION PRODUCT TRANSPORT + FISSION PRODUCT, IODINE

7-11694 MISHIMA J + SCHWENDIMAN LC + BURGER LL + HASTY RA REMOVAL OF METHYL IODIDE FROM SIMULATED REACTOR CONTAINMENT ATMOSPHERES WITH HYDPAZINE BATTELLE NORTHWEST, PACIFIC NORTHWEST LABORATORY, RICHLAND

CONF-660904 +. 19 PAGES, 6 FIGURES, TABLES, PRESENTED AT 9TH AEC AIR CLEANING CONFERENCE, BOSTON, MASS., SEPTEMBER $1.3-16,1966$, SOURCE

THE REACTION OF HYDRAZINE AND METHYL IOOIDE IS UNDER STUDY TO DETERMINE THE FEASIBILITY OF USING HYDRAZINE IN REACTOR SPRAY SYSTEMS TO REMOVE ORGANIC AND MOLECULAR FOPMS OF RADIOACTIVE IODINE. RATE STUDIES SHOWED THAT THE STAYIC REMOVAL OF METHYL IODIDE FROM THE VAPOR PHASE OVER A 50 PERCENT HYDRAZINE SOLUTION PROCEENS HITH A HALF-LIFE OF ABOUT 6 MIN AT $50 \mathrm{C}$. REACTION RATE AND/OR RATE. OF TRANSFER TO THE SOLUTION VARIES WITH AIRBDRNE METHYL IODIDE CONCENTRATION, LIQUID HYDRAZINE CONCENTRATION, AND THE AVAILABLE LIQUID SURFACE AREA. SPRAYING 35 PERCENT HYDRAZINE SOLUTIONS THROUGH AIR CONTAINING METHYL IOOIDE AT ROOM TEMPERATURE AND AT 75 C EFFECTIVELY SCAVENGED METHYL IODIDE EVEN IN THE PRESENCE DF 50 MG OF MOLECULAR IOOINE PER CU. METER.

AIR CLEANING + CHARCOAL + COOLANT CHEMISTRY + DECONTAMINATION SPRAY + FTI.TFR + FISSIDN PRODUCT TPANSPORT + FISSIUN PRODUCT, IODINE + IODINE + ORGANIC IODIDE

7-11695 PARKER GW + CREEK CE + FERRELI A

RETENTION OF METHYL IODIDE BY IMPREGNATED CARBONS UNDER AMBIENT CONDITIONS

OAK RIDGE NATIONAL LABORATORY, OAK RIDGE

CONF-660904 +. 27 PAGES, 10 FIGURES, 6 TARLES, 4 RFFERENCES, PRESENTED AT 9TH AEC AIR CLEANING CONFERENCE, BOSTON, MASS., SEPTEMBER 13-16, 1966 , SOURCE

THE EXTENT OF THE PRODUCTION OF METHYL IODIDE AND THE CONTAINMENT OF THIS FORM OF RADIOIODINE HAVE BECOME TWO OF THE MOST IMPORTANT FACTORS THAT MUST BE CONSIDERED IN THF PREPARATION OF REACTOR-SAFEGUARDS ANALYSES. VARIOUS ESTIMATORS OF THE AMOUNT AND MODE OF FOPMATION OF METHYL IODIDE HAVE GENERALLY CONCLUDEO THAT LESS THAN 5 PERCENT OF THE IODINE SHOULD BE PRESENT IN THIS FORM, HOWEVER, EVEN THIS AMOUNT LEADS TO SERIOUS IMPLICATIONS BECAUSE CONVENTIONAL CARBON-FILTER SYSTEMS ARE RELATIVELY INEFFECTIVE IN TRAPPING THIS COMPOUND. SIGNIFICANT ADVANCES IN METHODS OF TRAPPING METHYL IODIDE HAVE BEEN DISCOVERED INOEPENOFNTLY IN THE U. S. AND IN ENGLAND. VERY PROMISING RESULTS FROM THE TESTING OF VAPIOUS.CHEMICAL AODITIVES TO COCONUT CHARCOALS WERE OBTAINED. AN ISOTOPIC EXCHANGE REACTION APPARENTLY OCCURS WHEN THE ADDITIVE IS NATURAL MOLECULAR IODINE, AND A COMPOUND IS FORMED WHEN THE ADDITIVE IS AN ORGANIC AMINE. THE MECHANISM RESPONSI BLE FOR IMPROVED RETENTION WHEN THE ADDITIVE IS AN IODIDE SALT IS NOT CLEAR AT PRESENT. UNDER FAVORABLE CONOITIONS, VERY HIGH RETENTION EFFICIENCIES ARE. OBTAINEO WITH HIGH AIR VELOCITIES AND RELATIVELY SHALLNW BEDS. THE LOWER EFFICIENCY OBSERVED WHEN THE CARRIER GAS IS VERY HUMID IS A RELATIVELY MINOR PROBLEM THAT CAN BE EASILY CIRCUMVENTED BY AN INCREASE IN BED DEPTH. FOR MOST CONDITIONS, AN ATTENUATION FACTOR OF FROM 5 TO 10 PER CENTIMETER OF BED DEPTH CAN BE EXPECTED.

* CHARCOAL + \#FILTER, EFFICIENCY OF + \#FILTER, TRAP + \#FISSION PRODUCT, IODINE + \#ORGANIC IODIOE + *WATER VAPOR + AIR CLEANING + FILTER + FISSION PRODUCT TRANSPORT + IODINE

7-11696 DURANT WS

PERFORMANCE OF AIRBORNE ACTIVITY CONFINEMENT SYSTEMS IN SAVANNAH RIVER PLANT REACTOR BUILDINGS SAVANNAH RIVER LABORATORY, AIKEN, S. C.

CONF-66C904 + DP-MS-66-52 +. 21 PAGES, 6 FIGURES, 1 TABLE, 21 REFERENCES, PRESENTED AT 9TH AEC AIR CLEANING CONFERENCE, BOSTON, MASS., SEPTEMBER 13-16, 1966, SOURCE 
CATEGORY 7

FISSION PRODUCT RELEASE, TRANSPORT, ANO REMOVAL

7-1169E *CONTINUED*

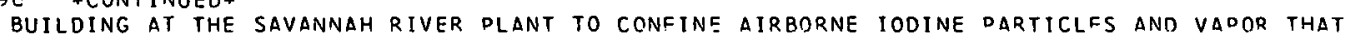
MIGHT BE RELEASED IN THE HIGHLY UNLIKELY EVENT OF A QEACTOR ACCIDENT. AIP. FROM THE PRDCESS AREAS OF EACH BUILDING IS DASSED CONTINUOUSLY THPOUGH MOISTURE SEPARATOOS, THFN THROUGH PARTICULATE FILTERS, AND FINALLY THROUGH IONINE ADSORRER BEDS OF ACTIVATED CARBON. THE UNITS HAVE THE DEMONSTRATED ABILITY TO COLLECT OVER 99 PERCENT OF AIRBORNE PARTICULATE ACTIVITY ANI OVER 99.9 PERCENT OF AIRBORNE HALOGEN ACTIVITY UNDER EMERGENCY CONDITIONS. A CONTINUING, PROGRAM OF DEVELOPMENT. TESTING, AND MAINTENANCE ENSURES THAT THESE HIGH EFFICIENCIES WILL BF. MAINTAINED DURING OPERATION. EXPERIENCF HAS BEEN SATISFACTORY FOR MOPE THAN? YEARS OF OPERATION.

* CONTAINMENT FILTERING SYSTFM + \#CONTAINMENT SYSTEM, OPERATION OF + \#FILTFR DESIgN + * SAVANNAH RIVER PLANT + \#WATER VAPOR + AIR CLEANING + CONTAINMENT aIR COOLING + ENGINEEPED SAFEgUARD + FILTER + FILTER INSTALLATION + FILTER OPERATION + FILTER SYSTEM

7-11697 FIRST MW + SILVERMAN L + PENOER D + DAWSON S

FLOATING ROOF CONTAINMENT VESSELS

HARVARO UNIVERSITY, BOSTON

CONF-GCO904 $t$. 18 PAGES, 5 FIGURES, DRESENTED AT 9 TH $\triangle E C$ AIR CLEANING CONFERENCE, BNSTON, MASS.,

SEPTEMBER 13-16, 1966 , SOURCE

THE PURPOSE OF THIS INVESTIGATION WAS TO DEVELOP MECHANISMS FOR, ANU IO STUUY THE PERFORMANCE CHARACTERISITLS OF, A FLOATING-ROOT REACTOR AND OFF-GAS CONTAINMFNT VFSSEL. THE PRESSURE SURGE FOLLOWING A MAJCR COCLANT LINE RUPTURE WOULD BE ABSORBED AND SUPPRESSED BY MOVEMENT OF A LEAK-TIGHT MOVABLE ROOF. ACTIVATION OF COOLING-WATER SPRAYS AFTER THE ACCIDENT WOULD CONDENSE STEAM AND PERMIT THE ROOF TO FALL SLOWLY TO ITS NORMAL PDSITION. THF ADVANTAGES OF THIS SCHEME ARE - 111 IN THE EVENT OF A MAXIMUM CREDIBLE ACCIDENT, THE POOF WOULD RISE IN RESPONSE TO THE APPLIED PRESSURE, PREVENTING THE SHELL FROM BEING SUBJFCTED TO STRESSES IN EXCESS OF A FRACTION OF $\triangle$ POUND PER SQUARE INCH. AS RECOVERY MEASURES TOOK EFFECT, THE FLOATING ROOF WOULO SETTLE AND RETURN TO ITS ORIGINAL POSITION WHEN THE PRESSURE INSIDE THE CONTAINMENT VESSEL RETURNED TO NORMAL. (2) AS THE PRFSSURE OF THE STATIONARY PARTS OF THF CONTAINMENT SHELL WOULD NOT EXCEED 0.25 PSI, IT MIGHT BE POSSIRLE TO LIGHTEN AND SIMPLIFY THE STRUCTURE AND THEREEY EFFECT SUBSTANTIAL SAVINGS HHILE MAINTAINING AN EDIJAL DEGPEE OF SAFETY.

\#CONTAINMENT DESIGN + \#CONTAINMENT LEAKAGE CONTROL + \#CONTAINMENT RESEARCH AND DEVELOPMENT + \#CONTAINMENT SPRAY + \#CONTAINMENT STRUCTURE + \#CONTAINMENT, SHOCK GENERATION AND PROTECTION + AIR CLEANING + CONTAINMENT CONSTRUCTION + CONTAINMENT, PRESSUPE VFSSEL

7-11698 SMITH ML

CONFINEMENT SYSTEMS TESTS PERFCRNED DURING DEACTIVATION OT THE IOC-F REATTOR.

DOUGLAS UNITED NUCLEAR, INC., RICHLAND

CONF-660904 + DUN-SA-15 +. 30 PAGES, 18 FIGURES, 5 TABLES, PRESENTED AT 9TH $\triangle E C$ AIR CLEANING CONFEPENCE, BOSTON, MASS., SEPTEMBER 13-1€, 1966, SOURCE

PERMANENT SHUTOOWN OF THE 1OO-F PLUTONIUM PRODUCTION REACTOP AT HANFORD MADE THE SYSTEM FOR CONFINING THE PARTICLES AND HALOGEN IN THE EXHAUST AIR AVAILARLE FOR TESTING. THF FCLLOWING TESTS WERE PERFORMED, AND THE RESULTS ARE GIVEN THROUGHOUT THE TEXT - IDDINE DEPDSITION FROM IHE AIRSTREAM, IODINE RLMOVED FROM AIPSTREAM BY FOG SPRAY, ENCAPSULATION OF THE REACTOR EXHAUST AIR IN FOAM, EFFECTIVENESS OF FOG SPRAY FOR REMOVING NOBLE GASES FROM THE AIP, EFFECTIVENESS OF THE FILTER SYSTEM FOR REMOVING IODINE FROM THE EXHAUST AIR. ABOUT IIJU CURIES OF I-128 WAS RELEASED INTO THE DISCHARGE-AREA SUPPLY AIR WITH THE FOG SDOAY OPERATING. THE SPRAY REDUCED THE CONCENTRATION IN THE AIR EXHAUSTEO FROM THE OISCHARGE AREA BY A FACTOR OF 500. ABOUT 10 CURIES OF KR-85 HAS RELEASED INTO THE EXHAUST AIR. THE DOSE WAS MEASUPED UP AND DOWN STREAM OF A FOG SPRAY INSTALLED IN THE DUCT. NINETY-FIVE PERCENT OF THE KR-85 WAS STILL IN THE EXHAUST AIR AFTER IT PASSED THROUGH THE FOG SPRAY. THE EXPOSURF. OF THE AIR TO THE TOG WAS LESS THAN 3 SECONOS.

\#DECONTAMINATION SPRAY + \#FILTER SYSTEM + \#FISSION PROOUCT, IOOINE + \#FOAM + *FOG + \#NOBLE GAS + AIR CLEANING + CONTAINMENT, GENERAL + DECONTAMINATION + DEPOSITION + FISSION PRODUCT TRANSPORT + SPRAY, GENERAL

7-11699 COLLINS RD + HILLARY JJ + TAYLOR JC AIR CLEANING FOR REACTORS WITH VENTED CONTAINMENT UNITED KINGDOM ATOMIC ENERGY AUTHORITY, WINDSCALE

CONF- $66 C 904+.36$ PAGES, 11 FIGURES, 6 TABLES, 9 REFERENCES, PRESFNTED AT OTH AEC AIR CLEANING CONFERENCE, BOSTON, MASS.. SEPTEMBER 13-1E, 1966, SOURCE

A PROGRAMME OF EXPERIMENTAL WCRK MAS REEN CARRIED OUT UNDER CONDITIONS APPRODRIATE TO DOSSIRLE DEPRESSURIZATION-TYPE ACCIDENTS TO THE STEAM GENERATING HEAVY WATER REACTOR (SGHW) AT WINFRITH HEATH WHICH HAS VENTED CGNTAINMENT. THE YORK HAS INCLUDED SMALL-SCALE EXOERIMENTS IN GLASS OR SILICA APPARATUS IN WHICH MEASURFMFNTS HAVE SEEN MADE OF THE EXTENT AND FORM OF THE IODINE RELEASE FROM 2 IRCALOY-CLAD UO2 INTO STEAM UNDER MELTING CONDITIONS AND AT ABOUT $1000 \mathrm{C}$. $\triangle$ NUMBER OF TESTS HAVE BEEN CONDUCTED WITH SIMULATED FOR YS OF IODINE ON THO LARGE-SCALE STEEL MOOELS OF THE REACTOR HATER-LUTE STEAM SUPPRESSION SYSTEM. TESTS HAVE ALSO BEEN CARRIED OUT ON 10OO-CFM FILTER UNITS TO DEVELOP DROPLET DISENTRAINMENT DEVICFS. WORK ON THE DEVELOPMENT OF CHARCOALS TO DEAL WITH PENETRATING IODINE IMETHYL IDDIDEI UNDFR WET CONOITIONS IS REPORTED SEPARATELY. THE RESULTS OF THIS WORK SHOW THAT - (A) AN EFFECTIVE TRAPPING PLANI CAN BE SPECIFIED TO DEAL WITH FISSION DRODUCT IDOINE IN WFT ATMOSPHFRES. (B) AT LEAST UP TO 1000 MWD/TE U FUEL BURN-UP, $\triangle$ CAN-RFTENTION FACTOR OF 1O $\triangle P P L I E S$ FOR IODINE EXPECTED TO BE FREE WITHIN THE CAN, ALSO THAT PASSAGE THROUGH A WATER LUTE IS LIKELY TO REDUCE THE IODINE RELEASE BY A FURTHER FACTOR OF 10.

* Charcoal + \#CONTAINMENT DESTGN + \#CONTAINMENT, PRESSURE VENTING + \#FISSION ORODUCT, IODINE + \#OPGANIC IOOIDE + *WATER VAPOR + $\triangle$ IR CLEANING + CONTAINMFNT FILTERING SYSTEM + 
CATEGORY 7

FISSION PROOUCT RELEASE, TRANSPORT, AND REMOVAL

7-11699 \#CONTINUED*

CONTAINMENT RESEARCH AND DEVELOPMENT + CONTAINMFNT, PRESSURE RELIEF + CONTAINMENT, PRESSURE SUPPRESSION + CONTAINMENT, WATER FILLED

7-11700 PARKER GW + CREEK GE + NARTIN WJ + PARSLY LF EFFECTS OF CONTAINMENT SYSTEM SIZE ON FISSION PRODUCT BFHAVIOR OAK RIDGE NATIONAL LABORATORY, OAK RIDGE

CONF-660904 +. 13 PAGES, 2 FIGURES, 3 TABLES, 10 REFERENCES, PRESENTED AT 9TH AEC AIR CONFERENCE, BOSTON, MASS., SEPTEMBER $13-16,1966$, SOURCE

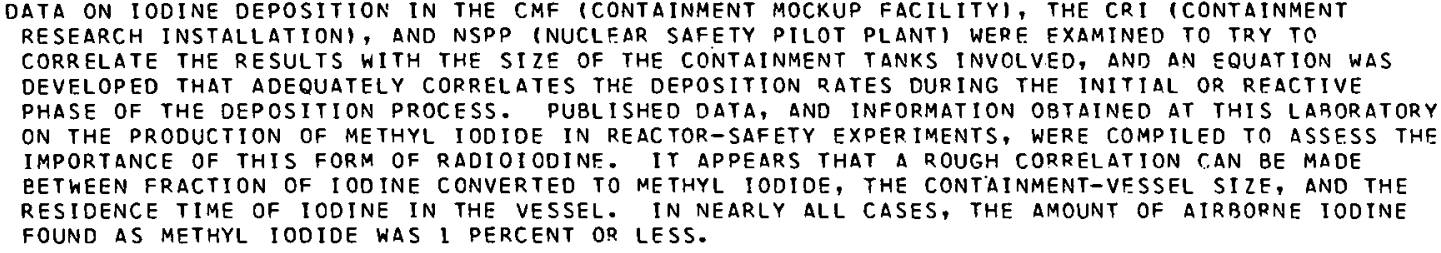

* CONTAINMENT FILTERING SYSTEM + *CONTAINMENT RESEARCH AND DEVELOPMENT + *FISSION PRODUCT R.ELEASE, GENERAL + \#FISSION PRODUCT, IODINE + \#ORGANIC IODIDE + AEROSOL + AIR CLEANING + CONTAINMENT

CONTAINMENT DESIGN + DEPOSITION

7-11701 ACKERMAN J + BUNDRICK R + COWLES J + DUVAL V + GRENS J + HOLZMAN R + HANNON C + HARRAR J + MORRIS C + RIGOON L + HECKMAN R + SNOEBERGER O

VENT GAS TREATMENT PLANT

LAWRENCE RADIATION LABORATORY, LIVERMORE

VUF-3016 + CONF-660904+ 14 PAGES, 2 .FIGURES, PRESENTED AT 9TH AEC AIR. CLEANINR. CONFERENCE, ROSTON,

MASS., SEPTEMBER $13-16,1966$, SOURCE

AS PART OF THE VELA UNIFORM PROGRAM, PROJECT DRIBRLE WAS CONCERNEO WITH THE MEASUREMENT OF SEISMIC SIGNALS GENERATED BY A NUCLEAR DETONATION IN A SALT DOME. THE VENT-GAS TREATMENT FACILITY MUST REMOVE RADIOIODINE AND RAOIOACTIVE NOBLE GASES TO ELIMINATE ANY POSSIBLE PUBLIC SAFETY PROBLEMS. THE PROBLEM WAS TO RELEASE AT A CONTROLLED AND SAFE RATF APPROXIMATFLY 560,000 CU. FT. OF GAS INITIALLY AT A PRESSURE OF 10 PSI OR LESS. THE FACILITY IS A REMOTELY OPERATED GAS SCRUBBINE AND FILTERING SYSTEM WITH CHARCOAL ADSORPTION UNITS INCORPORATED WITH THE FILTERS. IT IS SIZED TO. TAKE UP TO 200 CFM OF CAVITY GAS MIXED WITH 2000 CFM OF. AIR TO CILUTE HYDROGEN. EFFLUENT GAS IS OISCHARGED FROM A 150 FT STACK AFTER MIXING WITH 20,0OO CFM OF ADDITIONAL AIR, LIQUID WASTES FROM THE SCRUBRERS ARE STORED IN FOUR 25, OOO-GAL TANKS FOR LATER DISPOSAL. FROM THE MEASURED PERFORMANCE OF THE CHARCOAL SCRUBBERS, WE BELIEVE MUCH OF THE RADIOIODINE RELEASED WAS PRESENT AS ORGANIC COMPOUNDS, POSSIBLY CH3I. BASIC STUDIES OF THE CHEMICAL NATURE OF AN UNDERGROUND NUCLEAR EXPLOSION ARE UNDERWAY.

\#CONTAINMENT, GENERAL + \#CONTAINMENT, SHOCK gENERATION AND PROTECTION + \#FILTER DESIGN * \#FILTER INSTALLATION + AIR CLEANING + CONTAINMENT FILTERING SYSTEM + CONTAINMENT SYSTEM, OPERATION OF + CONTAINMENT, PRESSURE VENTING

7-11705 REIST PC

SIZE DISTRIBUTION SAMPLING ERRORS INTRODUCEO BY THE POINT-PLANE ELECTROSTATIC PRECIPITATOR SAMPLING DEVICE HARVARD UNIVER SITY

CONF-660904 +. 12 PAGES, 3 FIGURES, 3 TABLES, 10 REFERENCES, PRESENTED AT 9TH AEC AIR CLEANING

CONFERENCE, BOSTON, MASS., SEPTEMBER 13-16, 1966, SOURCE

IN USING THE POINT-PLANE ELECTROSTATIC PRECIPITATOR IT IS GENERALLY ASSUMED THAT THE SIZE DISTR IBUTION OF THE SAMPLE COLLECTED REPRESENTS REASONABLY WELL THE ACTUAL PARTICLE-SIZE DISTRIBUTION OF THE TEST AEROSOL. THIS PAPER REPORTS AN INVESTIGATION MADE TO DETERMINE THE MAGNITUDE OF THIS SAMPLING ERROR.

*ELECTROSTATIC PRECIPITATION + \#PARTICLE SIZE + \#PARTICLE SI7E DISTRIBUTION + *SAMPLING + AIR CLEANING + FILTER, EFFICIENCY OF + FILTER, ELECTROSTATIC

7-1170E SPIEGLER P + MORGAN JG + GREENFIELD MA + KOONTZ RL

EVALUATION OF THE EQUATION THAT GOVERNS THE COAGULATION OF AN AEROSOL

ATOMICS INTERNATIONAL, CANOGA PARK

CONF-66C904 t. 21 PAGES, 13 FISURES, 14 REFERENCES, PRESENTED AT 9TH AEC AIR. CLEANING CONFERENCE, BOSTDN,

MASS., SEPTEMBER 13-16, 1966, SOURCE

AN IBM 7094 DIGITAL COMPUTER WAS USED IN SOLVING THE EQUATION. THAT DESCRIBED IN TIME THE REHAVIOR OF AN AEROSOL. THE TOPICS INVESTIGATED INCLUDE COAGULATION OF A HETEROGENEOUS AEROSOL, COAGULATION COUPLEO WITH STIRRED SETTLING, AND AN EXTERNAL SOURCE THAT CONTINUOUSLY GENERATES NEW PARTICLES. IN SOME INSTANCES, APPROXIMATIONS TO THE CODE RESULTS MAY BE OBTAINED, PROVIDED THAT SIMPLIFYING ASSUMPTIONS ARE MADE. THE RESULTS INDICATE THAT THE AEROSOL CONCENTRATION IS A MORE IMPORTANT FACTOR THAN THE INITIAL PARTICLE SPECTRUM. ONE OF THE STRIKING FACTS TO EMERGE FROM EVEN THE LIMITED NUMBER OF PRORLEMS WORKED PY THE CODE IS THE RAPID DISAPPEARANCE OF SMALL PARTICLES, PROVIDED THAT THE INITIAL CONCENTRATION IS HIGH ENOUGH.

\# AEROSOL PROPERTIES + *ANALYTICAL MODEL + \#PARTICLE SIZE + *PARTICLE SIZE DISTRIBUTION +

* THEORETICAL INVESTIGATION + AEROSOL + AIR CLEANING + COMPUTER PROGRAM 
CATEGORY 7
FISSIOA PRODUCT RELEASE, TRANSPOPT, AND REMOVAL

7-11707 DAWSON SV

MECHANICS OF COLLECTION OF PARTICLES PY INERTIA ANO INTERCEPTION IN A FIBROUS AIR FILTER HARVARD UNIVERSITY

CCNF-6EC9O4 +. 11 PAGES, 7 REFERENCES, PRESENTED AT 9TH $\triangle F C$ AIR CLEANING CONFERENCE, BOSTDN, MASS., SFPTEMBER $13-16,1966$, SOURCE

AN APPROXIMATE EXPRESSION WAS OEVELOPED FOR THE EEFICIENCY OF COLLECTION OF PARTICLFS RY SMALL INERTIAL FORCE AND RY DIRECT INTEPCEPTION FROM AN ATR STREAM AROUND A CIRCULAR CYLINDFR. THC FIELD USED TO DESCRIBE THE FLUID FLOW IS IN $\triangle G R E E M E N T$ WITH THE LAW OF DAPCY FOR DPESSURF DROD THROUGH AN ARRAY OF CYLINDERS. THE USUAL METHOD OF CALCULATION, BASED ON THE LOCATION OFF GRAZING TRAJECTORY OF A SPHERICAL PARTICLE, IS USED EXCEPT THAT THE EQUATIONS OF MOTION ARE NANTPULATEO TO FACILITATE AN ANALYTIC APPROXIMATION VALID FOR SMALL VALUES OF THE IMPACTION ANO INTERCEPTION PARAMETERS. COMPAPISON OF THE PREDICTED EFFICIENCY WITH VALUES FIVEN IN AN EXPERIMENTAL REPORT IS INCONCLUSIVF IN ASSESSING THE VALIDITY OF THF PREDICTION. PEPTINENT EXPERIMENTAL VARIABLES ARE - 111 A HOMOGENEOUS AEROSOL SHOULD BE USED. IT SHOULD BE CHARACTERIZED NOT ONLY EY MEAN OIAMETER RUT ALSN RY STANDARD DEVIATION. (2) THE FILTER SHOULD BE UNIFORM AND WITH KNOWN POPOSITY AND DARCY COEFFICIENT. THE FLOW THROUGH THE FILTER SHOULD BE UNIFORM.

* AEROSOL PPOPERTIES + *ANALYTICAL MODEL + \#PARTICLE SIZE + \#PARTICLE SIZE DISTRISUTION + \#THEORETICAL INVESTISATION + AEROSOL + AIP. CLEANING + FILTER + FILTER THEORY, DIFFUSION + FILTER THEORY, IMPACTION + FILTER THEORY, INTERCEPTION

7-11708 BILLINES CE

EFFECTS OF PARTICLE ACCUMULATICN ON AEROSOL FILTER LIFE

CALIFORNIA INSTITUTE OF TECHNOLOGY, PASACENA

CONF-GCO304 +. 21 PAGES, 5 FIGURFS, ? TABLES, 23 REFERENCES, PRESENTED AT 9TH AEC AIR CLEANING

CONFERENCE, BOSTON, MASS.; SEPTEMBER 13-16, 1966, SOURCE

THE ACCUMULATION OF DEPOSITED MATERIAL DURING FIRER FILTRATION OF SOLID AEROSOL DARTICLES CAUSES A DECREASE IN FILTER PENETRATION AND INCREASE IN FILTER RESISTANCE. THE OPERATIMG CHARACTERISTICS OF A FIBROUS FILTER ARE SHOWN TO BE FUNCTIONS OF THIS ACCUMULATION. TEST DATA ARE PRESENTED FOR THE EFFECTS ON PERFORMANCE OF 1.3-MICPON DOLYSTYRENE DARTICLES COLLECTED IN 1S-MICPON CLASS-FIBER. FILTER MATS. IN GENERAL, FILTER FFFICIENCY IS ADEQUATE FOR THE DESIGNATED TASK AT THE START OF FILTRATION, AND AN INCREASE IN FILTER EFFICIENCY AS A RESULT OF ACCUMULATION IS OF NO CONSEQUENCE. FOR HIGH-EFFICIENCY FILTERS, A TWO-FDLD INCREASE IN THE SIZE OF THE INITIAL INSTALLATION OF A FILTER SYSTEM SHOULD PRODUCE APPROXIMATELY A FOUR-FOLD INCREASE IN FILTEP LIFE. THE RELATIVE COST OF INCREASING THE SIZE OF A FILTER SYSTEM AS OPPOSEO TO MORE FREQUENT FILTER CHANGES DEPENDS UPDN CAPITAL CHARGES AND OTHER CONSIDERATIONS UNIQUE TO A GIVFN SYSTEM, IT SHOULO BE POSSIRLE TO OPTIMIZE SYSTEM CESIGN VELOCITY WITH THE INFORMATION RESULTING FROM THIS STUDY. THF EFFECT OF VELOCIIY UN FILTER EFFILIENCY HAS BEEN WELL ESTARLISHED.

*FILTER LIFE + *FILTER, EFFICIENCY OF + $\triangle E R O S O L$ + $\triangle I R$ CLEANING + FILTER MAINTENANCE + FILTER, FIBER + FILTER, HIGH EFFICIENCY + OPERATING EXPERIENCE

7-11709 SILVERMAN MD + TRUITT J + RROWNING WE + FRANZEN LF + ADAMS RE CHARACTER IZATION OF RADIOACTIVE PARTICULATE AFROSOIS BY THE FIBROLS FILTER ANALYZER OAK RIDCE NATIONAL LARORATORY UAK RIOFE

CONF-660904 +. 21 PAGES, 7 FIGURES, 3 TABLES, 19 REFEPENCES, PRESENTED AT OTH AEC AIR CLEANING CONFERENCE, BOSTON, MASS., SEPTEMBER 13-16, 1966, SOURCE

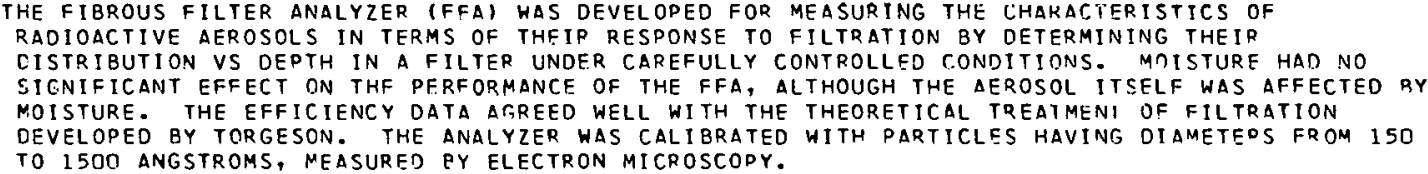

* ANALYTICAL TECHNIQUE, AIR + \#anALYTICAL TECHNIQUE, CALIBRATION + \#FILTER THEORY, DIFFUSION +

\#FII. TER IHEUKY, IMPACTION + *FILTCR THFORY, INTEPCEPTION + *FTITFR, FIBER + \#PARTICLE SIZE DISTPIBUTION + AEROSOL + AIR CLEANING + TILTER + FILTER EFFICIENCY + FILTER, HIGH EFFICICNCY

7-1171C HARSTAD JB + DECKER HM + BUCHANAN LM + FILLER MF

PENETRATION OF SUBMICPON TI BACTERIOPHAGE AEROSOLS ANO BACTERIAL AEROSOLS THROUSH COMMERCIAL AIR FILTERS U. S. ARMY BIOLOGICAL CENTER, FT. DETRICK, MD.

CONF-660904 +. 12 PAGES, 5 FIGURES, I TAELE, 10 REFERENCES, PRESENTED AT OTH AEC AIR CLEANING CONFERENCE, BOSTON, MASS., SEPTEMRER $13-16,1966$, SOURCE

A NEW METHOO IS DESCYIGEC FOR EVALUATING FILTERS FOR THE P.EMOVAL OF SURMICRON PARTICLES FROM AIR. THE METHOD IS UNIOUE IN THAT THE AEROSOLS USED TO TEST THE FILTERS WERE VIABLE, OF A HIGH CONCENTRATION, AND COMPOSEO ENTIRELY OF SUBMICRON PARTICLES. THEY WERE PRODUCED WITH A DAUTREBANDE AEROSOL GENERATOR FROM CONCENTRATED AQUEOUS SUSPENSIONS OF A HIGHLY PURIFIED TI BACTERIOPHAGE. TESTS WERE CONDUCTED TO COMPAPE THF EFFECTIVFNESS OF SEVEPAL UL IRAHIGH-EFFICIENCY AIR FILTERS IN REMOVING TI PHAGE AEROSOLS AND QACTERIAL AEROSDLS OF BACILLUS SUBTILIS (VARIETY NIGER) SPORES. THE TI PHAGE AEROSOLS HAD A NIJMBER MEDIAN DIAMETER (NMD) UF U.1 MICRON. TIIE BACTERIAL AEROSOLS WERE COMPOSFD MAINLY OF SINGLE SPORES AND HAD AN NMD OF I MICRON. THE FILTERS EXHIBITED A HIGH REMOVAL OF SUBMICRON DARTICI.FS BUT, AS EXPECTED, WERE MORE EFFECTIVE AGAINST THE LARGER PARTICLES OF BACTERIA. SUBMICRON AFROSOL PENETRATION AVERAGED 0.003 PERCENT. THE COMPARABLE VALUE FOR BACTERIAL AEROSOLS WAS O.OOO 4. ARCHITECTS, ENGINEERS, AND RESEARCH INVESTIGATORS CONCERNED WITH THE CONTROL OF SUBMICRON PARTIGLES MICHT TINSIRFR FIITRATION RATHER THAN OTHER WAYS OF AIP CLEANING. 
CATEGORY T

FISSION PRODUCT RELEASE, TRANSPORT, AND REMOVAL

7-11710 \#CONTINUEO*

\#AEROSOL, BIOLOGICAL + \#ANALYTICAL TECHNIQUE, AIR + \#PARTICLE SIZE + AEPOSOL + AEROSOL PROPERTIES + AIR CLEANING + ANALYTICAL TECHNIQUE, CALIBRATION + FILTER, EFFICIENCY OF + TEST, FILTER + TRACER, GENERAL

7-11711 ADAMS RE + GILL JS + YUILLE WD + BROWNING WE + PARSLY LF + GUTHRIE CF PERFORMANCE OF FILTER SYSTEMS UNDER ACCIDENT CONDITIONS

OAK RIDGE NATIONAL LABORATORY

CONF-660904 +. 24 PAGES, 14 FIGURES, PRESENTED AT 9TH AEC AIR CLEANING CONFERENCE, ROSTON, MASS., SEPTEMBER 13-16, 1966, SOURCE

THE EFFECT OF ACCIDENT ENVIRONMENTS ON THE PERFORMANCE OF FILTER SYSTEMS IS BEING STUDIED ON BOTH A LABORATORY AND A PILOT-PLANT SCALE. IN THE LABORATORY THE WORK HAS INCLUDED THE DEVELOPMENT OF A SIMPLE METHOD FOR GENERATING A SIMULANT $\triangle E R O S O L$, TESTS OF THESE AEROSOLS TO DETERMINE THEIR VALIDITY AS SIMULANTS, AND MEASUREMENTS, UNDER VARIOUS ATMOSPHERES, OF THE EFFICIENCY OF HIGH-EFFICIENCY FILTER MEDIA FOR REMOVING THFSE AEROSOLS. MOISTURE HAS BEEN NOTEO TO HAVE A SIGNIFICANT EFFECT ON THE BEHAVIOR OF THE AEROSOLS. A LIMITED NUMBER OF LARGE-SCALE FILTER TESTS HAVE BEEN CONOUCTED AT THE NUCLEAR SAFETY PILOT PLANT.

* ACCIDENT, RADIOISOTOPE + *AEROSOL PROPERTIES + \#CONTAINMENT FILTERING SYSTEM + \#FILTER EFFICIENCY + * FISSION PRODUCT, IODINE + \#ORGANIC IODIDE + ACCIDENT ANALYSIS + AEROSOL + $\triangle I R$ CLEANING + FILTER + FILTER, HIGH EFFICIENCY + SAMPLING

7-11712 KESSIE RW

REMOVAL OF PLUTONIUM HEXAFLUORIDE FROM CELL EXHAUST AIR BY HYOROLYSIS AND FILTPATION ARGONNE NATIONAL LABORATORY

CCNF-660904 +. 20 PAGES, 8 FIGURES, 2 TABLES, 7 REFERENCES, PRESENTFD AT OTH AEC AIR CLEANING CONFERENCE, BOSTON, MASS, SEPTEMBER 13-16, 1966 , SOURCE

THE FLUORIDE VOLATILITY PROCESS FOR RECOVERING FISSIONABLE PLUTONIUM FROM SPENT REACTOR FUEL AS THE VOLATILE PLUTONIUM HEXAFLUORIDE (PUFG) REQUIRES A DEMONSTRATED ABILITY TO C.ONTAIN THE HIGHLY TOXIC PLUTONIUM. THE EXPFRIMENTAL STUDIFS INDICATE. THAT AT LOW CONCENTRATIONS OF PUFG AND MOISTURE, THE HYDROLYSIS REACTION RATE IS DIRECTLY PROPORTIONAL TO BOTH THE PARTIAL PRESSURE. OF THE PUFG AND MOISTURE AND TO THE AR.EA OF THE SOLID SURFACES AVAILABLE FOR REACTION. ADSORBED PUFG AND HF REDUCE THE REACTION RATE AT PARTIAL PRESSURES GREATER THAN O.OO $M M$ HG AT HIGH CCNCENTRATIONS OF PUFG AND MOISTURE, THE REACTION PROCEEDS RAPIDLY IN THE GAS PHASE TO PRODUCE A FINELY DISPERSEO PRDDUCT PUOZF2. MOST OF THE PAPTICLES ARE THE GAS PHASE TO PRODUCE A FINELY DISPERSEO PRDDUCT PUO2F2. MOST OF THE PAPTICLES ARE
SMALLER THAN O.I MICRON. WITH AIR CONTAINING EXCESS MOISTURE, THE FRACTION OF RELEASED PLUTONIUM PENETRATING TWO HIGH-EFFICIENCY FILTERS IN SERIES AMOUNTS TO BETWEEN IO (MINUS 9THI) AND 10 (MINUS GTHI AT A'FILTER-MEDIA VELOCITY OF 1.0 CM/SEC. FILTER EFFICIENCY IS INCREASED BY THE AGGLOMERATION OF PARTICLES BEFORE FILTRATION AND BY LOADING EFFECTS OF THE COLLECTED PARTICLES ON THE FILTERS. WHEN AN EXCESS OF MOISTURE IS AVAILABLE, AGGLOMEPATION EFFECTS TEND TO LIMIT THE MAXIMUM DISCHARGE RATE. OF PLUTONIUM, AND LOADING FFFECTS TEND TO LIMIT THE MAXIMUM AMOUNT OF PLUTONIUM THAT CAN BE DISCHARGED FROM A SINGLE FILTER.

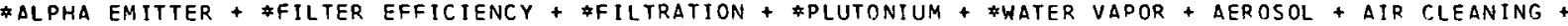
FILTER + PARTICLE SIZE + PLUTONIUM OXIDE

7-11713 KNUTH RH

AN EVALUATION OF TWO PORTABLE THERMAL AEROSOL GENERATORS FOR IN-PLACE FILTER TESTING NEW YORK OPERATIONS OFFICE, USAEC, HEALTH AND SAFETY LABORATORY

CONF-660904 +.. 18 PAGES, 8 FIGURES, 3 TABLES, 5 REFERENCES, PRESENTED AT 9TH AEC AIR. CLEANING CONFERENCE, BOSTON, MASS., SEPTEMRER 13-16, 1966, SOLIRT.

TWO COMMERCIAL, PORTABLE, THERMAL AEROSOL genERATORS WERE EVALUATED TO DETERMINE THEIR PRACTICABILITY FOR IN-PLACE TESTING OF HIGH-EFFICIENCY FILTERS. PENETRATION VALUES OF VARIOUS FILTERS WERE DETERMINED WITH THE TWO THERMAL GENERATORS, AND RESULTS WERE COMPARED WITH VALUES OBTAINED BY USING STANDARD AIR-OPERATED. AEROSOL GENERATORS OF THE TYPF DFVELOPED BY THE NAVAL RESEARCH LABORATORY. VEPY CLOSE AGREEMENT WAS FOUND. ALSO, THE AEROSOL PRODUCED BY THE THERMAL GENERATORS WAS QUITE STABLE, AND THE PARTICLE-SIZE DISTRIBUTION WAS VERY CLOSE TO THAT OF THE AIR-OPERATEO GENERATORS. THE THERMAL GENERATORS HAVE THE IMPORTANT AOVANTAGE THAT COMPRESSED AIR IS NOT REQUIRED, AND A SMALL, COMPACT UNIT CAN SERVICE A LARGE FILTER INSTALLATION, FOR EXAMPLE 20,000 CFM. ALTHOUGH THE THERMAL GENEPATORS HAVF MINOR DESIGN LIMITATIONS, THEIR USE FOR IN-PLACE TESTING, PARTICULARLY OF HIGH VOLUME SYSTEMS, IS RECOMMENDED. THE TWO THERMAL TYPE GENERATORS STUDIEO IN THIS EVALUATION USE 2-1/2-LR CYLINDERS OF CO2, RATHER THAN COMPRESSED AIR, AND OPERATE ON $110-$ OR $220-V$ ELFCTRICAL SUPPLY.

\#AEROSOL PRODUCTION + \#AEROSOL PROPERTIES + \#FILTER + \#FILTER INSPECTION + \#TEST, FILTER + AEROSOL + AEROSOL + AEROSOL + AEROSOL + AIR CLEANING + FILTER + FILTER SAFETY EVALUATION + FILTER SAFETY EVALUATION + THERMAL EXPERIMENT + THERMAL EXPERIMENT

7-11715 BLUMKIN S + BRIGGS H + DOUNOUCOS A + VON HALLE E + HOLMES JM + RAINFY RH PRELIMINARY RESULTS OF DIFFUSION MEMBRANE STUDIES FOR THE SEPARATION OF NOBLE GASES FROM REACTOP: ACCIDENT ATMOSPHERES

OAK RIDGE GASEOUS DIFFUSION PLANT + GENERAL ELECTRIC COMPANY, SCHENECTADY + OAK RIDGE NATIONAL LABORATORY CONF-660904 +. 23 PAGES, 10 FIGURES, 3 TABLES, 10 REFERENCES, PRESENTED AT OTH AEC AIR CLEANING

CONFERENCE, BOSTON, MASS., SEPTEMBER 13-16, 1966, SOURCE

RECENTLY, THE GE RESEARCH AND DEVELOPMENT CENTER DEVELOPED A THIN SILICONE-RUBBER MEMRRANE THAT HAS ATTRACTIVE SELECTIVE-PERMEABILITY PROPERTIES FOR THE RARE GASES AND CAN RE OPERATED AT AMBIENT TEMPERATURE. INITIAL RESULTS OF A STUDY TO DEVELOP A SEPARATION PROCESS USING THIS MEMBRANE ARE REPORTED. A DIFFUSION CASCADE WAS DESIGNED TO REDUCE THE KRYPTON LEVEL IN A CONTAINMENT VESSEL 13 MILLION CU. FT. I BY A FACTOR OF IOC IN ONE WEEK. IT IS PROPOSED THAT

$$
\text { ACCESSION NUMBER } 7-1.1710 \text { TO } 7-11715
$$


CATEGORY 7

FISSION DRODUCT RELEASE, TRANSDORT, ANO REMOVAL

7-11715 \#CONTINUED*

SUCH A SYSTEM BE MADE PORTABLE SO THAT IT COULD SERVE AS AN EMERGENCY STANDBY FOR SEVERAL

REACTORS AND THUS SAVE PART OF THE COST OF A DERMANENT INSTALLATION AT EACH REACTOR SITF.

\#KRYPTON + \#NOBLE GAS + \#POROUS DIFFUSION + \#SEPARATOR + \#XFNON + AIR CLEANING + DIFFUSION + RADIOISOTOOE

7-11716 UNOERHILL D

MASS TRANSFER OF KRYPTON-85 IN CHARCOAL ACSORPTION BEOS

HARVARD UNIVERSITY

CONF-660904 +. I9 PAGES, 9 FIGURES, 1 TABLE, 5 REFERENCES, PRESENTEO AT 9TH AEC AIR CLEANING CONFERENCE, BOSTON, MASS., SEPTEMBER 13-16, 1966, SOURCE

A FUNOAMENTAL FACTOR IN THE DESIGN OF CHAPT,OAL ADSORPTION BEDS FOR FISSION GASES IS THE NUMEER OF MASS-TRANSFER UNTTS (THEORETICAL PLATES) OF THE BFD - THE GREATER THE NUMBER OF TRANSFER UNITS THE MORE EFFICIENT THF BLD, WITH THE USE OF KQ-RS IN AN AIR CARPIER, THE NUMBFR NF TRANSFER UNITS IN CHARCOAL REDS COOLED WITH ORY ICE WAS DETERMINED UVER A WIDE RANGE OF FLOW VELOCITIES AND CHARCOAL PARTICLE DIAMETERS FOR BOTH ADSORPTION AND DESORPTION. FPOM $\triangle N$ ANALYSIS OF MASS TRANSFER AS A FUNCTION OF PEDUCED VELOCITY, THE. MECHANISMS OF MASS TRANSFER WERE IDENTIFIED AND THE APPLICABILITY OF THE VAN DFEMTER EOUATION CONFIRMED.

\# DOSORPTION + \#CHARCOAL + \#KRYPTON + \#NOPLE GAS + AIR CLEANING + DIFFUSION + DOROUS DIFFUSION + WUKUUS MEOIA + RADIOISOTOFI

7-11717 KOONTZ RL + NELSONCT + BAURNASH L

STANDARCIZED GENERATION OF VAPOR-PRODUCEO SODIUM AEROSOLS AND THEIR BEHAVIOR

ATOMICS INTERNATIONAL, CANOGA PARK

CONF-660904 t. 13 PAGES, 5 FIGURES, 2 TABLES, PRESENTED AT OTH AEC AIR CLEANING CONFERENCE, BOSTON,

MASS., SEPTEMBER 13-16, 1966 , SOURCE

A METHOD FOR GENERATING REPRODUCIRLE SODIUM AEROSOLS IN GAS MEDIA OF KNOWN COMPOSITION IS REQUIRED TO ESTABLISH GROWTH PHENOMENON AND MEASUREMENT TECHNIQUES FOR DARTICLES DRDOUCED FROM A SODIUM FIRE FOLLOWING A PRIMARY-COOLANT SOILL IN A SODIUM-COOLEO REACTIR. SODIUM AEROSOLS WERE PRODUCED BY CONIACIING SODIUM VAPOR IN TIIC PRESENCE DF NITROSEN WTTH VARIOUS MIXTURES OF NITROGEN AND AIR. BY SUITABLE VARIATION OF THE CONDITIONS OF GENERATION, THE. CONCENTRATION AND DISTRIBUTION DATA ARE PRESENTED AS MEASURED BY DIFFERENT SIZING TECHNIQUES, AND ARE COMPARED WITH THOSE PRODUCED BY THE REACTION GETWEEN LIQUID SODIUM AND AIR.

\#AEROSOL PRODUCTION + \#AEROSCL PROPERTIES + \#FIPE + \#PARTICLE SIZF + \#SODIUM + AEROSOL + AIR CLEANING + FISSION PROOUCT TRANSPORT + METAL, LIQUID

7-11718 NELSON CT + BAURMASH L + KOONTZ RL

TECHNIQUES FOR SAMPLING SODIUM SMOKE AND FISSION PRODUCTS

ATOMICS INTERNATIONAL, CANOGA PARK

CONF-660904 +. 17 PAGES, G FIGURES, 1 TABLE, 7 REFERENCES, DRESENTED AT 9TH AEC AIR CLFANING CONFERFNCF, BOSTON, MASS., SEPTEMBER $13-16,1966$, SOURCE

VARIOUS SAMPLING TECHNIQUES ARE UESCRIBEO WHICH ALLOW ONE TO CHAPACTEP.IZE THE DFPOSOI.S PRODUCED FROM SODIUM FIRES IN A CONTROLLED-ENVIRONMENT TEST CHAMBFR. BY USING OLATING AND FALLOUT-DEPOSITION SAMPLERS COMBINED WITH CASCADE IMPACTORS, ELECTROSTATIC PRECIPITATORS, AND MILLIPORE AIR SAMPLERS, STUDIES WERE MADE OF THE SPATIAL AND TEMPORAL BEHAVIOR DUPIN!G THE PRODUCIION, UISPERSION GROWTH, AND REMOVAL OF THE SIISPFNMFN PARTICULATES. THF ROLE OF EACH SAMPLING TECHNIQUE IN VERIFYING ANALYTICAL MODELS IS DISCUSSED.

* $A E R O S O L$ PROPERTIES + \#FILTER IMPACTION + \#FILTER, CASCADE IMPACTOR + \#FILTER, ELECTROSTATIC + \#FILTER, MEMBRANE + \$SAMPLING + \#SODIUM + AEROSOL + AIR CLEANING + DFPOSITION + FISSION PKOUUCT TRANSPORT + SMOKE

7-11719 HIMOT P + VILES FJ + SULLIVAN J + FIRST MW

SODTUM AEROSOL, ITS GENERATION, PROPERTIES AND FILIKAIION

HARVARD UNIVERSITY

CONF-66C904 +. 16 PAGES, 10 FIGURES, 9 TABLES, 5 REFERENCES, PRESENTED AT 9TH AFC $\triangle I R$ CLEANTNG CONFERENCE, BOSTON, MASS., SEPTEMBER 13-16, 1966 , SOURCE

ACCIDENTAL LOSS OF COOLANT FROM A SODIUM-COOLED REACTOR CAN RESULT IN RAPID VAPOPIZATION AND BURNING OF THE METAL TO PRODUCE AN AIRBORNE FUME. RESTRICTIONS ON THE QUANTITY DISCHARGED TO IHE ATMOSPHERE REQUIRE 37 PLRCENT REMOVAL TO PRFVFNT A HEALTH HAZARD IN THE SURROUNDING AREA. VARIOUS CONFIGURATIONS OF GRADED, DEEP-BED FILTEPS RANGING IN FIRER SIZES FPOM $10 D$ TO $\because . U$ MICRONS WERE TESTED AT FACE VELOCITIES RANGING FROM 5 TO 40 AND OPERATED TO A TDTAL RESISTANCE OF $20 \mathrm{IN}$. (WATER GAGE) TO DETERMINE MAXIMUM FILTER LOADING CADACITY. TOTAL FILTER STORAGE OF ABOUT 0.75 LH OF SODIUM PFR SQUARE TOOT OF FILTER AREA CAN RE ORTAINED RY DROPEP FILTER DESIGN AND OPERATION. IN EXCESS OF 99 PERCENT EY WEIGHT OF SOOIUM FUME, WITH SIZE AVERAGING 1.5 MICRONS MMD, WAS RETAINED IN THE REEP BED FILTER PACK. $\triangle N$ ABSOLUTE-TYPE FILTEQ WAS USED AS THE FINAL STAGE. NO IODINF, AS ELEMFNTAL IODINE OR SODIUM IOOIDE, PENETRATFD THE FILTER PACK WHEN THE SODIUM MELT CONTAINED 3.5 PPM OF IODINE AS SODIUM IODIDE, ALTHDUGH IT WAS DETECTED AT THE FILTER ENTRANCE.

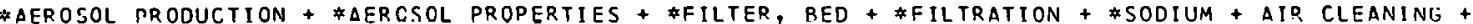
FILTER IMPACTION + FILTER, HIGH EFFICIENCY + FISSION PRONUCT TRANSPORI + FISSION PRODUCT, IODINE + PARTICLE SIZE + SAMPLINE 
CATEGORY T

FISSION PRODUCT RELEASE, TRANSPORT, AND REMOVAL

7-1172C ETTINGER HJ + MOSS WD + BUSEY H

CHARACTERISTICS OF THE AEROSOL PRODUCED FROM BURNING PLUTONIUM

LOS ALAMOS SCIENTIFIC LABORATORY, LOS ALAMOS + DOUGLAS ATRCRAFT COMPANY

CONF-660904 +. 22 PAGES, 12 FIGURES, 3 TABLES, 10 REFERENCES, PRESENTED AT 9TH AEC $\triangle 1 R$ CLEANING CONFERENCE, BOSTON, MASS., SEPTEMBER 13-16,1966, SOURCE

SAFETY ANALYSIS OF SOOIUM-COOLED, PLUTONIUM-FUELED, FAST-REACTOR PLANTS MUST BE CONCERNED WITH THE POSSIBILITY OF FIRES INVOLVING THESE MATERIALS. THUS, DESIGN OF AN AIR-CLEANING SYSTEM REQUIRES BASIC DATA DEFINING THE AEROSOL CHARACTERISTICS OF SODIUM AND PLUTONIUM RELEASED DURING A FIRE. SIZE CHARACTERISTICS OF THE AEROSOL PRODUCFD DURING PLUTONIUM FIRES WERE DETERMINED FOR DIFFERENT ATMOSPHERES RANGING FROM 20.8 DERCENT OXYGEN, 79.2 PERCENT NITROGEN TO 0.5 PERCENT OXYGEN, 99.5 PERCENT NITROGEN. PLUTONIUM-COBALT-CERIUM ALLOY, AND ALPHA- AND DELTA-PHASE PLUTONIUM WERE BURNED. DATA WERE OBTAINFD TO ESTIMATE THE FRACTION OF PLUTONIUM ALLOY AIRBORNE DURING A PLUTONIUM FIRE. FIRES SIMULATING A REACTOR ACCIDENT INVOLVING BOTH FUEL ANO COOLANT DEFINED THE RELATIVE AIRBORNE CONCENTRATION OF PLUTONIUM AND SODIUM.

\#FIRE + \#PARTICLE SIZE + \#PARTICLE SIZE OISTRIBUTION + \#PLUTONIUM + \#PLUTONIUM OXIDE + AEROSOL PRODUCTION + AEROSOL PROPERTIES + AIR CLEANING + AIRBORNE PELEASE + ALPHA EMITTER + SODIUM

7-11721 CHEEVER CL + MCFEE DR + SEDLET J + DUFFY TL ZPR ROOF SAND FILTRATION OF URANIUM, PLUTONIUM AND URANINE AEROSOLS ARGONNE NATIONAL LABORATORY

CONF-66C904 t. 18 PAGES, 13 FIGURES, 4 TAELES, 3 REFERENCES, PRESENTED AT 9TH AEC AIR CLEANINF CONFERENCE, BOSTON, MASS., SEPTEMBER 13-16, 1966 , SOURCE

THE FILTRATION SYSTEM (REACTOR ACCIDENTS) FOR ARGONNE NATIONAL LABORATORYS PROPOSED ZERO POWER PLUTONIUM REACTOR CONSISTS OF A SAND-AND-GRAVEL ROOF FOLLOWEO BY HEPA FILTERS. FILTRATION EFFICIENCY TESTS WERE RUN WITH URANIUM, PLUTONIUM, AND URANINE AEROSOLS TO PREOICT THE EFFECTIVENESS OF THIS SYSTEM FOR CONTAINMENT OF PLUTONIUM FUMES. PENETRATION OF URANIUM AND PLUTONIUM FUMES THROUGH 30 IN. OF SAND RANGED FROM 0.0004 TO 0.02 PERCENT. WITH THE BACKUP HEPA FILTERS, THE OVERALL PENETRATION OF PLUTONIUM FUME FROM A REACTOR ACCIDENT SHOULD NOT EXCEED 0.0ODI PERCENT. RESULTS INDICATE THAT UPANINE AEROSOL WILL BE SATISFACTORY FOR IN-PLACE TESTING OF THE SAND AND GRAVEL ROOF.

\#FILTER EFFICIENCY + \#FILTER, BED + \#FILTER, SAND + \#PLUTONIUM + \#URANIUM + $\triangle E R O S O L$ PRODUCTION + AIR CLEANING + FILTER + FILTER, HIGH EFFICIENCY + FILTRATION + FISSION PRODUCT TRANSPORT + TEST, FILTER

7-117.22 MCCLINTOCK RO

THE DESIGN, TEST AND USE OF THE BROOKHAVEN NATIONAL LABORATORY (BNL) REACTOR BYPASS FILTER FACILITY BROOKHAVEN NATIONAL LABORATORY

CONF-660904 +8 PAGES, 3 FIGURES, 7 REFERENCES, PRESENTED AT 9TH AEC AIR CLEANING CONFERENCE, BOSTON, MASS, SEPTEMBER 13-16, 1966 , SOURCE

THE PURPOSE OF THE BNL REACTOR BYPASS FILTER FACILITY IS TO PROVIDE IMPROVED AIR CLEANING IN THE EVENT OF A FUEL ELEMENT FAILURE AT EITHER THE BRIOKHAVEN GRAPHITE RESEARCH REACTOR (BGRR) OR THE HIGH FLUX BEAM REACTOR (HFBR). IT ALSO PROVIDES SUFFICIENT AIR CLEANING TO ALLOW THE USE OF AIR COOLING AS A METHOD OF COMBATING A GRAPHITE FIRE AT THE BGRR. FDR NORMAL BGRR COOLING, ABOUT 365,000 CFM IS REQUIRED. ALTHOUGH THE FILTERS PROVIDED ARE SUFFICIENT FOR NORMAL OPERATION, ADDITIONAL CLEANING IS REQUIRED FOR FUEL RUPTURE AND GRAPHITE FIRE SITUATIONS. THIS SYSTEM WAS THEREFORE DESIGNED TO ACCOMMODATE 1 DO, OOO CFM WITH HIGH FILTERING EFFICIENCY UNDER EMERGENCY CONDITIONS. EACH FILTER UNIT WAS TESTED FOP. BOTH PARTICLE-RETENTION EFFICIENCY AND IODINE RETENTION. THE PARTICLE-EFFICIENCY TEST USED DOP SMOKE, AND THE IODINE TEST WAS MADE WITH I-12B VAPOR. IN-PLACE TESTS WERE MADE WITH DOP AND THE RADIOACTIVE EFFLUENT FROM THE BGRR DURING A GRAPHITE-ANNEALING RUN. ALL TESTS SHOWED THE FACILITY TO BE OVER 99.98 PERCENT EFFICIENT FOR PARTICLE REMOVAL WHILE AT THE SAME TIME REMOVING 99.9 PERCENT OF THE DETECTABLE IODINE VAPORS.

* BNL (BROOKHAVEN NATIONAL LABORATORY) + *CHARCOAL + \#FILTER OESIGN + *IODINE + *TEST, DOP FILTER + AIR CLEANING + FILTER + FILTER EFFICIENCY + FILTER SYSTEM + FILTER, HIGH EFFICIENCY + FISSION PROOUCT, IOOINE + TEST, FILTER

7-11723 SCHINDLER RE

CONTINUOUS SAMPLER - MONITOR FOR FISSION PRODUCTS IN CONTAMINATED ATMOSPHERES IDAHO NUCLEAR CORPORATION, IDAHO FALLS

CONF-660904 + 3 PAGES, 1 FIGURE, PRESENTED AT OTH AEC AIR CLEANING CONFERENCE, BOSTON, MASS., SEPTEMBER

$13-16,1966$, SOURCE

A CONTINUOUS SAMPLER-MONITOR IS BEING DEVELOPED FOR USE IN SAMPLING FISSION-PRODUCT CONCENTRATIONS IN THE CONTAINMENT-BUILOING ATMOSPHERE DURING THE LOSS-OF-FLUID TEST. A SPRAY SCRUBBER, PLACED IN THE CONTAINMENT ATMOSPHERE, WASHES NEARLY ALL THE IODINE AND OTHER CONDENSIBLE FISSION PRODUCTS FROM A CONTINUOUSLY DRAWN ATMOSPHERE SAMPLE, LEAVING ESSENTIALLY ONLY RARETGAS FISSION PROOUCTS IN THE GAS STREAM. THE GAS AND LIQUID STREAMS THEN FLOW OUTSIDE THE CONTAINMENT BUILDING FOR SEPARATE MONITORING OF THEIR GROSS GAMMA ACTIVITY.

\#FISSION PRODUCT, IOOINE + \#MONITOR, RAOIATION, AIR + \#MONITOR, RAOIATION, STACK + \#SAMPLING + \#SCRUBBER + AIR CLEANING + FISSION GAS RELEASE + FISSION ORODUCT TRANSPORT + FISSION PRODUCT, AIRRORNE + MCNITOR, RADIATION, EMERGENCY + MONITOR, RAOIATION, SAMPLING + NOBLE GAS

7-11724 HUNTER HH + MITCHELL RI

PORTAELE SMOKE PHOTOMFTER

PATTELLE MEMORIAL INSTITUTE, COLUMBUS

CONF-660904 †. 14 PAGES, 4 FIgURES, PRESENTED AT 9TH AEC AIR CLEANING CONFERENCE, ROSTON, MASS., 
CATERORY $?$

FISSION PRODUCT RFLFASF, TRANSPDRT, AND REMOVAL

7-11724 *CONTINUED*

SEPTEMEER $13-16,1966$, SOURCE

IN THE EVALUATION OF $\triangle$ BSOLUTE FILTERS IT IS NECESSARY TO TEST THEM WITH AN AFROSOL AND MEASUPE THE CONCENTRATION OF THE $\triangle E R O S O L$ REFORE AND AFTER IT PASSFS THROUSH THE CILTEP. THE PRESENT PR.OCEDURE IS TO MEASURE THFSE AEROSOL CONCENTRATIONS WITH A SMOKF PHOTOMETFR WHICH DETERMINES CONCENTRATION BY MEASURING THE AMOUNT OF LIGHT SCATTEREO BY THE AEPOSCL PARTICLES. THE AMOUNT OF LIGHT SCATTERED IS PROPCRTICNAL TO THE NUMAER OF PADTICLES OF A GIVEN SIZT IN THE VIEW VOLUME OF THE INSTRUMENT. THE PURPOSE OF OUR RESEARCH PROGPAM IS TO MINIATUPITE THE SMOKE PHOTOMETER AND TO INCREASE ITS RELIABILITY BY THE USE OF SEMICONDUCTORS IN PLACE OF VACUUM TUBES. TO DATE, THE ELECTRONICS PORTION OF THE INSTRUMENT HAS BFFN COMPLETED AND WILL EE DESCRIBED IN THIS PAPER. THE OPTICS PORTION OF THE INSTRUMFNT IS STILL UNDER DEVELOOMENT.

*FILTER, HIGH EFFICIENCY + \#INSTRUMENTATION, AIR SAMPLING + \#INSTRUMENTATION, RACIATION MONITORING + * SMOKE + AEROSOL + AIR CLEANING + PARTICLE SIZE + TEST, FILTER

7-11725 PANCHUK F + RACHUK W

THE FILTER TESTING PROGRAM OF ATOMIC ENERGY OF CANADA LIMITED

ATOMIC ENERGY OF CANADA LIMITED, CHALK RIVER

CONF-660904 t. 41 PAGES, 27 FIGURES, 3 TARLES, 3 REFERENCES, PRESENTED AT OTH AEC AIR CLEANING

CONFERENCE, BOSTON, MASS., SEPTEMBER 13-16, 1966 , SOURCE

AT THE CHALK RIVER NUCLEAR LARORATORIES, AIR EXHAUSTED FROM EQUIPMENT, SYSTEMS, AND AREAS WHICH MAY ACT AS SOURCES OF AIPBORNE RADIOACTIVE PARTICLES IS CLEANFD WITH HIGH-EFFICIENCY AIR FILTERS. A PROGRAM OF TESTING THE INTEGRITY OF FILTERS AND FILTPATION SYSTEMS WAS STARTED IN 1964. THE BASIC EQUIPMENT AND TECHNIQUF USED ARE THOSE DEVELOPED RY THE USAEC, THE U. S. NAVAL RESEARCH LAB, AND THF DAK RIDGE NATIONAL LAB. THE FILTER-TEST RIG ANA MOBILE EQUIPMENT MADE FOR LABORATORY AND FIELD USE AT CHALK RIVER NUCLEAR LARORATORIES ARE CESCRIBED, AS ARE TYPICAL FILTER INSTALLATIONS. THE TESTS APE ALSO DESCRIBED AND THE RESULTS ARE SUMMARIZED. FIELD TESTS SHOWED THAT THE PERFORMANCE OF THE SELF-CONTAINED FILTEPS HAS REEN EXCELLENT. HOWEVER, WITH OPEN-FACEO FILTEPS, UNLESS THE INSTALLATION IS CARFFULLY CESIGNED AND MAINTAINED, EXCESSIVE PENETRATION COULD OCCUR.

\#AEROSOL PRODUCTION + \#FILTER SYSTEM + \#FILTFR TFST PFQUIREMENT + \#TEST, FILTER SYSTFM + AEROSOL + AIR CLEANING + CANADA + CHALK RIVER + FILTER EFFICIENCY + FILTER, HIGH EFFICIENCY +

INSTRUMENTATION, AIR SAMPLING + TEST, DOP FILTER + TEST, FILTER

7-11726 BILLARDF+ BRION J

TESTING OF AIR CLEANING SYSTEMS - TESTING OF THE COMPONENTS - IN-PLACE TESTS

COMMISSARIAT A L ENERGIE ATOMIOUE, CENTRE D ETUDES NUCLFAIRES, FONTENAY-AUX-ROSES

CONF-660904 +. 10 PAGES, 16 REFERENCES, PRESFNTED AT 9TH AFC AIR CLEANING CONFERENCE, SOSTON, MASS.,

SEPTEMBER 13-16, 1966, SOURCE

ALTHOUGH IN-PLACE TESTS OF AIR-CLEANING SYSTEMS ARE THE MOST IMPORTANT BECAUSE THEY ACT AS FINAL TESTS UPON ACHIEVED PLANTS, COMPONENT TESTS ARE NECESSAPY TOO. SUCH TESTS ALLOW DETECTION OF DEFECTIVE UNITS BEFORE THEY ARE INSTALLED, PARTITION OF UNIT DEFECTS FROM MOUNTING DEFECTS, AND THEY ARE MORE SENSITIVE. FOR SIMILAR REASONS, MATERIAL TESTS ADE MOST USEFUL. VARIOUS TESTS ARE DESCRIRED FOR AEROSOL FILTERS AND IODINE TRAPS. THE TESTS INCLUDE THOSE FOR MATERIALS, EFFICIENC,, AIR RESISTANCE, FLAMMABILITY, HUMIDITY RESISTANCF, TEMPERATURE RESISTANCE, ETC.

$\triangle E R O S O L$ + AIR CLEANING + CHARCOAL + FILTER + FILTER EFFICIENCY + FILTER SYSTEM + FILTER, HIGH EFFICISNCY + FILTER, TRAP + FISSION PRODUCT, IOCINE + ORGANIC IODIOE + TEST, FILTER + TEST, FILTER SYSTEN

7-11727 FLYGER H + ROSENEAUM HC

ON-SITE TESTING OF FILTERS WITH SPECIAL REFERENCE TO SOLID AEROSOLS

DANISH ATOMIC ENERGY COMMISSION

CONF-660904 +. 13 PAGES, 9 FIGURES, REFERENCES, PRESENTED AT 9TH AEC AIR CLEANING CONFERENCE, BOSTON,

MASS., SEPTEMBER $13-16,1966$, SOUP.CE

A LITHIUM FLAME-PHOTOMETER TEST IS PROPOSFD FOR ON-SITE TESTING OF FILTER INSTALLATIONS. THE TEST IS INTERCAL IBRATED WITH THE STANDARD SODIUM FLAME TEST. THE SPRAYING TIME NFEDED TO INTRODUCE THE LITHIUM SALT INTO A VENTILATION SYSTEM IS CONSIDEPED INCONVENIENT FOR SYSTEMS HANDL ING MORF THAN 100,000 CU. MIHR. FOR SUCH SYSTEMS, PHOTOELFCTRIC PARTICLF COUNTERS CAN BE USED WITH THE DUST NATURALLY PRESENT IN THE LOCAL ATMOSPHERE. WHERE THE DUST LEVEL IS TOO LOW, AITKEN NUCLEI CAN EASILY BE ARTIFICIALLY GENERATED IN SUFFICIENT AMOUNTS. THE RELATION BETWEEN FILTER EVALUATION BY SUCH PARTICLE COUNTING AND BY LITHIUM MEASUREMENTS IS

ESTABL I SHED.

\#INSTRUMENTATION, AIR SAMOLING + \#LITHIUM + \#TEST, FILTER + \#TEST, FILTFR SYSTEM + AEROSOL + AIR CLEANING + DENMARK + TARTICLE SIZE DISTRIBUTION

7-11728 CUKEISEN CA + MNLABY KL

IN-PLACE TESTING OF CHARCOAL FILTER BANKS AT AMES LABORATORY RESEARCH REACTOR (ALRR)

AMES LABORATORY, AMES, IOWA

CONF-660904 +. 6 PAGES, 1 FIGURE, 2 REFERENCFS, PRESENTED $\triangle T$ TTH AEC $\triangle I R$ CLEANING CONFERENCE, BOSTON,

MAS5., SEPTEMBER 13-16, 1968, SOURCE

THE AIR EXHAUST SYSTEM AT THE ALRR IS DESCRIBED. AN EXPERIMENTAL PROGRAM WAS CONDUCTED TO DEVELOP AN APPEOPRIATE IN-PLACE IODINE TEST FOR THE CHARCOAL FTLTER BANKS. THREE TECHNIOUES WERE TESTEO - (1) SPECTROPHOTOMETRIC ANALYSIS, 12 ) NEUTRON ACTIVATION, AND (3) I-I31 TRACER. COMPARISONS OF THE RESULTS WITH EXPERIENCE ARE ENUMERATED, WITH COMMENTS ANO RECOMMENDATIONS. 
CATEGORY 7

FISSION PRODUCT RELEASE, TRANSPORT, AND REMOVAL

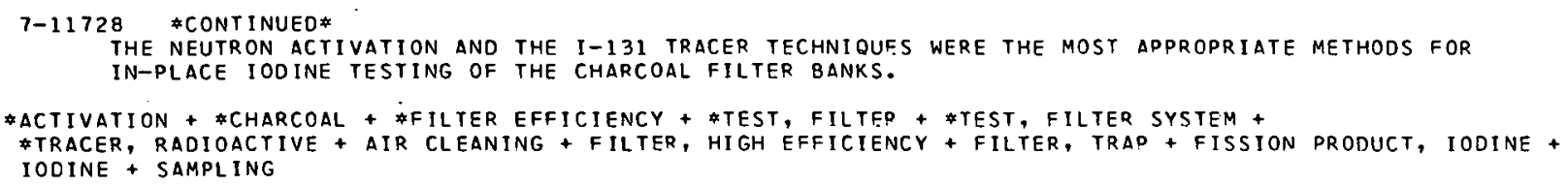

A NONDESTRUCTIVE IN-PLACE TEST FOR DETECTING LEAKS IN A BANK OF INSTALLEO CARBON BEDS WITH FREON-112 TRACER WAS DEVELOPEO BY THE SAVANNAH RIVER LABORATORY AND DEMONSTRATED IN THE REACTOR-CONFINEMENT FACILITIES OF THE SAVANNAH RIVER PLANT. LEAKAGE FLOW. IFLOW THAT RYPASSES THE (ARBON) OF D.01 PERCENT THROUGH THE REDS IS DETECTED REAOILY. CARBON BEDS WITH $\triangle B O U T 2$ YEARS OF EXPOSURE TO EXHAUST AIRFLOW IN THE CONFINFMENT SYSTEM WERE EVALUATED SUCCESSFULLY WITH THE TEST. AN EQUATION WAS ALSO DEVELOPED THAT CORRELATES THE CONDITIONS FOR F-1I2 TESTING OF CARBON BEDS OF DIFFERENT DESIGN.

\#CHARCOAL + \#FILTER SYSTEM + \#FILTER, BED + *LEAK DETECTION + \#TEST, FILTER SYSTEM + AIR CLEANING + FILTER, TRAP + FISSION PRODUCT, IODINE + IODINE + HATER VAPOR

7-1173C SWANKS JH

IN-PLACE IODINE FILTER TESTING

OAK RIDGE NATIONAL LABORATORY

CONF-660904 +. 13 PAGES, 5 FIGURES, 5 TABLES, 3 REFERENCES, PRESENTED AT 9TH AEC AIR CLEANING CONFERENCE, BOSTON, MASS., SEPTEMBER 13-16, 1966, SOURCE

A SERIES OF IN-PLACE ICOINE FILTER TESTS WAS PERFORMED ON THE CHARCOAL IODINE FILTERS AT THE HIGH FLUX ISOTOPE REACTOR. TWO SETS OF CHARCOAL FILTERS WERE TESTEO - THE FIRST FOR ELEMENTAL IOOINE RETENTION AND THE SECOND FOR METHYL IODIDE AND ELEMENTAL IODINE RETENTION. THIS PAPER PRESENTS THE RESULTS OF THOSE TESTS AND DISCUSSES THE CONCLUSIONS DRAWN FPOM THOSE RESULTS.

\#CHARCOAL + \#FILTER EFFICIENCY + \#FISSION PRODUCT, IODINE + \#TEST, FILTER + \#TEST, FILTER SYSTEM + AIR CLEANING + FILTER, BED + FILTER, TRAP + IODINE + TRACER, RADIOACTIVE

7-11731 VILES FJ + SILVERMAN L IN-PLACE IODINE REMDVAL EFFICIENCY TEST HARVARD UNIVERSITY

CONF-660904 +. 10 PAGES, 3 FIGURES, 2 TABLES, 8 REFERENCES, PRESENTED AT 9TH AEC AIR CLEANING CONFERENCE, BOSTON, MASS, SEPTEMBER $13-16,1966$

STUDIES WERE MADE OF ULTRASENSITIVE ANALYTICAL METHODS FOR DETERMINING IODIDE FOR USE IN IN-PLACE IODINE-REMOVAL-EFFICIENCY TESTS. INVESTIGATION OF THE VARIOUS TECHNIQUES, USING THF IODIDE CATALYTIC REDUCTION OF CERIC IONS LED TO SELECTION OF A METHOD. BEDS OF COPPER PEADS WERE USED AS IODINE SAMPLING UNITS AND WERE INVESTIGATED FOR COLLECTION EFFICIENCY AT VERY LOW CONCENTRATIONS OF IODINE. THE UNITS WERE VERY USEFUL.

*CHARCOAL + \#COPPER + \#FILTER EFFICIENCY + \#FISSION PRODUCT, IODINE + \#TEST, FILTER +

*TEST, FILTER SYSTEM + AIR CLEANING + FILTER, TRAP + IODINE + TRACER, PADIOACTIVE

7-11732 - THOMSON WG + GROSSMAN RE

IN-PLACE TESTING FOR IOOINE REMOVAL EFFICIENCY USING AN ELECTRONIC DETECTOR TODD SHIPYAROS CO.+ U. S. ATOMIC ENERGY COMMISSION

CONF-660904 +. 17 PAGES, 5 FIGURES, 2 TABLES, 7 REFERENCES, PRESENTED AT 9TH AEC AIR CLFANING CONFERFNCE, BOSTON, MASS., SEPTEMBER $13-16,1966$, SOURCE

TECHNICAL SPECIFICATIONS OF THE N. S. SAVANNAH REQUIRE OUARTERLY QUALIFICATIONS OF THE AIR CLEANING SYSTEMS FOR ABILITY TO REMOVE IODINE. SUCH PERIODIC TESTING CAN BE ACCOMPLISHED $\triangle T$ LOW COST USING AN ELECTRONIC DETECTOR-RECORDER THAT IS SENSITIVE TO ELEMENTAL IODINE VAPOR. CONCENTRATIONS OF ONE PART IN A BILLION PARTS OF AIR. THIS TEST METHOO HAS PROVEN SATISFACTORY ABOARD THE N. S. SAVANNAH, ALTHOUGH A CAREFUL LABORATORY-TYPE OPERATING TECHNIQUE IS REQUIRED. THE COMBINATION OF EQUIPMENT ANO OPERATING TECHNIQUE HAS QUALIFIED THE AIR-CLEANING SYSTEM WITH GOOD CORRELATION TO MORE EXPENSIVE, TEDIOUS, AND TIME-CONSUMING TESTS USING RADIOIODINE 131

\#CHARCOAL + \#FILTER EFFICIENCY + \#FISSION PRODUCT, IODINE + \#INSTRUMENTATION, AIR SAMPLING + *TEST, FILTER + \#TEST, FILTER SYSTEM + AIR CLEANING + ANALYTICAL TECHNIQUE, CALIBRATION + IODINE + N S SAVANNAH + SAMPLING 
CATEGחRY 8

SOURCES OF ENEPGY RELEASF UNDER ACCIDENT CONDITIONS

8-09971 SAUER MC

A METHOD FOR AUTOMATIC ANALYSIS OF DATA ON THE KINETICS OF FAST CHFMICAL REACTIONS IN THE FORM OF DICTURES OF OSCILLOSCOPE TRACES

ARECNNE NATIONAL LABORATOPY

$\triangle N L-7113+$. 15 PAGES, 10 FIGURES- OCTOBER 1965- CFSTI, \$1.NO CY, \$0.50 MN

THE CHLOE SYSTEM FOR DIRECT DIGITIZATION OF PHOTOGRAPHIC DATA WAS IJSED IN CONJUNCTION WITH THF CONTROL DATA CORFORATION 3600 COMPUTEP. SYSTEM TO ANALYZE TATA, IN THF FORM OF PICTUPES OF OSCILLOSCOPE TRACES, ON THE KINETICS OF FAST CHEMICAL REACTIONS. ALL MEASUREMFNTS AND ANALYTICAL PROCESSES WERE DONE RY MACHINE IN A COMPLETFLY DUTOMATIC METHOD.

\#ANALYTICAL MODEL + \#CHEMICAL KINETICS + \#CHEMICAL REACTION + \#COMPUTER PROGRAM + \#COMDUTER, DIGITAL

8-10294 GENS TA

VAPOR PRESSURES OF GASEOUS PRODUCTS FROM CHEMILAL REACTIONS OF SOL-GEL FUFLS

OAK RIDGE NATIONAL LABORATORY, OAK RIDGE

ORNL-TM-1418 +. 13 PAGES, 2 FIGURES, 2 TARLES, 16 REFERENCES, FEBRUARY 1966, CFSTI, \$1. MT C.Y, \$O. AD MN

CALCULATIONS HAVF P.FFN MADE OF THE PARTIAL PRESSURES OF GASFS EXPECTED TO BE FORMED IN VARICUS REACTOR-FUEL MATERIALS. THESE CALCULATIONS ARE RASED ON DATA FROM THE CHEMICAL LITERATUPE. THF CO PRESSURE DUE TO REACTION BETWEEN COATING AND OXIDE INSIDE CAREON-COATED UO2 AND THO2 MICROSPHERES WILL REACH 450 PSI WHEN THE TEMPERATURES APE 240 T AND 23 TIO UFGKELS 6

RESPECTIVELY. NITROGEN PRCSSURES FROM THFPMALLY DFCOMDOSING UN $\triangle N O$ DIIN MICROSOHERES WILL P.EACH EQUILIBRIUM VALUES OF 450 PSI AT 3000 AND 2800 DEGREES C RESDECTIVELY. THIS IS THF. HELIUM PRESSURE EXPECTEC IN THE TARGET GAS-COOLED REACTOR. THEREFODE, IT ADPEARS THAT THESE COATED-FUEL MICROSPHERES WOUL NOT DEVFLOP EXCFSSIVF. INTERNAL PRESSIJRES AT THF PD.FSSURE ANO RESPECTIVE TEMPERATURES LISTED APOVF. PRESSURES EXPECTED AT OTHER TEMPFRATURFS ARE ALSO TABULATED.

\#CHEMICAL REACTION + \#COATED PARTICLE + \#SOL-GEL PROCESS + \#VAPOR, VAPOP PRESSURE + CARRON + NITRIDS + OXIDE + THORIUM + URANIUM

8-10295 PITTS SH

CRITICAL TEMPERATURE OF PLUTONIUM-CHLORINATED SOLVFNT PEACTIONS

DOW CHEMICAL COMPANY, ROCKY FLATS

RFP-688 +. 9 PAGES, 4 FIGURES, 3 TABLES, FERRUARY 1966, CFSTI, \$1.00 CY, \$0.50 MN

IN PLUTONIUM FRODUCTION MACHINING AND HANOLING OPERATIONS, A HAZAPD EXISTS IN THE COMPATIBILITY OF PLUTONIUM AND CERTAIN CHLORINATEO SOLVENTS. BURNING PLUTONIUM, AT 75D-8OR DEGREES C, REAOILY ANO VIOLENTLY REACTS WITH CAPBON TETRACHLORIDE PUT NOT WITH SOME OTHER CHLORINATED SOLVENTS. CRITICAL TEMPERATUPES WERE DETERMINED FOR SOME REACTIONS BFTWEEN PLUTONIUM AND CHLORINATED SOLVENTS. CCL4 CONSISTENTLY HAD THE LOWEST CRITICAL TEMPERATURFS. CHLOROTHENE AND FREON TB-1 SOLVENTS HAD ALMOST THE SAME C.RITICAL TEMPERATURE, WHTCH WAS LOWER THAN FOR PERCHLOROETHYLENE AND 1,1,2-TRICHLOROETHYLENE. OF THE SOLVENTS STUDTED,

TRICHLOROETHYLENE WAS THE LEAST REACTIVE AND THEPEFORE THE SAFEST UNDER THESE TEST

CONDITIONS. THE CRITICAL TEMPERATURE OF PLUTONIUM IN CCL 4 WAS INCREASED RY ADDING TEXACO

REGAL CUTTING OIL.

\#CHEMICAL PEACTION + \#PLUIONIUM + CHIORTNE + HTRH TEMPERATURF.

8-10311 MARKS RE + ROGERS LA

SHOCK FRONT STUDIES OF THE HANDCAR EVENT

LAWRENCE RADIATION LABORATORY, LIVERMORE, CALIFORNIA

PNE-801F +. 61 PAGES, 47 FIGIIRFS, 13 TAELES, 9 PEFERENCES, APRIL 1966- CFSTI, \$3.0D CY

CLOSE-IN SHOCK-WAVE AND SEISMIC EFFECTS WERE MEASURED SUBSEQUENT TO A 12-KT DFTONATIUN IN A NEVADA TEST SITE DOLOMITE MEDIUM ANO COMPARED WITH PREOETONATION CODE-PREDICTED RESULTS. COMPARATIVE AGREEMENT OF EXPERIMENTAL STRESSES WITH C.ALCULATED STRESSES IN THE HYOPODYNAMIC PRESSURE REGION WAS WITHIN 13 DERCENT, WHEREAS SIMILAR COMPARISONS IN THF LOW-PRFSSURF AREA INDICATEO A MAXIMUM DISAGREEMENT OF 330 FEPCENT. QRIEF DESCRIOTIONS OF THE CONOF, CONF INPUT DATA, AND COOL-PREDICTED RESULTS APE ALSO OPESENTEO DLONG, WTTH MORF DFTAILFD DESCRIPTIONS CF THE SHOCK-HAVE INSTRUMENTATION, ITS INSTALLATION ANO CHFCKMIT, AND THE MFASURED RESIJLTS.

\#COMPARISON, THEORY ANO EXPERIENCE + \#PLOHSHARE PROGRAM + \#SHOCK WAVE + SEISMOLOGY

8-10341 RUTHERFORD JL + BLAKELY JP + OVERHOLSER LG

OXIDATION OF UNFUELED AND FUELED GRAPHITE SPHERES BY STEAM

OAK RIDEF NATIONAL LAQORATORY

ORNL-3947 +. 37 PACES, 14 FIGUNES, 7 TABLES, MOY 196, CSFTI $\$ 2.00 \mathrm{CY}$

THE OXIDATION OF VARIOUS UNFUELED ANO FUELED GRAPHITE SPHERES BY STEAM WAS STUDIEO AT BOT, 900, AND $1000 \mathrm{C}$, USING A PARTIAL PRESSURE OF ABOUT 730 TORR AND FLOW RATSS OF 6QD TO 1200 CM 3/MIN (STP) OF STEAM. THE FUELED SPHERES CONTAINED PYROLYTIC.CAP.BON COATED UC, OR (U,TH) C2 PARTICLES DISPERSED IN GRAPHITF MATRICES REACTION RATFS WERE DETEPMINFD FROM WE IGHT CHANGES AND ANALYSES OF THE EFFLUENT GASES. PRONOUNCED EFFECTS OF BURNOFF ON REACTION RATES AND CO/CO2 RATIOS WERE OBSERVED. REACTION RATES MFASUIRED FOR THE FUELED SDHERES WERE, IN GENERAL, COMPARABLE TO THOSE FOUND FOR THE UNFUELED SPHERES. THE GRADHITE MATRICES APPFAR TO HAVE AFFOROEO CONSIDERABLE PROTECTION FOR THE COATED FUEL PARTICLES AGAINST ATTACK BY STEAM.

\#GRAPHITE + \#OXIDATION + \#STEAM + CHEMICAL REACTION + COATEO PARTICLE + PYROLYTIC 
CATEGORY

SOURCES OF ENERGY RELEASE UNDER ACCIDENT CONDITIONS

8-10359 MUENCHOW HO

REVIEW OF ATOMIC POWER DEVELOPMENT ASSOCIATES SODIUM-WATER REACTION PROGRAM

ATOMIC POWER DEVELOPMENT ASSOCIATES, INC.

CONF-650620 +. 12 PAGES, 8 FIGURES, PP. 232-243 OF PROCEEDINES OF SODIUM COMPONENTS DEVELOPMENT PROGRAM

INFORMATION MEETING, CHICAGO, JUNE 16-17, 1965 , CFSTI $\$ 3.00 \mathrm{CY}$

THE STEAM GENERATOR IS RECOGNIZED AS THE WEAKEST LINK IN THE HEAT-TRANSPORT CHAIN OF SODIUM-COOLED REACTORS. ADPA HAS BEEN AWARDED A CONTRACT TO CONDUCT A SERIES OF SODIUM-WATER REACTION TESTS WHICH WILL ESTABLISH A MEANS OF ESTIMATING THE EXTENT OF TUBE WASTAGF DURING A SMALL LEAK OF WATER INTO THE SOOIUM OF A SODIUM-HEATEO STEAM GENERATOR, AND DETERMINE THE DOMINANT PARAMETERS OF TUBE WASTAGE DURING A SMALL WATER LEAK SO THAT THEY MAY BE APPLIED TO THE DESIGN OF A UNIT.

*FERMI + \#METAL WATER REACTION + *SODIUM + EQUIPMENT DESIGN + REACTOR, LIQUID METAL COOLED

8-10410 GREENBANK JC + HARPER S

THE MECHANISM OF BREAKAWAY OXIDATION IN ZIRCONIUM ALLOYS

UNITED KINGDOM ATOMIC ENERGY AUTHORITY, RISLEY

TRG-1174 (C/X) +. 11 PAGES; 6 FIGURES, I TABLE, 7 REFERENCES, JANUARY 1966, UKAEA

THE OXIDE FILMS FORMED ON SEVERAL ZIRCONIUM ALLOYS IN A VARIETY OF OXIDIZING ATMOSPHERES WERE STUDIED IN BOTH PRE- AND POSTBREAKAWAY CONDITIONS. IT IS SUGGESTED THAT BREAKAWAY OCCURS DUE TO THE MECHANICAL FAILURE OF THE OXIDE FILM, WITH THE STRESSES GENERATED IN THE GROWING FILM BEING SUCH THAT IN POSTBREAKAWAY CONDITIONS THE OUTER LAYER OF OXIDE IS CRACKED PROGRESSIVELY DEEPER, WHILE THE RATE OF OXIDATION IS CONTROLLED BY DIFFUSION THROUGH THE INNERMOST UNCRACKED OXIDE LAYER, WHICH REMAINS OF CONSTANT THICKNESS.

*ALLOY + *OXIDATION + *ZIRCONIUM

8-10530 DREVON GA + FALGAYRETTES MF + WALFORD FJ

COMPARISON OF PRESSURE LOADING PRODUCED BY CONTAINED EXPLOSIONS IN WATER AND SODIUM

CENTRE D ETUDES NUCLEAIRES DE SACLAY + CENTRE D ETUDES NUCLEAIRE DE CADARACHE + UNITED KINGDOM ATOMIC ENERGY AUTHORITY, SOUTHEND-ON-SEA, ESSEX

ANL-7120 + 14 PAGES, 11 FIGURES, 4 TABLES, 5 REFERENCES, PP, $720-733$ OF PROCEEDINGS OF THE CONFERENCE ON SAFETY, FUELS, ANO CORE DESIGN IN LARGE FAST POWER REACTORS, OCTO8ER 11-14, 1965, CFSTI, \$9.25 CY

JOINT EXPERIMENTS BY THE CEA-EURATOM ANO THE UKAEA WERE CARRIEO OUT AT CADARACHE, FRANCE, USING WATER AND HOT SODIUM COOLANT IN A SMALL-SCALE MODEL REPRESENTAYIVE OF CURRENT FAST-REACTOR DESIGN, THE SINGLE, STAINLESS-STEEL COOLANT TANK WAS ABOUT 9.5 IN. IN DIAMETER AND 16.5 IN. DEEP, AND CONTAINED A MODEL BREEDER AND REFLECTOR. IT IS CLEAR THAT FOR A GIVEN EXPLOSIVE RELEASE OF ENERGY IN A FIXED GEOMETRY, THE BLAST EFFECTS WILL BE GREATER IN SODIUM THAN IN WATER.

*EXPLOSION + *METAL WATER REACTION + *SODIUM + \#WATER, GENERAL +

CONTAINMENT, SHOCK GENERATION AND PROTECTION + PPESSURE, INTERNAL + REACTOR, FAST

8-10531 SAMUELS DE

OESIGN FACTORS INFLUENCING THE CONTAINMENT OF INTERNAL EXPLOSION IN FAST REACTORS

UNITED KINGDOM ATOMIC ENERGY AUTHORITY, SOUTHEND-ON-SEA, ESSEX

ANL-7120 +. 15 PAGES, 3 FIGURES, 3 REFERENCES, PP. 734-740 OF PROCEEDINGS OF THE CONFERENCF ON SAFETY,

FUELS, AND CORE DESIGN IN LARGE FAST POWER REACTORS, OCTORER 11-14, 1965, CFSTI, \$9.25 CY

IN RECENT YEARS THE FOULNESS ESTABLISHMENT OF THE U.K. A. E. A. HAS BEEN ENGAGED IN A CONTINUING INVESTIGATION OF THE CONTAINMENT OF CORE EXPLOSIONS IN FAST REACTOR SYSTEMS. IN THIS WORK SMALL CHARGES OF CHEMICAL HIGH EXPLOSIVE HAVE BEEN OETONATED IN SCALED MODELS OF THE REACTOR STRUCTURE. GEOMETRICAL ARRANGEMENTS ARE STUDIED IN INSTRUMENTED, OVERSTRONG MODELS, WHILE INFORMATION ON MODES OF DEFORMATION AND ENERGY ABSORPTION IS OBTAINED FROM MODELS HAVING CORRECTLY SCALED STRUCTURAL STRENGTH. PROCESSES STUDIED INCLUDE THE PLASTIC FLOW AND RUPTURE OF METALS, SHOCK-WAVE INTERACTIONS, VENTING AND PRESSURE RISE IN GAS SPACES, CRUSHING OF POROUS MATERIALS, AND THE IMPACT OF SHOCK-DRIVEN LIQUIDS. THIS HAS LED TO THE POSSIBILITY OF DDJUSTING THE BALANCE BETWEEN THESE PROCESSES BY APPROPRIATE DESIGN SO AS TO ACHIEVE THE NECESSARY STRUCTURAL INTFGRITY WITH THE LEAST ECONOMIC PENALTY OR INTERFERENCE WITH NORMAL WORKING.

\#CONTAINMENT, SHOCK GENERATION AND PROTECTION + \#DESIGN CRITERIA + \#EXPLOSION + \#REACTOR, FAST + MOCKUP + PRESSURE, INTERNAL + TESTING

8-10872 FIRST SUPPLEMENT TO PRELIMINARY SAFETY ANALYSIS REPORT INDIAN POINT NUCLEAR GENERATING UNIT NO. 2

CONSOLICATED EOISON COMPANY OF NEW YORK

2 PAGES OF FIRST SUPPLEMENT TO PRELIMINARY SAFETY ANALYSIS REPORT. INDIAN POINT NUCLEAR GENERATING UNIT

NO. 2, MARCH 31, 1966, DOCKET NO. 50-247, PDR

QUESTION 2, CRITERION $2-2$ 2IRCONIUM-WATER REACTION IS QUENCHED $\triangle N D$ CORE REFLOODED IN 430 SEC

WITH ONLY 5 PERCENT REACTION FOLLOWING A DOUBLE-ENOED PIPE RUPTURE WITH ONLY 2 OF 3 DIESELS, ONLY 1 OF 3 SAFETY INJECTION PUMPS, ANO 1 OF. 2 RESIDUAL HEAT REMOVAL PUMPS WORKING. RESULT -

CONTAINMENT DESIGN PRESSURE NOT EXCEEDED.

* DESIGN CRITERIA + \#METAL WATER REACTION + \#REGULATION, AEC +

* SAFEguARDS REPORT, RESPONSE TO AEC QUESTIONS + INDIAN POINT II + REACTOR, PRESSURIZED WATER +

SAFETY INJECTION

ACCESSICN NUMBER $8-10359$ TO $8-10872$ 
CATEGOPY B

SOURCES OF ENEPGY RELFASF UNOER ACCIDENT CONDITIONS

8-10887 FIRST SUPPLEMENT TO PRELIMINARY SAFETY ANALYSIS. INDIAN POINT NUCLEAR GFNERATING, UNIT ND ?. CONSOLICATED EDISON COMPANY OF NEW YORK

3 PAGES OF FIRST SUPPLEMENT TO PRELIMINARY SAFETY DNALYSIS. INDIAN POINT NUCLEAR GENERATING UNIT NO. 2, MARCH 31,1966 , DOCKET NO. 50-247, PNR

QUESTION 2, CRITERION 17 -- IN ANALYSIS HHFREIN NO SAFETY WATEP. INJECTION ALLOWED RUT ONLY ONF EACH CONTAINMENT SPRAY PUMPS OR AIR COOLERS FAILED, PRESSUPE PEAK WAS 43.4 DSIG IHYDRNGEN BURNS AFTER 44 PFRCENT ZIRCONIUM REACTIONI. IN OTHER DOUPLE-ENDED PIPE RUPTURFS, PRFSSURF PEAK WAS 40 DSIG.

\#CONTAINMENT DESIGN + \#CESIGN CPITERIA + \#PRESSURE, INTERNAL + \#RFGULATIDN, $\triangle E C$ + INDIAN POINT II + LOSS OF COOLANT + METAL WATFR REACTION + REACTOR, PRESSURIZED WATEP +

SAFEGUAROS REPDRT, RESPONSE TC AEC QUESTIONS

8-1U४YG FIRST SUPPLEMENT TO PRELIMINARY SAFETY ANALYSIS. TNDTAN POINT NUCLEAR GENFRATING UNIT NO. 2 CONSOL IOATED EDISON COMPANY OF NEW YORK

37 PAGES, 21 FICURES OF FIRST SUPPLFMFNT TO ORELIMINARY SAFETY ANALYSIS, INDIAN POINT NUCLEAR CEENEPATING UNIT NO. 2, MARCH 31, 1966 , DOCKET NO. 50-247, DDP.

QUESTION 4 IS REALLY FIVE QUESIIONS RELATING TO CALCULATION OF DOUSLE-ENOED PIPF RUDTIJRE CONTAINMENT-PRESSURE TRANSIENT AND EFFECT OF VARIOUS FNGINEERED SAFEGUARDS - (A) RELATES TO METAL-WATER, HYUKUEEN REACTION, AND OTHEF CNTPGY SOURCES, (B) SHDLS THE FNFRGY DISSIPATION FOR THE FIRST 3O MIN PCST INCIOENT, (C) SHOWS PERCENTAGE OF CORE ZIRTONIUM AROVE CEPTAIN TEMPERATURES VS TIME, (D) (E) (F) PROVIDES GRAPHS OF PRESSURE TRANSIENTS WTTH VARIOUS ENGINEERED SAFEGUARDS NCT WOPKING, AND WITH VARIOUS STFP INCPEASES OF ENERGY.

\#ENGINEERED SAFEGUARD + \#LCSS CF COCLANT + \#SAFEGUAROS REPORT, RESPONSE TO $\triangle E C$ OUFSTIDNS + INDIAN POINT II + DPESSURE, INTERNAL + REACTOR, PRESSURIZFO WATER

8-1136t QUAD-CITIES STATION, UNIT 1 - PLANT DESIGN ANALYSIS, VOLUME 1 COMMONWEALTH EDISON COMPANY, CHICAGO

14 DNGES, 3 REFFRFNCES, 1 TABLE, DAGES V-1-16 T0 31, DOCKET NO. 5C-254, MAY 31, 1966 PDR

IMMECIATFLY AFTER THE MAJOR PIPE RUPTURE, THE TEMPERATURE OF THE WATER IN THE SUPPRESSION CHAMBER APPROACHES $130 \mathrm{~F}$, AND THE MAXIMUM SYSTEM DRESSUPE APPQOACHES 39 DSIG DUPING THE ELOWDOWN OF THE PRIMARY COOLANT INTO THE DRYWELL. THE CONTAINMENT PRESSURE IS A FUNCTION OF THE METAL-WATER REACTION RATE. ALTHOUGH THE CORE-CONLING SYSTEMS ARE ASSUMED NOT TO FUNCTIDN IN ORDER TO PROVIDE A BASIS FOR METAL-WATER RFACTIONS, ONE OF THE TWO CONTAINMENT COOLING SYSTEMS IS ASSUMED TO FUNCTION NORMALLY. THF DRYWELL SPRAY IS SUFFICIENT TO TRANSPORT THE CECAY HEAT, THE HEAT STORED IN THF R.ORE, AND ANY HEAT RFSULTING FROM THE METAL-WATER REACTION TO THE WET-WELL IN THF FORM OF HOT LIOUID. THE FNERFY TRANSPORTED TO THE WATER IN IHE SUPPRESSION CHAMRER IS REMOVED FROM THE CONTAINMENT SYSTEM BY HEAT EXCHANGEPS. TO ORVIATE THE POSSIBILITY OF AN ENERGY RELEASE WITHIN THE PRIMARY CONTAINMFNT FROM A HYDROGEN-OXYGEN REACTION UNDEP CONDITIONS MORF SEVERE THAN CAN CURRFNTLY RE FORFSEEN, THE DESIGN INCLUDES AN INERTING SYSTEM TO REDUCE THE OXYTEN CONCENTRATION OF THE ATMOSPHERE WITHIN THF PRIMARY CONTA INMENT.

\#CONTAINMENT SPRAY + *CONTAINMENT, PRESSURE SUPPRESSION + \#METAL WATER REACTION + \#QUAD CITIES I + * IIRCALOY + CHEMICAL R.CACTION + CONTAINMENT ATMOSPHFRF, INERT + HYUYOLEN + OXYGEN +

REACTOR, gOILING WATER + SAFEGUAROS RFPORT, ORELIMINARY

8-11413 SKARPELOS JM

CHEMISTRY OF ESADE-VAWR NUCLEAR SUPERHEAT LOOP

GENERAL ELECTRIC COMPANY, SAN JOSE, CALIFORNIA

GEAP-4813 . 38 PAGES, FEBRUARY 1964, CFST1, $\$ 2.00 \mathrm{CY,} 30.5 \mathrm{C} \mathrm{MN}$

THE CHEMISTRY PROGRAM ASSOCIATED WITH THE ESADE-VBWR NUCLEAR SUPERHFAT LOOP WAS CARRIFD ON WITH THE PRIMARY PURDOSE OF DETECTING THE FAILUPE OF FUEL CLADDING AND MEASURING THE FISSION-PRODUCT RELFASE RATE. TO ACCOMPLISH THIS OBJECTIVE, NOBLE-GAS FISSION ORODUCTS AND RADIOIODINES WERE MONITORED IN THE LOOP INLFT AND DUTLET STEAM. RADIOCHEMISTRY MFASUREMENTS MADE UURING IRRADIATION GAVE NO INDICATION OF DEFECTIVE FUEL. RFSULTS AFIEK SIDPING THF FUFL BUNDLE AT THE COMPLETION OF THE IRRADIATION INDICATED THAT A FUEL. ELFMENT MIGHT HAVE AECN DEFECTIVE. HOWEVER, THE SIGNAL WAS SUFFICIENTLY HEAK THAT IF A DEFECT WFRE PRFSENT IT WAS VERY SMALL. PROSLEMS ASSOCIATED WITH STEAM SAMPLING DIO NOT DETRACT FROM THE MAJOR CBJECTIVE, WHICH WAS TO DETERMINE OPERATING LIMITS FOR SUDFRHEAT FUEL ELEMENTS OF INTEREST.

\#CHEMICAL REACTION + \#FAILURE, FUEL ELEMENT + \#VRWR (VALLFCITOS BOILING WATER REACTOR) +

REACTOR, BOILING WATEY + REACTOR, SUPERHEAT 
CATEGORY

NUCLEAR INSTRUMENTATION, CONTROL, AND SAFETY SYSTEMS

9-C8716 CORNELL DC

SAFE-PCRS. A COMPUTER PROGRAM FDR THE STRESS ANALYSIS OF COMPOSITE BODIES OF REVOLUTION. INPUT INSTRUCTIONS

GENERAL ATOMIC

GA-6588 +. 40 PAGES, FIGURES, TABLES, 2 REFERENCES- AUGUST $1,1965-$ C.FSTI, $\$ 2.00$ CY, $\$ 0.75$ MN.

A COMPUTER PROGRAM FOR THE STRESS ANALYSIS OF COMPOSITE BODIES OF REVOLUTION. INPUT INSTRUCTIONS.

\#COMPUTER PROGRAM + \#STRESS ANALYSIS + DESIGN STUDY + PROPERTY, PHYSICAL

9-09416 ZIEMANN DL

MODIFICATION OF PNPF CONTROL ROD CABLES DUE TO EXCESSIVE ROO DROPS

PIQUA NUCLEAR POWER FACILITY

PNPF-69-66 +. 4 PAGES, MARCH 22, 1966, DOCKET NO. 115-2, PDR

MANY CASES OF SHORTING-TO-GROUND HAVE OCCURREO DUE TO COOLANT CARRURIZATION AND MFCHANICAL

CAMAGE. VARIOUS MODIFICATIONS WILL BE MADE RATHER THAN CHANGE TO A COMPLETELY SEALED SYSTEM.

\#FAILURE, COMPONENT + \#PIQUA + *REACTOR, ORGANIC COOLED + *SCRAM, FALSE + MODIFICATION, SYSTEM OR EQUIPMENT

9-10040 WASHBURN B + HUDSON CE

PIN TECHNIQUE FOR DISPLACEMENT MEASUREMENTS IN KIWI TNT

LOS ALAMOS SCIENTIFIC LABORATORY, LOS ALAMOS

LA-3388-MS +. 21 PAGES, 14 FIGURES, JUNE 1965, CFSTI, \$1.0 CY, \$0.05 MN

A PIN TECHNIQUE THAT WAS USED TO MEASURE RELATIVELY SMALL, EARLY, DUTWARD DISPLACEMENTS OF THE TNT REACTOR CORE AND REFLECTOR CYLINDER COMPONENTS DURING THE KIWI TRANSIENT NUCLFAR TEST IS DESCRIBED. CONSIDERATIONS NECESSARY TO ADAPT THIS METHOD TO THE ENVIRONMENT OF THE REACTOP TRANSIENT AND THE RESULTS ARE PRESENTED. AN EXPERIMENT TO DETERMINE THE TIMES OF CLOSING OF SELECTED PROPELLANT PASSAGES BY USING COAXIAL WIRES IS ALSO GIVEN.

\#KIWI TNT (TRANSIENT NUCLEAR. TEST) + INSTRUMENTATION, GENERAL

9-10156 RUDY GC + SWANSON DH + GREGORY JG + PEARCE WR + SHULTZ TG + STONE JT SAFETY INSTRUMENTATION REVIEW AND RESULTING MODIFICATIONS FOR PATHFINDER POWER PLANT ALLIS-CHALMERS MANUFACTUR ING COMPANY, BETHESOA

ACNP-64638 +. 83 PAGES, 74 FIGURES, FEBRUARY 12, 1966, DOCKET ND. 50-130, PDR

THE AS-BUILT NUCLEAR AND PROCESS SAFETY INSTRUMENTATION WAS GIVEN A COMPLETE REVIEW BY EVALUATING IT AGAINST A MODERN GENERAL SAFETY POLICY AND A SET OF SDECIFIC DESIGN SPECIFICATIONS. THE ORIGINAL OESIGN WAS DEFICIENT IN MANY AREAS, AND MODIFICATIONS WERE MADE TO SATISFY THE DESIGN SPECIFICATIONS. SEVERAL NEW PROTECTIVE CHANNELS WERE ADDED, AND SECONI CHANNELS WERE ADDED TO MOST OF THE PROCESS CHANNELS. PROVISION WAS MAOE TO TEST-ALL THE

CHANNELS AT POWER. RELAY MATRICES WERE ADDED. TO BACK UP THE SOLID-STATE LOGIC. SCRAM C.IRC.UITS.

\#DESIGN CRITERIA + \#MODIFICATION, SYSTEM OR EQUIPMENT + \#PATHFINDER + \#PLANT PROTECTIVE SYSTEM +

* SAFETY PRINCIPLES AND PHILOSOPHY + REACTOR SAFETY SYSTEM + REACTOR, BOILING WATER + REGULATION, AFC

9-10282 MIROWSKY BJ

EFFECTS OF SHORT-DURATION POWER INTERRUPTIONS ON THE COMPUTERIZED CHECKOUT SYSTEM FOR NASA GENERAL ELECTRIC COMPANY, DAYTONA BEACH, FLA.

36 PAGES, 18 FIgURES, 2 TABLES, PRESENTED AT THE AMERICAN POWER CONFERENCE $28 T H$ ANNUAL MEETING, APRIL 26-28, 1966, CHICAGO, ILLINOIS, APC, \$0.25 CY

PROBLEM - EXAMINE AND FINO CORRECTIVE METHODS FOR THE DISTUP.BANCES TO ONLINE COMPUTER.S CAUSED BY BRIEF POWER INTERRUPTIONS. APPROACHES - (1) THEORETICAL EVALUATION OF TIME RESPONSES, (2) TEST RESPONSE OF SYSTEM TO VARIABLE DISTURBANCES. RESULTS - 11 ) COMPUTER PERFORMANCE WAS UNACCEPTABLE FOR INTERRUPTIONS LONGER THAN 1 MSEC, $(2)$ MINIMUM RECOVERY TIME FOR COMMERCIAL POWER SYSTEMS IS 80 MSEC. CONCLUSIONS - (1) IT IS NOT PRACTICAL TO MODIFY THE COMPUTER SYSTEMS OR THE COMMERCIAL POWER SYSTEMS TO GIVE SATISFACTORY RECOVERY, (2) PQACTICAL ANSWER IS TO INTERPOSE A LOCAL, CONTINUOUS, AC-POWER SYSTEM OF EITHER A DIESEL-DRIVEN CLUTCH, CONNECTED ROTATING SYSTEM, OR A BATTERY-BACKED, STATIC, AC GENERATOR.

* COMPUTER, DIGITAL + \#ELECTRIC POWER, VITAL + \#EMERGENCY P.OWER, ELECTRIC + \#FAILURE, GENERAL + COMPARISON, THEORY AND EXPERIENCE + TEST, SYSTEM OPERABILITY

S- 10290 WHITTEN LG

POSITION MONITORING DEVICES

UNION CARBIOE CORP., OAK RIDGE, Y-12 PLANT

$Y-1506+32$ PAGES, 41 FIGURES, APRIL 1966, CFSTI, $\$ 2.00 \mathrm{CY}, \$ 0.50 \mathrm{MN}$

A BRIEF REVIEW OF POSITION-MEASURING SYSTEMS IS PRESENTED. MECHANICAL, OPTICAL, AND

ELECTRICAL SYSTEMS ARE COVERED. THE EMPHASIS IS ON SYSTEMS THAT ARE USED WITH MACHINE TOOLS.

HOWEVER, SOME SYSTEMS MAY BE USEFUL FOR ACCURATE POSITION MEASUREMENTS OF CONTROL-ROD DRIVES.

*INSTRUMENTATION, GENERAL + \#MEASUREMENT, GENERAL + CONTROL ROD CRIVE 


\author{
CATEGORY 9
NUCLEAR INSTRUNENTATICN, CONTROL, AND SAFETY SYSTEMS
}

9-1C291 ROUX DP

PARALLEL-PLATE MULTISECTION IONIZATION CHAMBERS FOR HIGH-PEDFORMANCE REACTORS

OAK RIDEE NATIONAL LABORATORY, OAK RIDGE

ORNL-3929+, 17 PAGES, 9 FIGURES, 6 TABLES, APRIL 1966 , CFSTI, \$2.00 CY

A NEW MODEL OF PARALLEL-PLATE MULTISFCTION IONIZATION CHAMBFRS WAS DFVFLOPED FOR RFACTOR CONTROL APPLICATIONS IN HIGH-PERFORMANCE REACTORS. THF ARPANGEMFNT OF THF CHAMREP ALLOWS THE COMBINATION OF OIFFERENT ACTIVE SECTIONS IN A SINGLE REACTOR PENETRATION. FACH ACTIVE SECTION IS COMPRISED OF PARALLEL-PLATE ELECTRODES, EACH 1.8 IN. IN DIAMETER AND O.OOS IN. THICK. THE ELECTRODES ARE COATEO WITH 9-10 FOR USE AS NEUTRON-SFVSITIVE CHAMBERS, WITH U-2?S FOR USE AS FISSION CHAMBERS, OR LEFT UNCOATED FOP USF AS GAMMA-SENSITIVE CHAMREDS. ALSO, A GAMMA-COMPENSATED NEUTRON-SENTITIVE CHAMBER CAN RF MADE BY USING BORON-COATED AND UNCOATED ELECTROOES. A NEW ELECTRODE CONFIGURATION IS USED TO ACHIEVE AN ELFCTRICALLY ADJUSTASLE GAMMA COMPENSATION. EXPERIMENTAL RESULTS SHOW THE INSENSITIVITY OFF THE GAMMA COMPENSATION TO WIDE VARIATIONS IN INTENSITY, ENERGY, AND GEOMETRY OF THE GAMMA RACKGPOUND.

CHANBER, COMPENSATED + CHAMBER, FISSION + CHAMAER, ION + CHAMBER, NEUTRON + CHAMRER, UNCOMPENSATED + EQUIPMENT DESIGN + INSTRUMENTATION, NUCLFAR + ORNL (OAK RIDGE NATIONAL LABORATORY) + TEST, COMPONFNT

9-10292 KING W

REACTOR CONTROL AND PROTECTION SYSTEMS FUNCTIONAL REQUIREMENTS AND PERFORMANCE

WESTINGHOUSE ELECTKIC CUKMURAIIUN, PITTSBURGH, ATOMIC DOWFR DIV.

WCAP-3269-45 +. 114 PAGES, GI FIFIIRFS, MARC.H 1965 , CFSTI, \$4.00 CY, \$0.75 MN

PURPOSE - DESIGN STUDY FOR CONTROL AND PROTECTION SYSTEMS FOR A 305-MWE PWR. APDROACH - (I) DETERMINE FUNCTIONAL REQUIREMENTS, (2) EXAMINE DERFORMANCE OF PROPOSED SYSTEMS UITH AN ANALNF COMPUTER SIMULATION, (3) EXAMINE THE SENSITIVITY OF PLANT PPSPCNSES TO CHANGES IN THE PLANT DESIGN PARAMETERS. RESULTS - $(1)$ PROPOSED CONTROL SYSTEM SHCWED GOOD TRANSIENT RESPONSES TO VARIOUS CHANGES IN ELFCTRICAL LOAD, 121 PROPOSED PROTECTION SYSTEM GAVE ADEQUATE PERFORMANCE FOR VARIOUS POSTULATEO ACCIDENTS.

\#CONTROL SYSTEM + \#DESIGN CRITERIA + \#DFSIGN STUDY + \#PLANT DROTECTIVE SYSTEM + \#RFACTOR CONTROL + \#REACTOR SAFETY SYSTEM + COMPUTER, ANALOG + MATHEMATICAL STUDY + REACTOR STABILITY + REACTOR, PRESSUP.IZED WATER

9-1C388 BATES AFG

DESCRIPTION AND OPERATING INSTRUCTIONS FOR THE LITP REACTOR CONTROL AND INSTRUMENTATION SYSTFMS OAK RIDGE NATIONAL LABORATORY, OAK RIDGE

ORNL-TM-1190+. 41 PAGES, 9 FIGURES, 2 TABLFS, JULY 1965, CFSTI, $\$ 2.00$ CY, $\$ 0.50$ MN

THE REACTOR CONTROL AND INSTRUMENTATION SYSTEMS FOR THE LITR WERE UPGRADED. THE PROCESS-SYSTEM HARDWARE WAS COMPLETELY PEPLACED WITH THE MOST MODERN AND VERSATILE ALL-ELECTRONIC EQUIPMENT. THE NUCLEAR-SYSTEM ASSEMBLIES WERE RESUILT AND IMPROVED SO THAT THEY WOULD BE INTERCHANGEABLE DIRECTLY, OR AFTER MINOR MODIFICATION, WITH COMPAPABLF DAK RIDGE RESEARCH PEACTOR (ORR) ASSEMRLIES. ALL CONTPOL-SYSTEM HARDWARE WAS REPLACED WITH NEW ASSEMBLIES AND COMPONENTS. THIS REPORT DESCRIBES THE SYSTEMS AND DISCUSSES THEIR DPFRATION.

*CONTROL SYSTEM + *MODIFICATION, SYSTEM OR EQUIPMENT + \#REACTOR SAFFTY SYSTEM + INSTRUMENTATION, GENFRAL + ORNL (GAK RIDGE NATIONAL LABORATORY) + REACTOR, RESEARCH + SERVOMECHANISM + SYSTEM DESCRIPTION

$9=10434 \quad$ COSTRELL L

STANOARD NUCLEAR INSTRUMENT MODULES

NATIONAL BUREAU OF STANDARDS

TID-208S3 (REV.) +. 21 PAGES, 3 FIGURES, 1 TABLE- JANUARY 1966 GPO, \$0.20

REPORT PRESENTS THE SPECIFICATIONS FOR TRANSISTORIZED MODULAR INSTRUMENTS ADOPTED BY THE AEC COMMITTEE ON NUCLEAR INSTRUMENT MODULES FOR STANDARD NUCLEAR INSTRUMENT MODULES. REPORT INCLUDES CORRECTIONS AND CHANGES MADE TO THE ORIGINAL SPECIFICATIONS.

DESIGN CRITFRIA + INSTRUMENTATION, GENEPAL + INSTPUMENTATION, NUCLEAR

9-10439 BUMP TR + SIMMONS WR

HOLD-DOWN REQUIREMENTS FOR POISON CONTROL RODS

ARGONNE NATIONAL LABORATORY, ARGONNE

3 PAGES, 3 REFERENCES, PRESENTED AT ANS ANNUAL MEETING, JUNE 20-23, 1966, DENVER, COLOPADO

PROBLEM--IN REACTORS WITH LIQUID-METAL COOLANTS, THE VFSSEL OR CLOSURE DESIGN MAY BE DICTATED BY THE ROD HOLO-DOWN REQUIRFMENTS, RATHER THAN BY COOLANT PRESSURE. IT IS NECESSAPY TO ENSURE THAT A MINOR ACCIDENT CANNOT FORCE THE RODS OUT OF THE REACTOR CORE AND CAUSF A MORE SERIOUS ACCIOENT. APPROACH-FOUR POSSIBLE MECHANISMS THAT MIGHT LORCE THE RODS FROM THE CORE WERE EXAMINED FOR THE FARET DESIGN.

ACCIDENT, REACTIVITY + CONTROL P.OD DPIVE + DESICN CRITERIA + EXCURSION, LARGE + REACTOR, LIQUID METAL COOLED

9-10447 HIGH-TEMPERATURE MATERIALS PROGRAM. PROGRESS REPORT NO. 41, PART A GENERAL ELECTRIC COMPANY, CINCINNATI 15 , OHIO

GEMP-41A + 76 PAGES, 49 FIGURES, 21 TABLES, NOVEMRER 30, 1964, CFSTI, 53.00 CY

THIS REPORT IS ONE OF A SERIES OF SUCH REPORTS ON THE SUBJECTS ENUMERATED BELOW. NO FURTHER

ACCESSION NUMEER $0-10291$ TO $0-10447$ 
CATEGOPY 9
nUCLEAR instrumentation, CONTROL, and SAFETY SYSTEMS

9-10447 \#CONTINUED*

REPORTS IN THE SERIES WILL BE SUMMARIZED UNLFSS A SIGNIFICANT CHANGE IN THE PROGRAM OR A SIGNIFICANT ITEM OF INTEREST TO NSIC IS REPORTED. TOPICS COVERED IN THIS PEPORT ARE 111 HIGH-TEMPERATURE THERMOCOUPLE AND ELECTRICAL MATERIALS RESEARCH, (2) ERRORS IN THERMOCOUPLES PRODUCED BY RADIATION EXPOSURE, (3) ELECTRICAL RESISTANCE OF MATERIALS IN HIGH-TEMPERATURE ENVIRONMENTS.

\#INSTRUMENTATION, TEMPERATURE + \#MEASUREMENT, TEMPERATURE + high TEMPERATURE + Radiation EFFECT

9-10448 SYMPOSIUM ON IN-CORE INSTRUMENTATION, OSLO, JUNE 15-19, 1964, VOLUME I AND II EUROPEAN NUCLEAR ENERGY AGENCY, PAR IS AND NORWAY + OECD HALDEN REACTOR PROJECT

CONF-640607 +. 1023 PAGES, FIGURES, TABLES, JUNE 15,1964 , DEP/MN

A SERIES OF PAPERS REVIEW THE WORK ON IN-CORE INSTRUMENTATION IN THE MAJORITY OF THE EUROPEAN COUNTRIES AND THE USA AND CANADA. ALSO PAPERS ON INDIVIDUAL INSTRUMENTS SUCH AS TURBINE FL OWMETERS, VOID MEASUREMENT, STEAM-QUALITY MEASUREMENT, BURNOUT-PROTECTION DEVICES, THERMOCOUPLES, CHAMBERS, AND FAILED-FUEL-ELEMENT DETECTORS. THE MAJORITY OF tHe PAPERS APE ON INSTRUMENTS ASSOCIATED WITH THE HALDEN REACTOR DROJECT.

*IN CORE MEASUREMENT + *INSTRUMENTATION, IN CORE + INSTRUMENTATION, DETECTION FAILED FUEL ELEMENT + INSTRUMENTATION, FLOW + INSTRUMENTATION, NUCLEAR + INSTRUMENTATION, TEMPERATURE + REVIEW

S-10461 WILMER HB + BICKLEY JD + STUDLEY RV + TAYLOR WM + THOMPSON JJ REACTOR ON-L.INE COMPUTER

SAVANNAH RIVER PLANT

DPSPU 66-30-6 + CONF-660408-3 +. 27 PAGES, MARCH 1966, PRESENTED AT INSTRUMENT SOCIETY OF AMER ICA

SOUTHEASTERN CONFERENCE AND EXHIBIT, AUGUSTA, GEORGIA, APRIL 19-21, 1966, CFSTI, \$2.0D CY, \$O.50 MN

PROBLEM - MCNITOR 3000 SENSORS FOR THE REACTOR AND COOLING SYSTEMS OF A LARGE PRODUCTION REACTOR. APPROACH - ON-LINE DIGITAL COMPUTER IS USED TO MONITOR THE LARGE NUMBER OF OPERATING VARIABLES AND ALARM WHEN LIMITS ARE EXCEEDED. THE COMPUTER PROVIDES OPERATORS WITH DATA FOR ADJUSTING RADIAL AND AXIAL POWER DISTRIBUTIONS. REPORT GIVES DEYAILS OF THE COMPUTER HARDWARE, MAINTENANCE, AND PROCUREMENT. RESULTS - THE SYSTEM HAS BEEN OPERATING SATISFACTORILY FOR OVER A YEAR AND WILL BE PROTOTYPE FOR. THREE OTHER REACTORS. THE INPUT SYSTEM IS DESCRIBED IN DPSPU 66-30-6 (NSIC NO. 10569 ).

*COMPUTER, DIgITAL + \#DATA PROCESSING + *INSTRUMENTATION, GENERAL + \#INSTRUMENTATION, IN CORE + \#MONITORING SYSTEM + \#REACTOR, HEAVY WATER + \#SAVANNAH RIVER PRODUCTION REACTORS

S-10469 REACTOR INSTRUMENTATION AND CONTROL. PROGRESS REPORT NO. B7 GENERAL ELECTRIC COMPANY, CINCINNATI, OHIO

GEMP-87 +. 19 PAGES, 12 FIGURES, I TABLE, MARCH 31,1965 , CFSTI, $\$ 1.00$ CY

THIS REPORT IS ONE OF A SERIES OF SUCH REPORTS ON THE SUBJECTS ENUMERATED BELUW. NO FURTHER REPORTS IN THE SERIES WILL BE SUMMARIZED UNLESS A SIGNIFICANT CHANGE IN THE PROGRAM OR A SIGNIFICANT ITEM OF INTEREST TO NSIC IS REPORTED. TOPICS COVERED ARE (I) DEVELOPMENT OF A CAPACITANCE PROBE-TYPE TEMPERATURE SENSOR, (2) DEVELOPMENT OF A-C NEUTRON CHAMBERS, (3) DEVELOPMENT OF AN A-C FLUX CONTROL SYSTEM, AND 14 ) CHARGED-FRAGMENT NEUTRON DETECTORS.

\# CHAMBER, GENERAL + \#INSTRUMENTATION, CONTROL + *INSTRUMENTATION, NUCLEAR + \#INSTRUMENTATION, TEMPERATURE + HIGH TEMPERATURE + MEASUREMENT, TEMPERATURE + TFST, INSTRUMENT RESPONSE

Q-1ח470 REACTOR INSTRUMENTATION AND CONTROL. PROGRESS REPORT NO. 83 GENERAL ELECTRIC COMPANY, CINCINNATI, OHIO

GEMP-83 +. 25 PAGES, 15 FIGURES, JULY 31,1964, CFSTI, $\$ 0.50 \mathrm{CY}$

SEE NSIC 10469 FOR A LIST OF THE PROBLEMS BEING STUOIEO ON THIS PROJECT.

* CHAMBER, GENERAL + \&INSTRUMENTATION, CONTROL + \#INSTRUMENTATION, NUCLEAR + \#INSTRUMENTATION, TEMPERATURE + HIGH TEMPERATURE + MEASUREMENT, TEMPERATUPE + TEST, INSTRUMENT RESPONSE

9-10471 REACTOR INSTRUMENTATION AND CONTROL. PROGRESS REPORT NO. 85 GENERAL ELECTRIC COMPANY, CINCINNATI, OHIO

GEMP-85 .23 PAGES, 14 FIGURES, NOVEMBER 30, 1964, CFSTI, $\$ 2.00 \mathrm{CY}$

SEE NSIC 10469 FOR A LIST OF THE PROBLEMS BEING STUDIED ON THIS PROJECT.

*CHAMBER, CENERAL + \#INSTRUMENTATION, CONTROL + \#INSTRUMENTATION, NUCLEAR + \#INSTRUMENTATION, TEMPERATURE + HIGH TEMPERATURE + MEASUREMENT, TEMPERATURE + TEST, INSTRUMENT RESPONSE

9-10472 WILOE N + BOLAND TJ + ANDERSON SD

INSTRUMENT DEVELOPMENT BRANCH ANNUAL REPORT, 1964

PHILLIPS PETROLEUM COMPANY, IDAHO

IDO-17112+. 94 PAGES, 79 FIGURES, 8 TABLES, 36 REFERENCES, DECEMBER 1965, CFSTI, \$4.0ก CY, \$1.00 MN

PHILLIPS PETROLEUM COMPANY, NRTS, INSTRUMENT DEVELOPMENT BRANCH ANNUAL REPORT, 1964 . THIS REPORT IS ONE OF A SERIES OF SUCH REPORTS ON THE SUBJECTS ENUMERATED BELOW. NO FURTHER REPORTS IN THE SERIES WILL BE SUMMARIZED UNLESS A SIGNIFICANT CHANGE IN THE PROGRAM OR A 
CATEGORY O

NUCLEAR INSTRUMENTATION, CONTROL, AND SAFETY SYSTEMS

9-10472 \#CONTINUED*

SIGNIFICANT ITEM OF INTEREST TO NSIC IS REPORTED. TOPICS COVFRED ARE - (1) TRANSIENT ANALYSIS, 121 MEASUREMENT OF KINETIC PARAMETEPS, 131 INSTRUMENT COMDONENT AND SYSTEMS
DEVELOPMENT.

*HYORAULIC ANALYSIS + \#INSTRIJMENTATION, GENERAL + \#MATHEMATICAL STUDY + \#MEASUREMENT, GENERAL + *NRTS (NATIONAL REACTOR TEST STATION) + \#RFACTOR DYNAMICS

9-10473 PRESSURIZED WATER REACTOR (PWR) PROJECT. TECHNICAL PPOGRESS REPORT, OCTOBER 24, 1O64 JANUARY 23,1965

BETTIS ATOMIC POWER LABCRATORY, PITTSBUREH, PENNSYLVANIA

WAPD-MRP-111+. 98 PAGES, 10 FIGURES, 14 TAPLES, CFSTI, \$2.50 CY

BETTIS ATOMIC POWER LABORATORY PROGRESS REPORT, OCTOBER - JANUARY, 1065 . THIS REPORT IS ONE OF A SEPIES OF SUCH REPORTS ON THE SIJBJECTS ENUMEPAIED BELOW. NO FURTHER REDORTS IN THE SERIES WILL BE SUMMARIZEO UNLESS A SIGNIFICANT CHANGE IN THE PROGRAM OQ A SIGNIFICANT ITEM OF INTEREST TO NSIC IS REPORTED. TOPICS COVERED IN THIS RFPART ARE II) SHIPPINGPORT PWR OPERATING EXPER IENCE, (2) PLANT DEVFLOPMENT, (3) ANALYSIS OF PLANT DYNAMICS AND SAFETY LIMITS, (4) XENON OSCILLATIONS, AND (5) FEDAL OR FAILED FUEL ELEMENT IFTECTION SYSTEM.

\# INSTRUMENTATION, CENERAL + \#MATHEMATICAL STUDY + \#MODIFICATION, SYSTEM OR EOUIPMENT + *OPFRATINS EXPERIENCE + CONTROL SYSTEM, INGTRUMENTATION, DETFCTION FAILEU FIJEL ELEMENT + REACTOR OYNAMICS + REACTOP SAFETY SYSTEM + REACTOR, PRESSURIZED WATER + SHIPPINGPORT + XENON OSCILLATION

9-10504 QUARTERLY TECHNICAL PROGRESS REPORT - AEC UNCLASSIFIEO PROGRAMS - JANUARY TO MAPCH 19G5 ATOMICS INTERNATIONAL, CANOGA PARK, CALIFOPNIA

NAA-SR-11200+. 256 PAGES, FIGURES, TABLFS, APRIL 15, 1965 , CFSTI, \$6. CO CY

ATOMICS INTERNATIONAL PROGRESS REPOPT, JANUAPY TO MARCH, 1965 - THIS REPORT IS ONE OF A SERIES OF SUCH REPORTS ON THE SUBJECTS ENUMERATED BELOW. NO FURTHER REPORTS IN THE SEPIES WILL RE SUMMARIZED UNLESS A SIGNIFICANT CHANGE IN THF DROSRAM OD A SIGNIFICANT ITEM OF INTEREST TO NSIC IS REPORTED. TOPICS COVERED IN THIS RFPORT ARE FAST-REACTOD DEVEL DOMENT, BOILING STUDIES FOR SOOIUM REACTOR SAFETY, SODIUM FIRES AND CISSION PRODUCT P.ELEASE, FUFL ELEMFNT TRANSIENT HEATING, HALLAM FUEL SURVEILLANCE PROGRAM, MEASUREMENT OF DODPLEP. COEFFICIENTS, FAST-SPECTRUM DOPPLER MEASUREMENTS, FISSION-PPODUCT RETFNTION BY REACTOR COOLANTS, CONTINUOUS NEUTRON FLUX MONITOR AND ATMOSPHERIC DECONTAMINATION IN REACTOR ACCIDENTS.

* aIR CLEANING + \#OOPPLER COEFFICIENT + \#FILTER + \#FIRE + \#FISSION PROOUCT RELEASF, fiFNFRAL + -FISSION PRODUCT RETENTION + \#FUEL INTFGRITY + \#HALLAM + \#INSTRUMENTATION, IN CORE + \#REACTOR, FAST + *REACTOR, LIQUID METAL COOLED + \#SODIUM + REACTOR, GOAPHITF, MOOERATED

9-10508 SCHNEICER MF

ADVANCED SPACEBORNE DOSIMETRY INSTPUMENTATION

KIRTLAND AIR FORCE BASE, NEW MEXICO

AFWL-TDR-64-96 t. 16R PAGES, 80 FIGURES, 12 TARLFS, 15 RFFFRENCFS, DECFUBFR 1965

PROBLEM - MEASURE THE RADIATION DCSE TO PERSONNEL IN MANNEC SPACE FLIGHTS. ADDRDACH - A RASIC DOSIMETER SYSTEM WAS OEVELOPEO CONSISTING OF - TISSUE-EOUIVALENT ION C.HAMRFR, A LOGARTTHMIC ELECTROMETER, MAGNETIC AMPLIFIFRS, A DECADE SWITCHIN, UNIT, AND AN AUTOMITC CALIBRATION CIRCUIT FOR PULSING THE CHAMBER HIGH VOLTAGE. THE RASIC UNIT WAS ADAPTED FOR A GEMINI DOSIMETER, AIR FORCE SATELLITE DOSIMETER, ANF MANNEU-SPACE-SYSTEMS DORTABLE SURVEY DNSIMFTER. RESULTS-- PERFORMANCE UNDER EXTENSIVE TFSTING PQOGRAMS AND IN THF GEMINI GT-4 FLICHT IS PRESENTED.

\#DOSE MEASUREMENT, EXTERNAL + *INSTRUMENTATION CALIBRATION + \#INSTRUMENTATION, PADIATION MONITORING + * MONITOR, RADIATION, PERSONNEL + COMPARISON, THEORY AND EXPERIENCE + EQUIPMENT DESIGN + SPACECRAFT + TEST, INSTRUMENT RESPONSE

9-1050 ONALOG MONELS FOR HNPF CONTROL AND RROTECTION STUDIES ATOMICS INTERNATIONAL, CANUGA PARK

NAA-SR-8579 +. 69 PAGES, 16 FIGURES, 7 TABLES, 10 REFERFNCFS, JUNE 1964, CFSTI, \$1.50 CY

PROBLEM - DEVELOP A MODEL FOR THE CYNAMIC REHAVIOR OF THE HNPF. APPROACH - AN ANALOG COMPUTER MODEL WAS DEVELOPED FOR USE IN STUDIES OF THE CONTROL AND SAFETY SYSTEMS. THE MODEL INCLUTES - NEUTRON KINETICS, AFTERHEAT, CORE HEAT-TRANSFFR FOR AVERAGE CHANNEL AND HOT CHANNEL, PRIMARY-COOLANT HYDP.AULIGS TOR TORCLD AND CONVECTION FLOWS, HUU UKIVES, CUNTROL SYSTEM, AND PROTECTIVE SYSTEM. THE SIMULATIONS DF THE VARIOUS SECTIONS ARE DESCRIBEO IN DETAIL.

* ANALYTICAL MODEL + \#COMPUTER PROGRAM + \#COMPUTER, ANALOG + \#REACTOR DYNAMICS + CONTROL SYSTFM + HALLAM + MATHEMATICAL STUDY + REACTDR SAFETY SYSTEM + REACTOR, LIQUTD METAL COOLED

C-ICSI3 RUSSELL JA + KNOWLES DJ

DESCRIPTION OF FACILITY RADIATION AND CONTAMINATION ALARM SYSTEMS INSTALLED IN THE HIGH-FLUX ISOTOPE REACTOR FACILITY, BUILDING 7900

UAK RIDEE NATIONAL LABORATORY

ORNL-TM-1393 +. 21 PAGES, 8 FIGURES, 2 TAELES, DECEMBER 8, 1065, CF\$TI $\$ 1.00$ CY, \$0.50 MN

PROBLEM - TO MONITOR THE GAMMA-RADIATION LEVEL ANO AIR-CONTAMINATION LEVEL IN THE ENTIRE FACILITY. APPROACH - NINE MONITRONS CONTINUOUSLY MONITOR FOP GAMMA RAOIOACTIVITY. NIINE CONSTAPST AIR. HONITORJ CONTINUUUSL SAMHLE IHE AIR IN THE GUILOING FOR RAOIOACTIVE 
CATEGORY

$9-10513$ *CONTINUED*

(BETA-GAMMA) PARTICLES. ABNORMAL RADIATION LEVELS OR AIR ACTIVITY PRODUCE THE FOLLOHING ACTIONS - SOUND LOCAL ALARM, SOUND ALARM IN REACTOR-CONTROL ROOM, SDUND THE BUILDING-EVACUATION AIR HORNS, AND ACTIVATE AN ALARM IN THE LABORATORY EMERGENCY CONTROL CENTER.

EQUIPMENT DESIGN + INSTRUMENTATION, RADIATION MONITORING + MONITOR, RADIATION, AIR +

MONITOR, RADIATION, BACKGROUND + MONITOR, RADIATION, ENVIRONMENTAL + SYSTEM DESCRIPTION

9-10515 BYRD JS + DEXTER AH + GOOSEY MH + HUTTER CR + LEEP RW + WILSON JN

DESCRIPIION OF A TEMPERATURE MONITOR FOR LARGE REACTORS. PART IIT, PERFORMANCE SAVANNAH RIVER LABORATORY, DUPCNT

DP-944 +. 28 PAGES, 21 FIGURES, JANUARY 1965, CFSTI $\$ 2.00 \mathrm{CY}, \$ 0.50$ MN

PROBLEM - EVALUATE TWO ANALOG AND SCANNING DEVICES FOR A DIGITAL COOLANT-TEMPERATURE

MONITORING SYSTEM. THE DESIGN OF THE PROTOTYPE SYSTEM IS DESCRIBED IN EARL IER PEPORTS, DP-834 AND DP-836. APPROACH - TEST AND COMPARE THE PERFORMANCE OF THE RELAY-COMMUTATOR AND SOLID-STATE COMMUTATOR DESIGNS. RESULTS - THE RELAY-COMMUTATOR SYSTEM GAVE LESS NOISE AND HAD GREATER UNIFORMITY THAN DID THE SOLID-STATE COMMUTATOR, BUT THE LATTER GAVE CONSIDERABLY MORE OVERALL RELIABILITY. CONCLUSION - MONITORING SYSTEM SHOULD BE ADFOUATE FOR TEMPERATURF MONITORING IN A REACTOR, AND THE SOLID-STATE COMMUTATOR WILL BE USED IN PREFERENCE TO THE RELAY TYPE.

* Computer, digital + \#instrumentation, general + *instrumentation, tempfrature +

*TEST, SYSTEM OPERABILITY + CONTROL, COMPUTER + EQUIPMENT DESIGN + MONITORING SYSTEM

9-1056E WITHERS WT

ROD DRIVE VENTED AT BONUS TO RELIEVE RADIOLYTIC GASES, JUNE 15, 1966

PUERTO RICO WATER RESOURCES AUTHORITY

3 PAGES, JUNE 15, 1966 , DOCKET 115-4, ATOMIC ENERGY CLEARING HOUSE, 12(27), PAGES 21-23, (JULY 4, 1066)

SEVENTY-SEVEN PERCENT HYCROGEN AND 17 PERCENT OXYGEN WERE FOUND IN RACK-HOUSING O. THREE DAYS AT FULL POWER IS ENOUGH FOR THE MIXTURE TO PRODUCE A HYDROGEN-OXYGEN REACTION. VENTS WERE INSTALLED TO THE MAIN STEAM LINE hITH ORIFICES. TESTS SHOWED THAT A BROKEN VENT LINE WOULD NOT SIGNIFICANTLY AFFECT THE ROD-DROP TIME. SAFETY ANALYSIS DESCRIBED.

*CCNTROL ROD ORIVE + \#MODIFICATION, SYSTEM OR EQUIPMENT + *RADIOLYTIC GAS +

BONUS (BOILING NUCLEAR SUPERHEAT PROJECT) + EXPLOSION + OPERATING EXPERIENCE + REACTOR, SUPEPHEAT

9-10569 STUDLEY RV + BICKLEY JD

REACTOR ON-LINE COMPUTER INPUT SIGNAL SYSTEM

E. I. DU PONT DE NEMOURS AND COMPANY, SAVANNAH RIVER DLANT

DPSPIJ-66-30-3 + CONF-660408-2 + 34 PAGES, 17 FIGURES, TABLES, MARCH 1966, PRFSENTED AT INSTRUMENT

SOCIETY OF AMERICA SOUTHEASTERN CONFERENCE ANU EXHIBIT, AUGUSTA, GEORGIA, APRIL 19-21, 1966, CFSTI, S1.00 C.Y. SU. $50 \mathrm{MN}$

PROBLEM - COUPLE 3300 SENSOR OUTPUTS TO AN ON-LINE DIGITAL COMPUTER USED FOR MONITORING A LARGE PRODUCTION REACTOR. APPROACH - ELEVEN SIGNAL-CONDITIONING SYSTEMS ARE REOUIRED FOR THE LARGE NUMBER ANO VARIETY OF INPUT SIGNALS. A MATRIX SWITCHING SYSTEM, USING CROSSBAR SHITCHES, PROVIDES RANDOM SELECTION OF 3600 SIGNAL CIRCUITS FOR CONNECTION TO 36 COMPUTER INPUTS. RESULTS - THE INPUT SYSTEMS GIVE GOOD PERFORMANCE AND ACCURACY. THE SWITCHING SYSTEM HAS A LOW COST OF LESS THAN TEN DOLLARS PER SIGNAL. THE COMPLETE MONITORING SYSTEM IS DESCRIBED IN DPSPU 66-30-3 (NSIC NO. 10461 ).

*COMPUTER, DIGITAL + \#DATA PROCESSING + *INSTRUMENTATION, GENERAL + *MONITORING SYSTEM + INSTRUMENTATION, IN CORE + REACTOR, HEAVY WATER

9-10620 LEAMER RO + HANLEN DF + HAMILTON GN + TAYLOR EG

CRITICAL EXPERIMENTS PERFORMED WITH CLUSTERED AND UNIFORM ARRAYS OF RODDED ABSORBERS WESTINGHOUSE ELECTRIC CORPORATION, PITTSBURGH

WCAP-3269-39 t. 103 PAGES, 67 FIGURES, 15 TABLES, 2 REFERENCES, NOVEMBER 1965, CFSTI, \$4.00 CY, \$D. 75 MN

CRITICALITY EXPERIMENTS ON REACTIVITY WORTHS OF CLUSTERS AND UNIFORM ARRAYS OF AG-IN-CD ABSORBER RODS WERE MEASURED IN WATER-MODERATED URANIUM OXIDE CORES OF LOW ENRICHMENT. EXPER IMENTAL - FACTOR S INCLUDED ENRICHMENT, LATTICE PITCH, DIAMETER OF POISON AND FUEL RODS, AND ABSORBER-ROD-CLADDING THICKNESS. FUEL INCLUDED STAINLESS-STEEL-CLAD FUEL RODS OF 2.7 , 3.7, AND 5.7 PERCENT ENRICHMENTS, AND ZIRCALOY-4-CLAD RODS OF 2.72 PERCENT ENRICHMENT.

*CONTROL ROD WORTH + \#CRITICALITY EXPERIMENT + REACTOR, HATER + URANIUM OXIDE

9-10709 EICKELPASCH N

NUCLEAR SAFETY IN THE DESIGN OF POWER REACTORS

NUCLEAR ENERGY AND RADIATION PROTECTION GROUP, GERMANY, TECHNISCHER UBERWACHUNGSVEREIN BAYERN

ORNL-TR-930 +. 14 PAGES, 2 TABLES, 2 FIGURES, TRANSLATED FROM ATOMKERNENERGIE 10 (5-6)- $187-190$ (1965)

THE MOST IMPORTANT SAFETY FEATURES OF POWFR REACTORS ARF LISTED, AND THEIR MECHANISM OF ACTION

IS EXPLAINED. THE IMPORTANCE OF THF REACTIVITY COEFFICIENTS IS ILLUSTRATED IN PARTICULAR WITH THE EXAMPLE DF SPECIAL REACTOR ACCIDENTS. A CONCEPT OF THE ORDER OF MAGNIIUUE OF THE SAFETY FACTORS CITED IS TO BE ESTABLISHED. 
S-1070S \#CONTINUED*

FAILURE, FUEL ELEMENT + FUEL MELTOOWN + GERMANY + REACTIVITY COEFFICIENT + REACTTVITY, EXCESS +

REACTOR, BOILING WATER + REACTOR, PRESSURIZED WATER + SAFETY PRINCIPLES AND PHILOSOPHY

9-10714 DIETZ KA + MELLOWEW + PACE NE

QUARTERLY TECHNICAL REPORT - STEP PROJECT - JULY 1964-SEPTEMBER 1964 - OCTORFR 1964-DECEMBEP 1964

PHILLIPS PETROLEUM COMPANY, IDAHO FALLS, IDAHO

IDO-17077 +. 219 PAGES, 154 FIGURES, 29 TARLES, 37 REFERENCES, MARCH 1966, CFSTI, \$6. П. CY, \$1.25 MN

BRIEF OISCUSSION OF ANALYSIS OF SNAPTRAN $2 / 10 A-3$ FUEL WATER-IMMEPSION TEST. SNAPTRAN $2 / 1 C A-1$ NON-DAMAGE, STEP-REACTIVITY-INSEPTION, TRANSIENT TESTS. EXDERIMENTAL MEASUREMENTS AND INSTRUMENTATION. TESTS INITIATED FROM AMBIENT TEMPERATURES OF LESS THAN IOT F. DIGITAL COMPUTER CALCULATIONS OF THE POWFQ AND ENERGY RESPONSE OF THF SNAPTRAN $2 / 1 D A-1$ PEACTOR DURING AN IMPULSE REACTIVITY INSERTION. PROPOSED SNAPTQAN 2/10A-2 DESTRUCTIVE TEST.

* SNAPTRAN (SNAP TRANSIENT REACTOR TEST SERIES) + COMPUTER, DIGITAL + REACTOR TRANSIENT + TFST, DFSTRUCTIVE

9-1071E MAGNUSUN UW

STATIC ANO OYNAMIC TPANSPORT CALCULATIONS FOR PULSED-NEUTRON EXPERIMENTS WITH SOHERES OF URANYL NITRATE SULUTION

OAK RIDGE NATIONAL LABORATORY, OAK RIDGE, TFNNESSEE

ORNL-TM-1213 +. 15 PAGES, I FIGURE, 3 TABLES, APRIL 26, 1966, CFSTI, \$1.D! CY, S1J. DLI MN

IN STATIC REACTOR CALCULATIONS, THE NEUTRON BALANTE IS MAINTAINED BY ACDING NEUTRONS AT FISSION ENERGIES. IN OYNAMIC REACTOR CALCULATIONS, THE BALANCE MAY RE MAINTAINFD BY ADOING NEUTRONS WHICH HAVE A SPECTRUM PROPORTIONAL TO THE FLUXES AND INVERSELY PPOPORTIONAL TO THE NEUTRON VELOCITY. SINCE THE NEUTRONS ADDED IN THE TWO METHODS HAVE UNEQUAL IMPORTANCFS, THE REACTIVITIES ARE UNEQUAL. CALCULATIONS FOR APPLICATION TO PULSED-NFUTRON EXPERIMENTS ON

SPHERES OF URANYL NITRATE SOLUTION.

*PULSED NEUTRON TECHNIQUE

9-10717 FOULKE LR + GYFTOPOULOS EP

THE USE OF OSCILLATION TESTS TO JNVESTIGATE FLUX TILTING

MASSACHUSETTS INSTITUTE OF TECHNCLOGY, CANBRIOGE, MASSACHUSETTS

4 PAGES, I FIGURE, 6 REFERENCES, $1966^{\circ}$ ANNUAL MEETING AMERICAN NUCLEAR SOCIETY, DFNVER, COLORADO, JUNF $20-23,1966$, TRANSACTIONS OF AMERICAN NUCLEAR SOCIETY O(1)- 271

SMALL-AMPLITUDE OSCILLATION TESTS CAN BE USED TO MEASURE CEPTAIN MODAL EIFENVALUES, WHICH MAY BE USED TO INFER THE SUSCEPTIBILITY OF A POWER RFACTOR TO FLUX TILTING. THE PROCEDURE HAS BEEN APPLIED ROTH TO COMPUTER EXPERIMENTS AND TO EXPERIMENTAL DATA FROM THE NORA REACTOR, WITH SATISFACTORY RESULTS. IT IS SUGGESTED THAT THE OSCILLATION TECHNIQUE BE USED TO MONITOR CHANGING SPACE-TIME CHARACTERISTICS OF A REACTOR CORF DUPING ITS LIFETIME.

*FLUX TILT + *OSCILlaTOR, REACTIVITY + NORWAY + SPACE DEDENDENT DYNAMICS

9-10851 SAKATAH + SCHMID LC

SAFETY POD INTERACTION IN THE PRCF

RATTELLE-NOP.THWEST, RILHLANÚ, WASHINGTON

BNWL-130+. 18 PAGES, AUGUST, 1965, CFSTI, \$1.00 CY, \$ก..50 MN

IN THE D2O-MODERATED PLUTONIUM RECYCLE CRITICAL FACILITY (PRCF), THE DVERAGE WOPTH DF A SAFETY ROD IS 26.1 MK, AND THE WORTH OF ALL THREF RODS INSERTED SIMULTANEOUSLY IS 34 PERCENT LARGER (ANTISHADOWING EFFECT) THAN THE SUMS OF THE RODS. THE INTERACTION EFFECTS WEPE CALCULATED RY THE METHOD OF NORDHEIM AND SCALETTAR AS A FUNCTION OE RADIUS, AND COMPARED WITH THE

EXPERIMENTAL RESULTS. A 31 PERCENT ANTISHADOWING EFFECT IS CALCULATED FOR ARADIUS OF 16 IN., AND THE EFFECT DEPENDS ON THE LOCATION OF THE RODS IN THE C.ORE.

CONTROL ROD INTERACTION + HEAVY HATER + PLUTONIUM

9-10855 HAEGGBLOM H

THEORETICAL WORK FOR FAST ZERO-POWER REACTOR FRO

AKTIEBOLAGET ATOMENERGI, STOCKHOLM, SWEDEN

AE- 104 +. 45 PAGES, TABLES, FIgURES, REFEPENCES, AUGUST, 1065 , DEP/MN

FOR THE FRO REACTOR, CALCULATIONS OF CONTROL ROD WORTH, PROMPT NEUTRON LIFETIME, EFFECTIVE DEL AYED NEUTRON FRACTION AND OTHFR ITEMS. USE OF CAQLSON CODES IN SPHERICAL AND T.YLINDPICAL GEOMETRY, AND OF PERTURBATION THEORY AND VARIATIONAL CALCULUS.

\#REACTOR, FAST + \$SWEDEN + CCNTROL ROD WORTH + DELAYED NEUTRON + PROMPT NEIJTRON LIFETIME

9-10877 FIRST SIIPPI.FMENT TO PRELIMINARY SAFETY ANALYSIS. INDIAN POINT NUCLEAD. GFNERATING UNIT NO. 2. CONSOLICATED EDISON COMPANY OF NEW YORK

2 PAGES OF FIRST SUPPLEMENT TO PRELIMINARY SAFETY ANALYSIS. INDIAN POINT NUCLEAR GENEPATING UNIT NO. 2 . MARCH 31,1966 , DOCKE T NO. 50-247, PDR

QUESTION 2, CRITERION 7 - OF THF 53 MAGNETIC-LATCH-DRIVFN RODS, HALE $\triangle P E$ FULL OIIT FOR POWFP OPERATION, AND REST LIMITED IN SPEED BY DRIVE MOTOR. BORON SIIIM CONTROL THUS LIMITS

$$
\text { ACCESSION NUMBER 9-10709 TO 9-10877 }
$$


9-10877 \#CONTINUED*

REACTIVITY AVAILABLE FOR RAPID INSERTION. CONTROL-ROD EJECTION IS CONSIDERED INCREDIBLE.

\# ACCIDENT, CONTROL ROD WITHDRAHAL + \#DESIGN CRITERIA + \#REGULATION, AEC *

* SAFEgUARDS REPORT, RESPONSE TO AEC QUESTIONS + INDIAN POINT II + REACTOR, PRESSURIZED WATER

9-10878 FIRST SUPPLEMENT TO PRELIMINARY SAFETY ANALYSIS. INDIAN POINT NUCLFAR GENERATING UNIT NO. 2. CONSOLIOATED EOISON COMPANY OF NEW YORK

1 PAGE OF FIRST SUPPLEMENT TO PRELIMINARY SAFETY ANALYSIS. INDIAN POINT NUCLEAR GENERATING UNIT NO. 2, MARCH 31,1966 , DOCKET NO. 50-247, PDR

QUESTION 2, CRITERION 8 -- MAXIMUM AVAILABLE EXCESS REACTIVITY IS 0.3O5, COLD C.LEAN. SHUTDOWN GROUP OF ROOS MAKE REACTOR K-EFFECTIVE EQUAL TO D.99 IN HOT ZERO-POWER FROM HOT POWER

CONDITION. WITH MOST WORTHWHILE ROD STUCK OUT, CHEMICAL SHIM KEEPS REACTOR SHUT DOWN.

\#DESIGN CRITERIA + \#REGULATION, AEC + \#SAFFGUARDS REPORT, RESPONSE TO AEC QUESTIONS + \#SHUTDOWN MARGIN + INDIAN POINT II + REACTOR, PRESSURI ZED WATER

9-10879 FIRST SUPPLEMENT TO PRELIMINARY SAFETY ANALYSIS. INDIAN POINT NUCLEAR GENERATING UNIT NO. ? CONSOL IOATED EDISON COMPANY OF NEW YORK

1 PAGES OF FIRST SUPPLEMENT TO PRELIMINARY SAFETY ANALYSIS. INOIAN POINT NUCLEAR GENERATING UNIT NO. 2 , MARCH 31 , 1966, DOCKET NO. 50-247, PDR.

QUESTION 2, CRITERION 9-- BACKUP REACTIVITY IS INDEPENDENT OF CONTROL PROVISIONS, AS POWER TO ROD MECHANISIMS SHUT OFF ON SCRAM, REGARDLESS OF CONTROL SIGNALS. BORIC ACIO INJECTION WITH ONE PUMP. WILL SHUT REACTOR DOWN IN 15 MIN WITH NO RED INSERTION, AND IN ANOTON MAY THEN BE INJECTED FOR COLD SHUTDOWN.

* DESIGN CRITERIA + \#REgULATION, AEC + \#SAFEgUARDS REPORT, RESPONSE TO AEC QUESTIONS +

* SHUTOOWN SYSTEM, SECONDARY + CHEMICAL SHIM + INDIAN POINT II + REACTOR, PRESSURIZED WATER

9-10882 FIRST SUPPLEMENT TO PRELIMINARY SAFETY ANALYSIS. INDIAN POINT NUCLEAR GENERATING UNIY NO. 2 CONSOLIDATED EDISON COMPANY OF NEW YORK

1 PAGE OF FIRST SUPPLEMENT TO PRELIMINARY SAFETY ANALYSIS. INDIAN POINT NUCLEAR GENERATING UNIT NO. 2 ,

MARCH 31,1966, DOCKET NO. 50-247, PDR

QUESTION 2, CRITERION 12 -- ROD-CLUSTER. CONTROL ASSEMRLIES ARE FULLY GUIDED AND FLEXIBLE.

TESTS SHOW NO FUNCTIONAL IMPAIRMENT WITH MISALIGNMENTS IN EXCESS OF MAXIMUM POSSIBLE.

\#CONTROL ROC + \#DESIGN CRITERIA + \#REGULATION, AEC + \#SAFEgUARDS REPORT, RESPONSE TO AEC QUESTIONS + INDI AN POINT II + REACTOR, PRESSURI ZED WATER

9-10884 FIRST SUPPLEMENT TO PRELIMINARY SAFETY ANALYSIS. INDIAN POINT NUCLEAR GENERATING UNIT NO. 2. CONSOLIDATED EDISON COMPANY OF NEW YORK

2 PAGES OF FIRST SUPPLEMENT TO PRELIMINARY SAFETY ANALYSIS. INDIAN POINT NUCLEAR EENEPATING UNIT NO. 2, MARCH 31, 1966, DOCKET NO. 50-247, PDR

QUESTION 2, CRITERION $14-$ PERIODIC BORON CONCENTRATION SAMPLES ARE TAKEN AT POWER AND DURING SHUTDOWN. DURING REFUELING, BF3 MONITORING GIVES AN AUDIBLE INDICATION OF DECREASING SHUTDOWN MARGIN. THE MAXIMUM DILUTION RATE (580 PPM/HR) GIVES AMPLE TIME FOR CORRECTIVE ACTION.

*CHEMICAL. SHIM + \#DESIGN CRITERIA + \#REGULATION, AEC + \#SAFEFUARDS REPORT, RESPONSE TO AEC QUESTIONS + INCIAN POINT II + INSTRUMENTATION, NUCLEAR + REACTOR, PRESSURIZED WATER

9-10885 FIRST SUPPLEMENT TO PRELIMINARY SAFETY ANALYSIS. INDIAN POINT NUCLEAR GENERATING UNIT NO. 2 CONSOLIDATED EDISON COMPANY OF NEW YORK

3 PAGES OF FIRST SUPPLEMENT TO PRELIMINARY SAFETY ANALYSIS. INDIAN POINT NUCLEAR GENERATING UNIT NO. 2, MARCH 31 , 1966, DOCKET NO. 50-247, PDR

QUESTION 2, CRITERION 15 -- COINCIDENCE ALLOWS ON-LINE TESTING, USING SIMULATED SIGNALS, OF SCRAM CHANNELS UP TO THE THREE RELAYS PROVIDING TWO-OF-THREE MATRICES FOR TRIPPING THE TWO SCRAM BREAKERS. ALSO; ENGINEERED SAFEGUARDS. CORE IS COUPLED SO THAT ALL OUT-OF-CORE INSTRUMENTS WILL SEE A ROD EJECTION ACCIDENT.

* COUPLED CORES + \#DESIGN CRITERIA + \#INSTRUMENTATION, COINCIDENT + \#REGULATION, AEC + * SAFEgUARDS REPORT, RESPONSE TO AEC QUESTIONS + \#TEST, SYSTEM OPERARILITY + EMERGENCY SYSTEM + PLANT PROTECTIVE SYSTEM

9-10886 FIRST SUPPLEMENT TO PRELIMINARY SAFETY ANALYSIS. INDIAN POINT NUCLEAR GENERATING UNIT NO. 2 CONSOLIDATED EDISON COMPANY OF NEW YORK

2 PAGES OF FIRST SUPPLEMENT TO PRELIMINARY SAFETY ANALYSIS. INDIAN POINT NUCLEAP. GENERATING UNIT NO. 2 ,

MARCH 31,1966 , DOCKEY NO. 50-247, PDR

QUESTION 2, CRITERION 16 -- LOSS OF ELECTRIC POWER CAUSES ROD INSERTION, EITHER DIRECTLYY OR THROUGH THE INSTRUMENTS. COMPONENTS ARE DESIGNED SO THAT ACCIDENT WILL NOT INTERFERE WITH FUNCT IONING . 
CATEGORY O

NUCLEAR INSTRUMENTATION, CONTROL, AND SAFETY SYSTEMS

Q-1088E \#CONTINUED*

\#DESIGN CRITERIA + *LOSS OF POWFR + \#REGULATIDN, AEC + \#SAFCGUARTS REPORT, PFSPONSF TO AFC OUFSTIONS +

INOIAN POINT II + INSTRUMENTATION, GENERAL + REACTOR, PRESSURIZED WATER + SAFE FAILURF T.RITEPION

9-10891 FIRST SUPPLEMENT TO DRELIMINARY SAFETY ANALYSIS. INDIAN POINT NUCLEAR GENERATING IJNIT NO. ?. C.ONSOI. IDATEO EDISON COMPANY DF NEW YORK

1 PAGE OF FIRST SUPDLEMENT TC DRELIMINARY SAFETY ANALYSIS. INDIAN POINT NUCLEAR GENERATING UNIT NO. 2,

MARCH 31, 1966, DOCKET NO. 5ח-247, PDR

QUESTION 2, CRITERION $21-$ TWO OF THE THREE DIESELS PROVIDE ADEQUATE POWER FOR ENGINEERED

SAFEGUARDS. VITAL INSTRUMENTS AND CONTROLS ARE SUPPLIED EROM $125-V$ DC BATTFRIES.

*CESIGN CRITERIA + *EMEPEENCY POWER, ELECTRIC + *SAFEGUARDS REPORT, RESPONSE TD AEC DUESTIONS + ELECTRIC POWER, VITAL + INDIAN POINT II + REACTOD, PRESSURIZED WATER + REGULATION, AEC

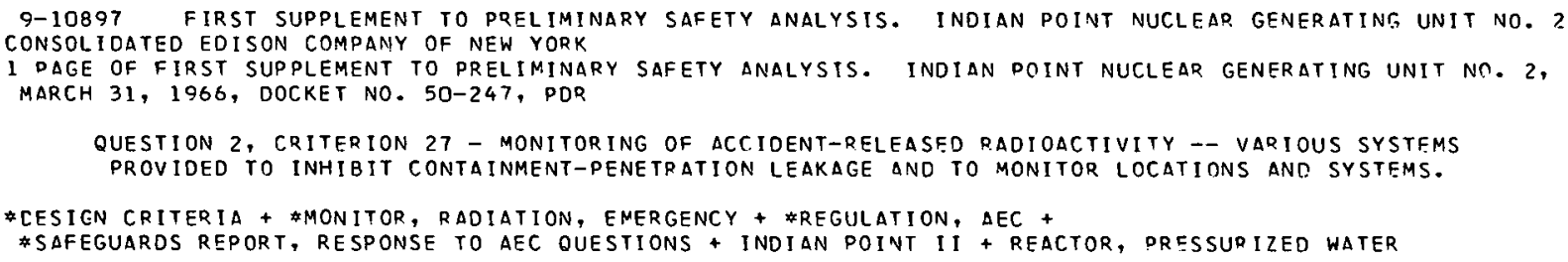

9-10897 FIRST SUPPLEMENT TO PRELIMINARY SAFETY ANALYSIS. INDIAN POINT NUCLEAR GENERATING UNIT NO. ? CONSOLIDATED EDISON COMPANY OF NEW YORK

1 DAGE OF FIRST SUPPLEMENT TO PRELIMINARY SAFETY ANALYSIS. INDIAN POINT NUCLEAR GENERATING UNIT NO. 2 , MARCH 31 , 1966, DOCKET NO. 50-247, POR

QUESTION 2, CRITERION 27 - MONITORING OF ACCIDENT-RELEASFD RAOIOACTIVITY -- VARIOUS SYSTFMS PROVIDED TO INHIBIT CONTAINMENT-PENETRATION LEAKAGE AND TO MONITOR LOCATIONS AND SYSTEMS.

*CESIGN CRITERIA + \#MONITOR, RAOIATION, EMERGENCY + \#REGULATION, $\triangle E C$ +

* SAFEgUARDS REPORT, RESPONSE TO AEC QUESTIONS + INDIAN POINT II + REACTOR, PRESSURIZEO WATER

5-1C928 FIRST SUPPLEMENT TO PRELIMINARY SAFETY ANALYSIS. INOIAN POINT NUCLEAR GFNERATING UNIT NO. 2 CONSOLIDATED EDISON COMPANY OF NEW YORK

1 PAGE CF FIRST SUPPLEMENT TO PRELIMINARY SAFETY ANALYSIS. INDIAN POINT NUCLEAR GENERATING UNIT NO. 2, MAP.C.H 31 , 1966, MOR.KFT NO. $5 \Pi-247$, PQR

QUESTION IOJ - DESIGN CRITERIA AND JUSTIFICATION, HOW FULFILLED, $\triangle N D$ TEST METHOD -- FOR THE OPERATIONAL RELIABILITY OF REACTOR SAFETY, CONTAINMENT ISOLATION, AND FNFINCERED SAFET,UARDS SYSTEM, THE DESIGN INCLUDES FAIL-SAFE AND/OR REDUNDANCE, ETC. ANSWERS ARE DISCUSSED IN QUESTION 2 ICRITERIA $15,22,231$, QUESTIONS 6 THROUGH 10.

* OESIGN CRITERIA + *ENGINEERED SAFEgUARD + *SAFEgUARDS RFPDRT, RESPONSE TO AEC DUESTIONS + INDIAN TOINT II + REACTOR, FRLSSURIZCD HATER + REDUNDANCE + SAFE FAILURE CRITERION

G- 10935 MCVEAN RL + GOIN Rh + WEITZREPG A + LERIDON A

CRITICAL $\triangle S S E M B L Y$ MOCKUP OF THE SEFGQ REACTOR IN ZPR-?

ARGONNE NATIONAL LABORATORY, IDAHO + GENERAL ELECTRIC COMPANY, VALLET,ITOS ATOMIC, POWFR LABORATODY + CENTRF NUCLEAIRE DE CADARACHE, ERANCE

1 PAGE, 1 TABLE, 5 REFERENCES, ANS TRANSACTIONS, 9(1), PAGE 226 (JUNE, 1966), AMEPICAN NUCLEAR SOCIETY ANNUAL MEETING, DENVER, COLORADO, JUNE 20-23, 1966

AVERAGE CONTROL-ROD WORTH IS 117 CFNTS. ONE HUNDRED, THIRTY-NINF CENTS REACTIVITY REDIICTION DUE TO HALF-INCH ELONGATION OF FUEL RODS. MEASUREMENTS OF CENTRAL REACTIVITY WORTHS, DOPPLFR [FFECT, AND ROSSI ALDHA.

*SEFOR (SOUTHWEST EXP. FAST OXIDE REACTOR) + \#ZPR III (ANL TERO POWER. PEACTOR) + CONTROL ROD WORTH + CRITICAL ASSEMBLY FACILITY + DOPPLER EFFECT + FUEL EXPANSION COEFFICIENT + REACTIVITY EFFECT + REACTOR, BREEDER + REACTOR, FAST + ROSSI ALPHA

S-1C937 REYNOLDS AB + STEWART SL

ANALYSIS OF SEFOR MOCKUP IN ZRR-II

GFNFKAL. ELETIRIE: COMPANY, SAN JOSE

2 PAGES, 13 REFERENCES, ANS TRANSACTIONS, $9(1)$, PAGES 227-228 (JUNE, 1966), $\triangle M E R I C A N$ NUCLEAR SOCIETY

ANNUAL MEETING, DENVER, COLCRADO, JUNE 20-23, 1966

COMPUTED REACTIVITY REDUCTION DUE TO HALF-INCH ELONGATION OF FUEL - 130 CENTS COMPARED WITH A MEASURED VALUE OF 140. COMPUTED AVERAGE CONTROL-ROD WORTH - 127 CENTS, COMPARED WITH 131 CENTS, MEASURED.

*SEFOR (SOUTHWEST EXP. FAST OXIDE REACTOR) + \#ZPR III (ANL ZERO POWER REACTOR) + COMPUTER, DIGITAL + CONTROL ROD WORTH + CRITICAL ASSEMBLY FACILITY + FUEL EXDANSION COEFFICIENT + REACTOR, BRFFDFP + REACTOR, TAST

S- 10944 SHOMORB + HAMILTON GN + LEANER PD

ANALOG COMPUTER TECHNIQUES IN CRITICAL FXOERIMENTS

WESTINGHOUSE ELECTRIC CORPORATION, ATOMIC POWER DIVISION

1 PAGE, 1 FIGURE, 2 REFERENCES, ANS TRANSACTIONS, 9(1), PAGE 261 (JUNE 1966), AMERICAN NUCLEAR SOCIETY

ANNUAL MEETING, DENVER, COLORADO, JUNE 20-23, 1966

EXPERIMENTS AT THE WESTINGHOUSE REACTOR EVALUATION CENTER (WRECI WERE PERFORMED ALMOST

EXCLUSIVELY USING ON-LINE ANALOG COMPUTERS FOR THE MEASUREMENT OF BOTH POSITIVE AND NEGATIVE

VALUES OF REACTIVITY. THIS METHOD OF REACTIVITY MEASUREMENT WAS USED IN ROTH HEAVY-WATER-

AND LIGHT-WATER-MODERATED SYSTEMS AND WITH CORES CONTAINING BOTH HIGHLY ENRICHED AND

ACCESSICN NUMRED $9-10886$ TO $9-10944$ 
CATEGORY

NUCLEAR INSTRUMENTATION, CONTROL, AND SAFETY SYSTEMS

9-10944 *CONTINUED*

LOW-ENR ICHED URANIUM FUEL, AND RECENTLY WITH SYSTEMS CONTAINING URANIUM DIOXIDE AND PLUTONIUM/URANIUM DIOXIDE FUEL. A UNIQUE CIRCUIT WAS DESIGNED AND BUILT AT THE WREC TO IMPROVE THE ACCURACY, GAIN AND READ-OUT TIME ON THE RECORDER.

9-10945 COHN CE

FURTHER USE OF AN ON-LINE COMPUTER IN REACTOR PHYSICS EXPERIMENTS

ARGONNE NATIONAL LABORATORY

1 PAGE, 3 REFERENCES, ANS TRANSACTIONS, 911), PAGE 262 (JUNE 1966), AMERICAN NUCLEAR SOCIETY ANNUAL MEETING, DENVER, COLORADO, JUNE 20-23, 1966

DIGITAL COMPUTER FOR ON-LINE DATA REDUCTION IN CRITICAL-ASSEMBLY EXPERIMENTS USED FOR REACTOR NOISE MEASUREMENTS, USING THE CROSS-CORRELATION TECHNIQUE TO REDUCE REQUIREMENTS FOR DETECTOR EFFICIENCY. A STUDY LOOKING TOWARD THE AUTOMATIC CONTROL OF CRITICAL EXPERIMENTS WAS STARTED WITH EXPER IMENTS ON THE STARTUP OF THE ZPR-9 FAST CRITICAL. UNDER COMPUTER CONTROL, THF LAST CONTROL DRAWER IS INSERTED TO TAKE THE REACTOR THROUGH CRITICAL TO A DEMAND PFRIOD AND UP TO A DEMAND POWER.

*ZPR IX (ANL ZERO POWER REACTOR) + COMPUTER, DIGITAL + CRITICAL ASSEMBLY FACILITY +

CRITICALITY EXPERIMENT + NOISE ANALYSIS + REACTOR, FAST + SHUTDOWN MARGIN

9-10946 STANLEY L + HOLLAND LK + HOLLADAY RL

DEVELOPMENT OF A CONTROL-ROD WORTH MINIMIZER

GENERAL ELECTRIC COMPANY, SAN JOSE, CALIFORNIA + CONTROL DATA CORPORATION

1 PAGE, ANS TRANSACTIONS 911), PAGE 265 (JUNE, 1966), AMERICAN NUCLEAR SOCIETY ANNUAL MEETING, DENVER, COLORADO, JUNE $20-23,1966$

THE ROD-WORTH MINIMIZER (RWM) WAS DEVELOPED FOR INCORPORATION INTO THE NUCLEAR POWER PLANT TO SIGNIFICANTLY REDUCE THE PROBABILITY OF REACTOR-VESSEL DAMAGE DUE TO SUDDEN UNEXPECTED WITHDRAWAL OF ANY CONTROL ROO FROM THE CORE. THE RWM ENSURES THAT ALL CONTROL RODS IN THE CORE DO NOT EXCEED A PREDETERMINED ROD-WORTH LIMIT BY APPROPRIATF RESTRICTIONS ON CONTROL-ROD-ORIVE MOVEMENTS.

\#CONTROL ROD, WORTH + ENGINEERED SAFEGUARD + REACTOR, BOILING WATER

S-10955 WILLOUGHBY W + NATH RJ + WYKE TF

COMPARISON OF ANALYTICAL AND EXPERIMENTAL LIFETIME AND CONTROL ROD WORTHS FOR CVTR

CAROL INAS-VIRGINIA NUCLEAR POWER ASSOCIATION + WESTINGHOUSE ELECTRIC CORPORATION, ATOMIC POWER DIVISION 2 PAGES, 1 FIGURE, 1 TABLE, 5 REFERENCES, ANS TRANSACTIONS, 9(1), PAGES $276-277$, (JUNE 1966), AMERICAN

NUCLEAR SOC IETY ANNUAL MEETING, DENVER, COLORADO, JUNE 20-23, 1966

THE RESULTS OF ANALYTICAL AND EXPERIMENTAL DETERMINATIONS OF ROD GROUP WORTHS ARE GIVEN.

*CCNTROL ROD WORTH + \#CVTR (CAROLINAS VIRGINIA TUBE REACTOR) + COMPUTER, DIGITAL + FUEL BURNIJP + REACTOR, HEAVY WATER + REACTOR, PRESSURE TUBE

S $\rightarrow 10960$ LAWRENCE BR

DETERMINATION OF THE POWER VS REACTIVITY FREQUENCY RESPONSE FUNCTION OF A POWER REACTOR, WITH APPLICATION TO THE HIGH FLUX ISOTOPE REACTOR

OAK RIDGE NATIONAL LABORATORY, OAK RIDGE, TENNESSEE

ORNL-TM-1471 +. 21 PAGES, 2 TABLES, 2 FIGURES, 5 REFFRENCES- JULY 5, 1966, CFSTI, \$2.01 CY, \$O.50 MN

A NUMERICAL TECHNIQUE IS PRESENTED FOR CALCULATING THE POWER VS REACTIVITY-FREQUENCY-RESPONSE FUNCTION OF A POWER REACTOR. THE APPROACH AVOIDS THE EVALUATION OF TRANSFER FUNCTIONS IN AN ALGEBRAIC FORM. THE SPACE-INDEPENDENT REACTOR-KINETICS MODEL IS USED IN CONJUCTION WITH A GENERAL SET OF FIRST-ORDER EQUATIONS TO REPRESENT THE THERMAL PERFORMANCE OF THE REACTOR. RESULTS OBTAINED BY APPLYING THE TECHNIQUE TO THE OAK RIDGE HIGH FLUX ISOTOPE REACTOR INDICATE THAT THE REACTOR OPERATING AT FULL POWER OF 100 MW WITH THE FLUX CONTROLLER OFF HAS A FREQUENCY RESPONSE WHICH PEAKS BROADLY'AT IO CPS WITH A PARTIAL-DERIVATIVE-OF-P OVER P-SUPER SCRIPT-ZERO VS PARTIAL-DERIVATIVE-OF-K OVER K-SUPERSCRIPT-ZERO GAIN OF 140.

*HFIR (HIGH FLUX ISOTOPE REACTCR) + REACTOR OYNAMICS + REACTOR, RESEARCH + PEACTOR, TEST + TRANSFER FUNCTION

9-10978 REACTOR PHYSICS EFFORTS REQUIRED IN SUPPORT OF THE FAST BREEDER DEVELOPMENT PROGRAM OIVISION OF REACTOR DEVELOPMENT AND TECHNOLOGY, U.S. ATOMIC ENERGY COMMISSION, WASHINGTON, D. C. WASH-1066 t. 41 PAGES, 3 TABLES, JANUARY 1966, CFSTI, \$3.00 CY, \$0.50 MN

SCATTERED THROUGHOUT THE REPORT ARE PEFERENCES TO SOOIUM COFFFICIENT, DOPPLER COEFFICIENT, CONTROL SYSTEM, AND DYNAMICS OF LARGE SYSTEMS.

*CONTROL SYSTEM + \#SODIUM COEFFICIENT + CRITICAL ASSEMBLY FACILITY +

EBR I AND I.I (EXPERIMENTAL BREEDER REACTORS) + FERMI + REACTOR OYNAMICS + REACTOR, RREEDER +

REACTOR, FAST + REACTOR, FAST + REACTOR, LARGE + REACTOR, LIOUID METAL COOLED +

SEFOR (SOUTHWEST EXP. FAST OXIDE REACTOR) + SPACE DEPENDENT DYNAMICS +

ZPPR (ANL ZERO POWER PLUTONIUM REACTOR) + ZPR III (ANL ZERO POWER REACTOP) +

ZPR IX (ANL ZERO POWER REACTOR) + ZPR VI (ANL ZERO POWFR REACTOR) 


\author{
CATEGORY 9
NUCLEAR INSTRUMENTATION, CONTROL, ANO SAFETY SYSTEMS
}

S-1100E JAKEMAN D

PHYSICS OF NUCLEAR REACTORS. CHAPTER 9 - REACTIVITY CHANGES AND CONTROL

356 PAGES, THE ENGLISH UNIVEPSITIES PRESS LTD (1966)

CHAPTER 9 CONTAINS A FEW TOPICS OF SAFETY INTEREST. THESE INCLUDE REACTIVITY EFFECTS OF

TEMPFRATURE IN THERMAL REACTOPS, RFACTIVITY EFFECTS IN FAST REACTOPS DUJE TO FUEL FXPANSICN, SODIUM VOIDS AND DOPPLER EFFECT, CONTROL METHODS, THEORY OF CONTPOL RODS, DND REACTOR

KINETICS.

CONTRCL ROD + CONTROL, GENERAL + DOPPLER EFFECT + FUEL EXPANSION COEFFICIENT + REACTOR DYNAMICS + REACTOR, FAST + REACTOR, THERMAL + SCDIUM COEFFICIFNT + TEMPERATURE COEFFICIFNT

9-11043 MCEWEN LH

TVISR CONTROL BLADES TO USF ZIRCALOY INSTEAD OF STAINLESS SIEEL

CENERAL ELCCTRIC COMPANY, SAN JOSE, CALIFORNIA

1 PAGE, JULY 12, 1966, DOCKET 50-183, ATOMIC ENERGY CLEARING MOUSE, 12(31), PAGE 17, (AUGUST 1, 1966)

CHANGES INCLUDE DIFFERENT DESIGN AND USE OF ZIRCALOY INSTEAO OF STAINLESS STEEL IN THE FDUP GRAY CONTROL ROOS LOCATED IN THE CENTFR OF THE CORE.

\#CONTROL ROD, SHIM SAFETY + REACTOR, SUPERHEAT + VESR (VALLECITOS EXP. SUPERHEAT REACTOR-ESADA) + ZIRCALOY

S-11049 WOLTER EE

ELK RIVER CONTROL ROD DAMAGE AND VESSEL INSPECTION

RURAL COOPERATIVE POWER ASSOCIATION, ELK RIVER, MINN.

2 PAGES, JUNE 22, 1966 , DOCKET 115-1, ATOMIC ENERGY CLEARING HOUSE, 12(28), PAGFS 18-19, (JULY 11, 1966)

THE APRIL 1966 INSPECTION SHOWER CRACKS AT SHIM-ROD RIVETS AND CRACKS IN RERULATING ROD MATERIAL, ALL OF BORON-STAINLESS-STEEL CONSTRUCTION. BORON CARBIDF RODS $\triangle R E$ DEDLACING SOME RODS. DYE-PENETRANT INSPECTION OF THE REACTOR VESSEL SHOWEO SHALLOW CRACKS JUST BELOW HEAD FLANGE IN MARTENSITIC WELDING. CRACKS SHOULD NOT PRESENT A PROBLEM. STRESSED U-REND CORROSION SPECIMENS IN THE EVAPORATORS SHOWED CRACKING AFTER. 22 MONTHS. ULTRASONIC TESTS OF TEN WELDS SHOWED NO DEFECTS.

*CONTROL ROD, SHIM SAFETY + \#DAMAGE + CONTAINMENT, PRESSURE VESSEL + ELK RIVER + EXAMINATION + REACTOR, BOILING WATER

K-11240 KALKER KJ
STUDY OF SHUT-DOWN INSTRUMENTATION AND CONDITIONS FOR STEADILY INCRFASING DERTURBATIONS IN IN-MW OPFRATION OF FRJ-2 (DIOO)

$N P-T R-1367+J U L-239-R E+$. EO PAGES, $1 S E 5, J C L, \$ 5.60=5, \$ 2.00 \mathrm{MF}$

AN ANALOG SIMULATION, USING COMPONENTS FROM THE PEACTOR-CONTROL SYSTEM, WAS MADE.

CALCULATIONS FOR THE MAXIMUM PERMISSIBLE TIME DELAYS BEFORE ROD DROP ARE GIVEN. THE REACTOR

SHUTDOWN SYSTEM IS EXAMINED ACCOPDING TO THE RESULTS OF THE SIMULATION AND CALCULATIONS.

* ACCIDENT ANALYSIS + *SAFETY PRINCIPLES AND PHILOSOPHY + ACCIOENT, REACTIV!TY + COMPIITER, ANALOG + INSTRUMENTATION, PROTECTIVE + PERIOD METER

S-11253 BUDGE E

OPERATIONAL AMPLIFIERS FOR MAXIMUM FLEXIBILITY IN PEACTOR CONTROLS

EDGERTON, GERMESHAUSEN AND GRIER, INCORPORATED, LAS VEGAS, NEVADA

EGG-1183-1130 + CONF-650412-1 +. 23 PAGES, APRIL 13, 1065, CFSTI, \$1.00 CY

A REVIEW AND DISCUSSION OF THE CHARACTERICS OF OPERATIONAL AMPLIFIERS IS GIVEN. APOLICATIONS TO REACTOR CONTROL SYSTEMS ARE DISCUSSED.

* INSTRUMENTATION, AMPI TFIFR + INSTRUMENTATION, GENER.AL

S- $11304 \quad$ KRUZIC TP

BORON POISON SYSTEM EVALUATION

ALLIS-CHALMERS MANUFACTUR ING COMPANY, BETHESDA

ACNP-65541 +. 16 PAGES, JULY 1065 , CFSTI, \$1.00 CY, \$0.50 MN

ERR SODIUM PENTABORATE SYSTEM: ELIMINATING CRYSTALLIZATION OF SODIUM PENTABORATF. SUTH CRYSTALLIZATION HAS PREVIOUSLY CAUSED VALVE AND LINE BLDCKAGE. $\triangle$ MINOP, SINPLE AND CHEAD MODIFICATION TO THE PRESENT SYSTEM IS SUGGESTED WHICH WOULD PROVIDE FOR IMMEDIATE DILIITION OF ANY PENTABORATE SOLUTION LEAKING PAST THE CLOSURE VALVES. THE PRESENT SOLUTION-INJECTION TIME WOULD BE MAINTAINED, AND NO CHANGES TO THE TECHNICAL SPECIFICATIONS WOULD BE REQUIRED.

\#ELK RIVER + \#POISON, SOLUBLE + REACTOR, ROILINC WATER

9-11416 BORKOWSKI CJ. HARTILL CS

INSTRUMENTATION AND CONTROLS DIVISION ANNUAL PROGRFSS REPORT FOR PERIOD ENDING SFPTEMBER 1 , 1 OG5

OAK RIDGE NATIONAL LABORATORY, OAK RIDGE, TENNESSEE

ORNL-3875 +. 187 PAGES, AUGUST 1966 , CFSTI, \$3.00 CY, \$1.00 NN

TrIS IS A COLLEĊTIIÓN ÓF I4I ARTICLES DEALING WITH NEW AND CONTINUING PROJECTS IN THE FOLLOWING

ACCFSSION NIJMBFR 9-11006 TO $9-11416$


9-11416 *CONTINUED*

FIELDS OF INSTRUMENTATION - NANOSECOND CIRCUITRY, - PULSE COUNTING, ELECTROMETERS, ELECTRONICS DEVELOPMENT, FABRICATION, AUTOMATIC CONTROL, BIOMEDICAL RESEARCH, PARTICLE DETECTORS, RADIATION MONITORING, DATA COLLECTION, PROCESS INSTRUMENTATION AND CONTROL-SYSTEM ENGINEER ING, PROCESS-INSTRUMENT DEVELOPMENT, REACTOR INSTRUMENTATION AND CONTROLS.

* INSTRUMENTATION, GENERAL + INSTRUMENTATION, CONTROL + INSTPUMENTATION, FLOW + INSTRUMENTATION, NUCLEAR + INSTRUMENTATION, PROCESS + INSTRUMENTATION, TEMPERATURE + MONITORING SYSTEM + PLANT PROTECTIVE SYSTEM

S- 11417 PETERSON RE

CONTROL ELEMENT DR IVE MECHANISMS FOR LAMPRE. I

LOS ALAMOS SCIENTIFIC LABORATORY, LOS ALAMOS, NEW MEXICO

LA-DC-6608 + CONF-756-1 +. 23 PAGES, FROM MEETING OF FAST REACTOR CONTROL ROD DRIVES, GERMANTOWN, MARYLAND, SEPTEMBER 1964, CFSTI, \$1.00 CY

THE USE OF HYORAULICALLY POWERED CONTROL-ROD-DRIVE SYSTEMS MAY IN SOME APPLICATIONS OFFER CERTAIN ADVANTAGES OVER THE MORE CONVENTIONAL CONTROL-ELEMENT ACTUATORS. THIS PADER DEALS WITH, AN INSTANCE IN WHICH SUCH A ROD DRIVE WAS SUCCESSFULLY USED ON AN EXPERIMENTAL RFACTOR.

\#CONTROL ROD DRIVE + \#LAMPRE I (LASL MOLTEN PU REACTOR EXPERIMENT) + CONTROL ROD SCRAM MECHANISM + REACTOR, FAST

9-11418 DEAN RA

HYORAULIC DESIGN OF A ROD CLUSTER CONTROL FUEL ASSEMBLY

WESTINGHOUSE ELECTRIC CORP., PIITSBURGH, ATOMIC POWER DIVISION

WCAP-3269-62 +. 43. PAGES, 3 FIGURES, 3 TABLES, 6 REFERENCES, SEPTEMBER 1965, CFSTI \$3.DO CY, \$0.50 MN

A TEST WAS MADE TO FVALUATE THE HYDRAULIC CHARACTERISTICS OF THE ROD-CLUSTER CONTROL AND THE CONTROL-ROD SYSTEM. FLOW PATTERNS AND HYDRAULIC RESISTANCES ARE DETERMINED. AN ANALYTICAL MODEL FOR PREDICTING THE PRESSURE-LOSS COEFFICIENT IS PRESENTED. PRESSURE-DROP MEASUREMENTS WERE ALSO MADE TO DETERMINE THE FRICTION FACTOR FOR FLOWS IN ANNULI 0.014 TO 0.053 IN. WIDE. MEASUREMENTS WERE MADE FOR THE RANGE OF FLOW FROM LAMINAR TO THAT HAVING A REYNOLDS NUMBER OF 15,000 .

*CONTROL ROD + \#HYRAULIC ANALYSIS + \#SAN ONOFRE + FUEL ELEMENT + REACTOR, PRESSURIZED WATEP

S-11424 HORST KM

SOUTHWEST EXPERIMENTAL FAST OXIDE REACTOR DEVELOPMENT PROGRAM. THIRD QUARTERLY REPORT, OCTOBER I964 JANUARY 1965

GENERAL ELECTRIC, SAN JOSE

GEAP-4799 +. 150 PAGES, FEBRUARY 1965, CFSTI $\$ 4.00 \mathrm{CY}, \$ 1.00 \mathrm{MN}$

THIS REPORT IS ONE OF A SERIES OF SUCH REPORTS ON THE FOLLOWING SUAJECTS - PLANNING, EXPERIMENTAL PROGRAM IN ZPR-III, FUEL DEVELOPMENT, INSTRUMENTATION, CURE OYNAMICS, REACTIVITY CONTROL, FUEL HANDLING, AND CORE DESIGN

*RESEARCH CONTRACT + \#SEFOR (SOUTHWEST EXP. FAST OXIDE REACTOR) + *ZPR III (ANL ZERO POWER REACTOR) + CRITICAL ASSEMBLY FACILITY + DOPPLER COEFFICIENT + FUEL ELEMENT + FUEL HANDLING + HEAT TRANSFER + INSTRUMENTATION, GENERAL + INSTRUMENTATION, TENPFRATURE + REACTOR, BREEDER + REACTOR, FAST + REACTOR, LIQUIO METAL COOLED + TEST, PHYSICS

9-11433 DAVIES NF

DEVELOPMENTAL IRRAOIATION TEST OF SNAP-8 ELECTRICAL COMPONENTS (HF-8) ATOMICS INTERNATI ONAL

NAA-SR-11924 +. 25 PAGES, 7 FIGURES, 5 TABLES, JULY 15, 1966, CFSTI $\$ 2.00$ CY, $\$ 0.50$ MN

FOUR TYPES OF ELECTRICAL CONNECTORS, TWO TYPES OF CABLES, AND FIVE TYPES OF INSULATION SPECIMENS WERE IRRADIATED FOR 2250 HR AT 900 TO $1200 \mathrm{~F}$ AND A VACCUM OF 10 TO THE MINUS 6 TORR. TOTAL EXPOSURE WAS FROM 8 TIMES 10 TO THE 9 TO 9 TIMES 10 TO THE $10 R$ (GAMMA) AND FROM IO TO THE 17 TO 10 TO THE 19 FAST NEUTRONS (NVT). THE EVALUATION WAS IN SUPPORT OF THE SNAP 8 PROGRAM ANO SHOWED THAT ALL BUT TWO CONNECTORS WERE SUITABLE.

* INSTRumentation, general + \#RADIATION DAMAGE + Electric power, general + SNAP 8 (SYSTEMS FOR NUCLEAR AUXILIARY POWER)

9-1143E JOHNSON TR + TEATS FG + PIERCE RD

AN INDUCTION PROBE FOR MEASURING LIQUID LEVELS IN LIQUTD METALS

ARGONNE NATIONAL LABORATORY, ARGONNE

ANL-7153 +. 24 PAGES, 13 FIGURES, 1 TABLE, 17 REFERENCES, FEBRUARY 1966, CFSTI \$2.00 CY, \$O.5O MN

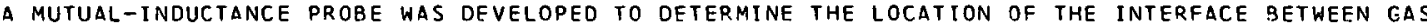
AND LIQUID METAL AND BETHEEN LIQUID SALT AND LIQUID METAL. PROBES 5 AND 14 IN. LONG WERE CALIIERATED IN LIOUIC CADNIUM, BISMUTH, AND SODIUM AT TEMPERATURES FROM 200 TO 700 C. THE AVERAGE DEVIATION IN MEASURED LIQUID LEVEL WAS 2 TO 3 PERCENT OF PROBE LENGTH.

* MOLTEN FUEL + *RADIOCHEMICAL PROCESSING + INSTRUMENTATION, LIOUID LEVEL DETECTION +

INSTRUMENTATION, PROCESS I METAL, LIQUID 
CATEGORY 9

NUCLEAR INSTRUNFNTATION, CONTROL, AND SAFETY SYSTEMS

9-11437 PANGHER JD + NICHOLS LL

A PRECISION LONG COUNTER FOR MFASURING FAST NEUTRDN FLUX DENSITY

BATTELLE-NORTHWEST, RICHLAND

BNWL-260 +. 63 PAGES, 16 FIGURES, 11 TABLES, 23 PEFERENCES, JUNE 1966, CF\$TI \$3.00 C,Y, \$O.75 MN

A REDRODUCIBLE VERSION OF THE HANSON-MCKIRREN PRECISION LONG COUNTER (PLC) WAS RUILT, AND A COMPREHENSIVE EXPEP.IMENTAL INVESTIGATION OF ITS CHAPACTERISTITS WAS MADE. THE COUNTER. IS MADE FROM POLYFTHYLFNE AND ALUMINUM. IT. HAS CLOSELY REPRODUCIBLE PRDPERTIES DND T.AN BE

CALIBRATEO TO WITHIN PLUS OR MINUS I PEPCFNT. THE PROBLEM OF USING A DLC WITH

ACCELERATOR-PRODUCED NEUTRONS IS DI SCUSSED.

\#CHANBER, NEUTRON + \#FAST NEUTRON + INSTRUMFNTATION, NUCLEAR + MEASUREMENT, REACTIVITY

S- 11450 MELSA JL + SCHUL TZ DG

RESEARCH IN AND APPLICATION OH MUUERN AUTOMATIC CONTROL THEORY TO NUCLEAR ROCKET DYNAMIC AND CONTROL. VOLUME II

UMIVEREITY OF ATIZOHA, TUCSOP

N-65-21462 + NASA-CR-62187+. 165 PAGES, PEFERENCES, MARCH 1965, CFSTI \$5.00 CY, \$1.00 MN

THIS REPORT REPRESFNTS THE COMPLETICN OF ONE PHASE OF THE STUOY OF SUBOPTIMAL CONTROL METHOOS

AS APPLIED TO THE THEORY OF MODERN AUTOMATIC CONTROL, MODERN-ROCKET DYNAMICS AND CONTRML. THE SECOND METHOD OF LIAPUNOV WAS USED AS A BASIS FOR DEVELOPING A METHOD OF CLOSED-LOOP, APPRDXIMATELY TIME-OPTINAL CONTROL OF LINEAR SYSTEMS WITH ROUNDED CONTPOL NORMS. THERE ARE THREE MAJOR CONTRIBUTIONS - 111 EIGNEVECTOR SCALAR PRODUCT SOLUTIONS TO THE HAMILTON-JACOSI EOUATIONS ARE SHOWN TO FXIST, (2) A MFTHOO OF JUDGING THE OUALITY OF THE SUBODTIMAL SYSTEM IS DEVELOPED, (3) THE. EIGNEVECTOR SCALAR PRONUCT SOLITTIONS ARE USEO TO DEVELOP SEVERAL METHODS OF CLOSED-LOOP, SUBOPTIMAL CONTROL.

* LIAPUNOVS FUNCTION + \#MATHEMATICAL STUOY + CONTROL, gENERAL

$9-11451$ KEETON DC

A CIMMPIITFR STUOY OF A RATE-OF-CHANGE-OF-PRESSUDE SCDAM SYSTEM

TENNESSEE VALLEY AUTHORITY, OAK RIDEE

TID-22754 +. 15 PAGES, MARCH 7, 1965, CFSTI \$1.00 CY, \$D.50 MN

THIS REPORT DESCRIRES A PROPOSED RATE-OF-CHANGE-OF-PRESSURE SCRAM SYSTEM TO RF USED DURING PHASE-IVA EGCR PHYSICS TEST. THE RESULTS OF CALCULATIONS TO DETERMINE AN OPTIMUM PNEUMATIC SYSTEM ARE PRESENTEC ALONG WITH A METHOD FOR CALIBRATING THE FLOW DRIFICF. RESULTS OF TESTS TO DETERMINE THE ORIFICE SITE ARE SHOWN. NO DETAILED PLANS FOR THE ELECTRICAL PODTION OF THE SYSTEM ARE PRFSENTED.

*CONTAINMENT INSTRUMENTATION + EGCR (FXPFRIMENTAL GAS COOLED REACTOR) + INSTRUMENTATION, PROCFSS + MATHEMATICAL STUDY 
CATEGORY 10

ELECTRICAL POWER SYSTEMS

10-10282 MIROWSKY BJ

EFFECTS OF SHORT-OURATION POWER INTERRUPTIONS ON THE COMPUTFRIZED C.HFCKOUT SYSTEM FOR NASA

GENERAL ELECTRIC COMPANY, DAYTONA BEACH, FLA.

36 PAGES, 18 FIGURES, 2 TABLES, PRESENTED AT THE-AMERICAN POHER CONFERENCE $28 T H$ ANNUAL MEETING, APRIL

$26-28,1966$, CHICAGO, ILLINOIS, APC, \$0.25 CY

PROBLEM - EXAMINE AND FIND CORRECTIVE METHOOS FOR THE OISTURBANCES TO ONLINE COMPUTERS CAUSED BY BRIEF POWER INTERRUPTIONS. APPROACHES - 11 ) THEORETICAL EVALUATION OF TIME RESPONSES, (2) TEST RESPONSE OF SYSTEM TO VARIABLE DISTURBANCES. RESULTS - 11 ) COMPUTER PERFORMANCE WAS UNACCEPTABLE FOR INTERRUPTIONS LONGER THAN 1 MSEC, $(2)$ MINIMUM RECOVERY TIME FOR COMMERCIAL POWER SYSTEMS IS 80 MSEC. CONCLUSIONS - 11 IT IS NOT PRACTICAL TO MODIFY THE COMPUTFR SYSTEMS OR THE COMMERCIAL POWER SYSTEMS TO GIVE SATISFACTORY RECOVERY, (2) PRACTICAL ANSWER IS TO INTERPOSE A LOCAL, CONTINUOUS, AC-POWER SYSTEM OF EITHER A DIESEL-DRIVEN CLUTCH, CONNECTED ROTATING SYSTEM, OR A BATTERY-BACKED, STATIC, AC GENERATOR.

\#COMPUTER, DIGITAL + \#ELECTRIC POWER, VITAL + \#EMERGENCY POWER, ELECTRIC + *FAILURE, GENERAL + COMPAR ISON; THEORY AND EXPERIENCE + TEST, SYSTEM OPERABILITY 
CATEGOQY 11

11-C9393 YOSHIDAT + MIYANO K + YOSHIZAWA A

STEEL PLATE FOR NUCLEAR POWER REACTOPS

JAPAN ATOMIC ENERGY RESEARCH INSTITUTE, TOKYO, JAPAN

NSJ-TR-37 + 30 PAGES, 17 TABLES, Q FIGURES, REFERENCES- FERRUARY 1OG5- TRANSLATEN FROM JADAN STCEL WORKS

TECH. REV, (16)- $1782-1796$ (MARCH 1964),- JAERI

THIS REPORT SUMMARIZES CURRENT PROCEDURES AND PROBLEMS RELATED TO THE PRDNUCTION OF

HIGH-QUALITY STEEL PLATE FOR NUCLEAR SERVICE IN JAPAN. PROBLFMS AND DUALITY-CONTROL

PROCEOURES RELATED TO BRITTLENESS AND RADIATION DAMAGE ARE DISCUSSED.

* MATERIAL + \#METAL + BRITTLE FRACTURE + CODES AND STANDARDS + DESIGN CRITERIA +

NOT DATA (NIL DUCTILITY TRANSITION) + RADIATION DAMAGE

11- 19394 OOI H H HARIMAT+ IIZUKA H + KATAOKA G

RESEARCH ON THE COLLISION RFSISTING CONSTRUCTION OF THE SIDFS OF $\triangle$ NUCLEAR DOWFP.ED SHID (PEPORT NO. 3 ) JAPAN ATOMIC ENERGY RESEARCH INSTITUTE, TOKYO, JAPAN

NSJ-TR-30 +. 29 PAGES, 2 TABLES, 29 FIGURES, JANUARY 1965- TRANSLATED FR.OM TECH. PEV. MITSURISHI NIPPON HEAVY-IND., 4 (2) - 145-155 (DECEMBFR 1963), JCL \$2.60 CY

COLLISION EXPERIMENTS WERE MADE WITH FIVE TYPES OF CONSTPUSTION MODELS FOP THE SIDES OF SHIPS. THE MODELS WERE ABOUT $1 / 15$ THE SIZE OF THE COLLISION-RESISTING COMPARTMENT OF THE NUCLEAR POWERED OCEANOGRAPHIC RESEARCH AND TENDER SHIP AND WERE SUBJECTED TO ROTH IMPACT AND STATIC LOADING AT THE CENTER. THE RELATIONSHIP BETWEEN ENFRGY ABSORPTION AND DEFORMATION OF THF SIDE, THE MECHANISM OF DESTRUCTION OF BOW AND SIDE, AND HOW TO PREDICT THE OFFORMATION OF THF SIDES AT COLLISION WERE MADE CLEAP.

ACESIGN STUDY + 4 IMPACT SHOCK + FAILURE, GENERAL + SHELL

11-C9618 EICHLER JE + GALLAGHER EV + LIEBERMAN P

STUDIES OF REACTOR CONTAINMENT

ILLINOIS INSTITUTE OF TECHNOLOGY RESEARCH INSTITUTE, CHICAGD

11YR1-578P21-11+111K1-T6042-17+. 11 PAGES, DECEMBER 1965 - JANUARY 1966, CFSTI, \$1.00 CY, \$0.50 MN

IN THIS PROGRESS REPORT, COVEPING WORK PERFORMED RETWEEN DECEMGER 1965 AND JANUADY 1966 , THREE TASKS OF THE IITRI PROGRAM CONCEONING STUOIES OF RFACTOR CONTAINMENT ARE DESTPIBED. THE THREE TASKS ARE (1) CRUSHABLE SHIELO ANALYSIS ANO DESIGN (2) SHOCK IMPINGEMENT FXPCRIMENTS ON CRUSHARLE SHIELOS $(3)$ COOLANT DECOMPRESSION EXPERIMENTS AND ANALYSIS.

\#CONTAINMENT ANALYSIS + \#CONTAINMENT, SHOCK GENERATION AND PROTECTION + COMPUTFR PROFRAM + CSE ICONTAINMENT SYSTEMS EXPERIMENTI + PRESSURE, INTERNAL + REACTDR, PRESSURIZED WATEP

11-C9676 FERGUSON KR

UNITEO STATES PRACTICES IN THE CONTROL AND CONTAINMENT OF RADIOACTIVE CONTAMINATION ARGONNE NATIONAL LABORATOPY

29. PAGES, 1965 , PP. 889-917 OF VOL. 2, PROCEEDINGS OF AN INTERNATIONAL SYMOOSIUM ON WORKING METHODS IN HIGH ALIIVIIY HUI LABOKATURIES, GRENOBLE, JUNE 15-18, 1965, ENEA, OECD, PUBLISHERS

THE TYPES OF RADIOLOEICAL CONTAINMENT SYSTEMS AND OPERATING DRACTICES USER IN RESFARCH OPERATIONS REOUIRING THICK RIOLOGICAL SHIELDING ARE SURVEYED. SOME CONTAINMENT ENCLOSURES ARE AN INTEGRAL PART OF THE SHIELDING, AND OTHERS ARE SEPAPATE AND REMOVARLE. THF MANY PARTS OF THE COMPLETE CONTAINMENT SYSTEM ARE CHOSEN ON THE BASIS OF NUMCROUS SAFETY AND ECONOMIC FACTORS, SUCH AS SITE LOCATION, AEROSOL-HANDLING HAZARO, TYPE AND SIZE OF THE OPERATIONS, MANIPULATORS, AND THE LONG-PANGE OBJECTIVES. INITIAL OPERATING EXPERISNCE HAS REFN DBTAINED RECENTLY WITH SEVERAL LARGE CONTAINMLNT COMPLEX[S. NEW DEVELOPMTNTS ARE PEVIFWED IN VENTILATION, FIRE CONTROL ANO MASTER-SLAVE MANIPULATION.

*CONTAINMENT DESIGN + *CONTAINMENT, GENERAL + AEROSOL, RADIOACTIVE + CONTAINMFNT ANALYSIS + CONTAINMENT RESEARCH AND DEVELOPMENT + CONTAINMFNT SYSTEM, OPERATION OF + CONTAMINATION + ENEA (EUROPEAN NUCLEAR ENERGY AGENCY) + FIRE + UNITED STATSS + VENTILATION SYSTEM

11-C9746 SIMMONS WR + PERSIANI PJ + BUMP TR

FAST REACTOD. TEST FACILITY (FARET) ANO INITIAL EXPERIMENTAL PROGRAM ARGONNE NATIONAL. LABORATORY, ARGONNE, ILLINOIS

ANS-1DO(SUPPL.) + CONF. 6504171SUDPL.) +. 10 PAGES, 3 FIGURES, PAGES $37-55$ OF FAST QEACTDR OF TECHNOLOGY, ANS NATIONAL TOPICAL MEETING, DETROIT, MICHIGAN, APRIL 26-29, 19R5, SNIIRCF

THE FAST REACTOR TEST FACILITY SITE, BUILOING, CONTAINMENT STRUCTURE, FUEL-HANOLING SYSTEMS, SHIELDING, COOLANT SYSTEMS, REACTOR PROPER, CONTROL SYSTEMS, EXPFRIMENTAL CAPABILITIES, DESIGN SPECIFICATIONS, LOADING, AND FUEL-TESTING PROGRAM $\triangle N D$ ORJECTIVFS ARE DFSCRIBED.

\#CONTAINMENT STRUCTURE + \#FARET (FAST ARGONNE REACTOR EXPERTMENT TESTI + \#REACTOR DESCRIPTION + CONTAINMENT, HIGH PRESSURE + CONTAINMENT, PRESSURE VESSEL + REACTOR, BREEDER + REACTOR, FAST + REACTOR, LIQUID METAL COOLED

$11-C 9747$ BELLIER J

PRESTRESSED CONCPETE PRESSURE VESSEL

COMMISSARIAT A L ENERGIE ATOMIQUE, FRANCE

BRITISH PAT. $1,012,262+.3$ PAGES, 2 FIGURES, DECEMRER 8, 1965- PATENT (FOREIGN)

THE INVENTION IS A PRESTRESSED CONCRETE PPFSSURE VESSEL WITH A STEEL LINER FOR USE IN NUCLEAP 
11-C9747 \#CONTINUED*

REACTORS USING A GASEOUS COOLANT.

\#CONCRETE, PRESTRESSED + \#CONTAINMENT, PRESSURE VESSEL + CYLINDER + REAT.TOR, GAS COOLED + STEEL LINER

11-09748 ARRANGEMENT FOR CONTROLLING AN ESCAPE OF PRESSURIZED FLUID FROM A NUCLEAR P.EACTOR WESTINGHOUSE ELECTRIC CORPORATION

BRITISH PAT. $1,011,137+\ldots 3$ PAGES, 2 FIGURES, NOVEMBER $24,1965-$ PATENT (FOREIGN)

THE INVENTION IS A PRESSURE-SUPPRESSION CONTAINMENT SYSTEM FOR A PRESSURIZFD-WATFR REACTOR.

*CONTAINMENT DESIGN + \#CONTAINMENT, PRESSUPE SUPPRESSION + \#REATOR, DRESSURIZED WATER + SCRUBBER

11-09751 JOHNSON RM

PWR REACTOR PLANT CONTAINER LEAK RATE TEST, DLCS 57201

BETTIS ATOMIC POWER LABORATORY, WEST MIFFLIN, PA.

WAPD-PWR-TE-201 +. 19 PAGES, IO FIGURES, AUGUST 6, 1965, CFSTI, \$1.00 FS, \$0.50 MN

IN APRIL 1965 THE PWR REACTOR PLANT CONTAINER WAS SUCCESSFULLY LEAK-RATE TESTED BY THE

REFERENCE VESSEL METHOD AT A PRESSURE OF 10 PSIG AND AN AVERAGE AMBIENT AIR TEMPERATURE OF 74.4 DEGREES F. THE CONTAINER LEAK RATE WAS IN THE ORDER OF 0.0120 TO 0.0137 PERCENT OF CONTAINER VOLUME PER $24 \mathrm{HR}$, WHICH IS WELL BELOW THE 0.065 PERCENT PER 24 HR ALLOWABLE. A SUPER IMPOSEO LEAK RATE EQUAL TO THE TEST ALLOWABLE VALUE WAS APPLIED TO THE CONTAINER BY A SPECIAL FLOWMETER DURING THE LAST 12 HOURS OF THIS TEST. USE OF THIS CALIBRATED LEAK RATE VERIFIED THE ACCURACY OF THE TEST INSTRUMENTATION FOR OBTAINING DATA TO BE USED IN

CALCULATING THE CONTAINER LEAK RATE. THE SUPERIMPOSED LEAK-RATE PORTION OF THE TEST PRODUCED A LEAK RATE WHICH WAS WITHIN 14 PERCENT OF THE CALCULATED RATE PRIOR TO IHIS PHASE OF THE TEST .

* CONTAINMENT LEAKAGE + \#LEAK RATE + \#SHIPPINGPORT + \#TEST, LEAK RATE +

CONTAINMENT REFERENCE MEASURING SYSTEM + REACTOR, PRESSURIZED WATER + THERMAL CONSIDERATION

$11-[.9917$ GROZIN BD +. CHERNENKO VS

POSSIBILITY OF STRENGTHENING STEEL BY ELECTRON BOMBARDMENT

JPRS-32107+ TT-65-32600+. 7 PAGES, SEPTEMBER 22, 1965, TRANSLATED FROM DOPOVIDI AKADEMIYI NAUK UKRAYINSKOYI RSR, (2), PAGES 202-5 (1963), CFSTI, \$1.00 CY, \$0.50 MN

THEORETICAL CONSIDERATIONS PERMIT THE POSSIBILITY OF STRENGTHENING STEEL BY ELECTRON

BOMBARDMENT. EXPERIMENTS HAVE CONFIRMED THE CORRECTNESS OF THIS PREMISE. THE HARDNESS OF STEEL IS RAISED TO 900-SSO KG/MM SQUARED BY ELECTRON BOMBARDMENT. THE IRRADIATEO ZONE HAS A SPECIFIC MICROSTRUCTURE.

\#RADIATION EFFECT + \#STEEL + *TENSILE PROPERTY + ALLOY + CREEP PROPERTY + RADIATION DAMAGE + X-RAY

$11-[9918$ SMITH BE

AN X-RAY STUDY OF FISSION FRAGMENT DAMAGE IN STEELS

UNITED KINGDOM ATOMIC ENERGY AUTHORITY, HARWELL

5 PAGES, 4 TABLES, 1 FIGURE, 11 REFERENCES, JOURNAL OF NUCLEAR MATERIALS, 17(1), PAGES 167-171 (1965)

LATTICE-PARAMETER MEASUREMENTS WERE MADE ON STEELS BOMBAROED WITH FISSION FRAGMENTS AT ABOUT 60 C. THE RESULTS FOR ONE AUSTENITIC STEEL ICR, 20 WT PERCENT, NI, 20 WT PERCENT, NR, O.44 WT PERCENT, ARF DISCUSSED IN CONJUNCTION WITH PUBLISHED RESULTS OBTAINFD BY ELECTRON MICROSCOPY AND ARE CONSIDERED CONSISTENT WITH THE HYPOTHESIS THAT THE PROPORTION OF SMALL DEFECTS IN THIS STEEL IS GREATEST WHEN IRRADIATION DOSE RATES ARE HIGH. IN TWO OTHER AUSTENITIC STEELS (CR, 18 WT PERCENT, NI, 37 WT PERCENT) AND (CR, 18 WT PERCENT, NI, 12 WT PERCENT) AND A FERRITIC STEEL (CR, 15 WT PERCENT, NI, 5 WT PERCENT), A MEASURABLE PROPORTION OF SMALL DEFECTS WAS PRESENT AFTER IRRADIATION AT A DOSE RATE INTERMEDIATE BETWEEN THE TWO USEO FOR THE 20\%.20 AUSTENITE.

*ALLOY + *RADIATION DAMAGE + \#STEEL + ELECTRON MICROSCOPY + RADIATION EFFECT + X-RAY

11-09920 COWAN A

METALLURGICAL TESTING AT CULCHETH

UNITED KINGDOM ATOMIC ENERGY AUTHORITY, REACTOR MATERIALS LABORATORY, CULCHETH

4 PAGES, 3 FIGURES, ATOM(112), PAGES 33-36 (FEBRUARY, 1966)

A LARGE PROPORTION OF THE WORK AT THE REACTOR MATFRIALS LABORATORY IS METALLURGICAL, AND EXTENSIVE FACILITIES HAVE BEEN DEVELOPEO TO ALLOW FULL-SCALE INVESTIGATIONS OF THE BEHAVIOUR OF METALS RANGING IN SECTION FROM THIN FOIL TO THICK STEEL PLATES. IN $\triangle O D I T I O N$ TO CONVENTIONAL TESTS, EQUIPMENT HAS BEEN OEVISED TO GIVE BETTER SIMULATION OF ACTUAL SERVICE CONDITIONS, ESPECIALLY WHERE -APPLICATION OF NORMAL TEST DATA IS INADEQUATE OR EVEN UNREALISTIC. IN SEVERAL CASES THIS INCLUDED TES.TS ON EITHER THE FULL-SIZE COMPONENT OR LARGE SAMPLES, NECESSARY TO BE REASONABLY REPRESENTATIVE OF THE FINAL PRODUCT. CREEP TESTING. BRITTLE FRACTURE TESTS. TESTS ON MODEL VESSELS. POSTIRRADIATION TESTING FACILITIES. OTHER - FACILITIES.

*EQUIPMENT DESIGN + \#METAL + \#TESTING + BRITTLE FRACTURE + CORROSION + CREEP PROPERTY + IMPACT PROPERTY + RADIATION EFFECT + TENSILE PROPERTY + TEST, PRESSURE VESSEL 
CATESORY 11

CONTAINMENT OF NUCLEAR EACILITIES

11-C9921 JABLONOWSKI EJ + RITZMAN RL + DEMASTRY JA

FISSION-FRAGMENT EFFECTS IN STPUCTUPAL MATFRIALS. QUARTERLY PROGDESS DEPOPT, JULY-SEPTEMREP I965

BATTELLE MEMORIAL INSTITUTE

BMI-X-1C14E+EURAEC-1527+. 7 PAGES, OCTOBER 1, 1065, CESTI, \$1. חO CY, \$O.50 MN

THE OBJECTIVE OF THIS PRCGRAM IS TO DETERMINE THE TYPE AND MAGNITUDE OF MECHANTCAL-PROPERTY CHANGES PRODUCED ANNEALED AISI TYPE 304 STAINLESS STEEL AND ANNEALED ZIRICALDY-2 BY

FISSION-FRAGMENT IRRADIATIONS. TESTING OF TURE-RURST AND BEND SDECIMENS OF

PECOIL-IMPREGNATED ZIRCALOY-2 AND TYPE 304 STAINLESS STEEL WAS COMPLETED. NOMINAL INTREASES

OF 8 TO 10 PERCENT IN AVERAGE PROPORTIONAL LIMIT AND YIELD-STRENGTH VALUES OF

FISSION-FRAGMENT-DAMAGED OVER NEUTRON-DAMAGED MATERIALS WERE NOTED FROM BOTH THF BEND AND

TUBE-BURST DATA. LIGHT AND ELECTRON METALLOGRAPHIC. ANALYSES OF THE RECOIL-IMDREGNATED

MATERIALS WERE COMPLETED. NO STRUCTURAL CHANGES WERC NOTED AS THE RESULT DF FISSION-FRAGMENT

OR NEUTRON DAMAGE. FPACTURE ANALYSIS DF PUPTURES PRODUCFD IN THE TUBE-DUPST FXPEPIMFNTS

INDICATED NO CHANGE IN FRACTURE MODE (DUCTILE) AS A RESULT OF FISSION-FRAGMENT IRRAOIATION. THE MAXIMUM RADIATIUN-INUUCEO TENSILE AND COMORFSSIVE STRESSES IN ZTRTAIOY-? ANN TYPT 3D4 STAINLESS STEEL WERE CALCULATEO ON THE BASIS OF EXPERIMENTALLY DETERMINED VALUES OF PADIATION

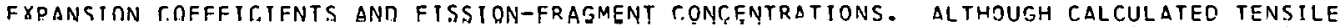
STRESSES WERE NOMINAL, COMPRESSIVE STRESSES CF 14,300 PSI (STAINLESS STEEL) ANO 42,400 PSI (ZIRCALOY-2) WERE ORTAINED.

* RACIATION DAMAGE + \#STEEL, STAINLESS + \#TENSILE PROPERTY + ALLOY + ELECTRON MICRDSCOPY + FAILURE, DIDF + IESTING + ZIKCONIUM

11-CQ922 ROMUALDI JP

THE EFFECT OF LOADING GEOMETRY ON THE FRACTURE TOUGHNESS OF BIAXIAL RRITTLE FRACTURE SPECIMENS CARNEGIE INSTITUTF. OF TECHNOLOGY

WAPC-TM-554 +. 45 PAGES, TABLES, FIGURFS, APRIL, 1964, CFSTI, $\$ 2.00 \mathrm{CY}, \$ 0.50 \mathrm{MN}$

EXPERIMENTS ON THE MANJOINE BRITTLE-FRACTURE TEST SPECIMEN CONDUCTED DURING 1963 INDICATED THAT FRACTURE TOUGHNESS DEPENDS ON THE GEOMETRY OF LOADING. THIS EFFECT IS ASSOCIATED WITH THE STRESS GRADIENT IMMEDIATELY AHFAD OF THE TIP OF THF CRACK. WITH A MANJDINE TEST SPECIMEN SCALED UP TENFOLD DIMENSIONALLY, STRAINS WFRE MEASURED NEAR THE CRACK TIP, AND CONVERTED TO STPESSES IN ORDER TO ORTAIN THE STRESS-INTENSITY FACTOR AS A FUNCTION OF APPLIED LOAU. IHE ENERGY RELEASED PER UNIT CRACK EXTENSION IS DIRECTLY RELATED TO THE STRESS-INTENSITY EACTOR. IT APPEARS THAT THE CRITICAL-STRAIN-ENERGY RFLEASE RATE FOR A MANJOINE TEST SPECIMEN IS ABDUT ONE-THIRD THE VALUE FOR A WIDE-PLATE TEST.

*BRITTLE FRACTURE + \#TENSILE PROPERTY + CONTAINMENT, PRESSURE VESSEL + ELASTICITY +

FAILURE, PRESSURE VESSEL + MEASUREMENT, STRAIN GAGE + METAL + STRESS

11-0S923 CONSTANT + PRUDHOMME + WEISZ + LE BRET + ORERMOSSEP

STUDIES ON THE BRITTLE FRACTURE STRENGTH OF HEAVY-GAGE STEEL DLATE. FINAL REDORT NO. 1

INSTITUT DE RECHERCHES DE LA SIDERUPGIE, ST. GERMAINE-EN-LAYE (FRANCEI + COMMISSARIAT A L ENERGIE

ATOMIQUE, SACLAY (FRANCE), CENTRE D ETUDES NUCLFAIRES

EURAEC-1520+EUR-2672+. 29 PAGES, 1965, CFSTI, \$2.CO CY, \$0.5C MN

THE DEVELOPMENT OF A BENO TEST TO ORTAIN DETATIFD DATA ON THF RRITTLE-FRACTUNE MHENUMHNA ENCOUNTERED IN WELDED AND UNWELDED STEEL PLATES 2 DO MM THICK IS RESCPIBED. PRELIMINARY RESULTS INDICATE THAT THE TRANSITION TEMPFRATURE OF SPECIMENS CONTAINING FIVF. SCATTCPEO WELDS IS HIGHER THAN THAT OF SDECIMENS CONTAINING ONE SINGLE CENTRAL WELD, REGARDLESS OF WHETHFR THIS WELD CONSISTS OF ONE BEAD OR FIVE JOINED BEADS. THE BRITTLE ZONF CAUSED BY SEVERAL READS DEPOSITED ALONGSIDE FACH OTHER WAS NOT GREATER THAN THAT CAUSFO BY ONE BEAD.

\#BRITTLE FRACTURE + \#NDT DATA (NIL DUCTILITY TRANSITION) + \#TENSILE PROPERTY +

CONTAINMENT, PRESSURE VESSEL + METAL + STRESS + WELUUS

$11-09924$ RIPLING EJ + CROSLEY P

DEVELOPMFNT NF TFST PROC.FNURFS. FRACTURE TOUGHNESS OF REACTOR PRESSURE VFSSEL STEELS

MATFRIALS RESEARCH LABORATORY, INC.

CCO-1477-1+. 5 PAGES, JULY 1965-CFSTI, \$1.ON CY, \$0.5C MN

a DOUBLE CANTILEVER QEAM (DCB) DEVICE IS BEING DEVElopeo TO MEASURE THF FRACTURE TOUGHNESS OF MILD STEEL. BECAUSE IRRADIATED SAMPLES MUST BE TESTED, A MAJOR PEQUIPEMENT IS THAT THE

SPECIMENS BE AS SMALL AS POSSIBLE. AN ADIITIONAL AOVANTACE OF THE DCE SPECJMFN IS THAT CRACK ARREST AS WELL AS CPACK INITIATION CAN BE PRODUCED. THIS IS IMPORTANT BFCAUSF, IN A WELDEO STRUCTURE, CRACKS APE LIKELY TO ORIGINATE IN A WELD REGION, AND A DESIGN SPECIFICATION SHOULD BE BASED ON THE ABILITY DF THE MILD-STEEL BASE METAL TO ARREST THE EXPANDING CRACK. EPOXY AND ALUMINUM SPECIMENS HAVE BEEN TESTED.

* BRITTLE FRACTURE + \#TENSILE PROPERTY + CONTAINMENT, PRESSURE VESSEL + MET AL + NCT DATA (NIL DUCTILITY TRANSITION) + STRESS + WELDS

11-C9925 KILSBY ER + IMHOFF DH

PEACTOR PRIMARY CONI ANT SYSTEM RUPTURE STUOY. OUARTERLY PROGRESS REPORT NUMEER 2 GCNCRAL ELECTRIC, DTOMIC POWER. FQIJIPMENT DFPT

GEAP-4964 +. 60 PAGES, 18 PEFERENCES, 18 FIGURES, 4 TABLES- OCTOBER 1965- CFSTI, \$4.00 C.Y, \$1.00 MN.

FOUR ASPECTS OF THE STRUCTURAL PERFORMANCE OF REACTOR PRIMARY PIPING SYSTEMS ARE RFING STUDIED. THESE ASPECTS ARE (1) RELIABILITY, (2) STRESS ANALYSIS, (3) FRACTURE MECHANICS, AND (4) FATIGUE. INITIAL CRACKS AND FATIGUE CRACKS ARE THE MOST LIKELY CAUSES NF FLAWS. STRFSS ANALYSIS DETERMINES THF CONDITIONS IN THF NEIGHBORHOOD OF FLAWS. FRACTURE MECHANTCS IS USED 
CATEGORY 11

CONTAINMENT OF NUCLEAR FACILITIES

11-09925 *CONTINUED*

TO DETERMINE IF AND WHEN CRACKS WILL PROPAGATE. RELIABILITY ANALYSIS DETERMINES THF PROBABILITY OF FAILURE. A LIST OF FACTORS GOVERNING RELIABILITY IS PRESENTED, TOGETHER WITH AN EXAMPLE OF A RELIABILITY CALCULATION. METHODS OF STRESS ANALYSIS FOR DIFFICULT PIPING COMPONENTS ARE BEING DEVELOPED. CRACK GROWTH UNDER FATIGUE CONDITIONS IS AN IMPORTANT PROBLEM IN PIPING DESIGN. FATIGUE CRACKING IN AREAS OF STRESS CONCENTRATION IS BEING EXAMINED.

\$BRITTLE FRACTURE + \#FAILURE, FATIGUE + \$FAILURE, PIPE + \#PIPING + \#RELIABILITY ANALYSIS + BIRLIOGRAPHY + COMPUTER PROGRAM + CONTAINMENT RESEARCH AND DEVELOPMENT + CONTAINMENT STRUCTURE + ELASTICITY + LOSS OF COOLANT + METAL + STRESS ANALYSIS

$11-C 9926$ STEELE LE

RADIATION EMBRITTLEMENT OF REACTOR PRESSURE VESSEL STEELS

U.S. NAVAL RESEARCH LABORATORY, WASHINGTON, D.C.

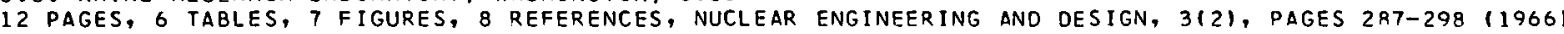

THE PROSLEM OF RADIATION EMBRITTLEMENT OF REACTOR PRESSURE VESSEL STEELS IS CONSIDERED WITHIN THE FRAMEWORK OF NEW NAVAL RESEARCH LABORATORY CONCEPTS OF FRACTURE ANALYSIS AND IN REFERENCE TO THE PRIMARY VAR IABLES, COMPOSITION OF THE STEEL, NEUTRON EXPOSURE, AND EXPOSURE TEMPERATURE. THIS PAPER SUMMARIZES THE STATUS OF THE NRL EMBRITTLEMENT STUDY, WITH EMPHASIS ON MAJOR FACTORS SUCH AS THE EFFECTS ON DIFFERENT STEELS AND THE EFFECTS OF NUCLEAR AND THERMAL ENVIRONMENT DURING IRRADIATION. IN ADOITION, POSTIRRADIATION HEAT TREATMFNT TO RESTORE NOTCH DUCTILITY WAS INVESTIGATED OVER A RANGE OF IRP.ADIATION AND ANNEALING CONDITIONS. CURRENT AND PLANNED PROGRAMS ARE REVIEWED WITH REFERENCE TO SUMMARY OBSERVATIONS.

*BRITTLE FRACTURE + \#EMBRITTLEMENT + \#FALURE, PRESSURE VESSEL + \#IMPACT PROPERTY + \#RADIATION DAMAGE + *RADIATION EFFECK + \$STEEL + ALLOY + ANALYTICAL TECHNIQUE, CALIBRATION + CONTAINMENT, PRESSURE VESSEL + FLAW + IMPACT SHOCK + NOT DATA (NIL DUCTILITY TRANSITION) + REACTOR, PRESSURIZED WATER + STRFSS + STRESS ANALYSIS + TENSILE PROPERTY + TEST, DESTRUCTIVE

11-10007 THIN WALLED NUCLEAR REACTOR

AKTIEBOLAGET ATOMENERGI

FRENCH PAT. 1,368,813 + ORNL-TR-1327+.8 PAGES, JUNE 1964, PATENT (FOREIGNI

THE INVENTION CONCERNS A REACTOR VESSEL HAVING RELATIVELY THIN WALLS FOR A BOILING-WATER REACTOR. THE VESSEL CAN BE THIN-WALLED SINCE IT IS NOT REQUIRED TO SUPPOPT THE FIILL WORKING PRESSURE. THE REACTOR CONSISTS OF A PRESSURE VESSEL OF PRESTRESSED CONCRETE, HAVING AN ORIFICE AT THE TOP END, WHICH IS CLOSED BY A PLUG. THE INTERIOR OF THE VESSEL IS LINED WITH A SEALING SKIN OF CARBON STEEL. THIS VESSEL CONTAINS A REACTOR VESSEL HAVING THIN WALLS OF STAINLESS STEEL. THE LATTER RESERVOIR IS PROVIDEO WITH AN ORIFICE AT ITS TOP END, THROUGH WHICH THE REACTOR VESSEL IS IN FREE COMMUNICATION WITH THE SPACE FORMED BETWEEN THE RFACTOR VESSEL AND THE PRESSURE VESSEL. THIS SPACE IS FILLED WITH A GAS WHICH DOES NOT CONDENSE AT NORMAL TEMPERATURES AND WHICH IS AT THE SAME PRESSURE AS THE PRESSURE OF THE STEAM IN THE REACTOR VESSEL.

*STEEL, STAINLESS + \#THICKNESS + CONCRETE, PRESTRESSED + CONTAINMENT, PRESSURE VESSEL + DESIGN CRITERIA + STEEL LINER

11-10034 MCGHIE RD

DEFORMATION, VIBRATION, ANO STABILITY OF SHELLS. A PARTIALLY ANNOTATEO BIRLIOGRAPHY UNIVERSITY OF CALIFORNIA

UCRL-13196 +. 70 PAGES (APPROX.), JUNE 1965

THE LITERATURE CONCERNING DEFORMATION, VIBRATION, AND STABILITY OF SHELLS WAS SURVEYED, AND A BIBLIOGRAPHY WAS PREPARED, PLACING PARTICULAR EMPHASIS ON LITERATURE RELEVANT TO THE FAILURE MECHANISIMS OF SHELLS CONFINED IN RIGID CAVITIES. THIS BIBLIOGRAPHY COVERS THE PERIOD IO57

TO 1965. A PREVIOUS ONE COVERED THE PERIOD 1880 TO 1957.

\#BI8LIOCRAPHY + \#SHELL + \#STRESS ANALYSIS + BUCKLING + BURST PRESSURE + CONTAINMENT STRUCTURE + CREEP BEHAVIOR + ELASTICITY + INSTABILITY + PLASTICITY + STRESS + STRESS ANALYSIS

11-10035 TASI J + FELDMAN A + STANG DA

THE BUCKLING STRENGTH OF FILAMENT-WOUND CYLINDERS UNDER AXIAL COMPRESSION MARTIN-MARIETTA CORPORATION, DENVER

NASA-CR-266 t. 58 PAGES, 24 FIGURES, 4 TABLES, 17 REFERENCES, JULY 1965, CFSJ1, \$3.00 CY

THE BUCKLING STRENGTHS OF 11 AXIALLY COMPRESSED FILAMENT-WOUND CYLINDERS WITH

DIAMETER-TO-THICKNESS RATIOS RANGING FROM 167 TO 643 ARE DETERMINED EXPERIMENTALLY ANR ANALYTICALLY. THE ANALYTICAL. PREDICTIONS OF BUCKLING LOADS ARE MADE BY USING LINFAR ANISOTROPIC SHELL THEORY. THE RESULTS OF THE COMPRESSION TESTS GENERALLY INDICATE THAT THE CYLINDERS BUCKLED AT E5 TO 85 PERCENT OF THE LOADS PREDICTEO BY LINEAR ANALYSIS. THE COMPOSITE MODULI FOR EACH OF THE CYLINOERS ARE DETERMINED EXPERIMENTALLY AND ARF IN REASONABLE AGREEMENT WITH THE THEORY OF S. TSAI.

* BUCKLING + \#COMPARISON, THEORY AND EXPERIENCE + \#INSTABILITY + \#MEASUREMENT, STRAIN GAGE + \#PRESSURE, EXTERNAL + \$SHELL + \#STRESS ANALYSIS + COMPUTER PROGRAM + CONTAINMENT STRUCTURE + ELASTICITY + STRESS + STRESS ANALYSIS 
CATEGORY 11

CONTAINMENT OF NUCLEAR FACILITIFS

11-10293 *CONTINUED*

CONTAINMENT SYSTEMS EXPERIMENT. PART III. MATHEMATICAL MODELS OF PRESSURE-TEMPERATURE TDANSIENTS BATTELLE NORTHWEST, PACIFIC NORTHWEST LABORATORY

BNWL-233 +. 150 PAGES, FIGURES, TABLES, PEFERENCES, MAY 1966, CFSTI, $\$ 5.00 \mathrm{CY}, \$ 1.00 \mathrm{MN}$

DOCUMENT SUMMARIZES THE INITIAL EFFORTS TO DEVELOP A MATHEMATICAL MODEL OF PRESSURE-TEMPERATURE TRANSIENTS, THESE MODELS, AFTER REFINEMENT AND ADJUSTMENT, MAY DROVIDE A SATISFACTORY SIMULATION OF TEST OATA FROM CONTAINMENT SYSTEMS FXPFRIMFNT (CSE). SINCF IT IS A CONTINUING SEGMENT OF THE CSE PROGRAM, THIS DOCUMENT IS INTENDED TO PROVIDE A MANUAL FOR THE COMPLETE UNDERSTANDING OF THE WORK THROUGH 1965, WITH SUGGFSTIONS FOR REFINEMENT $\triangle S$ DATA BECOMES AVAILABLE. ALTHOUGH MODELS OF PRESSURE ANO TEMPERATURE TRANSIENTS IN CONTAINMENT SYSTFMS HAVE BEEN DEVELOPED ELSEWHERE, THEY APE PROPRIETARY ANO NOT AVAILAGLE FOR UNRESTRICTED USES OR DETAILED SCRUTINY. SEVERAL PROGRAMS WERE DFVELOOFD AND PUN, UTILIZING THE MIDAS (MODIFIED INTEGRAL DIGITAL ANALOG SIMULATOR) GENERALIZED PROGRAM. THIS APDROACH UTILIZES THE DIGITAL COMPUTER TO SIMULATE THE BEHAVIOR OF AN ANALOG SYSTEM IN THE SOLUTION OF SIMULTANEOUS DIFFERENTIAL EOUATIONS. IT HAS THE DARTICULAR ADVANTAGE OT PERMITTING A RAPID DEVELOPMENT OF THE PROBLEM ON THE ANALOG COMPUTER (WHEN IT RECOMES DESIRAPLE TO DO SO) TO ATTEMPT A FIT DETWEEN THE MATHEMATICAL MODEL AND EXPEP.IMENTAL DATA BY THE VARYING OE PARAMETERS.

* ACCIDENT MODEl + *CONTAINMENT RESEARCH aNO DEVElopment + \#CONTAINMENT VESSEL loADING + *CSE (CONTAINMENT SYSTEMS EXPERIMENT) + COMPUTER PROGRAM + COMPUTEP, ANALOG + COMPUTER, OIGITAL + CONTAINMENT ANALYSIS + CONTAINMENT, GENERAL + CONTAINMENT, PRESSURE SUDORESSION + LOSS DF COOLANT + PRESSUPE, INTEPMAL + TEMPERATURE TRANSIENT + THFRMAI. ANAI YSTS

11-10308 SPALLER AE + SHOBE LR

STRUCTURAL ANALYSIS OF SHIPPING CASKS VOL. I. ANALYSIS OF A SHIPPING CASK SURJFCTED TO INTFRNAL PRESSIJRF OAK RIDEE NATIONAL LABORATORY, OAK RIOGE

ORNL-TM-1312+.58 PAGES, 19 FIGURES, 9 TABLES, MARCH 1968, CFSTI, \$3.00 CY, \$0.75 MN

FORMULAS TO BE USED EY THE DESIGN ENGINEER TO CALCULATE THE MAXIMUM STRESS DRODUCED IN A CASK USED TO SHIP RADIOACTIVE MATERIALS WHEN IT IS SUBJFCTED TO INTERNAL PRESSURF ARE PRESENTEN. THE FORMULAS WERE DEVELCPEO FOR IISF AS A GUIDF TO INDICATE COMPLIANCE WITH THE PROPRSED AFC REGULATION PERTAINING TO THE DESIGN RFQUIPEMENT FOR RESISTANCE TO INTERNAL PRESSURE. HOWEVER, USE OF THFSE FORNULAS, WHICH TAKE INTO ACCOUNT THE ELASTIC NATIJRE OF THE LEAR SHIELDING, ARE DERIVED TO DETERMINE THE THICKNESS OF THE CAVITY WALL FOP CASKS OF BOTH PRISMATIC AND CYLINDRICAL CONFIGUPATION, THE FORMULAS ARE TARULATEO, AND EXAMPLE PROPLEMS ARE GIVEN. CREEP OF THE LEAD SHIELD IS EVALUATED, AND IT IS CONCLUDED THAT THE CREED PRODLLEM TENDS TO BE SFIF-ALI.EVIATING.

*PRESSURE, INTERNAL + \#SHIPRING CONTAINER * \#STEES ANALYSIS + \#TRANSPORTATION DNO HANIIING

11-10325 MOBERG CA

FLANGED JOINT

AKTIEBOLAGET ATOMENERGI

U.S. PAT. 3,219,370 +6 PAGES, 4 FIGURES, REFERENCES, NOVEMBER 1965, DATENT IU.S.I

A FLANGED JOINT IS DESCRIBED FOR CONNECTING DIFFERENT PARTS OF CONTAINERS, RECEIVERS, PIPES, OR, PARTICULARLY, DIFFERENT PARTS OF A REACTOR PRESSURE VESSEL. THE JOINT IS SUBSTANTIALLY FREE FROM STRESSING CAUSED BY EITHER THE FORCES KEEPING THE PARTS TOGETHFR OR BY THF LARGF INTERNAL PRESSURE OR TEMPERATURE OIFFERENCES THAT MAY CCCUR BETWEEN THE OIFFERENT DAPTS OF THE JOINT. THE TWO FLANGES ARE FIXED BY WELDING TO THE PARTS TO BE JOINED, AND SEVERAL TENSION MEMBERS (E.G., BOLTS) EXTENDED OBLIQUELY FROM EACH FLANGE AND OUTSIDE THE ADJACFNT ONE. EACH TENSION MEMBER IS CONNECTED WITH $\triangle$ THRUST MEMBEP RESTING AGAINST THE ADJACENT FLANGE AND ALSO CONNECTED WITH TWO ADJACENT IDENTICAL THRUST ELEMENTS ASSOCIATED WITH TWO ADJACENT TENSION MEMRERS FROM THE OTHER FLANGE, PRFFERABLY THROUGH SPECIAL SPACING MEMRERS. $\triangle$ PART OF THE COMMON FACE BFTWEEN THE FLANGES IS DESIGNED TO ACT AS $\triangle$ PACKING AREA AND IS TAKEN UP BY A SEAL.

\#CONTAINMENT, PRESSURE VESSEL + \#FLANGF + \#SELL + DESIGN CRITERIA

11-10331 NICHOLS RW + QUIRK A + IRVINE WH + BEVITT E A LIMIT APPROACH TO THE PREVENTION OF PRESSURF VESSEL FAILURE UNITEO KINGDOM ATOMIC ENERGY AUTHORITY, RISLEY

TRG-1004 (C) +. 46 PAGES, 19 FIGURES, 5 TABLES, 17 REFERENCES, MAY 1965, UKAEA

THE CONDITIONS GIVING RISE TO FASITFRACTURE INITIATION AND PROPAGATION ARE DISCUSSED IN RELATION TO THE CASE OF A PRESSURE VESSEL CONTAINING COMPRESSIRLE FLUID, WITH PARTICULAR REFERENCE TO THE SIZE OF DEFECT LEADING TO ULTIMATE FAILURE. EXPERIMENTAL WORK CARRIED OUT TO PROVIDE NUMERICAL DATA IS SUMMARI ZED AND INTERDRETFD. THE SIGNIFICANCE OF THE RESIJLTS IS THEN CONSIDERED IN RELATION TO THE PROPOSED USE OF HIGHER DESIGN STRESSES, OF NEW MATFRIALS, AND OF PARTICULAR ENVIRONMENTS, AND WITH RESPECT TO THE OPERATIONAL SAFETY OF REACTOP PRESSURE CIRCUITS.

\#BRITTLE FRACTURE + \#CONTAINMENT, PRESSURE VESSEL + \#FAILURF, PRESSURE VESSEL + *FLOW THEORY AND EXPERIMENTS + \#TEST, PRESSURE VESSEL + BURST PRESSURE +

COMPARISON, THEORY AND EXPERIENCE + CONTAINMENT INTEGRITY + CONTAINMENT RESEARCH AND DEVELOPMENT + CONTAINMENT, HIGH PRESSURE + CYLINDER + INSTABILIIY + NDT DATA (NIL DUCTILITY TRANSITION) + PLASTICITY + PRESSURE, INTERNAL + SHELL + STEEL + STRESS + TENSILE DROPERTY

11-10529 REES NJ

A MODEL INVESTIGATION OF EXPLOSION CONTAINMENT IN SINGLE TANK FAST PEACTORS 
CATEGORY 11
CONTAINMENT OF NUCLEAR FACILITIES

11-10529 \#CONT INUED

UNITED KINGDOM ATOMIC ENERGY AUTHORITY, SOUTHEND-ON-SEA, ESSEX

ANL-7120 +28 PAGES, 24 FIGURES, 11 TABLES, 4 REFERENCES, PP. 692-719 OF PROCEEDINGS OF THE CONFERENCE

ON SAFETY, FUELS, AND CORE DESIGN IN LARGE FAST POWER REACTORS, OCTOBER 11-14, 1965 , CFSTI, \$9.25 CY

THE PRESSURE VESSELS OF FAST REACTORS MUST BE DESIGNED TO RFSIST THE EXPLOSIVE LOADS WHICH COULD BE CAUSED BY AN ACCIDENTAL SUPER-PROMPT CRITICAL EXCURSION. EXPERIMENTS WERE PERFORMED WITH CHEMICAL EXPLOSIVES DETONATED INSIDE WATER-FILLED MODEL STEEL PRESSURE VESSELS. MILD STEEL AT ROOM TEMPERATURE WAS USED TO SIMULATE STAINLESS STEFL AT ELEVATED TEMPERATURES. DIRECT AND REFLECTED PRESSURES WERE RECORDED. EJECTION OF THE CORE ACCESS PLUG AND FAILURE OF THE PRESSURE VESSEL WERE OBSERVEO. DESIGN DATA WERE OBTAINED.

* ACCIDENT, EXPLOSION + \#CONTAINMENT VESSEL LOADING + \#CONTAINMENT, MISSILE GENERATION AND PROTECTION + \#CONTAINMENT, SHOCK GENERATION ANO PROTECTION + *EXPLOSION + *REACTOR, FAST + BURST PRESSURE + CONTAINMENT RESEARCH AND DEVELOPMENT + CONTAINMENT, HIGH PRESSURE + EXCURSION, LARGE + FAILURE, PRESSURE VESSEL + IMPACT SHOCK + PLASTICITY +. PRESSURE, INTERNAL + SHOCK WAVE

11-10530 DREVON GA + FALGAYRETTES MF + WALFORD FJ

COMPARISON OF PRESSURE LOADING PRODUCED BY.CONTAINED EEXPLOSIONS IN HATER AND SODIUM

CENTRE D ETUDES NUCLEAIRES DE SACLAY + CENTRE D ETUDES NUCLEAIRE DE CADARACHE + UNITED KINGDOM ATOMIC ENERGY AUTHORITY, SOUTHEND-ON-SEA, ESSEX

ANL-7120 +. 14 PAGES, 11 FIGURES, 4 TABLES, 5 REFERENCES, PP. $720-733$ OF PROCEEDINGS OF THE CONFERENCE ON SAFETY, FUELS, AND CORE DESIGN IN LARGE FAST POWER REACTORS, OCTOBER 11-14, 1965, CFSTI, \$9.25 CY

JOINT EXPERIMENTS BY THE CEA-EURATOM AND THE UKAEA WERE CARRIED OUT AT CADARACHE, FRANCE, USING WATER AND HOT SODIUM COOLANT IN A SMALL-SCALE MODEL REPRESENTATIVE OF CURRENT FAST-REACTOR DESIGN. THE SINGLE, STAINLESS-STEEL COOLANT TANK WAS ABOUT 9.5 IN. IN DIAMETER AND 16.5 IN. DEEP, AND CONTAINED A MODEL BREEDER AND REFLECTOR. IT IS CLEAR THAT FOR A GIVEN EXPLOSIVE RELEASE OF ENERGY IN A FIXED GEOMETRY, THE BLAST EFFECTS WILL BE GREATER IN SODIUM THAN IN WATER.

*EXPLOSION + \#METAL WATER REACTION + * SOOIUM + *WATER, GENERAL + CONTAINMENT, SHOCK GENERATION AND PROTECTION + PRESSURE, INTERNAL + REACTOR, FAST

11-10531 SAMUELS DE

DESIGN FACTORS INFLUENCING THE CONTAINMENT OF. INTERNAL EXPLOSION IN FAST REACTORS UNITED KINGDOM ATOMIC ENERGY AUTHORITY, SOUTHEND-ON-SEA, ESSEX

ANL-71.20 +. 15 PAGES, 3 FIGURES, 3 REFERENCES; PP. 734-740 OF PROCEEDINGS OF THE CONFERENCE ON SAFETY, FUELS, AND CORE DESIGN IN LARGE FAST POWER REACTORS, OCTOBER 11-14, 1965, CFSTI, \$9.25 CY

IN RECENT YEARS THE FOULNESS ESTABLISHMENT OF THE U.K.A.E. A. HAS BEEN ENGAGEO IN A CONTINUING INVESTIGATION OF THE CONTAINMENT OF CORE EXPLOSIONS IN FAST REACTOR. SYSTEMS. IN THIS WORK SMALL CHARGES OF CHEMICAL HIGH EXPLOSIVE HAVE BEEN DETONATED IN SCALED MODELS OF THE REACTOR STRUCTURE. GEOMETRICAL ARRANGEMENTS ARE STUDIED IN INSTRUMENTED, OVERSTRONG MODELS, WHILE INFORMATION ON MODES OF DEFORMATION AND ENERGY ABSORPTION IS OBTAINED FROM MODELS HAVING CORRECTLY SCALED STRUCTURAL STRENGTH. PROCESSES STUDIED INCLUDE THE PLASTIC FLOW AND RUPTURE OF.METALS, SHOCK-WAVE INTERACTIONS, VENTING AND PRESSURE RISE IN GAS SPACES, CRUSHING OF POROUS MATERIALS, AND THE IMPACT OF. SHOCK-DRIVEN LIQUIDS. THIS HAS LEO TO THE POSSIBILITY OF ADJUSTING THE BALANCE BETWEEN THESE PROCESSES BY APPROPRIATE. OESIGN SO AS TO ACHIEVE THE NECESSARY STRUCTURAL INTEGRITY WITH THE LEAST ECONOMIC PENALTY OR INTERFERENCE WITH NORMAL WORKING.

*CONTAINMENT, SHOCK GENERATION AND PROTECTION + \#DESIGN CRITERIA + *EXPLOSION + \#REACTOR, FAST + MOCKUP + PRESSURE, INTERNAL + TESTING

11-10699 GROUNES $M$

SWEDISH WORK ON BRITTLE-FRACTURE PROBLEMS IN NUCLEAR REACTOR PRESSURE VESSELS

AKT IEBOLAGET ATOMENERGI, STOCKHOLM, SWEDEN

$A E-221+50$ PAGES, 23 FIGURES, 31 REFERENCES, MARCH 1966, DEP/MN

FOR A REACTOR PRESSURE VESSEL TO BE SAFE AGAINST BRITTLE FRACTURE, THE CRACK-PROPAGATION TRANSITION TEMPERATURE FOR A GIVEN STRESS MUST NOT EXCEED THE ACTUAL TEMPERATURE FOR THAT STRESS. THREE TYPES OF STEEL HAVE BEEN CONSIDERED FOR NUCLEAR SERVICE - MILD STEEL, LOW-ALLOY INTERMEDIATE-STRENGTH STEEL, AND ALLOY HIGH-STRENGTH STEEL. THE USE OF HIGH-STRENGTH STEEL HELPS MINIMIZE WALL. THICKNESSES AND TOTAL WEIGHT. MINIMIZING WALL THICKNESSES FACILITATES WELD INSPECTION. MINIMIZING WEIGHT FACILITATES TRANSPORTATION. THE FINAL TRANSITION TEMPERATURE DEPENDS ON THE TYPE OF STEEL, FABRICATION METHODS, WELDING TECHNIQUES, SHAPE, AGE, AND IRRADIATION. TEST DATA ON IRRADIATED STEELS ARE PRESENTED.

* BRITTLE FRACTURE + \#CONTAINMENT, PRESSURE VESSEL + \#EMBRITTLEMENT + \#IRRADIATION TESTING + \#NDT DATA (NIL DUCTILITY TRANSITION) + CONTAINMENT INTEGRITY + CONTAINMENT RESEARCH ANO OEVELOPMENT + FAILURE, PRESSURE VESSEL + FLAW + HIGH RADIATION + IMPACT PROPERTY + RADIATION DAMAGE + STEEL + STRESS + TENSILE PROPERTY + WELDS

11-10720 MARIN J

NEW EVALUATIONS FOR MULTIAXIAL-STRESS' PROPERTIES OF CERAMIC MATERIALS

PAGES 162-170 OF EXPERIMENTAL STRESS ANALYSIS, PROCEEDINGS, VOL. XXIII, NO. 1, E. ROSSI, EDITOR, 1966, SCCIETY FOR EXPERIMENTAL STRESS ANALYSIS, WESTPORT, CONNECTICUT

A THEORY FOR EVALUATING THE MULTIAXIAL STRESS PROPERTIES OF BRITTLE-TYPE MATERIALS WITH UNEQUAL TENSILE AND COMPRESSIVE YIELD STRENGTHS IS PRESENTED. THE THEORY IS BASED ON A NONLINEAR RELATIONSHIP BETHEEN THE MAXIMUM SHEAR STRESS AND THE NORMAL STRESS ON THE SAME 
CATEGORY II
CONTAINMENT OF NUCLEAR FACILITIES

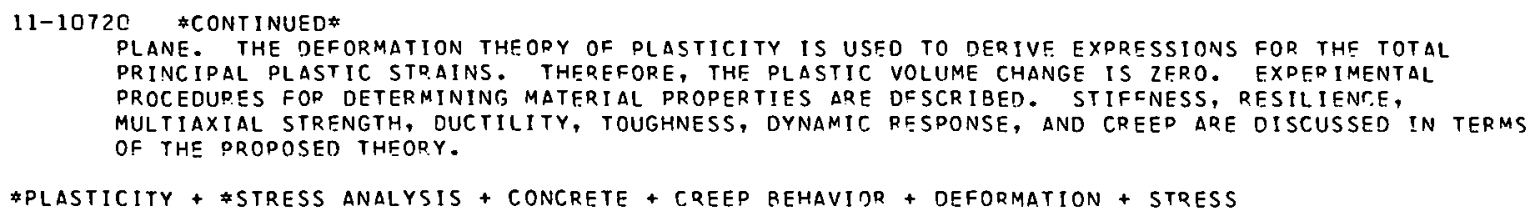

11-10873 FIRST SUPPLEMENT TO PRELIMINAPY SAFETY ANALYSIS. INOIAN POINT NUCLEAR GFNERATING UNIT NO. 2 CONSOL IOATED EDISON COMPANY OF NEW YORK

2 DAGES OF FIRST SUPPLEMENT TO PRELIMINARY SAFETY ANALYSIS. INOIAN DOINT NUCLEAR GENERATING UNIT NT. 2. MARCH 31,1966 , DOCKFT NO. 50-247, PDR

QUESTION 2, CRITFRION 3 -- GIVES DETAILED CPITERTA TO WHICH PLANT WILL BE DESIGNED, EXAMPLES CF MISSILES.

* CESIGN CRITERIA + \#REgULATION, AEC + *SAFEguARDS RFPORT, PFSPONSE TO AEC DUESTIONS + CONTAINMENT, MISSILE GENERATION AND PROTEC. ION

11-10887 FIRST SUPPLEMENT TO PRELIMINAPY SAFETY ANALYSIS. INDIAN POINT NUCLFAD GENFRATING UNIT NO 2 . CONSOL IDATEI) EUISON COMPANY OF NEW YORK

3 PAGES OF FIRST SUPPLEMENT TO PRELIMINARY SAFETY ANALYSIS. INDIAN POINT NUCLEAR GENERATING UNIT ND. 2 , MARCH 31,1966 , DOCKET NO. 50-247, PDR

QUESTION 2, CRITERION $17--$ IN ANALYSIS WHFPEIN NO SAFETY WATER INJECTION ALLOWER RUT ONLY ONF EACH CONTAINMENT SPRAY PUMPS OR AIR COOLERS FAILED, PRESSURE PEAK WAS 43.4 PSIG IHYDROGEN BURNS AFTER 44 PERCENT ZIRCONIUM REACTIONI. IN OTHER DOUPLE-ENDFD PIPE RUPTIJRES, DRESSURE PEAK WAS 40 PSIG.

\#CONTAINMENT DESIGN + \#DESIGN CRITEPIA + \#PDESSURF, INTERNAL + \#REGULATION, DEC + INDIAN POINT II + LCSS OF COOLANT + METAL WATER REACTION + REACTOR, PRESSURIZED WATER +

SAFEGUARDS REPORT, RESPONSE TC AEC QUESTIONS 
CATEGORY 11
CONTAINMENT OF NUCLEAR FACILITIES

11-10892 FIRST SUPPLEMENT TO PRELIMINARY SAFETY ANALYSIS. INOIAN POINT NUCLEAR GENERATING UNIT NO. 2 CONSOLIDATED EDISON COMPANY OF NEW YORK

5. PAGES OF FIRST SUPPLEMENT TO PRELIMINARY SAFETY ANALYSIS. INOIAN POINT NUCLEAR GENERATING UNIT NO. 2 , MARCH 31,1966 , DOCKET NO. 50-247, PDR

QUESTION 2, CRITERION 22 -- SIX CLASSES OF CONTAINMENT-ISOLATION VALVE SCHEME ARE SET UP, WITH VARIOUS COMBINATIONS OF AUTOMATIC AND OR REMOTE MANUAL VALVE ClOSURE, AND AUTOMATIC OR MANUAL SEAL-WATER INJECTION INTO THE CLOSED LINE.

*CONTAINMENT PENETRATION, ClOSURE OF + \#DESIGN CRITERIA + *SAFEguARDS REPORT, RESPONSE TO AEC OUESTIONS + INCIAN POINT II + REACTOR, PRESSURIZEO WATER

11-10929 FIRST SUPPLEMENT TO PRELIMINARY SAFETY ANALYSIS. INDIAN POINT NUCLEAR GENERATING UNIT NO. 2 CONSOLICATEO EDISON COMPANY OF NEH YORK

25 PAGES, I TABLE OF FIRST SUPPLEMENT TO PRELIMINARY SAFETY ANALYSIS. INDIAN POINT NUCLEAR GENERATING UNIT NO. 2, MARCH 31,1966 , DOCKET NO. 50-247, PDR

ELEVEN QUESTIONS ON CONTAINMENT DESIGN ARE ANSWERED; RELATED TO LOAD CARRIED BY THE LINER, SPLICING OF RE-BARS, PENETRATION REINFORCEMENT, EARTHQUAKE DESIGN, DAMPING FACTORS, ADDITIVE STRESSES, AND WIND LOADING.

*CONTAINMENT STRUCTURE + \#SAFEGUARDS REPORT, RESPONSE TO AEC OUESTIONS + \#SEISMOLOGY + INDIAN POINT II + REACTOR, PRESSURIZED WATER + STRESS ANALYSIS

11-11009 A STUDY ON PLASTIC FATIGUE EMBRITTLEMENT OF REACTOR VESSEL STEELS

CENTRE NATIONAL DE RECHERCHES METALLURGIQUES, BELGIUM

EURAEC-1547 + EUR-2689 + 46 PAGES, QUARTERLY REPORT NO. 8, OCTOEER 1-DECEMBER 31, 1965, CFSTI, \$2.0ก CY, $\$ 0.50 \mathrm{MN}$

DURING THE QUARTER, A SERIES OF CHARPY $V$ IMPACT-STRENGTH TESTS WERE MAOE ON SAMPLES THAT HAD BEEN SUBJECTED TO PLASTIC FATIGUE AT 20 AND AT 300 C. THE RESULTS SHOWED THAT THE INCREASE OF THE TRANSITION TEMPERATURE WITH 50 PERCENT OF' CRYSTALLINITY IS NOT A CONTINUOUS FUNCTION OF THE NUMBER OF CYCLES OF DAMAGE BY FATIGUE; AND THAT A FEH. CYCLES OF PLASTIC FATIGUE AT 30 D C ARE ALREADY ENOUGH FOR CAUSING QUITE A NOTFWORTHY EMBRITTLEMENT OF THE STEEL. THIS CONFIRMS THE EXPECTED EXISTENCE OF EMBRITTLEMENT MAXIMA NOTICED - IN THE IMPACT STR.ENGTH TEST AFTER MONOAXIAL FATIGUE AT $300 \mathrm{C}$.

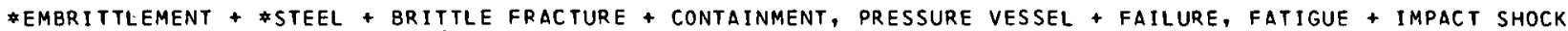

$11=11010$ RIPLING EJ + CROSLEY P

FRACTURE TOUGHNESS OF REACTOR PRESSURE VESSEL STEELS. DEVELOPMENT OF TEST PROCEOURES, MAY 1, I965-MAY 1 , 1966

MATERIALS RESEARCH LABORATORY,. INCORPORATEO, RICHTON PARK, ILLINOIS

CO0-147.7-4 +. 17 PAGES, MAY 31, 1966, CFSTI, \$1.00 ․CY, \$0.50 MN.

A TAPERED, DOUBLE-CANTILEVER BEAM SPECIMEN FOR FRACTURE-TOUGHNESS TESTING WAS DEVELOPED, ANO EXPER IMENTAL COMPL IANCE CALIBRATIONS OF THE SPECIMEN WERE MADE. THE EFFECT OF SIDE GROOVES WAS INVESTIGATED HITH ALUMINUM ALLOYS. THE RESULTS INDICATE THAT THE USE OF SIDE GROOVES PROMOTES PLANE-STRAIN FRACTURING. VERY HIGH LOADING RATES WERE USED FOR ROOM-TEMPERATURE TESTING OF A302-B SPECIMENS PRECRACKED IN FATIGUE. WITH PULSE LOADING, CRACK. ARRESTS WERE OBTAINED. THE PROCEDURE OFFERS THE PROMISE OF YIELDING ROOM-TEMPERATURE PLANE-STRAIN FRACTURE-TOUGHNESS DATA, FOR FRACTURE INITIATION AND ARREST OF A3O2-B STEEL WITH SPECIMENS OF A REASONABLE SIZE.

*FAILURE, FATIGUE + \$TEST, DESTRUCTIVE + ALLOY + ALUMINUM + CONTAINMENT, PRESSURE VESSEL + STEEL

11-11011 HAMADA K

REACTOR PRESSURE VESSEL HITH REDUCED SECONDARY STRESSES

HIDACHI SEISAKUSHO COMPANY

JAP. PATENT 1964-15090 + ORNL-TR-1328+. 3 PAGES, PATENT (FOREIGN), JULY 30,1964

A REACTOR PRESSURE VESSEL MADE WITH A CURVED BOTTOM PLATE AND CYLINDRICAL BODY WITH CONSIDERABLY REDUCED SECONDARY STRESSES IS PROPOSED. A MATERIAL WITH A LARGER THERMAL EXPANSION COEFFICIENT THAN THE BOTTOM-PLATE MATERIAL IS WELDED ALONG THE PERIPHERY OF THE JUNCTION OF THE BODY. THIS JOINT TENDS TO EXPAND THE BOTTOM PLATE AY THE LARGER THERMAL EXPANSION COEFFICIENT, THUS SECONDARY STRESSES IN THE VESSEL WALLS ARE REDUCED TO A MINIMUM, WITH THE DESIGN LIMITATIONS BEING LARGELY ELIMINATED.

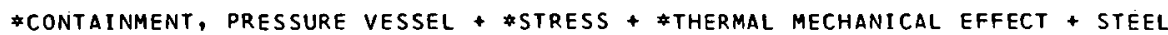

11-11012 BELLERMANN W + SCHWIERS HG

REACTOR PRESSURE VESSEL AND STRUCTURAL COMPONENTS

1 PAGE, ATOMWIRTSCHAFT, XII5), PAGE 239 (MAY 1966), IN GERMAN

THO PRINCIPAL MEASURES WERE TAKEN IN DESIGNING THE AVR PRESSURE VESSEL TO PROVIOE FOR THE LEVEL OF ACTIVITY PERMITTED IN THE PRIMARY LOOP - INTEGRAL CONSTRUCTION AND ENCLOSURE IN A SECOND PRESSURE VESSEL. SPECIAL PROBLEMS OCCURRED IN CONNECTION WITH PASSAGE THROUGH THE DOME AND COVER OF THE VESSEL, ESPECIALLY IN THE CASE OF THE FAN SUPPORTS, THE MOUNTING OF THE COVER, THE CONSTRUCTION OF THE PEDIMENT, AND THE SUPPORT OF THE VESSEL. AMONG THE COMPONENTS, THE RADIAL SUPPORTING FRAMEWORK ANO THE CARBON AND GRAPHITE MEMBERS WERE OF 
CATEGORY 11

CONTAINMENT DF NUCLEAR FACILITIES

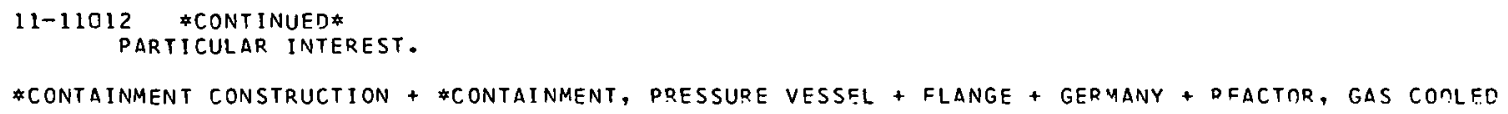

* CONTA INMENT, DRESSURE VESSEl + \#CONTAINMENT, ShoCk generation and PROTECTION +

* INSTRUMENTATION, COMPONENT + IINSTRUMENTATION, TESTING + \#SHOCK WAVE + FAILURE, COMPONENT + IMPACT SHOCK + MEASUREMENT, STRAIN GAGE + TEST, PRESSURE VESSFL

11-11020 WILLIAMS HE

AN EVALUATION OF THE EFFECT OF FINITE SHEAR STRAIN IN A SHALLOW, SDHERICAL SHELL

CALIFORNIA INSTITUTE OF TECHNOLOGY

JPL-TR-32-780 +. 23 PAGES, 10 FIGURES, 1 TABLE, 6 REFERENCES, OCTOBER 1065, SOURCE

IN AN EFFORT TO ASSESS THE EFFECT OF INCLUDING TRANSVERSE SHEAR STRAIN IN THF ANALYSIS OF THIN SHELLS, THE EQUATIONS PROPOSED BY E. REISSNER ARE SPECIALIZED FOR SHALLOW, SPHERICAL SHELLS AND ARE SOLVED FOR CASES OF LOAOING FOR WHICH THE EFFECT MIGHT BF EXPECTED TO BE APORECIABLE. IT IS FOUND THAT, FOR MATERIALS THAT ARE NEARLY ISOTROPIC, THE SOLUTION FOR AN FDGE-LOADEO SHELL DIFFERS SLIGHTLY FROM THAT OF THE CLASSICAL EQUATION HOWEVER, THE SOLUTION IN THE NEIGHBORHOOD OF A CONCENTRATED LOAD APPLIEO AT THE APEX IS FOUND TO DIFFER SIGNIFICANTLY FROM ITS CLASSICAL COUNTERPART.

\# SHELL + *SPHERE + *STRESS ANALYSIS + CREEP BEHAVIOR 
CATEGORY 11

CONTAINMENT OF NUCLEAR FACILITIES

11-11272 JOHNSON RE

FRACTURE MECHANICS- A BASIS FOR BRITTLE FRACTURE PREVENTION

WESTINGHOUSE ELECTRIC CORP., BETTIS ATOMIC POWER LAB

WAPD-TM-505 +. 82 PAGES, 32 FIGURES, 2 TABLES, 81 REFEPENCES, NOVEMBER 1965, CFSTI \$3.00 CY

THE DEVELOPMENT OF FRACTURE MECHANICS IS PRESENTED HISTORICALLY ANO MATHEMATICALLY. THE CENTRAL PROBLEMS ANO LIMITATIONS OF EXPERIMENTAL FRACTURE MECHANICS ARE DETAILED, ALONG WITH THE ASSUMPTIONS AND APPROXIMATIONS USED. THE MEANING, MEASUREMENT, AND UTILITY OF PLANE STRAIN FRACTURE TOUGHNESS (CRITICAL STRAIN ENERGY RELEASE RATE OR CRITICAL STRESS INTENSITY FACTORI ARE DISCUSSED. THE ROLF OF DEFECTS IN COMPONENTS IS DISCUSSED, SPECIFICALLY WITH RESPECT TO THE RELATIONSHIPS BETWEEN STRESS FIELDS, DEFECT GEOMETRY, AND MATERIAL CONDITION. BASIC ASPECTS OF ULTRASONIC TESTING ARE DISCUSSED WITH RESPECT TI QUANTITATIVE MEASUREMENT OF DEFECT GEOMETRIES IN STRUCTURES. SELECTED EXPERIMENTS DEALING WITH APPLICATION OF FRACTURE MECHANICS TO PREDICT ACTUAL COMPONENT FAILURES ARE REVIEWED. IT IS SHOWN THAT THE RELATIONSHIPS BETWEEN STRESS STATE, DEFECT GEOMETRY, ELASTIC CONSTANTS, AND FRACTURE TOUGHNESS EMPLOYED IN AOPLIED FRACTURE MECHANICS CAN BE UTILITED TO PREOICT BRITTLE FAILURE CONDITIONS IN A MORE QUANTITATIVE MANNER THAN TRANSITION TEMPERATURE CONCEPTS. BASED ON A DETAILED REVIEW OF THE METHODS AND PHYSICAL SIGNIFICANCE OF THE ENGINEERING METHOD OF FRACTURE MECHANICS, THE FOLLOWING CONCLUSIONS WFRE REACHED - (1) THE METHOOS OF:FRACTURE MECHANICS CAN PROVIDE MOPE ACCURATE PREDICTIONS OF BRITTLE FRACTURE CONDITIONS THAN TT CONCEPTS. 121 THE FRACTURE MECHANICS PARAMETER, PLANE STRAIN FRACTURE TOUGHNESS, APPEARS TO PROVIDE A MEASURE OF THE FRACTURE RESISTANCE OF METALS. (3) PLANE STRAIN FRACTURE TOUGHNESS CAN BE MEASURED USING LARORATORY FRACTURE TESTS ANO APPLIED TO COMPONFNTS: 141 GEOMETRY FACTORS ENTER FRACTURE MECHANICS EOUATIONS THROUGH ELASTIC NOTCH "STRESS ANALYSES:" 151 THE FRACTURE MECHANICS $\triangle P P R O A C H$ TO OPERATIONAL LIMITATIONS IS COMPATIBLE WITH OTHER DESIGN CRITERIA AND WITH OBSERVED FRACTURF BEHAVIOR.. (6) A POSSIBLE METHOD RY WHICH OPERATIONAL STRESS LIMITS CAN BE CALCULATED AND USED TO PROTECT COMPONENTS FOOM BRITTLE FRACTURE WAS PRESENTED.

\#BRITTLE FRACTURE + \#COMPARISON, THEORY AND EXPERIENCE + \#IMPACT PROPERTY + \#TEST, PRESSURE VESSEL + CONTAINMENT, PRESSURE VESSEL + NDT DATA (NIL DUCTILITY TRANSITION) + STRESS + STRESS ANALYSIS + . STRESS RUPTURE + SUPPORT STRUCTURE + TENSILE PROPERTY

11-11274 MARTIN WR + WEIR JR

IRRADIATION EMBRITTLEMENT OF LOW- AND HIGH-CARBON STAINLESS STEFLS $\triangle T$ TDO, 8DO, AND 9O0 DEGREES C. OAK RIDGE NATIONAL LABORATORY, OAK RIDGE

ORNL-TM-1516 + CONF-660 613-1+. 27 PAGES, 19 FIGURES, 3 TABLES, JUNE, 1966, CFSTI \$2.0ก CY, \$ח.50 MN

IN GENERAL, THE DUCTILITY CF THE IRRADIATED ALLOY DECREASES WITH INCREASING IRRADIATION TEMPERATURE WHEN THESE DUCTILITIES ARE DETERMINED AT TENSILE TEST TEMPERATURES WITHIN THE 65O TO 842 C TEMPERATURE RANGE, A MARKEO DIFFERENCE IN THE DUCTILITY OF LOW $\triangle N D$ HIGH-CARBON IRRADIATED STAINLESS STEELS WAS OBSERVED AND APPEARS TO BE RELATED TO THE QUANTITY OF GRAIN-BOUNDARY CARBIDES. THESE DATA ARE INTERPRETEO AS INDICATING THAT GRAIN-BOUNDARY CARBIDES FORMEO IN IRRADIATED MATERIAL IN THIS TEMPERATURE RANGE ARE CAPABLE OF INCREASING THE STRESS AT WHICH WEDGE-TYPE GRAIN-BOUNDARY CRACKS ARE NUCLEATED AND ALSO REDUCING THE RATE OF CRACK PROPAGATION. THUS, IT APPEARS THAT AGGLOMERATED CARBIDES IN THE GRAIN BOUNDARY ARE CAPABLE OF REDUCING THE MAGNITUDE OF IRRADIATION EMBP. ITTLEMENT.

*EMBRITTLEMENT + \#RADIATION EFFECT + \#STEEL, STAINLESS + ALlOY + BRITTLE FRACTURE + CARBIOE + CLAD + RAOIATION DAMAGE

11-11678 WATSONGM + PERE2 RP + FONTANA MH

EFFECTS OF CONTAINMENT SYSTEM SIZE ON FISSION PRODUCT BEHAVIOR OAK RIDGE NATIONAL LABORATORY, OAK RIDGE

CONF-660904 +. 2 PAGES, PRESENTED AT 9TH AEC AIR CLEANING CONFERENCE, BOSTON, MASS., SEPTEMBER I3-16,

1966 ," SOURCE

SIMPLE MATHEMATICAL MODELS TO AID IN THE DETERMINATION OF EFFECT OF CONTAINMENT SIZE ON PLATE-OUT BEHAVIOR OF IODINE HAVE BEEN POSTULATED. TWO GENERAL CLASSES OF SYSTEMS HAVE BEEN CONSIDERED, DEPENDING ON THE ABSENCE OR ON THE PRESENCE OF STEAM. IN THE ABSFNCE OF STEAM, THE PRINCIPAL ASSUMPTIONS MADE WERE - 111 HOMOGENEOUS MIXING, 121 BOUNDARY GAS LAYFR ENVELOPING ALL SURFACES, (3) DIFFUSION THROUGH BOUNDARY LAYER TO BE THE RATF LIMITING PROCESS, $(4)$ MOLECULAR IODINE PRESENT, METHYL IODIDE ABSENT. MATHEMATICAL PELATIONS IN TERMS OF MASS TRANSFER COEFFICIENTS AND SURFACE-TO-VOLUME RATIOS OF CONTAINERS AND SURFACE CHARACTERIZATION PARAMETERS WERE DEVELOPED FOR CASES WITH AND WITHOUT DESORPTION FROM PARTIALLY COVERED SURFACES. IN THE PRESENCE OF CONDFNSING STFAM, THERE IS BULK FLOW OF STEAM TOWARD THE WALLS. IN SUCH CASES, IT HAS ASSUMED THAT DIFFUSIVE AND BULK FLOW COMPONENTS MAY BE APPROXIMATED BY THE BULK-FLOW COMPONENT ALONE, NEGLECTING THE DIFFUSIVE COMPONENT. FURTHERMORE, IT HAS BEEN ASSUMED THAT THE SOLUBILITY OF IODINF IN STEAM-CONDENSATE IS HIGH ENOUGH TO PERMIT THE IODINE AND THE STEAM TO CONDENSE TOGETHER WITH THE SAME COMPOSITION AS THE GAS PHASE. AS A RESULT OF THESE ASSUMPTIONS, MATHEMATICAL RELATIONS WERE DERIVED FOR THE CONCENTRATION OF IODINE AS A FUNCTION OF TIME IN TERMS OF THE SURFACE-TO-VOLUME RATIOS, CONDENSING STEAM FLUXES, AND STEAM CONCENTRATIONS.

* ANALYTICAL MODEL + \#CONTAINMENT FILTERING SYSTEM + \#DEPOSITION + \#FISSION PRODUCT, IODINE + AIR CLEANING + CONTAINMENT, GENERAL + IODINE + MASS TRANSFER + ORGANIC IODIDE + STEAM + SURFACE TO VOLUME RATIO + WATER VAPOR

11-1169t DURANT WS

PERFORMANCE OF AIRBORNE ACTIVITY CONFINEMENT SYSTEMS IN SAVANNAH RIVER PLANT REACTOR BUILOINGS SAVANNAH RIVER LABORATORY, AIKEN, S. C.

CONF-66C904+DP-MS-66-52+. 21 PAGES, 6 FIGURES, 1 TABLF, 21 REFERENCES, PRESENTFO AT $9 T H A E C$ AIR

CLEANING CONFERENCE, BOSTON, MASS., SEPTEMBER 13-16, 1966 , SOURCE 
CATEGORY 11

CONTAINMENT OF NUCLEAR FACILITIES

11-11696 *CONTINUED*

A FILTRATION-ADSORPTION SYSTEM IS INSTALLEO IN THE VENTILATION EXHAUST OF EACH RFACTOR BUILDING AT THF SAVANNAH RIVER OLANT TO CONFINE AIRBCRNE IODINE PARTICLES AND VADOR THAT NIGHT BE P.ELSASED IN THE HIGHLY UNLIKELY EVENT DF A REACTOR ACCIDENT. AIP FROM THE PROCFSS AREAS OF EACH RUILDING IS PASSEO CONTINUOUSLY THROUGH MOISTURE SEPARATORS, THEN THROUSH PARTICULATE FILTEOS, AND FINALLY THROUGH ICOINE ADSORBER BEDS DF ACTIVATED CARRON. THE UNITS HAVE THE DEMONSTRATED ABILITY TO COLLECT OVER 99 PERCENT OF AIRBORNE PARTICULATF ACTIVITY ANI OVER 99.9 PERCENT OF AIRBORNE HALOGEN ACTIVITY UNDER EMERGENCY CCNDITIDNS. $\triangle$ CONTINUING PROGRAM OF DEVELOPMENT, TESTING, AND MAINTFNANCE ENSURES THAT THESE HIGH EFFICIFNCIFS WILL BE MAINTAINED DUP.ING OPERATION. EXPEPIENCE HAS PIEEN SATISFACTOPY FOR MOPE THAN 3 YEARS OF OPERATION.

*CONTAINMENT FILTERING SYSTEM + \#CONTAINRENT SYSTEM, OPEDATION OC + \#FILTER DESIGN + * SAVANNAH RIVER PLANT + *WATER VAPOR + AIR CLFANING + CONTAINMFNT AIR COOLING + FNGINEERED SAFEGUARD + FILTER + FILTER INSTALLATION + FILTER OPERATION + FILTER SYSTEM

11-11U97 FIR3T HW + 3ILVERMAN L + PENCEF D + UAWSÜIN FLOATING ROOF CONTAINMENT VESSELS

HARVARD UNIVERSITY, BOSTON

CONF-660904 +. 19 PAGES, 5 FIGURES, PRESENTED AT 9TH AEC AIP CLEANING CONFERENCE, BOSTON, MASS., SEPTEMBER $13-16,1966$, SOURCE

THE FURPOSE OT TIIIS INVESTIGATION WAS TO DEVELOP MECHANISMS FCR, AND TO STUDY THE PEPFORMANCE CHARACTERISTICS OF, A FLOATING-ROOF REACTOR AND DFF-GAS CONTAINMFNT VESSFL. THF PRESSURE SURGE FOLLOWING A MAJOR COOLANT LINE RUPTURE WOULO BF ABSOPBET AND SUPPDESSFD BY MOVEMENT OF A LEAK-TIGHT MOVABLE ROOF. ACTIVATION OF COOLINF-WATER SPRAYS AETER THE ACCIDENT WOULD CONDENSE STEAM AND PERMIT THE ROOF TO FALL SLOWLY TO ITS NORMAL POSITION. THE ADVANTAGES OF THIS SCHEME APE - 111 IN THE EVENT OF A MAXIMUM CRFDIRLE ACCIDENT, THE RDOF WDULD RISF IN RESPONSE TO THE APPLIED PRESSURE, PPEVENTING THF SHELL FROM PEINE SUBJFCTED TO STRESSES IN EXCESS OF A FRACTION OF A POUND PER SOUAPE INCH. AS RECOVERY MEASURES TOOK FFFFCT, THE FLOATING ROOF WOULD SETTLE AND RETURN TO ITS ORIGINAL POSITION WHEN THF DRESSURE INSIDE THE CONTAINMENT VESSEL RETURNED TO NORMAL. (2) AS THE PRESSURE OF THE STATIONADY PARTS OF THE CONTAINMENT SHELL WOULD NOT EXTEED 0.25 PSI, IT MIGHT RE POSSIBLE TO LIGHTEN AND SIMOLIFY THE STRUCTURE AND THEREEY ETrRCT SUBSTANTIAL SAVINGS hHILE MAINTAINING AN EQUAL DEGREE OF SAFETY.

*CONTAINMENT DESIGN + \#CONTAINMENT LEAKAge CONTROL + \#CnNTAINMFNT RESEAPCH AND DEVELOPMENT + \#CONTAINMENT SPRAY + \#CONTAINMENT STRUCTURE + \#CONTAINMFNT, SHOCK GENERATION AND PROTECTION + AIR CLEANING + CONTAINMENT CONSTRUCTION + CONTAINMENT, PRFSSURE VESSEL

$11-11698 \quad S M I T H M L$

CONFINEMENT SYSTEMS TESTS PERFORNED DURING DEACTIVATION OF THE 1OOGF REACTOR

DOUGLAS UNITED NUCLEAR, INC., RICHLAND

CONF-660904 + DUN-SA-15 + 30 PAGES, 19 FIGURES, 5 TABLES, PRESENTED AT 9TH AEC AIR CLEANING CONFFRFNCF, BOSTON, MASS., SEPTEMBER 13-16, 1966, SOURCE

PERMANENT SHUTDOWN OF THE 1OD-F PLUTONIUM PPODUCTION REACTOP AT HANFOPD MADE THE SYSTEM FOR CONFINING THE PARTICLES AND HALOGEN IN THE EXHAUST AIR AVAILABLE FOR TESTING. THE FOLLOWING TESTS WERE RERFORMED, AND THE RESULTS ARE GIVLN THROUSHOUT THE TFXT - IODINF. DEPOSITION FROM IHE AIRSTREAM, IODINE REMOVED FROM AIRSTREAM BY FOG SPRAY, ENCAPSULATION OF THE REACTDP EXHAUST AIR IN FOAM, FFFECTIVENESS OF FOG SPRAY FOR REMOVING NOBLE GASES FROM THE AIR, EFFECTIVENESS OF THE FILTER SYSTEM FOP REMCVING IODINE FROM THE EXHAUST AIR. ABOUT 1OO CURIES OF I- 128 WAS RELEASED INTO THE DISCHARGE-AREA SUPPLY AIR WITH THE FDG SPPAY OPERATING. THE SPRAY REDUCED THE CONCENTRATION IN THE AIP EXHAUSTED FROM THE DISCHARGE AREA RY $\triangle$ FACTOR OF 500. ABOUT 10 CURIES OF KR-85 WAS RELEASED INTO THE EXHAUST AIR. THE DOSF WAS MEASURED UP AND DOWN STREAM OF A FOG SPRAY INSTALLED IN THE NUCT. NINETY-FIVE PFRCENT OF THE KR-RS WAS STTI.I. IN THE EXHAUST AIR. AFTER IT PASSER THROUGH THE FOG SOPAY. THE EXDOSUDE OF THE AIP. TO THE FOG WAS LESS THAN 3 SFR.ONDS.

* CECONTAMINATION SPRAY + \#FILTER SYSTEM + \#FISSION PRODUCT, IODINE + \#FOAM + \#FOG + \#NOBLE GAS + AIR CLEANING + CONTAINMENT, GENERAL + DECONTAMINATION + DFDOSITION + FISSION PRODUCT TRANSPORT + SPRAY, GENERAL

11-11699 COLLINS RD + HILLARY JJ + TAYLOR JC AIR CLEANING FOR REACTORS WITH VENTED CONTAINMENT UNITED KINGOOM ATOMIC FNERGY AUTHORITY, WINDSC,ALE

CONF-660904 +. 36 PAGES, 11 FIGURES, 6 TARLES, 9 REFEPENCES, PRESENTEO AT 9TH AEC AIR CLEANINR, CONFERENCF, BOSTON, MASS, SEPTEMBFR 13-1\%, 196G, SOURT,F

A PROGRAMME OF EXPERIMENTAL WORK HAS BEEN CARRIED OUT UNOER CONOITIONS APPROPRIATE TO POSSIPLE DEPRESSUR IZATION-TYPE ACCIDENTS TO THF STFAM GENERATING HEAVY WATFR RFACTOP. (SGHW) AT WINFRITH HEATH WHICH HAS VENTED CONTAINMENT. THE WORK HAS INCLUDFD SMALL-SCALE EXDEPIMFNTS IN GLASS OR SILICA APDARATUS IN WHICH MEASUREMENTS HAVE BEEN MADE OF THE EXTENT AND FORM DF THE IODINE RELEASF FROM ZIRCALOY-CLAD UO2 INTO STEAM UNDER MELTING CONDITIONS AND AT ABOUT $1000 \mathrm{C}$. A NUMBER OF TESTS HAVE BEEN CONDUCTED WITH SIMULATED FORMS OF IODINE ON TWO LARGE-SCALE STFEL MODELS OF THE REACTOR WATER-LUTE STEAM SUPPRESSION SYSTEM. TESTS HAVF ALSO BEEN CARRIED OUT ON IOOO-CFM FILTER. UNITS TO DEVELOP DPODLET DISENTRAINMENT DEVICES. WORK CN THE DEVELOPMENT OF CHARCOALS TO DEAL WITH PENETRATING IODINE (METHYL IODIDE) UNDEP WFT CONDITIONS IS REPOPTED SEPARATELY. THE RFSULTS OF THIS WORK SHOW THAT - (A) AN EFFECTIVE TRAPPING PLANT CAN BE SPECIFIED TO DEAL WITH FISSION PRODUCT IODINE IN WET ATMOSPHERES. IRI AT LEAST UP TO 1000 MWD/TE U FUEL RURN-UP, A CAN-RFTENTION FACTOR OF IO ADOLIES FOR IOOINE EXPECTED TO BE FREE WITHIN THE CAN, ALSO THAT PASSAGE THROUGH A WATER LUTE IS LIKFLY TO REDUCE THE IODINE RELEASE GY A FURTHFR FACTOP OF 10.

\#CHARCOAL + \#CONTAINMENT DESIGN + *CONTAINMENT, PRESSURE VENTING + *FISSION PRODUCT, IODINE + 
CATEGORY II

CONTAINMENT OF NUCLEAR FACILITIFS

11-11699 *CONTINUED*

\#ORGANIC IODIOE + \#WATER VAPOR + AIR CLEANING + CONTAINMENT FILTERING SYSTEM +

CONTAINMENT RESEARCH AND DEVELOPMENT + CONTAINMENT, PRFSSURE RELIEF + CONTAINMENT, PRESSIJRE SUPPPESSION + CONTAINMENT, WATER FILLED

11-11700 PARKER GW + CREEK GE + MARTIN WJ + PARSLY LF

EFFECTS OF CONTAINMENT SYSTEM SIZE ON FISSION PROOUCT REHAVIOR

OAK RIDGE NATIONAL LABORATORY, OAK RIDGE

CONF-660904 +. 13 PAGES, 2 FIGURES, 3 TABLES, 10 REFERENCES, PRESENTEO AT 9TH AEC AIR CONFFRENCF, ROSTDN,

MASS., SEPTEMBER $13-16,1966$, SOURCE

DATA ON IODINE DEPOSITION IN THE CMF (CONTAINMENT MOCKUP FACILITY), THE CRI (CONTAINMENT RESEARCH INSTALLATION), AND NSPP (NUCLEAR SAFETY PILOT PLANT) WERE EXAMINED TO TRY TO CORRELATE THE RESULTS WITH THE SIZE OF THE CONTAINMENT TANKS INVOLVED, AND AN EQUATTON WAS DEVELOPED THAT ADEQUATELY CORRELATES THE DEPOSITION RATES DURING THE INITIAL OR REACTIVE PHASE OF THE DEPOSITION PROCESS. PUBLISHED DATA, AND INFORMATION OBTAINED AT THIS LARORATORY ON THE PRODUCTION OF METHYL IODIDE IN REACTOR-SAFETY EXPERIMENTS, WERE COMPILED TO ASSESS THE IMPORTANCE OF THIS FORM OF RADIOIODINE. IT APPEARS THAT A ROUGH CORRELATION CAN EE MADE BETHEEN FRACTION OF IODINE CONVERTED TO METHYL IODIDE, THE CONTAINMENT-VESSEL SIZE, ANO THE RESIDENCE TIME OF IODINE IN THE VESSEL. IN NEARLY ALL CASES, THE AMOUNT OF AIRBORNE IODINE FOUND AS METHYL IODIOE WAS I PERCENT OR LESS.

* CONTAINMENT FILTERING SYSTEM + \#CONTAINMENT RESEARCH AND OEVELOPMENT + \#FISSION PRODUCT RELEASE, GENERAL + \#FISSION PRODUCT, IODINE + \#ORGANIC IODIDE + AEROSOL + AIR CLEANING + CONTAINMENT ANALYSIS +

CONTAINMENT DESIGN + DEPOSITION 
CATEGORY 12

PLANT SAFETY FEATIJES

$12-09311 \quad H I L L T M$

RIVERTON, WYOMING. ADMINISTRATIVE CONTROL PREVENTS HIGH RANIATION EXPOSURE DURING ORE-CRUSHING FEDERAL-RADOROCK-GAS HILLS PARTNERS

2 PAGES, MARCH 16, 1966, ATONIC ENERGY CLEARING HOUSE, 12(14), PAGES 15-16 (APRIL 4, 1966)

SINCE EARLY 1965, HIGH-CLAY ORES ARE PROCESSED DURING DRY SEASONS. DRYING OPERATIONS (DURING WET SEASONS) (CAUSES SEVFRF DUSTING. LARGE VENT FANS ARE KEPT RUNNINR DURING MAINTENANCE. NO CNE HAS EXCEEDED MPC SINCE THESE MEASURES STARTED.

* adinistrative controls and practices + contamination + milling

12-C9402 AIR COOLING UNIT FOR PQOTECTIVE CLOTHING AND THE LIKE

SO. $\triangle F$. PATENT $1822 / 64+$. APRIL 20, 196\%, PATENT (FOREIGN)

THIS INVENTION PROVIDES A DEVICE FCR COOLING GAS SUPPLIED TO A PERSON WEARING PROTECTIVE CLOTHING AND COMPRTSES A SOURCE OF PRESSURIZEO GAS, A CONDUIT FOR CONDUCTINE SAID GAS TO SAID PERSON, $\triangle N D$ A VORTEX TUBE ATTACHABLE TO THE BODY OF SAID PERSON. THE CONDUIT IS ATTACHED TO THE INLET OF THE VORTEX TUBE DISTRIBUTION CONDUITS CONNECTED TO THE COLD OUTLET OF THE VORTEX TURE ARE PROVIOED FOR CONDUCTING THE COOLED GAS EITHER TO A FACS MASK ONLY OR. TO VARIOUS POSITIONS WITHIN A PROTECTIVE SUIT PARTIALLY OR WHOLLY COVERING THE PTRSON. A NOISE MUFFLER IS ALSO PROVIDEO WHERE NECESSARY IN THE CDLD OUTLET LINE OF THE VORTEX TURE.

\#PFSONNEL PROTECTIVE DEVICE

12-09602 MANN $S+$ YOUNGRLOOD EL

DECONTAMINATION OF THE ORNL MOLTEN-SALT FLUORIDE-VOLATILITY PILOT PLANT AFTER PROCESSING IRRADIATED ZIRCONIUM-URANIUM ALLOY FUEL

OAK RIDGE NATIONAL LABORATORY, OAK RIDGE, TENNESSEE

ORNL-3891 +. 35 PAGES, 13 TABLES, 2 FIGURES, 14 REFERFNCFS, FFBRUARY 1966- CFSTI, \$2.00 CY, \$T.5O MN

THE MOLTEN-SALT FLUORIDE-VOLATILITY PROCESS FOR RECOVERING URANIUM FROM IRPAOIATED $7 . I P C O N I U M-$ OR ZIRCALOY-2-CLAD FUEL ELEMENTS WAS DEMONSTRATED SIJCCESSFULLY IN THE ORNL MOLTEN-SALT FLUORIDE-VOLATILITY PILOT PLANT. THIS REPCRT DESCRIBES DECONTAMINATION METHODS THAT HAVF BEEN USED TWICE, FOLLOWING TWO PERIOOS OF HOT OPERATION, TO REDUCE RADIATION LEVELS IN EXCFSS OF 2000 R/HR TO VALUES SUFFICIENTLY LOW TO PERMIT EXTENSIVE DIRECT MAINTENANCE AND EOUIPMENT MOOIFICATION. RADIATION DOSAGE TO INDIVIDUALS WHO DIO THE MECHANICAL WORK IN NO CASE EXCEEDED THE QUARTERLY 1.3-R ALLOWANCE. FINAL BACKGROUNDS WERE LESS THAN IOD MR/HR IN THE MAJORITY OF CELL LOCATIONS, WITH MAXIMUM READINGS OF 500 MR/HR ADJACENT TO SOMF PARTS OF THE PROCESS EQUIPMENT. THF DFCONTAMINATION SEQUENCE WAS BASED ON LARORATORY CEVELOPMENT WORK. IT INCLUDES FLUSHING WITH A MOLTEN SALT, FOLLOWED BY TREATMENT WITH THRFE TYPES OF ADUEOUS SOLUTIONS FOR REMOVING SALT FILM, METAL SCALE, AND DEOOSITED RADIATION EMITTERS. THE RESPECTIVE COMPOSITIONS WERE - AMMONIUM OXALATE 10.3 TO $0.35 \mathrm{M}$ ), ALUMINUM NITRATE (O.I M), OR AL (NO-3)3-HNO-3 (0.1-0.01 M), SOOIUM HYDPOXIDE-HYDROGEN PEROXIDE-SODIUM TARTRATE (ARDUT 5-1-1 WT PERCENTI. THIS PROCEDURE IS SUITABLE FOR RADIATION LEVELS AT LEAST AS HIGH AS THOSE ENCOUNTERED IN THE TWO RADIOACTIVE OPERATING PERIOOS CITED.

*FUEL ELEMENT + \#MOLTEN FUEL + \#RADIOCHEMICAL PROCESSING + CLAD + DECONTAMINATION + SALT + URANIUM + ZIRCALOY + ZIPICONIUM

12-09607 DICE DT + WICKEK LU

URETHANE MANIPULATOR GAUNTLETS

OAK RIDGE NATIONAL LABORATORY, OAK RIDGE, TENNESSEE

ORNL-TM-1326 +. 13 PAGES, 4 FIGURES, NOVEMBER 9, 1965- CFSTI, \$1.DO CY, \$O.50 MN

RESEARCH SERVICES PERSONNEL IN COLLABORAIION WITH THE CERAMICS AND DLASTICS DEPARTMENT OF THE Y-12 DEVELOPMENT DIVISION DEVELOPED A METHOD FOR MAKING MANIPULATOR GAUNTLETS FROM LIDUID URETHANE MONOMER. IN MOST HOT CELLS, THE EXPECTED SFRVICE LIFE OF THESE GAUNTLETS IS NEARLY FIVE TIMES THAT OF THE NEOPRENE GAUNTLETS PREVIOUSLY USED. IT IS NECESSARY TO ADD A COATING, OF NERPRENF TO MAINTAIN THIS LIFE EXPECTANCY IN AREAS WHERE OXIDIZING ACIDS ARE ENCOUNTEPED. AS AN ADDITIONAL BENEFIT, SPECIAL UPETHANE BOOTS, BELLOWS, AND OTHER OBJECTS ARE FASILY MAUE BY THIS METHOD.

* MAINTENANCE AND REPAIR + \#PERSONNEL PROTECTIVE DEVICE + *RFMOTE MANIPULATING ANC VIEWING + GLOVE BOX + HOT CELL

12-09652 GRAF P + STAUFFER M

TRANSFER METHODS FOR IRRADIATION RIGS AND FUEL ELEMENTS FOR POSTIRPADIATION EXAMINATION IN THE HOT CELLS OF THE EIR - WURENLINGEN (SWITZERLAND)

SWISS FEDERAL INSTITUTE FOR REACTOR RESEARCH, HURENL INGFN

16 PAGES, 7 FIGURES, 5 REFERENCES- $1965-$ PP $485-500$ OF THE PROCEEDINGS OF AN INTERNATIONAL SYMPOSIUM ON WORKING METHODS IN HIGH ACTIVITY HOT LARORATORIES, GRENOBLE, JUNE 15-18, 1965, VOL. 2- ENEA, OECD, PUBL ISHERS

THE DIFFERENT TRANSFER METHODS FOR HIGHLY ACTIVE MATERIALS IN THE FIVE INTERCONNECTED HOT CELLS WITH ADEOUATE SHIELOING UP TO 100,000 MEV-CURIES OF THE HIGH-LEVEL LARORATORY OF THE SWISS REACTOP PESEARCH CENTRE ARF DESCRIBFD. ALL TRANSFER SYSTEMS OF THE CELLS ARE BETA-GAMMA-SHIELDED AND TIGHT, BUT THEY ARE NOT ALPHA-SEALED. WORK WITH IRRADIATED FUEL WITH HIGH PLUTONIUM CONCENTRATION IS ACCOMPLISHED IN UNDERPRESSURED IN-CELL BOXES. THE TRANSFER METHODS USED BETWEEN THE SHIELDED CELL AND THE SEALED BOX WITH THE HELP OF THE POWER MANIPULATOR ARE BY THE ADAPTED GLOVE-BOX TECHNIOUE THROUGH AIRLOCKS.

*EXAMINATION + *FUEL ELEMENT + \#FUEL HANDLING + \#HOT CELL + \#IRRADIATION TESTING + \#SWITZERLAND + 
CATEGORY

PLANT SAFETY FEATURES

$12-09652$ \#CONTINUED*

* TRANSPORTATION AND HANDL ING + CONTAINMENT AIR LOCK + ENEA (EUROPEAN NUCLEAR. ENERGY AGENCY) + GLOVE BOX

12-C9653 DJURLE S + NANBERG R

GENERAL DESIGN PRINCIPLES AND EXPERIENCE OF THE FLOW, TRANSFER AND STORAGE OF PADIOACTIVE MATERIAL IN THE STUDSVIK HOT LABORATORY

AE $\triangle T$ TOMENERGI, SWEDEN

10 PAGES, 3 FIGURES, 1 REFERENCE- 1965- PP. 501-510 OF VOL. 2, PROCEEDINGS OF AN INTERNATIONAL SYMPOSIUM

ON WORKING METHOOS IN HIGH ACTIVITY HOT LABORATORIES, GRENOBLE, JUNE 15-18, 1965- ENEA, DELD, PUBLISHERS

THE ACTIVE LABORATORY FOR FUEL ELEMENTS AT STUDSVIK, SWEDEN, INCLUDES SEVEN CONCRETE CELLS AND A LEAD CELL. THE DESIGN OF THE LABORATORY WITH SPECIAL REGARD TO THE FLOW, TRANSFER, AND STORAGE OF MATERIALS IS DISCUSSED. THE OPERATING EXPERIENCE HAS INOICATED THAT THE DESIGN PRINCIPLES WERE CORRECT IN GENERAL, ALTHOUGH SOME MOOIFICATIONS OF THE LABORATORY HAVE PROVED BENEF ICIAL.

*FUEL HANOLING + *TRANSPORTATION AND HANDLING + ENEA (EUROPEAN NUCLEAR ENERGY AGENCY) + FUEL STORAGF + HOT CELL + OPERATIONS REPORTS, GENERAL + SWEDEN

12-09654 LARSEN FB

TRANSFER OF MATER IALS, EQUIPMENT AND PERSONNEL THROUGH ALPHA-GAMMA BARRIERS IN THE RISO HOT CELLS DANISH ATOMIC ENERGY COMMISSION

12 PAGES, 6 FIGURES- 1965- PP. 511-522 OF VOL. 2, PROCEFDINGS OF AN INTERNATIONAL SYMPOSIUM ON WORKING

METHODS IN HIGH ACTIVITY HOT LABORATORIES, GRENOBLE, JUNE, 15-18, 1965, ENEA, OECD, PUBLISHERS

THE HOT-CELL FACILITY AT THE RESEARCH ESTABLISHMENT RISO, DENMARK, WAS DESIGNED AS AN ALPHA-GAMMA FACILITY. THIS PAPER DESCRIRES HOW THE GAMMA SHIELD AND/OR THE $\triangle L P H A$ SEAL OF THE CONCRETE-SHIELDED CELL BANK ARE MAINTAINED DURING TRANSFER OF MATERIALS, EQUIPMENT, AND PERSONNEL BY THE USE OF SHUTTERS, MECHANICAL. ALPHA SEALS; AIR BARRIERS, AND AIR LOCKS.

* DENMARK + \#FUEL HANDLING + CONTAINMENT AIR LOCK + ENEA (EUROPEAN NUCLEAR ENERGY AGENCY) + GROSS ALPHA + GROSS BETA + HOT CELL + RISO (RESEARCH LABORATORY, DENMARK) + TRANSPORTATION AND HANDLING

12-C9655 SCHULTE JW + PETERSON PJ + WILSON MT + DEILY GJ + FLEISCHER ES

METHOOS USED IN THE UNITED. STATES FOR TRANSFERRING MATERIALS THROUGH RADIATION BARRIFRS

LOS ALAMOS SCIENTIFIC LABORATORY + SAVANNAH RIVER LABORATORY' + LAWRENCE RADIATION LARORATORY

22 PAGES, 21 FIGURES, 32 REFERENCES- 1965- PP. 523-544 OF VOL.:2, PROCEEDINGS OF AN INTERNATIONAL SYMPOSIUM ON WORKING METHODS IN HIGH ACTIVITY HOT LABORATORIES, GRENOBLE, JUNE 15-18, 1965, ENEA, OECD, PUBL I SHERS

VARIOUS METHODS IN USE THROUGHOUT THE UNITEO STATES ARE DESCRIBED BY WHICH MATERIALS ARE PASSED THROUGH THE SHIELDING OF HIGH-ACTIVITY HOT CELLS. DISTINCTIONS ARE MADE BETWEEN OPERATIONS INVOLVING $(1)$ THE TRANSFER OF COLD MATERIALS INTO CELLS, (2) THE INTRODUCTION AND REMOVAL OF HOT MATERIALS THROUGH GAMMA BARRIERS, AND (3) THE INTRODUCYION AND REMOVAL OF HOT MATERIALS THROUGH ALPHA-GAMMA BARRIERS. THE PROCEDURES PRESENTED WERE TAKEN FROM PUBLISHED ARTICLES, PERSONAL OBSERVATIONS AT VARIOUS FACILITIES, AND CONTRIBUTIONS BY THE AUTHORS.

* Fuel hanol ing + enea IEURopean nuclear energy agencyi + hot CEll + united States

12-09656 RITCHIE AB +. WEBB GG

THE TRANSFER OF RACIOACTIVE SOURCES

UNITED KINGDOM ATOMIC ENERGY ESTABLI SHMENT, HARWELL

20 PAGES, 10 FIGURES, 2 REFERENCES- 1965- PP. $551-570$ OF VOL. 2 , PROCEEDINGS OF AN INTERNATIONAL SYMPOSIUM ON WORKING METHOOS IN HIGH ACTIVITY HOT LABORATORIES, GRENOBLE, JUNE 15-18, 1965- ENEA, OSCD, PUBLISHERS

A REVIEW OF METHODS IN USE AT A NUMBER OF ACTIVE HANDL ING FACILITIES IN THE U.K.A.F. A. FOR THE TRANSFER OF KILOCURIE SOURCES OF RADIOACTIVE MATERIAL BETWEEN SHIELDED FLASKS AND BETA-GAMMA, ALPHA-BETA-GAMMA AND CONTROLLED-ATMOSPHERE CELLS.

*FUEL HANDLING + \#RANSPORTATION AND HANDLING + \#UNITED KINGDOM + ENEA (EUROPEAN NUCLEAR ENERGY AGENCY) + SOURCE, RADIATION + STORAGE CONTAINER

12-0965E BOEHME G + GOTTLOB P + NOWAK A

TRANSFER PROCEDURES USED IN THE ALPHA-GAMMA HOT LABORATORY AT KARLSRUHE KARLSRUHE NUCLEAR RESEARCH CENTER, GERMANY

12 PAGES, 7 FIGURES, 5 REFERENCES- 1965- PP. 583-595 OF THE PROCEEDINGS OF AN INTERNATIONAL SYMPOSIUM ON WORKING METHODS IN HIGH ACTIVITY HOT LABORATORIES, GRENOBLE, JUNE 15-18, 1965, VOL. 2- ENEA, OECD, PURL I SHERS

SEVERAL SYSTEMS ARE APPLIED FOR GAS-TIGHT INTER-CELL TRANSFER AND LOADING AND UNLOADING OF I RADIOACTIVE MATERIALS AND PARTS OF CELL EQUIPMENT UNDER GAS-TIGHT AND ALPHA-TIGHT CONDITIONS WITHOUT PERSONNEL HAVING TO ENTER THE CELLS. TESTSS HAVE BEEN CARRIED OUT TO SHOW THE RELIABILITY OF THE TRANSFER OPERATIONS.

*FUEL HANDL ING + *GERMANY + *HOT. CELL + ENEA (EUROPEAN NUCLEAR ENERGY AGENCY) + TEST, PROOF + TRANSPORTATION ANO HANDLING 
CATEGORY 12

PLANT SAFETY FEATURES

12-09659 \#CONT INUED*

CESIGN AND PROCEDURES FOR HANDLING HIGH-LEVEL ALPHA-GAMMA BOXES AT THE LABORATORY FOR RADIOACTIVE SOLIDS KERNFOR SCHUNGSANL AGE JULICH, GERMANY

15 PAGES, 7 FIGURES, 5 REFERENCES- 1965 - PP. 596-611 OF THE PROCEEDINGS DF AN INTERNATIONAL SYMPOSIUM ON WORKING METHODS IN HIGH ACTIVITY HOT LABOPATORIES, GRENOBLE, JUNE 15-18, 1065, VOL. 2- ENEA, OECD, PUEL I SHERS

CONCRETE HOT CELLS WITH SUFFICIENT SHIELDING FOR 10,ODO CURIES OF A 1-MEV GAMMA EMITTER ARE DESIGNED FOR EXPERIMENTS ON HUMIDITY-SENSITIVE, VERY DUSTY, ALPHA-GAMMA-EMITTING REACTOR-FUEL MATERIALS. THIS PAPER OISCUSSES PROBLEMS ARISING FROM 11 TRANSFFR OPEPATIONS OF EXPERIMENTAL MATERIALS AND WASTES INTO AND OUT OF BOXFS, AND OF BOXES THEMSELVES INTO AND OUT OF THE CELLS, (2) EXCHANGE, REPAIR, AND MAINTENANCE OF BOX EQUIPMENT, AND (3) PLASTIC-BAGGING, TECHNI QUES.

\#HOT CELL + CONTAINMENT DESIGN + DESIGN CRITERIA + ENEA (FUROPEAN NUCLEAR ENERGY AGENCY) + FUEL HANDLING + GERMANY + MATNTENANCE AND REPAIR + STORAGE CONTAINER + TRANSPORTATION AND HANDLING

12-[966C PESENTI P + CAZALIS JP

SPECIAL PROC.FDURE FOR ALPHA-BETA-GAMMA TRANSFERS OF LARGE PIFCES OF FQUIOMENT

EUROPEAN ATOMIC ENERGY COMMUNITY

23 PAGES, 7 FIGURES, 5 REFERENCES- $1965-$ PP. 612-635 OF THE PROCEEDINGS ORF AN INTERNATIONAL SYMPOSIUM DN WORKING METHODS IN HIGH ACTIVITY HOT LARORATORIES, GKENUBLE, JUNE 15-18, 1965, VOL. 2\% ENCA, OECD, PUBL I SHERS

THE TELE H. F. EQUIPMENT HAS BEEN OESIGNED TO PROVIDE A MULTIPURPOSE TRANSFER SYSTEM CONSISTENT WITH THE LARGEST USEFUL SIZE AND THE MOST DANGEROUS RADIATION EMITTERS. ITS UTILIZATION REQUIRFS A GAMMA-SHIELDED TRANSFER ZONE COMMUNICATION WITH THE HOT CELLS PY AN CPENING IN THEIR CEILINE. A REMOTE-CONTROLLED TRAVELLING BELL EOUIPPED WITH A WINCH IS USED FOR HOISTING. AN H. F. MACHINE PERFORMS THE DOUBLE P.EMOTF. WELDING OF THE JUNCTION SLFEVE TO SEPARATE THE BELL FROM THE CELL. PROTOTYPE EQUIPMENT HAS BEEN TESTEO AT MOL (BELSIUM).

\#BELGIUN + \#TRANSPORTATION AND HANDLING + ENEA (FUPOPEAN NUCLEAR ENERGY AGENCY) + FUEL HANDLING + GROSS ALPHA + GROSS BETA + MAINTENANCE ANO REPAIP

12-C9661 RETZ A + SCHMIDDEM RJ + STEPHAN W + RAU J

PACKAGING DISASSEMBLED FUEL ELEMENTS AND RAOIOACTIVE WASTE IN THE HOT CELLS AT THE KERNFORSCHUNGSANLAGE JULICH

KERFORSCHUNCSANLACE JUL ICH, GERMANY

17 PAGES, 7 FIGURES, 5 REFERENCES- 1965 - PP. 636-653 OF THE PROCEFDINGS OF AN INTFPNATIONAL SYMPUSIUM ON WURKING METHODS IN HIGH ACTIVITY HOT LABOPATORIES, GRENOBLE, JUNE 15T18, 1965, VOL. 2T FNEA, OECD, PUBL I SHERS

DEPENDING ON THE TYPE OF MATERIAL, ACTIVITY LEVEL, AND FIRE AND HEALTH HAZARD, SEVERAL METHOOS OF WASTE AND FUEL PACKAGING ARE USED IN THE HOT CELLS AT THE KERNFOR SCHUNGSANLAGE JULICH (K.F.A.). LOW-LEVEL WASTES SUCH AS PLASTICS, PAGS, AND SMALL TOOLS APE REMOTFLY WELDED INTO PLASTIC BAGS OF O.2 TO C.4 MM THICKNESS. FOR HIGHLY ACTIVE FUFL WASTES WHICH MUST BE MOST SECURELY PACKAGED AND STORED, THREE METHODS HAVE BEEN TESTED- 1 (I REMOTE ARGON-ARC, WELDING Or STAINLESS STEEL AND ALUMINUM R.ANS, (?) ELECTROMAGNETIC CLOSING OF ALUMINUM CANS, AND (3) COLD-PRESSURE WFI DING OF ALUMINUM CANS. AFTER COMPARISON OF LEAK-TIGHTNESS, RESISTANCE IU MECHANICAL DAMAGE, AND COSTS, THE MFTHOD OF C.OLD-PRESSURE WELDING WAS CHUSEN.

\#DECONTAMINATION + \#GFRMANY + \#WASTE HANDLING + ENEA (FUROPFAN NUCLEAP ENFRGY AGFNCY) + FUEL ELEMENT + HOT CELL + SHIPPING CONTAINER + STORAGE C.ONTAINLR

12-09662 BRINKMANN G + SCHENK W + SCHULZ W + STOCKSCHLADER F

IMPROVING ECONDMY WITH THE USE OF STANDARDIZED, MOVABLE, IN-CFLL ROXES, AND THF DECONTAMINATION OF THEIR EQUIPMENT AT THE CENTRAL DECONTAMINATION FACILITY

KERFORSCHUNGSANLAGE JULICH, GERMANY

13 PAGES, 7 FIGURES, 5 REFERENCES- 1965- PP. 654-667 OF THE PROCEEDINGS OF AN INTERNATIONAL SYMPOSIUM ON HORKIING METHOOS IN HIGH ACTIVITY HOT LAROP.ATOR.IES, GRENORI.F, IUINE 15-18, 1965, VOL. 2- ENEA, DCED, PUELI SHERS

WHEN A NUCLEAR RESEARCH CENTER HAS SEVERAL HOT LABORATORIES, ALL OF WHICH USE IN-CELL BOXES, IT IS DESIRABLE TO STANDARDIZE THE CELLS AND BOXFS AS FAR AS ODSSIBLE TO ACHIEVE MAXIMUM ECONOMY, EFFICIENCY, AND CONVENIFNCE. THE FOLLOWING REPORT SHOWS THE PRINCIPLES OF PLANNING WHICH ARE LAID DOWN AT KFA-JULICH, IN CONNECTION WITH THE CONSTRUCTION OF SEVERAL DLANTS. IT ENUMERATES THE ADVANTAGES AND DESCRIBES THE CONDITIONS WHICH MUST BE OBSERVED DURING PLANNING. THE SECTION ON THE DECONTAMINATION FACILITY IS INCLUDEO AS AN IMPORTANT PART OF THE ENTIRE BOX-EXCHANGE SYSTEM. IN ADOITION, SOME OF THE MORE INTERESTING POINTS CONCERNING EQUIPMENT AND TECHNIQUES, ESPECIALLY A NEW MANIPULATOR EXCHANGE TECHNIOUE, ARF DESCRIBED.

\# ACMINISTPATIVE CONTROLS AND PRACTICES + \#DECONTAMINATION + \#GERMANY + ECONOMICS + ENEA (EUROPEAN NUCLEAR ENERGY AGENCY) + HOT CELL

$12-09663$ TROTT AF

CONTAMINATION CONTROL AND HASTE DISPOSAL IN THE HIGH LEVEL TSOTOPE OPERATIONS AT ATOMIC ENERTY OF CANADA LIMITED COMMERCIAL PKOOUCTS

ATONIC ENERGY OF CANADA LIMITED

9 PAGES, 7 FIGURES, 5 REFERENCES- 1965 - PP. 668-677 OF THE PROCEEDINGS OF AN INTERNATIONAL SYMPOSIUM ON WORKING METHODS IN HIGH ACTIVITY HOT LABORATORIES, GRENORLE, JUNE 15-18, 1965, VOL. 2- ENEA, OEC , PURL I SHFRS 
CATEGORY 12

PLANT SAFETY FEATURES

12-09663 \#CONTINUED*

TEN YEARS OF EXPERIENCF IN HANDLINE MULTIKILOCURIE QUANTITIES OF CO-6O $\triangle N D$ OTHER ISOTOPES IN A PLANT NEAR THE CENTRE OF THE CITY OF OTTAWA AND REMOTE FROM RADIOACTIVE-WASTE-DISPOSAL FACILITIES IS REVIEWED. CONTAMINATION CONTROL, INCLUDING VENTILATION DESIGN, CONTINUNUS EFFLUENT-AIR MONITORING AND FILTRATION, CONTINUOUS EFFLUENT-WATER MONITORING, IN-CELL MONITORING AND CONTAMINATION CONTROL, LIOUID ANO DRY WASTE PROCESSING AND REMOVAL FROM HOT CELLS, AND CONTAMINATION CONTROL, LIQUID AND DRY HASTE PROCESSING AND REMOVAL FROM HOT CFLLS, ANO THE REMOVAL, PACKAGING, AND TRANSPORTATION OF WASTE FROM THE PLANT SITE TO BUPIAL ARE DESCRIBED.

*CANADA + *CONTAMINATION + *WASTE OISPOSAL, GENEPAL + EFFLUENT + ENEA IEUROPEAN NUCLFAR ENERGY AGENCYI + FILTRATION + MONITOR, RADIATION, AIR + TRANSPORTATION AND MANDLING + VENTILATION SYSTEM

12-09664 HATSON CO + RERRETH EA + DUMMER JE + FULLER RK + STEARNS RF POLICY AND PROCEDURES USED IN THE UNITED STATES FOR DECONTAMINATING HOT CELLS OAK RIDGE NATIONAL LABORATORY + BATTELLE NORTHWEST + LOS ALAMOS SCIENTIFIC LABORATORY 36 PAGES, 7 FIGURES, 5 REFERENCES- 1965- PP. 678-705 OF THE PROCEEDINGS OF AN INTERNATIONAL SYMPOSIUM ON WORKING METHODS IN HIGH ACYIVITY HOT LABORATORIES, GRENOBLE, JUNE 15-18, 1965, VOL. 2- ENEA, OECD, PUBL I SHERS

IN THE UNITED STATES, HOT CELLS ANO EQUIPMENT FOR HANDLING RADIOACTIVE SOLIOS OR LIQUIDS ARE SUCCESSFULLY DECONTAMINATED AS REQUIRED. THE FREQUENCY VARIES FROM ABOUT THREE TIMES A YEAR. TO ONLY ONCE IN THREE YEARS FOR THE LARGER PILOT-PLANT UNITS. THE NORMAL TIME REQUIRED TO DECONTAMINATE A FACILITY IS ABOUT TWO TO SIX WEEKS. DECONTAMINATION IS USUALLY DONE REMOTELY, THROUGH APPROPRIATE DESIGN, PRECONTAMINATIDN APPLICATION OF PROTECTIVE COATINGS, EXPENDABLE EQUIPMENT, THE PROPER CHOICE OF CLEANING REAGENTS IDETERGENTS, ORGANIC SOLVENTS, ACIDS, ALKALIES, CHELATING AGENTS) AND PHYSICAL METHODS (GRINDING, ULTRASONIC CLEANING, BLASTING, AND ABRADING). METHODS HAVE BFEN DEVELOPED AND ARE PRESENTED IN THIS PAPEP FOR CECONTAMINATING HOT CELLS AND ADJACENT AREAS SUBJECTED TO THE UNCONTROLLED RELEASE OF RADIOACTIVITY.

* ADMINISTRATIVE CONTROLS AND PRACTICES + \#DECONTAMINATION + \#HOT CELL + ENEA (EUROPEAN NUCLEAR ENERGY AGENCY) + UNITEO STATES

12-09665 CESARANO C + GHEZZIE + LAURO M

DECONTAMINATION EXPERIENCE AT THE HOT LABORATORY OF CASACCIA CENTRO STUDI NUCLEARI DELLA CASACCIA, C.N.E.N.

13 PAGES, 7 FIGURES, 5 REFERENCES- 1965 - PP. 706- 719 OF THE PROCEEDINGS OF AN INIERNATIONAL SYMPOSIUM ON WORKING METHODS IN HIGH ACTIVITY HOT LABORATORIES, GRENOBLE, JUNE 15-18, 1965, VOL. 2- FNEA, OECD, PUBL I SHERS

THE EXPERIENCE GAINED IN THREE YEARS OF OPERATION IS DESCRIBED. THE KEY FACTORS FOR FFFICIENT AND FAST DECONTAMINATION CAN BE SUMMARIZED AS FOLLOWS. THE IN-CELL FQUIPMENT SHOULD BE AS SMALL AS POSSIBLE AND EASY TO DISASSEMBLE AND REMOVE. THE DECONTAMINATION PROCESS SHOULD BE PLANNED IN DETAIL. A SUITABLE TRANSFER TECHNIQUE SHOULD BE ADOPTED TO KEEP THE CONTAMINATION AS CONFINED AS POSSIBLE IN THE LOADING AREA. SINCE OUR LABORATORY IS NOT EQUIPPED WITH I SOLATION ROOMS, PLASTIC TENTS ARE BUILT IN THE BACK OF THE CELL DOOR. THE CONTAMINATED EQUIPMENT IS TRANSFERRED OUT OF THE HOT CELL BY PERSONNEL WEARING FROG SUITS OR PREFERABLY TUNNEL SUITS.

\# OECONTAMINATION + \#FRANCE + \#HOT CELL + ENEA (EUROPEAN NUCLEAR ENERGY AGENCY) + OPERATIONS REPORTS, GENERAL + TRANSPORTATION ANO HANDLING

12-09666 WELLS H

DECONTAMINATION PROCEDURES FOR HIGH ACTIVITY CELLS AT A.E.R.E, HAPWELL

ATOMIC ENERGYY RESEARCH ESTABLISHMENT, HARWELL, UNITED KINGDOM

15 PAGES, 7 FIGURES, 5 REFERENCES- 1965- PP. $720-735$ OF THE PROCEEDINGS OF AN INTERNATIONAL SYMPOSIUM ON WORKING METHODS IN HIGH ACTIVITY HOT LABORATORIES, GRENOBLE, JUNE 15-18, 1965, VOL: 2- ENEA, OECD, PUBL I SHER

DECONTAMINATION PROCEDURES, PARTICULARLY WHEN CARRIED OUT REMOTELY, ARE TIME-CONSUMING AND EXPENSIVE. IT FOLLOWS THAT EFFORTS AIMED AT PREVENTING CONTAMINATION ARE VERY WORTHWHILE. THIS PAPER ILLUSTRATES PREVENTIVE MEASURES TAKEN AT HARWELL, AND REPORTS PROCEDURES WHICH ENSURE THAT THE DECONTAMINATION OF CELLS AND EOUIPMENT IS CARRIED OUT EFFICIENTLY AND SAFELY.

* DECONTAMINATION + \#HOT CELL + *UNITED KINGDOM + ENEA (EUROPEAN NUCLEAR ENERGY AGENCY) + HARWELL (UK) + PERSONNEL PROTECTIVE DEVICE

12-09667 VALENTIN A + HAYET L

DECONTAMINATION PROCEDURES AND FREQUENCIES IN (ALPHA-BETA-GAMMA) METALLURGICAL hOT CELLS

CENTRE D ETUDES NUCLEAIRE FONTENAY-AUX-ROSES, FRANCE

23 PAGES, 7 FIGURES, 5 REFERENCES- 1965- PP. 736-759 OF THE PROCEEDINGS OF AN INTERNATIONAL SYMPOSIUM ON WORKING METHODS IN HIGH ACTIVITY HOT LABORATORIES, GRENORLE, JUNE 15-18, 1965, VOL. 2- ENEA, OECD, PUBLI ISHER

AN ALPHA-BETA-GAMMA LABORATORY AT SACLAY HAS BEEN USED FOR METALLURGICAL RESEARCH ON IRRADIATEO PLUTONIUM SINCE 1961. IT COMPRISES ALPHA SEALED REMOVABLE BOXES WHICH ARE CONTAINED IN A BETA-GAMMA SHIELDED ENCLOSURE, ON THE COMPLETION OF AN OPERATION, THE BOX IS TAKEN BY A SPECIAL CRANE TO THE DECONTAMINATION ROOM. DECONTAMINATION IS ACCOMPLISHED MANUALLY. THE PROCESS HAS BEEN IMPROVED WITH USE AND THE PERIODS OF THE DECONTAMINATION CYCLES WERE LOHERED. PRE-EQUIPPED BOXES ARE USED TO REPLACE THOSE BEING DECONTAMINATED, THUS THE OPERATING SPEEDS ARE INCREASED. THE EXPERIENCE GAINED ON THIS INSTALLATION IS NOW BEING 
CATEGORY 12

PLANT SAFETY FEATURES

12-09667*CONTINUEO

USED IN THE BUILDING OF A NEW HOT LABORATORY, NAMED LABORATOIRE DE RADIOMETALLURGIE, AT THE FONTENAY-AUX-ROSES NUCLEAR CENTRE.

* ADMINISTRATIVE CONTROLS AND PRACTICES + \#FRANCE + \#HOT CELL + ENEA (EUROPEAN NUCLEAR ENERGY AGENCY) + GROSS ALPHA + GROSS BETA + GROSS GAMMA + TRANSPORTATION AND HANDLING

12-09668 BITEAU J + GARRIC C + HILHELEM A

DISMANTL ING MORKSHOP FOR ORGEL FUEL ELEMENTS (ADECO)

EUROPEAN ATOMIC ENERGY COMMUNITY, ISPRA

19 PAGES, 7 FIGURES, 5 REFERENCES- 1965 - PP. $760-779$ OF THE PROCEEOINGS OF AN INTERNATIONAL SYMPOSIUM ON WORK ING METHODS IN HIGH ACTIVITY HOT LABORATORY, GRENOBLE, JUNE 15-18, 1965, VOL. 2- ENEA, OECD, PUELISHERS

THE DISMANTLING WORKSHOP FOR ORGEL FUEL ELEMENTS (ADECO) IS CONNECTED TO THE ESSOR REACTOR BY A SWIMMING POOL. THIS WORKSHOP WILL BE USED FOR (1) CLEANING, VISUAL OBSERVATIONS AND RADIOGRAPHY OF THE ORGEL FUEL CLUSTER, (2) DISMANTLING OF THIS CLUSTER, (3) SECTIONING AND EVACUATION OF THE DIFFERENT PARTS, ANR $(4)$ ACCESSORILY, FOR OTHER USES. THE DIFFERENT CONCEPT AND INTERVENTION PRINCIPLES, AS WELL AS THE EQUIPMENT, ARE DESCRIBED IN THIS PAPER.

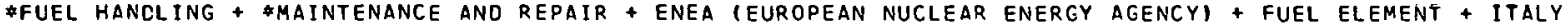

12-C.9669 SCHMIDDEM PJ + STEPHAN W + ZAMJA K

DISASSEMBLY OF TEST IRRADIATIONS AND FUEL ELEMENTS IN SMALL CAST IRON, ALPHA-GAMMA CFLLS AND THEIR SUBSEQUENT HANDL ING

KERNFORSCHUNGSANLAGE JULICH, FEDERAL REPUBLIC OF GERMANY

12 PAGES, 1965 , PP. 779-790 OF VOL. 2, PROCEEDINGS OF AN INTERNATIONAL SYMPOSIUM ON WORKING METHODS IN

HIGH ACTIVITY HOT LABORATORIES, GRENOBLE, JUNE 15-18, 1965, ENEA, OECD, PUBLISHERS

THREE FAIRLY SMALL ALPHA-GAMMA CELLS, MADE FROM CAST IRON BLOCKS, ARE BEING BUILT FOR DISASSEMBLING OF TEST IRRADIATIONS AND TUEL ELEMENTS. ASIDE FROM DISASSEMBLY EQUIPMENT, THE CELLS WILL ENABLE THE USUAL CRITICAL EVALUATION OF THE PERFORMANCE OF THE FUELLED SECTION TO BE MADE. THE CELLS USE GAS-TIGHT STAINLESS-STEEL BOXES. ON THE OUTSIDE, SPECIAL GAS-TIGHT, EXTENDED-REACH MANIPULATORS OF A SHORTENED DESIGN WITH A SHIELDED THROUGH-WALL PLUG ARE USED. THESE MANIPULATORS ARE GAS-TIGHT AND DO NOT REQUIRE PLASTIC BOOTINGS FOR SEALING TO THE

BOXES. SOME EQUIPMENT (PERISCOPE, DIMENSIONAL MEASUREMENT, GAMMA-SCAN) IS OF SPECIAL DESIGN

TO SAVE SPACE IN THE NARROW DOXES.

\#FUEL HANDLING + GERMANY + ENEA (EUROPEAN NUCLEAR ENERGY AGENCY) + EXAMINATION + FUEL ELEMENT + HOT CELL + IRRADIATION TESTING + MAINTENANCE AND REPAIR

12-0.9671 THOMAS MH

HORKSHOP CELL OPERATIONS AT CHALK RIVER NUCLEAR LABORATORIES

ATOMIC ENERGY OF CANADA LIMITED, CHALK RIVER

20 PAGES, 1965, PP. 805-824 CF VOL. 2, PROCEEOINGS OF AN INTERNATIONAL SYMPOSIUM ON WORKING METHODS IN HIGH ACTIVITY HOT LABORATORIES, GRENOBLE, JUNE 15-18, 1965, ENEA, OEC.N, PIIRLISHERS

THE CRNL EXPERIMENTAL PROGRAM HAS REQUIRED A FLEXIBLE WORKSHOP CELL. FLEXIBILITY TO CHANGE FROM ONE OPERATION TO ANOTHER HITH THE MINIMUM OF DIFFICULTY IS IMPORTANT WHEN FACILITIES ARE LIMITED. SUCCESSFUL HANDLING PROCEDURES ARE DESCRIBEO FOR MOVING HIGHLY ACTIVE FUEL AND SAMPLES BETWEEN CELL AND REACTOR OR STORAGE POSITIONS. THE PRINCIPLES AND OPERATIONAL PROCEDURES FOR THE MAINTENANCE OF LOOP FUEL, THE EXAMINATION OF FUEL UNITS, THE DISMANTLING AND SECTIONING OF VARIOUS FUELS ARE ILLUSTRATEN. SPFCIAL PROCEDURES FOR RESEARCH AND CEVELOPMENT EXPERIMENTS ON IRRATIATFD REACTOR MATERIALS ARE MENTIONED.

*CaNADA + *HOT CELL + adMINISTRATIVE CONTROLS AND PRACTICES + CHALK RIVER + ENEA (EUROPEAN NUCLEAR ENERGY AGENCY) + FUEL HANDLING + TRANSPORTATION AND MANDLING

12-Q9672 SKINNER J + VAUGHAN EA + VALLELY J TECHNIQUES AND WORKING METHODS FOR THE EXAMINATION OF IRRAOIATED CERAMIC FUEL ELEMENTS AT WINDSCALE UNITED KINGDOM AIUMIC ENERGY AUTHORITY, WINDSCALE

18 PAGES, 1965, PP. 825-842 OF VOL. 2 , PROCEEDINGS OF AN INTERNATIONAL SYMPOSIUM ON WORKING METHODS IN HIGH ACTIVITY HOT LABORATORIES, GRENOBLE, JUNE 15-18, 1965, ENEA, OECD, PUBLISHERS

THE REMOTE HANDLING FACILITIES USEO FOR EXAMINING IRRADIATED CERAMIC FUEL STRINGERS DISCHARGED FROM THE HINDSCALE AGR ARE BRIEFLY DESCRIBED. THESE FACILITIES ARE OF TWO TYPES, CONCRETE SHIELDED CAVES AND SEPARATE LINES OF LEAD SHIELDED CELLS, AND ARE CAPABLE OF EXAMINING SOME 3000 FUEL PINS PER YEAR. THE TECHNIQUES FUR UISMANTLING FUEL STRINGERS AND FOR CUTTING SAMPLES OF CAN AND FUEL FROM IRRADIATED FUEL PINS ARE DESCRIBED, WITH EMPHASIS ON THE METHOOS. FOUR CUTTING TECHNIQUES HAVE BEEN DEVELOPED FOR CERAMIC FUEL PINS - SIMPLE PIPE CUTTING, UNDERWATER HIGH-SPEED DIAMOND CUTIING WHEELS, SPARK MACHINING, AND ULTRASONIC DRILLING. THE PAPER CONCLUDES WITH SOME GENERAL COMMENTS ON THE ADMINISTRATIVE CONTROL OF THE WORK.

\#FUEL HANOLING + \#HOT CELL + *UNITED KINGDOM + ADMINISTRATIVE CONTROLS AND PRACTICES + CERAMICS + DECONTAMINATION + ENEA (EUROPEAN NUCLEAR ENERGY AGENCYI + EXAMINATION + IRRAOIATION TESTING + MAINTENANCE AND REPAIR + TEST, NONDESTRUCTIVE + WINDSCALE AGR (UK)

12- 99673 BAIN $\triangle S$ + MACUCNALC RD + KERR CB + KELM JR + CHENIER RJ WORK METHODS FOR THE POST-IRRACIATION EXAMINATION OF EXPERIMENTAL FUEL ELEMENTS 
$12-09673$ *CONTINUED*

ATOMIC ENERGY OF CANADA LIMITED, CHALK RIVER

14 PAGES, 1965 , PP. 843-856 OF VOL. 2, PPOCEEDINGS OF AN INTERNATIONAL SYMPOSIUM ON WORKING METHODS IN HIGH ACTIVITY HOT LABORATORIES, GRENOBLE, JUNE 15-18, 1965, ENEA, OECD, PUBLISHERS

AT CHALK RIVER, THOSE ENGAGED ON MATERIALS RESEARCH OPERATE TWO HIGH-DENSITY CONCRETE

HOT-CELLS AND A LINE OF SEVEN LEAD-SHIELDED DRY-BOXES FOR THE EXAMINATION OF IRRADIATED FUEL SPECIMENS, BOTH METALLIC AND CERAMIC. TRANSFER TECHNIQUES. AND WORKING METHODS FOR. A TYPICAL EXAMINATION ARE DESCRIBED. EXPERIENCE OVER THE PAST NINE YEARS HAS SHOWN THAT HAVING THE RESEARCHERS DIRECTLY IN CHAREE OF THE DETAILED POSTIRRADIATION EXAMINATION HAS SEVERAL ADVANTAGES, SUCH AS FLEXIBILITY IN SCHEDULING, KNOWLEOGE OF THE LIMITS OF REMOTE-CONTROL OPERATION TO PERMIT RAPID DEVELOPMENT OF SUITABLE EQUIPMENT, AND ELIMINATION OF MISUNDERSTANDINGS AND DELAYS IN THE DISSEMINATION OF RESULTS.

\#CANADA + \#FUEL HANDLING + \#OT CELL + ENEA (EUROPEAN NUCLEAR ENERGY AGENCY) + EXAMINATION + FUEL ELEMENT + IRRACIATION TESTING + TRANSPORTATION AND HANDLING

$12-C 9674$ EDMONOS E

OPERATIONAL EXPERIENCE IN THE DOUNREAY BETA-GAMMA HOT CELLS

UNITED KINGDOM ATOMIC ENERGY AUTHORITY, DOUNREAY

12 PAGES, 1965 , PP. 857-868 CF VOL. 2, PROCEEDINGS OF AN INTERNATIONAL SYMPOSIUM ON WORKING METHODS IN

HIGH ACTIVITY HOT LABORATORIES, GRENOBLE, JUNE 15-18, 1965, ENEA, OECD, PUBLISHERS

THE HIGH-ACTIVITY BETA-GAMMA FACILITY AT DOUNREAY HAS BEEN IN OPERATION FOR SIX YEARS. THE MAJOR ROLE OF THE CELLS HAS BEEN TO PROVIDE A RAPID FEEDBACK OF INFORMATION TO THE P.EACTOR OPERATORS ON THE BEFAVIOUR ANO CONDITIONS OF FUEL ELEMENTS IN DOUNREAY FAST REACTOR. MANY MODIFICATIONS HAVE BEEN MADE IN THE LIGHT OF EXPERIENCE GAINED DURING OPERATION ANO SOME OF THESE ARE DESCRIBED. CELL DECONTAMINATION CONTROL ANO SPECIFIC RIG HANDLING ARE ALSO DISCUSSED.

\#HOT CELL + \#OPERATIONS REPORTS, GENERAL + \#UNITED KINGOOM + CONTAMINATION + DECONTAMINATION + DOUNREAY (UK) + ENEA (EUROPEAN NUCLEAR ENERGY AGENCY) + FUEL HANOLING + OPERATING EXPERIENCE

12-[9675 PEREZ BL + NOGUEIRA ED + URIARTE A + SALVADOR LR A PILOT PLANT FACILITY FOR THE REPROCESSING OF IRRADIATED MTR TYPE FUELS AT THE SPANISH J.E.N. JUNTA DE ENERGIA NUCLEAR, MADRID

20. PAGES, 1965 , PP. 869-888 CF VOL. 2, PROCEEDINGS OF AN INTERNATIONAL SYMPOSIUM ON WORKING METHODS IN HIGH ACTIVITY HOT LABORATORIES, GRENOBLE, JUNE 15-18, 1965, ENEA, OECD, PUBLISHERS

THE GENERAL LAYOUT AND MAIN FEATURES OF A PILOT PLANT FOR REPROCESSING IRRADIATED MTR-TYPE FUELS UNDER CONSTRUCTION AT THE CENTRO NACIONAL DE ENERGIA JUAN VIGON, MADRID, ARE OISCUSSED. THE PLANT WILL BE USED FOR REPROCESSING THE JEN-1 REACTOR ELEMENTS, TO OBTAIN DIRECT INFORMATION ON THE SUBJECT, AND TO TRAIN PERSONNEL WITH A VIEW TO THE FUTURE NEEDS OF THE SPANISH NUCLEAR POWER PROGRAM.

\#HOT CELL + \#RADIOCHEMICAL PROCESSING + \#SPAIN + ENEA (EUROPEAN NUCLEAR ENERGY AGENCY) + FUEL ELEMENT + FUEL HANDLING + MTR (MATERIAL TESTING REACTOR)

$12-C 9852$ RENGEL JC

SAFETY RELATED ASPECTS OF LOCATING NUCLEAR POWER PLANTS IN CITIES

WESTINGHOUSE ELECTRIC CORPORATION, PITTSBURGH, ATOMIC POWER DIV.

5 PAGES, PRESENTED AT THE ANS SYMPOSIUM CN LOCATING NUCLEAR POWER PLANTS IN CITIES, MARCH 22 , 1966, NEW YORK CITY

PUTS RELIAEILITY ANO ACCIDENT-PREVENTION SAFEGUARDS AHEAD OF CONSEQUENCE-LIMITING SAFEGUARDS RELIABILITY ENSURED BY DESIGN, INTEGRITY OF MANUFACTURER, INSPECTION, TEST, AND OPERATION CRITERIA FOR URBAN SITING.

\# ITING, REACTOR + CODES AND STANDARDS + DESIGN CRITERIA + ENGINEERED SAFEGUARD

12- 99854 SZAWLEWICZ SA

THE AEC REACTOR SAFETY PROGRAM

U. S. ATOMIC ENERGY COMMISSION

7 PAGES, PRESENTED AT THE ANS SYMPOSIUM ON LOCATING NUCLEAR POWER PLANTS IN CITIES, MARCH 22 , 1966 , NEW YORK CITY

STEER ING COMMITTEE ON SAFETY RESEARCH. ACCIDENT-PREVENTING AND CONSEQUENCE-LIMITING SAFEGUARDS. ENGINEERED SAFEGUARDS. LOSS-OF-COOLANT ACCIDENT AND MECHANICAL LOAD IT CREATES, IN-CORE SPRAY AND EMERGENCY COOLING SYSTEM, METAL-WATER REACTION, FUEL MELTDOWN, FISSION-PRODUCT RELEASE, RELIABILITY OF PIPING. LIST OF PLANNED ORNL SUMMARY REPORT BUDGET. IN-PLANT TEST PROGRAM. NUCLEAR SAFETY PILOT PLANT, CONTAINMENT SYSTEMS EXPERIMENT, LOFT, POWER BURST FACILITY.

CSE (CONTAINMENT SYSTEMS EXPERIMENT) + ENERGENCY COOLING + ENGINEERED SAFEGUARD + FISSION PRODUCT RELEASE, GENERAL + FUEL MELTDOWN + LOFT (LOSS OF FLUID TEST) + METAL WATER REACTION + NSPP (NUCLEAR SAFETY PILOT PLANT) + PBF (POWER BURST FACILITY) + REACTOR, PRESSURIZED WATER

12-C9855 BECK CK

CURRENT TRENDS AND PERSPECTIVES IN REACTOR LOCATION AND SAFETY REQUIREMENTS U. S. ATOMIC ENERGY COMMISSION, WASHINGTON 
12-09855 \#CONTINUED*

14 PAGES, PRESENTEO AT THE ANS SYMPOSIUM ON LOCATING NUCLEAR POWER PLANTS IN CITIES, MARCH 22 , 1966 , NEW YORK CITY

SAFETY RECORD OF NUCLEAR PLANTS. HIGH STANDARDS. ACCIDENT PREVENTION AND

CONSEQUENCE-LIMITING SAFEGUARDS. MCA ANALYSIS. ISOLATED SITES. REVIEWS BY EXPERTS.

INCREASE IN FISSION INVENTORY. STANDARDIZATION. TREND TOWARD MORE CENTRAL LOCATION.

REQUIREMENTS FOR LESS-I SOLATED LOCATION - HIGH STANDAROS, DEFINITION OF TECHNICAL AREAS OF

UNCERTAINTY, ESTABLISHMENT OF ADEQUACY OF SAFEGUARD SYSTEM, SUFFICIENT EXPERIENCE. THESE

REQUIREMENTS HAVE NCT YET BEEN FULLY MET.

* SITING, REACTOR + ACCIDENT, MAXIMUM CREDIBLE (MCA) + ACCIDENT, PROBABILITY OF + ENGINEERED SAFEGUARD + REGULATION, AEC + REVIEW + SAFETY PRINCIPLES AND PHILOSOPHY

12- 99856 CAHILL WJ

REMARKS BY WILLIAM J. CAHILL, JR. MECHANICAL PLANT ENGINEER CONSOLIDATED EDISON COMPANY OF NEH YORK, INC. AT THE SYMPOSIUM ON LOCATING NUCLEAR POWER PLANTS IN CITIES, AMERICAN NUCLEAR SOCIETY, MARCH 22 , I966 CONSOL ICATED EDISON COMPANY, NEH YORK

2 PAGES, PRESENTED AT THE ANS SYMPOSIUM ON LOCATING NUCLEAR POWER PLANTS IN CITIES, MARCH 22 , 1966

BRIEF OESCRIPTION CF ENGINEERED SAFEGUARDS, SITES, LICENS ING EXPERIENCE, AND PUBLIC ACCEPTANCE OF INDIAN POINT 1 AND 2 , AND RAVENSWOOD.

*INOIAN POINT I + \#INDIAN POINT II + *RAVENSWOOD + *SITING, REACTOR + ENGINEERED SAFEgUARD + REACTOR, PRESSURIZED WATER + REGULATION, AEC

12-1050E KIEFER RJ + WINKLER EO

GENERAL ATOMIC IN-PILE LOOP FISSION PRODUCT TRAPPING SYSTEM. REGENERATIVE HZO-CO2 TRAP AND LIOUID NITROGEN COOLEO NO. 2 CHARCOAL TRAP ASSEMBLY. INFORMATION OATA PACKAGE AND DESIGN ANALYSIS GENERAL ATOMIC DIVISION, SAN DIEGO, CALIFORNIA

GAMC-5434 +. 55 PAGES, 4 FIGURES, 5 TABLES, JULY 1964, CFSTI, $\$ 3.00 \mathrm{CY}, \$ 0.50 \mathrm{MN}$

THE FISSION PRODUCT TRAPPING SYSTEN (FPTSI INITIALLY INSTALLED IN THE GAIL, HAS BEEN IN CONTINUOUS SERVICE FOR APPROXIMATELY THREE YEARS SINCE THE LOOP WAS FIRST OPERATED WITH NUCLEAR FUEL. THROUGHOLT THIS TIME, THE SYSTEM HAS EFFECTIVELY PERFORMED ITS INTENDED FUNCTION OF REMOVING FISSION PRODUCTS AND IMPURITIES FROM THE PURGE GAS STREAM.

* ChARCOAL aDSORBER + \#CRYOGENICS + \#DESIGN CRITERIA + \#FILTER, BED + \#FISSION PRODUCT RETENTION + *NITROGEN + CHARCOAL + FILTER, TRAP + FISSION PRODUCT, VOLATILE + IN PILE LOOP + OPERATING EXPERIENCE

12-10564 FREOERICKSON RL

IOOINE 131 RELEASE AT ABBOTT LABORATORIES, MAY 31,1966

ABBOTT LABORATORIES

1 PAGE, MAY 31, 1966, ATOMIC ENERGY CLEARING HOUSE, 12(27), PAGE 28, (JULY 4, 1966$)$

A 48-HR AIR SAMPLE TAKEN FROM INSIDE $\triangle$ HOT-CELL EXHAUST DUCT OVERWHELMED THE GEIGER-TUBE COUNTING SYSTEM, GIVING FALSELY LOW READINGS. THE NEXT DAY, GAMMA SCINTILLATION INDICATED THAT THE SAMPLE WAS 3580 TIMES THE MPC. LATER ANALYSIS SHOWED THE AVERAGE AIR CONCENTRATION WAS 38,800 TIMES MPC, AND OUTDOOR SAMPLING DURING THE RELEASE SHOWED ONLY O.69 MPC. NO UNUSUAL BUILDING CONCENTRATIONS NOR EXPOSURE OF PERSONS OUTSIDE RESULTED. A BUBBLE OF IODINE IS BELIEVED TO HAVE PASSED OUT OF THE VESSEL REACTING A TELLURIUM TARGET. VARIOUS CHANGES TO SYSTEMS AND PROCEDURES ARE BEING STUDIED.

*FAILURE, INSTRUMENT + \#FISSION PRODUCT RELEASE, GENERAL + \#HOT CELL + *INCIDENT, ACTUAL, NONREACTOR + *IOOINE + MODIFICATION, SYSTEM OR EQUIPMENT + TRACER, RADIOACTIVE.

$12-10600$ I SOCHEM INC.

750 PAGES APPROX., 83 FIGURES, 71 TABLES, REFERENCES, JUNE 1966, DOCKET NO, 50-258, PDR

REPORT GIVES ALL THE GENERAL AND DETAILED TECHNICAL INFORMATION REQUIRED FOR AEC LICENSING OF A RAOIOCHEMICAL PLANT. INCLUDEO ARE SECTIONS ON - SITE DESCRIPTION, PLANT DESCRIPTION, PROCESS DESCRIPTION, EQUIPMENT DESCRIPTION, SYSTEMS ANALYSIS, PUBLIC PROTECTION, PERSONNEL PROTECTION, SAFETY, PLANT ORGANIZATION, AND STARTUP PLANS.

* APPLICATION FOR AEC LICENSE + *CERIUM + \#CESIUM + *FPCE PLANT + \#PROMETHIUM + \#RADIOCHEMICAL PROCESSING + * SAFEGUAROS REPORT, GENERAL + \#STRONTIUM + FISSION PRODUCT, SEPARATION FROM WASTE +

FISSION PRODUCT, USE OF IN HASTES + HAZARDS ANALYSIS + ISOCHEM, INC. + RAOIOCHEMICAL PLANT SAFETY

12-10687 PAXTON HC

THE CRISIS IN CRITICALITY

2 PAGES, NUCLEAR NEWS $9(8)-27-28$ (AUGUST 1966)

RFASON FOR NATTONAL TOPICAL ANS MEETING ON ÇRITICALITY SAFETY, LAS VEGAS, DECEMBER 13-15, 19GG. MAINIY TO RRTNG INDUSTRY INTO DISCUSSION WITH AEC AND ITS CONTRACTORS AND TÓ RESÓLVE THE DOUBLE STANDARD OF REGULATION WHICH REGULATES LICENSEES AND AEC PRODUCTION PLANTS DIFFERENTLY.

WCRITICAL ITY SAFETY * *RECULATION, AEC 
CATEGORY 12

PLANT SAFETY FEATURES

RADIOACTIVE DECONTAMINATION. A LITERATURE SEARCH

UNITED STATES ATOMIC ENERGY COMMISSION, DIVISION OF TECHNICAL INFORMATION EXTENSION, OAK RIDGE, TENNESSEE TID-3535 (SUPPL. 1 ) +71 PAGES, APRIL 1965, CFSTI, $\$ 3.00$

INCLUDEO ARE 336 REFERENCES TO UNCLASSIFIED PUBLICATIONS ON PHYSICAL AND CHEMICAL METHODS FOR REMOVING RADIOACTIVE CONTAMINATION. THE REFERENCES COVER THE PERIOD FROM JULY 1959 THROUGH

CECEMBER 1964. SUBJECT, AUTHOR, AND REPORT-NUMBER INDEXES ARE PROVIDED.

\# BIBLIOGRAPHY + \#DECONTAMINATION + \#WASTE OISPOSAL, GENERAL

12-10809 WATSON HE

THE NRL HIGH LEVEL RADIATION LABORATORY. PART III. OPERATING EXPERIENCE

U. S. NAVAL RESEARCH LABORATORY

11 PAGES, 11 FIGURES, I REFERENCE, NUCLEAR ENGINEERING AND DESIGN, 4 (1) PAGES 97-107, (1966)

REPORT CONTAINS A GENERAL DESCRIPTICN OF ALL PHASES OF THE OPERATIONAL, SAFETY, AND AUXILIARY SYSTEMS OF A HIGH-LEVEL RADIATION LABORATORY.

* HOT CELL + DECONTAMINATION + VENTILATION SYSTEM + WASTE DISPOSAL, LIQUIO

12-10827 MALONEY.JC + MEREDITF JL

DECONTAMINATION OF LAND TARGETS, VEHICLES, AND EQUIPMENT

U.S. ARMY NUCLEAR DEFENSE LABORATORY, EDGEWOOD ARSENAL, MARYLANO

NDL-TR-66 + AD-632989+. 72 PAGES, 9 TABLES, 13 FIGURES, REFERENCES, MAY 1966- CFSTI, \$3.00 CY, \$0.75 MN

THE OBJECTIVE OF THIS PRCJECT IS TO DEVELOP AND TEST RADIOLOGICAL COUNTERMEASURES THAT CAN EE USED IN POSTNUCLEAR-ATTACK RECOVERY OPERATIONS. THE SPECIFIC OBJECTIVE OF THIS PHASE OF THE PROJECT WAS TO CONDUCT DECONTAMINATION EXPERIMENTS ON EXTERIOR SURFACES MADE RADIOACTIVE WITH SMALL-PARTICLE SIMULANT, AND TO CONDUCT OECONTAMINATION STUDIES ON RAILROAD TRACKS,

TRANSPORTATION VEHICLES, AND MECHANICAL EQUIPMENT USED IN RAOIOLOGICAL RECOVERY OPERATIONS. TO ACCOMPLISH THESE OBJECTIVES, APPROXIMATELY 150 DECONTAMINATION TRIALS WERE CONDUCTED AT CAMP MCCOY, WISCONSIN, DURING THE PERIODS JANUARY-JUNE 1964 AND FEBRUARY-MARCH 1965.

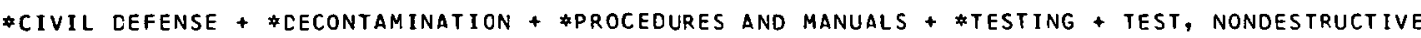

12-10883 FIRST SUPPLEMENT TO PRELIMINARY SAFETY ANALYSIS. INOIAN POINT NUCLEAR GENERATING UNIT NO. 2. CONSOLICATEO EOISON COMPANY OF NEW YORK

1 PAGE OF FIRST SUPPLEMENT TO PRELIMINARY SAFETY ANALYSIS. INDIAN POINT NUCLEAR GENERATING UNIT NO. 2, MARCH 31,1966 , DOCKET NO. 50-247, POR

QUESTION 2, CRITERION $13-$ CCNTROL-ROOM SHIELDING IS PROVIDED SO THAT A REFERENCE ACCIDENT WOULD RESULT IN LESS THAN 1.5 REMS WHOLE BODY AND 3 REMS THYROID, EVEN IF WORKERS REMAIN THERE INDEF INITELY.

\# DESIGN CRITERIA + \#REgULATION, AEC + \#SAFEgUAROS REPORT, RESPONSE TO AEC QUESTIONS + \#SHIELOING + BUILDING + INDIAN POINT II + REACTOR, PRESSURIZED WATER

12-10888 FIRST SUPPLEMENT TO PRELIMINARY SAFETY ANALYSIS. INDIAN POINT NUCLEAR GENERATING UNIT NO. 2. CONSOLICATED EDISON COMPANY OF NEW YORK

2 PAGES OF FIRST SUPPLEMENT TO PRELIMINARY SAFETY ANALYSIS. INDIAN POINT NUCLEAR GENERATING UNIT NO. 2 , MARCH 31,1966 , DOCKET NO, 50-247, PDR

QLESTION 2, CRITERION 18 -- EITHER FOUR OF THE FIVE CONTAINMENT AIR COOLERS OR ONE OF THE TWO SPRAY PUMPS IS ADEQUATE FOR HEAT REMOVAL FROM CONTAINMENT FOLLOWING A PIPING RUPTURE. ANY TWO OF THE THREE DIESELS WILL SUPPLY THESE LOADS. AUTOMATIC BUS SWITCHING ARRANGEMENTS ALLOW DIESEL B OR C TO SUPPLY CURRENT TO PUMP A IF DIESEL A FAILS.

*CONTAINMENT AIR COOLÍNG + \#CONTAINMENT SPRAY + \#DESIGN CRITERIA + \#LOSS OF COOLANT + \#REGULATION, AEC + * SAFEgUARDS REPORT, RESPONSE TO AEC QUESTIONS + EMERGENCY POWER, ELECTRIC + INDIAN POINT II + PRESSURE, INTERNAL + REACTOR, PRESSURIZED WATER

12-10889 FIRST SUPPLEMENT TO PRELIMINARY SAFETY ANALYSIS. INDIAN POINT NUCLEAR GENERATING UNIT NO. 2. CONSOL IDATED EDISON COMPANY OF NEW YORK

1 PAGE OF FIRST SUPPLEMENT TO PRELIMINARY SAFETY ANALYSIS. INDIAN POINT NUCLEAR GENERATING UNIT NO. $2 .$, MARCH 31,1966 , DOCKET NO. 50-247, PDR

QUESIION 2, CRITERION 19 -- WITH THE DESIGN LEAK RATE AT 47 PSIG ID.I PERCENT PER DAYI AND FOUR FAN-FILTER UNITS OPERATING THE HYPOTHETICAL LOSS OF COOLANT (WITH NO SAFETY INJECTIONI OFFSITE DOSE WILL BE HALF THE 10-CFR-100 LIMITS. REFERENCE-VOLUME LEAK-RATE TEST IS USED PLUS AIR MEASURED ON RETURN. TO PRESSURE AFTER THE TEST. THICK-WALLED CONCRETE VESSEL WILL MINIMIZE ATMOSPHERIC EFFECTS. TEST MUST BE MADE VITH PLANT SHUT DOWN.

\#CONTAINMENT. LEAKAGE + \#DESIEN CRITERIA + \#DOSE + \#PEGULATION, AEC +

* SAFEgUAROS REPORT, RESPONSE TO AEC QUESTIONS + INDIAN POINT II + LOSS OF COOLANT +

REACTOR, PRESSURIZED WATER + TEST, LEAK RATE

12-10890 FIRST SUPPLEMENT TO PRELIMINAR SAFETY ANALYSIS. INOIAN POINT NUCLEAR GENERATING UNIT NO. 2. 
12-10890 \#CONTINUED*

CONSOLIDATED EDISON COMPANY CF NEW YORK

1 PAGE OF FIRST SUPPLEMENT TO PRELIMINARY SAFETY ANALYSIS. INDIAN POINT NUCLEAR GENERATING UNIT NO. 2,

MARCH 31, 1966, DOCKET NO. 50-247, POR

QUESTION 2, CRITERION $20 \rightarrow$ CONTAINMENT PENETRATIONS ARE PRESSURIZED SLIGHTLY ABOVE CONTAINMENT PRESSURE BY AIR. BACKED WITH NITR.OGEN. EXCESSIVE LEAKAGE IS MONITOR.ED BY INTEGRATED AIR FLOW. EACH PENETRATION CAN BE TESTED SEPARATELY AT ANY TIME.

\#CONTAINMENT PENETRATION + \#CESIGN CRITERIA + \#REGULATION, AEC +

* SAFEgUARDS REPORT, RESPONSE TO AEC QUESTIONS + CONTAINMENT LEAKAGE CONTROL + INDIAN POINT II +

REACTOR, PRESSURIZED WATER + IEST, LEAK RATE

12-10893 FIRST SUPPLEMENT TC PRELIMINARY SAFETY ANALYSIS. INDIAN POINT NUCLEAR GENERATING UNIT NO 2. CONSOLIDATED EDISON COMPANY OF NEW YORK

4 PAGES OF FIRST SUPPLEMENT TO PRELIMINARY SAFETY ANALYSIS. INDIAN POINT NUCLEAR EENERATING UNIT NO. 2, MARCH 31, 1966, DOCKET NO. 50-247, PDR

QUESTION 2, CRITERION 23 -- LISTS VARIOUS TESTS OF ENGINEERED SAFEGUARDS THAT CAN BE PERFORMED IN THE PLANT DURING ITS LIFE. FOR EXAMPLE, SAFETY INJECTION CAN INJECT WATER INTO REACTOR DUR ING HEATUP OR COCLDOWN BY ENERGIZING SYSTEM AND OBSERVING PRESSURIZER WATER LEVEL PUMPS CAN BE TESTED BY USING MINIMUM FLOW RECIRCULATION LINE DURING OPERATION, AND CONTAINMENT AIR COOLING AND FILTRATION UNITS BY ACTUATING VALVES AND BY AEROSOL INJECTION.

*ENGINEEREO SAFEgUARD + \#REgULATION, AEC + \#SAFEgUARDS REPORT, RESPONSE TO AEC QUESTIONS +

\#TEST, SYSTEM OPERABILITY + DESIGN CRITERIA + INDIAN POINT II + REACTOR, PRESSURIZED WATER

12-1G894 FIRST SUPPLEMENT TO PRELIMINARY SAFETY ANALYSIS. INDIAN POINT NUCLEAR GENERATING UNIT NO. 2 CONSOLIDATED EOISON COMPANY OF NEW YORK

1 PAGE OF FIRST SUPPLEMENT TO PRELIMINARY SAFETY ANALYSIS. INDIAN POINT NUCLEAR GENERATING UNIT NO. 2, MARCH 31,1966 , DOCKET NO. 50-247, PDR

QUESTION 2, CRITERION 24 - SPENT FUEL IS STORED IN A STAINLESS-STEEL-LINED CONCRETE PIT HITH NO ERAVITY DRAINS. SPILLED LIQUID hASTE MOVES THROUGH FLOOR DRAINS TO A HOLDUP TANK.

CONTROLLEO VENTILATION SHEEPS AIR FROM VARIOUS ROOMS TO THE PLANT VENTILATION SYSTEM.

* CONTAINMENT, General + \#DESIEN CRITERIA + \#REgULATION, AEC *

* SAFEguaros REPORT, ResPONSE TO aEC QUESTIONS + FUEL STORAGE + INDIAN POINT II + REACTOR, PRESSURIZEO WATER + WASTE HANOLINE

12-10895 FIRST SUPPLEMENT TO PRELIMINARY SAFETY ANALYSIS. INDIAN POINT NUCLEAR GENERATING UNIT NO. 2 CONSOLIDATED EOISON COMPANY OF NEW YORK

2 PAGES OF FIRST SUPPLEMENT TO PRELIMINARY SAFETY ANALYSIS. INDIAN POINT NUCLEAR GENERATING UNIT NO. 2 , MARCH 31,1966 , DOCKET NO. 50-247, PDR

QUESTION 2, CRITERION 25 - FUEL STORAGE AND HANDLING -- REFUELING WATER IS BORATED. SPENT ASSEMBLIES ARE STORED UNDERWATER WITH 12-IN. EDGE-TO-EDGE SPACING, SO THE RACK MULTIPLICATION IS LESS THAN 0.9. WATER-FILLEO CANALS, ETC., ARE LINED WITH STAINLESS STEEL.

*CESIGN CRITERIA + \#FUEL HANDLING + \#FUEL STORAGE + \#REGULATION, AEC +

* SAFEGUARDS REPORT, RESPONSE TO AEC QUESTIONS + INDIAN POINT II + REACTOR, PRESSURIZED WATER

12-10896 FIRST SUPPLEMENT TC PRELIMINARY SAFETY ANALYSIS. INDIAN POINT NUCLEAR GENERATING UNIT NO. 2. CONSOLICATED EDISON COMPANY OF NEW YORK

1 PAGE OF FIRST SUPPLEMENT TO PRELIMINARY SAFETY ANALYSIS. INDIAN POINT NUCLEAR GENERATING UNIT NO. 2, MARCH 31,1966 , DOCKET NO. 50-247, PDR

QUESTION 2, CRITERION 26 - HOLDUP CAPACITY FOR RADIOACTIVE EFFLUENIS -- VARIOUS STORAGE AND CLEANUP FACILITIES PROVIDED.

*DESIGN CRITERIA + \#REgULATION, AEC + \#SAFEgUARDS REPORT, RESPONSE TO AEC QUESTIONS + \#WASTE STORAGE + INDIAN POINT II + REACTOR, PRESSURI ZEO WATER

12-10897 FIRST SUPPLEMENT TC PRELIMINARY SAFETY ANALYSIS. INOIAN POINT NUCLEAR GENERATING UNIT NO. 2 CONSOLIDATED EDISON COMPANY OF NEW YORK

1 PAGE OF FIRST SUPPLEMENT TO PRELIMINARY SAFETY ANALYSIS. INDIAN POINT NUCLEAR GENERATING UNIT NO. 2 , MARCH 31,1966 , DOCKET NO. SO-247, PDR

QUESTION 2, CRITERION 27 - MONITORING OF ACCIOENT-RELEASED RADIOACTIVITY -- VARIOUS SYSTEMS

PROVIDEO TO INHIBIT CONTAINMENT-PENETRATION LEAKAGE AND TO MONITOR LOCATIONS AND SYSTEMS.

* CESIGN CRITERIA + \#MONITOR, RADIATION, EMERGENCY + \#REGULATION, AEC +

* SAFEgUAROS REPORT, RESPONSE TO AEC QUESTIONS + INOIAN POINT II + REACTOR, PRESSURIZED WATER

12-1096E COURTAULT J + DE KERCELLEAN J + MASTRE E

THE ULTRASONIC COPPER AND BRASS DECONTAMINATION STUDY

COMMIŚSARIAT A L ENERGIE ATONIGUE, SACLAY, CENTRE D ETUDES NUCLEARIES

CEA-R-2823 +. 20 PAGES, JULY, 1965, DEP/MN 
CATEGORY 12

PLANT SAFETY FEATURES

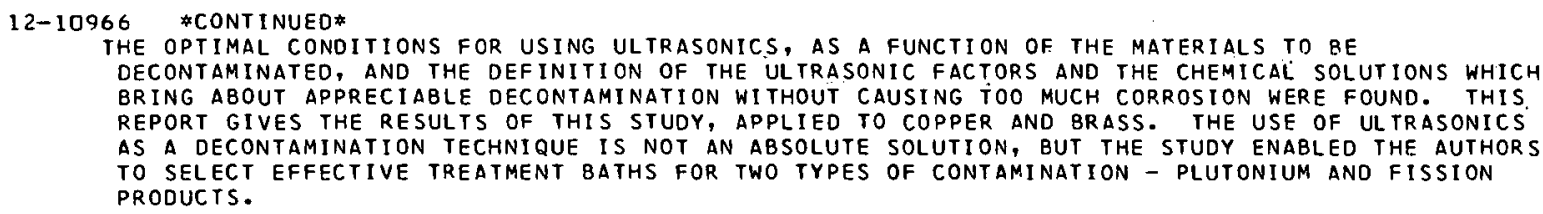

\#COPPER + \#DECONTAMINATION + \#FISSION PRODUCT ACTIVITY, GROSS + \#NETAL + \#PLUTONIUM

12-11C12 BELLERMANN H + SCHKIERS HG

REACTOR PRESSURE VESSEL AND STRUCTURAL COMPONENTS

1 PAGE, ATOMWIRTSCHAFT, XI(5), PAGE 239 (MAY 1966), IN GERMAN

TWO PRINCIPAL MEASURES WERE TAKEN IN DESIGNING THE AVR PRESSURE VESSEL TO PROVIDE FOR THE LEVEL OF ACTIVITY PERMITTED IN THE PRIMARY LOOP - INTEGRAL CONSTRUCTION AND ENCLOSURE IN A SECOND PRESSURE VESSEL. SPECIAL PROBLEMS OCCURRED IN CONNECTION WITH PASSAGE THROUGH THE DOME AND COVER OF THE VESSEL, ESPECIALLY IN THE CASE OF THE FAN SUPPORTS, THE MOUNTING OF THE COVER, THE CONSTRUCTION OF THE PEDIMENT, AND THE SUPPORT OF THE VESSEL. AMONG THE COMPONENTS, THE RADIAL SUPPORTING FRAMEWORK ANO THE CARBON AND GRAPHITE MEMBERS WERE OF PARTICULAR INTEREST.

*CONTAINMENT CONSTRUCTION + *CONTAINMENT, PRESSURE VESSEL + Flange + germany + REACTOR, GaS COOLED

12-1105E MAKSIMOVIC ZB + NASSCNOV PM + NIKOLIC RM + MARINKOVIC MD + JELIC LM

DECONTAMINATION OF THE HEAVY WATER SYSTEM OF THE RA REACTOR

ELECTROCHEMISTRY INSTITUTE, ACADEMY OF SCIENCES, USSR, MOSCOW

11 PAEES, 3 FIGURES, 5 TABLES, 6 REFERENCES, BULLETIN OF THE INSTITUTE OF NUCLEAR SCIENCES, BORIS KIDRIC, $16(4)$, PAEES 239-250 (MAY 1965$)$

THE HEAVY-WATER SYSTEM OF THE RA REACTOR WAS DECONTAMINATED OF CO-60. USED A MIXTURE OF 7 PERCENT PHOSPHORIC ACID AND 3 PERCENT CHROMIUM THIOXIDE. THE OECONTAMINATION FACTORS RANGED FROM 10 TO 100. FROM THE RESULTS, THE DISTRIBUTION OF CO-60 IN THE HEAVY WATER, AND ON STAINLESS AND ALUMINUM PARTS, WAS DETERMINED.

*aluminum * \#DeCONTAMINATION * \#TEEL, STAINLESS

12-11328 ULLMANN JW

ORNL FACILITIES CAPABLE OF CONTRIBUTING TO PLUTONIUM FUEL CYCLE DEVELOPMENT

OAK RIDGE NATIONAL LABORATORY, OAK RIDGE

ORNL-TM-1268+.74 PAGES, FIGURES, NOVEMEER 1965 , CFSTI $\$ 3.00 \mathrm{CY}, \$ 0.75 \mathrm{MN}$

THIS REPORT IS A COMPILATION OF BRIEF DESCRIPTIONS OF ORNL FACILITIES THAT COULD BE USEO YO SUPPORT DEVELOPMENT OF A FUEL CYCLE BASED ON PLUTONIUM. THE CAPABILIIY ANU EXUEKIENCE OF EACH FACILITY IS SUMMARIZED, WITH EMPHASIS PLACEO ON HANCLING PLUTONIUM AND OTHER INTENSE ALPHA EMITTERS.

\#ALPHA FACILITIES + \#ORNL (OAK RIDGE NATIONAL LABORATORY) + \#PLUTONIUM

$1 \bar{Z}-11424$ HORST KM

SOUTHWEST EXPERIMENTAL FAST OXIDE REACTOR DEVELOPMENT PROGRAM. THIRD QUARTERLY REPORT, OCTOBER I964 JANUARY 1905

GENERAL ELECTRIC, SAN JOSE

GEAP-4799 +. 150 PAGES, FEBRUARY 1965, CFSTI \$4.00 CY,\$1.00 MN

THIS REPORT IS ONE OF A SERIES OF SUCH REPORTS ON THE FOLLOWING SUBJECTS - PLANNING, EXPERIMENTAL PROGRAM IN ZPR-III, FUEL DEVELOPMENT, INSTRUMENTATION, CORE DYNAMICS, REACTIVITY CONTROL, FUEL HANDLING, AND CORE DESIGN

*RESEARCH CONTRACT + \#SEFOR (SOUTHWEST EXP. FAST OXIDE REACTOR) + *ZPR III (ANL ZERO POWER REACTOR) + CRITICAL ASSEMBLY FACILITY + DOPPLER COEFFICIENT + FUEL ELEMENT + FUEL HANDLING + HEAT TRANSFER + INSTRUMENTATION, EENERAL + INSTRUMENTATION, TEMPERATURE + REACTOR, BREEDER + REACTOR, FAST + REACTOR, LIQUID METAL COOLED + TEST, PHYSICS

12- 11444 ENGEL JR + HAURENREICH PN + BALL SJ

ANALYSIS OF FILLING ACCIDENTS IN MSRE

OAK RIDGE NATIONAL LABORATORY

ORNL-TM-497 +. 41 PAGES, 14 FIGURES, 1 TABLE, AUGUST 16, 1966, CFSTI $\$ 2.00$ CY, $\$ 0.50$ MN

POSTULATED ACCIDENTS WERE ANALYZED TO HELP DESIGN FILLING-RATE VALVES AND GAS-CONTROL VALVES TO LIMIT SUCH EXCURSION. SEQUENTIAL FAILURE WOULD BE NEEDEO TO CAUSE THE ACCIDENT, ALSO SELECTIVE SALT FREEZING TO CONCENTRATE THE FUEL.

* ACCICENT, REFUELING + MSRE (MOLTEN SALT REACTOR EXPERIMENT) + REACTOR, CIPCULATING FUEL + REACTOR, MOLTEN SALT 
CATEGORY 13

13-C.9657 LEFORT E

TRANSFER IN A HIGH ACTIVITY CHEMISTRY CELL

CENTRE D ETUDES NUCLEAIRE, FONTENAY-AUX-ROSES

12 PAGES- $1965-$ PP. $571-582$ OF VOL. 2, PROCEEDINGS OF AN INTERNATIONAL SYMPOSIUM ON WORKING METHODS IN

HIGH ACTIVITY HOT LABORATORIES, GRENOBLE, JUNE 15-18, 1965- ENEA, OECD, PUBLISHERS

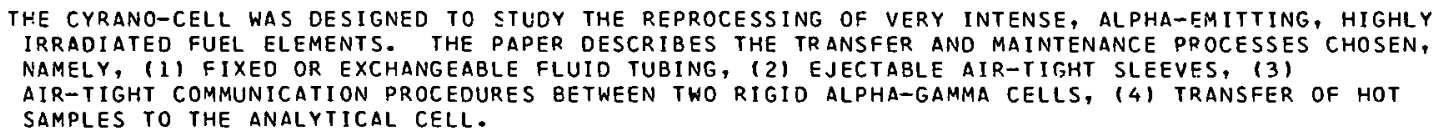

*FUEL HANOLING + *HOT CELL + \#MANTENANCE AND REPAIR + ENEA (EUROPEAN NUCLEAR ENERGY aGENCY)

$13-[9670$ GANDOLFO JM

WORKING METHODS - EQUIPMENT IN USE AT THE 1000 CURIE - 1 MEV TRANSPLUTONIUM COMPLEX AT THE MEDIUM ACTIVITY LABORATORY

EUROPEAN ATOMIC ENERGY COMMUNITY

14 PAGES, 1965 , PP. 791-804 OF VOL. 2, PROCEEDINGS OF AN INTERNATIONAL SYMPOSIUM ON WORKING METHODS IN

HIGH ACTIVITY HOT LABORATORIES, GRENOBLE, JUNE 15-18, 1965, ENEA, OECD, PUBLISHERS

THIS PAPER DESCRIBES THE EQUIFMENT USED FOR THE CHEMICAL PROCESSING OF A SLUG CONTAINING 2.5 G OF AM-241 IRRADIATED FOR FOUR YEARS IN THE MTR AT A MEAN FLUX OF 5 TIMES 10 TO THE 14. FOR THIS PROCESSING, SPECIAL EQUIPMENT ADAPTABLE TO THE PRESENT FACILITIES HAD TO BE DESIGNED.

*EELGIUM + *GLOVE BOX + \#HCT CELL + ENEA (EUROPEAN NUCLEAR ENERGY AGENCY) + FUEL HANDLING + TRANSURANIUM ELEMENT

13-10035 SECTION II - PHYSICS

11 PAGES, 1 FIGURE, 1 TABLE, 56 REFERENCES, FALL 1965 , POWER REACTOR TECHNOLOGY 8(4), PAGES $210-220$, SECTION II

THE SUBSECTION ON CRITICAL AND EXPONENTIAL EXPERIMENTS WITH PLUTONIUM REVIEWS WORK ON POWER AND TEMPERATURE COEFFICIENTS. INCLUDES U.S. AND FRENCH WORK WITH U-PU MIXTURES AND WITH PU THAT CONTAINS PU-24C AND -241

*CRITICALITY EXPERIMENT + *CRITICALITY SAFETY + \#PLUTONIUM + FRANCE + POWER COEFFICIENT + TEMPERATURE COEFFICIENT

12-10600 APPLICATION FOR LICENSES FPCE PLANT

I SOCHEM INC.

750 PAGES APPROX., 83 FIGURES, 71 TABLES, REFERENCES, JUNE 1966, DOCKET NO. 50-258, PDR

REPORT GIVES ALL THE GENERAL AND DETAILED TECHNICAL INFORMATION REQUIRED FOR AEC LICENSING OF A RADIOCHEMICAL PLANT. INCLUDED ARE SECTIONS ON - SITE DESCRIPTION, PLANT DESCRIPTION, PROCESS DESCRIPTION, EQUIPMENT DESCRIPTICN, SYSTEMS ANALYSIS, PUBLIC PROTECTION, PERSONNEL PROTECTION, SAFETY, PLANT ORGANIZATION, AND STARTUP PLANS.

\#APPLICATION FOR AEC LICENSE + \#CERIUM + \#CESIUM + \#FPCE PLANT + \#PROMETHIUM + \#RADIOCHEMICAL PROCESSING + *SATEGUAROS RLPORT, GENIRAL * * STRONTIUM + FIJSION PRODUCT, SEPARATION FROM WASTE +

FISSION PRODUCT, USE OF IN WASTES + HAZARDS ANALYSIS + ISOCHEM, INC. + RADIOCHEMICAL PLANT SAFETY

13-1C65E MALAKHOF $V+$ SIMCN W

CRITICALITY OF FUEL REPROCESSING EQUIPMENT

GENERAL ATOMIC

GAMD-6623 +. 20 PAGES, AUGUST 17,1965, CFSTI, $\$ 1.00 \mathrm{CY}, \$ 0.50 \mathrm{MN}$

A STIIDY OF THF CRITICALITY DF FUEL-PARTICLE STORAGE CONTAINERS AND OF ARRAYS OF SUCH

CONTAINERS WAS CARRIED OUT. THE OBJECTIVE WAS TO COMPUTE THE MULTIPLICATION FACTOR AS A FUNCTION OF LENGTH AND DIAMETER FCR CYLINDRICAL CONTAINERS AND TO COMPUTE MASS LIMITS FOR VARIOUS KINDS OF FUEL PARTICLES THAT HAVE BEEN COATED WITH PYROLYTIC CARBON.

*CARBON + \#CRITICALITY SAFETY + \#PYROLYTIC + \#URANIUM + COMPUTER, DIGITAL + THORIUM

13-10702 GOODE JH

HOT-CELL EVALUATION OF THE RELEASE OF TRITIUM AND KRYPTON-85 DURING PROCESSING QF THOZ-UOZ FUELS OAK RIOGE NATIONAL LABORATORY, OAK RIDGE, TENNESSEE

ORNL-3956 +. 19 PAGES, 3 FIGURES, 4 TABLES, 11 REFERENCES, JUNE 1966, CFSTI, \$2.00 CY, \$O.50 MN

HOT-CELL EXPERIMENTS WITH PROTOTYPE THO2-UO2 POWER REACTOR FUEL SPECIMENS IRRADIATED TO 24,600 MHD/METRIC TON (TH + U) SHOWEO THAT UP TO 0.2 PERCENT OF THE FISSION-PRODUCED TRITIUM AND I PERCENT OF THE KR-85 WERE RELEASEC WHEN THE FUEL WAS SHEARED INTO SHORT LENGTHS. IN OUR APPARATUS, ANOTHER 0.2 PERCENT OF THE TRITIUM AND THE BALANCE OF THE KRYPTON WERE RELEASED TO THE ATMOSPIICRE WHEN THE TULL HAS CISSOLVID TO MAKE SOLVENT EXTRACTION FEED. THIS QUANTITY OF TRITIUM IS LESS THAN 0.5 PERCENT OF THE ESTIMATED 1200 CURIES OF H-3 THAT MAY BE SAFELY DISCHARGED TO THE ATMOSPHERE FROM A 6-TON-PER-DAY PROCESSING PLANT.

\#RACIOCHEMICAL PLANT SAFETY + \#WASTE DISPCSAL, ATMOSPHERIC + ATMOSPHERIC POLLUTION + KRYPTON + RADIOCHEMICAL PROCESSING + THORIUM + TRITIUM + URANIUM DIOXIOE 
13-10703 CLARK HK

CRITICAL AND SAFE MASSES AND OIMENSIONS OF LATTICES OF U AND UOZ RODS IN WATER

SAVANNAH RIVER LABORATORY, AIKEN, SOUTH CAROLINA

DP-1014 + CONF-651103-29+. 60 PAGES, 1 FIGURE, 8 TABLES, 11 REFERENCES, FEBRUARY 1966, CFSTI, \$3.00 CY, $\$ C .75 \mathrm{MN}$

A SURVEY IS GIVEN OF CRITICAL AND EXPONENTIAL DATA OBTAINED WITH WATER-REFLECTED LATTICES OF SLIGHTLY ENRICHED URANIUM AND URANIUM OXIDE RODS. CALCULATIONS ARE MADE FOR THESE LATTICES EY AN ASYMPTOTIC MULTIGROUP BUCKLING CODE AND BY A TWO-GROUP DIFFUSION THEORY CODE EMPLOYING PARAMETERS GENERATED IN THE FIRST CODE. COMPARISON BETHEEN CALCULATIONS AND EXPERIMENTS IS MADE IN TERMS OF A K-SUB-EFF, WHICH IS THE RATIO OF THE CALCULATED K TO THAT CALCULATED FROM THE EXPERIMENTAL DIMENSIONS AND FLUX TRAVERSES AND FROM THE CALCULATED MIGRATION AREAS AND EXTRAPOLATION DISTANCES. FOR SOME OF THE DATA, COMPARISONS ARE ALSO MADE BETWEEN THE PRESENT METHOD OF CALCULATION ANO A MORE COMPLICATED METHOD.

*CRITICALITY SAFETY + \#URANIUM + \#URANIUM DIOXIDE + RADIOCHEMICAL PLANT SAFETy + SAVANNAH RIVER PLANT

13-10704 DREISSIGACKER H + FICHTNER H + REINARTZ W

CONSTRUCTION OF THE DISSOLVER FOR THE EUROCHEMIC REPROCESSING PLANT

1 PAGE, ATOMWIRTSCHAFT XI $141-170$, APRIL 1966

PARTICULAR ATTENTION WAS PAID TO THE TECHNIQUES USED FOR WELDING THE SPECIAL ALLOY CS-M2 EMPLOYEO FOR THE ACTIVE PARTS SINCE MICROCRACKS HAD OCCURRED IN TEST-WELDS MADE IN THIS MATERIAL. A SPECIAL WELOING PROCESS WAS DEVELOPEO TO OBVIATE THIS CRACKING. THE SAME CARE WAS DEVOTED TO THE MECHANICAL WORKING AND COLD FORMING AS TO THE WELDING. ALL TOOLS USEO DURING THE TREATMENT OF THE SHEET METAL AND DURING ASSEMBLY WERE CASED WITH HIGH-GRADE STEEL. EXTREMELY SEVERE REQUIREMENTS WERE PLACED ON TOLERANCES FOR OPERATIONAL AND CRITICALITY REASONS.

*EUROCHEMIC + \#RADIOCHEMICAL PLANT SAFETY + CRITICALITY SAFETY

13-10705 SMILEY SH + BRATER DC + PASHLEY JH

ORGDP FUEL REPROCESSING STUOIES - SUMMARY PROGRESS REPORT - JULY THROUGH DECEMBER, 1965

OAK RIDGE GASEOUS DIFFUSION PLANT, OAK RIDGE, TENNESSEE

K-1669 +. 56 PAGES, 9 FIGURES, 11 TABLES, JUNE 28, 1966, CFSTI, \$6.00 CY, \$0.50 MN

AMONG OTHER FLUORIDE VOLATILITY STUDIES, THE REPORT CONTAINS CRITICALITY CALCULATIONS FOR 2NAF-UF6 MATERIALS (6 PERCENT URANIUM-235) REQUIRED FOR DESIGN OF MODERATED SODIUM FLUORIDE FLUID-BEO SORBERS.

*CRITICALITY SAFETY + *URANIUM HEXAFLUORIDE + EQUIPMENT DESIGN + RADIOCHEMICAL PROCESSING

13-10806 REPORT OF INVESTIGATION OF THE AMERICIUM SHIPPING CONTAINER EXPLOSION IN BUILDING 7I ON SEPTFMAER 25,1964

THE DCW CHEMICAL COMPANY, DENVER, COLORACO

15 PAGES, 12 FIGURES, OCTOBER 20, 1964, SOURCE

ON SEPTEMBER 25, 1964, A SHIPPING CONTAINER AT DOW CHEMICAL COMPANY, ROCKY FLATS SITE, CONTAINING 5 G OF AMERICIUM AQUEOUS CHLORIDE SOLUTION, EXPLOOEO. INVESTIGATION INDICATED THAT THERE WAS INSUFFICIENT DATA TO DETERMINE WHETHER THE SHIPPING CONTAINER FAILED DUE TO CHEMICAL EXPLOSION OR SLOW PRESSURE BUILOUP. EITHER IS POSSIBLE BECAUSE OF RADIOLYTIC

DECOMPOSITION OF THE SOLUTION. THE MAIN RECOMENOATION FOR FUTURE RACIOACTIVE SHIPMENTS IS TO AVOID SENDING THE MATERIAL IN SOLUTION FORM WHEN POSSIBLE.

*AMERICIUM + *EXPLOSION + *STORAGE CONTAINER

13-10809 WATSON HE

THE NRL HIGH LEVEL RADIATION LABORATORY. PART III. OPERATING EXPERIENCE

U. S. NAVAL RESEARCH LABORATORY

11 PAGES, 11 FIGURES, 1 REFERENCE, NUCLEAR ENGINEERING AND DESIGN, 4 (1) PACES 97-107, (1966)

REPORT CONTAINS A GENERAL DESCRIPTION OF ALL PHASES OF OTHE OPERATIONAL, SAFETY, AND AUXILIARY SYSTEMS OF A HIGH-LEVEL RADIATION LABORATORY.

* HOT CELL + DECONTAMINATION + VENTILATION SYSTEM + WASTE DISPOSAL, LIQUID

13-10810 FRANK HS

TECHNICAL CRITERIA FOR THE PREVENTION OF CRITICALITY CHEMICAL PROCESSING DEPARTMENT

HANFORO ATOMIC PRODUCTS OPERATION

HW-81460 +. 8 PAGES, APRIL 8, 1964, CFSTI, \$1.00

THIS DOCUMENT SUPPLEMENTS THE OPG INFORMATION BY DEFINING THE TECHNICAL CRITERIA TO BE USEO IN DEVELOPING THE LIMITS WITHIN WHICH CPD FACILITIES ARE TO BE DESIGNEO AND OPERATEO AT HANFORD.

* CRITICALITY SAFETY + \#HANFORD SITE + RADIOCHEMICAL PROCESSING 
CATEGORY 13

RADIOCHEMICAL PLANT SAFETY

13-10842 *CONTINUEO

OAK RIDGE GASEOUS DIFFUSION PLANT

K-1663 +. 20 PAGES, MAY 31,1966 , CFSTI, \$1.00 CY, \$0.5C MN

THE USE OF HYOROGEN MODERATION AS A PRIMARY NUCLEAR SAFETY CONTROL HAS BEEN IN EFFECT FOR MANY YEARS FOR LARGE-SCALE UFG SHIPMENTS AMONG AEC-OWNEO CONTRACTOR OPERATED FACILITIES. THE EXTENSION OF THE USE OF MODERATION-CONTROLLED SHIPMENTS TO LICENSEES AS WELL AS CONTRACTOR ORGANIZATIONS IS DESIRABLE, AND THIS REPORT SUMMARIZES, IN SUPPORT OF THIS METHOD, THE WORK DONE IN DEVELOPING BASIC CRITICALITY DATA AND THE NECESSARY EQUIPMENT AND OPERATIONAL TECHNI QUES.

* TRANSPORTATION ANO HANDLING + \#URANIUM HEXAFLUORIDE + CONTROL, GENERAL + HYDROGEN + SAFETY REVIEW (OPERATIONS, EXPERIMENTS)

1.3-1.0981 REED PE

CRITICALITY SAFETY OF FISSILE MATERIALS IN THE CHEMICAL PROCESSING DIVISION

I SOCHEM INC., RICHLAND, WASHINGTON

ISO-270 +. 12 PAEES, APKIL 1, 1966, CFSTI, \$1.00 CY, \$0.50 MN

THESE PROCEDURES PROVIDE A UNIFORM BASIS FOR APPLYING CRITICALITY SAFETY CONTROLS WITH RESPECT IO THE SHIPPING AND RECEIVING OF FISSILE MATERIALS. THE TRANSFER OF FISSILE MATERIALS RETWEEN CHEMICAL PROCESSING DIVISION FACILITIES SHALL BE ACCORDING TO NUCLEAR SAFETY

SPECIFICATIONS AS REQUIRED UNDER CPD OPG 11.9.

\#CR IT ICALITY SAFETY

$13-11133$ HENSLEY G

NUCLEAR FUEL REPROCESSING - INSTRUMENTATION SAFETY CONSIDERATIONS

UNITED KINGDOM ATOMIC ENERGY AUTHORITY, WARRINGTON

5 PAGES, 3 FIGURES, 3 REFERENCES, CHEMICAL AND DROCESS ENGINEERING, 47(3), PAGES 113-117, (MARCH, 1966)

SOLVENT-EXTRACTION-PLANT INSTRUMENTATION IN BRITISH PRODUCTION PLANTS IS COVERED FROM THE

SAFETY AND PROCESS-CONTROL ASPECTS. SPECIFIC SUBJECTS DISCUSSED ARE - CRITICAL-INCIDENT

PROTECTION, CRITICAL-INCIDENT DETECTION, AIRBORNE RADIOACTIVE CONTAMINATION, CONTAMINATED

LIQUID EFFLUENTS, AND FIRE AND EXPLOSION. INSTRUMENT PERFORMANCE IS EVALUATED.

* instrumentation, general + *Radiochemical plant safety + insikumentation, nuclear * INSTPUMENTATION, PROCESS + INSTRIIMENTATION, PROTECTIVE + INSTRUMENTATION, TESTING + RADIOCHEMICAL PROCESSING + UNITED KINGDOM

13-11221 JAPAN RETURNING IRRACIATED FUEL ELEMENTS TO U.S. FOR REPROCESSING - FIRST TO BE SHIPPED FROM

ATOMIC ENERGY COMMISSION, WASHINGTON, D.C

PRESS REL. J-194 +. I PAGE, AUGUST 15, 1966, DPI

THE FIRST CONSIGNMENT OF IRRADIATED NUCLEAR FUEL FROM ASIA TO BE REPROCESSED IN THE UNITED STATES WILL ARR IVE FROM JAPAN AT SEATTLE, WASHINGTON, ON AUGUST 16, 1966 . TWENTY-FOUR IRRADIATED FUEL ELEMENTS, CONTAINEO IN TWO 11-TON CASKS, WILL BE REMOVED. FROM THE NIKKEI-MARU OF THE JAPANESE SHOWA LINE ANN SHIPPED DIRECTLY BY TRUCK TO THE AEC IDAHO CHEMICAL PROCESSING PLANT AT THE NATIONAL REACTOR TESTING STATION IN IDAHO. SEATTLE IS AMONG THE 44 U. S. PORTS THAT HAVE NOTIFIED THE U.S. COAST GUARD THAT THEIR PORT AND COMMUNITY FACILITIES ARE

AVAILABLE FOR THE ACCEPTANCE AND TRANSIT OF SHIPMENTS OF RADIOACTIVE MATERIALS, PROVIOEO THAT THERE IS COMPLIANCE WITH THE REGULATIONS OF THE U.S. AGENCIES EXERCISING JURISDICTION OVER THE ENIRY ANÜ MOVEMENT OF SUCH MATERIALS INTO AND WITHIN THE COUNTRY.

\#FUEL HANOLING + JAPAN + SHIPPING CONTAINER + TRANSPORTATION AND FANDLING

$13-11328$ ULLMANN JW

ORNL FACILITIES CAPABLE OF CONTRIBUTING TO PLUTONIUM FUEL CYCLE DEVELUPMENI OAK RIDGE NATIONAL LABORATORY, OAK RIDGE

ORNL-TM-1268 +. 74 PAGES, FIGURES, NOVEMEER 1965, CFSTI $\$ 3.00 \mathrm{CY}, \$ 0.75 \mathrm{MN}$

THIS REPORT IS A COMPILATICN OF BRIEF DESCRIPTIONS OF ORNL FACILITIES THAT COULD BE USED TO SUPPORT DEVELOPMENT OF A FUEL CYCLE BASED ON PLUTONIUM. THE CAPABILITY AND EXPERIENCE OF EACH FACILITY IS SUMMARIZED, WITH EMPHASIS PLACED ON HANDLINE PLUTONIUM AND OTHER INTENSE ALPHA EMITTERS.

*alpha facilities + *ornl (OAK RIDge national laboraiuky) + \#PLutonium

13-11329 REPORT ON STATUS OF COMPLETION OF CONSTRUCTION AND RESEARCH AND OEVELOPMENT $\triangle S P E C T S$ - RESULTS OF PRE-OPERATIONAL TESTING OF FACILITY, APRIL 1,1966

NUCLEAR FUIL SEP.VITES, INT.

75 PACES, APRIL 1,1966 , SUBMISSION NO. 27 FINAI SAFETY ANALYSIS REPORT, DOCKËT NO. 50-201, PUK

THIS REPORT ON THE PREOPERATIONAL TESTING OF EQUIPMENT ANO SYSTEMS OF THE NUCLEAR FUEL SERVICES, INC., FACILITY AS REQUESTED BY AEC-DML IS COMBINED WITH THE SEMI-ANNUAL REPORT TO OML ON THE STATUS OF COMPLETION OF CONSTRUCTION AND RESEARCH AND DEVELOPMENT ASPECTS FOR THE PERIOD ENDING APRIL 1, 1966. IT COVERS IN SOME DETAIL THE SPECIFIC TESTS, MECHANICAL, HYDRAULIC, PNEUMATIC, ELECTRICAL, CHEMICAL, AND ENVIRONMENTAL, PERFORMED BY NFS IN PLANT AREAS AND ENVIRONS IN PREPARATION FOR COMMERCIAL OPERATION. 
CATEGORY 13

RADIOCHEMICAL PLANT SAFETY

$12-11329$ \#CONTINUED*

\#LICENSING STATUS OF NUCLEAR PROJECTS + \#NFS (NUCLEAR FUEL SERVICES) + \#RADIOCHEMICAL PROCESSING + \#TEST, PREOPERATIONAL + SOLVENT EXTRACTION PROCESS + WASTTE MANAGEMENT

12-11330 PROVISIONAL OPERATING LICENSE - LICENSE CSF-1

NUCLEAR FUEL SERVICES INC.

83 PACES, APRIL 27,1966 , DOCKET. NO. 50-201, POR

APPENDIX A OF TECHNICAL SPECIFICATIONS LICENSF CSF-I FOR THE PLANT CONTAINS INFORMATION ON (1) PLANT SITE, LOCATION AND FLOW OF MATERIALS, 121 POSSESSION LIMITS AND FORM OF MATERIALS, (3) SAFETY LIMITS FOR RADIOACTIVE MATERIALS, 141 MINIMUM OPERATING REQUIREMENTS, (5) SURVEILLANCE REQUIREMENTS, (6) ADMINISTRATIVE REQUIREMENTS. SPECIFICATIONS COVER IN DETAIL THE HANDLING AND STORAGE OF LIQUID, GASEOUS, AND SOLIO RADIOACTIVE MATERIALS.

\#LICENSING STATUS OF NUCLEAR PROJECTS + \#NFS (NUCLEAR FUEL SERVICES) + \#RADIOCHEMICAL PROCESSING + CRITICALITY SAFETY + FUEL HANDLING + FUEL STORAGE + RADIOCHEMICAL PLANT SAFETY +

SOLVENT EXTRACTION PROCESS + WASTE DISPOSAL, ATMOSPHERIC + WASTE MANAGEMENT + WASTE TREATMENT, GENERAL

13-11704 MANNESCHMIDT JF

RECENT ADVANCES IN MONITORING OF RADIOACTIVE GASEOUS WASTES AT ORNL

OAK RIDEE NATIONAL LABORATORY, OAK RIDGE

CONF-66C904 +. 27 PAGES, 17 FIGURES, 6 REFERENCES, PRESENTED AT 9TH AEC AIR CLEANING CONFERENCE, BOSTON, MASS., SEPTEMBER 13-16, 1966 , SOURCE

MANY ACTIVITIES AT THE OAK RIDGE NATIONAL LABORATORY ARE CONCERNED WITH THE CHEMICAL PROCESSING OF RADIOACTIVE MATERIALS. GASEOUS EFFLUENTS FROM THESE OPERATIONS ARE TREATED TO REMOVE DANGEROUS CONTAMINANTS BEFORE RELEASE TO THE ATMOSPHERE. ROUTINE MONITORING: OF SUCH EMISSIONS WAS STARTED IN 1966 WHEN MANUALLY OPERATED PARTICULATE MONITORS WERE INSTALLED. AT EACH OF THREE PROCESS STACKS. SINCE THAT DATE, COVERAGE HAS BEEN EXTENDED TO SIX STACKS, THE SAMPLE WITHDRAWAL SYSTEM HAS BEEN REBUILT, AND THE DETECTION EQUTPMENT HAS BEEN ADOED TO AND MODERNIZED. THE INTENSIVE MONITORING HAS LEAD TO PROCESS IMPROVEMENTS THAT HAVE REDUCED THE ENVIRONMENTAL RELEASES OF RAOIOACTIVITY IN THE GASEOUS WASTE EFFLUENTS BY A FACTOR OF 3 SINCE 1962 .

\#NONITOR, RADIATION, EMERGENCY + \#MONITOR, RADIATION, GAS + *MONITOR, RADIATION, GENERAL PRACTICE + \#MONITOR, RADIATION, SAMPLING + \#MONIYOR, RADIATION, STACK + MONITOR, RADIATION, AIR +

MCNITOR, RADIATION, BACKGROUND + MONITOR, RADIATION, ENVIRONMENTAL + MONITOR, RADIATION, GENERAL 
CATEGORY 14
R.AOINNIIS.I IDF RELEASE AND MOVEMENT IN THE ENVIRONMENT

$14-[8712$ GOOOE JH

FIXATION OF INTERMEDIATE LEVEL RADIOACTIVE WASTE IN ASPHALT- HOT-CELL TESTS

OAK RIDGE NATIONAL LABORATORY

ORNL-TM-1343+. 20 PAGES, FIGURES, TAELES, 4 REFERENCES- NOVEMBER 18, 1965, CFSTI, \$1.00 CY, \$O.5O MN

HOT-CELL TESTS ON THE FIXATION OF INTERMEDIATE-RAOIOACTIVITY-LEVEL WASTE (5 CURIES/GAL) IN EMULSIFIED ASPHALT CONFIRMED EARLIER SUCCESSFUL NONRAOIOACTIVE AND TRACER TESTS OF THE PROCESS. LEACHING, HITH STATIC DEMINERALIZED WATER, REACHED AN APPARENT STEADY-STATE RATE OF ABOUT 2 TIMES 10 TO THE MINUS 4 G PER SQUARE CM PER DAY, WHICH IS ADEQUATE FOR PERMANENT OISPOSAL BY BURIAL IN STEEL DRUMS. RADIOLYTIC-GALS GENERATION FOR FIVE MONTHS, DURING WHICH TIME THE ASPHALT RECEIVED AN INTERNAL DOSE OF ABOUT 1.2 TIMES 10 TO THE 7 RAD, WAS NOT MEASURARLF. THE SUCCESS OF THESE TESTS SUGGESTS THAT THE PROCESS SHOULD BE EXTENDED TO INCLUDE EXPERIMFNTS WITH MORE RADIOACTIVE WASTES, INCLUDING TYPES DIFFERENT FROM THE ONE USED HERE.

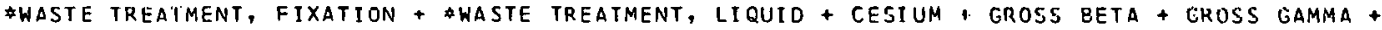
RADIATION EFFECT + RARE EARTH + RUTHENIUM + STRONTIUM + WASTE TREATMENT, EQUIPMENT

14- 99274 TRIULZI C

TREND OF GROSS BETA RADIOACTIVITY IN PLANKTON SAMPLES COLLECTED IN THE ADRIATIC AND LIGURIAN-TYRRHENIAN SEAS DURING $1961-1964$

IASTITUTO LOMBARDO, MILAN + CISE, MILAN

TID-22112+. 17 PAGES, MEETING HELD ON JUNE 24, 1965- CFSTI, \$1.00 CY, \$0.50 MN

GROSS BETA RADIOACTIVITY WAS MEASURED ON PLANKTON ASH SAMPLES COLLECTED IN THE LIGURIAN-TYRRHENIAN SEA AND UPPER AORIATIC DURING 1961-1964. THE TREND OF GROSS BETA RADIOACTIVITY DURING THIS PERIOD IS CORRELATED WITH RAINFALL AND RADIOACTIVE FALLOUT IN THE SAME ZONE. VALUES OF GROSS BETA ARE REPORTED, WHICH HAS BEEN MEASURED IS AND 200 DAYS AFTER THE TOW. RATIO BETWEEN THESE VALUES SUPPLIES A USEFUL INOICATION OF THE DATE OF NUCLEAR EXPLOSIONS RESPONSIELE FOR SAMPLE CONTAMINATION.

* Bi logical concentration, algae + \#iological concentration, aQuatic organisms + * SURVEY, RADINTION, ENVIRONMENTAL + FALIIDIIT + GROSS BETA + OCEAN AND SEA + RAINOUT + SURFACE WATER, NUCLIDE OCCURRENCE

14-C9483 INVESTIGATION OF THE ION ADSORPTION CHARACTERISTICS OF SOILS

INTERNATIONAL ATOMIC ENER,GY AGENCY, VIFNNA, AUSTRIA + STATE AGRICULTURAL UNIVERSITY WAGENINGEN, NETHERLANOS NP-15085 +. 81 PAGES, DECEMBER 1964, DEP. MN.

THIS REPORT COMPRISES A SUMMARY OF INVESTIGATIONS OEALING WITH SEVERAL ASPECTS OF ION-ADSORPTION PHENOMENA OCCURRING IN SOILS AND CLAYS, WITH SPECIAL EMPHASIS ON THE USE OF RADIOACTIVE TRACERS.

\# ADSORPTION + \#TRACER, RADIOACTIVE + CALCIUM + POTASSIUM + SOIL, NUCLIDE OCCURRENCE + SOIL, PROPERTY

14-119485 SMITH OB + PARSONS TV + CLOET RL

AN INVESTIGATION USING RADIOACTIVE TRACERS INTO THE SILT MOVEMENT IN AN EBB CHANNEL, FIRTH OF FUKIH, I965 UNITED KINGDOM ATOMIC ENERGY AUTHORITY, HANTAGE, ENGLAND

AERE-R-5080 +. 15 PAGES, 7 FIGURES, NOVENBER 1965,8 IS, $\$ 0.80$

INVESTIGATIONS OF THE SILT MOVEMENT FROM THE OXCARS SPOIL GROUND, USING RACIOACTIVE TRACERS (AERE - R 4980), SHOWED THAT THE SPOIL GROUND IS UNSATISFACTORY DUE TO EXTENSIVE UPSTREAM

TRANSPORT OF SPOIL. AN INVESTIGATION OF AN ALTERNATIVE SPOIL GROUND IN AN EBB CHANNEL NEAR

OXCARS HAS UNDERTAKEN, USING GROUND-GLASS TRACER LABELLED WITH LA-14O. THE RESULTS SHOW THAT

THE SPOIL WOULD BE WIDELY DISTRIBUTED DOWNSTREAM OF THE DEPOSITION AREA WITHOUT APPROACHING

EXISTING HARBORS ON THE ESTUARY. UPSTREAM MOVEMENT OF SPOIL WAS VERY LIMITED DURING THE

THREE-DAY INVESTIGATION.

*LANTHANUM + \#SEDIMENT + \#SUPFACE WATER, SEDIMENT + \#SIIRFACF WATER, TRACER + *TRACER, RADIOACTIVE + SURFACE WATER, DISPOSAL MEQIA + IJNITEC KTNGDOM

14-CS48E LANDSTROM O + WENNER CG NEUTRON-ACTIVATION ANALYSIS OF NATURAL WATER APPLIED TO HYOROGEOLOGY AKTIEBOLAGET $\triangle$ TOMENERGI, STOCKHOLM, SWEDEN

$\triangle E-204+28$ PAGES, CECEMBER 1965 , DEP. MN.

THE NATURAL CONTENT OF ELEMENTS IN WATER WAS USED TO CHARACTERIZE DIFFERENT GROUNDWATER SUPPLIES AND REVEAL THE PRESENCE OF GROUNOWATER STP.EAMS. A NEUTRON-ACTIVATION MFTHOD INCLUDING CHEMICAL-GROUP SEPARATION TECHNIQUES HAS BEEN USED FOR THE OETERMINATION OF TRACE ELEMENTS. ANALYZED WATER SAMPLES FROM THREE DIFFERENT PLACES IN NORTHERN SWEDEN ILLUSTRATE THE APPLICATION TO COMMON AND IMPORTANT HYDROGEOLOGICAL PROBLEMS, SUCH AS THE QUALITY AND CAPACITY OF WATER SUPPLIES, THE ORIGIN AND EXISTENCE OF GROUNDWATER STREAMS, AND GROUNDWATER EXCHANGE WITH RIVERS.

\#ACTIVATION PRODUCT + \#GEOLOGICAL CONSIDERATIDN, GEOC.HEMTCAL + \#HYDROLOGICAL CONSIDERATION, GENERAL + AC'I IVATION + GEOLOGICAL CONSIDERATION, GENERAL + SWEDEN

14-TQAT3 THQMP\$ON RC

SNPO AND SNAP EIOLOGICAL STUDIES. SUMMARY TECHNICAL REPORT

BATTELLE NORTHWEST, PACIFIC NORTHWEST LABORATORY, RICHLAND 
CATEGORY 14

RADIONUCLIDE RELEASE AND MOVEMENT IN THE ENVIRONMENT

14-C9603 *CONTINUED*

BNWL-182 +. 19 PAGES, 3 TABLES, JANUARY 3,1966 , CFSTI $\$ 1.00, \$ 0.50$ MN

A SHARP DISTINCTION CANNOT BE MADE BETWEEN THOSE PHASES OF OUR INVESTIGATIONS WHICH WERE PRIMARILY CONCERNED WITH SNPO (SPACE NUCLEAR PROPULSION OFFICE) PROBLEMS ANO THOSE PHASES CONCERNED WITH SNAP (SYSTEMS FOR NUCLEAR AUXILIARY POWER) PROBLEMS BECAUSE THE OBJECTIVES WERE VERY SIMILAR. THEREFORE, WE ARE NOT SEPARATING THIS REPORT INTO SNPO AND SNAP SECTIONS. HOWEVER, IF SUCH DISTINCTION IS NECESSARY, THE PU-238 FEEDING STUDY IS PRIMARILY RELATED TO SNAP, AND: THE STUDIES WITH THE OAK RIDGE-PREPARED SIMULATED FUEL PARTICLES ARE PRIMARILY RELATED TO SNPO. THE LARGE-PARTICLE INHALATION STUDIES AND THE SOLUBILITY STUDIES CLEARLY HAVE APPLICATION TO BOTH SNPO AND SNAP PROBLEMS. EXPERIMENTAL WORK CONSISTED OF SEVERAL SEPARATE INVESTIGATIONS. IN MANY INSTANCES, THESE INVESTIGATIONS ARE STILL CONTINUING, AND FINAL CONCLUSIONS CANNOT BE DRAHN.

* aERospaCe saFETy + \#iOMEOICAL + \#PARTICLE, RADIOACTIVE +

* SNAP, GENERAL (SYSTEMS FOR NUCLEAR AUX. POWER) + EXPERIMENT, GENERAL + INEESTION + INHALATION + PLUTONIUM

$14-C 9663$ TROTT AF

CONTAMINATION CONTROL ANO WASTE DISPOSAL IN THE HIGH LEVEL ISOTOPE OPERATIONS AT ATOMIC ENERGY OF CANADA LIMITEC COMMERCI I AL PRODUCTS

ATOMIC ENERGY OF CANADA LIMITED

9 PAGES, 7 FIGURES, 5 REFERENCES- 1965- PP. 668-677 OF THE PROCEEDINGS OF AN INTERNATIONAL SYMPOSIUM ON WORKING METHODS IN HIGH ACTIVITY HOT LAEORATORIES, GRENOBLE, JUNE 15-18, 1965, VOL. 2- ENEA', OECD, PUBL I SHERS

TEN YEARS OF EXPERIENCE IN HANDLING MULTIKILOCURIE QUANTITIES OF CO-GO AND OTHER ISOTOPES IN A PLANT NEAR THE CENTRE OF THE CITY OF OTTAWA AND REMOTE FROM RADIOACTIVE-WASTE-DISPOSAL FACILITIES IS REVIEWED. CONTAMINATION CONTROL, INCLUDING VENTILATION DESIGN, CONTINUOUS EFFLUENT-AIR MONITORING AND FILTRATION, CONTINUOUS EFFLUENT-WATER MONITORING, IN-CELL MONITORING AND CONTAMINATION CONTROL, LIQUID AND DRY WASTE PROCESSING AND REMOVAL FROM HOT CELLS, ANO CONTAMINATION CONTROL, LIQUID AND DRY WASTE PROCESSING AND REMOVAL FROM HOT CELLS, AND THE REMOVAL, PACKAGING, AND TRANSPORTATION OF WASTE FROM THE PLANT SITE TO BURIAL ARE DESCRIBED.

*CANADA + *CONTAMINATION + \#ASTE DISPOSAL, GENERAL + EFFLUENT + ENEA IEUROPEAN NUCLEAR ENERGY AGENCYI + FILTRATION + MONITOR, RADIATION, AIR + TRANSPORTATION ANO HANOLING + VENTILATION SYSTEM

14-C.9528 UPSON UL FIXATION OF HIGH-LEVEL RAOIOACTIVE WASTES IN PHOSPHATE GLASS-OHOT CELL GLASS EXPERIMENT BATTELLE-NORTHWEST

BNW-2GO+ CONF-660208-9+. 6S PAGES, 28 FIGURES, 12 REFERENCES, 12 TABLES- JANUARY 1966, CFSTI, 3.00 CY, \$0.75 MN, FROM SYMPOSIUM ANO LONG-TERM STORAGE OF HIGHLY RAOIOACTIVE WASTES, RICHLAND, WASH.

PHOSPHATE GLASS WAS PRODUCED FROM ACTUAL, HIGHLY RADIOACTIVE FUEL-REPROCESSING WASTE, OEMONSTRATING THE TECHNICAL FEASIBILITY PROCESS, AN AQUEOUS WASTE IS CONVERTED DIRECTLY TO A PHOSPHATE GLASS, WITH NO INTERMEDIATE DRYING OR CALCINATION STEP. THE CONVERSION TO GLASS YIELDS A WASTE-PRODUCT VOLUME OF ABOUT 5 GAL PER TON OF URANIUM PROCESSED, A 15- TO 20-FOLD REDUCTION FROM THAT OF CURRENTLY STORED LIQUID PUREX WASTES. IN THIS DEMONSTRATION, AGED PUREX IWW WASTE, DEFICIENT IN CE-144 AND ZR-NB-95 WAS 400 CURIES OF GAMMA ACTIVITY PER LITER AND PRODUCING ABOUT $2 W$ OF THERMAL POWER PER LITER.

* Waste treatment, fiXATION + waste management + waste storage + waste treatment, equipment

14-10074 CARNAHAN CL

a PROCECURE FOR THE CALCULATION CF NEUTRCN ACTIVATION OF AN INFINITE HOMOGENEOUS MEDIUM

HAZELTON-NUCLEAR SCIENCE CORPORATION, PALO ALTO, CALIFORNIA

HNS-1229-54 +. 67 PAGES, REFERENCES, SEPTEMBER 15, 1964, CFSTI, \$3.00

A METHOD FOR CALCULATING QUANTITIES OF RADIONUCLIDES INDUCED IN INFINITE, HOMOGENEOUS MEDIA BY NEUTRONS FROM UNDERGROUND NUCLEAR DETONATIONS IS DEVELOPED THEORETICALLY, AND A PROCEDURE FOR PRACTICAL APPLICATION OF. THE THEORY IS PRESENTED. RESULTS OF CALCULATIONS ARE GIVEN FOR RADIONUCLIDES, HAVING HALF LIVES GREATER THAN 0.5 YEARS, INDUCED BY NEUTRONS FROM FUSION REACTIONS AND FROM FISSION REACTIONS IN MEDIA HAVING THE COMPOSITIONS OF THE AVERAGE EARTHS CRUST, AVERAGE CARBONATE ROCKS, AND THE IATUM SALT DOME, HATTIESBURG, MISSISSIPPI S SEPARATE CALCULATIONS ARE MADE FOR FUSION NEUTRONS AND FOR FISSION NEUTRONS. BECAUSE OF THE GREAT DIFFERENCES IN THE INITIAL NEUTRON ENERGY DISTRIBUTIONS AND IN THE TOTAL NUMBERS OF NEUTRONS PRODUCED PER UNIT ENERGY YIELD, BY THE THO PROCESSES. A SAMPLE CALCULATION IS INCLUDED.

* ACTIVATION + \#ACTIVATION PRODUCT + \#GROLND WATER, NUCLIDE OCCURRENCE + \#PLOWSHARE PROGRAM + CRITICAL + NUCLIOE + GEOLOGICAL CONSIDERATION, GENERAL + NUCLEAR DETONATION

14-10077 GUSTAFSON PF + KASTNER J + LUETZELSCHWAB J

ENVIRONMENTAL RADIATION. MEASUREMENTS OF DOSE RATES

ARGONNE NATIONAL LABORATORY

4 PAGES, 2 TABLES, 2 FIGURES, 16 REFERENCES, SCIENCE, 145(3627), PAGES 44-47 (JULY 3, 1964)

THE EXPOSURE DOSE FROM ENVIRONMENTAL SOURCES OF RADIATION WAS DETERMINED BY AN IONIZATION CHAMBER, BY GAMMA-RAY SPECTROMETRY IN THE FIELD, AND BY MEASURING RADIOACTIVITY IN SOIL

CORES. THE EXPOSURE DOSE FROM COSMIC RADIATION WAS FOUND TO BE 4.4 PLUS OR MINUS O.2

MICROROENTGENS/HR, THAT FROM NATURAL RADIOACTIVITY 8.0 PLUS OR MINUS O.3, ANO THE

CONTRIBUTION FROM FISSICN PRODUCTS VARIED FROM 2.0 TO 7.5 DURING THE INTERVAL IN QUESTION. 
CATEGORY 14

$14-10077$ \#ONTINUED*

\# DOSE CALCULATION, EXTERNAL + \#DOSE MEASUREMENT, EXTERNAL + *MONITOR, RADIATION, ENVIRONMENTAL + CESIUM + COBALT + FALLOUT + GROSS ALPHA + MONITOR, RADIATION, BACKGROUND + POTASSIUM + RADON +

SOIL, NUCLIDE OCCURRENCE + TEST, WEAPONS (HP ASPECTS) + THORIUM + THORON + URANIUM

14-1008C BECK HL + CONDON WJ + LCWDER WM

SPECTROMETRIC TECHNIQUES FOR MEASURING ENVIRONMENTAL GAMMA RADIATION

NEW YORK OPERATIONS OFFICE

HASL-150 +. 71 PAGES, 22 FICURES, 6 TABLES, 34 REFERENCES, OCT08ER 1964, CFSTI, \$3.00 CY

PULSE-HEIGHT SPECTRA OETAINED IN THE FIELD BY USING A LARGE NAIITII CRYSTAL CAN BE ANALYZED BY RELATIVELY SIMPLE METHODS TO DETERMINE ACCURATELY TOTAL ENVIRONMENTAL GAMMA-RAY DOSE RATES, AS WELL AS THE INDIVICUAL DOSE RATE CONYRIBUTIONS FROM K-40, THE U238 SERIES, THE THZ32 SERIES, AND THE PRINCIPAL GAMMA-RAY EMITTING FISSION PRODUCTS. THE CALIBRATION OF A 5 BY 3-IN. DETECTOR IS DESCRIBED IN DETAIL, AND THE APPLICABILITY AND LIMITATIONS OF THE SPECTRAL-ANALYSIS ARE EXAMINED. SEVERAL PROBLEMS ASSOCIATED WITH FIELD MEASUREMENTS ARE DISCUSSED, IN PARTICULAR THE EFFECTS OF RADON MIGRATION FROM THE SOIL, SOIL MOISTURE, AND NATURAL FALLOUT. EVIDENCE IS DOSIMETRIC AND RELATED INFORMATION OBTAINED FROM FIELD SPECTRA ANALYZED BY THESE METHODS.

\#CRITICAL NUCLIOE + \#FALLOUT + \#GAMMA EMITTER + *INSTRUMENTATION CALIBRATION + *SOIL + CESIUM + DIFFUSION + HYOROLOGICAL CONSIDERATION, GENERAL + MONITOR, RADIATION, ENVIRONMENTAL + NIOBIUM + POPULATION EXPOSURE + POTASSIUM + RADON + SOIL, RADIONUCLIDE NOVEMENT THROUGH + THORIUM + URANIUM + ZIRCONIUM

14-1CG85 INGOLD WC + HUDDLESTON CM

AN EMPIRICAL FORMULA FOR CALCULATING GAMMA-RAY DOSE ATTENUATION IN CONCRETE DUCTS

NAVAL CIVIL ENGINEERING LAB., PORT HUENEME, CALIFORNIA

AC- $609049+.72$ PAGES, NOVEMBER 25, 1964, CFSTI, \$2.00

A SURVEY IS PRESENTED OF THE STATUS OF THE CALCULATION OF GAMMA DOSE-RATE ATTENUATION IN AIR DUCTS THR.OUGH CONCR.ETE. A SIMPLE EMPIRICAL FORMULA IS EXHIBITED THAT SHOWS SATISTACTORY

AGREEMENT WITH THE RESULTS OF MORE COMPLICATEO COMPUTATIONAL TECHNIQUES AND WITH EXPERIMENTAL

RESULTS. THIS SIMPLE FORMULA, WHICH MAY BE USEO FOR HAND COMPUTATION, REPRESENTS A SAVING IN COMPUTATION TIME 2 SECONDS PER CASE COMPARED TO 400 SECONDS EY IBM-1620.

* Comparison, theory and experience + \#DOSE CALCulation, external + concrete + Fallout + SHIElding

14-11091 ELLMER $M$

SITE SELECTION

2 PAGES, ATOMWIRTSCHAFT, $10(11)$, PAGES 567-568 (NOVEMBER 1965), IN GERMAN

FOR THE POWER PLANT RWE-BAYERNWERK (KRB), THE MOST FAVORABLE SITE ORIGINALLY SEEMED TO BE ONE NEAR 8ERTOLDSHEIM. HOWEVER, THE WATER AUTHORITIES REJECTED IT FOR TECHNICAL AND EMCTIONAL-POLITICAL REASONS, ALTHOUGH ATTEMPTS WERE MADE TO DEMONSTRATE THAT DRINKING WATER AND NUCLEAR. POWER. AP.E NOT MUTUALLY EXCLUSIVE. THE ATOMIC PLANT WILL BE RUILT IN GUNDREMMINGEN. A METEOROLOGICAL TOWER $118 \mathrm{M}$ HIGH WILL BE ERECTED. A SMALLER DESIGN OF THE PLANT WAS REQUIRED. WE STUDIED THE COOLING-WATER REMOVAL AND RECYCLE TO FIND THE OPTIMUM COMPROMISE RETWEEN WATER ECONOMY AND ENERGY ECONOMY.

- CERMANY + METEOROLOGY + WATER PCLLUTION + HATER, ORINKING

14-11124 JEANMAIRE L + PATTI F + DABURON ML + GROS R + BERTRAND S

TESTS ON THE MEASUREMENT OF I-131 IN MILK USING ANIONIC ION EXCHANGERS

COMMISSARIAT A L ENERGIE ATOMI GUE, FONTENAY-AUX-ROSES, FRANCE

CEA-R-2897 +. 11 PAGES, 4 FIGURES, 1 TABLE, JANUARY 1966, DEP.MN, IN FRENCH

THE MILK PRODUCED BY A CCW CONTAMINATED BY A SINGLE INEFSTION WAS PASSED OVER A DOWEX-1 RESIN TO FIX THE IODINE IT CONTAINED. THE P ERCENTAGE FIXED, ORIGINALLY AROUND 100 PFRCENT, FALLS TO 5C PERCEN T AFTER 15 DAYS.

* analytical technique, milK + \#IODINe + Biological CONCENTRATION, MILK + INGESTION + ION EXChange

14-11130 BURT AK + GIBSON JA

A METHOD FOR CONTINUOUS MEASUREMENT OF TRITIATED HATER IN AIR

ATOMIC FNERGY RESFARCH FSTABI.T SHMENT, HARWELL

JOURNAL OF NUCLEAR ENERGY 20 (3), PAGES 185-190, 6 FIGURES, 7 REFERENCES, 1966

AN INSTRUMENT HAS BEEN DEVELOPED FOR THE CONTINUOUS MEASUREMENT OF TRITIUM (AS HTO) IN AIR IN THC VICINITY OF A HLAVY-HATER REACTOR. WATER IS CONDENSED CONTINUOUSLY FPOM THE AIR AT THE RATE OF 1OG/HR, AND THE TRITIUM ACTIVITY IS MEASURED IN A FLOW CELL FILLED WITH ANTHRACENE CRYSTALS. THE METHOD WAS DEVELOPED TO IMPROVE THE SENSITIVITY OF DETECTION FROM 2.5 DC/CU.CM TOR AN ION CIIAMBCR SYSTCM TO ENABLE THE CHRONIC LEVEL OF 0.4 PC/CU.CM (O.OB MPC FOR AIR) TO BE CONTINUOUSLY MEASURED. THE RANGE OF THE INSTRUMENT, USING A LOGARITHMIC RATEMETER, IS FROM THE BACKGROUNO SENSITIVITY OF 0.1 TO 1000 PC/CU.CM (2SO MPC). THE INSTRUMENT CAN BE OPERATED IN A HIGH GAMMA-RAY BACKGROUND AND DOES NOT DETECT RADIOACTIVE GASES SUCH AS AR-4L. CONTAMINATION OF THE CELL IS RAPIDLY REMOVED FOLLOWING A LARGE RELEASE OF TRITIUM ACTIVITY.

* INSTRUNentation, aIR SAMPLING + \#MONITOR, RADIATION, AIR + \#TRITIUM + DECONTAMINATION +

REACTOR, HEAVY WATER 
14-11131 BROECKER WS + ROCCO GG + VOLCHOK HL

STRONTIUM-90 FALLOUT - COMPARISON OF RATES OVER OCEAN AND LAND

COLUMBIA UNIVERSITY + TRACERLAB, INC., 'WALTHAM, MASS. + HEALTH AND SAFETY LABORATORY, N.Y.

2 PAGES, 2 FIGURES, 7 REFERENCES, SCIENCE 11521 , PAGES 640-641 -(APRIL 29, 1966)

MEASUREMENTS OF SR-9O IN WATERS RESIOING ON THE BAHAMA BANKS FOR PERIODS BETWEEN 12 AND I8O DAYS SUGGEST THAT FALLOUT RATES ONTO THESE WATERS ARE SUBSTANTIALLY THE SAME AS THE AVERAGE RATES AT ALL FALLOUT COLLECTION STATIONS BETWEEN .20 AND 30 DEGREES LATITUDE. IF THE AMOUNT OF PRECIPITATION ON THE BAHAMA BANKS IS REASONABLY REPRESENTATIVE OF THE OCEANIC AREAS IN THIS LATITUDE BAND, OUR RESULTS SUPPORT THE CONCLUSION THAT THE AMOUNT OF SR-9O DEPOSITED PER UNIT AREA OF OCEAN SURFACE IS WITHIN A FACTOR OF 2 OF THAT ON LAND.

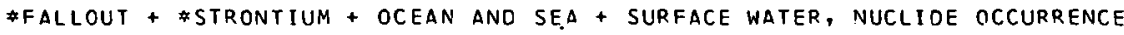

14-11132 OWEN WL + KAWAHARA FK + WILTSHIRE LL

RADIOLOGICAL RECLAMATION PERFORMANCE SUMMARY. VOLUME 1. PERFORMANCF TEST OATA COMPILATION NAVAL RADIOLOGICAL DEFENSE LABORATORY, SAN FRANCISCO, CALIFORNIA

USNROL-TR-967 +. 124 PAGES, 36 TABLES, 4 FIGURES, 25 REFERENCES, OCTOBER 13, 1965, CFSTI, \$4.00 FS, \$0.75 PN

THIS VOLUME PRESENTS TABULATED DATA SUMMARIZING THE PERFORMANCE OF LANO-RECLAMATION METHODS $\triangle N D$ EQUIPMENT. THE TABLED ENTRIES WERE GATHERED FROM 18 EXPERIMENTS AND FIELD OPERATIONS. THEY INCLUDE THOSE OPERATIONAL AND ENVIRONMENTAL FACTORS KNOWN TO INFLUENCE RECLAMATION EFFECTIVENESS. A SECOND VOLUME WILL BE DEVOTED TO THE EVALUATION AND REORGANIZATION OF THE ABOVE COMPILATION INTO A FORM COMPATIBLE WITH THE PLANNING OF RADIOLOGICAL RECOVERY OPERATIONS.

\#CIVIL DEFENSE + \#DECONTAMINATION + \#FALLOUT + DEPOSITION + PARTICLE SIZE + RADIATION SAFETY AND CONTROL + TCPOERAPHY

14-11252 HENDERSON RW + LARSON OW + FULTYN RV

RADIATION MEASUREMENTS OF THE EFFLUENT FROM THE PHOEBUS IA-321 REACTOR

LOS ALAMOS SCIENTIFIC LABORATORY, LOS ALAMOS

LA-3396-MS +. 62 PAGES, 22 FIGURES, 9 TABLES, 2 REFERENCES, FEBRUARY 1966, CFSTI \$3.00 CY, \$0.75 MN

PRESENTED ARE THE RESULTS CF DOCUMENTATION STUDIES ON THE EFFLUENT FROM THE FULL-POWER TEST OF THE PHOEBUS IA-321 REACTOR. A OESCRIPTION OF PROCEDURES AND EQUIPMENT IS GIVEN. AN ANALYSIS OF THE ENVIRONMENTAL EFFECTS DUE TO THE PASSAGE AND DEPOSITION OF THE RELEASED MATERIAL IS GIVEN, AS WELL AS DEPOSITION VELOCITIES MEASUR.ED AT VARIOUS LOCATIONS. APPENDIX A GIVES THE RESULTS OF THE STUOY OF SELECTED RESIN-COATED TRAYS BY THE LASL INDUSTRIAL HYGIENE GROUP $(\mathrm{H}-5)$.

\# AEROSPACE SAFETY + \#EFFLUENT + \#TEST, PROOF + LOSS OF COOLANT + SAMPLING

14-11309 LESS LN + SWALLOW JS

ESTIMATING THE HAZARO DUE TO RADIOLYTIC PRODUCTS FROM AIR

IMPERIAL COLLEGE, LONDON + CHRISTIE HOSPITAL AND HOLT RADIUM INSTITUTE, MANCHESTER

5 PAGES, NUCLEONICS 22 (9), PAGES 58-65, SEPTEMBER 1964

THE PRINCIPAL PRODUCT OF THE IRRADIATION OF AIR IS OZONE. SINCE IT IS TOXIC IT MAY LIMIT THE OPERATION OF LARGE ISOTGPE SERVICES OR HIGH-INTENSITY ACCELERATORS. ESTIMATES OF OZONE PRODUCTIONS AND VENTILATION REQUIREMENTS ARE MADE.

\#CHEMICAL TOXICITY + \#OZONE + RADIATION EFFECT

14-11312 DEBORTOLI M + GAGLIONE P + MALVICINI A

ENVIRONMENTAL RADIO-ACTIVITY, ISPRA 1965

EUROPEAN ATOMIC ENERGY COMMUNITY (EURATOM), ISPRA, ITALY

EUR-2965E +. 72 PAGES, 1966 , DEP. MN

THIS REPORT SUMMARIZES THE RESULTS OF THE MEASUREMENTS OF ENVIRONMENTAL RAOIOACTIVITY PERFORMED BY. THE SITE-SURVEY GROUP OF THE PROTECTION SERVICE OF THE EURATOM ISPRA

ESTA8LISHMENT. THE RESULTS INDICATE THAT THE ENVIRONNENTAL RADIATION EXPOSURE FOR THOSE

LIVING IN THE NEIGHBOURHOOD OF THE ESTABLISHMENT WAS DUE, ALMOST EXCLUSIVELY, TO NATURAL

SOURCES AND WORLD-WIDE FALLOUT.

* BIOLOGICAL CONCENTRATION, AQUATIC ORGANISMS + \#BIOLOGICAL CONCENTRATION, FOOD +

* BIOLOGICAL CONCENTRATION, MILK + \#BIOLOGICAL CONCENTRATION, VEGETATION + CESIUM + EURATOM + FALLOUT +

ITALY + MONITOR, RADIATION, ENVIRONMENTAL + RAINOUT + SOIL, NUCLIDE OCCURRENCE + STRONTIUM +

SURVEY, RAOIATION, ENVIRONMENTAL + WASTE DISPOSAL, ATMOSPHERIC + WASTE DISPOSAL, LIQUID

14-11313 - DOLPHIN GW + DUNCAN KP + DUNSTER HJ + JACKSON S

MAXIMUM PERMISSIBLE CONCENTRATIONS IN AIR FOR COMPOUNDS OF PU-230

UNITEO KINGDOM ATOMIC ENERGY AUTHORITY, HARWELL

AHSBIRPIR-69 +. 13 PAGES, APRIL 1966, BIS, \$0:50

THE DER IVATION OF THE VALUES FOR THE MPS (AIR) AS GIVEN IN ICRP PUB 2. (1959). FOR SOLUBLE. AND INSOLUBLE PLUTONIUM IS BRIEFLY REVIEWEO FOR THE CASES OF BONE, LIVER, AND LUNGS AS ORGANS OF PEFERENCE. IN THE MODEL USED IN ICRP PUB 2 FOR CALCULATING THE MPC FOR INSOLUBLE RADIOACTIVE DUSTS IN THE LUNG IT IS ASSUMED THAT 12-1/2 PERCENT OF THE INHALED RACIOACTIVITY IS 
CATEGORY 14

14-11313 \#CONTINUED*

TRANSFERRED TO THE BODY FLUIDS. THIS TRANSFER COULD LEAD TO A BUILDUP OF RADIOACTIVITY IN A BODY ORGAN OTHER THAN THE LUNG. HOWEVER, RECENT DATA FROM DOG EXPERIMENTS AND HUMAN AUTOPSIES SHOW THAT THIS IS NOT THE CASE AND THAT THE LUNG IS THF CRITICAL ORGAN FOLLOWING INHALATION OF PLUTONIUM OXIDE. INHALED NITRATE IS FAIRLY READILY TRANSFERRED TO THE LIVER AND BONE. CONSEQUENTLY, THE MORE RESTRICTIVE MPC (AIR) FDR SOLUBLE PLUTONIUM, MUST BE USED WHEN THIS COMPOUND IS INVOLVED. A LIST OF PLUTONIUM COMPOUNDS IS GIVEN AND DIVIDED INTO THOSE COMPOUNDS BEHAVING LIKE PLUTONIUM NITRATE AND THOSE BEHAVING LIRE PLUTONIUM OXIDE IN THE HUMAN BODY.

* NAXIMUM PERMISSIBLE CONCENTRATION (MPC) + \#PLUTONIUM + AIR + DOSE CALCULATION, INTERNAL + INHALATION

14-11?14 WASTE BURNING AT CHALK RIVER

2 WAGES, 3 FIGURES, NUCLEAP ENGINEERING 10(115), 472-473, DECEMGER 1965

OPERATING EXPERIENCE AT THE LCW-ACTIVITY WASTE INCINERATOR IS DESCRIEEC. THE INCINERATOR AND MONITORING EQUIPMENT ARE DESCRIBED, AND OPERATING DATA ARE GIVEN, ALONG WITH THE COSTS.

*CANADA + \#CHALK RIVER + \#INCINERATION + WASTE TREATMENT, ECONOMICS + WASTE TREATMENT, SOLID

14-11317 SCHULTZ NB

REMOVAL OF LOW-LEVEL RADIOACTIVE WASTES RY A SANITARY WATER TREATMENT PROCESS

UNION CARBIDE CORPORATION, OAK RIDGE, OAK RIDGE GASEOUS DIFFUSION PLANT

K-1651 +. 13 PAGES, 3 FIGURES, 4 TABLES, 8 REFERENCES, APRIL 12,1966, CFSII \$1.00 CY, \$O.50 MN

OUR PRESENT KNOWLEDEE INDICATES THAT CONVENTIONAL POTABLE-WATER-TREATMENT PROCESSES ARE RELATIVELY INEFFICIENT FOR REMOVAL OF RADIOELEMENTS FROM THE LOW-LEVEL WASTES WHICH CAN BE EXPECTED TO BE FOUNE CONCENTRATIOA (MPC) WATER SUPPLIES. THUS, STRICT CONTROL OF WASTE OISCHARGE CONCENTRATIONS MUST BE MAINTAINED TI INSURE THE PURITY OF FUTURE WATER SUPPLIES. ASSUMING THAT THESE RECOMMENDED OISCHARGE LEVELS ARE MAINTAINED, IT IS UNL IKFIY THAT ADOITIONAL, SPECIFIC TREATMENT WILL BE NEEOED. RATIIER, OUR PRIMARY JOB WILL BE THAT OF CONTINUING EFFECTIVE MONITORING OF THE WATER SUPPLY TO REASSURE OURSELVES THAT POLLUTION-CONTROL MEASURES ARE IN FACT ADEQUATE. ON THE OTHER HAND, UNDER EMERGENCY CONDITICNS, IT IS ANTICIPATED THAT SIGNIFICANT REDUCTION CAN BE MADE IN THE LEVELS OF THESE RADIOACTIVE CONSTITUENTS BY SOME OF THE PRESENT METHODS.

*WASTE TREATMENT, LIQUID + *WATER TREATMENT + GROSS BETA + MAXIMUM PERMISSIBLE CONCENTRATION (MPC) + RADIOCHEMICAL ANALYSIS + STRONTIUM + HATER, DRINKING

14-1132C TAPPAN JT + MOORE WE

PROJECT DRIBBLE-SALMON EVENT ON-SITE HEALTH AND SAFETY REPORT

REYNOLDS ELECTRICAL AND ENGINEERING CO., INC.

VUF-1025 +. 49 PAGES, 11 FIGURES, 10 TABLES, NOVEMBER 1965, CFSTI \$2.00 CY, \$0.50 MN

THE SALMON EVENT WAS DETONATFD AT PRO.IFC.T DRIBBLE TEST SITE, TATUM SALT DOME, NEAR

HATTIESBURG, MISSISSIPPI, ON 22 OCTOBER 1964. RADIATION MEASUREMENTS WERE RECORDED OURING AND AFTER THE DETONATION BY A REMOTE-AREA MONITORING SYSTEM. AFTER THE DETONATION, RADIATION MONITORS EQUIPPED WITH PORTABLE RADIATION-DETECTION INSTRUMENTS SURVEYED THE ROUTE INTO SURFACE GROUND ZERO BEFCRE OTHER PLANNEO REENTRIES WERE MADE. CONTINUOUS MONITORING WAS PROVIDED WHILE WORKFRS WERE IN THE AREA. ONLY BACKGP.OUND RAOIATION MEASUREMENTS WERE OBSERVED FROM ZER.O TIME UNTIL COMMUNICATION WITH THE CAVITY HAD BEEN ESTABLISHED DURING POSTSHOT DRILLING OPERATIONS AT A DEPTH GREATER THAN $2600 \mathrm{FT}$. FIFTY-TWO INDIVIDUALS RECEIVED RADIATION DOSES IN EXCESS OF 100 NILLIREMS DURING THE PROGRAM. THE MAXIMUM ACCUMULATED INOIVIDUAL DOSE WAS 1065 IWELL BELOW THE DOSAGE LIMITS LISTED IN THE AEC MANUAL, C.HAPTFR D524, OF 3 REMS PER QUARTER AND 5 REMS PER YEARI.

\# RACIATION PROTECTION, ORGANIZATION + *SURVEY, RAOIATION, ENVIRONMENTAL +

* VELA UNIFORM PROGRAM, PROJECT SHOAL + AIR + CHEMICAL TOXICITY + DOSE MEASUREMENT, EXTERNAL + GROSS BETA + IODINF + PERSONNEL EXPOSURE, RADIATION + WASTE DISFOSAL, LIQUID + WASTE DISPOSAL, SOLID + WATER, GENERAL

14-11350 MARBLE E + BERNIER M + EERTET M + GAUDE G

DOSAGE OF SODIUM AND POTASSIUM IN BIOLOGICAL MEDIA BY NEUTRON ACTIVATION WITHOUT CHEMICAL SEPARATION CENTRE DETUDES NUCLEAIRE FONTENAY-AUX-ROSES, FRANCE

CEA-R-2837 +. 26 PAGES, 11 FIGURES, 4 TABLES, JULY 1965, DE9. MN, IN FRENCH

A RELATIVELY SIMPLE METHOD FOR DOSING SODIUM AND POTASSIUM IN BIOLOGICAL MEDIA WAS DEVELOPED. NO CHEMICAL SEPARATION IS REQUIRED. THE MEASUREMENT OF THE GAMMA AND BETA ACTIVITIES INOUCEO BY ACTIVATION IS CARRIED OUT USING SCINTIIIATION RFTECTORS CONNECTED TO $A$ MULTICHANNEL AMPLITUDE SELECTOR AND A COUNTING, UNIT. THE RESULTS ARE EXCELLENT FOR SODIUM, AND SATISFACTORY FOR POTASSIUM IN BIOLCGICAL EXPERIMENTS.

*aCtivation + *traCER, RADIOACTIVE + BIOLOgICAL CONCENTRATION, General + POTASSIUM + SODIUM

14-11351 TERRON-TROUSGLAU T

CAESIUM ABSORPTION BY BARLEY - INFLUENCE OF ITS RETENTION BY THE SOIL - COMPETITIVE ACTION OF POTASSIUM CENTRE DETUDES NUCLEAIRE FONTENAY-AUX $\rightarrow$ ROSES, FRANCE

CEA-R-2708 +. 60 PAGES, FIGURES, 8 TABLES, MAY 1965, DEP. MN, IN FRENCH

THE ABSORPTION OF CESIUM BY BARLEY ANO THE MINERAL EXCHANGE OF CESIUM BY THE SOIL WERE STUDIED AS A FUNCTION OF POTASSIUM CONCENTRATION. THE SOIL HAS A PRONOUNCED EFFECT ON THE UPTAKE OF 
CATEGORY 14

RADIONUClide RELEASE AND MOVEMENT IN THE ENVIRONMENT

\begin{abstract}
14-11351 \#CONTINUED*
CESIUM BY 'eARLEY, FOR EXAMPLE, THE PRONOUNCED SELECTIVITY OF ILLITE FOR CESIUM P.EDUCES ITS UPTAKE BY BARLEY.

\#IOLOGICAL CONCENTRATION, VEGETATION + \#CESIUM + \#MINERAL EXCHANGE + BIOLOGICAL CONCENTRATION, FOOD + POTASSIUM
\end{abstract}

14-11352 LEISTNER L

RESEARCH INTO THE RADIOACTIVE CONTAMINATION OF FOODSTUFFS OF ANIMAL ORIGIN

CENTRE DETUDES NUCLEAIRE FONTENAY-AUX-ROSES, FRANCE

CEA-R-2738 + EUR-2226.F +. 69 PAGES, TABLES, MARCH 1965, DEP. MN, IN FRENCH

THE AUTHOR ASSEMBLES IN A VERY COMPLETE WAY ALL THE AVAILABLE DATA RELATING TO THE TRANSFER OF THE MOST IMPORTANT RADIONUCLIDES FROM THE ENVIRONMENT THROUGH ANIMAL PRODUCTS TO MAN. AS THESE DATA ARE NOT DIRECTLY UTILIZABLE BY THE COUNTRIES OF THE EUROPEAN COMMUNITY, HF PROPOSES TO GO FURTHER INTO THE QUESTION TO BE ABLE TO TAKE INTO ACCOUNT THE CHANGING ECOLOGICAL CONOITIONS.

* B IOLOGICAL CONCENTRATION, ANIMAL + \#BIOLCGICAL CONCENTRATION, ANIMAL FEED + *ECOLOGICAL CONSIDERATION + BARIUM + BIOLOGICAL CONCENTRATION, AGRICULTURAL PRODUCE + BIOLOGICAL CONCENTRATION, AQUATIC ORGANISMS + EIOLOGICAL CONCENTRATION, FOOD + BIOLOGICAL CONCENTRATION, MILK + EIOLOGICAL CONCENTRATION, VEGETATION + CALCIUM + CESIUM + IODINE + STRCNTIUM

14-1150E COEBIN WC + OWEN WL

DEVELOPMENT AND TEST OF A SOD-RENOVAL PROCEDURE FOR MOIST LAWNS CONTAMINATED BY SIMULATED FALLOUT U.S. NAVAL RADIOLOGICAL DEFENSE LABORATORY, SAN FRANCISCO

USNRDL-TR-965 + AD-631529+.67 PAGES, FIGURES, TABLES, 7 REFERENCES, $\triangle P R I L 11,1966,00 C$

a SOC-CUTTING MACHINE WAS EVALUATED FOR ITS USEFULNESS IN THE RADIOLOGICAL RECLAMATION OF SMALL LAWN AREAS. FALLOUT WAS APPROXIMATED BY CONTAMINATING LAWN TEST AREAS WITH

RADIO-TRACEO SAND. NOMINAL PARTICLE SIZE RANGES OF 44-88,88-177, $177-350$, AND $350-700$ MICRONS WERE USEO. THE SAND WAS DISPERSED AT NOMINAL CONCENTRATIONS OF 25 , 50 AND 100 G/SO. FT, RESPECTIVELY. RECLAMATION EFFECTIVENESS OF SOD CUTTING WAS DEPENDENT UPON MACHINE FACTORS (BLADE DEPTH), SOIL CHARACTERISTICS (MOISTURE CONTENT) AND MASS LOADING. THE LEAST EFFECTIVE RESULTS WERE OBTAINED IN CONFINED LAWNS WITH HIGH MOISTURE CONTENT AND HEAVY ROCK CONCENTRATIONS. THE BEST SOD-CUTTING AND REMOVAL EFFECTIVENESS RESULTS HERE OBTAINED ON MORE ACCESSIBLE LAWNS HAVING LESS MOISTURE CONTENT AND ONLY A LIGHT CONCENTRATION OF ROCKS. PARTICLE SIZE WAS FOUND TO HAVE LITTLE, IF ANY, WITH RESPECT TO EFFORT REQUIRED OR REMOVAL EFFECTIVENESS ACHIEVED.

*RECOVERY PROCESS + CONTAMINATION + FALLOUT + PARTICLE SIZE + PARTICLE SIZE DISTRIBUTION + TRACER, RADIOACTIVE

14-11702 LACHAPELLE DG

AN ENCINEERING FVALUATION OF A RADICACTIVE-WASTE INCINERATOR

U. S. ARMY NUCLEAR DEFENSE LABCRATORY, EDGEWOOO ARSENAL, MARYLAND

CONF-660904 +. 67 PAGES, 32 FIGURES, TAELES, 4 REFERENCES, PRESENTED AT 9TH AEC AIR CLEANING CONFERENCE, BOSTON, MASS.; SEPTEMBER 13-16, 1966 , SOURCE

A 50-LB/HR INCINERATOR AND ASSOCIATED GAS-CLEANING EQUIPMENT FOR THE CONCENTRATION OF LOW-LEVEL RADIOACTIVE WASTE WERE EVALUATEU GY USE OF NONRADIOACTIVE MATERIAL, AND OPTIMUM OPERATING CONDITIONS FOR THE INCINERATOR AND THE GAS CLEANING EQUIPMENT RESULTED. THESE CONDITIONS WERE USED OURING THE RADIOLOGICAL EVALUATION. TESTS WITH SAWDUST CHARGES CONTAINING UP TO 200 MICROCURIES PER KG OF CHARGE HERE SUCCESSFULLY INCINERATED. ACTIVITY CONCENTRATION OF THE SR-89 OISCHARGED TO ATMOSPHERE WAS ALWAYS BELOW MPC LIMITS. TESTS ARE PRESENTLY BEING CONDUCTED IN WHICH ANINALS INJECTED INTRAVENOUSLY WITH SR-89 ARE BEING INCINERATED TO DETERMINE IF THIS TYPE CHARGE CAN BE SAFELY HANDLED BY THE FACILITY. THE MAXIMUM AMOUNT OF SR INJECTED CORRESPONDS TO 200 MICROCURIES PER KG OF BODY HEIGHT.

* INCINERATION + \#STRONTIUM + \#HASTE DISPOSAL, General + \#WASTE TREATMENT, EQUIPMENT + * WASTE TREATMENT, SOLID + AIR CLEANING + FISSION PRODUCT TRANSPORT + WASTE DISPOSAL, SOLIO + HASTE HANDLING

14-11703 FIRST MW + ZILLES P' + WALKLEY J

DISPOSAL OF LOW LEVEL RADIOACTIVE WASTE IN COMMERCIAL INCINERATORS

HARVARD UNIVERSITY

CONF-660904 t. 12 PAGES, 5 FIGURES, 7 REFERENCES, PRESENTED AT 9TH AEC AIR CLEANING CONFERENCE, BOSTON,

MASS., SEPTEMBER 13-16, 1966, SOURCE

THE HARVARD BOILER-INCINERATOR, HANDLING PACKAGED WASTES IN MECHANICAL SYSTEMS, IS A SANITARY WAY OF HANDLING AND BURNING ESPECIALLY TROUBLESOME LABORATORY WASTES EFFICIENTLY AND FAST. THE CYCLONE PRECOLLECTOR IS SUPERFLUOUS WITH GAS OR OIL FUELS AND CAN BE ELIMINATED WITHOUT CECREASING OVERALL COLLECTION. EFFICIENCY BY THE ELECTROSTATIC PRECIPITATOP THAT FOLLOWS IT THE REASONS FOR THE POOR EFFICIENCY OF THE ELECTROSTATIC PRECIPITATOR IN THIS TYPE OF SERVICE REQUIRE ADDITIONAL STUDY.

* INCINERÁtION + \#WASTE DISPOSAL, GENERAL + \#WASTE TREATMENT, EOUIPMENT + \#WASTF TREATMENT, SOLID + AIR CLEANING + WASTE DISPOSAL, SOLID + HASTE HANOLING 
14-11704 *CONTINUEO

RECENT ADVANCES IN MONITORING OF RAOIOACTIVE GASEOUS WASTES AT ORNL

OAK RIDGE NATIONAL LABORATORY, OAK RIDGE

CONF-660904 +. 27 PAGES, 17 FIGURES, 6 REFERENCES, PRESENTED AT 9TH AEC AIR CLEANING CONFERENCE, BOSTON,

MASS., SEPTEMBER $13-16,1966$, SOURCE

MANY ACTIVITIES AT THE OAK RIOGE NATIONAL LABORATORY ARE CONCERNED WITH THE CHEMICAL

PROCESSING OF RADIOACTIVE MATERIALS. GASEOUS EFFLUENTS FROM THESE OPERATIONS ARE TREATEO TO REMOVE DANGEROUS CONTAMINANTS BEFCRE RELEASE TO THE ATMOSPNERE. ROUTINE MONITORING OF SUCH EMISSIONS WAS STARIED IN 1966 WHEN MANUALLY OPERATED PARTICULATE MONITORS WERE INSTALLED AT

EACH OF THREE PROCESS STACKS. SINCE THAT DATE, COVERAGE HAS BEEN EXTENDED TO SIX STACKS, THE

SAMPLE WITHORAWAL SYSTEM HAS BEEN REBUILT, AND THE DETECTION EQUIPMENT HAS BEEN ADDED TO AND MODERNIZED. THE INTENSIVE MONITOR ING HAS LEAD TO PROCESS IMPROVEMENTS THAT HAVE REOUCED THE ENVIRONMENTAL RELEASES OF RACIOACTIVITY IN THE GASEOUS WASTE EFFLUENTS BY A FACTOP OF 3 SINCE 1962 .

* MCNITOR, RADIATION, EMERGENCY + \#MONITOR, RADIATION, GAS + \#MONITOR, RADIATION, GENERAL PRACTICE + -MONITOR, RADIATION, SAMPLING, \#MONITOR, RADIATION, STACK I MONITOR, RADIATION, AIR +

MONITOR, RADIATION, BACKGROUND + MONITOR, RADIATION, ENVIRONMENTAL + MONITOR, RADIATION, GENERAL 
HEALTH PHYSICS INSTRUMENTATION AND TECHNIQUES USED AROUND THE 7 GEV PROTON SYNCHROTRON NIMROD ARE REPORTED. MEASUREMENTS ARE GIVEN OF THE STRAY RADIATION FIELD DURING OPERATIONAL PERIODS AND OF INOUCED ACTIVITY IN THE ACCELERATOR. A REVIEH IS MADE OF PERSONNEL DOSE RECORDS DUR ING 1964.

* DOSE MEASUREMENT, EXTERnAL + \#PERSONNEl EXPOSURE, RADIATION + aCTIVATION PRODUCT + INSTRUMENTATION, RADIATION MONITORING

15-08719 MORGAN KZ

PRESENT STATUS OF RECOMMENDATICNS OF THE INTERAATIONAL. COMMISSION ON RADIOLOGICAL PROTECTION, NATIONAL COUNCIL ON RAOIATION PROTECTION AND FEDERAL RADIATION COUNCIL

OAK RIDCE NATIONAL LABORATORY

32 PAGES, TABLES, 35 REFERENCES, JUNE 14, 1965, PUBLISHED IN PROGRESS IN NUCLEAR ENERGY SERIES XII, VOL. 2, PERGAMON PRESS, LONDON

THE HISTORICAL BACKGROUNDS OF THE INTERNATIONAL COMMISSION ON RADIOLOGICAL PROTECTION (ICRP) THE NATIONAL COUNCIL ON RADIATION PROTECTION (NCRP) AND THE FEDERAL RADIATION COUNCIL (FRC) ARE DISCUSSED AS WELL AS MANY CURRENT RECOMMENDATIONS MAOE BY THESE ORGANIZATIONS AS THEY APPLY TO RADIATION PROTECTION IN MAN. THIS INCLUDES WORKERS IN THE RADIATION INDUSTRY, BUT ALSO THE POPULATION AT LARGE:

\#RACIATION PROTECTION, ORGANIZATION + PERSONNEL EXPOSURE, RADIATION + RADIATION IN PERSPECTIVE + RADIATION SAFETY AND CONTROL

15- C9274 TRIULZI C

TREND OF GROSS BETA RADIOACTIVITY IN PLANKTON SAMPLES COLLECTED IN THE ADRIATIC AND LIGURIAN-TYRRHENIAN SEAS DURING $1961-1964$

INSTITUYO LOMBARDO, NILAN + CISE, MILAN

TID-22112 +. 17 PAGES, MEETING HELO ON JUNE 24, 1965- CFSTI, \$1.00 CY, \$0.50 MN

GROSS BETA RADIOACTIVITY WAS MEASURED ON PLANKTON ASH SAMPLES COLLECTEC IN THE LIGURIAN-TYRRHENIAN SEA AND. UPPER ADRIATIC DURING 1961-1964. THE TREND OF GROSS BETA RADIOACTIVITY DURING THIS PERIOD IS CORRELATED WITH RAINFALL AND RADIOACTIVE FALLOUT IN THE SAME ZONE. VALUES OF GROSS BETA ARE. REPORTED, WHICH HAS BEEN MEASURED 15 AND 200 DAYS AFTER THE TOW. RATIO BETWEEN THESE VALUES SUPPLIES A USEFUL INDICATION OF THE DATE OF NUCLEAR EXPLOSIONS RESPONSIBLE FOR SAMPLE CONTAMINATION.

* EIOLOGICAL CONCENTRATION, ALGAE * *BIOLOgICAL CONCENTRATION, AQUATIC ORgANISMS + * SURVEY, RADIATION, ENVIRONMENTAL + FALLOUT + GROSS BETA + OCEAN AND SEA + RAINOUT + SURFACE WATER, NUCLIDE OCCURRENCE

15-09932 RAMSCAN D + PEABODY CO + PASSANT FH + SPEIGHT RG

RADIOIODINE UPTAKES IN THE THYROID STUOIES OF THE BLOCKING ANO SUBSEQUENT RECOVERY OF THE GLAND FOLLOHING THE AOMINISTRATION OF STABLE IODINE

UNITEO KINGDOM ATOMIC ENERGY AUTHORITY, WINFRITH

AEEW-R 444 +. 23 PAGES, 8 FIGURES, 6 TABLES, 18 REFERENCES- JULY 1965- UKAEA

SMALL AMOUNTS OF RADIOACTIVE IOOINE WERE GIVEN TO NINE VOLUNTEERS, AND THEIR THYROID UPTAKE AND URINARY EXCRETION PATTERNS HERE STUDIED. THE EFFECT OF DOSES OF STABLE IODINE ON THESE PATTERNS WAS INVESTIGATED. MODELS OF THYROID METABOL ISM WERE STUDIED AND AMPLIFIED TO GIVE SATISFACTORY EXPLANATIONS OF THE EXPERIMENTAL RESULTS. THE MINIMUM AMOUNT OF STARLE IOOINE REQUIRED TO BLOCK THE THYROID COMPLETELY WAS ABOUT 30 MG. THYROID UPTAKE CEASED WITHIN HALF AN HOUR OF THE ADMINISTRATION OF A BLOCKING DOSE. THYROID UPTAKE WAS BACK TO NORMAL ABOUT EIGHT DAYS AFTER A SINGLE BLOCKING DOSE. REPEATED DOSES OF STABLE IODINE MAY BE GIVEN AT. INTERVALS IN ORDER TO MAINTAIN EFFECTIVE THYROID BLOCKING. THE REQUIRED DOSES RANGE FROM 35 MG EVERY 12 HR TO 250 MG EVERY 48 HR. THE BEST PROTECTION AGAINST A LONG-TERM EXPOSURE TO RAOIOACTIVE IOOINE., WHILE AOMINISTERING THE LEAST POSSIBLE TOTAL AMOUNT OF STABLE IODINE, WOULD BE GIVEN BY 35 MG EVERY 12 HR. BLOCKING DOSES SHOULD BE GIVEN AS SOON AS POSSIBLE AFTER ANY KNOWN OR SUSPECTED EXPOSURE TO RADIOACTIVE IODINE.

* EIOMEOICAL + \#IOOINE + BIOLOGICAL CONCENTRATION, MAN + DOSE

15-C9937 MORRIS AC + ROSS DA

THE DESIGN OF A LOH-BACKGROUND WHOLE-BODY COUNTING FACILITY

OAK RIDGE INSTITUTE OF NUCLEAR STUDIES, INC., OAK RIDGE

ORINS-51 +. 49 PAGES, 40 FIGURES, 3 TABLES, JANUARY 1966, CFSTI, $\$ 3.00 \mathrm{CY}$

IN SEPTEMBER 1964 THE MEDICAL DIVISION, OAK RIDGE INSTITUTE OF NUCLEAR STUDIES (ORINS), BEGAN PRELIMINARY STUDIES AND OPERATIONS WITH A NEWLY COMPLETED LOW-LEVEL WHOLE-BODY COUNTER, THE LATEST IN A SERIES OF WHOLE-BODY COUNTERS BUILT AT ORINS--THE OBJECTIVE BEING TO PROVIDE A SERIES OF INSTRUMENTS THAT WILL ALLOW WHOLE-BODY CDUNTING STUDIES OVER A CONTINUOUS RANGE OF ACTIVITIES FROM THE THERAPEUTIC DOSES DOWN TO NATURAL BODY-BACKGROUND LEVELS. THE HIGH-LEVEL AND DIAGNOSTIC-LEVEL COUNTERS WERE EARLIER, ALTHOUGH CERTAIN MODIFICATIONS HAVE BEEN MADE SINCE TO IMPROVE THEIR PERFORMANCE. THE DESIGN OF A LOW-LEVEL COUNTER IS THE SUBJECT OF THIS REPORT .

*COUNTER, WHOLE BODY + *SHIELDING + BIOMEDICAL + DESIGN CRITERIA 
CATEGORY 15

ENVIRONMENTAL SURVEYS, MONITORING AND RADIATION EXPOSURE OF MAN

15-CS9B4 BIG ROCK POINT AUTHORIZED TO USE AIR MASK PROTECTION FACTORS FOR AIRBORNE CONTAMINATION UNITED STATES ATOMIC ENERGY COMMISSION

3 PACES, MAY 19, 1966, COCKET 50-155, ATOMIC ENERGY CLEARING HOUSE, 12(23), PAGES 16-18 (JUNE 6, 1966 )

VARIOUS PROTECTION FACTORS FOR AIR-PURIFYING AND AIR-SUPPLYING EQUIPMENT USED WHEN EXPOSED TO

AIRBORNE CONCENTRATIONS IN EXCESS OF 10 CFR 20 ARE AUTHORIZED BY AEC IN RESPONSE TO I962

RFGUFST.

* INHALATION + \#PERSONNEl PROTECTIVE DEVICE + BIg ROCK POINT + DOSE CALCULATION, INTERNAL + REACTOR, BOILING WATER + P.EGULATION, AEC

15-1CC74 CARNAHAN CL

A PROCEDURE FOR THE CALCULATION OF NEUTRON ACTIVATION OF AN INFINITE hOMOGENEOUS MEDIUM

HALELIUN-NUCLEAK SCIENCE CUKPOHATIUN, PALO ALTO, CALIFORNIA

HNS-1229-54 +. 67 PAGES, REFERENCES, SEPTEMBER 15, 1964, CFSTI $\$ 3.00$

A METHOO FOR CALCULATING QUANTITIES OF RADIONUCLIDES INDUCED IN INFINITE, HOMOGENEOUS MEOIA BY NEUTRONS FROM UNDERGROUNO NUCLEAR DETONATIONS IS DEVELOPED THEORETICALLY, ANO A PROCEDURE FOR PRACTICAL APPLICATION OF THE THEORY IS PRESENTED. RESULTS OF CALCULATIONS ARE GIVEN FOR RADIONUCLIDES, HAVING HALF LIVES GPEATER THAN 0.5 YEARS, INDUCED BY NEUTRONS FROM FUSION REACTIONS AND FROM FISSION REACTIONS IN MEOIA HAVING THE COMPOSITIONS OF THE AVERAGE EARTHS CRUST, AVERAGE CARBONATE ROCKS, AND THE TATUM SALT DOME, HATTIESBURG, MISSISSIPPI. SEPARATE CALCULATIONS ARE MADE FOR FUSION NEUTRONS AND FOR FISSION NEUTRONS SECAUSE OF THE GREAT DIFFERENCES IN THE INITIAL NEUTRON ENERGY DISTRIBUTIONS AND IN THE TOTAL NUMBERS OF NEUTRONS PRODUCED PER UNIT ENERGY YIELD, BY THE TWO PROCESSES. A SAMPLE CALCULATION IS INCLUDED.

\# $\triangle C T I V A T I O N+$ \#ACTIVATION PROOUCT + \#GROUND WATER, NUCLIDE OCCURRENCE + \#PLOWSHARE PROGRAM + CRITICAL NUCLIDE + GEOLOGICAL CONSIOERATION, GENERAL + NUCLEAR DETONATION

15-10077 GUSTAFSON PF + KASTNER J + LUETZELSCHWA8 J

ENVIRONMENTAL RADIATION. MEASUREMENTS OF DOSE RATES

ARGONNE NATIONAL LABORATORY

4 PAGES, 2 TABLES, 2 FIgURES, 16 REFERENCES, SCIENCE, 145(3627), PAGES 44-47 (JULY 3, 1964)

THE EXPOSURE DOSE FROM ENVIRONMENTAL SOURCES OF RADIATION WAS DETERMINED BY AN IONIZATION CHAMBER, BY GAMMA-RAY SPECTROMETRY IN THE FIELO, AND BY MEASURING RADIOACTIVITY IN SOIL CORES. THE EXPOSURE DOSE FROM COSNIC RADIATION WAS FOUND TO $8 E 4.4$ PLUS OR MINUS 0.2 MICROROENTGENSIHR, THAT FROM NATURAL RADIOACTIVITY 8.0 PLUS OR MINUS 0.3, AND THE CONTRIBUTION FROM FISSION PRODUCIS VARIED FR.OM 2.0 TO 7.5 DURING THE INTERVAL IN QUESTION.

\#COSE CALCULATION, EXTERNAL + \#DCSE MEASUREMENT, EXTERNAL + \#MONITOR, RADIATION, ENVIRONMENTAL + CESIUM + COBALT + FALLOUT + GROSS ALPHA + MONITOR, RADIATION, BACKGROUND + POTASSIUM + RADON +

SOIL, NUCLIDE OCCURRENCE + TEST, WEAPONS (HP ASPECTS) + THORIUM + THORON + URANIUM

15-10078 KOVAR Z

A SIMPLE CALORIMETRIC METHOD OF NEASURING $X$-RAY DOSES

UCRL-TRANS-1184+FTO-TT-65-363+.5 PAGES, FEBRUARY, 1965, TRANSLATED FROM JADERNA ENERGIE, (10), PAGES

$1-5,(1963), \mathrm{JCL}, \$ 1.60 \mathrm{FS}, \$ \mathrm{C} .80 \mathrm{MF}$

A SIMPLE CALORIMETRIC METHOD IS DESCPIBED OF A DIRECT AND ABSOLUTE MEASUREMENT OF ABSORBED DOSES AND OF CALIBRATING THE X-RAY BEAMS. THE SUGGESTED METHOD CAN BF CARRIED OUT WITH THE CONVENTIONAL DEVICES FOUND IN A PHYSICAL LABORATORY ANO IS PARTICULARLY SUITABLE FOR HIGH-POWER AND HIGH-ENERGY X-RAY APPARATUS SUCH AS THOSE USED, FOR EXAMPLE, IN X-RAY THERAPY, DEFECTOSCOPY, OR RADIATION CHEMISTRY.

* DOSE MEASUREMENT, INTERNAL + \#X-RAY + BIOMEDICAL + DOSE + MONITCR, PADIATION, PERSONNEL

15-1COBC BECK HL + CONDON WJ + LOWDER WM

SPECTROMETRIC TECHNIQUES FOR MEASURING ENVIRONMENTAL GAMMA RADIATION

NEW YORK OPERATIONS OFFICE

HASL-15C +. 71 PAGES, 22 FIGURES, 6 TABLES, 34 REFERENCES, OCTOBER 1964, CFSTI, \$3.00 CY

PULSE-HEIGHT SPECTRA ORTAINED IN THE FIELD BY USING A LARGE NAI (TI) CRYSTAL CAN BE ANALYZED RY RELATIVELY SIMPLE METHOOS TO DETERMINE ACCURATELY TOTAL ENVIRONMENTAL GAMMA-RAY DOSE RATES, AS WELL AS THE INDIVIDUAL DOSE RATE CONTRIBUTIONS FROM KO4C, THE U23B SERIES, THE TH232 SERIES, AND THE PRINCIPAL GAMMA-RAY EMITTING FISSION PRODUCTS. THE CALIBRATION OF A 5 BY 3-IN. DETECTOR IS DESCRIBED IN DETAIL, AND THE APPLICABILITY AND LIMITATIONS OF THE SPECTRAL-ANALYSIS ARE EXAMINED. SEVERAL PRDBLEMS ASSOCIATED WITH FIELD MEASUREMENTS ARF CISCUSSED, IN PARTICULAR THE EFFECTS OF RADON MIGRATION FROM THE SOIL, SOIL MOISTURE, AND NATURAL FALLOUT. EVIDENCE IS DOSIMETRIC AND RELATED INFORMATION OBTAINED FROM FIELD SPECTRA ANALYZEO BY THESE METHODS.

\#CRITICAL NUCLIDE + \#FALLOUT + \#GAMMA EMITTER + \#INSTRUMENTATION CALIBRATION + \#SOIL + CESIUM + DIFFUSION + HYDROLOGICAL CONSIDERATION, GENERAL + MONITOR, RADIATION, ENVIRONMENTAL + NIOBIUM + POPULATION EXPOSURE + POTASSIUM + RADON + SOIL, RADIONUCLIDE MOVEMENT THROUGH + THORIUM + URANIUM + ZIRCONIUM

15-1CO83 HAYWOOD FF

SPATIAL DOSE DISTRIBUTION IN AIR-OVER-GROUND GEOMETRY

UAK RIOEE NAIIONAL LABURATURY

8 PAGES, 13 FIGURES, 15 REFERENCES, HEALTH PHYSICS, $11(3)$, PAGES 185-192 (MARCH, 1965) 
15-10083 *CONTINUED*

SPATIAL DISTRIBUTIONS OF GAMMA-RAY EXPOSURE AND NEUTRON DOSE WERE MEASURED BY USE OF A POINT CO-60 SOURCE (BOO C) AND THE ORNL HEALTH PHYSICS RESEARCH REACTOR AS A SMALL FISSION SOURCE. THE SOURCES WERE SUPPORTED ON A 1527-FT TOWER, AT THE NEVADA TEST SITE, AT HEIGHTS RANGING FROM 27 TO 1500 FT. FOR A GIVEN SLANT RANGE GREATER THAN ABOUT ONE RELAXATION LENGTH, THEPE IS AN INCREASE IN NEUTRON DOSE RATE AT THE INTERFACE BY A FACTOR OF 2.4 AS THE REACTOR IS RAISED FROM 27 TO 1500 FT ABOVE THE GROUND, AND, SIMILARLY, THERE IS AN INCREASE IN GAMMA-RAY EXPOSURE RATE BY A FACTCR OF 2.1. THESE INCREASES APPEAR FIXEO FOR SOURCE-DETECTOR SEPARATIONS GREATER THAN ABOUT 400 YARDS. AN EFFECT OF THE PRESENCE OF THE INTERFACE WAS OBSERVED BY COMPAR ING EXPERIMENTALLY DETERMINED VALUES OF THE EXPOSURE BUILDUP FACTOR FOR. CO-60 GAMMA RAYS TO CALCULATED BUILDUP FACTORS IN AN INFINITE MEDIUM. BOUNDARY-CORRECTION FACTORS KIEXP) WERE DETERMINED EXPERIMENTALLY. K(EXP) IS DEFINED AS THE RATIO OF DOSE IN THE FINITE AIR MEDIUM TO DOSE IN THE INFINITE AIR MEDIUM AT THE SAME SLANT RANGE. THE DEPENDENCE OF NEUTRON DOSE RATE ON VARIATION OF DETECTOR HEIGHTS AND ON VARIATION OF SOURCE HEIGHTS IS COMPARED TO THEORETICAL MODELS, WITH SATISFACTORY AGREEMENT.

\#COSE MEASUREMENT, EXTERNAL + COBALT + COMPARISON, THEORY AND EXPERIENCE + NEVADA TEST SITE + SOURCE, NEUTRON + SOURCE, POINT + TEST, HEAPONS (HP ASPECTS)

15-10085 INGOLD WC + HUDDLESTON CM

AN EMPIRICAL FORMULA FOR CALCULATING GAMMA-RAY DOSE ATTENUATION IN CONCRETE DUCTS NAVAL CIVIL ENGINEER ING LAB., PORT HUENEME, CALIFORNIA

$A[-609049+.72$ PAGES, NOVEMBER 25,1964, CFSTI, $\$ 2.00$

a SURVEY IS PRESENTED OF THE STATUS OF THE CALCULATION OF gamMa doSE-RATE ATTENUATION IN AIR DUCTS THROUGH CONCRETE. A SIMPLE EMPIRICAL FORMULA IS EXHIBITEO THAT SHOWS SATISFACTORY AGREEMENT WITH THE RESULTS OF MORE COMPLICATED COMPUTATIONAL TECHNIQUES AND WITH EXPERIMENTAL RESULTS. THIS SIMPLE FORMULA, WHICH MAY BE USED FOR HAND COMPUTATION, REPRESENTS A SAVING IN COMPUTATION TIME 2 SECONDS PER CASE COMPAREO TO 400 SECONOS BY IBM-1620.

*CONPARISON, THEORY AND EXPERIENCE + \#OOSE CALCULATION, EXTERNAL + CONCRETE + FALLOUT + SHIELDING

15-1008E ENDRES GW

NEUTRON SPECTRUM MEASUREMENTS AT HANFORD WORK LOCATIONS

HANFORD ATOMIC PRODUCTS OPERATION

HW-SA-3525 + CONF-642-33 +. 31 PAGES, MAY 15, 1964, HEALTH PHYSICS SOCIETY MEETING, CINCINNATI, OHIO, JUNE $15-18,1964$, CFSTI, $\$ 2.00 \mathrm{CY}$

HANFORD OCCUPATIONAL EXPOSURES TO NEUTRON RADIATION ARE DUE MAINLY FROM TWO TYPES OF NEUTRON SOURCES - PRODUCTION REACTORS ANO PLUTONIUM IN CHEMICAL-PROCESSING FACILITIES. A KNOWLEDGE OF THE INCIDENT' NEUTRON SPECTRUM IS NECESSARY TO ACCURATELY INTER.PRET OATA OBTAINED FROM THE CURRENT NUCLEAR-TRACK-TYPE NEUTRON DOSIMETERS. (PERSONNEL) .

* DOSIMETRY, GENERAL + \#SOURCE, NEUTRON + ACTIVATION + BATTELLE NORTHWEST + DOSE MEASUREMENT, EXTERNAL + HANFORD PRODUCTION REACTOR + MONITOR, RADIATION, PERSONNEL + PLUTONIUM + REACTOR, GAS COOLEO + REACTOR, GRAPHITE MODERATED

15-10087 UNRUH CM

THE STATUS OF NEW PERSONNEL NEUTRON DOSIMETER OEVELOPMENT

HANFORD ATOMIC PRODUCTS OPERATION

HW-SA-3526 + CONF-642-34 + 12 PAGES, MAY 15, 1964 , HEALTH PHYSICS SOCIETY MEETING, CINCINNATI, OHIO, JUNE $15-18,1964$, CFSTI, $\$ 1.00$

PRESENT PERSONNEL NEUTRON DOSIMETERS ARE BASED PRIMARILY ON NUCLEAR-TRACK COUNTING IN THICK-FILM.EMULSIONS FOR FAST-NEUTRON-DOSE EVALUATIONS. THESE METHODS ARE RECOGNIZED AS NOT WHOLLY ADEQUATE: A NEUTRON-DOSIMETER SENSITIVITY TO A FULL-ENERGY SPECTRUM OF FAST AND INTERMEDIATE ENERGY NEUTRONS IS REQUIRED TO PROVIDE PERSONNEL NEUTRON DOSIMETRY COMPARABLE WITH THAT PROVIDED FOR GAMMA RADIATION.

\#DOSIMETRY, GENERAL + \#FAST NEUTRON + \#MONITOR, RADIATION, PERSONNEL + DOSIMETRY, THERMOLUMINESCENCE

15-1C091 PEGG TG + SAXBY WN + HALLACE CM

THE AUTOMATIC PROCESSING ANO EVALUATION OF FILM BADGE DOSIMETER DATA AT AWRE

UNITED KINGDOM ATOMIC ENERGY AUTHORITY, ALDERMASTON

AWRE $\rightarrow 0-93 / 63+23$ PAGES, MARCH, 1964, DEP/MN

THE INTRODUCTION OF A NEW MULTIFILTER FILM BADGE FOR PERSONNEL RADIATION DOSIMETRY, AND THE APPEARANCE OF DETAILEO STATUTORY REQUIREMENTS FOR RECORDING PERSONAL RADIATION DOSES, LED TO THE DEVELOPMENT OF A SEMIAUTOMATIC SYSTEM FOR PROCESSING AND RECOROINE FILM-BADGE DATA. A SYSTEM USING THE IBM 14 CI COMPUTER TO PRODUCE CERTIFICATES GIVING DETAILS OF RADIATION DOSES RECEIVED BY INDIVIDUALS IS DESCRIBED. THE METHOD OF DATA MEASUREMENT, DOSE EVALUATION, AND THE COMPUTER SERVICES ARE DISCUSSED. BRIEF COMMENTS ON OPERATIONAL EXPERIENCE AND COSTS ARE INCLUDED. FIGURES ILLUSTRATE THE PROCESSING AND RECORDING SYSTEM.

*CONPUTER PROGRAM + \#DOSE MEASUREMENT, EXTERNAL + \#DOSIMETRY, geNERAL + PERSONNEL EXPOSURE, RADIATION

15-10093 MAERKER RE + MUCKENTHALER FJ

CALCULATION AND MEASUREMENT OF THE FAST-NEUTRON DIFFERENTIAL DOSE ALBEDO FOR CONCRETE

OAK RIDGE NATIONAL LABORATORY

20 PAGES, 3 TABLES, FIGURES, 1965 


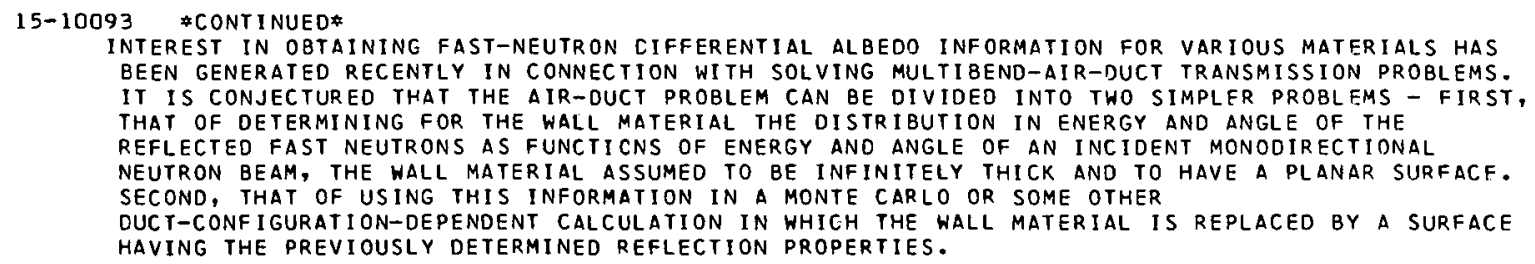

IN 1956, THE HEALTH PHYSICS DIVISION OF THE OAK RIDGE NATIONAL LABORATORY ATTEMPTED A METHOD FOR EVALUATING THE RADIATION DOSES RECEIVED BY THE SURVIVORS OF THE NUCLEAR BOMBINGS OF HIROSHIMA AND NAGASAKI, JAPAN. DATA FOR THIS PROJECT WERE OBTAINED IN NUCLEAR WEAPONS TESTS, OPERATION BREN, LABORATORY EXPERIMENTS, PHYSICAL SURVEYS IN JAPAN, ANO IN CALCULATIONAL STUDIES. THE APPROACH TO THE PROBLEM WAS AS FUNDAMENTAL AS POSSIBLE, WITH EMPHASIS ON QUANTITATIVE MEASUREMENTS AND CALCULATIONS OF THE ENERGY, ANGULAR, AND SPATIAL OISTRIBUTIONS OF HEAPONS RADIATIONS IN AN AIR-OVER-GROUND SITUATION. SPATIAL DISTRIRUTIONS OF DOSE IN VARIOUS SHIELDS, INCLUDING JAPANESE DWELLINGS, WERE MEASURED. TECHNIQUES WERE OEVELOPED IN JAPAN FOR VERIFYING THE LOCATION OF SURVIVORS AND ACCURATELY DESCRIBING THEIR SHIELDING ENVIRONMENTS. SIMPLE EMPIRICAL EQUATIONS WERE FOR CALCULATING THE SHIELDING FACTORS FOR JAPANESE RESIDENTIAL-TYPE STRUCTURES PROBABLE ERROR, ABOUT PLUS OR MINUS 6 PERCENT.

* DOSIMETRY, GENER.AL + \#JAPAN + ANALYTICAL TECHNIQUE, CALIBRATION + DOSE MEASUREMENT, EXTFRNAL + EQUATION, GENERAL + FLUX DISTRIBUTION + GROSS GAMMA + LASL (LOS ALAMOS SCIENTIFIC LABORATORY) + MOCKUP + NEVACA TEST SITE + ORNL (OAK RIDGE NATIONAL LABORATORY) + SOURCE, NEUTRON + TEST, WEAPONS (HP ASPECTS)

15-10195 CALOWELL R

NUCLEAR MATERIALS AND EQUIPMENT CORPORATICN. OFFSITE AIR-SURVEILLANCE PROGRAM NUCLEAR MATERIALS AND EOUIPMENT CORPORATION, APOLLO, PA.

2 PAGES, APRIL 20, 1966, ATOMIC ENERGY CLEARING HOUSE, $12(20)$, PAGES 32-33 (MAY 16, 1966)

APOLLO PLANT DOES NOT LEND ITSELF READILY TO CONVENTIONAL OIFFUSION MODELS FOR OFFSITE AIR-SAMPLE-DATA ANALYSIS. A SIX-MONTH PROGRAM WILL BE UNDERTAKEN TO ESTABLISH LOCATION AND FREQUENCY OF OFFSITE SAMPLING. AN INTERIM SCHEDULE OF STACK SAMPLING IS PROPOSED.

* SURVEY, RADIATION, ENVIRONMENTAL + MONITOR, RADIATION, STACK + RADIOCHEMICAL PROCESSING

15-10196 GENERAL TESTING COMPANY. OVEREXPOSURE UNREPORTED BECAUSE OF UNRELIABLE READINGS GENERAL TESTING COMPANY, LISBON, OHIO

1 PAGE, ATOMIC ENERGY CLEARING HOUSE, 12(20), PAGE 35, (MAY 16, 1966)

GARORAY FILM BADGE SERVICE SHOWED A 3.5-REM EXPOSURE FOR ONE INDIVIDUAL, WHILE THE CONTROL BADGES AND FOUR INDIVIDUALS SHOWED NO EXPOSURE. THIS HAS NOT REPORTED BECAUSE IT HAS THOUGHT IN ERROR. PREVIOUSLY READINGS WERE SHOWN FOR UNUSED BADEES, AND USED-BADCE READINGS WERE IN EXCESS OF DAILY DOSIMETER RECORDS. WE RELOCATED THE BADGE-STORAGE RACK AWAY FROM A GAS HEATER. AFTER THE FEBRUARY INSPECTION, TWO FILM BADGES WERE WORN, BUT THE READINGS ARE NOT IN AGREEMENT.

* OPERATING EXPERIENCE + *PERSONNEL PROTECTIVE DEVICE + FAILURE, INSTRUMENT + PERSONNEL EXPOSURE, RADIATION + RADIOGRAPHY

15-10475 COATES RL + HORTON NR RSAC--A RACIOLOGICAL SAFETY ANALYSIS COMPUTER PROGRAM PHILLIPS PETROLEUM COMPANY, IDAHO

IO0-17151 +208 PAGES, 3 TABLES, 7 REFERENCES, MAY 1966, CFSTI, $\$ 6.00$ CY, $\$ 1.25$ MN 
15-10475 \#CONT INUED*

AN IBM 7040 PROGRAM WHICH COMPUTES THE POTENTI.AL RADIOLOGICAL DOSES RESULTING. FROM A CONTINUOUS OR INSTANTANEOUS RELEASE OF FISSION PRODUCTS TO THE ATMOSPHERE. DEVELOPED AS PART OF LOFT AND GENERAL NUCLEAR SAFETY PROGRAMS TO PROVIDE A GENERALI ZED COMPUTER PROGRAM FOR A COMPLETE PARAMETRIC INVESTIGATION OF RAOIOLOGICÄL HAZARDS. DOSES CONSIDEREO ARE CLOUR GAMMA, DEPOSITION GAMMA, INGESTION, ANO INHALATION, ANO ARE BASED UPON THE RELEASE OF UP TO 200 ISOTOPES, THE RELATIVE ABUNDANCE OF EACH ISOTOPE BEING DEPENDENT UPON THE OPERATING HISTORY OF THE NUCLEAR REACTOR UNOER CONSIDERATION. INCLUDED ARE THE MATHEMATICAL MODELS, CONVERSION FACTORS, ASSUMPTIONS, FLOh CHARTS, PROGRAM LISTIINGS, ANO OTHER DATA PERTINENT TO THE OVERALL CEVELOPMENT OF THIS PROGRAM.

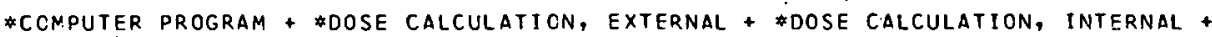
\#FISSION PRODUCT RELEASE, GENERAL + SUTTON DIFFUSION. FORMULA

15-10508 SCHNEIDER MF

ACVANCEC SPACEBORNE DOSIMETRY INSTRUMENTATION

KIRTLAND AIR FORCE BASE, NEW MEXICO

AFWL-TOR-64-96 +. 168 PAGES, 80 FIGURES, 12 TABLES, 15 REFERENCES, DECEMBER 1965

PROBLEM - MEASURE THE RACIATION DCSE TO PERSONNEL IN MANNED SPACF FLIGHTS. APPROACH - A BASIC DOSIMETER SYSTEM WAS DEVELOPED CONSISTING OF - TISSUE-EQUIVALENT ION CHAMBER, A LOGARITHMIC ELECTROMETER, MAGNETIC AMPLIFIERS, A DECADE SWITCHING UNIT, ANO AN AUTOMITC CALIBRATION CIRCUIT FOR PULSING THE CHAMBER HIGH VOLTAGE. THE BASIC UNIT WAS ADAPTED FOR A GEMINI DOSIMETER, AIR FORCE SATELLITE DOSIMETER, AND MANNED-SPACE-SYSTEMS PORTABLE SURVEY DOSIMETER. RESULTS-- PERFORMANCE UNDER EXTENSIVE TESTING PR.OGRAMS AND IN THE GEMINI GT-4 FLIGHT IS PRESENTED.

* COSE MEASUREMENT, EXTERNAL + * INSTRUMENTATION CALIBRATION + \#INSTRUMENTATION, RAOIATION MONITORING + *MCNITOR, RADIATION, PERSONNEL + COMPARISON, THEORY AND EXPERIENCE + EOUIPMENT DESIGN + SPACECRAFT + TEST, INSTRUMENT RESPONSE

15-ICS13 RUSSELL JA + KNOWLES DJ

DESCRIPTION OF FACILITY RADIATION AND CONTAMINATION ALARM SYSTEMS INSTALLEO IN THE HIGH-FLUX ISOTOPE REACTOR FACILITY, BUILDING 7900

OAK RIDGE NATIONAL LABORATORY

ORNL-TM-1393 +. 21 PAGES, 8 FIGURES, 2 TABLES, DECEMBER 8, 1965, CFSTI \$1.00 CY, \$0.50 MN

PPOBLEM - TO MONITOR THE GAMMA-RADIATION LEVEL AND AIR-CONTAMINATION LEVEL IN THE ENTIRE FACILITY. APPROACH - NINE MONITRONS CONTINUOUSLY MONITOR FOR GAMMA RADIOACTIVITY. NINE CONSTANT AIR-MONITORS CONTINUCUSLY SAMPLE THE AIR IN THE BUILDING FOR RADIOACTIVE (BETA-GAMMA) PARTICLES. ABNORMAL RADIATION LEVELS OR AIR ACTIVITY PROOUCE THE FOLLOWING ACTIONS - SOUND LOCAL ALARM, SOUND ALARM IN REACTOR -CONTROL ROOM, SOUND THE

BUILDING-EVACUATION AIR HORNS, AND ACTIVATE AN ALARM IN THE LABORATORY EMERGENCY CONTROL CENTER.

EQUIPMENT DESIGN, + INSTRUMENTATION, RADIATION MONITORING + MONITOR, RADIATION, AIR + MONITOR, RADIATION, BACKGROUND + MONITOR, RADIATION, ENVIRONMENTAL + SYSTEM DESCRIPTION

15-10563 GULIK AE

INCINERATION OF P32 SOURCE AT CETROIT GRACE CENTRAL HOSPITAL, MAY 22,1966

GRACE CENTRAL HOSPITAL, DETROIT, MICHIGAN

2 PAGES, MAY 24, 1966, ATOMIC ENERGY CLEARING HOUSE, 12(27), PACES 28-29 (JULY 4, 1966)

SATURDAY, A JANITRESS AT GRACE CENTRAL HOSPITAL DISCARDED AN APPARENTLY EMPTY SHIPPING CARTON CONTAINING A JUST-RECEIVEO 30-MILLICURIE SOURCE OF P-32. THE SOURCE WAS INCINERATED. MONOAY, THE LOSS OF THE SOURCE FROM THE LOCKED CONTAINER WAS DISCOVERED, AND TRACED TO THE INCINERATOR. THREE TINS OF CONTAMINATEO ASHES WERE RECOVERED.

*FIRE + * INCIDENT, ACTUAL, NONREACTOR + \#RADIOACTIVITY, RELEASE + *SOURCE, RADIATION, LOST + * TRACER, RADIOACTIVE + FAILURE, ADMINISTRATIVE CONTROL

$15-1067 C$ BATES RG

AER CRADIOACTIVITY SURVEY AND AREAL GEOLOGY OF PARTS OF OHIO AND INDIANA (ARMS-1) U. S. GEOLOGICAL SURVEY

CEX-59.4.23 +. 19 PACES, 5 FIGURES, 12 REFERENCES, JUNE 1964, CFSTI, $\$ 1.00$ CY, $\$ 0.50$ MN

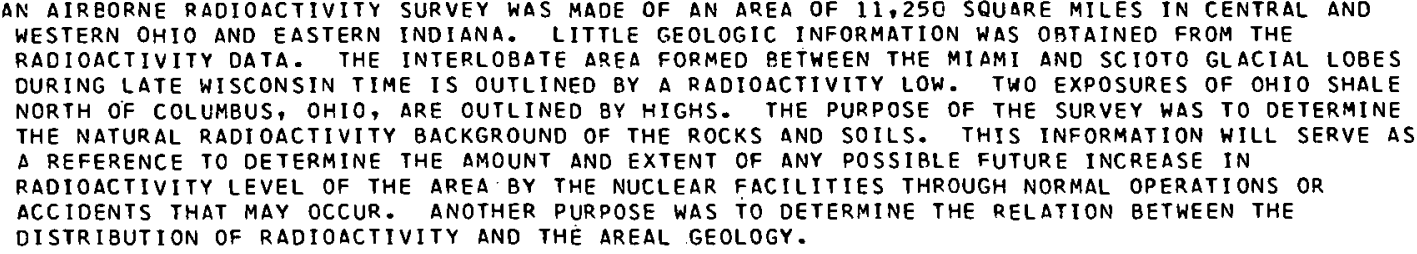


CATEGORY 15

ENVIRONMENTAL SURVEYS, MONITORING AND RADIATION EXPOSURE OF MAN

15-10812 NICHOLS JP + BROOKSBANK RE + FERGUSON OE RACIATION EXPOSURES IN FABRICATION U233-THORIUM FUELS OAK RIDGE NATIONAL LABORATORY

9 PAGES, I FIGURE, I DRAWING, I TABLE, 3 REFERENCES, NUCLEAR APPLICATIONS, APRIL, 1965

THIS REPORT GIVES A DESCRIPTICN OF THE TH--U-233 FUEL-FABRICATION PROCESS AT ORNL, ALONG WITH CRITICAL NUCLIDES ENCOUNTERED IN THE PROCESS. EXPOSURES FROM GAMMA RAYS AND SHIELDING ARE INCLUOED IN THIS PAPER.

* MAXIMUN PERMISSIBLE DOSE (MPO) + *TELLURIUM + *URANIUM + \#URANIUM DIOXIDE + CALCINATION + COMPACTION + DOSE MEASUREMENT, EXTERNAL + GLOVE BOX + LEAD + MAXIMUM PERMISSIBLE CONCENTRATION (MPC) + CRNL (CAK RIOGE NATIONAL LABORATORY) + THORIUM

15-11041 DIVISION OF REACTOR LICENSING SENDS QUESTIONNAIRE REGARDING RADIOACTIVITY ENVIRONMENTAL MONITORING PROGRAMS

CIVISION OF REACTOR LICENSING, U. S. ATOMIC. ENERGY COMMISSION

2 PAGES, ATOMIC ENERGY CLEARING HOUSE, 12(31), PAGES 13-14, (AUGUST 1, 1966)

QUESTIONNAIRE REQUESTS UP-TO-DATE DESCRIPTION OF CURRENT PROGRAM REGARDING OBJECTIVES AND PROCEDURES, INCLUDING (1) SAMPLING OF SOIL, AIR, WATER, AND LIVING ORGANISMS, (2) DIRECT-READING RAOIOACTIVITY MONITORS, (3) CORRELATION OF EMISSIONS WITH BIOLOGICAL RESULTS, (4) SPECIAL STUOIES, ANO (5) COOPERATION WITH NON-AEC AGENCIES.

*MONITOR, RADIATION, ENVIRONMENTAL + \#SURVEY, RADIATION, ENVIRONMENTAL + REGULATION, AEC

15-11C91 ELLMER $M$

SITE SELECTION

2 PAGES, ATOMWIRTSCHAFT, 10(11), PAGES 567-568 (NOVEMBER 1965), IN GERMAN

FOR THE POWER PLANT RWE-EAYERNWERK (KRB), THE MOST FAVORABLE SITE ORIGINALLY SEEMED TO BE ONE NEAR BERTOLOSHEIM. HOHEVER, THE WATER AUTHORITIES REJECTED IT FOR TECHNICAL AND EMOTIONAL-POLITICAL REASONS, ALTHOUGH ATTEMPTS WERE MAOE TO DEMONSTRATE THAT DRINKING WATER. AND NUCLEAR POWER ARE NOT MUTUALLY EXCLUSIVE. THE ATOMIC PLANT WILL BE BUILT IN GUNDREMMINGEN. A METEOROLOGICAL TOWER 118 M HIGH WILL BE ERECTED. A SMALLER OESIGN OF THE PLANT WAS REQUIRED. WE STUDIED THE COOLING-WATER REMOVAL AND RECYCLE TO FIND THE OPTIMUM COMPROMISE EETWEEN WATER ECONOMY AND ENERGY ECONOMY.

*GERMANY + METEOROLOGY + WATER POLLUTION + WATER, ORINKING

15-11121 VAN HORN WH

SUMMARY REPORT OF OPERATIONAL AND MANAGEMENT ASPECTS OF PERIPHERAL RADIOLOGICAL COUNTERMEASURES, FINAL REPORT

U. S. NAYAL RADIOLOGICAL DEFENSE LAEORATORY, SAN FRANCISCO, CALIFCRNIA

URS-646-4 + USNRDL-TRC-5 + AD-632211+. 150 PAGES, 28 FIGURES, 2 TABLES, MARCH, 1966, CFSTI, \$5.00 CY, $\$ 1$. CE MN

THE OPERATIONAL CONSTRAINTS aND MANAGEMENT PROBLEMS ASSOCIATED With THE PLANNING and IMPLEMENTATION OF PERIPHERAL RADIOLOGICAL COUNTERMEASURES ARE PRESENTED IN THIS REPORT. THE FOUR COUNTERMEASURES STUDIED IPOSTATTACK EVACUATION, $\triangle P P L I E D$ SHIELDINE, DOSE EQUALIZATION INCLUDING GROUP SHIELDING - AND EXPOSURE SCHEDULINGI CAN BE USEFUL TO THE LOCAL CIVIL-DEFENSE ORGANIZATION IN PROVIDING A SIGNIFICANT DEGREE OF CONTROL OVER RADIATION EXPOSURE IN THE EARLY POSTATTACK PERIOD, AND THEIR USE MAY RESULT IN A REDUCTION OF DOSE TO PERSONNEL AND OR A DECREASE IN THE TIME TILL. EMERGENCE FROM SHELTER IS POSSIBLE. MOREOVER, THE FLEXIBILITY IN SCHEDUL ING MADE POSSIBLE BY THE USE OF PERIPHERAL COUNTERMEASURES CAN INCREASE THE SCOPE OF LIFESAVING ACTIVITIES AND PERMIT EARLIER INITIATION OF THE RECOVERY PHASE.

*CIVIL DEFENSE + DOSE + FALLOUT + PERSONNEL EXPOSURE, RADIATION + POPULATION EXPOSURE + SHIELDING

15-11123 RAABE OG + PATTERSON FS

A METHOD OF ANALYSIS OF AIP SANPLING DATA FOR PARTICULATE ALPHA EMITTERS IN A RADON-THORON DAUGHTER ATMOSPHERE

UNIVERSITY OF ROCHESTER, NEW YORK

UR-658 +. 92 PAGES, FEBRUARY 1,1965 , CFSTI, $\$ 3.00 \mathrm{CY}$

THE ANALYSIS OF AIR-SAMPLING DATA OF PARTICULATE ALPHA EMITTERS IN A RADON-DAUGHTER AND THORON-DAUGHTER ATMOSPHERE IS GENERALIZEO TO ALLOW RAPID AND ACCURATE CALCULATIONS HITH A MINIMUM OF RESTRICTIONS. A RIGOROUS REGRESSION ANALYSIS IS DESCRIBED, GIVING

STATISTICAL-ERROR CONFIDENCE LIMITS AND THE SIZE OF INHERENT MATHEMATICAL ERRORS. THE METHOD CESCRIBED FOR THIS ANALYSIS DOES NOT REOUIRE EQUILIBRIUM CONDITIONS FOR THE ALPHA EMITTERS, AVERAGING OF THE ALPHA COUNTS OVER THE PERIOO OF COUNTING, OR LIMITING OF THE MAXIMUM NUMBER OF ALPHA-COUNT OBSERVATIONS THAT MAY BE MADE AND USED IN THE COMPUTATIONS. ALSO DESCRIBED IS A COMPLETE IBM FORTRAN PROGRAM FOR PERFORMING THE ANALYSIS AND PLOTTING THE DECAY RESULTS BY USING THE CALCOMP DIGITAL PLOTTER IN CONJUNCTION WITH AN IBM 7074 COMPUTER.

*AIR + \#MATHEMATICAL STUDY + \#SAMPLING + ANALYTICAL TECHNIQUE, AIR + COMPUTER PROGRAM + GROSS ALPHA + PARTICLE, RADIOACTIVE + RADON + THORON

15-11125 SANDEP.S FW

DOSE RATE MEASUREMENTS ON THE KIWI B-4D-202 AND KIWI B-4E-3DI REACTORS

LOS ALAMOS SCIENTIFIC LABORATORY, NEW MEXICO 
CATEGORY 15

ENVIRONMENTAL SURVEYS, MONITORING AND RADIATION EXPOSURE OF MAN

15-11125 *CONTINUED*

LA-3447-MS +. 21 PAGES, 1 TABLE, 15 FIGURES, 12 REFERENCES, JANUARY, 1966, CFSTI, \$1.00 CY, SO.50 MN

THE FIELD STUDIES GROUP CF THE HEALTH DIVISION OF THE LOS ALAMOS SCIENTIFIC LABORATORY MEASURED GAMMA-RAY DOSE RATES AT SEVEERAL DISTANCES FROM KIWI REACTORS B-4D-202 AND B-4E-3O1 DURING THE TESTING OF THESE REACTCRS AT THE NUCLEAR ROCKET DEVELODMENT STATION IN NEVADA. MEASUREMENTS PERFORMED YERE SIMILAR TO THOSE MADE ON PREVIOUS KIWI REACTORS. PEAK GAMMA-RAY DOSE RATES OF 31,700 R PER MIN AND 32,200 R PER MIN WERE MEASURED 60 FT FROM B-4D AND B-4E, RESPECTIVELY. THE EIGHT KIHI REACTORS TESTED HAVE YIELDED RATHER UNIFORM GAMMA-RAY DOSE RATES PER MEGAWATT OF REACTOR POWER. THE AVERAGE VALUE IS 35.1 R PER MIN-MW, MEASURED AT GO FT.

\#DOSE MEASUREMENT, EXTERNAL + \#KIWI + DOSE + GROSS GAMMA + INSTRUMENTATION, RADIATION MONITORING + NEVADA TEST SITE + REACTOR, SPACE + ROVER PROGRAM

15-11126 SPLICHAL WF

PORTABLE MULTIPURPOSE RADIATION MONITOR

SAVANNAH RIVER LABORATORY, AIKEN, SOUTH CAROL INA

DP-\$93 †. 13 PAGES, 6 FIGURES, I REFERENCE, MAY, 1966, CFSTI, \$1.00 CY, \$0.50 MN

A EASIC ELECTRONIC. PACKAGE FOR A PCRTABLE MULTIPURPOSE RADIATION MONITOR WAS DESIGNED, BUILT, AND FIELD TESTED. TRANSISTORIZED PLUG-IN CIRCUITS POWERED BY RECHARGEABLE NICKEL-CADMIUM BATTERIES, AREADOUT METER, AND AN ELECTROMECHANICAL REGISTER ARE CONTAINED IN A $4 X 5 \times$ 6-IN. CASE. NEUTRON, ALPHA, BETA-GAMMA, OR ALPHA-BETA-GAMMA DETECTORS CAN BE INDIVIDUALLY COUPLED TO THE ELECTRONIC PACKAGE. CALIBRATION FOR EACH DETECTOR IS SIMPLE ANO STABLE BECAUSE THE PACKAGE IS UNAFFECTED EY TEMPERATURE CHANGES BETWEEN 20 AND 100 DEGREES F. THE MONITOR WEIGHS ABOUT 7 LB, CAN BE CARRIED IN ONE HAND, REQUIRES NO WARMUP PERIOD, ANO IS EASY TO OPERATE AND SERVICE.

*INSTRUMENTATION, RADIATION NONITCRING + *MONITOR, RADIATION, GENERAL PRACTICE + GROSS ALPHA + GROSS BETA + GROSS GAMMA + INSTRUMENTATION CALIBRATION + INSTRUMENTATION, TESTING + NEUTRON +

RACIATION SAFETY ANO CONTROL

15-11127 GREENWOOD JA

ESTIMATION OF PARAMETERS IN MULTIVARIATE EXPERIMENTAL OESIGN AND A HYPOTHETICAL APPLICATION TO ESTIMATING FRACTIONAL DOSE RECOVERY EFFECTS

ARMED FCRCES RADIOBIOLOGY RESEARCH INSTITUTE, BETHESDA, NARYLAND

AFRRI-TN-66-2 + AD-635167+. 22 PAGES, 4 TABLES, 5 FIGURES, FEBRUARY, 1966, CFSTI, \$1.00 CY, \$O.50 MN

A STATISTICAL TECHNIQUE IS EXPLAINED, DERIVED, aNO ILLUSTRATED. ANALYSIS OF VARIANCE, COMPONENTS OF VARIANCE ANALYSIS, AND THE ESTIMATION TECHNI QUE DESCRIBED HEREIN APPLIED TO A PROPERLY CESIGNED EXPERIMENT WILL GO FAR TOWARD EXTRACTING ALL THE RELEVANT INFORMATION FROM A SAMPLE. ESTIMATION FORMULAS FOR THE TERMS OF THE ASSUMED MATHFMATICAL MODEL ARE OERIVED FOR TWO OF THE MOST USEO STATISTICAL EXPERIMENTAL DESIGNS, THE FACTOP.IAL ANO THE ORTHOGONAL SQUARES. THE METHOD IS ILLUSTRATED ON A THREE-VARIABLE, HYPOTHETICAL DOSE-RECOVERY EXPERIMENT. THE METHOD GIVES ONE A HANDLE ON MEASURING QUANTITATIVELY THE SEPARATE AND JOINT CONTRIBUTIONS TO THE OBSERVED EFFECT OF VARIABLES OTHERHISE HOPELESSLY CORRELATED AND OVERLAPPING.

\#DOSE + \#MATHEMATICAL STUDY + STATISTICAL CORRELATION

15-11128 IZAWA M

REVIEW OF THE NEW 1962 ICRP RECOMMENDATIONS

NATIONAL INSTITUTE OF RADIOLOGICAL SCIENCES, CHIBA, JAPAN

UCRL-TRANS-10055 +. 20 PAGES, TRANSLATED FROM NIPPON GENSHIRYOKU GAKKAISHI, 7 , PAGES $418-22$ (1965), JCL, $\$ 1.60 \mathrm{FS}, \$ 0.80 \mathrm{MF}$

THE NEH RECOMMENDATIONS OF THE INTERNATIONAL COMMISSION ON RADIOLOGICAL PROTECTION ADOPTED IN 1962 ARE REVIEWED. THE BASIC PRINCIPLES ARE THE SAME AS THOSE OF THE 1958 RECOMMENDATIONS, BUT A NUMBER OF AMENDMENTS AND CLARIFICATIONS ARE MADE IN THE NEW PUBLICATION. ADOPTION OF THE NEW RECOMMENDATIONS TO REGULATIONS OF RADIATION PROTECTION IN JAPAN ARE DISCUSSED.

*ICRP (INT. COMM. ON RADIOLOGICAL PROTECTION) + \#RADIATION PROTECTION, ORGANIZATION + JAPAN + RACIATION SAFETY AND CONTROL

15-11129 SCHREIEER B

THE OCEANS AND THE PROBLEM OF ARTIFICIAL RADIOACTIVITY

INSTITUTO DI ZOOLOGIA E ANATOMIA COMPARATA, PARMA, ITALY

7 PAGES, SCIENTIA, (100), PAGES 158-164 (1966), IN ITALIAN

THE MILITARY APPLICATION OF THE DISCOVERY OF ATOMIC FISSION AND THE SUCCESSIVE EXPLOITATION OF ATOMIC ENERGY ON AN INDUSTRIAL SCALE HAVE POSED SOME IMPORTANT QUESTIONS REGARDING THE APPEARANCE ON THE EARTH OF PPEVIOUSLY NONEXISTENT RADIOACTIVE ISOTOPES OF NATURAL ELEMENTS. THE OCEANS HAVE SUDDENLY BECOME INVOLVED IN THESE PROBLEMS, ON THE ONE HAND, THROUGH THE POLLUTION DUE TO RACIOACTIVE FALLGUT FROM EXPLOSIONS OR TO EXPLOSIONS THEMSELVES MADE TO OCCUR IN THE OCEAN. ON THE OTHER HAND, THE OCEANS ARE INVOLVED BECAUSE INDUSTRIAL RADIOACTIVE WASTES, WHICH MUST AT ALL COSTS BE REMOVED FROM POPULATED AREAS, ARE DISCHARGED INTO THE SEA. FROM THIS HAVE ARISEN PROBLEMS FOR STUDY WHICH, RENDEREO NECESSARY TO FILL GAPS PERTAINING TO PROTECTION AGAINST THESE PRODUCTS, hAVE AT THE PRESENT TIME MADE FORESEEN CONTRIBUTIONS TO PHYSICAL AND BIOLOGICAL OCEANOGRAPHY.

* OCEAN and SEa + Biological concentration, aquatic organisms + Fallout + 
CATEGORY 15

ENVIRONMENTAL SURVEYS, MONITORING AND RADIATION EXPOSURE OF MAN

15-11129 \#CONTINUED

SURFACE WATER, NUCLIDE OCCURRENCE + SURFACE WATER, PROPERTY + WASTE DISPOSAL, OCEAN

15-11130 BURT AK + GIBSCN JA

A METHOD FOR CONTINUOUS MEASUREMENT OF TRITIATED HATER IN AIR

ATOMIC ENERGY RESEARCH ESTABLI SHMENT, HARHELL

JOURNAL OF NUCLEAR ENERGY 20 (3), PAGES 185-190, 6 F1GURES, 7 REFERENCES, 1966

AN INSTRUMENT HAS BEEN DEVELOPED FOR THE CONTINUOUS MEASUREMENT OF TRITIUM (AS HTO) IN AIR IN THE VICINITY OF A HEAVY-WATER REACTOR. WATER IS CONDENSED CONTINUOUSLY FROM THE AIR AT THE RATE OF IOG/HR, AND THE TRITIUM ACTIVITY IS MEASURED IN A FLOW CELL FILLED WITH ANTHRACENE CRYSTALS. THE METHOD WAS DEVELOPED TO IMPROVE THE SENSITIVITY OF DETECTION FROM 2.5 PCICU.CM FOR AN ION CHAMBER SYSTEM TO ENABLE THE CHRONIC LEVEL OF 0.4 PC/CU.CM (O.OB MPC FOR AIR) TO BE CONTINUOUSLY MEASURFD. THF RANGE OF THE INSTRUMENT, USING A LOGARITHMIC RATEMFTER, IS FROM THE BACKGROUND SENSITIVITY OF 0.1 TO 1000 PC/CU.CM $(250$ MPC). THE INSTRUMENT CAN RE OPERATED IN A HIGH GAMMA-RAY BACKGROUND AND DOES NOT DETECT RADIOACTIVE GASES SUCH AS AR-4I. CONTAMINATION OF THE CELL IS RAPIDLY REMOVEO FOLLOWING A LARGE RELFASE OF TRITIUM ACTIVITY.

* INSTRUNENTATION, AIR SAMPLING + \#MCNITOR, RADIATION, AIR + "TRITIUM + DECONTAMINATION + REACTOR, HEAVY WATER

15-11131 BROECKER WS + ROCCO GG + VOLCHOK HL STRONTIUM-90 FALLOUT - COMPARISON OF RATES OVER OCEAN AND LAND

COLUMBIA UNIVERSITY + TRACERLAB, INC., WALTHAM, MASS. + HEALTH AND SAFETY LABORATORY, N.Y.

2 PAGES, 2 t 1GUKES, 7 REFERENCES, SCIENCE (152), PAGES 640-641 (APRIL 29, 1966 )

MEASUREMENTS OF SR-90 IN WATERS RESIDING ON THE BAHAMA BANKS FOR PERIODS BETWEEN 12 ANO 180 DAYS SUGGEST THAT FALLOUT RATES ONTO THESE WATERS ARE SUBSTANTIALLY THE SAME AS THE AVERAGE RATES AT ALL FALLOUT COLLECTION STATIONS BETWEEN 20 AND 30 DESREES LATITUDE. IF THE AMOUNT OF PRECIPITATION ON THE BAHAMA BANKS IS REASONABLY REPRESENTATIVE OF THE OCEANIC AREAS IN THIS LATITUDE BAND, OUR RESULTS SUPPORT THE CONCLUSION THAT THE AMOUNT OF SR-9D DEPOSITED PER UNIT AREA OF OCEAN SURFACE IS WITHIN A FACIUK UF 2 OF THAT ON LAND.

*Fallout + \#Trontium + ocean and sea + surface water, nuclide occurrence

15-11132 OWEN WL + KAWAHARA FK + WILISHIKE LL

RADIOLOGICAL RECLAMATION PERFORMANCE SUMMARY. VOLUME 1. PERFORMANCE TEST DATA COMPILATION NAVAL RADIOLUGICAL UEFENSE LABORATORY, SAN FRANCISCO, CALIFORNIA

USNROL-TR-967 +. 124 PAGES, 36 TABLES, 4 FIGURES, 25 REFERENCES, OCTOBER 13, 1965, CFSTI, \$4.00 FS, \$O.75 NN

THIS VOLUME PRESENTS TABULATED DATA SUMMARIZING THE PERFORMANCE OF LAND-RECLAMATION METHODS AND EQUIPMENT. THE TABLED ENTRIES WERE GATHERED FROM 18 EXPERIMENTS AND FIELD OPERATIONS. THEY INCLUDE THOSE OPERATIONAL AND ENVIRONMENTAL FACTORS KNOWN TO INFLUENCE RECLAMATION EFFECTIVENESS. A SECONO VOLUME WILL BE DEVOTED TO THE EVALUATION AND REORGANIZATION OF THE AROVF COMPII ATION INTO A FORM COMPAIIBLE WITH THE PLANNING OF RADIOLOGICAL PECOVERY OPERAIIUNS.

*CIVIL DEFENSE + \#ECONTAMINATION + \#FALLOUT + OEPOSITION + PARTICLE SIZE + RADIATION SAFETY AND CONTROL + TOPOSRAPHY

15-11165 PELLERIN P + MORCNI JP + REMY ML

FIRST RESULTS OF A SYSTEMATIC STUDY OF. INTERNAL CONTAMINATIONS DUE TO P.ADIOACTIVE FALLOUT

CENTRAL SERVICE OF PROTECTION AGAINST IONIZING RADIATION

SCPRI-(S)-107 +. 11 PAGES, 6 FIGURES, 2 TABLES, MARCH 1964, IN FRENCH

SINCE SEPTEMBER 1961, MORE THAN 500 TOTAL-BOOY-COUNTER MEASUREMENTS, ASSOCIATED WITH URINARY

ANALYSIS, HAVE BEEN DONE BY THE SCPRI. THE COMPARATIVF STIIDY OF THESE RESULTS BRINGS OUT SOME FACTS RELATING TO THE INTERNAL CONTAMINATIUN UUE IU FALLUUT - $(1)$ CS- 137 ALONE 1 S

CONSTANTLY FOUND AND THE RATIO BETWEEN ITS URINARY EXCRETION AND THE TOTAL CHARGE IN THE

ORGANISM. (2) FISSION PRODUCTS WITH MEAN LIFE (ZR-95 + NB-95, RU-107, ETC.) WERE FOUNO

TRANSITORILY. (3) THE SR-90 TOTAL BODY BURDEN OF THE HUMAN ORGANISM WAS INDIRECTLY ESTIMATEO BY COMPARING THE PERCENTAGE CF CS-137 IN FALLOUT IWHICH IS ESSENTIALLY THE SAME AS THAT OF SR-90I AND THE URINARY EXCRETION OF SR-SO.

* BIOLOGICAL CONCENTRATION, MAN + \#FALLOUT + ANALYTICAL TECHNIOUE, URINE + CESIUM + COUNTER, WHOLF BODY + DOSE + NIOBIUM + RUTHENIUM + STRONTIUM + ZIRCONIUM

15-11167 TOCHILIN E + GOLDSTEIN N

DOSE RATE AND SPECTRAL MEASUREMENTS FROM PULSED X-RAY GENERATORS

U.S. NAVAL RADIOLOGICAL DEFENSE LABCRATORY, SAN FRANCISCO

DASA-17C3 + USNRDL-TR-939+ AD-627567+. 33 PAGES, 7 FIGURES, 1 TABLE, 15 REFERENCES, DECEMBER 3 , I96E, CFSTI $\$ 1.00 \mathrm{CY}, \$ 0.50 \mathrm{MN}$

TYPICAL X-RAY SPFCTRA FROM HIGH INTENSITY, PULSED X-RAY SOURCES WERE DETERMINED BY MEANS OF AN EQUIVALENT-CONSTANT-VOLTAGE ACCELERATOR. THE PHOTON-ENERGY SPECTRUM FOR THE FORWARD X-RAY BEAM WAS MEASURED WITH VARIOUS X-RAY TARGET THICKNESSES AT ACCELERATOR VOLTAGES OF 1.0, 1.5, AND 2.0 MV. X-RAY SPECTRA WERE ALSO OBTAINED FROM A REFLECTION X-RAY TARGET AT ANGLES OF 7 ANO 45 DEG WITH RESPECT TO THE X-RAY BEAM AT APPLIED POTENTIALS OF 0.55, 1.0, AND 2.0 MV. THE DOSE-RATE DEPENDENCE OF THERMOLUMINESCENT LIF, SILVER-ACTIVATED PHOSPHATE GLASS, AND 
CATEGORY 15

ENVIRONMENTAL SURVEYS, MONITORING ANO RADIATION EXPOSURE OF MAN

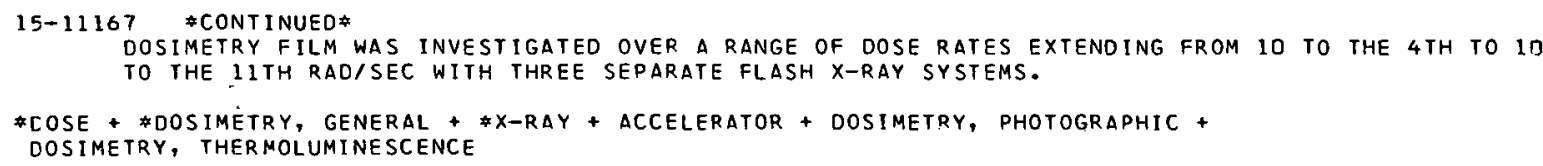

THE PRINCIPAL PRODUCT OF THE IRRADIATION OF AIR IS OZONE. SINCE IT IS TOXIC IT MAY LIMIT THE OPERATION OF LARGE ISOTOPE SERVICES OR HIGH-INTENSITY ACCELERATORS. ESTIMATES OF OZONE PRODUCTIONS AND VENTILATION REQUIREMENTS ARE MADE.

*CHEMICAL TCXICITY + *OZONE + RACIATION EFFECT

15-11311 MILBURN GS

TAGGING STUDIES TO DETERMINE THE OFFSHORE-INSHORE EXCHANGE OF GROUNDFISH OFF OREGON AND HASHINGTON, JUNE 1961 - FEBRUARY 1966

CREGON FISH COMMISSION, ASTORIA

RLO-1731-5 +. 35 PAGES, FEBRUARY 1966, CFSTI, $\$ 2.00 \mathrm{CY}, \$ 0.50 \mathrm{MN}$

A COOPERATIVE STUDY WAS STARTED IN JUNE 1961 BY THE ATOMIC ENERGY COMMISSION, BUREAU OF COMMERCIAL FISHERIES, AND THE OREGON FISH COMMISSION TO DETERMINE THE OFFSHORE-INSHORE MOVEMENTS OF DOVER SOLE AND SABLEFISH. FROM JUNE 1961 TO MAY 1964,9013 DOVER SOLE AND 4657 SABLEFISH WERE TAGGED AND RELEASED AT APPROXIMATELY 25-FATHOM INTERVALS FROM 50 TO 450 FATHOM IN A 35-MILE-LONG AREA. SOUTHWEST OF THE COLUMBIA RIVER.

* Ecological consideration + ocean ano sea + waste disposal, ocean

15-11312 DEBORTOLI M + GAELIONE P + MALVICINI A

ENVIR ONMENTAL RADIO-ACTIVITY, ISPRA 1965

EUROPEAN ATOMIC ENERGY COMMUNITY (EURATOM), ISPRA, ITALY

EUR-2965E +. 72 PAGES, 1966 , DEP. MN

THIS REPORT SUMMARIZES THE RESULTS OF THE MEASUREMENTS OF ENVIRONMENTAL RADIOACTIVITY PERFORMED BY THE SITE-SURVEY GROUP OF THE PROTECTION SERVICE OF THE EURATOM ISPRA

ESTABLISHMENT. THE RESULTS INDICATE THAT THE ENVIRONMENTAL RADIATION EXPOSURE FOR THOSE

LIVING IN THE NEIGHEOURHOCD OF THE ESTABLISHMENT WAS OUE, ALMOST EXCLUSIVELY, TO NATURAL

SOURCES AND WORLD-WIDE FALLOUT.

* EI OLOGICAL CONCENTRATION, AQUATIC ORgANISMS + \#IOLOGICAL CONCENTRATION, FOOD +

\#BIOLOGICAL CONCENTRATION, MILK + *BIOLOGICAL CONCENTRATION, VEGETATION + CESIUM + EURATOM + FALLOUT +

ITALY + MONITOR, RADIATION, ENVIRONMENTAL + RAINOUT + SOIL, NUCLIDE OCCURRENCE + STRONTIUM +

SURVEY, RAOIATION, ENVIRONMENTAL + WASTE DISPOSAL, ATMOSPHERIC + WASTE DISPOSAL, LIOUID

15-11314 WASTE BURNING AT CHALK RIVER

2 PAGES, 3 FIGURES, NUCLEAR ENGINEERING 101115), 472-473, DECEMBER 1965

OPERATING EXPERIENCE AT THE LOW-ACTIVITY WASTE INCINERATOR IS DESCRIBEO. THE INCINERATOR AND MONITORING EQUIPMENT ARE DESCRIBED, AND OPERATING DATA ARE GIVEN, ALONG WITH THE COSTS.

* CANAOA + \#CHALK RIVER + \#INCINERATION + WASTE TREATMENT, ECONOMICS + WASTE TREATMENT, SOLID

$15-11318$ SEABORN GB

D DETECTOR FOR ALPHA RADIOACTIVITY IN FLCWING WATER

UNION CARBIDE CORPORATION, OAK RIDGE, OAK RIDGE GASEOUS DIFFUSION PLANT

K-1656+. 19 PAGES, 8 FIGURES, APRIL 19, 1966, CFSTI \$1.00 CY, \$0.50 MN

A DETECTOR WAS OEVELOPED FOR CONTINUOUSLY MONITORING THE ALPHA RADIOACTIVITY IN FLOWING WATER. THE INSTRUMENT IS CAPABLE OF DETECTING ALPHA LEVELS DOWN TO 1 PERCENT OF THE MAXIMUM. PERMISSI ELE CONCENTRATICN ALLOWED FOR HUMAN CONSUMPTION. THE REQUIRED MAINTENANCE IS MINIMAL, AND IT IS SUITABLE FOR LOCATION IN A REMOTE AREA. THE DESIGN AND TEST RESULTS ARE DESCRIBED. 
CATEGORY 15

ENVIRONMENTAL SURVEYS, MONITORING AND RADIATION EXPOSURE OF MAN

15-11312 \#CONTINUED

* INSTRUMENTATION, RADIATION MONITORING + \#MONITOR, RADIATION, LIQUIC + GROSS ALPHA + WATER POLLUTION

I5-1132C TAPPAN JT + NOGRE WE

PROJECT DRIBBLE-SALMON EVENT ON-SITE HEALTH AND SAFETY REPORT

REYNOLOS ELECIKILAL ANU ENEINEEKING CU., INC.

VUF-1025 +. 49 PAGES, 11 FIGURES, 10 TABLES, NOVEMBER 1965, CFSTI \$2.00 CY, \$O.50 MN

THE SALMON EVENT WAS DETONATED AT PROJECT DRIBBLE TEST SITE, TATUM SALT DOME, NEAR HATTIESBURG, MISSISSIPPI, ON 22 OCTOBER 1964. RADIATION MEASUREMENTS WERE RECORDED DURING AND AFTER THE DETONATION BY A REMOTE-AREA MONITORING SYSTEM. AFTER THE DETONATION, RADIATION MONITORS EQUIPPEO WITH PORTABLE RADIATION-DETECTION INSTRUMENTS SURVEYED THE ROUTE INTO SURFACE GROUND ZERO BEFCRE OTHER PLANNED REENTRIES WERE MADE. CONTINUOUS MONITORING WAS PROVIDED WHILE WOPKERS WERE IN THE AREA. ONLY BACKGROUND RADIATION MEASUREMENTS WERE OBSERVED FROM ZERO TIME UNTIL COMMUNICATION WITH THE CAVITY HAD BEEN ESTABLISHED DURING POSTSHOT ORILLING OPERATIONS AT A DEPTH GREATER THAN $2600 \mathrm{FT}$. FIFTY-TWO INDIVIDUALS RECEIVEO RADIATION DOSES IN EXCESS OF 100 MILLIREMS OURING THE PROGRAM. THE MAXIMUM ACCUMULATED INOIVIOUAL DOSE WAS 1 C65 IWELL BELOW THE DOSAGE LIMITS LISTED IN THE AEC MANUAL, CHAPTER ก524, NF 3 RFMS PFR QIIARTER AND 5 REMS PER YEAR\}.

* RAOIATION PROTECTION, ORGANIZATION \& *SURVEY, RADIATION, ENYTRONMFNTAL +

\#VELA UNIFORM PROGRAM, PROJECT SHOAL + AIR + CHEMICAL TOXICITY + DOSE MEASUREMENT, EXTERNAL + GROSS BETA + IODINE + PERSONNEL EXPOSURE, RADIATION + WASTE DISPOSAL, LIQUID + WASTE DISPOSAL, SOLID + WATER, GENERAL

15-11348 FITOUSSI L + LEBOULEUX P + BRICAR.O P + MOREAU A

RADIOPROTECTION PROBLEMS RESULTING FROM THE PRESENCE OF EXPERIMENTAL DEVICES AROUND AN ATOMIC REACTOR CENTRE CETUDES NUCLEAIRES DE SACLAY

CEA-R-2799+. 15 PAGES, 1 TABLE, APRIL 1965, DEP. MN, IN FRENCH

THE SETTING UP OF EXPERIMENTAL DEVICES AROUND A REACTOR PRODUCES DANGERS OF IRRAOIATION AND RADIOACTIVE CONTAMINATION, WHICH CAN BECOME VERY GREAT IN THE CASE OF AN ACCIDENT, ESPECIALLY IT TIIC IN-PILC PORTION CONTAINS FISSILE MATTER. THIS MAY RESULT IN IRRADIATION OF PERSONNEL, PROHIBITION OF ACCESS TO THE EXPERIMENTAL ZONES UNTIL THE SOURCES OF IRRADIATION AND CONTAMINATION HAVE BEEN ELIMINATED, AND A PROLONGED STOPPAGE OF THE REACTOR. THE PLANS FOR AN IN-PILE EXPERIMENT SHOULD TAKE INTO ACCOUNT RADIO-PROTECTION FACTORS. THE AUTHORS SUMMARIZE THE PHYSICAL AND TECHNICAL DATA REQUIRED BY RADIO-PROTECTION SPECIALISTS AND GIVE THE RULES AND GENERAL ADVICE CONCERNING RADIO-PROTECTION WHICH SHOULD BE USEFUL DURING THE PLANNING OT AN IN-PILL CXPLRIMLNT.

* in pile eXPERIMENI + *RAUIAIICN SAFEIY AND CONIKUL + PERSUNNEL EXPUSURE, RACIATION + RAOIATION PROTECTION, ORGANIZATION

15-11349 RODIER J + CHASSANY J + GUILLERMIN P HEALTH PHYSICS DUR ING WORK ON THE G.2 AND G.3 REACTOR EXCHANGES COMMISSARIAT A LENERGIE ATOMIQUE

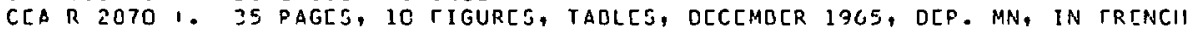

DURING THIS WORK AND ITS PREPARATION, WHICH TOOK PLACE FIRST AT G.2 AND THEN AT G.3 OVER A PERIOD OF 11 MONTHS, 15,000 RESULTS WERE OBTAINED. THEIR ANALYSIS, TOGETHER WITH A CONSIDERATION OF THE OP.GANIZATION ON THE SITE AND OF THE CONCLUSIONS DR.AWN FROM THE EXPERIMENT, SHOWS THE VARIOUS FACTORS THAT DETERMINE THE IMPORTANCE OF THE RADIOACTIVE CANGERS.

\#RADIATION PROTECTION, ORGANIZATION + FRANCE + RADIATION IN PERSPECTIVE + RADIATION SAFETY AND CONTROL + VFNT II_ $\triangle T$ ION SYSTEM

15-11352 LEISTNER L

RESEARCH INTO THE RAOIOACTIVE CONTAMINATION OF FOOOSTUFFS OF ANIMAL ORIGIN CENTRE DETUDES NUCLEAIRE FONTENAY-AUX-ROSES, FRANCE

CEA-R-2738 + EUR-2226.F +. 69 PAGES, TABLES, MARCH 1965, DEP. MN, IN FRENCH

IHE AUTHOR ASSEMBLES IN A VERY COMPLETE WAY ALL THE AVAILABLE DATA RELATING TO THE TRANSFER OF THE MOST IMPORTANT RADIONUCLIDES FROM THE ENVIRONMENT THROUGH ANIMAL PRODUCTS TO MAN. AS THESE DATA ARE NOT DIRECTLY UTILIZABLE BY THE COUNTRIES OF THE EUROPEAN COMMUNITY, HE PROPOSES TO GO FURTHER INTO THE QUESTION TO BE ABLE TO TAKE INTO ACCOUNT THE CHANGING ECOLOGICAL CONDITIONS.

* BIOLOGICAL CONCENTRATION, ANIMAL + \#BIOLOGICAL CONCENTRATION, ANIMAL FEED + \#ECOLOGICAL CONSIDERATION + BARIUM + BIOLOGICAL CONCENTRATICN, AGRICULTURAL PRODUCE + BIOLOGICAL CONCENTRATION, AQUATIC ORGANISMS + EIOLOGICAL CONCENTRATION, FOOD + BIOLOGICAL CONCENTRATION, MILK + BIOLOGICAL CONCENTRATION, VEGETATION + CALCIUM + CESIUM + IODINE + STRCNTIUM

15-1150E COBBIN HC + OWEN WL

DEVELOPMENT AND TEST OF A SOD-REMOVAL PROCEDURE FOR MOIST LAWNS CONTAMINATED BY SIMULATED FALLOUT

U.S. NAVAL RAUIULULILLL ULFENSE LABUKAIURY, SAN FRANL I SLU

USNRDL-TR-965 + AC-631529+.67 PAGES, FIGURES, TABLES, 7 REFERENCES, APRIL 11, 1966, DDC

a SOD-CUtTING MACHINE Was EVALUATEO FOR ITS USEFULNESS IN THE RADIOLOGICAL RECLAMATION OF SMALL LAWN AREAS. FAILLIJT WAS APPROXIMATEN RY C.NNTAMINATING I AWN TFST ARFAS WITH

RADI0-TRACED SAND. NOMINAL PARTICLE SIZE RANGES OF 44-88, 88-177, 177-350, AND 350-700 
CATEGORY 15

ENVIRONMENTAL SURVEYS, MONITORING AND RADIATION EXPOSURE OF MAN

$15-11506$ \#CONTINUED*

MICRONS WERE USED. THE SAND WAS DISPERSED AT NOMINAL CONCENTRATIONS OF 25,50 AND 100 G/SQ. FT, RESPECTIVELY. RECLAMATION EFFECTIVENESS OF SOD CUTTING HAS DEPENDENT UPON MACHINE FACTORS (BLADE DEPTH), SOIL CHARACTERISTICS (MOISTURE CONTENT) AND MASS LOADING. THE LEAST EFFECTIVE RESULTS WERE OBTAINED IN CONFINED LAWNS WITH HIGH MOISTURE CONTENT AND HEAVY ROCK
CONCENTRATIONS. THE BEST SOD-CUTIING AND REMOVAL EFFECTIVENESS RESULTS WERE OBTAINED ON MORE ACCESSIBLE LAWNS HAVING LESS MOISTURE CONTENT AND ONLY A LIGHT CONCENTRATION OF ROCKS. PARTICLE SIZE WAS FOUND TO HAVE LITTLE, IF ANY, WITH RESPECT TO EFFORT REQUIRED OR REMOVAL EFFECTIVENESS ACHIEVED.

* RECOVERY PROCESS + CONTAMINATION + FALLOUT + PARTICLE SIZE + PARTICLE SIZE DISTRIBUTION + TRACER, RADIOACTIVE

15-11704 MANNESCHMIDT JF

RECENT ADVANCES IN MONITORING OF RAOIOACTIVE GASEOUS WASTES AT ORNL

OAK RIDEE NATIONAL LABORATORY, OAK RIDGE

CONF-660904 +. 27 PAGES, 17 FIGURES, 6 REFERENCES, PRESENTED AT 9TH AEC AIR CLEANING CONFERENCE, BOSTON, MASS., SEPTEMBER $13-16,1966$, SOURCE

MANY ACTIVITIES AT THE OAK RIDGE NATIONAL LABORATORY ARE CONCERNED WITH THE CHEMICAL PROCESSING OF RADIOACTIVE MATERIALS. GASEOUS EFFLUENTS FROM THESE OPERATIONS ARE TREATED TO REMOVE DANGEROUS CONTAMINANTS BEFORE RELEASE TO THE ATMOSPHERE. ROUTINE MONITORING OF SUCH EMISSIONS WAS STARTED IN 1966 WHEN MANUALLY OPERATED PARTICULATE MONITORS WERE INSTALLED AT EACH OF THREE PROCESS STACKS. SINCE THAT DATE, COVERAGE HAS BEEN EXTENDED TO SIX STACKS, THE SAMPLE HITHDRAWAL SYSTEM HAS BEEN REBUILT, AND THE DETECTION EQUIPMENT HAS BEEN ADDED TO AND MODERNIZED. THE INTENSIVE MONITORING HAS LEAD TO PROCESS IMPROVEMENTS THAT HAVE REDUCED THE ENVIRONMENTAL RELEASES OF RADIOACTIVITY IN THE GASEOUS WASTE EFFLUENTS BY A FACTOR OF 3 SINCE 1962 .

\#MONITOR, RADIATION, EMERGENCY + \#MONITOR, RADIATION, GAS + \#MONITOR, RADIATION, GENERAL PRACTICE + \#MONITOR, RADIATION, SAMPLING + \#MONITOR, RADIATION, STACK + MONITOR, RADIATION, AIR +

MONITOR, RADIATION, BACKGROUND + MONITOR, RADIATION, ENVIRONMENTAL + MONITOR, RAOIATION, GENERAL

15-11714 SMITH OG + REIST PC + SILVERMAN L

INCREASED DETECTION SENSITIVITY FOR KRYPTON-85

HARVARD UNIVERSITY

CONF-660904 †. 14 PAGES, 6 FIGURES, 1 TABLE, 4 REFERENCES, PRESENTED AT 9TH AEC AIR CLEANING CONFERENCE, BOSTON, MASS., SEPTEMBER 13-16, 1966, SOURCE

INCREASING THE FIELO DETECTION SENSITIVITY FOR KR-85 TO A LEVEL OF 3(MINUS 8TH) MICROCURIE/CC BY USING A 2.8-LITER IONIZATION CHAMBER ANO VIBRATING-REED-ELECTROMETER DETECTION SYSTEM, PLUS AN ADSORPTION-DESORPTION KR-85 CONCENTRATING SYSTEM, WAS INVESTIGATED. THE KR-85 IN THE SAMPLE STREAM WAS CONCENTRATED BY ADSORBING IT ON AN ACTIVATED CARBON BED AT - T8.5 C AND CESORBING IT INTO THE IONIZATION CHAMBER AT $20 \mathrm{C}$. A CONCENTRATION FACTOR WAS DEFINED AND OBSERVED TO BE INDEPENOENT OF THE INLET CONCENTRATION OF KR-85. 
CATEGORY 16

METEOROLOGICAL CONSIDERATIONS

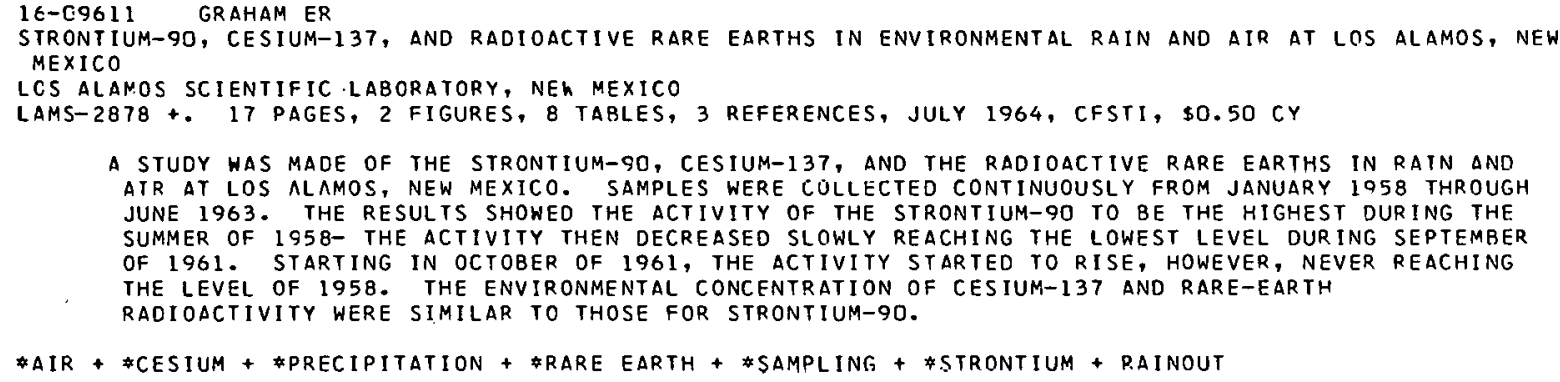

*nuclear explosion debris + *Radiation efFect + sOURCE, neutron

$16-09614$ HEDMAN FA

CALCULATION OF FREE-FALL VELOCITY OT SPHERICAL PARTICLES AI VARIOUS ALTITUDES

NATIONAL MILITARY COMMAND SYSTEM SUPPORT CENTER

AC-4633S2 +. 19 PAGES, 2 TABLES, 16 REFERENCES, MARCH 1965

A GENERAL EQUATION USING REYNOLD NUMEER RELATIONSHIPS IS CERIVED FDR THE FREE-FALL VELOCITY OF SPHERICAL PARTICLES (CR DROPLETS) CF ANY DENSITY FOR ALL ALTITUDES OF INTEREST IN

NUCLEAR-FALLOUT CALCULATIONS. IT IS A MODIFIED STOKE EQUATION. TABLES OF THE VALUES OF STOKE CONSTANT AND MAXIMUN APPLICABLE DIAMETER OF UNIT-DENSITY PARTICLES ARE PRESENTED FOR ALTITUDES TO 105, ODO FEET. DATA, APPLICABLE ONLY TO LARGE PARTICLES, ARE INCLUDED FOR USE WITH NEWTON EQUATION. ENPIRICAL EQUATIONS OF THESE PARAMETER VALUES AS FUNCTIONS OF ALTITUDE ON INTEGRATION, GIVE TOTAL DESCENT TIME.

\# ANALYTICAL MODEL + \#DEPOSITION + \#EQUATION, GENERAL + \#FALLOUT + \#PARTICLE SIZE + \#PARTICLE, RADIOACTIVF

16-C9616 TORDANOV D

OIFFUSION FROM A POINT SOURCE IN A SURFACE AIP LAYER WITII UNSTABLE STRATIFILAIIUN

EULCARIAN ACADEMY OF SCIENCE, SUFIA

ORNL-TR-905 +. 5 PAGES, 11 REFERENCES, 1965- TRANSLATED FROM DOKLADY BOLGARSKOI AKAD. NAUK I8I2I-

$109-112(1965)$, CFSTI $\$ 1.00 \mathrm{CY}, \$ 0.50 \mathrm{MN}$

A THEORY OF OIFFUSION FROM CONTINUOUS POINT AND LINE SOURCES LOCATED AT VARIOUS HEIGHTS IN THE SURFACE, OR CONSTANT STRESS LAYER OF THE ATMOSPHERE (ROUGHLY, THE LOWEST 10 TO 100 METERS ABOVE GROUNDI, IS DESCRIBED. THE THEORY IS BASED ON THE MONIN AND OBUKHOV TWO-LAYER MODEL OF THE SURFACE LAYER, FOR THE CASE OF UNSTABLE THERMAL STRATIFICATION. GENERAL RESULTS INVOLVF SUMS OF BESSEL FUNCTIONS. SONE SPECIAL, LIMITING CASES ARE DISCUSSED. THESE RFSIIITS DRE PR.IMAPILY OF THEORETICAL INTEREST. NÚ GRAPHICAI OR TABULAR SUMMARIES ARE INCLUDED.

ATMOSPHERIC. DIFFUSION + BOUNDARY LAYER + LAPSE RATE, UNSTABLE + SOURCE, CONTINUOUS + SOURCE, ELEVATED + SOURCE, LINE + SOURCE, POINT

1E-C9617 LIGDA MG

IHE LASER IN METEOROLOGY

6 PAGES, 5 FIGURES, OISCOVERY 26(7), PAGES 30-35, 50 (JULY 1965 )

A NCH AND NOVFI INSTRUNENT, BASED CN THE GIANT-PULSE RUBY LASER, HAS RECENTLY BEEN DEVELOPED FOR WEATHER OBSERVATION. ITS USE FOR PROBING CLOUDS AND STUDYING AEROSOLS IN THE ATMOSPHERE IS NOW REVEALING NEW INFORMATION ABOUT THE ATMOSPHERE, IIS STRUCTURE, FINE-SCALE MOTION, AND THE MODIFICATION OF IT BY MAN. THE LIDAR (LIGHT DETECTION AND RANGING INSTRUMENTI IS BASED ON THE PRINCIPLE OF RADAR FOR DETECTING AND RANGING ATMOSPHERIC TARGETS BY THE RADIATION THAT THEY REFLECT - THEIR BACKSCATTER. A NUMBER OF THESE INSTRUMENTS HAS ALREADY REEN BUILT IN THE LABORATORIES OF STANFORD RESEARCH INSTITUTE.

* InETRUMENTATIOH, METEOROLOBICAL - AEKUSUL + AIR POLLUTION + ATMOSPHERIC. STABILITY + SCATTERING (SKYSHINE) + WIND WROFILE 
CATEGORY 16

METEOROLOGICAL CONSIDERATIONS

$16-C 9620$ \#CONTINUED*

CCMITATO NAZIONALE PER L ENERGIA NUCLEARE, ROME

BIO/04/64 +. 204 PAGES, FIGURES, TABLES, APRIL 1964, DEP MN

THIS DOCUMENT CONTAINS GRAPHS, MAPS, ANO TABLES ON THE ENVIRONMENTAL RADIOACTIVITY COLLECTED IN ITALY FROM JULY TO DECEMBER 1963. THE DOCUMENT IS OIVIDED INTO SECTION REPORTS FROM NATI ONAL NETWORKS, LOCAL NETHORKS, AND ISOLATED AND VARIOUS STATIONS. A LIST IS INCLUDED OF RECENTLY PUBLISHED ITALIAN PAPERS ON DATA ON ENVIRONMENTAL RADIOACTIVITY.

\#ENVIRONMENTAL CONDITION + IITALY + \#RADIOISOTOPE + AIR + CESIUM + GROSS BETA + SAMPLING + STRONTIUM

16-10195 CALDWELL R

NUCLEAR MATERIALS AND EQUIPMENT CORPORATION. OFFSITE AIR-SURVEILLANCE PROGRAM

NUCLEAR MATERIALS AND EQUIPMENT CORPORATION, APOLLO, PA.

2 PAGES, APRIL 20, 1966, ATOMIC ENERGY CLEARING HOUSE, 12(20), PAGES 32-33 (MAY 16, 1966)

APOLLO PLANT DOES NOT LEND ITSELF READILY TO CONVENTIONAL DIFFUSION MODELS FOR OFFSITE AIR-SAMPLE-DATA ANALYSIS. A SIX-MONTH PROGRAM WILL BE UNDERTAKEN TO ESTABLISH LOCATION AND FREQUENCY OF OFFSITE SAMPLING. AN INTERIM SCHEDULE OF STACK SAMPLING IS PROPOSED.

* SURVEY, RADIATION, ENVIRONMENTAL + MONITOR, RADIATION, STACK + RADIOCHEMICAL PROCESSING

$16-1 C 644$ HERING WS + BORDEN TR

OZONESONDE OBSERVATIONS OVER NORTH AMERICA. VOLUME 3

AIR FORCE CAMBRIDGE RESEARCH LABCRATORIES, BEOFORD

AFCRL-64-30 (III) +. 270 PAGES, I TABLE, AUGUST 1965, CFST

SYSTEMATIC OBSERVATIONS CF THE VERTICAL OZONE DISTRIBUTION HAVE BEEN OBTAINED SINCE JANUARY 1963 FROM A NETWORK OF STATIONS IN NORTH AMERICA. OBSERVATIONS FOR THE FIRST EIGHT MONTHS OF THE PROGRAM (JANUARY THROUGH AUGUST 1963) WERE PUBLISHED IN OZONESONDE OBSERVATIONS OVER NORTH AMERICA, AFCRL-64-3011). AND $(2)$. VOLUME 3 CONTAINS THE OBSERVATIONS OBTAINEO DURING THE ONE-YEAR PERIOD SEPTEMBER 1963 THROUGH AUGUST 1964. THIS REPORT ALSO CONTAINS A SPECIAL SERIES OF OZONESONOE ASCENTS MADE AT LA PAZ, BOLIVIA 116.5 DEGREES 5 , 68.0 DEGREES WI UNDER THE DIRECTION OF L. ALDAZ, OF THE UNIVERSITY OF NEW MEXICO. IT. BECAME EVIDENT DURING THE COURSE OF THE PROGRAM THAT THE CHENILUMINESCENT SENSORS USED IN THE FIELD FROM ABOUT SEPTEMBER 1963 TO MAY 1964 WERE SUBJECT TO A LOSS IN SENSITIVITY DURING ASCENT. BEGINNING WITH OBSERVATIONS IN SEPTEMBER 1963, DATA WERE EXTRACTED FROM THE ORIGINAL FLIGHT RECOROS AT ONE-MINUTE INTERVALS IN LIEU OF THE HALF-MINUTE INTERVALS USED PREVIOUSLY. OZONAGRAMS FOR. THE PERIOD SEPTEMBER 1963 THROUGH AUGUST 1964 ARE PRESENTED.

* ENVIRONMENTAL CONDITION + *METEOROLOGY + \#OZONE + ATMOSPHERIC CHEMISTRY + INSTRUMENTATION, METEOROLOGICAL

$16-10645$ PROJECT DRIBBLE

U. S. WEATHER BUREAU

VUF-1020 +. 38 PAGES, 9 FIGUPES, 2 TABLES, DECEMBER 1965, CFSTI, $\$ 2.00 \mathrm{CY}$

THE WEATHER BUREAU PROVIDED WEATHER PLANNING AND PREDICTION FOR THE RADIOLOGICAL SAFETY PROGRAM OF THE SALMON EVENT, PROJECT ORIBBLE. OBSERVATIONS OF HINDS AND WEATHER CONOITIONS AT THE SITE BEGAN 20 MONTHS PRIOR TO THE EVENT. WIND AND TEMPERATURE SOUNDINGS AND WEATHER AND RADIOACTIVITY FORECASTING FACILITIES WERE ADDED DURING THE DETONATION AND POST-EVENT CRILLING PHASES. THE WINCS OURING THE 4 WEEKS FOLLOWING THE READY DATE WERE SUFFICIENTLY ABNORMAL IN DIRECTION ANO SPEED THAT THE PLANNED FIRING CRITERIA WERE NOT MET, RESULTING IN CELAYS AND CHANGES IN CRITERIA TO ACCEPT A WIOER RANGE OF CONDITIONS.

* ENVIRONMENTAL CONOITION + \#METEOROLOGY + \#NUCLEAR DETONATION + \#RADIOLOGICAL ASSISTANCE + * SITE Climatology + INSTRUMENTATION, METEOROLOGICAL

16-1064E STONE WA

METEOROLOGICAL INSTRUMENTATION OF THE HANFORO AREA

HANFORD ATOMIC PRODUCTS OPERATION, RICHLAND

HW-62455 +. 21 PAGES, 14 FIGURES, 1 TABLE, MARCH 1964, CFSTI, $\$ 0.50 \mathrm{CY}$

THIS REPORT LISTS THE METEOROLOGICAL INSTRUMENTS IN USE IN THE HANFORD AREA AND GIVES A BRIEF EXPLANATION OF HOW THEY WORK. IT ALSO INCLUDES INSTALLATION DATES, MAINTENANCE INFORMATION, AND SOME DISCUSSION OF SPECIAL PROELEMS. TYPES OF INSTRUMENTS INCLUDE - THE BENDIX-FRIEZ AEROVANE WIND-SPEED ANO DIRECTION TRANSMITTER, FOXBORO HUMIDITY SENSING CELL, FRIEZ MOOEL MICROBAROGRAPH, BENDIX-FRIEZ AUTOMATIC RAIN GAGE, THE EPPLY IO- JUNCTION PYRHELIOMETER, AND A CROUSE-HINDS TYPE DCE-16 CEILING PROJECTOR.

\#HANFORD SITE + \#INSTRUMENTATION, METEOROL OGICAL + \#MAINTENANCE ANO REPAIR + ENVIRONMENTAL CONOITION + MEASUREMENT, TEMPERATURE + METEOROLOGY + PRECIPITATION + SITE CLIMATOLOGY + WIND STATISTICS

$16-10648$ AEBY JW + KENNEDY WR

BETA-GAMMA RADIOACTIVITY IN ENVIRONMENTAL AIR AT LOS ALAMOS, NEW MEXICO, FOR 1963

LOS ALAMOS SCIENTIFIC LABNRATORY, LOS ALAMOS

LANS-3071 +. 22 PAGES, 3 FIGURES, 1 TABLE, JUNE 1964 , CFSTI, $\$ 0.50 \mathrm{CY}$

THIS REPORT IS A CONTINUATION OF WORK REPORTED IN THE LOS ALAMOS SECTION OF - RADIOACTIVE FALLOUT DATA COLLECTED FROM ELEVEN ATOMIC ENERGY INSTALLATIONS FOR 1958-(LAMS-2329), 1960, 
CATEGORY 16

METEOROLOGICAL CONSIDERATIONS

16-10648 \#CONTINUED*

1961, ANO 1963. THE 8ETA ACTIVITIES WERE NOT IDENTIFIED. HOWEVER, SINCE THE MEASUREMENTS WERE MADE IN THE SAME MANNER, THE VALUES ARE RELATIVE TO ONE ANOTHER. DAILY SAMPLES WERE

COLLECTED THROUGHOUT 1963. THE FIRST HALF OF 1963 SHOWED RESULTS CONSISTENTLY HIGHER THAN

THE FIRST HALF OF 1962. THE LAST HALF OF 1963 SHOWED A CONTINUOUS DECLINE IN ACTIVITIES.

* ENVIRONMENTAL CONDITION + \#FALlCuT + \#GAMMA + \#LASL (los alamos scientIFIC LABORATORY) +

*MONITOR, RADIATION, AIR

16-1C650 SCHUMCHYK MJ + MCNEILLY JH + HAMPTON WC + SACCENTI JC + MURSCHEL I + JACOBSON J MEASUREMENTS OF GAMMA RADIATION AND GAMMA SPECTRA VERSUS HEIGHT ABOVE A FALLOUT FIELD SIMULATED WITH CO-GO US NUCLEAR DEFENSE LABORATORY, EDGEWOOD ARSENAL

NDL-TR-70 + AD-474-963 +. 156 PAGES, FIGURES, TABLES, 22 REFERENCES, DOD

THIS EXPERIMENT DLTERMINEC THE FREE-FIELO DOSE RATES, GAMMA RADIATION BUILDUP FACTORS, AND AIR-TO-GROUND DOSE-RATE CORRELATION FACTORS AT VARIOUS HEIGHTS ABOVE A FALI DIIT FIELD SIMULATED RY $\triangle$ CO-60 SOURCE [XPOSED AT SEVERAL SOURCE-TO-DETECTOR DISTANCES. ANALYSIS OF SPECTRAL DATA OBTAINED ABOVE A CO-60 POINT SOURCE FOR SOURCE-TO-DETECTOR DISTANCES DISCUSSED IN THIS REPORT INDICATED THAT (A) SCATTERFR GAMMA RADIATION HAS OBSERVEO AT ALL ANGLES, (B) ENERGY OF THE SCATTER PEAKS VARIED FROM $50 \mathrm{KEV} \mathrm{TO} 70 \mathrm{KEV}$, (C) A COLLIMATED DETECTOR SAW NO OIRECT RADIATION COMPONENT THERE WERE NO HIGH-ENERGY GAMMA PHOTO PEAKS IN THE SPECTRAL DATA.

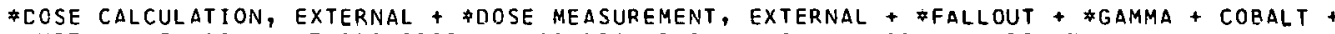

INSTRUMENTATION, METEOROIOGICAL + SOURCE, GROUND LEVEL + SOURCE, POINT

ILWIEUSI KAYNUR GS

RADIOACTIVE COPPER AS AN ATMOSPHERIC TRACER

RROOKHAVEN NATIONAL LABORATORY, UPTON

CONF-641 207-2 +. 34 PAGES, 20 FIGURES, 4 REFERENCES, DECEMBER 1964 , TO BE PRESENTED AT THE 1964 WINTER MEETING OF THE AMERICAN SOCIETY OF AGRICULTURAL ENGINEERS, DECEMBER 8-II, NEW ORLEANS, LOUISIANA, CFSTI

TECHNIQUES AND INSTRUMENTS HAVE BEEN DEVELOPLD FOR USING RACIOACTIVE COPPER AS A TRACER IN STUDIES OF DIFFUSION AND DISPERSION THROUGH THE ATMOSPHERE AND OF DEPOSITION ON THE GROUND AND VEGETATION. THE COPPER, IN THF FORM OF SPHERICAL PARTICLES, 2 TO 12 MICRONS IN DIAMETER, OR IN A SOLUBLE COMPOUND, IS ACTIVATED BY EXPOSURE TO A SLOW NEUTRON FLUX TO PRODUCE CU-G4. AFTER THREE YEARS OF ACTUAL FIELD EXPERIMENTATION, THIS TRACE SYSTEM HAS PROVEO SATISFACTORY FOR ITS DESIGNED PURPOSE AND IS CONSIDEREO WELL-ADAPTED FOR ANY APPLICATION WHERE MEASUREMENTS ARE DESIRED ON VEGETATIVE AND SOIL SURFACES AS WELL AS AIR.

* ATMOSPHERIC DIFFUSTON + *COPPER + \#TRACER, RADIOACTIVE + BNL (BROOKHAVEN NATIONAL LABORATORY) + DISPERSION + INSTRUMENTATION, METEOROLOGICAL

1E-15652 ATMOSPHERIC RACIOACTIVITY ANO FALLOUT RESEARCH OIVISION OF BIOLOGY ANO MEDICINE DIVISION OF TECHNICAL INFORMATION, USAEC

TIO-12616 (REV. 2$)+$. 127 PAGES, 5 FIGURES, DECEMBER 1964, CFSTI, $\$ 1.50 \mathrm{CY}$

THIS BOOKLET ON ATMOSPHERIC RADIOACTIVITY AND FALLOUT RESFARCH IS A SECOND REVISION OF ONE IN A SERIES OF SUCH PUBLICATIONS TO DESCRIBE THE RESEARCH SUPPORTED BY THE DIVISION OF BIOLOGY ANO MEOICINE, U. S. ATOMIC ENERGY COMMISSION. ITS PURPOSE IS TO ACQUAINT INTERESTED SCIENTISTS WITH THE OBJECTIVES, NFFDS, AND CONTENT OF THE PROGRAM. INDIVIDUAL DESCRIPTIVE SUMMARIES OF RESEARCH UNDER EACH CONTRACT ARE INCLUDED, MOSTLY BASED ON INFORMATION PROVIDED BY THE PRINCIPAL INVESTIGATOR OF EACH PROJECT. RESULTS OF THE INVESTIGATIONS ARE NOT INCLUDED HERE, BUT A SELECTION OF SCIENTIFIC PAPERS AND REPORTS ARE LISTED.

- AEROSOL + \#AIRBORNE RELEASE + \#ATMOSPHERIC DIFFIISION EXPERIMENT + \#FALLOUT + \#PRECIPIIATION + TRADIOACTIVITY, RELEASE + \$SAMPLING, HIGH ALTITUDE

1E- 1CE5Z MISKEL .IA + BONNEP. NA

DISTRIBUTION OF THE RADIOATTIVIIY FP.OM A NUCLLAR CRATERING EXHEKIMENT. PROJECT DANNY BOY LAWRENCE RADIATION LABQRATORY, LIVERMORE, CALIFORNIA

W1-1817 +. 23 PAGES, 4 FIGURES, 4 TABLES, 6 REFERENCES, SEPTEMBER 1964, CFSTI, \$2.DO CY

THE PRINCIPAL OBJECTIVE OF THE RADIOCHEMISTRY PROGRAM ON DANNY BOY WAS TO MEASURE THE AMOUNT AND DISTRIBUTION OF VENTED RADIONUCLIDES. THE TWO METHODS USED - CLOSE-IN FALLOUT COLLECTION AND AIRCRAFT SAMPLING - GIVE CONPLEMENTARY INFORMATINN, A FEW TENTIIS OF A PERCENT UL IHE NONVOLATILE FISSIÚN MRUOUCTS AND 10 TO 20 PERCENT OF THE MORE VOLATILE SPECIES WERE VENTED. A LARGE FRACTION OF THE NONVCLATILE PRODUCTS FELL OUT WITHIN IO MILES, WHEREAS THE MAJOR PORTION OF THE VOLATILE PRODUCTS DID NOT.

\DEPUSIIION + \#EXCAVATION, NUCLEAR + CESIUM + CONCENTRATION, GROUND LEVEL + CONCENTRATION, ISOPLETH + SAMPLING, HIGH ALTITUDE

16-10657 VAUGHN HR + MATEJKA DQ

PROJCCT SAND FINAL PROGRAM REPORT. VOLUME III. DYNAMIC ANALYSIS OF THE SAND SAMPLER FLICHT SANDIA CORPORATION, ALBUQULRQUE

SC-RR- $65-286+.71$ RACES, 24 FIGURES, 5 REFERENCES, SEPTEMBER 1965, CFSTI, \$3.00 CY, \$0.75 MN.

THE SAND (SAMPLER FOR AEROSPACE NUCLEAR DEBRIS) WAS DEVELOPED TO COLLECT SAMPLES OF NUCLEAR DEBRIS IN THE 100 TO 225 KILQFEFT AITITIINF RAMIgE. THE SAHD SAHPLER LUNSISIS UL A RULAEI-BUUSIED SAMPLER PAYLOAD THAT IS RETARDED IN DESCENT BY A LAREE I5O FEET CONSTRUCTED 
16-10657 \#CONTINUED*

DIAMETERI PARACHUTE. IMMEOIATELY AFTER THE PARACHUTE HAS OPENED NEAR APOGEE, SAMPLING VANES ARE EXTENDED FROM THE PAYLOAD, AND THE ENTIRE PAYLOAD IS SPUN. AT FIVE REVOLUTIONS PER SECOND BY HYDROGEN PEROXIDE JETS LOCATEO IN THE VANE TIPS. THE, SAMPLING MATERIAL, LOCATED IN THE VANES EXTRACTS THE NUCLEAR PARTICLES FROM THE AIR THAT FLOWS THROUGH THE VANES. THIS REPORT PRESENTS DYNAMIC ANALYSIS OF THE APPARENT OYNAMIC INSTABILITY AND CONSEQUENT STRUCTURAL FAILURE OF THE SAMPLER PAYLOAD. IT WILL BE SHOWN THAT THE FAILURE WAS CAUSEO BY A STRUCTURAL OVERLOAD THAT RESULTED FROM RESONANCE COUPLING BETWEEN THE PAYLOAD MOTION AND THE FIRST BENDING MODE OF THE SAMPLING VANES. FURTHER, THE RESONANCE OCCURRED $\triangle S$ A RESULT OF AN UNFORTUNATE CHOICE OF SPIN RATE, WHICH WOULO HAVE BEEN PRACTICALLY IMPOSSIBLE TO PREDICT PRIOR TO THE FLIGHT TEST.

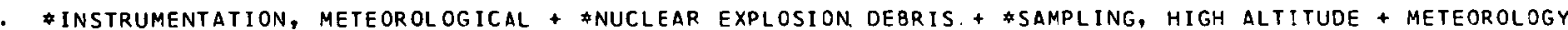

16-1065S JACKSON BS

BIBLIOGRAPHY OF ATMOSPHERIC OZONE TO $40 \mathrm{KM}$ - ITS CONCENTRATION, DISTRIBUTION, METHODS OF DETECTION, ANO RELATIONSHIP WITH OTHER METEOROLOGICAL PHENOMENA

LCS ALAMOS SCIENTIFIC LABORATORY, LOS ALANCS

LA-3328-MS +. 36 PAGES, JULY 1965, CFSTI, \$2.00 CY, \$0.50 MN

THE PERIOD COVERED IN THIS LITERATURE SEARCH ON ATMOSPHERIC OZONE IS 1960 THROUGH MARCH 1965. THIS BIBLIOGRAPHY INCLUDES REFERENCES TO JOURNALS, BOOKS, AND REPORTS. THE REFERENCES ARE ARRANGED ALPHABETICALLY BY AUTHOR ANO ALPHABETICALLY BY TITLE. EACH REFERENCE INCLUDES A NOTATION IDENTIFYING WHERE IT IS ABSTRACTED.

\# ATNOSPHERIC CHEMISTRY + \#BIBLIOGRAPHY + \#OZONE + \#STRATOSPHERE + METEOROLOGY

$16-1066 C$ ENGELMANN RJ

MIDAS COMPUTAIION OF WATEROROP EVAPORATION

BATTELLE-NORTHWEST, RICHLAND

BNWL-74 +. 39 PAGES, 8.FIGURES, I TABLE, 14 REFERENCES, JULY 1965, CFSTI, \$2.00 CY, \$0.50 MN.

ALTHOUGH THE THEORY AND FORMULAE FOR CALCULATING THE EVAPORATION OF FALLING WATERDROPS HAVE BEEN AVAILABLE FOR MANY YEARS, ONLY A. FEW CALCULATIONS HAVE BEEN MADE FOR SPECIFIC

TEMPERATURE AND HUMIDITY REGIMES. SEVERAL PROBLEM AREAS REQUIRING EVAPORATION ESTIMATES FROM METEOROLOGISTS INCLUDE - CHANGES IN RAINDROP SIZE DISTRIBUTIONS BETWEEN THE CLOUD AND THE MEASURING SITE AT GROUND LEVEL, EXTENT OF COOLING OF HEATED WATER BETWEEN A SPRINKLER AND VEGETATION OR POND, AND EXTENT OF EVAPORATION OF CARRIER DROPLETS FOR INSECTICIDES AND PESTICIDES BEFORE THEY REACH THEIR TARGEYS. THE MIDAS PROGRAM (MODIFIED INTEGRAL DIGITAL ANALOG SIMULATORI PROVIDES A METHOD FOR OBTAINING DIGITAL SOLUTIONS ON AN IBM 7090 . COMPUTER FOR SYSTEMS OF ORDINARY DIFFERENTIAL EQUATIONS. PROGRAMMING TECHNIQUES ARE VERY SIMILAR TO ANALOG PROGRAMMING. THE SIMPLICITY OF MIDAS AND SIMILAR PROGRAMS CURRENTLY BEING DEVELOPED ENABLE SCIENTISTS TO QUICKLY LEARN TO DO THEIR OWN PROGRAMMING AND DEAL DIRECTLY WITH THE COMPUTER--INDEP ENDENTLY OF FORTRAN AND THIRD PERSONS。

* COMPUTER PROgRAM, METEOROLOGICAL + \#EVAPORATION + \#WATER, GENERAL + HUMIOITY + METEOROLOGY

16-106E1 DOURY A + CAPUT C

DAILY MEASUREMENTS OF THE LONG LIVED ATMOSPHERIC RADIOACTIVITY PRESENT ON THE MAIN FRENCH NUCLEAR SITES IN 1963

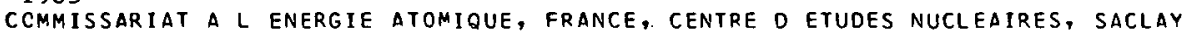

CEA-R-2627 +. 45 PAGES, JANUARY 1965, CEA, DEP. MN.

THIS REPORT FOLLOWS ON TO THE CEA REPORT 2397 AND IS DESIGNED PRIMARILY TO PROVIDE A DETAILED AND CONVENIENT RECAPITULATION OF THE MAIN MEASUREMENT RESULTS OBTAINFD DURING THE CONTINUOUS SUPERVISION OF FRENCH NUCLEAR SITES. THE RESULTS PUBLISHED CORRESPOND TO THE RADIO-ACTIVE. CONSTITUENT OF THE ATMOSPHERE WHICH SHOULD BE THE MOST AFFECTED BY ANY WASTF COMING FROM AN INSTALLATION (FISSION PRODUCTS). UP TO THE PRESENT, ONLY TEST EXPLOSIONS CAN REASONABLY BE HELD RESPONSIBLE FOR ATMOSPHERE POLLUTION, WHOSE LEVEL NEVERTHELESS REMAINS VERY LOW WITH

RESPECT TO PERMISSIBLE NORMS. ALL GRAPHS AND. CHART MATERIAL - NOT MUCH TEXT.

*NUCleAR EXPLOSION DEBRIS + *TEST, WEAPONS (HP ASPECTS) + \#TROPOSPHERE + PRECIPITATION

16-10662 CARBON-14 MEASUREMENTS IN THE ATMOSPHERE

U.S. ATOMIC ENERGY COMMISSION, NEW YORK, HEALTH AND SAFETY LAB

HASL-166 +. 73 PAGES, JANUARY 1966, CFSTI, $\$ 2.50 \mathrm{CY}, \$ 0.75 \mathrm{MN}$

CONTAINS A COMPILATION OF DATA FORWARDED TO THE HEALTH AND SAFETY LABORATORY THROUGH THE WEATHER BIIREAU, ENVIRONMENTAL SCIENCES SERVICES ADMINISTRATION. MOST OF THE DATA PERTAINS TO AIRCRAFT OBSERVATIONS, BUT A' FEH DEAL WITH BALLOON-BORNE SAMPLING $\triangle N D$ GROUND-LEVEL

COLLECTIONS. THE REPORT WAS EXPANDED TO INCLUDE THE DEFENSE ATOMIC SUPPORT AGENCY STAR DUST. PROGRAM ANO SOME EARLIER DATA FROM A UNITEO KINGDOM PROGRAM.

* ATMOSPHERIC CHEMISTRY + \#CARBON + \#MEASUREMENT, GENERAL + METEOROLOGY + SAMPLING, HIGH ALTITUDE

1E- 10663 CROC.KER GR + OCONNOR JD + FREILING EC

PHYSICAL AND RADIOCHEMICAL PROPERTIES UF FALLOUT PARTICLES

U. S. NAVAL RADIOLOGICAL OEFENSE. LABORATORY, SAN FRANCISCO

USNRDL-TR-899 +. 20 PAGES, 4 FIGURES, 2 TABLES, 11 REFERENCES,. JUNE 1965, CFSTI.\$1.00 CY, \$0.50 MN. 
CATEGORY 16

METEOROLOGI CAL CONSIDERATIONS

\begin{abstract}
$16-10663$ \#CONTINUED
A SURVEY HAS BEEN MADE OF THE LITERATURE ON THE CHARACTERISTICS OF FALLOUT PARTICLES. AN ATTEMPT IS MADE TO SUMMARIZE IN CONCISE FORM THE RANGES OF PHYSICAL AND RADIOCHEMICAL PROPERTIES OF PARTICLES OF THE OEBRIS PRODUCED BY DEVICES DETONATED UNDER VARIOUS CONDITIONS. THE PHYSICAL AND RADIOCHEMICAL PROPERTIES OF FALLOUT PARTICLES FROM NUCLEAR WEAPONS DO NOT FALL INTO NARROWLY DEFINED RANGES. DETONATIONS AT ALTITUDES SUFFICIENT TO PREVENT INCORPORATION OF SOIL INTO THE FIREBALL TENO TO PRODUCE SMALL, SPHERICAL, HIGHLY ACTIVE PARTICLES, WITH THE ACTIVITY DISTRIBUTED THROUGHOUT. IF SOIL AND OTHER ON-SITE MATERIAL IS INCORPORATED INTO THE FIREBALL, ONE OBSERVES INCREASED FREQUENCY OF PARTICLES WITH LOWER SPECIFIC ACTIVITY, IRREGULAR SHAPE, LARGER SIZE, EVIDENCE OF PARTIAL MELTING AND AGGLOMERATION, AND ACTIVITY CONCENTRATED ON THE SURFACE OF THE PARTICLE. THE LEACHING ACTION OF VARIOUS SOLVENTS ON FALLOUT PARTICLES DEPENDS UPON THE NATURE OF THE PARTICLES THEMSELVES AS WELL AS THAT OF THE SOLVENT.
\end{abstract}

\#FALLOUT + \#PROPERTY, PHYSITAL + \#RADIOCHEMICAL ANALYSIS

16-1CE64 RENOUX A

STUCY OF RAOIONCTIVE IONS IN THF ATMOSPHERE

CENTRE C ETUDES NUCLEAIRES, FONTENAY-AUX-ROSES

CEA-R-2771 + . RA PAFFS, 31 FIGURES, TABLES, MARCH 1965 , CEA

a COMPARATIVE STUDY IS MADE OT ACTIVE DEROSITS OF PADON ANO THORON IN SIISDFNSION IN THE ATMOSPHERE BY MEANS OF ALPHA RADIATION COUNTING, USING ZELENY TURES, SCATTERING EQUIPMENT, FILTER PAPERS, OR MEMBRANES. IT HAS BEEN POSSIBLE TO SHOW THE EXISTENCE OF SMALL AND LARGE IONS WHICH ARE NEGATIVE AND POSITIVE, AS WELL AS OF NEUTRAL RADIOACTIVE NUCLEI. THEIR PROPCRTIES ARE STUDIED. A THEORETICAL INTFRPRFTATION OF THE RESULTS IS PRESENTED. THE AVERAGE CONTENT OF RADON (USING THE RA A CONCENTRATION) AND OF TH B IN THE AIR HAS BEEN DETERMINED. THE RADIOACTIVE EQUILIBRIUM BETWEEN RADON AND ITS DAUGHTER PRODUCTS IN ATMOSPHERIC AIR ARE EXAMINED. THE TECHNIQUES DEVELOPED FOR ACTIVE RADON AND THORON DEPOSITS ARE APPLIED TO THE STUDY OF ARTIFICIAL RADIOACTIVITY, THE ANALYSES BEING CARRIED OUT BY MEANS OF GAMMA SPECTROMETRY.

* ATMOSPHERIC CHEMISTRY + *RADON * *THORON + MEASUREMENT, GENERAI + MFTEOROLOGY + TROPOSPHERE

$16-10665$ AEBY JW + KENNEDY WR

BETA-GAMMA RADIOACTIVITY IN ENVIRONMENTAL AIR AT LOS ALAMOS, NEW MEXICO, FOR 1964 LOS ALAMOS SCIENTIFIC LADORATORY, LOS ALAMOS

LA-3245-MS +. 24 PAGES, 3 FIGURES, 1 TABLE, APRIL 1965, CFSTI, $\$ 2.00 \mathrm{CY}$

THE REPORT IS A CONTINUATICN CF WORK REPORTED IN THE LOS ALAMOS SECTION OF RADIOACTIVE FALLOUT DATA COLLECTED FROM ELEVEN ATOMIC ENERGY INSTALLATIONS FOR 1958, LAMS-2397 INOV., DEC. OF 1958 AND ALL OF 1959), LANS-2499 (FOR 1960), LAMS-2702 (FOR 1961), LAMS-2870 (FOR 1962), AND LAMS-3071 (FOR 1963). THE BETA ACTIVITIES WERE NOT IDENTIFIED. HOWEVER, SINCE THE MEASUREMENTS WERE MADE IN THE SAME MANNER, THE VALUES ARE RELATIVE TO ONE ANOTHER. THE MONTHLY AVERAGE-PER-DAY GRAPHS SHOW, IN GENERAL, LOWER TRENDS THROUGHOUT THIS YEAR THAN LAST. FALLOUT FROM THE CHINESE DETONATION, ARRIVING LATE IN OCTOBER, SENT THE AVEPAGES FOR THAT MONTH SLIGHTLY HIGHIR THIAN WOULD HAVE NOR.MALLY BEEN EXPFT.TFD.

*FALLOUT + \#AMMA + \#LASL ILOS ALAMOS SCIENTIFIC LABORATORYI + \#NUCLEAR EXPLOSION DERRIS + FILTER + PRECIPITATION + SAMPLING

$16-10668$ KUCK GA

TIMI ECHAVIOR OF CHAPGED PAPTICLES INJECTFO BY 1962 HIGH ALTITUDE RUSSIAN NUCLEAR TESTS AIR FORCE INSTITUTE OF TFR.HNOI OGY, OHIO

AC- - $03599+.88$ PAGES, 28 FIGURES, 9 TABLES, AUGUST $1964, \mathrm{CFSTI}, \$ 4.00 \mathrm{CY}$

THE TIME BEHAVIOR OF THE CONCENTRATION OF CHARgED PARTICLES INJECTED BY THE HIGH-ALTITUDE RUSSIAN NUCLEAR TEST SERIES (1962) WAS FOLLOWED BY THE INSTRUMENTS ON AIR FORCE SATELLITE 1962 SY THE AIK FORCE CAMBRIDGE RESEARCH LADORATORIES. TWO WIOE-ANGLE RACIATION DFTFRTORS WERE ABLE TO FOLLOW THE TIME OLCAY OF THE CHARGED PARTICLES FOR 45 MAYS AFTER THE EXPLOSIONS. THE DATA FOR THIS TIME PERIOD WAS ANALYZED AND PRESENTEO AS PITR.H-ANGLE DISTRIBUTIONS AND MAXIMUM COUNTING RATES OF THE DETECTORS IN THE L-SHELL REGIONS OF SPACE 1.70-2.00 AT

DIFFERENT MAGNETIC LATITUDES. THE DECAY RATE OF THE INJECTED CHARGFD PARTICLES IN THESF I SHELLS WAS CONSISTENT WITH AN EXPONENTIAL DECAY HAVING A HALF-LIFE OF 9 TO 18 DAYS.

\#NUGLEAR FXPI OSION DFRRIS + \#PARTICLE, RADIOACTIVE + *SAMPLING, hIGH ALTITUDE +

\#UNION OF SOVIET SOCIALIST REPUBLICS + DATA PROCESSING + INSTRUMENTAIIUN, MEIEUKULUGICAL

16-10669 HANFORD RADIOLOGICAL SCIENCES RESEARCH AND DEVELOPMENT ANNUAL REPORT FOR 1964 BATTELLE-NORTHWEST, RICHLAND

BNWL-36 +. 344 PAGES, FIGURES, TABLES, REFERENCES, JANUARY $1965, \mathrm{CFST1, \$ 8.71} \mathrm{CY,} \$ 2.50 \mathrm{MN}$

THIS DOCUMENT IS THE ANNUAL REPORT OF THE ATMOSPHERIC PHYSICS GROUP OF BATTELLE-NORTHWEST. TOPICS COVERED INCLUDE - A MODEL OF DIFFUSION AND TRANSPORT FOR A CONTINUOUS RELEASE IN A STABLE ATMOSPHERE, MEASUREMENTS OF DISPERSION FROM A CONTINUOUS ELEVATED POINT SOURCE, ATMOSPHERIC TURBULENCE MEASUREMENIS, AREA DOSAGE RELATIONSHIPS DOWNHIND OF A POINT SOURCES PRECIPITATION SCAVENGING STUDIES, A SAMPLER FOR RECORDING THE CONCENTRATION AT AIPBORNE ZINC SULFIDE ON A REAL TIME SCALE, AND IMPROVEMENTS IN MICROMETEOROLOGICAL INSTRUMENTATION.

+ ATHOFRHERIG ETARILITY + \#PATTFIIF NORTHWFST + \#DISPERSION + \#INSTRUMENTATION, METEOROLOGICAL + *METEOROLOGY + \#PRECIPITATION + *SAMPLING, HIGH ALTITUDE + *SOURCE, CONTINUOUS + \#SUURCE, ELEVAILU + * SOURCE, POINT 
1E-10671 PROJECT HANDCAR. WEATHER AND RADIOLOGICAL SURVEILLANCE

WEATHER AND SURFACE RADIATION PREDICTION + U. S. PUBLIC HEALTH SERVICE + REYNOLOS ELECTRICAL AND ENGINEERING CO., INC.

PNE-8U7F +. 56 PAEES, FI IURES, TABLES, NCVEMBER 1965, CFSTI, \$3.CO CY, \$C.5C MN

PROPER EVALUATION ANO NININIZATION OF THE POTENTIAL RADIATION HAZARC ASSOCIATEO WITH THE POSSIBLE VENTING OF RADIOACTIVE MATERIALS FROM THE HANDCAR UNDERGROUND NUCLEAR DETONATION REQUIRED THE USE. OF METECRCLCGICAL FACILITIES FOR MEASURING ANO PRECICTING ATMOSPHERIC CONDITIONS. RADIATION MEASUREMENTS AT AND AFTER THE DETONATION INDICATED THAT THE ACTIVITY LEVELS REMAINED AT NORMAL BACKEROUND THROUGHOUT THE ENTIRE SAMPLING ARRAY. IT IS CONCLUDED THAT A RELEASE OF RAOIOACTIVITY, IF IT OCCURRED, WAS EXTREMELY SMALL AND BELOW DETECTABLE LIMITS.

* environmental conoition + \#MEteorology + \#UClear detonation + *Site Climatology + DOSE MEASUREMENT, EXTERNAL + SAMPLING, HIGH ALTITUDE

$1 E-10672$ VOLCHOK HL

HEALTH ANO SAFETY LABORATORY. THE HASL SURFACE AIR SAMPLING PROERAM SUMMARY REPORT FOR I9G3 NEW YORK OPERATIONS OFFICE, USAEC

HASL-156 +. 68 PAGES, 12 FIGURES, 4 TAELES, JANUARY 1965, CFSTI, $\$ 1.75 \mathrm{CY}$

TH IS REPORT COVERS THE FIRST YEAR OF OPERATION OF THE SURFACE AIR SAMPLING PROGRAM AT THE HEALTH AND SAFETY LABORATORY. THE DATA DEVELOPED IN 1963 AND A DESCRIPTION OF THE SAMPLING SITES, SAMPLING EQUIPMENT, AND METHCDS ARE PRESENTED. DURING 1963, OVER 1, TOO AIR-FILTER SAMPLES AND 400 SAMPLES OF PRECIPITATION WERE ASSAYED FOR GROSS-GAMMA CONCENTRATION, FISSION $\triangle N O$ NEUTRON ACTIVATION PRODUCTS. THE RESULTS INDICATE THAT IN NORTHERN HEMISPHERIC SURFACE AIR IN 1963, THE WELL-DOCUMENTED SPRING PEAK OCCURRED AND THAT IN GENERAL THE AIR HAS WELL NIXED WITH RESPECT TO FISSICN PRODLCTS. THROUGH MOST OF THE YFAR, THE AIR OF THE SOUTHERN HEMISPHERE WAS NOT AS THOROUGHLY NIXED. THE TRENDS OF VARTOUS RADIONUCLIDE CONCENTRATIONS ANO RADIONUCLIDE RATIOS SUGGEST THAT A SUBSTANTIAL PORTION OF THE NUCLEAR DEBRIS DETECTED AT GROUND LEVEL IN THE SOUTHERN HEMISPHERE CAME ACROSS THE EQUATOR FROM THE TROPOSPHERE OF THE NORTHERN HEMISPHERE.

\#AIR + \#AMPLING + FILTER + ERCSS GAMMA + NEUTRON + PRECIPITATION + TROPOSPHERE

$1 E-1$ C674 DE VRIES TW

FALLOUT RACIATION ENERGY DISTRIBUTION AS A FUNCTION OF ALTITUDE GENERAL DYNAMICS, FORT HORTH

$A D-602492+F Z K-187+N 64-27864+.209$ PAGES, 17 FIGURES, 22 TABLES, 5 REFERENCES, JULY 15,1964, CFSTI $\$ 6.00$

THE gamMa-RAY SPECTRA IN THE AIR ABOVE A PLANE CONTAINING FALLOUT FISSION PRODUCTS hERE CALCULATED AS A FUNCTION OF TIME AND ALTITUDE. SIMILAR CALCULATIONS WERE MADE BY USING THE SPECTRA OF COBALT-GC ANC CESIUM-137 AS SOURCE TFRMS. AN EXPERIMENT HAS DESIGNED TO MEASURE THE SPECTRA CALCULATED FOR COBALT-60, UTILIZING 11 COBALT-6O SOURCES ANO A VERY SENSITIVE NAI CAMMA-RAY SPECTRCMETER. THE RESULTS OF THE C.ALCIII,ATIONS INDICATE THAT THE PELATIVE SPECTRA ARE CONSTANT ABOVE 800 FT FOR TIMES AFTER FISSION GREATER THAN ONE DAY AND, FURTHERMORE, THAT THE VARIATION OF THE DCSE RATE WITH ALTITUDE IS CONSTANT FOR THIS TIME INTERVAL.

* DOSE CALCULATION, EXTERNAL + \#FLLOUT + \#URVEY, RAOIATION, AERIAL + CESIUM + COBALT + GaMMA

$16-10675$ BARRY PJ

THE WINC PROFILE

CHALK RIVER NUCLEAR LABORATORIES, CHALK RTVER

AECL-2574 +. 12 PAGES, 2 FIGURES, 1 TAELE, 14 REFERENCES, JUNE 1966 , PRESENTED AT NATIONAL METEOROLOGY

CONGRESS ROYAL METEOROLOGICAL SOCIETY, SHERBROOKE, QUEBEC, JUNE 8-10, 1966, AECL, \$O.5O CY

THE MAIN INTEREST IN THE WIND PROFILE IS BASED ON THE POSSIBILITY THAT IT MAY BE USED TO ESTIMATE THE SHEARING STRESS AT THE SURFACE. THIS PAPER REVIEHS SEVERAL SUGGESTED RELATIONSHIPS BETWEEN SURFACE STRESS AND WIND PROFILES FOR BOTH $\triangle D I A B A T I C$ AND DIABATIC CONDITIONS. A COMPARISON HAS BEEN MADE BETWEEN THE SHEARING STRESS ESTIMATED BY USE OF THEORETICAL EOUATIONS AND THE RESULTS FOUND IN. THE FEW AVAILABLE EXPERIMENTS. PROTAGONISTS CF SOME OF THE THEORIES HAVE MADE SWEEPING CLAIMS FOR THE ACCURACY OBTAINABLE WHEN ESTIMATING THE STRESS. THESE CLAIMS ARE CAREFULLY EXAMINED AND IT IS CONCLUDED THAT THERE IS AT PRESENT NO WAY OF RELIABLY MEASURING SURFACE STRESS FROM A WIND PROFILE.

* Wind PROFILE + CANADA + METEOROLOGY + TURRULENCE, SHEAR (WIND)

1E-1C67t BARRY PJ

FREQUENCY OF OCCURRENCES OF MAXIMUM POLLUTION LEVELS FROM SINGLE STACKS

CHALK RIVER NUCLEAR LABORATORIES, CHALK RIVER

$\triangle E C L-2575+.6$ PAGES, 9 FIGURES, 3 TAELES, 5 REFERENCES, JUNE 1966, AECL, \$O.50 CY

ARGON-41 IS CISCHARGED CCNTINUCUSLY FROM THE CRNL STACK AT AN ALMOST CONSTANT RATE. THE CONCENTRATION AT GROUND LEVEL WAS MEASURED CONTINUOUSLY AT FOUR SAMPLING STATIDNS AT VARIOUS DISTANCES AROUND THE STACK. THE NACNITUDE OF EXTREME POLLUTION LEVELS OCCURRING IN THE VICINITY, ANO ALSO THE FREQUENCY WITH WHICH EXTREME LEVELS OF DIFFERENT MAGNITUDES OCCUR, WERE ESTIMATED FROM THE RESULTS. THE OCCURRENCE OF EXTREME POLLUIIUN LEVELS IS RELATED TO SUCH VARIABLES AS ATMOSPHERIC STABILITY AND WIND TURBULENCE.

\# AREON + *ATMOSPHERIĆ POLLUTION + \#CHALK RIVER + \#NOBLE GAS + *STACK + ATMOSPHERIC STABILITY + METEOROLOGY 
CATEGORY 16

METEOROLOGICAL. CONSIDERATIONS

1E-10677 KRASNOPEVTSEV YV

TRANSPORT OF RADIOACTIVE AEROSCLS IN THE TROPOSPHERE FROM THE NORTHERN TO THE SOUTHERN HEMISPHERE

AD-617948 + FTD-TT-65-342 +. 10 PAGES, I FIGURE, 3 TABLES, METEOROLOGIYA I GIDROLOGIYA 4, PP. 3-8 (1964), CFSTI, \$1.00 CY

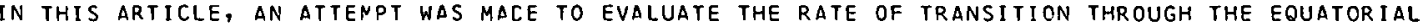
ZONE OT RADIOACTIVE AEROSOLS FORMED AS A RF.SIIIT OF NUCLEAR EXPLOSIONS IN THE NOP.THERN

HEMISPHERE. IT IS POSSIBLE TC CONCLUDE THAT THE TIME OF THE TRANSITION OF THE RADIOACTIVE AEROSOLS ACROSS THE EQUATORIAL ZONE AMOUNTS TO ABOUT THREE TO THREE-AND-ONE-HALF MONTHS. IN THIS CASE, ALL THE POINTS OF OBSERVATION WERE ALREADY ON THE I8OTH.MERIDIAN.

\# $A E R C S O L$ + \#FISSICN PRODUCT TRANSPORT + \#TROPOSPHERE + \#UNION OF SOVIET SOCIALIST REPUBLICS + NUCLEAR EXPLOSION DEBRIS

16-1C678 HUFF FA + BRADLEY WE

SIUL'I OP RATISOUT OF RADIOACTIVITY IN ILLINOIS

U. S. ATOMIC ENERGY COMMISSION, DIVISION OF BIOLOGY AND MEDICINE, WASHINGTON

CON-1199-8 +. 20 PAGES, 5 FIGURES, 2 REFERENCES, OCTOBER 1965, CFSTI, \$2.00 CY, \$O.5O MN

SURFACE-AIR ANC PRECIPITATION SAMPLES WERE COLLECTED DURING 14 RAINS ANG ANALYZED FOR GROSS RETA RADIOACTIVITY. PRELIMINARY INSPECTION INDICATES RELATIVELY WEAK CORRELATION BETWEEN RAOIOACTIVITY CONCENTRATIONS IN SURFACE AIR AND PRFCIPITATION. AN EXCEPTION OCCURRED ON MAY 26 WHEN HIGH AIR AND WATER CCNCENTRATIONS OCCURRED CLOSE TOGETHER IN THE SECOND AND THIRD SHOWERS. NO CONSISTENT INCREASE IN RADIOACTIVITY CONCENTRATIONS HAS BEEN FOUND IMMEDIATELY PRECEDING THE ONSET OF RAINSTORMS TO CORRESPOND WITH THE INITIALLY HIGH CONCENTRATIONS OF RAINWATER RAOIOACTIVITY USUALLY FOUND AT THE LEADING EDGE OF STORMS. AIRBORNE MEASUREMENTS OF PRECIPITATION RACIOACTIVITY DURING ONE STORM INDICATED AN INCREASE IN GROSS BETA ACTIVITY EETWEEN FLIGHT ALTITUDE ANO THE SURFACE. THE INCREASE IN CONCENTRATION IS MORE THAN CAN BE ACCOUNTED FOR BY EVAPORATION. FURTHER ANALYSIS OF THE DATA IN CONJUNCTION WITH ASSOCIATED METEOROLOGICAL CONDITIONS MUST BE MADE BEFORE FIRM CONCLUSIONS CAN BE ESTABLISHED.

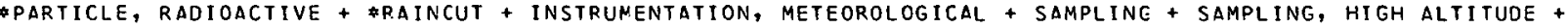
SURVEY, RADIATION, AERIAL

16-1067S FREILIN EC + KAY NA

RACIONUCL IDE FRACTIONATION IN AIR-BURST DEBRIS

U. S. NAVAL RADIOLOGICAL DEFENSE LAPORATORY, SAN FRANCISCO

USNRDL-TR-933 t. 21 PAGES, 1 FIGURE, 5 TABLES, 8 REFERENCES, SEPTEMBER 1965, CFSTI, \$1.00 CY, \$0.50 MN

RADIOCHEMICAL DATA FROM FRACTIONATEC SAMPLES FROM 15 AIRBURSTS PROVIOEO A SOURCE OF

EQUIVALENT-FISSION VALUES FOR 24 RADIONUCLIDES. THE AIRBURSTS RANGED IN YIELD BY A FACTOR OF OVER 300. THE EQUIVALENT-FISSION VALUES WERE CONVERTED TO RATIOS BASED ON ZR95, AND THESE RATIOS WERE COPRELATED LOGARITHMICALLY. THE CORRELATION SLOPES WERE RELATIVELY INSENSITIVE TO YIELD, AND THEIR VALUES PERMITTED THE PLACEMENT OF THE RACIONUCLIDES ON A SCALE OF VOLATILITY. SEVERAL GRCUPS OF RACIONUCLIDES DIO NOT FRACTIONATE FROM EACH OTHER. THE NUCLIDES CS137 ANO BAI4C HAD ESSENTIALLY THE SAME SLOPES FOR AIR BURSTS AS FOR HIGH-YIELD SURFACE BURSTS, BUT MO99 AND NP?39 PFHAVFD MORE VOLATILITY INFERRED FROM FRACTIONATION BEHAVIOR, CUKRFI ATFI WELL WITH THAT BASED ON TIIERMOOYNAMIC CALCULATIONS.

\#AIREORNE RELEASE + \#AIRBURST + \#FALLOUT + \#NUCLEAR EXP
BARIUM + T.FSTIIM + MOLYBDENUM + NEPTUNIUM + ZIRCONIUM

16-10680 WALKER ER

METFOROI OGICAL ASPECTS OF SANPLING CF AIREORNE ARTIFICIAL RADIOACTIVITY OVER CANAUA

SUFFIELD EXPERIMENTAL STATION, CANADA

CONF-64CECG-9 +. 22 PAGES, 16 FIGURES, JLLY 1964, PRESENTED AT THE 45TH ANNUAL MEETING OF THE PACIFIC

CIVISION, AMERICAN ASSOCIATION FOR IHE ADVANCEMENT OF SCIENCE, VANCOUVER, JUNE 23,1964, SOURCE

THE PAPER PRESENTED FAIRLY WELL ALL THE CANADIAN SAMPLING TO DATE (1964). DURING PERIODS OF CURRENT NUCLEAR TESTS THE PATTERNS IN IHF R.HARTS WERE AFFECTED BY CURRENT EVENTS. IN UNDISTURBED PERIODS, WHEN MATERIAL WAS FFD FROM THE STRATOSPHERE, THE ACTIVITY WAS ARRANGED IN CHARACTERISTIC PATTERNS WITH A MAXIMUM OF CONCENTRATIONS ON THE CANADIAN PRAIRIES. THE MAIN FEATURES OF THESE PAIIERNS CAN BE FXPLAINED IF THE DOWNWARD-MOTION MECHANISM MENTIONED IS CONSIDERED THE IMPORTANT TRANSFER AGENT. THE CANADIAN DATA SUGGESTS THAT DRY DEPOSIT IS NORMALLY ONLY A SMALL FRACTICN OF DEPOSIT IN PRECIPITATION.

* A IRBORNE RELEASE + *CANADA + *METECROLOGY + *SAMPLING + PRECIPITATION + STRATOSPHERE

$16-10681$ ERADQURY HG

ATNOSPHERIC DIFFUSION STUDIES AT THE NARF SITE

AIR FORCE WEAPONS LABORATORY, KIRTLAND, NEW MEXICO

AFWL-TR-64-156 +. 104 PAGES, 39 FIGURES, 15 TABLES, 24 REFERENCES, JUNE 1965, CFSTI

FOUR ATMOSPHERIC DIFFUSICN EXPERIMENTS WERE CONDUCTED IN THE NUCLEAR DEROSPACE RESEARCH FACILITY AREA AT GENERAL DYNAMICSIFORT WORTH TO STUDY THF DISPERSAL ANO OILUTION FACTORS OF THE ATMOSPHERE AS THEY PERTAIN TO THE RELEASE OF AIRBORNE RADIOACTIVITY IN THF NARF AREA. FLUORESCENT OYE WAS RELEASED TO THE ATMOSPHERE FROM A POINT NEAR THE REACTOR OPERATIONS BUILDING AND SAMPLED DOHNAINO TO MEASURE DEPLETION FACTORS UNDER VARYING METEOROLOGICAL CONDITIONS. THE TESTS WERE PERFORMED WITH AIR-TEMPERATURE GRADIENTS RANGING FROM SLIGHTLY UNSTABLF TO MILDLY STABLE (INVERSION) SITUATIONS. THE SAMPLING DATA OBTAINED WERE APPLIED IN THE EVALUATION OF THE PARAMETERS ASSOCIATED WITH THE STATISTICAL OIFFUSION EQUATION.

ALTHOUGH THE FOUR TESTS WERE TOO FEW TO PROVIDE SUBSTANTIAL STATISTICAL DATA, THE RESULTS 
CATEGORY 16

METEOROLOGICAL CONSIDERATIONS

16-10681 \#CONTINUED*

SHOW THAT UNDER THE POOREST DIFFUSION CONDITIONS EXPERIENCED, THE EFFLUENT DEPLETION FACTORS RANGES FROM APPROXIMATELY 10 TO THE MINUS 4 TO 10 TO THE MINUS 6 BETWEEN 88 AND 704 M FROM THE RELEASE POINT. THESE FACTORS ARE CONSIDERABLY LESS THAN THOSE ACTUALLY BEING APPLIED UNDER NUCLEAR SAFETY CONSIDERATIONS WITHIN THE NARF REACTOR OPERATIONS AREA.

\#OIFFUSION + \#ILUTION + \#ISPERSION + METECROLOGY + SAMPLING + TRACER, FLUORESCENT

1E-10682 FEELY HW + FRIEND JP + KREY PW + RUSSELL BA

FLIGHT DATA AND RESULTS OF RADIOCHEMICAL ANALYSES OF FILTER SAMPLES COLLECTED DURING 1961 AND 1962 I SOTOPES, INC., WESTWOOD, NEK JERSEY

HASL-15+. 219 PAGES, TABLES, JANUARY 1965 , CFSTI, \$3.00 CY

THIS IS THE FIRST OF A SERIES OF REPORTS OF FLIGHT DATA AND RESULTS OF RADIOCHEMICAL ANALYSES OF STRATOSPHERIC AND TROPOSPHERIC AIR-FILTER SAMPLES COLLECTED DURING PROJECT STAR. DUST. THE REPORT CONTAINS DAT.A FOR SAMPLES COLLECTED DURING JUNE 1961 TO DECEMBER 1962, THE FIRST YEAR-AND-A-HALF OF THE PRCJECT, PROJECT STAR DUST WAS DESIGNED TO PROVIDE INFORMATION NEEDED TO EVALUATE THE INFLUENCE. EXERTED BY THE UPPER ATMOSPHERE UPON GASEOUS AND PARTICULATE MATTER INTRODUCED INTO IT. THE WORK IS LEADING TO THE DEVELOPMENT OF A MODEL OF ATMOSPHERIC TRANSPORT PROCESSES THAT WILL DESCRIBE MIXING AND TRANSFER OF TRACE MATERIALS IN THE STRATOSPHERE AND UPPER ATMOSPHERE. THIS WILL PERMIT THE DETERMINATION OF LONG-RANGE RADIOACTIVE FALLOUT DISTRIBUTIONS AND BIOLOGICAL DOSES TO BE EXPECTED FROM ALL KINDS OF RELEASES OF RADIOACTIVITY IN THE ATMOSPHERE. A CLOSELY RELATED ASPECT OF THE PROJECT INVOLVES THE DETERMINATION OF THE DISTRIBUYION IN THE STRATOSPHERE OF RADIOACTIVE DERRIS PRODUCED BY NUCLEAR HEAPONS TESTS CONDUCTED PRIOR TO AND DURING THE PERIOD OF THE PROJECT, AND. THE INFLUENCE OF STRATOSPHERE-TROPOSPHERE EXCHANGE PROCESSES ON THAT DEBRIS.

\#FILTER + \#RADIOCHEMICAL ANALYSIS + \#SAMFLING, HIGH ALTITUDE + \#STRATOSPHERE + \#TROPOSPHERE + ATMOSPHERIC DIFFUSION EXPERIMENT + BARIUM + CERIUM + MOLYBOENUM + STRONTIUM + ZIRCONIUM

$16-10684$ ENGELMANN RJ

THE PHYSICS OF PRECIPITATION SCAVENGING

PATTELLE-NORTHWEST, RICHLAND

BNHL-SA-400 + CONF-651122-1 +, 10 PAGES, TO BE PRESENTED AT THE AMERICAN ASSOCIATION OF PHYSICS TEACHERS,

RICHLAND, WASHINGTON, NOVEMBER 13,1965, CFSTI

DETERMINING THE COLLISION PROCESS. IS A NONLINEAR EQUATION INVOLVING SEVERAL FORCE FIELDS ANO THE RATHER UNCERTAIN VELOCITY FIELO OF THE AIR FLONING PAST THE FALLING DROPLET OR FLAKE. NUMERICAL SOLUT IONS OF THIS EQUATION HAVE BEEN MAOE ONLY FOR UNCHARGEO PARTICLES OF RATHER SMALL SIZE BEING OVERTAKEN BY SPHERICAL RAINDROPS. MUCH EXPERIMENTAL WORK HAS FOLLOWED THIS ATTACK OF II) MEASURING. THE COLLECTION OF EACH SIZE OF DROP ON EACH SIZE OF PARTICLE, (2) SEPARATELY MEASURING THE SIZES OF DROPS THAT FALL IN A RAIN, AND THEN (3) IN INTEGRATING THE RESULTS TO OBTAIN THE WASHOUT COEFFICIENT.

*ATMOSPHERIC POLLUTION + \#PRECIPITATION + \#SAMPLING + METEOROLOGY + HASHOUT

16-10765 FENDLER H + KNOERZER G

RACIATION PROTECTION FOR PCWER STATIONS AND SURROUNDINGS

AEG ALLGEME INE ELEKTRICITATS-GESEILSCHAFT, FRANKFURT, GERMANY + KERNKRAFTWERK RWE-BAYERNWERK GMBH, GUNOREMMINGEN, GERMANY

5 PAGES, 3 FIGURES, 3 TABLES, REFERENCES, NOVEMBER 1965. TRANSLATED FROM ATOMWIRTSCHAFT 10 (11)- 627-631 (NOVEMBER 19651

FOR german POWER PLANTS, THE TEMPERATURE, HUMIDITY, AND WIND DIRECTION IN THF ATR laYYSP NEAR THE GROUNO ARE MEASURED AT A $118-\mathrm{M}-\mathrm{HIGH}$ MAST AT THE PLANT. MEASUREMENTS WERE MADE FROM FALL OF 1963 TO EARLY 1965 AT HEIGHTS CF $2,10,40,80$, AND 118 M. AFTER THE PLANT STARTUP, THE WIND DIRECTION AND VELOCITY ARE CONTINUOUSLY MEASURED AND RECORDED BOTH AT THE WEATHER MAST WIND DIRECTION AND VELOCITY ARE CONTINUOUSLY MEASURED AND RECORDED QOTH AT THE WEATHER
AND ABOVE THE REACTOR BUILDING. THE METEOROLOGICAL OPINION IWHICH TAKES IN THE GENERAL CLIMATOLOGICAL RELATIONSHIPS OF THE PLANT SITEI WAS USEO TO ESTABLISH THE MAXIMUM PERMISSIBLE QUANTITIES OF ACTIVITY ABOVE THE 110-M CHIMNEY DURING PLANT OPERATION.

\#GERMANY + *MEASUREMENT, EENERAL + \#METEOROLOGY + \#SITE ClimaTOLOGY + HUMIOITY + STACK + WIND PROFILE

16-1076E PETERSEN AH

WASHOUT OF PARTICULATE MATTER IN LONG-TERN CLOUDS PRODUCED BY NUCLEAR EXPLOSIONS

LAWRENCE RADIATION LABORATCRY, LIVERMORE, CALIFORNIA

UCRL-14700 +. 22 PAGES, 5 FIGURES, 2 TABLES, 33 REFERENCES, MARCH 1966, CFST1, $\$ 2.00 \mathrm{CY}, \$ 0.50$ MN

THE THEORY OF RAIN-SCAVEAGING GF AIREORNE PARTICLES IS EXTENDED TO THE MORE GENERAL CASE OF MOVING, POLYOISPERSE POPULATIONS. VALUES FOR A MULTIDIMENSIONAL HASHOUT COEFFICIENT AS A FUNCTION OF PARTICLE RADIUS AND RAIN INTENSITY ARE GIVEN. BY USING EXPRESSIONS FOR THE CONCENTRATION HITHIN AN INSTANTANEOUS POINT-SOURCE CLOUD WITH A SPECTRUM OF PARTICLE SIZES, FORMULAE ARE DER IVED WHICH GIVE THE RATE OF DEPOSITION AND INTEGRATED DEPOSITION OF RADIOACTIVITY OR PARTICLES FROM A LONG-TERM NUCLEAR-DEVICE CLOUD AT ANY POINT DOWNWIND. BY EMPLOYING RECENT EMPIRICAL OATA FOR THE DISTRIBUTION OF RADIOACTIVITY WITH PARTICLE SIZE WITHIN THE CLOUD FROM THE SEDAN EVENT, THE EQUATIONS ARE USED TO CALCULATE THE MAXIMUM INTEGRATEO DEPOSITICN OF RADIOACTIVITY THAT MIGHT BE SCAVENGED FROM LONG-TEPM CLOUDS PRODUCED INY CLOUD DEPOSITED WITHIN THE FIRST METER IS PRESENTED NOMOGRAPHICALLY, WITH VARIOUS WIND SPEEDS IN MILES PER HOUR ANO RAIN INTENSITIES IN MILLIMETERS PER HOUR.

* AIRBORNE RELEASE + \#DEPOSITION + \#EXCAVATION, NUCLEAR + \#NUCLEAR EXPLOSION CEBRIS + 
CATEGORY 16

METEOROLOGICAL CONSIDERATIONS

16-1076E \#CONTINUED

*PARTICLE, RAOIOACTIVE + \#HASHOUT + EQUATION, GENERAL + METEOROLOGY + PARTICLE SIZE DISTRIBUTION

16-1076S LAVRENCHIK VM

GLODAL TALLOUT PRODUCTS OF NUCLEAP. EXPLOSIONS

AEC-TR-6666 +. 192 PAGES, 68 FIGURES, 17 TABLES, 173 REFERENCES, TRANSLATION OF GLOBAL NOE VYPADENIE PRODUKTOV YADERNYKH VZRYVOV, ATOMIZDAT, MOSCOW, 1965, CFSTI, \$5.0O CY, \$1.0C MN.

THIS WORK WAS TRANSLATED FRCM RUSSIAN. THE TRANSLATION CONSISTS OF SEVEN CHAPTERS. IN CHAPTER I, WITHOUT A MFTAII.FD SURVEY OF THE PHYSICS OF FISSION, THE BASIC QUANTITATIVE RELATIONSHIPS OF THE FORMATION OF THE PRODUCTS OF NUCLEAR EXPLOSIONS ARE CONSIDEREO. CHAPTER II IS DEVOTED TO THE PROCESS OF THE FORMATION OF RAOIOACTIVE AEROSOLS. THE CONNECTION PFTHEFN THE RATE OF COOLING OF THE FIREBALL AND THE YIELD OF THE BURST IS ESTABLISHED. IN CHAPTER III, A SURVEY $1 S$ GIVEN OF THE BASIC METHODS OF COLLECTING AND ANALYZINC SAMPLES OF THE PRODUCTS OF NUCLEAR BURSTS IN THE ATMOSPHERE. IN CHAPTERS IV AND V, THE BEHAVIOR OF RADIOACTIVE AEROSOLS IN SPACE (IN THE ATMOSPHERE) AND IN TIME IS DESCRIBED. IN CHAPTER VI, DATA ARE COLLECTED ON FORECASTING RADIOACTIVE FALLOUT FROM THE TROPOSPHERE AND THE STRATOSPHERE. IN CHAPTER VII, WE GIVE A BRIEF SURVEY OF CONTEMPORARY CONCEPTS OF THE HARMFUL BIOLOGICAL EFFECTS OF THE RADIOACTIVITY ON MAN.

\# AEROSOL, RADIOACTIVE + \#FALLOUT + \#NUCLEAR EXPLOSION DEBRIS * *SAMPLING + \#STRATOSPHERE + \#TROPOSPHERE + -UNION OO SOVIET SOCIALIST REPUBLICS + NEROSOL PROQUETION + PRFCIPITATION

16-1078E SPURR C

CCRRESPCNDENCE, THE BENT-OVER PLUME CF HCT GAS

CENTRAL ELECTRICITY RESEARCH LABORATORIES

1 PAGE, ROYAL METEOROLOGICAL SOCIETY QUARTERLY JOURNAL 83- $269(1957)$

IN THIS CORRESPONDENCE, THE AUTHOR DEVELOPS A CUBIC EQUATION FOR FINDING $Z-S U B-1$, FROM WHICH THE CEILING HEIGHT OF THE PLUME CAN BE FOUND USING THE PRIESTLY FORMULA, (EG. 12) IN QUARTERLY JOURNAL OF THE ROYML METEOROLOGICAL SNCIFTY B2, P. $165,1956$.

\# EUOYANT RISE + HEIGHT OF RISE

$16-10787$ SCHMIDT FH

ON THE RISE OF HOT PLUMES IN THE ATMOSPHERE

RCYAL NETHERLANOS METEOROL OGIC.AI INSTITUTE

24 PAGES, 7 FIGURES, 7 TABLES, 19 REFERENCES, INTERNATIONAL JOURNAL OF AIR AND WATER POLLUTION $9(4)-$ $175-198$ (APRIL 1965 )

A THEORY FOR THE RISE OF A HOT PLUNE IN A STABLE ATMOSPHERE HAS BEEN DEVELOPED AND APPEARS POSSIBLE TO COMPUTE THE MINIMUM PLUME RISE. THE RESULTS OF THE COMPUTATIONS HAVE BEEN COMPARED WITH AVAILABLE PLUME RISE OBSERVATIONS. THEORETICAL AND EXPERIMENTAL VALUES ARE IN SATISFACTORY AGREEMENT.

*BUOYANT RISE + ATMOSPHFRIC. STABILITY + COMPARISON, THEORY AND EXPERIENCE + HEIGHT OF RISE + SOURCE, ELEVATED + STACK

16-10811 WILSON IJ

A.E.A. WORK FOR THE CONCORD

UNITEO KINGOOM ATOMTC ENERGY AUTHORITY, ALOERMASTON

8 PAGES, 6 FIGURES, ATOM, (108), PAGES 211-218 (OCTOBER, 1965)

PASSENGERS AND CREW OF THE FUTURE, FLYING AT ABOUT 65, 000 FT OR ABOVE S3 PERCENT OF THE ATMOSPHERE, WILL ENCOUNTER HIGHER DOSE RATES DUE TO COSMIC RADIATION. THIS RADIATION COMES FROM TWO SOURCES - THE NORMAL, STEADY, LOW-INTENSITY FLUX OF HIGH- AND VERY-HIGH-ENERGY PARTICLES WHICH ORIGINATE OUTSIDE OUR SOLAR SYSTEM, AND FREQUENT, SHORT-LIVFN, VARIABLE, HIGH-INTLNSITY FLUX OF MODERATE- AND HIGH-ENERGY PARTIG.I.FS RFI.EASED FROM THE SUN BY SOLAR TLARES. THE AVERAGE ENERGY OF THESE PAR.TICLES IS MFASURFD IN THOUSANOS OF MILLIONS OF ELECTRON VOLTS. BECAUSE CF THE WAY IN WHICH PRIMARY GALACTIC PARTICLES INTERACT WITH THE TOP OF THE ATMOSPHERE, IT IS NOT POSSIBLE TO OBTAIN CONCORD CRUISE ALTITUDE DOSE-RATES BY SIMPLY SCALING UP THE VALUES MEASURED IN JET AIRLINES.

AEROSPACE SAFETY + COSMIC RADIATION

16-10813 SMITH FB

THE ROLE OF WIND SHEAR IN HORIZONTAL DIFFUSION OF AMBIENT PARTICLES

METEOROLOGICAL OFFICE, BRACKNELL, BERKSHIRE

12 PAGES, 5 FIGURES, REFERENCES, QUARTERLY JOURNAL OF THE RDYAL METEOROLOGICAL SOCIETY, $91(389)$, PAGES 318-329 (JULY, 1965 )

A CHANGe IN THE HIND VECTOR WITH HEIGHT CAN HAVE A VERY MARKED EFFECT ON THE OIFFUSION OF TRACERS. CORRSIN (1953), SAFFMAN (1962), ANO HOGSTROM (1964) SHOWED THAT AT LARGE DISTANCES FROM THE SOURCE OF A TRACER, THE HORIZONTAL SPREAD OF THIC CLOUD VARIES WITH TIME T LIKE T TO THE 3/2 POWER, PROVIDED THAT THE VELOCITY SHEAR IS MAINTAINED OVER A SUFFICIENT DEPTH OF THE ATMOSPHERE. THEIR RESULT IS EXTENDED IN TWO WAYS, FIRST TO ALL VALUES OF $T$, AND SECOND BY TAKING INTO ACCOUNT THE CORRELATION BETWEEN HORIZONTAL AND VERTICAL EDDY VELOCITIES. THE MOST SITNIFIT.ANT RFSUIIT OF THE LAITER EFFECT IS TO REDUCE THE DISPLACEMENT OF THE PLUME AT ANY LEVEL IN THE DIRECTION OF THE SHEAR. AT SMALL TIMES OF TRAVEL, IT IS SHOWN THAI IHE RELATIVE SPREAD IS ACTUALLY LESS IN THE PRESENCE OF SHEAR THAN PREDICTED BY THE CONVENTIONAL 
CATEGORY 16

METEOROLOGICAL CONSIDERATIONS

16-10813 *CONTINUED*

TAYLOR METHOD.

ATMOSPHERIC DIFFUSION + ATMOSPHERIC DIFFUSION COEFFICIENT + TURBULENCE, SHEAR (WINDI +

TURBULENCE, STATISTICS

16-10814 HARDIN J + GOLD S + KAHN B + STRAUB CP

MEASUREMENT OF RADIOACTIVE FALLOUT ON AIREORNE PARTICLES

RCBERT A. TAFT SANITARY ENGINEER ING CENTER, CINCINNATI, OHIO

12 PAGES, 5 TABLES; 5 FIGURES, 14 REFERENCES, HEALTH PHYSICS, 10, PAGES 563-575 (FEBRUARY, 1964)

RADIOACTIVE FALLOUT IN AIR WAS MEASURED AT CINCINNATI, OHIO, BY ANALYSIS OF FILTER SAMPLES COLLECTED WITH HIGH-VOLUME AIR SAMPLERS. FALLOUT FROM THE USSR NUCLEAR TESTS DURING THE FALL OF 1961 WAS FIRST DETECTED ON SEPTEMBER 15. RADIOACTIVITY LEVELS WERE MEASURED DAILY FOR THE NEXT 6 MONTHS. RADIONUCL IDES WERE IDENTIFIED AND MEASURED RADIOCHEMICALLY ANO BY GAMMA SPECTRAL ANALYSIS. THE RELATIVE CONCENTRATIONS OF THE MAJOR FISSION PRODUCTS HERE COMPARABLE TO COMPUTED VALUES BASED"ON FISSION YIELD AND RADIOACTIVE DECAY.

*AIR + \#FALLOUT + \#MONITOR, RADIATION, AIR + FILTER, FIBERGLASS + SAMPLING

16-10817 WHITEHEAD HC + FETH JH

CHEMICAL COMPOSITION OF RAIN, DRY FALLOUT, ANO BULK PRECIPITATION AT MENLO PARK, CALIFORNIA, I957-1959 U. S. GEOLOGICAL SURVFY, MENLO PARK, CALIFORNIA

14 PAGES, 3 TABLES, 5 FIGURES, 18 REFERENCES, JOURNAL OF GEOPHYSICAL RESEARCH 69(16), PAGES $3319-3333$

(AUGUST 15,1964 )

WINTER PRECIPITATION IS DEFINEO AS RAIN, DRY FALLOUT, AND BULK PRECIPITATION - THE LAST BEING A MIXTURE OF THE OTHER TWO. THE OIVISION OF WINTER PRECIPITATION INTO PHASES IS RASED ON COLLECTION PROCEDURES. EACH PHASE SHOWS DISTINCTIVE CHARACTERISTICS OF CHEMICAL COMPOSITION. RAIN OISPLAYS THE STRONG INFLUENCE OF THE NEARBY PACIFIC OCEAN AND SAN FRANCISCO BAY. DRY FALLOUT, COLLECTED BETWEEN RAINS, SHOWS STRONG EFFECTS FROM LOCALLY DERIVED MATERIALS IN THE ATMOSPHERE. BULK PRECIPITATION SHOWS, IN CHEMICAL COMPOSITION, THE EXPECTED BLENDING OF THE TWO ENVIRONMENTAL INFLUENCES AND IS $\triangle B O U T$ 4 TO NEARLY 10 TIMES HIGHER IN MINERAL

CONCENTRATION THAN RAINWATER IS. BULK PRECIPITATION IS CONSIDERED THE GEOCHEMICALLY

SIGNIFICANT PHASE THAT SHOULD BE USED IN STUDIES RELATING CONTRIBUTIONS OF ATMOSPHERIC SALTS

TO SURFACE- AND GROUNDWATER SUPPLIES, TO WEATHERING, AND TO THE NOURISHMENT OF GROWING PLANTS.

*ATMCSPFERIC CHEMISTRY + \#FALLCUT + \#RAINCUT + SAMPLING

16-10818 VAN HULSTEYN DB

THE ATMOSPHERIC PRESSURE WAVE GENERATED BY A NUCLEAR EXPLOSION - PART 1 AND PART 2

UNIVERSITY OF MICHIGAN, RADIATION LABORATORY, ANN ARBOR

22 PAGES, 5 FIGURES, 23 REFERENCES, JOURNAL OF GEOPHYSICAL RESEARCH, 70(2), PAGES $257-278$ (JANUARY 15, 1965)

THE PROBLEM OF DESCRIBING THE PRESSURE HAVE DETECTED BY AN OBSERVER ON THE GROUND A FEH THOUSAND KILOMETERS FROM A LOW-ALTITUDE NUCLEAR EXPLOSION IS FORMULATED. TO AVOID NUMERICAL COMPLICATIONS, THE ATMOSPHERE IS ASSUMED TO HAVE AN I SOTHERMAL TEMPERATURE DISTRIBUTION. WITH THIS SIMPLIFICATION A GREENS FUNCTION FOR THE PROBLEM IS DEVELOPED AS AN EXPANSION IN LEGENDRE POLYNOMIALS. THIS REPRESENTATION YIELDS A TIME-DEPENDENT PRESSURE FUNCTION WHICH SATISFIES THE CONDITION OF CAUSALITY BUT WHICH CONVERGES FAR TOO SLOWLY TO BE USEFUL. AN ALTERNATIVE SCHEME, WHICH IS ENTIRELY EQUIVALENT, MAKES USE OF A WATSON TRANSFORMATION AND REQUIRES THE DETERMINATION OF THE SET OF REGGE POLES. THE BEHAVIOR OF THE COMPLETE GREENS FUNCTION IS THEN SHOWN TO BE DOMINATED BY THE SO-CALLEO GRAVITY WAVE MODE, AND THF GORM OF THIS APPROXIMATE SOLUTION IS DEVELOPED.

*TEST, WEAPONS (HP ASPECTS) + \#TROPOSPHERE + EQUATION, GENERAL + EXPLOSION + PRESSURE, EXTERNAL

$1 \in-10967$ SINGER IA

WINO GUST SPECTRA

EROOKHAVEN NATIONAL LABORATORY

ENL-7328 +.17 PAGES, 12 FIGURES, 1 TABLE, 12 REFERENCES, ANNALS NEW YORK ACADEMY OF SCIENCES, $116(11$, PACES $116-134(1964)$

THE MAJOR POINTS OF THIS PAPER ARE - $(1)$ INTENSITY OF TURBULENCE IS CONSTANT HITH HEIGHT. $(2)$ LOCAL ISOTROPY EXISTS AT WAVE LENGTHS SHORTER THAN ABOUT $100 \mathrm{M}$. (3) HORI ZONTAL ISOTROPY CONTINUOUS UP TO WAVE LENGTHS OF ABOUT $500 \mathrm{M}$. (4) CROSS SPECTRA ARE ESSENTIALLY ZERO IN RANGE OF INTEREST. (5) CROSS-CORRELATION COEFFICIENT OF SIMILAR WIND COMPONENT IS A FUNCTION OF RATIO OF HEIGHTS. THE RESULTS ARE ONLY APPLICABLE BETWEEN 75 AND 300 FT OVER FAIRLY SMOOTH TERRAIN.

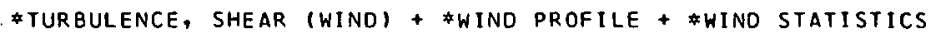

$16-10968$ SAYERS $J$

THE ELECTRON DENSITY OISTRIBUTION IN THE TOPSIDE IONOSPHERE. II. EFFECTS OF THE NUCLEAR EXPLOSION OVER JOHNSTON ISLAND AND THE IONIZATION PRODUCED BY CORPUSCULAR RADIATION AT HIGH MAGNETIC LATITUDES

6 PAGES, 5 FIGURES, 1 REFERENCE, PROCEEDINGS OF THE ROYAL SOCIETY, SERIES A, $281(13871$, PAGES $459-464$, (OCTOBER 10,1964

CORPUSCULAR RADIATION SEEMS TO BE A MAJOR SOURCE OF IONIZATION IN THE TOPSIDE IONOSPHERE IN 


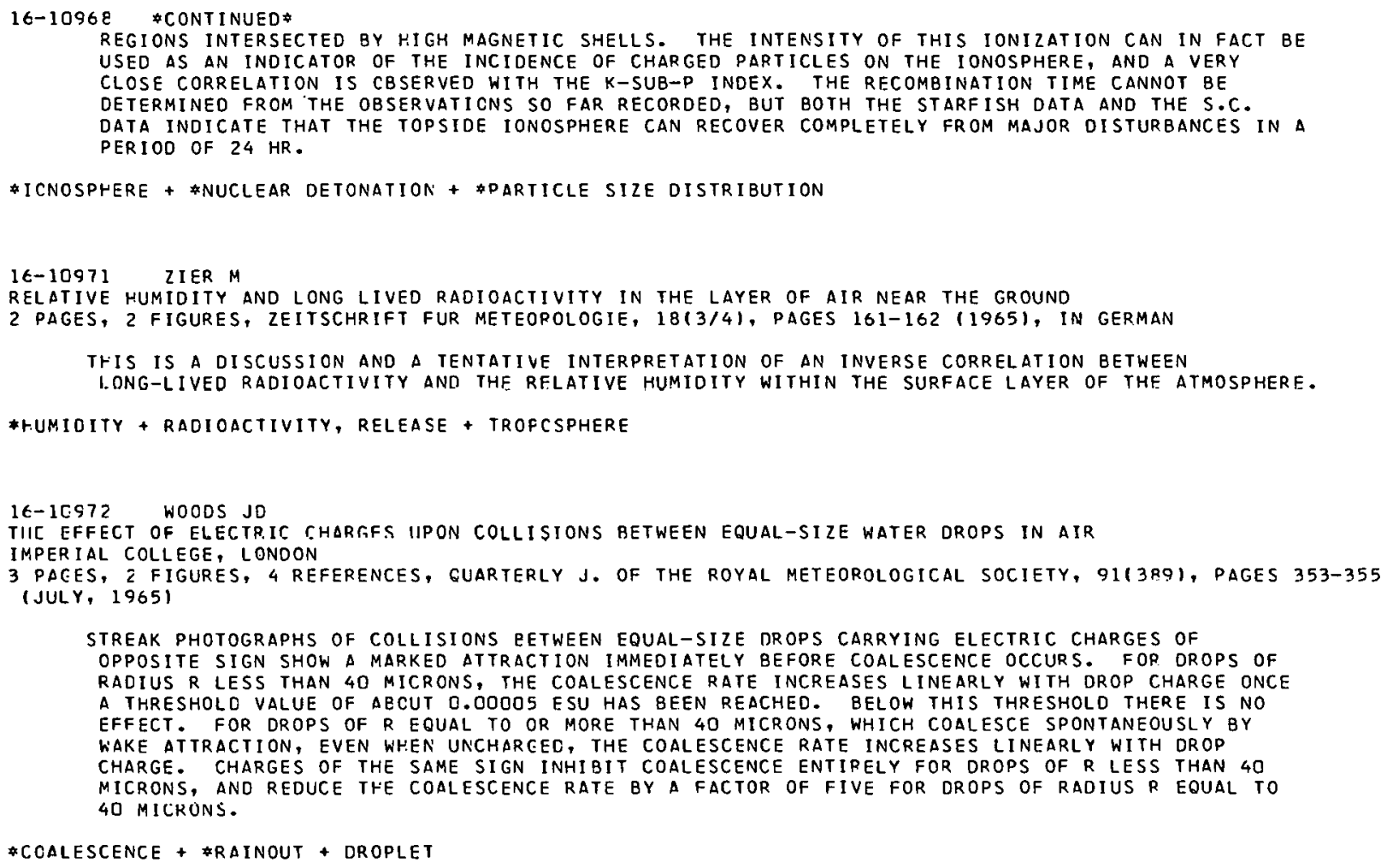

16-11114 KENNEDY WR + AEBY JH

BETA-CAMMA RADIOACTIVITY IN ENVIRONMENTAL AIR AT LOS ALAMOS, NEW MEXICO, FOR 1965 LOS ALAMOS SCIENTIFIC LABORATORY, NEW MEXICO

LA-3516 +. 22 PAGES, 1 TABLE, 3 FIGURES, JANUARY, 1966 , CFSTI, $\$ 2.00 \mathrm{CY}, 50.50 \mathrm{MN}$

AS PART OF THE ENVIRCNMENTAL RADIATION MONITORING PROGRAM AT LOS ALAMOS, MEASUREMENTS OF AIRBORNE RADIOACTIVE PARTICLES AND RADIOACTIVITY IN PRECIPITATION ARE MADE PERIODICALLY. C.AILY SAMPLES WERE COLLECIEO THROUEHOUT 1965. TIIE DECLINE IN PACIOACTIVITY THAT STARTED IN THE I.AST HALF OF 1963 CONTINUED THROUGHOUT 1965 . NO FALLOUT HHICH COULD BE ATTPIBUTED TO ATMOSPHERIC TESTING COULD EE DETECTED.

\#FALLOUT + \#LASL (loS ALAMOS SCIENTIFIC LABORATORY) + \#MONITOR, RADIATION, ENVIRONMENTAL + RAINOUT + 
CATEGORY 16

METEOROLOGICAL CONSIDERATIONS

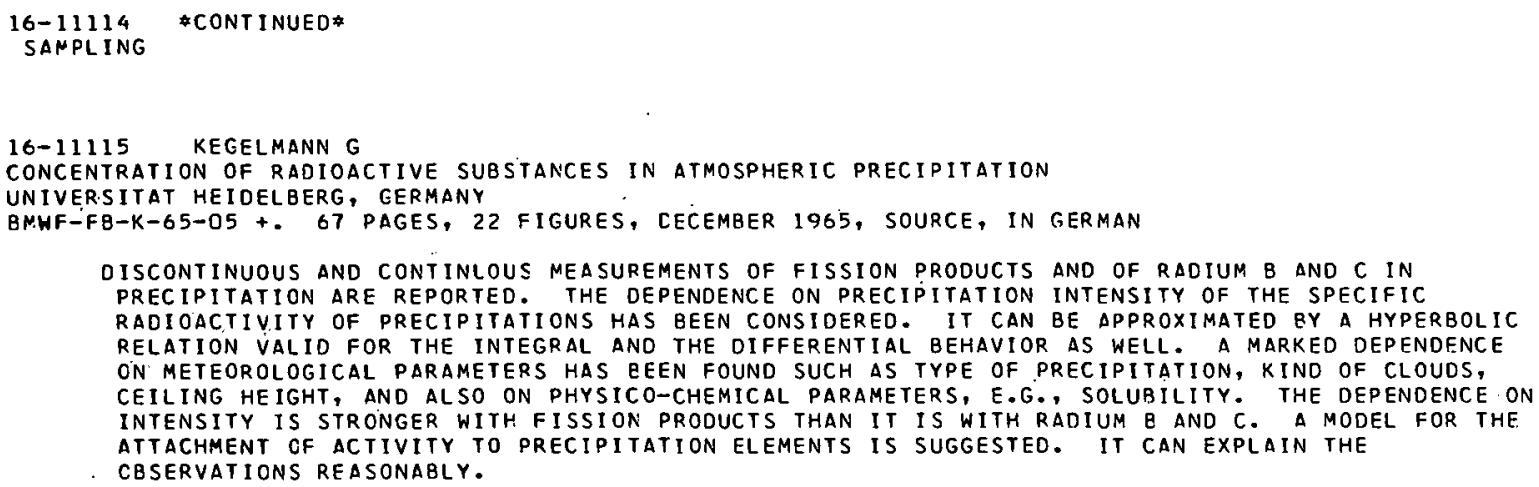

THE DATA INCLUDED IN THIS REPORT WERE COMPILED FOR THE INFORMATION INTEGRATION GROUP OF IHE LRL BIO-MEDICAL DIVISION. THE TABULATION IS PUBLISHEO HERF REC.AISE OF ITS POSSIBLE LSEFULNESS TO OTHER RESEARCH WORKERS. THE TABULATION IS ORGANIZED EY GEOGRAPHICAL LOCATION OF THE DETONATION, WITH THE EXCEPTION OF THE NUCLEAR VELA UNIFORM SEISMIC SERIES. THIS SERIES, DUE TO ITS UNIQUE CHARACTER, IS LISTED SEPARATELY.

*NUCLEAR DETONATION + EXPLOSION + FRANCE + UNION OF SOVIET SOCIALIST REPUBLICS + UNITED KINGDOM

16-1112C KATZ EJ

ATMOSPHERIC DIFFUSION OF SETTLING PARTICLES WITH SLUGGISH RESPONSE

THE HEBREW UNIVERSITY OF JERUSALEM, ISRAEL

B PAGES, 4 FIGURES, 2 TABLES, 10 REFERENCES, JOURNAL OF ATMOSPHERIC SCIFNCES, $23(2)$, PAGES $159-166$ (MARCH 19661

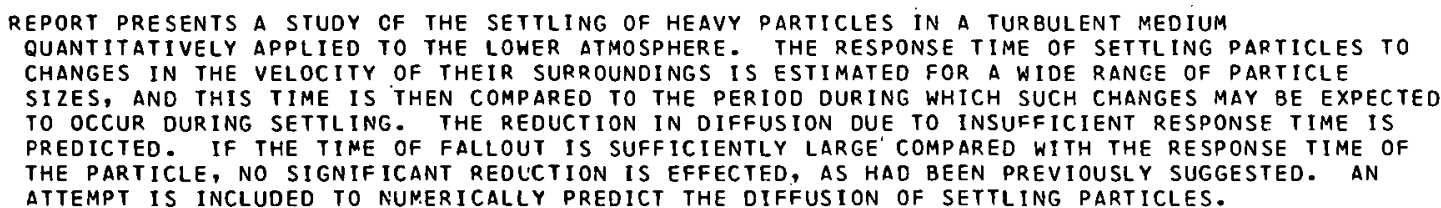


CATEGORY 17

OPERATIONAL SAFETY AND EXPERIENCE

17-G8480 LARSON C + LACY PS + NIRSCHL R

PATHFINDER ATOMIC POWER PLANT. PATHFINDER ROILER CORE. SLAB EXPERIMENT TEST 301

ALLIS-CHALMERS MFG. CO., EETHESDA

ACNP-64601 +. 29 PAGES, 1G FIGURES, 9 TARLES, 5 REFERENCES, SEPTEMBER 1964, CFSTI, \$2.00 CY

TEST 301 CHECKED VALIOITY CF NUCLEAR DESIGN MODEL. SOURCE AND DETECTORS AT BOTTOM OF CORE AND RODS AT TOP OF CORE FLATTENED MULTIPLICATION DATA, WHICH DROPPED SHARPLY AT CRITICALITY. TWO ACDITIONAL ELEMENTS WERE NEECED, REPRESENTING A REACTIVITY LOSS OF 1.3 PERCENT. CHANGING FROM TWO TO FOUR GROUPS AND TO A MORE EXACT REPRESENTATION OF FUEL ANO EQUIPMENT EXPLAINED THE DIFFERENCE.

* COMPAR ISON, THEORY AND EXPERIENCE + *REACTOR STARTUP TESTING + CRITICALITY EXPERIMENT + FUEL ELEMENT + PATHFINDER + REACTOR, BOILING WATER + REACTOR, SUPERHEAT + REACTOR, SUPERHEAT

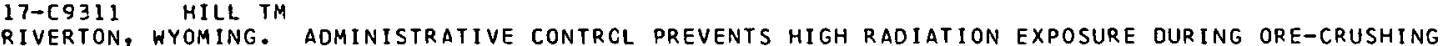
FEOERAL-RACOROCK-GAS HILLS PARTNERS

2 PAGES, MARCH 1E, 1966, ATOMIC ENERGY CLEARING HOUSE, $12(14)$, PAGES 15-16 (APRIL 4 , 1960)

SINCE EARLY 1965, HIGH-CLAY ORES ARE PROCESSED DURING ORY SEASONS. DRYING OPERATIONS IDURING WET SEASONSI CAUSES SEVERE DUSTING. LARGE VENT FANS ARE KEPT RUNNING DUR ING MAINTENANCF. NO CNE HAS EXCEEDED MPC SINCE THESE MEASURES STARTED.

\#ACMINISTRATIVE CONTROLS AND PRACTICES + CONTAMINATION + MILLING

17-09312 MILLER WA

CONAM INSPECTION, INC., OVEREXPOSURE, JANUARY 25,1966

CONAM INSPECTION, INC

2 PAGES, JANUARY 25, 1966, ATOMIC ENERGY CLEARING HOUSE, 12(14), PAGES 17-18 (APRIL 4, 1966)

$\triangle A$ EMPLOYEE RECEIVED 3.83 REMS IN CNE QUARTER. THIS WAS NOT REPORTED TO THE $\triangle E C$ EARLIER BECAUSE HE HAD BEEN THOUGHT TO BE WORKING ONLY ON THE X-RAY MACHINE. THE DOSE-REPORTING SYSTEM WAS THEN CHANGED TO PINPOINT HOW MUCH RECEIVED FROM X-RAY AND HOW MUCH FROM GAMMA RACIATION FROM ISOTCPES.

\#PERSONNEL EXPOSURE, RADIATION + FAILURE, ADMINISTRATIVE CONTROL + X-RAY

17-C9313 JANNEY CD

DEGOESBRIAND MEMORIAL HOSPITAL, BURLINGTON, VT., OVEREXPOSURE, MARCH 8,1966

DEGOESBRI AND MEMORI AL HOSPITAL, BURLINGTON, VT.

1 PAGE, MARCH 8, 1966, ATONIC ENERGY CLEARING HOUSE, 12(14), PAGE 18 (APRIL 4, 1966)

THE FILM BADGE OF A STUDENT X-RAY TECHNICIAN READ 4.5 REMS, A SMALL FRACTION FROM LICENSED MATERIAL. HIS DUTIES WERE NORMAL, AND THE OVEREXPOSURE WAS THE RESULT OF EITHER A PRANK OR AN ACCIDENTAL X-RAY EXPCSURE.

\#PERSONAEL EXPOSURE, RACIATION + FAILURE, ADMINISTRATIVE CONTROL + X-RAY

17-09416 ZIEMANN DL

MOCIFICATION OF PNPF CONTRCL RCD CAELES OUE TO EXCESSIVE ROD DROPS

PIQUA NUCLEAR POWER FACILITY

PNPF-69-66 +4 PAGES, MARCH 22, 1560, DOCKET NO. 115-2, PDR

MANY CASES OF SHORTING-TC-GROUNO HAVE OCCURRED DUE TO COOLANT CARBURIZATION AND MECHANICAL

DAMAGE. VARIOUS MODIFICATIONS WILL BE MADE RATHER THAN CHANGE TO A COMPLETELY SEALED SYSTEM.

\#FAILURE, COMPONENT + \#PIQUA + \#REACTOR, ORGANIC COOLED + \#SCRAM, FALSE + MODIFICATION, SYSTEM OR EQUIPMENT

17-09417 WEISMAN J + BARTNOFF S

THE SAXTON CHEMICAL SHIM EXPERIMENT

WESTINGHOUSE ELECTRIC CORPORATION, PITTSBURGH

WCAP-3269-24 t. 87 PAGES, 11 FIGURES, 10 TABLES, JULY 1965, DOCKET NO. 50-146: CFSTI, \$3.00 CY, \$0.75 MN

SPECIAL FUEL ELEMENTS hERE INSERTED AND LATER EXAMINED TO SHOW NO BORON ACCUMULATION DURING 4521 MWD/TON U IN CHEMICAL-SHIM OPERATION, MOST OF WHICH WAS AT 23.5 MW, WITH 16 PERCENT OF CORE SURFACE IN NUCLEATE EOILING. UNACCOUNTABLE REACTIVITY VARIED LESS THAN O.2 PERCENT AT ALL TIMES. COOLANT PH WAS VARIEO ANO SHOWED NO REACTIVITY CHANGE AT ZERO POWER, ABOUT + O. 16 DELTA RHO/DELTA PH IHIGH BORON, WHETHER OR NOT BOILING), AND ABOUT + C.13 (LOW BORON, NO BOILING). LITHIUM HYDROXIDE AND POTASSIUM HYDROXIDE WERE USED TO ADJUST PH.

*CHEMICAL SHIM + *NUCLEATE BCILING + \#OPERATIONS REPORTS, ANALYSIS + \#SAXTON + COOLANT CHEMISTRY + REACTIVITY EFFECT, ANOMALOUS + REACTOR, PRESSURIZEO WATER + SURFACE FILM DEPOSIT

17-C9435 O EOYLE MJ

YANKEE CORE EVALUATION PROGRAM QUARTERLY PROGRESS REPORT FOR THE PERIOD ENOING DECEMBER 31 , 1965 WESTINGHOUSE ELECTRIC CORPORATION, ATOMIC POHCR DIVISION

HCAP-6079 +. 80 PAGES, JANUARY 1 S66, OOCKET NO. 50-29, PDR, CFSTI $\$ 3.00$ CY $\$ 0.75$ MN 
CATEGORY 17

OPERATIONAL SAFETY AND EXPERIENCE

\begin{abstract}
$17-09439 *$ CONTINUED*
A CORE I HIGH-BURNUP ASSEMBLY $(46$, CCO. MWO/METRIC TON U, PEAK) WAS EXAMINEח (AFTER CORE, IV IRRADIATION). THE FUEL ASSEMBLY LENGTHENED 0.118 IN. (ABOUT 0.1 PERCENT). CORE I AND II ASSEMBLIES HAD MINOR CRUD AT UPPER TIPS OF FUEL RODS. THIS ASSEMBLY HAD CRUD DEPOSITS 27 IN. DOWN FROM TOP OF FUEL IN IRREGULAR PATTERNS. CRUD DID NOT DEPOSIT ON SURFACE NEXT TO CONTROL-ROD CHANNELS. GRIITY DEPOSITS, A SLIPPED FERRULE, AND A STRANGE OBJECT WERE FOUND. SPECIFIC ACTIVITY OF CRUD IMPLIED A 125-DAY RESIDENCE TIME. LAST 127 DAYS OF CORE IV WERE AT 60 PERCENT POWER, HIGH PH. CRUD WAS 4 MILS THICK - A SCALY, LOOSELY ADHERTNG DEPOSIT. CLADDING WAS CUT FOR BURST-PRESSURE TESTS.
\end{abstract}

*FUEL ELEMENT + \#IRRADIATION TESTING + \#SURFACE FILM DEPOSIT + COOLANT CHEMISTRY + FUEL BURNUP + REACTOR, PRESSURIZED WATER + YANKEE

17-C9594 GARRETT AW + SEYFRIT KV + SIMS WH + SPENCER HC + TABOR WL + WHITT KW + ZIEMANN DL PIQUA NUCLEAR POWER FACILITY MONTHLY OPERATING REPORT NO 28 , AUGUST 1965 PIQUA NUCLEAR POWER CO.

COO-652-18+. IE PAGES, I FIGURE, AUGUST 1965, PDR

THE REACTOR WAS SHUT DOKN THRCUGHOUT THE MONTH TO REPAIR CONTROL-ROD LEADS, TO REPLACE INVESSEL FILTERS, ANO OTHER WORK. TWENTY-ONE FAILURES IN THE MACNETIC-JACK CONTROL-ROD CRIVES ARE REPORTED, MOSTLY SHORTED WIRES AND DEFECTIVE LEADS. IN-VESSEL FILTERS MEASURED UP TO 3.3 RODS/HR DUE TO ACTIVATION AT TIPS. TECHNICAL SPECIFICATIONS WERE REVISED TO PERMIT REMOVAL OF THE NEUTRON KINDOW, ALLOWING A METAL LINER TO BE PLACED INSIDE THE LEAKING FUEL-STORAGE POOL.

*COOLANT CHEMISTRY + \#FAILURE, SCRAM MECHANISM + FILTER, GLASS + FUEL STORAGE +

CPERATIONS REPORTS, GENERAL + PIQUA + REACTOR, ORGANIC COOLED

17-C96C2 MANN S + YOUNGBLOOD EL

DECONTAMINATION OF THE ORNL MOLTEN-SALT FLUORIOE-VOLATILITY PILOT PLANT AFTER PROCFSSING IRRADIATED ZIRCONIUM-URANIUM ALLOY FUEL

OAK RICGE NATIONAL LABORATORY, OAK RIDGE, TENNESSEE

ORNL-3891 +. 35 PAGES, 13 TABLES, 2 FIGURES, 14 REFERENCES, FEBRUARY 1966- CFSTI, \$2.00 CY, \$O.50 MN

THE MOLTEN-SALT FLUORIDE-VCLATILITY PROCESS FOR RECOVERING URANIUM FROM IRRADIATED ZIRCONIUMOR ZIRCALOY-2-CLAD FUEL ELEMENTS WAS DEMONSTRATED SUCCESSFULLY IN THE ORNL MOLTEN-SALT FLUORIDE-VOLATILITY PILOT PLANT. THIS REPORT DESCRIBES DECONTAMINATION METHODS THAT HAVE BEEN USED THICE, FOLLOWING TWO PERIODS OF HOT OPERATION, TO REDUCE RADIATION LEVELS IN EXCESS OF $2000 \mathrm{R} / \mathrm{HR}$ TO VALUES SUFFICIENTLY LOW TO PERMIT EXTENSIVE DIRECT MAINTENANCE AND EQUIPMENT MODIFICATION. RADIATION DOSAGE TO INDIVIDUALS WHO DID THE MECHANICAL WORK IN NO CASE EXCEEDED THE QUARTERLY 1.3-R ALLOWANCE. FINAL BACKGROUNDS WERE LESS THAN IOO MR/HR IN THE MAJORITY OF CELL LOCATIONS, WITH MAXIMUM REAOINGS OF 500 MR/HR ADJACENT TO SOME PARTS OF THE PROCESS EQUIPMENT. THE DECONTAMINATION SEQUENCE WAS BASED ON LABORATORY DEVELOPMENT WORK. IT INCLUDES FLUSHING WITH A MOLTEN SALT, FOLLOWED BY TREATMENT WITH THREE TYPES OF AQUEOUS SOLUTIONS FOR REMOVING SALT FILM, METAL SCALF, AND DEPOSITED RADIATION EMITTERS. THE RESPECT.IVE COMPOSITIONS WERE - AMMONIUM OXALATE 10.3 TO 0.35 M), ALUMINUM NITRATE (O.1 MI, OR AL (NO-3) 3-HNO-3 (0.1-0.01 M), SODIUM HYDROXIDE-HYDROGEN PEROXIDE-SODIUM TARTRATE (ABOUT 5-1-1 WT PERCENT) THIS PROCEDURE IS SUITARLE FOR RADIATION LEVELS AT LEAST AS HIGH AS THOSE ENCOUNIERED IN THE TWO RACIOACTIVE OPERATING PERIODS CITED.

* FUEl ELEMENT + *MOLTEN FUEL + \#RADIOCHEMICAL PROCESSING + CLAD + DECONTAMINATION + SALT + URANIUM + ZIRCALOY + ZIRCONIUM

17-C9650 A REVIEW OF FAST BREEDER REACTORS AND OF HIGH TEMPERATURE REACTORS (DRAGON PROJECTI 15 PAGES, 10 FIGURES, 5 TABLES, 19 REFERENCES, NUCLEAR ENGINEERING $11(122)-527-542(J U L Y 1966)$

REVIEW OF THO CONFERENCES OF THE BRITISH NUCLEAR ENERGY SOCIETY ON FAST BREEDER REACTORS, HIGH-TEMPERATURE REACTORS, AND THE DRAGON PROJECT. PRESENTS BASIC TRENDS AND IDEAS.OF THE MANY PAPERS RELATING OPERATING EXPERIENCE, NEW DESIGN, AND FUTURE (ECONOMIC) PROJECTIONS.

* CESIEN STUDY + \#OPERATING EXPERIENCE + REACTOR, BREEDER + REACTOR, GAS COOLED

17-09788 PRESSURIZED WATER REACTOR (PWR) PROJECT. TECHNICAL PROGRESS REPORT, OCTOBER 22, 1965-JANUARY 21,1966 EETTIS ATOMIC POWER LABORATORY, PITTSBURGH, PENNSYLVANIA

WAPC-MRP-115 +. 105 PAGES, 13 FIGURES, 21 TABLES, JANUARY 21,1966, CFSTI, \$4. OO CY, \$O.75 MN

REMAINS OF A THIN SHEET OF FIRRCUS GASKET MATERIAL WERE FOUND ON THE OUTLET FLANGE OF THE SAFETY-INJECTION BOOSTER PUMP, AS WELL AS RUST AND SCALE IN THE CARBON-STEEL SUCTION LINE. A PH GREATER THAN 10.2 ARRESTED INCREASING CORE-PRESSURE DROP, BUT INCREASE BEGAN WHEN PH LOWERED. CONIROL-ROD CALIBRATIONS DURING XENON TRANSIENTS SHOWED A DOUBLE HUMP BECAUSE OF FLUX SHIFTS IN THE CORE. POTASSIUN PENTABORATE WAS INJECTED DURING MAINTENANCE. CRITICAL ROD POSITION BEFORE AND AFTER AGREED WITHIN XENON AND PRESSURE REACTIVITY EFFECTS, HOWEVEP. DIFFERENTIAL WORTH WAS ALMOST HALF AFTER BORON REMOVAL. FUEL ELEMENT AND POISON-PLATE IRRADIATION-TEST RESULTS REPORTED.

* CONTROL ROD CALIBRATION + \#SHIPPINGPORT + \#SURFACE FILM DEPOSIT + IN PILE LOOP + IRRADIATION TESTING + POISON, SOLUBLE + REACTIVITY EFFECT + REACTOR, PRESSURIZED WATER + XENON 
CATEGORY 17

OPERATIONAL SAFETY AND EXPERIENCE

17-0S578 \#CONTINUED*

SAXTON PLUTONIUM PROGRAM. NUCLEAR DESIGN OF THE SAXTON PARTIAL PLUTONIUM CORE

WESTINGHOUSE ELECTRIC CORPORATION, PITTSBURGH, ATOMIC POHER DIV.

WCAP-3385-51 t. 350 PAGES (APPROX.), 108 FIGURES, 70 TABLES, DECEMBER 1965, CFSTI \$7.0D CY, \$1.75 MN.

REPORTS PARAMETER STUDIES CN PERFORNANCE IN SAXTON SPECIFIC-DESIGN CALCULATION TO SET ENRICHMENT AND PERFORMANCE, AND CRITICALITY EXPERIMENTS TO CONFIRM DESIGN. PLUTONIUM ELEMENTS ARE EXPECTED TO REACH 13,600 MWD/METRIC TON (AV), WITHIN A LINEAR POWER LIMIT OF 16 KW/FT. NINE UO2-PUO2 ELEMENTS WERE SURROUNDED BY 12 UO2 ELEMENTS. INITIAL STUDIES SHOWED A 2.6 PERCENT DELTA K/K DISCREPANCY EETWEEN CALCULATION AND HANFORD EXPERIMENTS. ANALYSIS ALSO UNDERESTIMATED ROD WORTH IN PLUTONIUM REGIONS. MORE-SEVERE LOCAL POWER PEAKING NEAR WATER SLOTS OCCURRED IN PLUTONIUM REGIONS.

*COMPARI SON, THEORY AND EXPERIENCE + \#CRITICALITY.EXPERIMENT + \#FUEL ELEMENT + \#HOT SPOT + *PLUTONIUM OXIDE + *REACTIVITY EFIECT + \#SAXTON + \#URANIUM DIOXIDE

17-C9982 RANDALL JD

MOVADLE-BRIDGE LOCKING MLCIIANISM TAILURE AT TEXAS A AND M UNIVERSITY

TEXAS A AND M UNIVERSITY

2 PAGES, MAY 16, 1966, DOCKET 50-128, ATCMIC ENERGY CLEARING HOUSE, 12(23), PAGES 19-20 (JUNE 6, 1966)

THE REACTOR WAS MOVEC UNDER CCNTROLLED CONOITIONS, ALTHUUGH THE SUPERVISOR HAD FORGOTTEN TO UNLOCK THE BRIOGE. THIS DEMONSTRATED THAT THE FRICTION-TYPE LOCKING MECHANISM WAS NOT A POSITIVE LOCK, BECAUSE THE RUBBER ERAKING MATERIAL HAD BECOME HARD AND SLICK WITH AGE. THE FRICTION-ERAKE CONCEPT IS BEING REPLACED WITH A PADLOCKED ROD PLACED THROUGH ONE OF MANY IOLE3 BRILLEO IN FHE ERIVE WHREL:

* FaILURE, DESIGN ERROR + \#FUEL hANOLING + REACTOR, POOL TYPE

17-09984 BIG ROCK POINT AUTHORIZED TO USE AIR MASK PROTECTION FACTORS FOR AIRBORNE CONTAMINATION UNITED STATES ATOMIC ENERGY.CONMISSION

3 PAGES, MAY 19, 1966, DOCKET 50-155, ATCNIC ENERGY CLEARING HOUSE, 12(23), PAGES 16-18 (JUNE 6, 1966)

VARIOUS PROTECTION FACTORS FOR AIR-PURIFYING ANO AIR-SUPPLYING EGUIPMENT USED WHEN EXPOSED TO AIRBORNE CONCENTRATIONS IN EXCESS OF 10 CFR 20 ARE AUTHORIZED BY AEC IN RESPONSE TO 1962 REQUEST.

* INHALATION + *PERSONNEL PROTECTIVE DEVICE + BIg POCK POINT + DOSE CALCULATION, INTERNAL + REACTOR, BOILING WATER + REGULATION, AEC

17-1CC44 HOYT HK + ASCHERL RJ + COX ET

DRESDEN AND GARIGLIANO TURBINE MAINTENANCE EXPERIENCE

COMMONWEALTH EDISON COMPANY + GENERAL ELECTRIC COMPANY, SAN JOSE + GENERAL ELECTRIC COMPANY, CHICAGO

15 PAGES, 8 FIGURES, APRIL 1966 , PP. $18-33$ OF OPERATING AND MAINTENANCE EXPERIENCE WITH BWR POWER PLANTS, PRESENTED AT THE AMERICAN POWER CONFERENCE 28TH ANNUAL MEETING, APRIL 26-28, 1966, CHICAGO, ILLINOIS,

$\triangle P C, \$ 0.25 \mathrm{CY}$

CORROSION/EROSION PROBLEMS. FIRST INSPECTION REQUIRED PLASTIC FACE SHIELD BECAUSE OF HIGH BETA FIELDS. ON LOAD DUMP, THE GARIGLIANO TURBINE WOULD OVERSPEED AND TRIP BECAUSE OF FLASHING OF WATER ON SHIELDS AND PIPING.

*HEAT SINK + *MAINTENANCE ANO REPAIR + CORROSION + DRESDEN I + GROSS BETA + ITALY + REACTOR, BOILING HATER

17-10045 HOYT HK + ASCHERL RJ + COX BT

GARIGLIANO (SENN) NUCLCAR POHER STATION OPERAIING EXPCRICNCL

COMMONWEALTH EDISON COMPANY + GENERAL ELECTRIC COMPANY, SAN JOSE + GENERAL ELECTRIC COMPANY, CHICAGO

6 PAGES, 1 TABLE, APRIL 1966 , PP. 12-17 OF OPERATING AND MAINTENANCE EXPERIENCE WITH BWR POWER PLANTS,

PRESENTED AT THE ANERICAN POWER CONFERENCE 28TH ANNUAL MEETING, APRIL 26-28, 1966, CHICAG0, ILLINOIS

OURING FIRST YEAR, CORE-PRESSURE DROP INCREASEO FROM 3.5 PSI TO 7 PSI. UNDERWATER TV REVEALEO CRUD DEPOSITS ON THE BOTTOM GRID, REMOVED FASTER BY BRUSHES THAN ULTRASONIC. THE HIGH COPPER CONTENT INDICATED THE MONEL FEEOWATER HEATERS AND STEAM-GENERATOR TUBES.

*CRUD + \#PRESSURE DROP + ITALY + REACTOR, BOILING WATER

17-1004E HOYT HK + ASCHERL RJ + COX B J

CRESDEN NUCLEAR POWER STATION CPERATING EXPERIENCE

COMMONHEALTH EDISON CO. + GENERAL ELECTRIC CO., SAN JOSE + GENERAL ELECTRIC COMPANY, CHICAGO

12 PAGES, APRIL 1966 , PP. 1-11 OF OPERATING AND MAINTENANCE EXPERIENCE WITH BWR POWER PLANTS, PRESENTED AT THE AMERICAN POWER CONFERENCE $28 \mathrm{TH}$ ANNUAL MEETING, APRIL 26-28, 1966, CHICAGO, ILLINOIS

FUEL-CYCLE 3 CONTAINED ENOUGH LEAKERS SO THAT STACK-DI SCHARGE LIMITS FORCED BASELOAD OPERATION AT 70 PERCENT POWER. (1) CONDENSATE-PUMP STUFFING BOX SPLIT, LEAKING HATER. CONDENSATE STORAGE WATER MAINTAINED WATER IN DRUM. (2) LIGHTNING ARRESTER FAILED, TRIPPED GENERATOR AND 2 CIRCULATING PUMPS. FLOW REDUCTION OVERCAME PRESSURE INCREASE, WHICH NORMALLY CAUSES A HIGH FLUX SCRAM. (3) TORNADC CAUSED FAILURE OF ALL 5 TRANSMISSION LINES. EMERGENCY DIESEL LOAOED PROPERLY. (4) FAILURE OF A 1O-CENT CARBON RESISTOR IN A LOGIC MOOULE CAUSED THE FIRST IN-CORE FLUX - MONITORIAG SCAAM".

\#EMERgENCy POWER, ELECTRIC + \#FAILURE, PIPE + DRESDEN I + FAILURE, INSTRUMENT + INSTRUMENTATION, IN CORE + 
CATEGORY 17

OPERATIONAL SAFETY AND EXPERIENCE

17-1004E \#CONTINUED*
OPERATING EXPERIENCE + REACTOR, BOILING WATER

17-1C04E POCOCK FJ + LUX JA + SEIEEL RV

CONTROL OF IRON PICK-UP IN CYCLES UTILIZING CARBON STEEL FEEDWATER HEATERS

THE BABCOCK AND WILCOX COMPANY, CHIO

30 PAGES, 8 FIGURES, 9 TABLES, APRIL 1966, PRESENTED AT THE AMERICAN POWER CONFERENCE $28 T H$ ANNUAL MEETING,

APRIL 26-28, 1966, CHICAGO, ILLINOIS, APC, $\$ 0.25 \mathrm{CY}$

CONVENTIONAL STATION, STEEL-TUBED FEEDWATER HEATERS MAINTAINED AT PH ABOVE 9.3 MINIMIZED IRON IN WATER. RESULTS OF VARIABLE PH TESTS AT 3 STATIONS. 10O-FT-LONG SAMPLE LINE REDUCED IRON CONTENT OF SAMPLE WATER TO ZERO. PH CONTROLLED BY AMMONIA INJECTION.

\#CORROSION + \#HEAT EXCHANGER + CCOLANT CHEMISTRY + STEEL, STAINLESS

17-10C49 PRESTELE JA + EDLUNO MC

INDIAN POINT UNIT NO. I CORE A PERFORMANCE SUMMARY APRIL 1966

CONSOLIDATED EDISON CO., NEW YORK + BABCOCK AND WILCOX CO., LYNCHBURG

TP-285 + 17 PAGES, 3 FIGURES, 3 TABLES, 9 REFERENCES, APRIL 1966 , PRESENTED AT THE AMERICAN POWER

CONFERENCE $28 T H$ ANNUAL MEETING, APRIL $26-28$, CHICAGO, ILLINOIS, APC, \$O.25 CY

BR IEF SUMMARY OF CORE A HISTORY. ZERO-POWER TESTS INDICATED LIFETIME OF 450 PLUS/MINUS 65 DAYS, MID-LIFE TESTS 420 PLUS/MINUS 40 DAYS. FULL-POWER LIFE WAS 385 DAYS, 442 WITH

STRECHOUT. 18 POWER-RANGE DETECTORS LOCATED OUTSIDE VESSEL FOLLOWED ROD ASYMMETRIC AND XENON TRANSIENT WELL. NON-UNIFORM BORON BURNUP WAS A MAXIMUM AT THE INTERPHASE BETWEEN FIXED SHIM AND ITS TIP, ANO RESULTANT STRESS FRACTURED RODS.

CONTROL ROD + FUEL BURNUP + INDIAN POINT I + OPERATING EXPERIENCE + REACTOR, PRESSURIZED WATER + XENON OSCILLATION

17-1005C - COCHRAN JD + MONSON HO + OWENS JE

OPERATING EXPERIENCE WITH LARGE SODIUM COOLED REACTOR PLANTS

CONSUMERS PUBLIC POWER, HALLAM + ARGONNE NATIONAL LABORATORY, ARGONNE + ATOMICS INTERNATIONAL, CANOGA PARK 48 PAGES, 17 FIGURES, 7 TAELES, 11 REFERENCES, APRIL 1966, PRESENTED AT THE AMERICAN POWER CONFERENCE 28 TH ANNUAL MEETING, APRIL 26-28, 1966, CHICAGO, ILLINOIS, APC, \$U.25CY

FERMI STEAM GENERATORS FAILED TWICE, ONCE DUE TO STRESS CORROSION CRACKING INITIATED BY A CLEANING-SOLUTION RESIDUE, ONCE DURING CLEAN-UP OPERATION DUE TO VIBRATION. THE SODIUM-WATER REACTION WAS HANDLED BY THE PRESSURE-RELIEF SYSTEM. HALLAM SECONDARY EXPANSION TANK FAILED BECAUSE A HALIDE-COATED WELDING ROD WAS USED FOR FIELD INSTALLATION OF AN INTERNAL BAFFLE.

*CORROSION + *STRESS + FERMI + HALLAM + OPERAIING EXPERIENCE + REACTOR, BREEDER + REACTOR, FAST + REACTOR, GRAPHITE MODERATEO + REACTOR, LIQUID METAL COOLEO

17-10051 WEST JM + FRAGOSC JH

BONUS OPERATING EXPERIENCE

COMBUSTION ENGINEERING, INC., WINDSOR + PUERTO RICO WATER RESOURCES AUTHORITY, RINCON

12 PAGES, 6 FIGURES, 4 TABLES, 1 REFERENCE, APRIL 1966, PRESENTED AT THE AMERICAN POWER CONFERENCE $28 T H$ ANNUAL MEETING, APRIL 26-28, 1966, CHICAGO, ILLINOIS, APC, \$C.25 CY

BRIEF REVIEW PRIMARILY OF CONVENTIONAL EQUIPMENT. BORON HAS REACFED HOTWELL, APPARENTLY AS VENTING THE BORON TANK CAUSES FOAMING AND CARRYOVER. LEAKAGE OF PENTABORATE OUT VALVE STEMS CONTINUES. THREE TIMES THE EMERGENCY CORESPRAY SYSTEM HAS INADVERTANTLY BEEN ACTUATED DURING A SHUTDOWN. ONCE ENOUGH WATER WAS AOMITTEO TO FILL VESSEL AND FLOOD SUPERHEATER WITH IMPURE WATER. TURBINE OPERATED AGAINST LOAD LIMIT TO AVOIO LOAD SWINGS AND TRANSIENTS IN STEAM-FLOW/POWER. MAJOR ALTERATIONS HAVE BEEN NECESSARY IN FEEDWATER AND STEAM-FLOW CONTROL VALV.ES TO OBTAIN SMOOTHER OPERATION, BECAUSE OF EXTREME SENSITIVITY OF CLAD TEMP. TO STEAM FLOW/POWER RATIO AT LOW POWER. CONTROL ROD DRIVE SEALS AND BUSHING DETERIORATE TOO RAPIOLY.

\#CORE SPRAY + \#OPERATING EXPERIENCE + \#SAFETY INJECTION + \#VALVE + FAILURE, GENERAL + REACTOR, SUPERHEAT

17-10052 EEATTY DC + FARBMAN GF:

ACCUMULATED EXPERIENCE WITH NUCLEAR POWER PLANTS

WESTINGHOUSE ELECTRIC COMPANY, PITTSBURGH

22 PAGES, 4 FIGURES, 5 TABLES, APRIL 19E6, PRESENTED AT THE AMERICAN POWER CONFERENCE $28 T H$ ANNUAL MFETING, APR IL 26-28, 1966, CHICAGO, ILLINOIS, APC, $\$ 0.25 \mathrm{CY}$

GENERAL DISCUSSION OF FUEL-CYCLE LENGTH, OUTAGES, AND USE FACTORS. WHEN THE NOVEMBER 9 , 1965 BLACKOUT OCCURRED, YANKEE ROWE WAS IN STARTUP TESTS FOR CORE $V$. ON 3-HOUR NOTICE, HEATUP WAS BEGUN, AND IN 12 HOURS YANKEE WAS SYNCHRONI ZED TO THE LINE. WITH INCREASED OPERATIDN EXPERIENCE AND REPETITIVE CORES, THE SAME STARTUP TESTS CAN BE BETTER PROGRAMMED. CORE-V PHYSICS TESTS TOOK 20 HOURS.

* OPERATING EXPERIENCE + LOSS OF POWER + POWER UPRATING + REACTOR, PRESSURIZED WATER + TEST, PHYSICS + YANKEE

17-1C053 REES DR + HUGGINS RA 
CATEGORY 17

OPERATIONAL SAFETY AND EXPERIENCE

$17-10053$ \#CONTINUED*

THE OYSTER CREEK NUCLEAR STATION- DESIGN CONCEPT, CONSTRUCTION, AND TRAINING PROGRAM

JERSEY CENTRAL POWER AND LIGHT COMPANY, MORRISTOWN + GENERAL ELECTRIC COMPANY, SAN JOSE

12 PAGES, 6 FIGURES, APRIL 1966, PRESENTED AT THE AMERICAN POWER CONFERENCE $28 T H$ ANNUAL MEETING, APRIL

26-28, 1966, CHICAGO, ILLINOIS, APC, $\$ 0.25 \mathrm{CY}$

ALTHOUGH RATED FOR 540 MWE GROSS, TURBINE AND REACTOR HAVE CAPABILITY FOR 640. SPECIAL

FACILITY FOR DILUTING CONDENSER WATER DISCHARGE. CRITICAL PATH SCHEOULING AND PARTIALLY

CONCURRENT CONSTRUCTION HAS HELD SCHEDULE. WELLS ARE NECESSARY TO KEEP WATER TABLE LOW FOR

BELOW-GRADE CONSTRUCTION. EXTENSIVE TRAINING OF CREW DISCUSSED.

* CONTAINMENT CONSTRUCTION + \#STAFFING, TRAINING, QUALIFICATION + OYSTER CREEK + REACTOR, BOILING WATER

17-10C54 LONG NA

RECENT OPERATING EXPERIENCES WITH STAINLESS STEEL CONDENSER TUBES

WALLINGFORD STEEL COMPANY, HALLINGFORD

22 PACES, APRIL 1966, PRESENTED AT THE ANERICAN POWER CONFERENCE $28 T H$ ANNUAL MEETING, APRIL $26-28,1966$, CHICAGO, ILLINOIS, APC, $\$ 0.25$ CY

REVIEW OF STEAM-ELECTRIC PLANT EXPERIENCE WITH 304 AND 316 SS TUBING INSTEAD OF COPPER BASED ALLOYS, OF 176 CONDENSERS, 155 HAVE HAD NO DIFFICULTIES, 4 HAVE HAD MANGANESE DEPOSITS, 9 HAVE HAD MINOR PROBLEMS, AND 8 HAVE HAD SIGNIFICANT TUBE FAILURE. IN GENEPAL PITTING OCCURS UNDERNEATH SURFACE FILM DEPOSITS ISLIME, CARBONATE, MANGANESEI WHICH HOLD CHLORINE. A PROPER SCHEDULE OF CLEANING AND CIRCULATION DURING OUTAGES GIVES GENERALLY EFFECTIVE CONTROL.

\#CHLORINE + \#CORROSION + \#FALURE, PIPE + \#HEAT SINK + COOLANT CHEMISTRY + OPERATING EXPERIENCE + SURFACE FILM DEPOSIT

17-10192 JOHNSON RU

HARVARO UNIVERSITY. TWO CURIES OF KR-85 LOST BECAUSE OF THFFT

HARVARD UNIVERSITY, CAMBRIDGE, MASS.

1 PAGE, DECEMBER 29, 1965, ATOMIC ENERGY CLEARING HOUSE, 12(20), PAGE 36, (MAY 16, 1966)

TWO CURIES OF KR-85 WAS HELD IN VIALS BY 5 POUNDS OF MERCURY, IN A HOOD. ON NOVEMBER 29 , 1965, THE MERCURY WAS FOUND MISSING. THE RELEASE WAS ESTIMATED AS 500 TIMES THE MPC. A SERIES OF MERCURY THEFTS HAD OCCURRED OVER SFVFRAI, MONTHS. WHILE THE DOOR WAS LOCKED, 15 TO 20 KEYS WERE IN EXISTENCE.

\#FISSION GAS RELEASE + \#INCIDENT, ACTUAL, HUMAN ERROR + TRACER, RADIOACTIVE

17-10193 HALL WF

WESTERN NEH YORK NUCLEAR RESEARCH CENTER. N-16 TO BE USED FOR POWER-LEVEL CHANNEL

WESTERN NEW YORK. NUCLEAR RESEARCH CENTER, INC.

2 PACES, MAY 3, 1966, DOCKET 50-57, NTOMIC ENERGY C.IFARING HOIISE, 12(20), PAGES 30-31 (MAY 16, 1966)

SINCE CECEMBER 1964 AN N-1E SYSTEM HAS BEEN INSTALLED IN THE CORE-COOLANT-OUTLET LINE. THE SYSTEM IS HIGHLY RELIABLE BETWEEN $100 \mathrm{KW}$ AND 2 MW, HAS A 7-SEC RESPONSE TIME, AND IS

INSFNSITIVE TO CHANGING XENON-INDUCED FLUX PATTERNS. FLOW AND TEMPERATURE DIFFERENCES ARE ACCEPTABLE MEASURES OF REACTOR POWER, WHEN THE POOL REACHES TEMPERATURE EQUILIBRIUM 45 MIN AFTER STARTUP. ON APPROACHING FULL POWER, THE N-16 SIGNAL IS SWITCHED ONTO THE

STARTUP-CHANNEL LOG-COUNTING-RATE RECORDER.

\#INSTRUMENTATION, PROCESS + \#NITROGEN + \#OPERATING EXPERIENCE + \#REACTOR POWER + \#REACTOR, POOL TYPE + REACTOR, PULSED

17-10194 HALL WF

WESTERN NEH YORK RESEARCH CENTER REACTOR. THERMOCOUPLES GAVE FALSE POWER INTICATION

WLSTLRN NEW YORK NUCLEAR RESEARCH CENTER, INC.

2 PAGES, MAY 3, 1966, DOCKEY 50-57, ATOMIC ENERGY CLEARING HOUSE, 12(20), PAGES 30-31 (MAY 16, 1966)

DURING TESTING OF AN N-IE POWER-RANGE CHANNEL, VERY PRECISE INSTRUMENTS WITH RESISTANCE BULBS

SHOWED THAT THE THERMOCOUPLE TEMPERATURE-DIFFERENTIAL SYSTEM WAS UNDERESTIMATING THERMAL

POWER BY 14.7 PERCENT. RESISTANCE BULBS WERE USED AFTER THAT.

\#FAILURE, DESIGN ERROR + \#INCIDENT, ACTUAL, EQUIPMENT + \#INSTRUMENTATION, TEMPERATURE + \#REACTOR POWER + REACTOR, POOL TYPE + REACTOR, PULSED

17-10196 GENERAL TESTING CONPANY. OVEREXPOSURE UNREPORTED BECAUSE OF UNRELIABLE READINGS GENERAL TESTING COMPANY, LISBON, OHIO

1 PAGE, ATOMIC ENERGY CLEARING HOUSE, 12(20), PAGE 35, (MAY 16, 1966)

GARDRAY FILM BACGE SERVICE SHCWED A 3.5-REM EXPOSURE FOR ONE INDIVIOUAL, WHILE THE CONTROL BADGES AND FOUR INDIVIDUALS SHOWED NO EXPOSURE. THIS WAS NOT REPORTED BECAUSE IT WAS THOUGHT IN ERROR. PREVIOUSLY READINGS WERE SHOWN FOR UNUSED BADGES, AND USEC-BADGE READINGS WERE IN EXCESS OF DAILY DOSIMETER RECORDS. WE RELOCATED THE BADGE-STORAGE RACK AWAY FROM A GAS HEATER. AFTER THE FEBRUARY INSPECTION, TWO FILM EADGES WERE WORN, BUT THE READINGS ARE NOT IN AGREEMENT.

\#OPERATING EXPERIENCE + *PERSONNEL PROTECTIVE DEVICE + FAILURE, INSTRUMENT +

PERSONNEL EXPOSURE, RADIATION + RADIOGRAPHY 
CATEGORY 17

OPERATIONAL SAFETY AND EXPERIENCE

17-10197 ADVISORY COMMITTEE ON REACTOR SAFEGUARDS REVIEW OF BONUS

1 PAGE, ATOMIC ENERGY CLEARING HOUSE, 12(22), PAGE 30 (MAY 30, 1966)

ACRS APPROVES TRANSFER OF EONUS DPERATING CONTRACT TO PUERTO RICO WATER RESOURCES AUTHORITY, AND RECOMMENDS A REVIEW OF UNSOLVED OPERATING PROBLEMS, FOR EXAMPLE, FAILED FUEL, CRACKED SUPERHEATER PIPING INSIDE VESSEL, CONTROL ROD DRIVE AND INSTRUMENT DEFECTS.

\# $A C R S$ (ADVISCRY COMMITTEE ON REACTOR SAFEGUARDS) + *OPERATING EXPERIENCE +

BONUS (BOILING NUCLEAR SUPERHEAT PROJECT) + REACTOR, SUPERHEAT

17-1C198 SCHENDEL KR

OVEREXPOSURE AT WESTINGHOUSE, WALTZ MILL, PA.

WEST INGHOUSE ELECTRIC CORP., PITISBURGH, PA.

3 PAGES, APRIL 28, 1966, ATOMIC ENERGY CLEARING HOUSE, 12(22), PAGES 23-25 (MAY 30, 1966)

ONE EMPLOYEE RECEIVED A GUARTERLY 99-REM (MOSTLY BETA) DOSE TO THE LEFT HAND HHILE ANALYZING IRRADIATED FUEL, BECAUSE RADIATION READINGS WERE CUSTOMARILY TAKEN AT 9 IN., AND THIS BATCH HAD CONSI-DERABLY HIGHER CONTACT BETA DOSE RATES THAN BEFORE. ANOTHER EMPLOYEE RECEIVED A 28 AND 18-REM (MOSTLY BETA) QUARTERLY DOSE, FOR THE SAME REASON, WHILE PREPARING THE SAMPLES.

\# GRCSS RETA + \#PERSONNEL EXPOSURE, RADIATION + FISSION PRODUCT ACTIVITY, GROSS +

INCIDENT, ACTUAL, HUMAN ERROR + RADIOCHEMICAL PROCESSING

17-1C19S CRONIN OF

BACKFLOW OF UFG FROM HOOD, CAUSED BY ROOM DOOR ADMITTING AIR. UNITED NUCLEAR CORPORATION UNITED NUCLEAR CORPORATICN, NEW HAVEN, CONN.

3 PAGES, APRIL 21, 1966, ATOMIC ENERGY CLEARING HOUSE, 12(22), PAGES 21-23 (MAY 30, 1966)

A PUZZLING RANDOM SOURCE OF AIR CONTAMINATION MAY HAVE BEEN BACKFLOW FROM A LEAKING CONNECTION. AN OPERATOR HAD INSTALLED A FILLED UFG CYLINDER IN A HOOD, NOTICEO A LEAK IN THE CONNECTION ANO WAS TIGHTENING IT, WHEN ANOTHER PERSON OPENED THE ROOM DOOR. A BACKFLOW OF AIR FROM THE HOOD BROUGHT A BRIEF UNPLEASANT ODOR TO THE OPERATOR. URINE SPECIMENS INDICATED SOME UPTAKE. MODIFICATICNS ARE EEING MADE.

* aIRBorne release + *GLOVE BOX + MOdIFICATION, SYSTEM OR EQUIPMENT + URANIUM

17-10200 TRITIUM CONTAMINATION AT THFOCORE R. SCHWALM, INC.

DIVISION OF STATE AND LICENSEE RELATIONS, USAEC

2 PAGES, APRIL 14, 1966, ATOMIC ENERGY CLEARING HOUSE, 12(22), PAGES 20-21 (MAY 30, 1966)

AEC INSPECTION REVEALED THAT EMPLOYEES LEAVING TRITIUM PAINTING AREAS HAD 59, OOO DIS/MIN OF REMOVABLE TRITIUM ON THEIR HANDS AND STREET SHOES, EMPLOYEES HAD MONITOREO THEMSELVES WITH AN ULTRAVIOLET LIGHT (USED FOR LUNINOUS PAINT) INEFFECTIVE AGAINST TRITIUM. IN AODITION, CONTAMINATEO CLOTHES ARE REUSED WITHOUT WASHING, INADEQUATE CHANGE ROOMS EXIST, ANO CONT AMINATED DIAL HCLDERS ARE PASSEO INTO UNRESTRICTED AREAS. AEC INDICATES THAT OTHER PAINTERS WITH CAPEFUL HOUSEKEEPING CAN OPERATE WITHIN THEIR LIMITS.

*CONTAMINATION + \#aIluRE, aOMINISTRATIVE CONTROl + \#TRITIUM

17-1C2G1 AIRBORNE CONTAMINATION AT NUCLEAR MATERIALS AND EQUIPMENT CORPORATION, APOLLO, PA. NUCLEAR MATERIALS ANO EQUIPMENT CORPORATION

1 PAGE, MAY 5, 1966 , ATOMIC ENEREY CLEARING HOUSE, 12(22), PAGE 18 (MAY 30, 1966)

EIGHT OPERATORS RECEIVED EXPCSURES MORE THAN 40 MPC (AIR) EQUIVALENT HOURS IN LESS THAN SEVEN DAYS RECENTLY. WHEN THE FUEL-WAFER AREA WAS CONVERTED FROM DEPLETED URANIUM TO ENRICHEO URANIUM, SEVERAL PROCESS VENTILATION INADEQUACIES WERE DISCOVERED. IN ADDITION, WORKERS WERE REINDOCTRINATED.

\# AIREORNE RELEASE + \#MILLING + URANIUM

17-10202 IRIRARTE M

FURTHER INFORMATION ON BONUS ACTIVITY RELEASES FOLLOWING SCRAMS

PUERTO RICO WATER RESOURCES $\triangle U T H O R I T Y$

4 PAGES, MAY 4, 1966, DOCKET 115-4, ATOMIC ENERGY CLEARING HOUSE, 12(21), PAGES 6-9 (MAY 23, 1966)

INFORMATION ON FIVE SCRAMS BETWEEN MARCH 10 FILING AND MAY 4 INDICATE THAT THE PROBLEM CONTINUES BUT THAT PROCEDURAL AND EQUIPMENT MODIFICATIONS REDUCE RELEASE. CHANGE OF PRESSURE AND TEMPERATURE ALLOWS LEAKS THROUGH. VARIOUS VALVES, RESULTING IN THE WEARING OF FACEMASKS FOR SEVERAL HOURS. VENTILATION IS BEING IMPROVEO AND KNOWN VALVES DETERMINED QUICKER.

*FISSION GAS RELEASE + \#OPERATING EXPERIENCE + \#VALVE + BONUS (BOILING NUCLEAR SUPERHEAT PROJECT) + REACTOR, SUPERHEAT

$17-10278$ KNAPP WG

METHCD FOR NEUTRON-FLUX STUDIES IN AN OPERATING POWER REACTOR USING BARE AND CADMIUM-COVERED RADIOACTIVANTS ARGONNE NATIONAL LABORATORY

ANL-7C11 t. 26 PAGES, 17 FIGURES, REFERENCES, MARCH 1965 , CFSTI $\$ 2.00 \mathrm{CY}$ 
CATEGORY 17

OPERATIONAL SAFETY AND EXPERIENCE

\section{7-10278 \#CONTINUED*}

SMALL PNEUMATIC TRANSFER LOOPS WERE INSERTED INTO EBHR TO MAKE FLUX $\rightarrow$ PLOT IRRADIATIONS AT POWER, USING RADIOACIIVANTS ARRANGED IN BEAD-CHAIN FASHION (SIMILAR TO ORDINARY KEY CHAINS) THIS MINIMIZED THE SHUTDChN TIME FOR FLUX PLOTTING AND ENAELED MORE EXTENSIVE PHYSICS DATA-TAKING. IN-CORE TUBING WAS 3/16-INCH INCONEL, AND A SPARE 3-INCH INSTRUMENTATION NOZZLE ALLOWED SIX LOOPS AT A TIME. REPORT DESCRIBES EQUIPMENT USED AND GIVES SUGGESTIONS FOR IMPROVEMENT.

\#FLUX DISTRIBUTION + \#IN CORE MEASUREMENT + EBWR (EXPERIMENTAL BOILING WATER REACTOR) + OPERATING EXPERIENCE + REACTOR, BOILING HATER

17-1G335 BARON

ENGINEERING FOR COMMUNITY ACCEPTANCE - THE ARCHITECT-ENGINEER ROLE BURNS AND ROE, INC.

13 PAGES, 1 FIGURE, PRESENTED AT THE AMERICAN POWER CONFERENCE 28 TH ANNUAL MEETING, APRIL 26-28, 1966, CHICAGO, APC

COMMENTS ON AEC DESIGN CRITERIA ANO TURNKEY CONTRACTS. SUGGESTS TIGHT CONTRACT PRICE LEAVES LITTLE LEEWAY FOR AEC - REQUIRED MODIFICATIONS, TURNKEY CONTRACT A-E CANNOT SERVE AS SUBCDNTRACTOR AND STILL ENGINEER PLANT FOR COMMUNITY ACCEPTANCE. LITTLE OR NO STANDBY CAPACITY AVAILABLE FOR MAJOR COMPONENT FAILURE, CHEAPER BUT LESS RELIABLE EQUIPMENT INEVITABLE. CONCENTRATION ON ACCIDENT ANALYSES, CONTAINMENT, AND SAFETY SYSTEMS REDUCE EFFORT ON MAINTAINABILITY AND LOCAL RADIATION CONTROL. SUGGESTS ELIMINATION OF FIXED-PRICE CONTRACTS TO ALLOW CONTINUED ENGINEERING RATHER THAN TOO-EARLY STANDARDIZATION, TO MEET ECONOMIC CHALLENGE.

*CESIGN CRITERIA + * SAFETY PRINCIPLES AND PHILOSOPHY + RADIATION, PUBLIC EDUCATION/ACCEPTANCE

17-10343 CHASSANY JP + GUILLERMIN D + DELMAR J RACIOACTIVITY MEASUREMENTS INSIDE THE PRESSURE VESSEL OF THE REACTOR G3 AFTER 4 YEARS OPERATION COMMISSARIAT A L ENERGIE ATOMIGUE

CEA-R 2785 +. 8 PAGES, 4 FIGLRES, APRIL 1965, DEP MN

EARLIER ENTRY INTO G2 AND G3 OCCURRED DURING STARTUP PHASE OF INTERMITTENT OPERATION. THIS ENTRY WAS MADE DURING MODIFICATION OF HEAT EXCHANGERS TO INSPECT AND ESTABLISH REQUIREMFNTS SHOULD SUCH ENTRY EE NECESSAPY. AT THE END OF THE PIPING COMING INTO THE VESSEL, THE DOSE RATE REACHED 75 MR/HR ANO 100 MR/HR NEAR THE DEFLECTOR. ON THE OTHER SIDE OF THIS DEFLECTOR IT WAS STILL 100 MR/HR AND THEN INCREASED RAPIDLY TO OVER 1 R/HR AT I M FROM THE STARTING-UP CHAMBERS. ON THE SIDES, THE FLUX TENDED TO DECREASE 180 MR/HR) ANDHAS 2 R/HR AT A HEIGHT OF $3 \mathrm{M}$. THIS DOSE RATE COULD CERTAINLY HAVE BEEN DECREASED BY DISCHARGING THE PERIPHERAL ZONE CF THE REACTOR. CONSEQUENTLY IT SHOULD BE POSSIBLE TO INTRUDE INTO THE VESSEL IF NECESSARY, ON CONDITION THAT GREAT CARE IS TAKEN TO AVOID CONTAMINATION AND THAT THE TOTAL DOSE IS FOLLOHED AS PRECISELY AS POSSIBLE DURING THE OPERATIONS.

*CONTAINMENT, PRESSURE VESSEL + \#INCIDENT, ACTUAL, RECOVERY FROM + \#SURVEY, RADIATION, GENERAL + FRANCE + REACTOR, GAS COOLED + SHIELDING

17-10344 HORSMAN JC

THE DEVEL OPAENT OF STEAM-WATER REACTOR LOORS AT CHALK RIVER

ATOMIC ENERGY OF CANADA, LTD., CHALK RIVER

$A E C L-2415+$ CONF-660521-1+. 17 PACES, 15 FIGURES, 1 TABLE, APRIL 1966, AECL \$O.75 CY

A SMALL PRESSURIZED-WATER LOOP IN ARX, $X-4$, WAS MODIFIED IN 1960 TO PROVIDE FOR COOLING WITH SUPERHEATED STEAM, AND IN 1962 FOR BOILING WATER AND FOG COOLANT, SEVERAL PROBLEMS IN STEAM GENERATION, CONTROL STABIL ITY, DEGASSING, OUT-LEAKAGE, AND PUMPING WERE OVERCOME. EXPERIENCE CENERAT I N, CONTROL STABILITY, DEGASSING, OUT-LEAKAGE, AND PUMP ING WERE OVER.COME. EXPERIENCE
WITH $X-4$ PROVIDED A BASIS FOR THE DESIGN OF A LARGE STEAM-WATER LOOP, U-1, THAT WAS ADOED TO THE NRU REACTOR IN 1964. THIS SYSTEM HANDLES FROM 1 TO 4 MW OF NUCLEAR HEAT, DEPENDING ON THE COOLING MODE. THESE THO LOOPS ARE NOW FULLY OPERATIONAL, BEING USED TO DETERMINE THE CRITICAL HEAT FLUX, AND, IN NOST RESPECTS, MEET THE REQUIREMENTS. U- 1 HAS EXCELLENT CONTROL STABILITY OVER A RANGE CF CONDITIONS. IT IS DIFFICULT TO DEGAS TO LOW CONCENTRATIONS, AND PERSISTENT LEAKAGE FROM SMALL VALVES IS ALSO A CONTINUING PROBLEM. IMPROVEMENTS. ARE NEEDED IN DESIGN AND IN COMPONENT RELIABILITY TO REOUCE COMPLEXITY, MAINTENANCE, AND CAPITAL COSTS.

\#CANADA + \#DESIGN CRITERIA + \#HEAT TRANSFER + *IN PILE LOOP + \#OPERATING EXPERIENCE + REACTOR, RESEARCH

17-1C345 SIMON RH

DESIGN, CONSTRUCTION, ANO INITIAL OPERATION OF GENERAL ATOMIC IN-PILE LOOP

GENERAL ATOMIC DIVISION, GENERAL DYNAMICS CORP.

GA-5\$38 +. 53 FIGURES, 15 TABLES, FEBRUARY 15, 1965, CFSTI \$4.0C CY

REVIEWS DESIGN, ETC., AND ACCIDENT EVALUATION OF A 6OO-KW TEST LOOP FOR PEACH BOTTOM FUEL ELEMENTS.

\#COATED PARTICLE + \#FUEL ELEMENT + \#FUEL INTEGRITY + \#GETR (GENERAL ELECTRIC TEST REACTOP) +

* IN PILE LOOP + \#OPERATING EXPERIENCE + REACTOR, GAS COOLED + REACTOR, TEST

17-10517 RICE RE

EYPERIMENTS WITH PFRIPHFRAI SIJPFRHFATFR CORF PSH-I . RORAX-V

ARGONNE NATIONAL LABORATORY, ARGONNE

ANL-6962 +. 287 PAGES, 147 FIGURES, 43 TABLES, 18 REFERENCES, JULY 1965, CFSTI, \$6.00 CY, \$1.50 MN 
CATEGORY 17

OPERATIONAL SAFETY AND EXPERIENCE

17-10517 \#CONT INUED*

THE FUEL ELEMENTS WERE REPAIRED AND THE CORE MODIFIED FOR PSH-I OPERATION FROM APRIL THROUGH AUGUST 1964. EARLY TERMINATION LIMITED TESTS TO THE USUAL PHYSICS TESTS PLUS SPECIAL SUPERHEAT TESTS, TRANSFER-FUNCTION MEASUREMENTS, POWER SPLIT, DEFECTIVE-ELEMENT TESTS --ALL WITH LOW POWER (NATURAL CIRCULATION). REPORT INCLUDES SIGNIFICANT RESULTS AND DISCUSSION OF THE MAJOR TESTS.

* HEAT TRANSFER, NATURAL CONVECTICN + \#OPERATIONS REPORTS, ANALYSIS + \#TEST, PHYSICS +

*TEST, SYSTEM OPERABILITY + BORAX, ALL FBOILING REACTOR EXPERIMENTS, NRTSI + COOLANT CHEMISTRY +

FAILURE, FUEL ELEMENT + REACTCR, SUPERHEAT + TRANSFER FUNCTION

17-10561 VAUGH HA

TRITIUM EXPOSURE AT U. S. RADIUM CORPORATION, JUNE 2, 1966

U. S. RADIUM CORPORATION

1 PAGE, JUNE 2, 1966, ATOMIC ENERGY CLEARING HOUSE, $12(27)$, PAgE 29 (JULY 4, 1966 )

AN INOIVIDUAL BIOASSAY AVERAGED 30 MICROCURIES OF TRITIUM PER LITER FOR 7 DAYS, DUE TO TWO

CONTINGENCIES NOT FORESEEN IIMPROPER HANDLING OF LEAKING TRITIUM-FILLED GLASS TUBFS, AND

REING TOO CLOSE TO A LEAKING GAS-FILLING PORTI.

* INCIDENT, ACTUAL, NONREACTOR + \#PERSONNEL EXPOSUPE, RADIATION + \#TRITIUM + FAILURE, ADMINISTRATIVE CONTROL

17-10562 MECKSTROTH GR

IRICIUM-192 INCINERATION AT TULANE SCHOOL OF MEDICINE, MAY 25, 1966

TULANE UNIVERSITY SCHOOL OF NEDICINE, NEW ORLEANS, LA.

1 PAGE, ATOMIC ENERGY CLEARING HOUSE, $12(27)$, PAGE 29 (JULY 4, 1966)

IRIDIUM-192 SEEDS WERE INPLANTED IA DOGS KEPT IN MARKEC CAGES. A DOG DIED AND WAS INCINERATEO

WITHOUT NOTIFYING PROPER AUTHORITIES. ONE OF THE 16 STAINLESS-STEEL-SHEATHED IRIDIUM SEEDS

SURVIVED THE FIRE. THE ASHES REAC 120 MR/HR AT CONTACT. 9.2 MILLICURIES OF IRIOIUM WAS

INVOLVED.

*FIRE + \#INCIDENT, aCTUAL, NONREACTOR + *RAOIOACTIVITY, RELEASE + *SOURCE, RAOIATION, LOST +

FAILURE, ADMINISTRATIVE CONTRCL

$17-10563$ GULIK AE

INCINERATION OF P32 SOURCE AT DETROIT GRACE CENTRAL HOSPITAL, MAY 22, 1966

GRACE CENTRAL HOSPITAL, DETROIT, MICHIGAN

2 PACES, MAY 24, 1966, ATOMIC.ENERGY CLEARING HOUSE, 12(27), PAGES 28-29 (JULY 4, 1966)

SATURDAY, A JANITRESS AT GRACE CENTRAL HOSPITAL DISCARDED AN APPARENTLY EMPTY SHIPPING CARTON CONTAINING A JUST-RECEIVED 30-MILLICURIE SOURCE OF P-32. THE SOURCE WAS INCINERATED. MONDAY, THE LOSS OF THE SCURCE FROM THE LOCKED CONTAINER WAS DISCOVERED, AND TRACED TO THE INCINERATOR. THREE TINS OF CONTAMINATED ASHES WERE RECOVERED.

\#FIRE + *INCIDENT, ACTUAL, NONREACTCR + \#RADIOACTIVITY, RELEASE + \#SOURCE, RADIATION, LOST + * TRACER, RADIOACTIVE + FAILURE, AUMINISTRATIVE CONTROL

17-10564 FREDERICKSON RL

IODINE 131 RELEASE AT ABBOTT LABORATORIES, MAY 31,1966

ABROTT LABORATORIES

1 PAGE, MAY 31, 1966, ATOMIC ENERGY CLEARING HOUSE, 12(27), PAGE 28, (JULY 4, 1966)

A 48-HR AIR SAMPLE TAKEN FROM INSIDE A HOT-CELL. EXHAUST DUCT OVERWHELMED THE GEIGER-TUBE COUNTING SYSTEM, GIVING FALSELY LOW READINGS. THE NEXT DAY, GAMMA SCINTILLATION INOICATED THAT THE SAMPLE WAS 358E TIMES THE MPC. LATER ANALYSIS SHOWED THE AVERAGE AIR CONCENTRATION WAS 38,800 TIMES MPC, AND OUTDOOR SAMPLING DURING THE RELEASE SHOHED ONLY O.69 MPC. NO UNUSUAL BUILDING CONCENTRATIONS NOR EXPOSURE OF PERSONS OUTSIDE RESULTED. A BUBBLE OF IODINE IS BELIEVED TO HAVE PASSED OUT OF THE VESSEL REACTING A TELLURIUM TARGET. VARIOUS CHANGES TO SYSTEMS AND PROCEDURES ARE BEING STUDIED.

*FAILURE, INSTRUMENT + *FISSION PRODUCT RELEASE, GENERAL + *HOT CELL + \#INCIDENT, ACTUAL, NONREACTOR + \#IODINE + MODIFICATION, SYSTEM OR EQUIPMENT + TRACER, RADIOACTIVE

17-10565 SMITH CB

UCLA REQUESTS RE-EVALUATION OF REQUEST TC ALLOW VISITORS OPERATE REACTOR DURING OPEN HOUSE UNIVERSITY OF CALIFORNIA, LOS ANGELES, CALIFORNIA

2 PAGES, JUNE 13, 1966, DOCKET 50-142, ATOMIC ENERGY CLEARING HOUSE, 12(27), PAGES 23-24, (JULY 4, 1966)

UCLA REQUESTS THAT AEC ALLCW VISITORS TO PUSH REACTOR CONTROL BUTTONS UNDER CLOSE SUPERVISICN TO ADJUST POWER LEVEL AND TO.INCREASE POWER TO THE (LOWERED) SCRAM LEVEL. UCLA BELIEVES THAT SUCH CAREFULLY CONTROLLED DENONSTRATIONS OF REACTOR. SAFETY MAY LESSEN PUBLIC MISUNDERSTANDING AND FEAR. UCLA INVITES AEC REPRESENTATIVE TO PRESENT BRIEF TV DISCUSSION DURING CEMONSTRATION.

* Raciation, public education/ACCeptance + Reactor, research

17-1056t WITHERS WT 
CATEGORY 17

OPERATIONAL SAFETY ANO EXPERIENCE

17-10566 \#CONTINUEO*

RCD DRIVE VENTED AT BONUS TO RELIEVE RADIOLYTIC GASES, JUNE 15,1966

PUERTO RICO WATER RESOURCES AUTHORITY

3 PAGES, JUNE 15, 1966, DOCKET 115-4, ATOMIC ENERGY CLEARING HOUSE, 12(27), PAGES 21-23, (JULY 4, 1966)

SEVENTY-SEVEN PERCENT HYCROGEN AND 17 PERCENT OXYGEN WERE FOUND IN RACK-HOUSING 9. THREE DAYS AT FULL POWER IS ENOUGH FOR THE MIXTURE TO PRODUCE A HYOROGEN-OXYGEN REACTION. VENTS WERE INSTALLED TO THE MAIN STEAN LINE hITH ORIFICES. TESTS SHOWED THAT A EROKEN VENT LINE WOULD NOT SIGNIFICANTLY AFFECT THE ROD-DROP TIME. SAFETY ANALYSIS DESCRIBED.

\#CCNTROL ROD DRIVE + \#MODIFICATION, SYSTEM OR EQUIPMENT + \#RADIOLYTIC GAS +

BONUS (BOILING NUCLEAR SUPERHEAT PROJECT) + EXPLOSION + OPFRATING EXPERIFNCE + REACTOR, SUPERHEAT

17-10567 POHER REACTOR DEVCLOPMENT COMPANY REOUESTS TECH. SPEC. CHANGE FOR POWER COEFFICIENT POWER REACTOR DEVELOPMENT COMPANY

1 PAGE, JUNE 24, 1966, DOCKET 50-16, ATOMIC ENERGY CLEARING HOUSE, 12(27), PAGE 21 (JULY 4, 1966)

PRESENT POWER-COEFFICIENT MEASUREMENTS HAVE A PLUS OR MINUS UNCERTAINTY OF 25 PERCENT BECAUSE OF INACCURACIES IN HEAT BALANCE AT LOW POWER. THE LOWER LIMIT IS MINUS O.15 CENT/MW, LESS THAN THE SAFEGUARDS-REPORT VALVE OF 0.2 . THE SAFETY ANALYSIS WAS REDONE IN SUPPORT OF REQUESTING A CHANGE TO THE LOWER COEFFICIENT.

\#OPERAIING LIMITSITECHNICAL SPECIFICATIONS + \#POWER COEFFICIENT + FERMI + REACTOR, BREEDER + TEST, PHYSICS

17-10568 HAUETER RL

CCNTROL ROD WITHDRAWAL AT BIG ROCK POINT WITHOUT ACTUATION BY CONTROLS, JANUARY 1966

CONSUMERS POWER COMPANY

3 PAGES, JUNE 22, 1966 , DOCKET 5C-155, ATOMIC ENERGY CLEARING HOUSE, 12127), PAGFS 16-18, (JULY 4, 1966)

ON THO OCCASIONS HYDRAULICALLY DRIVEA CONTROL RODS WITHDREW DOWNWARDS AFTER A SCRAM AND SUBSEQUENT REACTOR DEPRESSURIZATION TO ABOUT 60 PSIG, WHEN INDIVIDUAL DRIVES WERE VALVED OFF FROM THE ROD-ORIVE SUPPLY PUMP. INTERNAL DRIVE LEAKAGE WOULD THEN PRESSURIZE THE CLOSED SCRAM DUMP TANK ABOVE THE LOWERED REACTOR PRESSURE ENOUGH TO OPEN THE ROD-DRIVE LOCKING COLLET. VALVING OUT THE INDIVIOUAL DRIVE WOULD REMOVE ROD-INSERTION PRESSURE, ALLOWING THE ROD TO DRIFT OUT OF THE CORE. MODIFICATION WAS TO VENT THE SCRAM DUMP TANK TO THE REACTOR SYSTEM DURING A SCRAM, WITH CHECK VALVES TO PREVENT BACKFLOW OF REACTOR WATER.

*CONTROL ROD DRIVE + *FAILURE, EQUIPMENT + *INCIDENT, ACTUAL, EQUIPMENT + ACCIOENT, CONTROL ROD WITHDRAWAL + BIG ROCK POINT + MOOIFICNTION, SYSTEM OR. EOUIPMENT + REACTOR, BOILING WATER

17-1C602 RAFFETY SJ + THOMAS JT

EXPERIMENTAL DETERMINATION OF SAFE HANDLING PROCEDURES FOR HIGH FLUX ISOTOPE REACTOR FUEL ELEMENTS OUTSIDE THE REACTOR

OAK RIOEE NATIONAL LABORATQRY, OAK RIDGE, TENNESSEE

ORNL-TM-1488 t. 22 PACES, 13 FICURES, 2 TABLES, JULY 1966, CFSTI, $\$ 1.00 \mathrm{CY}, \$ 0.50 \mathrm{MN}$

CRITICALITY EXPER IMENTS WERE PERFORMEO TO DETERMINE POISONING REQUIREMENTS DURING UNDERWATER STORAGE AND HANOLING. ELEMENT WAS 1.15 DOLLARS SHUTDOWN IN WATER. REACTIVITY OF VARIOUS SOL ID REFLECTORS AND GF VOIDS IN TARGET REGION EXPERIMENTALLY DETERMINED, ALSO WORTH OF VARIOUS POISONS ADOEO. INTERACTION BETWEEN ADJACENT ELEMENTS MEASURED.

*CRITICALITY EXPERIMENT + \#FUEL HANDLING + \#FUEL STORAGE + HFIR (HIGH FLUX ISOTDPE REACTOR) + REACTOR, FLUX TRAP + SHUTDOHN MARGIN

17-1C603 KEGLEY TM

EVALUATION OF ALUMINUM FUEL ELEMENT CORROSION SAMPLE FROM PAKISTAN RESEARCH REACTOR OAK RIDGE NATIONAL LABORATORY, OAK PIDGE, TENNESSEE

ORNL-TM-15G7+, I0 PAGES, 3 FIGURES, 3 TABLES, JUNE 1966, CFSTI, \$1.00 CY, \$0.50 MN

A THREE-LAYER CORROSION-PRODUCT FILN WAS ANALYZED AFTER AN EARLY 1966 MISOPERATION. WHILE THE MATERIAL WAS ANALYZED, THE EXACT CAUSE OF THE RATHER EXTREME CORROSION CANNOT BE DETERMINED DUE TO LACK OF DETAILS ON THE MISOPERATION (PH, TEMP. , TIME, FLOWRATE, ETC.). CHLORINE WAS PRESENT.

*CLAC + \#CORROSION + INCIDENT, ACTUAL, GENERAL + PAKISTAN + REACTOR, RESEARCH

17-10604 PRESSURIZED WATER REACTOR PROJECT, JANUARY 22, 1966 TO APRIL 22, 1966 BETTIS ATOMIC POWER LABORATORY, PITTSBURGH, PENNSYLVANIA

WAPC-MRP-116 +. 91 PAGES, FIGURES, TABLES, APRIL, 1966 , CFSTI $\$ 4.00 \mathrm{CY}, \$ 0.75$ MN

VARIOUS FUEL-DEVELOPMENT AND CPERATIONS-ANALYSIS PROGRAMS DISCUSSED. A XENON TILT WAS INTRODUCED AND DAMPING FACTOR FOUND TO BE -0.052 PER HOUR (WITH OVERSHODTSI. MAXIMUM DEVIATION AFTER ROD RETURNED TO NORMAL WAS ABOUT TWICE EQUILIBRIUM VALUE. CORE PRESSURE DROP INCREASE AT TH 0.9 WAS STOPPED AT PH 10.2. CRUD-DEPOSITION MODEL INCORPORATED INTO POWER-CAPABILITY CALCULATIONS. FAILURE OF FEDAL ISOLATION VALVE CAUSED BY HYDRAULIC POWER DEPRESSURIZATION THROUGH CONTROL VALVE, CURED BY DELAYING CLOSURE SIGNAL $B$ SEC TO ALLOW HYORAUL IC PRESSURE TO BUILO UP FIRST. ASINGLE ROD DROP AT 75 PERCENT POWER CAUSED PRESSURIZER LEVEL DROP OF 80 INCHES TO 10 INCHES, WHILE A FULL SCRAM GIVES HALF THE DROP AND STOPS AT 40 INCHES. 
CATEGORY, 17

OPERATIONAL SAFFTY AND EXPERIENCE

17-10604 \#CONTINUED*

* OPERATING EXPERIENCE + \#OPERATIONS REPORTS, ANALYSIS + COOLANT CHEMISTRY + FAILURE, EQUIPMENT + PRESSURIZER + REACTOR, PRESSURIZED WATER + SCRAM, FALSE + SHIPPINGPORT + SURFACE FILM DFPOSIT + XENON OSCILLATION

17-10605 ARNOLC JL

IRRAOIATION PERFORMANCE OF PIQUA CORE I FUEL ELEMENTS

ATONICS INTERNATIONAL, CANOGA PARK

NAA-SR-11712+. 42 PAGES, 13 FIGURES, 2 TABLES, 3 REFERENCES, MAYI966, CFSTI, \$2.00 CY, \$O.5O MN

THO ELEMENTS WERE SECTIONED (INCLUDING ONE THAT HAD RUN HOT). GENERAL CONOITION, INCLUDING NICKEL DIFFUSION BARRIER, OK. PEAK BURNUP, 2550 MWD / METRIC TON U. THIN SURFACE FILM FOUND, TIGHTLY AOHERENT BUT WITH $\triangle$ VERY ROUGH SURFACE. COKE HAD JAMMED THE INNER PROCESS TUBE DRAIN VALVE CLOSED, SO THE TUBE WAS STILL FILLED WITH REACTOR COOLANT. ABOUT 5 PERCENT OF THE TUBE CONTENTS CONSISTED OF COKE PARTICLES.

* EXAMINATION + \#FUEL ELEMENT + \#IRRACIATION TESTING + PIQUA + REACTIVITY EFFECT, ANOMALOUS + REACTOR, ORGANIC COOLED + SURFACE FILM DEPOSIT

17-10GOE KRAMER WC + MCCUAIG FD + EEATTY RA + BEAN CH + NOLAND RA FABRICATION OF SPIKED-CORE FUEL ELEMENTS FOR THE EXPERIMENTAL BOILING WATER REACTOR ARGCNNE NATIONAL LABORATORY

ANL-6283 +. 63 PAGES, 39 FIGURES, 35 TAELES, NOVEMBER 1965, CFSTI \$3.00 CY, \$0.50 MN

IN THE 1962 MODIFICATION OF EBHR FOR 100 MWT, 28 OF THE ORIGINAL SLIGHTLY ENRICHED, METAL-FUEL ELEMENTS WERE REPLACED WITH 35 ELEMENTS CONTAINING HIGHLY ENRICHED CERAMIC FUEL. 32 CONTAINED A SOLID-SOLUTION CERAMIC FUEL COMPOSED OF 9.01 WITHOUT UO2 (93 E PERCENT U235), 9.07 PERCENT CAD, ANO 81.92 PERCENT ZRO2 IN THE FORM OF CYLINORICAL PELLETS. THREE CDNTAINED A CERMET FUEL COMPOSED OF A CISPERSION OF 11.83 PERCENT U308 IN A MATRIX OF X-8OOI ALUMINUM. ALL THE FUEL WAS JACKETED IN ZIRCALOY-2 TUBING, EXCEPT FOR THE RODS COMPRISING ONE CERMET FUEL ELEMENT, WHICH HAD A-288 ALUMINUM JACKETS. COMMERCIAL PROCUREMENT AND OR ANL FABRICATION OF ZIRCALOY-2, 304 STAINLESS STEEL AND ALUMINUM HARDWARE FOR FUEL-ELEMENT COMPONENTS ARE DISCUSSED. NETHODS ARE REVIEWEO COVERING FUEL-ROD FABRICATION, FUEL-ELEMENT ASSEMBL Y AND EVALUATION PROCEDURES.

*FABRICATION + \#FUEL ELEMENT + EBWR (EXPERIMENTAL BOILING WATER REACTORI + REACTOR, BOILING WATER

$17-10607$ TAYLOR EG

SAXTON PLUTONIUM PROGRAM - CRITICAL EXPERIMENTS FOR THE SAXTON PARTIAL PLUTONIUM CORE WESTINGHOUSE ELECTRIC CORPORATION, ATOMIC POWER DIVISION, PITTSBURGH, PENNSYLVANIA WCAP-3385-54 + EURAEC-1493 + 3CO PAGES (APPROXIMATELY), 14 FIGURES, 2 TABLES, 2 REFERENCES, DECEMBER 1965 , CFSTI $\$ 7.00 \mathrm{CY}, \$ 1.50 \mathrm{MN}$.

UNRODDED SLAB GEOMETRIES WERE TAKEN CRITICAL BY ADJUSTING MODERATOR HEIGHT. VARIOUS BUCKLING, POWER DISTRIBUTION, ETC.., MEASUREMENTS MADE TO VERIFY CALCULATIONAL TECHNIOUES IN UOZ, FPOZ, AND CORES CONTAINING BOTH UO2 FUEL RODS AND UO2-PUO2 FUEL ROOS. REPORT CLAIMS CLOSE AGREEMENT BETWEEN PREDICTED AND MEASURED NUCLEAR CHARACTERISTICS, NOTES THAT WATER-SLOT POWER PEAKING IS IMPORTANT IN THERMAL REACTORS.

*CRITICALITY EXPERIMENT + \#PLUTONIUM + POWER DISTRIBUTION + REACTOR, PRESSURIZED WATER + SAXTON

17-10608 SOULIS RE + ENGLISH WF + KIMLRA LA + WILCOX TP + TITUS GW ARMY GAS COOLED REACTOR SYSTEMS PROGRAM, ML-1-II FUEL ELEMENT DESIGN REPORT AEROJET-GENERAL NUCLEONICS, SAN RAMON, CALIFORNIA

AGN-TM-415 +. 223 PAGES, 25 FIGURES, 37 TABLES, JANUARY 1966, CFST1, \$6.00 CY, \$1.25 MN

INCLUDES DESCRIPTION, NELTRONIC-THERNAL-MECHANICAL OESIGN, STRESS, VIBRATION-FATIGUE AND

THERMAL ANALYSIS. MATERIAL, MECHANICAL FLUID FLOW, AND IN-CORE TESTS. COMPREHENSIVE

* DESIgN STUDY + \#FUEL ELEMENT + ML 1 (MOEILE LOW POWER PLANT NO. 1) + REACTOR, GAS COOLED

17-10616 WALKER VA + GRABER MJ + GIBSON GW ATR FUEL MATERIALS DEVELOPMENT IRRADIATION RESULTS. PART II PHILLIPS PETROLEUM COMPANY, IDAHO FALLS, IDAHO

ID0-17157 +. 97 PAGES, 69 FIGURES, 25 TABLES, 18 REFERENCES, JUNE 1966, CFSTI \$4.00 CY

DESCRIEES ETR\#PAEC 5S LOCD USEO, PREPARATION OF SAMPLES, ANO RESULTS OF PROOF TEST OF VARIOUS $\triangle T R$ AND HFIR FUEL PLATES AT APPROXIMATE REACTOR CONDITIONS. BOTH U3OB AND UAL3, WITH AND WITHOUT BORON CARBIDE, WERE CLAD HITH 6061-0 ALUMINUM AND IRRAOIATED WITH HEIGHT PERCENT OF FUEL VARYING. CORROSION RATES AGREEO WITH PREDICTIONS. POSTIRRADIATION ANNEAL SHOWED EREAKAWAY SWELLING, BEGINNING AT $750 \mathrm{~F}$ FOR U308 AND $800 \mathrm{~F}$ FOR UAL 3.

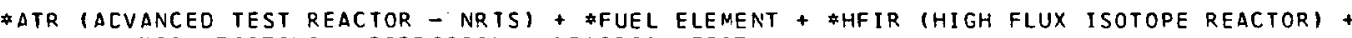

* IRRADIATION TESTING + CORRCSION + REACTOR, TEST

17-10712. RANDEN KG + GOLLIHER KG

STARTUP AND OPERATION OF THE ONE-MEGAWATT SHIELD TEST AND IRRADIATION REACTOR ATONICS INTERNATIONAL, CANOGA PARK, CALIFORNIA 
CATEGORY 17

OPERATIONAL SAFETY AND EXPERIENCE

$17-10712$ \#ONTINUEO*

NAA-SR-11175 +. 40 PAGES, 27 FIGURES, 3 TABLES, MARCH 25, 1966, CFSTI, $\$ 2.00$ CY

COMPLETELY NEW CORE AND HEAT-REMOVAL SYSTEM CONVERTED THIS 50-KW FACILITY TO 1 MW. BPIEF DESCRIPTION OF 1-MW STARTUP TESTS AND FIRST 6 MONTHS OPERATION GIVEN. UNIQUE FEATURES CALIERATION OF FISSION PLATE, DIFFERENTIAL ROD EXPANSION CORRECTION TO ISOTHERMAL TEMPEPATURE COEFFICIENT, AND WATER-FILLED CENTRAL VOID MEASUREMENTS. NITROGEN-16 JET OIFFUSERS ARE SLIGHTLY UPTILTED, SO TCO HIGH A FLOW RATE AIDS RISE TO SURFACE. AIR THIMBLE USED FOR SOME SAMPLES, SO GAMMA-HEATING TEMPERATURES OF WATER AND LEAD MEASURED.

*POWER UPRATING + \#REACTOR STARTUP EXPERIENCE, INITIAL + HEAT GENERATION, INTEPNAL + REACTOR, RESEARCH + TEMPERATURE COEFFICIENT

17-1071? BROOKHAVEN NATIONAL LABORATORY - ANNUAL REPORT - JULY 1,1965

BROOKHAVEN NATIONAL LABORATORY, UPTON, LONG ISLAND, NEW YORK

BNL-929+. 229 PAGES, FIGURES, TABLES, JULY 1, 1965, CFSTI, \$6.00 CY, \$1.25 MN

OPERATIONAL EXPERIENCE AT THE MEDICAL RESEARCH REACTOR - CONSIDERABLE FOUL ING OF THE SECONDARY WATER SIDE OF THE HEAT EXCHANGERS INCREASED THE OPERATING TEMPERATURES OF THE REACTOR WATER. PERMANENT TAPS WERE INSTALLED TO FACILITATE CHEMICAL CLEANING. A CITRIC ACID SOLUTION GAVE EXCELLENT RESULTS. A PROTOTYPE BORATED STAINLESS STEEL CONTROL ROD INSTALLED ON AUGUST IT, 1964, PROVED SATISFACTORY. INSPECTION REVEALED NO ABNURMALITIES AFTER SIX MONTHS OF USE. ANOTHER ROD INSTALLED ON MARCH 30, 1965. DURING THE WINTER MONTHS, CONDENSATE IN THE COMPRESSED-AIR SUPPLY CAUSED FREEZING OF AIR-OPERATED COMPONENTS OF THE INLET AIR INCIDENT DAMPER. THE ORIGINAL WATER-CHILL UNITS WERE REPLACED BY REFRIGERATION DRYEPS ON BOTH REACTOR AIR COMPRESSORS. THE ROUTINE ANNUAL ANNEALING OF THE CORE GRAPHITE WAS COMPLETED ON APRIL G, 1965. SEVERAL CONTROL-ROD MAGNET FAILURES OCCURRED BECAUSE OF WATER LEAKAGE INTO THE CANS DUE TO CONTAINER FATIGUE.

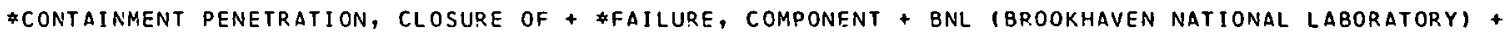
OPERATING EXPERIENCE + REACTOR, RESEARCH

17-10746 KIGER EO

OPERATIONAL SUMMARY OF THE HEAVY WATER CCMPONENTS TEST REACTOR - OCTOBER 1961 - DECEMBER 1964 SAVANNAH RIVER LABORATORY, AIKEN, SOUTH CAROLINA

DP-591+. 74 PAGES, 27 FIGURES, 6 TABLES, 9 REFERENCES, APRIL 1966, CFSTI, \$3.00 CY, \$D.75 MN

AN EXCELLENT SHORT SUMMARY OF THE LIFE HISTORY OF THIS TEST REACTOR, WITH MAJOR SYSTEMS BRIEFLY DESCRIBED ANO PROBLEMS AND SOLUTIONS DISCUSSED. FAILURES DISCUSSED INCLUDED UNUSUAL PRESSURE-TUBE WEARING THRCUGH BY COMPONENT VIBRATION, FAILURE OF CONTROL-ROD GUIDE TUBES DETECTED BY SHORTER ROD-DROP TIMES, INTERNAL-STRUCTURE BOLTS FAILED BY INSTALLATION OVERSTRESS PLUS THERMAL STRESS, ETC. D2O LEAKAGE FROM STEAM GENERATOR TUBE-TO-SHFET JOINTS CONTRIBUTED AT LEAST HALF THE NEARLY 16 LB OF LEAKAGE PER DAY. FAILED FUEL ELEMENTS WERE LOCATED BY STOPPING ALL FLOW THROUGH ASSEMBLIES AND ALLOWING THEM TO HEAT UP, THEN SAMPLING A SMALL FLOW FROM EACH ELEMENT.

\#FAILURE, EQUIPMENT + \#OPERATING EXPERIENCE + \#OPERATIONS REPORTS, ANALYSIS + HWCTR (HEAVY WATER COMPONENT TEST REACTOR) + INSTRUMENTATION, DETECTION FAILEO FUEL ELEMENT + REACTOR, HEAVY WATER + REACTOR, PRESSUPIZEO WATER

17-10799 TAYLOR EG

SAXTON PLUTONIUM PROGRAM - CRITICAL EXPERIMENTS FOR THE SAXTON PARTIAL PLUTONIUM CORE. ADPENDIX D WESTINGHOUSE ELECTRIC CORPORATION, ATOMIC POWER DIVISION, PITTSBURGH, PENNSYLVANIA

WCAP-3385-54 + EURAEC $1493+.56$ PAGES, 29 FIGURES, 19 TABLES, 4 REFERENCES, DECEMBER 1965, CFSTI \$7.00 CY, $\$ 1.50 \mathrm{MN}$.

THIS REPORT DESCRIBES A METHOC FOR DIRECT MEASUREMENT OF FUEL-ROD FISSION POWER THROUGH THE USE OF HEATING RATES. THESE MEASUREMENTS, WHEN USED IN CONJUNCTION WITH SUBSEQUENT MEASUREMENTS OF FISSION-PROOUCT GAMMA DECAY, PROVIDE USEFUL DATA FOR THE INTERPRETATION OF POWER SHARING IN LOW-POWER CRITICALITY EXPERIMENTS. A DIRECT RELATIONSHIP IS PROVIDED TO RELATE CONVENTIONAL MEASUREMENTS CF GAMMA ACTIVITY FOR FUELS HAVING DIFFERENT FISSILE ELEMENTS TO THE POWER SHARING OF THE FUELS. THE PARTICULAR EXPERIMENTS PERFORMED RELATED POWER SHARING IN A MULTIZONED CORE HAVING BOTH PLUTONIUM AND URANIUM FUELS. RESULTS FROM MEASUREMENTS AT THE HESTINGHOUSE REACTOR EVALUATION CENTER SHOW THAT A TIME-DEPENDENT CORRECTION IS NECESSARY BECAUSE OF DIFFERENCES IN THE FISSION-PRODUCT DECAY CHARACTERISTICS OF THE FUELS. THIS CORRECTION REACHES A MAXIMUM VALUE OF 30 PERCENT ABOUT 4 HR AFTER SHUTDOWN.

\#CRITICALITY EXPERIMENT + \#HIGH TEMPERATURE + \#POWER DISTRIBUTION + PLUTONIUM + URANIUM DIOXIDE

17-10833 ABLITT JF

CONTRIBUTION OF SYSTEMATIC INCIDENT EVALUATION TO THE ACHIEVEMENT OF REACTOR SAFETY

UNITED KINGDOM ATOMIC ENERGY AUTHORITY, HEALTH AND SAFETY BRANCH

14 PAGES, 6 FIGURES, 5 TABLES, 10 REFERENCES, NUCLEAR SAFETY, 7(3), PAGES 279-292 (SPRING, 1966), GP0, $\$ 0.55$

THE UKAEA PROCEDURE FOR COLLECTING FAULT DATA FROM OPERATINC SITES AND THEN RECORDING, ANALYZING, AND DISSEMINATING THE DATA IS DESCRIBED. THIS PROCEDURE IS A MEANS FOR EXTRACTING THE MAXIMUM PRACTICAL VALUE FROM THE SAFETY ASPECTS OF EXPERIENCE IN REACTOR DESIGN AND OPERATION. FAULTS ARE CLASSIFIED INTO FOUR CATEGORIES - PLANT TYPE, COMPONENT TYPE, FAULT IMPORTANCE, AND FAULT TYPE. THESE CATEGORIES AND THE DEGREE OF DETAIL INVOLVED IN EACH ARE ILLUSTRATED BY EXTRACTS FROM THE UKAEA FAULT CODE. THUS FAR, SOME GOO DATA ITEMS HAVE BEEN 
CATEGORY 17

OPERATIONAL SAFETY AND EXPERIENCE

$17-10833$ *CONT I NUED*

COLLECTED FROM 25 REACTORS IN A SIX-MONTH PERIOD. SIX PERCENT OF EVENTS REPORTED ADVERSELY AFFECTED THE SAFETY STATUS OF A REACTOR. THE FAULT DATA ARE APPLIED TO A NUMERICAL

EVALUATION OF RELIABILITY, AND SEVERAL TYPICAL FAULTS DESCRIBED.

* INCIOENT COMPILATION + \#OPERATING EXPERIENCE + \#RELIABILITY, COMPONENT + FAILURE, COMPONENT + FAILURE, OPERATOR ERROR + REACTOR, GAS COOLED + UNITED KINGDOM

17-10834 MEEM JL

RACIATION SAFETY AT THE UNIVERSITY OF VIRGINIA

UNIVERSITY OF VIRGINIA

5 PAGES, 1 FIGURE, NUCLEAR SAFETY, 7(3), PAGES 292-296, (SPRING, 1966), GP0, 50.55

THE ORGANIZATION FOR RADIATION SAFETY IS DESCRIBED AS APPLIED TO THE NUCLEAR REACTOR, THE PARTICLE ACCELERATORS, AND THE THO LARGE COBALT SOURCES AT THE UNIVERSITY OF VIRGINIA HOSPITAL AND AT BLANOY EXPERIMENTAL FARM. RADIATION SAFETY IS ACMINISTERED BY A RADIATION SAFETY COMMITTEE AND A REACTOR SAFETY COMMITTEE UNDER LICENSE WITH THE ATOMIC ENERGY COMMISSION. SELF-REGULATION UNDER RATHER BROAD LIMITS HAS BEEN ESTABLISHED.

\# ADMINISTRATIVE CONYROLS ANO PRACTICES + \#RACIATION SAFETY ANO CONTROL + ACCELERATOR + REACTOR, RESEARCH

17-10835 CRAMER EN

PROFUCTION AND UTILIZATION FACILITY OPERATOR LICENSING

OAK RIDGE NATIONAL LABORATCRY

5 PAGES, I FIGURE, I TABLE, 13 REFERENCES, NUCLEAR SAFETY, 7(3), PAGES 297-301, (SPRING, 1966), GPO, \$0.55

THIS REVIEW OISCUSSES CURRENT PRACTICES IN THE LICENSING OF REACTOR OPERATOPS AND SENIOR REACTOR OPERATORS AND PRESENTS IN TABULAR FORM BY REACTOR TYPE THE NUMBER OF OPERATOP. LICENSES GRANTED TO OATE, THUS INDICATING THE GENERAL TRENCS OF OPERATOR REPLACEMENT FOR EXISTING LOW-POWER REACTORS AND OF NEW OPERATORS FOR NEW POWER-REACTOR STARTUPS. A LICENSING GUIDE HAS BEEN PUBLISHED EY THE AEC FOR USE BY PROSPECTIVE REACTOR OPERATORS. THE FIRST EXAMINATIONS AT LICENSED FUEL-REPROCESSING PLANTS HAVE BEEN GIVEN.

* STAFFING, tRAINING, QUAL IfICATION + RADIOCHEMICAL PROCESSING + REACTOR, GENERAL

17-1083E WAGONER CC + NABOW SE

CVTR OPERATING EXPERIENCE

CAROLINAS-VIRGINIA NUCLEAR POWER ASSOCIATES, INC.

8 PAGES, 4 FIGURES, 24 REFERENCES, NUCLEAR SAFETY, 7(3), PAGES:375-383, (SPRING, 1966) GP0, \$0.55

PERTINENT BACKGROUND INFORNATION AND RELATED PROELEMS ENCOUNTERED IN THE CHECKOUT AND OPERATION OF THE PLANT ARE PRESENTEO. THE REACTOR IS A 65-MH (TH) PROTOTYPE FOR A 2OO-MW UNIT TO PROVIDE DATA ANC OPERATING EXPERIENCE WITH THE PRESSURE-TUBE DESIGN AND LOW-ENRICHMENT FUEL ANO TC PROVIDE A BASIS FOR FUTURE DESIGN OF A RELAYED CONCEPT ON A LARGER SCALE. PROBLEMS INCLUDED LEAVING DESICCANT IN PRESSURIZER, HALIDE RELEASE FROM HEADER-CAVITY THERMAL INSULATION, U-TUBE CHROME-PLATED NUTS GALLED, DUST AND FOAM-GLASS GALLED CONTROL-ROD DRIVES, VIBRATING TUBES IN SIX HEAT EXCHANGERS. DRIFTING OF CONTROL RODS WAS CAUSED BY CONTROL-ROD DRIVE ANPLIFIERS, AND SOLID-STATE DEVICES REPLACED TUBES.

\#OPERATING EXPERIENCE + \#REACTOR STARTUP EXPERIENCE, INITIAL + CONTROL ROD DRIVE + CORROSION + CVTR (CAROLINAS VIRGINIA TUBE REACTOR) + FAILURE, FATIGUE + REACTOR, HEAVY WATER +

REACTOR, PRESSURE TUBE + REACTOR, PRESSURIZED WATER + SCRAM, FALSE + TEST, SYSTEM OPERABILITY + VIBRATION

17-10858 LUMB RF

REACTOR MODIFICATION, MAY 1,1565 TO APRIL 30,1966

WESTERN NEW YORK NUCLEAR RESEARCH CENTER, INC.

2 PAGES, JULY 21,1966 , DOCKET 5C-57, PDR

CHANGES NOT CONSIDEREO NECESSARY FOR OIVISION OF REACTOR LICENSING APPROVAL INCLUDE - CHANGE THE ROD-NOT-SEATED CIRCUIT FROM $6 \mathrm{~V}$ DC TO $24 \mathrm{~V}$ AC TO ELIMINATE BATTERY PROBLEMS, REWIRE ROD-POSITION SWITCH SEQUENCE.

* MODIFICATION, SYSTEM OR EQUIPMENT + REACTOR, PULSED + REACTOR, RESEARCH

17-10860 MINNICK LE

YANKEE OPERATION REPORT NO, 66, FOR THE NONTH OF JUNE, 1966

YANKEE ATOMIC ELECTRIC COMPANY

11 PAGES, 2 FIGURES, JULY 22, 1966, DOCKET 50-29, PDR

REPORTS IN THIS SERIES WILL BE INDEXEO AS PERTINENT ITEMS ARE REPORTED. SIXTY-DAY CONTAINMENT LEAK RATE AVERAGED C.011 PERCENT PER DAY, ANO EXTRAPOLATED TO 0.11 PERCENT PER DAY AT TEST PRESSURES. A PH.D. CANOIDATE TESTED A PORTABLE GAMMA SPECTROMETER IN ENVIRONMENTAL WATERS. NITROGEN BOTTLE INSTALLED FOR ALTERNATE AIR PRESSURE FOR VALVES IN STEAM-DRIVEN EMERGENCY EOILER FEED PUMP. PRIOR TO BORON REMOVAL, IN-CORE INSTRUMENTS EVALUATEO FZ EQUAL 2.2 , FH EQUAL 1.9, AND MINIMUM ONBR 3.28. FOLLOWING DILUTION, I-131 CONTENT DOUBLED. TRITIUM AVERAGED 2.4 MICROCURIES PER MILLILITER IN PC, AND SOME 435 MC GROSS EETA-GAMMA AND SOME 180 C TRITIUM DISCHARGED FROM WASTE-DISPOSAL SYSTEM.

\#OPERATIONS REPORTS, GENERAL + CONTAINMENT LEAKAGE + HOT SPOT + POISON, SOLUBLE +

REACTOR, PRESSURIZED WATER + TRITIUM + YANKEE 
CATEGORY 17

OPERATIONAL SAFETY AND EXPERIENCE

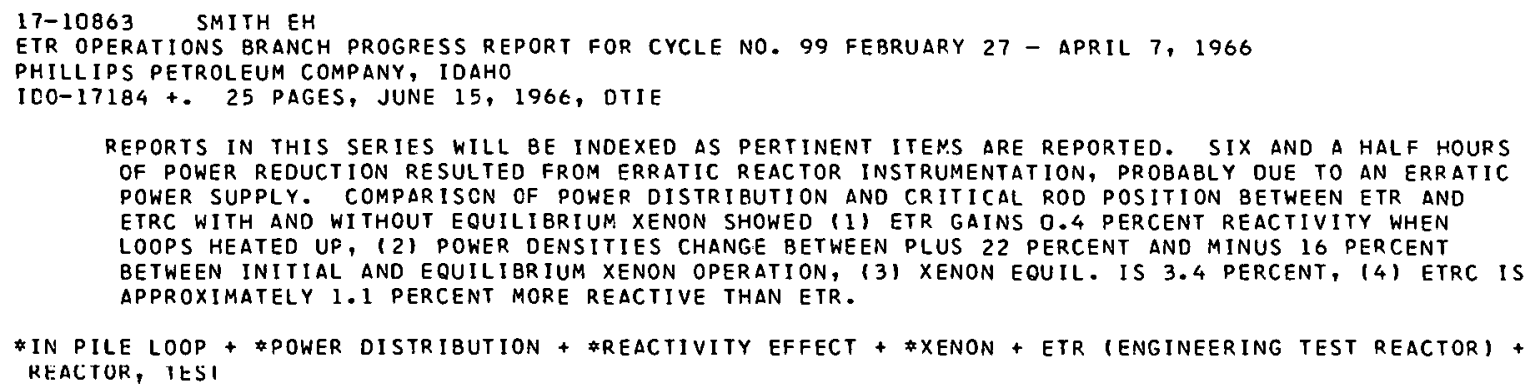

OISCUSSES EFFECTS OF IONIZING RAYS AND OF INTERACTION WITH CONTAINING WALLS. EL-3 EXPERIENCE IS FREQUENTLY QUOTED IN SECTIONS ON RADIOACTIVATION, CONSERVATION, RADIO-DECOMPOSITION, AND CHEMICAL CONTAMINATION AND PURIFICATION. LITHIUM-G SULPHATE WAS TESTED AS A SOLURLE POISON IN EL-3, HITH LITHIUM RLCOVERLD TROM TIIC DCMINLRALI ZLR. LITHIUM IS CONSIDERED THE BEST CHOICE AMONG THE 5 POISCNS (INCLUDING H2O) CONSIDERED, DESPITE THE TEMPORARY TRITIUM (NCREASE (FACTOR OF 5) AND DESPITE THE TRITON REACTION WITH OXYGEN TO PRODUCE F-18. A STILL IS USED TO RECLAIM DEGRADEO WATER AT EL-3. EL-3 INFRARED ANALYSIS WITH INTERFERENCE FILTER WILL DETECT 10-100 PPM D20 IN. HZC SECONDARY COOLANT. DISSOLVED HYDROGEN, IN ABSENCE OF OXYGEN, SUPPRESSES EVALUATION OF RAOIOLYTIC GASES.

\#OPERATING EXPERIENCE + \#POISON, SOLUBLE + ACTIVATION PRODUCT + COOLANT CHEMISTRY + FRANCE + RAOIOLYTIC GAS + REACTOR, HEAVY WATER

17-10983 MONAHAN JM + HALPINE PA

PM-2A REACTOR VESSEL TEST - PHASE

WESTINGHOUSE ELECTRIC CORP. BETTIS ATOMIC POWER LABORATORY, PITTSBURGH

WAPD-TM-604 +. 87 PAGES, 47 FIGURES, 4 TABLES, 14 REFERENCES, JULY 1966, CFSTI, \$3.00 CY, \$0.75 MN.

THIS PROGRAM IS TO OBTAIN DIRECT CONFIRMATION OF PRESSURE-VESSEL BRITTLE-FRACTURE-PREVENTION CRITERIA BY TESTING A FULL-SIZE IRRADIATED REACTOR VESSEL. PHASE I OBTAINED NONDESTRUCTIVE TEST DATA TO ALLOW PREDICTION OF BRITTLE-FRACTURE FAILURE UNDER THE CONTROLLED CONDITIONS OF THE PRESSURE-TEMPERATURE TESTING TO BE CONDUCTED AS PHASE II. DIMENSIONAL, ULTRASONIC, AND LIQUID-PENETRANT EXAMINATIONS WERE MADE TO PROVIDE DATA FOR A DETAILED STRESS ANALYSIS. STUDY OF THE MN-54 RESIDUAL ACTIVITY REVEALED THE MAXIMUM INTEGRATED FAST NEUTRON FLUX SEEN BY THE VESSEL AS $1.4 \times 10$ TO THE 19.

* BritTle fracture * \#CONTAINMENT, PRESSURE VESSEl + \#TEST, DESTRUCTIVE + COMPARISON, THEORY AND EXPERIENCE + OM 24 (PORTABLE MEDIUM NUCLEAR POWER PLANTI + REACTOR, $\triangle R M Y$ + REACTOR, PRESSURIZED WATER

17-10S84 MURRI EL + KEELEY CS

UNDERWATER REPAIRS INSIDE IRRADIATED REACTOR VESSEL, BIG ROCK POINT NUCLEAR PLANT

PHILLIPS PETROLEUM COMPANY, IDAHO FALLS, IOAHO + CONSUMERS POWER COMPANY, JACKSON, MICHIGAN CONF-642-13 +. 17 PAGES, 2 TABLES, 4 FIGURES, 2 REFERENCES, SEPTEMEER 1, 1964, PRESENTED AT HEALTH PHYSICS SOCIETY NINTH ANNUAL MEETING, CINCINNATI, OHIO, JUNE 15-18, 1964, SOURCE

DIVERS WERE ABLE TO ASSIST IN THE ALIGNMENT OF THE CORE-SUPPORT PLATE LOCATED ABOUT 6 FT BELOW THE BOTTOM OF THE CORE. TECHNIQUES AND EQUIPMENT LIMITED DOSE TO ABOUT 120 MR ( 8 DIVESI IN THE 50-MR/HR FIELDS. FILN BADGES READ A FACTOR OF 2 LOWER THAN DOSIMETERS BECAUSE OF THE ISOTROPIC EXPOSURE UNDER WATER.

\#CONTAINMENT, PRESSURE VESSEL + \#MAINTENANCE AND REPAIR + BIg ROCK POINT + OPERATING EXPERIENCE + REACTOR, BOILING WATER + SHIELDING 
CATEGORY 17

OPERATIONAL SAFETY AND EXPERIENCE

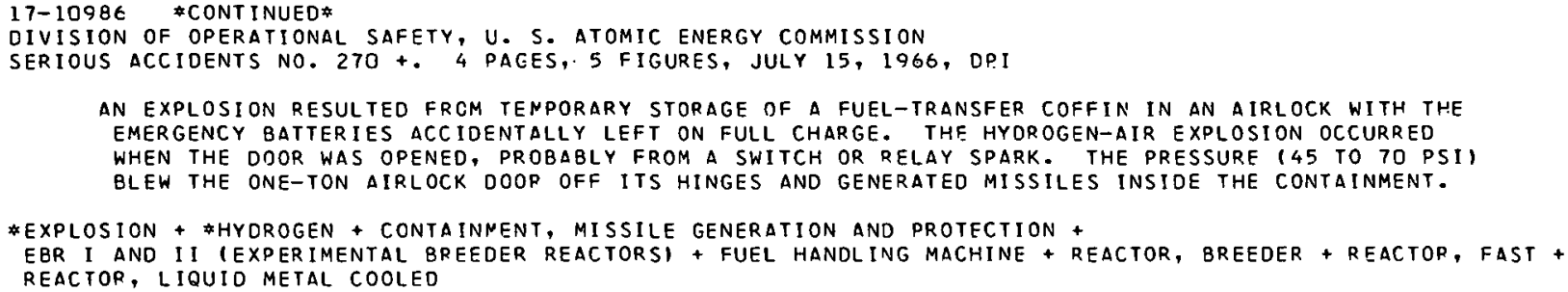

17-10987 FIRE OURING GLOVEBOX CLEANUP LEADS TO \$23, O00 DAMAGE VIA CONTAMINATION SPRFAD DIVISION OF OPERATIONAL SAFETY, U. S. ATOMIC ENERGY COMMISSION

SERIOUS ACCIDENTS NO. $269+.2$ PAGES, 1 FIGURE, JULY 8,1966 , OPI

PAINT WAS BEING STRIPPEO FROM A GLOVE-BOX LINE, USING BOTH A NONFLAMMABLE AND A FLAMMABLE I5O PERCENT ACETONE) PAINT REMOVER CALLED COCOON. WHILE THE WORK PERMIT REQUIRED AN INERT ATMOSPHERE, AND PERSONS INVOLVED KNEW THAT A MUFFLE FURNACE WAS IN THE SAME GLOVE-BOX LINE, THE GUILLOTINE DOOR SEPARATING THE PAINT STRIPPING AND THE FURNACE WAS LEFT SLIGHTLY AJAR. $\triangle F T E R$ REMOVING STRIPPED PAINT AND RECOCOONING THE BOX, THE FIRE STARTED WHILE THE AIRLOCK DOOR WAS OPENED, AND CONTAMINATION SPREAD TO THE NEXT .FLOOR THROUGH DUCTWORK BEING MODIFIED.

* CONTAMINATION + \#FIRE + \#GLOVE BOX + FAILURE, aDMINISTRATIVE CONTROL + INCIOENT, ACTUAL, NONREACTOR

17-10988 FUEL ELEMENT RLPTURE TEST FACILITY INCIDENT AT THE PLUTONIUM RECYCLE TEST REACTOR U. S. ATOMIC ENERGY COMMISSION, DIVISION OF OPERATIONAL SAFETY

ROE-66-1 +. 3 PAGES, AUGUST 5, 1966, OPERATING EXPERIENCES, REACTOR SAFETY EULLETIN, DPI

ON SEPTEMBER 29, 1965 , A U02-PUO2 FUEL ELEMENT WITH AN INTENTIONAL DEFECT, IRRADIATED IN A TEST LOOP, CAUSED THE FAILURE OF A PRESSURE TUBE. THE RESULTANT PRESSURE DECREASE CAUSED TOO $G$ OF MOLTEN FUEL TO BE EJECTED FROM THE FUEL ROD THROUGH THE FAILED TUBE. ALTHOUGH THE MOLTEN FUEL WAS STOPPED BY THE SURROUNDING SHROUD TUBE, SOME. FUEL AND FISSION PRODUCT WAS SPREAD BY THE DRY GAS AND THE CONTAINMENT VENTILATION SYSTEM. THE HYPOTHESIZED COURSE OF THE INCIDENT WAS AS FOLLOWS - WATER OXIDIZED THE FUEL TO UO2.1, THERMAL CONDUCTIVITY WAS LOWERED, INCREASING THE VOLUME OF MOL TEN FUEL AND THE INTERNAL PRESSURE, WHICH SPLIT THE CLAODING. THE SWOLLEN FUEL INTERFERED WITH THE COOLING OF THE PRESSURE TUBE, WHICH THEN FAILED UNDER PRESSURE.

*CENTERL INE MELTING + \#FAILURE, CLACOING + \#INCIDENT, ACTUAL, GENERAL + \#OXIDATION + FAILURE, PIPE + IN. PILE LOOP. + PRTR (PLUTONIUN RECYCLE TEST REACTOR) + REACTOR, AEC OWNED + REACTOR, HEAVY WATER + REACTOR, PRESSURE TUBE + URANIUN DIOXIDE

17-10989 MALFUNCTION OF EQUIPMENT INVOLVING SHUTDOWN RODS IN THE PROCESS DEVELOPMENT PILE (PDP) DIVISION OF OPERATIONAL SAFETY, U. S. ATOMIC ENERGY COMMISSION

ROE-66-2 +. 2 PAGES, AUGUST 5, 1966, OPERATING EXPERIENCES, REACTOR SAFETY PULLETIN, DPI

ON ThO OCCASIONS, PDP DRUM-AND-CABLE-TYPE CONTROL-ROD-DRIVE MOTORS WERE NOT SHUT OFF WHEN THE RODS REACHEO THEIR TRAVEL LIMIT, BECAUSE OF MECHANICAL INTERFERENCE. IN ONE CASE, THE CABLES EROKE. IN THE OTHER, THE DRUNS UNWOUND COMPLETELY AND REWOUND IN THE WRONG DIRECTION. IN ROTH CASES, MISALIGNMENT OR MECHANICAL INTERFERENCE RESULTEO.

*CONTROL ROD, SHIM SAFETY + \#FAILURE, COMPONENT + CRITICAL ASSEMELY FACILITY + FAILURE, DESIGN ERROR + INSTRUMENTATION, SWITCH + REACTOR, AEC OWNED + SAVANNAH RIVER PLANT

17-10990 SMOKE DETECTORS CONTAINING RADIOACTIVE SOURCES

U. S. ATOMIC ENERGY COMMISSION, DIVISION OF OPERATIONAL SAFETY

HEALTH AND SAFETY INFO. NO. 235, 2 PAGES, JUNE 28,1966 , DPI

REVIEWS DESIGN AND HANCLING PROBLEMS. RADIATION MAY BE AS HIGH AS 8OO MR/HR (CONTACT) FROM AN RA-226 (40 MICROGRAMS) DETECTOR, WHILE THE AM-241 IS LESS THAN 1 MR/HR (CONTACT). IN CASE OF FIRE OR CAMAGE, THEY ARE A SCURCE CF CONTAMINATION. LEAK TEST SHOULO BE MADE AT INTERVALS LESS THAN THREE YEARS.

\#FIRE + \#INSTRUMENTATION, PROCESS + \#SOURCE, RADIATION

17-10991 FILTER UNIT INSPECTION ANO TESTING SERVICE, FISCAL YEAR 1967

U. S. ATOMIC ENERGY COMMISSION, DIVISION OF OPERATIONAL SAFETY

HEALTH AND SAFETY INFO. NO. 24C, 4 PAGES, JULY 1,1966 , DPI

PROVIDES INFORMATION AND CHARGES FOR TESTING HIGH-EFFICIENCY FILTERS AT OAK RIDGE AND HANFORD.

\#FILTER, HIGH EFFICIENCY + *TEST, FILTER

17-10992 ACCELERATOR RADIATION MONITORING AND HEALTH PHYSICS COURSE

U. S. ATOMIC ENERGY COMMISSION, DIVISION OF OPERATIONAL SAFETY

HEALTH AND SAFETY INFO. NO. 241, 1 PAGE, JULY 20, 1966, DP I 


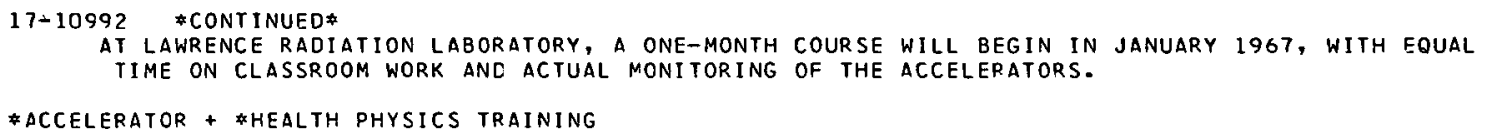


CATEGORY 17

OPERATIONAL SAFETY AND EXPERIENCE

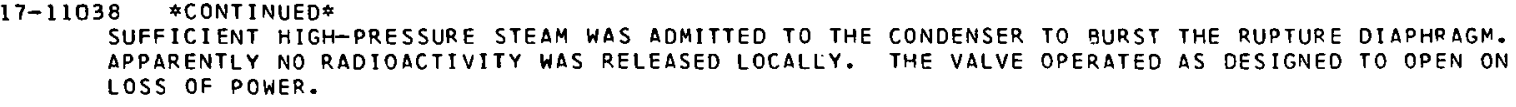

17-11C39 TEMPORARY AUTHORIZATION TO OPERATE INDIAN POINT WITH PUMP FLOW TECHNICAL SPECIFICATIONS REQUIREMENT DELETED

U. S. $\triangle T O M I C$ ENERGY COMMISSION

1 PAGE, JULY 27, 1966, DOCKET 50-8, ATOMIC ENERGY CLEARING HOUSE, 12(32), PAGE 11 (AUGUST 8, 1966)

TEMPORARY FULL-POWER AUTHORIZATION WITH A LOWER-THAN-TECHNICAL-SPECIFICATION VALUE ON PRIMARY COOLANT FLOW PER PUMP GRANTED TO DETERMINE ACCURATELY FULL-FLOW VALUE.

\#OPERATING LIMITS/TECHNICAL SPECIFICATIONS + FLOW, HIGH SPEED + INOIAN POINT I + PUMP +

REACTOR, PRESSUR IZED WATER

17-11040 FERMI POWER COEFFICIENT ANALYSIS

POWER REACTOR DEVELOPMENT COMPANY

2 PACES, JULY 22, 1966, ATOMIC ENERGY CLEARING HOUSE, $12(32)$, PAGES 12-13 (AUGUST 8,1966$)$

REVIEW OF DATA SHOWS THAT POWER COEFFICIENT IS LINEAR WITH POWER, AND TRANSFER-FUNCTION MEASUREMENTS SHOW REACTOR STRONGLY STABLE. PRINCIPLE CHANGES WERE - MORE-NEGATIVE CORE SODIUM EXPANSION EFFECT AND LESS-NEGATIVE CORE RADIAL EXPANSION EFFECT. "NO CAUSE FOR CONCERN EXISTS, AS PREVIOUS SAFETY ANALYSIS USED POWER COEFFICIENTS AS LOW AS MINUS O.15 CENT PER MEGAWATT, AND PRESENT CCEFFICIENT IS MINUS 0.18 .

* COMPARISON, THEORY AND EXPERIENCE + \#POHER COEFFICIENT + FERMI + REACTOR, FAST BREEDER + REACTOR, L.IQUID METAL COOLED

17-11041 DIVISION OF REACTOR LICENSING SENOS QUESTIONNAIRE REGARDING RADIOACTIVITY ENVIRONMENTAL NONITORING PROGRAMS

DIVISION OF REACTOR LICENSING, U. S. ATOMIC ENERGY COMMISSION

2 PAGES, ATOMIC ENERGY CLEARING HOUSE, $12(31)$, PAGES 13-14, (AUGUST 1, 1966)

QUESTIONNAIRE REQUESTS UP $\rightarrow$ TO-DATE DESCRIPTION OF CURRENT PROGRAM REGARDING OBJECTIVES AND PROCEDURES, INCLUDING (1) SAMPLING OF SOIL, AIR, WATER, AND LIVING ORGANISMS, (2)

DIRECT-READING RADIOACTIVITY MONITORS, (3) CORRELATION OF EMISSIONS WITH BIOLOGICAL RESULTS, (4) SPECIAL STUDIES, AND (5) COOPERATION WITH NON-AEC AGENCIES.

\#NONITOR, RAOIATION, ENVIRONMENTAL + \#SURVEY, RADIATION, ENVIRONMENTAL + REGULATION, AEC

17-11C42 CREUTZ E

SERVO SYSTEM CAUSES REACTOR TRANSIENT WHEN RECORDER INFORMATION MISINTERPRETED AT TRIGA

GENERAL ATOMIC, SAN DIEGO, CALIFORNIA

2 PAGES, JULY 22, 1966, DOCKET 50-227, ATOMIC ENERGY CLEARING HOUSE, 12(31), PAGES 15-16, (AUGUST 1, 1966)

AFTER FUEL MOVEMENTS, THE SIGNAL LEAD TO THE LINEAR POWER CHANNEL WAS NOT RECONNECTEO. DURING THE STARTUP, BLUE INK FROM THE LINEAR CHANNEL MINGLED WITH REO INK FROM THE LOG-N CHANNEL, CAUSING THE LOG N TO START DRAWINE A TRACE RESEMBLING THE LINEAR CHANNEL RESPONSE. THE OPERATOR SWITCHED TO SERVO WITH THE REACTRR NEARLY CRITICAL, AND THE TRANSIENT RESULTED BECAUSE THE SERVO WAS FED A ZERO SIGNAL FROM THE LINEAR CHANNEL. THE EXCESS REACTIVITY ADDED WAS LESS THAN 1.1 DOLLARS, THE MINIMUM PERIOD LESS THAN 0.23 SEC, AND THE EXCURSION LESS THAN $1.3 \mathrm{MW}-S E C$. IN ADDITION, A EYPASS WAS FOUND, RENDERING THE AUXILIARY SCRAM CHANNEL

1.3 MW-SEC. IN ADDITION, A EYPASS WAS FOUND, RENDERING THE AUXILIARY SCRAM CHANNEL
INEFFECTIVE. APPARENTLY THE ONE HIGH-RANGE SCRAM CHANNEL WAS EFFECTIVE AND SCRAMMED.

\# ACCIDENT, CONTROL ROO WITHORAWAL + \#INCIDENT, ACTUAL, HUMAN ERROR + \#INSTRUMENTATION, REGULATING + \$REGULATING SYSTEM + FAILURE, ADMINISTRATIVE CONTROL + FAILURE, DESIGN ERROR +

OPERATING LIMITSITECHNICAL SPECIFICATIONS + REACTOR, RESEARCH + TRIGA (TRAINING REACTOR, ISOTOPES, G.A.)

17-11043 MCEWEN LH

EVESR CONTROL BLADES TO USE 2IRCALOY INSTEAD OF STAINLESS STEEL

GENERAL ELECTRIC COMPANY, SAN JOSE, CALIFORNIA

1 PAGE, JULY 12, 1966, DOCKET 50-183, ATONIC ENERGY CLEARING HOUSE, 12(31), PAGE 17, (AUGUST 1, 1966)

CHANGES INCLUDE DIFFERENT CESIGN AND USE OF ZIRCALOY INSTEAD OF STAINLESS STEEL IN THE FOUR GRAY CONTROL RODS LOCATED IN THE CENTER OF THE CORE.

*CCNTROL ROD, SHIM SAFETY + REACTOR, SUPERHEAT + VESR (VALLECITOS EXP. SUPERHEAT REACTOR-ESADA) + ZIRCALOY

$17-11044$ COE RJ

YANKEE REPLY TO DIVISION OF REACTOR LICENSING LETTER ON REACTOR VESSEL NDT

YANKEE ATOMIC ELECTRIC COMPANY

2 PAGES, JULY 18, 1966, DOCKET 50-129, DTOMIC ENERGY CLEARING HOUSE, 12(31), PAGES 18-19, (AUCUST 1, 1966)

MAXIMUM NOT SHIFT IS PREDICTEO TO EE $305 \mathrm{~F}$. PROCEOURES REQUIRE 1 CO F $\triangle B O V E$ NOT. MEASUREMENTS 
CATEGORY 17

OPERATIONAL SAFETY ANO EXPERIENCE

17-11044 \#CONTINUED*

8Y NRL ON SEVEN CHARPY IMPACT SPECIMENS EXPOSEO TO THICF EXPECTED DOSE INDICATE ABOUT 40 F CONSERVATISM IN CURVE FROM WHICH ABOVE LIMITS WERE SET.

\#BRITTLE FRACTURE + \#NDT DATA (NIL DUCTILITY TRANSITION) + CONTAINMENT, PRESSURE VESSEL +

REACTOR, PRESSURIZED WATER + YANKEE

17-11045 PUECHL KH

EXPOSURES AT NUCLEAR MATERIALS AND EQUIPMENT CORP . , JUNE 24,1966

NUCLEAR MATERIALS ANO EQUIPMENT CORPORATICN, APOLLO, PA.

1 PAGE, JUNE 24 AND JULY 8, 1966, ATOMIC ENERGY CLEARING HOUSE, 12(31), PAGE 21 (AUGUST 1 , 1966)

THO EMPLOYEES (PLUTONIUM LABORATORY) WERE EXPOSED TO AIRBORNE PLUTONIUM NITRATF SLIGHTLY ABCVE 40 MPC HOURS IN TWO DAYS BECAUSE OF LEAKAGE PAST O-RINGS IN $\triangle$ GI OVF PORT. A HOT-CELL TECHNICIAN RECEIVED 3.74 REMS OF GAMMA DURING THE SECOND QUARTER, ACCORDING TO FILM BADGES. THERE IS A 2-TO-3 WEEK DELAY IN GETTING FILM-BADGE RESULTS, AND THERE WAS A SIGNIFICANTLY LOWER DOSE RECORDED ON SELF-READING DOSIMETERS. COMPANY IS NOW CONSIDERING THERMOLUMINESCENT DOSIMETRY FOR FASTER DOSE EVALUATION.

*AIRBORNE RELEASE + \#PERSONNEL EXPOSURE, RADIATION + FAILURE, AOMINISTRATIVE CONTROL + FILM, GenERAL + INCIDENT, ACIUAL, NUNREACTOR + PLUTONIUM

$17-11046 \quad$ ANDERSON AN

CORE B LOWER FLOWS REQUIRE TECHNICAL SPECIFICATION CHANGE AT INOIAN POINT UNIT I

CONSOLICATEO EDISON COMPANY OF NEW YORK, INC.

2 PAGES, JULY 14, 1966, DOCKET 50-3, ATOMIC ENERGY CLEARING HOUSE, 12(31), PAGES 14-15, (AUGUST 1, 1966)

PRELIMINARY HEAT BALANCES INDICATE THE PRIMARY-COOLANT FLOW IS ABOUT 2.5 PERCENT BELOW DESICN VALUE, ALTHOUGH THERE DOES NOT APPEAR TO BE HIGHER PRESSURE DROP ACROSS THE CORE. SINCE SPECIFICATIONS REQUIRE 18,500 GPM FLOW PER PUMP, REACTOR WILL BE LIMITED TO 7 (OF 8 ) PUMPS RUNNING TO PRODUCE REQUIRED FLOW PER PUMP WITH LOWER CORE DELTA-P. THIS IS DONE FOR LITERAL COMPLIANCE WITH SPECIFICATIONS, ALTHOUGH THERE IS NO REASON TO BE SURE IHAI THEY WOULD NOT BE IN COMPLIANCE WITH ALL PUNPS RUNNING.

* OPERATING LIMITS/TECHNICAL SPECIFICATIONS + FLOW, HIGH SPEED + INDIAN POINT I + PUMP + REACTOR, PRESSURIZED WATER

17-11047 WOLTER EE

FUEL ROD BOWING AT ELK RIVER

RURAL COOPERATIVE POWER ASSOCIATION, ELK RIVER, MINN.

1 PAGE, JUNE 28, 1966, DOCKET 115-1, ATONIC ENERGY CLEARING HOUSE, 12(29), PAGE 42, (JULY 18, 1966)

TWENTY-THREE OF THE 100 CORE- 1 ELEMENTS SHOWED MINOR BOWING, ANO 23 SHOWED BOWING GREATER THAN 100 MILS. THE FUEL TUBES ARE 450 MILS IN DIAMETER, WITH 300-MIL SPACING. THE GREATEST DISPLACEMENT DUE TO BOWING WAS 150 MILS. ALL 26 WERE REPLACED.

ELK RIVER + FAILURE, FUEL ELEMENT + REACTCR, BUILING̈ WATER

17-11048 MILLER PH

FUEL CLACDING DISTORTION AT FLAIR-TRIGA

GENERAL ATOMIC

1 PAGE, DOCKET 50-163, JUNE 23, 1966, ATOMIC ENERGY CLEARING HOUSE, 12(28), PAGE 18, (JULY 11, 1966)

AFTER 426 PULSES AT LEVELS THAT GAVE MAXTMUM MEASURED FUEL TEMPERATURE OF 680 C, TWO OF THE HIGHLY LOADED TEST ELEMENTS HAD DEVELOPED SMALL LOCALI ZED CLADDING EXPANSIONS. MAXIMUM MEASUREO INTERNAL PRESSURE WAS 35 PSIA. LOCALIZED FUEL EXPANSION HAD OCCURRED DUE TO OVER.HEATING. THESE TESTS HAVF BEEN DEFERRED UNTIL CAUSE OF THE EXPANSION IS MORE FULLY DETFRMINED.

*FUEL ELEMENT + \#THERMAL MECHANICAL EFFECT + CLAD + REACTOR, PULSED + TRIGA (TRAINING REACTOR, ISOTOPES, G.A.)

17-11049 WOLTER EE

ELK RIVER CONTROL ROD DAMAGE AND VESSEL INSPECTION

RURAL C.OOPERATIVE POWER ASSOCIATION, ELK RIVER, MINN

2 PAGES, JUNE 22, 1966, DOCKET 115-1, ATOMIC ENERTSY CIEARING HOUSE, 12(29), PAGES 18-19, (JULY 11, 1966)

THE APRIL 1966 INSPECTION SHOWEO CRACKS AT SHIM-ROD RIVETS AND CRACKS IN REGULATING ROD MATERIAL, ALL OF BORON-STAINLESS-STEEL CONSIRUCTION. BORON CARBIDE RODS ARE REPLACING SOME ROOS. DYE-PENETRANT INSPECTION OF THE REACTOR VESSEL SHOWED SHALLOW CRACKS JUST RELOW HEAD FLANGE IN MARTENSITIC WELDING. CRACKS SHOULD NOT PRESENT A PROBLEM. STRESSED U-BEND CORROSION SPECIMENS IN THE EVAPORATORS SHOWED CRACKING AFTER 22 MONTHS. ULTRASONIC TESTS OF TEN WELDS SHOWEO NO DEFECTS.

\#CONTROL ROD, SIIIM SAFETY + "DAMAGE + CONTAINMENT, PRESSURF VFSSFL + ELK RIVER + EXAMINATION + REACTOR, BOIL ING WATER

$17-11051$ ANDER SON AN 
CATEGORY 17

OPERATIONAL SAFETY AND EXPERIENCE

17-11051 \#CONTINUED*

EVALUATION OF STEAM GENERATOR TURING FAILURES, INDIAN POINT UNIT I

CONSOLICATED EOISON COMPANY OF NEW YORK, INC.

2 PAGES, DOCKET 50-3, JUNE 20, 1566, ATOMIC ENERGY CLEARING HOUSE, 12(28), PAGES 16-17, (JULY 11, 1966)

EIGHT TUBE LEAKS HAVE OCCURRED SO FAR IN BOILERS 11 AND 14, WITH NO LEAKS IN 12 OR 13 . FIVE LEAKS WERE LOCATED IN THE U-BENDS IINSPECTION SHOWED SAGGED TUBE SUPPORTS IN BOILER I4 AT THE U-BENDI, AND ALL LEAKS OCCURRED DURING A PLANT HEATUP. THE LARGEST LEAK IEQUIVALENT TO A 3/4-IN. HOLEI CAUSED PRESSURIZER LEVEL TO OROP 105 IN. IN 6 MIN WITH NORMAL MAKEUP. THE INVESTIGATION CONTINUES.

\#FAILURE, PIPE + \#HEAT EXCHANGER + INDIAN POINT I + REACTOR, PRESSURIZED HATER + SUPPORT STRUCTURE + THERMAL MECHANICAL EFFECT

17-11C52 ROLSTON BF

LOSS OF COOLANT AT MANHATTAN COLLEGE REACTOR, MAY 19,1966

MANHATTAN COLLEGE, BRONX, N. Y.

1 PAGE, MAY 31, 1966, DOCKET 5C-199, ATOMIC ENERGY CLEARING HOUSE, 12(26), PAGE 39 (JUNE 27, 1966)

IN THE EVENING, A PIPE ON THE DISCHARGE SIDE OF THE OPERATING POOL DEMINERALIZER EROKE, AND THE POOL WAS DRAINED INTO THE BASEMENT. NEXT MORNING, THIS WAS DISCOVEREO. NO AREA-MONITOR READINGS ABOVE BACKGROUND WERE SEEN. CENTRAL FUEL ELEMENT WAS ALL RIGHT - LESS THAN 1 MPIHR AT CONTACT. THIRTY-SIX HUNDRED GALLONS OF POOL WATER HAD DRAINED INTO THE GROUND THROUGH AN UNSEALED CRACK IN THE FLOOR. A LCW-WATER-LEVEL PUMP CUTOFF SWITCH WAS ADDED, AND THE CRACK WAS SEALED.

\# INCIOENT, ACTUAL, general + \#LOSS OF COCLANT + FAILURE, DESIGN ERROR + FAILURE, PIPE + REACTOR, POOL TYPE

17-11057 EVALUATION OF CAMAEE, SAN ONCFRE STEAM GENERATOR

WESTINGHOUSE ELECTRIC CORP., HEAT TRANSFER DIV., LESTER, PA. + BECHTEL CORPORATION, VERNON, CALIFORNIA

113 PAGES, 32 FIGURES, DOCKET NO. 5C-206, APRIL, 1966, PDR

THE GENERATOR WAS DROPPED 1 FT DURING THE LIFT AFTER IT WAS INSIDE CONTAINMENT. THE GENERATOR WITHSTOOD THE HYDRAULIC TEST, BUT 32 INCONEL TUBES WERE DEFORMED AS SEVERAL TUBE-SUPPORT SHEETS WERE CRUSHED. REPORT CONTAINS VARIOUS STRESS ANALYSIS ON TUBES AND SUPPORTS,

DESCRIBES PROGRAM OF TUBE PLUGGING ANO INSPECTION, AND CONCLUDES THAT DAMAGE CAN BE REPAIRED WITHOUT CHANGING PLANT CHARACTERISTICS.

* CAMAGE + \#HEAT EXCHANGER + REACTOR, PRESSURIZED WATER + SAN ONOFRE + STRESS ANALYSIS

17-11058 NAHAVANDI AN + VON HCLLEN RF

PRESSURE EFFECTS ON SPACE-DEPENDENT DYNAMICS IN BOILING SYSTEMS

WESTINGHOUSE ELECTRIC CORPORATION, PITTSBURG, PA., ATOMIC POWER DIVISION

CONF-650,413 +. 18 PAGES, 5 FIGURES, 5 REFERENCES, APRIL 1965, PAGES 566-583 OF NEUTRON DYNAMICS AND

CONTROL, PROCEEDINGS OF THE SYMPOSIUM ON NUCLEAR ENGINEERING, UNIVERSITY OF ARIZONA, TUCSON, APRIL 5-7,

1965 , CFSTI $\$ 4.50 \mathrm{CY}, \$ 2.50 \mathrm{MN}$

EARLIER WORK WAS DONE ON CONSTANT-PRESSURE REACTOR. THIS ARTICLE REPORTS WORK DONE WHEN IT WAS REALIZED THAT LOSS GF LOAD WOULD CAUSE TURBINE-SPEED REGULATOR TO OVERCOME THE

CONSTANT-DEMAND SIGNAL. EARLIER hORK AND THIS WORK WERE CHECKED AGAINST LOAD RAMP AT FULL

POWER. MODEL WAS ALSO APPLIED TO CYNAMIC ANALYSIS OF A 400-MW (THI VERTICAL STEAM GENERATOR.

\#HEAT TRANSFER, BOILING + HEAT EXCHANGER + LOSS OF LOAD + REACTOR, BOILING WATER

17-11059 MILEY GH + KURSTEOT HA + BECK GP

FEEGBACK EFFECTS DURING SHORT-INTERVAL SERIES PULSING

UNIVERSITY OF ILLINOIS

CONF-650, $413+$ +. 17 PAGES, 7 FIGURES, 2 TABLES, 14 REFERENCES, APRIL 1965, PAGES $420-436$ OF NEUTRON

DYNAMICS AND CONTROL, PROCEEDINGS OF THE SYMPOSIUM ON NUCLEAR ENGINEERING AT THE UNIVERSITY OF ARIZONA,

TUCSON, APRIL 5-7, 1965, CFSTI \$4.50 CY, \$2.50 MN

THE EFFECTS OF INITIAL PULSE AMPLITUDE, TIME BETWEEN PULSES, AND TIME AFTER PEAK FOR ROD DROP WERE INVESTIGATED FOR 0.5 TO 3 PULSES PER MINUTE. A CALCULATIONAL MODEL FOR TIME-DEPENDENT TEMPERATURE WAS FOUND. CALCULATIONS SHOW THAT THE WATER-TEMPERATURE COEFFICIENT IS POSITIVE.

* TENPERATURE COEFFICIENT + REACTCR TRANSIENT + REACTOR, PULSED + REACTOR, RESEARCH +

TRIGA (TRAINING REACTOR, ISOTOPES, G.A.)

17-11E6C HORNYIK K + WYNAN NE

STUDY OF THE DYNAMICS OF A TRIGA IYPE REACTOR

UNIVERSITY OF ILLINOIS

CONF-650 413 +. 15 PAGES, 14 FIGURES, 1 C REFERENCES, P.P. $457-572$ OF NEUTRON DYNAMICS AND CONTROL, APRIL

7, 1966, CFSTI $\$ 4.50 \mathrm{CY}, \$ 2.50 \mathrm{MN}$

COOLANT FLOW AND TEMPERATURE ANALYSES MADE FROM STEACY-STATE POWER UP TO 1 MW AND PULSES UP TO 2 DOLLARS. A SIMPLE HEAT-TRANSFER MODEL WAS DEVELOPED THAT WAS IN GOON $\triangle G R E E M E N T$ AFTER LESS THAN 1-DOLLAR PULSES. HEAT OENSITY AND TEMPERATURE IS CONCENTRATED IN OUTER LAYERS OF FUEL ELEMENT DURING A PULSE AND AFFECTS BOTH REACTIVITY ANO HEAT TRANSFER.

\#ANALYTICAL MOOEL + HEAT TRANSFER ANALYSIS + REACTOR TRANSIENT + REACTOR, PULSED + REACTOR, RESEARCH + 
CATEGORY 17

OPERATIONAL SAFETY AND EXPERIENCE

17-11060 *CONTINUEO*

TRIGA (TRAINING REACTOR, ISOTOPES, G.A.)

17-11081 COFFER CO + OEE JB + SHOPTAUGH JP + WEST GB

CHARACTERISTICS OF LARGE REACTIVITY INSERTIONS IN A HIGH-PERFORMANCE TRIGA URANIUM-ZIRCONIUM HYDRIOE CORE GENERAL ATOMIC OIVISION OF GFNERAL OYNAMICS

CONF-650 $413+.21$ PAGES, 16 FIGURES, 2 TABLES, 5 REFERENCES, PP. $398-419$ OF NEUTP.ON DYNAMICS AND CONTROL, APRIL 7,1966, CFSTI $\$ 4.50 \mathrm{CY}, \$ 2.50 \mathrm{MN}$

MORE THAN 400 PULSES BETWEEN 4.0 AND 4.6 DOLLARS INDICATE THAT THE STAINLESS-STEEL-CLAD I304 SSI FUEL CAN WITHSTAND SUCH SERVICE. PEAK POWER, TEMPERATURE, ETC., IN A BURST COMPARE FAVORABLY WITH FUCHS-NORDHEIM-SCALLETAR MODEL USING VARIABLE HEAT CAPACITY. AT THE HIGHEST POWER $16480 \mathrm{MW}, 44.5$ MW-SEC FILM BOILING OCCURED, AS INDICATED BY SMALL PATCHES OF BLUE, OXIDIZED CLAD. EXPERIMENTS SHOWED THAT 3-4 DOLLAR PULSING RAISED FUEL TEMPERATURF INT C. WHEN REACTOR OPERATEO AT $800 \mathrm{KW}$. BECAUSE GAS PRESSURES ARE LOWER THAN PREDICTED AND VARY LINEARLY WITH DOLLARS, AUTHORS BELIEVE THAT INTERNAL PRESSURE IS DUE TO AIR HEATING RATHER THAN FYOROGEN OISASSOCIATION.

\#FUCHS MODEL + *FUEL ELEMENT + \#REACTOR TRANSIENT + COMPARISON, THEORY AND EXPERIENCE I PRESSUKE, INTERNAL + REACTOR, PULSED + REACTOR, RESEARCH + TRIGA (TRAINING REACTOR, ISOTOPES, G.A.)

17-11082 LONG RL

OPERATING CHARACTERISTICS OF THE WSMR FAST BURST REACTOR

ARMY MISSILE TEST AND EVALUATICN DIRECTORATE

CONF-650 $413+12$ PAGES, 6 FIGURES, 2 TARLES, 3 REFERENCES, PP. $386-397$ OF NEUTRON DYNAMICS AND CONTROL, APRIL 7, 1966 , CFSTI $\$ 4.50 \mathrm{CY}, \$ 2.50 \mathrm{MN}$

BRIEFLY DESCRIBES REACTOR. THE REACTOR (SIMILAR TO THE HPRR AT ORNL) HAS BURST YIELD LIMITED BY THERMAL SHOCK CAPABILITY, UNLIKE HPRR TEMPERATURE LIMITATIONS. SCATTER IN CURVES OF TOTAL FISSIONS VS PERIOD LED TO FINDING THAT THERMAL SHOCKS WERE PREVENTING SAFETY-BLOCK RELEASE, SINCE THE SWITCH ACTUATORS WERE BEING DISPLACED. CORE-ASSEMBLY BOLTS WERE BEING STRETCHED CURING EACH BURST.

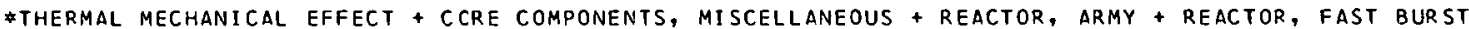

17-11083 DICKERMAN CE + ROBINSON LE TREAT EXPERIMENTS TO PROVIDE DATA FOR FAST REACTOR SAFETY KINETICS CALCULATIONS ARGONNF NATIONAL L $\triangle B O R \wedge T O R Y$

CONF-650 $413+.14$ PAGES, 10 FIGURES, 18 REFERENCES, PP. $371-385$ OF NEUTRON DYNAMICS AND CONTROL, APRIL 7, 1966 , CFSTI $\$ 4.50 \mathrm{CY}, \$ 2.50 \mathrm{MN}$

TREAT EXPERIMENT ON EBR-II-TYPE UOZ FUEL ENABLED THE INCLUSION OF VARIATIONS IN POWER AND COOLANT FLOW IN HYPOTHETICAL ACCIDENT MODELS. SUCH VARIATIONS MAY REDUCE REACTIVITY INSERTION RATES TENFOLD FROM SINGLE-PIN-FAILURE DATA. URANIUM SULPHIDE WAS MECHANICALLY SUPERIOR TO VO2. SIGNIFICANTLY DIFFERENT FAILURE MODES WITH DIFFERENT FAILURE THRESHOLDS WERE FOUND FOR UO2 IN FAST-RFOCTOR-FUEL SIZE.

\#+UEL ELEMENT + *REACTOR TRANSIENT + EBR I AND II (EXPERIMENTAL BREEDER REACTORS) + REACTOR, GRAPHITE MODERATED + REACTOR, TEST + TREAT (TRANSIENT TFST REACTOR FACILITY) + URANIUM DIOXIDE + URANIUM SULFIDE

17-11084 RAJAGOPAN $V$ + SWEN GE MEASUREMENT OF LOCAL KINETIC PARAMETERS IN THE SAXTON REACTOR WESTINGHOUSE ELECTRIC CORPORATION, PITTSBURGH

CONF-650 $413+10$ PAGES, 6 FIGURES, 2 TABLES, 3 REFERENCES, PP. $299-311$ OF NEUTRON DYNAMICS AND CONTROL, APRIL 7, 1966 , CFSTI \$4.50 CY, \$2.50 MN

A ROTATING RFACTIVITY OSCILLATOR AND MINIATURE IN-CORE ION CHAMBERS YIELUED POWFR AND CROSS-POWER SPECTRAL ANALYSES. THE DETECTOR LOCATION WAS VARIED AXIALLY. MEASUREMENTS SHOWED THAT THE LOCAL PROMPT POWER COEFFICIENT DECREASES TOWARO THE CORE CENTER IOR AS HEAT FLUX INCREASESI AND COMPARES WELL WITH CALCULATIONS.

\#OSCILLATOR, REACTIVITY + \#POWER COEFFICIENT + REACTOR, PRESSURIZED WATER + SAXTON + TRANSFER FUNCTION

17-11085 PLUTA PR

CCUFLED-CORE KINETHIC BEHAVIOR

GFNERAL ELECTRIC COMPANY, ATOMIC POWER FQUITPMENT OEPT., SAN JUSE

CONF-650 $413+21$ PAGES, 17 FIGURES, 1 TABLE, 16 REFERENCES, PP. 544-565 OF NEUTRON DYNAMICS AND

CONTROL, APRIL 7,1966, CFSTI $\$ 4.50 \mathrm{CY}, \$ 2.50 \mathrm{MN}$

POWER TRANSIENTS AND TRANSFER FUNCTIONS WITHOUT FEEDBACK ARE SHOWN. THE MODEL PROPOSED BY AVERY WAS USED. WITH CENTRAL SUPERHEAT ZONES, TWO CORES WERE USED, ONE HAVING A FAST SPECTRUM, AND ONE THERMAL.

\#COUPLEC CORES + REACTOR TRANSICNT + REACTOR, SUPERHEAT + IRANSFER FUNCTION

17-11090 CAMERON IR + DRAGESET A + FREEMANTLE RG

GTUDIE 3 WITH PLUTONIUM-FUELLEO CURES IN THE ZERO-ENERGY, HIGH-TEMPERATURE NUCLEAR REACTOR ZENITH 
CATEGORY 17

OPERATIONAL SAFETY AND EXPERIENCE

17-11090 \#CONTINUED*

UNITED KINGOOM ATOMIC ENERGY AUTHORITY, WINFRITH + OECD HIGH TEMPERATURE REACTOR PROJECT (DRAGON), WINFRITH + IBM(U.K.) LTD., LONDON

26 PAGES, 11 FIGURES, 6 TABLES, 38 REFERENCES, JOURNAL OF NUCLEAR ENERGY PARTS A/8, 20141 , PAGES $285-311$ $(1966)$

A SERIES OF EXPERIMENTS CARRIED OUT THE AIM OF TESTING CURRENT THEORETICAL METHODS FOR CALCULATING EXCESS REACTIVITY, TEMPERATURE COEFFICIENTS, DIFFERENTIAL SPECTRUM, AND REACTION-RATE DISTRIBUTIONS. TWO CORES OF WIDELY DIFEERENT FISSILEIMODERATOR ATOM RATIOS WERE LOADED TO OBTAIN SIGNIFICANTLY VARIED SPECTRUM CONDITIONS. THE GENERAL. AGREEMENT IS COMPARABLE WITH THAT FOUND FOR THE U-235 CORES PREVIOUSLY INVESTIGATED.

* COMPAR ISON, THEORY AND EXPERIENCE + \#CRITICALITY EXPERIMENT + \#PLUTONIUM + REACTIVITY, EXCESS + REACTOR, GAS COOLED + REACTOR, GRAPHITE MODERATED + TEMPERATURE COEFFICIENT + UNITED KINGDOM

17-11174 SANDERS JP APPROPRIATE VALUES FOR THE THERMAL CONOUCTIVITY OF UOZ FOR USE IN THE DESIGN OF THE. RONUS SUPERHEATERS OAK RIDGE NATIONAL LABORATORY, OAK. RIDGE, TENNESSEE

ORNL-TM-1450 +. 11 PAGES, 1 FIGURE, 6 REFERENCES, APRIL 22, 1966, CFSTI\$1.00 CY, \$O.50 MN

A Literature SURVEY WAS NACE, AND A THERMAL CONDUCTIVITY OF $1.0-1.2$ BTU/HR-FT-DEG F WAS CHOSEN. VARIOUS REPORTS INCLUDED GAS-GAP EFFECT. THERMAL CYCLING AND IRRADIATION HISTORY AFFECT CHOICE ALSO.

BONUS (BOILING NUCLEAR SUPERHEAT PROJECTI + HEAT CONOUCTION + REACTOR, BOILING WATER + REACTOR, SUPERHEAT + URANIUM DIOXIOE

17-11238 NUCLEAR TECHNOLOGY BRANCHES GUARTERLY REPORT, OCTOBER 1-OECEMEER 31 , 1965

PHILLIPS PETROLEUM COMPANY, IDAHO FALLS

ICO-17191 t. 49 PAGES, 40 FIGURES, 4 TAELES, 23 REFERENCES, JUNE 1966, CFSTI $\$ 3.00$ CY, $\$ 0.50$ MN

FOR THE ATRC, CRITICALITY EXPERIMENTS SHOW FLUX PEAKING RETWEEN FUEL PLATES ONLY AT THE TWO END PLATES, THAT IS, NEXT TO THE ALUMINUM OR BERYLLIUM. A 500 F PRESSURIZED WATER LOOP WAS INSTALLEO. FUEL-ELEMENT-TEMPERATURE DISTRIBUTIONS WERE OBTAINED SO STRESS CALCULATIONS COULD BE MADE. SOME LOCATIONS ARE ABOVE THE YIELD STRESS FOR 6061-0 ALLOY. AS TO THE MTR, BERYLLIUM LATTICE PIECE LBI6 FAILED DURING HANDLING, AFTER 2 TO 5 TIMES 10 TO THE 21 INTEGRATED NEUTRON FLUX ABOVE 1 MEV. VARIOUS FRACTURE TESTS WERE RUN.

* BERYLLIUM + \#FLUX DISTRIBUTION + \#STRESS ANALYSIS + ATR (ADVANCED TEST REACTOR - NRTS) + FUEL FLEMENT + MTR (MATERIAL' TESTING REACTOR) + RADIATION DAMAGE + REACTOR, TEST + THERMAL MECHANICAL EFFECT

17-1124E SCHMIOT ER

ELK RIVER REACTOR CONTROL ROD PERFORMANCE

NUCLEAR UTILITY SERVICES, WASHINGTON, D.C.

NUS-TM-ENG-138 +. 14 PAGES, 5 FIGURES, DOCKET NO, 115-1, JULY 11, 1966, PDR

SUMMARY OF PERFORMANCE OF 2 PERCENT RORON-STEEL ALLOY. (1) GROSS CRACKING OF THE REGULATING ROD, BECAUSE IT IS DEPLETED 5-6 TIMES MORE THAN THE OTHER RODS. A B4C ROD WILL REPLACE THIS. (2) ONE SPOT-WELD HAO A PARTIAL CIRCUMFERENTIAL CRACK. NOT SERIOUS, BECAUSE OVER 6O PERCENT OF THE EBWR SPOT WELOS HAD CRACKED. (3) TWO RODS HAD CRACKS AT THE JOINT BETWEEN ZIRCALOY AND THE BORON-STAINLESS STEEL. $(4)$ GUSSETS AT THE TIPS OF THE ROD HAD CRACKS BECAUSE OF LOW DUCTIBILITY OR WELD SHRINKAGE OR HANDLING. REPAIRS DESCRIBED.

\# QORON + \#CONTROL ROD, SHIM SAFETY + \#EMBRITTLEMENT + \#STEEL, STAINLESS + DAMAGE + ELK RIVER + MAINTENANCE AND REPAIR + REACTOR, BOILING WATER

17-11248 BUSBOOM HJ + BOYLERF + HARLING G + HAZEL VE

POST-IRRADIATION EXAMINATION OF EVESR MARK III SUPERHEAT FUEL $10.008-I N C H$ CLADDING FAILURE) GENERAL ELECTRIC COMPANY, PLEASANTON, CALIFORNIA

GEAP $=5135+.35$ PAGES, MARCH 1966, CFSTI, $\$ 2.00 \mathrm{CY}, \$ 0.50 \mathrm{MN}$

SHORTLY AFTER INCREASING POWER FROM 15 TO 17 MW(TH) (APPARENTLY FOR THE FIRST TIME), AN 8-MIL INCOLOY CLAD SUPERHEAT ROO FAILED. THE REACTOR HAS OPERATED FOR TWO MONTHS TO GAIN

RELEASE-RATE INFORMATION. A 5-IN.-LONG CRACK WAS FOUND, AND GRAIN GROHTH SHOWED CLAD HAD BEEN ABOVE $1900 \mathrm{~F}$. URANIUM DIOXIDE UNDER THE CRACK WAS U02.42, AND HAD SWELLED. THE FAILURE WAS CAUSED BY HIGH-TEMPERATURE MECHANICAL STRESS WITHOUT CORROSION, OXIDATION, OR HIGH INTERNAL PRESSURE.

*FAILURE, FUEL ELEMENT + CLAD + INCONEL + REACTOR, SUPERHEAT + STOICHIOMETRY + VESR (VALLECITOS EXP. SUPERHEAT REACTOR-ESADA)

17-11258 FASSBENDER $J+$ KRAMER H + MEISTER $G$

RESULTS OF STARTUP TESTING EXPERIMENTS ON FRJ-2 REACTOR KERNFORSCHUNGSANLAGE, JUELICH, WEST GERMANY

JUL-236-RE +. 213 PAGES, JULY 1965, DEP. MN, IN GERMAN

TESTS RAN FROM NUVEMBER 1962 TO DECEMBER 1963. TYPICAL TEMPERATURE C.OEFFICIENT, REACTIVITY

WORTH OF CONTROL ROD, XENON ANO SAMARIUM REACTIVITY EFFECTS ARE REPORTED.

OIDO (UK) + GERMANY + REACTOR STARTUP TESTING + REACTOR, HEAVY WATER + REACTOR, HIGH FLUX + REACTOR, TEST 
CATEGORY 17

OPERATIONAL SAFETY AND EXPERIENCE

17-11259 STOLLER SM

SOME CONSIOERATIONS ON THE ROLE OF ADVANCEO CONVERTER REACTORS

S. MTOLLER ASSOCIATES, NEW YORK

4 PAGES, JUNE 20, 1966 , ANS TRANS., PAgE 213, PRESENTEO AT THE TWELFTH ANNUAL MEETING OF THE AMER ICAN NUCLEAR SOCIETY IN DENVER, COLORADO, JUNE 20, 1966

MARKETING WILL BE DIFFICULT BECAUSE OF THE SQUEEZE BETWEEN RREEDERS AND IMPROVEMENTS IN WATER REACTORS. THE HTGR HAS SURVIVEO ANU MAY BE A BRIDGE TO IHE GAS-COOLED BREEDER. THE POTENTIAL FOR BEING CHEAPER ON PAPER MAY NOT BE ENOUGH. SAVINGS ARE NOT LARGE FOR EVEN SECOND-GENERATION DEVICES AND DEPEND ON SUCCESSFUL R AND D FOR DIFFICULT PROGRAMS, WITH LITTLE FABRICATION EXPERIENCE. THERE ARE PERHAPS 30 UTILITIES BUYING REACTORS, AND NONE WILL WANT MUCH RISK.

\#ECONOMICS + REACTOR, BREEDER + REACTOR, POWER

17-11276 DUFFIELD RB

DEVELOPMENT OF THE HIGH-TEMPERATURE GAS-COOLED REACTOR AND THE PEACH BOTTOM HIGH-TEMPERATURE GAS COOLED REACTOR PROTOTYPE

GENERAL ATOMIC

GA-7143 +. 30 PAGES, 14 FIGURES, 4 TABLES, MAY 12, 1966, DOCKET NO. 50-171, PAPER PRESENTED AT THE BRITISH NUCLEAR ENERGY SOCIETY SYMPOSIUM ON HIGH-TEMPEP.ATURE REACTORS AND THE ORAGON PROJECT, AND WTLL BE PUELISHED IN THE JOURNAL OF THE BRITISH NUCLEAR ENERGY SOCIETY.

THE 4O-MW(E) PEACH BOTTOM POWER STATION IS DESCRIBED. RESULTS OF LOW-POWER NUCLEAR MEASUREMENTS ARE PRESENTED. SIGNIFICANT CONCLUSIONS OF THE RESEARCH AND DEVELOPEMENT PROGRAM ARE - II) COATED PARTICLES OF U AND TH ARE VERY PROMISING AS HIGH-TEMPERATURE FUELS BECAUSE OF FISSION-PRODUCT RETENTION. (2) LEAK-TIGHT SYSTEMS CAN BE MAOE FOR HELIUM AT HIGH TEMPERATURES AND PRESSURES. (3) MANY CHARACTERISTICS, SUCH AS FUEL LOADING, POWER DISTRIBUTIONS, AND CONTROL ROD WORTHS, MAY BE CALCULATEO WITH GOOD PRECISION. TWO TIME-CONSUMING PROBLEMS ENCOUNTERED WERE - 111 THE FUEL-TRANSFER MACHINE HAD TO BE MODIFIED TO OPERATE PROPERLY. (2) STRESS CORROSION WAS OBSERVED IN THE AUSTENITIC SUPERHEATER TUBES OF THE STEAM GENERATOR, WHICH MUST EE REPLACED.

*REACTOR DESCRIPTION + \#REACTOR STARTUF TCSTING + COATED PARTICLE + CORKOSION + FISSION PRODUCT RETENTION + HELIUM + LEAK RATE + PEACH BOTTOM + REACTOR, GAS COOLED + REACTOR, GRAPHITE MODERATED + STRESS

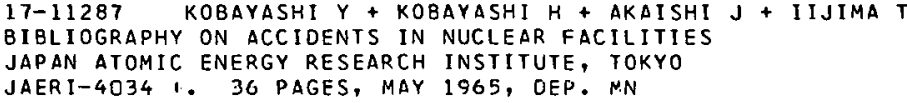

THE BIBL IOGRAPHY CONTAINS 120 ABSTRACTS FROM NUCLEAR SCIENCE ABSTRACTS, 1948 TO 1964 , DEALING WITH PERSONAL EXPOSURES TO RADIATION OR RADIATION ACCIDENTS IN NUCLEAR FACILITIES. THE ABSTRACTS ARE ARRANGED IN THE NSA NUMERICAL ORDER. THE SUBJECT INDEX IS DIVIDED INTO EMERGENCY PLANNING AND ACCIOENTS, EACH GROUP BEING FURTHER DIVIDEO INTO SMALLER CLASSES.

\#RIELIOGRAPHY + INCIDENT, ACTUAL, GENERAL + PERSONNEL EXPOSURE, RADIATION

17-11364 QUAD-CITIES STATION, UNIT 1 - PLANT DESIGN ANALYSIS, VOLUME 1 COMMONWEALTH EDISON COMPANY. C.HICAGO

1 PAGE, DOCKET NO. 50-254, PAGE III-4-4, MAY 31, 1966 PDR

DURING THE EQUIVALENT OF IG FULL-PGWER YEARS OF OPERATION OF GE BOILING-WATER REACTOR, A STEACY-STATE THERMAL OVER-POWER CCNOITION IN THE RANGE OF 105 TO 110 PERCENT OF RATED REACTOR POWER OCCURRED ONLY ONCE.

\# INCIDENT, ACTUAL, geNERAL + \#REACTOR POWER + REACTOR, BOILING WATER

$17-11413$ SKARPELOS JM

C.HFMISTRY OF ESADE V VWR NUCLEAR SUPCRHEAT LOOP

GENERAL ELECTRIC COMPANY, SAN JOSE, CALIFCRNIA

GEAP-4813 +. 38 PAGES, FEBRUARY 1964, CFSTI, \$2.00 CY, \$0.5C MN

THE CHEMISTRY PROGRAM ASSOCIATED WITH THE ESADE-VBWR NUCLEAR SUPERHEAT LOOP WAS CARRIED ON WITH THE PRIMARY PURPOSE OF DETECTING THE FAILURE OF FUEL CLADDING AND MEASURING THE FISSION-PRODUCT RELEASE RATE. TO ACCOMPLISH THIS OBJECTIVE, NOBLE-GAS FISSION PRODUCTS AND RADIOIODINES WERE MONITORED IN THE LOOP INLET AND OUTLET STEAM. RADIOCHEMISTRY MEASUREMENTS MADE DURING IRRADIATION GAVE NO INDICATION OF DEFECTIVE FUEL. RESULTS AFTER SIPPING THF FIIFI DUNDLE AT THE COMPLETION OF IHE IRRADIATION INDICATED THAT A FUEL ELEMENT MIGHT HAVE BEEN DEFECTIVE. HOWEVER, THE SIGNAL WAS SUFFICIENTLY WEAK THAT IF A DEFECT WERE PRESENT IT WAS VERY SMALL. PROBLEMS ASSOCIATED WITH STEAM SAMPLING DID NOT DETRACT FROM THE MAJOR OBJECTIVE, WHICH WAS TO DETERMINE OPERATING LIMITS FOR SUPERHEAT FUEL FLEMENTS OF INTEREST.

\#CHEMICAL REACTION + \#FAILURE, FUEL ELEMENT \& \#VBWR (VALLECITOS BOILING WATER REACTOR) + REACTOR, BOILING WATER + REACTOR, SUPERHEAT

17-11422 SMITH EH PHILLIPS PETROLEUM COMPANY, ETR OPERATIONS PROGRESS RFPORT, CYCLE NO, 81, MAY $22,1966-3 U L Y 4,1966$ PHILLIPS PETROLEUM, IDAHO

IDO-17201 +. 36 PAGES, 2 FIGURES, AUGUST 5, 1966, DTIE 
CATEGORY IT

OPERATIONAL SAFETY AND EXPERIENCE

17-11422 *CONTINUED*

THIS REPORT IS ONE OF A SERIES OF SUCH REPORTS ON THE FOLLOWING SUBJECTS - PLANT OPERATIONS, OPERATING SUMMARY, IRRACIATION PROGRAM, AND REACTOR IRRADIATION SUMMARY.

\#OPERATIONS REPORTS, GENERAL + ETR (ENGINEERING TEST REACTOR): + ' REACTOR, TEST

17-11427 EXPERIMENTAL BERYLLIUM OXIDE REACTOR PROGRAM. QUARTEPLY PROGRESS REPORT FOR THE PFRIOD ENDING MARCH 31,1966

GENERAL ATOMIC

GA-7130 +26 PAGES, 2 FIGURES, MARCH 1966 , CFSTI $\$ 2.00 \mathrm{CY}, \$ 0.50 \mathrm{MN}$

INSPECTION AFTER THE LIFE-CYCLE TEST OF THE PROTOTYPE CONTROL-ROD-DRIVE MECHANISM SHOWED SLIGHT POLISHING OF THE GEAR TEETH AND SOME DETERIORATION OF THE MOTOR BEARINGS. TO ENSURE RETTER PERFORMANCE AT ZERO-POWER TEMPERATURE CONDITIONS, A-LESS VISCOUS LUBRICANT WAS

SELECTED. MANIPULATIONS WITH THE FUELTHANDLING MACHINE REVEALED INTERFERENCE. B.ETWEEN THE GRAPPLING HEAO ANO CORE ELEMENTS ADJACENT TO THE ELEMENT BEING HANDLED. MINOR PEWORKING THE HEAD CORRECTED THE CONDITION. OURING THE VALVE. TESTS, 50 GAL OF LUBRICATING WAS DISCHARGED . INTO THE MAIN LOOP VIA A CAMAGEO OIL SEAL ON THE MAIN HELIUM CIRCULATOR.

* OPERATING EXPERIENCE + EBOR (EXPERIMENTAL BEPYLLIUM OXIDE REACTOR) + FAILURE, EOUIDMENT +

FUEL HANDLING MACHINE + REACTCR, BEO MOOERATEO + REACTOR, SAS COOLED + TEST, CONTROI ROD DRIVE. 
CATEGORY 18

SAFETY ANALYSIS AND DESIGN REPORTS

18-C8716 CORNELL OC

SAFE-PCRS. A COMPUTER PROGRAM FOR THE STRESS ANALYSIS OF COMPOSITE BODIES OF REVOLUTION. INPUT INSTRUCTIONS

GENERAL ATOMIC

GA-6588 +. 40 PAGES, FIGURES, TABLES, 2 REFERENCES- AUGUST $1,1965-$ CFSTI, \$2.00 CY, \$0.75 MN.

A COMPUTER PROGRAM FOR THE STRESS ANALYSIS OF COMPOSITE BODIES OF REVOLUTION. INPUT INSTRUCTIONS.

* COMPUTER PROGRAM + *STRESS ANALYSIS + DESIGN STUDY + PROPERTY, PHYSICAL

18-09415 UNIVFRSITY OF KANSAS TO USE NEPTUNIUM OXIDE FOILS FOR NEUTRON SPECTRUM MEASUREMENTS UNIVERSITY OF KANSAS

2 PAGES, FEBRUARY 14, 1966 , DOCKET NO. SE-140, PDR

FOUR $0.4-G$ FOILS OF NP-237 OXIDE ENCAPSULATED IN COPPER TO BE USED ON LOAN.

\#FLUX DISTRIBUTION + *NEPTUNIUN + *REACTOR, TRAINING

18-09740 HOUNGHTALING JE + NORBERG JA + HAIRE JC

ACDENDUM TO THE SNERI 1 II HAZARDS SUNMAPY REPORT -- LOW-ENRICHMENT OXIDE CORE

PHILLIHS PETHULEUM CUMPANY, IDAHO

IDO-17CC3 IREV. $21+92$ PAGES, 22 IABLES, 21 FIGURES, 34 REFERENCES, OCTOBER 1965, CFSTI, \$3.00 CY, $\$ 0.75 \mathrm{MN}$

PERTINENT MECHANICAL CHARACTERISTICS OF THE E-CORE aRe Explained, as well as Changes made to THE SPERT III CONTROL SYSTEM. INCLUDED ARE THE NUCLEAR CHARACTERISTICS OF THE CORE AS CETERMINED BY CALCULATION AND EXTRAPOLATION OF PREVIOUS EXPEP.IMENTAL RESULTS. ALSO, THE PREDICTED KINETIC BEHAVIOR FOR THE PLANNED TESTS AND CERTAIN ACCIOENT CDNDITIONS ARE DISCUSSED. SEVERAL ACCIDENT SITUATIONS ARE CONSIDERED AND ANALYZED TO OBTAIN NUMERICAL ESTIMATES OF RADIOLOGICAL HAZARDS.

* SPERT 3 (SPECIAL POWER EXCURSION REACTOR TEST) + ACCIDENT ANALYSIS + CONTROL SYSTEM + DOSE + HAZARDS ANALYSIS + REACTOR KINETICS + REACTOR, PRESSURIZED WATER + REACTOP., TEST + SAFEGUARDS REPORT, GENERAL

18-C.9744 VAUGHAN RD

BRACWELL NUCLEAR POWER STATION

THE NUCLEAR POWER GROUP, KNUTSFORD, CHESHIRE, ENG.

39 PAGES, 38 FIGURES, 4 TABLES, 1964 , PP. $1-39$ OF THE BERKELEY AND BRADWELL BOOK, INSTITUTION OF MECHANICAL ENGINEERS, LONDON

THE BRADWELL POWER STATION IS DESIGNED FOR A NET OUTPUT OF 300 MW(E). IT INCDRPORATES TWO IDENTICAL REACTORS OF THE GRAPHITE-MODERATED GAS-COOLED TYPE. THE DESIGN OF THE REACTORS ANO POWER STATION ARE DISCUSSED, INCLUDING PLANT CONFIGURATION, REACTOR CORE DIMENSIONS, FUEL ELEMENT PARAMETERS, THE CHOILE ÜF KEACIUK GAS IEMPERATURES, THE STEAM CYCLE, THE FUEL ELEMENT, THE REACTOR CORE, FUEL HANDLING, AND BURST-CARTRIDGE EQUIPMENT. OTHER TOPICS INCLUDE REACTOR VESSEL AND GAS CIRCUITS, THE MAIN BLOWERS, CONTROL AND INSTRUMENTATION, AND TURBO-ALTERNATORS. ALTHOUGH BRADWELL IS NOT YET OPERATED AT DESIGN TEMPERATURE LEVELS, A BRIEF REVIEW IS GIVIN OF THE PERFORMANCE OF THE VARIOUS COMPONENTS. OIAGRAMS ARE TNCLUOEU, AND A LIST OF DESIGN PARAMETERS IS GIVEN.

\#REACTOR DESCRIPTION + CONTAINNENT STRUCTURE + REACTOR, GAS COOLED + UNITED KINGDOM

18-09745 SOUTHWOOD JRM

BERKELEY NUCLEAR POWER STATION

THE NUCLEAR POWER GROUP, KNUTSFORO, CHESHIRE, ENG.

31 PAEES, 27 FIGURES, 1964 , PP. 40-70 OF THE BERKELEY AND BR ADWELL BOOK, INSTITUTION OF MECHANICAL ENGINEERS, LONUÚN

A NUMBER OF THE MAJOR FEATURES OF THE BERKELEY NUCLEAR POWER STATION ARE DISCUSSED. THESE ILLUSTRATE THE EXPERIENCE GAINED AS THE WORK PROGRESSED AND INDICATE HOW CHANGES PROMPTED BY NEW DATA WERE INCLUDED IN THE DESIEN WHERE ESSENTIAL OR WHERE CONSIDERED PRACTICALLY WITHIN THE CONSTRUCTION PROGRAM. THE TOPICS INCLUDE A BRIEF DESCRIPTION OF THE PLANT, DESIGN

CONSIDERATIONS, FUEL ELEMENTS, STATION PERFORMANCE, THE CORE PERFORMANCE INCLUDING GRAPHITE CORES, SHIELDING, AND A PRESSURE VESSEL DESCRIPTION. ALSO DISCUSSED ARE BLOWERS, BOILERS, BURST CARTRIDGE DETECTION GEAR, FUELING HANDLING, THE TURBINE HOUSE, CIRCULATING WATER, AND THE ELECTRIC SYSTEM. THE CONTROL OF THE REACTOR ANO THE COMMISSIONING PROGRAM ARE ALSO DISCUSSEO.

\#REACTOR DESCRIPTION + CONTAINMENT STRUCTURE + REACTOR, GAS COOLED + UNITED KINGDOM

18-C.974E SIMMONS WR + PERSIANI PJ + BUMP TR

FAST REACTOR TEST FACILITY (FARET) AND INITIAL EXPERIMENTAL PROGRAM ARGONNE NATIONAL LABORATORY, ARGONNE, ILLINOIS

ANS-100(SUPPL.) + CONF. 650417(SUPPL.) +. 19 PAGES, 3 FIGURES, PAGES $37-55$ OF FAST REACTOR OF TECHNOLOGY, ANS NATIONAL TOPICAL MEETING, DETROIT, MICHIGAN, APRIL 26-28, 1965, SOURCE

THE FAST REACTOR TEST FACILITY SITE, BUILDING, CONTAINMENT STRUCTURE, FUEL-HANDLING SYSTEMS, SHIELDING, COOLANT SYSTEMS, REACTOR PROPER, CONTROL SYSTEMS, EXPERIMENTAL CAPABILITIES, 
CATEGORY 18

CATEGORY 18
SAFETY ANALYSIS ANO DESIGN REPORTS

18-09746 *CONTINUED*

DESIGN SPECIFICATIONS, LOADING, AND FUEL-TESTING PROGRAM AND OBJECTIVES ARE DESCRIBED.

\#CCNTAINMENT STRUCTURE + \#FARET (FAST ARGONNE REACTOR EXPERIMENT TEST) + \#REACTOR DESCRIPTION + CONTAINMENT, HIGH PRESSURE + CONTAINMENT, PRESSURE VESSEL + REACTOR, BREEDER + REACTOR, FAST + REACTOR, LIQUID METAL COOLED

19-09783 A STUDY OF A GAS-COOLED FAST BREEOER REACTOR. INITIAL STUDY, CORE DESIGN ANALYSIS AND SYSTEM DEVELOPMENT PROGRAM. FINAL SUMMARY REPOR.T

GENERAL ATOMIC DIVISION, GENERAL DYNAMICS CORP.

GA-5537 + 255 PAGES, FIGURES, TABLES, REFERENCES, AUGUST 15, 1964, CFSTI

REPORT RELATES TO DESIGN BASED ON MINIMAL EXTENSION OF PRESENT TECHNOLOGY, USING ESTABLISHED REACTOR MATERIALS, OPERATEO WELL HITHIN THEIR CAPABILITIES. CONCLUSIONS ARE THAT GAS COOLING OFFERS ADVANTAGES BEYOND PROVISION OF AN ALTERNATIVE TECHNOLOGY, AS IT AVOICS SOME PRACTICAL PROBLEMS ASSOCIATED WITH SODIUM. DVOIDANCE OF THE SAFETY - AND STABILITY - DICTATED DESIGN COMPROMISES IMPOSED BY NUCLEAR-COOLANT INTERACTION ALLOWS THE REALIZATION OF A COMBINATION OF HIGH INTERNAL CONVERSION RATIO AND FUEL RATING WITH VERY LOW BURNUP REACTIVITY CHANGE AND LOW COOLANT-VOID EFFECTS. THE RECUCEC MODERATION INFLUENCE OF THE COOLANT RESULTS IN A TOLERABLE COOLANT-VOID EFFECTS. THE RECUCEE MODERATION INFLUENCE OF THE CODLANT RESULTS IN A TOLERAB
REDUCTION OF DOPPLER COEFFICIENT IN VIEW OF THE REDUCED COOLANT-VOID COEFFICIENT AND LOW EXCESS REACTIVITY REQUIREMENTS. COOLANT-LOSS RATES SUFFICIENT TO HALVE PRFSSURF. IN 20 SEC CAN BE DEALT WITH BY THE NORMAL GAS CIRCULATORS. FOR THE MORE-DETAILED STUDIES, INCLUDING ILLUSTRATION OF CONSTRUCTIONAL FEATURES AND KINETIC-BEHAVIOR EVALUATION, A 500 MWIEI REFERENCE DESIGN BASED ON A 5ODO-LITER CORE WAS SELECTED.

*CESIGN STUDY + *REACTOR, BREEDER + \#REACTOR, GAS COOLED + DOPPLER EFFECT + FLOODING COEFFICIENT + LOSS OF COOLANT + REACTOR STABILITY + VOID COEFFICIENT

18-0S948 DRESDEN NUCLEAR POWER STATION UNIT 3 PLANT DESIGN AND ANALYSIS REPORT VOL. I COMMONWEALTH EDISON COMPANY

183 PAGES (APROX.), TABLES, FEBRUARY 1966, DOCKET NO. 50-249, POR

UNIT 3 WILL BE IDENTICAL WITH UNIT 2, AS AMENDED, DND IS SCHEDULED FOR 1 YEAR LATER. UNIT 3 IS A NOMINAL $2300 / 809$ MWE NET. UNITS 2 AND 3 WILL SHARE A $310-F T$ STACK, A DISCHARGE CANAL, AND A ONE (OF 3 ) CONTAINMENT COOLING SYSTEMS. WHILE THEY SHARE A COMMON REACTOP BUILDING AND A COMMON TURBINE. BUILDING, EACH REACTOR HAS ITS OWN PRESSURE-SUPPRESSION SYSTEM AND CONTAINMENT. FUEL IS ZIRCALOY-2-CLAD UO2, POWFR CONTROL BY MOVABLE ROOS AND BY VARYING JET-PUMP CIRCULATING FLOW, TWO CORE-SPRAY SYSTEMS. EACH SUPPLIES ENOUGH WATEP TO PREVENT MELTING ON LOSS-OF-COOLANT ACCIDENT BECAUSE OF INNER REACTOR VESSEL. ALL DESIGN-EASIS ACCIDENTS GIVE LESS THAN 1 RAD DOSE OFF-SITE. VOL II CONTAINS DRAWINGS AND APPENDIXES. SITE AND ENVIRONS DESCRIBED IN VOL. III OF UNIT 2.

\#CONTAINMENT, PRESSURE SUPPRESSION + \#ORESDEN III + \#SAFEGUAROS REPORT, GENERAL + REACTOR, BOILING WATER

18-C9949 DRESDEN NUCLEAR POWER STATION UNIT 3 PLANT DESIGN AND ANALYSIS REPORT VOL. II COMMONWEALTH EOISON COMPANY

152 PAGES (APPROX.), 100 FIGURES, FEBRUARY 1966, DOCKET NO. 50-249, PDR

CONTAINS DRAWINGS FOR VOL. I, PLUS SHORT APPENDIXES ON JET-PUMP DESIGN, CONTROL-ROD ORIVE, EXCURSION - DAMAGE LIMITS, HYPOTHETICAL NUCLEAR-EXCURSION LIMITS, AND STABILITY.

\# CRESDEN III + \#AFEgUARDS REPCRT, GENERAL + ACCIDENT, HYPOTHETICAL + CCNTROL ROD DRIVE + REACTOR, BOILING WATER

1 C-09883 DENISE RP

N. S. SAVANNAH TO REMOVE AUXILIARY FEEDWATER LINES

FIRST ATOMIC SHIP TRANSPORT, INC.

1 PAGE, MAY 17, 1966, DOCKET 5C-238, ATOMIC ENERGY CLEARING HOUSE, 12(23), PAGE 19 (JUNE 6, 1966$)$

ORIGINAL FEEDWATER LINES INSTALLED ACCOROING TO CONVENTIONAL PLANT PRACTICE DESPITE NO DANGER OF TUBES EXCEEDING PRIMARY COOLANT TEMPERATURE. BECAUSE OF GOOD OPERATING HISTORY, AUXILIARY LINES REQUIREMENT REQUESTED REMOVED FROM TECHNICAL SPECIFICATIONS, THOUGH SYSTEM HILL BE RETAINED.

\#HEAT EXCHANGER + \#OPERATING LIMITS/TECHNICAL SPECIFICATIONS + N S SAVANNAM + REACTOR, PRESSURIZED WATER

18-C9987 CARLSMITH RS + DELENE JG

RESPONSE OF. A HELIUM-COOLED FAST REACTOR TO CHANGES IN COOLANT FLOW AND REACTIVITY OAK RIDGE NATIONAL LABORATORY

ORNL-P-1698 + CONF-651009-4 +. 24 PAGES, PRFSENTED AT CONFERENCE ON SAFETY, FUELS AND CORE DESIGN IN

LARGE FAST POWER REACTORS, ARGONNE NATIONAL LABORATORY, OCTOBER 11-14, 1965, CFSTI, \$1. OO CY, \$O.5O MN

ORNL DESIGN OF A HELIUM-COCLED FAST REACTOR STUDIED WITH RESPECT TO STEP AND RAMP REACTIVITY

INSERTIONS AND LOSS OF COOLANT PRESSURE AND FLOW.

*REACTOR, FAST + ACCIDENT; REACTIVITY + HELIUM + LOSS OF FLOW + LOSS OF PRESSURE + REACTOR, GAS COOLED 
CATEGORY 18

SAFETY ANALYSIS AND DESIGN REPORTS

\author{
$18-10047$ \#CONTINUED* \\ THE OYSTER CREEK NUCLEAR BOILER CESIGN \\ GENERAL ELECTRIC COMPANY, SAN JOSE \\ 18 PAGES, 9 FIGURES, 3 TABLES, 2 REFERENCES, APRIL 1966 , PRESENTED AT THE AMERICAN POWER CONFERENCE 28 TH \\ ANNUAL MEETING, APRIL 26-28, CHICAGO, ILLINOIS, APC, \$0.25 CY \\ BRIEF DESCRIPTION OF REACTOR, FLOW DIAGRAM, CORE DESIGN ANO INSTRUMENTATION. \\ * REACTOR DESCRIPTION + OYSTER CREEK + REACTOR, BOILING WATER
}

18-10117 PRWRA APPLICATION FOR MODIFICATION OF OPERATING AUTHORIZATION DPRA-4 BONUS REACTOR PUERTO RICO WATER RESOURCES AUTHORITY, SAN JUAN

1 IS PAGES, DECEMBER 24, 12E5, COCKET NO, $115-4$, POR

PUERTO RICO WATER RESOURCES AUTHORITY REQUESTS TO TAKE OVER SOLE RESPONSIBILITY FOR OPERATING BONUS REACTOR. REPORT CONTAINS ORGANIZATION CHARTS, JOB DESCRIPTIONS, AND EXPEPIENCE SUMMARIES OF BONUS-ASSIGNED PRWRA PERSONNEL.

*BONUS (BOILING NUCLEAR SUPERHEAT PROJECT) + *STAFFING, TRAINING, QUALIFICATION + REACTOR, SUPFRHEAT

18-1015E RUDY GC + SWANSON DH + GREGORY JG + PEARCE WR + SHULTZ TG + STONE JT SAFETY INSTRUMENTATION REVIEW AND RESULTING MODIFICATIONS FOR PATHFINDER DOWER PLANT ALLIS-CHALMERS MANUFACTURING COMPANY, BETHESDA

ACNP-64638 +. 83 PAGES, 74 FIGURES, FERRUARY 12, 1966, DOCKET NO. 50-130, POR

THE AS-BUILT NUCLEAR AND PROCESS SAFETY INSTRUMENTATION WAS GIVEN A COMPLETE REVIEW BY EVALUATING IT AGAINST A MODERN GENERAL SAFETY POLICY AND A SET OF SPECIFIC DESIGN SPECIFICATIONS. THE ORIGINAL DESIGN WAS DEFICIENT IN MANY AREAS, AND MONIFICATIONS WERE MADE TO SATISFY THE DESIGN SPECIFICATIONS. SEVERAL NEW PROTECTIVE CHANNELS WERE ADDFD, AND SECOND CHANNELS WERE ACDED TO MOST OF THE PROCESS CHANNELS. PROVISION WAS MADE TO TEST ALL THE CHANNELS AT POWER. RELAY MATRICES WERE ADDED TO BACK UP THE SOLID-STTATE LOGIC SCRAM CIRCUITS,

\#CESIGN CRITERIA + \#MODIFICATICN, SYSTEM OR EQUIPMENT + \#PATHFINDER + \#PLANT PROTECTIVE SYSTEM + * SAFETY PRINCIPLES AND PHILOSCPHY + REACTOR SAFETY SYSTEM + REACTOR, BOILING WATER + REGULATION, AEC

$18-10191$ MCELROY DF

PATHFINDER TECHNICAL SPECIFICATIONS CHANGE. HIGH VESSEL COOLING RATE ALLOWED DURING INITIATION OF EMERGENCY CONDENSER COOLING

NORTHERN STATES POWER COMPANY

2 PAGES, MAY 3, 1966, DOCKET 50-130, ATOMIC ENERGY C.LEARING HOUSE, 12(20), PAGES 29-30 (MAY 16, 1966)

TECHNICAL SPECIFICATION REVISION ALLOWS EXCEEOING VESSEL CDOLING RATE OF 200 F/HR, DURING TEST ING OF EMER GENCY CONDENSER, PROVIDED THAT THE TEMPERATURE CHANGE IS LESS THAN SO F ANO THAT THE HALF-HOUR CHANGE IS LESS THAN IOO F. THE 200 F/HR LIMIT WAS INTENDED FOR THF FLOODED CONOITION, NOT OURING ORAINED OPERATION WHEN STEAM INSULATES THE REACTOR-VESSEL HEAD AND FLANGE FROM THE EFFECTS OF RAPID CHANGES OF REACTOR COOLANT TEMPERATURE. A SO F COOLDOWN IN 2 MIN OCCURS WITH SCRAM WHILE IN MANUAL PRESSURE CONTROL, OR OPENING OF THE SAFETY VALVE UPON CLOSURE OF THE TURBINE VALVES AND DUMP VALVE.

\#CONTAINMENT, HIGH PRESSURE + \#MERGENCY COOLING + \#OPERATING LIMITS/TECHNICAL SPECIFICATIONS + \#PATHF INDER + REACTOR, SUPERHEAT

18-1C270 ARNETT LM + ROSS CP + RUSCHE Bi + TAYLOK CU FINAL SAFETY ANALYSIS OF THE MAXIMUM CREDIBLE ACCIDENT IN THE HEAVY WATER COMPONENTS TEST REACTOR SAVANNAF RIVER LABORATORY, DUPONT

OP-1037+. 30 PAGES, 4 FIGURES, 7 TABLES, REFERENCES, DECEMBER 1965, CFSTI \$2.00 CY, $\$ 0.50$ MN

THE MAXIMUM CREDIBLE ACCIDENT IN THE HWCTR. IS ANALYZED FOR THE CONOITIONS THAT EXIST SINCE IODINE ABSORBERS WERE INSTALLED IN THE CONTAINMENT BUILDING. THE ABSORBERS REMOVE

RADIOIODINE ISOTOPES TO THE EXTENT THAT THE THYROID AND WHOLE-BODY DOSES AT THE SAVANNAH

RIVER PLANT BOUNDARY WOULD BE LESS BY FACTORS OF SIX AND TWENTY-FIVE, RESPECTIVELY, THAN THE

ALLOWABLE LIMITS SET FORTH IN THE CODE OF FEDERAL REGULATIONS (IO-CFR 1 GO).

* ACCIDENT, MAXIMUM CREDIBLE (MCA) + HHWCTR (HEAVY WATER COMPONENT TEST REACTOR) + FILTER + IODINE + SAFEGUARÓS REPORT, GENERAL

18-10328 CONSUMERS POWER CONPANY. PALISADES PLANT. PRELIMINARY DESCRIPTION AND SAFETY ANALYSIS REPORT, VOLUME III

CONSUMERS POWER CONPANY

109 PAGES, 15 FIgURES, 2 TABLES, JUNE 1966, DOCKET NO. 50-255, PDR

VOL III CONTAINS VARIOUS APPENDIXES, MAINLY PERTAININF TO CONTAINMENT AND STRUCTURAL DESIGN BASIS, AND VARIOUS HINDROSES AND SUBSTANTIATION FOR CHOSEN METEOROLOGICAL PARAMETERS.

* SAFEguAROS REPORT, GENERAL + ATMOSPHERIC DIFFUSION COEFFICIENT + CONTAINMENT DESIGN + PALISADES PLANT + REACTOR, PRESSURIZED WATER

18-10329 CONSUMERS POWER CONPANY. PALISADES PLANT. PRELIMINARY DESCRIPTION AND SAFETY ANALYSIS 
CATEGORY 18

SAFETY ANALYSIS AND DESIGN REPORTS

$18-10329 \quad$ \#CONTINUED*

REPORT, VOLUME II

CONSUMERS POWER COMPANY

172 PAGES, 12 FIGURES, JUNE 1966, DOCKET NO. 50-255, PDR

PROTECTIVE SYSTEM USES DLAL SENSORS IN EACH OF TWO CHANNELS, WITH EACH CHANNEL IEITHER THROUGH RELAY OR SOLID-STATE ACTIONI REQUIRED TO TRIP TO CAUSE A SCRAM. SELF-POWERED IN-CORE NEUTRON DETECTORS GIVE OPERATING INFCRMATION. SUPERVISORS WILL BE TRANSFERREO FROM BIG ROCK POINT. 1.5-IN. DROP OF CORE AWAY FROM RODS DUE TO CORE-BARREL FAILURE ANALYSED AS NO REACTIVITY PROBLEM, ALTHOUGH SOME MECHANICAL CAMAGE POSSIBLE. MAXIMUM HYPOTHETICAL ACCIOENT (DOUBLE-ENDEO PIPE RUPTURE, 23 PERCENT ZIRCONIUM CLAD-WATER REACTIONI YIELOS 203 REMS THYROID DOSE ( 2 HR) AT SITE BOUNDARY. VOL. II DESCRIBES ENGINEERED SAFEGUAROS ISAFETY INJECTION, CONTAINMENT SPRAY, CONTAINMENT AIR COOLINGI, I AND C, SAFETY ANALYSIS, AND CONFORMANCE WITH AEC CONSTRUCTION-PERMIT SPECIFICATIONS.

*PAL ISADES PLANT + FAFEgUARDS REPORT, GENERAL + ACCIDENT, HYPOTHETICAL + DESIGN CRITERIA + ENGINEERED SAFEGUARD + REACTOR, PRESSURIZED WATER

18-10340 DUNGENESS B AGR NUCLEAR POWER STATION

CENTRAL ELECTRICITY GENERATING SOARD

12 PAGES, FIGURES, JULY 1965 , SCURCE

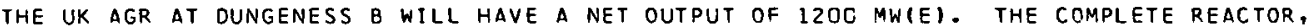
INCLUDING CORE, GAS CIRCULATORS AND BOILERS, IS HOUSED WITHIN A CONCRETE PRESSURE VESSEL. AN INNER PRESSURE CYLINDER IN THE FORM OF A BELL SEPARATES THE CORE FROM THE BOILERS. THE INTERNAL WALLS OF THE CCNCRETE PRESSURE VESSEL ARE CLAD WITH STAINLESS STEEL THERMAL INSULATION. THE BOILERS ARE OF THE ONCE-THROUGH TYPE WITH A SINGLE REHEATER STAGE. THE TUBE ENDS ARE LED OUT IN SUCH A WAY THAT ACCESS IS AVAILABLE FOR PLUGGING OR OTHER PURPOSES WITHOUT ENTRY INTO THE PRESSURE VESSEL. THE URANIUM OIOXIDE FUEL IS CONTAINED IN STAINLESS-STEEL CANS, ARRANGED IN THREE-RING CLUSTERS OF 36 PINS WITHIN GRAPHITE SLEEVES, TO FORM 40-INCH-LONG FUEL ELEMENTS. THE MEAN FUEL RATING IS SOME THREE TIMES GREATER THAN FOR THE MAGNOX SYSTEM.

* MIINGENESS B (UK) + *REACTOR DESCRIPTION + AGR (AOVANCED GASCOOLEC REACTOR, WINDSCALE, UK) + REACTOR SAFETY SYSTEM + REACTOR, GAS COOLED + UNITED KINGDOM

18-10392 LUMB RF

TECH SPEC FOR SHORT TERM OISCHARGE RATE LIMITS MORE THAN LONG-TERM LIMITS

WESTERN NEW YORK NUCLEAR RESEARCH CENTER INC.

1 PAGE, JUNE 3, 1966, DOCKET 50-57, ATOMIC ENERGY CLEARING HOUSE, 12(26), PACE. 40 (JUNE 27, 1966)

CERTAIN OPERATIONS RELEASE RADIOISOTOPES THAT MOMENTARILY EXCEED STACK-OISCHARCE LIMITS AT WESTERN NEW YORK NUCLEAR RESEARCH CENTER. CHANGES IN TECHNICAL SPECIFICATIONS WOULD ALLOW EXCEEDING MPC EQUIVALENT OF ART41, WITH ONLY A LOCAL INVESTIGATION, AND REPORTING TO AEC IF RELEASE EXCEEDS $100 \mathrm{MPC}$.

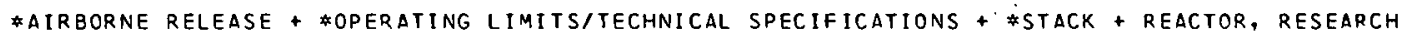

$12-10475$ COATES RL + HORTON NR

RSAC--A RACIOLOGICAL SAFETY ANALYSIS COMPUTER PROGRAM

PHILLIPS PETROLEUM COMPANY, IOAHO

IDO-17151+. 208 PAGES, 3 TABLES, 7 REFERENCES, MAY 1966, CFSTI, \$6.00 CY, \$1.25 MN

AN IBM 7040 PROGRAM WHICH COMPUTES THE POTENTIAL RADIOLOGICAL DOSES RESULTING FROM A CONTINUOUS OR INSTANTANEOUS RELEASE OF FISSION PRODUCTS TO THE ATMOSPHERE. DEVELOPED AS PART GF LOFT AND GENERAL NUCLEAR SAFETY FROGRAMS TO PROVIDE A CENERALIZED COMPUTER PROGRAM FOR A COMPLETE PARAMETRIC INVESTIGATION OF RADIOLOGICAL HAZARDS. DOSES CONSIDERED ARE CLOUD GAMMA, CEPOSITION GAMMA, INGESTION, AND INHALATION, AND ARE BASED UPON THE RELEASE OF UP TO 200 ISOTOPES, THE RELATIVE ABUNDANCE OF EACH ISOTOPE BEING DEPENDENT UPON THE OPERATING HISTORY OF THE NUCLEAR REACTOR UNDER CONSIDERATION. INCLUDED ARE THE MATHEMATICAL MODELS, CONVERSION FACTORS, ASSUMPTIONS, FLOW CHARTS, PROGRAM LISTINGS, AND OTHER DATA PERTINENT TO THE OVERALL DEVELOPMENT OF THIS PROERAM.

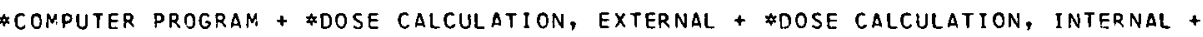

\#FISSION PRODUCT RELEASE, GENERAL + SUTTON DIFFUSION FORMULA

18-10600 APPLICATION FOR LICENSES FPCE PLANT

I SOCHEM INC

750 PAGES APPROX., 83 FIGURES, 71 TABLES, REFERENCES, JUNE 1966, DOCKET NO. 50-258, PDR

REPORT GIVES ALL THE GENERAL AND DETAILED TECHNICAL INFORMATION REQUIRED FOR AEC LICENSINE OF $\triangle$ RADIOCHEMICAL PLANT. INCLUDED ARE SECTIONS ON - SITE DESCRIPTION, PLANT DESCRIPTION, PROCESS DESCRIPTION, EQUIPMENT DESCRIPTION, SYSTEMS ANALYSIS, PUBLIC PROTECTION, PERSONNEL PROTECTION, SAFETY, PLANT ORGANIZATION, AND STARTUP PLANS.

\#APPLICATION FOR AEC LICENSE + \#CERIUM + \#CESIUM + \#FPCE PLANT + \#PROMETHIUM + \#RADIOCHEMICAL PROCESSING + * SAFEGUARDS REPORT, GENERAL + \#STRONTIUM + FISSION PRODUCT, SEPARATION FROM WASTE +

FISSION PROOIIT, USE OF IN WASTES + HAZARDS ANALYSIS + ISOCHEM, INC. + RADICCHEMICAL PLANT SAFETY 
CATEGORY 18

SAFETY ANALYSIS AND DESIGN REPORTS

18-10742 \#CONTINUED

THE RANDOML $Y$ PACKED SETTLED BED FAST REACTOR CONCEPT - 10OD-MWIEI REACTOR DESIGN

BROOKHAVEN NATIONAL LABORATORY, UPTON, NEW YORK

BNL-887 +. 56 PAGES, 36 FIGURES, 20 TABLES, 32 REFERENCES, JUNE 1, 1965, CFSTI, \$3.00 CY, \$0.50 MN

CONCEPTUAL DESIGN FOR SODIUM-COOLED U-PU CARBIDE SPHERES. MAJOR LIMITATION IS INTEGRITY OF UNCLAD 0.12-IN. FUEL PARTICLES. BREEDING RATIO IS 1.7 TO 1.8 . REPORT CONSISTS OF BED PHYSICS AND ENGINEERING (13 PAGES), THERMAL-HYORAULIC OESIGN 17 PAGESI, PLANT DESIGN 112 PAGESI AND ECONOMICS (14 PAGES).

*CESIGN STUDY + \#FLUIDIZED BED + \#REACTOR DESCRIPTION + REACTOR, FAST + REACTOR, LIQUID METAL COOLEO

$18-10837$ BOYD R.S

PROPOSED CHANGE NO. 2 TO LICENSE R-G8, NEROJET-GENERAL NUCLEONICS INDUSTRIAL P.EACTOR (AGNIR)

DIVISION OF REACTOR LICENSING, USAEC

3 PAGES, AUGUST 1,1966 , DOCKET 50-228, POR

AGNIR MAY BE LOADED WITH FUEL ELEMENTS WITH A 15-IN. ACTIVE LENGTH (INSTEAD OF 14) 8ECAUSE ALL TRIGA ELEMENTS MANUFACTURED IN THE NEAR FUTURE WILL BE THIS TYPE. PERMISSION GRANTED, AS INVENTORY UNCHARGED, AND REACTIVITY-STEP ANALYSIS PERFORMED WITH 3.0 PERCENT NOT INVALIOATED.

\#FUEL ELEMENT + \#MOCIFICATION, SYSTEM OR EQUIPMENT + \#OPERATING LIMITS/TECHNICAL SPECIFICATIONS + REACTOR, RESEARCH + TRIGA (TRAINING REACTOR, ISOTOPES, G.A.)

$18-10 E 57$ BOYÕ KS

PROPOSED CHANGE I TO LICENSE R-31. THE CATHOLIC UNIVERSITY OF AMERICA - AGN-2OI

DIVISION OF REACTOR LICENSING, USAEC

3 PAGES, AUGUST 1,1966 , DOCKET 5C-77, PDP

CATHOLIC UNIVERSITY AUTHCRIZED TO OPEN CORE TANK OF AGN-201 (MODEL 101 ) TO EXAMINE FUEL OISKS AND MEASURE WEIGHT AND DIMENSIONS. PRECAUTIONS LISTED.

\#EXAMINATION + \#FUEL ELEMENT + \#PERATING LIMITS/TECHNICAL SPECIFICATIONS +

AGN (TRAINING REACTOR, AEROJET-GEN. NUCLEONICS) + REACTOR, IRAINING

$18-10859-108 B-H T$

CHANGE REQUEST NO. 10 FOR LICEASE NO, DPR- 8

CAROLINAS VIRGINIA NUCLEAR POWER ASSOCIATES, INC.

5 PAGES, JULY 22,1966 , DOCKET 5C-144, POR

REQUESTS THAT LATEST DATE OF THE 1 S6E INTEGRAL CONTAINMENT-LEAK-RATE TEST BE JANUARY 1, 1967, RATHER THAN AUGUST 31,1966 , SO A SPECIAL SHUTDOWN WOULD NOT BE REQUIRED. NO INDICATION OF EXCESSIVE LEAKAGE EXISTS (ON CONTINUOUS MONITORING OF SYSTEM).

\%OPERAIING LIMITS/TECHNICAL SPECIFICATIONS + CONTAINMENT LEAKAGE + CVTR (CAROLINAS VIRGINIA TUBE REACTOR) + REACTOR, HEAVY WATER + REACTOR, PRESSURE TUBE + REACTOR, PRESSURIZED WATER + TEST, LEAK RATE

$12-10801$ NEIOIG RE

SAXTON TECHNICAL SPECIFICATICN CHANEE REQUEST NO. 24

SAXTON NUCLEAR EXPERIMENTAL CORPORATION

7 PACES, 2 TABLES, JULY 28,1966, DOCKET 50-146, PDR

ThO ELEMENTS WILL BE REINSERTEO INTO PERIPHERAL CORE POSITIONS, CONTAINING SOME TEST FUEL RODS

(EITHER STAINLESS STEEL OR ZIPCALOY-4 CLADI AND INTERNALLY PRESSURIZED TO STRESS CLAD A

MAXIMUM OF 41,500 PSI. OTHER TEST RODS CONTAIN COMPONENTS OF AN ACVANCED FUEL-ROD-GRIO

CESIGN. THE END CLOSURES OF FIVE STANDARD RODS ARE SUBSTANDARD FOR TEST PURPOSES.

*FUEL ELEMENT + \#IRRADIATION TESTING + \#PRESSURE, INTERNAL + REACTOR, PRESSURIZED WATER + SAXTON

18-10862 CASE EG

AMENOMENT 3 TO LICENSE DPR-9, POWER REACTOR DEVELOPMENT COMPANY

DIVISION OF REACTOR LICENSING, USAEC

8 PAGES, JULY 27, 1966 , DOCKET SC-16, PDR

ANENDMENT 3 ALLOWS AN INCREASE OF SB-124 (NEUTRON SOURCE) ACTIVITY TO 15 KILOCURIES FROM 3.6 , AND LIMITS NUMBER OF SOURCES TO FOUP. SOURCE MAY BE CONTAINED IN TANTALUM OR STAINLESS STEEL.

* CPERATING LIMITS/TECHNICAL SPECIFICATIONS + FERMI + REACTOR, BREEDER + REACTOR, FAST +

REACTOR, LIQUID METAL COOLED + SOURCE, NEUTRON

$18-10868$

FIRST SUPPLEMENT TO PRELIMINARY SAFETY ANALYSIS REPORT.

INDIAN POINT NUCLEAR GENERATING UNIT

NO. 2

CONSOLICATED EDISON COMPANY OF NEW YORK

284 PAGES, FIGURES, TABLES, MARCH 31, 1966, DOCKET NO. 50-247, PDR

CCNTAINS ANSWERS TO REQUESTS FOR SPECIFIC INFORMATION PLUS GENERAL DESIGN CRITERIA FULFILLMENT, PLUS CONSIDERATION GIVEN ACRS VIEWS CONCERNING REACTOR PRESSURE VESSELS. 
CATEGORY 18

SAFETY ANALYSIS AND DESIGN REPORTS

18-10868 \#CONTINUED*

* SAFEgUARDS REPORT, RESPONSE TO AEC QUESTIONS + INDIAN POINT II + REACTOR, PRESSURIZED WATER

\begin{abstract}
$18+10869$
NO. 2

FIRST SUPPLEMENT TC PRELIMINAPY SAFETY ANALYSIS REPORT. INCIAN POINT NUCLEAR GENERATING UNIT

CCN'SOLICATED EOISON COMPANY OF NEW YCRK

35 PAGES, 1 FIGURE, 2 TABLES OF FIRST SUPPLEMENT TO PRELIMINARY SAFETY ANALYSIS. INOIAN POINT NUCLEAR

EENERATING UNIT NO. 2, MARCH 31, 1966, DOCKET NO. 50-247, PDR

QUESTION 1 - APPLICANT EXPLAINS SIGNIFICANT DIFFERENCES BETWEEN INDIAN POINT II AND

BROOKWOOD, CONN. YANKEE PLANTS. SHORT DISCUSSION OF THERMAL-HYDRAULIC DESIGN USING W-3

CORRELATION, FUEL-CLADDING STRESS AND HYDRIDE, XENON, AND MODERATOR-COEFFICIENT INSTABILITY,

AND USE OF SECTION III OF BOILER CODE INSTEAD OF SECTION VIII.
\end{abstract}

\author{
18-10870 FIRST SUPPLEMENT TO PRELIMINARY SAFETY ANALYSIS REPORT. INDIAN POINT NUCLEAR. GENERATING UNIT \\ NO. 2 \\ CONSOLICATED EOISON COMPANY OF NEW YCRK \\ 1 PAGE OF FIRST SUPPLEMENT TO PRELIMINARY SAFETY ANALYSIS. INDIAN POINT NUCLEAR GENFRATING UNIT. NO. 2, \\ MARCH 31, 1966, DOCKET NO. 50-247, PDR \\ QUESTION 2 -- CONTAINS ANALYSIS TO SHOW THAT THE PLANT MEETS 27 GENERAL DESIGN CRITERIA FOR \\ NUCLEAR POWER PLANT CONSTRUCTION PERMITS, NOVEMBER 22, 1965. \\ \#DESIGN CRITERIA + \#REgULATION, AEC + \#SAFEgUAROS REPORT, RESPONSE TO AEC QUESTIONS + INDIAN POINT II

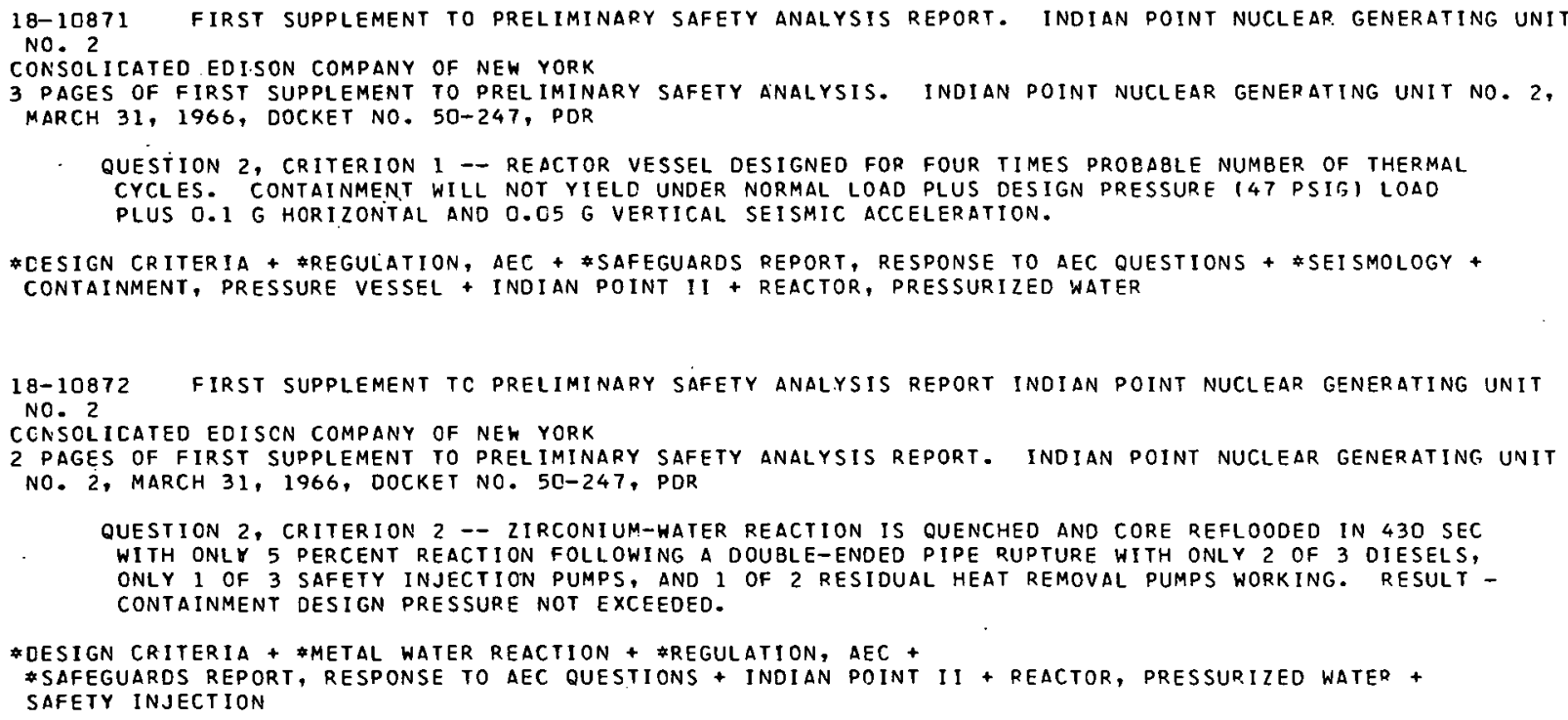

18-10873 FIRST SUPPLEMENT TO PRELIMINARY SAFETY ANALYSIS. INDIAN POINT NUCLEAR GENERATING UNIT NO. 2 CONSOLIDATEO EDISON COMPANY OF NEW YORK

2 PAGES OF FIRST SUPPLEMENT TO PRELIMINARY SAFETY ANALYSIS. INDIAN POINT NUCLEAR GENERATING UNIT NO. 2, MARCH 31,1966 , DOCKET NO. 50-247, PDR

QUESTION 2, CRITERION 3 - GIVES DETAILED CRITERIA TO WHICH PLANT WILL BE DESIGNED, EXAMPLES CF MISSILES.

\#OESIGN CRITERIA + \#REgULATION, AEC + \#SAFEgUARDS REPORT, RESPONSE TO AEC QUESTIONS +

CONTAINMENT, MISSILE GENERATION AND PROTECTION

18-10874 FIRST SUPPLEMENT TO PRELIMINARY SAFETY ANALYSIS. INDIAN POINT NUCLEAR GENERATING UNIT NO. 2 . CONSOLIDATED EDISON COMPANY OF NEH YORK

2 PAGES OF FIRST SUPPLEMENT TO PRELIMINARY SAFETY ANALYSIS. INCIAN POINT NUCLEAR GENERATING UNIT NO. 2 , MARCH 31, 1966, DOCKET NO. 50-247, PDR

QUESTION 2, CRITERION 4 -- LOSS OF LOAD ANO LOSS OF FLOW ARE PROTECTED AGAINST BY ROD

INSERTION, STEAM DUMP., AND BY ROTATIONAL INERTIA OF CONTROLLED LEAKAGE PUMPS.

\#CESICN CRITERIA + \#LOSS OF FLCW + *LOSS OF LOAD + *REGULATION, AEC +

* SAFEGUARDS REPORT, RESPONSE TO AEC OUESTIONS + INDIAN POINT II + REACTOR, PRESSURIZED WATER

18-10875 FIRST SUPPLEMENT TC PRELIMINARY SAFETY ANALYSIS. INCIAN POINT NUCLEAR GENERATING UNIT NO. 2 . 
CATEGORY 18

SAFETY ANALYSIS AND DESIGN REPORTS

18-1C875 \#CONTINUED

CONSOLIOATED EDISON COMPANY OF NEW YORK

5 PAGES, I FIGURE, 1 TABLE OF FIRST SUPPLEMENT TO PRELIMINARY SAFETY ANALYSIS. INOIAN POINT NUCLEAR

GENERATING UNIT NO. 2, MARCH 31, 1966, DOCKET NO. 50-247, PDR

QUESTION 2, CRITERION E -- SPATIAL-POWER-DISTRIBUTION INSTABILITIES IDUE TO XENON OSCILLATION OR MODERATOR TEMPERATURE VARIATIONSI WILL BE EXAMINED IN DETAIL. PRELIMINARY STUDIES

INDICATE THAT THESE CAN BE CONTROLLED IF NECESSARY. MOST OF THE EXPERIMENTAL DATA IS ON

STAINLESS-STEEL CORES, SO DAMPING DUE TO POWER COEFFICIENT CANNOT BE ACCURATELY CHECKEO IN

ZIRCALOY-CLAD CORE.

\#CESIGN CRITERIA + \#REgULATION, AEC + \#SAFEgUARDS REPORT, RESPONSE TO AEC QUESTIONS + \#XENON OSCILLATION + INDIAN POINT II + MODERATOR COEFFICIENT + POWER DISTRIBUTION + REACTOR, PRESSURIZED WATER

18-1087E FIRST SUPPLEMENT TC PRELIMINARY SAFETY ANALYSIS. INDIAN POINT NUCLEAR. GENERATING UNIT NO. 2. CONSOLIDATED EDISON COMPANY OF NEW YORK

1 PAGE OF FIRST SUPPLEMENT TC PRELIMINARY SAFETY ANALYSIS. INDIAN POINT NUCLEAR GENERATING UNIT NO. 2 ,

MARCH 31, IGGK, DOCKFT NO. 50-747, POR

QUESTION 2, CRITERION 6 -- EQUILIBRIUM CORE 13.92 PERCENT ENRICHMENT) WILL YIELD (AV- 27,OOCI

(MAX-45000) MWDIMETRIC TCN OF U BURNUP. CLADDING, 0.0243 ZIRCALOY. CLADDING INTEGRITY

ENSURED BY KEEPING INTERNAL GAS PRESSURE LESS THAN REACTOR PRESSURE, DNB RATIO GREATER THAN

1.3, NO FUEL CENTERLINE MELTING, AND CLADOING STRESS BELOW YIELO POINT.

\#CESIGN CRITERIA + \#FAILURE, CLACDING + \#FUEL BURNUP + \#REGULATION, AEC +

* SAFEGUARDS REPORT, RESPONSE TO AEC QUESTIONS + INDIAN POINT II + REACTOR, PRESSURIZED WATER + STRESS

18-10877 FIRST SUPPLEMENT TC PRELIMINARY SAFETY ANALYSIS. INIIAN POINT NUCLEAR GENERATING UNIT NO. 2. CONSOLIDATED EDISON COMPANY OF NEW YORK

2 PAGES OF FIRST SUPPLEMENT TO PRELIMINAPY SAFETY ANALYSIS. INDIAN POINT NUCLEAR GENERATING UNIT NO. 2, MARCH 31,1366 , DOCKET NO. 50 -247 , PDR

QUESTION 2, CRITERION 7 -- OF THE 53 MAGNETIC-LATCH-DRIVEN RODS, HALF ARE FULL OUT FOR POWER

OPERATION, AND REST LIMITED IN SPEEO BY ORIVE MOTOR. BORON SHIM CONTROL THUS LIMITS

REACTIVITY AVAILABLE FOR RAPID INSERTION. CONTROL-ROD EJECTION IS CONSIDERED INCREDIBLE.

\# ACCIDENT, CONTROL ROD WITHDRAWAL + *DESIGN CRITERIA + \#REGULATION, $\triangle E C+$

* SAFEgUAROS REPORT, RESPONSE TO AEC QUESTIONS + INDIAN POINT II + REACTOR, PRESSURIZED WATER

18-10878 FIRST SUPPLEMENT TO PRELIMINARY SAFETY ANALYSIS. INDIAN POINT NUCLEAR GENERATING UNIT NO. 2 . CONSOLIDATED EDISON COMPANY OF NEW YORK

1 PAGE OF FIRST SUPPLEMENT TO PRELIMINARY SAFETY ANALYSIS. INDIAN POINT NUCLEAR GENERATING UNIT NO. 2 , MARCH 31,1966 , DOCKET NO. 50-247, PDR

QUESTION 2, CRITERION \& -- MAXIMUM AVAILABLE EXCESS REACTIVITY IS 0.305, COLD CLEAN. SHUTOOWN GROUP OF RODS MAKE REACTOR K-EFFECTIVE EOUAL TO 0.99 IN HOT ZERO-POWER FROM HOT POWER

CONOITION. WITH MOST WORTHWHILE ROD STUCK OUT, CHEMICAL SHIM KEEPS REACTOR SHUT DOWN.

\#CESIGN CRITERIA + \#REGULATICN, AEC + \#SAFEGUARDS REPORT, RESPONSE TO AEC QUESTIONS + \#SHUTDOWN MARGIN + INDIAN POINT II + REACTOR, PRESSURIZED WATER

18-10879 FIRST SUPPLEMENT TO PRELIMINARY SAFETY ANALYSIS. INDIAN POINT NUCLEAR GENERATING UNIT NO. 2 CONSOLICATED EDISON COMPANY OF NEW YORK

1 PAGES OF FIRST SUPPLEMENT TO PRELIMINARY SAFETY ANALYSIS. INOIAN POINT NUCLEAR GENERATING UNIT NO. 2 , MARCH 31,1966 , DOCKET NO. 50-247, PDR

QUESTION 2, CRITERION $9--$ EACKUP REACTIVITY IS INDEPENOENT OF CONTROL PROVISIONS, AS POWER TO ROD MECHANISIMS SHUT OFF ON SCRAM, REGARDLESS OF CONTROL SIGNALS. BORIC ACID INJECTION WITH ONE PUMP WILL SHUT REACTOR DOWN IN 15 MIN WITH NO RED INSERTION, AND IN ANOTON MAY THEN BE INJECTED FOR COLD SHUTDOWN.

* DESIGN CRITERIA + \#REGULATION, AEC + \#SAFEgUARDS REPORT, RESPONSE TO AEC OUESTIONS +

* SHUTDOWN SYSTEM, SECONDARY + CHEMICAL SHIM + INDIAN POINT II + REACTOR, PRESSURIZED WATER

18-1C88C FIRST SUPPLEMENT TO PRELIMINARY SAFETY ANALYSIS. INDIAN POINT NUCLEAR GENERATING UNIT NO. 2. CONSOL ICATED EDISON COMPANY OF NEW YORK

3 PAGES OF FIRST SUPPLEMENT TO PRELIMINARY SAFETY ANALYSIS. INOIAN POINT NUCLEAR GENERATING UNIT NO. 2 , MARCH 31,1966 , DOCKET NO. 50-247, PDR

QUESTION 2, CRITERION 10 -- ADEQUATE CONDENSATE IS STORED TO RELEASE OECAY HEAT FOP 24 HR BY SECONDARY STEAM DUMP. RESIDUAL HEAT EXCHANGERS AND CONTAINMENT AIR COOLERS ALSO SUPPLIED.

* CECAY rEAT + \#DESIGN CRITERIA + \#REGULATION, AEC + *SAFEgUAROS REPORT, RESPONSE TO AEC OUESTIONS + INDIAN POINT II + REACTOR, PRESSURIZEO WATER

18-10881 FIRST SUPPLEMENT TC PRELIMINARY SAFETY ANALYSIS. INDIAN POINT NUCLEAR GENERATING UNIT NO. 2. CONSOLIDATED EDISON COMPANY OF NEW YORK

2 PAGES OF FIRST SUPPLEMENT TO PRELIMINARY SAFETY ANALYSIS. INOIAN POINT NUCLEAR GENERATING UNIT NO. 2 , 
CATEGORY 18

SAFETY ANALYSIS AND DESIGN REPORTS

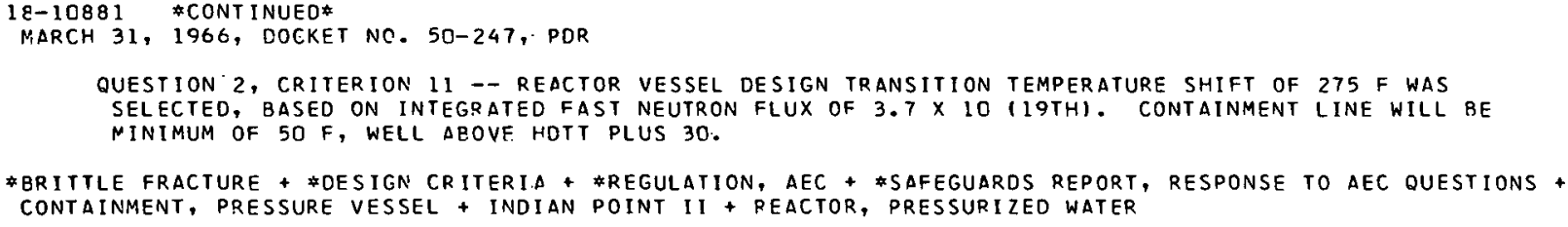

18-10883 FIRST SUPPLEMENT TC PRELIMINARY SAFETY ANALYSIS. INOIAN POINT NUCLEAR GENERATING UNIT NO. 2. CONSOL ICATED EDISON COMPANY OF NEW YORK

1 PAGE OF FIRST SUPPLEMENT TO PRELIMINARY SAFETY ANALYSIS. INDIAN POINT NUCLEAR GENERATING UNIT NO. 2, MARCH 31 , 1966, DOCKET NO. 50-247, PDR

QUESTION 2, CRITERION $13-$ - CCNTROL-ROOM SHIELDING IS PROVIDED SO THAT A REFERENCE ACCIDENT WOULD RESULT IN LESS THAN 1.5 REMS WHOLE BODY AND 3 REMS THYPOID, EVEN IF WORKERS REMAIN THERE INDEF INITELY.

\#DESIGN CRITERIA + \#REGULATION, AEC + \#SAFEgUARDS REPORT, RESPONSE TO AEC QUESTIONS + \#SHIELOING + BUILDING + INDIAN POINT I! + REACTOR, PRESSURIZED WATFR

18-10884 FIRST SUPPLEMENT TO PRELIMINARY SAFETY ANALYSIS. INDIAN POINT NUCLEAR GENERATING UNIT NO. 2 . CONSOLICATED EDISON COMPANY OF NEW YORK

2 PAGES OF FIRST SUPPLEMENT TO PRELIMINARY SAFETY ANALYSIS. INDIAN POINT NUCLEAR GENERATING UNIT NO. 2 , MARCH 31, 1966, DOCKET NO. 50-247, PDR

QUESTION 2, CRITERION $14-$ PERIOOIC BORON CONCENTRATION SAMPLES ARE TAKEN AT POWER AND DURING SHUTDOWN. DURING REFUELING, BF3-MONITORING GIVES AN AUDIBLE INDICATION OF DECREASING SHUTDOWN MARGIN. THE MAXIMUN DILUTION RATE (580 PPM/HR) GIVES AMPLE TIME FOR CORRECTIVE $\triangle C T I O N$.

\#CHEMICAL SHIM + *DESIGN CRITERIA + \#REgULATION, AEC + \#SAFEgUAROS REPORT, RESPONSE TO AEC QUESTIONS + INDIAN POINT II + INSTRUMENTATION, NUCLEAR + REACTOR, PRESSURIZED WATER

18-10885 FIRST SUPPLEMENT TO PRELIMINARY SAFETY ANALYSIS. INDIAN POINT NUCLEAR GENERATING UNIT NO. 2 CONSOL IDATED EDISON COMPANY OF NEW YORK

3 PACES OF FIRST SUPPLEMENT TO PRELIMINARY SAFETY ANALYSIS. INDIAN POINT NUCLEAR GENERATING UNIT NO. 2, MARCH 31,1966 , DOCKET NO. 50-247, PDR

QUESTION 2, CRITERION 15 -- COINCIOENCE ALLOWS ON-LINE TESTING, USING SIMULATED SIGNALS, OF SCRAM CHANNELS UP TO THE THREE RELAYS PROVIDING TWO-OF-THREE MATRICES FOR TRIPPING THE TWO SCRAM BREAKERS. ALSO, ENGINEERED SAFEGUARDS. CORE IS COUPLED SO THAT ALL OUT-OF-CORE INSTRUMENTS WILL SEE A ROC EJECTION ACCIDENT.

* COUPLEC CORES + \#DESIGN CRITERIA + \#INSTRUMENTATION, COINCIDENT + \#REgULATION, AEC + \#SAFEGUARDS REPORT, RESPONSE TO AEC QUESTIONS + \#TEST, SYSTEM OPERABILITY + EMERGENCY SYSTEM + PLANT PRCTECTIVE SYSTEM

18-1088E FIRST SUPPLEMENT TO PRELIMINARY SAFETY ANALYSIS. INOIAN POINT NUCLEAR GENERATING UNIT NO. 2 . CONSOLICATED EDISON COMPANY OF NEW YOP.K

2 PAGES OF FIRST SUPPLEMENT TO PRELIMINARY SAFETY ANALYSIS. INDIAN POINT NUCLEAR EENERATING UNIT NO. 2 , MARCH 31, 1966, DOCKET NO. 50-247, PDR

QUESTION 2, CRITERION 16 -- LOSS OF ELECTRIC. POWER CAUSES ROD INSERTION, EITHER DIRECTLY OR THROUGH THE INSTRUMENTS. COMPONENTS ARE DESIGNED. SO THAT ACCIDENT WILL NOT INTERFERE WITH FUNCTIONING.

*DESIGN CRITERIA + \#LOSS OF POLER + \#REGULATION, AEC + \#SAFEGUARDS REPORT, RESPONSE TO AEC OUESTIONS + INDIAN POINT II + INSTRUMENTATION, GENERAL + REACTOR, PRESSURIZED WATER + SAFE FAILURE CRITEPION

18-10887 FIRST SUPPLEMENT TC PRELIMINARY SAFETY ANALYSIS. INOIAN POINT NUCLEAR GENERATING UNIT NO 2. CONSOL IDATED EDISON COMPANY OF NEW YOP.K

3 PAEES OF FIRST SUPPLEMENT TO PRELIMINARY SAFETY ANALYSIS. INDIAN POINT NUCLEAR GENERATING UNIT NO. 2, MARCH 31 , 1966, DOCKET NO. 50-247, PDR

QUESTION 2, CRITERION 17 - IN ANALYSIS WHEREIN NO SAFETY WATER INJECTION ALLOWED BUT ONLY ONE 
CATEGORY 18

SAFETY ANALYSIS AND DESIGN REPORTS

$18-10887$ \#ONTINUED*

EACH CONTAINMENT SPRAY PUMPS OR AIR COOLERS FAILED, PRESSURE PEAK WAS 43.4 PSIG IHYDROGEN BURNS AFTER 44 PERCENT ZIRCONIUM REACTIONI. IN OTHER DOUBLE-ENDED PIPE RUPTURES, PRESSURE

PEAK WAS 40 PSIG.

\#CONTAINMENT DESIGN + \#DESIGN CRITERIA + \#PRESSURE, INTERNAL + \#REGULATION, AEC + INDIAN POINT II + LOSS OF COOLANT + METAL WATER REACTION + REACIUR, PRESSURIZED WATER +

SAFEGUARDS REPORT, RESPONSE TO AEC QUESTIONS

18-10888 FIRST SUPPLEMENT TO PRELIMINARY SAFETY ANALYSIS. INDIAN POINT NUCLEAR GENERATING UNIT NO. 2 . CONSOLIDATED EDISON COMPANY OF NEW YORK

2 PAGES OF FIRST SUPPLEMENT TO PRELIMINARY SAFETY ANALYSIS. INDIAN POINT NUCLEAR GENERATING UNIT NO. 2 , MARCH 31,1966 , DOCKET NO. 50-247, PDR

QUESTION 2, CRITERION 18 -- EITHER FOUR OF THE FIVE CONTAINMENT AIR COOLERS OR ONE OF THE THO SPRAY PUMPS IS ADEQUATE FOR HEAT REMOVAL FROM CONTAINMENT FOLLOWING A PIPING RUPTURE. ANY TWO OF THE THREE DIESELS hILL SUPPLY THESE LOADS. AUTOMATIC BUS SWITCHING ARRANGEMENTS ALLOW DIESEL B OR C TO SUPPLY CURRENT TO PUMT A IF DIESEL A FAILS.

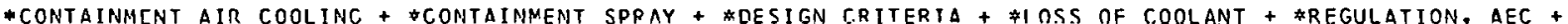
* SAFEgUARDS REPORT, RESPONSE TO AEC QUESTIONS + EMERGENCY POWER, ELECTRIC + INOIAN POINT II + PRESSURE, INTERNAL + REACTOR, PRESSURIZED WATEK

18-10889 FIRST SUPPLEMENT TO PRELIMINARY SAFETY ANALYSIS. INOIAN POINT NUCLEAR GENERATING UNIT NO. 2. CONSOLI DATED EDISON COMPANY OF NEW YORK

1 PAGE OF FIRST SUPPLEMENT TO PRELIMINARY SAFETY ANALYSIS. INDIAN POINT NUCLEAR GENERATING UNIT NO. 2., MARCH 31, 1966, DOCKET NO. 50-247, PDR

QUESTION 2, CRITERION $19--$ WITH THE DESIGN LEAK RATE AT 47 PSIG (O.1 PERCENT PER DAY) FOUR FAN-FILTER UNITS OPERATING THE HYPOTHETICAL LOSS OF COOLANT (WITH NO SAFETY INJECTION) OFFSITE DOSE WILL BE HALF THE IU-CFR-IOO LIMITS. REFERENCE-VOLUME LEAK-RATE TEST IS USED PLUS AIR MEASURED ON RETURN TO PRESSURE AFTER THE TEST. THICK-WALLED CONCRETE VESSEL WILL MINIMIZE ATMOSPHERIC EFFECTS. TEST MUST BE MADE WITH PLANT SHUT DOWN.

*CONTAINMENT LEAKACE + \#DESICN CRITERIA + \#OOSE * *REgULATION, AEC * \#SAFEGUARDS REPORT, RESPONSE TO AEC QUESTIONS + INDIAN POINT II + LOSS OF COOLANT + REACTOR, PRESSURIZED WATER + IEST, LEAK RATE

18-10890 FIRST SUPPLEMENT TO PRELIMINARY SAFETY ANALYSIS. INOIAN POINT NUCLEAR GENERATING UNIT NO. 2 . CONSOLIDATED EDISON COMPANY OF NEW YORK

1 PAGE OF FIRST SUPPLEMENT TO PRELIMINARY SAFETY ANALYSIS. INDIAN POINT NUCLEAR GENERATING UNIT NO. 2, MARCH 31 , 1966, DOCKET NO. 50-247, PDR

QUESTION 2, CRITERION 20 -- CONTAINMENT PENETRATIONS ARE PRESSURIZED SLIGHTLY ABOVE C.ONTAINMENT PRESSURE BY AIK HALKEO WITH NITROGEN. EXCESSIVE LEAKAGE IS MONITORED BY INTEGRATED AIR FLOW. EACH PENETRATION CAN BL TLGTLD SETARATELY AT ANY TIME.

* CONTAINMENT PENETRATION + \#DESIGN CRITERIA + \#REgulation, aEC +

\#SAFFGIIARDS REPORT, RESPONSE TO AEC QUESTIONS + CONTAINMENT LEAKAGE CONTROL + INDIAN POINT II + REACTOR, PRESSURIZED WATER + TEST, LEAK RATE

18-10891 FIRST SUPPLEMENT TO PRELIMINARY SAFETY ANALYSIS. INDIAN POINT NUCLEAR GENERATING UNIT NO. 2 . CONSOLICATED EDISON COMPANY OF NEW YORK

1 PAGE OF FIRST SUPPLEMENT TO PRELIMINARY SAFETY ANALYSIS. INDIAN POINT NUCLEAR GENERATING UNIT NO. 2 , MARCH 31,1966 , DOCKET NO. 50-247, PDR

QUESTION 2, CRITERION 21 -- ThO OF THF THREE DIESELS PROVIDE ADEQUATE POWER FOR ENGINEERED

SAFEGUARDS. VITAL INSTRUMENTS AND CUNTKOLLS ARE SUPPLIED FROM 125-V OC BATTERIES.

\#DESIGN CRITERIA + \#EMERGENCY POWER, ELECTRIC + \#SAFEGUARDS REPORT, RESPONSE TO AEC QUESTIONS + ELECTRIC POWER, VITAL + INDIAN POINT II + REACTOR, PRESSURIZED WATER + REGULATION, AEC

18-10892 FIRST SUPPLEMENT TC PRELIMINARY SAFETY ANALYSIS. INDIAN POINT NUCLEAR GENERATING UNIT NO. 2 CONSOLILATED EDISON COMPANY OF NEW YORK

5 PACFS OF FIRST SUPPLEMENT TO PRELIMINARY SAFETY ANALYSIS. INDIAN POINT NUCLEAR GENERATING UNIT NO. 2 , MARCH 31, 1966, DUCKE'I' NO. 50-247, POR

QUESTION 2, CRITERION 22. - SIX CLASSES OF CONTAINMENT-ISOLATION VALVE SCHEME ARE SET UP, WITH VARIOUS COMBINATIONS OF AUTONATIC AND OR REMOTE MANUAL VALVE CLOSURE, AND AUTOMATIC OR MANUAL SEAL-WATER INJECTION INTO THE CLOSED LINE.

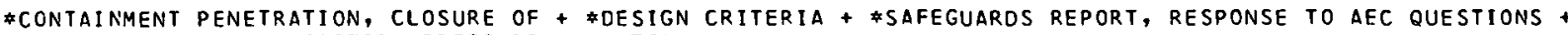
INDIAN POINT II + REACTOR, PRESSURI ZEO WATER

18-10893 FIRST SUPPLEMENT TO PRELIMINARY SAFETY ANALYSIS. INDIAN POINT NUCLEAR GENERATING UNIT NO 2. CONSOLIDATED CDISON COMTANY OF NEW YORK.

4 PAGES OF FIRST SUPPLEMENT TO PRELIMINARY SAFETY ANALYSIS. INDIAN POINT NUCLEAR GENERATING UNIT NO. 2 , MARCH 31,1966 , DOCKET NO. 50-247, PDR 
CATEGORY 18

SAFETY ANALYSIS AND DESIGN REPORTS

\begin{abstract}
$18-10893$ \#CONTINUEO *
QUESTION 2, CRITERION 23 - - LISTS VARIOUS TESTS OF ENGINEERED SAFEGUARDS THAT CAN EE PERFORMED IN THE PLANT DURING ITS LIFE. FOR EXAMPLE, SAFETY INJECTION CAN INJECT HATER INTO REACTOR. DURING HEATUP OR COOLDONN BY ENERGIZING SYSTEM AND OBSERVING PRESSURIZER WATER LEVEL. PUMPS CAN BE TESTED BY USING NINIMUM FLOW RECIRCULATION LINE DURING OPFRATION, AND CONTAINMENT AIR COOLING AND FILTRATION UNITS BY ACTUATING VALVES AND BY AEROSOL INJECTION.
\end{abstract}

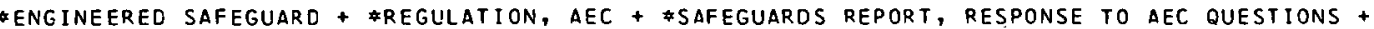
* TEST, SYSTEM OPERABILITY + DESIGN CRITERIA + INDIAN POINT II + REACTOR, PRESSIJRIZED WATEP

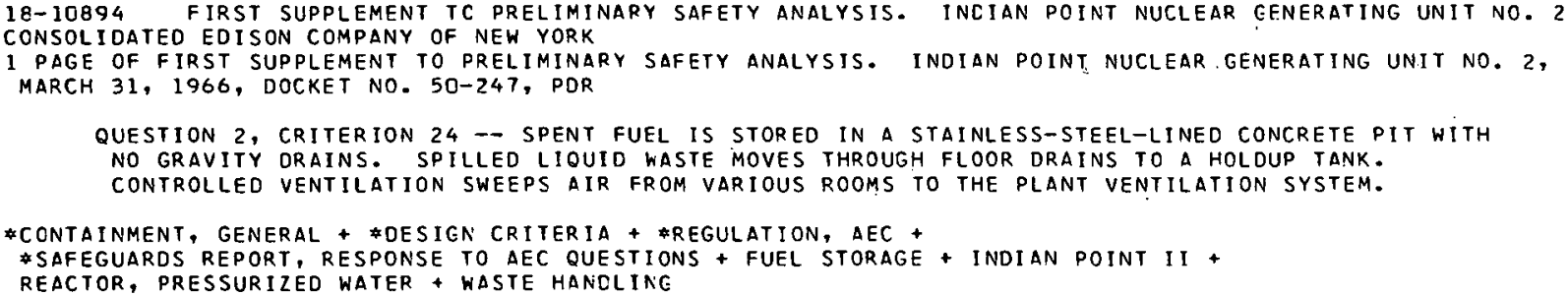

18-10895 FIRST SUPPLEMENT TC PRELIMINARY SAFETY ANALYSIS. INDIAN POINT NUCLEAR GENERATING UNIT NO. 2 CONSOLI DATED EDISON COMPANY OF NEW YORK

2 PAEES OF FIRST SUPPLEMENT TO PRELIMINARY SAFETY ANALYSIS. INCIAN POINT NUCLEAR GENERATING UNIT NO. 2 ,

MARCH 31, 1966, DOCKET NO. 50-247, PDR

QUESTION - 2, CRITERION 25 - FUEL STCRAGE AND HANDLING -- REFUELING WATER IS BORATED. SPENT ASSEMBLIES ARE STORED UNDERWATER WITH 12-IN. EOGE-TO-EDGE SPACING, SO THE RACK MULTIPLICATION IS LESS THAN 0.9. WATER-FILLED CANALS, ETC., ARE LINED HITH STAINLESS STEEL.

* CESIGN CRITERIA + \#FUEL HANDLING + \#FUEL STORAGE + *REGULATION, $\triangle E C+$

* SAFEgUARDS REPORT, RESPONSE TO AEC QUESTIONS + INDIAN POINT II + REACTOR, PRESSURIZED WATER

18-1089t FIRST SUPPLEMENT TC PRELIMINARY SAFETY ANALYSIS. INCIAN POINT NUCLEAR GENERATING UNIT NO. 2 . CONSOLICATEO EDISON COMPANY OF NEW YORK

1 PAGE OF FIRST SUPPLEMENT TO PRELIMINARY SAFETY ANALYSIS. INDIAN POINT NUCLEAR GENERATING UNIT NO. 2 , MARCH 31,1966 , DOCKET NO. 50-247, PDR

QUESTION 2, CRITERION 26 - HOLDUP CAPACITY FOR RAOIOACTIVE EFFLUENTS -- VARIOUS STORAGE AND CLEANUP FACILITIES PROVIDED.

*DESIGN CRITERIA + \#REgULATION, AEC + *SAFEgUARDS REPORT, RESPONSE TO AEC QUESTIONS + *WASTE STORAGE + INDIAN POINT II + REACTOR, PRESSURIZED WATER

18-10897 FIRST SUPPLEMENT TC PRELIMINARY SAFETY ANALYSIS. INDIAN POINT NUCLEAR GENERATING UNIT NO. 2 CONSOLIDATED EDISON COMPANY OF NEW YORK

1 PAGE OF FIRST SUPPLEMENT TO PRELIMINARY SAFETY ANALYSIS. INDIAN POINT NUCLEAR GENERATING UNIT NO. 2 , MARCH 31,1966 , DOCKET NO. 50-247, PDR

QUESTION 2, CRITERION 27 - MONITORING OF ACCIDENT-RELEASED RADIOACTIVITY -- VARIOUS SYSTEMS

PROVIDED TO INHIBIT CONTAINMENT-PENETRATION LEAKAGE AND TO MONITOR LOCATIONS AND SYSTEMS.

\#CESIGN CRITERIA + \#MONITOR, RADIATION, ENERGENCY + \#REGULATION, AEC +

* SAFEgUARDS REPORT, RESPONSE TO AEC QUESTIONS + INDIAN POINT II + REACTOR, PRESSURIZED WATER

18-10927 FIRST SUPPLEMENT TC PRELIMINARY SAFETY ANALYSIS. INCIAN POINT NUCLEAR GENERATING UNIT NO. 2 CONSOLIDATED EDISON COMPANY OF NEW YORK

3 PAGES OF FIRST SUPPLEMENT TO PRELIMINARY SAFETY ANALYSIS. INOIAN POINT NUCLEAR GENERATING UNIT NO. 2 , MARCH 31,1966 , DOCKET NO. 50-247, POR

QUESTION 19 I - DESIGN CRITERIA AND JUSTIFICATION, HOW FULFILLED, AND TEST METHODS - WHILE FAILURE OF CORE SUPPORT IS CONSIDERED INCREDIBLE, CORE DOWNWARO CROP HOULD BE LIMITED TO LESS THAN 2 IN. (LESS THAN 0.3 PERCENT REACTIVITY) BY THE IN-CORE INSTRUMENTATION STRUCTURE AND ENERGY ABSORBERS. THE ENERGY ABSORBERS WOULD REST ON THE INSIDE OF THE BOTTOM HEAO OF THE VESSEL AND WOULD SUPPORT THE CORE THROUGH THE IN-CORE INSTRUMENTATION STRUCTURES.

\#CORE COMPONENTS, MISCELlaneOUS + \#DESIGN CRITERIA + \#SAFEguARCS REPORT, RESPONSE TO AEC QUESTIONS + * SUPPORT STRUCTURE + FAILURE, COMPONENT + INDIAN POINT II + INSTRUMENTATION, IN CORE + REACTOR, PRESSURIZEO WATEP

18-10928 FIRST SUPPLEMENT TC PRELIMINARY SAFETY ANALYSIS. INDIAN POINT NUCLEAR GENERATING UNIT NO. 2 CONSOLI CATED EDISON COMPANY OF NEW YORK

1 PAGE OF FIRST SUPPLEMENT TO PRELIMINARY SAFETY ANALYSIS. INDIAN POINT NUCLEAR GENERATING UNIT NO. 2 , MARCH 31,1966 , DOCKET NO. 50-247, PDR

QUESTION,19J - DESIGN C.RITERIA AND JUSTIFICATION, HOW FULFILLED, AND TEST METHOD - FOR THE 
CATEGORY 18

CATEGORY 18
SAFETY ANALYSIS AND DESIGN REPORTS

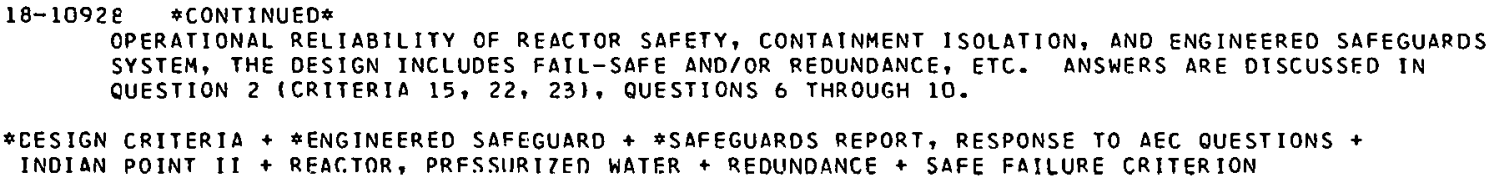

18-11.995 MOLTEN-SALT REACTOR PROGRAM, SEMIANNUAL PROGRESS REPORT FOR PERIOD ENDING FEBRUARY 28 , 1966 OAK RIDGE NATIONAL LABORATORY

ORNL-3936 +. 216 PAGES, FIGURES, REFERENCES, JUNE, 1966 , CFSTI, $\$ 6.00 \mathrm{CY}, \$ 1.25 \mathrm{MN}$

REPORTS IN THIS SERIES WILL BE INOEXED AS PERTINENT ITENS APPEAR. SECTIONS TREAT MSRE OPERATIONS AND COMPONENT DEVELOPMENT, GENERAL MATERIALS AND FUEL-SALT WORK, AND LARGE REACTOR DESIGN.

\# OPERATING EXPERIENCE + COOLANT CHEMISTRY + MATERIAL + MSRE (MOLTEN SALT REACTOR EXPERIMENT) + REACTOR, M.OLTEN SALT

18-11000 KELLER OL

PROGRESS RELATING TO CIVILIAN APPLICATIONS DURING APRIL, 1966

EATTELLE MEMORIAL INSTITUTE

BMI- $1771+33$ PAGES, 5 TABLES, SEPTEMBEP 1,1966 , CFSTI $\$ 2.00 \mathrm{CY}, \$ 0.50$ MN

REPORTS IN THIS SERIES WILL BE ABSIRACTED AS PERTINENT INFORMATION IS RECORDED. PROGRAMS ARE REACTOR MATERIALS AND COMPONENTS IIRRADIATION EFFECTS ON 347 STAINLESS STEEL, GRAPHITE DENSIFICATION, CHROMIUM-RHENIUM ALLOY, EXPLOSIVE WELDING OF ZIRCALOY-ALUMINUM TUBINGI, PLUS STUDIES OF FUELS IDEVELOPMENT OF AARR FUEL PLATES AND BEO-THO2-PUO2 FUELS, EFFECT OF HIGH BURNUP ON UO2 CEO2 AND U02-ZR02 FUELSI, PLUS URANIUM-PLUTONIUM MONONITRIDE FUELS, COATED PARTICLE FUELS, AND CORROSION STUDIES OF THE FLUORIDE VOLATILITY PROCFSS.

\# RESEARCH CONTRACT + FIIEI. BURNUP + FUEL ELEMENT + NITRIDE + PLUTONIUM + URANIUM + URANIUM DIOXIDE + WELDING

18-11001 KELLER OL

PROGRESS RELATING TO CIVILIAN APPLICATIONS DURING MAY, 1966

EATTELLE MEMORIAL INSTITUTE

BMI-1774 +. 22 PAGES, 5 TABLES, SEPTEMEER 1,1966, CFSTI $\$ 2.00 \mathrm{CY}, \$ 0.50$ MN

REPORTS IN THIS SERIES WILL BE ABSTRACTED AS PERTINENT INFORMATION IS RECOROFD. PROGRAMS ARE REACTOR MATERIALS AND COMPONENTS IIRRADIATION EFFECTS ON 347 STAINLESS STEEL, GRAPHITE DENSIFICATION, CHROMIUM-RHENIUM ALLOY, EXPLOSIVE WELOING OF ZIRCALOY-ALUMINUM TUBINGI, PLUS STUDIES OF FUELS IDEVELOPMENT OF AARR FUEL PLATES AND BEO-THO2-PUO2 FUELS, EFFECT OF HIGH BURNUP ON UO2 CEO2 AND UO2-ZRO2 FUELSI, PLUS URANIUM-PLUTONIUM MONONITRIDE FUELS, COATED PARTICLE FUELS, AND CORROSION STUDIES OF THE FLUORIDE VOLATILITY PROCESS.

* RESEARCH CONTRACT + FUEL BURNUP + FUEL ELEMENT + NITRIDE + PLUTONIUM + URANIUM + URANIUM DIOXIDE + WELDING

18-11021 QUARTERLY STATUS REPCRT CN ACVANCED REACTOR TECHNOLOGY (ART) FOR PERIOD ENDING APRIL 3O, I966 LOS ALAMOS SCIENTIFIC LABORATORY

LA-3524 +. 69 PAGES, 5 FIGURES, 26 TABLES, MAY, 1966 , CFSTI \$3.CC CY, $\$ 0.75$ MN

THIS REPORT IS ONE OF A SERIES OF SUCH REPORTS ON THE SUBJECTS ENUMERATED BELOW. PROGRAMS 
CATEGORY 18

SAFETY ANALYSIS AND DESIGN REPORTS

18-11021 \#CONTINUED*

REPORTED ON MOLTEN PLUTONIUM SUPPORTING RESEARCH, UHTREX, PLASMA THERMOCOUPLE, AND HEAT PIPES.

FPLUTCNIUM + REACTOR, BREECEP + REACTOR, LIQUID METAL COOLED

$18-11 C 28$ PENNINGTON RT

THREE TANK SEPARATE SUPERHEAT REACTCR

U. 5. PAT. 3,212,986 +. 6 PACES, OCTOBER 19, 1965, PATENT (U. S.)

IMPROVED REFUELING, CONTROL, AND SAFETY ARE CLAIMED BY PLACING THE MODERATOR (WATER) IN A PROCESS TUBE, SURROUNOING IT WITH FUEL RODS, AND THEN LETTING STEAM FLOW THROUGH AND AROUND RODS. THUS, COMPLICATEC DUCTING AND STEAM CONNECTIONS ARE NOT NEEDED. CONTROL IS ACHIEVED EY VARYING MODERATOR CONTENT. SHOULD A PROCESS TURE SREAK, WATER WOULO DRAIN OUT OF THE EOTTOM OF THE STEAM PLENUM RATHFR THAN REFLOOD THE CORE.

\#CONTROL, GENERAL + \#FLOODINE, SUPERHEATER + \#FUEL HANOLING + MODERATOR + REACTOR, PRESSUPE TUBE + REACTOR, SUPERHEAT

18-11029 SILVESTER AG

NUCLEAR REACTOR WITH EMERGENCY CCOLANT CROSS FLOW

U. S. PAT. 3,215,606 +. 10 PAEES, NOVEMBER 2, 1965, PATENT (U. S.)

THIS FAST-REACTOR. DESIGN IS INTENDED TO MINIMIZE (A) SOCIUM JETS HITTING THE VESSEL HEAD IN A REACTIVITY ACCIDENT, (B) EXCESSIVE NEUTRONS HITTING THE VESSEL HEAD DURING CDOLANT BOILING, (C) AND TO RENDER THE CCRE SAFE IN A PIPE-RUPTURE ACCIDENT. NOP.MALLY, COOLANT FLOWS THPOUGH THE CORE THEN UP PAST A SOLID MODERATOR SECTION (PROTECTION B), AND IS DIVERTED HORIZONTALLY THROUGH HOLES IN CLOSED PRCCESS FUBES (PROTECTION A). THE NORMAL COOLANT LINES ARE WELL $\triangle B O V E$ CORE TOP, SO SPECIAL EMERGENCY COOLANT LINES ARE PROVIOED TO MAINTAIN COOLANT LEVEL $\triangle B O V E$ CORE (PROTECTION CI, USING HOLES IN PROCESS TUBE ABOVE CORE BUT BELOW NORMAL COOLANT OUTLET.

\#EMERGENCY COOLING + \#LOSS OF COOLANT + CORE COMPONENTS, MISCELLANEOUS

1E-11030 ASTLEY ER + FINCH LM + HENNING RJ

FAST FUEL TEST REACTOR

U. S. PAT. 3,212,982 +. 6 PAGES, OCTOBER 19, 1965, PATENT (U. S.)

TO PROVIDE A MINIMUM VOID CCRE VOLUME YET WITH THE ENDS OF THE PROCESS TURE ADEQUATELY SEPARATED, HEXAGONAL PROCESS TUSES ARE ARRANGED IN A SKEWED-CONICAL RELATIONSHIP (AS IN BELGIAN BR-21, WITH EACH PROCESS TUBE TWISTED WITH RESPECT TO THE VERTICAL. CONVFNTIONAL FUEL RODS ARE USED IN THE PROCESS TUBES, BEING CODLED WITH LIQUID SODIUM. SIX REFLECTOR-CONTROL DRUMS ARE USED.

* CORE COMPONENTS, MISCELlaneOUS + REACTOR, FAST + reactor, PRESSURE TUBE + REACTOR, TEST

18-11C31 GUENTHER RW

NUCLEAR REACTOR CORE CLAMPING SYSTEM.

U. S. PAT. 3,215,608 +. G PAGES, NOVEMBER 2, 1965, PATENT (U. S.)

SPECIAL CLAMPS TO MINIMIZE SEPARATION BETWEEN CORE AND REFLECTOR ELEMENTS, DESPITE THERMAL EXPANSION OR DIFFERENT DIMENSIONS OF THE MATERIALS.

* CCRE COMPONENTS, MISCELLANECUS + REFLECTOR + SUPPORT STRUCTURE

18-11050 YANKEE REQUESTEO TC CLARIFY REACTOR VESSEL MATERIAL YIELD STRENGTHS U. S. ATOMIC ENERGY COMMISSICN

1 PAGE, COCKET 50-29, JUNE 25, 1566, ATOMIC ENERGY CLEAPING HOUSE, 12(28), PAGE 20 (JULY 11, 1966)

YANKEE REQUESTEO TO SUPPLY INFCRMATIOA BASED ON THE IN-VESSEL SURVEILLANCE SPECIMENS TO DETERMINE IF RAOIATION HAS SIGNIFICANTLY ALTERED PROPERTIES OF MATERIALS.

* CONTAINMENT, PRESSUP. VESSEL + \#RALIATION DAMAGE + BRITTLE FRACTUPE + REACTOR, PRESSURIZED WATER + yANKEe

18-11C8E REACTOR DEVELOFMENT PROGRAM PROGRESS REPORT, JULY 1966

ARGONNE NATIONAL LABORATORY

ANL-7245 +. 74 PAGES, 17 FICURES, 17 TABLES, REFERENCES, AUGUST 26, 1965, CFSTI, \$3.00 CY

ARGONNE NATIONAL LABCRATCRY PROCRESS REPORT, JULY 1966. THIS REPORT IS ONE OF A SERIES OF

SUCH REPORTS ON THE SUBJECTS ENUMERATED BELOW. TOPICS COVERED IN THIS REPORT ARE -

IRRADIATION OF FUEL PINS, TREAT MELTDOWN TEST, INTEGRAL SOOIUM LOOP, FAST-REACTOR SAFETY

CONTAINMENT, EQUATION OF STATE OF REFRACTORIFS SUCH AS UO2, METAL-WATER REAT,TIONS, AND

PLUTONIUM VOLATILITY SAFETY.

CONTAINMENT DESIGN + EQUATION OF STATE + FUEL MELTDOWN + METAL WATER P.EACTION + PLUTONIUM +

REACTOR DYNAMICS + REACTOR, FAST + SODIUM + TREAT (TRANSIENT TEST REACTOR. FACILITY) + URANIUM DIOXIDE 
CATEGORY 18

SAFETY ANALYSIS AND DESIGN REPORTS

\section{8-11C89 NILSON R}

HEAVY WATER STEAM IN DIRECT CYCLE MARVIKEN

AB ATOMENERGI, STOCKHOLM

5 PAGES, 4 FIGURES, 1 TABLE, 6 REFERENCES, NUCLEAR ENGINEERING, 11(121), PAGES 456-463 (JUNE 1966)

BRIEF REACTOR DESCRIPTION CF SUPERHEAT REACTOR, 593 MW(TH), 200 MW(E). UNIOUE STEAM FLOW OUT BOTTOM OF VFSSFL. MODIFIED PRESSURE-SUPPRESSION SYSTEM USED.

\#REACTOR DESCRIPTION + REACTOR, HEAVY WATER + REACTOR, SUPERHEAT + SWEDEN

18-11163 CAMPANA RJ

CESIGN OF THE SNAP-15A GENERATCR

GENERAL ATOMIC

GA-5296 +. 34 PAGES, 9 FIGURES, 12 TABLES, JUNE 1964, CFSTI $\$ 2.00$ CY, $\$ 0.50$ MN

THIS REPORT SUMMARIZED THE CONSIDERATIONS AND ANALYSIS LEADING TO THE CESIGN OF A PU-23B FUELED, METAL-THERMOCOUPLE GENERATOR PROVIDING ABOUT 1 MW AT GREATER THAN $4.5 V$ FOR 5 YEARS WITH VERY HIGH RELIABILITY EVEN UNDER EXTREME ENVIRONMENTAL CONDITIONS. BEFORE THE DESIGN WAS COMPLETED, A FEW EXPERIMENTAL GENERATORS WERE BUILT AND TESTED. THEY INFLUENCED THE FINAL DESIGN, ESPECIALLY WITH RESPECT TO THE TRANSIENT RESPONSE OF THE GENERATOR LOAD VOLTAGE TO STEP CHANGES IN THE AMUIENT TEMPERATURE. THE PRESENTATION OF THE WORK IS MADE IN THE C.HRONOLOG ICAL SEQUENCF IN WHICH THE DESIGN EVOLVED.

\#DESIGN STUOY + \#PLUTONIUM + \#THERMOELECTRIC CONVERSION + SNAP 15 (SYSTEMS FOR NUCLEAR AUXILIARY POWER)

18-11164 NUCLEAR REACTOR INSTALLATION

SULZER FRERES COSIETE ANONYME, SWITZERLAND

FRENCH PATENT 1,382,728+CRNL-TR -1309+. FEBRUARY 17, 1964, PATENT (FOREIGN), JCL \$1.10 FS, \$O.80 MF

a LEAK DETECTOR FOR THE STEAM genERATOR OF A GAS-COOLED REACTOR MAY BE MAOE BY PLACING A PH METER IN THE STEAM CIRCUIT BECAUSE CO2 CAUSES PH CHANGES. OR, A BYPASS-STEAM CONDENSER DRAINS INTO A TANK WITH A LIQUID LEVEL AND A VACUUM PUMP. CARBON DIOXIDE LEAKAGE WOULD CAUSE A CHANGE IN THE TANK PRESSURE NOT ACCOUNTED FOR BY THE TEMPERATURE OF THE CONDENSATE. ALSO, THF PH OF THE CONDENSED STEAM MAY INDICATE THE LEAK IN THE TUBE.

* HEAT EXChANGER + INSTRUMENTATION, PROCESS + *LEAK DETECTION + CARBON DIOXIDE + FPANCE + REACTOR, GAS COOLED

18-11224 THTR STATUS REPORT, 1965

EUROPEAN ATOMIC ENERGY COMMUNITY - EURATOM + BROWN BOVERI, KURPP REAKTORBAU GMBH, DUSSELDORF + KERNFORSCHUNGSANLAGE JULICH DES LANDES NORDRHEIN-WESTFALEN

EUR-3000.E +. 122 PAGES, 54 FIGURES, 3 TABLES, DECEMBER 1965, DEP. MN.

THE THTR IS A 3O0-MW(E) PEBBLE-BED HIGH-TEMPERATURE HELIUM-COOLED REACTOR ON THE THORIUM CYCLE. BRIEF OISCUSSIONS OF VARIOUS MECHANICAL, THERMAL, AND PHYSICS DESIGN ASPECTS AND PROBLEMS. SIX-HUNDRED FUEL BALLS PER HOUR MUST BE TESTED FOR BURNUP. ONE SCHEME IS TO BLOW THE BALLS THROUGH THE GLORY HOLE OF L LOW-POWER WATER BOILER ANO HAVE NUCLEAR INSTRUMENTS DIVERT SPENT BALLS.

* REACTOR DESCRIPTION + FUEL BURNUP + GERMANY + REACTOR, GAS CUULEU

18-11230 ADVISORY COMMITTEE ON REACTOR SAFEGUARDS REPORTS TO AEC ON PROPOSED MINNESOTA SITE ATOMIC ENERGY COMMISSION, WASHINGTON, D.C.

PRESS REL. J-137+. DOCKET NO. 50-263, NAY 27,1966 , DPI

PRELIMINARY REVIEW OF MONTICELLO, NINNESOTA, SITE IS ACCEPTABLE, BASED ON PRELIMINARY INFORMATION. FLOOOS, MINIMUM RTVER FI, OWS IAND FFFFC.TS ON C.ONDENSER COOLING AND WASTE CISC.HARGEI, TORNADOS, AND DESIGN WERE CONSIDERED.

* ACRS (AOVISORY COMMITTEe ON REACTOR SAFEGUARDS) + MONTICELlO + REACTOR, BOILING WATER + SITING, REACTOR + SITING, WASTE DISPOSAL

18-11231 NSP - MONTICELLO NUCLEAR GENERATING PLANT - FACILITY DESCRIPTION AND SAFETY ANALYSIS REPORT VOLUME I

NCRTHERN STATES POWER COMPANY

333 PAGES, FIGURES, TABLES, AUGUST 1966, DOCKET NO. 50-263, PDR

SINGLE-CYCLE BWR (SIMILAR TO CRESDEN 2), 1469 MW(TH) INITIAL OPERATING POWER, WITH DESIGN FOR 1674. ZIRCALOY-CLAD FUEL, TWO CONTROLLED-RECIRCULATION-FLOW LOOPS FEEDING 20 JET PUMPS, PRESSURE-SUPPRESSION CONTAINMENT, 13 ENGINEERED SAFESUAROS. ALL NEUTRON MONITORS ARE IN THE CORE. CONTAINMENT INERT ATMOSPHERE WILL PREVENT HYDROGEN-OXYGEN REACTION AFTER LOSS OF COOLANT. DURING CONTAINMENT ISOLATION, STEAM IS RELIEVED TO THE SUPPRESSION POOL (RCIC). VARIOUS ACCIDENTS CONSIDERED. ALL LEAKAGE IS ASSUMED TO BE COLLECTFD BY BUILDING-EXHAUST SYSTEM, FILTERED BY A STANDBY SYSTEM, AND DISCHARGED UP THE STACK. THUS, OFF-SITE DOSES ARE WELL BELOW 10 C.TR 100 SPECIFICATIONS.

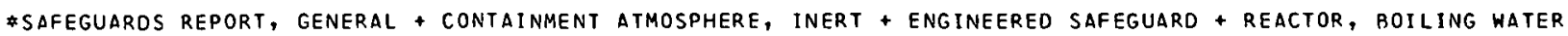


CATEGORY 18

SAFETY ANALYSIS AND DESIGN REPORTS

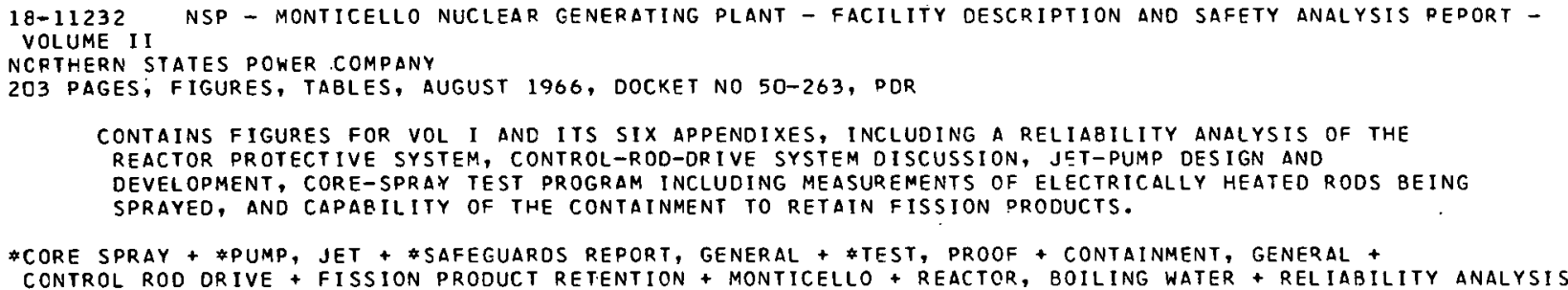

18-11235 BOILING NUCLEAR SUPERHEATER (EONUS) POWER STATION. PROJECT COMPLETION REPORT USAEC, OAK RIDGE OPERATIONS DFFICE, OAK RIDGE

CRO-649 +. 160 PAGES, FIGURES, TABLES, JUNE 1966, CFSTI $\$ 5.00 \mathrm{CY}, \$ 1.00 \mathrm{MN}$

BRIEF DESCRIPTION OF REACTCR, PLUS PROJECT SCHEDULES ANO COSTS. INCICATES REASONS WHY SCHEDULES SLIPPED ANO COST INCREASEO. PHOTOGRAPHS SHOW STAGES OF CONSTRUCTION.

\#ECONOMICS + \#REACTOR DESCRIPTION + BONUS (BOILING NUCLEAR SUPERHEAT PROJECT) + REACTOR, BOILING WATER + REACTOR, SUPERHEAT

18-11247 LEYPUNSKII AI

THE BN-350 ATOMIC POWER STATION

JPRS-31,193 + TT65-31690 +. PAGES 1-30, TRANSLATED FROM ATOMNAYA STANTSIYA, APRIL 1965, CFSTI, \$2.00 CY, $\$ C .50 \mathrm{MN}$

REVIEW OF CESIGN OF 1000 MW(TH), FAST, SODIUM-COOLED REACTOR FOR POWER AND DESALTING: BR-5

TESTS SHOW THAT SWELLING OF THE PLUTONIUM DIOXIDE CORE CRACKED THE CLAD. WHERE THE CLAD-CORE

GAP WAS MINIMAL. MIXEO IPU, UIOZ CAN GET A 10 PERCENT BURNUP. TWO RADIAL ZONES ARE USEO TO

EVEN THE POWER OISTRIBUTION.

* REACTOR DESCRIPTION + FAILURE, FUEL ELEMENT + PLUTONIUM DIOXIDE + REACTOR, BREEDER +

REACTOR, DESALINATION + REACTOR, FAST + REACTOR, LIQUID METAL COOLED +

UNION OF SOVIET SOCIAL.IST REPUBLICS + URARIUM DIOXIDE

18-1125C WORDEN JR + PURCELL' WL + SCHMID LC

PHYSICS EXPERIMENT HIGH POWER DENSITY CCRE OF THE PRTR

BATTELLE-NORTHWEST, RICHLAND

BNWL-221 +. 35 PAGES, 11 FIGURES, 7 TABLES, 20 REFERENCES, JANUARY 1966, CFSTI $\$ 2.00 \mathrm{CY}$

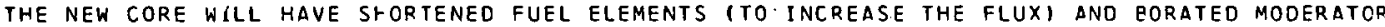

(TO REDUCE FLUX PEAKS). THE DRIVER. FUEL WILL BE MIXED (U, PU) OXIDE. THIRTEEN CORE

POSITIONS HILL BE AVAILABLE FOR LONG-TERM (2 YEARS) TEST FUEL. DESCRIBES STARTUP AND

AT-POWER TESTING OF NEW FUEL, AND PRESCRIPTIONS FOR VARIOUS. REACTOR-PHYSICS PROPERTIES.

* reactor startup testing + plutonium dioxide + prtr (Plutonium recycle test reactor) +

REACTOR, HEAVY WATER + REACTOR, PRESSURE TUBE + URANIUM OIOXIDE

18-11251 ENGINEERING MATERIALS LIST

DIVISION OF TECHNICAL INFORMATION USAEC

TID-4100 (SUPPLEMENT 34) + 54 PAGES, AUGUST 1966, DTIE, FREE

MISCELLANEOUS INSTRUNENTS ANO EQUIPMENT.

\#ENGINEERING ORAWING LIST

18-11260 HTGR BASE PROGRAM. QUARTERLY PROGRESS REPORT FOR THE PERIOD ENDING NOVEMBER 30, 1965 GENERAL ATOMIC

GA-6869 +. 62 PAGES, FIGURES, TABLES, JANUARY 15, 1966, DOCKET NO. 50-171, CFSTI \$3.00 CY, \$0.75 MN.

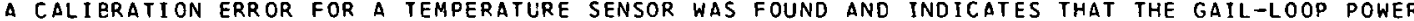
ESTIMATED FOR THE PAST NINE CYCLES MAY HAVE BEEN 5 TO ID. PERCENT LOHER THAN REPORTED. CESIUM-137 PLATEOUT IN THE MAIN PIPING OF THE IN-PILE LOOP INDICATES A DECREASE IN ACTIVITY AT ELBOWS, WHICH IS CONTRADICTORY TO BENCH STUDIES. PROTOTYPE SAFETY-ROD TESTS INDICATED AN INACEQUATE SHOCK ABSORBER, RESULTING IN PROGRESSIVE ROD FAILURE. A SHOCK ABSORBER IS BEING INCORPORATED INTO THE ROD, WITH NO CHANGE IN OTHER COMPONENTS.

*INSTRUMENTATION, ABNORMAL INDICATION + PEACH BOTTOM + REACTOR, GAS COOLED + REACTOR, GRAPHITE MODERATED

18-11261 HTGR BASE PROGRAM. QUARTERLY PROGRESS REPORT FOR THE PERIOD ENDING AUGUST 31,1965 GENERAL ATOMIC

GA-6\$71 +. 107 PAGES, FIGURES, TABLES, SEPTEMBER 30, 1965, DOCKET NO. 50-171, CFSTI $\$ 4.00 \mathrm{CY}, \$ 0.75$ MN

THIS REPORT IS ONE OF A SERIES OF SLCH REPORTS ON THE FOLLOWING SUBJECTS - TESTING OF PRESTRESSED CONCRETE REACTOR VESSELS, IN-PILE LOOP STUDIES, REACTOR-PHYSICS ANALYSIS, AND FUEL DEVELOPMENT ANO REPROCESSING STUOIES FOR A 1000 MWIEI REACTOR. THE GAIL INTPILE LOOP 
CATEGORY 18

SAFETY ANALYSIS AND DESIGN REPORTS

$18-11261$ CONTINUED*

OPERATED AT FULL POWER CF $77.2 \mathrm{KW}$. DURING THE FIRST 200 MWHR, THE FISSION-PRODUCT-RELEASE INCREASE WAS ATTRIBUTED TO TEMPERATURE INCREASE, WHICH CHANGES BY AN ORDER OF MAGNITUDE FOR EACH 100 DEGREES C. THE ECONOMICS OF LOW-ENRICHMENT U ANO TH-U WITH PU MAKEUP FUEL CYCLES IS REVIEWED. DESIGN AND PERFORMANCE STUDIES ARE REVIEWED FOR SHORT HEXAGONAL BLOCK ELEMENTS AS AN ALTERNATIVE TO CYLINDRICAL ELEMENTS. THE BLOCK ELEMENTS SHOULO OPERATE 9O F LOWER AND RETAIN METALLIC FISSION PRODUCTS BETTER. DEVELOPMENT STUDIES ARE REVIEWED FOR LOOSE AND RONDED COATEO-PARTICLE FUEL SYSTENS.

\#FISSION PRODUCT RELEASE, GENERAL + \#FISSION PRODUCT TRANSPORT + COATED PARTICLE + CONCRETE, PRESTRESSED + CONTAINMENT, PRESSURE VESSEL + GRAPHITE + PEACH BOTTOM + RADIOCHEMICAL PROCESSING + REACTOR, GAS COOLED + REACTOR, GRAPHITE MODERATED

18-11270 ETTINGER HJ + MOSS WD + BUSEY H

CHARACTERISTICS OF THE AEROSOL PRODUCED FROM BURNING SODIUM AND PLUTONIUM

LOS ALAMOS SCIENTIFIC LABORATORY, LCS ALAMOS

LA-3491 +. 51 PAGES, 28 FIGURES, 7 TABLES, 12 REFERENCES, FEBRUARY, 1966, CFSTI \$3.00 CY, \$D.50 MN

SIZE CHARACTERISTICS OF IHE AEROSOL PRODUCED DURING SODIUM AND PLUTONIUM FIRES WERE DETERMINED FOR DIFFERENT ATMOSPHERES RANGING FROM AIR. TO 100 PERCENT NITROGEN. GRAM QUANTITIES OF SODIUM, PLUTONIUM-COBALT-CERIUM ALLOY, AND ALPHA- AND DELTA-PHASE PLUTONIUM WERF RURNED SEPARATELY. THE AEROSOL PRODUCED BY BURNING GRAM QUANTITIES OF SODIUM WAS COMPARED WITH THAT PRODUCED BY A FIRE INVOLVING 600 POUNOS OF SODIUM. DATA WERE ORTAINEC REGARDING THE FRACTION OF PLUTONIUM ALLOY AIRBORNE DURING A PLUTONIUM FIRE. FIRES SIMULATING A REACTOR ACCIDENT INVOLVING BOTH FUEL AND COOLANT DEFINED THE RELATIVE AIRBORNE CONCENTRATIONS OF PLUTONIUM AND SODIUM. SODIUM AEROSOLS PRODUCED FROM SMALL- AND LARGE-SCALE FIRES HAVE COMPARABLE SIZE CHARACTERISTICS. AEROSOL PARAMETEPS CAN BE DETFRMINED FOR ANY SPECIAL CONDITIONS WITHOUT BUILOING A LARGE SYSTEM FOR SUCH TESTS. OXYGEN CONCENTRATION OF THE BURNING ATMOSPHERE DOES NOT AFFECT THE PARTICLE SIZE OF THE AEROSOL PRODUCED FROM BURNING PLUTONIUM METAL OR ALLOY. FIRES INVOLVING PLUTONIUM ALLOY ANO SOOIUM PRODUCE AIRBORNE PARTICLES THAT HAVE A

PLUTONIUM-SODIUM RATIO RANGING FROM 0.34 TO LESS THAN C.OOB PERCENT. THE HIGH INITIAL RATIO IS RAPIDLY REDUCED AS THE MOLTEN SODIUM BLANKETS THE RELEASE OF PLUTONIUM.

* PARTICLE SIZE + \#PLUTONIUM + \$SOOIUM + AEROSOL PRODUCTION + AEROSOL PROPERTIES + AEROSOL, RADIOACTIVE + AIR CLEANING + AIRBORNE RELEASE + ALLOY + FIRE + INCINERATION + OXIDATION

18-11277 FACILITY DESCRIPTICN AND SAFETY ANALYSIS REPORT FOR THE GENERAL ELECTRIC TEST REACTOR - VOLUME I I

EFNFRAI. FLECTRIC, VALLECITOS DTONIC POWER LABORATORY

APED-5000-A +. 208 PAGES, FIGURES, TABLES, DOCKET 50-70 JULY 1965, PDR

BRIEFLY DESCRIBES TESTING AND OPERATING PROCEDURFS, AND THE MONITORING PROGRAM FOR WASTES AND EFFLUENTS. THE MCA IS DESCRIBED AS A LOSS OF COOLANT WHILE AT FULL POWER, PLUS CONCURRFNT FAILURE TO SCRAM, RESULTING IN MELTING OF THE FUEL PLATES. FISSION-PRODUCE RELEASE FROM A 5O-DAY EQUILIBR IUM CORE WOULD RESULT IN 2-HR EXPOSURE DOSES AT THE BCUNOARY FOR THE WORST METEOROLOGICAL CONDITIONS OF 0.824 RAD DIRECT GAMMA, 0.235 RAD FROM A PASSING CLOUD, AND O.015 RAD FROM GROUND DEPOSITION. DESCRIPTIONS AND SAFETY ANALYSES OF THE EXPERIMENTAL FACILITIES ARE GIVEN. THESE INCLUDE IN-CORE AND POOL IRRADIATION, CAPSULE EXPERIMENTS, A EEAM-PORT FACILITY, A HIGH-TEMPERATURE GAS LOOP (GAIL), A BOILING-WATER LOOP, A PRESSURIZED-WATER LOOP, A GENERAL-PURPOSE GAS LOOP, AND A GAMMA-IRRADIATION FACILITY.

* IN PILE lOOP + \#AFEguards REPORT, General + \#SAFETY REVIEW cOPERATIONS, EXPERIMENTSI * GETR (GENERAL ELECTRIC TEST REACTOR) + POWER UPRATING + REACTOR, TEST

18-11278 FACILIIY UESCRIPIIUN AND SAFETY ANALYSIS REPORT FOR THE GENERAL ELECTRIC TEST REACTOR. VOLUME GENERAL ELECTRIC, ATOMIC POWER EQUIPMENT DEPT, CALIFORNIA

APED-5000-A, VOL. I +. 161 PAGES, FIGURES, JULY 1965 , DOCKET NO. 50-70, PDR

THIS REPORT SUPERSEDES APED-5COO IN REPLY TO $\triangle E C$ REQUESTS FOR $\triangle D D I T I O N A L$ TECHNICAL INFORMATION AS A RESULT OF A REQUEST FOR POWER UPRATING OF THE GETR FROM 33 MW TO 50 . INCLUDED IS A DESCRIPTION OF THE SITE, ASPECTS OF ADMINISTRATION, AND A DETAILED DESCRIPTION OF THE FACILITY. ETR ELEMENTS ARE USED WITH LIGHT WATER AT 150 PSI FOR COOLANT. THE DESIGN ACCOMODATES LOOP EXPERIMENTS AROUND THE VESSEL IN A THERMAL FLUX OF 1.5 TIMES 10 TO THE 14.

* power uprating + * safeguaros report, general + getr (general electric test reactor) + rfactor, test

18-11289 DELETION OF RAEIATION LEVEL LIMIT IN CONTROL ROOM GENERAL ELECTRIC COMPANY

2 PAGES, AUGUST 1966 , DOCKET NO. 50-203, PDR

CHANEE 7. RECENT SURVEYS INDICATE THAT CERTAIN UNOCCUPIED PORTIONS OF THE CONTROL ROOM EXCEED 'THE LIMIT OF 10 MR/HR. ADEQUATE SHIELDING EXISTS AT OCCUPIED AREAS, SO THE SECTION REFERRING TO DOSE RATE IN CONTROL ROOM IS DELETED.

* OPERATING LIMITS/TECHNICAL SPECIFICATICNS + CRITICAL ASSEMBLY FACILITY + PERSONNEL EXPOSURE, RADIATION

18-11290 PATHFINDER REQUESTS SUBSTITUTION OF NOISE ANALYSIS FOR REACTIVITY OSCILLATOR FOR TRANSFER FUNCTION MEASUREMENTS

NORTHERN STATES POWER COMPANY 
CATEGORY 1 P

SAFETY ANALYSIS AND DESIGN REPORTS

18-11290 *CONTINUED*

5 PAGES, AUGUST 1966 , DOCKET NO. 50-130, PDR

REQUEST STATES THAT 1957 DECISION hAS BASED ON LACK OF ASSURANCE IN NOISE-ANALYSIS TECHNIQUES, NOW CONSIDERED MORE RELIABLE. STABILITY-ANALYSIS PROGPAM WOULD BE ESSENTIALLY UNCHANGED.

* NOISE ANALYSIS + PATHFINDER + REACTOR, BCILING WATER + REACTOR, SUPERHEAT

18-11291 CHANGES AT THERMAL CRITICAL ASSEMBLY

GENERAL ELECTRIC COMPANY

4 PAGES, AUGUST 1966 , DOCKET NC. 5C-24, PDR

CHANGE 7 DELETES REQUIREMENT THAT COATROL-ROOM DOSE RATE EE LESS THAN 10 MR/HR, AND REVISES SPECIFICATIONS FOR BORAL AND BORON-STAINLESS STEEL SAFCTY SHEETS.

* OPERATING LIMITS/TECHNICAL SPECIFICATIONS + CONTROL ROD, SHIM SAFETY + CRITICAL ASSEMBLY FACILITY + PERSONNEL EXPOSURE, RADIATION

18-11292 CATHOLIC UNIVERSITY SUBMITS AGN-201 TECHNICAL SPECIFICATIONS

THE CATHOLIC UNIVERSITY OF AMERICA, WASHINGTON, D. C.

2 PAGES, AUGUST 1966 , DOCKET NO. 50-77, PCR

TECHNICAL SPECIFICATICNS SECTIONS INCLUDE THOSE FOR THE REACTOR, THE CORE, CONTROL AND INSTRUMENTATION SYSTEMS, EXPERIMENTAL LIMITATIONS, SURVEILLANCE REQUIREMENTS, AND ADMINISTRATIVE REQUIREMENTS. THEY WERE BASED ON

*CPERATIAE LIMITS/TECHNICAL SPECIFICATIONS + AGN (TRAINING REACTOR, AEROJET-GEN. NUCLEONICS) + REACTOR, TRAINING

18-11293 NEW TECHNICAL SPECIFICATIONS MOCEL FOR RESEARCH REACTCR

BRIGHAM YOUNG UNIVERSITY, PROVO, UTAH

3 PAEES, AUGUST 1966 , DOCKET NC. 50-262, PDR

IN A LETTER REQUESTING NORE INFORMATION REGARDING THE PROPOSED AI L-T7 REACTOR FOR THE UNIVERSITY OF UTAH, DRL INCLUDED A COPY OF THE TECHNICAL SPECIFICATIONS FOP. A TRIGA SETUP AS CONFORMING TO THE NEW FCRNAT FOR RESEARCH REACTORS.

*OPERATING LIMITS/TECHNICAL SPECIFICATIONS + REACTOR, HOMOGENEOUS + REACTOR, RESEAPCH

18-11295 FERMI TECHNICAL SPECIFICATIONS POWER COEFFICIENT REQUIREMENT LOWERED

POWER REACTOR DEVELOPMENT COMPANY, CETROIT

7 PAGES, AUGUST 1966 , DOCKET NC. 50-16, PDR

EXTREMELY CONSERVATIVE ASSUMPTIONS AND USE OF ACTUAL REACTOR PARAMETERS ALLOW ADEQUATE LEEHAY,

SO THE ACTUAL COEFFICIENT OF 0.18 PLUS OR MINUS 0.013 (RATHER THAN C.2) LEADS TO THE SAME

SAFE RESULTS IN VARIOUS ACCIDENT ANALYSES.

\#OPERATING LIMITS/TECHNICAL SPECIFICATIGNS + FERMI + POWER COEFFICIENT + REACTOR, BREEDER + REACTOR, FAST + REACTOR, LIQUID METAL COOLED

18-11306 $\triangle M E N D M E N T 17$ - ANSWERS TO OUESTIONS ABOUT LACBHR RECEIVED FROM DIVISION OF REACTOR LICENSING ALLIS-CHALMERS MANUFACTURING CCMPANY, BETHESDA

ACNP-66512 +. 22 PAGES, 3 TABLES, 3 REFERENCES, FEBRUARY 1966, DOCKET NO. 115-5, PDR

$\triangle$ FENCE IS ERECTED 3CO FT OR MORE FROM THE STACK TO ALLOW OPERATION WITH A SINGLE

STACK-BLOWER. OTHER BHR EXPERIENCE JUSTIFIES ASSERTION THAT THERE IS A LARGE DECONTAMINATION FACTOR FOR IODINE RELEASEC TO PQIMARY COOLANT. STACK MONITORS ARE TO ALARM AT MAXIMUM

DOWNWINO CONCENTRATION EQUAL TO THE MDC, AND REACTOR BUILDING ISOLATES AT MAXIMUM DOWNWIND

CONCENTRATION EQUAL TO 10 TIMES THE MPC. ALTERNATIVE POWER SOURCES FOR CRUCIAL ISOLATION

VALUES LISTED. CONTROL-ROD LATERAL RESTRAINTS WERE SHOWN TO BE NOT NECESSARY BY MOCKUP TESTING.

*CCNCENTRATION, CENTERLINE, MAXIMUM + \#EMERgENCY POWER, ELECTRIC + \#LICENSING STATUS OF NUCLEAR PROJECTS + \#MCNITOR, RADIATION, STACK + CONTROL ROE + ENGINEERED SAFEGUARO + LACROSSE BOILING WATER REACTOR +

REACTOR, BOILING WATER + SOURCE, CONTINUOUS

18-11361 QUAO CITIES STATION, UNIT 1 - PLANT DESIGN ANALYSIS APPLICATION FOR CONSTRUCTION PERMIT ANO OPERATING LICENSE

CCMMONHEALTH EOISCN CCMPANY, CHICAGC

7 PAGES, MAY 31, 1966, DOCKET NO. 5C-254, POR

CORPORATE INFORMATION AND URANIUM REQUIREMENTS. UNIT I WILL BE SIMILAR TO THAT OF DRESDEN 2 , AND LICENSED FOR A REFERENCE DESIGN OF $2300 \mathrm{MW}(T H) / 715 \mathrm{MW}$ (E) NET BUT INTENDED FOR LATER. OPERATION OF 2600 MW(TH). LOCATED 20 MILES NE OF ROCK ISLAND-MOLINE ON THE MISSISSIPPI RIVER. ZIRCALCY-2-CLAD FUEL IS IN A CORE 15-3/4 FT IN DIAMETER ANO 12 FT TALL, WITH IIT B4C CONTROL RODS AND 324 TEMPCRARY IIXED-CONTROL RODS. CONTROLLED CIRCULATING FLOW WITH 2 LOOPS AND 20 JET PUMPS. PRESSURE-SUPPRESSION CONTAINMENT, WITH A CONCRETE REACTOR BUILOING CESIGNEO FOR 1/4-PSI INTERNAL PRESSURE, AND EXHAUST TO 310-FT STACK THROUGH STANDBY 
CATEGORY 18

SAFETY ANALYSIS AND DESIGN REPORTS

$18-11361$ \#CONTINUED*

GAS-TREATMENT SYSTEM REDUCES ALL OFFSITE DOSES TO LESS THAN 1 REM.

* SAFEgUAROS REPORT, PRELIMINARY + ECONONICS + QUAO CITIES 1 + REACTOR, BOILING WATER

18-11362 QUAO-CITIES STATION, UNIT 1 - PLANT DESIGN ANALYSis, volume 1

COMMONWEALTH EDISON COMPANY, CHICAGO

3 CO PAGES, DOCKET NO. 50-254, NAY 31,1966 PDR

POPULATION CENTER $134,00 C)$ IS 5 MILES NE OF SITE. GROWTH FIGURES GIVEN. MOLINE, ILLINOIS, IS 20 MILES AWAY. DATA INDICATES LOW-LEVEL NIGHTTIME INVERSION ONE-THIRD OF TIME BASED ON WIND AND CLOUD COVER ANO SIMILARITY TO CONDITIONS FOR JOLIET, ILLINOIS. GROUND MOTION EQUIVALENT TO 0.12 G IS BASIS FOR PLANT DESIGN- 0.24G FOR CONTAINMENT AND HEAT REMOVAL. FUEL-ELEMENT PERFORMANCE LIMITS ESTABLISHED BY TESTS AND OPERATING EXPERIENCE. EXCURSIONS YIELDING LESS THAN 425 CAL/G OF UO2 WILL NOT RUPTURE RODS, AND 280 IS DESIGN LIMIT. INTEGRATED

FAST-NEUTRON FLUX IS 2.3 TIMES 10 (17TH) IN 40 YEARS, IN THE 6-1/8-IN. 3028 VESSEL CLAD WITH STAINLESS STEEL, AND CESIGNED FOR IO (ISTH) WITH AN NDT SHIFT OF 260 F. RELAYS WILL BE USED IN THF SAFFTY SYSTEM.

* SAFEgUARDS REPORT, PRELIMINARY + BRITTLE FRACTURE + CONTAINMENT, PRESSURE VESSEL + FUEL ELEMENT + LAPSE RATE, STABLE + QUAD CITIES 1 + REACTOR, BOILING WATER

18-11363 QUAD CITIES STATION, UNIT 1 - PLANT DESIGN ANALYSIS, VOLUME II

CCMMONWEALTH EDISON COMPANY, CHICAGC

$3 \in O$ PAGES, DOCKET NO. 50-254, MAY 31, 1966 POR

CONTAINS ILLUSTRATIONS AND SIX APPENOIXES IGLOSSARY, RELIABILITY ANALYSIS OF REACTOR PROTECTIVE SYSTEM, CONTROL-ROD-DRIVE SYSTEM, JET-PUMP DEVELOPMENT, CORE-SPRAY TEST, EARTHQUAKE-DESIGN CRITERIAI. APPENDIX B CONSISTS OF A SERIES OF ASSERTIONS WITH A PLOT OF RELIABILITY VS FAULT RATE FOR $1 / 2,2 / 3,2 / 4$, AND DUAL BUS $(1 / 2) \times 2$. $\triangle P P E N D I X D$ DESCRIBES SOME DESIGN AND OPERATIONAL CONSIDERATIONS. APPENDIX E - TESTS SHOW THAT O.O5 GPM IS NEEDED PER FUEL ROD TO LIMIT THE CLADOING TEMPERATURE TO $1600 \mathrm{~F}$. APPENDIX F IS AN INDEPENDENT SEISMOLOGICAL REPORT RECOMMENDING THAT CRITICAL COMPONENTS BE DESIGNED FOR O.12 G.

* SAFEGUAROS REPORT, PRELIMINARY + CCNTROL ROD ORIVE + CORE SPRAY + CESIGN STUDY + PUMP, JET + QUAD CITIES I + REACTOR SAFETY SYSTEM + REACTOR, BOILING WATER + RELIABILITY ANALYSIS + SEISMOLOGY

18-113t4 QUAD-CITIES STATION, UNIT 1 - PLANT DESIGN ANALYSIS, VOLUME 1

COMMONWEALTH EDISON COMPANY, CHICAGO

1 PAGE, COCKET NO. 50-254, PAGE III-4-4, MAY 31, 1966 PDR

DURING THE EQUIVALENT OF IC FULL-PCWER YEARS OF OPERATION OF GE BOILING-WATER REACTOR, A STEADY-SIATE THERMAL OVER-POWER CONDITION IN THE RANGE OF 105 TO 110 PERCENT OF RATED REACTOR POWER OCCURRED ONLY ONCE.

*INCIOENT, ACTUAL, GENERAL + \#REACTOR PCWFR + REACTOR, BOILING WATER

18-113E5 QUAD CITIES STATION, UNIT 1 - PLANT DESIGN ANALYSIS, VOLUME 1 COMMONWEALTH EDISON COMPANY, CHICAGO

18 PAGES, PAGES XIV-3-3 TO 6 AND 3-15 TO 30 OF QUAD CITIES STATION, PLANT DESIGN ANALYSIS, VOLUME I DOCKET NO. $50-254$, MAY $31,19 K A$ POR

DRESDEN 1 EXPERIENCE WITH FUEL FAILURES QUOTED TO BE LESS THAN 1 MILLICURE/SEC, IKR-85 TO REPRESENT 54 CURIES - LESS THAN 1 PERCENT) IN THE GAS PLENUM. HALOGENS IN STEAM ARE ABOUT IO TO THE MINUS 5 THAT IN WATER. A FURTHER FACTOP. OF 10 TO THE MINUS 2 OCCURS IN THE CONDENSER. THUS A REACTOR EXCURSION RUPTURING 330 FUEL RODS WOULD RELEASE ONLY 10 TO THE MINUS 4 CURIES/SEC OF HALOGENS UP THE STACK TIROUGII AIR EJECTER STEAM-LINE BP.EAK. ESTIMATEO ON CRESDEN-1 COOLANT ACTIVITY AND WATER CARRYOVER- HOT CLOUD BREAKS BUILOING WALLS AND RISES TO 164-4100 FT (DEPENDING ON WIND), WITH DOSES IN MILLIREM RANGE. LOSS OF COOLANT WITH 1OO PERCENT MEL TDOWN GIVES LESS THAN C.5 REM OFF-SITE BECAUSE OF THE HALOCEN RETENTION IN WATER, CHARCOAL ASSORPTION, ANO STACK RELEASE. EVESR CHARCOAL FILTER HAS BEEN RETAINING ORGANIC HALOGENS WITH A FILTER EFFTCIENCY OF 99.8-99.9 PERCENT AT RELATIVE HUMIDITY OF 10 TO 15 PERCENT.

* $\triangle I R E O R N E$ RELEASE + \#DOSE + \#SAFEguARDS REPORT, PRELIMINARY + ACCIDENT, CONTROL ROD DROPOUT + FAILURE, FUEL ELEMENT + LOSS CF COOLANT + OPERATING EXPERIENCE + QUAD CITIES I + REACTOR, BOILING WATER + STEAM. LINE RUPTURE

18-11366 QUAD-CITIES STATION, UNIT 1 - PLANT DESIGN ANALYSIS, VOLUME 1 COMMUNWEALIH EOISON COMPANY, CHICAGO

14 PACES, 3 REFERENCES, 1 TA8LE, PACES V-1-16 T0 31, DOCKET NO. 50-254, MAY 31 , 1966 PDR

IMMEDIATELY AFTER THE NAJOR PIPE RLPTURE, THE TEMPERATURE OF THE WATER IN THE SUPPRESSION CHAMBER APPROACHES $13 U$, ANU THE MAXIMUM SYSTEM PRESSURE APPROACHES 30 PSIG DURINC THE ELOWDOWN OF THE PRIMARY COOLANT INTO THE DRYWELL. THE CONTAINMENT PRESSURE IS A FUNCTION OF THE METAL-WATER REACTION RATE. ALTHOUGH THE CORE-COOLING SYSTEMS ARE ASSUMED NOT TO FUNCTION IN ORDER TO PROVIOE A BASIS FOR METAL-WATER REACTIONS, ONE OF THE TWO CONTAINMENT COOLING SYSTEMS IS ASSUMED TO FUNCTION NORMALLY. THE DRYWELL SPRAY IS SUFFICIENT TO TRANSPORT THE DECAY HEAT, THE HEAT STOREO IN THE CORE, AND ANY HFAT RESULTING FROM THE METAL-WATER REACTION TO THE WET-WELL IN THE FORM OF HOT LIQUID. THE ENERGY TRANSPORTED TO THE WATER IN THE 
CATEGORY

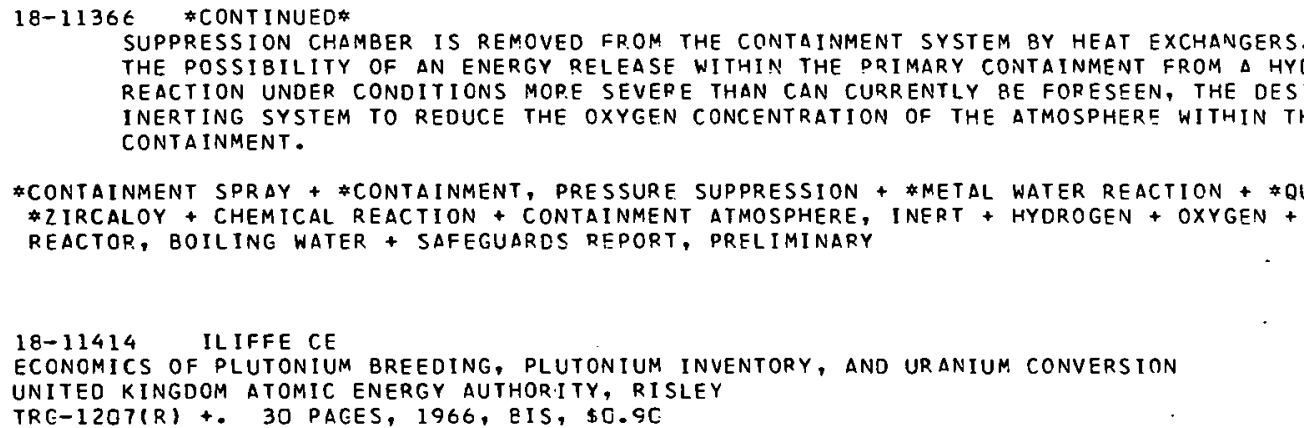

$18 \rightarrow 11414$ IL IFFE CE

ECONOMICS OF PLUTONIUM BREEDING, PLUTONIUM INVENTORY, ANO URANIUM CONVERSION

UNITEO KINGDOM ATOMIC ENERGY AUTHORITY, RISLEY

TRG-1207(R) +. 30 PAGES, 1966 , EIS, \$O.GC

A FORMULA IS DERIVED FOR THE COST CF A NUCLEAR POWER PROGRAM, THAT CONSUMES ONLY SUCH PLUTONIUM AS IS PRODUCED WITHIN IT. AS APPLIED TO PLUTONIUM-FUELED FAST REACTORS, THE FORMULA ACCOUNTS FOR PLUTONIUM THROUGH $\triangle$ OUANTITY X ITHE CISCOUNTEO AMOUNT OF ELECTRICITY GENERATED BY SUCH REACTCRS EXPRESSED A.S A FRACTION OF THE CORRESPONDING AMOUNT FOR ZERO COUBLING TIME) AND A UNIT CREDIT K, (THE REDUCTION IN SYSTEM GENERATING COST PER UNIT VALUE OF ANY PLUTONIUM SURPLUS TO THE SYSTEMI. THE FRACTION $X$ ANO UNIT CREDIT K ARE DISPLAYED GRAPHICALLY IN TERMS OF FAST-REACTOR INVENTORY RATING AND DOUBLING TIME FOR BOTH POWER PROGRAMS AND FOR DIFFERENT RATES OF PLUTONIUM PRODUCTION FROM ADVANCED THERMAL REACTCRS, BOTH WITH AND WITHOUT OPERATION OF SOME OF THE FAST REACTORS ON A U-235 FEED. A, SIMILAR FORMULA IS SHOWN TO APPLY TO ADVANCED THERMAL REACTORS.

*ECONOMIC STUDY + \#PLUTONIUM + \#REACTOR, BREEDER + MATHEMATICAL STUCY + STATISTICAL ANALYSIS

18-11429. HORST KM SCUTHHEST EXPERIMENTAL FAST OXIDE REACTOR DEVELOPMENT PROGRAM. QUARTERLY REPORT NO. 6 GENERAL ELECTRIC COMPANY, SAN JOSE, CALIFORNIA

GEAF-4994 +. 129 PAGES, 45 FIGURES, 17 TABLES, OCTOBER 1965, CFSTI, \$4.00 CY, \$1.00 MN

SOUTHWEST EXPERIMENTAL FAST OXIDE REACTOR DEVELOPMENT PROGRAM PROGRESS REPORT. THIS REDORT IS ONE OF A SERIES OF SUCH REPORTS ON THE SUBJECTS ENUMFRATED BELOW. THESE INCLUDE EXPERIMENTAL PROGRAM IN ZPR III, FUEL, SPECIAL INSTRUMENTATION, CORE ASSEMBLY STEAOY-STATE AND TRANSIENT (HEAT TRANSFERI CHARACTERISTICS, REACTIVITY CONTROLS FOR EXPERIMENTATION, FUEL HANOLING, CORE DESIGN.

* RESEARCH CONTRACT + CRITICAL. ASSEMELY FACILITY + FUEL HANDLINE + HEAT TRANSFER +

INSTRUMENTATION, GENERAL + REACTDR, BREEDER + REACTOR, FAST + REACTOR, LIOUID METAL COOLED + SEFOR (SOUTHWEST EXP. FAST OXIOE REACTOR) + TEST, PHYSICS 
CATEGORY 19

BIELIOCRAPHIES

19-10430 ARGONNE NATIONAL LABCRATORY PUBLICATIONS, JULY 1, 1964 - JUNE 30, 1965

ARGONNE NATIONAL LABORATORY, ARGONNE, ILLINOIS

ANL-7087+. 328 PAGES, AUCUST 1965 CFSTI, \$7.00 CY, \$1.50 MN

THIS PUBLICATION LIST IS A BIBLIOGRAPHY OF SCIENTIFIC AND TECHNICAL ACCOUNTS ORIGINATED AT ARGONNF AND PUBL ISHED DURING FISCAL YEAR 1965. IT. INCLUDES ITEMS PUBLISHED AS JOURNAL ARTICLES, TECHNICAL REPORTS, BOOKS, ETC., ALL OF HHICH HAVE BEEN MAOE AVAILABLE TO THE

PUBL IC. THE LIST IS DIVIDED INTO THREE PARTS - THE FIRST A LIST DIVISION, THE SECOND AN ALPHABETICAL AUTHOR INDEX, AND THE THIRD PART A KWIC SUBJECT INDEX. INCLUDEO ARE SECTIONS ON RADIOLOGICAL PHYSICS, REACTOR PHYSICS, REACTOR ENGINEERING, INDUSTRIAL HYGIENE AND SAFEIY, FIRE PROTECTION, AND CHEMICAL ENGINEERING.

*BIBLIOERAPHY + *BURNOUT HEAT FLUX + *CHEMICAL REACTION + *DOSE MEASUREMENT, EXTERNAL + \#HEAT TRANSFER + \#REACTOR DYNAMICS + *REACTOR STABILITY, ACCIDENT ANALYSIS +

FARET (FAST ARGONNE REACTOR EXPERIMENT TEST) + METAL WATER REACTION + NOISE + REACTIVITYY COEFFICIENT + REACTOR KINETICS + REACTOR TRANSIENT + REACTOR, BREEDER + REACTOR, FAST + REACTOR, LIQUID METAL COOLEO + SPACE DEPENDENT OYNAMICS + VOID COEFFICIENT

19-1128E TEETER CE + LECKY JA + MARTENS JH

CATALOG OF NUCLEAR REACTOR CONCEPTS. PART I. HOMOGENEOUS AND QUASI-HOMOGENEOUS REACTORS. SECTION VI. SOL 10 HOMOGFNFOUS (SEMI-HOMOGENEQUSI REACTORS

AREONNE NATIONAL I. $\triangle R O R A T O R Y$, ARGONNE, ILLINOIS

ANL-7228 +. 78 PAGES, REFERENCES, JUNE 1966 , CFSTI $\$ 3.00 \mathrm{CY}, \$ 0.75 \mathrm{MN}$.

THIS REPORT HAS NO DIRECT SAFETY IMPLICATIONS. HOWEVER, TOGETHER WITH ANL-6906, ANL-7092, ANL-7138, AND ANL-7180, IT FORMS A CATALOG OF REACTOR CONCEPTS THAT MIGHT BE USEFUL IN SAFETY WORK.

\#REACTOR, HOMOGENEOUS

19-1134t BITTEL R

SOME ASPECTS OF RADIOHYOROLOGY - LITERATURE SURVEY

COMMISSARIAT A LENERGIE ATOMIQUE + CENTRE DETUDES NUCLEAIRES OE SACLAY

CEA-BIB-59 +. 46 PAGES, 2 FIGURES, 2 TABLES, SEPTEMBER 1965, DEP. MN, IN FRENCH

THIS WORK IPART OF RESEARCH UNDERTAKEN IN THE HEALTH PROTECTION DEPARTMENT WITH A VIEW TO EXAMINING THE CONSEQUENCES OF LIQUID WASTE IN WATERI IS CONCERNED WITH THE VARIOUS ASPECTS OF KYOROLOGICAL PROBLEMS ARISINE FROM THE PRFSFNC.F OF RADIOELEMENTS IN RIVERS BETWEEN THE POINT OF DISPOSAL AND THE PLACES AT WHICH THE WATER IS USED BY MAN. THE FOLLOWING QUESTIONS ARE CONSIDERED - PHYSICAL AND MECHANICAL FACTORS INVOLVED IN THE DISPERSION OF THE EFFLUENTS, CHEMICAL FACIORS DUE TO THE BEHAVIOUR OF THE RADIOELEMENTS, STUDY OF EXCHANGES BETWEEN LIQUID AND SOLIO PHASES INVOLVING RAOIOELEMENT TRANSFER, AND STUDY OF PARTICULAR PROBLEMS (SEDIMENTATION, SEOIMENT OISPERSION, PROBLEMS DUE TO THE WATER BEO ITSELF, PHENOMENA OCCURRING AT THE MOUTH OF RIVERS).

*HYOROL OGICAL CONSIOERATION, GENERAL + \#SURFACE WATER, DISPOSAL MEDIA + DISPERSION + HYDROLOGICAL CONSIDERATION, QUALITY OF WATER + HYDROLOGICAL CONSIDERATION, RATE OF MOVEMENI + MINERAL EXCHANGE + PRECIPITATION + RIVER, GENERAL + SEDIMENI + SURFACE HATER, GENERAL + SURFACE WATER, PROPERTY + SURFACE WATER, SEOIMENT + SURFACE WATER, SUSPENDED MATERIAL + WASTE DISPOSAL, RIVER + WATER TREATMENT + WATER, DRINKING 
INFORMATION AT NSIC IS DIVIDED INTO 19 CATEGORIES. AN ITEM OF INFORMATION MAY BE KEYED TO AS MANY AS THREE OF THESE. A COLLECTION OF SELECTORS OR KEYWORDS IS USED TO DENOTE THE MAIN SAFETY RELATED POINTS COVERED IN AN ARTICLE. THE FOLLOWING INDEX IS AN ALPHABETICAL LISTING OF SELECTORS GIVING REFERENCES TO EACH ARTICLE WHICH WAS KEYED TO IT. THE CATEGORY NUMBER IS GIVEN FIRST, FOLLOWED RY THE ACCESSION NUMBER. THE ACCESSION NUMBERS ARE USED TO LOCATE BIRLIOGRAPHIC ITEMS WITHIN A CATEGORY.

ACCELERATOR

$$
15-11167
$$

ACCIDENT ANALYSIS

$5-10430 \quad 5-10554$

6-11415

$7-11711$

$19-10430$

ACCIDENT MODEL

7-11679 7-11680 11-10293

ACCIDENT, CONSEQUENCES

3-10839

ACCIDENT, CONTROL ROD DROPOUT

$$
\text { 7-11365 18-11365 }
$$

ACCIDENT, CONTROL ROD WITHDRAWAL

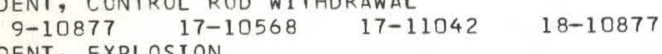

ACCIDENT, EXPLOSION

7-09729 11-10529

ACCIDENT, GENERAL

$$
\text { 5-10550 5-10554 5-10555 6-10550 }
$$
$7-10550$

ACCIDENT, HYPOTHETICAL

18-09949 18-10329

ACCIDENT, MAXIMUM CREDIBLE IMCA

$\begin{array}{llrl}1-09855 & 2-09855 & 5-10532 & 5-10554 \\ 5-10555 & 6-10532 & 7-10270 & 7-10532\end{array}$

$5-10555 \quad 6-1053$

$\begin{array}{ll}12-09855 & 18-10270\end{array}$

$\begin{array}{ccc}\text { ACCIDENT, PROBABILITY OF } \\ 1-09855 & 2-09855\end{array}$ $\begin{array}{lr}1-09855 & 2-098 \\ \text { DENT, RADIOI SOTOPE }\end{array}$

$12-09855$ 7-11711

ACCIDENT, REACTIVITY

$$
\text { 6-09987 9-1 }
$$

ACCIDENT, REFUELING

6-11444 12-11444

ACRS (ADVISORY COMMITTEE ON REACTOR SAFEGUARDS) $17-10197 \quad 18-11230$

ACTIVATION

$7-11728 \quad 14-09486$ $15-10074 \quad 15-10086$

ACTIVATION PRODUCT

$14-09486 \quad 14-10074 \quad 15-08713 \quad 15-10074$

$17-10866$

ADMINISTRATIVE CONTROLS AND PRACTICES

$\begin{array}{llll}1-09662 & 1-09664 & 12-09311 & 12-09662\end{array}$

$\begin{array}{llll}12-09664 & 12-09667 & 12-09671 & 12-00672\end{array}$

$17-09311 \quad 17-10834$

ADSORPTION

7-09369 7-10586 7-11716 774 14-09483

ADSORPTION SURFACE

7-10586

AEROSOL

$7-08805$

$7-09735$

$7-10589$

$7-11700$

7-11709

7-11713

$7-11717$

$7-11725$

$16-09617 \quad 16-1$

AEROSOL PRODUCTION

7-09729 7-11270

7-11717 7-11719

7-11725 16-10769

AEROSOL PROPERTIES

7-09371 7-09725

$7-10588 \quad 7-10589$

$7-11680 \quad 7-11706$

$7-11711 \quad 7-11713$

7-11719 7-11720

AEROSOL, BIOLOGICAL

7-11710

AEROSOL, RADIOACTIVE

$7-11270$
AEROSPACE SAFETY

$4-09603$

4-11252

16-10811

$7-09729$

$7-11716$

$4-09483$

OMERATE

7-10587

$7-10588$

$7-11708$

7-11713

7-11724

$11-11700$

16-10973

7-11727

16-10677

$7-1168 \mathrm{C} \quad 7 \rightarrow 11713$

$7-11720 \quad 7-11721$

$7-10587$

$7-11270$

$7-11707$

$7-11717$

$18-11270$

1679

$7-11718$

$16-10765$

$18-11270$

4-10037

$4-10520$

$4-11055$

$14-09603 \quad 14-11252$
AGN (TRAINING REACTOR, AEROJET-GEN. NUCLEONICS) $18-10857$. $18-11292$

AGR (ADVANCED GASCOOLED REACTOR, WINDSCALE, UK) $18-10340$

$A I R$

$5-11463 \quad 14-11313 \quad 14-11320 \quad 15-11123$

$15-11320 \quad 16-09611 \quad 16-09620 \quad 16-10672$

$16-10814$

AIR CLEANING Y 7-09735 $7-10505 \quad 7-11270$

$\begin{array}{llll}7-09370 & 7-09735 & 7-10505 & 7-11270 \\ 7-11271 & 7-11678 & 7-11679 & 7-11680\end{array}$

$\begin{array}{llll}7-11681 & 7-11683 & 7-11684 & 7-11685\end{array}$

$\begin{array}{llll}7-11686 & 7-11687 & 7-11688 & 7-11689\end{array}$

$\begin{array}{llll}7-11690 & 7-11691 & 7-11692 & 7-11693\end{array}$

$\begin{array}{llll}7-11694 & 7-11695 & 7-11696 & 7-11697\end{array}$

$\begin{array}{llll}7-11698 & 7-11699 & 7-11700 & 7-11701\end{array}$

$\begin{array}{llll}7-11705 & 7-11706 & 7-11707 & 7-11708\end{array}$

$7-11709 \quad 77-11710 \quad 7-11711 \quad 707-11712$

$\begin{array}{llll}7-11713 & 7-11715 & 7-11716 & 7-11717\end{array}$

$\begin{array}{llll}7-11718 & 7-11719 & 7-11720 & 7-11721\end{array}$

$7-11722 \quad 7-11723 \quad 7-11724 \quad 7-11725$

$\begin{array}{llll}7-11726 & 7-11727 & 7-11728 & 7-11729\end{array}$

$\begin{array}{llll}7-11730 & 7-11731 & 7-11732 & 0-10504\end{array}$

$\begin{array}{llll}11-11678 & 11-11696 & 11-11697 & 11-11698\end{array}$

$11-11699 \quad 11-11700 \quad 14-11702 \quad 14-11703$

AIR POLLUTIS

$18-11270$

16-09617

AIRBORNE RELEASE

$7-09729$

$7-11365$

$7-10302$

$7-11720$

16-10680 16-10766

$7-11270$

$16-10652$

$16-10973$

$17-10201 \div 17-11045378-10392 \times 18-11270$

$17-10201 \div 17-11045378-10392 \times 18-11270$

$7-11271$

$16-10679$

$\triangle A$ IRBURST

ALLOY

$16-10679$

$$
\begin{array}{r}
5-09917 \\
7-11270
\end{array}
$$

$11-09918$

$11+11274$

5-09918

$7-11274$

11-09921

$18-11270$

ALPHA EMITTER

7-11712

FACILITIES

12-11328

13-11328

ALUMINUM

6-10957 6-10958

11-11010

$12-11056$

$\triangle M E R I C I U M$

3-10806 11-10806

ANALYTICAL MODEL

1-09971 3-1084

$6-09725 \quad 3-10840$

$7-09359 \quad 7-09370$

$7-10578 \quad 7-10586$

$7-10589 \quad 7-11275$

$\begin{array}{rr}7-11706 & 7-11707 \\ 11-11678 & 15-10096\end{array}$

$11-11678$

ANALYTICAL TECHNIQUE, AIR

7-09729 7-10577

15-11123 15-11714

5-09921

8-10410

$11-09926$

5-09926

$11-09917$

$7-11720$

13-10806

$5-10316$

$16-09614$

$11-11010$

ANALYTICAL TECHNIQUE, CALIBRATION

$\begin{array}{rrrr}5-09926 & 7-09352 & 7-09369 & 7-09371 \\ 7-09730 & 7-10302 & 7-10535 & 7-10577 \\ 7-11709 & 7-11710 & 7-11732 & 11-09926\end{array}$

15-10099

ANALYTIC,AL TECHNIQUE, GAS

$15-11714$

ANALYTICAL TECHNIQUE, MILK

14-11124

ANALYTICAL TECHNIQUE, SOLID 7-10350

ANALYTICAL TECHNIQUE, URINE $15-11165$

ANNULUS

$\begin{array}{cccc}5-09628 & 5-09958 & 5-10844 & \\ \text { APPLICATION FOR } & \text { AEC LICENSE } & & \\ 12-10600 & 13-10600 & 18-10600 & \\ \text { ARGON } & & & \\ \text { 7-11273 } & 16-10676 & & \\ \text { ATMOSPHERIC CHEMISTRY } & & \\ \text { 4- } 99601 & 16-10644 & 16-10659 & 16-10662\end{array}$

6-10578

$7-09678$

$7-10587$

$7-11678$

$8-09971$

7-11709

$5-10578$

6-11060

$7-10557$

$7-11679$

9-10509

17-11060

$7-11710$

7-11732 


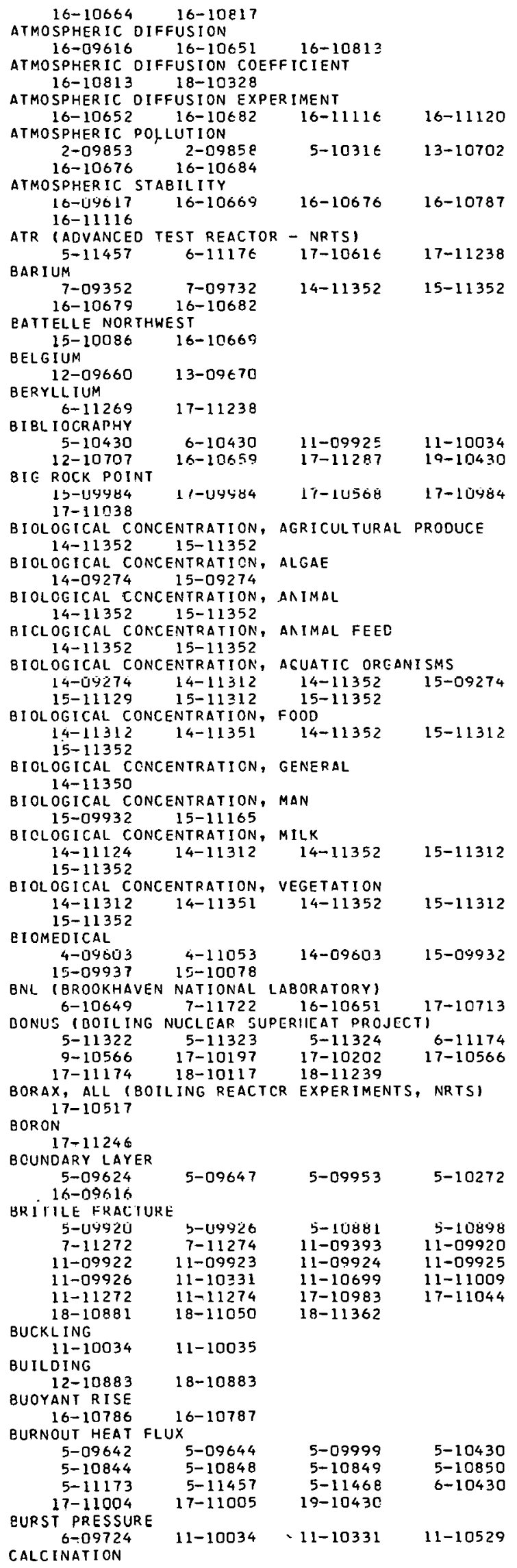

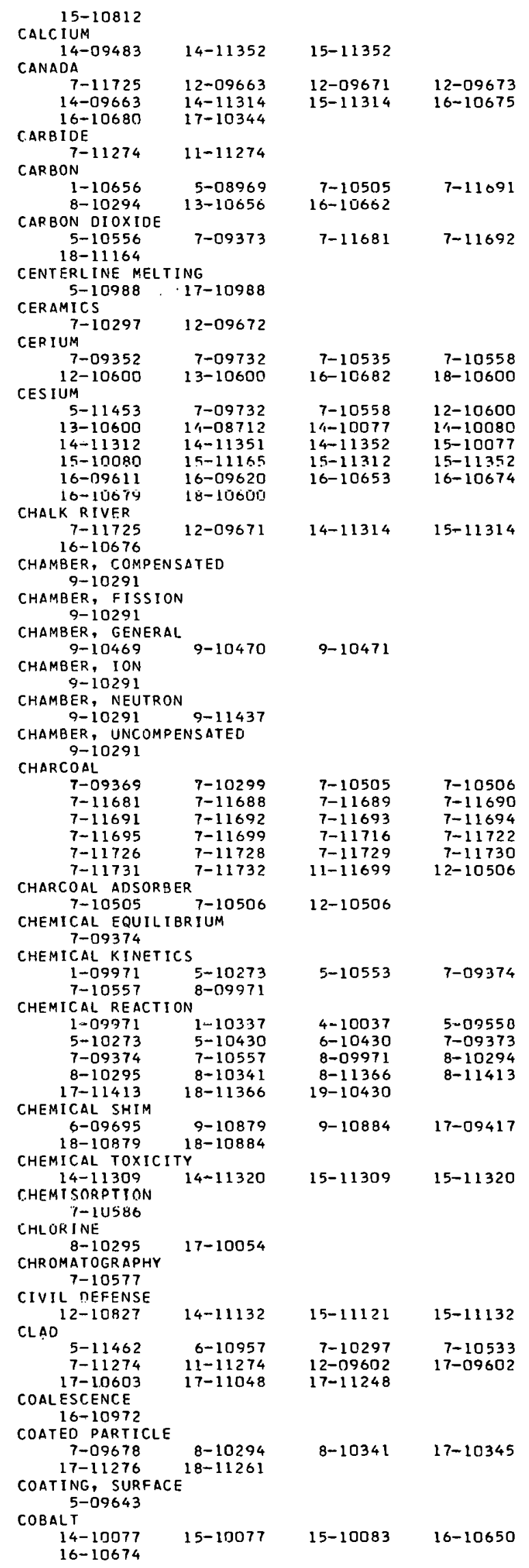


CODES AND STANDARDS $\begin{array}{llll}1-09852 & 2-09852 & 11-09393 & 12-09852\end{array}$ COMPACTION 15-10812

COMPARISON, THEORY AND EXPERIENCE

$\begin{array}{rrrr}3-10311 & 4-10037 & 5-09632 & 5-09633 \\ 5-09634 & 5-09635 & 5-09641 & 5-09644 \\ 5-09978 & 5-11040 & 6-11081 & 6-11090 \\ 7-11272 & 8-10311 & 9-10282 & 9-10508 \\ 10-10282 & 11-10035 & 11-10331 & 11-11272 \\ 14-10085 & 15-10083 & 15-10085 & 15-10508 \\ 16-10787 & 17-08480 & 17-09978 & 17-10983 \\ 17-11040 & 17-11081 & 17-11090 & \\ \text { UTER PROGRAM } & & & \\ 1-08716 & 1-09971 & 1-10525 & 5-10316 \\ 5-10475 & 6-09377 & 6-10346 & 6-10509 \\ 7-09273 & 7-09678 & 7-11706 & 8-09971 \\ 9-08716 & 9-10509 & 11-09618 & 1-09925 \\ 11-10035 & 11-10293 & 11-10743 & 15-10091 \\ 15-10096 & 15-10475 & 15-11123 & 18-08716\end{array}$

$15-10096$

$15-10475 \quad 15-11123$

COMPUTER PROGRAM, METEOROLOGICAL

16-10660 16-10973

COMPUTER, ANALOG

$6-10509$

COMPUTER, DIGITAL

$\begin{array}{llll}1-09971 & 1-10656 & 1-10932 & 2-11158 \\ 5-09622 & 5-09623 & 5-09635 & 5-09636 \\ 5-09641 & 5-10428 & 5-11321 & 6-09377 \\ 6-09725 & 6-10346 & 6-10536 & 6-10537 \\ 6-10538 & 6-10615 & 6-10641 & 6-10643 \\ 6-10654 & 6-10658 & 6-10714 & 6-10937 \\ 6-10945 & 6-10949 & 6-10950 & 6-10952 \\ 6-10955 & 6-10959 & 6-11153 & 6-11178 \\ 6-11303 & 6-11415 & 8-09971 & 9-10282 \\ 9-10461 & 9-10515 & 9-10569 & 9-10714 \\ 9-10937 & 9-10945 & 9-10955 & 10-10282\end{array}$

$11-10293 \quad 13-10656$

CONCENTRATION, CENTERLINE, MAXIMUM

18-11300

CONCENTRATION, GROUND LEVEL

16-10653

CONCENTRATION, ISOPLETH

16-10653

CONCRETE

$11-10720 \quad 14-10085 \div 15-10085$

$15-10093$

CONCRETE, PRESTRESSED

$\begin{array}{llll}11-09747 & 11-10007 & 11-11013 & 18-11261\end{array}$

CONDENSAT I ON

\begin{tabular}{l|l|l|l|l}
$5-09637$ & $5-09638$ & $5-09954$ & $5-11453$
\end{tabular}

CONTAINMENT AIR COOLING

$\begin{array}{llll}7-11696 & 11-11696 & 12-10888 & 18-10888\end{array}$

CONTAINMENT AIR LOCK

$\begin{array}{ll}12-09652 & 12-09654\end{array}$

CONTAINMENT ANALYSIS

5-10701 3 3-11700 $11-09618$ ep 11-09676

$11-10293 \quad 11-11700$

CONTAINMENT ATMOSPHERE, INERT

$8-11366 \quad 18-11231 \quad 18-11366$

CONTAINMENT CONSTRUCTION

$7-11697$ 11-11012

$17-10053$

CONTAINMENT DESIGN

$5-10578$ OIGN

$11-11697$

$12-11012$

5-10578 6-10578

7-11697 6-11088

$7-10578$

$8-10887$

11-11697

$18-10328$

$11-11699 \quad 11-11700 \quad 12-09659$

$18-10887 \quad 18-11088$

CONTAINMENT FILTERING SYSTEM

$\begin{array}{llll}5-10578 & 5-10867 & 6-10578 & 7-10578 \\ 7-10867 & 7-11678 & 7-11696 & 7-11699\end{array}$

$\begin{array}{llll}7-10867 & 7-11678 & 7-11696 & 7-11699\end{array}$

$7-11700 \quad 7-11701$ 7-11711 009 11-10867

$\begin{array}{llll}11-11678 & 11-11696 & 11-11699 & 11-11700\end{array}$

CONTAINMENT INSTRUMENTATION

$5-10578 \quad 6-10578$

CONTAINMENT INTEGRITY

$11-10331 \quad 11-106$

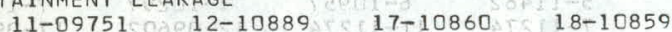

$18-10889$

CONTAINMENT LEAKAGE CONTRCL $\begin{array}{llll}7-11697 & 11-11697 & 12-10890 & 18-10890\end{array}$

CONTAINMENT PENETRATION

$12-10890 \quad 18-10890$

CONTAINMENT PENETRATION, CLOSURE OF $\begin{array}{lll}11-10892 & 17-10713 \quad 18-10892\end{array}$

CONTAINMENT REFERENCE MEASURING SYSTEM 11-09751

CONTAINMENT RESEARCH AND CEVELOPMENT 5-10867 $7-10867 \quad 7-11697$

$7-11699$

\begin{tabular}{|c|c|c|}
\hline $7-11700$ & $11-09676 \quad 11-09925$ & don $11-10293$ \\
\hline $11-10331$ & $111-10699$ & $11-10867$ \\
\hline $11-11013$ & $11-11699$ & $11-11700$ \\
\hline TAINMENT & SPRAY & POMTA \\
\hline $7-11697$ & $11-11697$ & $12-10888$ \\
\hline $18-10888$ & $18-11366=1107247=19$ & ЯРН420M1A \\
\hline CONTA INMENT & STRUCTURE & $617 f-81$ \\
\hline $7-11697$ & $11-09925$ & $11-10034$ \\
\hline $11-10035$ & $11-11697$ & $18-09744$ \\
\hline $18-09745$ & $18-10929$ & $5001-01$ \\
\hline TAINMENT & SYSTEM, OPERATION OF & 209740 \\
\hline $\begin{array}{l}7-11696 \\
\text { NTA INMENT }\end{array}$ & VESSEL LOADING & $13 p-11-1$ \\
\hline $11-10293$ & $11-105292095 \quad 72=$ & (2WIZYOA) 97 \\
\hline
\end{tabular}

CONTAINMENT, FUEL REPROCESSING

$$
\text { 6-10719 }
$$

CONTAINMENT, GENERAL

$\begin{array}{rrrr}2-11014 & 7-10297 & 7-11678 & 7-11698 \\ 7-11701 & 11-09676 & 11-10293 & 11-11014 \\ 11-11678 & 11-11698 & 12-1089480018-10894\end{array}$

CONTAINMENT, HIGH PRESSURE

$\begin{array}{llll}11-79746 & 11-10331 & 11-10529 \quad 18-09746\end{array}$ $18-10191$

CONTAINMENT, MISSILE GENERATION AND PROTECTION 11-10529 11-10873 17-10986 18-10873 CONTAINMENT, MULTIPLE

$$
\text { 2-11014 11-11014 }
$$

CONTAINMENT, PRESSURE RELIEF

7-11699 11-11699

CONTAINMENT, PRESSURE SUPPRESSION

$$
\begin{array}{rrrr}
7-11699 & 8-11366 & 11-09748 & 11-10293 \\
11-11699 & 18-09948 & 18-11366 & 100919
\end{array}
$$

CONTAINMENT, PRESSURE VENTING

$$
\text { 7-11699 } 7-11701 \text { 11-11699 }
$$

CONTAINMENT, PRESSURE VESSEL

$\begin{array}{cccc}5-09926 & 5-10881 & 5-10898 & 7-11272\end{array}$

$\begin{array}{llll}7-11697 & 9-11049 & 11-09746 & 11-09747\end{array}$

$11-09922 \quad 11-09923 \quad 11-09924 \quad 11-09926$

$11-10007 \quad 11-10325 \quad 11-10331$ se $11-10699$

$11-11009 \quad 11-11010 \quad 11-11011 \quad 11-11012$

$11-11013 \quad 11-11019 \quad 11-11272 \quad 11-11697$

$12-11012 \quad 17-10343 \quad 17-10983 \quad 17-10984$

$17-11044 \quad 17-11049 \quad 18-09746 \quad 18-10871$

$18-10881 \quad 18-11050 \quad 18-11261 \quad 18-11362$

CONTAINMENT, SHOCK GENERATION AND PROTECTION

$$
\text { 7-11697 7-11701101TA 8-10530 BAJ 8-10531 }
$$

$11-09618 \quad 11-10529+11-10530 \quad 11-10531$

11-11019 11-11697

CONTAINMENT, WATER FILLE
$7-11699 \quad 11-11699$

CONTAMINATION

$\begin{array}{llll}11-09676 & 12-09311 & 12-09663 & 12-09674\end{array}$

$\begin{array}{llll}14-09663 & 14-11506 & 15-11506 & 17-09311\end{array}$

17-10200 17-10987

CONTROL ROD

$\begin{array}{llll}6-09725 & 6-11006 & 9-10882 & 9-11006\end{array}$

$9-11418 \quad 17-10049 \quad 18-10892 \quad 18-11300$

CONTROL ROD CALIBRATION

$$
\text { 6-10611 } \quad 17-09788
$$

CONTROL ROO ORIVE

$\begin{array}{llll}9-10290 & 9-10439 & 9-10566 & 9-11417\end{array}$

$\begin{array}{llll}17-10566 & 17-10568 & 17-10836 & 17-11005\end{array}$

$18-09949 \quad 18-11232 \quad 18-11363 \quad 1 A$ A

CONTROL ROD INTERACTION

9-10851

CONTROL ROD SCRAM MECHANISM

9-11417

CONTROL ROD WORTH

$\begin{array}{llll}1-10805 & 6-09694 & 6-09695 & 6-10620 \\ 6-10803 & 6-10805 & 6-10855 & 6-10935 \\ 6-10937 & 6-10946 & 6-10955 & 6-11432 \\ 9-10620 & 9-10855 & 9-10935 & 9-10937\end{array}$

$9-10620 \quad 9-10855 \quad 9-10935 \quad 9-10937$

OL ROD, SHIM SAFETY

$9-11043 \quad 9-11049 \quad 17-10989 \quad 17-11037$

$\begin{array}{llll}17-11043 & 17-11049 & 17-11246 & 18-11291\end{array}$

CONTROL SYSTEM

$6-09740 \quad 6-10509$ E $6-10978$ 6 $9-10292$

$\begin{array}{llll}9-10388 & 9-10473 & 9-10509 & 9-10978\end{array}$

$18-09740$

CONTROL, COMPUTER

$9-10515$

CONTROL, GENERAL

3-10842 $6-11006,3009-11006 \quad 9-11450$

CONVECTIVE BOILING

$\begin{array}{lll}5-09385 & 5-09644 & 5-11464\end{array}$

COOLANT CHEMISTRY

$7-11580$ : $7-11681,7+11693$

$\begin{array}{lll}17-09417 & 17-09439 & 17-09594\end{array}$

$17-10048$ 


\begin{tabular}{|c|c|c|c|c|}
\hline & $\begin{array}{l}17-10054 \\
17-10995\end{array}$ & $\begin{array}{l}17-10517 \\
18-10995\end{array}$ & $17-10604$ & $17-10866$ \\
\hline COPPE & & & & \\
\hline & $7-10586$ & $7-11731$ & $12-10966$ & $16-10651$ \\
\hline CORE & COMPONENTS, & 5, MI SCELLA & INEOUS & \\
\hline & $5-10927$ & $17-11082$ & $18-10927$ & $18-11029$ \\
\hline & $18-11030$ & $18-11031$ & & \\
\hline CORE & MELTDOWN & & & \\
\hline & $5-10550$ & $5-10551$ & $6-10550$ & $7-10550$ \\
\hline CORE & SPRAY & & & \\
\hline & $17-10051$ & $18-11232$ & $18-11363$ & \\
\hline CORE, & $\begin{array}{l}\text { CAPSULE OR } \\
\text { S-09724 }\end{array}$ & RRIVER ICDC & & \\
\hline CORRO & OSION & & & \\
\hline & $5-09920$ & $11-09920$ & $17-10044$ & $17-10048$ \\
\hline & $17-10050$ & $17-10054$ & $17-10603$ & $17-10616$ \\
\hline & $17-10836$ & $17-11276$ & & \\
\hline $\cos M I$ & IC RADIATION & DN & & \\
\hline & $16-10811$ & & & \\
\hline COUNT & IER, WHOLF R & RONY & & \\
\hline COUPL & $\begin{array}{l}15-09937 \\
\text { LED CORES }\end{array}$ & $15-11165$ & & \\
\hline & $6-11085$ & $9-10885$ & $17-11085$ & $18-10885$ \\
\hline CREEP & D BEHAVIOR & & & \\
\hline CREEP & $\begin{array}{l}11-\ln 34 \\
\text { D PROPERTY }\end{array}$ & 11-1ח7רמ & $11-1102 n$ & \\
\hline & $5-09917$ & $5-09920$ & $5-10847$ & $11-09917$ \\
\hline $\begin{array}{ll}1 \\
\text { CRITI }\end{array}$ & $\begin{array}{l}11-09920 \\
\text { ICAL ASSEMBL }\end{array}$ & $\angle Y F A C I L I T$ & & \\
\hline & $1-10695$ & $6-10695$ & $6-10935$ & $6-10936$ \\
\hline & $6-10937$ & $6-10938$ & $6-10945$ & $6-10978$ \\
\hline & $6-11424$ & $9-10935$ & $9-10937$ & $9-10945$ \\
\hline & $9-10978$ & $9-11424$ & $12-11424$ & $17-10989$ \\
\hline & $18-11289$ & $18-11291$ & $18-11429$ & \\
\hline CRITI & ICAL NUCLIDE & & & \\
\hline & $14-10074$ & $14-10080$ & $15-10074$ & $15-10080$ \\
\hline CRITI & ICAL I TY EXPE & ER I MEN T, & & \\
\hline & $\begin{array}{l}1-08441 \\
1-1161\end{array}$ & $\begin{array}{l}1-10618 \\
5-09978\end{array}$ & $\begin{array}{l}1-10619 \\
6-08441\end{array}$ & $\begin{array}{l}1-10695 \\
6-09725\end{array}$ \\
\hline & $6-10039$ & $6-10617$ & $6-10619$ & $6-10620$ \\
\hline & $6-10695$ & $6-10945$ & $6-11090$ & $6-11161$ \\
\hline & $9-10620$ & $9-10945$ & $13-10039$ & $17-08480$ \\
\hline & $17-09978$ & $17-10602$ & $17-10607$ & $17-10793$ \\
\hline & $17-11090$ & & & \\
\hline CRITI & ICALITY SAFE & ETYY & & \\
\hline & $1-08441$ & $1-10618$ & $1-10619$ & $1-10656$ \\
\hline & $1-10687$ & $1-10703$ & $1-10705$ & $1-10805$ \\
\hline & $1-10932$ & $3-11222$ & $6-08441$ & $6-10039$ \\
\hline & $6-10619$ & $6-10642$ & $6-10805$ & $12-10687$ \\
\hline & $13-10039$ & $13-10656$ & $13-10703$ & $13-10704$ \\
\hline & $13-10705$ & $13-10810$ & $13-10981$ & $13-11330$ \\
\hline CROSS & S SECTION & & & \\
\hline CRUD & & & & \\
\hline & $17-10045$ & & & \\
\hline YOG & GENICS & & & \\
\hline & $7-10506$ & $12-10506$ & & \\
\hline CSE 1 & I CONT A I NMENT & IT SYSTEMS & EXPER IMENT) & \\
\hline & $\begin{array}{r}1-09854 \\
12-09854\end{array}$ & $7-09854$ & $11-09618$ & $11-10293$ \\
\hline CVTR & ICAROL INAS & VIRGINIA & TUEE REACT(R) & \\
\hline & $\begin{array}{r}6-10954 \\
18-10859\end{array}$ & $6-10955$ & $9-10955$ & $17-10836$ \\
\hline CYLIN & NDER & & & \\
\hline & $11-09747$ & $1.1-10.331$ & $11-11.016$ & \\
\hline CZECH & $\begin{array}{l}\text { HOSL OVAKIA } \\
6-11415\end{array}$ & & & \\
\hline & & & & \\
\hline & $9-11049$ & $17-11049$ & $17-110$ & $17-11246$ \\
\hline OANGE & ER COEFFICIE & & & \\
\hline & $6-10611$ & $6-10017$ & & \\
\hline & PROCESSING & & & \\
\hline & $9-10461$ & $9-10569$ & $16-10668$ & \\
\hline & $\begin{array}{l}\text { HEAT } \\
5-10880\end{array}$ & $18-10880$ & & \\
\hline DECON & VTAMINATION & & & \\
\hline & $1-09662$ & $1-09664$ & $7-09373$ & $7-09374$ \\
\hline & $7-11698$ & $11-11698$ & $12-09602$ & $12-09661$ \\
\hline & $12-09662$ & $12-09664$ & $12-09665$ & $12-09666$ \\
\hline & $12-09672$ & $12-09674$ & $12-10707$ & $12-10809$ \\
\hline & $12-10827$ & $12-10966$ & $12-1105 t$ & $13-10809$ \\
\hline & $14-11130$ & $14-11132$ & $15-11130$ & $15-11132$ \\
\hline & $17-$ & & & \\
\hline DECON & NTAMINATION & SPRAY & & \\
\hline & $7-11693$ & $7-11694$ & $7-11698$ & $11-11698$ \\
\hline$=0 R$ & RMATION & & & \\
\hline DELAY & $\begin{array}{l}11-10720 \\
Y \in O \text { NEUTRON }\end{array}$ & & & \\
\hline & $1-11161$ & $\begin{array}{l}6-10697 \\
6-11107\end{array}$ & $\begin{array}{l}6-10855 \\
6-11155\end{array}$ & $\begin{array}{l}6-10947 \\
6-11161\end{array}$ \\
\hline & $\begin{array}{l}0-10950 \\
9-10855\end{array}$ & & & \\
\hline
\end{tabular}

DENMARK

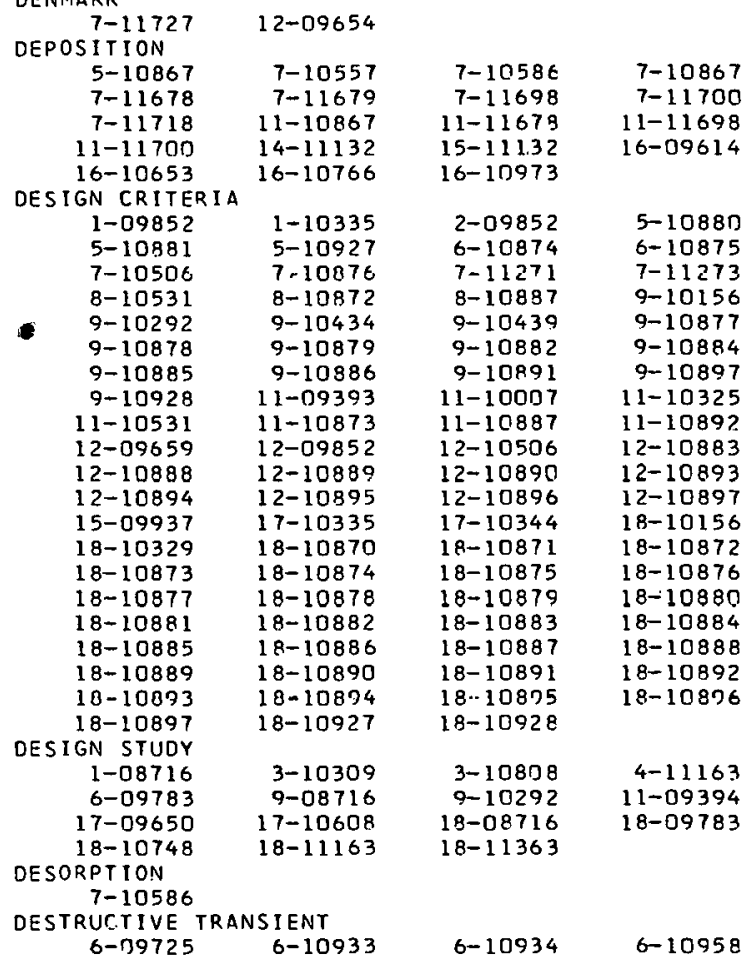


$\begin{array}{llll}15-10086 & 15-10087 & 15-10091 & 15-10099\end{array}$

$15-11167$

$15-11167$

DOSIMETRY, THER NOLUMINESCENCE

15-10087 $15-11167$

DOUNREAY (UK)

$12-09674$

DRESDEN I

$17-10044 \quad 17-10046$

DRESDEN III

$18-09948 \quad 18-09949$

DROPLET

$16-10972$

DUNGENESS B (UK)

$18-10340$

DYNAMICS, NONLINEAR

DYNAMICS, NONLINEAR
EBOR (EXPERIMENTAL BERYLLIUM OXIDE REACTOR)

$17-11427$

EBR I AND II (EXPERIMENTAL BREEDER REACTORS)

$\begin{array}{llll}5-11083 & 6-10978 & 9-10978 & 17-10986\end{array}$ $17-11083$

EBWR (EXPERIMENTAL BOILING WATER REACTOR)

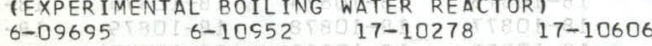

ECOLOGICAL CONSIDERATION

$$
\text { 14-11352 } 15-11311 \quad 15-11352
$$

ECONOMIC STUDY

$$
\begin{array}{llll}
1-10409 & 3-10309 & 5-10120 & 7-10297
\end{array}
$$

ECONOMICS

$$
\begin{array}{rrrr}
1-09662 & 2-09857 & 2-09858 & 7-10533 \\
12-09662 & 17-11259 & 18-11239 & 18-11361
\end{array}
$$$$
18-11414
$$

EFFLUENT

4-11252 $12-09663 \quad 14-09663 \quad 14-11252$

EGCR (EXPERIMENTAL GAS COCLED REACTOR) 6-11266 9-11451

ELASTICITY

$\begin{array}{llll}11-09922 & 11-09925 & 11-10034 & 11-10035\end{array}$

CTRIC POWER, GENERAL

$$
9-11433
$$

ELECTRIC POWER, VITAL

9-10282 9-10891 10-10282 18-10891

ELECTRON MICROSCOPY

$$
\text { 5-09918 } 15-09921 \quad 11-09918 \quad \text { 11-09921 }
$$

ELECTROSTATIC CHARGE 7-09273

ELECTROSTATIC PRECIPITATION 7-11705

ELK RIVER

$$
\text { 9-11049 }
$$

$$
9-11304
$$

$17-11047$

$17-11246$

EMBR ITTLEMENT

$1-10337$ $11-11009$

11-1069 COOLING

$$
1-09854
$$

$7-09854$ $18-11029$

EMERGENCY POWER, ELECTRIC

$\begin{array}{rrrr}9-10282 & 9-10891 & 10-10282 & 12-10888 \\ 17-10046 & 18-10888 & 18-10891 & 18-11300\end{array}$

EMERGENCY SYSTEM

$$
9-10885 \quad 18-10885
$$

ENEA (EUROPEAN NUCLEAR ENEREY AGENCY)

$\begin{array}{llll}1-09662 & 1-09664 & 11-09676 & 12-09652 \\ 12-09653 & 12-09654 & 12-09655 & 12-09656 \\ 12-09658 & 12-09659 & 12-09660 & 12-09661 \\ 12-09662 & 12-09663 & 12-09664 & 12-09665 \\ 12-09666 & 12-09667 & 12-09668 & 12-09669 \\ 12-09671 & 12-09672 & 12-09673 & 12-09674 \\ 12-09675 & 13-09657 & 13-09670 & 14-09663\end{array}$

ENEREY SOURCE $5-10121$

ENGINEERED SAFEGUARD

$\begin{array}{rrrr}1-09852 & 1-09854 & 1-09855 & 1-09856 \\ 2-09852 & 2-0985 & 2-09856 & 2-11014 \\ 2-11158 & 5-10899 & 6-10946 & 7-09854 \\ 7-11696 & 8-10899 & 9-10928 & 9-10946 \\ 11-11014 & 11-11696 & 12-09852 & 12-09854 \\ 12-09855 & 12-09856 & 12-10893 & 18-10329 \\ 18-10893 & 18-10928 & 18-11231 & 18-11300 \\ \text { INEERING DRAWING LIST } & & \\ 18-11251 & & \\ \text { RONMENTAL CONDITICN } & & \\ 16-09620 & 16-10644 & 16-10645 & 16-10646 \\ 16-10648 & 16-10671 & & \\ \text { AT ON OF STATE } & & \\ 5-10553 & \text { 6-11088 } & 18-11088 & \\ \text { TION, GENERAL } & & \\ \text { 15-10099 16-09614 } & 16-10766 & 16-10818\end{array}$

EQUATION, IN HOUR

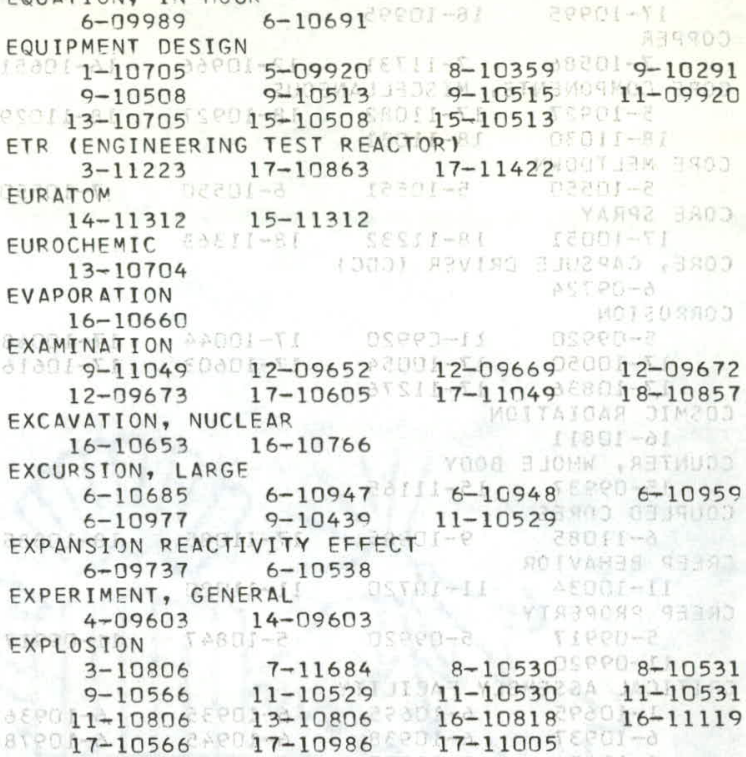

EXPLOSTVE, CONVENTIONAL 6-10685

FABR I CATION

$17-10606$

FAILURE, ADMINISTRATIVE CONTROL

$$
15-10563 \quad 17-09312 \quad 17-09313 \quad 17-10200
$$$$
\begin{array}{llll}
17-10561 & 17-10562 & 17-10563 & 17-10987
\end{array}
$$$$
17-11042 \quad 17-11045
$$

FAILURE, CLADDING$$
5-10988
$$

$6-11316$

$7-10876$

$17-10988$

FAILURE, COMPONENT

$$
\text { 5-10927 }
$$

$\begin{array}{rr}11-11019 & 17-09416 \\ 17-10989 & 18-10927\end{array}$

FAILURE, DESIGN ERROR

$17-09982 \quad 17-10194$

17-11042 17-11052

FAILURE, EQUIPMENT

17-10568 17-10604

FAILURE, FATIGUE

11-09925 11-11009

FAILURE, FUEL ELEMENT

6-09724 6-09725

6-10709 6-10854

7-10559 7-10854

8-11413 9-10709

$17-11248 \quad 17-11413$

FAILURE, GENERAL

9-10282 10-10282

FAILURE, INSTRUMENT

$12-10564 \quad 15-10196$ $17-10564$

FAILURE, OPERATOR ERROR

17-10833 17-11036

FAILURE, PIPE

5-09921 5-10988

$11-09925 \quad 17-10046$

17-11051 17-11052

FAILURE, PRESSURE VESSEL 5-09926 11-09922 $11-10529$ 11-10699

FAILURE, SCRAM MECHANISM $17-09594$

FALLOUT

$\begin{array}{rlll}14-09274 & 14-10077 & 14-10080 & 14-10085 \\ 14-11131 & 14-11132 & 14-11312 & 14-11506 \\ 15-09274 & 15-10077 & 15-10080 & 15-10085 \\ 15-11121 & 15-11129 & 15-11131 & 15-11132 \\ 15-11165 & 15-11312 & 15-11506 & 16-09614 \\ 16-10648 & 16-10650 & 16-10652 & 16-10663 \\ 16-10665 & 16-10674 & 16-10679 & 16-10769 \\ 16-10814 & 16-10817 & 16-11114 & 16-11116 \\ 16-11120 & & & \\ \text { FARET IFAST ARGONNE REACTOR } & \text { EXPERIMENT TESTI } \\ \text { 5-10430 } & 6-10430 & 11-09746 & 18-09746 \\ 19-10430 & & & \\ \text { FAST NEUTRON } & & & \\ 1-10718 & 6-10718 & 9-11437 & 15-10087 \\ 15-10093 & & & \end{array}$

5-11051 11-0992

$11-09926 \quad 11-10331$

$\begin{array}{rr}7-11686 & 9-09416 \\ 17-10713 & 17-10833\end{array}$

$17-10989 \quad 17-11036$

$17-10746 \quad 17-11427$

11-11010 17-10836

6-10539 6-10610

6-10934 6-11316

$\begin{array}{rr}7-11365 & 7-11681 \\ 17-10517 & 17-11047\end{array}$

$18-11247 \quad 18-11365$

11-09394 17-10051

$17-10046 \quad 17-10196$ 
FERM I 9-10978 6-10567 18-10862 17-10050

FILM, GENERAL 5- $09637 \quad 5-09638$

FILTER 5-09958 17-1104

7-0936

$7-10299$

$7-11686$

$7-11689$

$7-11693$

$7-11707$

$7-11713$

7-11726

16-10672

7-09735

7-11684

7-11687

$7-11690$

7-11694

7-11709

$7-11713$

9-10504

16-10682

FILTER COST

$7-11682$

7-11683

7-11682

7-11687

7-11683

7-11696

11-11696

FILTER EFFICIENCY

\begin{tabular}{|c|c|c|c|}
\hline 1 & $7-11709$ & $7-11711$ & $7-11712$ \\
\hline 11721 & $7-11722$ & $7-11725$ & $7-11726$ \\
\hline 11728 & $7-11730$ & $7+11731$ & $7-11732$ \\
\hline $\begin{array}{l}\text { IMPACTION } \\
11718\end{array}$ & & & \\
\hline $\begin{array}{l}-11718 \\
\text { INSPECTION }\end{array}$ & $v^{7-11719}$ & & \\
\hline-11713 & & & \\
\hline ER INSTALL & & & \\
\hline $7-11685$ & $7-11696$ & $7-11701$ & $11-1.1696$ \\
\hline
\end{tabular}

7-1168

7 LIFE
$7-11708$

FILTER MAINTENANCE

7-11686

$7-11696$

7-11701

$11-1.1696$

7-11692

7-11708

11-11696

7-11271

7-1169t

FILTER PACK

7-10302

FILTER QUALITY ASSURANCE STATION 7-11682

FILTER SAFETY EVALUATION

$$
\text { 7-11685 7-11686 }
$$

$7-11713$

$7-11713$

TILTER SPRAY

$7-11271$

FILTEK SYSTEM

$7-11271$

$7-11696$

$7-11682$

$7-11698$

$7-11726$ 7-11729

FILTER TEST REQUIREMENT 7-11682, 7-11725

FILTER THEORY, DIFFUSION 7-11707 7-11709

ГILTER THEORY, IMPACTION 7-11707 7-11709

FILTER THEORY, INTERCEPIION $7-09273 \quad 7-11707$

7-11709

FILTER, BED

7-09735 7-10299

7-11692 7-11719 $7-11730 \quad 12-10506$

FILTER, CASCACE 7-09913

FILTER, CASCACE IMPACTOR $7-09913$

7-11718

FILTER, COMMERCIAL

7-09735

FILTER, CYCLONE 7-09735

FILTER, DAMAGEO

$$
\text { 7-11685 7-11686 }
$$

FILTER, EFFICIENCY OF

$$
\text { 7-11681 7-11688 }
$$

7-11695 7-11705

FILTER, ELECTROSTATIC

$$
\text { 7-09735 7-11705 }
$$

FILTER, FIBER

$7-11708 \quad 7-11709$

TILTER, FIBERGLASS

16-10814

FILTER, GLASS

7-11682

7-11683 $17-09594$

FILTER, HIGH EFFICIENCY

$\begin{array}{rrrr}7-11682 & 7-11683 & 7-11684 & 7-11685 \\ 7-11686 & 7-11687 & 7-11708 & 7-11709 \\ 7-11711 & 7-11719 & 7-11721 & 7-11722 \\ 7-11724 & 7-11725 & 7-11726 & 7-11728\end{array}$

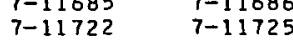

$11-11696 \quad 11+11698$

$7-11720$

7-11721

7-11683

$7-11689 \quad 7-11690$

$7-11718$

$7-11710$

FILTER, HIGH TEMPERATURE 7-11691

FILTER, MEMBRANE

$$
\text { 7-11718 }
$$

FILTER, SAND 7-11721

FILTER, TRAP 7-09369 $7-11688$

$7-11692$

$7-10299$

$7-10596$

$7-11681$ $7-11729$

$7-11689$

$7-11730$

$7-11690$

7-11726

7-11731

$7-11728$

12-10506

FILTRATION

7-09735

FIN

12-09663

$7-11712$

$7-11719$

$7-11721$

FIRE

5-09841 5-09954

3-11222

$7-11270$

$7-11717$

$15-10563$

3-1150்

$7-11680$

$7-11720$

$17-10562$

$17-10990 \quad 18-11270$

FISSION GAS RELEASE

6-10933 7-09350

7-09732 7-10533

7-11723

$17-10192$

FISSION PROMUCT ACTIVITY,

12-10966

17-10198

FISSION PRODUCT RELEASE, GENERAL

$1-09854 \quad 5-10475 \quad 5-10867$

$\begin{array}{ll}7-09359 & 7-09854 \\ 7-10559 & 7-10867 \\ 7-11100 & 9-10504\end{array}$

$9-10504$

12-09854 12-10564

$18-10475$

FISSION PRODUCT REIENTION

$\begin{array}{ll}6-10933 & 7-10297 \\ 7-10933 & 9-10504\end{array}$

$18-11232$

FISSION PRODUCT TRANSPORT

$5-10316 \quad 5-1057$

$7-08682 \quad 7-08895$

$7-09360 \quad 7-09369$

$7-10533 \quad 7-10535$

$7-10577 \quad 7-10578$

$7-11679 \quad 7-11680$

$7-11690 \quad 7-11691$

$7+11695 \quad 7-11698$

$7-11719$

$7-11698$

11-11698 14-11702

FISSION PRODUCT, AIPBORNE

7-11723

FISSION PRODUCT, IODINE

6-10933

$7-99369$

$7-10577$

$7-08682$

$7-10290$

$7-11681$

$7-10506$

$7-11693$

$7-11688$

$7-11699$

$7-11722$

7-11729

$7-11694$

$7-11700$

$7-11723$

$1-11678$

7-11730

FISSION PRODUCT, NONVOLATILE

$1-11698$

7-09352 7-10535 FISSION PRODUCT, SEPARATION FROM WASTE
$12-10600$ 13-10600 18-10600 $12-10600$

6-10715

$7-11685$

17-10563

7-10505

7-11691

$11-09676$

17-10987

7-09359

17-10202

$7-0973$

7-10933 7-10557

$7-11679$

15-10475

7-10299

12-10506

5-10867

7-09352

$7-09731$

(0557

7-11688

$7-11693$

7-11717

16-10677

7-09350

7-10558

7-11680

11-11700

17-10564

7-10506

17-11276

6-10578

7-09359

$7-09732$

$7+10558$

$-10867$

$7-11689$

7-11694

7-11718

$18-11261$

7-08895

$7-10557$

$-10933$

7-11689

7-11695

7-11711

$7+11726$

7-11731

$11-11699$

7-08895

$7-10558$

7-11690

7-11698

7-11719

7-11728

7-11732

$11-11700$

IN WASTES

12-10600

13-10600

18-10600

FISSION PRODUCT, VOLATILE

$\begin{array}{rr}7-08895 & 7-04732 \\ 7-11679 & 12-10506\end{array}$

i- 10506

$7-10557$

FLANGE

AGE

$12-11012$

FLAW

$\begin{array}{ll}1-10325 & 11-11012 \\ 5-09926 & 11-09926\end{array}$ 


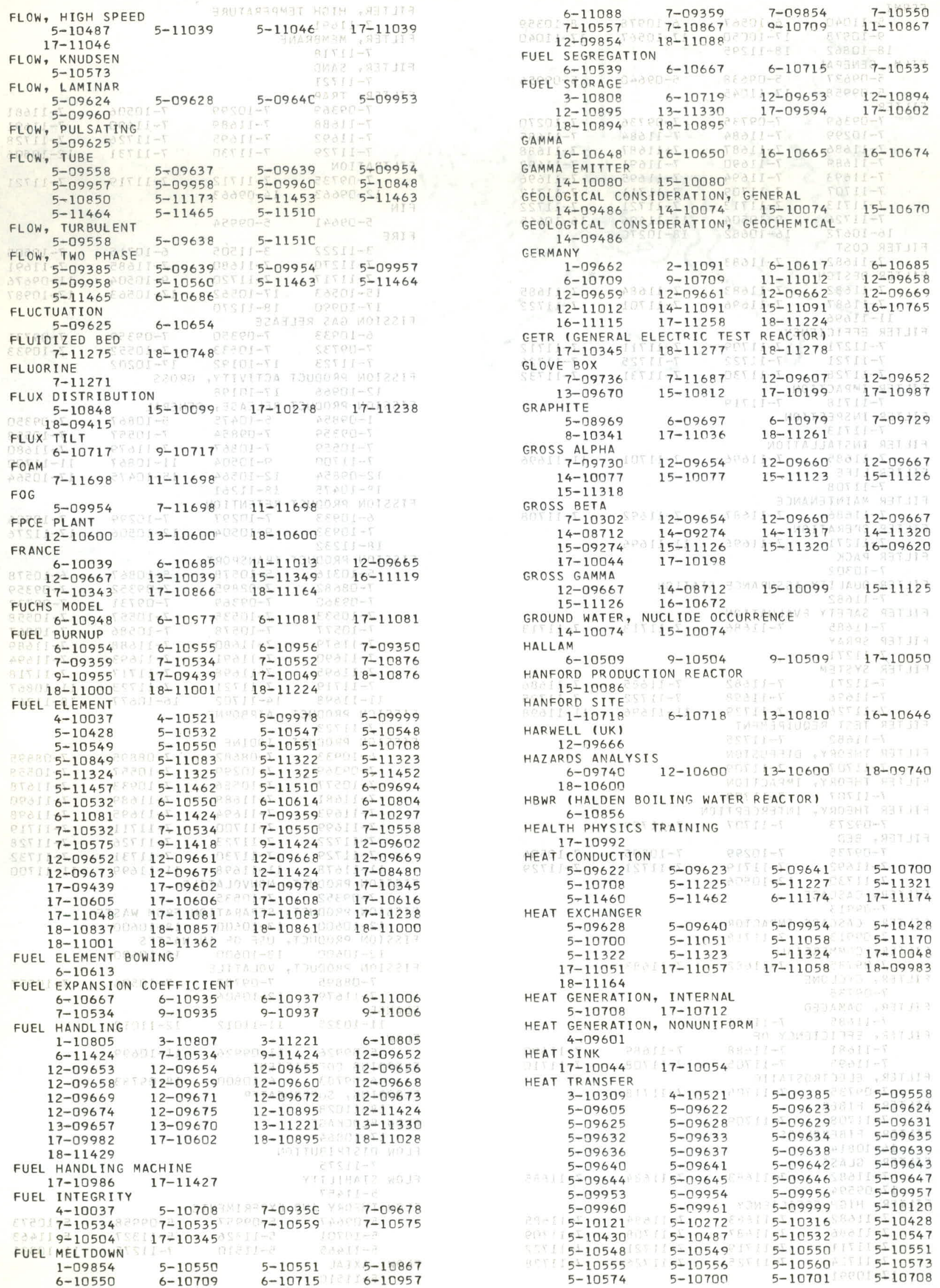




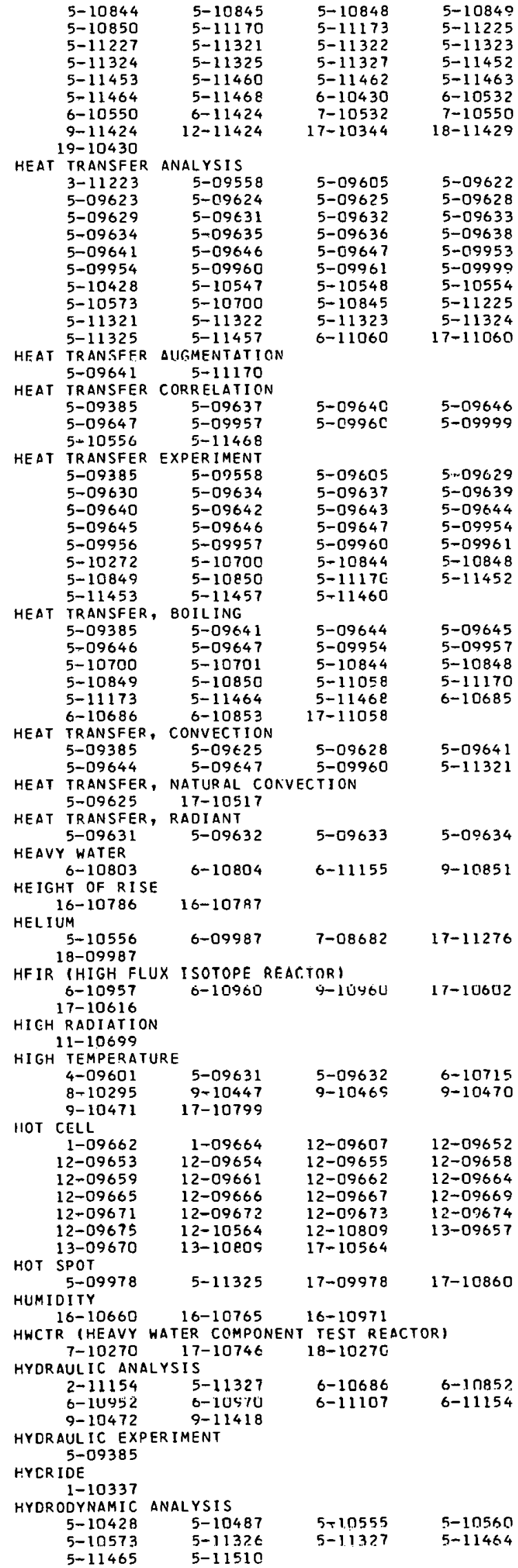

HYCROGEN

$\begin{array}{rrrr}1-10337 & 3-10842 & 6-10933 & 6-10934 \\ 7-09374 & 7-10933 & 8-11366 & 13-10842 \\ 17-10986 & 18-11366 & & \\ 14-09486 & 14-10080 & 15-10030 & 19-11346\end{array}$

$14-09486$
HYDROLOGICAL CONSIDERATION, QUALITY OF WATER

19-11346 CONSIDERATION, RATE OF MOVEMENT HYDROLOGICAL CONSIDERATION, RATE OF MOVEMENT
$19-11346$

ICRP (INT. COMM. ON RADIOLOGICAL PROTECTIONI $15-11128$

IGNITION

$\begin{array}{crrr}7-10505 & 7-11685 & 7-11691 & \\ \text { IMPACT DROPERTY } & & & \\ 5-09920 & 5-09926 & 5-10847 & 7-11272 \\ 11-09920 & 11-09926 & 11-10699 & 11-11272 \\ \text { IMPACT SHOCK } & & & \\ 3-10840 & 3-11505 & 5-09926 & 11-09394 \\ 11-09926 & 11-10529 & 11-11009 & 11-11016 \\ 11-11019 & & & \\ \text { IN CORE MEASUREMENT } & & \\ 9-10448 & 17-10278 & & \\ \text { IN PILE EXPERIMENT } & & \\ \text { 7-OB895 } & 7-10534 & 7-10575 & 15-11348 \\ \text { IN PILE LOOP } & & & \\ 5-08969 & 5-10988 & 7-08895 & 7-09350 \\ 7-10506 & 7-11681 & 12-10506 & 17-09789 \\ 17-10344 & 17-10345 & 17-10863 & 17-10988\end{array}$$$
18-11277
$$

$17-10345$

$17-10863$

$17-10988$

INC IDENT COMPILATION

$17-10833$

INCIDENT, ACTUAL, EOUIPMENT

17-10194 17-10568

INCIDENT, ACTUAL, GENERAL

$\begin{array}{llll}5-10988 & 17-10603 & 17-10988 & 17-11052\end{array}$

17-11287 17-11364 18-11364

INC IDENT, ACTUAL, HUMAN ERROR

17-10192 17-10198 17-11042

INCIDENT, ACTUAL, NONNUCLEAR

17-11037

INCIOENT, ACTUAL, NONREACTOR

$\begin{array}{cccc}12-10564 & 15-10563 & 17-10561 & 17-10562 \\ 17-10563 & 17-10564 & 17-10987 & 17-11045\end{array}$

INCIDENT, ACTUAL, RECOVERY FROM

17-10343

INC INERATI ON

$\begin{array}{rlll}7-1177 n & 14-11314 & 14-11702 & 14-11703 \\ 15-11314 & 18-11270 & & \end{array}$

INCONFL

$17-11248$

INOIAN POINT I

$1-09856$

5-11046

$2-09856$
$5-11051$

2-09857

5-11039

17-11039

$17-11046$

$12-09856$

$17-11051$

INOIAN POINT II

$1-09856$

$2-09856$

2-09857

$5-10899$

$7-1087 t$

$\begin{array}{ll}5-10881 & 5-10898 \\ 6-10874 & 6-10875\end{array}$

8-10887 8-10899

$9-10879 \quad 9-10882$

9-10891 $5-10897$

$11-10892 \quad 11-10929$

12-10888 12-10889

12-10894 12-10895

18-10868 $\quad 18-10871$

$18-10874 \quad 18-10875$

$18-10878 \quad 18-10879$

$18-10882 \quad 18-10883$

18-10887 18-10888

18-10891 18-10892

18-10895 18-10896

9- 10877

$0-10884$

$9-10928$

12-09856

12-10890

12-10896

$18-10871$

$18-10876$

$18-10880$

18-10884

18-1.0899

$18-10893$

$18-10897$

17-10049

18-10928

INFORMATION RETRIEVAL

$1-10525$

INGESTION

$$
\begin{array}{cccc}
\text { 4-09603 } & 14-09603 & 14-11124 & \\
\text { INHALAIION } & & \\
4-09603 & 14-09603 & 14-11313 & 15-09984 \\
17-09984 & & & \\
\text { INSTABILITY } & & & \\
11-10534 & 11-10035 & 11-10331 & \\
\text { INSTRUMENTATION CALIBRATION } & & \\
5-11326 & 9-10508 & 14-10080 & 15-10080 \\
15-10508 & 15-11126 & 15-11714 & \\
\text { INSTRUMENTATION, ABNORMAL } & \text { INDICATION } & \\
18-11260 & & & \\
\text { INSTRUMENTATION, AIR SAMPLING } & & \\
7-11724 & 7-11725 & 7-11727 & 7-11732 \\
14-11130 & 15-11130 & 16-11113 &
\end{array}
$$

INSTRUMENTATION, AMPL IFIER 
9-11253

INSTRUMENTATION, COINCIOENT

9-10885 18-10885

INSTRUMENTATICN, CONPONENT

$11-11019$

INSTRUMENTATION, CONTROL 9-10469, 9-10470,9-10471, 9-11416

INSTRUMENTATION, DETECTION FAILED FUEL ELEMENT

9-10448 9-10473 $17-10746$

$17-10746$

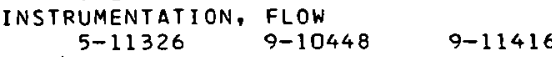

INSTRUMENTATION, GENERAL

1-10409 5-1057

$6-10578$

$5-10578$

5-11326

$7-10578$

$9-10434$

9-10515

$9-11416$

9-10473

Q-11253

$13-11133$

6-10040

9- 10472

$12-11424$

$9-11433$

18-11429

INSTRUMENTATION, IN CCRE

$\begin{array}{rrrr}5-10927 & 9-10448 & 9-10461 & 9-10504 \\ 9-10569 & 17-10046 & 17-11004 & 17-11005\end{array}$

18-10927

INSTRUMENTATION, LIQUIO LEVEL DETECTION 9-11436 17-11005

INSTRUMENTATION, METEOROLOGICAL

16-09617 16-10644 16-10645 16-10646

$\begin{array}{llll}16-10650 & 16-10651 & 16-10657 & 16-10646\end{array}$

16-10669 16-10678 16-11113

INSTRUMENTATION, NUCLEAR

$\begin{array}{llll}7-10559 & 9-10291 & 9-10434 & 9-10448\end{array}$

$9-10469 \quad 9-10470$

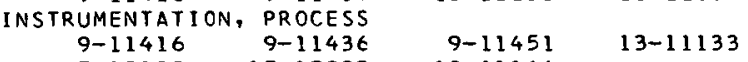

INSTRUMENTATION, PROTECTIVE

$$
\text { S-I1240 13-11133 }
$$

$\begin{array}{cccc}\text { INSTRUMENTATION, RADIATION MONITORING } & \\ 7-11724 & 9-10508 & 9-10513 & 15-08713\end{array}$

$\begin{array}{rrrr}15-117508 & 15-10513 & 15-10670 & 15-11125\end{array}$

15-11126 15-11318

INSTRUMENTATION, REGULATING

17-11042

INSTRUMENTATION, SURVEILLANCE 7-10559

INSTRUMENTATION, $5 W I T C H$

17-10989

INSTRUMENTATION, TEMPERATUPE

$\begin{array}{llll}5-11452 & 5-11460 & 5-11462 & 6-11424 \\ 9-10447 & 9-10448 & 9-10465 & 9-10470 \\ 9-10471 & 9-10515 & 9-11416 & 9-11424\end{array}$

9-10471

$9-10515$

$9-11416$

$9-11424$

INSTRUMENTATION, TESTING

$$
\text { 11-1.1019 13-11.133 15-11126 }
$$

IOO INE

$\begin{array}{rrrr}5-10578 & 6-10578 & 7-08682 & 7-08895 \\ 7-09369 & 7-10270 & 7-10557 & 7-10577 \\ 7-10578 & 7-10586 & 7-11678 & 7-11688 \\ 7-11689 & 7-11690 & 7-11691 & 7-11693 \\ 7-11694 & 7-11695 & 7-11722 & 7-11728 \\ 7-11729 & 7-11730 & 7-11731 & 7-11732 \\ 11-11678 & 12-10564 & 14-11124 & 14-11320 \\ 14-11352 & 15-09932 & 15-11320 & 15-11352 \\ 17-10564 & 18-10270 & & \end{array}$

ION $17-10564$

EXCHANGE

IONOSPHERE

16-10968

IRRADIATION TESTING

$\begin{array}{rrrr}7-10575 & 11-10699 & 12-09652 & 12-0.669 \\ 12-09672 & 12-09673 & 17-09439 & 17-09788 \\ 17-10605 & 17-10616 & 18-10861 & \end{array}$

ISOCHEM, INC.

$$
12-10600 \quad 13-10600 \quad 18-10600
$$

I T ALY

$$
\text { 6-10865 12-00668 } 14-11312 \quad 15-11312
$$

JAPAN

$$
\begin{array}{rrr}
6-10865 & 12-00668 & 14-11312
\end{array}
$$

$15-10099$

$3-11221$

$6-10642$

$13-11221$

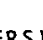

K.IW I

KINETIC EXPERIMENT CN WATER BOILERS

$$
\text { 2-11154 S-11154 }
$$

15-11125

KIWI TNT (TRANSIENT NUCLEAR TEST

$\begin{array}{rrrr}4-10520 & 6-10040 & 6-11316 & 9-10040 \\ \text { KRYPTON } & & & \\ 7-09350 & 7-09731 & 7-10558 & 7-11715 \\ 7-11716 & 13-10702 & 15-11714 & \end{array}$

IACROSSE BOILING WATER REACTOR
5-10846 18-1130

LAMPRE I (LASL MOLTEN PU REACTOR EXPERIMENT) 6-10959 O-11417

LANTHANUM

14-09485

LAPSE RATE, STABLE

$18-11362$

LAPSE RATE, UNSTABLE

$16-09616$

LASL (LOS ALAMOS SCIENTIFIC LABORATORY)

LEAD $15-1009$

16-10648 16-10665

$16-11114$

$15-10812$

LEAK DETECTION

7-10559

$7-1172^{\circ} \quad 18-11164$

LEAK RATE

$11-09751 \quad 17-11276$

LIAPUNOVS FUNCTION

9-11450

LICENSING STATUS OF NUCLEAR PROJECTS

13-11329 13-11330 18-11300

LIOUIO SCRUBBER

7-09373

LITHIUM

5-09629 5-09647 7-11727

LOFT (LOSS OF FLUID TEST)

$\begin{array}{llll}1-09854 & 4-11054 & 5-10578 & 5-10867\end{array}$

$\begin{array}{llll}1-09854 & 4-11054 & 5-10578 & 5-10867 \\ 6-10578 & 7-09854 & 7-10578 & 7-10867\end{array}$

LOSS OF COOLANT

4- 11252

$5-10701$

2-09854

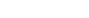

6-10532

$5-09605$

$5-1089$

$5-09954$

$-10532$

5-11452

7-11365

$11 \sim 10293$

$0-10887$

$8-10899$

$11-09925$

$12-10888 \quad 12-10889$

$\begin{array}{ll}18-09783 & 18-10887 \\ 18-11029 & 18-11365\end{array}$

$14-11252$

11-10887

$18-10888$

$17-11052$

18-10889

LOSS OF FLOW

5-09639

6-09987

$6-10874$

$18-09987$

LOSS OF LOAD

5-11058

$6-10874$

$17-11058$

$18-10874$

OF 10886

17-10052

17-11038

18-10886

OF PRESSURE

5-10701 6-09987

MAINTENANCE AND REPAIR

$12-09669 \quad 12-09672$

$12-09660$

13-09657

$1.7-11246$

12-09668

$16-10646$

MASS TRANSFER

$17-10984$

5-09624 5-09053

7-11678 11-11678

5-11327

$7-10586$

MAT ER I AL

5-10847 11-09393

17-10995

$18-10995$

ICAL STUOY

5-10316 5-10487

7-11275 0-10292

9-10509 9-11450

15-11127 18-11414

5- 10548

9-10472

$6-10509$

9-11451 9-10473

NAXIMUM PERMISSIBLE CONCENTRATION (MPC)

14-11313 14-11317 15-10812

MAXIMUM PERMISSIBLE DOSE (MPD)

15-10812

MEASUREMENT, GENERAL

$$
\text { 6-09697 } \quad 6-09725 \quad 9-10290 \quad 9-10472
$$

16-10662 $16-10664 \quad 16-10765 \quad 16-11115$

MEASUREMENT, REACTIVITY

6-10804 O-11437

MEASUREMENT, STRAIN GAGF

6- 09725 11-09922 MEASUREMENT, SUBCRITICALITY

$11-11019$

MEASUREMENT, TEMPERATURE

9-10447

16-10646

9-10469

$9-10470$

MERCURY

METAL 5-09629

$5-09920$

$7-10350$ $12-10966$

$7-10350$

$11-09393$

$11-09924$

$11-09920$

METAL WATER REACTION

$1-09854 \quad 5-10430 \quad 6-10430 \quad 6-10610$

6-10957 6-10958 6-11088 7-09854

8-10359 $8-10530 \quad 8-10872 \quad 8-10887$

$8-11366 \quad 11-10530 \quad 11-10887$

$\begin{array}{rlll}8-11366 & 11-10530 & 11-10887 & 12-09854 \\ 18-10872 & 18-10887 & 18-11088 & 18-11366\end{array}$

$19-10430$

NETAL, LIQUID

$5-09629$

$5-09630$

$5-09638$

$5-09642$ 


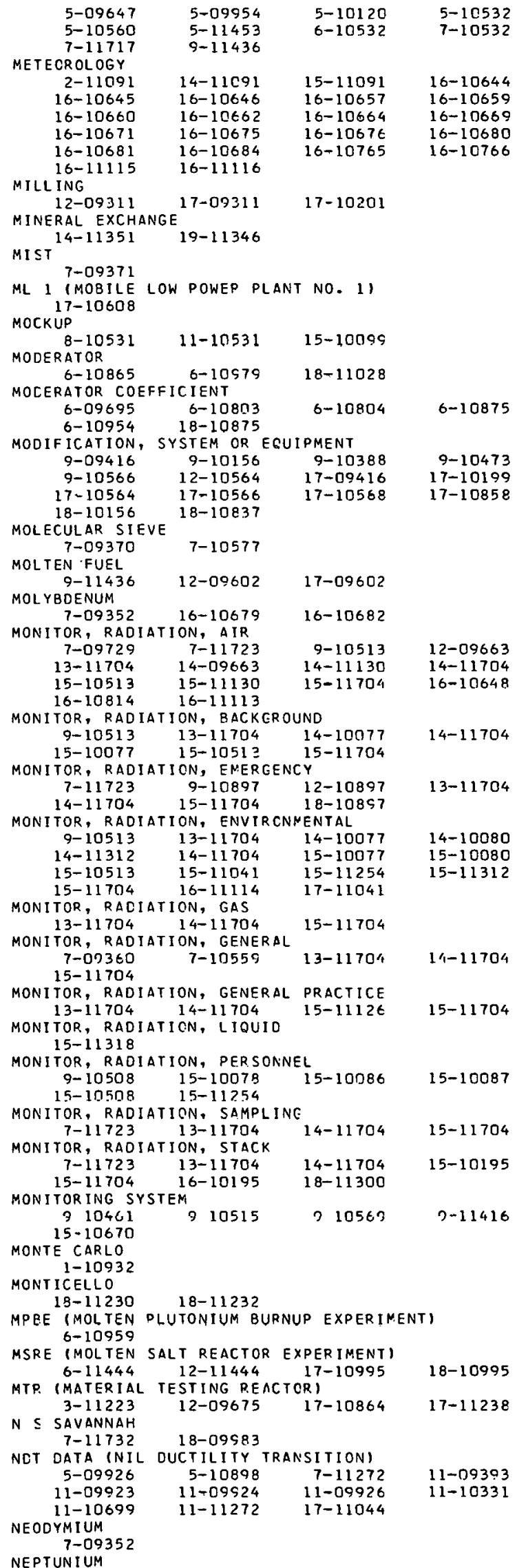

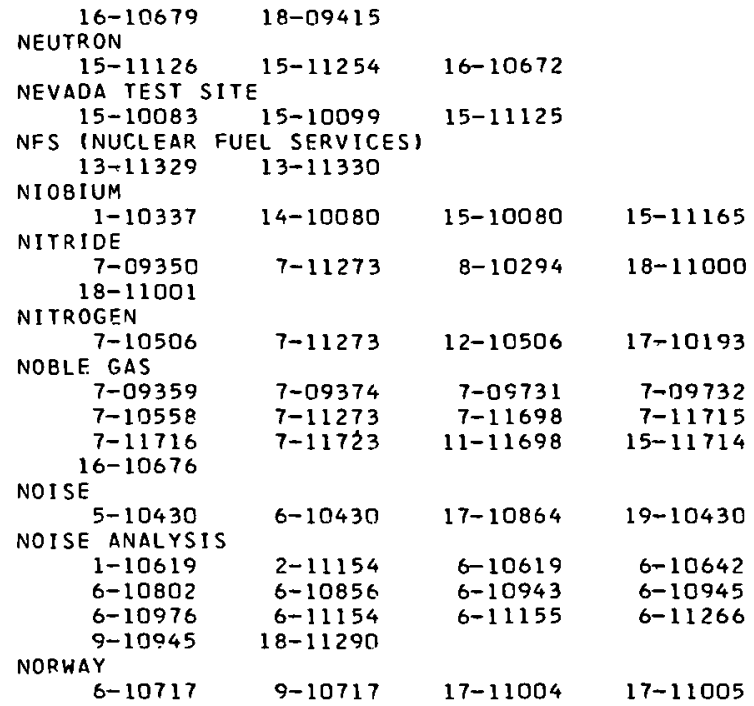

NOZZLE 5-10272 11-10743

NRTS (NATIONAL REACTOR TEST STATION) 9-10472

NSPP (NUCLEAR SAFETY PILOT PLANT) $\begin{array}{lll}1-09854 & 7-09854 & 12-09854\end{array}$ NUCLEAR DETONATION

$14-10074 \quad 15-10074 \quad 16-10645 \quad 16-10671$

NUCLEAR EXPLOSION DEBRIS

$\begin{array}{llll}16-09613 & 16-10657 & 16-10661 & 16-10665\end{array}$

$16-10668 \quad 16-10677 \quad 16-10679 \quad 16-10766$

16-10769 16-11116

NUCLEATE BOILING

5-09643 5-09646 17-09417

OCEAN AND SEA

$\begin{array}{llll}14-09274 & 14-11131 & 15-09274 & 15-11129\end{array}$

OPERATING EXPERIENCE

$\begin{array}{rrrr}7-10506 & 7-11365 & 7-11708 & 9-10473 \\ 9-10566 & 12-09674 & 12-10506 & 15-10196 \\ 17-09650 & 17-10046 & 17-10049 & 17-10050 \\ 17-10051 & 17-10052 & 17-10054 & 17-10193 \\ 17-10196 & 17-10197 & 17-10202 & 17-10278 \\ 17-10344 & 17-10345 & 17-10566 & 17-10604 \\ 17-10713 & 17-10746 & 17-10833 & 17-10836 \\ 17-10866 & 17-10984 & 17-10995 & 17-11427\end{array}$

18-10995 $18-11365$

OPERATING LIMITS/TECHNICAL SPECIFICATIONS

$\begin{array}{rrrr}5-11039 & 5-11046 & 6-10567 & 17-10567 \\ 17-11039 & 17-11042 & 17-11046 & 18-09983 \\ 18-10191 & 18-10392 & 18-10837 & 18-10857 \\ 18-10859 & 18-10862 & 18-10993 & 18-11289\end{array}$

18-10859 18-10862 18-10993 $18-11289$

$18-11291 \quad 18-11292 \quad 18-11293 \quad 18-11295$

OPERATIONS REPORTS, ANALYSIS

$\begin{array}{llll}17-09417 & 17-10517 & 17-10604 & 17-10746\end{array}$

$\begin{array}{cccc}\text { OPERATIONS REPORTS, GENERAL } & & \\ 12-09653 & 12-09665 & 12-09674 & 17-09594\end{array}$

ORGANIC COOLANT

5-09956

ORGANIC IODIDC

$\begin{array}{rrrr}7-08895 & 7-10577 & 7-11678 & 7-11681 \\ 7-11688 & 7-11689 & 7-11690 & 7-11693 \\ 7-11694 & 7-11695 & 7-11699 & 7-11700 \\ 7-11711 & 7-11726 & 11-11678 & 11-11699 \\ 11-11700 & & & \end{array}$

11-1.1700

ORNL (OAK RIDGE NATIONAL LABORATORY) $\begin{array}{rrrr}9-10291 & 9-10388 & 12-11328 & 13-11328 \\ 15-10093 & 15-10096 & 15-10099 & 15-10812\end{array}$

OSCILLATOR, REACTIVITY 6-10717 6-11084 9-10717

$17-11084$

OUT OF PILE LDOPS AND EXPERIMENTS 7-10586

OXIDATION

$\begin{array}{rlrr}\text { OXIDATION } & & & \\ 5-10988 & 7-09374 & 7-10505 & 7-11270 \\ 7-11691 & 8-10341 & 8-10410 & 17-10988 \\ 18-11270 & & & \\ \text { OXIDE } & & & \\ 5-10553 & 7-10534 & 7-10535 & 8-10294 \\ \text { UXYGEN } & & & \end{array}$

$7-04374$
OYSTER CREEK 


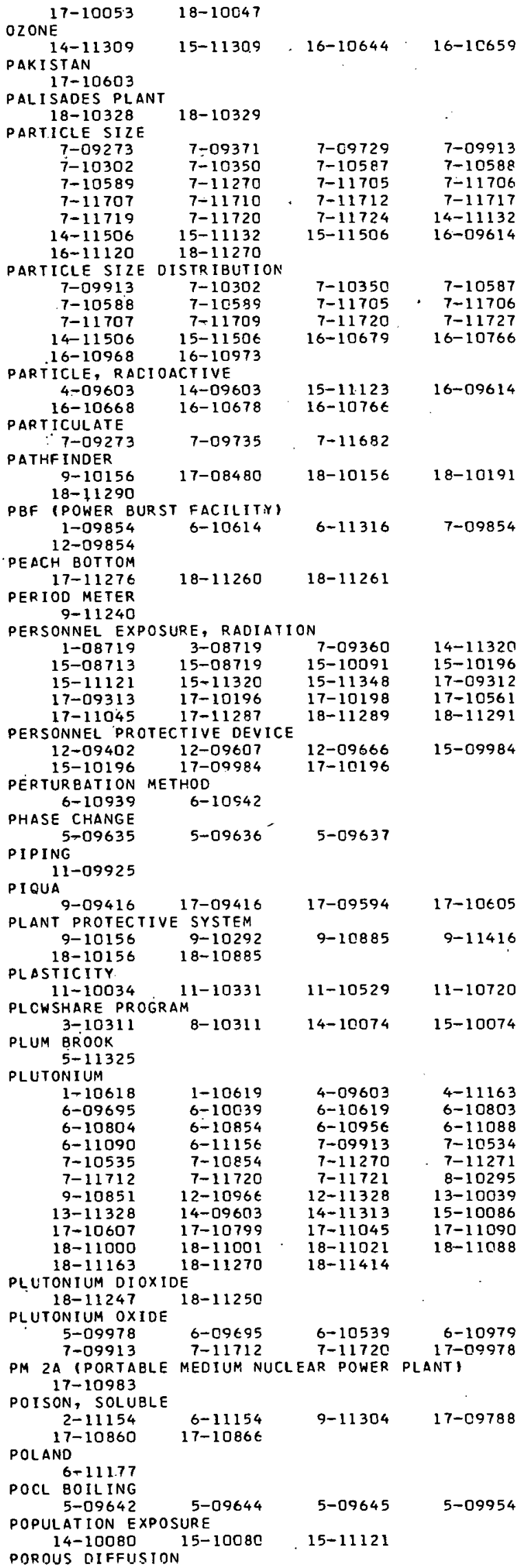




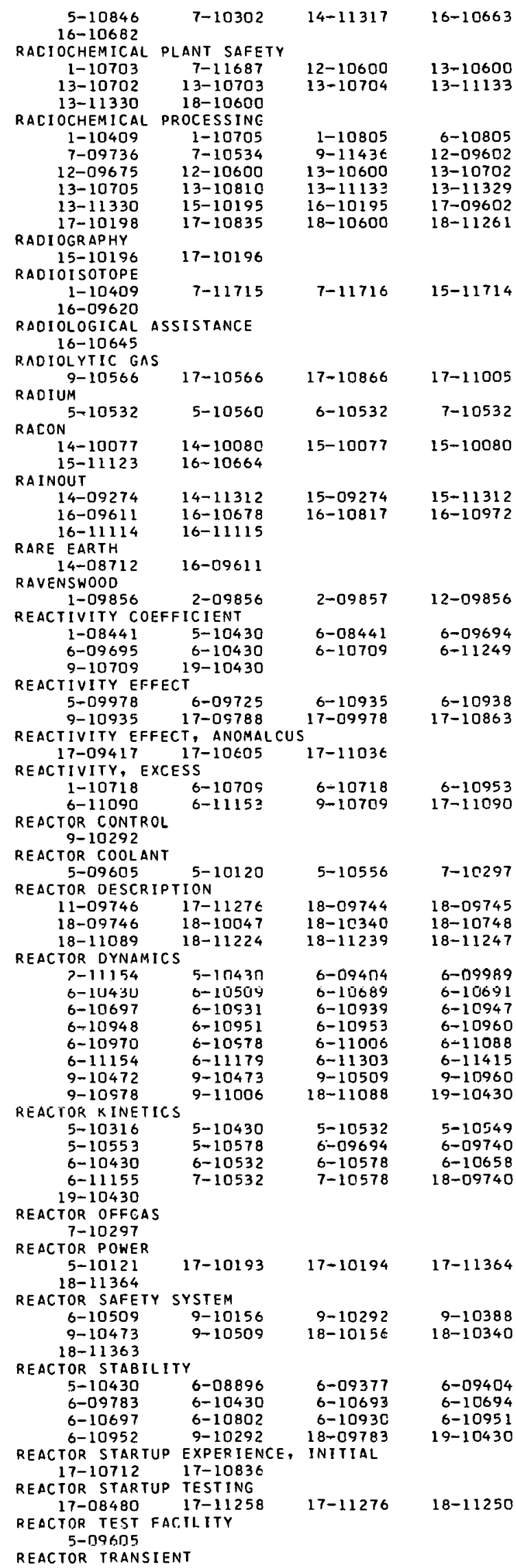

$\begin{array}{rrrr}5-10430 & 5-11083 & 6-10430 & 6-10538 \\ 6-10612 & 6-10613 & 6-10615 & 6-10641 \\ 6-10649 & 6-10685 & 6-10688 & 6-10714 \\ 6-10800 & 6-10933 & 6-10950 & 6-11059 \\ 6-11060 & 6-11081 & 6-11085 & 6-11415 \\ 7-10933 & 9-10714 & 17-11059 & 17-11060 \\ 17-11081 & 17-11083 & 17-11085 & 19-10430\end{array}$

6-10610

6-11153

9- 10504

$17-11090$

$6-10955$

9-10955
$5-11322$

6-10709

6-10952

8-11413

9-11049

17-09984

$17-1,053$

$17-10984$

$17-11038$

$17-11174$

$18-11230$

$18-11290$

$18-11363$

$6-10430$

$6-10936$

6-11424

$9-10935$

$11-09746$

$17-10567$

18-11295

5-10532

5-10550

6-10532

$6-10544$

$6+10611$

$6-10855$

$6-1093$

$6-11006$

$6-11424$

8-1053

$9-10937$

$11-10529$

7-10050

$18-11247$

5-10547

5-10551

5-10560

6-10536

6-10541

$6-10545$

6-10617

6-10695

6-10865

6-10938

$6-10959$

$6-11088$

7-10297

$7-10533$

9-10504

9-10945

9-11417

$11-10530$

$17-10986$

18-10862

$18-11295$

6-11090

11-11012

$17-11090$

18-09745

6-11266

12-11012

$17-10345$

$17-11276$

18-09783

18-11224

6-10614

6-11249

15-10086

$17-11276$

$6-11415$
$14-11130$ 


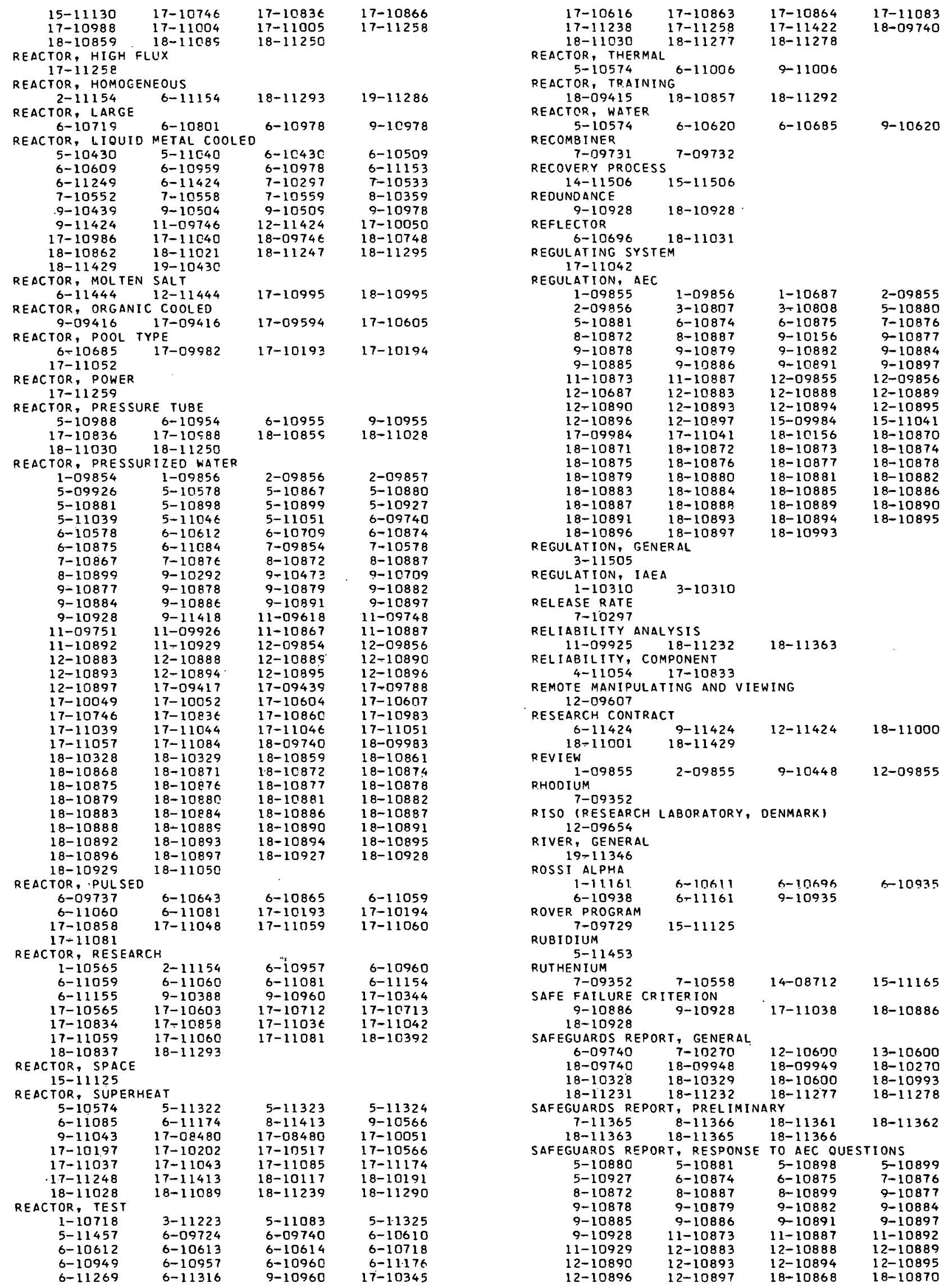




\begin{tabular}{|c|c|c|c|}
\hline $18-10871$ & $18-10872$ & $18-10873$ & $18-10874$ \\
\hline $18-10875$ & $18-1087 t$ & $18-10877$ & $18-10878$ \\
\hline $18-10879$ & $18-10880$ & $18-10821$ & $18-10882$ \\
\hline $18-10883$ & $18 \div 10884$ & $18-10885$ & $18-10886$ \\
\hline $18-10887$ & $18-10888$ & $18-10889$ & $18-10890$ \\
\hline $18-10891$ & $18-10892$ & $18-10893$ & $18-10894$ \\
\hline $18-10895$ & $18-10896$ & $18-10897$ & $18-10927$ \\
\hline $18-10928$ & $18-10929$ & & \\
\hline \multicolumn{4}{|c|}{ SAFETY INJECTION } \\
\hline \multirow{2}{*}{\multicolumn{4}{|c|}{$\begin{array}{l}8-10872 \text { SAFETY PRINCIPLES AND PHILOSOPHY } \\
\text { SAFE }\end{array}$}} \\
\hline & & & \\
\hline $1-\Pi 9855$ & $1-10335$ & $1-10525$ & $2-09855$ \\
\hline $5-10553$ & $6-10709$ & $7-10297$ & $7-10552$ \\
\hline $9-10156$ & $9-10709$ & $9-11240$ & $12-09855$ \\
\hline $17-10335$ & $18-10156$ & & \\
\hline AFETY REVIEW & IOPERATIONS, & EXPERIMENTSI & \\
\hline $3-10842$ & $13-10842$ & $18-11277$ & \\
\hline \multicolumn{4}{|l|}{ SALT } \\
\hline & $17-09602$ & & \\
\hline SAMPLING & $5-10: 78$ & $0-10570$ & $7+09729$ \\
\hline $7-09736$ & $7-10578$ & $7-11705$ & $7-11711$ \\
\hline $7-11718$ & $7-1.719$ & $7-11723$ & $7-11728$ \\
\hline $7-11732$ & $14-11252$ & $15-11123$ & $16-09611$ \\
\hline $16-09620$ & $16-10665$ & $16-10672$ & $16-10678$ \\
\hline $16-10680$ & $16-10681$ & $16-10684$ & $16-10769$ \\
\hline $16-10814$ & $16-10817$ & $16-11114$ & \\
\hline SANPLING, HIGH & ALTIIUUE & & \\
\hline $1 A-10 K 5 ?$ & $16-10653$ & $16-10657$ & $16-10662$ \\
\hline $16-10668$ & $16-10 € 69$ & $16-10671$ & $16-10678$ \\
\hline \multicolumn{4}{|l|}{ SAN ONOFRE } \\
\hline $9-11418$ & $17-11057$ & & \\
\hline SAVANNAH RIVER & PLANT & & \\
\hline $1-10703$ & $7-11696$ & $11-11696$ & $13-10703$ \\
\hline $17-10989$ & & & \\
\hline SAVANNAH RIVER & PRODUCTION F & REACTORS & \\
\hline SAXTCN & & & \\
\hline $5-09978$ & $6-11084$ & $17-09417$ & $17-09978$ \\
\hline $17-10607$ & $17-11084$ & $18-10861$ & \\
\hline SCATTERING ISKY & YSHINEI & & \\
\hline $16-09617$ & & & \\
\hline SCRAM, FALSE & & & \\
\hline $9-09416$ & $17-09416$ & $17-10604$ & $17-10836$ \\
\hline SCRUBBER & & & \\
\hline $7-09735$ & $7-11271$ & $7-11723$ & $11-09748$ \\
\hline SEAL & & & \\
\hline $11-10325$ & & & \\
\hline SECIMENT & $19-11346$ & & \\
\hline $\begin{array}{l}14 \text { TO9485 } \\
\text { SEFOR (SOUTHWES }\end{array}$ & $\begin{array}{l}19-11346 \\
\text { ST EXP. FAST }\end{array}$ & OXIDE REACTOR & \\
\hline $1-10695$ & $6-10695$ & $6-10935$ & $6-10936$ \\
\hline $6-10937$ & $6-10978$ & $6-11424$ & $9-10935$ \\
\hline $9-10937$ & $9-10978$ & $9-11424$ & $12-11424$ \\
\hline $18-11479$ & & & \\
\hline SEISMOLOGY & & & \\
\hline $3-10311$ & $8-10311$ & $11-10929$ & $18-10871$ \\
\hline $18-10929$ & $18-11363$ & & \\
\hline SEPARATOR & & & \\
\hline $\begin{array}{c}7-11715 \\
\end{array}$ & & & \\
\hline $\begin{array}{l}\text { SERVOMECHAN I SM } \\
9-10388\end{array}$ & & & \\
\hline SHELL ${ }^{9-10388}$ & & & \\
\hline SHELL $11-09394$ & $11-10034$ & $11-10035$ & $11-10331$ \\
\hline $11-11016$ & $11-11020$ & & \\
\hline SHIELDING & & & \\
\hline $12-10883$ & $14-10085$ & $15-09937$ & $15-10085$ \\
\hline $15-11121$ & $17-10343$ & $17-10984$ & $18-10883$ \\
\hline SHIPPIN & NER. & & \\
\hline $1-19310$ & $3-10056$ & $3-10.308$ & $3-10309$ \\
\hline $3-10310$ & $3-10207$ & $3-10808$ & $3-10839$ \\
\hline $3-11221$ & $3-11222$ & $3-11 \geq 23$ & $11-10308$ \\
\hline $12-09661$ & $13-11221$ & & \\
\hline SHIPP INGPORT & & & \\
\hline $9-10473$ & $11-09751$ & $17-09788$ & $17-10604$ \\
\hline CK WAVE & & & \\
\hline $3-10311$ & $5-10497$ & $5-10560$ & $8-10311$ \\
\hline $11-10529$ & $11-11019$ & & \\
\hline SHUTDOWN MARGIN & & & \\
\hline $1-10805$ & $6-09.725$ & & $6-10802$ \\
\hline $6-10805$ & $6-10939$ & $6-1094 \mathrm{C}$ & $6-10941$ \\
\hline $6-10942$ & $6-10543$ & $6-10945$ & $6-11432$ \\
\hline $9-10878$ & $9-10945$ & $17-10602$ & $18-10878$ \\
\hline SHUTDOWN SYSTEM & $M$, SECONDARY & & \\
\hline 10879 & $18-10879$ & & \\
\hline SILVER & & & \\
\hline $7-10$ & & & \\
\hline CLIMATOL & & & \\
\hline $16-10645$ & $16-10 \epsilon 46$ & $16-10671$ & $16-10765$ \\
\hline
\end{tabular}

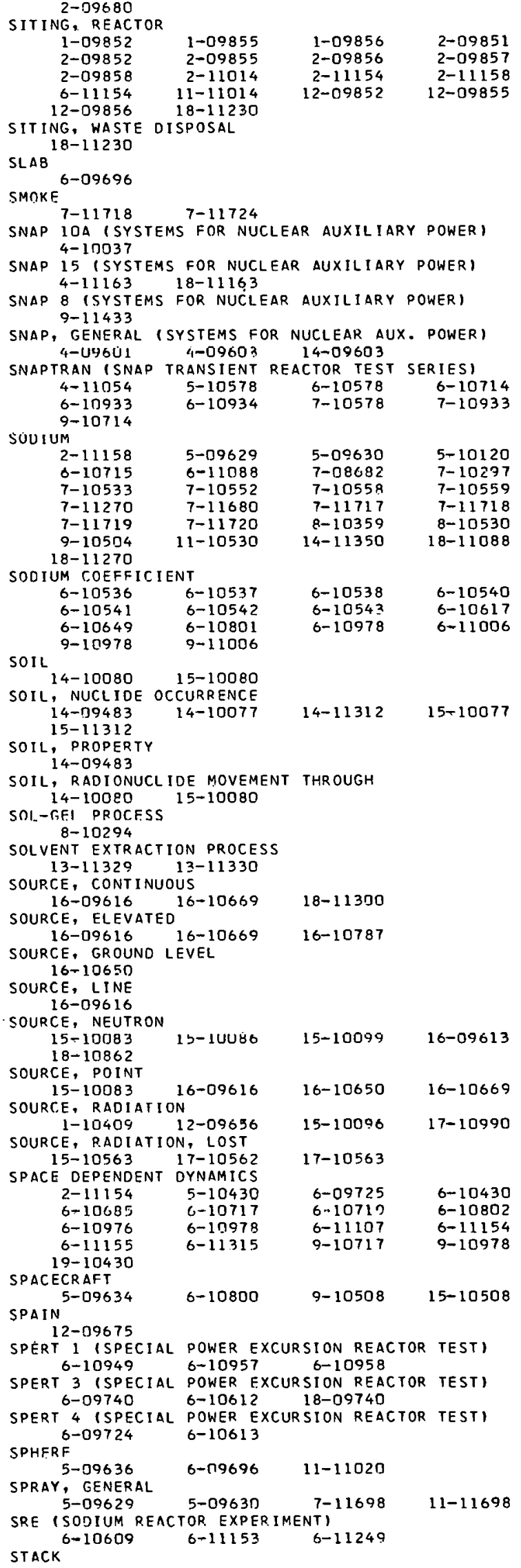




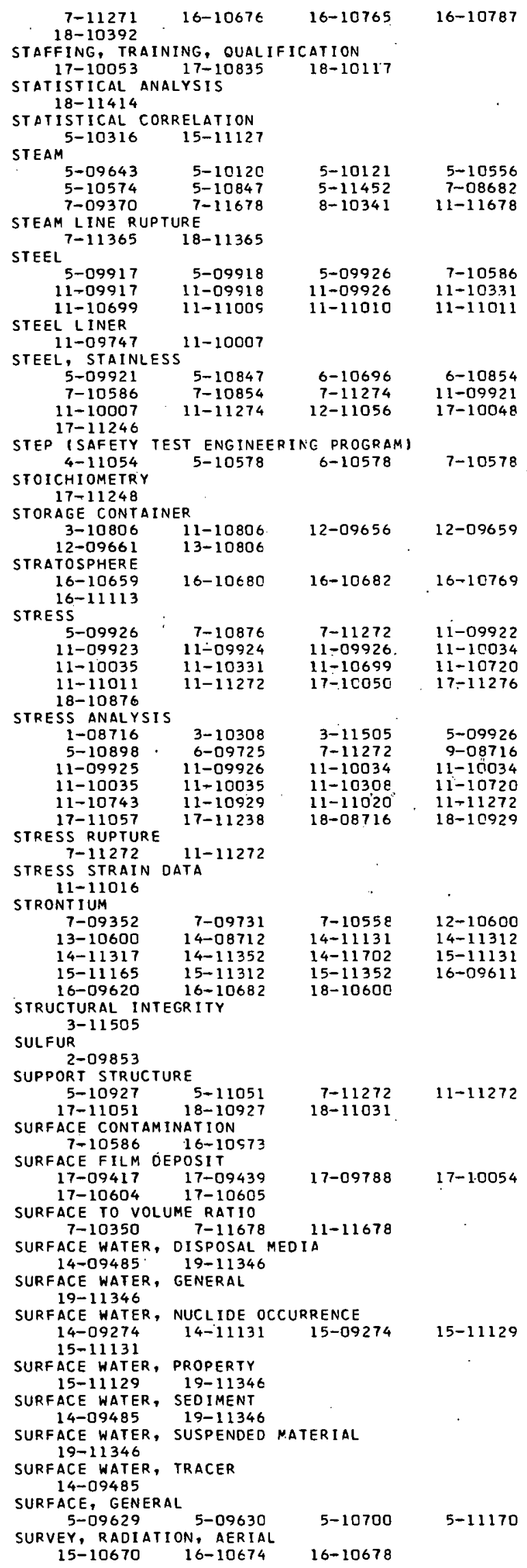

SURVEY, RADIATION, ENVIRONMENTAL

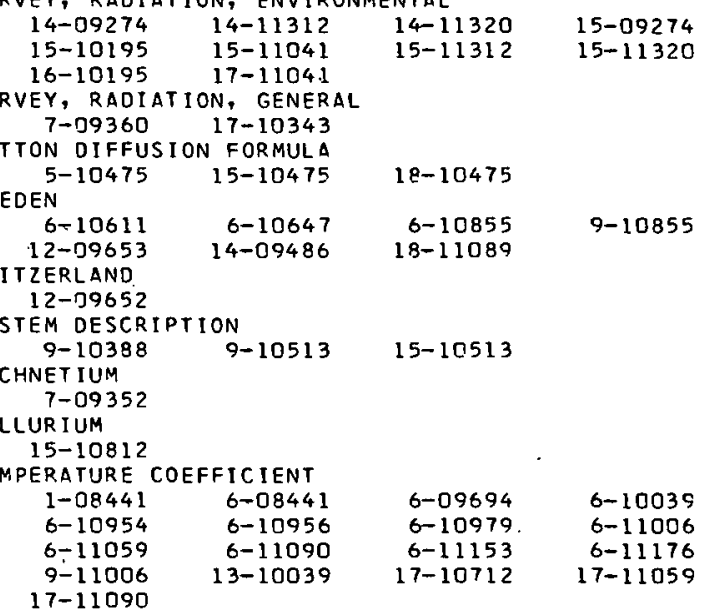

TEMPERATURE GRADIENT 5-11225 6-10975

TEMPERATURE TRANSIENT

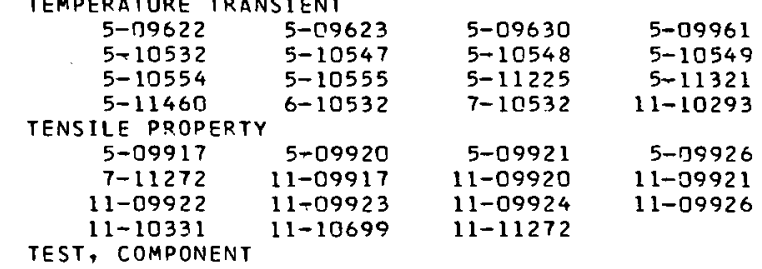

TEST, 9020291 17-11427

TEST, DESTRUCTIVE

$\begin{array}{ccrr}3-11222 & 5-09926 & 6-10610 & 6-10613 \\ 6-10714 & 9-10714 & 11-09926 & 11-11010 \\ 17-10983 & & & \end{array}$

TEST, DOP FILTER

7-11722 7-11725

TEST DROP

3-11222

TEST, FILTER

7-10299

$7-11721$

7-11726

7-11692

$7-11722$

7-11731 7-11732

TEST, FILTER SYSTEM

$\begin{array}{rrrr}7-11692 & 7-11725 & 7-11726 & 7-11727\end{array}$

$\begin{array}{llll}7-11692 & 7-11725 & 7-11726 & 7-11727 \\ 7-11728 & 7-11729 & 7-11730 & 7-11731\end{array}$

TEST, INSTRUMENT RESPONSE 9-10469 9-10470

$9-10471$

$9-10508$

TEST, LEAK RATE

$\begin{array}{ll}11-09751 & 12-10889 \\ 11-10889 & 18-10890\end{array}$

1)-1 1 non

$18-10859$

TEST, NONDESTRUCTIVE

7-10299 12-09672

TEST, PHYSICS

4-09601 6-10567 12-11424 17-10052 $18-11429$

7-11710

$7-11713$

$7-11725$

7-11728 7-11730

T PREDPERA

TEST, PRESSURE VESSEL

$$
\begin{array}{rrrr}
5-09920 & 7-11272 & 11-09920 & 11-10331 \\
11-11019 & 11-11272 & &
\end{array}
$$

TEST, PROOF

$12-10827$

6-11424

9-11424

17-10517 17-10567

$$
\text { 4-11252 12-09658 14-11252 18-11232 }
$$

TEST, SYSTEM OPERABILITY

9-10282 9-10515

12-10893 17-10517

$18-10893$

9-10885 10-10282

17-10836 18-10885

TEST, WEAPONS (HP ASPECTS)

$\begin{array}{llll}14-10077 & 15-10077 & 15-10083 & 15-10099\end{array}$

TESTING

$16-10661-15=10818$

$15-10083$

15-10099

$4-10521$

$16-10818$

$7-10299$

$11-10531$

$4-11054$
$8-10531$

$12-1082.7$

$5-09920$

$5-09921$ ORETICAL INVESTIGATION 6-09696 $7-11706$

7-11707

THERMAL ANALYSIS 


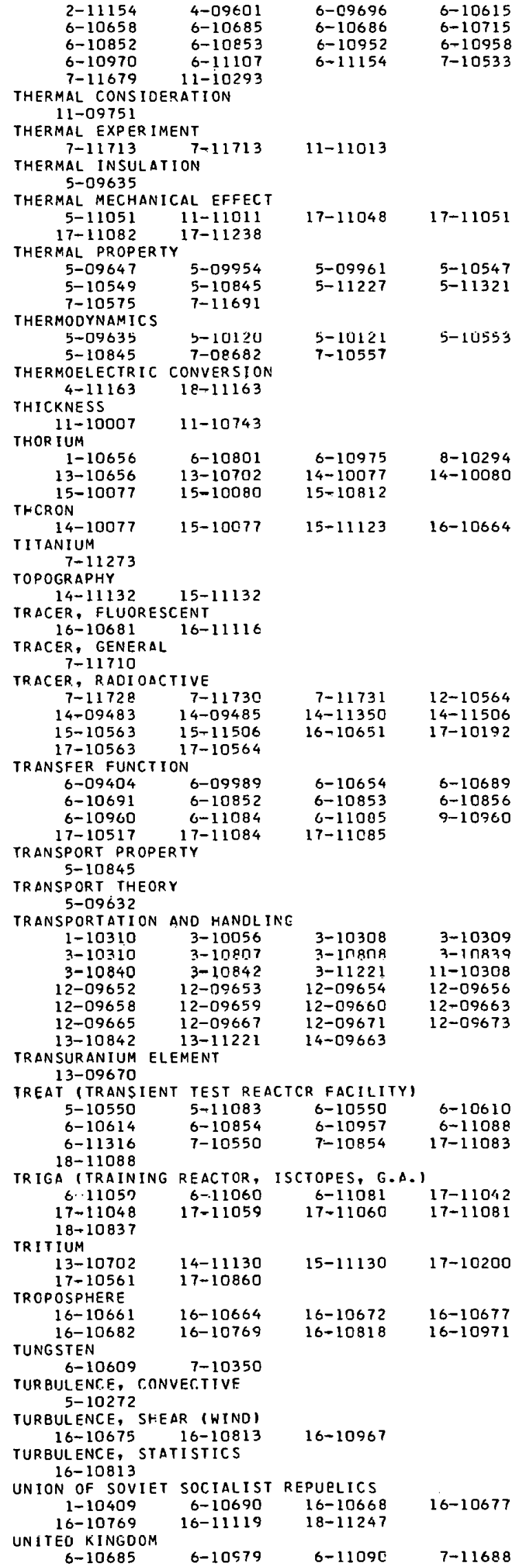

\begin{tabular}{|c|c|c|c|}
\hline & & & 1 \\
\hline $13-11133$ & $14-09485$ & $16-11119$ & $17-10833$ \\
\hline $17-11090$ & $18-09744$ & $18-09745$ & $18-10340$ \\
\hline UNITED STATES & & & \\
\hline $1-09664$ & $2-09680$ & $11-09676$ & $12-09655$ \\
\hline $12-09664$ & & & \\
\hline URANIUM & & & \\
\hline $1-08441$ & $1-10618$ & $1-10619$ & $1-10656$ \\
\hline $1-10703$ & $5-10273$ & $5-10553$ & $6-08441$ \\
\hline $6-10619$ & $6-10938$ & $6-10956$ & $6-10957$ \\
\hline $6-11156$ & $7-08682$ & $7-09350$ & $7-09730$ \\
\hline $7-10534$ & $7-10535$ & $7-10557$ & $7 \div 10575$ \\
\hline $7-11721$ & $8-10294$ & $12-096 \pi 2$ & $13-10656$ \\
\hline $13-10703$ & $14-10077$ & $14-10080$ & $15-10077$ \\
\hline $15-10080$ & $15-10812$ & $17-09602$ & $17-10199$ \\
\hline $17-10201$ & $18-11000$ & $18+11091$ & \\
\hline URANIUM CARBIDE & & & \\
\hline$\frac{5-11156}{6}$ & $7-08682$ & $7-09350$ & $7-10557$ \\
\hline URANIUM DIOXIDE & & & \\
\hline $1-10703$ & $5-09978$ & $5-10273$ & $5-10532$ \\
\hline $5-10988$ & $5-11083$ & $5-11227$ & $6-09695$ \\
\hline $6-10532$ & $6-11088$ & $6 \div 11174$ & $7-10532$ \\
\hline $13-10702$ & $13-10703$ & $15-10812$ & $17-09978$ \\
\hline $17-10799$ & $17-10988$ & $17-11083$ & $17-11174$ \\
\hline $18-11000$ & $18-11001$ & $18-11088$ & $18-11247$ \\
\hline $18-11250$ & & & \\
\hline URANIUM KEXAFLU & & & \\
\hline $1-10705$ & $3-10056$ & $3-10842$ & $13-10705$ \\
\hline $13-10842$ & & & \\
\hline UR.ANIUM HYOP.IDE & & & \\
\hline $4-10037$ & & & \\
\hline URANIUM OXIDE & & & \\
\hline $6-10539$ & $6-10610$ & $6-10612$ & $6-10615$ \\
\hline $6-10620$ & $6-10938$ & $6-10949$ & $6-10957$ \\
\hline 10070 & b-11156 & $7-09352$ & $7-09359$ \\
\hline
\end{tabular}




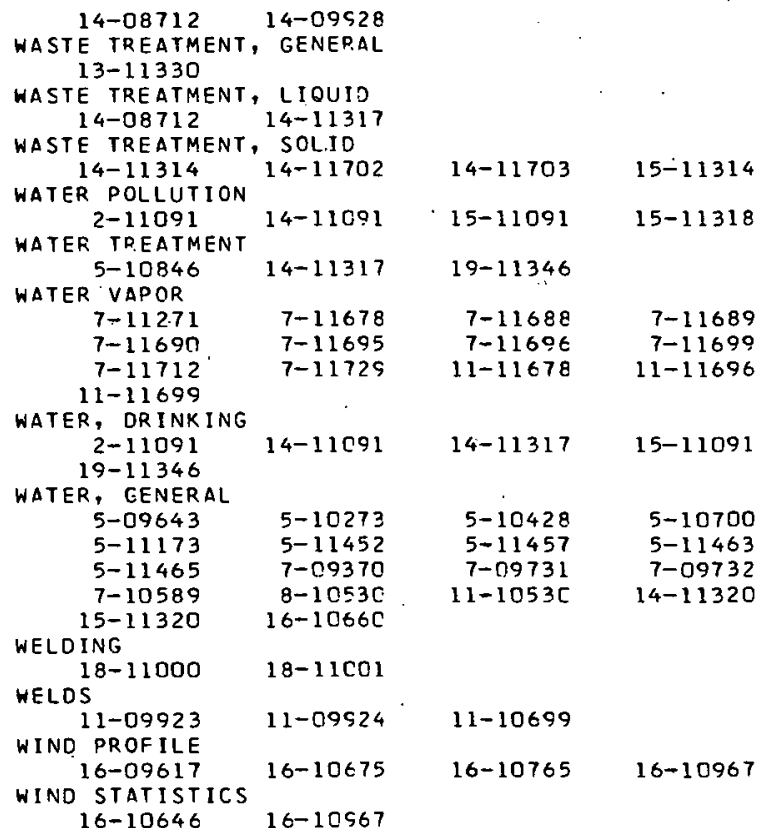

\begin{tabular}{|c|c|c|c|c|}
\hline \\
\hline & & \multicolumn{3}{|c|}{$X-R A Y$} \\
\hline & $5-09917$ & $5-09918$ & $11-09917$ & $11-09918$ \\
\hline & $15-10078$ & $15-11167$ & $17-09312$ & $17-09313$ \\
\hline \multicolumn{5}{|c|}{ XENON } \\
\hline & & $6-09695$ & $6-10688$ & $6-11432$ \\
\hline & $7-09350$ & $7-09731$ & $7-09732$ & $7-10558$ \\
\hline & & $17-09788$ & $17-10863$ & \\
\hline \multicolumn{5}{|c|}{ XENON OSCILLATION } \\
\hline & $6-10346$ & $6-10694$ & $6-10875$ & $6-11432$ \\
\hline & $9-10473$ & $17-10049$ & $17-10604$ & $18-10875$ \\
\hline \multicolumn{5}{|c|}{ YANKEE } \\
\hline & $17-09439$ & $17-10052$ & $17-10860$ & $17-11044$ \\
\hline \multicolumn{5}{|c|}{$18-11050$} \\
\hline \multicolumn{5}{|c|}{ ZIRCALOY } \\
\hline & $8-11366$ & $9-11043$ & $12-09602$ & $17-09602$ \\
\hline \multicolumn{5}{|c|}{ ZIRCONTUM } \\
\hline & $4-10037$ & $5-09921$ & $7-09352$ & $7-10558$ \\
\hline & $8-10410$ & $11-09921$ & $12-09602$ & $14-10080$ \\
\hline & $15-10080$ & $15-11165$ & $16-10679$ & $16-10682$ \\
\hline \multicolumn{5}{|c|}{$17-09602$} \\
\hline \multicolumn{5}{|c|}{$\begin{array}{l}\text { ZPPR (ANL ZERO POWER PLUTONIUM REACTOR) } \\
6-10978\end{array}$} \\
\hline \multicolumn{5}{|c|}{ ZPR III (ANL ZERO POWER REACTOR) } \\
\hline & $\begin{array}{l}1-10695 \\
6-10936\end{array}$ & $\begin{array}{l}6-10541 \\
6-10937\end{array}$ & $\begin{array}{l}6-10695 \\
6-10978\end{array}$ & $\begin{array}{l}6-10935 \\
6-11424\end{array}$ \\
\hline & $9-10935$ & $9-10937$ & $9-10979$ & $9-11424$ \\
\hline \multicolumn{5}{|c|}{$12-11424$} \\
\hline \multirow[t]{2}{*}{ ZPR } & IX (ANL & ERO POWER R & CTORI & \\
\hline & $\begin{array}{l}6-10938 \\
9-10978\end{array}$ & & & $9-10945$ \\
\hline \multicolumn{5}{|c|}{ VI IANL ZERO POWER R } \\
\hline
\end{tabular}


FOLLOWING IS A LIST OF AUTHORS WHOSE DOCUMENTS HAVE BEEN ABSTRACTED IN THIS PUBLICATION

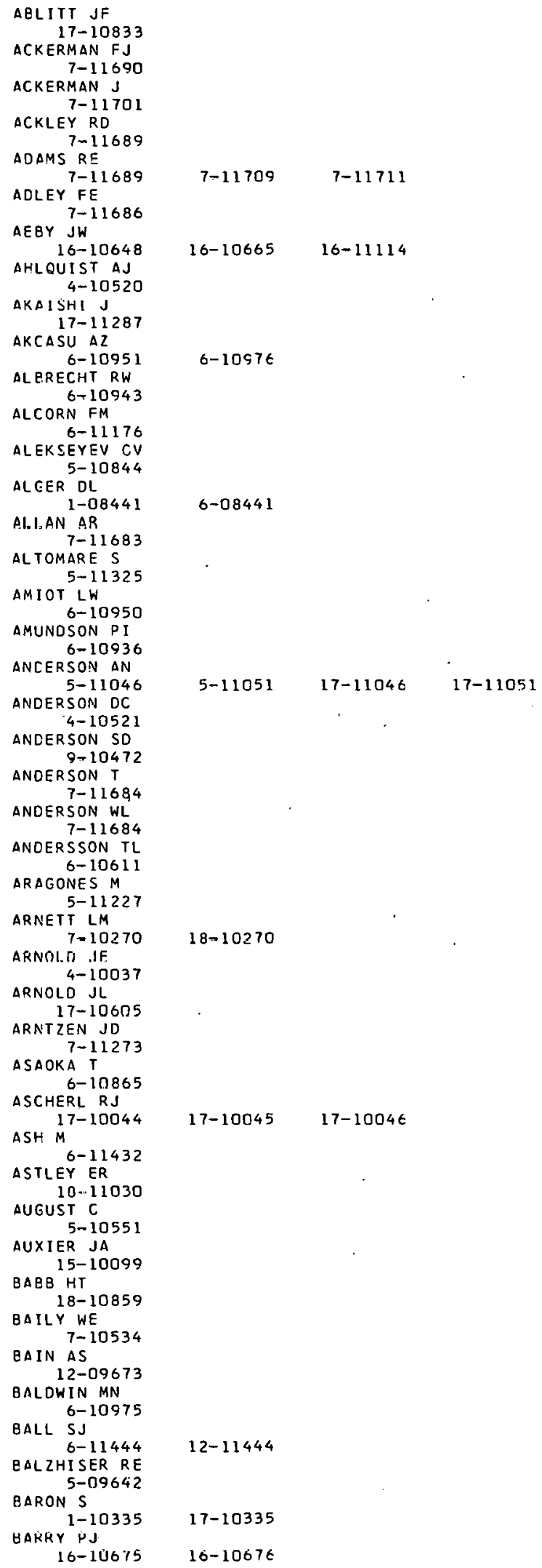


ROCARDUS HF 7-11692 BOFLANDER H 6-10852

BOLAND TJ

$$
\text { 9-10472 }
$$

BOLDMAN DR 5-10272

BOLOTOV AA 5-11170

BONNER NA

$$
\text { 16-10653 }
$$

BORDEN TR

16-10644

BORKOWSKI CJ 9-11416

BOUZYK $J$

6-11177

Boro RS

18-10837

BCYETT RH

$$
\text { 1 5-10096 }
$$

BOYLE RF

$$
\text { 17-11248 }
$$

BRADBURY BT 7-09352

ERACBURY HG 16-10681

BRADLEY HE

16-10678

BRAMSON PE

15-11254

BRATER DC

QR I CARD P

15-11348

BRIGGS $H$

7-11715

BRINKMANN $G$

BR.ION 1 O

$$
1-09662
$$

$7-11726$

BRITTAN RO

2-11014

BROCK JR

7-10588

BROCKETT GF

6-10933

BROECKER: WS

14-11131

BROOKSBANK RE

15-10812

BROWN AR

$$
\text { 5-09960 }
$$

BROWN-CL.. :

$-10718$

6-09696

BROWNING WE

$$
\text { 5-10867 }
$$

BRUNA JG

A-10619

BRUNET JP

1-10619

ERUNFELTER $B$

6-10611

BRYANT LT

6-10950

BUCHANAN JR

BUCHANAN LM

$$
\text { 7-11710 }
$$

QUCGE $E$

9-11253

BUMP TR

9-10439

BUNORICK R

$$
\text { 7-11701 }
$$

BUPP LP

17-11036

BURCHSTED CA

7-11682

QURGE HL

5-09629

QURGER LL

7-11694

BURNET $G$

7-09370

BURT AK

$$
14-11130
$$

$18-10857$

13-10705

$12-09662$

5-10547 11-11014

$7-10933$

$15-11 \cdot 131$

$6-10718$

$$
7-10867 \quad 7-11689 \quad 7-11709
$$

11-10867

$6-10619$

$6-10619$

$11-09746 \quad 18-09746$

$15-11130$
PUSBOOM HJ $17-11248$ QUSEY $H$

BUVAT $7-11270$

$7-11720$

$18-11270$

$11-11013$

RYRD JS

$9-10515$

CAHILL WJ

1-09856

$12-09856$

$1-10619$

CALDWELL $R$

15-10195

6-10619

16-10195

17-11090

6-11090

18-11163

4-11163

ANILE A

$5-10850$

CANOSA J

6-10947

CAPUT $C$

16-10661

CARFI $\mathrm{N}$

$7-0.9730$

CARLSMTTH RS 6-09987

CARMICHAEL BM 6-10959

CARNAHAN CL 14-10074

CARNE $M$

5-09645

CARPENTER SE 6-10609

CARTER DH

6-10.979

CARTER JC

CASE EG

5-10547 6-10950

18-10862

CASTLEMAN AW

7-08682

CAZALIS JP

12-09660

CESARANO $C$

12-09665

CHADOV VN

5-11170

CHALMERS JH. $1-10618$

CHASSANY'J

15-11349

CHASSANY JP

17-10343

CHASTAIN RH 5-09978

CHEEVER $\mathrm{CL}$

7-11721

CHELINTSEV NG

6-09989

CHEMEZOV VA

5-11170

CHENIER RJ

12-09673

CHERNENKO VS

5-09917

CHERNICK J

6-10649

CHERNOZUBOV VA

5-11170

CHERRY BH

6-10977

CHEZEM CG

6- 10800

CHUBAKOV AA 7-09369

CHURCHILL SH

5-09632

CHUYANOV VA

6-09988

CLARK HK

1-10703 13-10703

CLARK TG

15-10096

CLARKE HG

3-10840

CLARKE WG

6-10931

CLEMENT JD
$18-09987$

$15-10074$

$7-10557$

$17-09978$

$6-10691$

$11-09917$

$5-09635 \quad 5-09636$ 


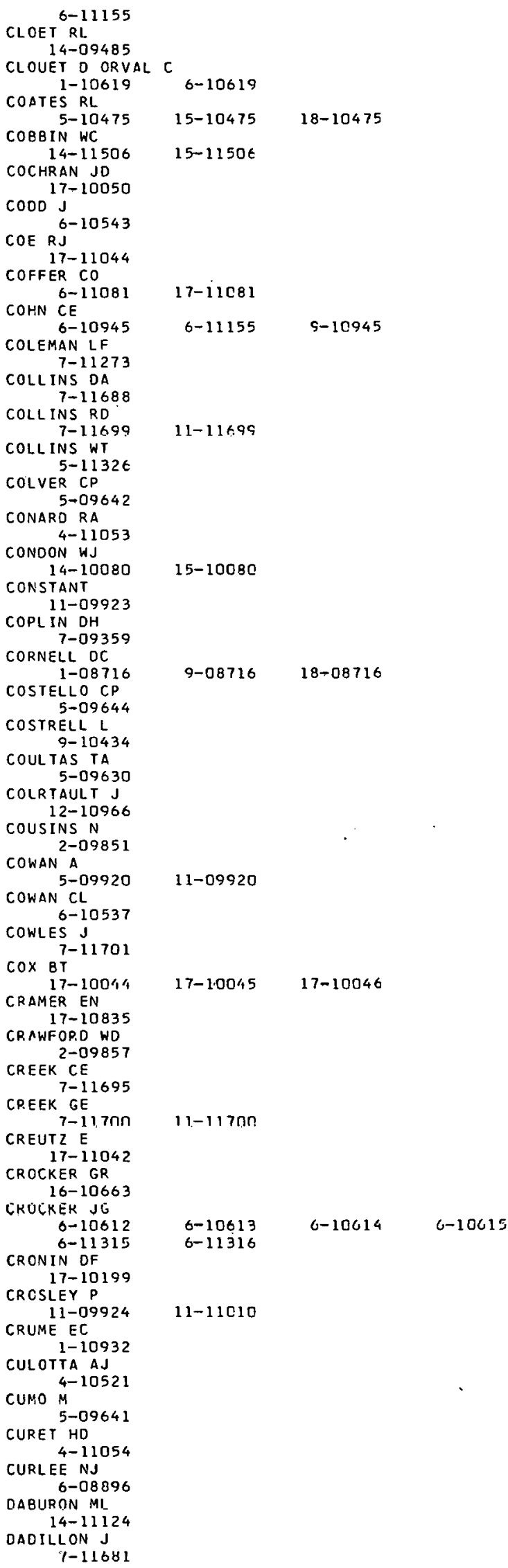

CLOET R-11155

14-09485

CLOUET D ORVAL C

1-10619

COATES RL.

5-10475 15-10475 18-10475

COBBIN WC

14-11506

COCHRAN JD

$17-10050$

$\operatorname{COOD} \mathrm{J}$

COE RJ $6-10543$

17-11044

COFFER CO

COHN ${ }_{6-109}^{6-11081}$

6-1094

$7-11273$

COLLINS DA

7-11688

COLLINS RD

COLLINS WT

5-1132t

COLVER CP

5-09642

CONARD RA

4-11053

CONOON WJ

14-10080

CONSTANT

11-09923

COPLIN DH

7-09359

CORNELL DC

$1-08716$

COSTELLO CP

5-09644

COSTRELL L

9-10434

COULTAS TA

5-09630

COLRTAULT J

12-10966

COUSINS $\mathrm{N}$

2-09851

COWAN A

5-09920

$\mathrm{N} \mathrm{Cl}$

6-10537

COWLES J

$\operatorname{cox}$ BT

$7-11701$

17-100\%

CRAMER EN

17-10835

CRAWFOP.D HD

CREEK CE

7-11695

CREEK GE

CREUTZ E

17-11042

CROCKER GR

16-1066

CKULKEK JE

$$
\begin{aligned}
& 6-10612 \\
& 6-11315
\end{aligned}
$$

CRONIN DF

17-10199

CRCSLEY $P$

11-09924

CRUME EC

1-10932

CULOTTA AJ

4-1052

$M$

5-09641

CURET HD

4-11054

CURLEE NJ

6-08896

DABURON ML

14-11124

OAOILLON J

1-11681

$17-11081$

$15-10080$

$9-08716 \quad 18-08716$

$11-09920$

$17-10045 \quad 17-10046$

$11-117 n \pi$

6-10613 6-10614 0-10015

11-11010

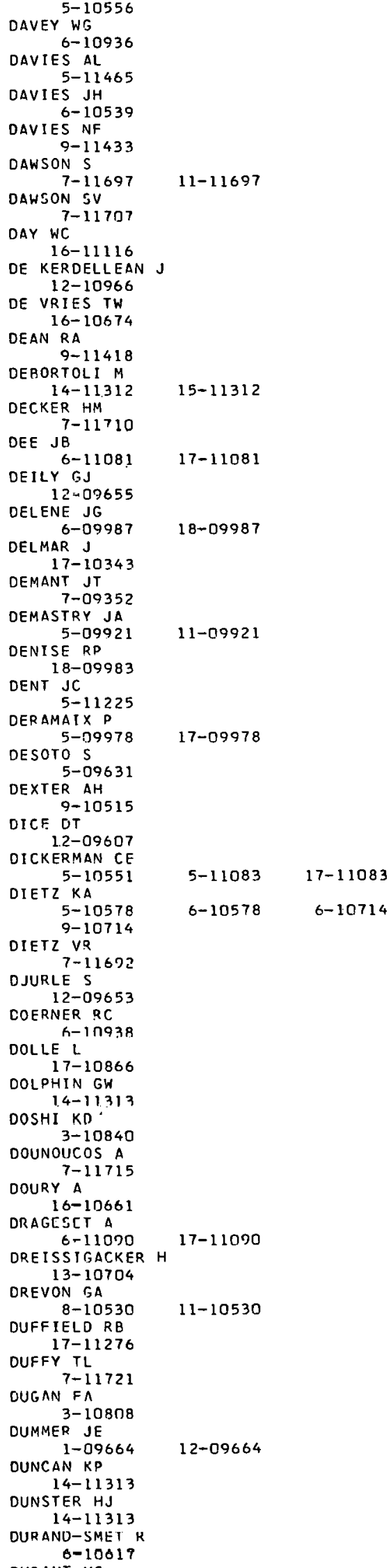




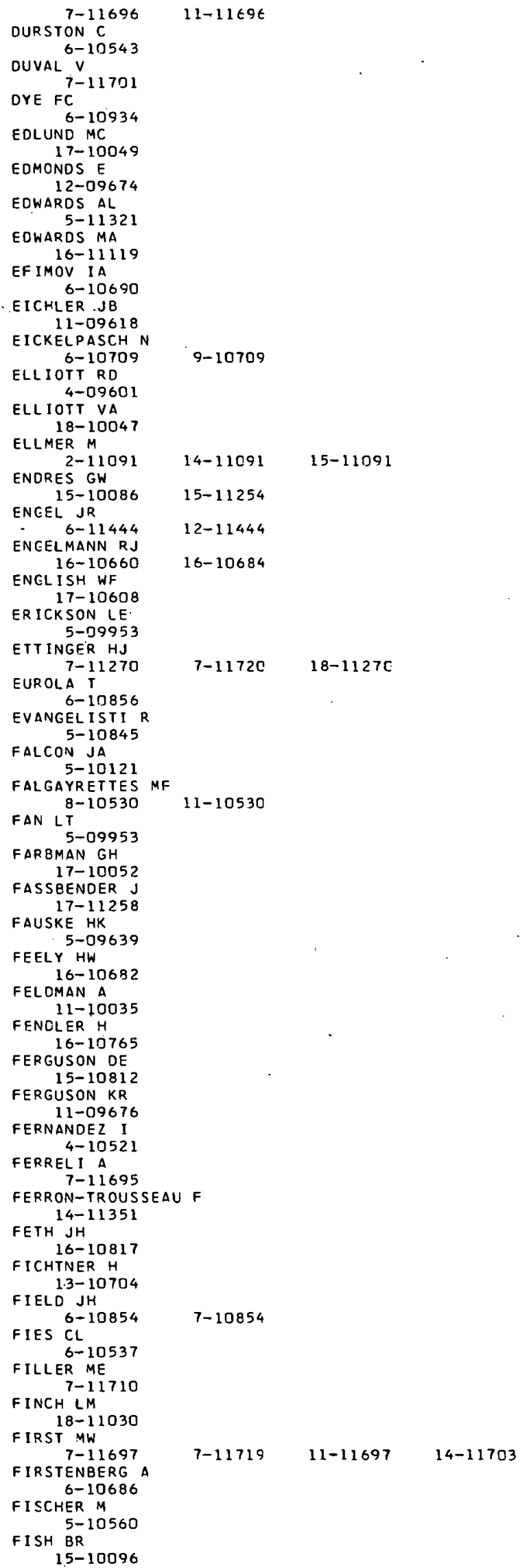

$9-10709$

FISHER CR FITOUSSIL $15-11348$

FLEISCHER ES $12-09655$

FLYGER H

$7-11727$ FONTANA MH 7-11679 11-11678

FORD $\mathrm{CH}$

1-08441 6-08441

FORTINT A 5-10272

FOUCAULT 11-1.1013 FOULKE LR

6-10717

FOX T.A

Fox $V G \quad 1-08441 \quad 6-08441$ 5-09953

FRAGOSO JH $17-10051$

FRANK WS 13-10810 FRANZEN LF 7-11709

FREOER ICKSON RL

12-10564 17-10564 FREEMANTLE RG 6-11090 17-11090

FREILIN EC 16-10679

FREILING EC

$16-10663$

FR I EDL ANDER SK 7-10589

FRIEND JP

FROELICH R 6-10544

FULLER RK

1-99664 $1-39664$
RV 4-11252

GAGLIONE $P$ 14-11312

GALIMI G 5-10850

GALLAGHER EV 11-09618 GANDOLFO JM 13-09570 GARLID KL 6-10719 GARRETT AW 17-09594 GARRIC C 12-09668 GASKILL JR 3-11222 GATES JE $7-09350$ GAUINF $r_{0}$ 14-11350

GENS TA 8-10294 CHEZZI 5 12-09665 GIACCHETTI 7-10535

GIBSON GW 17-10616 GIBSON JA 14-11130 15-11130 GIBSON $M$ 6-10979 GIEOT WH $5-11460$ CIESEKE JA

7-09371 7-11679

GILL JS 7-11711 EILL WN GODTS J COFFI $M$

5-10548 . 6-10970 5-10850

GOIN RH
$16-10682$

$6-11022$

$12-09664$

14-11252

15-11312 


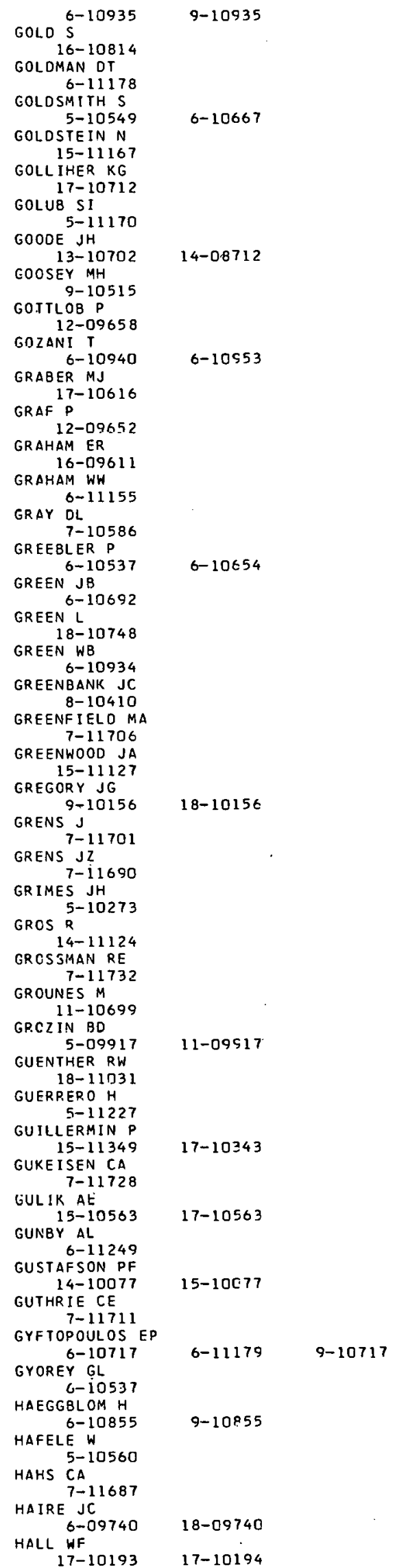

HALPINE PA 17-10983 HAMADA K 

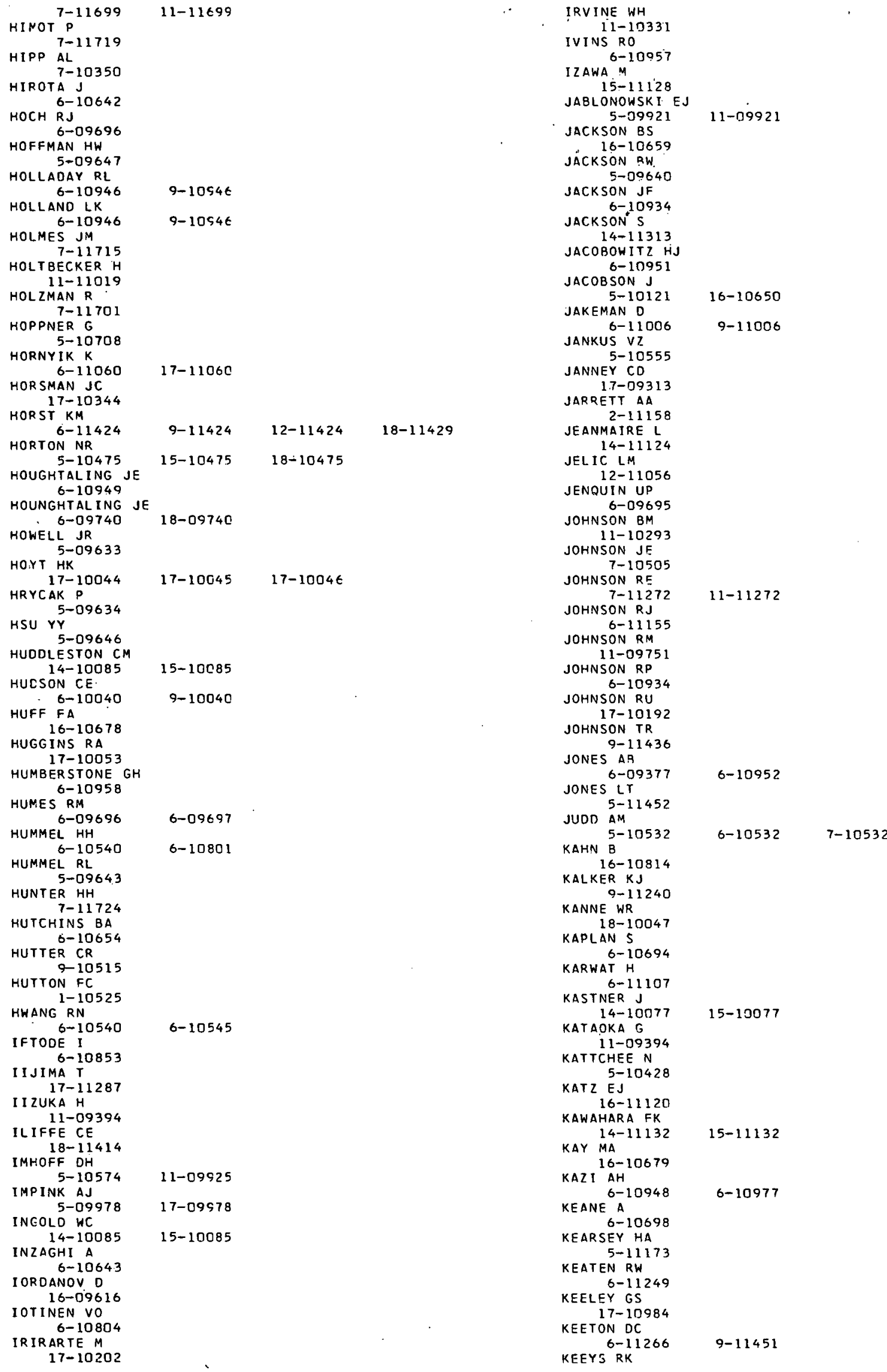


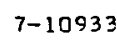

KYLE ML

KYLE ML 71273

LACHAPELLE DG 14-12702

7-09731 7-0973?

LONG NA

14-11252
$9-10960$

$6-10944$

7-10552

6-10695

6-10935

$9-10935$

15-11309

18-1074?

$18-1074$ 


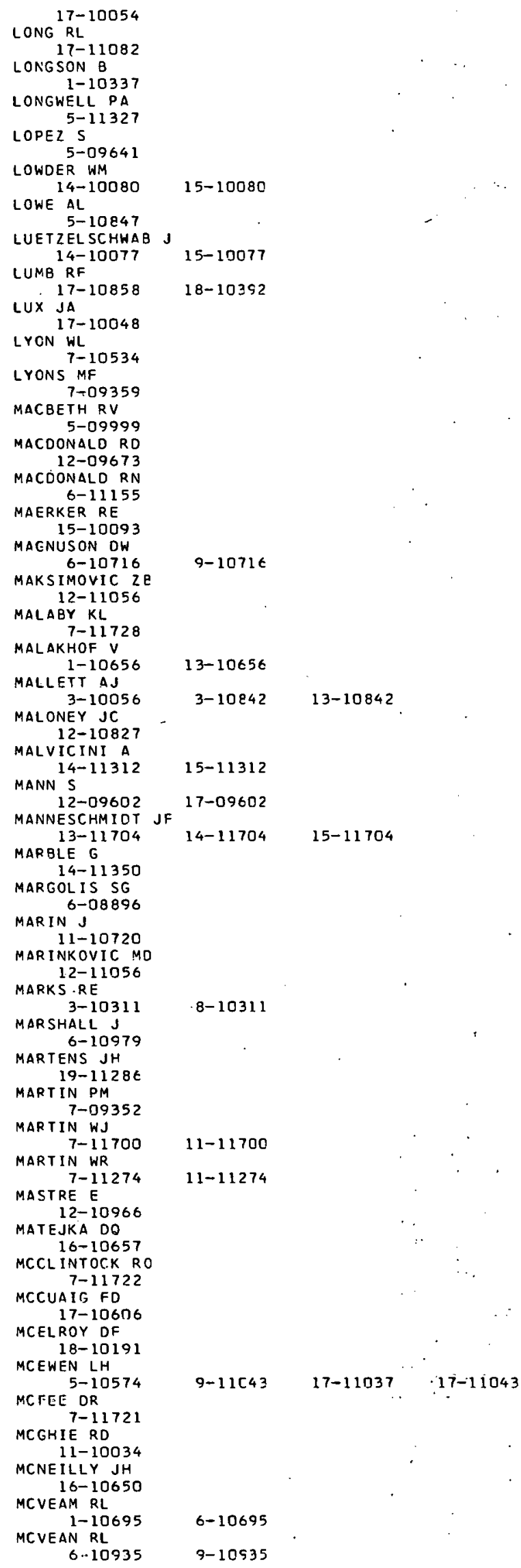

$11-11700$

$11-11274$

15-11704

$.8-10311$

13-10842

14-11704

MECKSTROTH GR

MEEM JL

17-10834

MEISTER G

17-11258

MELEHAN JB

7-09350

MELLOW EW

MFLSA JL

$0-11450$

MENZIES DC

5-10554

MEREDITH JL

12-10827

MERRILL M

6-10658

MET ZENROTH M 6-10542

MICKLE RA 6-11176

MIHALCZO JT 6-10696

MIKHEILE A 6-10853

MILBURN GS 15-11311

MILEY GH 6-11059 MILHAM RC 7-11691

MILLER CE

MILLER D 5-10867

5-09623

MILLER PH 17-11048

MILLER WA 17-09312

MINNICK LE 17-10860 MINOR JE 3-11505 MINUKHIN LA 5-11170

MIROWSKY BJ $9-10 \geq 82$ MISENTA R 6-10643

MI SHIMA J 7-11694

MTSKFI, JA 16-10653 MITCHELL RI MIYANO K 11-09393 MDEERG CA 11-10325 MONAHAN JM 17-10983 MONSON HO 17-10050 MONTAGNANI M 11-11019 MONTGOMERY LD 4- 10037

MOORE WE 14-11320 MOREAU A 15-11348 MORGAN JG 7-11706 MORGAN KZ 1-08719 MORONI JP 15-11165 MORRIS AC 15-09937 MORRIS 7-11701

MORR IS JR 5- 10273

MORRISON OL 7-11679 MORRISON GW $1-10932$

MOSKALEV OB

MOSS LI
$9-10714$

$17-11059$

$\begin{array}{lr}7-10867 & 11-10867 \\ 5-09954 & 5-10553\end{array}$

$10-10282$

6-10865

$7-11724$

$15-11320$

3-08719

$15-08719$ 


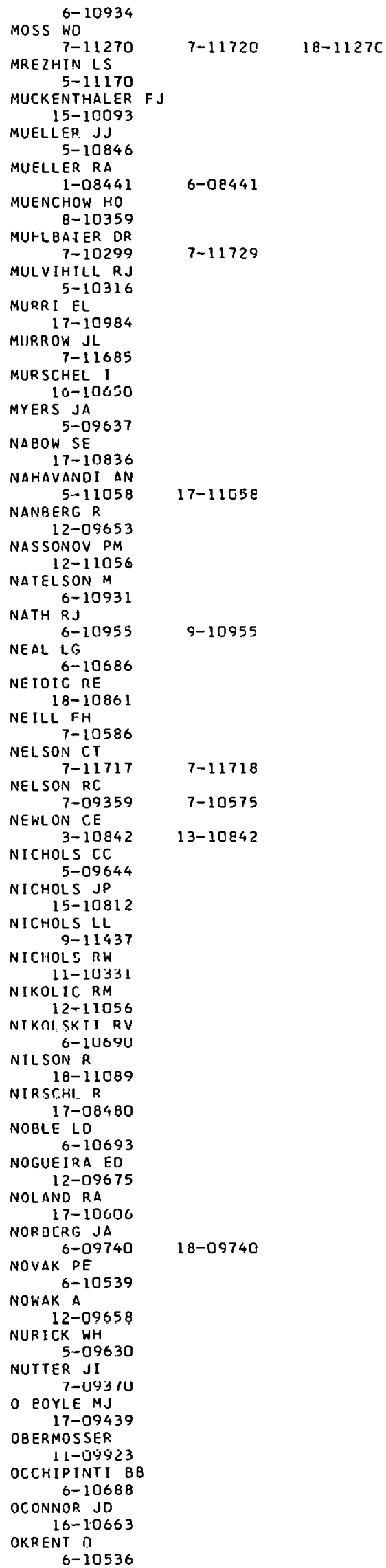

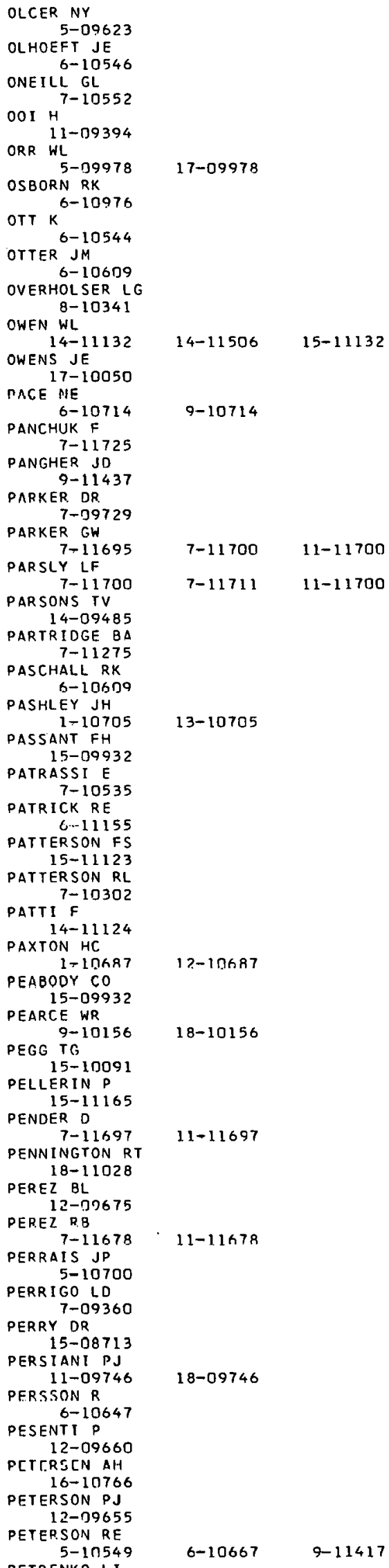

13-10705

$11-11697$

$11-11678$

$11-11700$ 


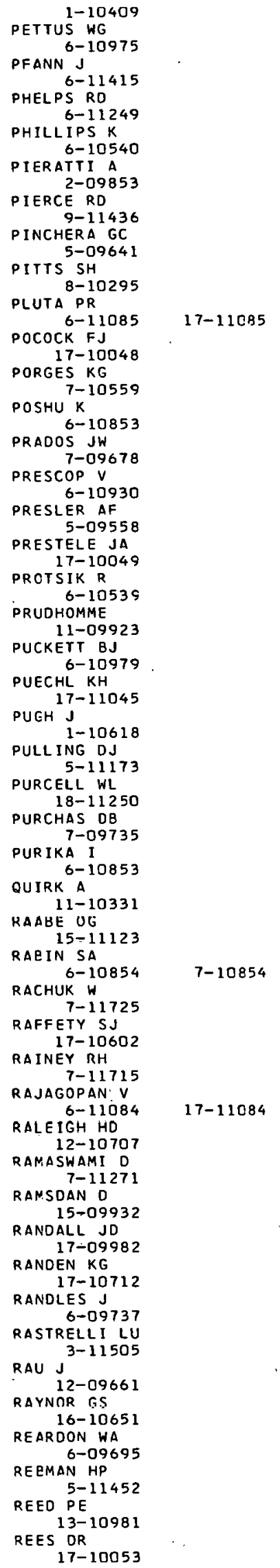

$7-10854$

REES NJ

REILLY HJ 5-1132

REINART $Z$ H 13-10704 REIST PC

7-11705

REMY ML

15-11165

RENGEL JC 1-09852

RENOUX A

16-10664

RESTELLI EF 5-10548

RET 2 A

12-09661

REYNOLDS $A B$

1-10695

REYNOLDS JM 6-11155

REYNOLDS WC

DES WA

RHOADES W- 10934

RICE RE

17-10517

RICHARDS AE

RIGDON L

7-11701

RIPLING EJ

11-09924

RITCHIE $A B$

12-09656

RIT ZMAN RL

5-09921

ROBINSON LE
$5-10551$

ROCCO GG

14-111131

ROOIER J

15-11349

ROGERS JT

5-09956

ROGERS LA

3-10311

ROHERER RF

16-11116

ROLSTON BF

17-11052

ROMM RF

1-10409

ROMUALOI JP

11-09922

ROSENBAUM HC 7-11727

ROSS CP

7-10270

DA

ROSSON HF

ROUX DP

9P 10291

ROWE PN

7-11275

ROYDEN HN 6-10609

RUDY GC 9-10156

RUSCHE BC

$7-10270$

T-1 5

6-10852

RUSSELL BA

$16-10682$

RUSSELL JA

9-10513

RUTHERFORD JL 8-103亿1

SACCENT I JC $16-10650$

SAKATA H

9-10851

SALMON R

3-10309

SALVADOR LR

SAMUELS DE
$15-11714$

$2-09852 \quad 12-09852$

$6-10695 \quad 6-10937 \quad 9-10937$

$11-11010$

$7-11679 \quad 11-09921$

5-11083 17-11083

$15-11131$

8-10311

$18-10270$

$18-10156$

$18-10270$

15-10513 


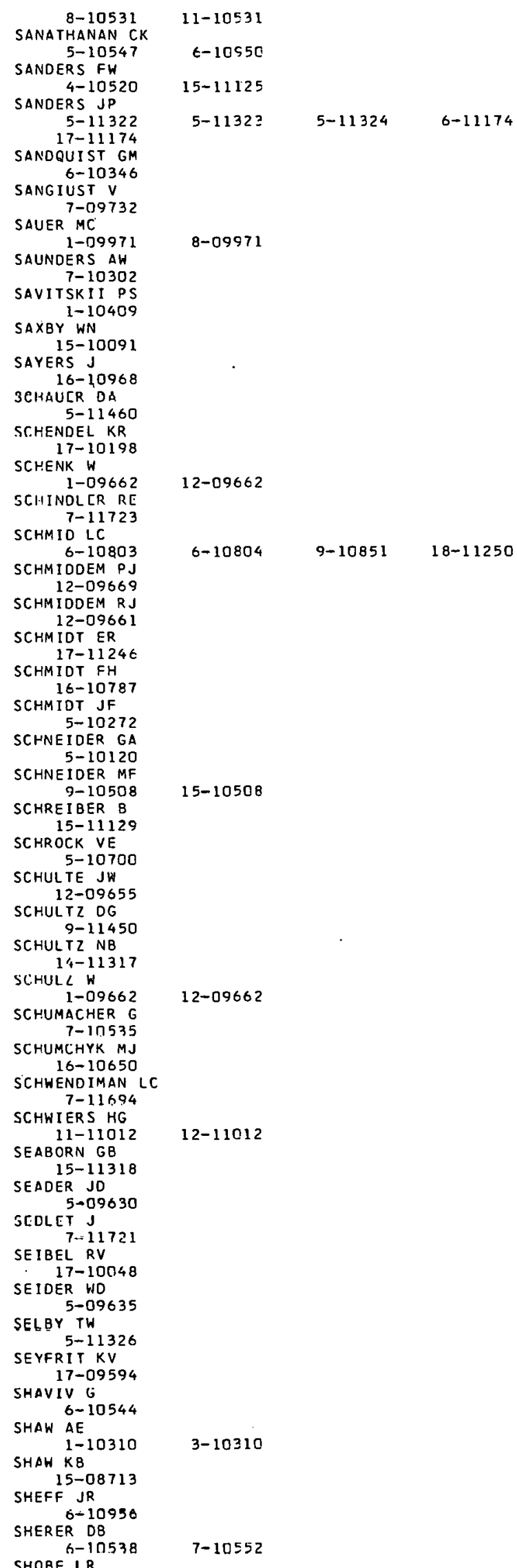

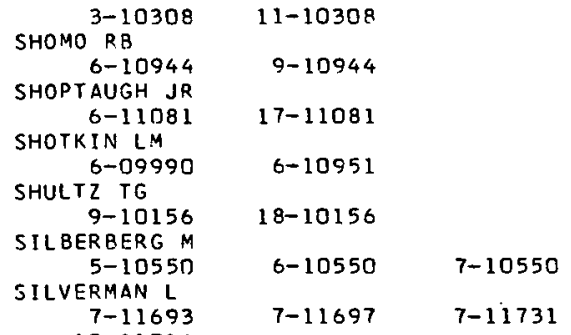




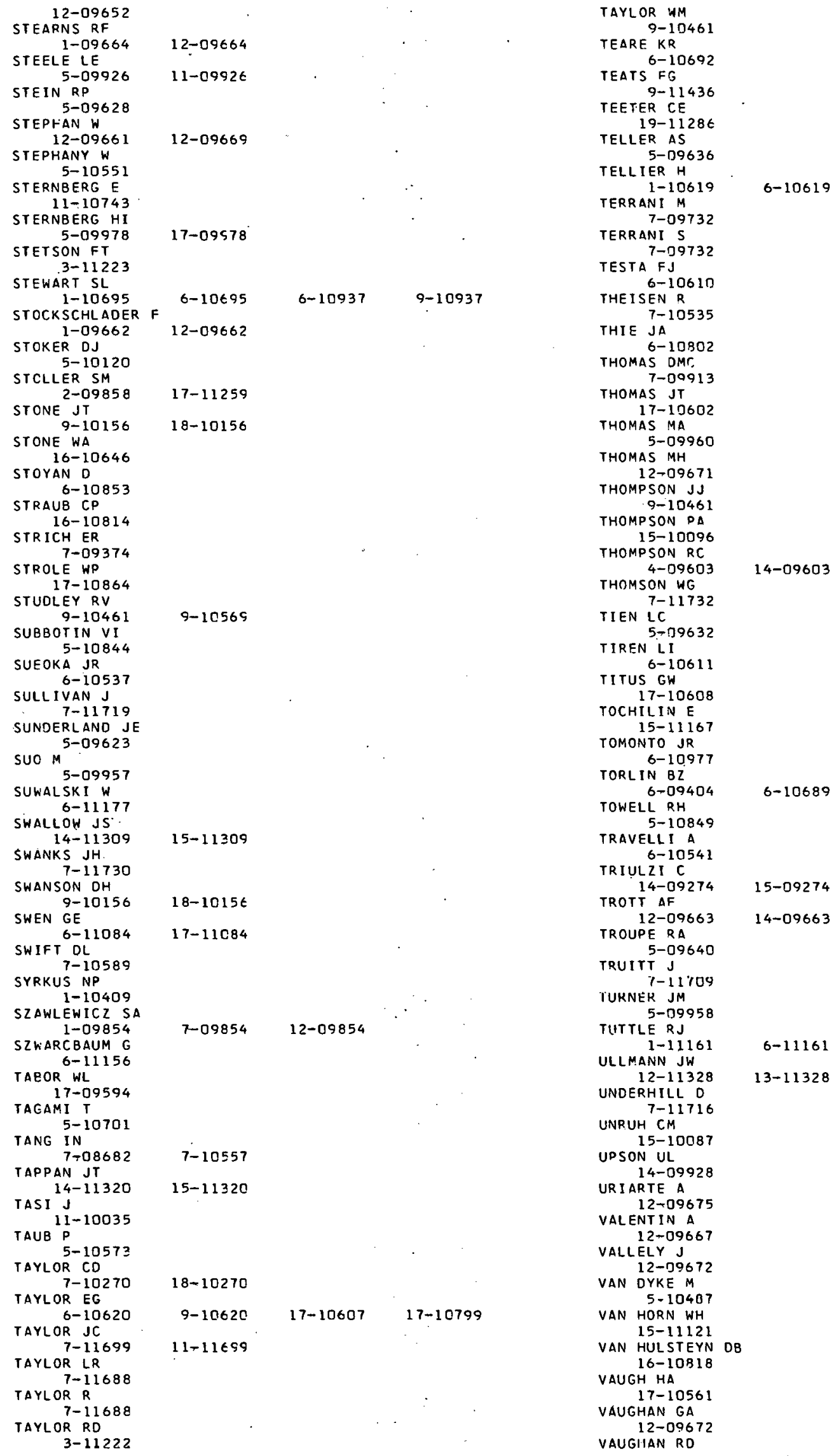




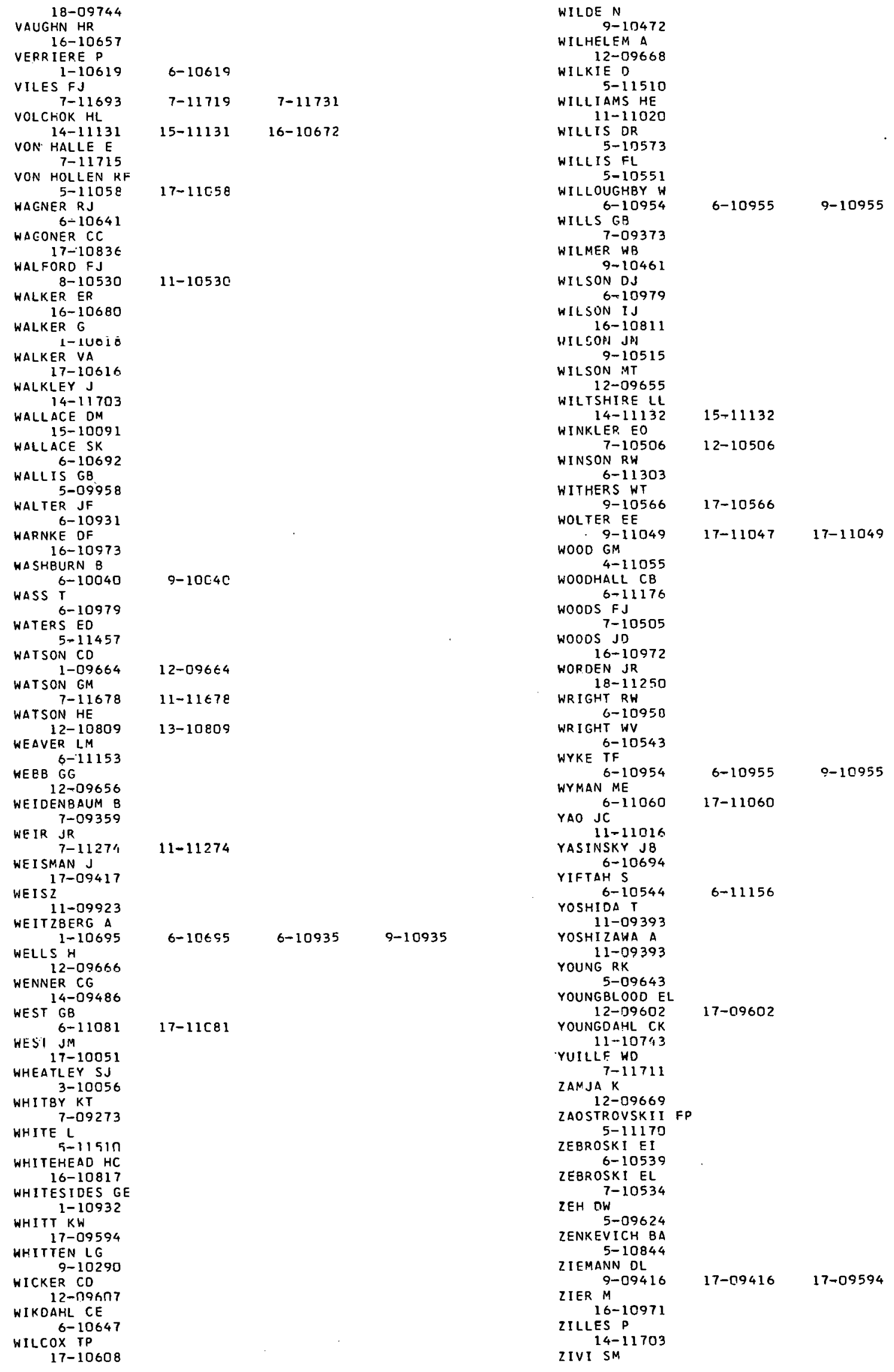


PAGE 236

6-10952

ZIYA AKCASU A
AUTHOR INOEX

6-10693 
APPENDIX

REFERENCE SOURCES

THE ONLY REPORTS DISTRIBUTED BY NSIC ARE THOSE GENERATED BY THE CENTER, I.E., THOSE WITH ORNL-NSIC NUMBERS. UNOER NO CIRCUMSTANCES ARE COPIES OF THE OTHER REPORTS REFERENCED IN THIS BIBLIOGRAPHY FURNISHED, ALTHOUGH ALL AVAILABLE DOCUMENTS MAY BE EXAMINED AT THE CENTER BY QUALIFIED PERSONNEL.

INFORMATION ON DOCUMENT AVAILABILITY AND COST HAS BEEN INCLUDED WITH EACH BIBLIOGRAPHIC ITEM WHEN APPLICABLE AND AVAILABLE. IT OCCURS AT THE END OF THE LINE PRECEDING THE DOCUMENT ABSTRACT. WHEN ORDERING REPORTS USE THE DOCUMENT NUMBER, NOT THE NSIC ACCESSION NUMBER. PREPAYMENT IS NORMALLY REQUIRED. ABBREVIATIONS USED FOR THE AVAILABILITY CODE ARE AS FOLLOWS

\begin{tabular}{|c|c|}
\hline $\begin{array}{l}A E C-D O S \\
A E C-F L\end{array}$ & $\begin{array}{l}\text { \#AEC, DIVISION OF OPERATIONAL SAFETY, WASHINGTON, D. C, } \\
\text { AEC FILM LIBRARY, OAK RIDGE OPERATIONS OFFICE, OAK RIDGE, } \\
\text { TENNESSEE }\end{array}$ \\
\hline$\triangle E C L$ & ATOMIC ENERGY OF CANADA, LTD., CHALK RIVER, ONTARIO, CANADA \\
\hline IF & TOMIC INDUSTRIAL FORUM, 850 THIRD AVENUE, NEW YORK $22, \mathrm{~N} . \mathrm{Y}$. \\
\hline$A P C$ & $\begin{array}{l}\text { AMERICAN POWER CONFERENCE E.R. HHITEHEAD, SECRETARY, } \\
\text { ILLINOIS INSTITUTE OF TECHNOLOGY, CHICAGO, ILLINOIS }\end{array}$ \\
\hline ASME & $\begin{array}{l}\text { (PREPRINTS) AMERICAN SOCIETY OF MECHANICAL ENGINEERS ORDER DE- } \\
\text { PARTMENT, } 345 \mathrm{E} .47 \mathrm{TH} \text { ST., NEW YORK, N. Y. } 10017\end{array}$ \\
\hline BIS & $\begin{array}{l}\text { BRITISH INFORMATION SERVICE, } 845 \text { THIRD AVE., NEW YORK, N. } Y \text {. } \\
10022\end{array}$ \\
\hline CEA & $\begin{array}{l}\text { DOCUMENTATION FRANCAISE, SECRETARIAT GENERAL DU GOVERNMENT, } \\
\text { DIRECTION DE LA DOCUMENTATION } 16 \text {, RUE LORD BYRON, PARIS VIIIEME }\end{array}$ \\
\hline FST I & $\begin{array}{l}\text { CLEARINGHOUSE FOR FEDERAL SCIENTIFIC AND TECHNICAL INFORMATION, } \\
\text { NBS, USDC, SPRINGFIELD, VIRGINIA }\end{array}$ \\
\hline $\mathrm{DCC}$ & $\begin{array}{l}\text { DEFENSE DOCUMENTATION CENTER, CAMERON STATION, ALEXANDRIA, } \\
\text { VIRGINIA }\end{array}$ \\
\hline $\begin{array}{l}\text { DP I } \\
\text { GI }\end{array}$ & $\begin{array}{l}\text { AEC, DIVISION OF PUBLIC INFORMATION, WASHINGTON, O. C. } 20545 \\
\text { GMELIN INSTITUTE, } 40-42 \text { VARRENTRAPPSTRASSE, FRANKFURT } \\
\text { (MEST GERMANY }\end{array}$ \\
\hline GIH & $\begin{array}{l}\text { AMERICAN CONFERENCE OF GOVERNMENTAL HYGENISTS, } 1014 \text { BROADWAY, } \\
\text { CINCINNATI, OHIO }\end{array}$ \\
\hline $\begin{array}{l}\text { GPO } \\
\text { HMSO }\end{array}$ & $\begin{array}{l}\text { U. S, GOVERNMENT PRINTING OFFICE, WASHINGTON, D. C. } 20402 \\
\text { (HER) MAJESTY S STATIONERY OFFICE, LONDON }\end{array}$ \\
\hline I AEA & INTERNATIONAL ATOMIC ENERGY AGENCY (NEW YORK OR GENEVA) \\
\hline & $\begin{array}{l}\text { JOHN CRERAR LIBRARY, } 35 \text { WEST 33RD ST, CHICAGO, ILLINOIS } 60616 \\
\text { JUL. GJELLERUP, } 87, \text { SOLVGADE, COPENHAGEN K, DENMARK }\end{array}$ \\
\hline MC OR DE & $\begin{array}{l}\text { MICROCARD EDITIONS, INC. (FOR SALE) ACCOUNTING AND SHIPPING DE- } \\
\text { PARTMENT, WEST SALEM, WISCONSIN } 54669\end{array}$ \\
\hline $\begin{array}{l}\text { VRC } \\
\text { VSIC }\end{array}$ & $\begin{array}{l}\text { NATIONAL RESEARCH COUNCIL OF CANADA, OTTAHA, CNTARIO, CANADA } \\
\text { NUCLEAR SAFETY INFORMATION CENTER, OAK RIDGE NATIONAL LABORATORY, } \\
\text { P. O. BOX Y, OAK RIDGE, TENNESSEE } 37831\end{array}$ \\
\hline$O C E$ & $\begin{array}{l}\text { SAFETY OFFICE, OFFICE OF THE CHIEF OF ENGINEERS, } \\
\text { DEPARTMENT OF THE ARMY, WASHINGTON, D.C. }\end{array}$ \\
\hline OEEC & $\begin{array}{l}\text { 0.E.E.C. MISSION, PUBLICATIONS OFFICE, SUITE } 1223, \\
1346 \text { CONNECTICUT, WASHINGTON, D.C. }\end{array}$ \\
\hline $\begin{array}{l}\text { PATENTS } \\
\text { (BRITIS }\end{array}$ & $\begin{array}{l}\text { THE PATENT OFFICE, } 25 \text { SOUTHAMPTON BUILDING, LONDON, W. C. } 2 \text {, } \\
\text { ENGLAND }(49 \text { CENTS PER COPY })\end{array}$ \\
\hline $\begin{array}{l}\text { PATENTS } \\
\text { (FOREIC }\end{array}$ & $\begin{array}{l}\text { (OTHER THAN BRITISH) IT IS OUR UNDERSTANDING THAT FOREIGN } \\
\text { PATENTS MAY BE OBTAINED IN PHOTOCOPY FROM THE U. S. PATENT } \\
\text { OFFICE, DEPARTMENT OF COMMERCE, HASHINGTON, D. C. (30 CENTS PER } \\
\text { PAGE) }\end{array}$ \\
\hline $\begin{array}{l}\text { ATENT } \\
\text { (U. S S }\end{array}$ & $\begin{array}{l}\text { THF U. S. PATENT OFFICE, DEPARTMENT OF COMMERCE, WASHINGTON, } \\
\text { D. C. }(25 \text { CENTS PER COPY })\end{array}$ \\
\hline $\begin{array}{l}\text { PDR } \\
\text { SOUR }\end{array}$ & $\begin{array}{l}\text { * *USAEC PUBLIC DOCUMENT ROOM, WASHINGTON, D. C. } \\
\text { OR IGINATOR OF DOCUMENT (AUTHOR, CORPORATE AUTHOR, OR PUBLISHER) }\end{array}$ \\
\hline $\begin{array}{lll}\text { UKA } \\
\text { IL }\end{array}$ & $\begin{array}{l}\text { UNITED KINGDOM ATOMIC ENERGY AUTHORITY, } 11 \text { CHARLES II STREET, } \\
\text { LONDON, S. W. } 1 \\
\text { U. S. GEOLOGICAL SURVEY, WASHINGTON, D. C. } 20242\end{array}$ \\
\hline
\end{tabular}

* PREPARED BY USAEC DIVISION OF OPERATIONAL SAFETY, AVAILABLE FROM DOS IF THE SUPPLY OF A PARTICULAR ISSUE IS NOT EXHAUSTED.

* \#ISI:AIIY DOCUMENTS MAY BE EXAMINED ONLY AT THE PUBLIC DOCUMENT ROOM. OCCASIONALLY EXTRA COPIES ARE AVAILABLE FOR DISTRIBUTION. 
THIS PAGE

WAS INTENTIONALLY

LEFT BLANK 
INTERNAL

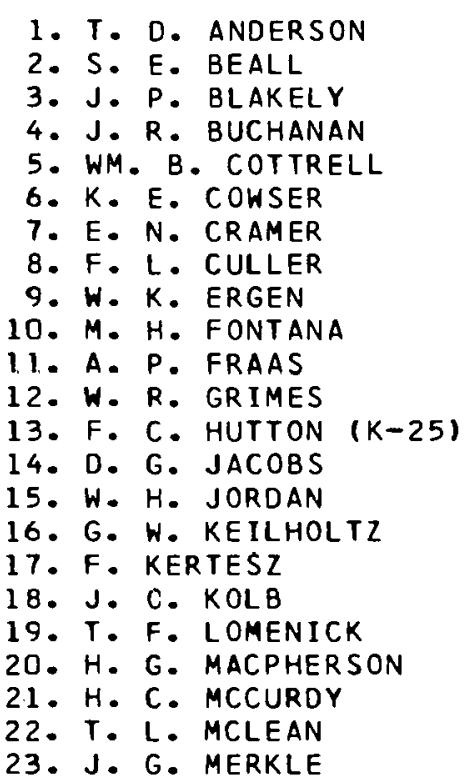

1. T. D. ANDERSON

2. S. E. BEALL

3. J. P. BLAKELY

4. J.R. BUCHANAN

6. K. E. COWSER

7. E. N. CRAMER

8. F. L. CULLER

9. W. K. ERGEN

10. M. H. FONTANA

- A. P. FRA

13. F. C HUTTON

14. D. G. JACOBS

15. W. H. JORDAN

16. G. W. KEILHOLTZ

17. F. KERTESZ

18. J. C. KOLB

20. H. G. MACPHERSON

21. H. C. MCCURDY

23. J. G. MERKLE

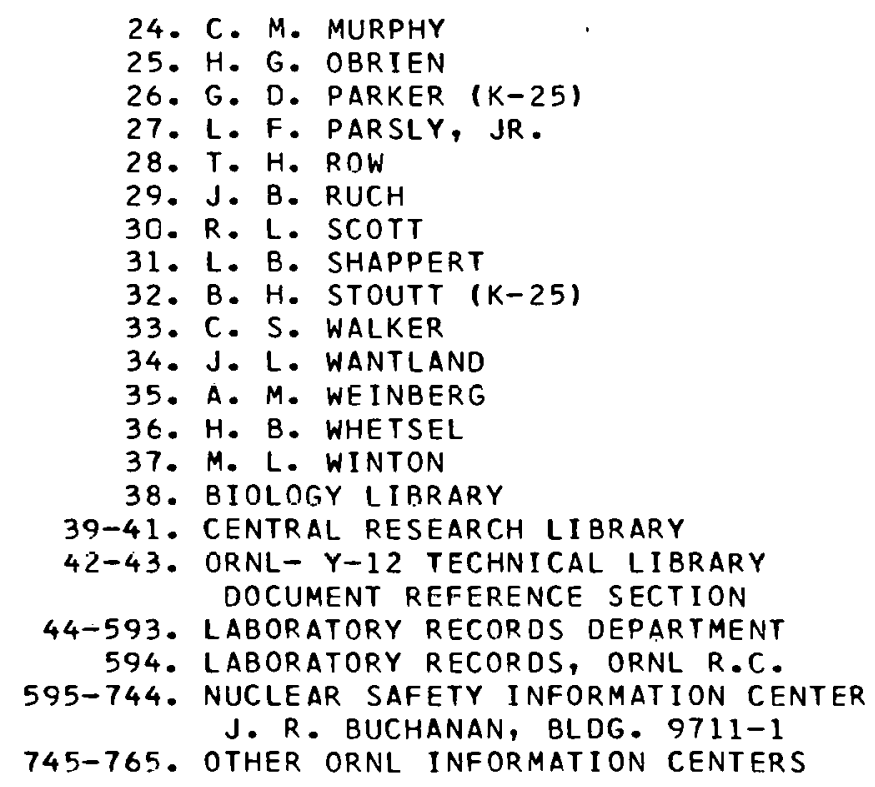

EXTERNAL

766. H. A. KEE AEC-DTI

767. F. A. GIFFORD USWB-ORO

768-771. A. .. PRFSSESKY AEC-DRD

772. J. A. LIEBERMAN AEC-DRD

773-1044. GIVEN DISTRIBUTION AS SHOWN IN

TID - 4500 UNDER REACTOR TECHNOLOGY

CATEGORY $(25$ COPIES - CFSTI) 